\title{
Książka \\ na łamach katolickich czasopism społeczno-kulturalnych w Polsce w latach 1945-1953
}


Duszom postępujacym... droga pożyteczna jest używać ksiażki św. Teresa od Jezusa, Dzieła 


\title{
Evelina Kristanova
}

\author{
Książka \\ na łamach katolickich czasopism \\ społeczno-kulturalnych \\ w Polsce w latach 1945-1953
}

\section{【إ


Evelina Kristanova - Katedra Bibliotekoznawstwa i Informacji Naukowej Uniwersytet Łódzki, 90-237 Łódź, ul. Matejki nr 34a e-mail: kbin@uni.lodz.pl

\section{RECENZENT}

Oskar Stanisław Czarnik

REDAKTOR WYDAWNICTWA UŁ

Matgorzata Szymańska

SKŁAD I ŁAMANIE

ESUS - Agnieszka Buszewska

OKŁADKĘ PROJEKTOWAŁA

Barbara Grzejszczak

\section{INDEKSY}

Zbigniew Gruszka, Katarzyna Krakus

(C) Copyright by Uniwersytet Łódzki, Łódź 2012

Wydane przez Wydawnictwo Uniwersytetu Łódzkiego Wydanie I. 5092/2012

ISBN 978-83-7525-782-3

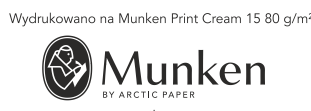

Wydawnictwo Uniwersytetu Łódzkiego 90-131 Łódź, ul. Lindleya 8 www.wydawnictwo.uni.lodz.pl e-mail: ksiegarnia@uni.lodz.pl tel. (42) 6655863 , faks (42) 6655862

Druk i oprawa: Quick Druk 


\section{Spis treści}

Wstęp

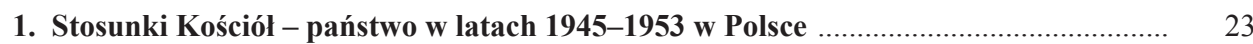

1.1. Ogólna sytuacja polityczna Polski po zakończeniu II wojny światowej ...................... 23

1.1.1. Polska na tle wydarzeń międzynarodowych ....................................................... 23

1.1.2. Sfałszowane wybory 1947 r. .............................................................................. 31

1.1.3. Episkopat wobec wyborów ………………................................................... 38

1.1.4. Apogeum stalinizmu w Polsce w latach 1949-1953 ........................................ 39

1.2. Sytuacja polskiego Kościoła katolickiego w latach 1945-1947 .................................... 41

1.2.1. Położenie ogólne ....................................................................................... 41

1.2.2. Organizacja Kościoła i pierwsze prawne ograniczenia ...................................... 49

1.2.3. Światopogląd katolicki a marksistowski ........................................................ 52

1.2.4. Sacrum i profanum ............................................................................................. 55

1.2.5. Pogrom kielecki jako pretekst do ataku na Kościół ........................................... 58

1.2.6. Odbudowa organizacji społeczno-katolickich i próba utworzenia partii kato-

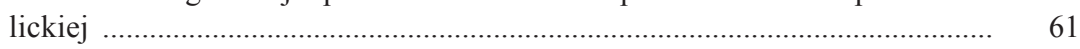

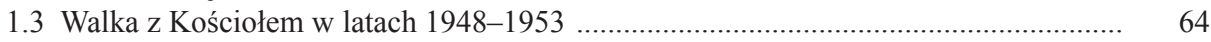

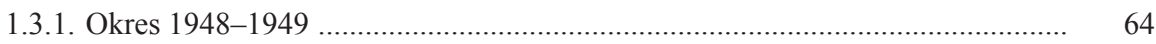

1.3.1.1. „Księża patrioci” i ruchy pseudokatolickie ........................................... 68

1.3.1.2. Nauczanie religii w szkołach przeszkodą w indoktrynacji komunistycz-

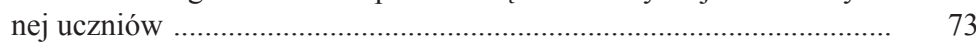

1.3.2. Frontalny atak na Kościół w latach 1950-1953 ................................................ 79

1.3.2.1. Zamknięcie Caritasu ......................................................................... 86

1.3.2.2. Porozumienie z 1950 r. .................................................................. 87

1.3.2.3. Dekret o obsadzaniu duchownych stanowisk kościelnych w 1953 r. .... 94

1.3.2.4. Aresztowanie prymasa Stefana Wyszyńskiego ...................................... 95

2. Polska prasa i książka katolicka w latach 1945-1953 _............................................. 107

2.1. Sytuacja wydawnicza prasy katolickiej w pierwszych latach powojennych ............... 107

2.1.1. Ilościowa prezentacja prasy katolickiej ……................................................... 110

2.1.2. Ingerencje cenzury . ............................................................................ 111

2.2. Działalność i dorobek katolickich wydawnictw książkowych ................................... 117

2.3. Typologia prasy katolickiej .................................................................................. 119

2.3.1. Prasa kurii diecezjalnych, seminariów i zakonów ......................................... 120

2.3.2. Prasa katolickich towarzystw, spółdzielni wydawniczych i organizacji charytatywnych ............................................................................................. 122

2.3.3. Krąg prasy Stowarzyszenia PAX .................................................................. 123

2.4. Charakterystyka katolickich czasopism społeczno-kulturalnych ................................ 125

2.4.1. „Tygodnik Powszechny” (1945-1953) ......................................................... 125

2.4.2. „Głos Katolicki” (1945-1948) .................................................................... 167

2.4.3. „Tygodnik Warszawski” (1945-1948) ................................................................. 193 
2.4.4. „Tygodnik Katolicki” (1946-1953) ................................................................... 219

2.4.5. Miesięcznik „Znak” (1946-1953)................................................................... 253

2.4.6. „Przegląd Powszechny” (1947-1953) .............................................................. 269

3. Recenzje książek na łamach wybranych periodyków ................................................ 281

3.1. Ilościowa prezentacja recenzji omówionych książek oraz ich wydawców .................. 282

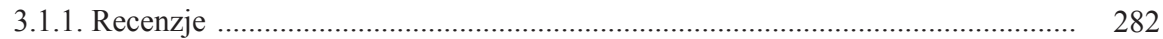

3.1.2. Książki zrecenzowane ………...................................................................... 292

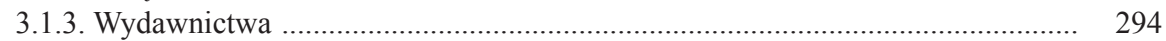

3.2. Książka katolicka (nieliteracka) ............................................................................... 304

3.2.1. Przekłady Nowego Testamentu i komentarze do Ewangelii ............................. 305

3.2.2. Pisma Ojców Kościoła .................................................................................. 309

3.2.3. Dzieła mistyków. ................................................................................. $\quad 310$

3.2.4. Życiorysy świętych .................................................................................. 311

3.2.5. Biografie zasłużonych kapłanów ................................................................. 316

3.2.6. Encykliki, katechizmy i modlitewniki. ......................................................... 317

3.2.7. Dzieła teologiczne, prace z zakresu filozofii chrześcijańskiej i nauki społecznej

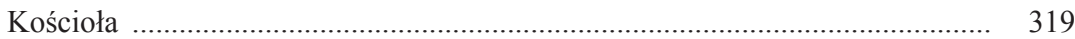

3.2.8. Rozważania religijne ................................................................................ 322

3.2.9. Encyklopedie i słowniki katolickie ............................................................. 325

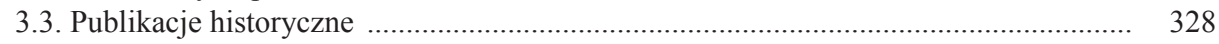

3.3.1. Książki poświęcone przebiegowi II wojny światowej ..................................... 328

3.3.2. Książki o tematyce obozowej .......................................................................... 332

3.3.3. Książki o tematyce okupacyjnej ..................................................................... 336

3.3.4. Rozprawy dotyczące historii Kościoła ........................................................ 338

3.3.5. Opracowania historyczne o różnej tematyce .................................................. 339

3.3.6. Biografie ............................................................................................... $\quad 343$

3.3.7. Pamiętniki i wspomnienia .................................................................... 346

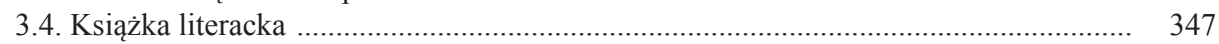

3.4.1. Powieści ……………….......................................................... 347

3.4.1.1. Powieść katolicka .................................................................... 348

3.4.1.2. Powieść historyczna ....................................................................... 356

3.4.1.3. Powieść o tematyce wojennej .............................................................. 360

3.4.1.4. Powieść społeczno-obyczajowa ....................................................... 362

3.4.1.5. Inne odmiany tematyczne powieści ................................................. 367

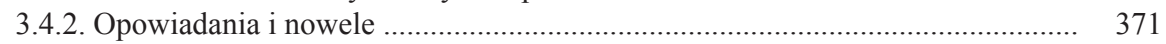

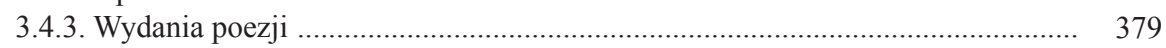

3.4.4. Dramat ….................................................................................................. $\quad 387$

3.4.5. Publikacje literaturoznawcze, językoznawcze i historycznoliterackie .............. 392

3.5. Książki z innych dziedzin ................................................................................ 402

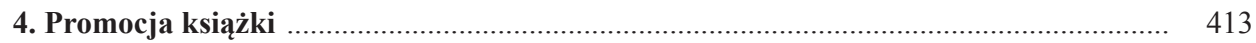

4.1. Reklama książek ........................................................................................... 414

4.1.1. Reklama wydawnicza ……………..................................................... 417

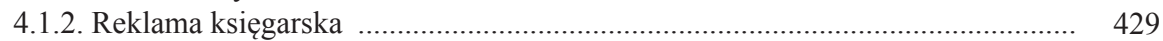

4.1.3. Reklama tytułów i serii książkowych. ......................................................... 436

4.2. Informacje o nowościach wydawniczych ................................................................. 444

4.3. Książki w przeglądach piśmiennictwa ………......................................................... 457

4.4. Książki nadesłane do redakcji ................................................................................. 461

4.5. Zakres tematyczny promowanych książek ............................................................... 466 


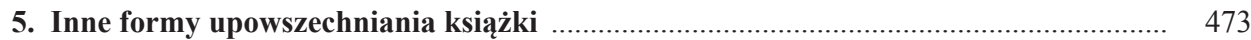

5.1. Publikacja fragmentów książek jako forma ich promocji ........................................... 473

5.2. Powieści literackie w odcinkach .......................................................................... 479

5.3. Imprezy kulturalne związane z książką ................................................................ 481

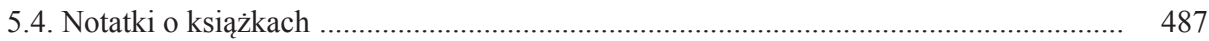

5.5. Ludzie książki .................................................................................................. 491

5.6. Ogólne rozważania o książce ................................................................................ 494

5.7. Publikacje o instytucjach obiegu książki ................................................................. 506

5.8. Zagadnienia czytelnictwa ................................................................................ 517

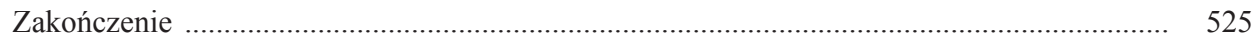

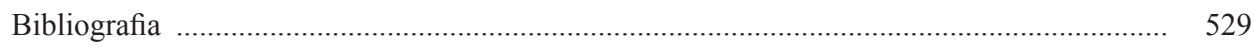

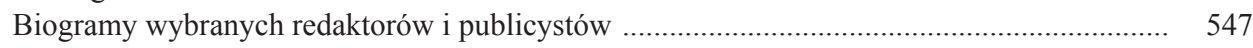

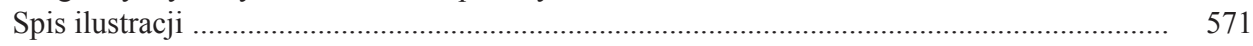

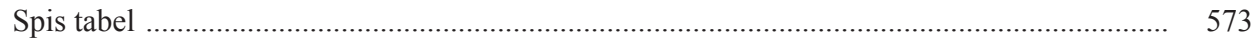

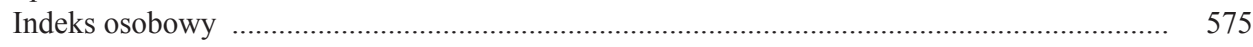

Indeks księgarni, wydawnictw i wydawców ....................................................................... 603 



\section{Wstęp}

Książka, jako jedna z najważniejszych form przekazu kultury duchowej, odegrała w historii narodu polskiego istotną rolę, dzieląc losy Polaków w różnych okresach. W czasach niewoli podlegała cenzurze i była świadomie niszczona przez zaborców i okupantów, natomiast po odzyskaniu państwowości „odżywała” wraz ze społeczeństwem, świadcząc o sytuacji politycznej, społecznej i kulturalnej Drugiej Rzeczypospolitej. Po II wojnie światowej nauka o książce uzyskała samodzielność, stając się dyscypliną uniwersytecką. Jako pierwsza prawa akademickie otrzymała w 1945 r. Katedra Bibliotekoznawstwa w Łodzi. Placówką kierował Jan Muszkowski, znany w okresie międzywojennym ze swych koncepcji teoretycznych. Kolejni znaczący polscy bibliolodzy, tej miary co Karol Głombiowski, Krzysztof Migoń, Radosław Cybulski i Janusz Dunin, przyczynili się do dalszego rozwoju księgoznawstwa w szerokim aspekcie społecznym i kulturowym ${ }^{1}$. Badali przy tym książkę z uwzględnieniem najważniejszych kwestii: procesu jej produkcji, upowszechniania, odbioru i udostępniania. W okresie powojennym bardzo ważna część studiów nad dawną książką dotyczyła jej perspektywy społecznej i funkcjonalnej. Świadczą o tym liczne opracowania dotyczące historii książki na terenach polskich w różnych epokach i okresach².

Ważne a zarazem osobne miejsce $\mathrm{w}$ polskim księgoznawstwie zajmują prace o charakterze interdyscyplinarnym, dotyczące książki w powiązaniu z analizą

\footnotetext{
${ }^{1}$ Książka według definicji Jana Muszkowskiego jest produktem „,materializacji graficznej treści kulturalnych stanowiących pewną zamkniętą całość, podjętą w celu utrwalenia ich, przekazania i rozpowszechniania wśród ludzi”. Źródło: J. Muszkowski, Wstęp do socjologii książki, „Studia o Książce” 1973 t. 3 s. 100. Na społeczny aspekt rozwoju książki i jej „niezbędności” w społeczeństwie zwrócił uwagę Karol Głombiowski w pracy Książka w komunikacji społecznej, Wrocław 1980; tenże, O funkcjonalną koncepcję nauki o książce, „Studia o Książce” 1970 t. 1 s. 9-18; K. Migoń, Nauka o książce. Zarys problematyki, Wrocław 1984. O społecznym i funkcjonalnym sposobie badania książki wspomniał K. Migoń w artykule zatytułowanym Bibliologia historyczna w kręgu wrocławskiego bibliotekoznawstwa uniwersyteckiego, w: Bibliologia i informatologia, pod red. D. Kuźminy, Warszawa 2011, s. 47-55.

${ }^{2}$ Np. A. Żbikowska-Migoń, Dzieje książki i jej funkcji społecznej: wiek XVIII, Wrocław 1987; taż, Historia książki w XVIII wieku: początki bibliologii, Warszawa 1989; taż, Ksią̇̇ka naukowa w kulturze polskiego Oświecenia, Wrocław 1977; E. Gondek, Polska książka literacka na Śląsku pod panowaniem pruskim 1795-1863, Katowice 1995; J. Konieczna, Kultura ksiązki polskiej w Łodzi przemysłowej (1820-1918), Łódź 2005; B. Koredczuk, Udziat inteligencji prawniczej Królestwa Polskiego w kształtowaniu kultury książki (1815-1915), Wrocław 2011; D. Wańka, Świat kaliskiej ksiązki pod zaborem rosyjskim (1815-1914), Kalisz 2002.
} 
zawartości prasy. Łamy periodyków były bowiem bogatym źródłem materiału o „życiu książki” w danej rzeczywistości dziejowej³. Krzysztof Migoń zwrócił szczególną uwagę na interdyscyplinarny charakter bibliologii, która znajduje wspólne pole badawcze m.in. z prasoznawstwem i medioznawstwem ${ }^{4}$. Z perspektywy bibliologicznej na tytuły prasowe i czasopiśmiennicze XVIII w. spojrzała Danuta Hombek ${ }^{5}$. Czasopisma kaliskie XIX i XX w. zainteresowały Krzysztofa Walczaka ${ }^{6}$. Aspekty literackie i kulturowe na łamach wybranych tytułów prasowych przedstawili m.in. Oskar Stanisław Czarnik i Jolanta Chwastyk-Kowalczyk ${ }^{7}$. Rzadziej przedmiotem zainteresowania badaczy były zagadnienia związane z upowszechnianiem książki przez poszczególne tytuły prasowes.

Do podjęcia problematyki książki na łamach katolickich czasopism społeczno-kulturalnych ${ }^{9} \mathrm{~W}$ pierwszych latach po wojnie skłoniła autorkę wyraźna luka istniejąca w badaniach naukowych. Wśród wydanych w ostatnich dwudziestu latach opracowaniach prasoznawczych dotyczących katolickich periodyków brakuje prac w zakresie zagadnień książki na ich łamach ${ }^{10}$. Książka znalazła natomiast

${ }^{3}$ Zob. J. Muszkowski, Życie książki, Kraków 1951.

${ }^{4}$ Szerzej zob. K. Migoń, Nauka o książce..., s. 222-303; tenże, Bibliologia wobec medioznawstwa: izolacja, komplementarność czy integracja. W: Książa i prasa w systemie komunikacji społecznej: przeszłość - dzień dzisiejszy - perspektywy, pod red. M. Judy, Lublin 2002, s. 14.

${ }^{5}$ D. Hombek, Prasa i czasopisma polskie XVIII wieku w perspektywie bibliologicznej, Kraków 2001; ta sama autorka uczestniczyła w pracach nad bibliografią pt. Książka polska w ogłoszeniach prasowych XVIII: źródła, t. 1-5, Wrocław-Kraków 1992-2005. 2005.

${ }^{6} \mathrm{~K}$. Walczak, Czasopisma kaliskie XIX i początków XX w. Studium bibliologiczne, Kalisz

${ }^{7}$ O.S. Czarnik, Ideowe i literackie wybory „, Robotnika” w latach 1918-1939, Warszawa 1996; J. Chwastyk-Kowalczyk, Londyński „Dziennik Polski i Dziennik Żotnierza” 1944-1989, Kielce 2008.

${ }^{8}$ A. Kaleta, Tematyka i metody popularyzacji ksiązki na łamach „Przeglądu Powszechnego” w latach 1884-1918. W: Kraków - Lwów. Książki - czasopisma - biblioteki, pod red. H. Kosętki, Kraków 2006, s. 369-380; E. Kristanova, Problematyka książki i bibliotek na łamach "Tęczy” (1927-1939), „Acta Universitatis Lodziensis. Folia Librorum” 2005 nr 12 s. 35-49; taż, Reklama książki na łamach „Rodziny Polskiej” (1927-1939), „Toruńskie Studia Bibliologiczne” 2009 nr 2 s. $27-47$.

${ }^{9}$ Do grupy czasopism społeczno-kulturalnych należą periodyki (najczęściej tygodniki i miesięczniki), w których dominuje problematyka społeczna i kulturalna. Przeznaczone dla elity intelektualnej zazwyczaj nie cechują się wysokim nakładem, jednak pomimo tego odgrywają znaczącą rolę w kształtowaniu opinii publicznej (nazywane też czasopismami opinii). Osobno wyodrębnił je wraz z periodykami literackimi Andrzej Paczkowski w Prasie polskiej 1918-1939 (Warszawa 1980), sytuując ich powstanie w latach trzydziestych XX w., oraz Kazimierz Koźniewski w Historii co tydzień (Warszawa 1976). Obaj autorzy wyeksponowali ich upolitycznienie.

${ }^{10}$ Warto wymienić następujące książki: J. Giela, Polska prasa katolicka $w$ diecezji wrocławskiej 1895-1939, Lublin 1989; M. Habowski, Nauka społeczna Kościoła w świetle prasy katolickiej w Polsce (1989-1995), Wrocław 2002; J. Plis, Kościót katolicki w Polsce a prasa, radio, film 1918-1939, Lublin 2001; K. Pokorna-Ignatowicz, Kościót w świecie mediów, Kraków 2002; J. Stefaniak, Polityka władz państwowych PRL wobec prasy katolickiej w latach 1945-1953, 
swoje stałe miejsce $\mathrm{w}$ zawartości wspomnianych czasopism skierowanych do inteligencji w latach 1945-1953. Zespoły redakcyjne zadbały o jej upowszechnienie poprzez liczne recenzje, omówienia, informacje o nowościach, wykazy, anonse, reklamy, przytaczane fragmenty i powieści w odcinkach. Tematyka książki obecna była jednocześnie w nagłaśnianych na łamach periodyków imprezach kulturalnych z nią związanych, ogólnych rozważaniach, jak też wypowiedziach o bibliofilach, bibliotekarzach i księgarzach. Książka zatem występująca w postaci materialnej, a zarazem będąca nośnikiem kultury, stała się elementem łączącym dwa kręgi zjawisk zachodzących w polskim społeczeństwie powojennym i pozwoliła na uchwycenie relacji między kulturą książki ${ }^{11}$ promowaną na łamach wybranych tytułów prasowych a kulturą chrześcijańską.

Prasa katolicka, posiadająca silną pozycję i bogatą tradycję z okresu dwudziestolecia międzywojennego, w latach 1945-1953 odegrała znaczącą rolę w walce o nowy kształt kultury powojennej. Publikacje na jej łamach stanowiły też poważny głos w dyskusji nt. wolności wypowiedzi i światopoglądu. Dowodem tego mogą być działania represyjne wobec redaktorów i współpracowników pism. Redakcje najważniejszych czasopism o profilu społeczno-kulturalnym chciały aktywnie uczestniczyć w budowie Polski powojennej, stąd szeroko podejmowana przez publicystów problematyka społeczna oparta na nauczaniu Kościoła oraz kulturalna i literacka. Ta ostatnia zaprezentowana została pod hasłem literatury katolickiej.

Celem badań było ukazanie całościowe problematyki książki obecnej na łamach sześciu najważniejszych czasopism katolickich o profilu społecznokulturalnym, w latach 1945-1953. W pracy wzięto pod uwagę najbardziej znane, a zarazem reprezentatywne tytuły dla różnych regionów Polski, zważywszy, że główne ośrodki prasy katolickiej mieściły się w Warszawie, Krakowie i Poznaniu. W gronie przebadanych pism znalazły się cztery tygodniki: stołeczny „Tygodnik Warszawski”, krakowski „Tygodnik Powszechny”, gorzowski „Tygodnik Katolicki” i poznański „Głos Katolicki” oraz dwa miesięczniki - jeden o długiej tradycji wydawniczej, jakim był „Przegląd Powszechny” ukazujący się w Warszawie, i nowo powstały „Znak” w Krakowie. W przypadku „Głosu

\footnotetext{
Lublin 1998. Z opracowań poszczególnych katolickich tytułów prasowych ukazały się: R. Graczyk, Cena przetrwania? SB a „Tygodnik Powszechny”, Warszawa 2011; A. Grajewski, Twój Gość, Katowice 2008; M. Jagiełł, Próba rozmowy. Szkice o katolicyzmie odrodzeniowym i „, Tygodniku Powszechnym" 1945-1953, t. 1-2, Warszawa 2001; E. Kristanova, Program spoleczny i kulturalny „Tęczy” (1927-1939) na tle prasy katolickiej w II Rzeczypospolitej, Łódź 2006; Sandomierski Gość Niedzielny. Idzie z gałazka oliwna ..., pod red. R.B. Sieronia, Sandomierz 2006; M. Strzelecka, Trudne kompromisy. Środowisko „, Tygodnika Powszechnego” wobec reform systemu oświaty $i$ wychowania w latach 1945-1989, Torun 2009.

${ }^{11}$ K. Migoń, Kultura książki. Program dla bibliologii i potrzeba studiów bibliotekoznawczych. W: Nauka o książce, bibliotece i informacji we współczesnym świecie, pod red. M. Banackiej, Warszawa 2003; tenże, Bibliologia - nauka o kulturze ksiązki, „Nauka” 2005 nr 2 s. 49-57.
} 
Katolickiego" uwzględniono zawartość roczników z lat 1945-1948, które ukazały się pod redakcją ks. Romana Mielińskiego. Po jego aresztowaniu oraz uwięzieniu kolejne numery wydane przez nowy zespół wykazały wyraźną zmianę linii programowej pisma i jego adresata. Poznański tygodnik w latach 1949-1956 stał się popularnym periodykiem religijnym dla ludu i nie mógł zostać uwzględniony w grupie czasopism społeczno-kulturalnych.

Problematyka badawcza będąca przedmiotem zainteresowania autorki niniejszej dysertacji dotyczy przede wszystkim trzech ważnych zagadnień. Pierwsze z nich odnosi się do sposobu i form upowszechniania książki na łamach pism przeznaczonych dla odbiorców o wyższych kompetencjach czytelniczych, a więc posiadających średnie i wyższe wykształcenie. Drugie wiąże się z odpowiedzią na pytanie, w jakiej mierze redakcje tychże periodyków w okresie silnego nacisku ideologii komunistycznej starały się propagować własny, niezależny model kultury i w jakiej mierze starały się wykorzystać książkę w celu umocnienia kultury chrześcijańskiej oraz utrwalenia katolickich wzorców życia społecznego. W tym też kontekście szczególnie interesujące stało się stwierdzenie, w jakim stopniu ów model był jawnie opozycyjnym wobec panującego systemu i mimo ostrej kontroli cenzuralnej.

Zwrócono uwagę na bogaty repertuar propagowanych książek, ich autorów, zawartą w nich tematykę oraz opinie o nich znanych publicystów. Zapytano jednocześnie, jakie wydawnictwa $\mathrm{w}$ wybranym okresie publikowały książki religijne i katolickie. Zaistniałe zjawiska bibliologiczne starano się uchwycić poprzez uwzględnienie najważniejszych procesów ,życia książki” w rozumieniu Jana Muszkowskiego, chociaż zgromadzony materiał prasowy nie w pełni na to pozwolił.

Praca pretenduje do miana bibliologicznej, prasoznawczej i historycznej. Dotyczy szeroko pojętych zagadnień książki na łamach wybranej grupy czasopism w niezwykle trudnych dla społeczeństwa polskiego kilku latach po ostatniej wojnie światowej. Powstała przede wszystkim na podstawie źródeł prasowych. Główny trzon analizowanych materiałów stanowiła zawartość sześciu wymienionych wyżej periodyków, które odegrały najważniejszą rolę w kształtowaniu opinii katolickiej inteligencji. Metodą autopsji przebadano łącznie 40 roczników (1166 numerów) ${ }^{12}$. W opracowaniu obszernego materiału prasoznawczego posłużono się metodą historycznoliteracką, elementami analizy zawartości i analizy treści (według Harolda Lasswella, Bernarda Berelsona, Walerego Pisarka, Ireny Tetelowskiej, Stanisława Pamuły, Ignacego S. Fiuta) ${ }^{13}$, analizą jakościową i ilo-

${ }^{12}$ W tym: 9 roczników „Tygodnika Powszechnego”, co stanowiło 414 numerów; 4 roczniki „Głosu Katolickiego” - 190 numerów; 4 roczniki „Tygodnika Warszawskiego” - 145 numerów; 8 roczników „Tygodnika Katolickiego” - 325 numerów; 8 roczników „Znaku” - 35 zeszytów; 7 roczników „Przeglądu Powszechnego” - 57 zeszytów.

${ }^{13}$ W. Pisarek, Analiza zawartości prasy, Kraków 1983; I. Tetelowska, Analiza i ocena zawartości dzienników, cz. 1 i 2, „Zeszyty Prasoznawcze” $1960 \mathrm{nr} 1$ i nr 5/6; taż, Analiza zawartości gazet - wstępne studium funkcjonalnej typologii prasy, „Zeszyty Prasoznawcze” $1962 \mathrm{nr}$ 4; taż, 
ściową oraz elementami technik statystycznych. W napisaniu książki pomocne były również liczne artykuły opublikowane w czasopismach naukowych i popularnonaukowych o profilu prasoznawczym, księgarskim, bibliotekoznawczym i innym, w których odniesiono się do uwzględnionych w opracowaniu tytułów prasowych lub ogólnej sytuacji wydawniczej lat 1945-1953. Z tego względu wykazano je osobno w bibliografii.

Oprócz bogatych źródeł prasowych stanowiących podstawową i najważniejszą bazę źródłową pracy, wzięto pod uwagę wybrane źródła archiwalne, które spełniły funkcję tylko uzupełniającą. Cenne okazały się akta dostępne w Instytucie Pamięci Narodowej, głównie dotyczące osób należących do redakcji wybranych czasopism (Jerzego Brauna, ks. Zygmunta Kaczyńskiego, o. Kazimierza Łabińskiego i in.). W sposób szczątkowy udało się skorzystać z przeznaczonych z początkiem 2012 r. do uporządkowania (zatem niedostępnych dla autorki) materiałów Głównego Urzędu Kontroli Prasy, Publikacji i Widowisk w zasobach Archiwum Akt Nowych, wśród których zachowały się dane dotyczące ingerencji cenzorskich w prasie katolickiej w latach 1945-1953. Krótki podrozdział dotyczący cenzury tego okresu został zasadniczo napisany na podstawie znów ogólnodostępnych publikacji odnoszących się jedynie do przykładowych czasopism katolickich cenzurowanych w tamtym czasie. Wśród nich dość szeroko został opracowany pod tym względem „Tygodnik Powszechny”"14. W książce zasygnalizowano jedynie dokuczliwą działalność ówczesnego Urzędu Kontroli. Badanie odrzuconych przez cenzurę tekstów nie było bowiem celem autorki pracy; w tytule dysertacji wyraźnie określono zakres i zasięg tematyczny. Obszerne źródła archiwalne pozwoliłyby zapewne na napisanie osobnej pracy na temat ingerencji w zawartość wybranych pism. Nie uwzględniono również archiwaliów redakcyjnych sześciu wybranych czasopism, które częściowo zostały opracowane przez Janusza Stefaniaka i Małgorzatę Strzelecką ${ }^{15}$. Materiały archiwalne dotyczące omawianych periodyków zasadniczo pozostawiono do opracowania historykom, gdyż i tak już obszerna praca wskazująca wyraźnie w tytule na aspekt badań książki na łamach prasy zbytnio by się rozrosła ${ }^{16}$.

Szkice prasoznawcze. W: Wybór rozpraw i artykułów, pod red. P. Dubiela, W. Pisarka, Kraków 1972; S. Pamuła, Metoda analizy zawartości prasy, Częstochowa 1996; I.S. Fiut, Pisma społeczno-kulturalne w latach 1989-2000, „Zeszyty Prasoznawcze” 2000 nr 3/4 s. 64-81; tenże, Prasa bezplatna w Polsce w latach 1999-2001, „Zeszyty Prasoznawcze” 2002 nr 1/2 s. 69-83.

${ }^{14}$ Zob. I. Pietrzkiewicz, M. Rogoż, Prewencyjne ingerencje cenzorskie $w$ „Tygodniku Powszechnym” na przełomie lat 40. i 50., „Rocznik Historii Prasy Polskiej” 2011 nr 1/2 s. 143-170; M. Rogoż, „Tygodnik Powszechny” w 1949 r. w świetle wtórnych ocen cenzorów Głównego Urzędu Kontroli Prasy, Publikacji i Widowisk, „Rocznik Bibliologiczno-Prasoznawczy” $2011 \mathrm{nr} 3$ s. $105-119$.

${ }^{15}$ Zob. J. Stefaniak, Polityka władz...; M. Strzelecka, Trudne kompromisy...

16 Źródła archiwalne dotyczące „Tygodnika Warszawskiego” bada współcześnie Mirosław Biełaszko (IPN). 
Osobną grupę wykorzystanych materiałów tworzą źródła drukowane wydane do 2011 r. (m.in. monografie, opracowania i liczne części prac zbiorowych) dotyczące historii Polski, relacji Kościoła z państwem, wydawnictw, księgarni oraz prasy i książki katolickiej pierwszych lat po wojnie. Najwięcej opracowań doczekał się „Tygodnik Powszechny” i „Tygodnik Warszawski”, zapewne ze względu na to, że tytuły skupiły wokół siebie znaczące środowiska katolickie tego okresu. Zainteresowanie prasoznawców znalazł też „Przegląd Powszechny”. Większej uwagi badaczy nie zwrócił natomiast „Głos Katolicki”, a najmniej publikacji ukazało się na temat „Tygodnika Katolickiego”. Można stwierdzić, że ostatnie z wymienionych pism nie spotkało się z uwagą naukowców i zostało poniekąd zapomniane. Opublikowane książki, artykuły i drobniejsze wypowiedzi dotyczące sześciu czasopism odnotowano w przypisach rozdziału drugiego we fragmentach poświęconych charakterystyce poszczególnych pism. Można je również odnaleźć w spisie bibliograficznym na końcu książki.

W przeglądzie literatury dotyczącej ogólnej historii Polski wybranego okresu niezwykle pomocne były wskazówki bibliograficzne Andrzeja Friszke ${ }^{17}$. Podstawę stanowiły także pozycje Andrzeja Paczkowskiego, Wojciecha Roszkowskiego, Antoniego Dudka, Zdzisława Zblewskiego i Antoniego Czubińskiego ${ }^{18}$. W pierwsze lata powojenne wprowadziła nas w sposób dojrzały Krystyna Kersten ${ }^{19}$. Istotnym opracowaniem ukazującym sytuację wszystkich partii i tworzenie przez PPR monopartyjnego systemu była książka Janusza Wrony System partyjny w Polsce 1944-1950 (Lublin 1995). Problematyka dotycząca stosunków Kościoła z państwem po II wojnie światowej posiada pokaźną literaturę; bezcenne były tutaj sugestie Jana Żaryna ${ }^{20}$ - specjalisty w tej dziedzinie. Po 1989 r. zagadnienia relacji państwa i Kościoła stały się bowiem jednym z najciekawszych tematów badawczych. Do najważniejszych

${ }^{17}$ A. Friszke, Polska: losy państwa i narodu 1939-1989, Warszawa 2003, s. 483-507.

${ }^{18}$ A. Paczkowski, Pół wieku dziejów Polski 1939-1989, Warszawa 1995; tenże, Historia polityczna Polski 1944-1948, Warszawa 1985; tenże, Zdobycie władzy 1945-1947, Warszawa 1993; tenże, Aparat bezpieczeństwa w latach 1944-1956, cz. 1-3, Warszawa 1994-2001; A. Friszke, Opozycja polityczna w PRL 1945-1980, Londyn 1994; tenże, Polska. Losy państwa i narodu 1939-1989, Warszawa 2003; tenże, Przystosowanie i opór: studia z dziejów PRL, Warszawa 2007; A. Czubiński, Dzieje najnowsze Polski 1944-1989, Poznań 1992; A. Dudek, Ślady PeeReLu. Ludzie - wydarzenia - mechanizmy, Kraków 2001; A. Dudek, Z. Zblewski, Utopia nad Wisłą. Historia Peerelu, Warszawa - Bielsko-Biała 2008.

${ }^{19}$ K. Kersten, Narodziny systemu władzy. Polska 1943-1948, Poznań 1990; taż, Polacy, Żydzi, komunizm. Anatomia pótprawd 1939-68, Warszawa 1992; taż, Historia polityczna Polski 1944-1956, Gdańsk 1989; taż, Jatta w polskiej perspektywie, Warszawa 1989; taż, Między wyzwoleniem a zniewoleniem. Polska 1944-1956, Londyn 1993.

${ }^{20}$ J. Żaryn, Dzieje Kościoła katolickiego w Polsce (1944-1989), Warszawa 2003, s. 7-14; tenże, Kościót a władza w Polsce (1945-1950), Warszawa 1997; tenże, Kościót w PRL, Warszawa 2004; tenże, Stolica Apostolska wobec Polski i Polaków w latach 1944-1958: w świetle materiałów ambasady RP przy Watykanie (Wybór dokumentów), Warszawa 1998. 
znawców tej problematyki należą również ks. Zygmunt Zieliński, Ryszard Gryz i Henryk Dominiczak ${ }^{21}$. Wartościowym opracowaniem jest także praca Bohdana Cywińskiego ${ }^{22}$. Peter Raina przedstawił relacje Kościoła z państwem w PRL na podstawie dokumentów ${ }^{23}$. Przydatną publikacją napisaną na podstawie archiwaliów była także książka Barbary Fijałkowskiej ${ }^{24}$, w której autorka rzetelnie opracowała dokumenty z okresu 1944-1955. Przedstawiła intencje, jakie towarzyszyły przedstawicielom władzy podczas rozmów z członkami hierarchii kościelnej, komentarze, korespondencje prominentów partyjnych, a także podejście ludzi partii do Kościoła, upowszechniając szczegółowe i mało znane informacje. Mniej obszerne opracowanie to fragment dzieła zbiorowego Justyny Piaseckiej Stosunki między Kościołem rzymskokatolickim i państwem w Polsce w latach 1944-195325. Wiele o relacjach władzy z Kościołem Chrystusowym dowiadujemy się z biografii poświęconych Prymasowi Tysiąclecia Stefanowi kard. Wyszyńskiemu. Do nich należy znane od lat opracowanie Andrzeja Micewskiego, nowa i ciekawie napisana książka Ewy Czaczkowskiej oraz ujawniające nieznane wcześniej fakty z działań Urzędu Bezpieczeństwa przeciw prymasowi dzieło Wiesława Wysockiego ${ }^{26}$. Niepretendująca do miana naukowego ujęcia praca Janusza Zabłockiego objęła okres 1948-195627. Bardzo ważnym źródłem wiedzy są również osobiste zapiski prymasa ${ }^{28}$. Niektóre z opracowań przybliżyły jego wizję Kościoła i przesłania społecznego ${ }^{29}$. Problematykę dotyczącą stosunku władzy ludowej do religii w szkole podjęła w oparciu

${ }^{21}$ Z. Zieliński, Kościót w Polsce: 1944-2007, Poznań 2009; A. Dudek, Państwo i Kościót 1945-1970, Kraków 1995; A. Dudek, R. Gryz, Komuniści i Kościół w Polsce (1945-1989), Kraków 2003; R. Gryz, Państwo a Kościót w Polsce 1945-1956: na przyktadzie województwa kieleckiego, Kraków 1999; H. Dominiczak, Organy bezpieczeństwa PRL w walce z Kościołem katolickim 1944-1990 w świetle dokumentów MSW, Warszawa 2000.

${ }^{22}$ B. Cywiński, Ogniem próbowane: z dziejów najnowszych Kościoła katolickiego w Europie Środkowo-Wschodniej, t. 2: „,.., i was prześladować będa”, Lublin-Rzym 1990 (rozdział I: Kościót $w$ Polsce, s. 13-151).

${ }^{23}$ P. Raina, Kościół w PRL. Kościól katolicki a państwo w świetle dokumentów 1945-1989, t. 1: Lata 1945-1959, Poznań 1994; t. 2: Lata 1960-1974, Poznań 1995.

${ }^{24}$ B. Fijałkowska, Partia wobec religii i Kościoła w PRL, t. 1: 1944-1955, Olsztyn 1999.

${ }^{25}$ J. Piasecka, Stosunki między Kościotem rzymskokatolickim i państwem w Polsce $w$ latach 1944-1953. W: Stosunki między państwem a Kościołem rzymskokatolickim w czasach PRL, pod red. A. Chojnowskiego i M. Kuli, Warszawa 1998, s. 9-68.

${ }^{26}$ A. Micewski, Kardynat Wyszyński, prymas i maż stanu, Paryż 1982; E.K. Czaczkowska, Kardynał Wyszyński, Warszawa 2009; W.J. Wysocki, Osaczanie prymasa. Kardynat Stefan Wyszyński jako „podopieczny” aparatu bezpieczeństwa w latach 1953-1956, Warszawa 2002; Kościót i Prymas Stefan Wyszyński 1956-1966, pod red. A. Dziuroka i W.J. Wysockiego, Katowice, Kraków 2008.

27 J. Zabłocki, Prymas Stefan Wyszyński. Opór i zwycięstwo 1948-1956, Warszawa 2002.

${ }^{28}$ S. Wyszyński, Pro memoria. Zapiski z lat 1948-1949 i 1952-1953, Warszawa 2007; tenże, Zapiski więzienne, Warszawa 2006.

${ }^{29}$ C. Strzeszewski, Kardynała S. Wyszyńskiego wizja Kościoła, Wrocław 1990; A.F. Dziuba, Przesłanie społeczne kardynała Stefana Wyszyńskiego Prymasa Polski, Warszawa 2004. 
o archiwalia Halina Konopka, natomiast kwestie organizacji młodzieży katolickiej - Tomasz Biedroń ${ }^{30}$.

Wydano również sporo prac zbiorowych i materiałów pokonferencyjnych poświęconych różnym aspektom historii powojennej ${ }^{31}$. Dorobek okresu PRL-u w kwestii stosunków Kościół - państwo świadczy w pełni o komunistycznej propagandzie i przez swoją jednostronną interpretację roli i sytuacji Kościoła nie posiada większej wartości naukowej. Wielu autorów podjęło analizę kwestii prawnego położenia Kościoła w państwie programowo wrogim religii ${ }^{32}$. Andrzej Friszke tłumaczył: „Nie było możliwe opisywanie dziejów najnowszych $\mathrm{w}$ sposób zgodny z prawdą [...] zmierzano raczej do przeobrażenia pamięci zgodnie z potrzebami nowej ideologii" ${ }^{33}$. Dzieje pierwszych lat powojennych (1945-1948) były w PRL przedmiotem szczególnie drastycznych manipulacji propagandy i cenzury ${ }^{34}$. Istniała też literatura nienacechowana ideologicznie oraz publikacje wydane $\mathrm{w}$ kręgach kościelnych ${ }^{35}$. W pracy nie

${ }^{30}$ H. Konopka, Religia w szkołach Polski Ludowej. Sprawa nauczania religii w polityce państwa 1944-1961, Białystok 1997; T. Biedroń, Organizacje młodzieży katolickiej w Polsce w latach 1945-1953, Kraków 1991.

${ }^{31}$ Polacy wobec przemocy, pod red. B. Otwinowskiej i J. Żaryna, Warszawa 1996; Skryte oblicze systemu komunistycznego. U źródet zła..., Warszawa 1997; Społeczeństwo - Państwo - Kościót (1945-2000). Materialy z ogólnopolskiej konferencji naukowej Szczecin, 15-16 VI 2000 r., pod red. A. Kaweckiego, K. Kowalczyka i A. Kubaja, Szczecin 2000; Pamiętny rok 1947, Rzeszów 2001; Rok 1948. Nadzieje i złudzenia polskich socjalistów, pod red. M.E. Ożóga, Rzeszów 2000 oraz Komunizm. Ideologia, system, ludzie, Warszawa 2001; Polacy wobec PRL. Strategie przystosowawcze, pod red. G. Miernika, Kielce 2003. W pracy uwzględniono również niektóre drobniejsze pozycje, niemalże broszurowe; np. ukazujące Kościół jedynie pod kątem „imperialistycznego wroga” Wiesława Mysłka Kierownictwo Kościoła rzymsko-katolickiego wobec Polski Ludowej 1944-1969 (Warszawa 1970) czy opracowanie napisane w odmiennym zupełnie spojrzeniu Wincentego Chrypińskiego Kościół a rząd i społeczeństwo w powojennej Polsce (Londyn 1989).

${ }^{32}$ M.in. J.F. Godlewski, Katolicka myśl kościelna o prawie i państwie, Warszawa 1985; A. Hanowski [A. Piekarski], Stowarzyszenia katolików i chrześcijan świeckich w Polsce Ludowej, Warszawa 1986; J. Majchrowski, S. Nawrot, Niektóre elementy stosunków państwowo-kościelnych w Polsce lat 1945-1950, Kraków 1984; S. Markiewicz, Stosunki między państwem a Kościołem rzymskokatolickim w Polsce Ludowej (1944-1981), cz. 1 i 2 (dokumenty), Warszawa 1982; tenże, Państwo i Kościól w Polsce, Warszawa 1984; A. Micewski, Kościót-państwo 1945-1989, Warszawa 1994; J. Siemaszkiewicz, Hierarchia Kościoła rzymskokatolickiego w Polsce wobec Ziem Zachodnich i Pólnocnych w świetle uroczystości kościelnych w latach 1945-1970, Warszawa 1970; A. Żełobowski, Episkopat Kościoła rzymskokatolickiego w Polsce wobec przemian społeczno-politycznych w kraju w latach 1944-1974, Warszawa 1989.

${ }^{33}$ A. Friszke, Polska. Losy państwa i narodu 1939-1989, Warszawa 2003, s. 7.

${ }^{34}$ Tamże, s. 488.

${ }^{35}$ Historia Kościoła, cz. V: 1848 do czasów wspótczesnych, pod red. L.J. Rogiera, R. Auberta, M.D. Knowlesa, Warszawa 1985; J. Kłoczowski, L. Müllerowa, J. Skarbek, Zarys dziejów Kościoła katolickiego w Polsce, Kraków 1986; Księga Sapieżyńska, t. 2: Działalność kościelna i narodowa Adama Stefana Sapiehy, pod red. J. Wolnego, Kraków 1986. 
pominięto opublikowanych pamiętników i wspomnień, choć nie posiadają one charakteru oficjalnego ${ }^{36}$.

Z sytuacją wydawniczą pierwszych lat po wojnie można zapoznać się dzięki opracowaniom Stanisława Kondka ${ }^{37}$. Pomocna w tym zakresie, choć nacechowana propagandowo, była również pozycja Adama Bromberga ${ }^{38}$. Ogólną politykę prasową tego okresu przedstawił Mieczysław Ciećwierz, natomiast kierunki działania władz wobec prasy katolickiej ukazał Janusz Stefaniak ${ }^{39}$. O znaczącej roli czasopism społeczno-kulturalnych i literackich w kształtowaniu autonomii życia literackiego powstałych po 1945 r. (z uwzględnieniem katolickich), pisał Leszek Szaruga ${ }^{40}$. Mniej przydatne w kontekście niniejszych rozważań są opracowania Tomasza Mielczarka ze względu na brak zainteresowania autora periodykami o profilu katolickim ${ }^{41}$. Ogólne wiadomości o czasopismach katolickich znaleziono w Dziejach prasy polskiej, niezwykle cenne informacje o tej grupie periodyków dostępne były również w drobnych artykułach ${ }^{42}$. Pomocne w weryfikacji danych o poszczególnych tytułach prasowych okazały się także bibliografie i katalogi ${ }^{43}$. W celu odnalezienia artykułów dotyczących prasy katolickiej w latach 1945-1953 przejrzano wszystkie dostępne w wersji drukowanej i elektronicznej

${ }^{36}$ J. Łopuski, Pozostać soba $w$ Polsce Ludowej: życie $w$ cieniu podejrzeń, Rzeszów 2007; J. Kuczyński, Między parafia a łagrem, Paryż 1982; T. Rostworowski, Zaraz po wojnie. Wspomnienia duszpasterza (1945-1956), Paryż 1986; tenże, Szerzyć królestwo. Wspomnienia i dzienniki 1939-1972, Warszawa 2004; S. Świeżawski, W nowej rzeczywistości: 1945-1965, Lublin 1991.

${ }^{37}$ S.A. Kondek, Papierowa rewolucja: oficjalny obieg ksiażek w Polsce w latach 1948-1955, Warszawa 1999; tenże, Władza i wydawcy. Polityczne uwarunkowania produkcji ksiażek w Polsce w latach 1944-1949, Warszawa 1993.

${ }^{38}$ A. Bromberg, Książki i wydawcy: ruch wydawniczy w Polsce Ludowej w latach 1944-1964, Warszawa 1966.

${ }^{39}$ M. Ciećwierz, Polityka prasowa 1944-1948, Warszawa 1989; J. Stefaniak, Polityka władz państwowych PRL...

${ }^{40}$ L. Szaruga, Czasopisma literackie. W: Literatura polska 1918-1975, t. 3: 1945-1975, pod red. A. Brodzkiej, Warszawa 1996, s. 207-230; tenże, Co czytamy? Prasa kulturalna 1945-1995, Lublin 1999.

${ }^{41}$ T. Mielczarek, Od Nowej Kultury do Polityki. Tygodniki społeczno-kulturalne i społecznopolityczne PRL, Kielce 2003; tenże, Problematyka literatury na tamach czasopism PRL. W: Ksiązka, biblioteka, informacja-między podziałami a wspólnota, Kielce 2007, s. 271-288; tenże, Czasopisma społeczno-kulturalne i społeczno-polityczne w okresie Polski Ludowej (1945-1989), „Rocznik Historii Prasy Polskiej” 2002 z. 1 s. 149-181.

${ }^{42}$ M. Ciećwierz, Z problematyki czasopiśmiennictwa katolickiego $w$ latach 1945-1948, „Zeszyty Naukowe Filii UW w Białymstoku”, Prace Historyczne, Humanistyka, t. 9 z. 50 s. 187-202; C. Lechicki, Polska prasa katolicka 1945-1948, „Kwartalnik Historii Prasy Polskiej” 1983 nr 2 s. 65-87; D. Wielgat, Prasa katolicka i religijna w Polsce w latach 1945-1989, „Archiwa, Biblioteki i Muzea Kościelne" 1996 nr 66 s. 54-444.

${ }^{43}$ D. Wielgat, Bibliografia katolickich czasopism religijnych $w$ Polsce 1945-1989, Lublin 1996; Bibliografia prasy polskiej 1944-1948. Prasa krajowa, Warszawa 1966; Katalog prasy polskiej, Warszawa 1957. 
edycje „Bibliografii Zawartości Czasopism” (lata 1947-2011) oraz bazy Biblioteki Narodowej dotyczące prasy dostępne online ${ }^{44}$.

Dolną granicę chronologiczną pracy wyznacza rok zakończenia II wojny światowej. W odradzającym się życiu społecznym i kulturalnym jedną z istotnych kwestii stało się powołanie oraz reaktywowanie prasy katolickiej, która stała się ważną trybuną dla wierzącej części społeczeństwa. W roku 1945 zaczęły ukazywać się najbardziej znaczące periodyki katolickie - „Tygodnik Powszechny” i „Tygodnik Warszawski”45. Górną granicę stanowi natomiast cezura istotna dla życia katolików w Polsce i prasy katolickiej. W roku 1953 bowiem walka z Kościołem osiągnęła w Polsce apogeum i jego autonomia znacznie została ograniczona. Liczne powojenne procesy pokazowe duchownych osiągnęly szczyt okrucieństwa w przeprowadzonym w tymże roku procesie biskupa kieleckiego Czesława Kaczmarka i księży kurii krakowskiej. Dekret o obsadzaniu i znoszeniu stanowisk kościelnych wydany 9 lutego miał zezwolić władzy na ingerencję w wewnętrzną strukturę Kościoła hierarchicznego. Dnia 5 III 1953 r. zmarł Józef Stalin i za odmowę wydrukowania jego nekrologu zamknięto „Tygodnik Powszechny”, a wraz z nim prawie wszystkie periodyki o profilu katolickim. Likwidacja pisma i przekazanie tytułu Stowarzyszeniu PAX otworzyło nowy etap w historii dziejów prasy katolickiej. Na przyjęcie „nowego kursu” i „odwilży” w krajach pod panowaniem ideologii komunistycznej trzeba było jeszcze poczekać. Wraz z wydaniem 8 V 1953 r. słynnego memoriału Non possumus Episkopatu Polski na czele z prymasem Stefanem Wyszyńskim skończył się czas dialogu w stosunkach Kościoła z państwem. Władze odpowiedziały na niego uwięzieniem prymasa 25 września, co z kolei przyczyniło się do nałożenia przez papieża Piusa XII ekskomuniki na sprawców.

Lata 1945-1953 to pierwszy i niewątpliwie najtrudniejszy okres w powojennych relacjach Kościoła z państwem w Polsce. Czas ten charakteryzowała niezamierzona przez duchownych próba sił. Upozorowaną swobodę pierwszych lat we wzajemnych relacjach zakończył terror i otwarte dążenie władz do zapanowania nad Kościołem. W świecie natomiast równolegle ukształtował się powojenny układ sił „od systemu wielobiegunowego do dwubiegunowego"46, co było wynikiem tzw. zimnej wojny pomiędzy mocarstwami zachodnimi a ZSRR.

Dążąc do szerokiego i gruntownego przedstawienia spraw książki na łamach katolickich czasopism społeczno-kulturalnych, zgromadzony i opracowany materiał ujęto w pięciu częściach. Rozdział pierwszy, o charakterze wprowadzającym

${ }^{44}$ Artykuły z czasopism polskich, Artykuły z gazet i tygodników, Wspólna baza artykułów z gazet i tygodników oraz Multiwyszukiwarka bazy BZCz i prasy w systemie FIDKAR. Dostępny w World Wide Web http://www.bn.org.pl/katalogi-i-bibliografie/bibliografia-narodowa/bibliografiazawartosci-czasopism [dostęp 20.06.2012].

${ }^{45}$ Pierwszym chronologicznie periodykiem o charakterze ogólnopolskim był „Gość Niedzielny" ukazujący się od 11 II 1945 r.

${ }^{46}$ W. Roszkowski, Pótwiecze: historia polityczna świata po 1945 roku, Warszawa 2002, s. 8-9. 
w problematykę pracy zatytułowany Stosunki Kościól - państwo w latach 1945-1953 w Polsce stanowi tło do dalszych rozważań bibliologicznych. Ma na celu ukazanie ogólnej atmosfery w relacjach instytucji od wieków wrośniętej w kulturę i życie narodu polskiego, którą był Kościół katolicki, z narzuconą i obcą ideologicznie władzą samozwańczą komunistów w pierwszych latach powojennych. Wiadomości te pomocne są w zrozumieniu niełatwej też sytuacji prasy i książki katolickiej w tym okresie. Rozdział ten przygotowany został głównie na podstawie analizy dostępnej i bogatej literatury naukowej dotyczącej historii Polski i stosunków Kościoła z państwem.

W pierwszej części rozdziału drugiego Polska prasa i książka katolicka w latach 1945-1953 omówiono ogólną sytuację wydawniczą wraz z ilościową prezentacją oraz typologią wybranych periodyków, następnie na podstawie analizy zawartości z autopsji przedstawiono dość szczegółową charakterystykę sześciu czasopism społeczno-kulturalnych. Informacje o niektórych materiałach promujących książkę pojawiły się dwukrotnie, w ogólnej charakterystyce czasopism (gdzie zostały jedynie zasygnalizowane) i w dalszych partiach książki w sposób bardziej wyczerpujący. Te powtórzenia były konieczne ze względu na konstrukcję pracy. Tygodnik „Dziś i Jutro” omawiany często w literaturze przedmiotu jako trzecie obok ,Tygodnika Powszechnego” i ,Tygodnika Warszawskiego” czołowe katolickie czasopismo społeczno-kulturalne, choć uwzględniony w podrozdziale, nie został potraktowany w opracowaniu równolegle do pozostałych. Powodem było stanowisko ideowe przyjęte przez redakcję (łączenia katolicyzmu z ideologią komunistyczną), które nie pozwoliło władzom Kościoła i części opinii publicznej uznać je za pismo katolickie.

Z pewnością nowum w niniejszej publikacji, szczególnie na tle innych opracowań, stanowi analiza statystyczna i opisowa zebranego materiału; jest ona ważną częścią kolejnego rozdziału pt. Recenzje książek na łamach wybranych periodyków. Oceny książek stanowiły najciekawszą część publicystyki. Zgromadzony i uporządkowany materiał stał się podstawą do sporządzenia spisu zrecenzowanych książek (łącznie 1375 omówień) w układzie alfabetycznym nazwisk autorów, z podziałem na polskich i obcych w formie tabelarycznej (umieszczony na płycie CD-ROM). Wykaz w wersji elektronicznej był niezwykle pomocny w tworzeniu wszelkich ujęć statystycznych dotyczących liczby omówionych książek, ich wydawców, autorów, recenzentów, rodzajów literackich, poruszanej problematyki itp. Uwzględniono w nim wszystkie recenzje książek, jakie ukazały się na łamach sześciu wybranych tytułów w latach 1945-1953, a więc zarówno obszerniejsze, jak i te krótsze, oraz zdawkowe ${ }^{47}$. Należy zaznaczyć, że nie ma zgodności co do wymienionych recenzji i tytułów książek w zestawieniu, które powstało na podstawie przeglądu z autopsji ,Tygodnika Powszechnego” a Spisem rzeczy rocznika

${ }^{47}$ Przykładem mogą być bardzo krótkie recenzje: P., Prawo o rehabilitacji, „Tygodnik Powszechny” [dalej „TP”] 1946 nr 27 s. 9; zsm. [Z. Starowieyska-Morstinowa], Franek, tamże. 
pierwszego i drugiego (za okres 24 III 1945 - 22 XII 1946) oraz wykazem pt. Recenzje. Ksiażkit8 (za 1951 r. R. 7 Recenzje. Recenzje z książek) opublikowanych w piśmie. Powodem są odmienne kryteria przyjęte przy opracowywaniu obu zestawien. $\mathrm{W}$ pracy wzięto bowiem pod uwagę omówienia, które sensu stricto były recenzjami. Zasadnicza różnica polega na tym, że w tabeli nie znalazły się niewielkie recenzje zamieszczane w stałych rubrykach Nowe książki i Wśród książek, które odnotowano w spisie treści „Tygodnika Powszechnego”. Rubryki te, ze względu na zawarte w nich bieżące informacje o nowościach oraz na ogólnie ogromną liczbę omówień książkowych w krakowskim periodyku, uwzględniono w kolejnym rozdziale zatytułowanym Promocja książki (podrozdział: Informacje o nowościach wydawniczych) ${ }^{49}$. Tych tytułów zatem z założenia nie wprowadzono do tabeli ${ }^{50}$. W zestawieniach tabelarycznych i w części czwartej pracy brak również opisów, które na podstawie wzmiankowanego jedynie tytułu książki stały się inspiracją do podjęcia szerszych zagadnień, gdyż te znalazły swoje miejsce w ostatnim piątym rozdziale ${ }^{51}$.

${ }^{48}$ Zob. Recenzje. Książki. W: Spis rzeczy. Rocznik pierwszy i drugi, oprac. A. Reiterowa, „TP” 1946, s. I-VI.

${ }^{49}$ Dokładne prześledzenie tytułów książkowych widniejących w Spisie rzeczy (za okres 24 III 1945-22 XII 1946) z zawartością periodyku potwierdziło fakt, że większość pozycji zestawienia to recenzje z rubryki Nowe książki. Np. J.S. Bandtkie, Wiadomości o języku polskim w Ślasku i o polskich Ślązakach (Wrocław 1945), Z. Baranowski, Matżeństwo w nowej Polsce, A. Borowski, Teologia moralna (Włocławek 1945), F. Barciński, Podstawowe zasady ekonomiki (Poznań 1946), R. Bauminger, Przy pikrynie i trotylu (Kraków 1946), F.W. Gruszczyński, Kościót i klasztor O.O. Reformatorów w Pilicy (Pilica 1946), J. Grycz, Bibliotekarstwo praktyczne w zarysie (Warszawa 1945), E. Garbacik, Wieś duńska dawniej i dziś (Kraków 1946), S. Knauff, Wojna zaczęła się w Gdańsku (Warszawa 1946), A. Bigay-Mianowska, Robinson Kruzoe (Kraków 1946) i in. Po dokładnym skonfrontowaniu wszystkich pozycji widniejących w spisie zawartości R. 1-2 za lata 1945-1946 „TP” zauważono błędy, np. wzmianka eg., Nowy taciński przekład Psalmów, „TP” $1946 \mathrm{nr} 30 \mathrm{~s} .2$ podana jako recenzja stanowi jedynie zapowiedź ukazania się nowości, pominięto natomiast w wykazie pozycję z rubryki Nowe książki J. Bochenka, W naszym domu (Tarnów 1946), tamże, nr 45 s. 9.

${ }^{50}$ Po porównaniu pozycji z części Recenzje z książek ze Spisu rzeczy rocznika siódmego tygodnika (za 1951 rok) z zestawieniem tabelarycznym stwierdzono różnice w recenzjach, które wydrukowano w rubryce Wśród książek. Np. A. Bukowski, Regionalizm kaszubski (Poznań 1950), J. Domaniewski, Najhrubszy gazda (Warszawa 1950), M. Jastrun, Rok urodzaju (Warszawa 1950), Nowele litewskie (Warszawa 1950), J. Podoski, Sewer szuka skarbu (Warszawa 1950), B. Uhse, Lustro i inne opowiadania (Warszawa 1950).

${ }^{51} \mathrm{~Np}$. nie uwzględniono jako recenzji artykułów: J.M. Święcickiego, Z mieszczańskich perspektyw oświecenia, „TP” $1951 \mathrm{nr} 19$ s. 9-10 będący przy okazji książki J. Kotta, Szkoła klasyków (Warszawa 1949) głębszym rozważaniem na temat całej epoki oświecenia i literatury; tegoż autora, Z pedagogiki radzieckiej, tamże, nr 42 s. 3-4 (szersze rozważania na temat światopoglądu marksistowskiego i chrześcijańskiego, pedagogiki oraz wychowania dzieci i młodzieży). Za takie uznano również następujące artykuły: B. Grodzicki, Arkusze poetyckie PAX-u, „TP” $1951 \mathrm{nr} 34$ s. 4-5 (autor omawia 10 tomików poezji pod kątem literackim) oraz M. Plezia, Dyplomata, biskup i poeta, tamże, nr 32 s. 4-5 (ocena twórczości poety Jana Dantyszka). 
W spisach książek zrecenzowanych (płyta CD-ROM) nazwiska autorów pochodzenia polskiego tworzących za granicą $\mathrm{w}$ języku obcym zaliczono do pisarzy zagranicznych, np. Josepha Conrada czy Bronisława Malinowskiego. W przypadku twórców beatyfikowanych i kanonizowanych zastosowano przepisy obowiązujące w katalogach bibliotecznych według obowiązującej obecnie normy na hasło autorskie. Zapisano je w naturalnej kolejności części nazwy, czyli zaczynając od imienia. Ujednolicono również różnie pisane przez recenzentów obce nazwiska autorów, unikając spolszczonych imion. Jeżeli książka była autorstwa dwóch lub trzech osób, zamieszczono jedynie nazwisko pierwszego autora w szeregu tabelarycznym. Brakujące dane bibliograficzne omówionych książek uzupełniono informacjami z elektronicznych katalogów Biblioteki Narodowej i NUKAT. Informacje te dla odróżnienia podano w nawiasach kwadratowych. Nie we wszystkich przypadkach udało się odnaleźć niezbędne elementy opisu.

W przedostatnim, czwartym rozdziale pt. Promocja ksiązki wzięto pod uwagę preferowane przez redakcje periodyków sposoby upowszechniania nowości wydawniczych. Były to głównie reklamy, informacje o świeżo wydanych książkach, przeglądy piśmiennictwa, spisy widniejące pod nagłówkami Ksiązki nadesłane do redakcji. Jako ostatnie ujęto tytuły książkowe występujące przy okazji omówień różnych zagadnień. $Z$ badań wynika, że najbardziej popularnym sposobem upowszechniania książek były, po recenzjach, ogłoszenia reklamowe.

Pracę zamyka rozdział figurujący w spisie treści pod nagłówkiem Inne formy upowszechniania ksiązki. Zawarto w nim, oprócz zaprezentowanych fragmentów książek i powieści w odcinkach, pozostałe wypowiedzi o książce. Pomimo że bibliologiczne rozważania nie były wpisane w założenia programowe katolickich czasopism społeczno-kulturalnych, to jednak pojawiały się w nich co pewien czas. Znalazły się tu nieliczne ogólne wypowiedzi z „życia książki”, a odnoszące się do instytucji związanych z jej obiegiem: drukarni, wydawnictw, księgarni i bibliotek, jak też artykuły dotyczące bibliofilstwa i osób związanych z książką. Rozważania wokół zagadnień czytelnictwa najczęściej dotyczyły wyboru dobrej lektury.

Rozprawę uzupełnia bibliografia oraz załączniki: Biogramy wybranych redaktorów i publicystów (spis utworzony według uznania autorki), wspomniane już spisy książek zrecenzowanych w omawianych czasopismach oraz Wykaz powieści drukowanych w odcinkach. Pracę dopełniają ponadto dwa rodzaje indeksów: osobowy oraz księgarni, wydawnictw i wydawców, jak też spis ilustracji.

$* * *$

Słowa wdzięczności za cenne uwagi i sprostowania pragnę przekazać Panu Profesorowi Oskarowi S. Czarnikowi. Najbliższym zaś dziękuję za słowa aprobaty, pomoc i życzliwość podczas pisania tej książki. 



\section{ROZDZIAŁ I}

\section{Stosunki Kościół - państwo w latach 1945-1953 w Polsce}

\subsection{Ogólna sytuacja polityczna Polski po zakończeniu II wojny światowej}

\subsubsection{Polska na tle wydarzeń międzynarodowych}

Okres II wojny światowej przyniósł Polsce poważne straty osobowe, materialne, gospodarcze, terytorialne i intelektualne ${ }^{1}$. Sytuacja, w jakiej znalazł się kraj, była szczególnie trudna. Warunki polityczne zdawały się być równie niesprzyjające. Jeszcze przed zakończeniem działań wojennych istniały bowiem „dwa rządy, dwie rady zastępujące parlament, [...] dwie armie, [...] dwa stronnictwa ludowe i dwie partie socjalistyczne..." ${ }^{2}$. Polski rząd emigracyjny w Londynie

${ }^{1} \mathrm{~W}$ czasie wojny zginęło ponad $6 \mathrm{mln}$ obywateli polskich (połowa z nich to Polacy pochodzenia żydowskiego). Najwięcej z rąk niemieckiego okupanta, następnie w wyniku okupacji radzieckiej oraz z rąk ukraińskich i litewskich. Straty w ludności spowodowały również masowe deportacje okupanta hitlerowskiego (1200 tys.) i radzieckiego (500 tys.). Wskutek strat biologicznych, terytorialnych i emigracji ludność Polski zmniejszyła się z 35,1 mln osób w 1939 r. do 23,7 mln w 1946 r. Po zakończeniu wojny liczba osób z wyższym wykształceniem wynosiła zaledwie 40 tys. Zniszczeniu uległo 65\% zakładów przemysłowych, sieć dróg, kolei, środków transportu. Wiele miast legło w gruzach (Warszawa, Wrocław, Białystok, Poznań), zubożała także wieś. Wszystkie straty materialne wyniosły $30 \%$ majątku narodowego, oceniono je na około 30,9 mld \$. Źródło: Wielka historia Polski 1945-1956, Kraków 2001, s. 6-8; W. Roszkowski, Pótwiecze: historia polityczna świata po 1945 roku, Warszawa 2002, s. 19-20.

${ }^{2}$ K. Kersten, Narodziny systemu władzy. Polska 1943-1948, Poznań 1990, s. 109. W okresie od stycznia do czerwca 1945 r. społeczeństwo polskie miało dwa zwalczające się wzajemnie rządy. Rezydujący na emigracji w Londynie, kontynuujący politykę Drugiej Rzeczypospolitej na czele z socjalistą Tomaszem Arciszewskim oraz drugi (działający od 1944 r. nazwany Polskim Komitetem Wyzwolenia Narodowego) przekształcony z nadania Związku Radzieckiego od 1 I 1945 r. w Rząd Tymczasowy również z socjalistą na czele Edwardem Osóbką-Morawskim w Warszawie. Ten drugi 21 IV 1945 r. zawarł ze Związkiem Radzieckim układ o przyjaźni, sojuszu i powojennej współpracy na 20 lat. Samemu Józefowi Stalinowi zależało na powstaniu drugiego ośrodka władzy państwowej w celu 
był aprobowany przez większość społeczeństwa, czego nie można było powiedzieć o Rządzie Tymczasowym Rzeczypospolitej Polskiej, jednak istotna różnica polegała na tym, że ,poparcie Zachodu [dla rządu londyńskiego - E.K.] było iluzoryczne, natomiast pomoc udzielana przez Stalina polskim komunistom najzupełniej realna"s.

W tworzeniu politycznego kształtu Europy po wojnie decydujące znaczenie miały trzy konferencje tzw. Wielkiej Trójki, którą reprezentowali: prezydent Stanów Zjednoczonych Franklin Roosevelt, premier Wielkiej Brytanii Winston Churchill i przewodniczący Rady Komisarzy Ludowych Związku Sowieckiego Józef Stalin ${ }^{4}$. Ostatni z przedstawicieli, jak się okazało, cieszył się dużym autorytetem i miał decydujący głos w sprawie Europy Środkowo-Wschodniej, a w tym Polski. Przywódcy USA, ZSRR i Wielkiej Brytanii stworzyli „sojusz osobliwy”. Józef Stalin kierujący państwem o ustroju totalitarnym, odmiennym od demokracji zachodnich, widział możliwość rozszerzenia swoich wpływów, stając się ,jedynowładcą - w niejednym rejonie wykraczającym poza granice zdobyte przez jego poprzedników - carów". Winston Churchill z kolei był gotów zapłacić każdą cenę za pomoc w pokonaniu hitlerowskich Niemiec (liczono na udział ZSRR w działaniach zbrojnych z Japonią), natomiast Franklin Roosevelt realizował koncepcję polityki wielkich mocarstw, godząc się na dwubiegunowy układ sił7.

Wpływy radzieckie w Europie Wschodniej określone zostały już na pierwszej konferencji w Teheranie w dniach 28 XI - 1 XII 1943 r., na której wstępnie wytyczono wschodnią granicę Polski ${ }^{8}$. Drugie, najbardziej znaczące spotkanie dla politycznej mapy Europy i Polski, nazywane też konferencją krymską, odbyło się od 4 do 11 II 1945 r. w Jałcie. Stało się symbolem nowego układu sił w świecie, tworzącego później system jałtański ${ }^{9}$. Na obradach rozstrzygnięto

osłabienia pozycji Polski na arenie międzynarodowej i zwycięstwa jego koncepcji politycznej. Źródło: Wielka historia Polski..., s. 14; A. Czubiński, Historia Polski XX wieku, Poznań 2005, s. 253, 257.

${ }^{3}$ W. Lizak, Historia Polski: od maja 1945 do marca 1956, Poznań 1998, s. 61.

${ }^{4}$ W czasie trwania konferencji w Jałcie prezydent Roosevelt był „chory i prawie umierający”. Pomimo tego, że „zdawał sobie sprawę z połowy tego, co mówiono przy stole” zależało mu na uzyskaniu poparcia ZSRR (osobiście darzył zaufaniem J. Stalina nazywając go „wujaszkiem Józiem”) dla amerykańskich koncepcji stworzenia nowej organizacji światowej pod nazwą Organizacji Narodów Zjednoczonych i uzyskaniu pomocy w ostatnich fazach wojny w Azji. „O Rosji miał nie wiedzieć nic, a o Europie bardzo niewiele...”, polski rząd na emigracji traktował jako przypadkowe zgromadzenie polityczne emigrantów, którego „reprezentatywny charakter był wątpliwy”. Unikał zatem sporów ze Stalinem o sprawy polskie, zostawiając to W. Churchillowi. Źródło: M. Łatyński, Nie paść na kolana: Szkice o polskiej polityce lat powojennych, Wrocław 2002, s. 27-29, 35-36.

${ }^{5}$ W. Roszkowski, Pótwiecze..., s. 20.

${ }^{6}$ M. Łatyński, Nie paść na kolana..., s. 39.

${ }^{7}$ W. Roszkowski, Pótwiecze..., s. 25.

${ }^{8}$ Tamże, s. 11-12. Wiele szczegółów z okoliczności konferencji i ich przebiegu podał M. Łatyński, Nie paść na kolana..., s. 25-62 (rozdział 2: W Jałcie, w Teheranie i przedtem).

${ }^{9}$ W. Roszkowski, Pótwiecze..., s. 15. 
główne kwestie międzynarodowe, m.in. sprawę okupacji Niemiec, powstanie Organizacji Narodów Zjednoczonych, zagadnienia dotyczące Dalekiego Wschodu, rozpatrzono udział ZSRR w wojnie z Japonią, temat Iranu oraz Europy Wschodniej. Ustalono także, bez udziału rządu polskiego, nowe granice Polski ${ }^{10}$. Wielka Trójka zgodziła się na wschodnią granicę wzdłuż linii Curzona ${ }^{11}$ i „znaczny przyrost terytorialny na północy i zachodzie”. Z formalnym ustaleniem jednak linii zachodniej należało jeszcze zaczekać12. Józef Stalin licząc na swoje wpływy, a niepewny dalszego przebiegu wypadków w powojennych Niemczech, chciał maksymalnego przesunięcia granicy polskiej na zachód ${ }^{13}$. W wyniku postanowień jałtańskich Polska utraciła prawie połowę przedwojennego terytorium. Od Polski odłączono ośrodki mocno wrośnięte w narodową historię i kulturę: Wilno, Nowogródek, Grodno i Lwów. Stratę miały zrekompensować ziemie na zachodzie, nie zagwarantowane od początku przez Stany Zjednoczone i Wielką Brytanię, mogące stać się powodem wielu konfliktów z Niemcami. Ustalenia dotyczące linii granicznej na południu trwały najdłużej i o nich również zadecydowała Wielka Trójka. Rząd odbudowanej po wojnie Czechosłowacji nawiązał do granicy czechosłowacko-polskiej sprzed $1938 \mathrm{r}$. Inicjatywę poparło ZSRR i Polska musiała zrezygnować z zajętego w 1938 r. Śląska Zaolziańskiego. Przed wojną państwo polskie graniczyło z pięcioma państwami, po wojnie tylko z trzema ${ }^{14}$. Ostatecznie po wytyczeniu granic obszar był

${ }^{10}$ Przebieg granicy wschodniej przesądził J. Stalin już w grudniu 1941 r., stawiając za warunek konsolidowania koalicji antyhitlerowskiej uznanie nabytków terytorialnych ZSRS z lat 1939-1941. Szerzej o tym zob. K. Kersten, Jatta w polskiej perspektywie, Warszawa 1989; Jatta. Szkice i polemiki. Zbiór studiów i materiałów, pod red. M.M. Drozdowskiego, Warszawa 1996; W.T. Kowalski, Wielka koalicja, t. 1-3 Warszawa 1973; L. Pastusiak, Roosevelt a sprawa polska, Warszawa 1981; L. Zyblikiewicz, Polityka Stanów Zjednoczonych i Wielkiej Brytanii wobec Polski 1944-1949, Warszawa 1984.

${ }^{11}$ Linia Curzona - potoczna nazwa linii demarkacyjnej pomiędzy wojskami polskimi i bolszewickimi, zaproponowana w lipcu 1920 r. bolszewikom przez brytyjskiego ministra spraw zagranicznych lorda George’a Nathaniela Curzona. Miała rozpoczynać się na północy w okolicach Grodna i biec na południe, przez Brześć Litewski, okolice Hrubieszowa i Przemyśla, w kierunku Karpat. Szef brytyjskiej dyplomacji wystąpił z tą propozycją na prośbę władz polskich, zaniepokojonych sukcesami ofensywy Armii Czerwonej, zmierzającej w kierunku Warszawy. Linia ta miała być jedynie tymczasowo obowiązującą do konferencji pokojowej, na której ustalonoby jej ostateczny kształt. Licząc na zajęcie całej Polski, bolszewicy odrzucili wówczas propozycje brytyjskie. Dyplomacja sowiecka odwołała się do nich podczas II wojny światowej, jeszcze w 1943 r. nieoficjalną zgodę na nią Stany Zjednoczone i Wielka Brytania wyraziły podczas konferencji w Teheranie. Źródło: A. Dudek, Z. Zblewski, Utopia nad Wisła..., s. 20.

${ }^{12}$ A. Friszke, Polska. Losy państwa i narodu 1939-1989, Warszawa 2003, s. 100-101; Ostatecznie postanowienia poczdamskie zatwierdzono na mocy układu w Zgorzelcu zawartego 6 VII 1950 r. z NRD (czyli po podziale Niemiec na RFN i NRD). Źródło: A. Czubiński, Polska i Polacy po II wojnie światowej (1945-1989), Poznań 1998, s. 322.

${ }^{13}$ W. Lizak, Historia Polski..., s. 83-84.

${ }^{14}$ A. Czubiński, Historia Polski XX wieku..., s. 259-260. 
mniejszy o 77,7 tys. km² od terytorium Drugiej Rzeczypospolitej ${ }^{15}$, co zubożyło powierzchnię państwa o $20 \%$. Po zakończeniu powojennych przemieszczeń, ludności było mniej o około $30 \%$ w stosunku do 1939 r. ${ }^{16}$

Nowe granice Polski objęły tereny zróżnicowane nie tylko geograficznie i pokoleniowo, ale też społecznie i mentalnie. Na konferencji w Jałcie za sugestią radziecką powołano Tymczasowy Rząd Jedności Narodowej (TRJN) przez zreorganizowanie popieranego przez J. Stalina Rządu Tymczasowego, do którego dopuszczono jedynie kilku przedstawicieli demokratycznych obozu londyńskiego. Nie liczono się tym samym z nowym rządem reprezentowanym przez premiera Tomasza Arciszewskiego na emigracji. Po zalegalizowaniu przez Wielką Trójkę TRJN został on zobowiązany do ,przeprowadzenia możliwie najprędzej wolnych wyborów, opartych na głosowaniu powszechnym i tajnym”. W wyborach mieli wziąć udział kandydaci wszystkich partii „,demokratycznych i antynazistowskich". Nie przewidziano jednak kontroli międzynarodowej nad głosowaniem ${ }^{17}$.

Rząd emigracyjny odmówił uznania decyzji jałtańskich, nazywając je „nowym rozbiorem Polski", tym razem dokonanym przez sojuszników ${ }^{18}$. Stolica Apostolska podtrzymała stosunki dyplomatyczne z rządem RP na uchodźstwie i choć była gotowa negocjować, to przedstawiciele TRJN 12 IX 1945 r. znieśli konkordat ${ }^{19}$. Papież Pius XII wyraził wątpliwości również co do zatwierdzenia zarówno granicy wschodniej, jak i zachodniej Polski. Największe kontrowersje budziła sprawa granicy polsko-niemieckiej. Stolica Apostolska opowiedziała się zatem za stanowiskiem rozstrzygnięcia przynależności Ziem Zachodnich na konferencji pokojowej z Niemcami. W związku z tym papież nie zmienił dotychczasowej niemieckiej administracji kościelnej na terenach przyłączonych przez aliantów do Polski, co spotkało się z ostrą krytyką komunistycznego rządu i stanowiło użyteczny argument w propagandzie antywatykańskiej, ale jednocześnie nadał pełnomocnictwo prymasowi ${ }^{20}$.

Pozycję komunistów w Polsce utwierdziły również postanowienia konferencji w Poczdamie, która odbyła się w dniach od 17 VII do 2 VIII 1945 r. ${ }^{21}$ Stany

${ }^{15}$ Na temat trudności z ustaleniem granic Polski zob. więcej Wielka historia Polski 1945-1956, Kraków 2001, s. 48-52.

${ }^{16}$ A. Paczkowski, Pół wieku dziejów Polski 1939-1989, Warszawa 1995, s. 147.

${ }^{17}$ W. Roszkowski, Pótwiecze..., s. 14; A. Friszke, Opozycja polityczna w PRL 1945-1980, Londyn 1994, s. 19.

${ }^{18}$ K. Kersten, Narodziny systemu ..., s. 113; A. Friszke, Opozycja polityczna ..., s. 12; W. Lizak, Historia Polski..., s. 85.

${ }^{19}$ Szerzej zob.: J. Żaryn, Stolica Apostolska wobec Polski i Polaków w latach 1944-1958: w świetle materiałów ambasady RP przy Watykanie (Wybór dokumentów), Warszawa 1998.

${ }^{20}$ A. Czubiński, Polska i Polacy po II wojnie światowej (1945-1989), Poznań 1998, s. 138; L.B. Paszkiewicz, Sytuacja Kościoła katolickiego w Polsce w latach 1945-1948 w świetle londyńskiego „, Jutra Polski”, „Perspectiva. Legnickie Studia Teologiczno-Historyczne” 2003 nr 1 s. 97-98.

${ }^{21}$ Szerzej zob.: Teheran - Jalta - Poczdam. Dokumenty konferencji szefów rzadów trzech wielkich mocarstw, Warszawa 1970; M. Łatyński, Nie paść na kolana..., s. 371-381 (rozdział pt. Poczdam). 
Zjednoczone po śmierci F. Roosevelta reprezentował prezydent Harry Truman, a W. Churchilla w drugiej części obrad zastąpił po wyborach w Wielkiej Brytanii nowy premier Clement Attlee. W imieniu Polski wystąpili Bolesław Bierut i Stanisław Mikołajczyk. Na spotkaniu uchwalono całkowite rozbrojenie Niemiec, które zostały obarczone odpowiedzialnością za II wojnę światową. Dowodem na to miały być procesy niemieckich zbrodniarzy wojennych. W wyniku obrad zadecydowano o oddaniu Polsce dawnych terenów niemieckich po linię Nysy Łużyckiej i Odry wraz ze Świnoujściem, a także obszaru byłego Wolnego Miasta Gdańska z południową częścią niemieckich Prus Wschodnich. Wywołało to sprzeciw mocarstw anglosaskich, gdyż przyznany teren uważano za zbyt znaczny i tym samym postanowienie za krzywdzące dla ludności niemieckiej. Nie zatwierdzono więc nadal granicy, odkładając formalności do przyszłej konferencji pokojowej z Niemcami. Rozwiązania poczdamskie były korzystne dla aliantów, lecz z Polski uczyniły „zakładnika” i ,wasala” Związku Sowieckiego za ,żelazną kurtyną"22. Działanie Wielkiej Trójki naznaczone było brakiem zgodności deklaracji zawartych w Karcie Atlantyckiej a realizmem postanowień konferencyjnych ${ }^{23}$. Na konferencji poczdamskiej zapadła zarazem decyzja o wysiedleniu ludności niemieckiej z terytoriów przyznanych Polsce i skierowaniu jej do zachodnich stref okupacyjnych w Niemczech. Podobnie postanowiono o przesiedleniu Niemców zamieszkałych dotąd w Czechosłowacji i na Węgrzech.

Andrzej Paczkowski słusznie zauważył, że „ustalenia dotyczące Polski sformułowano pod dyktando radzieckie" i dla części polskiego społeczeństwa zarówno w kraju jak i na emigracji „były szokiem”24. Bolesław Cywiński pisał: „Społeczeństwo wyniszczone wojną i oszołomione jej zakończeniem, oddającym los Polski, zasłużonego i szanowanego do niedawna alianta, w ręce Sowietów, którzy na progu wojny wespół z Hitlerem napadli na jej ziemie [...] w ogromnej mierze czuło się zdradzone przez swych zachodnich sprzymierzeńców”25.

${ }^{22}$ A. Dudek, Z. Zblewski, Utopia nad Wista..., s. 19-20; W. Roszkowski, Pótwiecze..., s. 17-18; J. Łopuski, Pozostać soba..., s. 10.

${ }^{23}$ Karta Atlantycka podpisana 12 VIII 1941 r. stanowiła ideową podstawę działania Wielkiej Brytanii i USA. Zawarła osiem podstawowych punktów: 1) sygnatariusze nie kierują się chęcią ekspansji, 2) nie poprą zmian terytorialnych, które nie byłyby zgodne ze swobodnie wyrażoną wolą zainteresowanych narodów, 3) respektują prawo narodów do wyboru formy rządów, 4) będą dążyć do rozszerzenia wolności handlu, 5) zmierzać będą do rozszerzenia współpracy międzynarodowej w gospodarce, 6) pragną ustanowienia pokoju, 7) zmierzają do poszerzenia swobody podróżowania, 8) wierzą, że wszystkie narody wyrzekną się użycia siły we wzajemnych stosunkach przez rozbrojenie i stworzenie systemu międzynarodowego bezpieczeństwa. Źródło: W. Roszkowski, Pótwiecze..., s. 12.

${ }^{24}$ A. Paczkowski, Pół wieku..., s. 138-139; J. Łopuski w ciekawie napisanych wspomnieniach z tego okresu potwierdził te nastroje słowami: ,Zdrada interesów Polski przez naszych zachodnich aliantów ciągle nie docierała w pełni do świadomości polskiego społeczeństwa”. J. Łopuski, Pozostać soba..., s. 24.

${ }^{25}$ B. Cywiński, Ogniem próbowane..., s. 26. 
Wojciech Roszkowski skonstatował wprost: „Wbrew głoszonym hasłom Wielka Trójka okazała się zgodna w pogardzie dla interesów mniejszych państw"26. Polska zatem pomimo przynależności do zwycięskiej koalicji antyhitlerowskiej i udziału polskich żołnierzy na frontach Europy nie mogła stanowić sama o sobie i znalazła się w strefie wpływów obcych, a o jej losie zadecydowały wielkie mocarstwa ${ }^{27}$.

Istotne znaczenie dla sprawy polskiej miało również spotkanie moskiewskie 28 VI 1945 r. realizujące postanowienia jałtańskie. Na zlecenie powołanej w Jałcie Komisji Dobrych Usług utworzono wspomniany TRJN ${ }^{28}$, usankcjonowany następnie przez większość państw świata ${ }^{29}$. Na czele rządu stanął socjalista Edward Osóbka-Morawski, wicepremierami zostali Władysław Gomułka i Stanisław Mikołajczyk. Formalnie był to rząd koalicyjny, faktycznie całkowicie zdominowany przez Polską Partię Robotniczą (PPR) ${ }^{30}$. Do Moskwy nie zaproszono przedstawicieli polskich sił demokratycznych. Jedynie ludowcy mogli zaprezentować swoje stronnictwo. Wedle ustaleń Wielkiej Trójki nowy rząd miał poddać się weryfikacji społeczeństwa poprzez wolne wybory. W manifeście PKWN członkowie PPR i jej sojusznicy zakładali zwołanie Sejmu Ustawodawczego, wybranego w głosowaniu powszechnym, który miał uchwalić jako wyraziciel woli narodu nową konstytucję. Do tego czasu miały obowiązywać podstawowe założenia konstytucji z 17 III 1921 r. Fakty późniejsze zaświadczyły jednak o tym, że mocarstwa zachodnie nie były zaangażowane w sprawy polskie i de facto dały wolną rękę J. Stalinowi ${ }^{31}$.

${ }^{26}$ W. Roszkowski, Pótwiecze..., s. 15.

${ }^{27}$ W. Lizak pisał: „Zachód swą obojętnością wręcz zachęcał komunistów do wzmożenia represji w Polsce. Gdyby do polityki można było przykładać kategorie etyczne, to trudno o większy przykład wiarołomstwa w stosunku do niedawnego - małego bo małego - ale jednak alianta”. Źródło: W. Lizak, Historia Polski..., s. 94; „Co sprawiło, że pomimo męstwa żołnierzy i wysiłku polityków Druga Rzeczpospolita przegrała pokój, a symbolem klęski stał się testament państwa podziemnego ogłoszony konspiracyjnie w Krakowie 1 lipca 1945 roku? Przyczyn upadku upatrywać należy w niekorzystnej sytuacji międzynarodowej, której głównym sprawcą był sowiecki dyktator Iosif Wissarionowicz Stalin. Przeprowadzony w Jałcie podział Europy na strefy wpływów dał wprawdzie państwom Europy Zachodniej pokój i możliwość niebywałego rozwoju technologicznego, jednakże skazał jej drugą część - przekazaną pod kuratelę Związku Sowieckiego - na cywilizacyjny zastój, degradację kultury i nauk oraz życie w ciągłym niedostatku”. Autor tych słów przebywając w powojennym środowisku emigracyjnym w Londynie stwierdził ponadto „wyraźną obojętność rządów Stanów Zjednoczonych i Wielkiej Brytanii w odniesieniu do sprawy polskiej”. Źródło: Z.K. Wójcik, Postowie. W: J. Łopuski, Pozostać soba..., s. 39, 172.

${ }^{28}$ A. Czubiński, Historia Polski XX..., s. 253, 257.

${ }^{29}$ Do nich należały: Francja, Włochy, Szwecja, Dania, Norwegia, Finlandia, Szwajcaria, Luksemburg, Bułgaria, Rumunia, Turcja, Chiny, Kanada, Meksyk, Syria. Źródło: A. Czubiński, Historia Polski 1864-2001, Wrocław 2002, s. 225.

${ }^{30}$ A. Czubiński, Historia Polski XX..., s. 258.

${ }^{31}$ M. Skoczylas, Wybory do Sejmu Ustawodawczego: z 19 stycznia 1947 r. w świetle skarg ludności, Warszawa 2003, s. 29; Por. J. Karski, Wielkie mocarstwa wobec Polski 1919-1945. Od Wersalu do Jatty, Warszawa 1992. 
Przed obradami moskiewskimi, jakby na kpinę, toczył się tzw. proces szesnastu $^{32}$, demonstrujący wpływ J. Stalina na losy Polski. Była to rozprawa o charakterze pokazowym podstępnie porwanych przywódców Polski Podziemnej, mająca na celu rozprawienie się z opozycją ${ }^{33}$. Mimo że na ławie oskarżonych 17 VI 1945 r. zasiadło piętnastu zasłużonych w walce z niemieckim okupantem Polaków (Antoni Pajdak odmówił złożenia zeznań i jego proces odbył się w listopadzie 1945 r.), to sprawa przeszła do historii jako ,proces szesnastu”. Wśród nich znaleźli się m.in. generał Leopold Okulicki, Kazimierz Pużak, Stanisław Jankowski, Adam Bienia, Stanisław Mierzwa, Kazimierz Bagiński i Stanisław Jasiukowicz ${ }^{34}$. Polskich polityków oskarżono o udział „w pracy wywrotowej na tyłach Armii Czerwonej” oraz używanie broni w ,celach przestępczych”35. Osadzono ich w moskiewskim więzieniu na Łubiance i skazano na długoletnie wyroki pozbawienia wolności. Proces służył manifestacji siły J. Stalina ${ }^{36}$. Zdyskredytowano i oskarżono o rzekome zbrodnie ludzi, którzy wykazali się w czasie wojny bohaterstwem i odwagą w obronie ojczyzny ${ }^{37}$. Torturowani fizycznie i psychicznie, zmuszani byli do składania obciążających siebie zeznań.

Nowy rząd w Polsce poparty przez uczestników konferencji poczdamskiej istniał do lutego 1947 r. W tym okresie komuniści głosili, iż raz przejętej władzy nikomu nie oddadzą. Największy wpływ na sytuację w kraju miało nie społeczeństwo polskie, jak to było po I wojnie światowej, lecz zwycięskie mocarstwa, głównie ZSRR ze Stalinem na czele ${ }^{38}$. W ciągu dwóch lat jego działalność nie wzbudziła większego zainteresowania Zachodu.

${ }^{32}$ A. Friszke, Losy państwa i narodu 1939-1989, Warszawa 2003, s. 100-102; szerzej zob.: Proces szesnastu. Dokumenty NKWD, oprac. W. Strzałkowski i in., Warszawa 1995; Szesnastu. W: M. Łatyński, Nie paść na kolana..., s. 227-247; A. Dudek, Z. Zblewski, Utopia nad Wisła..., s. $25-26$.

${ }^{33}$ K. Kersten, Narodziny systemu..., s. 138-139; Szerzej zob.: E. Duraczyński, Generat Iwanow zaprasza, Warszawa 1989; K. Leopold [A. Leinwald], Przywódcy Polski podziemnej przed sądem moskiewskim, Warszawa 1989.

${ }^{34}$ A. Dudek, Z. Zblewski, Utopia nad Wista..., s. 25-26; A. Czubiński, Historia Polski 1864-2001..., s. 224; J. Kupiec, W hołdzie ludowcom. W: Koniec jattańskich złudzeń: sfatszowane wybory - 19 I 1947, pod red. M. Wenklara, Kraków 2007, s. 9.

${ }^{35}$ Wielka historia Polski 1945-1956..., s. 25.

${ }^{36}$ A. Friszke, Opozycja polityczna ..., s. 15.

${ }^{37} \mathrm{~W}$ osobistych wspomnieniach członek Armii Krajowej J. Łopuski pisał: „Zakończyła się wojna o niepodległość Polski, w której od początku czynnie uczestniczyłem, zamiast korzystać z pewnych przywilejów czy udogodnień, zazwyczaj przyznawanych kombatantom przez państwo, miałem z tego właśnie powodu być poddany dyskryminacji w działalności zawodowej. To już godziło w podstawową zasadę głoszoną przez postępowe ideologie - zasadę równości wobec prawa. Ograniczając moje możliwości zatrudnienia, zaliczono mnie do określonej kategorii społecznej kategorii osób podejrzanych, jeżeli nie wręcz potencjalnych wrogów państwa; osoby te nie mogły korzystać w pełni z praw przysługujących obywatelom Polski Ludowej”. Źródło: J. Łopuski, Pozostać soba..., s. 54.

${ }^{38}$ A. Czubiński, Historia Polski XX..., s. 253. 
Andrzej Friszke stwierdził: „Polska w XX wieku miała szczęście i pecha. Bo w 1918 r. odzyskała niepodległość, ale wkrótce ją utraciła"39. Rozpoczęła się nowa epoka Polski pozbawionej niezależności, włączonej do wielkiego ideologicznego imperium. Wojska radzieckie, pokonując hitlerowskiego przeciwnika, opanowały znaczną część Europy Środkowo-Wschodniej, przejęły Bałkany i doszły do zachodniego Bałtyku. ZSRR odpowiadało też w pewnym sensie na wizję prezydenta Stanów Zjednoczonych, będącego zwolennikiem koncepcji porządku świata utrzymanego przez wielkie mocarstwa i szybkiego zakończenia wojny na Pacyfiku ${ }^{40}$. Ceną za pokonanie faszyzmu była zgoda Zachodu na terytorialną ekspansję komunizmu aż po Łabę.

$\mathrm{Na}$ początku 1946 r. relacje między aliantami i sytuacja w Europie uległy pogorszeniu. Pomimo zakończenia wojny ZSRR kontynuował bowiem nadal politykę ekspansji, a USA wraz z państwami zachodnimi starały się temu zapobiec $^{41}$. W latach 1945-1947 dyplomacja amerykańska dążyła do zawarcia traktatów pokojowych z Niemcami i ich satelitami - Bułgarią, Finlandią, Rumunią, Węgrami i Włochami, do czego ostatecznie doszło 10 II 1947 r. Sprawa Niemiec budziła jednak nadal liczne kontrowersje ${ }^{42}$. Sroga zima 1946/1947, kłopoty rynkowe, bezrobocie i depresja ekonomiczna tworzyły sprzyjające warunki do rozszerzenia wpływów komunizmu. Marzec 1946 r. to początek w polityce „zimnej wojny”43. Wobec niemożności porozumienia się z ZSRR i jego presji, członkowie Departamentu Stanu USA przygotowali w czerwcu 1947 r. projekt pomocy ekonomicznej dla Europy, tzw. plan Marshalla ${ }^{44}$, który przedstawiono na

${ }^{39}$ W. Lizak, Historia Polski..., s. 6.

${ }^{40}$ A. Paczkowski, Pół wieku..., s. 137-138, 143.

${ }^{41}$ W. Churchill w przemówieniu 5 III 1946 r. w Fulton zapowiedział postawienie tamy tej ekspansji, proponując w tej kwestii ścisły sojusz USA i Wielkiej Brytanii. Na początku 1947 r. nasiliły się wzajemne oskarżenia między ZSRR a państwami zachodnioeuropejskimi. Kreml posiadał przewagę wojskową w Europie, natomiast USA dysponowało lepszym potencjałem ekonomicznym i bombą atomową. Jednocześnie Francja i Wielka Brytania obawiały się nadmiernego uzależnienia od USA. W przemówieniu 12 III 1947 r. Harry Truman wystąpił z propozycją pomocy dla wolnych narodów opierających się zewnętrznym naciskom (chodziło przede wszystkim o Grecję i Turcję). Źródło: W. Roszkowski, Półwiecze..., s. 30-31.

42 Jedenastoma wyrokami śmierci zakończył się 30 IX 1946 r. proces głównych zbrodniarzy hitlerowskich w Norymberdze. ZSRR dążył do zjednoczenia Niemiec pod swoim panowaniem, natomiast Francja chciała całkowitego rozbicia Niemiec, czemu przeciwstawiała się Anglia licząc na tamtejsze rynki zbytu. USA przyjęło w stosunku do Niemiec stanowisko pośrednie. Ostatecznie w 1949 r. powstała Republika Federalna Niemiec i Niemiecka Republika Demokratyczna. Źródło: W. Roszkowski, Pótwiecze..., s. 28.

${ }^{43}$ Historycy różnie ustanawiają początek ,zimnej wojny” A. Paczkowski jest zdania, że stało się to w połowie 1948 r. Źródło: A. Paczkowski, Pół wieku..., s. 186.

${ }^{44}$ Plan sekretarza George'a Marshalla zgłoszony w czerwcu 1947 r. pod nazwą European Recorvery Programme miał na celu udzielenie znacznej pomocy w odbudowie gospodarczej zniszczonej wojną Europie. Państwa zainteresowane mogły przystąpić do niego. Dzięki pomocy materialnej USA państwa Europy Zachodniej (łącznie z RFN) szybko uzyskały ekonomiczną równowagę. Źródło: A. Paczkowski, Pół wieku..., s. 184-185. 
międzynarodowej konferencji. Przedstawiciele Kremla odrzucili go i wymusili taką decyzję na podległych sobie państwach, w tym na Polsce. Odpowiedzią ZSRR na „zimną wojnę” była coraz większa izolacja Kremla i powstanie Kominformu (Biura Informacyjnego Partii Komunistycznych i Robotniczych) w 1947 r. Celem było wytyczenie ,jednolitych kierunków walki z imperializmem”45. Panowanie ZSRR w 1947 r. zostało utrwalone, „opozycja zdławiona, sojusznicy komunistów ubezwłasnowolnieni, społeczeństwa wystraszone lub sterroryzowane, reformy rolne i nacjonalizacje przemysłu [...] przeprowadzone" ${ }^{\text {"46. }}$ W tymże roku nastąpił podział świata na dwa wzajemnie zwalczające się bloki polityczne. Politycy zachodni wobec rosnącego zagrożenia ze strony ekspansywnej polityki ZSRR utworzyli 4 IV 1949 r. Pakt Północno-Atlantycki (NATO) w celu zagwarantowania sobie wzajemnej pomocy wojskowej. Odpowiedzią państw bloku radzieckiego stał się Układ Warszawski podpisany 14 V 1955 r. Wydarzenia te spowodowały wyścig zbrojeń. W 1950 r. J. Stalin doprowadził do wojny w Korei, która trwała jeszcze po jego śmierci w 1953 r. Rozejm podpisano 27 VII $1953^{47}$.

\subsubsection{Sfalszowane wybory 1947 r.}

Zwolennicy demokracji w Polsce wiązali duże nadzieje z wolnymi wyborami parlamentarnymi, które zagwarantowano w umowie jałtańskiej. Prowadząc trwającą półtora roku (od lipca 1945 do stycznia 1947) batalię o nie, powszechnie uważano, że są „ostatnią deskę ratunku” ${ }^{48}$. Dążenie do przeprowadzenia wyborów stanowiło ponadto próbę sił między obozem zachodnim, popierającym S. Mikołajczyka reprezentującego jedyną jawnie działającą partię opozycyjną $\mathrm{PSL}^{49}$, i obozem wschodnim komunistów $\mathrm{PPR}^{50}$. Opozycję umiarkowaną, oprócz partii ludowców, stanowiło Stronnictwo Pracy (SP) na czele z Karolem Popielem ${ }^{51}$,

${ }^{45}$ W. Roszkowski, Pótwiecze..., s. 32, 51.

${ }^{46}$ A. Paczkowski, Pół wieku..., s. 185.

47 A. Czubiński, Historia Polski XX..., s. 271, 279.

${ }^{48}$ K. Kersten, Narodziny systemu ..., s. 114-119, 126, 208.

49 Wobec wejścia S. Mikołajczyka do nowego rządu jego zwolennicy latem 1945 r. utworzyli Polskie Stronnictwo Ludowe (PSL, wcześniej SL), zajmujące stanowisko opozycyjne wobec PPR. Zaplecze PSL tworzyła organizacja młodzieżowa Związek Młodzieży Wiejskiej „Wici”. Źródło: A. Czubiński, Historia Polski XX..., s. 267.

${ }^{50}$ K. Kersten, Narodziny systemu..., s. 206; A. Paczkowski, Pól wieku..., s. 177; szerzej zob.: J. Wrona, System partyjny w Polsce 1944-1950. Miejsce - funkcje - relacje partii politycznych $w$ warunkach budowy $i$ utrwalania systemu totalitarnego w Polsce, Lublin 1995.

${ }^{51}$ Karol Popiel (1887-1977) - działacz narodowy i chrześcijańsko-demokratyczny, publicysta, żołnierz walczący pod dowództwem Józefa Piłsudskiego, urzędnik w Ministerstwie Spraw Wewnętrznych Drugiej Rzeczypospolitej, po 1926 r. przeciwnik polityki J. Piłsudskiego. W 1930 r. osadzony w twierdzy brzeskiej. W 1936 r. wstąpił do Frontu Morges, stając się jednym z głównych 
reprezentujące nurt chrześcijańskiej demokracji. Druga partia, wspierana przez hierarchów Kościoła jako reprezentatywna dla katolików, odegrała dość istotną rolę w Państwie Podziemnym i na emigracji ${ }^{52}$. Z powodu słabości partii komunistycznej w Polsce jej prominenci opóźniali termin wyborów, licząc na skutki reform przeprowadzonych w latach 1944-1946 i umocnienie ZSRR na forum międzynarodowym ${ }^{53}$.

Chcąc nadać plebiscytowy charakter wyborom, wysunięto jedną listę wyborczą tzw. bloku demokratycznego sześciu partii (PPR, PPS, Stronnictwa Ludowego, Stronnictwa Demokratycznego, PSL i SP) ${ }^{54}$. W bloku zezwolono na legalną działalność tylko tym stronnictwom, które uznały program PPR $^{55}$. Od jesieni 1945 r. zaczęto wywierać nacisk na kierownictwo PSL, aby przystąpiło do wspólnego bloku wyborczego, otrzymując 30\% mandatów. Ludowcy kategorycznie odmówili, licząc na 70-80\% głosów i obawiając się dominacji przeciwników. $\mathrm{W}$ celu zasięgnięcia opinii społeczeństwa w sprawie kierunku zmian konstytucyjnych zaproponowali referendum. Przywódcy PPR, uznając to za dobry pomysł, ustalili głosowanie ludowe na 30 VI 1946 r. Pozwoliło to na kontynuację polityki odsuwania wyborów w czasie i zweryfikowanie nastrojów społecznych. Jednocześnie referendum miało znaczenie polityczne. Komplikowało sytuację opozycji antykomunistycznej i odwracało uwagę społeczeństwa od istotnych kwestii. Kierownictwo PPR mogło jednocześnie przystąpić do bezwzględnego

współpracowników generała Władysława Sikorskiego. Był zwolennikiem zjednoczenia ruchu chadeckiego, w wyniku czego powstało Stronnictwo Pracy (SP), opierające swój program na nauce społecznej Kościoła. Został przywódcą SP. Po utworzeniu TRJN wrócił do kraju, aby jako prezes SP podjąć przy boku PSL legalną walkę z komunistami. Uzyskał poparcie w osobie arcybiskupa Adama Sapiehy i prymasa Augusta Hlonda. Wobec ataków UB w lipcu 1946 r. zawiesił działalność SP. Po nieudanych próbach zawiązania legalnie nowej partii Chrześcijańskiego Stronnictwa Pracy wyemigrował w 1947 r. Źródło: J. Żaryn, Popiel Karol. W: Encyklopedia białych plam, t. 14, Radom 2004, s. 245-247.

${ }^{52}$ A. Paczkowski, Pół wieku..., s. 160. Autor twierdzi, że SP miało szansę stać się partią masową, lecz ,zostało skutecznie spętane”. Tamże, s. 174; szerzej o SP zob. W. Bujak, Historia Stronnictwa Pracy 1937-1946-1950, Warszawa 1988.

${ }^{53}$ A. Czubiński, Historia Polski 1864-2001 ..., s. 244.

${ }^{54}$ Uchwałą z 30 X 1945 r. formalnie ograniczono całe życie polityczne w Polsce do istnienia sześciu wyżej wymienionych partii. Źródło: J. Wrona, Wybory 1947 roku. Ordynacja, przebieg $i$ konsekwencje dziejowe. W: Koniec jattańskich złudzeń..., s. 42.

${ }^{55}$ Sama PPR nie była partią jednolitą. Część jej członków nawiązywała do tradycji Międzynarodówki Komunistycznej i głosiła hasła internacjonalistyczne, licząc na rozwój rewolucji socjalistycznej w skali światowej na czele z J. Stalinem (tę linię wyznawali m.in. B. Bierut, J. Berman, H. Minc, R. Zambrowski). Inna grupa przywódców z W. Gomułką na czele wierzyła w konieczność budowy socjalizmu i współpracę z ZSRR, ale na pierwszy plan wysuwała interes narodu i państwa polskiego. Współpracę ze wschodnim sojusznikiem pragnęła ograniczyć do spraw korzystnych dla Polski, jak np. sojusz wojenny przeciw Niemcom, granice, bezpieczeństwo odrodzonego państwa itp. Kolejna grupę tworzyli byli uczestnicy wojny domowej w Hiszpanii z generałem Władysławem Świerczewskim na czele. Źródło: A. Czubiński, Historia Polski XX..., s. 256. 
zwalczania PSL. W pierwszej połowie 1946 r. doszło zatem do konfrontacji. Ludowców oskarżono o wszelkie możliwe występki i antynarodową działalność, m.in. o współdziałanie z podziemiem (głównie organizacją Wolność i Niezależność - WiN), represjonowano, wymierzano wyroki, zastraszano, dokonywano mordów skrytobójczych, usuwano z urzędów i zawieszano działalność organizacji terenowych. Spowodowano nawet rozłam w łonie samej partii; odeszli Tadeusz Rek, Edward Bartold, Bronisław Drzewiecki i Kazimierz Iwanowski, zakładając w czerwcu prokomunistyczną PSL „Nowe Wyzwolenie" ${ }^{56}$. Działania takie podjęto, gdyż „Polska Partia Robotnicza <<wolnych, nieskrępowanych $>>$ wyborów do sejmu się bała i zdawała sobie sprawę, że nie może ich wygrać"s7.

W referendum zadano trzy pytania: 1. czy jesteś za zniesieniem senatu, 2. czy chcesz utrwalenia w przyszłej konstytucji ustroju gospodarczego wprowadzonego przez reformę rolną i unarodowienie podstawowych gałęzi gospodarki narodowej, z zachowaniem podstawowych uprawnień inicjatywy prywatnej, 3. czy chcesz utrwalenia zachodnich granic państwa polskiego na Bałtyku, Odrze i Nysie Łużyckiej. Ugrupowania obozu rządzącego (PPR, PPS, SL i SD) rozwinęły ogromną akcję propagandową z udziałem administracji państwowej, wojska, milicji i służb bezpieczeństwa. Poprzez zorganizowaną akcję ulotek, plakatów, broszur, radio wzywano do głosowania „3 razy tak”. Członkowie PSL sugerowali odpowiedź „nie” na pierwsze pytanie, na dwa pozostałe - tak. Środowisko związane z organizacją WiN postulowało na dwa pierwsze pytania odpowiedź negatywną, tylko na ostatnie pozytywną. Osoby należące do konspiracji antykomunistycznej i zbrojnego podziemia propagowały bojkot głosowania lub udzielenie negatywnej odpowiedzi na wszystkie trzy pytania. Referendum miało być swoistym sondażem wskazującym, czy w sytuacji represji bez masowego terroru, PPR i sprzymierzone z nią partie mają szanse uzyskać poparcie ${ }^{58}$. Krystyna Kersten napisała: „Ważnym elementem składającym się na atmosferę nadchodzącego referendum było powszechne przekonanie, że będzie ono sfałszowane" ${ }^{59}$. Tak też się stało, gdyż oficjalne wyniki wskazywały na zdecydowaną wygraną PPR-u. W referendum wzięło udział $85,8 \%$ uprawnionych. Na pierwsze pytanie miało odpowiedzieć pozytywnie $68,2 \%$, negatywnie $31,8 \%$ głosujących. Na pytanie drugie pozytywnie $-77,3 \%$, negatywnie $22,7 \%$; na trzecie pozytywnie odpowiedziało $91,4 \%$,

${ }^{56}$ K. Kersten, Narodziny systemu..., s. 224, 237; Wielka historia Polski..., s. 93-94; A. Czubiński, Historia Polski 1864-2001 ..., s. 245; M. Korkuć, Od ideologii antypaństwowej do fatszywego legalizmu PRL. W: Koniec jaltańskich złudzeń..., s. 32.

${ }^{57}$ M. Łatyński, Nie paść na kolana..., s. 474.

${ }^{58}$ K. Kersten, Narodziny systemu..., s. 226, 231, 239; Wielka historia Polski..., s. 94-95; M. Korkuć, Od ideologii antypaństwowej..., s. 32.

${ }^{59}$ K. Kersten, Narodziny systemu..., s. 247; szerzej o atmosferze referendum M. Łatyński, Nie paść na kolana ..., s. 513-566. 
negatywnie $8,6 \%$ głosujących. Według obliczeń dokonanych przez opozycję na pytanie pierwsze pozytywnie odpowiedziało $31 \%$ głosujących, na drugie $45 \%$, a na trzecie $68 \%{ }^{60}$.

W rzeczywistości głosowanie potwierdziło popularność PSL wśród społeczeństwa i niechęć do komunistów ${ }^{61}$. Oszacowane po latach rzeczywiste wyniki referendum pokazały, że co najmniej 3/4 ludności opowiedziało się przeciwko blokowi komunistów ${ }^{62}$. Dowiodły również, że opozycja może być eliminowana z komisji wyborczych, a protestów przeciw bezprawnym działaniom nie brano w ogóle pod uwagę.

Bezpośrednio po referendum nasilono represje i akcje rozłamowe nie tylko w opozycyjnych partiach SP i PSL, lecz również w stosunku do współrządzącej PPS. Szybko udało się rozbić SP. We wrześniu 1946 r. wskutek prowokacyjnych działań sześciu posłów stronnictwa z Karolem Popielem na czele podczas spotkania, na którym miano zadecydować o linii dalszego postępowania, demonstracyjnie złożyło mandaty członków KRN ${ }^{63}$.

W Polsce ruch komunistyczny miał zbyt małe poparcie, aby mógł otwarcie rywalizować z innymi partiami. Jedynie przy zastosowaniu kamuflażu i unikaniu deklaracji o charakterze jawnie komunistycznym można było niszczyć konkurentów ${ }^{64}$.

Wybory do Sejmu Ustawodawczego poprzedziła równie ostra kampania propagandowa komunistów. Przedstawiciele PPR uzyskawszy dane o geografii politycznych wpływów S. Mikołajczyka, wykorzystali je w okresie przedwyborczym. Przystąpiono do zawieszania list PSL i nie dopuszczania do komisji wyborczych mężów zaufania Stronnictwa. Prawo wyborcze przysługiwało osobom posiadającym obywatelstwo polskie, które w dniu głosowania ukończyły 21 lat. W wyborach nie mogły brać udziału osoby pozbawione zdolności do działań

${ }^{60}$ A. Czubiński, Historia Polski XX..., s. 266; szerzej zob.: Referendum z 30 czerwca 1946 r. Przebieg $i$ wyniki, oprac. A. Paczkowski, Warszawa 1993.

${ }^{61}$ Szerzej o tym zob. Gtosowanie ludowe z 30 czerwca 1946 r.w raportach Ministerstwa Bezpieczeństwa Publicznego. Wybór dokumentów, oprac. T. Kisielewski i M. Strzelecki, Bydgoszcz 2000; C. Osękowski, Wybory do sejmu z 19 stycznia 1947 roku w Polsce, Poznań 2000; Kampania wyborcza $i$ wybory do Sejmu Ustawodawczego 19 stycznia 1947, oprac. J. Wrona, Warszawa 1999; A. Paczkowski, Sztuka wygrywania wyborów, „Karta” 1996 nr 18; R. Buczek, Na przełomie dziejów. Polskie Stronnictwo Ludowe w latach 1945-1947, Wrocław 1989; R. Turkowski, Polskie Stronnictwo Ludowe w obronie demokracji 1945-1949, Warszawa 1992; B. Dereń, PSL w Krakowskiem 1945-1947, Warszawa 1998; B. Bidzińska-Jakubowska, PSL na Ślasku Opolskim, Opole 1993; S. Łach, PSL w latach 1945-1947, Gdańsk 1995.

${ }^{62}$ M. Korkuć, Od ideologii antypaństwowej..., s. 32-33; K. Kersten, Narodziny systemu..., s. 186; Liczby procentowe wyników referendum podawane przez historyków są różne. Pracownicy radzieckiego aparatu bezpieczeństwa sfałszowali 5994 protokołów z obliczonymi głosami i podrobili około 40 tys. podpisów członków komisji (czyli ponad połowę ogólnej liczby wszystkich obwodów). Źródło: A. Paczkowski, Sztuka wygrywania..., s. 132.

${ }^{63}$ Wielka historia Polski..., s. 96-97.

${ }^{64}$ N. Davies, Boże igrzysko: historia Polski, Kraków 1994, s. 702. 
prawnych, pozbawione praw publicznych, wpisane w czasie wojny na niemiecką listę narodowościową (jeżeli nie zostały zrehabilitowane), osoby współpracujące w czasie wojny z władzami okupacyjnymi oraz z ,podziemnymi organizacjami faszystowskimi” i ,organizacjami dążącymi do obalenia ustroju państwa polskiego". Ostatnia część odnosiła się do dowódców i żołnierzy AK oraz do zbrojnego podziemia niepodległościowego działającego po 22 VII 1944 r. Obywatela można było pozbawić prawa wyborczego decyzją komisji wyborczej, a nie jak praktykowano w państwach demokratycznych - prawomocnym wyrokiem sądu. Najczęstszym pretekstem do usuwania z list było oskarżenie o współpracę z Niemcami bądź z podziemiem niepodległościowym i „bandami leśnymi”. W rezultacie pół miliona osób, w tym 98 kandydatów na posłów, skreślono z list wyborczych pod fałszywym pretekstem współpracy z Niemcami. Zawieszono listy PSL w 10 okręgach wyborczych obejmujących 76 mandatów. W składzie 52 komisji okręgowych kraju nie znalazł się żaden członek PSL ${ }^{65}$.

Wybory do Sejmu przebiegły zatem w podobnym duchu, co referendum. Lista kandydatów była wcześniej skontrolowana przez rząd, natomiast z list wyborców usunięto nazwiska dwóch milionów głosujących. Robotników z fabryk doprowadzili do urn majstrzy, po czym pod groźbą utraty pracy kazano im głosować na rząd. Głosy liczyli sami aparatczycy ${ }^{66}$. O atmosferze przedwyborczej może świadczyć następująca notatka: ,przedstawiciele prasy zwrócili się do generała Grosza z zapytaniem, czy Stronnictwo Ludowe otrzyma taki sam przydział papieru na walkę wyborczą, co partie rządowe. W odpowiedzi na to Grosz oświadczył, że Stronnictwo Ludowe ma na usługach propagandę ze wszystkich ambon kościołów rzymsko-katolickich" ${ }^{67}$.

W 63 protestach powyboczych, które napłynęły do Sądu Najwyższego, szczególne miejsce zajęły opisy prześladowań, nękania przez organy bezpieczeństwa, przeprowadzonych rewizji, rozwiązywania terenowych zarządów PSL, wymuszania podpisów pod listą kandydatów Bloku Demokratycznego czy zmuszania do wycofywania podpisów złożonych na kandydatów PSL. Naruszenia prawa powtarzały się w różnych okręgach, m.in. nie uwzględniano przedstawicieli partii ludowej w okręgowych i obwodowych komisjach wyborczych, stwarzano problemy przy rejestracji okręgowych list kandydatów PSL, nie umieszczano w spisach wyborczych bądź skreślano z nich osoby podejrzane o chęć niezależnego głosowania, pozbawiano praw wyborczych pod zarzutem współpracy w czasie okupacji z władzami okupacyjnymi, wprowadzono przymus jawnego głosowania na listę Bloku nr 3 itp. Większość skarg, będących wyrazem odwagi osób, które je składały z możliwością narażenia się na szykany ze strony władz, wycofano z Sądu Najwyższego przed ich rozpatrzeniem ${ }^{68}$.

\footnotetext{
${ }^{65}$ J. Wrona, Wybory 1947 roku..., s. 45, 54-55, 58-59.

${ }^{66}$ N. Davies, Boże igrzysko..., s. 704.

${ }^{67}$ „Ostatnie Wiadomości PAT - KAP” 1946 nr 124 s. 2.

${ }^{68}$ M. Skoczylas, Wybory do Sejmu Ustawodawczego..., s. 22-23, 26-27. Dowodem nadużyć
} 
Zgodnie $\mathrm{z}$ oficjalnie podanym komunikatem o wynikach wyborów dokonano podziału mandatów. Blok Stronnictw Demokratycznych i Związków Zawodowych uzyskał 394 mandaty, PSL 28, SP 12, PSL „Nowe Wyzwolenie” siedem i niezależni katolicy trzy mandaty. W ramach bloku demokratycznego najwięcej mandatów zdobyła PPS, bo aż 116, PPR 114, SL 109 i SD $41^{69}$.

Nadzieja na wygranie głosowania przy jednoczesnym braku jakiegokolwiek poparcia ze strony zachodnich aliantów okazała się złudna. Alianci pomimo przekazów od własnych obserwatorów ograniczyli się jedynie do dyplomatycznych protestów ${ }^{70}$. Od lata 1946 r. walka członków PSL przestała być już batalią o władzę, zwłaszcza że w 1947 r. doszły aresztowania m.in. redakcji organu prasowego PSL „Gazety Ludowej”’1, szantażowanie, usuwanie z pracy, odpływ ludzi i rozpad na dwa odłamy ${ }^{72}$. Podobne wydarzenia miały miejsce też w innych krajach przejętych przez ZSRR, na Węgrzech, w Bułgarii i Rumunii, świadczące o pełnym przejęciu przez komunistów władzy ${ }^{73}$. Konfrontacja poprzedzająca wybory sprawiła, że coraz powszechniejsze było wśród opozycji przekonanie o bezskuteczności sprzeciwu. Panował ogólny pogląd, że możliwe jest tylko „współdziałanie z władzami lub emigracja wewnętrzna" ${ }^{\prime 4}$.

są opublikowane Dokumenty fatszerstw wyborczych w Polsce w roku 1947, oprac. M. Adamczyk, J. Gmitruk, t. 1-2, Warszawa 2000-2002; szerzej zob. C. Osękowski, Wybory do sejmu..., s. 146-152, s. 277-363; Kampania wyborcza i wybory do Sejmu Ustawodawczego...; Opozycja parlamentarna w Krajowej Radzie Narodowej i Sejmie Ustawodawczym 1945-1947, oprac. R. Turkowski, Warszawa 1997; J. Wtorkiewicz, Wojsko Polskie w akcji propagandowej $i$ wyborach do Sejmu w 1947 r., Warszawa 2002; B. Barnaszewski, Jak fatszowano wybory w roku 1947, „Odra” 1991 nr 9 s. 20-21; S. Jankowiak, PPR-owska koncepcja wyborów do Sejmu Ustawodawczego w 1947 r., „Dzieje Najnowsze” 1994 nr 4 s. 73-80; A. Paczkowski, Sztuka wygrywania wyborów..., s. 130-134; L. Pajórek, Fatszowanie wyborów. Z tajnych archiwów, „Polityka” 1990 nr 43 s. 14; N. Pietrow, Sztuka wygrywania wyborów, „Karta” 1996 nr 18 s. $121-129$.

${ }^{69}$ A. Czubiński, Historia Polski XX..., s. 270.

${ }^{70}$ A. Friszke, Opozycja polityczna ..., s. 31; R. Terlecki napisał: „Odtąd wybory były już całkowitą fikcją: «wyborcy» głosowali na jedną listę, a władze Polskiej Zjednoczonej Partii Robotniczej zawczasu ustalały, kto znajdzie się w Sejmie PRL - instytucji całkowicie dekoracyjnej i pozbawionej jakiejkolwiek realnej władzy. Na ponad czterdzieści lat Polska została zatrzaśnięta w pułapce wyznaczonej przez żelazną kurtynę i poddana stopniowej, ale systematycznej sowietyzacji. Dopiero nadzieja, wzbudzona wyborem kardynała Karola Wojtyły na papieża, a następnie powstanie «Solidarności» pozwoliły Polakom otrząsnąć się z apatii i zwątpienia”. Źródło: R. Terlecki, Wstęp. W: Koniec jałtańskich złudzeń..., s. 7.

71, ,...] dwa razy w ciągu ostatnich piętnastu dni Bezpieka plądrowała w siedzibie $<<$ Gazety Ludowej>> Mikołajczyka, aresztując redaktora naczelnego Augustyńskiego, redaktora Wyrzykowskiego i dwóch urzędników” donoszono w październikowych „Ostatnich Wiadomościach PAT-KAP” 1946 nr 83 s. 1; szerzej zob.: L.B. Paszkiewicz, ,, Gazeta Ludowa”. Próba walki o wolność myśli i stowa 1945-1947, Toruń 2007.

${ }^{72}$ Szerzej zob.: Koniec opozycji. W: M. Łatyński, Nie paść na kolana..., s. 5-24.

${ }^{73}$ A. Friszke, Opozycja polityczna ..., s. 33-35.

${ }^{74}$ K. Kersten, Narodziny systemu ..., s. 250. 
Po sfałszowanych wyborach 1947 r. uchwalono ustawę o ustroju i zakresie działania najwyższych organów Rzeczypospolitej Polskiej, tzw. małą konstytucję z 19 II 1947 r., stanowiącą jawny krok ku sowietyzacji. Na prezydenta wybrano uległego wobec polityki ZSRR Bolesława Bieruta oraz utworzono nowy rząd, na czele z premierem Józefem Cyrankiewiczem. W styczniu 1947 r. uchwalono ustawę o amnestii ${ }^{5}$ celem pogłębienia rozkładu organizacji podziemnych (głównie WiN i NSZ). Zachowywano przy tym pozory, utrzymując nazwy instytucji z okresu dwudziestolecia, tekst przysięgi prezydenckiej i dawny ceremoniał ${ }^{76}$. Po trzech dniach sejm uchwalił również deklarację o prawach i wolnościach obywatelskich, zawierającą „katalog pięknych haseł i zapowiedzi” niemających większego przełożenia praktycznego ${ }^{77}$.

Po wyborach zerwano z „kamuflażem wielopartyjności” i opozycja przestała właściwie istnieć. Wyeliminowano PSL i umocniono władzę komunistów. S. Mikołajczyk przy pomocy pracowników ambasady amerykańskiej zbiegł do Londynu $^{78}$. Jego zwolenników usunięto z władz i z całej organizacji. Szeregi PSL rozbito za pomocą grupy polityków na czele z Józefem Niećką i Czesławem Wycechem, tworząc PSL Lewicę w celu przyszłej współpracy z komunistami ${ }^{79}$. Na przeszkodzie stało jedynie PPS, pomocne co prawda w zdobyciu władzy, lecz posiadające przedwojenne tradycje, które nakazywały niezgodę na pewne komunistyczne rozwiązania. Pomimo sprzeciwu środowisk chłopskich i robotniczych ${ }^{80}$ oraz inteligenckich, rozpoczęto kampanię o upaństwowienie rynku oraz podporządkowanie władzom nauki i szkolnictwa wyższego (służył temu dekret o organizacji nauki i szkolnictwa wyższego z 27 X 1947) ${ }^{81}$.

Polską Zjednoczoną Partię Robotniczą utworzono z połączenia PPR i PPS 15 XII 1948 r. Do jej powstania deklarowano system demokracji ludowej,

${ }^{75}$ Amnestia objęła około 60 tys. osób. Więzienia opuściło 17 tys. ludzi, a z konspiracją zerwało około 54 tys. osób. Byli to głównie członkowie organizacji WiN, Konspiracyjnego Wojska Polskiego, Ruchu Oporu AK i in. Część aresztowanych nadal sądzono i skazywano na wieloletnie wyroki więzienia. Amnestia spowodowała zmniejszenie konspiracji, ale jej nie zlikwidowała. Działalność konspiracyjną kontynuowały jeszcze niektóre ogniwa WiN, dawnej AK oraz organizacji narodowych. Źródło: A. Czubiński, Historia Polski XX..., s. 271.

${ }^{76}$ K. Kersten, Narodziny systemu ..., s. 302-310.

${ }^{77}$ A. Czubiński, Historia Polski 1864-2001 ..., s. 251.

${ }^{78}$ Szerzej zob. Ucieczka Mikołajczyka z PRL w 1947 roku, „Zeszyty Historyczne” 1985 nr 74, oraz wspomnienia S. Mikołajczyka, The Rape of Poland, Chicago 1981; osobie lidera PSL poświęcono także następujące pozycje książkowe: A. Paczkowski, Stanisław Mikołajczyk, Warszawa 1994; J. Gmitruk, D. Pasiak, Stanisław Mikołajczyk (1901-1966), Warszawa 1996; S. Stępka, Stanistaw Mikołajczyk: rozprawy i studia, Warszawa 2001; G. Patro, Stanisław Mikołajczyk, Wągrowiec 2003.

${ }^{79}$ A. Friszke, Opozycja polityczna ..., s. 36; szerzej zob. J. Borkowski, Ksztattowanie się antymikołajczykowskiej opozycji w kierownictwie Polskiego Stronnictwa Ludowego 1946-1947. W: Polska Ludowa, t. 1, Warszawa 1962.

${ }^{80}$ Szerzej zob. D. Jarosz, Polityka władz komunistycznych $w$ Polsce w latach 1948-1956 a chłopi, Warszawa 1998.

${ }^{81}$ A. Czubiński, Historia Polski 1864-2000 ..., s. 251; K. Kersten, Narodziny systemu ..., s. 320. 
który miał być pośrednim między kapitalizmem i socjalizmem. Oficjalne zwycięstwo przyszło po pozbawieniu przez sowietów urzędu pierwszego sekretarza, Władysława Gomułkę. Zdecydowana większość członków partii, pomimo systematycznych szkoleń, nie była zakorzeniona w tradycji ruchu i nie miała nic wspólnego z komunizmem. Wraz z powstaniem PZPR przyjęto radykalniejszą linię polityczną. Koncepcję nowego ładu zreferował Hilary Minc, jeden z inicjatorów „bitwy o handel"\$2 mającej wyprzeć PPS ze spółdzielczości i handlu. Zaczęto realizację sześcioletniego planu budowy podstaw socjalizmu. Przystąpiono jednocześnie do intensywnego propagowania historii ruchu robotniczego i doktryny socjalistycznej, tłumacząc na język polski prace Karola Marksa, Fryderyka Engelsa, Włodzimierza Lenina i Józefa Stalina. W 1948 r. uroczyście obchodzono w celach propagandowych setną rocznicę Wiosny Ludów. Większego znaczenia nabrała cenzura, poprzez którą konfiskowano prace i publikacje niezgodne z obowiązującą doktryną. Idee opozycyjne wobec nowej rzeczywistości reprezentował tylko Kościół. Walkę $\mathrm{z}$ indoktrynacją stalinowską kontynuowała też emigracja polityczna ${ }^{83}$.

\subsubsection{Episkopat wobec wyborów}

Hierarchia kościelna nie zaangażowała swojego autorytetu w referendum, natomiast jej stanowisko w sprawie wyborów do sejmu przedstawione zostało w Orędziu Episkopatu Polski z 10 IX 1946 r. Przekazano w nim zależność pomiędzy państwem demokratycznym a jego prawem wyborczym i wskazano na obowiązki katolików wobec życia publicznego. Przestrzegano wiernych, aby nie oddawali głosów na kandydatów z list, których ,programy albo metody rządzenia są wrogie zdrowemu rozsądkowi, dobru narodu i państwa, moralności chrześci-

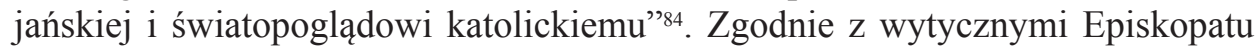
duchowni nie mogli kandydować w wyborach pod karą suspensy. Zasadniczo środowiska Kościoła poparły program SP, mającej charakter partii katolickiej. Aprobatę wyrażono poprzez religijne praktyki odprawiania nabożeństw i mszy św. za zmarłych członków Stronnictwa. Po zniszczeniu SP przez komunistów zdecydowano się wesprzeć PSL. Chociaż hierarchowie Kościoła podchodzili do wyborów z dystansem, to w pracach komitetu wyborczego na terenie całego kraju wzięło udział 703 kapłanów ${ }^{85}$.

${ }^{82}$ Bitwa o handel - akcja polityczno-gospodarcza w Polsce mająca na celu w latach 1947-1949 w ramach planu trzyletniego wyeliminowanie sektora prywatnego na rzecz nacjonalizacji. Dokonano tego drogą niszczenia handlu prywatnego, ustalania wysokich cen i podatków.

${ }^{83}$ N. Davies, Boże igrzysko..., s. 678, 680; A. Czubiński, Historia Polski XX..., s. 251, 275-276; tenże, Historia Polski 1864-2001 ..., s. 251, 276.

${ }^{84}$ Listy pasterskie Episkopatu Polski 1945-2000, cz. 1, Marki 2003, s. 23.

${ }^{85}$ J. Marecki, Kościót wobec wyborów w 1947 roku. W: Koniec jałtańskich złudzeń..., s. $154-156,161,164$. 
Po sfałszowanym referendum $i$ wyborach w pałacu arcybiskupim w Krakowie odbyła się 31 I 1947 r. narada z udziałem prymasa kardynała Augusta Hlonda, kardynała Adama Sapiehy i sekretarza Episkopatu biskupa Zygmunta Choromańskiego ${ }^{86}$. Wyniki głosowania do sejmu z 19 I 1947 r. prymas Hlond skomentował: ,[...] ostatnie wybory były aktem wielkiego terroru, oszukaństwa i kłamstwa [...]. Teraz rządowi chodzi o to, żeby stworzoną sytuację uznał Kościół"87.

Dostojnicy Kościoła 14 III 1947 r. wystosowali do premiera dokument zatytułowany Katolickie postulaty konstytucyjne będące powtórzeniem żądań rozpadającego się PSL, co usytuowało Kościół po stronie opozycji. Reakcja władz była negatywna, a więc po raz kolejny zaostrzono cenzurę prasy i wydawnictw kościelnych. Ostrożność nakazywała, aby Episkopat nie zaakceptował formalnie wyborów ani też nie wyraził swojej zdecydowanej dezaprobaty. Rozpoczęto grę na zwłokę oraz stosowano optymalizację ustępstw. Przykładem takiego działania była zgoda kardynałów Hlonda i Sapiehy na żądanie władz odprawienia nabożeństw z okazji wyboru Bieruta na prezydenta, ale bez udziału biskupów i bicia dzwonów. Strategię unikania konfrontacji potwierdziła instrukcja Episkopatu z kwietnia 1948 r. skierowana do wszystkich księży. Stwierdzono w niej, że duszpasterze nie będą polemizować z reżimem, ale będą pozytywnie wykładać naukę społeczną Kościoła i wskazywać na różnice światopoglądowe w relacji do materializmu ${ }^{88}$.

\subsubsection{Apogeum stalinizmu w Polsce w latach 1949-1953}

W pierwszej połowie 1949 r. wyraźniej zaznaczyły się w społeczeństwie polskim skutki nowej polityki gospodarczej i społecznej. Zakończono trzyletni plan odbudowy gospodarczej, a od 1950 r. rozpoczęto realizację planu sześcioletniego. Przewidziano w nim przyspieszenie „uspołecznienia”, a więc scentralizowanie i upaństwowienie gospodarki oraz wzmożono czujność w sprawach kadrowych ${ }^{89}$. W latach 1949-1953 system represji uległ zaostrzeniu, przy jednoczesnej rozbudowie organów bezpieczeństwa publicznego i armii ${ }^{90}$. Fikcyjne spiski i konspiracje powstawały po to, by uzyskać formalne uzasadnienie dla aresztowania wielu osób. Organizowano pokazowe procesy w celu zastraszenia społeczeństwa.

${ }^{86}$ Protokót spotkania prymasa A. Hlonda z kard. A. Sapiehą, Kraków 31 I 1947. W: Kościót katolicki a państwo $w$ świetle dokumentów 1945-1989, t. 1, 1945-1959, pod red. P. Rainy, Poznań 1994, s. 76-77.

${ }^{87}$ Cyt. za: P. Raina, Stefan kardynat Wyszyński, Prymas Polski, t. 1, Londyn 1979, s. 218.

${ }^{88}$ A. Dudek, R. Gryz, Komuniści i Kościół..., s. 25-26.

${ }^{89}$ J. Łopuski, Pozostać sobą..., s. 53.

90 Szerzej zob. H. Dominiczak, Organy bezpieczeństwa... 
Aresztowaniom nie uszli także czołowi politycy, z Władysławem Gomułką ${ }^{91}$ i Marianem Spychalskim na czele. Więziono również dostojników Kościoła ${ }^{92}$. W latach 1951-1953 zwiększono wydatki na zbrojenia, co przyczyniło się do niezrealizowania planu sześcioletniego, kłopotów w rolnictwie, wzrostu cen i spadku stopy życiowej. Wieś przeżywała kryzys, nastąpił odpływ ludności ze wsi do miast, gdzie znajdowano zatrudnienie w przemyśle ciężkim. Na wsi, oprócz kolektywizacji, tworzono państwowe gospodarstwa rolne, które były własnością państwa. Przechodzenie chłopów do spółdzielni produkcyjnych (kołchozów) na polskiej drodze do komunizmu natrafiło na opór. Rząd stosował przymus, naciski ekonomiczne i represje policyjne. Wobec sprzeciwu chłopów w wielu regionach kraju najwięcej spółdzielni powstało na Ziemiach Odzyskanych, gdzie łatwiej było odebrać gospodarstwa ludziom, którzy niedawno tam przybyli93.

Wprowadzenie konstytucji z 22 VII 1952 r. proklamującej Polską Rzeczpospolitą Ludową stało się oficjalnym potwierdzeniem systemu stalinowskiego. $\mathrm{Na}$ wzór analogicznych komunistycznych konstytucji innych państw, wszystkim obywatelom zagwarantowano prawo do pracy, wypoczynku, ochrony zdrowia i nauki oraz wolność słowa, zgromadzeń i sumienia, bez względu na rasę, płeć i wyznanie. Zadbano, aby wszystkie instytucje przejawiały pozory demokratycznych. Wprowadzono rozdział Kościoła od państwa, ustanawiając „przewodnią rolę" partii ${ }^{4}$. Treść konstytucji była konsultowana z J. Stalinem i nawiązywała do tzw. konstytucji stalinowskiej w ZSRR z 1936 r. Stwierdzono w niej m.in., że Polska zerwała $\mathrm{z}$ kapitalizmem i ma realizować program budowy socjalizmu. Zniesiono instytucję prezydenta, przekazując funkcję głowy państwa w ręce Rady Państwa. Demokracja ludowa stała się państwem dyktatury proletariatu ${ }^{95}$. Przystąpiono do dalszej rozbudowy organów bezpieczeństwa publicznego i sił zbrojnych. Władze sztucznie kreowały rzekomo wrogie organizacje, dokonywały aresztowań i organizowały procesy polityczne.

Po rozgromieniu siłą podziemia zbrojnego i legalnej opozycji skupionej wokół PSL przystąpiono do zaostrzenia walki z Kościołem. Podjęto prymitywną propagandę antyreligijną i antykościelną. Najpierw zajęto się środowiskami niezależnymi, związanymi z Kościołem. Zlikwidowano znaczną część szkolnictwa katolickiego, upaństwowiono kościelne szpitale, zainspirowano ruch „księży patriotów", wprowadzono podległy władzy zarząd nad Caritasem, wspierano

${ }^{91}$ Więcej na ten temat zob.: Między realizmem a utopia: Władysław Gomułka we wspomnieniach syna, rozmowa E. Syzdek z R. Strzeleckim-Gomułką, Warszawa 2003.

92 A. Czubiński, Historia Polski XX..., s. 279; szerzej zob.: M.R. Bombicki, Księża przed sąami specjalnymi 1944-1954, Poznań 1993; Męczennicy i świadkowie wiary. Represje komunistyczne wobec duchowieństwa na Rzeszowszczyźnie, Rzeszów 2006.

${ }^{93}$ A. Czubiński, Historia Polski 1864-2001..., s. 254; szerzej zob. D. Jarosz, Polacy a stalinizm, 1948-1956, Warszawa 2000.

${ }^{94}$ N. Davies, Boże igrzysko..., s. 716.

${ }^{95}$ A. Czubiński, Historia Polski 1864-2001..., s. 257. 
Stowarzyszenie PAX. Doprowadzono wreszcie do porozumienia w 1950 r. Jego podpisanie ,zaskoczyło Watykan”" lecz nie zapobiegło zaostrzaniu się walki z Kościołem. Punkt kulminacyjny w stosunkach Kościoła z państwem stanowiło ogłoszenie 9 II 1953 r. przez władzę dekretu o obsadzaniu stanowisk kościelnych, na który prymas Stefan Wyszyński odpowiedział słynnym memoriałem Non possumus. Głowę polskiego Kościoła paradoksalnie aresztowano po śmierci J. Stalina ${ }^{97}$. Odwilż odczuwalna była dopiero w 1. 1955-1956 ${ }^{98}$.

\subsection{Sytuacja polskiego Kościoła katolickiego w latach 1945-1947}

\subsubsection{Położenie ogólne}

W pierwszych latach powojennych komuniści zabiegali o utrzymanie poprawnych stosunków z Kościołem i stworzenie pozorów respektowania jego konstytucyjnych uprawnień. Celowo odwoływano się do prawnej spuścizny Drugiej Rzeczypospolitej, podkreślając dążenie do demokratyzacji stosunków wyznaniowych. Uprawiano „politykę wzajemnego $<<$ mijania się >> państwa i Kościoła, materii i ducha" ${ }^{99}$ czy też ,ukrytą wojnę podjazdową"100. Wyrazem tego było wyłączenie ziemskich majątków kościelnych (tzw. dóbr martwej ręki) ${ }^{101}$ z rozpoczętej

${ }^{96}$ Wielka historia Polski..., s. 167.

${ }^{97}$ J. Stalin był przeciwny uwięzieniu prymasa pomimo wielu zabiegów B. Bieruta. Kardynał Wyszyński mówił o tym Romualdowi Kukołowiczowi. Warto przytoczyć relację: „Bierut był konkretny, zwięzły i konsekwentny w stosunku do swoich słów. Gdy coś mówił, to z góry wiedziałem, co będzie, i że trzeba się będzie przygotować do nowej awantury [...] Z Bierutem wszystko było jasne. Kiedyś był on w Moskwie na uroczystości rocznicy rewolucji październikowej. Gdy powrócił, spytałem jak się udała wyprawa do Moskwy. Bierut odrzekł na to, że nie udała się. $<<$ Wie Ksiądz Prymas, rozmawiałem ze Stalinem i powiedziałem mu, że chcę Księdza Prymasa wsadzić do więzienia >>. Gdy Bierut powiedział to otwarcie Księdzu Prymasowi, to On - jak mi sam opowiadał - relacjonuje dalej Kukołowicz - prawie podskoczył do góry, ale opanował się i spokojnie zapytał: - I co na to Stalin? I wtedy Bierut ze smętną miną odpowiedział: - Stalin powiedział tak: <<wot, ty durak. Co za sztuka wsadzić Prymasa do więzienia, to każdy dureń potrafi. Ty zrób z Prymasa Wyszyńskiego komunistę. To dopiero będzie sztuka!>> - i za to właśnie cenię Bieruta kontynuował Ksiądz Prymas". Źródło: W cieniu Prymasa Tysiąclecia. Z Romualdem Kukołowiczem rozmawia Piotr Baczek, Warszawa 2001, s. 85-87. Za: E.K. Czaczkowka, Kardynat Wyszyński, Warszawa 2009, s. 146.

${ }^{98}$ Wielka historia Polski..., s. 167-170.

${ }^{99}$ Te słowa użyto w notatce adresowanej do Biura Politycznego KC PPR. Źródło: J. Żaryn, Kościół w PRL, Warszawa 2004, s. 11.

${ }^{100}$ J. Żaryn, Dzieje Kościoła katolickiego..., s. 56, 64; B. Cywiński, Ogniem próbowane..., s. 38; Z. Zieliński, Kościół w Polsce 1944-2007..., s. 49.

${ }^{101}$ Dobra ziemskie zabrano później, w 1950 r. 
w 1944 r. reformy rolnej, zwrot majątku zrabowanego Kościołowi przez Niemców, zezwolenie na nauczanie religii w szkole (już od września 1944 r.), reaktywowanie Katolickiego Uniwersytetu Lubelskiego i zgoda na wydawanie prasy katolickiej ${ }^{102}$. Istotne miejsce wśród nowych prasowych tytułów powojennych zajęły powstałe w 1945 r. periodyki „Tygodnik Warszawski” i „Tygodnik Powszechny”, skupiające wokół siebie środowiska inteligencji katolickiej.

Początkowo nie przeszkadzano w odnawianiu życia religijnego na terenach wyzwolonych spod okupacji niemieckiej oraz wyrażono zgodę na reaktywowanie struktur diecezjalnych i parafialnych. Pozwolono na wznowienie działalności długoletniej dobroczynnej instytucji kościelnej - Caritas i tolerowano działalność stowarzyszeń katolickich. Dygnitarze partyjni kierując się pragmatycznymi pobudkami wygłaszali szczytne hasła i deklaracje o demokracji. Chcąc zyskać aprobatę społeczeństwa, chętnie pokazywali się na uroczystościach kościelnych. Przedstawiciele nowej władzy stali bowiem przed trudnym zadaniem: należąc do niepopularnej partii rządzącej, mieli przeprowadzić atak na Kościół cieszący się szczególnym szacunkiem i autorytetem w społeczeństwie ${ }^{103}$.

Księża w czasie II wojny światowej byli częścią walczącego i ponoszącego ofiarę z życia narodu. Życie straciło ponad 2 tys. kapłanów polskich (w tym kilku biskupów, m.in. błogosławieni Michał Kozal, Antoni Nowowiejski, Leon Wetmański oraz Władysław Goral i Konstantyn Dominik). Tylko w obozie koncentracyjnym w Dachau więziono około 1400 polskich duchownych, z których 861 nie doczekało wyzwolenia. Masowych aresztowań kapłanów dokonano też na wschodzie. Wielu z nich zostało straconych lub wywiezionych do łagrów ${ }^{104}$. Wielkim autorytetem za postawę w okresie wojny cieszył się kardynał Adam Sapieha ${ }^{105}$. Udzielane przez duchownych wsparcie przybliżyło i spotęgowało uznanie w społeczeństwie. W uroczystościach kościelnych organizowanych po wojnie w dużych miastach, głównie w stolicy duchowej Polski - Częstochowie - kilkusettysięczne tłumy były regułą ${ }^{106}$. Komuniści nie mogli zatem cofnąc się przed najbardziej obłudnymi sposobami kamuflażu. Dobre stosunki z Kościołem miały rozwiać podejrzenia o sowietyzacji kraju. Władza przyjęła tzw. „taktykę salami - odcinania po plasterku”, mającą w efekcie

${ }^{102}$ A. Dudek, R. Gryz, Komuniści i Kościót..., s. 13.

${ }^{103}$ D. Thiriet, Marks czy Maryja? Komuniści i Jasna Góra wapogeum stalinizmu (1950-1956), Warszawa 2002, s. 19.

${ }^{104}$ J. Żaryn, Kościót w PRL..., s. 7-8; symbolem niezwykłego bohaterstwa i miłości do bliźniego stał się franciszkanin z Niepokalanowa św. Maksymilian Kolbe, który będąc więźniem w Auschwitz dobrowolnie oddał życie za Franciszka Gajowniczka. Szerzej zob. biografie m.in.: J. Domański, Ojciec Maksymilian Kolbe, Warszawa 1971; L. Dyczewski, Święty Maksymilian Maria Kolbe, Niepokalanów 1994; A. Wojtczak, Ojciec Maksymilian Maria Kolbe, t. 1-2, Niepokalanów 1989; papież Jan Paweł II w 1999 r. beatyfikował 108 męczenników czasów II wojny światowej.

${ }^{105}$ Potwierdza to w swoich wspomnieniach S. Świeżawski, W nowej rzeczywistości..., s. 22.

106 W. Lizak, Historia Polski..., s. 115. 
doprowadzić do powolnego i całkowitego przejęcia władzy ${ }^{107}$. Marginalizacja Kościoła w życiu publicznym miała nastąpić stopniowo, gdyż władze państwowe miały świadomość jego wielowiekowego złączenia z narodem. Poza tym katolicyzm w Polsce, jak pisał Kazimierz Koźniewski, był siłą, z którą należało się liczyć ${ }^{108}$.

Rozpoczęto jednocześnie poprzez akty prawne konsekwentnie zaplanowany proces laicyzacji życia społecznego, dążąc do rozdziału Kościoła od państwa. W 1945 r. zaczęto od spraw najważniejszych. Na początek zerwano 12 września konkordat zawarty jeszcze w 1925 r. Pretekstem do tego stało się mianowanie przez papieża w pierwszych miesiącach II wojny światowej Niemca - biskupa Karola Marię Spletta - administratorem apostolskim diecezji chełmińskiej ${ }^{109}$. Fakt ten potraktowano jako złamanie umów konkordatowych, w których zastrzeżono, że biskupem na terenie państwa polskiego może być mianowany tylko Polak ${ }^{110}$. Oskarżono zatem Stolicę Apostolską o jednostronne zerwanie umowy i uwolniono się od zobowiązań względem Kościoła. Drugim istotnym krokiem w przejmowaniu władzy nad życiem społecznym było wprowadzenie 25 IX 1945 r. obowiązkowych ślubów cywilnych z możliwością rozwodów ${ }^{111}$. Od początku powstania nowego państwa cała struktura Kościoła miała być pod kontrolą specjalnych urzędów. Wzorowano się przy tym na postępowaniu NKWD wobec Cerkwi prawosławnej ${ }^{112}$. Polityka państwa miała charakter

${ }^{107}$ J. Żaryn, Dzieje Kościoła katolickiego..., s. 64-65; J. Piasecka, Stosunki między Kościołem rzymskokatolickim i państwem w Polsce w latach 1944-1953. W: A. Kozłowska, T. Markiewicz, J. Piasecka, Stosunki między państwem a kościołem rzymskokatolickim w czasach PRL, pod red. A. Chojnowskiego i M. Kuli, Warszawa 1998, s. 13-14.

${ }^{108} \mathrm{~K}$. Koźniewski, Historia co tydzień: szkice o tygodnikach społeczno-kulturalnych 1944-1950, Warszawa 1977, s. 354.

${ }^{109}$ P. Raina, Stefan kardynał Wyszyński..., s. 202; Z. Zieliński, Kościół w Polsce 1944-2007, Poznań 2009, s. 49. Szerzej zob.: J. Żaryn, Kościót a władza w Polsce (1945-1950), Warszawa 1997, s. 63-79 rozdział pt. Zerwanie konkordatu z 1925 r. Geneza, cele i skutki (1945-1948).

${ }^{110}$ B. Cywiński, Ogniem próbowane..., s. 34; Stanowisko Watykanu napotkało na ostrą krytykę zarówno w Niemczech, jak i w Polsce. Biskupi niemieccy krytykowali papieża za pełnomocnictwa udzielone prymasowi A. Hlondowi, gdyż Kościół niemiecki liczył na utrzymanie prowincji wschodnich. Przebywało tam bowiem jeszcze wielu Niemców. Przywódcy PPS i PPR w Polsce stanowisko to uznali z kolei za proniemieckie i antypolskie. Efektem tych zarzutów było podjęcie 12 XI 1945 r. uchwały przez TRJN stwierdzającej, że konkordat zawarty pomiędzy Rzeczypospolitą Polską a Stolicą Apostolską w 1925 r. przestał obowiązywać w związku z naruszeniem go przez stronę kościelną (chodziło o decyzje z czasów wojny). W wyniku zerwania konkordatu władze rozpoczęły w Polsce działania zmierzające do wyparcia Kościoła z pozycji zajmowanych dotychczas w państwie i życiu społecznym. Źródło: L.B. Paszkiewicz, Sytuacja Kościoła katolickiego w Polsce w latach 1945-1948 w świetle londyńskiego „Jutra Polski”. Dostępny w World Wide Web http:// www.perspectiva.pl/perspectiva_LSTH_pdf/pdf/Paszkiewicz\%5Bs\%5D27.pdf [dostęp 5.01.2010].

${ }^{111}$ Z. Zieliński, Kościół w Polsce..., s. 49.

${ }^{112}$ Aparat bezpieczeństwa $w$ latach 1994-1956. Taktyka, strategia, metody, cz.1: Lata 1945-1947, oprac. A. Paczkowski, Warszawa 1994, s. 10-11. 
scentralizowany. Urzędy, szkoły i stowarzyszenia z założenia miały być ateistyczne. Wytyczne przychodziły odgórnie z Moskwy i obejmowały te same działania na terenie całego kraju, choć dostrzegalne były różnice w lokalnych realizacjach. Regionalną specyfikę można dostrzec w poszczególnych województwach ${ }^{113}$. Przykładowo w Łodzi w 1945 r. przy Wydziale V Wojewódzkiego Urzędu Bezpieczeństwa Publicznego powstała Sekcja V zajmująca się tzw. obsługą duchowieństwa, którą w 1953 r. przekształcono w Wydział XI, a następnie w Wydział VI. Ich zadaniem była pełna inwigilacja duchowieństwa. Kontrolowano treść kazań, wszelkich wystąpień publicznych, zawartość prasy katolickiej, w pełni ewidencjonowano działalność czytelni, redakcji, drukarni, organizacji i stowarzyszeń katolickich, interesowano się życiem prywatnym stosując prowokacje, podsłuchy telefoniczne i pokojowe, pozyskując księży do współpracy i tworząc podziały ${ }^{114}$. Obszar Kielecczyzny miał być wedle założeń terenem wzorcowym i eksperymentalnym dla komunistów w próbie sił z Kościołem ${ }^{115}$. Pierwotnie w strukturach resortu bezpieczeństwa nie było wyspecjalizowanej komórki zajmującej się sprawami wyznań. Do 1949 r. nadzór

${ }^{113}$ Sytuację w nich przedstawiają m.in. S. Bogdanowicz, Kościół gdański pod rządami komunizmu 1945-1984, Gdańsk 2000; A. Grajewski, Wygnanie. Diecezja katowicka w czasach stalinowskich, Katowice 2002; R. Gryz, Państwo a Kościót w Polsce w 1945-1956 na przykładzie województwa kieleckiego, Kraków 1999; J. Kopiec, Polityka ludowego państwa wobec Kościoła katolickiego na Ślasku Opolskim w latach 1945-1972. W: Spoteczeństwo, państwo, Kościót (1945-2000)...; A. Kopiczko, Stosunki państwo - Kościót w diecezji warmińskiej w latach 1945-1990, Olsztyn 1994; M. Mikołajczyk, Władza Ludowa a Diecezja Częstochowska, Częstochowa 2000; K. Kowalczyk, $W$ walce o ,rząd dusz”. Polityka władz państwowych wobec Kościoła katolickiego na Pomorzu Zachodnim w latach 1945-1956, Szczecin 2003; J. Myszor, Historia diecezji katowickiej, Katowice 1999; M. Ordyłowski, Polityka lokalnych władz PRL wobec Kościoła katolickiego na Dolnym Śląsku w latach 1945-1979. W: Stefan Kardynał Wyszyński wobec Ziem Zachodnich i Pólnocnych oraz stosunków polsko-niemieckich. W 100-lecie urodzin Prymasa Tysiaclecia, pod red. T. Dzwonkowskiego i C. Osękowskiego, Warszawa [i in.] 2001, s. 94-118; J. Stefaniak, Ze studiów nad stosunkami państwo-Kościól w woj. lubelskim w latach 1945-1953, „Annales Universitatis Mariae Curie-Skłodowska Lublin-Polonia” 2001 vol. 56 sectio F s. 181-209.

${ }^{114}$ J. Żelazko, Antykościelne struktury $i$ kierunki działania Wojewódzkiego Urzędu Bezpieczeństwa Publicznego (Wojewódzkiego Urzędu do spraw Bezpieczeństwa Publicznego) w Łodzi. W: Władze komunistyczne wobec Kościoła katolickiego w Lódzkiem 1945-1967, pod red. J. Wróbla i L. Próchniaka, Warszawa 2005, s. 35-48; R. Peterman, Dziatalność aparatu bezpieczeństwa wobec Kościoła rzymskokatolickiego w Łódzkiem w latach 1945-1956. Tamże, s. 49-53; szerzej zob. M. Przybysz, Kościół rzymskokatolicki w Łodzi w latach 1945-1956, Łódź 2007.

${ }^{115}$ O tym wspominał prymas S. Wyszyński, pisząc: „Wieczorem, o godzinie 19.00 zgłosił się biskup Sonik z Kielc i przedstawił mi przebieg ostatnich aresztowań w Kielcach i czterokrotne rewizje w katedrze. W czasie tych rewizji naruszono płytę grobowca i złamano ją. Rewizje odbywały się bez świadków. Pomimo oświadczenia pana Mazura, że nie idzie tu o sprawy polityczne, tylko karne, cała sprawa robi wrażenie planowego rozprzęgania diecezji. Kielce są polem doświadczalnym dla pracy w innych diecezjach. Postanowiłem wystąpić w sprawie Kielc z listem do Pana Prezydenta RP”. Źródło: S. Wyszyński, Pro memoria ... s. 71. 
nad strukturami polskiego Kościoła sprawował V Departament Ministerstwa Administracji Publicznej ${ }^{116}$.

Komuniści wykazywali ,instrumentalny i prymitywny stosunek do społecznej roli Kościoła, widząc w nim tylko rodzaj reakcyjnej partii politycznej”"117. Hierarchowie zaś, przyjmując postawę rezerwy wobec władz, jednocześnie starali się nie pogarszać sytuacji, pozostając otwarci wobec gestów pojednawczych. Niestety, czysto ideologiczne podejście ze strony rządowej oraz kolejne fakty historyczne świadczyły o niemożności jakiegokolwiek porozumienia. Nawet jeżeli do niego dochodziło „na papierze”, to nie było przestrzegane ze strony państwa. Wyznawcy ideologii komunistycznej, deklarując wolność sumienia i wyznania, jednocześnie prowadzili antykościelną działalność. Posługiwali się przy tym sprawdzonymi metodami sowieckimi. Dążąc do podważenia autorytetu Kościoła, inicjowano rozbijanie środowiska duchownych i świeckich katolików od środka, wykorzystując nieporozumienia i słabości. Mocnym uderzeniem w hierarchię były również propagandowe nagonki prasowe skierowane przeciw papieżowi, Stolicy Apostolskiej i polskim duchownym. Chciano bowiem wpierw oderwać polski Kościół od Watykanu, a następnie naruszyć jego wewnętrzną strukturę. Poważnym atakiem na prymasa A. Hlonda i ordynariusza kieleckiego biskupa Czesława Kaczmarka była akcja tzw. pogromu kieleckiego, w której oskarżono hierarchię kościelną o dokonanie morderstwa Żydów. Akcja miała miejsce bezpośrednio po sfałszowanym referendum w 1946 r. i chodziło bardziej o odwrócenie uwagi polskiej i międzynarodowej opinii publicznej. Władze kościelne odcięte od dostępu do prasy partyjnej mogły bronić się jedynie pisaniem listów pasterskich, komunikatów i pism protestujących kierowanych do władz, po których należało spodziewać się kolejnych represji. W liście z 15 IX 1946 r., wysłanym do przewodniczącego Krajowej Rady Narodowej, biskup Z. Choromański protestował przeciw zwalczaniu Kościoła przez zerwanie konkordatu, wprowadzenie nowego prawa małżeńskiego, zakaz tworzenia organizacji katolickich oraz laicyzację życia publicznego. Skargi często dotyczyły także antykościelnych restrykcji władz lokalnych. Broniąc się przed zaplanowaną dezinformacją, w celu dostarczania kuriom diecezjalnym bieżących i rzetelnych informacji dotyczących spraw duchowieństwa biskupi powołali Biuro Sekretarza Episkopatu Polski na czele z biskupem Z. Choromańskim ${ }^{118}$.

${ }^{116}$ Po zawarciu Porozumienia w 1950 r. powstał Urząd do Spaw Wyznań, a od 9 I 1953 r. Departament XI Ministerstwa Bezpieczeństwa Publicznego ds. walki z wrogą działalnością w związkach wyznaniowych i organizacjach z nimi związanych. Źródło: H. Dominiczak, Organy bezpieczeństwa PRL w walce... s. 45; W.J. Wysocki, Osaczanie Prymasa. Kardynat Stefan Wyszyński jako „podopieczny” aparatu bezpieczeństwa w latach 1953-1956, Warszawa 2002, s. 7.

${ }^{117}$ A. Dudek, R. Gryz, Komuniści i Kościół..., s. 18.

${ }^{118}$ Biskup Choromański był współpracownikiem prymasa A. Hlonda, a następnie S. Wyszyńskiego w trudnych sprawach Kościoła z władzą. Źródło: A. Dudek, R. Gryz, Komuniści i Kościół..., s. 18-21. 
Stronnictwo Pracy, będące jedyną legalną partią polityczną odwołującą się wprost do nauki społecznej Kościoła i reprezentującą środowiska katolickie, rozpadło się w połowie 1946 r. na skutek wewnętrznego rozłamu między chadecką grupą Karola Popiela a sprzyjającą PPR frakcją Feliksa Widy-Wirskiego. Zabrakło zatem w Polsce stronnictwa politycznego, które by walczyło o interesy środowisk kościelnych ${ }^{119}$. Stanowisko Kościoła wobec nowych wydarzeń politycznych wyrażone zostało w Orędziu Episkopatu Polski w sprawie wyborów do sejmu. Orędzia w prasie ogólnopolskiej nie opublikowano, ukazały się jedynie omówienia i streszczenia. Przed wyborami doszło do kilku spotkań biskupa Z. Choromańskiego z Władysławem Wolskim, na których strona komunistyczna w przyjemnej atmosferze bez konkretnych decyzji pozorowała zainteresowanie przyszłym modus vivendi między państwem a Kościołem. Sekretarz Episkopatu starał się wyegzekwować u władz prawo do swobodnych kontaktów ze Stolicą Apostolską, wprowadzenie obowiązkowej religii w szkołach, możliwość wydawania prasy katolickiej, zakładania organizacji katolickich, szkół wyznaniowych, zagwarantowanie nienaruszalności ziemskich majątków kościelnych, uznanie prawne przedwojennych instytucji kościelnych. Komuniści jednak nie mieli zamiaru iść na ustępstwa, stosowali jedynie propagandę przedwyborczą ${ }^{120}$.

Zapowiedzią zwrotu w polityce władz wobec Kościoła było wystąpienie pułkownik Julii Brystygierowej, dyrektora Departamentu V Ministerstwa Bezpieczeństwa Publicznego (MBP), na kwietniowym plenum KC PPR w 1947 r. Przedstawiając stanowisko kierownictwa partyjnego oskarżyła Kościół o prowadzenie działalności antykomunistycznej ${ }^{121}$. W dokumencie Uwagi w sprawie Kościoła rzymskokatolickiego $w$ Polsce zawarto projekt założeń polityki wyznaniowej państwa. Uznano w nim Kościół za wrogą siłę, „bastion tradycji i kultury polskiej” oraz naturalne źródło opozycji światopoglądowej i najpotężniejszą siłę reakcyjną ${ }^{122}$. Rozpoczynając otwartą walkę z Kościołem rozbudowano pion MBP i ogniwa Informacji Wojskowej. Od jesieni 1947 r. zaczął obowiązywać również specjalny program V Departamentu, mający na celu podział w środowisku duchownych na „pozytywnych i wrogich” czy „postępowych i reakcyjnych”. Przystąpiono również do dokonania rozłamu wśród katolików świeckich ${ }^{123}$. Konsekwentnie realizując plan

${ }^{119}$ Z propozycji sekretarza generalnego CKW PPS Józefa Cyrankiewicza i wiceministra administracji publicznej Władysława Wolskiego doszło do spotkania, na którym miano utworzyć niezależną partię katolicką. Udział w nim wzięli członkowie popielowskiej części SP oraz środowiska skupione wokół „Tygodnika Warszawskiego”, „Tygodnika Powszechnego”, „Dziś i Jutro” oraz „Odry”. Przy początkowej aprobacie prymasa A. Hlonda co do powstania takiej partii ostatecznie po spotkaniu 26 października i naradzie Komisji Głównej Episkopatu prymas ogłosił désintéressment Kościoła wobec tej inicjatywy. Źródło: A. Dudek, R. Gryz, Komuniści i Kościót ..., s. 21-24.

120 Tamże.

${ }^{121}$ Wielka historia Polski..., s. 113.

${ }^{122}$ A. Dudek, R. Gryz, Komuniści i Kościót..., s. 28-29.

${ }^{123}$ B. Fijałkowska, Partia wobec religii..., s. 78. 
zakładano teczki agenturalne. Z roku na rok wzrastała liczba aresztowanych i oskarżanych w procesach pokazowych księży. Głośnym echem odbiło się zamknięcie w 1948 r. „Tygodnika Warszawskiego” i aresztowanie ks. Zygmunta Kaczyńskiego wraz z redakcją pisma. Za udzielanie schronienia poszukiwanym sądzono również zakonnice. Zaczęto odbierać prawa państwowe szkołom kościelnym i zakonnym, likwidując wiele placówek. Utrudniano działalność kaznodziejską. Cenzurze poddano wszystkie druki kościelne. Opierając się rzekomo na prawie wolności sumienia i wyznania, powoli zaczęto ograniczać i podważać sens lekcji religii w szkołach. Zadecydowano o fakultatywnym ich charakterze jedynie na prośbę rodziców. Starano się ze szkół publicznych wyrzucić siostry katechetki oraz księży prefektów, oskarżanych, dzięki donosom, o przeciwstawianie się władzy „ludowej” w czasie lekcji. Od jesieni 1947 r. powstawały też szkoły ateistyczne Robotniczego lub Chłopskiego Towarzystwa Przyjaciół Dzieci (od 1949 r. zjednoczone w TPD, finansowane z budżetu Ministerstwa Oświaty). Nauczanie religii ze szkół eliminowano coraz częściej bez zgody rodziców ${ }^{124}$.

W następstwie tych działań relacje państwa z Kościołem w Polsce od drugiej połowy 1947 r. zaczęły ulegać znacznemu pogorszeniu. Dostrzegając wrogą politykę rządu, biskupi ocenili politykę państwa wobec Kościoła na Konferencji Plenarnej Episkopatu w dniach 5-7 IX 1947 r. Przede wszystkim zwrócili uwagę na walkę z religią, ograniczanie papieru na prasę katolicką i uniemożliwianie polemiki prasowej z organami partyjnymi oraz przymus wstępowania do partii. Przedstawiciele Kościoła zaprotestowali przeciwko ograniczeniom samorządności i praw katolików w liście pasterskim z 8 IX 1947 r. Odpowiedzią Biura Politycznego KC PPR było przesłuchanie przez funkcjonariuszy Urzędu Bezpieczeństwa (UB) ponad 400 księży, których zmuszano do podpisania „lojalki" odcinającej się od treści listu. Zaostrzono znów cenzurę prasy katolickiej i zlikwidowano jakikolwiek dostęp do źródeł papieru, wstrzymano dotacje państwowe na odbudowę zabytkowych kościołów, nie zapomniano też o ograniczeniu nabożeństw podczas uroczystości oraz ich transmisji przez radio. Ingerowano także w działalność wszystkich zrzeszeń religijnych ${ }^{125}$.

Przed wyborami w 1947 r. Episkopat wydał 10 IX 1946 r. wspomniane już orędzie; przypomniano w nim prawo katolików do aktywnego uczestnictwa w życiu politycznym. Zaznaczono, że nie mogą należeć do organizacji i partii, ani głosować na kandydatów, których zasady są sprzeczne z katolicką nauką społeczną. Zobowiązywano jednocześnie do głosowania. Apel był wyrazem bezkompromisowości wobec komunizmu. Sfałszowane styczniowe wybory 1947 r. pozwoliły ogłosić zwycięstwo nad opozycją i zamknęły czteroletni okres symulacji

${ }^{124}$ Z. Zieliński, Kościót w Polsce..., s. 60-61; J. Żaryn, Dzieje Kościoła katolickiego..., s. $90-93$.

${ }^{125}$ J. Żaryn, Dzieje Kościoła katolickiego ..., s. 91, przypis 117; A. Dudek, R. Gryz, Komuniści i Kościół..., s. 27-28. 
w odniesieniu do Kościoła. W wyniku amnestii ogłoszonej 25 II 1947 r. ujawniło się ponad 20 kapłanów, co posłużyło do dalszego rozpracowywania agenturalnego. Podczas walki z podziemiem niepodległościowym aresztowanymi byli również księża kapelani AK i pomagający w jakikolwiek sposób „żołnierzom wyklętym”, „ludziom leśnym” i „bandom”. Plebania stawała się często miejscem przechowywania archiwum oddziału i ostatnim schronieniem przed UB. Księży skazywano najczęściej na karę śmierci, przedstawiając procesy sądowe i wyroki jako obronę przed reakcyjnym podziemiem. Biskupi czynnie wstawiali się za oskarżonymi kapłanami, jednocześnie zakazując duchowieństwu pozaduszpasterskiego angażowania się w działalność podziemną. Funkcjonariusze UB zbierali materiały operacyjne o księżach związanych z opozycją w czasie wojny i odważnie wypowiadających się z ambon ${ }^{126}$.

O ile w pierwszych latach powojennych inicjowano spotkania przedstawicieli rządu z przedstawicielami Kościoła, to od 1948 r. strona partyjno-rządowa nie była już zainteresowana „całościowymi rozmowami” ${ }^{127}$. Władze komunistyczne rozpoczęły zdecydowane działania, nasilając stopniowo represje. Prowadzono je dwutorowo, przejmując kontrolę nad całym życiem publicznym oraz wnikając do wnętrza struktury kościelnej. Posługiwano się przy tym ustawami, dekretami i aktami prawno-administracyjnymi jak też ukrytym i jawnym terrorem ${ }^{128}$. Stosując taktykę psychologiczną, strona rządowa usiłowała przekonać polskie społeczeństwo, że to państwo broniło się przed agresorem - Kościołem.

Propagandowo zaogniono również konflikt państwa z Kościołem, przesadnie przedstawiając rzekomo antypolskie stanowisko Stolicy Apostolskiej wobec Ziem Zachodnich i Północnych. Warto wspomnieć, że wielką akcję propagandową przeciw papieżowi Piusowi XII rozpoczęły władze sowieckie już w latach 1945-1946. Wykorzystały w tym celu zachodnich komunistów, niektórych intelektualistów i przedstawicieli różnych środowisk. Była to akcja długotrwała. Komuniści polscy realizowali zatem część ogólnego planu. Jednocześnie poprzez antypapieską ofensywę w prasie nagłaśniali „proniemieckie” nastawienie Piusa XII, chcąc siać przysłowiowy ferment w obozie katolickim. Przedstawiano Stolicę Apostolską jako „zajadłego wroga rewolucji” i ,antypolską siłę”, nazywając papieża „agentem posiadaczy i wielkiego kapitału". Prymas A. Hlond w odpowiedzi na atak na głowę Kościoła wydał 24 V 1948 r. orędzie ${ }^{129}$.

W latach 1945-1948 następowało powolne umacnianie się władzy, skoncentrowanej w rękach PPR, wspieranej przez Stronnictwo Ludowe i Stronnictwo

${ }^{126}$ Z. Zieliński, Kościót w Polsce 1944-2002..., s. 61; J. Żaryn, Dzieje Kościoła katolickiego..., s. 58-59.

${ }_{127}$ J. Żaryn, Kościół a władza w Polsce (1945-1950), Warszawa 1997, s. 55.

128 Tenże, Dzieje Kościoła katolickiego..., s. 88.

129 Opublikowano je w „Tygodniku Powszechnym” 1948 nr 25 s. 1; A. Dudek, R. Gryz, Komuniści i Kościót..., s. 32-35; D. Thiriet, Marks czy Maryja? ..., s. 100. 
Demokratyczne. Należący do PPS przechodzili coraz częściej na pozycje jawnie komunistyczne, co ostatecznie doprowadziło w grudniu 1948 r. do połączenia PPR i PPS w PZPR. Kościół pozostał wtedy jedyną strukturą społeczną niepodporządkowaną partii ${ }^{130}$. Rok 1948 obfitował w różne trudne wydarzenia. Dnia 22 X 1948 r. zmarł nagle prymas August Hlond, którego posługę tak podsumował Janusz Zabłocki: „W czasach prymasa Hlonda Kościół w Polsce był bastionem przynajmniej w sferze duchowej - oporu przeciw nowej, komunistycznej władzy, a jego postawa podtrzymywała naród"131. Jego pogrzeb stał się narodową manifestacją. Ks. Zygmunt Zieliński nazwał lata 1945-1948 „czasem fikcji i pozorów” stwarzanych przez nową władzęę ${ }^{132}$. Przejawiło się to głównie w szukaniu porozumienia i tworzeniu pozornego klimatu swobód demokratycznych po to tylko, aby w ostateczności zaatakować Kościół. Zderzyły się dwa światopoglądy: materialistyczny oparty na poglądach Karola Marksa i Fryderyka Engelsa oraz chrześcijański, mający źródło w Ewangelii i nauce społecznej Kościoła. „Około tych dwóch światopoglądów skupiają się dziś ludy kontynentu europejskiego. Są to grupy życiowo pomieszane, myślowo bardzo oddzielone. Inaczej pojmują człowieka i drogi rozwoju ludzkości chrześcijanie, inaczej materialiści” mówił ks. prymas August Hlond podczas święta Chrystusa Króla 28 X 1945 r. w Poznaniu ${ }^{133}$.

\subsubsection{Organizacja Kościoła i pierwsze prawne ograniczenia}

Kościół katolicki, zarówno kapłani jak i wierni, wyszedł z II wojny światowej mocno okaleczony ${ }^{134}$. Duchowieństwo poniosło wiele strat, w wyniku czego brakowało posługujących kapłanów, a większość świątyń została zniszczona. Sprawy duszpasterskie były najbardziej naglące. Wpierw należało zatroszczyć się o zorganizowanie parafii, odbudowanie świątyń i rozpoczęcie katechezy. W latach czterdziestych największego wysiłku wymagało zorganizowanie życia religijnego na Ziemiach Zachodnich i Północnych, gdyż na tych terenach najbardziej odczuwalne były braki kadrowe. Najpilniejszym zadaniem było mianowanie administratorów apostolskich. Pracę na tych ziemiach dodatkowo utrudniały konflikty polsko-niemieckie. W całej Polsce należało przywrócić prasę diecezjalną oraz reaktywować Caritas. Utworzenie Biura Sekretariatu Episkopatu również było sprawą niecierpiącą zwłoki. Budynki zakonne wymagały odrestaurowania, podobnie była potrzebna odbudowa domów dziecka i opieki nad samotnymi matkami oraz

${ }^{130}$ Z. Zieliński, Kościół w Polsce 1944-2002 ..., s. 64-67.

${ }^{131}$ J. Zabłocki, Prymas Stefan Wyszyński..., s. 44.

${ }^{132}$ Z. Zieliński, Kościót w kręgu rzeczywistości politycznej, Lublin 2003, s. 168.

${ }^{133}$ A. Hlond, Chrześcijaństwo czy materializm, „,Tygodnik Warszawski” 1945 nr 4 s. 1.

${ }^{134}$ Szerzej zob.: Z. Fijałkowski, Kościót katolicki na ziemiach polskich w latach okupacji hitlerowskiej, Warszawa 1983; W.J. Wysocki, Bóg na nieludzkiej ziemi. Życie religijne w hitlerowskich obozach koncentracyjnych (Oświęcim, Majdanek, Stutthof), Warszawa 1999. 
szkół zakonnych. Przy reaktywowaniu i organizowaniu placówek kościelnych szukano wsparcia finansowego na Zachodzie. Oprócz działalności edukacyjnej zakonnicy organizowali w ramach Caritasu żłobki, przedszkola, domy dziecka, internaty, bursy, stołówki. Przy zakonach zaczęły też funkcjonować szpitale. Zakonnicy pracowali również w świetlicach dworcowych i więzieniach, podjęli działalność duszpasterską wśród młodzieży harcerskiej i akademickiej. Starano się nie zaniedbywać także działalności wydawniczej ${ }^{135}$.

Podstawę prawną organizacji Kościoła bezpośrednio po wojnie stanowiły: kodeks prawa kanonicznego z 1917 r., konkordat podpisany przez Stolicę Apostolską z rządem Drugiej Rzeczypospolitej w lutym 1925 r. oraz pełnomocnictwa nadane przez papieża ordynariuszom i administratorom w czasie wojny. Wstępne postanowienia odnośnie do spraw kościelnych podjęto na pierwszej powojennej konferencji Episkopatu Polski pod przewodnictwem metropolity krakowskiego Adama Sapiehy ${ }^{136}$, która odbyła się w dniach 26-27 VI 1945 r. w Częstochowie ${ }^{137}$.

W sprawach zasadniczych funkcjonowania Kościoła, jego odbudowy i ustosunkowania się do władzy oczekiwano powrotu prymasa A. Hlonda przebywającego za granicą ${ }^{138}$. Prymas wrócił do kraju posiadając specjalne uprawienia

${ }^{135}$ B. Cywiński, Ogniem próbowane..., s. 32; W latach 1945-1952 odbudowano i odrestaurowano 252 świątynie, 98 zbudowano od podstaw i postawiono 334 budynki gospodarcze. W 1952 r. w trakcie budowy było kolejnych 325 świątyń. Niezwykle pomocna stała się społeczna Rada Prymasowska Odbudowy Kościołów Warszawy, która objęła opieką 55 zabytkowych świątyń stolicy. Źródło: J. Żaryn, Dzieje Kościoła katolickiego..., s. 56, 76-8; J. Zabłocki, Prymas Stefan Wyszyński..., s. 39; Zgon i pogrzeb ks. Kardynała dr. Augusta Hlonda, [album].

${ }^{136}$ Szerzej o działalności kardynała A. Sapiehy zob. Księga Sapieżyńska, pod. red. J. Wolnego, t. 1-2, Kraków 1982-1986.

${ }^{137}$ J. Żaryn, Kościół a władza w Polsce..., s. 18-19, 55; B. Cywiński, Ogniem próbowane..., s. 33.

${ }^{138}$ August Hlond (1881-1948) - salezjanin, studiował w Rzymie i Krakowie, gdzie przyjął święcenia (1905). Przełożony domu zakonnego w Przemyślu i Wiedniu, inspektor prowincji austro-węgierskiej zgromadzenia. Od 1922 r. mianowany administratorem apostolskim Górnego Śląska. Był pierwszym biskupem katowickim (1925), od 1926 r. arcybiskupem metropolitą Gniezna i Poznania oraz prymasem Polski. Założyciel tygodnika „Gość Niedzielny”. Kapelusz kardynalski otrzymał w 1927 r. Przeprowadził I Synod Plenarny na Jasnej Górze (1936), koronował liczne obrazy Matki Bożej, m.in. w Ostrej Bramie w Wilnie (1927). Po rozpoczęciu działań wojennych przedstawiciele rządu polskiego, z obawy przed aresztowaniem prymasa przez Niemców, polecili mu opuścić kraj. Kardynał Hlond wyjechał 14 IX 1939 r. udając się wraz z rządem w kierunku Bukaresztu. Stamtąd przedostał się do Rzymu (przebywał tam do czerwca 1940 r.), a następnie do Francji. Wpierw był w Lourdes a potem Hautecombe, gdzie został aresztowany przez Niemców 3 II 1944 r. Przewieziony do Paryża został następnie internowany w Bar-le-Duc, po czym przebywał w klasztorze w Wiedenburch w Westfalii. Uwolniony został przez Amerykanów 1 IV 1945 r. Po krótkim pobycie w Paryżu i Rzymie powrócił z emigracji do siedziby prymasowskiej w Poznaniu. Jego powrót do kraju miał istotne znaczenie i utrudniał dążenia komunistów. Źródło: P. Nitecki, Biskupi Kościoła w Polsce. Stownik biograficzny, Warszawa 1992, s. 80; B. Fijałkowska, Partia wobec religii i Kościoła..., s. 22. Szerzej o jego życiu i działalności zob. Acta Hlondiana. Materiały do życia i działalności kardynała Augusta Hlonda Prymasa Polski, oprac. S. Kosiński, t. 5, Ląd 
(facultates specialae) nadane przez Świętą Kongregację dla Nadzwyczajnych Spraw Kościelnych (takie same kompetencje posiadał też Adam Sapieha) ${ }^{139}$. Na ich podstawie w okresie 1945-1946 przeprowadził reorganizację i uporządkowanie struktur Kościoła katolickiego na przyłączonych terenach zachodnich oraz wschodnich nienależących już do Polski. Nominował pięciu administratorów apostolskich, obsadził diecezje, zadbał o powstanie kurii, odbudowywanie świątyń i przejmowanie budynków kościelnych. Proces scalania ziem odbywał się w bardzo utrudnionych warunkach. Panował bowiem ogólny chaos, trwały aresztowania duchownych przez NKWD na obszarach wschodnich, wysyłano ich do łagrów, a księża niemieccy sprzeciwiali się zaistniałej sytuacji ${ }^{140}$. Władze lokalne odmawiały zwrotu Kościołowi budynków przejętych w czasie okupacji przez Niemców, np. domów katolickich, szkół, placów i innych nieruchomości. Na Ziemiach Odzyskanych negowano w ogóle prawo do mienia kościelnego, nie wyłączając budynków sakralnych. Dopomogły temu postanowienia Ministerstwa Ziem Odzyskanych z 15 VII 1946 r. oraz Rady Ministrów z 25 VII 1946 r., zatwierdzone przez KRN we wrześniu. Ponadto nowa władza nie pozwalała polskim biskupom swobodnie kontaktować się ze Stolicą Apostolską ${ }^{14}$.

W tym okresie dokonywała się także dramatyczna migracja ludów. Wysiedlenia ludności niemieckiej z terenów przyznanych Polsce w Jałcie (ziemie

k. Kalisza 1970; Kardynat August Hlond. W stużbie Boga i Ojczyzny, oprac. S. Kosiński, Warszawa 1988; S. Zimniak, „Dusza wybrana”. Rys salezjańskich korzeni myślenia i działania kardynała Augusta Hlonda Prymasa Polski (1881-1948), Rzym- Warszawa 2000.

${ }^{139} \mathrm{~W}$ okresie powojennym kontakty Stolicy Apostolskiej z władzami kościelnymi w Polsce były utrudnione. Wiedza na temat sytuacji Kościoła była niewystarczająca. Ziemie polskie zajęte przez Armię Czerwoną zostały potraktowane przez Watykan jak obszar objęty nadal działaniami wojennymi. Papież utrzymał zatem w mocy uprawnienia nadane biskupom w czasie wojny; Prymas przyjechał 21 VII 1945 r. (inne źródła podają datę 20 lipca, np. S. Zimniak, „Dusza wybrana”..., s. 123 i M. Fik, Kultura polska po Jatcie: kronika lat 1944-1981, Londyn 1989, s. 39) ,[...] nie odwiedzając Warszawy i nie przedstawiając się członkom rządu polskiego. Nie złożył też wizyty przedstawicielom wojewódzkich organów władzy, ograniczając się tylko do zawiadomienia ich na piśmie o swoim przyjeździe [...]". Dnia 22 VII 1945 r. o godz. 9 rano odprawił uroczystą mszę św. w poznańskiej katedrze. W tym dniu o godz. 10 rano rząd i władze lokalne zorganizowały wiec z okazji rocznicy opublikowania manifestu PKWN. Mieszkańcy Poznania musieli zatem wybrać między pójściem na wiec a obecnością na mszy. Liczba ludności zebranej w kościele była kilka razy większa niż liczba uczestników wiecu (ok. 15 tys., podczas gdy na wiecu 3 tys.). Źródło: B. Fijałkowska, Partia wobec religii i Kościoła..., s. 22-23.

${ }^{140}$ Kardynał August Hlond uważany za „nacjonalistę” (J. Żaryn) stał się przysłowiowym „kozłem ofiarnym” wielu niemieckich publikacji, które traktowały los Kościoła niemieckiego na Ziemiach Zachodnich i Północnych w oderwaniu od rzeczywistości politycznej. Zob. Z. Zieliński, Między rzeczywistościa a legendą. Na marginesie ksiązki Franza Scholza pt. „,Zwischen Staatsräson und Evangelium. Cardinal Hlond und die Tragödie der ostdeutchen Diözesen”, „Więź” 1989 nr 6 s. 73-90.

${ }^{141}$ Tenże, Kościót w Polsce 1944-2002 ..., s. 57; J. Żaryn, Kościót a władza w Polsce ..., s. 30, $38-46,54$. 
zachodnie i północne nazywano „darem Stalina”) występowały równolegle z tworzeniem polskich struktur kościelnych na tym obszarze. Prymas August Hlond działał energicznie, spiesząc się, aby nie pozostawić sytuacji status quo komunistom. Akt nominacji administratorów apostolskich został ostro skrytykowany przez władze jako „reakcyjna działalność kleru”. Była to zapewne odpowiedź władz na wcześniejszą decyzję wstrzymania się papieża Piusa XII z uznaniem rządu powstałego w wyniku układów z Teheranu i Jałty. Watykan wielokrotnie wyrażał opinię, że o systemach rządów w poszczególnych państwach powinny decydować ich narody ${ }^{142}$.

Pius XII mianował prymasa A. Hlonda metropolitą warszawskim, rozwiązując tym samym unię personalną Gniezna i Poznania, funkcjonującą na mocy bulli De salute animarum z 1821 r. Po nadaniu godności kardynalskiej Adamowi Sapieże podzielono odpowiedzialność za życie Kościoła w Polsce między obu dostojników decyzją z 30 III 1946 r. Kardynał książę Sapieha był pełnomocnikiem na obszarze prowincji krakowskiej i lwowskiej, natomiast kardynał prymas na pozostałej części terytorium Rzeczypospolitej ${ }^{143}$.

Podsumowując, należy zaznaczyć, że nowe ustawy i akty administracyjne (w niektórych przypadkach wyroki sądowe) miały na celu naruszenie życia wewnętrznego Kościoła. Dotyczyły m.in. ograniczenia jego praw majątkowych, działalności zakonów, usunięcia symboli religijnych ze szkolnictwa i innych instytucji życia publicznego. Starano się też uniemożliwiać działalność dobroczynną przez przejęcie bazy lokalowej i organizacji, uzyskać wpływ na obsadzanie stanowisk kościelnych, ograniczać wydawanie prasy katolickiej ${ }^{144}$.

\subsection{3. Światopogląd katolicki a marksistowski}

Norman Davies trafnie spostrzegł, że „naczelną troską Kościoła rzymskokatolickiego w Polsce - jak w każdym innym kraju - było zawsze leczenie ludzkich dusz” ${ }^{145}$. Dalej czytamy: „Byłoby [...] rzeczą bezpodstawną twierdzić, że sprawy Kościoła da się w ogóle skutecznie oddzielić od świeckiego świata, w którym się one toczą. [...] Kościół rzymskokatolicki zawsze stanowił

${ }^{142}$ Z. Zieliński, Kościół w Polsce 1944-2002..., s. 35-36, 45, 56. J. Żaryn, Kościół a wła$d z a$ w Polsce..., s. 30, 38-46, 54; Zob. J. Nowak [Z. Jeziorański], Walka z Kościołem w Polsce 1945-1951, maszynopis w Archiwum Radia Wolna Europa, s. 17-18. Za B. Cywiński, Ogniem próbowane..., s. 34, przypis 20.

${ }^{143}$ J. Żaryn, Kościół a władza w Polsce..., s. 30, 38-46, 54, 57.

${ }^{144}$ J. Krukowski, Stanowisko księdza prymasa S. Wyszyńskiego w sprawie normalizacji sytuacji prawnej Kościoła w Polsce, „Kościół i Prawo”, t. 4, Lublin 1985, s. 15; J. Godlewski, Kościót rzymskokatolicki w Polsce wobec sekularyzacji życia publicznego (1944-1974), Warszawa 1978.

${ }^{145}$ N. Davies, Boże igrzysko..., s. 266. 
część świata polskiej polityki, bez względu na to, czy się to komuś podoba czy nie” ${ }^{146}$. Jan Żaryn pisał natomiast: „Władza w Kościele - wspólnocie (a nie nad Kościołem), która ma pochodzenie boskie i ludzkie, jest rozumiana jako poszerzające się (od proboszcza przez biskupa po papieża) pole zadań, a więc obowiązków do spełnienia"147. Fenomen Kościoła katolickiego w dziejach powszechnych i jego ogromną rolę w historii Polski w czasach niewoli dostrzegł Wojciech Lizak, podkreślając fakt przejmowania funkcji nieistniejącego państwa i starania ochrony polskiej kultury ${ }^{148}$.

Zgodnie z katolicką doktryną społeczną Kościół jest posłany do głoszenia ewangelii ludziom żyjącym we wszystkich ustrojach oraz w każdych warunkach społecznych i politycznych ${ }^{149}$. Źródło nauczania społecznego tkwi w Piśmie świętym i nauczaniu Ojców Kościoła. Rozróżnia się nurt oficjalny, reprezentowany przez hierarchię kościelną ze Stolicą Apostolską na czele (encykliki, listy, adhortacje, orędzia itp.), oraz prywatny, na który składają się dzieła uczonych katolickich $^{150}$. Kościół pełniąc posłannictwo stróża moralności głosi naukę o godności człowieka, jego powołaniu społecznym i nadprzyrodzonym. Propaguje zasady współżycia społecznego zgodnie z etyką chrześcijańską. Pomimo że jego bezpośrednim zadaniem nie jest angażowanie się w sprawy społeczno-polityczne, to ze względu na błędne założenia wielu doktryn ustrojowych zajmował wobec nich odpowiednie stanowisko. Magisterium Kościoła, realizując zatem zasady dobra wspólnego, solidarności i miłości społecznej, pomocniczości, zależności jednostki od społeczeństwa, solidaryzmu społecznego, wypowiada się w kwestiach społecznych. Encykliki ogłoszone przez papieży służyły uporządkowaniu poglądów chrześcijańskich wobec państwa i ustroju, np. w Diuturnum illud (1881) znalazło się stanowisko dotyczące pochodzenia władzy państwowej od Boga jako najwyższego autorytetu, w Immortale Dei (1885) Leon XIII wyraźnie rozgraniczył władzę doczesną państwa od nadprzyrodzonej danej Kościołowi, podkreślając jego misję ewangelizacyjną różną od politycznej. Pogląd o ponadpartyjności powtórzyła encyklika Libertas (1888). Napisano w niej, że Kościół może współpracować $\mathrm{z}$ ustrojami szanującymi prawo natury, które stwarzają warunki normalnego rozwoju oraz wolności sumienia ${ }^{151}$. Do najważniejszych encyklik społecznych, na które powoływano się w okresie międzywojennym, należały Rerum novarum Leona XIII (1891) i Quadragesimo anno (1931) Piusa XI. Wobec rosnącego zagrożenia komunizmem w 1937 r. ukazała się encyklika Divini Redemptoris (znana pod tytułem $O$ bezbożnym komunizmie).

\footnotetext{
146 Tamże.

${ }^{147}$ J. Żaryn, Kościół a władza w Polsce..., s. 29.

148 W. Lizak, Historia Polski..., s. 114.

149 Por. J. Majka, Katolicka nauka społeczna, Warszawa 1988, s. 5-6.

${ }^{150}$ C. Strzeszewski, Ewolucja katolickiej nauki społecznej, Warszawa 1978, s. 70.

${ }^{151}$ Z. Zieliński, Papiestwo i papieże dwóch ostatnich wieków 1775-1978, Warszawa 1983,
} s. 448 . 
Konflikt Kościoła z państwem w krajach Europy Środkowo-Wschodniej w okresie po II wojnie światowej miał głębokie podłoże ideologiczne i światopoglądowe, chociaż walka $\mathrm{z}$ religią przejawiała charakter polityczny ${ }^{152}$. Prominenci partyjni postrzegali Kościół wyłącznie w kategoriach politycznych, wręcz partyjnych. Hierarchię natomiast traktowano jako politycznego przeciwnika i konkurenta w walce o władzę. Antoni Bida stawiając Kościół po przeciwnej stronie nie lekceważył faktu, że ma się do czynienia z „mądrym przeciwnikiem o ogromnym doświadczeniu"153. Ideologia komunistyczna z założenia odnosiła się wrogo do religii, przyjmując marksistowsko-leninowski dogmat o konieczności ateizacji społeczeństwa. Według klasyków marksizmu stanowiła ona hamulec dla procesów rewolucyjnych. Celem komunistów było zatem całkowite jej wyeliminowanie z życia narodu. Marksizm ze swej istoty był doktryną ateistyczną, uznającą w szczególności Kościół katolicki za głównego wroga ideowego. Marksistowski światopogląd naukowy głosił, że to człowiek tworzy boga w swojej wyobraźni, na obraz i podobieństwo swoje, co było zupełną odwrotnością światopoglądu chrześcijańskiego. Partia propagowała tezę o niemożności pogodzenia nauki i postępu z religią. Jednocześnie za jedynie naukowy światopogląd marksiści uznawali ateistyczny. Po wyparciu religii ze świadomości społecznej miano ją zastąpić ideologią materialistyczną ${ }^{154}$. Powyższe tezy potępił papież Pius XI w encyklice $O$ bezbożnym komunizmie, w której czytamy, że system komunistyczny „starannie i planowo przygotował bunt przeciw wszystkiemu, $<<$ co nazywa się Bogiem $>>(2$ Tes. 2,4). Bo komunizm jest $\mathrm{z}$ natury swej antyreligijny i uważa religię za $<<$ opium dla ludu $>>$, ponieważ jej zasady głoszące życie pozagrobowe odciągają proletariat od budowania na ziemi przyszłego raju sowieckiego"155. Ideologia komunistyczna wyznawała prymat materii nad duchem, błędną ideę wyzwolenia i sprawiedliwości, fałszywy mistycyzm równości i braterstwa w pracy, otumaniając masy propagandowymi i złudnymi obietnicami ${ }^{156}$. Marksiści źródeł i przyczyn religii upatrywali nie w miłości, lecz w strachu przed siłami przyrody i trudnościami społecznymi, na zasadzie „kiedy trwoga to do Boga”. Postrzegali religię bardzo jednostronnie, jako „nadbudowę społeczeństwa wyzysku”. Nie miało znaczenia, że tylko w wierze odnaleźć można odpowiedź na głębokie

${ }^{152}$ Por. J. Myszor, Prymasa Wyszyńskiego spór o przeszłość i przyszłość Polski. W: Polska Prymasa Wyszyńskiego. Sesja naukowa, Tarnów 26.04.2001, Tarnów 2001, s. 47; E. Kristanova, „Tygodnik Warszawski” (1945-1948) a wtadza komunistyczna. W: Niewygodne dla wtadzy. Ograniczanie wolności stowa na ziemiach polskich w XIX $i$ XX w., pod red. D. Degen i J. Gzelli, Torun 2010, s. 357-374.

${ }^{153}$ B. Fijałkowska, Partia wobec religii i Kościoła ..., s. 106.

154 Tamże, s. 7-8, 10-12, 21, 27.

${ }^{155}$ Pius XI, Encyklika Divini Redemptoris. Dostępny w World Wide Web: http://www.opoka. org.pl/biblioteka/W/WP/pius_xi/encykliki/divini_redemptoris_19031937.html [dostęp 22.03.2010].

156 Tamże. 
pytania egzystencjalne o sens życia i śmierci, że może być wyrazem zaufania do Stwórcy ${ }^{157}$.

Jan Widacki trafnie zauważył, że dla komunistów Kościół był przeciwnikiem na co najmniej trzech płaszczyznach. Na płaszczyźnie filozoficznej, gdyż głosił odmienną od marksistowskiej koncepcję człowieka i inny system wartości. „Kościół był nie do zniesienia dla komunistów” także w płaszczyźnie ideologiczno-politycznej ze względu na swoją strukturę niepodporządkowaną partii oraz w pojmowaniu człowieka wierzącego, który pozostawał wewnętrznie wolny. Ponadto dla komunistów Kościół jawił się jako ostoja opozycji158.

\subsubsection{Sacrum i profanum}

Pragnąc pozyskać kler i zalegitymizować swoją władzę, komuniści paradoksalnie łączyli w 1. 1945-1947 święta państwowe ${ }^{159} \mathrm{z}$ obrzędami kościelnymi ${ }^{160}$. Barbara Fijałkowska napisała: „Dziś mogą zaskakiwać fotografie Bolesława Bieruta, uczestniczącego na klęczkach w odprawianiu polowych mszy świętych, czy obecność pocztów sztandarowych z insygniami religijnymi w pochodach pierwszomajowych i różnego typu manifestacjach organizowanych przez wojsko. Były to jednak bez wątpienia przejawy specyficznego kamuflażu, obliczonego na oszukanie Polaków"161. Za najważniejsze święta komuniści uważali 1 maja i 22 lipca, będące ,imieninami” i ,urodzinami” systemu ${ }^{162}$. Piotr Osęka konstatował: „Ceremonie z okazji 1 maja, 22 lipca lub dożynek łączyły liturgię katolicką i afirmację tradycji marksistowskiej. Pochody manifestujące pod czerwonymi sztandarami i przy dźwiękach Międzynarodówki (zawierającej wszak obrazoburczą strofę ,nie nam wyglądać zmiłowania z wyroków bożych, z carskich praw”) rozpoczynały się nabożeństwem. Odprawiano również msze żałobne za

${ }^{157}$ J.M. Bocheński, Sto zabobonów, krótki filozoficzny słownik zabobonów, Warszawa 1988, s. 58. Za A. Anusz, Samotnie wśród wiernych. Kościót wobec przemian politycznych w Polsce (1944-1994), Warszawa 1994, s. 13.

${ }^{158}$ Czego nie powiedziat generat Kiszczak. Z Janem Widackim rozmawia Wojciech Wróblewski, Warszawa 1992, s. 389. Za: B. Fijałkowska, Partia wobec religii i Kościoła ..., s. 18.

${ }^{159}$ Pierwszymi świętami państwowym obchodzonymi w Polsce lubelskiej były rocznica rewolucji październikowej 7 listopada i urodziny J. Stalina - 21 grudnia; z obchodzenia tych świąt zrezygnowano jednak w następnych latach. Druga uroczystość, jak stwierdził Piotr Osęka, „była czołobitnością niespotykaną dotąd w polskiej kulturze politycznej" - nawet w czasie kultu Józefa Piłsudskiego w 1. 30. XX w. Świętowano bowiem 11 listopada oraz Święto Reformy Rolnej, Święto Armii Czerwonej i in. Źródło: P. Osęka, Rytuały stalinizmu: oficjalne święta i uroczystości rocznicowe $w$ Polsce 1944-1956, Warszawa 2007, s. 41.

${ }^{160}$ J. Żaryn, Sacrum i profanum. Uwagi o religijności Polaków w latach 1945-1955. W: Polska 1944/45-1989. Studia i materiaty, t. 5, Warszawa 2001, s. 274.

${ }_{161}$ B. Fijałkowska, Partia wobec religii i Kościoła ..., s. 22-23.

162 P. Osęka, Rytuaty stalinizmu..., s. 66. 
dusze milicjantów"163. Członkowie władz centralnych i lokalnych uczestniczyli w okresie referendum 1946 r., nawet w warszawskiej procesji Bożego Ciała ${ }^{164}$. Pogrzeby zmarłych z aparatu władzy odbywały się z udziałem księży. Program Polskiego Radia rozpoczynano w pierwszych latach po wojnie od religijnej pieśni Kiedy ranne wstaja zorze ${ }^{165}$.

Planowanie i organizowanie świąt oraz uroczystości państwowych przez Ministerstwo Informacji i Propagandy ${ }^{166}$ stało się istotnym narzędziem indoktrynacji. Było swoistą grą o pozyskanie sympatii społeczeństwa i legitymizacji władz. W 1946 r. dniami wolnymi od pracy były święta: cztery państwowe (1, 3 i 9 maja, 22 lipca) oraz aż 12 kościelnych, które członkowie administracji państwowej celebrowali do 1948 r. Święto 22 lipca najczęściej rozpoczynano nabożeństwem. Władze bardzo chętnie również organizowały zbiorowe „gwiazdki” $\mathrm{i}$, choinki” z prezentami dla dzieci w celu propagowania ustrojowych wartości. Przedstawiciele najwyższych władz Bolesław Bierut i Józef Cyrankiewicz fotografowali się w gronie dzieci. Obchodzono także Święto Wszystkich Świętych 1 listopada, a dowodem mistyfikacji było upamiętnienie nawet dnia „Cudu nad Wisłą”. Przedstawiciele Kościoła uczestniczyli w obchodach rocznicowych organizowanych przez władzę, a świętom katolickim początkowo zapewniono przedwojenną rangę świąt państwowych. Partyjni dygnitarze Krakowa Bolesław Drobner i marszałek Michał Rola-Żymierski zapraszali arcybiskupa Adama Sapiehę na uroczystości państwowe. Wyznawcy systemu dokonywali swoistego upaństwowienia świąt religijnych, zabiegając jednocześnie o wystrój religijny dla własnych świąt państwowych. Komuniści wykorzystując popularność Kościoła w społeczeństwie i zachowując pozory liczyli na zdobycie zaufania

${ }^{163}$ Tamże, s. 45.

${ }^{164}$ Znane są fakty prowadzenia w czasie procesji Bożego Ciała w Warszawie kardynała A. Hlonda przez ministra komunikacji Jana Rabanowskiego i wiceministra obrony Piotra Jaroszewicza oraz poświęcenie w stolicy w obecności B. Bieruta odnalezioną pod Nysą, a skradzioną przez hitlerowców figurę Chrystusa z kościoła św. Krzyża. W uroczystość 3 V 1945 r. komunistyczne władze na czele z B. Bierutem wzięły udział w nabożeństwie w kościele oo. Karmelitów w Warszawie. Źródło: Z. Zieliński, Kościót w Polsce 1944-2007..., s. 49 i K. Prostak, Chrystus sprzed kościoła, „Gazeta Wyborcza” 24 XI 1995, za M. Kula, Religiopodobny komunizm, Kraków 2003, s. 15; R. Dzwonkowski, Walka z Kościołem katolickim w PRL (1945-1989). Dostępny w World Wide Web: http://www.rodzinapolska.pl/dok.php?art=prawdahistor/archiwum/2006/766_1.htm [dostęp 27.06.2007].

165 J. Żaryn, Dzieje Kościoła katolickiego ..., s. 85; A. Dudek, R. Gryz, Komuniści i Kościót..., s. 13.

${ }^{166}$ Ministerstwo podległe de facto władzom PPR powołano w styczniu 1945 r. w związku z powstaniem Rządu Tymczasowego. Wcześniej od początku istnienia rządu lubelskiego powstał Resort Informacji i Propagandy - instytucja odpowiedzialna za treść i techniczne przygotowanie indoktrynacji. Składała się z sześciu wydziałów, m.in. prasowo-informacyjnego, radiowego, wydawnictw i propagandy masowej w kraju. Działano na szczeblu centralnym oraz wojewódzkim i powiatowym . Ministerstwo w połączeniu z cenzurą sprawowało pełną kontrolę nad komunikacją społeczną w kraju. Źródło: P. Osęka, Rytuały stalinizmu ..., s. 32-33. 
ludu. Prezydent brał udział w modlitwie i nawet klękał w czasie podniesienia ${ }^{167}$. Jednocześnie dążono do centralizacji i uniformizacji świąt ${ }^{168}$. Adaptując święta katolickie do propagandowego kalendarza, zarazem profanowano je i ,zamazywano ich sens i znaczenie"169. Po wyborach w 1947 r. władze w Katowicach zachowując pozory zwróciły się do biskupa Stanisława Adamskiego, aby w niedzielę 20 stycznia odprawił mszę św. w intencji zwycięstwa wyborczego. Podobną propozycję otrzymał z tej okazji biskup łódzki Włodzimierz Jasiński, którego ponadto poproszono o bicie dzwonów w kościołach ${ }^{170}$. W związku z tymi wydarzeniami Jan Żaryn stwierdził: „Nawet po 1948 r., gdy propaganda oficjalna coraz usilniej starała się wyłączyć Kościół z życia publicznego, nie rezygnowano z prób łączenia sacrum i profanum $[\ldots]<<$ Księża patrioci $>>$ opracowali specjalne pieśni (hymny) religijne, błagalne, w których modlono się za pomyślne rządy Bolesława Bieruta"171.

Można było odnieść wrażenie, że partia była w stanie wszystko zaplanować tylko po to, aby zalegalizować swoje rządy. Po umocnieniu władzy w $1948 \mathrm{r}$. zaczęto usuwać niepotrzebne już nabożeństwa z repertuaru uroczystości i świąt państwowych oraz szkół ${ }^{172}$. Ewolucja działania aparatu władzy była dobrze widoczna na przykładzie uroczystości religijnych w szkole. Podczas gdy do $1948 \mathrm{r}$. rozpoczynano i kończono rok szkolny mszą, kupowano pierniki i cukierki pod choinkę na Boże Narodzenie, a święty Mikołaj rozdawał prezenty, to w 1949 r. choinkę zastąpiono nagle obchodami siedemdziesiątych urodzin J. Stalina. W następnych latach szkolnych upowszechniano już choinkę noworoczną i Dziadka Mroza, a w kolejnych tylko zabawę sylwestrową ${ }^{173}$. Podobnie działo się w Wojsku Polskim, w którym do połowy 1949 r. prowadzono żołnierzy w towarzystwie orkiestry do kościoła i odmawiano modlitwy na apelach. Po wprowadzeniu ateizacji zabrakło modlitw, a wymarsz zastąpiono wyjściem do kina lub na boiska sportowe, natomiast „do repertuaru pieśni żołnierskich weszły piosenki antypapieskie i antykościelne"174. Rozpoczynając etap wyznawania komunizmu jako świeckiej sfery sacrum $^{175}$, zapowiedziano „walkę z religią”. Kościół stał się wrogiem numer jeden i należało według słów z referatu J. Cyrankiewicza pt. Ocena i zadania w sprawie kleru „wybić zęby wojującemu klerowi”"176.

${ }^{167}$ P. Osęka, Rytuaty stalinizmu..., s. 40, 46-51, 58.

${ }^{168}$ Zob. B. Rogowska, Funkcje polityczne świat religijnych $w$ Polsce $w$ latach 1945-1950, „Nomos. Kwartalnik Religioznawczy” 1999 nr 24/25 s. 133-134.

${ }^{169}$ P. Osęka, Rytuaty stalinizm..., s. 50.

${ }^{170}$ H. Dominiczak, Organy bezpieczeństwa PRL w walce..., s. 33.

171 J. Żaryn, Sacrum i profanum ..., s. 274.

172 P. Osęka, Rytuały stalinizmu..., s. 96; H. Konopka, Religia w szkołach Polski Ludowej, s. 73.

${ }^{173}$ K. Kosiński, O nowa mentalność. Życie codzienne w szkołach 1945-1956, Warszawa 2000, s. $245-248$.

${ }^{174}$ H. Dominiczak, Organy bezpieczeństwa ..., s. 42.

175 Szerzej zob.: M. Kula, Religiopodobny komunizm...

${ }^{176}$ P. Osęka, Rytuaty stalinizmu ..., s. 99-101. 


\subsubsection{Pogrom kielecki jako pretekst do ataku na Kościół}

Kazimierz Urban wyróżnił dwa kierunki w polityce wyznaniowej lat powojennych: restrykcyjny i utylitarny. Pierwszy miał na celu laicyzację społeczeństwa i walkę z wrogiem pierwszoplanowym - Kościołem rzymskokatolickim, drugi uwzględniał ewentualne wykorzystanie antagonizmów jednego wyznania przeciw drugiemu ${ }^{177}$. Do drugiej kategorii można zakwalifikować tzw. pogrom kielecki, który miał miejsce czwartego dnia po referendum ${ }^{178}$. W Kielcach 4 VII 1946 r. rozegrała się tragedia „gwałtu i bestialstwa”, w której zginęło 42 miejscowych Żydów ${ }^{179}$. W taki sposób przedstawił zajścia kieleckie Bohdan Cywiński: „W kilka dni po referendum, na początku lipca 1946 r. Kielce stają się widownią zajść antyżydowskich. Wywołuje je milicja, puszczając w thum plotkę o zabiciu przez ludność żydowską nieletniego chłopca, a następnie nie reagując na działanie tłumu, który szuka zemsty. W zajściach ginie 28 osób, a kilkadziesiąt odnosi rany. Wbrew prawu milicja nie dopuszcza prokuratora na miejsce wypadków i działa tak, jak gdyby świadomie chciała doprowadzić do masowej masakry. Bezpośrednio po zajściach cała prasa rządowa przypisuje prowokację tego wydarzenia PSL-owi $\mathrm{i}<<$ klerykalnej reakcji $>>$. Natychmiastowe wystąpienia biskupa częstochowskiego Teodora Kubiny i kardynała Hlonda w obronie zabitych i poranionych Żydów są ukrywane przez oficjalną cenzurę państwową"180. W książce Krystyny Kersten czytamy: „,bezpośrednio po wydarzeniach, przekonanie, że pogrom był inspirowany czy zgoła organizowany, podzielało bardzo wiele osób z różnych, nierzadko przeciwstawnych, obozów politycznych, w kraju i za granicą, w środowiskach polskich i żydowskich" ${ }^{181}$. Ambasador USA w Warszawie Arthur Bliss Lane nazwał go „starannie przygotowanym spiskiem”, który interpretowany zgodnie z oficjalną wersją odwrócił uwagę opinii publicznej od fałszerstw dokonanych w czasie referendum. W komunikacie ogłoszonym na łamach rządowej prasy ogólnopolskiej informowano o tym, że „wywołały go elementy reakcyjne”.

${ }^{177}$ K. Urban, Kościót prawosławny w Polsce w latach 1944-1956. Studia i materiaty, Kraków 1998, s. 29.

${ }^{178}$ Szerzej zob.: Antyżydowskie wydarzenia kieleckie 4 lipca $1946 r$. dokumenty i materiaty, t. 1-2, oprac. S. Meducki, Kielce 1992-1994; Pogrom kielecki w dokumentach, oprac. B. Szaynok i Z. Wrona, „Dzieje Najnowsze” 1991 nr 3; B. Szaynok, Pogrom Żydów w Kielcach 4 lipca 1946, Wrocław 1992; J. Śledzianowski, Pytania nad pogromem kieleckim, Kielce 1998; Wokót pogromu kieleckiego, pod red. Ł. Kamińskiego i J. Żaryna, Warszawa 2006.

179 J. Żaryn, Dzieje Kościoła katolickiego ..., s. 85; Na ten temat pisano też: „W przeciwieństwie do cyfr podanych przez komunikat oficjalny - donosi INS - liczba Żydów zabitych w Kielcach wynosi przeszło 50, podczas gdy liczba rannych przekroczyła setkę. Stronnictwo Ludowe oskarża rząd o prowokację i wspólnictwo w tych zbrodniach”. Źródło: Zajścia antysemickie w Kielcach, „Ostatnie Wiadomości PAT-KAP” 1946 nr 11 s. 1.

${ }^{180}$ B. Cywiński, Ogniem próbowane..., t. 2, s. 45-46.

${ }^{181}$ K. Kersten, Polacy, Żydzi, komunizm. Anatomia pótprawd 1939-68, Warszawa 1992, s. 90. 
Premier Edward Osóbka i Jakub Berman oświadczyli, że akcja została zaplanowana przez bandy podziemia, głównie NSZ i WiN. Oskarżano S. Mikołajczyka wraz z PSL-em oraz hierarchią kościelną (głównie prymasa A. Hlonda, kurię biskupią w Kielcach i biskupa częstochowskiego Teodora Kubinę) jako inspiratorów wydarzenia. Celem opozycji miało być rzekomo podburzenie społeczeństwa przeciw władzy po przegranym referendum ${ }^{182}$. Na łamach „Kuźnicy” stwierdzono, że pogromy są organizowane pod okiem kurii biskupich w celu skompromitowania rządu w oczach zagranicy ${ }^{183}$. Teksty zarzucające Kościołowi i prasie katolickiej milczenie w sprawie kieleckiej ukazały się także w takich tytułach, jak „Robotnik”, „Rzeczpospolita” i „Naprzód”. Stawiano zatem Kościół i opozycję wobec wyboru włączenia się w polityczną kampanię wokół sprawy lub bycia przedmiotem ataku ${ }^{184}$. Aresztowano komendanta i wicekomendanta milicji w Kielcach, oskarżając o współudział w zajściach. Proces przeprowadzono bez rozgłosu i zrezygnowano w nim z dowodzenia, że pogrom był dziełem podziemia. Później podczas procesu biskupa kieleckiego Czesława Kaczmarka pamiętano, aby obarczyć go winą za rzekome wspieranie tragedii ${ }^{185}$.

Z kolei środowiska opozycyjne podejrzewały władze bezpieczeństwa o zainspirowanie mordu. Twierdzono, że posługując się wypróbowaną metodą prowokacji, dążono do skompromitowania Kościoła i całej opozycji w oczach Zachodu. W zamierzeniu chciano też ukazać komunistów jako postępowych i demokratycznych ${ }^{186}$. Jak pisał Aleksander Wat: „Chodziło o rozegranie na terenie międzynarodowym polskiego antysemityzmu"187. Takie opinie wyrażano na łamach polskiej prasy emigracyjnej ${ }^{188}$. W rzymskich „Ostatnich Wiadomościach PAT-KAP” przy okazji wydarzeń kieleckich stwierdzono nowy etap kampanii przeciw Kościołowi; czytamy bowiem: „Dowodzą tego absurdalne oskarżenia, jak gdyby biskupi i księża nie potępiali wszelkich gwałtów [...]. W istocie, z okazji pogromu kieleckiego ułożono manewr polityczny, któremu Kościół nie mógł się podporządkować"189. Redakcja zwróciła również uwagę na kilka faktów towarzyszących wydarzeniom.

${ }^{182}$ Tamże, s. 94, 98, 103; R. Gryz, Państwo a Kościół w Polsce 1945-1956. Na przykładzie województwa kieleckiego, Kraków 1999, s. 146.

${ }^{183}$ P. Borowy, Co wart jest gest Piłata?, „Kuźnica” $1946 \mathrm{nr} 30$ za K. Kersten, Polacy, Żydzi..., s. 101.

${ }^{184}$ K. Kersten, Polacy, Żydzi..., s. 101; R. Gryz, Państwo a Kościół..., s. 152.

185 J. Żaryn, Kościót w PRL ..., s. 32; K. Kersten, Polacy, Żydzi..., s. 99-100; Udział policji w pogromie kieleckim, „Ostatnie Wiadomości PAT-KAP” 1946 nr 17 s. 2.

${ }^{186}$ A. Friszke, Opozycja polityczna w PRL 1945-1980, Londyn 1994, s. 31; J. Żaryn, Dzieje Kościoła katolickiego..., s. 85-86.

${ }^{187}$ A. Wat, Mój wiek. Pamiętnik mówiony, cz. 1, Warszawa 1990, s. 144.

${ }^{188}$ Przykładowo artykuł pt. Nowa prowokacja ,, bezpieki” po krwawym referendum, w londyńskim „Dzienniku Polski i Dzienniku Żołnierza” 8 VIII 1946 i dalszych numerach, czy Uwagi: Odpowiedzialność reżimu, „Myśl Polska” 1946 nr 8, za: K. Kersten, Polacy, Żydzi..., s. 93-94.

${ }^{189}$ Nowy etap kampanii przeciwko Kościołowi w Polsce, „Ostatnie Wiadomości PAT-KAP” $1946 \mathrm{nr} 20$ s. 1. 
Podczas rozruchów trwających prawie 5 godzin siły porządkowe władzy nie interweniowały i nawet nie próbowały powstrzymać masakry ${ }^{190}$. Grupa lotników natomiast nie tylko nie broniła Żydów, lecz wprost „ułatwiała zbrodniarzom działanie”. Pisano dalej: „Kardynał Prymas Hlond, w imieniu duchowieństwa polskiego, przeciwko któremu zwrócona jest kampania, zaczęta od sprawy kieleckiej, wykazał jasno, że bezpieka przeszkodziła interweniować księżom, którzy chcieli uspokoić rozruchy [...] bardzo prawdopodobne, że chciano skorzystać z morderstwa, aby skompromitować opozycję"191.

Pogrom kielecki był przygotowanym atakiem władz przeciwko „reakcyjnemu Kościołowi wspierającemu podziemie”. W kościołach kieleckich 7 VII 1946 r. odczytano na mszach św. odezwę kurii, w której wyrażono ubolewanie z powodu tragicznych wypadków. Pomimo jednak potępienia zbrodni przez Episkopat wzmożono nagonkę na Kościół ${ }^{192}$. Prymas A. Hlond wydał 11 VII 1946 r. oświadczenie dla dziennikarzy zagranicznych, w którym odparł zarzuty prasowe jakoby „Kościół katolicki niedostatecznie stanowczo potępiał antysemityzm” ${ }^{193}$. Stwierdził w nim, że duchowieństwo zawsze potępiało morderstwa niezależnie od tego, czy popełnione były na Polakach czy na Żydach. Wskazał na inną niż konflikt rasowy przyczynę przebiegu zajść kieleckich. Odsłonił również kulisy działania księży, którzy pospieszyli na miejsce wydarzeń, lecz nie zostali dopuszczeni przez żołnierzy do thumu, którzy chcieli uspokoić. Proboszcza katedry kieleckiej ks. R. Zelka chwilowo zatrzymano, pięciu księżom pozwolono dojść na miejsce wydarzeń dopiero po ich zakończeniu. Ponadto ze strony Kapituły katedralnej wyszła odezwa wzywająca do zachowania spokoju, której władze jednak nie ogłosiły. Przypomniał też liczne przypadki ratowania Żydów przez Polaków w czasie okupacji. Kardynał A. Hlond wyraził opinię, że powracająca fala antysemityzmu ,spowodowana jest raczej faktem, że Żydzi zajmują czołowe stanowiska w rządzie polskim i usiłują wprowadzić ustrój, którego większość polskiego społeczeństwa nie chce" ${ }^{194}$. Zaznaczył także, że ówcześnie ginęło zdecydowanie więcej Polaków niż Żydów. Prymas uprzedził, że jego wypowiedź nie będzie można opublikować w Polsce. Oświadczenie zostało

${ }^{190} \mathrm{~W}$ innym numerze podano: „Zapytany o zdanie w sprawie zajść antysemickich w Kielcach Mikołajczyk wyraził swoje zdumienie, że pogrom mógł ciągnąc się przez tyle godzin w mieście pełnym wojska i policji, $<<$ I wojsko i policja - dodał - są natomiast zawsze na zawołanie, jeśli chodzi o rozpędzanie zebrań mojego stronnictwa>>”. Źródło: „Ostatnie Wiadomości PAT-KAP” 1946 nr 17 s. 1.

${ }^{191}$ Amerykańskie echa prowokacji kieleckiej, „Ostatnie Wiadomości PAT-KAP” $1946 \mathrm{nr} 29$ s. $1-2$.

${ }^{192}$ R. Gryz, Państwo a Kościół ..., s. 149; K. Kersten, Polacy, Żydzi..., s. 102; J. Żaryn, Dzieje Kościoła katolickiego..., s. 85-86.

${ }^{193}$ Tekst oświadczenia kardynała Hlonda. Bezpieka aresztowała duchownych, którzy chcieli przeszkodzić pogromowi, „Ostatnie Wiadomości PAT-KAP” 1946 nr 21 s. 1.

194 Tamże. 
jednak nagłośnione. $Z$ tego powodu rząd rozpętał kampanię medialną, w której fałszowano i przemilczano niedogodne ustępy deklaracji. Pojawiły się również krytyczne głosy na Zachodzie ${ }^{195}$.

Wydarzenia kieleckie będące $\mathrm{w}$ rzeczywistości pretekstem do terroru wobec opozycji i społeczeństwa przed wyborami w 1947 r. mogą stanowić jeden z wielu przykładów ówczesnych metod prowokacji skierowanej przeciw Kościołowi.

\subsubsection{Odbudowa organizacji społeczno-katolickich i próba utworzenia partii katolickiej}

Po wojnie katolicki ruch stowarzyszeniowy zaczął odradzać się spontanicznie. W jego skład weszło wiele organizacji i stowarzyszeń religijnych, m.in. Katolickie Stowarzyszenie Młodzieży (KSM), Krucjata Młodzieży Niepokalanej, kółka różańcowe, koła ministrantów, struktury Caritas Academica, a także bardziej elitarne organizacje formacyjne, jak Iuventus Christiana, Sodalicja Mariańska czy Towarzystwo Przyjaciół KUL ${ }^{196}$. Ponownie powołano do życia Związek Harcerstwa Polskiego posiadający silne związki z przedwojennym skautingiem i katolicyzmem, kontynuujący walkę o niepodległość narodową ${ }^{197}$. Władza przejawiała niechęć do tego typu inicjatyw, zwłaszcza jeżeli chodziło o zrzeszenia młodzieżowe. Zaplanowaną przyszłością miał być bowiem komunizm, w którym „młodzież wychowana w nowym duchu” miała odegrać kluczową rolę ${ }^{198}$. Początkowo zgodnie z prowadzoną tzw. „polityką salami” władza nie mogła powstrzymać działalności wszystkich niepożądanych zrzeszeń. Widząc w rozwijających się stowarzyszeniach jedynie poszerzenie wpływów Kościoła w społeczeństwie, starała się utrudniać ich działalność. Nie pozwolono zatem na reaktywowanie prężnie działającej wcześniej Akcji Katolickiej ${ }^{199}$. Działacze KSM starali się w 1947 r. utworzyć strukturę ogólnopolską, na co władze również nie wyraziły zgody. Ostatecznie w tym samym roku stworzono listę legalnie funkcjonujących

195 Tamże, s. 2; R. Gryz, Państwo a Kościół..., s. 150.

${ }^{196}$ J. Żaryn, Dzieje Kościoła katolickiego ..., s. 78-81. Szerzej zob.: T. Biedroń, Organizacje młodzieży katolickiej...; M. Przybysz, Wyspy wolności. Duszpasterstwo akademickie w Łodzi 1945-1989, Łódź 2008.

${ }^{197}$ Szerzej zob.: K. Bluszcz, Ewolucja modelu wychowania skautingu w harcerstwie, Kraków 1987; J. Jagoszewska, Harcerstwo w PRL-u. W: Nim będzie zapomniana. Szkice o kulturze PRL-u, pod red. S. Bednarka, Wrocław 1997, s. 224-235; Komuniści wobec harcerstwa 1944-1950, oprac. K. Persak, Warszawa 1998.

${ }^{198}$ H. Dominiczak, Organy bezpieczeństwa PRL w walce..., s. 116.

${ }^{199}$ Akcja Katolicka - ruch katolików świeckich wywodzący się z ruchów społecznych XIX w. mający na celu szerzenie wartości ewangelicznych w społeczeństwie we współpracy z Kościołem hierarchicznym. Po raz pierwszy nazwy użył papież Pius X w Motu proprio z grudnia 1903 r. Szerzej zob.: Wczoraj, dziś, jutro Akcji Katolickiej, pod red. T. Borutki, Kraków 2004. 
organizacji młodzieżowych, na której zabrakło zrzeszeń katolickich ${ }^{200}$. Pomimo że w latach 1945-1946 pozwolenie na zarejestrowanie organizacji katolickich i tak wydawały organy bezpieczeństwa, to Kościół nie spotkał się z większymi trudnościami. Potęgujący się konflikt między Kościołem a państwem w 1947 r. przyniósł już poważne przeszkody zarówno w rejestrowaniu nowych organizacji, jak też w ich funkcjonowaniu ${ }^{201}$. Po dwóch latach dekret o stowarzyszeniach ułatwił rozwiązanie wszystkich stowarzyszeń o charakterze katolickim.

Środowiska katolickie próbowały również reaktywować partie, które wyrażałyby ich światopogląd. Dwie spośród partii Polskiego Państwa Podziemnego wprost powoływały się w programie na społeczną naukę Kościoła - Stronnictwo Narodowe (SN) i Stronnictwo Pracy (SP). Zgodnie z porozumieniem moskiewskim z czerwca $1945 \mathrm{r}$. komuniści zgodzili się tylko na powstanie partii chłopskiej (późniejsze PSL S. Mikołajczyka) i na włączenie się do życia politycznego przywódcy SP - Karola Popiela. Próbę legalizacji Stronnictwa Narodowego w sierpniu 1945 r., przy poparciu arcybiskupa A. Sapiehy, podjęli Stanisław Rymar, Szymon Poradowski, Kazimierz Kobylański i Jan Bielawski. Nie udało się jednak tego dokonać, gdyż władze odpowiedziały aresztowaniem inicjatorów. Do kolejnej próby narodowcy przystąpili jesienią 1946 r., chcąc powołać do życia Unię Narodową. Ze względu na okres przedwyborczy komuniści zgodzili się pod warunkiem, że partia wejdzie w skład utworzonego przez nich „bloku”. Nieprzyjęcie warunków spowodowało następną falę aresztowań. W sierpniu 1947 r. skazano uczestników rozmów na 10 lat więzienia. Politycy SN wspierali bliski im ideowo „Tygodnik Warszawski”. Aresztowania w latach 1946-1947 zakończyły działalność wielu polityków tej orientacji (m.in. Lecha Hajdukiewicza, Tadeusza Macińskiego, Leona Dziubeckiego, Włodzimierza Marszewskiego). W następnym okresie III Departament MBP prowadził sprawy przeciwko działaczom SN będącym jeszcze na wolności.

Prezes Stronnictwa Pracy Karol Popiel przybył z Londynu do Polski w lipcu 1945 r. Jego działalność polityczna napotkała na liczne przeszkody. Ataki wymierzono z kilku stron. Stosując znane już metody rozbijania środowisk, z wiernych reżimowi ludzi (m.in. Feliksa Widy-Wirskiego i Zygmunta Felczaka, tzw. „wojewodów” lub „zrywowców”) utworzono partię o tej samej nazwie reprezentującą odmienny program i światopogląd. Nie dopuszczono również do odbycia jawnego kongresu właściwej SP. Mimo że ugrupowanie działało legalnie od listopada 1945 r., było szykanowane przez UB i na skutek wewnętrznej dywersji przetrwało niespełna rok. Sam Popiel zawiesił je w lipcu 1946 r. ${ }^{202} \mathrm{~W}$ „Ostatnich Wiadomościach PAT-KAP” z dnia 23 VII 1946 r. zanotowano: „Pod koniec zebrania Karol Popiel, przywódca partii oświadczył, że członkowie partii wstrzy-

${ }^{200}$ J. Żaryn, Dzieje Kościoła katolickiego ..., s. 82.

${ }^{201}$ H. Dominiczak, Organy bezpieczeństwa ..., s. 116-117.

202 J. Żaryn, Kościót w PRL ..., s. 43-46. 
mują się od jakiejkolwiek akcji, wobec tego, że obecne warunki nie pozwalają partii na rozwijanie działalności. Zawieszenie działalności potrwa tak długo, jak długo nie zmieni się obecna polityka rządu"203.

Przedstawiciele Episkopatu zareagowali na to komunikatem: „Biskupi stwierdzają z bólem, że w partii, która opierała program na światopoglądzie katolickim i dążyła do realizacji zasad chrześcijańsko-społecznych, dokonano rozłamu, po którym partia w nowym składzie nie daje już rękojmi, że będzie urzeczywistniać myśli i zasady katolickie”204. „Popielowcy” jeszcze w październiku 1946 r. starali się wraz z grupą redaktorów „Tygodnika Powszechnego”, „Dziś i Jutro” oraz niezależnymi działaczami stowarzyszeń katolickich utworzyć partię katolicką. Nie znalazło to jednak poparcia wśród biskupów. Bezskutecznie również starano się w styczniu 1947 r. założyć nowe ugrupowanie polityczne o nazwie Chrześcijańskie Stronnictwo Pracy, aby móc uczestniczyć w styczniowych wyborach $1947 \mathrm{r}$. Władze nie wyraziły zgody na legalizację listy wyborczej chadeków mimo zabiegów biskupa Zygmunta Choromańskiego ${ }^{205}$. Po tych nieudanych przedsięwzięciach K. Popiel wyemigrował z Polski. Wytrwalsi działacze kontynuowali pracę do końca istnienia „Tygodnika Warszawskiego”, po czym zostali uwięzieni ${ }^{206}$. W tym czasie ster przejęli tzw. „katolicy postępowi” skupieni wokół tygodnika „Dziś i Jutro” Bolesława Piaseckiego ${ }^{207}$.

$$
* * *
$$

Nagła śmierć prymasa Augusta Hlonda, zamknięcie „Tygodnika Warszawskiego" wraz z aresztowaniem redakcji w 1948 r., zakaz działalności stowarzyszeń katolickich w 1949 r., jak też bezwzględna likwidacja Caritasu w 1950 r. otworzyły nowy etap w stosunkach Kościoła z państwem. Relacje z roku na rok stawały się trudniejsze, a pozory swobód demokratycznych coraz bardziej widoczne.

Pogrzeb prymasa stał się wielką manifestacją religijną. Rada Główna Episkopatu 16 XI 1948 r. wystąpiła z propozycją do Stolicy Apostolskiej o przywrócenie unii Gniezna z Poznaniem. Papież jednak zachował unię Gniezna z Warszawą. Na stolicę prymasowską oraz arcybiskupem gnieźnieńsko-warszawskim mianował

${ }^{203}$ Partia pracy zawiesza swoja wspótprace z rzadem, „Ostatnie Wiadomości PAT-KAP” $1946 \mathrm{nr} 22$ s. 1.

${ }^{204}$ Komunikat Konferencji Episkopatu Polski, 10 IX 1946 r. W: Listy pasterskie Episkopatu Polski 1945-1974, Paryż 1975, s. 45.

205 J. Żaryn, Dzieje Kościoła katolickiego..., s. 84.

${ }^{206} \mathrm{~Np}$. Józef Kwasiborski został aresztowany wraz z grupą polityków chrześcijańsko-demokratycznych i skazany w 1951 r. niesłusznie na dożywocie za rzekomą współpracę z gestapo. Zrehabilitowano go w $1957 \mathrm{r}$.

207 Od 1952 r. występujący pod nazwą Stowarzyszenia PAX, do którego należeli m.in. Andrzej Micewski, Janusz Zabłocki, Tadeusz Mazowiecki i in. Źródło: J. Żaryn, Kościół w PRL..., s. 47. 
najmłodszego wówczas biskupa Stefana Wyszyńskiego znanego z „nieugiętych zasad", ale potrafiącego rozmawiać z przeciwnikami ideowymi ${ }^{208}$.

Równolegle do zmian na najwyższych szczeblach w Kościele swoje pozycje umocnili komuniści. Przyczynił się do tego zjazd zjednoczeniowy i utworzenie PZPR. Na I Zjeździe partii jednoznacznie stwierdzono, że „podstaw socjalizmu” nie da się wprowadzić bez upowszechnienia światopoglądu materialistycznego; działania państwa nie mogły być zatem neutralne światopoglądowo. Podkreślając konieczność „bezwarunkowo lojalnego stosunku duchownych do państwa”, uznano ustalenie relacji pomiędzy Kościołem a państwem na zasadach władztwa i podporządkowania. Owo podporządkowanie często egzekwowano terrorem i przymusem. Uznając religię za „opium dla ludu”, traktowano Kościół jako przeciwstawną siłę ideologiczną ${ }^{209}$.

\subsection{Walka z Kościołem w latach 1948-1953}

\subsubsection{Okres 1948-1949}

Niszcząca polityka wyznaniowa objęła Kościół katolicki we wszystkich krajach okupowanych przez sowietów. Przyjęto bowiem ogólną strategię walki z religią i największą „,siłą reakcji i antykomunistycznego oporu” - Kościołem katolickim. Szczegóły działania omówiono na konferencji Kominformu w Karlovych Varach w dniach 11-12 II 1949 r. Te same metody zastosowano na Węgrzech, w Czechosłowacji, Rumunii, Bułgarii, na Ukrainie i Litwie ${ }^{210}$. Komuniści zjednoczeni w skali całego „bloku” zamierzyli stanowcze rozprawienie się z Kościołem w Polsce ${ }^{211}$.

Dążąc do totalnego zawładnięcia państwem i społeczeństwem, powoli przejmowano kolejne obszary życia publicznego. Niezmiennym celem polityki wyznaniowej nowej władzy była marginalizacja roli Kościoła w polskim społeczeństwie ${ }^{212}$. Zasadniczo w 1949 r. podziemie zostało rozbite, a władza komunistyczna umocniła się po wyborach i utworzeniu PZPR. Komuniści mogli zatem rozpocząć atak na ostatniego przeciwnika partii, jakim był Kościół. Jego pozycja

${ }^{208}$ J. Żaryn, Dzieje Kościoła katolickiego ..., s. 94; Z. Zieliński, Kościót w Polsce 1944-2002 ..., s. $67-68$.

${ }^{209}$ J. Żaryn, Dzieje Kościoła katolickiego ..., s. 95-96; W. Lizak, Historia Polski..., s. 240.

${ }^{210}$ Więcej o sytuacji w tych krajach zob. B. Cywiński, Ogniem próbowane..., s. 155-402; J. Zabłocki, Prymas Stefan Wyszyński..., s. 30-37.

${ }^{211}$ J. Żaryn, Dzieje Kościoła katolickiego ..., s. 95-96.

${ }^{212}$ A. Dudek, Polityka władz Polski Ludowej wobec Kościoła katolickiego - trwanie i zmiana. W: Represje wobec osób duchownych i konsekrowanych w PRL w latach 1944-1989, pod red. A. Grześkowiak, Lublin 2004, s. 13. 
była silniejsza niż w innych krajach. Zaważyła o tym istotna rola, jaką odegrał w historii narodu, stanowiąc dla niego moralne oparcie oraz większa świadomość wiernych. Janusz Zabłocki zauważył: „Katolicyzm był w naszym kraju zbyt silny i zbyt głęboko wrośnięty w naród i jego kulturę, by partia mogła sobie pozwolić - jak to czynili swego czasu bolszewicy w Rosji - na ogłoszenie otwartej walki z religią" ${ }^{\prime 213}$. Zdecydowano się jednak po okresie pozorów demokracji na ostrzejszą konfrontację niż dotychczas. Działania zaczęły mieć charakter systematyczny i zintensyfikowany.

Głosząc rozdział Kościoła od państwa chciano wpierw uzależnić go ekonomicznie, a następnie podporządkować administracyjnie. Pozbawienie wszelkich zabezpieczeń materialnych miało nastąpić w ramach ogólnych przemian społeczno-ustrojowych, głównie przez wprowadzenie reformy rolnej i kolektywizacji wsi. Uzależnieniu miała służyć również ścisła kontrola administracyjna nad życiem kościelnym i obsadą stanowisk. Ostatnim aktem podporządkowania miała być wymiana składu Episkopatu poprzez aresztowania i zastąpienie ich księżmi sprzyjającymi władzy ${ }^{214}$. Zaczęto od niszczenia struktur kościelnych i odbierania zakonom prawa do prowadzenia szkół, przedszkoli i szpitali. Usuwano kapelanów posługujących we więzieniach. Zadbano o laicyzację szkoły poprzez otwieranie nowych szkół bez przewidzianych lekcji religii. Podjęto działania zmierzające do całkowitego usunięcia ze szkół osób duchownych nauczających przedmiotów świeckich. Kolejny spór dotyczył funkcjonowania KUL, a zwłaszcza likwidacji niektórych wydziałów oraz obłożenie jego przychodów podatkami ${ }^{215}$. Nałożono również wysokie podatki na nieruchomości kościelne lub wprost zabierano je na terenach Ziem Zachodnich, gdzie przedstawiciele Kościoła nie byli właścicielami. Sukcesywnie prowadzono proces wywłaszczania majątków kościelnych. Akcji wymierzonych w Kościół było wiele ${ }^{216}$, na które przedstawiciele hierarchii

${ }^{213}$ J. Zabłocki, Prymas Stefan Wyszyński..., s. 42.

214 Tamże, s. 28-30.

${ }^{215}$ W 1952 r. aresztowano rektora KUL ks. prof. Antoniego Słomkowskiego pod zarzutem posiadania obcej waluty. Prawdziwym powodem zatrzymania była jego niezgoda na przyjęcie do środowiska uczelni katolickiej ateistycznego Związku Młodzieży Polskiej. Źródło: J. Żaryn, Kościót w PRL..., s. 27.

${ }^{216}$ Ze znanych można wymienić np. w niedzielę 1 V 1949 r. w licznych parafiach zabroniono nakazem administracyjnym bicia w dzwony i urządzania procesji nawet na terenie przykościelnym. Władze bezpieczeństwa wymogły na proboszczach, aby tego dnia nabożeństwa zakończono do godziny 8-9 rano; szykanowano również biskupów. Samemu prymasowi na podstawie zarządzeń lokalnych 13 V 1949 r. zabroniono wstępu do szpitala dziecięcego i miejskiego, a młodzież przygotowaną do bierzmowania wysłano pod groźbą usunięcia ze szkoły lub kar pieniężnych do kin, na imprezy i wycieczki; w „Życiu Warszawy” 10 V 1949 r. w celu zdyskredytowania Kościoła w oczach opinii publicznej opublikowano wyniki ankiety zatytułowanej Kościół a Państwo. Oskarżono przy tym Kościół o średniowieczny fanatyzm, wojujący antyklerykalizm i chęć rozpętania wojny religijnej. Zaniechano też emitowania w radiu niedzielnej mszy św. Źródło: J. Piasecka, Stosunki między Kościołem rzymskokatolickim i państwem..., s. 34-35. 
kościelnej mogli zareagować tylko protestem. Upaństwowiono zakonne zakłady poligraficzne i zamykano redakcje czasopism katolickich. Wzmożono ataki na duchowieństwo na łamach prasy partyjnej ${ }^{217}$.

Dążono przy tym do ogólnego osłabienia autorytetu duchowieństwa i odseparowania go od społeczeństwa, czemu miały służyć również organizowane procesy pokazowe. Wedle założeń instrukcji MBP z wiosny 1949 r. w każdej diecezji należało odbyć przynajmniej jeden proces księdza w ciągu roku ${ }^{218}$. Szczególny atak wymierzono przeciwko biskupom katowickiemu Stanisławowi Adamskiemu, kieleckiemu Czesławowi Kaczmarkowi i sandomierskiemu Janowi Lorkowi ${ }^{219}$ oskarżając ich o współpracę z hitlerowcami. Wzmożono w ogóle prześladowania i aresztowania wobec osób konsekrowanych ${ }^{220}$. „Nadużycia” Kościoła stały się też powodem przeprowadzenia przez UB wielu rewizji księży i kompromitowania ich przez sfabrykowane materiały. W strukturach ludowego państwa wypracowano wyrafinowane mechanizmy szantażu, prowokacji, fałszu i dezinformacji. Jednocześnie zaczęto werbować księży jako agentów. Część duchownych - z bardzo różnych powodów - podjęła różne formy kolaboracji ${ }^{221}$.

Rozbiciu Kościoła przeciwstawiała się Komisja Główna Episkopatu, która posiadała prerogatywy do decydowania o najważniejszych sprawach $\mathrm{w}$ stosunkach Kościoła z państwem i zrzeszeniach posługujących się etykietką katolicką. W decydujących sprawach najważniejszy głos w latach 1949-1953 należał do prymasa S. Wyszyńskiego. Oświadczenie ministra administracji publicznej Władysława Wolskiego w sprawie ,antypaństwowej postawy hierarchii kościelnej i uregulowania stosunków między państwem a kościołem [pisownia oryginalna E.K.]" upublicznione w marcu 1949 r. stało się powodem do pierwszej konfrontacji prymasa z komunistami. Jego treść wskazywała, jakoby władza troszczyła się o sprawy Kościoła i zapewniała swobody religijne. Naprawdę zaś dawano ostrzeżenie hierarchii, aby poprzez listy pasterskie i ,poufne instrukcje” nie wywoływała niepokoju, uświadamiając społeczeństwo o działalności antykościelnej władzy. Jednocześnie W. Wolski zastosował metodę oszczerstw, stwierdzając, że hierarchowie popierają rewizjonistyczne poglądy wobec Ziem Odzyskanych, tolerują przestępcze podziemie, a księża patronują , ,agentom angloamerykańskim”. Minister „bronił” też młodzież przed katechetami, którzy „,nadużywali religii dla siania niepokoju w ich umysłach". Prymas odpowiedział na zarzuty pismem

${ }^{217}$ Szerzej zob. J. Stefaniak, Polityka władz państwowych...

${ }^{218}$ J. Żaryn, Postawy duchowieństwa katolickiego wobec władzy państwowej $w$ latach 1944-1956. W: Komunizm. Ideologia, system, ludzie, pod red. T. Szaroty, Warszawa 2001, s. 293.

${ }^{219}$ Szerzej zob. B. Stanaszek, Usunać biskupa! Władze PRL wobec ordynariusza diecezji sandomierskiej Jana Kantego Lorka, Sandomerz 2004; S. Szymecki, R. Rak, Biskup Stanisław Adamski jakiego nie znamy, Katowice 2003; J. Śledzianowski, Ksiądz Czesław Kaczmarek - biskup kielecki 1895-1963, Kielce 2009.

${ }^{220}$ Szerzej zob.: Represje wobec osób duchownych i konsekrowanych...

${ }^{221}$ A. Grajewski, Kompleks Judasza, Poznań 1999, s. 8, 12. 
skierowanym do kancelarii ministra, udowadniając ograniczenia swobody działania $^{222}$. Henryk Dominiczak tak pisał o atmosferze w 1949 r.: „Nękające oskarżenia i pogróżki pod adresem Kościoła sypały się wówczas z lewa i prawa, komuniści wytaczali coraz to nowe zarzuty i oskarżenia, wtórowała im reżimowa prasa, która niepomiernie rozpętała antykościelną propagandę"223.

Latem 1949 r. stosunki państwa z Kościołem zdominowały dwa wydarzenia, nagłośnione propagandowo przez prasę rządową. Na początku lipca w katedrze lubelskiej wierni dostrzegli na obrazie łzę spływająca po policzku Matki Boskiej Częstochowskiej. Wieść o tym szybko rozeszła się po całym kraju. Władze państwowe natychmiast odpowiedziały oskarżeniem hierarchii Kościoła o szerzenie „ciemnoty”, „nową prowokację skierowaną przeciwko władzy ludowej”, po czym zamknęły kościól, a księży pracujących w nim aresztowały. Na placu Litewskim w Lublinie zorganizowano nawet ,wiec antycudowy”. Drugim konfliktem stał się atak władz na Stolicę Apostolską w związku z dekretem Świętego Oficjum wydanym 1 VII 1949 r., grożącym ekskomuniką katolikom popierającym lub należącym do partii komunistycznych ${ }^{224}$.

W 1949 r. wydano kilka dekretów godzących w Kościół i ograniczających jego swobodę w pełnieniu misji. Dekret o ochronie wolności sumienia i wyznania z 5 VIII 1949 r. wszedł w życie po powrocie B. Bieruta z Moskwy i pomimo tytułu miał w rzeczywistości utrudnić misję Kościoła ${ }^{225}$. W dokumencie znalazło się więcej informacji o karach za nadużycia niż o wolności wyznania, gdyż na 17 artykułów aż 12 odniosło się do kar więzienia. Proboszczowie mieli bezwzględnie podporządkować się postanowieniom dekretu ${ }^{226}$. Na jego mocy władzy administracyjnej podporządkowano wszystkie związki i stowarzyszenia, w tym religijne. Treść aktu prawnego zmusiła także biskupów do zawieszenia działalności wszystkich stowarzyszeń katolickich, nawet tych ściśle formacyjnych, co znacznie utrudniło pracę duszpasterską. Wyjątkowo tylko w metropolii krakowskiej pozostawiono spotkania działaczy Sodalicji Mariańskiej w domach parafialnych do 1953 r. Młodzież komuniści nakłaniali do wstępowania do ZMP. Do końca 1949 r. władze zajęły szpitale prowadzone przez siostry zakonne. Poprzez

${ }^{222}$ H. Misztal, Divide et impera. Niszczenie struktur kościelnych i represje wobec duchownych w Polsce jako jedna z metod walki systemu stalinowskiego z religia. W: Represje wobec osób duchownych i konsekrowanych..., s. 30-31; J. Piasecka, Stosunki między Kościołem rzymskokatolickim..., s. 33.

${ }^{223}$ H. Dominiczak, Organy bezpieczeństwa ..., s. 38.

${ }^{224}$ J. Żaryn, Dzieje Kościoła katolickiego..., s. 96-97; H. Dominiczak, Organy bezpieczeństwa ..., s. 40.

${ }^{225}$ Państwo i Kościót - kilka dokumentów, Warszawa 1949, s. 30-40. Za H. Dominiczak, Organy bezpieczeństwa ..., s. 41; Tekst dekretu podał P. Raina, Kardynat Wyszyński, t. 1: Droga na Stolicę Prymasowska, Warszawa 1993, s. 175-177. Zdaniem autora dekret był odpowiedzią władz na decyzję papieża o ekskomunice.

${ }^{226}$ A. Dudek, R. Gryz, Komuniści i Kościół..., s. 43-47; J. Żaryn, Kościół a władza ..., s. 265. 
kolejne dekrety i zarządzenia wykonawcze władze uzależniły każdorazowo wydawanie zgody na organizowanie zgromadzeń religijnych (z wyjątkiem procesji Bożego Ciała) od decyzji administracji państwowej. Zabroniono Kościołowi kwesty w miejscach publicznych, nałożono obowiązek wypełniania księgi rozrachunkowej w celu kontroli budżetu parafii i dochodów, nałożono również zbyt wysokie podatki gruntowe $\mathrm{w}$ stosunku do faktycznego zysku z dzierżawionej przez Kościół nieruchomości. Zarekwirowano księgi metrykalne, usunięto kapelanów z więzień i szpitali, aresztowano kolejnych księży. Przymierzano się do etapu walki, w którym miano przejść z fazy „Kościół wszędzie” w fazę „Kościół nigdzie". Organy państwa miały wniknąć w jego wewnętrzną strukturę organizacyjną i stać się pośrednio pracodawcą dla duchowieństwa ${ }^{227}$.

\subsubsection{1. „Księża patrioci” i ruchy pseudokatolickie}

Minister bezpieczeństwa Stanisław Radkiewicz stwierdził, że „odcinek kleru" wymagał największej czujności ze strony organów bezpieczeństwa, gdyż stanowił „najbardziej zorganizowaną część składową reakcji”228. Zgodnie z poleceniem dyktatora pieczę nad sprawami osób duchownych w Polsce miał sprawować rosyjski generał Iwan Sierow. Jesienią 1944 r. przesłuchując aresztowanego przez NKWD lidera polskiego prawicowego podziemia Bolesława Piaseckiego ${ }^{229}$ doprowadził do podpisania przez niego memoriału deklarującego współpracę z władzami komunistycznymi. Niespodziewanie B. Piaseckiego zwolniono w lipcu 1945 r. na żądanie W. Gomułki. Następnie dzięki protekcji I. Sierowa utworzył organizację tzw. ,postępowych katolików PAX” oraz zorganizował szeregi oddanego władzy duchowieństwa.

B. Piasecki stał się czołową postacią w rozbijaniu polskich środowisk katolickich w okresie powojennym ${ }^{230}$. Głosząc utopijny program współpracy katolików z komunistami utworzył pod szyldem katolicyzmu nowy ruch, dyspozycyjny wobec władzy i mający znaczny udział w polityce. Podobne poglądy, z których później jednak się wycofał, wyznawał Andrzej Micewski ${ }^{231}$. W publicznym oświadczeniu

${ }^{227}$ J. Żaryn, Dzieje Kościoła katolickiego ..., s. 98-100; tenże, Kościót w PRL..., s. 24; tenże, Kościót a władza ..., s. 312.

${ }^{228}$ A. Grajewski, Kompleks Judasza..., s. 185-186.

${ }^{229}$ Bolesław Piasecki (1915-1979) - szef przedwojennej organizacji narodowo-radykalnej ONR „Falanga” i konspiracyjnej Konfederacji Narodu, w czasie wojny nieprzejednany wobec ZSRR. W listopadzie $1944 \mathrm{r}$. aresztowany przez NKWD za działalność antykomunistyczną. Grożono mu karą śmierci. W lipcu 1945 r. wypuszczony na wolność. Więcej na jego temat zob. A. Dudek, G. Pytel, Bolesław Piasecki. Próba biografii politycznej, Londyn 1990; A. Micewski, Wspótrzadzić czy nie kłamać. PAX i ZNAK w Polsce 1945-1976, Warszawa 1981.

${ }^{230}$ B. Piasecki dążył do zrównania drogi katolicyzmu z socjalizmem. Swoje poglądy wyłożył w opracowaniu Zagadnienia istotne, które potępiło Święte Oficjum w 1955 r.

${ }^{231}$ B. Fijałkowska, Partia wobec religii..., s. 84-85. 
działaczy katolickich, opublikowanym na łamach organu B. Piaseckiego „Dziś i Jutro" w listopadzie 1946 r., szukano sposobu współpracy Kościoła z państwem. Konsekwencją tego było przedłożenie kardynałowi A. Hlondowi w grudniu 1946 r. przez tę grupę memoriału na temat konieczności ułożenia stosunków państwa z Kościołem ${ }^{232}$. Istotną rolę w działalności B. Piaseckiego odegrała pułkownik Julia Brystygierowa, zaangażowana w tworzenie agentury w Kościele. Przypisuje się jej odpowiedzialność za tworzenie Komisji Księży grupujących tzw. księży patriotów, w istocie zaś licznych tajnych współpracowników UB ${ }^{233}$.

Najdotkliwszym ciosem wymierzonym w Kościół katolicki stała się realizacja sugestii J. Stalina podziału księży na ,postępowych” i „,reakcyjnych”. Stalin przebywającemu w Moskwie 1 VIII 1949 r. B. Bierutowi przekazał: „Przy klerze nie zrobicie nic, dopóki nie dokonacie rozłamu na dwie odrębne i przeciwstawne sobie grupy, [...] sama propaganda nie zrobi tego, co potrzeba" ${ }^{234}$. Służyło to przede wszystkim wbiciu klina między przedstawicieli hierarchii a tak zwanym szeregowym klerem. Pracownicy UB stosowali przy werbowaniu księży niezwykle wyrafinowane metody. Najczęściej szantażowano skompromitowaniem w oczach opinii publicznej lub starano się przekupić, obiecując awans na odpowiedzialne stanowiska w Kościele. Kapłanom uległym wobec władzy udzielano ponadto wsparcia finansowego w postaci przydziału materiałów na budowę lub remont kościoła, wczasy, zniżki na kolej, bezzwrotne pożyczki itp. ${ }^{235} \mathrm{~W}$ powojennej biedzie mogło to stanowić pewien „,przywilej”.

Ruch „księży patriotów” współpracujących z władzą komunistyczną utworzono we wrześniu 1949 r., kopiując radzieckie wzorce ${ }^{236}$. Formacja oprócz we-

${ }^{232}$ Z. Zieliński, Kościót w Polsce..., s. 75-76.

${ }^{233}$ A. Paczkowski, Pót wieku dziejów Polski..., s. 160; J. Żaryn, Bolesław Piasecki. W: Encyklopedia białych plam, Radom 2004, t. 14, s. 114-115; A. Grajewski, Kompleks Judasza ..., s. $178-179$.

${ }^{234}$ Zacytowany fragment pochodzi z osobistych notatek B. Bieruta opublikowanych po raz pierwszy w: Bierut u Stalina, „Polityka” 1993 nr 18 s. 4; cyt. za A. Dudek, Państwo i Kościót 1945-1970, Kraków 1995, s. 40; tenże, Ślady PeeReLu. Ludzie - wydarzenia - mechanizmy, Kraków 2001, s. 242; J. Poksiński, Przeciw Kościołowi, „Karta” 1992 nr 9 s. 139.

${ }^{235}$ A. Poniński, Początki ruchu ,księży-patriotów” w poludniowej części diecezji włocławskiej. W: Władze komunistyczne wobec Kościoła katolickiego w Łódzkiem..., s. 77; B. Fijałkowska, Partia wobec religii..., s. 83.

${ }^{236}$ Nazwa wywodzi się z exposé premiera J. Cyrankiewicza z 10 I 1949 r. na posiedzeniu Sejmu. Na nim obiecał, że rząd zaopiekuje się kapłanami, którzy dowiodą swego „patriotyzmu” wobec państwa komunistycznego. Szerzej o ruchu „księży patriotów” pisali: B. Bankowicz, W imię Boga i ludowej ojczyzny. Z dziejów Komisji Księży przy ZBoWiD 1949-1950, „Zderzenia” 1990 nr 5; B. Bankowicz, Księża patrioci, „Mówią Wieki” 1995 nr 10; taż, Ruch księży patriotów 1949-1955, czyli „koń trojański” w polskim Kościele katolickim. W: Ze studiów nad dziejami Kościoła i katolicyzmu PRL, Kraków 1996; K. Kowalczyk, Rozważania o działalności „księży patriotów" w województwie szczecińskim (1950-1955). W: Ziemie Zachodnie i Pótnocne Polski w okresie stalinowskim, Zielona Góra 1999; R. Kozłowski, Kilka uwag o ruchu „księży patriotów”. W: W kraju i na Wychodźstwie. Księga pamiątkowa ofiarowana Profesorowi Sławomirowi 
wnętrznej dezintegracji środowiska kościelnego miała stanowić wygodne narzędzie propagandowo-polityczne na wzór podobnych przedsięwzięć w pierwszych latach Rewolucji Francuskiej i rosyjskiego ruchu „Żywej Cerkwi”237. Grono duchownych uległych wobec władzy wykorzystano do przeciwstawiania się biskupom, Episkopatowi i Stolicy Apostolskiej. Poparcie odłamu miało legalizować represje wobec „niepokornych” kapłanów. Do ruchu weszli księża uczestniczący w ogólnopolskiej strukturze organizacyjnej - Głównej Komisji Księży (GKK) przy Związku Bojowników o Wolność i Demokrację (ZBoWiD) z jej odpowiednikami w terenie. Pierwsze posiedzenie Zarządu Głównego ZBoWiD-u odbyło się 18 III 1950 r. W momencie powstania GKK liczyła 32 członków. Trzon stanowili kapłani wywodzący się z duszpasterstwa wojskowego ${ }^{238}$. Na czele centralnych władz stanął ks. kanonik Edmund Konarski ${ }^{239}$. Początkowo do ZBoWiD-u mogli należeć tylko byli więźniowie obozów koncentracyjnych i kombatanci. Od drugiej połowy 1950 r. uczestniczyć mógł każdy ksiądz pozytywnie nastawiony do władzy. Często byli to kapelani wojskowi, duchowni pozostający w konflikcie z hierarchią kościelną i kapłani mający za sobą bolesne doświadczenia w czasie wojny, na których łatwiej można było wywrzeć presję psychiczną $a^{240}$. Głośną akcją propagandową, w której posłużono się „księżmi patriotami”, była likwidacja Caritasu w styczniu 1950 r. Po przejęciu jego struktur przez władzę przymusowo z tych szeregów utworzono nowe zarządy. Na czele postawiono ks. Antoniego

Kalembce w sześćdziesięciopięciolecie urodzin, Toruń-Olsztyn 2001, s. 529; J. Stefaniak, „Księża patrioci” w latach 1945-1953, „Przegląd Powszechny” 1999 nr 3; J. Żaryn, ,Księża patrioci” geneza powstawania formacji duchownych katolickich. W: Polska 1944/45-1989. Studia i materiaty, t. 1, Warszawa 1995, s. 123-150; tenże, Trudne problemy historii najnowszej. Księża patrioci, „Słowo Powszechne” z 30 stycznia 1996; J. Żurek, Ruch „księży patriotów” w województwie katowickim w latach 1949-1956, Warszawa-Katowice 2009.

${ }^{237}$ Rozłam w kościele francuskim w pierwszych latach rewolucji francuskiej spowodowano poprzez uchwalenie w lipcu 1790 r. tzw. konstytucji cywilnej kleru, regulującej w kraju Ludwika XVI status Kościoła i wymagającej od księży złożenia przysięgi. Ówczesny papież Pius VI w breve Quod aliquatum z lutego 1791 r. potępił te rozwiązania prawne. W rezultacie część duchowieństwa odpowiedziała posłuszeństwem papieżowi, a część uległa władzy jako lojalni „księża konstytucjonaliści" (historycy szacują, że aż 48\% duchownych). Podobnie unicestwiono niezależność rosyjskiej Cerkwi prawosławnej poprzez stworzenie sterowanej przez władzę grupy nazwanej „Żywą Cerkwią" w latach 1922-1946. W obu przypadkach ruchy te przestały być przydatne po rozbiciu środowisk duchownych i wyeliminowaniu opornych. Źródło: T. Markiewicz, „Księża patrioci” w latach 1949-1955. W: A. Kozłowska, T. Markiewicz, J. Piasecka, Stosunki między państwem a Kościotem..., s. 73-75.

${ }^{238}$ J. Żaryn, „Księża-patrioci” - geneza powstawania formacji duchownych katolickich. W: Polska 1944/45-1989. Studia i materiały, t. 1, Warszawa 1995, s. 123-150.

${ }^{239}$ Najaktywniejszymi działaczami ZBoWiD-u byli księża: Roman Szemraj, Stanisław Owczarek, Antoni Lemparty i Bonifacy Woźny. Źródło: T. Markiewicz, „,Księża patrioci”..., s. 78. Szerzej o ZBoWiD zob. B. Bankowicz, Komisja Księży przy ZBoWiD (1949-1955), „Chrześcijanin w Świecie" 1994 nr 1 s. 173-190.

${ }^{240}$ T. Isakowicz-Zalewski, Księża wobec bezpieki, Kraków 2007, s. 44. 
Lampartego, aktywnego działacza komisji księży przy ZBoWiD-zie. Z udziałem tej frakcji organizowano również akcje rolne zachęcające chłopów do pracy i afirmacji stalinowskiego modelu państwa. Posługiwano się ich nazwiskami w prasie partyjno-rządowej dla upozorowania w społeczeństwie poparcia księży dla władzy. Duchowni ze ZBoWiD-u wzięli też udział w akcji składania podpisów pod Apelem Sztokholmskim. Urządzano zjazdy i masówki (m.in. głośne spotkanie we Wrocławiu), na których „księża patrioci” krytykowali stanowisko papieża i polskich biskupów w kwestii obrony polskości Ziem Odzyskanych. W zamierzeniu chciano wychować nowego „kapłana obywatela” lojalnego wobec państwa komunistycznego. Jan Żaryn podał nieco odmienną klasyfikację księży funkcjonującą w obozie rządzącym: pozytywnie odnoszący się do władzy, bierni (których należało pozyskać) i reakcyjni (do tej kategorii należał zdecydowanie prymas Wyszyński). Pierwsza grupa nie była liczna i stanowiła margines ogółu duchowieństwa. Przez następne kilka lat UB, stosując terror, zwerbowało do Komisji Księży przy ZBoWiD-zie ponad tysiąc duchownych (stanowiących około $10 \%$ ogółu $)^{241}$. Liczbę tę potwierdza ks. Tadeusz Isakowicz-Zalewski, dodając, że było „drugie tyle księży sympatyków” sporadycznie biorących udział w działalności ugrupowania ${ }^{242}$.

W nasilonej akcji przeciwko Kościołowi starano się również werbować kleryków i kandydatów do stanu duchownego. Pracownicy UB penetrowali także kadrę profesorską seminariów duchownych. W kwietniu 1950 r. powołano Urząd ds. Wyznań, który przejął wszystkie kontakty pomiędzy Kościołem a państwem. Urząd od początku był ściśle związany z organami bezpieczeństwa. Jego rola była znacząca zwłaszcza na Ziemiach Zachodnich, gdzie struktury kościelne były słabe, a stopień uzależnienia od władz znaczny. Ten wpływ powiększył się, gdy w styczniu $1951 \mathrm{r}$. władze państwa usunęly administratorów apostolskich z Gdańska, Gorzowa Wielkopolskiego, Opola, Wrocławia. Ich miejsce zajęli wybrani pod naciskiem władz wikariusze kapitulni ${ }^{243}$.

Dnia 4 XI 1950 r. powołany został z inspiracji szefa PAX-u B. Piaseckiego Komitet Intelektualistów i Działaczy Katolickich, posługujący się znacznie subtelniejszymi metodami niż ruch księży patriotów. Członkami Komitetu byli kapłani należący do elity umysłowej duchowieństwa. Organizacja ta, działająca przy Polskim Komitecie Obrońców Pokoju, miała za zadanie stworzenie oddanego Piaseckiemu ugrupowania duchownych i świeckich. Znaczące wpływy wojewódzkie komisje (komitety) posiadały wśród pracowników naukowych Wydziałów

${ }^{241}$ J. Żaryn, Dzieje Kościoła katolickiego..., s. 106; tenże, Księża patrioci. W: Encyklopedia „, biatych plam”, t. 10, Radom 2003, s. 254-258; A. Grajewski podał, że około 1500 polskich księży katolickich zrzeszonych było w prorządowych organizacjach, ruchu paksowskim, zbowidowskim oraz caritasowym. Źródło: A. Grajewski, Kompleks Judasza ..., s. 180-182, 185-186.

${ }^{242}$ T. Isakowicz-Zalewski, Księża wobec bezpieki..., s. 44.

${ }^{243}$ A. Grajewski, Kompleks Judasza ..., s. 185-186. 
Teologicznych Uniwersytetu Jagiellońskiego i Uniwersytetu Warszawskiego oraz KUL. Aktywna była również grupa profesorów z seminarium duchownego w Nysie. Przewodniczącym był dziekan Wydziału Teologicznego Uniwersytetu Warszawskiego ks. prof. Jan Czuj. Istotną rolę w ruchu odegrali m.in. znany biblista ks. prof. Eugeniusz Dąbrowski, historyk Kościoła ks. prof. Mieczysław Żywczyński oraz były rektor Uniwersytetu Jagiellońskiego prof. Tadeusz LehrSpławiński. Sekretarzami Komisji byli kolejno współpracownicy B. Piaseckiego: Dominik Horodyński, Ryszard Reiff i Andrzej Micewski. W szczytowym okresie rozwoju Komisja nie przekroczyła liczby 300 członków. Na jej forum dyskutowano m.in. o relacji między marksizmem i katolicyzmem, problemach międzynarodowych. Księży zachęcano do udziału w ruchu poprzez dawanie możliwości wydawania książek i publikacji w prasie. Propozycja była atrakcyjna w sytuacji prawie całkowitej likwidacji prasy katolickiej i blokowaniu przez cenzurę większości wypowiedzi o charakterze religijnym ${ }^{244}$. Episkopat widział w Komisji łagodniejszą odmianę ruchu „księży patriotów”. Andrzej Micewski ocenił, że organizacja PAX-owska nie była tak silnie infiltrowana przez UB jak szeregi komisji księży przy ZBoWiD-zie i przynajmniej do 1952 r. starała się poszukiwać porozumienia z lokalnymi biskupami. Oba nurty jednak poważnie zagrażały jedności Kościoła. W październiku 1953 r. PAX-owi udało się utworzyć Komisje Duchownych i Świeckich Działaczy przy Ogólnopolskim Komitecie Frontu Narodowego i przejąć kontrolę także nad częścią środowisk komisji księży, której liderzy nie ukrywali poirytowania nową sytuacją, określaną przez nich jako „sprzedanie” ich organizacji PAX ${ }^{245}$. Władze komisji „księży patriotów” podjęły uchwałę 30 I 1953 r., w której postulowano „uzdrowienie” stosunków w kuriach biskupich oraz usunięcie z urzędów kościelnych i z seminariów duchownych księży znanych z nieprzyjaznego stosunku do PRL. Pomijając grupę naiwnych i ludzi złamanych, szeregi „księży patriotów” zasilali też cyniczni karierowicze, starający się o stanowiska ${ }^{246}$.

Episkopat nie chciał dawać pretekstu władzy do ingerencji w wewnętrzne sprawy Kościoła pod pozorem obrony „księży patriotów”, dlatego też dopiero w październiku 1950 r. prymas S. Wyszyński wydał zakaz czytania ich organu

${ }^{244}$ Przykładem tego typu publikacji może być szeroko propagowana w prasie partyjnej książka Księża mówia wydana przez Spółdzielnię Wydawniczą Czytelnik. Znalazły się w niej wypowiedzi księży patriotów, np. ks. pułkownika Szemraja, który krytykował papieża za proniemieckie nastawienie. Źródło: B. Fijałkowska, Partia wobec religii..., s. 74. Broszurą propagandową była również Katolicy radykalni ks. Henryka Weryńskiego z 1946 r. wydana w Warszawie. Źródło: T. IsakowiczZalewski, Księża wobec bezpieki..., s. 45.

${ }^{245}$ A. Dudek, R. Gryz, Komuniści i Kościół..., s. 71-73; A. Grajewski, Kompleks Judasza..., s. $183-184$.

${ }^{246}$ A. Grajewski, Kompleks Judasza ..., s. 180-182; potwierdza to ksiądz patriota w swoim pamiętniku, S. Owczarek, Być zaangażowanym, być księdzem, Warszawa 1982, s. 116-117 i T. Isakowicz- Zalewski, Księża wobec bezpieki..., s. 44. 
prasowego - „Głosu Kapłana”247. Przedstawiciele Kościoła ustosunkowali się do ruchu „księży patriotów” w memoriale z 8 V 1953 r. do prezydenta B. Bieruta, stwierdzając jednoznacznie jego szkodliwą działalność wobec Kościoła ${ }^{248}$. W Non possumus biskupi nazwali komisję księży przy ZBoWiD-zie „dywersyjną”, a jej poczynania uznano za torujące „drogę do odszczepieństwa i herezji”. Sprzeciw dostojników Kościoła nie przyniósł jednak zamierzonego skutku, ruch rozwijał się nadal, a jego uczestnicy sięgali po wysokie urzędy kościelne. Dla ratowania jedności Kościoła prymas musiał uznać „księży patriotów” wyniesionych przez komunistyczne władze na stanowisko wikariuszy generalnych w Krakowie Bonifacego Woźnego i Stanisława Hueta. Zajęli oni miejsca po skazanych duchownych w głośnym procesie księży z Kurii Metropolitalnej w Krakowie ${ }^{249}$. Prymas S. Wyszyński, przeciwstawiając się dywersji wewnętrznej w Kościele, ukarał ekskomuniką najaktywniejszych działaczy ${ }^{250}$.

\subsubsection{Nauczanie religii w szkołach przeszkodą $w$ indoktrynacji komunistycznej uczniów}

Przemiany ustrojowe po $1945 \mathrm{r}$. zmierzały w kierunku laicyzacji i propagandy ateistycznej ideologii komunistycznej we wszystkich sferach życia publicznego. Szkolnictwo było ważnym odcinkiem, który należało poddać założeniom marksizmu-leninizmu. Zaczęto zatem przeobrażać oblicze szkoły. Chodziło o zmianę dotychczasowego wychowania młodzieży z ,państwowego, narodowego i religijnego na świeckie" ${ }^{251}$, a także o zaszczepienie nowego myślenia w młodym pokoleniu ${ }^{252}$. „Idealna szkoła” wedle marzeń komunistów miała służyć „,budownictwu socjalistycznemu", uczęszczający do niej ,idealni uczniowie” mieli działać w Związku Młodzieży Polskiej (ZMP) i demonstrować poparcie dla systemu, natomiast pracujący w niej „,idealni nauczyciele” powinni aktywnie działać politycznie ${ }^{253}$. Stosunek aparatu partyjno-państwowego do nauczania religii w szkole

247 „Głos Kapłana” założono 15 II 1950 r. i istniał do października tegoż roku. Osiągnął nakład 8 tys. egzemplarzy; skład redakcji był utajniony. Wiadomo, że redaktorem naczelnym był kapelan wojskowy ks. Stanisław Wilkowski. Prymas S. Wyszyński zakazał wydawania i czytania pisma dekretem z 13 X 1950 r. Wtedy zmieniono jego tytuł na „Ksiądz Obywatel” (XII 1950-VI 1953), a następnie na „Kuźnicę Kapłańską”, istniejącą do końca formacji „księży patriotów” (12 VII 1955). Zakaz ponowiono co do zmienionych tytułów 10 I 1951 r. i 12 II 1952 r. Źródło: J. Żaryn, Dzieje Kościoła katolickiego..., s. 105-106; tenże, Księża patrioci. W: Encyklopedia „,białych plam”..., s. 256; B. Stanaszek, Usunać biskupa!..., s. 59.

${ }^{248}$ J. Żaryn, Księża patrioci..., s. 257.

249 A. Grajewski, Kompleks Judasza..., s. 180-182.

${ }^{250}$ B. Fijałkowska, Partia wobec religii..., s. 127.

${ }^{251}$ H. Konopka, Religia w szkołach Polski Ludowej..., s. 12.

${ }^{252}$ W. Ozga, Organizacja szkolnictwa w Polsce, Warszawa 1960, s. 37.

${ }^{253}$ K. Kosiński, O nowa mentalność. Życie codzienne w szkołach 1945-1956, Warszawa 2000, s. $50-52$. 
uwarunkowany był ogólnym podejściem komunistów do Kościoła i religii ${ }^{254}$. Wiara miała być sprawą prywatną każdego obywatela, a religia traktowana była jako niezgodna $\mathrm{z}$,naukowym poglądem na świat”255. Chciano stworzyć szkołę bezwyznaniową i materialistyczną 256 . Walka, podobnie jak w innych sferach życia publicznego, toczyła się na polu ideologicznym, prawnym i administracyjnym. Nauczanie religii w szkołach było bardzo istotną kwestią w stosunkach Kościoła z państwem i elementem starć światopoglądowych.

System oświaty formalnie do 1952 r. podlegał postanowieniom Konstytucji marcowej z 1921 r. Jednak już w 1945 r. władze oświatowe postulowały, aby uczynić religię przedmiotem fakultatywnym i rozpoczęły proces laicyzacji polskiej szkoły ${ }^{257}$. Na Zjeździe Oświatowym w Łodzi w 1945 r. uchwalono kierunki reform polskiego szkolnictwa ${ }^{258}$. Przedstawiono na nim wiele koncepcji, z których w pierwszym rzędzie uwzględniono projekty Ministerstwa Oświaty i Związku Nauczycielstwa Polskiego. Grunt pod nowy system oświatowy mieli przygotować członkowie Robotniczego Towarzystwa Przyjaciół Dzieci (RTPD) i Chłopskiego Towarzystwa Przyjaciół Dzieci (ChTPD) ${ }^{259}$. Obie organizacje połączono w 1949 r., tworząc Towarzystwo Przyjaciół Dzieci. W szkołach założonych

${ }^{254}$ Zob. K. Marks, F. Engels, O religii, Warszawa 1962.

${ }^{255}$ H. Konopka, Religia w szkołach..., s. 16.

${ }^{256}$ Szerzej zob. H. Chylińska, Ideat wychowawczy w okresie rewolucji spotecznej $w$ Polsce (1944-1948), Warszawa 1981; T. Hejnicka-Bezwińska, Zarys historii wychowania (1944-1989). Oświata ipedagogika pomiędzy dwoma kryzysami, cz. 4, Kielce 1996; E.J. Kryńska, S.W. Mauersberg, Indoktrynacja młodzieży szkolnej w Polsce w latach 1945-1956, Białystok 2003; S. Mauersberg, Reforma szkolnictwa w latach 1944-1948, Wrocław 1974; B. Potyrała, Przemiany oświaty w Polsce 1944-1948, Wrocław 1991; M. Strzelecka, Rola wychowania w powojennej rzeczywistości politycznej w publicystyce ,,Tygodnika Powszechnego"(1945-1953). W: Wychowanie a polityka. Między wychowaniem narodowym a państwowym, pod red. W. Wojdyły, Toruń 1999, s. 145-151; L. Szuba, Polityka oświatowa państwa polskiego w latach 1944-1956, Lublin 2002; K. Trzebiatowski, Organizacja szkolnictwa w Polsce Ludowej, Warszawa 1972; J. Wojdon, Propaganda polityczna w podręcznikach dla szkót podstawowych Polski Ludowej (1944-1989), Torun 2001; W. Wyspiański, O podstawowe zatożenia nowej szkoły. W: Ogólnopolski Zjazd Oświatowy w Łodzi 19-22 czerwca 1945, Warszawa 1945.

${ }^{257}$ Pierwsza w założeniu komunistów „świecka” szkoła, bez nauczania religii, powstała 5 lutego 1945 r. w powiecie jarocińskim. Źródło: J.F. Godlewski, Kościół rzymskokatolicki w Polsce wobec sekularyzacji życia publicznego (1944-1974), Warszawa 1978, s. 148.

${ }^{258}$ Szerzej zob.: Ogólnopolski Zjazd Oświatowy w Łodzi (18-22 czerwca 1945), Warszawa 1945; S. Skrzeszewski, O nowa szkotę w nowej Polsce (na marginesie zjazdu oświatowego w Lodzi), „Nowa Szkoła” 1945 nr 3 s. 1-7; Zjazd oświatowy w Łodzi, „,Tygodnik Powszechny” 1945 nr 26 s. 6.

${ }^{259}$ RTPD powstało w 1919 r. w Warszawie przy PPS, nazwę przyjęło w 1926 r. Chcąc wpajać wychowanie socjalistyczne jego członkowie organizowali zakłady opiekuńczo-wychowawcze, szkoły i przedszkola. Po wojnie w 1946 r. wznowiło działalność. Na życzenie B. Bieruta połączono je z Chłopskim Towarzystwem Przyjaciół Dzieci w kwietniu 1949 r. tworząc Towarzystwo Przyjaciół Dzieci, które miało za zadanie ,wyeliminowanie zorganizowanych wpływów reakcyjnoklerykalnych”. Źródło: H. Konopka, Religia w szkołach..., s. 66 przypis 47. 
i będących pod opieką TPD nie prowadzono lekcji religii. Szkoły TPD miały być „realizacją ideału szkoły, w której owi idealni nauczyciele wychowywaliby idealnych uczniów, wedle teorii marksizmu-leninizmu"260.

Zerwanie konkordatu, który stanowił podstawę prawną nauczania religii w szkole, dało szerokie uprawnienia członkom władzy. Zmian dokonywano stopniowo poprzez zarządzenia, okólniki i instrukcje. Zaczęto od zakazu rzekomego przymusu uczęszczania na religię. $\mathrm{Z}$ formalnie obowiązkowej religii $\mathrm{w}$ szkole podstawowej i średniej mogli zwolnić rodzice wyrażający sprzeciw, co gwarantował okólnik z 13 IX 1945 r. Na mocy zarządzenia z 12 VI 1945 r. w liceach pedagogicznych religia przestała być przedmiotem egzaminacyjnym na maturze, a nauczycieli religii wyłączono z komisji egzaminacyjnych. W następnym roku zaczęto proces zamykania prywatnych szkół zakonnych. Rozpoczęty został proces sukcesywnego zmniejszenia liczby godzin nauczania religii, aby następnie całkowicie ją wyeliminować. Równolegle starano się też przeładować program innymi przedmiotami ${ }^{261}$.

W kształtowaniu polityki oświatowej uznano, że nauczyciel nie może być apolityczny. Po zwycięstwie wyborczym w 1947 r. nie było już potrzebne stwarzanie pozorów współpracy i przystąpiono do ofensywy ideologicznej. Do roku szkolnego 1948/1949 włącznie nauczano religii we wszystkich szkołach, gdyż przedmiot ten znajdował się w programach szkolnych. Sformułowano jednak już w tym roku szkolnym nowe zadania mające służyć ideologii socjalistycznej. Ograniczono wyraźnie praktyki religijne w szkole i działalność organizacji $^{262}$ takich jak Związek Harcerstwa Polskiego. W zamian tworzono koła ZMP, które stały się dobrym narzędziem władzy komunistycznej. W roku szkolnym 1947/1948 nasilono szykany przeciwko nauczycielom religii. Nauczanie chciano zastąpić „socjalistyczną moralnością”, chodziło też o ukształtowanie w młodzieży nowego myślenia ${ }^{263}$. Księży katechetów pozostawiono bez wynagrodzenia, a kiedy ci deklarowali bezpłatną posługę, i tak nie godzono się na ich obecność w szkole. Zarządzenia bądź ustne dyrektywy eliminowały lekcje religii ze szkół. W 1948 r. zamykano szkoły prywatne, tworząc w zamian sieć szkół Robotniczego Towarzystwa Przyjaciół Dzieci. W 1949 r. nastąpiło zdecydowane zaostrzenie kursu. Z dniem 30 VI 1949 r. zaplanowano zamknięcie wszystkich pozostałych trzydziestu szkół prowadzonych przez zgromadzenia zakonne. Zmuszano dzieci i rodziców, aby sami żądali usunięcia religii ze szkół. Dyrektorzy placówek szkolnych planowali lekcje z tego przedmiotu na pierwszą lub ostatnią godzinę. Ocenę z religii na świadectwie umieszczano po wszystkich innych ocenach

${ }^{260}$ K. Kosiński, O nowq mentalność..., s. 52.

${ }^{261}$ H. Konopka, Religia w szkołach..., s. 19-22, 24-26; M. Strzelecka, Trudne kompromisy..., s. 74 .

${ }^{262}$ H. Konopka, Religia w szkołach..., s. 51.

${ }^{263}$ K. Kosiński, O nowa mentalność..., s. 53, 83. 
z przedmiotów. W roku szkolnym 1949/1950 zmieniono wreszcie status religii z przedmiotu obowiązkowego na nadobowiązkowy. Przeprowadzano równocześnie akcję usuwania krzyży ze ścian, masowe zwalnianie księży, sióstr zakonnych i katechetów świeckich nauczających religii. Odciąganiu młodzieży od udziału w uroczystościach religijnych miało służyć organizowanie konkurencyjnych imprez. Zaczęto ograniczać modlitwę przed lekcjami, utrudniać ustalanie terminów rekolekcji, uniemożliwiać wydawanie podręczników do katechezy. Szkoły stawały się „ośrodkami wiary w socjalizm”, a wychowanie młodzieży odbywało się $\mathrm{w}$ duchu marksizmu-leninizmu ${ }^{264}$.

Religijne wychowanie młodzieży było szczególną troską przedstawicieli Kościoła. Prymas wyraził to w liście z 27 XII 1950 r. dotyczącym katolickiego wychowania dzieci i młodzieży skierowanym do rodziców, w którym zachęcił do wybierania przedszkoli i szkół z możliwością pobierania lekcji religii ${ }^{265}$.

Czynniki państwowe w realizacji polityki oświatowej posługiwały się osobami przynależącymi do Związku Nauczycielstwa Polskiego. Ożywioną akcję przeciw Kościołowi prowadzili również uczestnicy ZMP ${ }^{266}$. W oświadczeniu prasowym KC PZPR w sprawie stosunków państwa z Kościołem z marca 1949 r. czytamy: „Rząd [...] nie będzie tolerował nadużywania religii przez niektórych katechetów do siania niepokoju w umysłach młodzieży i podburzania przeciw władzy państwowej”"267. Tempo usuwania religii ze szkół było różne w poszczególnych regionach Polski. Zależało w dużej mierze od siły tradycji nauczania religii, autorytetu Kościoła, proboszcza, katechety i działania lokalnych władz oświatowych ${ }^{268}$.

Od 1950 r. do nauczania religii przyjmowano wyłącznie księży „,pozytywnych", natomiast nauczycieli świeckich zobowiązano do ślubowania na wierność władzy ${ }^{269}$. Zbieranie podpisów pod Apelem Sztokholmskim ${ }^{270}$ stało się okazją do zwolnień niewygodnych nauczycieli. Tylko w lipcu $1950 \mathrm{r}$. pracę straciło 434 prefektów i około 200 katechetów świeckich. Akcję skierowano też prze-

${ }^{264}$ H. Konopka, Religia w szkołach..., s. 28, 31, 40-41, 48- 65, 69, 112, 114, 119.

${ }^{265}$ B. Fijałkowska, Partia wobec religii..., s. 101.

${ }^{266}$ H. Konopka, Religia w szkołach..., s. 28.

267 Tamże, s. 62-63.

${ }^{268}$ H. Konopka, Nauczanie religii w województwie łódzkim na tle innych regionów. W: Władze komunistyczne wobec Kościoła katolickiego w Łódzkiem 1945-1967, Warszawa 2005, s. 135.

269 B. Fijałkowska, Partia wobec religii..., s. 98.

${ }^{270}$ Apel Sztokholmski - uchwalony na III Sesji Światowej Rady Pokoju (5-21 III 1950) w Sztokholmie, nawoływał do przeprowadzenia ogólnoświatowego plebiscytu w sprawie zakazu użycia broni jądrowej poprzez składanie indywidualnych podpisów pod jego tekstem. Komunistyczna i lewicowa inspiracja Ruchu Obrońców Pokoju, zaostrzająca się sytuacja międzynarodowa (m.in. wybuch wojny w Korei) spowodowały sprzeciw rządu USA i wielu krajów antykomunistycznych wobec podpisywania Apelu. Przeciwko składaniu podpisów pod nim wypowiedział się papież Pius XII (26 VII 1950 r.). Źródło: H. Konopka, Religia w szkołach... s. 90, przypis 6. 
ciwko Kościołowi ${ }^{271}$. W nowej szkole nie było już miejsca na religię, o czym świadczyły dalsze obostrzenia wprowadzone w 1952 r. Protest biskupów katowickich (Stanisława Adamskiego, Herberta Bednorza i Juliusza Bieńka) poparty podpisami rodziców zakończył się ich aresztowaniem. Dzieci z niższych klas wyłączono z uczestnictwa w rekolekcjach. Na przełomie 1951 i 1952 r. sprawa nauczania religii w szkołach zeszła na plan dalszy, a z początkiem roku szkolnego 1953/1954 w ponad 60\% szkół nauki religii nie rozpoczęto ${ }^{272}$.

Kwestia wychowania młodzieży była dyskutowana na I i II Konferencji Plenarnej Episkopatu Polski w latach 1945-1946. Owocem pierwszej z nich było powołanie do życia Komisji Szkolnej, w skład której weszli: arcybiskup A. Sapieha, biskupi - Włodzimierz Jasiński, Stanisław Rospond, Juliusz Bieniek i prałat Andrzej Wronka ${ }^{273}$. Przewodniczący Komisji oponował przeciw wszelkiemu ograniczaniu nauczania religii $\mathrm{w}$ szkole. $\mathrm{W}$ trosce o podnoszenie poziomu przygotowania pedagogicznego katechetów w ramach Komisji organizowano obowiązkowe kursy dokształcające w czasie wakacji. Sekretarz Episkopatu biskup Z. Choromański podjął rozmowę z ministrem oświaty Stanisławem Skrzeszewskim w dniu 12 IX 1947 r., dotyczącą całokształtu nauczania katolickiego. Niestety, rozmowa ze strony przedstawiciela rządu prowadzona była w kierunku jedynie rozważań politycznych i pouczeń, w jaki sposób księża powinni ustosunkować się do władzy. Minister zasugerował ponadto, że przedstawiciele Episkopatu „powinni wzywać księży” do wychowania prorządowego. Sprawy szkolne i wychowawcze podjęto również w Odezwie biskupów polskich do wiernych, odczytanej w kościołach 28 IX 1947 r. Zwrócono w niej uwagę na niepewny los prywatnych szkół katolickich i wychowywanie tzw. nowego człowieka, pozbawionego wiary w Boga. W odpowiedzi organy bezpieczeństwa rozpoczęły akcję wymierzoną we „wrogów rządu” i przesłuchały 412 księży. Odezwę skrytykowali też uczestnicy debaty sejmowej ${ }^{274}$. Sprawy wychowania na bieżąco rozważano też na łamach prasy katolickiej ${ }^{275}$. Zagadnienia te wróciły podczas obrad Konferencji Plenarnej Episkopatu Polski w dniach 14 i 15 IV 1948 r. Podjęto postanowienie co do usprawnienia pracy Komisji Szkolnej i wystosowano obszerny list Do katolickiej młodzieży polskiej, w którym skrytykowano światopogląd materialistyczny. Referent z ramienia Komisji Szkolnej Episkopatu biskup Jan Stepa zasygnalizo-

${ }^{271}$ J. Żaryn, Kościót w PRL..., s. 27; W.J. Wysocki, Osaczanie Prymasa .., s. 19.

${ }^{272}$ J. Żaryn, Kościót w PRL; H. Konopka, Religia w szkołach..., s. 80, 90, 95, 103-107, 127,149 .

${ }^{273}$ Więcej zob. M. Jakubiec, Abp Adam Stefan Sapieha jako przewodniczący Komisji Szkolnej Episkopatu Polski. W: Księga Sapieżyńska. Działalność kościelna i narodowa Adama Stefana Sapiehy, t. 2, pod red. J. Wolnego, Kraków 1996, s. 71-85.

${ }^{274}$ H. Konopka, Religia w szkołach..., s. 36-38.

275 Szerzej zob.: M. Strzelecka, Trudne kompromisy..., s. 47-94; E. Godlewski, O program katolicki, „Niedziela” 1947 nr 33; S. Cedro, Przeciw świeckości w wychowaniu, „Głos Katolicki” $1947 \mathrm{nr} 34$. 
wał Ministerstwu Oświaty kwestie odpowiednich kwalifikacji zakonnic uczących religii oraz zapewnienia warunków materialnych wizytatorom religii. Nowe założenia w szkolnictwie wprowadzone w roku szkolnym 1948/1949 i zamknięcie wielu szkół zakonnych spowodowały, że kardynałowie A. Hlond i A. Sapieha podjęli próbę listownej interwencji u prezydenta B. Bieruta. Rząd jednak nadal konsekwentnie prowadził wytyczoną przez siebie politykę. Pod koniec 1948 r. widząc stale pogarszającą się sytuację szkolnictwa, nawoływano do protestów u niższych władz oświatowych i postulowano przygotowanie nauczania religii poza szkołą. Po powstaniu PZPR kardynał A. Sapieha wystosował 22 XII 1948 r. memoriał do prezydenta, w którym podjął kwestię laicyzacji całego szkolnictwa w Polsce jako sprzeczną ze swobodami zagwarantowanymi w Konstytucji. Odpowiedzi jednak nie uzyskał ${ }^{276}$. Aktualne problemy szkolnictwa podjęto również w liście pasterskim Episkopatu z 25 III 1949 r. Podkreślono w nim, że religia nie może być jedynie przedmiotem dodatkowym, a powinna być podstawą wychowania. Członkowie Episkopatu, powołując się na encyklikę Piusa XI z 1929 r. O chrześcijańskim wychowaniu młodzieży, zarzucili władzom oświatowym dążenie do zagarnięcia wszystkich spraw wychowania i nauczania ${ }^{277}$. Komisja Szkolna po dokonaniu oceny złej sytuacji nauki religii w szkołach ${ }^{278}$ na posiedzeniu 23 VIII 1949 r. postanowiła organizować ją w kościołach, co nie spotkało się z aprobatą władz partyjnych ${ }^{279}$. Sformułowano też dyrektywy do rozmów z członkami rzą$\mathrm{du}$; zawierały one wszystkie ważniejsze problemy występujące w relacji Kościoła z państwem, a dotyczące katechizacji. Jednak większość postulatów nie miała szans realizacji. Ze strony sekretariatu KC PZPR uzyskano odpowiedź taktyczną, którą posługiwano się też przy innych okazjach dotyczących religii. Władze zapewniały, że nie zamierzają zmieniać obecnego stanu nauczania w szkołach ani likwidować szkół katolickich czy stawiać przeszkód w prowadzeniu religii poza szkołą. Domagały się natomiast zachowania lojalności ze strony Kościoła. Liczna korespondencja i rozmowy pomiędzy Episkopatem a rządem świadczyły o niemożności dojścia do porozumienia w rzeczowej dyskusji. Odmienne bowiem były wyznawane światopoglądy. Do konfliktu doszło przy okazji listu papieża Piusa XII do biskupów polskich napisanego na 10-lecie wybuchu wojny, w którym papież wspomniał o zakazie nauki religii w polskich szkołach. Komuniści zażądali zdementowania rzekomo fałszywego stwierdzenia. Konflikt narastał; w niezwykle ostrym tonie kardynał A. Sapieha i arcybiskup S. Wyszyński wystosowali list do prezydenta B. Bieruta z datą 16 II 1950 r. Pisano w nim: „Walka z Kościołem,

${ }^{276}$ H. Konopka, Religia w szkołach ..., s. 46-47, 55-56.

277 Tamże, s. 63, 68-69,

${ }^{278}$ Według ocen kościelnych w kwietniu 1949 r. w 20\% szkół religii nie było, w 35\% szkół przedmiot figurował tylko na papierze $\mathrm{w}$ jednej godzinie tygodniowo, a lekcje nie odbywały się. Tamże, s. 70.

${ }^{279}$ B. Fijałkowska, Partia wobec religii..., s. 103. 
z religią, z Bogiem w Polsce jest jaskrawo widoczna. Gdy ją stwierdzamy, jednego pragniemy, by nam nie wmawiano, że tej walki nie ma. Pragniemy chociaż tyle szacunku, należnego ludziom, by rzeczywistość nazwać po imieniu"280. Hierarchowie w kolejnym liście z 12 IX 1950 r. wymienili straty, jakich doznał Kościół w ostatnich pięciu latach, nie pomijając kwestii nauczania religii ${ }^{281}$.

Rozmowy prowadzone przez przedstawicieli Kościoła i państwa spełzły na niczym. Niewiele pomagały protesty i listy kierowane do wysoko postawionych urzędników państwowych. Żadnego efektu nie przynosiło też zbieranie podpisów pod petycjami o przywrócenie religii. Władzę pobudzało to raczej do kolejnych restrykcji i zaprzeczania, jakoby Kościół był w ogóle atakowany. Konsekwentne dążenie do sekularyzacji oświaty obłudnie thumaczono przestrzeganiem zasad wolności sumienia i wyznania. Zadaniem było bowiem wychowanie ateistycznego pokolenia. Proces wypierania religii ze szkół w latach 1945-1953 przebiegał zatem planowo i systematycznie.

\subsubsection{Frontalny atak na Kościół w latach 1950-1953}

Kolejne lata przyniosły nieukrywaną i bezpośrednią konfrontację Kościoła z państwem. Rok 1951 okazał się bardzo trudny. Na początku aresztowano biskupa kieleckiego Czesława Kaczmarka, którego przez następne dwa lata poddawano przesłuchaniom przygotowawczym do procesu pokazowego. Pod koniec stycznia $1951 \mathrm{r}$. władze usunęły i internowały administratorów apostolskich na Ziemiach Zachodnich, aby na ich miejsce powołać zaufanych „księży patriotów”. Propagandzie komunistycznej w latach 1951-1952 służyć miało również ożywienie ruchu „księży patriotów” i wzrost liczby członków Kół Księży przy ZBoWiDzie. Przedstawiciele kół partyjnych zastosowali nawet formy dyplomów i nagród pieniężnych we współzawodnictwie werbowania nowych członków do wyżej wymienionych kół. Nagradzano za liczbę poprawnych ideologicznie kazań czy rozprowadzenie egzemplarzy „Księdza Obywatela”. Kontynuowano przydzielanie aktywistom zapomóg i deficytowych materiałów budowlanych. Wprowadzano nawet pojęcie ideologiczne „walki klasowej” wśród kleru, wykorzystując konflikty między biskupami i ich podwładnymi oraz przeciwstawiając tzw. biedniaków kułakom. Stratą dla Kościoła w Polsce była śmierć 23 VII 1951 r. jednego z najważniejszych jego obrońców - kardynała A. Sapiehy.

Prymas Wyszyński odpierając ataki związane ze sprawą Ziem Odzyskanych, udzielił wywiadu „Tygodnikowi Powszechnemu”, broniąc stanowiska Ojca Świętego. Wyrazem niezadowolenia władz z tego powodu było wysiedlenie zakonnic z terenów Wybrzeża. Zbliżał się czas ogłoszenia nowej konstytucji. Episkopat

${ }^{280}$ H. Konopka, Religia w szkołach ..., s. 82.

${ }^{281}$ Tamże, s. 73-76, 106, 123, 140. 
wystosował 11 II 1952 r. do prezydenta Katolickie postulaty konstytucyjne jako odpowiedź na ogłoszony przez władze projekt nowej ustawy. Ustosunkowano się głównie do punktu dotyczącego rozdziału Kościoła od państwa oraz do podstawowych praw człowieka. Pseudodebata konstytucyjna, a następnie czas przed wyborami do sejmu był okresem wzmożonych ingerencji władz w zmiany personalne na stanowiskach proboszczów i dziekanów. Nową konstytucję ogłoszono w rocznicę Manifestu PKWN, 22 VII 1952 r. Był to już ostatni etap umocnienia się władzy komunistów w Polsce. Nie uwzględniono w niej żadnego z postulatów Episkopatu. Od połowy 1952 r. gwałtownie wzrosło napięcie w stosunkach państwo-Kościół. Nadal realizowano program usuwania religii ze szkół. Represje zastosowano również w odniesieniu do jedynej niezależnej wyższej uczelni, jaką był KUL, gdzie zmuszono senat do wyboru na rektora prorządowo nastawionego ks. Józefa Iwanickiego i usunięcia z uczelni 12 profesorów oraz zlikwidowania kilku katedr. W lipcu 1952 r. rozwiązano nakazem administracyjnym 46 niższych seminariów duchownych, część ich budynków przeznaczono na szpitale, hotele robotnicze, domy starców i inne cele. Kolejne represje dotknęly ordynariusza diecezji katowickiej biskupa Stanisława Adamskiego ostro protestującego przeciw usuwaniu religii ze szkół. Po uderzeniu na diecezję katowicką przyszedł czas rewizji w archidiecezji krakowskiej. W połowie listopada 1952 r. zabrano przyjęte po wojnie na przechowanie od osób prywatnych dzieła sztuki oraz kilka tysięcy dolarów. Aresztowano przy tym pięciu księży z Kurii. Przedstawiciele Episkopatu szli na ustępstwa, próbując złagodzić ataki, co nie przynosiło jednak żadnego rezultatu. Władza komunistyczna dążyła bowiem do całkowitej likwidacji Kościoła ${ }^{282}$. Pod koniec 1952 r. wygnano trzech biskupów z diecezji katowickiej, a ich miejsce zajęli duchowni współpracujący z władzami.

Wobec „księży patriotów” zaangażowanych w kampanię wyborczą do sej$\mathrm{mu}$ jesienią $1952 \mathrm{r}$. zastosowano ulgową politykę finansową, nękano natomiast księży „reakcyjnych”283. We Wrocławiu 12 XII 1952 r. odbył się kolejny propagandowy zjazd duchowieństwa i świeckich działaczy katolickich, tym razem pod hasłem polskości Ziem Zachodnich. Uczestniczyło w nim ok. 1500 duchownych, w tym wielu znanych intelektualistów, m.in. księża profesorowie Józef Iwanicki, Marian Michalski i Wincenty Kwiatkowski. Główny referat, krytycznie oceniający działania Episkopatu Polski i samego prymasa, wygłosił ks. prof. Eugeniusz Dąbrowski. Strona państwowa zademonstrowała poprzez „księży patriotów” swoją siłę. Na łamach prasy należącej do ruchu jawnie występowano przeciwko biskupom, wielu wprost atakowało prześladowanych przez UB. Podczas gdy biskup Kaczmarek był więziony, ks. Wacław Lagosz szkalował go na łamach „Słowa Powszechnego”. Księdza prymasa zaatakowali

${ }^{282}$ A. Dudek, R. Gryz, Komuniści i Kościót..., s. 73-81; J. Żaryn, Dzieje Kościoła katolickiego..., s. 120; J. Piasecka, Stosunki między Kościołem..., s. 52.

${ }^{283}$ A. Dudek, R. Gryz, Komuniści i Kościół ..., s. 63-71; W. Lizak, Historia Polski..., s. 245. 
na łamach organu PAX-u czołowi „księża patrioci” - ks. prof. E. Dąbrowski oraz rektor KUL, ks. prof. J. Iwanicki ${ }^{284}$.

Władza przystąpiła też do regulacji prawnej, która pozwoliłaby na nieograniczone panowanie nad Kościołem. Ostatecznej rozgrywce z kierownictwem Episkopatu miała służyć reorganizacja w Ministerstwie Bezpieczeństwa Publicznego dokonana w styczniu 1953 r. Departament XI przejął obowiązki dotychczasowego Departamentu V w sprawach kościelnych. Oznaczało to nowe struktury i większą liczbę funkcjonariuszy do wewnętrznego rozbijania Kościoła.

Punktem zapalnym w relacjach Kościół-państwo stało się przejęcie Caritasu w styczniu 1950 r. oraz kolejne kroki ustawowe ograniczające wolność Kościoła w Polsce. Sejm wydał 20 III 1950 r. ustawę o przejęciu dóbr „,martwej ręki”, na podstawie której państwo przejęło na własność wszystkie kościelne nieruchomości ziemskie. W wyniku tej akcji kościół utracił blisko 155 tys. ha ziemi. Pozostały jedynie same kościoły i cmentarze przykościelne ${ }^{285}$.

Ustawą z 19 IV 1950 r. utworzono Urząd do Spraw Wyznań (UdSW) na czele z Antonim Bidą do kontroli i koordynowania kwestii wyznaniowych. W celu realizacji zamierzonych zadań stworzono trzy wydziały: ogólny, rzymskokatolicki i wyznań nierzymskokatolickich. Oprócz tego powołano dwa samodzielne referaty do nadzoru stowarzyszeń wyznaniowych i nadzoru Funduszu Kościelnego, z którego korzystali głównie księża prorządowi. UdSW i wojewódzkie Wydziały do Spraw Wyznań wzięły „pod opiekę” wszelakie relacje państwa z Kościołem² ${ }^{286}$.

Akcja zbierania podpisów pod tzw. Apelem Sztokholmskim ogłoszonym w marcu 1950 r., mającym wymowę antyamerykańską i jednocześnie proradziecką, była kolejną próbą dla polskiego Kościoła. Komunistom zależało na podpisach proboszczów pod dwuznaczną akcją ,pokojową”, aby pociągnąć również mieszkańców wsi. Biskupi w dniu 9 czerwca odmówili podpisania apelu, motywując decyzję apolitycznością Kościoła, co dało pretekst do kolejnych prześladowań. Usunięto kolejnych księży ze szkół oraz świeckich katechetów. Zamknięto kilka domów zakonnych w Krakowie i Płocku.

Powodem do sporu między Kościołem a stroną rządową stała się również kwestia granicy zachodniej. Wraz z podpisaniem 6 VII 1950 r. w Zgorzelcu układu granicznego między Polską a Niemiecką Republiką Demokratyczną dla władz skończył się czas pretekstu do utrzymywania tymczasowej administracji kościelnej na Ziemiach Zachodnich. Zgodnie z umową Odra i Nysa miały stać się „granicą pokoju”, a mieszkańcom Ziem Zachodnich przestało zagrażać kolejne

${ }^{284}$ A. Grajewski, Kompleks Judasza ..., s. 186-187.

${ }^{285}$ J. Żaryn, Dzieje Kościoła katolickiego..., s. 95-96, 104; J. Żaryn, Kościót a władza..., s. 312; B. Fijałkowska, Partia wobec religii i Kościoła..., s. 100; A. Dudek, R. Gryz, Komuniści i Kościót..., s. 38-42, 53. Z. Zieliński, Kościót w Polsce..., s. 69-71; W. Lizak, Historia Polski..., s. 241; N. Davies, Boże igrzysko..., s. 715-716.

${ }^{286}$ A. Dudek, R. Gryz, Komuniści i Kościół..., s. 56-58; szerzej zob. H. Dominiczak, Organy bezpieczeństwa... 
przesiedlenie. Sytuacja Kościoła również wymagała ustabilizowania i Episkopat zobowiązał się wystąpić do papieża o ustanowienie stałej administracji tych ziem. W tej kwestii rząd wywierał presję na hierarchię, chcąc szybkich decyzji. Nie brano pod uwagę trybu ich podejmowania według Kodeksu prawa kanonicznego. Rząd domagając się zdecydowanych posunięć ze strony polskiego Episkopatu wystosował pismo z Urzędu do Spraw Wyznań dnia 23 X 1950 r., wzywające do przyspieszenia działań w tym kierunku. Stolica Apostolska nadal zwlekała z ustanowieniem nowych biskupów, co stało się sposobnością do ataku ze strony komunistów. W tej sprawie stosowano naciski głównie wobec prymasa S. Wyszyńskiego. Posługując się propagandą władze po raz pierwszy zakwestionowały też prawo Kościoła do poniemieckiej własności kościelnej na tych terenach ${ }^{287}$.

Rok 1951 przyniósł serię ataków prasowych na przedstawicieli Kościoła w związku ze sprawą zachodnich diecezji. Usunięto administratorów apostolskich z Olsztyna, Gdańska, Gorzowa, Opola, Wrocławia i wprowadzono na ich miejsce „księży patriotów”. Posunięcia rządu stały się niezaprzeczalną ingerencją w wewnętrzne sprawy Kościoła. Prymas S. Wyszyński znalazł się w wyjątkowo trudnej sytuacji, będąc przymuszony do zatwierdzenia kandydatów. Ostateczne uporządkowanie administracji kościelnej na Ziemiach Odzyskanych miała przynieść wizyta prymasa w Watykanie w kwietniu 1951 r. Przebiegła ona w przyjaznej atmosferze i papież przychylił się do mianowania nowych biskupów. Kardynał S. Wyszyński spełnił oczekiwanie władz kościelnych, jednak rząd stanął na przeszkodzie i nie zezwolił na wejście w życie postanowień. Prasa reżymowa pominęła te fakty milczeniem, a czasopismom katolickim objętym cenzurą nie pozwolono na poinformowanie o tym społeczeństwa. Na łamach prasy partyjnej rozpoczęto natomiast nową propagandę przeciw hierarchii i Watykanowi. Oskarżono „rządzącą kościołem katolickim klikę" o uleganie imperialistom amerykańskim i kołom watykańskim (np. „Trybuna Ludu” 1951 z 20 VII). Grudniowy wiec we Wrocławiu miał nagłośnić rzekome antypolskie nastawienie Stolicy Apostolskiej i polskiego Episkopatu oraz wbić klin między Episkopat a niższy kler ${ }^{288}$.

Aresztowanie biskupa Kaczmarka wraz z grupą księży (łącznie 20 osób) w Kielcach 20 I 1951 r. miało być wstępem do zasadniczego uderzenia w Kościół. Po nim miała miejsce tzw. sprawa katowicka i krakowska. Władze 6 XI 1952 r. wypędziły z Katowic biskupów Stanisława Adamskiego i Juliusza Bieńka. Biskup Herbert Bednorz został aresztowany, a w grudniu wyrzucony z diecezji z powodu apelu biskupa S. Adamskiego do wiernych o zbieranie podpisów pod petycją do Rady Państwa w sprawie przywrócenia usuwanej ze szkół katechezy. Pomimo zagrożenia utratą pracy i więzieniem, petycję odważyło się podpisać 72 tys. osób.

${ }^{287}$ A. Dudek, R. Gryz, Komuniści i Kościót..., s. 59-61; J. Piasecka, Stosunki między Kościolem ..., s. 45-46.

${ }^{288}$ J. Piasecka, Stosunki między Kościołem..., s. 46-47. P. Raina, Kardynat Wyszyński, t. 1: Droga na..., s. 238-245. 
Akcja choć „słuszna merytorycznie nie była uzgodniona z Episkopatem” i prymas nie zgodził się na przedłożenie petycji rządowi. Władze chciały wyboru na wikariusza kapitulnego diecezji „księdza patriotę” Filipa Bednorza, nie przyjmując ośmiu kandydatów zaproponowanych przez prymasa. Nie zakończono sprawy katowickiej, gdy rozpoczęto w listopadzie atak na archidiecezję krakowską. Dokonano rewizji w kurii, podczas której zarekwirowano tysiące dolarów i dzieła sztuki przyjęte na przechowanie od prywatnych właścicieli. Aresztowano czterech księży oraz trzy osoby świeckie i oskarżono o nielegalny handel dewizami i szpiegostwo na rzecz wywiadu amerykańskiego. W styczniu 1953 r. rozpoczął się też głośny proces księży z kurii krakowskiejes9. Zapadły trzy wyroki śmierci, których nie wykonano, w tym na księdza Józefa Lelito ${ }^{290}$. Aresztowano arcybiskupa, metropolitę krakowskiego (wcześniej lwowskiego) Eugeniusza Baziaka i jego sufragana biskupa Stanisława Rosponda. Proces spowodował eskalację napięcia w stosunkach Kościół-państwo. Akcja miała służyć w dużej mierze zniesławieniu zmarłego kardynala A. Sapiehy ${ }^{291}$.

W takiej atmosferze odmówiono prymasowi S. Wyszyńskiemu jako ,agentowi Watykanu" wyjazdu do Włoch w celu odebrania kapelusza kardynalskiego. Po procesie krakowskim nasilili swoją działalność również „księża patrioci”, którzy podjęli 30 I 1953 r. uchwałę o ,uzdrowieniu” stosunków w kuriach. Oznaczało to usunięcie księży o „wrogich poglądach”, stworzenie warunków „przychylnych wobec Polski Ludowej” i zaprzestanie rzekomych prześladowań „postępowych księży" przez hierarchię. Był to jawny bunt wobec Episkopatu. Prymas ogłosił wobec nich oraz redagujących „Księdza Obywatela” karę ekskomuniki. Odpowiedzią środowiska było zastosowanie wybiegu zmiany tytułu wspomnianego pisma ${ }^{292}$.

Prymas zażegnał konflikt bez wsparcia członków Episkopatu. Mocą swoich nadzwyczajnych uprawnień nadał jurysdykcję ks. F. Bednorzowi i wydał oświadczenie podpisane przez sekretarza Episkopatu biskupa Z. Choromańskiego, odcinające się od oskarżonych księży. W zamian prymasowi udało się wymóc na rządzie, by na stanowisko wikariusza kapitulnego w Krakowie wybrać biskupa Franciszka Jopa, a nie zwykłego duchownego, w dodatku „księdza patriotę"293.

Na początku 1952 r. Komisja Konstytucyjna ogłosiła projekt ustawy i wezwała naród do jego przedyskutowania. Strona kościelna czując się odpowiedzialna

${ }^{289}$ Bogaty materiał ikonograficzny z procesów zamieszczono w katalogu wystawy Wielkie procesy pokazowe w Krakowie. Wystawa, oprac. W. Frazik i in., Kraków 2003.

${ }^{290}$ Szerzej zob. F. Musiał, M. Lasota, Kościót zraniony. Proces księdza Lelity i sprawa kurii krakowskiej, Kraków 2003.

${ }^{291}$ J. Piasecka, Stosunki między Kościołem..., s. 52, 54; J. Żaryn, Postawy duchowieństwa katolickiego..., s. 293.

${ }^{292}$ A. Dudek, R. Gryz, Komuniści i Kościót..., s. 73-81.

${ }^{293}$ E.K. Czaczkowska, Kardynat Wyszyński..., s. 125-126, 135-138, 140-141. 
za wiernych, starannie przygotowała postulaty konstytucyjne i przedstawiła je oficjalnie 11 lutego prezydentowi B. Bierutowi. We wstępie zaznaczono, że uwagi dotyczyły spraw religijno-moralnych. W pierwszym punkcie odniesiono się do zagadnienia oddzielenia Kościoła od państwa, zapytując „Czy w ogóle jest miejsce dla religii w konstytucji Polski Ludowej?"294. Domagając się miejsca dla niej, wyjaśniano: „Religia [...] daje narodom trwałe i wzniosłe zasady moralne, według nich kształtuje i urabia sumienie obywateli, [...] wychowuje nie tylko jednostki, ale i całą społeczność [...] Stwarza rzetelne i niewzruszone podstawy dla dobrobytu, pokoju w duszach, w krajach i stosunkach między narodami” ${ }^{295}$. Po krótkim przedstawieniu zapisów dotyczących religii w historycznych konstytucjach polskich, skomentowano ,powściągliwe i nieufne" stanowisko w projekcie nowej konstytucji, w której „szczuplutki art. 70” wywołuje „fatalne wrażenie”. Dotyczył on oddzielenia Kościoła od państwa, będąc jednocześnie sprzecznym z dalszymi artykułami o stosunku państwa do Kościoła w kwestiach prawnych i majątkowych. W drugiej części odniesiono się do praw Kościoła do działalności katechetycznej i charytatywnej, prawo do opieki duszpasterskiej w szpitalach i więzieniach, prowadzenia seminariów, własnego szkolnictwa, możliwości nauczania religii. Ostatnia część była przypomnieniem praw i obowiązków obywateli ${ }^{296}$. Niestety, przedstawiciele komisji konstytucyjnej nie ustosunkowali się do propozycji biskupów, a cenzura znów wyeliminowała ich treść z prasy katolickiej. Nową konstytucję sejm uchwalił 22 VII $1952 \mathrm{r}$.

Lata 1951-1952 naznaczone były dalszymi aresztowaniami i procesami księży. O ile w okresie 1945-1948 prześladowano głównie dawnych kapelanów formacji zbrojnych AK, NSZ i Batalionów Chłopskich, udzielających pomocy „leśnym", to w kolejnych latach 1949-1953 wymierzono ostrze przeciwko księżom katechetom oraz duszpasterzom młodzieży ${ }^{297}$. Powodem do zatrzymania mógł stać się każdy pretekst: odmowa podpisania Apelu Sztokholmskiego, „odkrycie” składów broni lub ośrodków szpiegowskich czy też jakakolwiek „reakcyjna" działalność. Wśród wielu procesów duchownych jednym z najgłośniejszych był toczący się w styczniu 1951 r. proces przeciw podziemnej organizacji Armia Polska. Skazano wtedy na dożywocie dwóch księży należących do diecezji kieleckiej, zaś nagonkę prasową wymierzono głównie w biskupa Kaczmarka. Sam ordynariusz kielecki został aresztowany 20 I 1951 r. pod zarzutem współpracy z Niemcami w czasie II wojny światowej. Na ławie oskarżonych znalazł się też redaktor „Tygodnika Warszawskiego” ks. Zygmunt Kaczyński za kontakty z nielegalnym Stronnictwem Pracy (zatrzymany w maju 1949 r.). Wyrok skazujący na

${ }^{294}$ Postulaty konstytucyjne Episkopatu Polski dla Prezydenta B. Bieruta, 11 II 1952. W:

P. Raina, Kościót ..., t. 1, s. 329.

${ }^{295}$ Tamże.

296 Postulaty konstytucyjne Episkopatu Polski..., s. 329-335.

297 J. Żaryn, Postawy duchowieństwa katolickiego..., s. 291. 
10 lat więzienia ogłoszono w sierpniu 1951 r. Ks. Z. Kaczyński zmarł po dwóch latach $^{298}$. Podobnych procesów w latach $1951-1953$ było więcej ${ }^{299}$. Za przedwyborczą prowokację uznano zbieranie podpisów pod skierowaną do władz państwowych petycją o przywrócenie nauki religii w diecezji katowickiej, w wyniku czego w listopadzie 1952 r. aresztowano ordynariusza katowickiego biskupa Stanisława Adamskiego oraz biskupów Herberta Bednorza i Juliusza Bieńka, którzy przebywali we więzieniu do listopada $1956 \mathrm{r}^{300} \mathrm{Na}$ te wydarzenia Episkopat odpowiedział dokumentem Pro memoria do duchowieństwa i oświadczeniem w sprawie wydarzeń w kurii krakowskiej. Nawoływano w nich do zajęcia się „ściśle pracą kapłańską" i trzymania się z dala od sporów politycznych. Uznano też udział duchowieństwa w akcjach podziemnych za „szkodliwy dla działalności Kościoła" ${ }^{301}$. Szczytowym momentem w konflikcie Kościoła z państwem był Dekret o obsadzaniu stanowisk kościelnych z 9 II 1953 r., na który Episkopat Polski na czele z prymasem odpowiedział memoriałem do Rady Ministrów z 8 V 1953 r. zatytułowanym Non possumus.

W latach powojennych 1945-1953 w stosunkach Kościoła z państwem można wyróżnić dwie fazy ${ }^{302}$. Pierwszą, w okresie 1945-1947, charakteryzowały pozorowane ze strony rządzących próby stworzenia poprawnych stosunków. Chodziło jednak bardziej o zalegalizowanie i umocnienie własnych pozycji, a zarazem o powolne eliminowanie go z życia publicznego. Sfałszowane wybory i powstanie PZPR umożliwiły zapoczątkowanie drugiego etapu, w którym członkowie rządu przystąpili do jawnego ataku na Kościół jako na ostatniego wroga. W latach 1948-1949 wyraźnie wzmożono represje i ograniczenia prawne, uszczuplając pole działania. Wywierano jednocześnie silną presję na

${ }^{298}$ Por. IPN w Warszawie, Akta kontrolno-śledcze dotyczące ks. Zygmunta Kaczyńskiego, sygn. BU 0259/568, k. 176-179.

${ }^{299}$ J. Piasecka, Stosunki między Kościołem..., s. 50-51.

${ }^{300}$ J. Żaryn, Kościół w PRL ..., s. 27.

${ }^{301} 13$ maja 1951 Pro memoria Episkopatu Polski do duchowieństwa, w: P. Raina, Kościół..., t. 1, s. 298-299; 12 grudnia 1952, Warszawa Oświadczenie Episkopatu Polski w sprawie wydarzeń w kurii krakowskiej, tamże, s. 376-377.

${ }^{302}$ Historycy podają też inne, bardziej szczegółowe podziały. J. Żaryn zaproponował podział chronologiczny na: Kościół w latach względnej swobody (1944-1947) i Kościół w latach najcięższej próby (1947-1956). Źródło: J. Żaryn, Dzieje Kościoła..., s. 64, 88; ten sam autor gdzie indziej zaś zastosował podział na: polityka mijania (1944-1947), pierwsze starcie (1947-1950), Kościół milczenia (1950-1956). Źródło: tenże, Kościół w PRL ..., s. 11, 19, 27. P. Raina dokonał zaś następującego rozgraniczenia: Kościół katolicki a państwo 1945-1948, Kościół a państwo 1949-1951, eskalacja walki z Kościołem 1951-1956. Źródło: P. Raina, Kardynał Wyszyński, t. 1, s. 126,169 ; t. 2, s. 16; H. Dominiczak w okresie stalinizmu w latach 1944-1956 wyodrębnił trzy etapy: pierwszy to lata 1944-1948, charakteryzujący się względnym liberalizmem, drugi obejmujący lata 1949-1953, w którym przystąpiono do ostrej, otwartej walki i trzeci trwający od dnia aresztu prymasa S. Wyszyńskiego (25 IX 1953) do przemian październikowych. Źródło: H. Dominiczak, Organy bezpieczeństwa..., s. 28. 
hierarchię w celu przystąpienia do budowy nowego ładu w Polsce. Swoiste apogeum ataków nastąpiło w 1953 r., co wyraziło się ingerencją w jego wewnętrzną strukturę; odbyły się liczne procesy pokazowe duchownych, a w końcu uwięziono samego prymasa.

\subsubsection{Zamknięcie Caritasu}

Caritas - prężnie działająca organizacja dobroczynna Kościoła - została reaktywowana w czerwcu 1945 r. przez arcybiskupa A. Sapiehę. Organizacja posiadała cztery tysiące oddziałów prowadzących różne placówki społeczne, m.in. żłobki, przedszkola, świetlice, kuchnie dla ubogich, domy starców, domy dziecka, bursy i internaty. Dobre zaplecze finansowe zapewniono dzięki subwencji Episkopatu i diecezji, kweście i darowiznom zagranicznym oraz dotacjom państwowym i samorządowym. Nowa władza na przełomie lat 1947/1948 rozpoczęła atak na Caritas. Wpierw zakwestionowano prawną legalność organizacji, następnie pod pretekstem „nadużyć i nieprawidłowości w prowadzeniu ksiąg” przeprowadzono generalną kontrolę, aby 23 I 1950 r. mianować tymczasowy zarząd złożony z „księży patriotów” i przedstawicieli środowiska skupionego wokół B. Piaseckiego ${ }^{303}$. Do wybranych siedemnastu diecezjalnych związków wkroczyły komisje likwidacyjne pod nadzorem UB. Opieczętowano biura i magazyny, zablokowano konta bankowe. Zamknięcie Caritasu stanowiło istotny krok w polityce rządu wobec Kościoła ${ }^{304}$. Statut nowego stowarzyszenia przekształconego z organizacji kościelnej w stowarzyszenie świeckie został zarejestrowany 18 VIII $1950 \mathrm{r}^{305}$ Ofiarodawcy zagraniczni, głównie z USA, wstrzymali udzielanie pomocy finansowej. Władza przejęła majątek o łącznej wartości prawie $20 \mathrm{mln}$ zł. Podczas przejmowania Caritasu funkcjonariusze UB aresztowali ponad 20 księży, a kilkudziesięciu ukarali grzywnami. Nowy zarząd placówki funkcjonującej pod tą samą nazwą zaprzestał udzielania pomocy byłym ziemianom wyrzuconym ze swej ojcowizny, więźniom politycznym i żołnierzom AK. Osoby te znajdowały też pracę w Caritasie $^{306}$.

Działaniom likwidacyjnym towarzyszyła propaganda prasowa i masowe zebrania, na których potępiano rzekome nadużycia Kościoła. Hierarchowie w odpowiedzi na te metody i działania władz wystosowali kolejny pisemny protest. Tym razem był to telegram kardynała A. Sapiehy do prezydenta B. Bieruta z 24 I 1950 r. W jego treści wprost stwierdzono zamiar władzy zniszczenia

\footnotetext{
${ }^{303}$ A. Dudek, R. Gryz, Komuniści i Kościót..., s. 48-51; B. Fijałkowska, Partia wobec religii..., s. 77.

${ }^{304}$ D. Zamiatała, Caritas. Działalność i likwidacja organizacji 1945-1950, Lublin 2000, s. $305-306$.

${ }^{305}$ B. Fijałkowska, Partia wobec religii..., s. 100.

306 J. Żaryn, Dzieje Kościoła katolickiego..., s. 102-104.
} 
Caritasu i obrzucenie oszczerstwami odpowiedzialnych za jego działalność. Biskupi wydali również list do duchowieństwa. Omówili w nim bezprawne przejęcie instytucji, ostrzegając jednocześnie księży przed udziałem w zebraniach politycznych wrogich Kościołowi. W treści Oświadczenia Episkopatu do wiernych $w$ sprawie Caritas dementowano nieprawdziwe informacje propagandy komunistycznej. Poinformowano o likwidacji organizacji ze względu na niemożność wyrażenia zgody na przymusowy zarząd. Władze nie chciały dopuścić do odczytania oświadczenia w kościołach, stosując groźby, aresztowania i sankcje pieniężne oraz usilnie werbując do ruchu „księży patriotów”. Część księży, kilku biskupów i administratorów apostolskich uległa presji, wstrzymując się przed odczytaniem oświadczenia w kościołach. Prymas S. Wyszyński w trosce o duchownych warszawskich zwolnił ich z tego obowiązku. Sam jednak wygłosił radykalne kazanie poprzedzone słowami: „Niech mnie aresztują”, w którym zapowiedział opór Kościoła. Zarówno prymas S. Wyszyński jak i kardynał A. Sapieha wysyłali listy do prezydenta, polemizując z propagandą wokół Caritasu i sprzeciwiając się represjom wobec księży. Za bezkompromisową postawę i przeczytanie Oświadczenia zamknięto w areszcie domowym na szesnaście dni biskupa ordynariusza chełmińskiego Kazimierza Józefa Kowalskiego. Komuniści dawali do zrozumienia, że stawianie oporu doprowadzi do wzmożenia prześladowań ${ }^{307}$.

Zamknięcie Caritasu było kolejnym poważnym krokiem w ingerowaniu władzy w sprawy Kościoła. Stało się też następną okazją do kłamstw i oczerniania duchowieństwa. Główny atak w planowym niszczeniu skierowano przeciwko kapłanom, chcąc osłabić całą społeczność katolicką i stłumić jakikolwiek sprzeciw.

\subsubsection{Porozumienie $\mathrm{z} 1950 \mathrm{r}$.}

Od maja 1949 r. w atmosferze nasilającego się terroru wobec duchowieństwa rozpoczęto wstępne rozmowy między Episkopatem a władzą na temat uregulowania sytuacji prawnej Kościoła w Polsce. Pomimo wyraźnie antykościelnej polityki rządu, ze strony prymasa była chęć dialogu i znalezienia modus vivendi, co wyraził osobiście w rozmowie z Władysławem Wolskim 17 VII 1949 r. Do rozmów powołano specjalną Komisję Mieszaną. W jej skład ze strony Kościoła weszli: biskup Zygmunt Choromański - sekretarz Episkopatu Polski i sufragan diecezji warszawskiej, biskup Michał Klepacz - ordynariusz diecezji łódzkiej i biskup Tadeusz Zakrzewski - ordynariusz diecezji płockiej, natomiast ze strony rządu: Władysław Wolski - minister administracji państwowej, Franciszek Mazur - zastępca członka BP KC PZPR i Edward Ochab - wiceminister Obrony Narodowej. Pośrednikiem rozmów był lider „Dziś i Jutro” B. Piasecki. Przedstawiciele Kościoła

${ }^{307}$ A. Dudek, R. Gryz, Komuniści i Kościół..., s. 48-52. 
pragnęli powstrzymać prześladowania i uniknąć kolejnych strat. Rozmowy w ramach Komisji trwały około 10 miesięcy. Pierwsza tura spotkań odbyła się od 5 VIII do 19 XII 1949 r., kolejna dopiero w marcu 1950 r. po likwidacji Caritasu. Początkowo częstotliwość spotkań była większa wskutek starań rządu, następnie poprzez opór biskupów zmuszanych do podpisywania narzuconych deklaracji odbywały się rzadziej ${ }^{308}$. Jan Żaryn stwierdził: „Komuniści z jednej strony zasiadali do stołu, stwarzając pozory negocjacji, z drugiej zaś wprowadzali w życie coraz to nowe rozwiązania prawne i pozaprawne, ograniczające pole wolności Kościoła. Szantaż był więc czytelny"309.

Stosunki między Kościołem a państwem, zdaniem komunistów, miało w końcu unormować podpisanie tzw. Porozumienia w dniu 14 IV 1950 r. Do tej deklaracji skłoniły prymasa Stefana Wyszyńskiego nasilające się z roku na rok prześladowania. Opowiedział się za jej podpisaniem ze względu na chęć utrzymania - na ile to możliwe - względnego pokoju w okresie jawnej walki z Kościołem. Jego intencją było też spowolnienie represji wobec duchowieństwa. Swoją decyzję uzasadniał: „Od początku swej pracy stałem jednak na stanowisku, że Kościół polski zbyt wiele oddał już krwi w niemieckich obozach koncentracyjnych, by mógł nierozważnie szafować krwią pozostałych kapłanów. Męczeństwo jest, niewątpliwie, wysoce zaszczytne, ale Bóg prowadzi Kościół nie tylko drogą nadzwyczajną - męczeństwa, ale i zwyczajną - pracy apostolskiej. Owszem byłem zdania, że dziś nam potrzeba innego rodzaju męczeństwa - męczeństwa pracy, a nie krwi”’310. Podjął zatem ryzyko umowy, której komuniści mogli nie dotrzymać. Pojawiły się też wątpliwości, czy przeciwnicy Kościoła nie wykorzystają porozumienia, przedstawiając je w złym świetle wobec opinii publicznej. Sytuacja jednak wymusiła na polskim narodzie o światopoglądzie katolickim „współistnienie z materializmem upaństwowionym” ${ }^{311}$. Dalej pisał: „Mogliśmy nie ufać; Rząd dotychczasowymi wyczynami swoimi wobec Kościoła upoważniał do tej nieufności [...] Doświadczenie jednak pouczało, że Kościół nigdy nie mówił $<<$ nie $>>$ tam, gdzie można było dojść do pokoju i zgody"312.

Należy pamiętać, że aresztowania kapłanów pod byle jakim pretekstem były wówczas na porządku dziennym, a nagonki prasowe nie ustawały. Decyzja zatem nie wyniknęła z postawy naiwności czy też nieświadomości ideologicznych założeń komunizmu, które kardynał S. Wyszyński akurat dobrze znał. Prymas nie zamierzał też zmieniać poglądów ani ulegać władzy na drodze prowadzenia polskiego Kościoła. W swoich działaniach od początku był osamotniony i narażony

${ }^{308}$ J. Żaryn, Kościót a władza ..., s. 249-250. Szerzej o spotkaniach Komisji Mieszanej; tamże, s. 251-260; A. Dudek, R. Gryz, Komuniści i Kościół..., s. 43-47; J. Piasecka, Stosunki między Kościołem rzymskokatolickim..., s. 39.

309 J. Żaryn, Kościót w PRL..., s. 23.

${ }^{310}$ S. Wyszyński, Zapiski więzienne..., s. 18.

${ }^{311}$ H. Dominiczak, Organy bezpieczeństwa ..., s. 44-45.

${ }^{312}$ S. Wyszyński, Zapiski więzienne..., s. 21. 
na krytykę nie tylko ze strony komunistów, ale także ze strony biskupów, którzy byli przeciwni ugodzie. Prymas pisał w liście do kierującego wtedy Sekretariatem Stanu kardynała Domenico Tardiniego, że gdyby nie podpisano deklaracji, Kościół zlikwidowanoby wzorem czeskim ${ }^{313}$. W Zapiskach więziennych czytamy: ,[...] do Porozumienia prawdopodobnie by nie doszło, gdyby nie moja postawa [...] Jeśli więc kiedyś Episkopat będzie oskarżany o Porozumienie, to prawda wymaga, by wiedziano, że sprawcą Porozumienia od strony Episkopatu jestem ja"314.

Komisja Główna Episkopatu Polski, w skład której weszli: prymas Polski, kardynał Stefan Wyszyński, kardynał Adam Sapieha, arcybiskupi Romuald Jałbrzykowski (był nieobecny), Eugeniusz Baziak, Walenty Dymek, oraz biskupi Zygmunt Choromański, Czesław Kaczmarek, Michał Klepacz i Tadeusz Zakrzewski, zgromadzona w Krakowie w dniu 3 IV 1950 r., wyraziła życzenie zakończenia przez Komisję Mieszaną redagowania dokumentu ${ }^{315}$. We wstępie Porozumienia napisano, że zostało ono zawarte „W celu zapewnienia Narodowi, Polsce Ludowej i jej obywatelom najlepszych warunków rozwoju oraz możności wszechstronnej i spokojnej pracy"316. W części pierwszej (punkty 1-9) przedstawiono zobowiązania Kościoła wobec państwa. Hierarchowie zadeklarowali poszanowanie władzy państwowej i zasadę niewystępowania przeciwko niej. Mieli nawoływać wiernych do pracy nad odbudową kraju i nie oponować przeciw procesowi kolektywizacji. Ze strony kościelnej potępieniu miały podlegać wszelkie wystąpienia antypaństwowe, a także ,zbrodnicza działalność band podziemia”. Duchowni ,winni udziału w jakiejkolwiek akcji podziemnej i antypaństwowej” mieli być dodatkowo karani sankcjami kanonicznymi ${ }^{317}$. Biskupi oświadczyli również, że postarają się wyjednać u papieża zgodę na ustanowienie stałych diecezji na Ziemiach Zachodnich i Północnych. Zgodnie z drugą częścią deklaracji (punkty 10-17) rząd miał zagwarantować poszanowanie władzy papieskiej nad Kościołem w Polsce w kwestiach moralności i wiary ${ }^{318}$ oraz zachować status quo

${ }^{313}$ Wraz z internowaniem arcybiskupa Pragi Josefa Berana w czerwcu 1949 r. aresztowano kilkuset czeskich księży. Źródło: W. Lizak, Historia Polski..., s. 240; szerzej zob. B. Cywiński, Ogniem próbowane, t. 2, s. 217-274 (rozdział pt. Kościół w Czechosłowacji).

${ }^{314}$ S. Wyszyński, Zapiski więzienne..., s. 19.

${ }^{315}$ Kwestia zawarcia Porozumienia zaczęła się jeszcze w 1948 r., w okresie gdy prymasem był kardynał A. Hlond. Sekretarz Episkopatu biskup Z. Choromański wystąpił wówczas do władz z propozycją utworzenia komisji episkopalno-rządowej (tzw. Komisji Mieszanej) w celu ustalenia zasad modus vivendi. Początkowo strona rządowa nie była zainteresowana, lecz po roku, w lipcu 1949 r., powróciła do tej propozycji. Pomimo konfliktów w latach 1949-1950 w trakcie pracy komisji padła propozycja ze strony rządu zawarcia oficjalnego układu między Kościołem a państwem. Źródło: B. Cywiński, Ogniem próbowane..., s. 78.

${ }^{316} 14$ kwietnia 1950, Warszawa. Porozumienie zawarte między przedstawicielami Rzadu Rzeczypospolitej Polskiej i Episkopatu Polski. W: P. Raina, Kościót w PRL. Kościót katolicki a państwo w świetle dokumentów 1945-1989, t. 1, s. 232.

317 Tamże, s. 233.

318 Punkt piąty brzmiał: „Zasada, że Papież jest miarodajnym i najwyższym autorytetem 
w jego sprawach prawno-administracyjnych. Władze zobowiązywały się ponadto nie ograniczać religii w szkołach i nie utrudniać uczniom praktyk religijnych poza szkołą, zachować istniejące szkoły katolickie, umożliwić kontynuację działalności KUL, zapewnić swobodę stowarzyszeniom katolickim, prasie katolickiej, duszpasterstwu w wojsku i więzieniach oraz opiekę religijną w szpitalach. Służba wojskowa alumnów miała być odraczana, a księża i zakonnicy nie powoływani do wojska ${ }^{319}$. Ostatnią część dokumentu stanowił dodatkowy protokół o bieżących kwestiach dotyczących Caritasu i ustawy „o przejęciu przez państwo dóbr martwej ręki”. Kościołowi zwrócono część przejętych gruntów, a Fundusz Kościelny miał przekazywać „odpowiednie sumy do dyspozycji ordynariuszów diecezji” ${ }^{320}$.

Porozumienie podpisane między państwem a Kościołem polskim było pierwszym tego typu dokumentem w historii stosunków państw komunistycznych z Kościołem katolickim i spotkało się z zaskoczeniem papieża oraz dezaprobatą Watykanu ${ }^{321}$. Wywołało także „zdziwienie na całym świecie”"322. Bohdan Cywiński zauważył natomiast, że nie mogło w tym być nic zaskakującego, skoro wcześniej na podobny układ nalegał rząd węgierski ${ }^{323}$. Ceną za odmowę kardynała Jozsefa Mindszenty'ego było jego uwięzienie i przeprowadzenie pokazowego procesu, w czasie którego skazano go na dożywocie. Wobec nieprzejednanej postawy papieża Piusa XII wobec doktryny komunistycznej komuniści dążyli do zawierania tego typu umów, chcąc naruszyć jedność między Stolicą Apostolską a lokalnymi episkopatami. Drugim zamierzeniem było złagodzenie surowych ocen polityki komunistycznej płynące ze strony Zachodu w końcu lat czterdziestych XX w. ${ }^{324}$

Przeciwnikiem Porozumienia był natomiast kardynał A. Sapieha, który uważał, że rozmowy należy prowadzić w taki sposób, aby do podpisania deklaracji nie

Kościoła, odnosi się do spraw wiary, moralności oraz jurysdykcji kościelnej, w innych natomiast sprawach Episkopat kieruje się polską racją stanu". Źródło: 14 kwietnia 1950..., s. 233; J. Żaryn, Kościół a władza w Polsce..., s. 323-324.

31914 kwietnia $1950 \ldots$, s. 232-235.

320 Tamże, s. 233; J. Żaryn, Kościół a władza w Polsce..., s. 323-324; tenże, Dzieje Kościoła katolickiego..., s. 108-109.

${ }^{321}$ A. Dudek, R. Gryz, Komuniści i Kościót..., s. 56; P. Raina, Kardynat Wyszyński, t. 1, s. 197; Więcej na temat stosunków Watykanu z Polską zob. S. Krasowski, Watykan a Polska, Warszawa 1949; P. Michel, Kościót katolicki a totalitaryzm, Warszawa 1995; E.J. Pałyga, Polsko-watykańskie stosunki dyplomatyczne, Warszawa 1988; Pius XII a Polska 1939-1949. Przemówienia, listy, komentarze, oprac. K. Papèe, Rzym 1954; Polityka Watykanu. „Jutro Polski” 1945 nr 11 s. 2; J. Żaryn, Stolica Apostolska wobec Polski i Polaków w latach 1944-1958 w świetle materiałów ambasady RP w Watykanie, Warszawa 1998.

322 W. Lizak, Historia Polski..., s. 243.

${ }^{323}$ Do układu komuniści na Węgrzech doprowadzili 15 VIII 1950 r., gdy przewodniczącym węgierskiego Episkopatu był arcybiskup Jozsef Grosz. W treści dokumentu wykazano jednak większą lojalność wobec władzy niż w polskim Porozumieniu. W formie zaś odwołano się do polskiego pierwowzoru. Źródło: J. Żaryn, Kościół a władza w Polsce..., s. 340.

${ }^{324}$ B. Cywiński, Ogniem próbowane, t. 2, s. 78-79. 
doszło $^{325}$. Ponadto, jak pisał znawca problematyki Jan Żaryn: „W marcu 1950 r. atmosfera była tak napięta, że kardynał A. S. Sapieha bardziej niż o Porozumieniu myślał o ewentualnym aresztowaniu go przez funkcjonariuszy UB"326. W okresie sporządzania ostatecznej wersji umowy wyjechał do Rzymu, gdzie dotarła informacja o jej zawarciu. Stanął zatem przed trudnym wyzwaniem: z jednej strony obrony polskiego Episkopatu pomimo własnej niezgody na porozumienie, a $\mathrm{z}$ drugiej ustosunkowania się do jego krytyki podjętej w Watykanie ${ }^{327}$. Stolica Apostolska, o czym wiadomo z poufnych rozmów, przyjęła zawarte Porozumienie z „bólem”328. Zarzuty dotyczyły m.in. sposobu zawarcia układu i użycia terminu „,porozumienie” (po włosku accordo oznaczało układ ${ }^{329}$ ), merytorycznej oceny punktów dotyczących kwestii Ziem Zachodnich i Północnych oraz kompetencji papieża, a także spraw odnoszących się do spółdzielni produkcyjnych na wsi. Zastrzeżenia budził również propagandowy język dokumentu ${ }^{330}$. Nigdy jednak dyplomacja watykańska nie wypowiedziała się oficjalnie na ten temat. Wszystkie dokumenty, rozmowy i artykuły, które wyszły z Sekretariatu Stanu, miały charakter nieformalny. Jedynym urzędowym dokumentem był poufny list kardynała D. Tardiniego skierowany do prymasa S. Wyszyńskiego, którego treść mogli znać tylko członkowie Episkopatu Polski. Fakt podpisania Porozumienia szeroko komentowano w prasie światowej i polskiej. W lewicowych mediach na Zachodzie oskarżono Piusa XII o zbytni konserwatyzm i brak tolerancji wobec ,postępowych" teorii i praktyki marksistowskiej. Postawę polskich biskupów określano zaś jako duchownych współpracujących z komunistami Polski Ludowej. W kręgu watykańskim dominowało przekonanie, że polski Episkopat dał się „,podejść”. Giovanii Montini (późniejszy papież Paweł VI) wyraził nawet opinię, że dano się zastraszyć widmem pozbawienia Kościoła zasobów materialnych. Bliższe wyjaśnienia złożył dopiero prymas podczas pobytu w Rzymie wiosną $1951 \mathrm{r}^{331}$

Porozumienie było układem wymuszonym. Narastający konflikt koreański i ,zimna wojna” w Europie sprawiły, że władzom komunistycznym zależało na związaniu przyrzeczeniem lojalności jednej ze znaczących sił opozycyjnych w Europie Środkowowschodniej - Kościoła w Polsce. Episkopat,

${ }^{325}$ Szerzej zob.: T. Mianowicz, Kardynat Sapieha a „,modus vivendi” z 1950 r., „Zeszyty Historyczne" 1994 nr 108 s. 231-234.

${ }^{326}$ J. Żaryn, Kościół a władza w Polsce..., s. 325.

327 Tenże, Dzieje Kościoła katolickiego..., s. 107-108; tenże, Kościół a władza w Polsce..., s. 325, 335; B. Cywiński, Ogniem próbowane, t. 2..., s. 80.

${ }^{328}$ Wedle nieoficjalnych relacji G. Tardini po otrzymaniu wiadomości o zawarciu Porozumienia biegając po Sekretariacie Stanu i trzymając się za głowę miał wołać: „Jestem przejęty bólem”. Źródło: J. Żaryn, Kościół a władza w Polsce..., s. 335-336.

${ }^{329}$ Prymas S. Wyszyński wspomniał natomiast, że sama nazwa „wypłynęła w ostatniej chwili”. Źródło: S. Wyszyński, Zapiski więzienne..., s. 21.

${ }^{330}$ J. Żaryn, Kościót a władza w Polsce..., s. 335-336.

${ }^{331}$ Tenże, Dzieje Kościoła katolickiego ..., s. 110; Z. Zieliński, Kościót w Polsce 1944-2007..., s. 73-75; J. Żaryn, Kościót a władza..., s. 332-333. 
„,naciskany ze wszystkich stron przez władze, bardzo potrzebował chwili odpoczynku” ${ }^{332}$, a „biskupi byli świadomi szantażu, który wymuszał konieczność prowadzenia rozmów"333. Kościołowi groziło wówczas zagarnięcie wszystkich budynków zgromadzeń zakonnych wraz z aresztowaniem zakonników i zakonnic, jak miało to miejsce dokładnie 14 IV 1950 r. w Czechosłowacji. Władza państwowa była także przygotowana do wprowadzenia dekretu o obsadzaniu stanowisk kościelnych. Przygotowane były materiały operacyjne niezbędne do aresztowania i wytoczenia procesów dostojnikom Kościoła. Dzięki umowie i ustępstwom (głównie w kwestii kolektywizacji) restrykcji nie wprowadzono, a nawet zwolniono niektórych kapłanów aresztowanych w związku ze sprawą Caritasu. Proces niszczenia Kościoła, pomimo że nie został zahamowany, to uległ spowolnieniu do $1953 \mathrm{r}^{334}$

Należy podkreślić, że w umowie chodziło bardziej o stworzenie warunków do współżycia, tzw. modus vivendi, niż o układ polityczny Episkopatu z rządem. Do tego drugiego upoważniona była jedynie Stolica Apostolska. Peter Raina nazwał Porozumienie ,aktem rozsądku ze strony Episkopatu i prymasa”, natomiast Bohdan Cywiński pomimo korzyści „decyzją bardzo niebezpieczną" ${ }^{335}$. Drugi z autorów pisał: „Konieczne było bowiem wykazanie, że układ nie oznacza żadnej kapitulacji ani zrzeczenia się wewnętrznej niezależności Kościoła na rzecz przeciwnika [...] Wartość odsunięcia w czasie chwili rzeczywistej próby zależała z kolei od tego, czy <<czas pracował >> dla Kościoła czy dla komunistów”336. Surowo ocenił też sformułowania zamieszczone w Porozumieniu dotyczące kolektywizacji wsi potraktowanej jako normalny i swobodny ruch spółdzielczy (punkt 6) oraz nazwanie podziemia działalnością zbrodniczą. Dokument nie znalazł szerszego oddźwięku w społeczeństwie, mógł jedynie drażnić opinię publiczną „treścią i tonem zapożyczonym z oficjalnej prasy rządowej”, jednak „Czasy były na tyle ciężkie, że podobne deklaracje traktowano ze smutnym zrozumieniem"337. Strona rządowa po podpisaniu Porozumienia, jak zresztą przewidywano, nie zamierzała dotrzymać umowy i bezwzględnie łamała prawa przyznane Kościołowi. Niektóre z postanowień w ogóle nie weszły w życie, jak np. obecność kapelanów w więzieniach. Likwidowano kościelne przedszkola prowadzone przez państwowy Caritas w Gdańsku, wywłaszczano Kościół zabierając domy zakonne i gmachy seminariów, Ministerstwo Finansów wkraczało w wewnętrzną administrację kościelną, nadal represjonowano kapłanów i usuwano religię ze szkół, zmuszano młodzież do przynależności do ZMP, utrudniano praktyki

\footnotetext{
${ }^{332}$ H. Dominiczak, Organy bezpieczeństwa..., s. 44.

${ }^{333}$ J. Żaryn, Kościół a władza w Polsce..., s. 325.

334 Tenże, Dzieje Kościoła katolickiego..., s. 108.

${ }^{335}$ P. Raina, Kardynat Wyszyński, t. 1, s. 196-197; B. Cywiński, Ogniem próbowane..., s. 79.

${ }^{336}$ B. Cywiński, Ogniem próbowane..., s. 80.

337 Tamże, s. 84-85.
} 
religijne oraz ograniczano duszpasterstwo w zakładach zależnych od państwa ${ }^{338}$. Stosunki Kościoła z państwem nie tylko nie uległy poprawie, ale znacznie się pogorszyły.

Szybkim sprawdzianem nowego modus vivendi stał się Apel Sztokholmski propagowany przez Polski Komitet Obrońców Pokoju, który rozpoczął akcję zbierania podpisów kilka dni po zawarciu Porozumienia. Pomimo że Episkopat pozostawił decyzję w sprawie jego podpisania poszczególnym biskupom i większość księży ( $86 \%$ ) zadeklarowała poparcie ${ }^{339}$, to był to dobry powód do przeprowadzenia prasowej kampanii przeciw Kościołowi. W prasie szkalowano duchownych za „negatywną postawę wobec inicjatywy pokojowej”340. Rząd powołał też wspomniany już Urząd do Spraw Wyznań mający na celu - w ścisłej współpracy z UB - kontrolę instytucji kościelnych, które do tej pory były w gestii ministra administracji publicznej. Na czele Urzędu, jak wspomniano, postawiono Antoniego Bidę ${ }^{341}$. Wkrótce, bo we wrześniu 1950 r. Episkopat zwrócił się do prezydenta Bolesława Bieruta ze skargą na łamanie Porozumienia. Rząd jednak nie zareagował podejmując konsekwentnie kolejne kroki świadczące o prowadzeniu polityki antykościelnej.

Przedstawiciele władzy poprzez Porozumienie chcieli uwikłać hierarchię Kościoła w swoje propagandowe działania, nie mając zamiaru przestrzegać zawartych w nim warunków. Edward Ochab na naradzie redaktorów prasy partyjnej 18 IV 1950 r. oświadczył, że dekret stał się sukcesem rządu i „kompromisem z siłą klasową obcą i nieprzejednanie wrogą" ${ }^{342}$. Ze strony Kościoła ustępstwem przy podpisaniu dekretu było uznanie de facto powojennej sytuacji politycznej i przemian społeczno-gospodarczych w Polsce. Jedną z konsekwencji tego aktu było zobowiązanie biskupów do poparcia Apelu Sztokholmskiego ${ }^{343}$. Porozumienie miało też służyć propagandzie i osłabić ducha oporu w społeczeństwie. Rozmowy w Komisji Mieszanej były swoistą grą komunistów, stanowiącą kolejną formę walki z Kościołem mającą doprowadzić do wewnętrznego rozbicia. W kwestiach bieżących miało ułatwić tak trudną do przeprowadzenia kolektywizację w Polsce i zniwelować znaczenie niebezpiecznych kazań z ambony. Wobec opinii światowej chciano zaś upozorować brak konfliktu i jakiejkolwiek walki. Sprawa Ziem Zachodnich pogłębiła konflikt między biskupami polskimi i niemieckimi. Na krótko wbito

${ }^{338}$ J. Żaryn, Dzieje Kościoła katolickiego ..., s. 110-111.

${ }^{339}$ Szerzej zob.: J. Stefaniak, Duchowieństwo polskie wobec Apelu Sztokholmskiego z roku 1950, „Teki Archiwalne” 2001 t. 4 s. 43-57.

${ }^{340}$ Z. Zieliński, Kościót w Polsce 1944-2007..., s. 75-76.

${ }^{341}$ B. Fijałkowska, Partia wobec religii..., s. 95; H. Dominiczak, Organy bezpieczeństwa..., s. 45; P. Raina, Kardynat Wyszyński, t. 1: Droga na stolice..., s. 198.

${ }^{342}$ A. Dudek, R. Gryz, Komuniści i Kościół..., s. 56-57.

${ }^{343}$ B. Fijałkowska, Partia wobec religii..., s. 87, 89. 
klin między Kościół lokalny a Watykan, aż wyjaśnienia osobiście papieżowi złożył prymas S. Wyszyński. Komunistom chodziło zasadniczo o uznanie ich władzy przez hierarchię kościelną ${ }^{344}$. Przez to jednak, że przedstawiciele rządu nie wywiązali się z zadeklarowanych zobowiązań, stali się mniej wiarygodni w oczach społeczeństwa.

\subsubsection{Dekret o obsadzaniu duchownych stanowisk kościelnych w 1953 r.}

Rolę przełomową w stosunkach Kościoła z państwem odegrało wydanie 9 II 1953 r. przez Radę Państwa Dekretu o obsadzaniu duchownych stanowisk kościelnych. Na jego podstawie odebrano Kościołowi niezależność organizacyjną. Przy podejrzeniu o jakąkolwiek działalność niezgodną z polityką państwa dekret upoważniał do obsadzania i usuwania duchownych na wszystkich stanowiskach. Kapłani mieli przysięgać wierność PRL. Członkowie partii nie dostrzegali, że ta daleko idąca kontrola życia organizacyjnego i religijnego była niezgodna z przyjętą przez komunistów zasadą rozdziału Kościoła od państwa ${ }^{345}$. Prymas wyraził sprzeciw wobec dekretu wpierw listem z 23 II 1953 r. do Franciszka Mazura $^{346}$. Określił w nim stanowisko Episkopatu wraz z kościelną interpretacją prawną dokumentu. Ostatecznie prymas uznał porozumienie za bezprawne i wraz z Episkopatem odpowiedział 8 V 1953 r. Memoriałem do Bolesława Bieruta, w którym zawarł słynne Non possumus! Postawił tym samym granicę ustępstw komunistycznemu państwu. Przeciwstawił się tak daleko idącej ingerencji władz w sprawy Kościoła. Zagroził też duchownym, którzy się podporządkują, karą ekskomuniki. Komuniści zatem przystąpili do przełamania oporu części biskupów wobec nowych rozporządzeń władzy. Wysłali też B. Piaseckiego do prymasa, aby ten przekonał go do porzucenia stanowiska określonego w Memoriale. Kolejnym posunięciem komunistów były naciski na Episkopat, aby potępił sądzonego jesienią biskupa Kaczmarka. Prymas S. Wyszyński konsekwentnie odmówił. Proces umęczonego biskupa wielomiesięcznym przesłuchaniem szeroko upowszechniano w mediach. Kardynał znów zareagował pismem do rządu, który był już ostatnim przed internowaniem.

${ }^{344}$ J. Żaryn, Kościół a władza ..., s. 340-344.

${ }^{345}$ B. Fijałkowska, Partia wobec religii..., s. 114; W.J. Wysocki, Osaczanie Prymasa ..., s. 31; W. Lizak, Historia Polski... s. 246; S. Kisielewski, Stosunki Kościót-państwo w PRL, Kraków 1981, s. 10.

346 Tekst listu w: 23 lutego 1953, Warszawa. List Prymasa S. Wyszyńskiego do wicemarszałka sejmu F. Mazura ze stanowiskiem Episkopatu w sprawie Dekretu o obsadzaniu duchownych stanowisk kościelnych. W: P. Raina, Kościót w PRL..., s. 395-397. 


\subsubsection{Aresztowanie prymasa Stefana Wyszyńskiego}

Biografowie kardynała Stefana Wyszyńskiego ${ }^{347}$ podkreślają zgodnie, że jego pojawienie się w 1948 r. na czele polskiego Kościoła miało „charakter opatrznościowy" "348. Nominacja na prymasa została przyjęta z zaskoczeniem nie tylko przez członków Episkopatu, ale też i samego nominata. Komuniści natomiast przyjęli wiadomość z wyraźną wrogością ${ }^{349}$. Tej kandydatury nie chcieli ani biskupi, ani sam S. Wyszyński ${ }^{350}$. Na swojego następcę zaproponował go natomiast prymas August Hlond, który na łożu śmierci podyktował swojemu sekretarzowi list do papieża prosząc o jego nominację ${ }^{351}$. Kardynał Hlond poznał nominata

${ }^{347}$ Stefan Wyszyński (1901-1981) (pseud. dr Z, dr Zuzelski, idem, ks. W. S, X, Radwan III). Ur. w 1901 r. syn wiejskiego organisty. Od 1946 r. biskup lubelski, a od 1948 r. arcybiskup metropolita warszawsko-gnieźnieński i prymas Polski. Ważnym etapem w życiu były 4 lata spędzone na KUL (1925-1929) gdzie słuchał wykładów m.in. ks. prof. Antoniego Szymańskiego - twórcy lubelskiej szkoły katolickiej nauki społecznej i słynnego teologa moralisty o. Jacka Woronieckiego. Na KUL-u spotkał też ks. Władysława Korniłowicza, który wywarł ogromny wpływ na jego duchowość i styl duszpasterski. Tam też związał się z silnym ośrodkiem formacyjnym inteligencji KSMA „Odrodzenie”. Od 1931 r. prowadził we Włocławku Chrześcijański Uniwersytet Robotniczy; w 1944 r. w Laskach wstąpił do AK jako kapelan o pseud. „Radwan III”. Autor kilku książek (m.in. Duch pracy ludzkiej i ponad stu publikacji prasowych poświęconych problematyce społecznej. W latach 1921-1939 opublikował 701 artykułów, głównie na łamach „Ateneum Kapłańskiego” (od 1932 r. był jego redaktorem naczelnym) i „Prądu”. We Włocławku był współorganizatorem tygodnika dla rodzin „Ład Boży”. Jako biskup lubelski współredagował „Wiadomości Diecezjalne Lubelskie”. W wypowiedziach krytykował zarówno kapitalizm, jak i komunizm, widząc ogromne zagrożenie w świecie ze strony tego drugiego. Ostrzegał przed tendencją do „,hrzczenia komunizmu”, przewidywał też, że w walce z komunizmem decydującą rolę odegra katolicyzm. Jego broszury i książki zostały po wojnie wycofane z bibliotek. Źródło: E.K. Czaczkowska, Kardynat Wyszyński..., s. 35-46, 58-60, 76.

${ }^{348}$ J. Zabłocki, Prymas Stefan Wyszyński..., s. 11; Biskup S. Wyszyński objął prymasostwo w okresie zaostrzenia stosunków państwa z Kościołem także w innych krajach. Na Węgrzech w grudniu 1946 r. aresztowano prymasa Józefa Mindszenty'ego, którego skazano w 1949 r. na dożywotne więzienie. Arcybiskup Pragi Josef Beran został internowany w czerwcu 1949 r. Źródło: W. Lizak, Historia Polski..., s. 240; H. Dominiczak, Organy bezpieczeństwa ..., s. 34.

${ }^{349}$ H. Dominiczak, Organy bezpieczeństwa ..., s. 36.

${ }^{350}$ Jako następcę prymasa A. Hlonda widziano raczej metropolitę poznańskiego Walentego Dymka, biskupa łódzkiego Michała Klepacza, arcybiskupa i metropolitę wileńskiego Romualda Jałbrzykowskiego, metropolitę lwowskiego Eugeniusza Baziaka. Kandydatem na prymasa był również generał pallotynów ks. Wojciech Turowski. Źródło: E.K. Czaczkowska, Kardynał Wyszyński..., s. 21, 23, 31; W dniu nominacji młody biskup miał upaść na kolana przed kardynałem S. Sapiehą i prosić o oddalenie tego ciężaru obowiązków. P. Raina tak pisał o tym: „Wiadomość o nominacji na prymasa najbardziej zaskoczyła samego nominata. Biskup lubelski kilkakrotnie jeździł do Krakowa do kardynała Sapiehy. Prosił kardynała, aby przedstawił Ojcu Świętemu, że wybór ten absolutnie przerasta jego siły i możliwości, aby papież cofnął ten dla niego ciężki $<<$ wyrok $>>$. Kardynał odpowiedział: Panu Bogu i Ojcu Świętemu się nie odmawia; po czym dodał mu otuchy, zapewniając o swojej pomocy". Źródło: P. Raina, Kardynał Wyszyński, t. 1, s. 150.

${ }^{351}$ E.K. Czaczkowska, Kardynat Wyszyński..., s. 22; P. Raina, Kardynat Wyszyński, t. 1, s. $92,147$. 
we Włocławku w 1937 r. Zapewne docenił jego aktywność społeczną i zdolności przywódcze. Za przyjęciem kandydatury najmłodszego hierarchy, jakim był wtedy biskup S. Wyszyński (miał 47 lat), zaważyło również to, że uważany był za „zdecydowanego antykomunistę" i posiadał gruntowne wykształcenie w dziedzinie nauk społecznych ${ }^{352}$.

Prymas S. Wyszyński, będąc w okresie dwudziestolecia międzywojennego wykładowcą katolickiej nauki społecznej, dobrze znał prawa i obowiązki zarówno Kościoła, jak i państwa. Na bazie zasad pomocniczości i dobra wspólnego społeczeństwa starał się podjąć dialog i współpracę z przedstawicielami nowej władzy, tworząc specyficznie polski model w stosunkach Kościoła z państwem. Rolę obu instytucji w społeczeństwie postrzegał służebnie, wykluczając jednocześnie dominację jednej nad drugą. Ponadto odmienne były cele każdej z nich; Kościół pełnił przede wszystkim misję ewangeliczną i moralną, pragnąc pomóc człowiekowi w znalezieniu sensu życia oraz dojściu do zbawienia. Państwo natomiast, zajmując się bardziej porządkiem doczesnym, miało za zadanie uznanie praw człowieka, stworzenie mu warunków do godnego bytu i bezpieczeństwa. W pełnieniu obowiązków zobligowane było do poszanowania praw rodziny, narodu i Kościoła. W początkowej fazie nauczania prymas w oparciu o doktrynę społeczności doskonałej, tzw. societas perfecta ${ }^{353}$, stwierdził, że między wieloma dziedzinami życia dającymi się wyraźnie odróżnić, istniały też wspólne dla Kościoła i państwa. Do nich należały tak drażliwe w 1. 1945-1953 kwestie wychowania młodzieży, małżeństwa i rodziny. Biskup S. Wyszyński postrzegał wzajemne stosunki pomiędzy Kościołem a państwem na zasadzie wzajemnej pomocy w celu osiągnięcia dobra wspólnego ${ }^{354}$ na wzór relacji małżeńskiej. Wobec oskarżeń ze strony rządzących, że Kościół chce supremacji, odpowiadał: „Kościół to nie rywal, to sprzymierzeniec! Kościół nie pragnie doczesnej władzy, tylko pragnie miłości, uszanowania jego posłannictwa i praw Ludu Bożego do wolności czci Bożej”355. W swoim nauczaniu

${ }^{352}$ A. Dudek, R. Gryz, Komuniści i Kościół..., s. 37.

${ }^{353}$ Zgodnie z tą koncepcją kardynał S. Wyszyński uważał, że zarówno państwo jak i Kościół są społecznościami o charakterze doskonałym, gdyż obie istnieją z boskiego ustanowienia i z jego wewnętrznej natury. Pomimo że posiadają odrębne kierunki i różne cele, to wspólne jest ich boskie źródło. Władza państwowa zajmuje się porządkiem doczesnym, natomiast kościelna nadprzyrodzonym. Obie są od siebie niezależne i powinny się cieszyć wolnością; Kościół prowadząc ludzi do celu ponadziemskiego „musi korzystać z pomocy materialnej, to jednak głównymi środkami jego działania nie są siły polityczne, lecz nadprzyrodzone, moc Ducha świętego, sakramentów świętych i modlitwy". Źródło: List pasterski Episkopatu Polski o radościach i troskach Kościoła. W: Listy pasterskie Episkopatu Polski..., s. 66.

${ }^{354}$ Pojęcie dobra wspólnego obejmuje trzy obszary: dobro osoby ludzkiej, dobro rodziny i dobro narodu.

${ }^{355}$ Por. S. Wyszyński, Vratislavia - wróciła Stawa. Te Deum XX-lecia (Wrocław, 31.08.1965). W: Z rozważań nad kultura, Warszawa 1998, s. 73. Za R. Nęcek, Państwo w nauczaniu społecznym Prymasa Polski Stefana Wyszyńskiego. Studium teologiczno moralne, Kraków 2004, s. 201. 
wskazywał wprost na konieczność współpracy obu instytucji, akcentując ich służebną rolę wobec społeczeństwa. Osobiście dążył do swoistego modus vivendi poprzez zawarcie Porozumienia w 1950 r. z rządem PRL. Dialog ${ }^{356}$ traktował jako zasadę nadrzędną, dając przy tym dowód swej dobrej woli i zakładając równocześnie dobrą wolę drugiej strony ${ }^{357}$. Komuniści tymczasem po 1945 r. dążyli sukcesywnie do przejęcia całej władzy w państwie, podporządkowując sobie wszystkie sfery życia publicznego. Kiedy strona rządowa łamała prawa Kościoła, stosował metodę protestu.

Studia ukończył na KUL-u na dwu kierunkach - prawa kanonicznego, zakończone w 1929 r. doktoratem oraz prawa i nauk społeczno-ekonomicznych. Odznaczał się ponadto dynamizmem i konsekwencją w działaniu ${ }^{358}$. Naczelnik Wydziału V Wojewódzkiego Urzędu Bezpieczeństwa w Lublinie w notatce dla MBP scharakteryzował go następująco: „Działalność jego nacechowana jest zdecydowanie wrogim stosunkiem do marksizmu. Biskup Wyszyński prowadzi różnorodną wrogą działalność antyludową i antyradziecką. W swych kazaniach, konferencjach wszelkimi mniej lub więcej wyrafinowanymi sposobami usiłuje zohydzić obecny ustrój. [...] Dodać należy, że w/w jest wytrawnym socjologiem, politykiem i kaznodzieją. Wśród większości kleru nie cieszy się poparciem"359. W pasterskim Liście o chrześcijańskim wyzwoleniu czlowieka skierowanym do wiernych na adwent 1945 r. biskup lubelski wyraził opinię: „, [...] nieszczęściem tego świata jest, że pragnie on wyzwolenia człowieka, ale bez Boga [...] Krzywda wyrządzona religijnej duszy człowieka jest nie mniejsza. Rodzi się ona z chęci przewagi państwa nad Kościołem, cezara nad Bogiem. Do dzisiejszego dnia mści się na nas luterańska zasada - cuius regio eius religio - kto ma władzę, ten narzuca swą wiarę" 360 . W jednym z ostatnich kazań w Lublinie ostrzegał wiernych przed akcją zdejmowania krzyży w szkołach i urzędach ${ }^{361}$.

Obejmując urząd prymasa biskup S. Wyszyński nie zamierzał pełnić roli przywódcy opozycji politycznej, walczącej z państwem komunistycznym, niemniej stał się w tym okresie jedynym uznawanym autorytetem. Świadom posłannictwa Kościoła i dążeń nowej władzy, odegrał istotną rolę w obronie praw katolików w Polsce. Uważał, że między Kościołem a państwem musi istnieć choćby minimalne współdziałanie i dlatego też dążył do niego, pomimo nieprzestrzegania ze strony komunistów żadnych zasad ${ }^{362}$.

${ }^{356}$ Dialog mógł mieć charakter lokalny (Episkopat Polski i rząd PRL) lub centralny (Watykan i państwo). Źródło: R. Nęcek, Państwo w nauczaniu..., s. 215.

${ }^{357}$ Tamże, s. 194-229; A.F. Dziuba, Przesłanie społeczne kardynała Stefana Wyszyńskiego..., s. $46-76$.

${ }^{358}$ E.K. Czaczkowska, Kardynat Wyszyński..., s. 24.

359 B. Pylak, Stefan Wyszyński biskup lubelski 1946-1949, Lublin 2000, s. 231.

${ }^{360}$ E.K. Czaczkowska, Kardynat Wyszyński..., s. 77.

${ }^{361}$ Tamże, s. 79.

362 Tamże, s. 93, 96-97. 
Niemal w tym samym czasie, kiedy biskup S. Wyszyński przyjął nominację na prymasa, obóz komunistyczny umocnił się, tworząc PZPR. Był to bardzo trudny okres, w którym konfrontacja Kościoła z władzą była nieunikniona. Komuniści bowiem, głosząc materializm dialektyczny i wykluczając istnienie Boga, dążyli do stworzenia państwa totalitarnego, w którym obowiązywać miał jeden wzorzec światopoglądowy ${ }^{363}$. Janusz Zabłocki pisał: ,[...] pod koniec 1948 r. [...] zaostrzał się wyraźnie konflikt między państwem i Kościołem. Było oczywiste, że kończy się jakiś okres przejściowy, w którym władza ludowa, pochłonięta walką z podziemiem zbrojnym i legalną opozycją, starała się unikać równoczesnego konfliktu z Kościołem i dbała przynajmniej o pozory poprawnych z nim relacji. Lecz po pokonaniu przeciwników taki kamuflaż przestał być potrzebny. Można już było ukazać prawdziwą twarz"364. Współpracownicy UB mieli za zadanie odciągnąć młodzież od uroczystości powitalnych podczas ingresu prymasa w Gnieźnie 2 II 1949 r., Bydgoszczy, Inowrocławiu. W czasie swojej posługi biskup S. Wyszyński otoczony był licznymi agentami donoszącymi do Wydziału V Departamentu V $\mathrm{MBP}^{365}$. Był też stale obserwowany, podsłuchiwany i nękany w prymitywny sposób, odwiedzał go w kościele i na procesjach Bożego Ciała sam minister Antoni Bida - pierwszy szef utworzonego po podpisaniu Porozumienia w 1950 r. Urzędu do Spraw Wyznań. Prymas żartował, że nie było rządu pobożniejszego od tego ${ }^{366}$.

Lata 1950-1953 były dla prymasa w relacjach z władzami czasem defensywy. Dostojnikowi Kościoła zależało na utrzymaniu Porozumienia z 1950 r., nie chciał robić nic, co byłoby odebrane jako łamanie umowy przez stronę kościelną. Miał nadzieję, że zawarty układ spełni funkcję bufora hamującego ataki na Kościół. Dlatego też prowadził rozmowy z przedstawicielami rządu, B. Bierutem i F. Mazurem. Na przełomie lat 1952/1953 pośrednikiem w rozmowach między prymasem a rządem był B. Piasecki, z którym do aresztowania biskup

${ }^{363}$ Tamże, s. 26-29. Ponadto zmieniła się sytuacja międzynarodowa. ZSRR umocniło swoją pozycję jako mocarstwo atomowe, ideologia komunistyczna rozszerzyła się na obszarze Chin, co wbiło w pychę i rozbudziło wiarę w zwycięstwo komunizmu także i polskich komunistów na czele z B. Bierutem. Poczucie siły umocniło stalinowców w Polsce i pobudziło do mnożenia konfliktów z hierarchią Kościoła. Źródło: W.J. Wysocki, Osaczanie Prymasa..., s. 16.

${ }^{364}$ J. Zabłocki, Prymas Stefan Wyszyński..., s. 20.

${ }^{365}$ Historyk Mirosław Biełaszko ustalił, że w latach 1946-1948 było ich 16, natomiast od 1948 do 1963 r. -28. M. Biełaszko, wystąpienie na konferencji, Stefan kardynał Wyszyński. Pro memoria. Zapiski z lat 1948-1949 i 1952-1953, Spotkanie zorganizowane przez IPN i Instytut Prymasowski Stefana kardynała Wyszyńskiego, 29 X 2007, Warszawa. Do nich należeli m.in. agenci o pseudonimach: Kowalski (pierwszy kierowca prymasa Antoni Jędrzejczak), Heniek (ks. Hieronim Goździewicz), osoba o pseudonimie B. a od 1952 r. Bogucki (Witold Bieńkowski), Żagielowski (ks. Władysław Kulczycki) i Zygmunt (ks. Roman Len). Źródło: E.K. Czaczkowska, Kardynat Wyszyński..., s. 111-113; Wysocki ustalił, że byli nimi również podczas uwięzienia prymasa ks. Stanisław Skorodecki o pseudonimie Krystyna vel Krystian i s. Maria Leonia Graczyk o pseud. Ptaszyńska lub Ptaszyna. Źródło: W.J. Wysocki, Osaczanie Prymasa ..., s. 45-48.

${ }^{366}$ S. Wyszyński, Pro memoria..., s. 318. 
S. Wyszyński ${ }^{367}$ odbył około 30 rozmów. Rozmowy te nie przynosiły żadnych rozwiązań ${ }^{368}$. Rząd bowiem łamał Porozumienie od momentu jego podpisania, oskarżając jednocześnie prymasa o niewywiązywanie się z zobowiązań.

Większość biskupów krytykowała jego postępowanie wobec władzy, jednak - jak pisała E. Czaczkowska - ,po jego aresztowaniu, w sytuacji bezpośredniego zagrożenia - poszli na dalej idący układ z komunistami" ${ }^{369}$.

Nie wiadomo, kiedy ostatecznie zapadła decyzja o uwięzieniu prymasa. Aresztowanie miało odbyć się w styczniu 1953 r. wraz z ogłoszeniem dekretu o obsadzaniu stanowisk kościelnych, jednak zostało opóźnione ze względu na ogłoszenie przez Watykan jego nominacji na kardynała ${ }^{370}$. Wstępnie o izolacji postanowiono na posiedzeniu rządu i Biura politycznego KC PZPR 18 września, pod decyzją podpisali się: Jakub Berman, Bolesław Bierut, Józef Cyrankiewicz, Franciszek Jóźwiak, Franciszek Mazur, Hilary Minc, Edward Ochab, Stanisław Radkiewicz i Konstanty Rokossowski. Do Moskwy w tej sprawie wysłano sekretarza KC do Spraw Wyznań F. Mazura, który uzyskał już następnego dnia zgodę Nikity Chruszczowa i Iwana Sierowa ${ }^{371}$. Uchwałę o zakazaniu kardynałowi wykonywania funkcji „,W związku z jego ogólnie wrogą postawą” podjęto 23 września w Sekretariacie Biura Politycznego ${ }^{372}$.

W czasie przed uwięzieniem kardynała S. Wyszyńskiego prowadzący rozmowy F. Mazur żądał dalszych ustępstw. Pomimo że dekret o obsadzaniu stanowisk kościelnych z 9 II 1953 r. ${ }^{373}$ zaskoczył prymasa, jednak przyjmując zasadę

${ }^{367}$ Szerzej o trzyletnim okresie przebywania w izolacji zob. A. Jasiński, Kardynał Stefan Wyszyński - świadek wiary, t. 3: 1953-1956, Gniezno 1999; P. Raina, Kardynat Wyszyński. Losy więzienne, Warszawa 1993; Stefan Kardynat Wyszyński Prymas Polski w dokumentach aparatu bezpieczeństwa PRL (1953-1956), wybór i oprac. B. Piec, Warszawa 2001; W.J. Wysocki, Osaczanie Prymasa...; S. Wyszyński, Zapiski więzienne...,

368 W.J. Wysocki, Osaczanie Prymasa..., s. 30-32.

369 Tamże, s. 142-143.

${ }^{370}$ P. Raina, Stefan Kardynat Wyszyński Prymas Polski, t. 2, Londyn 1986, s. 10. Nie pozwolono mu jechać do Rzymu na wręczenie insygniów. Odebrał je dopiero po wyjściu z więzienia. Nominację kardynalską prymasa świętowano w seminarium warszawskim. Referat wygłosił kleryk, który wspominając kardynała Hozjusza, powiedział, ze kompromis jest potrzebny, byle tylko nie był kompromitacją. Kard. Wyszyński zrozumiał aluzję i spokojnie odpowiedział, że sytuacja w Kościele jest bardzo trudna. Po chwili dodał: „Widziałem kiedyś powódź. Rzeką płynęły drzewa połamane. Zauważyłem unoszącą się na wodzie budę z psem na łańcuchu. Łańcuch jest” i pokazał na krzyż biskupi na łańcuchu. To wstrząsnęło słuchaczami. Źródło: E.K. Czaczkowska, Kardynat Wyszyński..., s. 150.

${ }^{371}$ M.P. Romaniuk, Życie, twórczość i postuga Stefana kardynała Wyszyńskiego Prymasa Tysiąclecia, t. 1, Warszawa 1994, s. 651; A. Micewski, Wspótrządzić czy nie kłamać? PAX i Znak w Polsce 1945-1976, Paryż 1978, s. 59.

372 A. Dudek, Państwo i Kościół w Polsce..., s. 34-35.

${ }^{373}$ Dekret oznaczał przyjęcie względem organizacyjnej sfery Kościoła w Polsce sowieckiego modelu ,administrowania" Cerkwią. Podobnie uczyniono w Rumunii, na Węgrzech i w Czechosłowacji. Źródło: W.J. Wysocki, Osaczanie Prymasa ..., s. 31. 
„nie obrażamy się, rozmawiamy”, dalej prowadził dialog, co nie spotkało się z aprobatą części Episkopatu. W tym samym dniu członkowie Episkopatu obłożyli ekskomuniką uczestników styczniowego posiedzenia rozszerzonego zarządu ZBoWiD-u za „machinacje przeciwko władzy kościelnej” (dotyczyło to zmian na stanowiskach biskupów). Ostatnie spotkanie z F. Mazurem, bardzo upokarzające dla prymasa, odbyło się 3 III 1953 r. Dwa dni później zmarł Józef Stalin; na krótki czas sytuacja nieco się uspokoiła. Podczas uroczystości św. Wojciecha 26 kwietnia w Gnieźnie mówił, że ingerencja władz w sprawy personalne Kościoła poszła za daleko. Następnym krokiem było przygotowanie liczącego 25 stron dokumentu Non possumus (Nie możemy), datowanego na 8 maja, w którym wyliczono wszelkie bezprawne działania władzy od podpisania Porozumienia. Mianowanie i usuwanie biskupów było tylko w gestii Watykanu, Kościół nie mógł zatem tu pójść na żadne ustępstwa. Prymas 4 VI 1953 r. w czasie procesji Bożego Ciała w Warszawie wygłosił bardzo ważne kazanie krytyczne względem narzucania niewoli przez władzę $e^{374}$.

Stan stosunków państwa z Kościołem omówił F. Mazur na spotkaniu sekretariatu Biura Organizacyjnego KC PZPR 8 VI 1953 r., na którym zaplanowano dalsze zaostrzenie konfliktu wraz $\mathrm{z}$ uwięzieniem prymasa. Zgodę na pozbawienie wolności wydał szef NKWD Iwan Sierow oraz I sekretarz KC KPZR Nikita Chruszczow. Przygotowania do pozbawienia wolności rozpoczęto w resorcie bezpieczeństwa $26 \mathrm{~V} 1953$ r., pięć dni po wysłaniu do władz memoriału Non possumus. Ostatnie posiedzenie Episkopatu z udziałem kardynała S. Wyszyńskiego odbyło się 18 września, na którym podsumował trzy lata w stosunkach między Kościołem a państwem. Zwrócił uwagę na „dziwną sprzeczność”. Każde nowe ustępstwo Kościoła widziane było przez władze jako oznaka słabości i powodowało dalsze ataki ${ }^{375}$.

Prymas był przygotowany na uwięzienie, czego dał wyraz w przemówieniu 19 i 20 IX 1953 r. w czasie wizytacji parafii Serca Jezusowego na warszawskiej Pradze. Mówił wtedy: „Gdy będę w więzieniu, a powiedzą wam, że prymas zdradził sprawę Bożą - nie wierzcie! Nigdy nie zdradziłem i nie zdradzę sprawy Kościoła, choćbym miał za to zapłacić życiem i własną krwią" ${ }^{376}$. Bolesław Bierut podjął decyzję o zatrzymaniu prymasa 23 IX 1953 r. Próbowano jeszcze skompromitować kardynała, proponując mu podpisanie oświadczenia potępiającego skazanego na 12 lat więzienia kieleckiego biskupa C. Kaczmarka. Dzień przed aresztowaniem stanął w obronie Episkopatu i Kościoła, odrzucając oskarżenia w procesie biskupa. Wyraził to w liście do rządu ${ }^{377}$. W późnych

${ }^{374}$ E.K. Czaczkowska, Kardynat Wyszyński..., s. 152-157, 158-160.

375 Tamże, s. 160-167.

${ }^{376}$ L. Szała, W przededniu aresztowania. W: Wspomnienia o kardynale Stefanie Wyszyńskim: czas nigdy go nie oddali, Kraków 2001, s. 90.

377 E.K. Czaczkowska, Kardynat Wyszyński..., s. 168, 170. 
godzinach wieczornych 25 IX 1953 r. prymas S. Wyszyński został aresztowany i uwięziony. Pierwszym miejscem internowania był klasztor Kapucynów w Rywałdzie Królewskim ${ }^{378}$, drugim natomiast, od 12 października, stał się Stoczek Warmiński ${ }^{379}$. Tym samym uniemożliwiono mu sprawowania wszelkich funkcji na stanowiskach kościelnych ${ }^{380}$. Prymasowi zarzucono łamanie kwietniowego porozumienia z 1950 r., sprzeczne z interesem narodowym stanowisko wobec granic zachodnich i północnych Polski oraz uprawianie polityki antypaństwowej $^{381}$. Społeczeństwo polskie oficjalnie poinformowano o wydarzeniu dopiero 28 IX 1953 r. po wynegocjowanej deklaracji uległości biskupów wobec władzy; komunikat w prasie opublikowano 29 i 30 września $^{382}$. Miał być też odczytany z ambon kościołów ${ }^{383}$.

Nazajutrz po aresztowaniu, w sobotę 26 września na łamach organu prasowego KC PZPR „Trybunie Ludu”, ukazał się artykuł członka Biura Politycznego Edwarda Ochaba Kto przeszkadza w normalizacji stosunków między Kościołem $i$ Państwem? E. Ochab ostro zaatakował w nim kardynała S. Wyszyńskiego, oskarżając go o „politykę antypaństwową i warchołstwo”, o dążenie do rozbicia jedności narodu oraz o działania przeciwne utworzeniu stałych diecezji na Ziemiach Zachodnich. W dalszym wywodzie autor artykułu obarczył odpowiedzialnością prymasa „za sabotowanie i łamanie Porozumienia, za faktyczną pomoc okazywaną zachodnioniemieckim Krzyżakom i angloamerykańskim wrogom narodu w szkalowaniu i zohydzaniu Polski Ludowej"384. Dowodził, że wielokrotne ostrzeżenia ze strony rządu i społeczeństwa nie zatrzymały ,awanturniczego

${ }^{378}$ Data internowania prymasa S. Wyszyńskiego jest różnie podawana. Ks. M. Banaszak określił ją na dzień 24 września w: Historia Kościoła katolickiego, t. 4: Czasy najnowsze 1914-1978, Warszawa 1992, s. 75, podobnie W. Lizak, Historia Polski..., s. 248; biografowie prymasa zgodni byli co do 25 września. M.P. Romaniuk, Życie, twórczość i posługa ..., s. 656; W.J. Wysocki, Osaczanie Prymasa ..., s. 35; M. Fik podała natomiast dzień 26 września, gdyż uwięzienie nastąpiło w nocy. W: Kultura polska po Jałcie: kronika lat 1944-1981, Londyn 1989, s. 185.

379 Szerzej o udziale UB w walce z Kościołem i działaniach aparatu bezpieczeństwa w związku z uwięzieniem prymasa w: Stefan Kardynat Wyszyński Prymas Polski w dokumentach aparatu bezpieczeństwa PRL (1953-1956), oprac. B. Piec, Warszawa 2001.

${ }^{380}$ A. Dudek, R. Gryz, Komuniści i Kościót..., s. 90-91; W. Lizak, Historia Polski..., s. 247; szerzej o uwięzieniu prymasa zob.: J. Żakowski, Mroczne wnętrza, Warszawa 2000; P. Raina, Kardynat Wyszyński, t. 2: Losy więzienne, Warszawa 1993; M.P. Romaniuk, Życie, twórczość $i$ postuga ..., rozdział pt. Uwięzienie, s. 656-675; K. Poliński, Departament Prymas, „Głos Szczeciński” 2002 nr 115 s. 6; A. Kochański, Uwięzienie prymasa Wyszyńskiego, „Polityka” 1992 nr 5 s. 13.

${ }^{381}$ E.K. Czaczkowska, Kardynał Wyszyński..., s. 177-178, 183.

${ }^{382}$ M.P. Romaniuk, Życie, twórczość i postuga ..., s. 671.

${ }^{383}$ Reakcje duchowieństwa były różne. Niektórzy księża dziwili się, dlaczego list biskupów doręczony został przez przedstawicieli Prezydiów Rad Narodowych, inni wykazywali zdziwienie, odmawiali przyjęcia pism. Szerzej na ten temat W.J. Wysocki, Osaczanie Prymasa ..., s. 69-92.

${ }^{384}$ E. Ochab, Kto przeszkadza w normalizacji stosunków między Kościołem i Państwem?, „Trybuna Ludu” 1953 nr 268 s. 4. Cyt za: E.K. Czaczkowska, Kardynał Wyszyński..., s. 12. 
wychowanka i zausznika Watykanu". Jednocześnie zatrzymano sekretarza prymasa - biskupa Antoniego Baraniaka. Kampania prasowa miała uzasadnić usunięcie kardynała S. Wyszyńskiego ${ }^{385}$. Oficjalną informację o jego aresztowaniu władze ogłosiły dopiero po czterech dniach, obawiając się społecznego niezadowolenia. E. Ochab spotkał się w tym czasie w Sejmie z posłami Stowarzyszenia PAX. Niestety, członkowie PAX-u nie byli zainteresowani jakąkolwiek obroną prymasa. Wypowiedzi na łamach ich organu prasowego "Słowie Powszechnego" były zgodne z zamieszczonymi w „Trybunie Ludu” 386 .

Przedstawiciele Episkopatu na nadzwyczajnym posiedzeniu 28 IX $1953 \mathrm{r}$. chcieli wybrać tymczasowo przewodniczącego do czasu uwolnienia prymasa. $\mathrm{Na}$ kandydata wybrano poznańskiego arcybiskupa Walentego Dymka, lecz członkowie władzy komunistycznej przymusowo wysunęli na to miejsce kandydaturę ugodowego biskupa łódzkiego Michała Klepacza. Grożono członkom Kościoła, że w przypadku wyboru kogoś innego zostanie on uwięziony ${ }^{387}$. Następnie komuniści nakłonili do wydania oświadczenia autorstwa Bolesława Piaseckiego, które zdecydowanie odrzucił kilka dni wcześniej prymas S. Wyszyński. Potępiano w nim niesłusznie biskupa C. Kaczmarka, oskarżonego o szpiegostwo i skazanego na 12 lat więzienia oraz odrzucono wszelką „dywersję” wobec państwa. Potwierdzeniem miało być ślubowanie członków Episkopatu na wierność PRL złożone 17 XII 1953 r. Był to akt kapitulacji Episkopatu działającego pod ogromną presją ${ }^{388}$. W deklaracji napisano: „Episkopat nie będzie tolerował wkraczania przez kogokolwiek z duchowieństwa na drogę szkodzenia ojczyźnie i będzie stosował wobec innych odpowiednie sankcje zgodnie z prawem kanonicznym" ${ }^{\prime 38}$. W prasie obok tekstu deklaracji umieszczony został komunikat rządu stwierdzający: „W związku z uchwałą rządu o pozbawieniu ks. abpa Wyszyńskiego jego funkcji, Episkopat po powzięciu uchwał zabezpieczających ciągłość kierownictwa pracy konferencji Episkopatu, zwrócił się do rządu o wyrażenie zgody, aby ks. arcybiskup Wyszyński mógł zamieszkać w jednym z klasztorów”390.

Ewa Czaczkowska napisała o tym: „To był tragiczny dzień w historii Episkopatu Polski. Biskupi, którzy jeszcze niedawno krytykowali prymasa za zbytnią uległość wobec komunistów, sami skapitulowali na całej linii" ${ }^{391}$. Bohdan Cywiński główny powód postawy biskupów dostrzegł nie tyle w strachu przed

\footnotetext{
${ }^{385}$ W. Lizak, Historia Polski..., s. 248.

${ }^{386}$ E.K. Czaczkowska, Kardynat Wyszyński..., s. 13, 16.

${ }^{387} \mathrm{~W}$ tym czasie szesnastu biskupów wraz z prymasem uwięziono lub wydalono z diecezji.
} Tamże, s. 14.

${ }^{388}$ A. Dudek, R. Gryz, Komuniści i Kościót..., s. 90-91; E.K. Czaczkowska, Kardynat Wyszyński..., s. 14; A. Grajewski datę ślubowania podał 12 XII 1953 r. Źródło: A. Grajewski, Kompleks Judasza..., s. 189-190.

${ }^{389}$ A. Grajewski, Kompleks Judasza..., s. 188.

390 Tamże, s. 188.

${ }^{391}$ E.K. Czaczkowska, Kardynat Wyszyński..., s. 15. 
reakcją komunistów, co w fakcie wybrania ówczesnego biskupa na prymasa wbrew opinii większości z nich ${ }^{392}$. Andrzej Grajewski stwierdził natomiast, że biskupi nie wykazali się hartem ducha. Prymas Polski z goryczą wspominał później reakcję Episkopatu na to wydarzenie ${ }^{393}$.

Społeczeństwo polskie było w 1953 r. mocno zastraszone, więc jakiekolwiek protesty na uwięzienie prymasa stłumiono w zarodku. W obronie kardynała S. Wyszyńskiego protestowano głównie za granicą. Manifestacje odbyły się w Paryżu, Rzymie i Londynie, natomiast Pius XII nałożył ekskomunikę 30 września na wszystkich sprawców uwięzienia głowy polskiego Kościoła, w tym prezydenta Bolesława Bieruta ${ }^{394}$.

Ks. Marian Banaszak konstatował: „Kościół nie załamał się skazaniem biskupa Kaczmarka, internowaniem prymasa i więzieniem biskupa Baraniaka" ${ }^{939}$, jednak kolejne dwa lata przyniosły szerokie wpływy władzy na jego politykę personalną. Zapanowano nad kuriami i seminariami. Aparat wyznaniowy wsparł UB i PAX. Członkowie PAX-u sporządzali charakterystyki poszczególnych księży oraz instytucji kościelnych w celu propozycji zmian. Czasami księży stawiano przed alternatywą wstąpienia do „ruchu społecznie postępowego” lub zastąpieniu ich innymi księżmi, uległymi wobec władz. Pozostał zatem bierny opór i odrzucanie części wniosków o zmianę stanowisk. W roku szkolnym 1953/1954 zakazano ostatecznie katechezy w szkołach zawodowych i liceach pedagogicznych. W październiku 1953 r. doszło do połączenia paksowskiej Komisji Intelektualistów z Komisją Księży przy ZBoWiD-zie. W wyniku tego utworzono Komisję Duchownych i Świeckich Działaczy Katolickich (KDiŚDK) przy Ogólnopolskim Komitecie Frontu Narodowego, na czele z ks. prof. Janem Czujem. Ruch „księży patriotów" w ekstremalnym wydaniu nie był już potrzebny, bowiem wypełnił już oczekiwane zadania. Odbyło się to w atmosferze wielkiej kampanii politycznej z udziałem około czterech tysięcy duchownych, deklarujących przywiązanie do socjalizmu. Organizowane zjazdy, imprezy gromadziły księży demonstrujących poparcie dla decyzji o internowaniu prymasa ${ }^{396}$. Zresztą po aresztowaniu przełożonego Kościoła przestała działać obawa sankcji dyscyplinarnych.

392 Tamże, s. 16. Honor Episkopatu próbował ratować jedynie ks. Wojciech Zink - rządca diecezji warmińskiej, który jako jedyny hierarcha nie podpisał dokumentów, za co aresztowano go i więziono przez szesnaście miesięcy. Na to prymas miał zareagować później, że w momencie internowania ,tylko pies i Niemiec upomnieli się o niego". Owczarek prymasa ugryzł bowiem w palec funkcjonariusza UB przy aresztowaniu, a ks. W. Zink był warmińskim autochtonem. Źródło: J. Żakowski, Mroczne wnętrza ..., s. 50.

${ }^{393}$ S. Wyszyński, Zapiski więzienne...

${ }^{394}$ E.K. Czaczkowska, Kardynat Wyszyński..., s. 18-19.

${ }^{395}$ M. Banaszak, Historia Kościoła katolickiego, t. 4: Czasy najnowsze 1914-1978, Warszawa 1992, s. 76.

${ }^{396}$ A. Dudek, R. Gryz, Komuniści i Kościół..., s. 92-97; J. Żaryn, Dzieje Kościoła katolickiego..., s. 63; W. Lizak, Historia Polski..., s. 344. 
Funkcje zatrzymanego prymasa bardziej z wyboru władz niż członków Episkopatu przejął biskup łódzki Michał Klepacz. Episkopat wydał Deklarację, w której nie zaprotestowano przeciw bezprawiu Prezydium Rządu. Ograniczono się w niej jedynie do stwierdzenia faktu zakazania arcybiskupowi S. Wyszyńskiemu wykonywania funkcji w Kościele ${ }^{397}$.

W okresie lat 1950-1953 nie było już żadnej partii opozycyjnej ani nawet organizacji niezależnej od władz państwowych. Jedyną osobą i środowiskiem niezależności myśli i wolności był prymas i Kościół, kojarzone też często z opozycją wobec władz. Barbara Fijałkowska zwróciła uwagę na to, że w powojennej polskiej rzeczywistości ,[...]wolność sumienia i wyznania były w pierwszym rzędzie wolnością w upowszechnianiu ateizmu i dyskredytowaniu wszelkiej religii. Natomiast rozdział Kościoła od państwa oznaczał - paradoksalnie próbę $<<$ upaństwowienia>> Kościoła poprzez ingerencje w jego sprawy wewnętrzne oraz tworzenie kontrolowanych i finansowanych przez państwo ruchów społecznych katolików świeckich i duchownych”398. Walka w imię utworzenia „,nowej kultury”399 z polskimi tradycjami spowodowała, że w latach 1945-1953 Kościół jako jedyna autonomiczna siła społeczna zaczął kolejny raz pełnić rolę strażnika narodowej spuścizny. Miał odwagę przeciwstawić się dyktaturze nie tylko w imię interesów Kościoła i katolików, ale całego społeczeństwa. Od jesieni 1953 r. nie była to już konfrontacja dwóch instytucji: państwa i Kościoła, ale stały stan napięcia między strukturą władzy a katolikami na tle realizacji stalinowskiej polityki wyznaniowej ${ }^{400}$. Upominanie się o prawa człowieka w stalinowskiej Polsce było aktem wielkiej odwagi, której sterroryzowane społeczeństwo miało coraz mniej. Władze liczyły na to, że kiedy usuną kardynała S. Wyszyńskiego i najbardziej wrogich im biskupów, resztę Kościoła łatwo sobie podporządkują ${ }^{401}$.

$$
* * *
$$

Okres stalinizmu został nazwany przez Dariusza Jarosza „czasem największego w powojennej Polsce zniewalania rządzonych przez rządzących" ${ }^{\text {402 }}$. Okres 1945-1953 był najtrudniejszym dla Kościoła katolickiego w całym okresie trwania PRL. Wojciech Lizak pisał: „Komunizm był nowym, niespotykanym

${ }^{397}$ M. Banaszak, Historia Kościoła katolickiego..., s. 75-76; szerzej zob. K. Gruszczyński, Biskup Michat Klepacz 1893-1967, Łódź 1993.

${ }^{398}$ B. Fijałkowska, Partia wobec religii..., s. 114. Szerzej na ten temat zob. H. Misztal, Polskie prawo wyznaniowe. Zagadnienia wstepne, rys historyczny, Lublin 1997; A. Dudek, Polityka wtadz komunistycznych wobec Kościoła katolickiego w latach 1945-1955, „Wiadomości Historyczne” $1992 \mathrm{nr} 5$.

${ }^{399}$ Szerzej zob. Nim będzie zapomniana. Szkice o kulturze PRL-u, pod red. S. Bednarka, Wrocław 1997.

${ }^{400}$ W. Lizak, Historia Polski..., s. 250.

${ }^{401}$ E.K. Czaczkowska, Kardynat Wyszyński..., s. 125.

${ }^{402}$ D. Jarosz, Polacy a stalinizm ..., s. 5. 
i kuriozalnym epizodem w dziejach świata. Nie był kontynuacją żadnych wcześniejszych naturalnych tendencji rozwojowych, a raczej ich przerwaniem. Był próbą przeniesienia w świat realny intelektualnych pomysłów na równość i sprawiedliwość" 403 . Po śmierci dyktatora, jakim był J. Stalin, zaczął się schyłek „klasycznego” stalinizmu i okazało się, że Kościół polski dzięki działalności prymasa zyskał wiele na czasie ${ }^{404}$. Pomimo wszystko stalinizm w Polsce nie był aż tak okrutny, jak w sąsiednich krajach bloku sowieckiego. Kościół atakowano ze wszystkich stron, ale go nie stłamszono, jak to miało miejsce w Bułgarii czy na Ukrainie. Narzucenie komunistycznego reżimu wiernemu katolicyzmowi narodowi okazały się w Polsce wyjątkowo bezowocne. „Polska droga socjalizmu nie mogła żadną miarą biec trasą wytyczoną przez radzieckie znaki drogowe", w pełni aktualna stała się opinia Stalina o komunizmie w Polsce, „pasującym jak siodło do grzbietu krowy”. Polski komunizm różnił się w istotny sposób od jego rosyjskiej odmiany ${ }^{405}$.

W okresie 1945-1953 pokaźnie uszczuplono liczbę duchownych - ubyło 2247 księży (37 zabito, 260 zmarło lub zaginęło, 350 zesłano, 700 uwięziono, a 900 wygnano). W 1953 r. siedmiu biskupów więziono, dwóch pozbawiono możliwości wypełniania posługi. Podobnie uczyniono z zakonnikami i zakonnicami ubyło 724; 54 zabito, 20 zesłano, 300 wygnano ${ }^{406}$. Liczne pokazowe procesy sądowe księży miały zniechęcić i nastraszyć duchowieństwo oraz odpowiedzialnych za nie biskupów, a „opornego prymasa zmusić do zmiany polityki wobec państwa" ${ }^{407}$. Pomimo represji odnotowano wzrost kandydatów do stanu duchownego i ożywienie praktyk religijnych. Stąd władze sprzeciwiały się niektórym formom kultu np. procesji Bożego Ciała, zgromadzeniom na cmentarzach w uroczystość Wszystkich Świętych, nabożeństwom majowym odprawianym przy kapliczkach i krzyżach przydrożnych ${ }^{408}$. Zamknięto wiele kościołów, domów zakonnych, szkół katolickich, dzieł charytatywnych, drukarni. Własność kościelna w 1950 r. uszczuplona została w $80 \%{ }^{409}$. Punktem zapalnym w relacjach państwa z Kościołem były wszelkie organizacje i zrzeszenia katolickie. Zlikwidowano więc Akcję Katolicką, organizacje młodzieżowe KSM, Krucjatę Eucharystyczną, Sodalicję Mariańską oraz „ostatni bastion”: dobroczynny i prężnie działający Caritas. Założeniem komunistów było bowiem całkowite wyeliminowanie Kościoła z życia społecznego, do czego konsekwentnie dążono od początku $1945 \mathrm{r}$.

${ }^{403}$ W. Lizak, Historia Polski..., s. 5.

${ }^{404}$ A. Micewski, Kardynat Wyszyński..., s. 10.

${ }^{405}$ N. Davies, Boże igrzysko..., s. 682-685, 718.

${ }^{406}$ Z. Zieliński, Kościót w Polsce 1944-2002 ..., s. 87-88.

${ }^{407}$ J. Żaryn, Kościót w PRL..., s. 32.

${ }^{408}$ Z. Zieliński, Kościót w Polsce 1944-2002 ..., s. 87-88.

${ }^{409}$ Z. Wichrowski, Męczeństwo Kościoła w Polsce w latach 1945-1953. W: Spoleczeństwo państwo - Kościól (1945-2000). Materiały z ogólnopolskiej konferencji naukowej, Szczecin 15-16 VI 2000, pod red. A. Kaweckiego i in., Szczecin 2000, s. 23. 
Sytuację trafnie ocenili Anna i Andrzej Anuszowie:,,Stabilność i jednocześnie inercja postaw religijnych była przerywana konfliktami między władzami kościelnymi a państwowymi. W okresach przełomów politycznych rosło zaangażowanie religijne i społeczne katolików. Więcej ludzi brało udział w nabożeństwach, procesjach, pielgrzymkach, wzrosła aktywność stowarzyszeń i organizacji związanych z Kościołem. Wobec braku autentycznej wolności słowa, stowarzyszeń i organizacji, wobec zmonopolizowanego przez partię komunistyczną życia politycznego i społecznego, zwłaszcza po sfałszowanych wyborach $1947 \mathrm{r}$., religia rzymskokatolicka stała się substytutem zachowań politycznych. Dawała jedną z nielicznych możliwości wyrażenia niezgody na powojenną polską rzeczywistość. Religia posłużyła jako parawan dla niekomunistycznych poglądów i krytyk systemu. Ważną umiejętnością Kościoła w Polsce było zachowanie odpowiednich proporcji między jego funkcją profetyczną i duszpasterską a zadaniami społecznymi i politycznymi. Kościół dla zniewolonego społeczeństwa stał się oparciem, jako wspólnota wiary i nadziei. Wspólnota, która pomagała przekroczyć pokusę nienawiści wobec narzuconej władzy oraz miejsce, gdzie ludzie mogli czuć się wolni i nie słyszeć kłamstw”410. Religia rzymskokatolicka i Kościół w Polsce przyczyniły się do wzrostu świadomości narodowej, wykrystalizowania postaw społecznych i obudzenia politycznych aspiracji Polaków ${ }^{411}$. W stosunkach Kościoła i państwa w latach 1945-1953 komunistom zależało na stałym podsycaniu konfliktu w celu osłabiania wpływów Kościoła ${ }^{412}$.

${ }^{410}$ A.A. Anusz, Samotnie wśród wiernych. Kościót wobec przemian politycznych $w$ Polsce (1944-1994), Warszawa 1994, s. 16.

411 Tamże, s. 17.

412 J. Żaryn, Kościót w PRL..., s. 28. 


\section{ROZDZIAL 2}

\section{Polska prasa i książka katolicka w latach 1945-1953}

\subsection{Sytuacja wydawnicza prasy katolickiej w pierwszych latach powojennych}

Lata 1945-1947 zgodnie z prowadzoną przez nową władzę polityką pozorów charakteryzowały dogodne warunki dla rozwoju prasy katolickiej. Terminem tym objęto grupę periodyków, w których propagowane były wartości chrześcijańskie i zgodne z nauką Kościoła. W węższym znaczeniu, wedle definicji biskupa Adama Lepy, do prasy katolickiej przynależą ,wydawnictwa, które za zgodą władz kościelnych drukowane są periodycznie i rozpowszechniane publicznie"1, co w praktyce oznacza opiekę asystenta kościelnego. Po Soborze Watykańskim II przyjęło się rozróżnienie między prasą katolicką, kościelną a prasą katolików ${ }^{2}$.

Kontynuacji licznych tytułów prasowych o profilu katolickim dopomogły bogate tradycje edytorskie i dziennikarskie Kościoła z okresu dwudziestolecia międzywojennego, jak też świadomość wśród duchowieństwa roli prasy jako głównego medium w przekazie treści religijnych. Dostrzegano bowiem jej ważne zadanie „w linii bojowej o największą stawkę w kulturze człowieka [...] o nowy porządek społeczny, wiarę i moralność”3. Redaktor naczelny „Tygodnika Warszawskiego"

${ }^{1}$ A. Lepa, Katalog prasy katolickiej w Polsce, Łódź 1994 s. 4.

${ }^{2}$ W Encyklopedii wiedzy o prasie brak hasła „prasa katolicka”. W części opisu dotyczącego prasy kościelnej czytamy natomiast: „Jeśli idzie o prasę katolicką w Polsce, to część jej jest wydawana przez instytucje niekościelne, świeckie, z drugiej zaś strony hierarchia kościelna dysponuje specjalnymi pismami diecezjalnymi i zawodowo-kapłańskimi, redagowanymi przez duchownych i podlegającymi cenzurze kościelnej”. Pod szerszym terminem prasy religijnej napisano: „Prasa rzymskokatolicka zajmuje w prasie religijnej miejsce szczególne ze względu na ilość, różnorodność (od prasy codziennej do naukowych periodyków) oraz ze względu na jej światowy zasięg”. Źródło: Cz.L. [C. Lechicki], Prasa kościelna. W: Encyklopedia wiedzy o prasie, pod red. J. Maślanki, Wrocław, s. 174; tenże, Prasa religijna, tamże, s. 182.

${ }^{3}$ Prasa katolicka w stużbie Chrystusa Króla. Zbiór kazań na uroczystość Chrystusa Króla, Warszawa 1947, s. 11. 
ks. Zygmunt Kaczyński konstatował: „Prasa katolicka w naszym kraju ma swoją historię, której nie potrzebuje się wstydzić. Przed wojną światową [...] liczyła poważną liczbę czasopism i wywierała wielki wpływ na społeczeństwo nasze [...] odegrała dużą rolę, przypominając często społeczeństwu naszemu naukę Chrystusową, o prawach i godności człowieka, o jego celu i przeznaczeniu, o roli jego w społeczeństwie i państwie. Bronić wolności człowieka, wypowiadać się przeciwko reżimowi, przeciw omnipotencji państwa $\mathrm{w}$ okresie oszałamiającej propagandy systemów totalitarnych nie było rzeczą łatwą". Nawiązując do powojennej jej sytuacji ks. Kaczyński podkreślił, że służyła ona nadal tym samym ideałom, pozostając niezależną politycznie i finansowo. Szczególną misję tytułów katolickich postrzegał natomiast w „rechrystianizacji i odbudowie człowieka”.

Czesław Lechicki podał natomiast powody, dla których prasa katolicka zajęła ważne miejsce w prasie ogólnopolskiej pierwszych lat po wojnie. Miały o tym zadecydować: znaczna liczba tytułów, zakres i specyfika treści, zasięg rozpowszechniania oraz współpracownicy i poziom redakcyjny. Wyraził też opinię, że powinna być traktowana niezależnie od pozostałej prasy religijnej czy wyznaniowej, która raczej nie wychodziła poza zasięg lokalny i nie posiadała większego wpływu na życie społeczno-kulturalne kraju'.

Wydawane już od 1945 r. pisma o profilu katolickim miały do spełnienia istotną rolę, gdyż poszczególne redakcje wyrażały określone stanowiska i postawy wobec wydarzeń społeczno-politycznych Polski powojennej. Sylwester Dziki stwierdził, że w latach 1944-1948 „każdy organ prasowy prezentował swoje własne rozumienie rzeczywistości"”. Poszczególne grupy społeczne, kulturalne i światopoglądowe powoływały do życia najczęściej tygodniki ${ }^{8}$. W literaturze przedmiotu $\mathrm{w}$ odniesieniu do czasopism katolickich najczęściej zwracano uwagę na trzy środowiska, skupione wokół „Tygodnika Powszechnego”, „Tygodnika Warszawskiego" i „Dziś i Jutro".

Pierwsze periodyki katolickie ukazały się kilka miesięcy przed zakończeniem wojny. Na Śląsku 11 II 1945 r. reaktywowano „Gościa Niedzielnego”, drugi był krakowski „Tygodnik Powszechny”, powstały 24 III 1945 r. Kolejne tytuły to: częstochowska „Niedziela” - 8 kwietnia, po niej katowicki „Dzwonek Maryi”, poznański „Głos Katolicki” - 29 kwietnia, włocławski „Ład Boży” - 21 września, „Tygodnik Warszawski” - 11 listopada tegoż roku, krakowski „Znak”- lipiec 1946 r.

${ }^{4}$ Z.K. [Z. Kaczyński], Dzień prasy, ,Tygodnik Warszawski” [dalej „TW”] 1947 nr 43 s. 1-2.

${ }^{5}$ Tamże, s. 2.

${ }^{6}$ C. Lechicki, Polska prasa katolicka 1945-1948, „Kwartalnik Historii Prasy Polskiej” 1983 nr 2 s. 65.

${ }^{7}$ S. Dziki, Prasa polska w latach 1944-1948, tamże, 1984 nr 1 s. 69.

${ }^{8}$ Tamże, s. 65.

${ }^{9}$ J. Łojek, J. Myśliński, W. Władyka, Dzieje prasy polskiej, Warszawa 1988, s. 171; L. Szaruga, Czasopisma literackie. W: Literatura polska 1918-1975, t. 3 cz. 1: 1945-1975, Warszawa 1996, s. 220-223; J. Wiśniewski, Z historii prasy katolickiej w Polsce. Tygodnik Warszawski 1945-1948, Kraków 1998, s. 19-46. 
Największą poczytnością cieszyły się, podobnie jak w Drugiej Rzeczypospolitej, popularny „Rycerz Niepokalanej” i „Posłaniec Serca Jezusowego”10.

Organy prasowe od 1948 r. podlegały przymusowemu uspołecznieniu. Nacjonalizacji uległ też przemysł drukarski i poligraficzny ${ }^{11}$, a rząd stał na stanowisku, że gazety i czasopisma nie mogą przynależeć do osób i spółek prywatnych ${ }^{12}$. Wprowadzono scentralizowaną politykę wydawania zezwoleń na ukazywanie się tytułów prasowych. Pomimo że Kościół posiadał własną kadrę dziennikarską wśród duchowieństwa i inteligencji katolickiej, rozwój periodyków katolickich po wojnie natrafił na wiele trudności. Wprowadzono tzw. system koncesyjny na wydawanie czasopism. Zezwolenia (koncesje) w przypadku periodyków katolickich udzielano po zasięgnięciu opinii Ministerstwa Administracji Publicznej. Zatwierdzano przy tym nakłady i objętość pism ${ }^{13}$. Wszystkimi sprawami prasowymi zajmował się Resort Informacji i Propagandy na mocy dekretu PKWN z 7 IX 1944 r. ${ }^{14}$ Realizowanie głównych kierunków państwowej propagandy prasowej, kontrolę nad bazą poligraficzną i kolportażem prasy przejął Wydział Informacyjno-Prasowy, na czele którego stał Jerzy Borejsza ${ }^{15}$. Z powodów politycznych opóźniano często decyzje, aby następnie wydać odmowę lub zawiesić pismo.

Wyraźnie rysująca się różnica w postrzeganiu rzeczywistości między publicystami prasy rządowej a piszącymi na łamach prasy katolickiej była przyczyną zaostrzającej się polemiki między tymi obozami. Współpracownicy prasy partyjnej (m.in. „Kuźnicy” i „Wsi”) w swoich opiniach traktowali religię jako „prywatną sprawę obywateli", natomiast sami w założeniu mieli przyczynić się do ukształtowania nowego typu człowieka - człowieka socjalizmu ${ }^{16}$.

Porozumienie władz z Kościołem zawarte 14 II 1950 r. również nie zahamowało represji, a raczej zintensyfikowało politykę antykościelną. Przejęto kolportaż prasy katolickiej, ograniczano przydział papieru, nakład i objętość pism, utrudniano uzyskanie koncesji, przekazywano tytuły Stowarzyszeniu PAX ${ }^{17}$. Ostatecznie do 1953 r. zlikwidowano wszystkie samodzielne światopoglądowo periodyki, a pozostałe w pełni znalazły się w rękach władz.

${ }^{10}$ C. Lechicki, Polska prasa katolicka ..., s. 65-86.

${ }^{11}$ Szerzej o sytuacji wydawniczej i politycznych uwarunkowaniach produkcji książek w Polsce w latach 1944-1949 pisał S.A. Kondek, Papierowa rewolucja: oficjalny obieg ksiażek w Polsce w latach 1948-1955, Warszawa 1999; tenże, Władza i wydawcy. Polityczne uwarunkowania produkcji ksiązek w Polsce w latach 1944-1949, Warszawa 1993.

${ }^{12}$ Ustawa o nacjonalizacji podstawowych gałęzi gospodarki narodowej z 3 stycznia $1946 \mathrm{r}$.

${ }^{13}$ J. Stefaniak, Polityka władz państwowych PRL wobec prasy katolickiej w latach 1945-1953, Lublin 1998, s. 19, 21.

${ }^{14}$ Szerzej zob. M. Ciećwierz, Polityka prasowa 1944-1948, Warszawa 1989; tenże, Polityka prasowa rzadu polskiego w latach 1944-1948, „Kwartalnik Historii Prasy Polskiej” 1985 nr 1 s. 32.

${ }^{15}$ M. Ciećwierz, Ksztattowanie się państwowego aparatu nadzoru i kontroli prasy w Polsce w latach 1944-1948, „Kwartalnik Historii Prasy Polskiej” 1983 nr 1 s. 29.

${ }^{16}$ J. Lubiński, Najważniejsze zasady i cele polityki PZPR $w$ dziedzinie komunikowania $w$ latach 1948-1971, tamże, 1991 z. 2 s. 130.

${ }^{17}$ J. Stefaniak, Polityka władz państwowych ..., s. 182-183. 


\subsubsection{Ilościowa prezentacja prasy katolickiej}

Chociaż liczba tytułów prasowych związanych z Kościołem katolickim w pierwszych latach po wojnie była dość obszerna, nie dorównywała liczbie $\mathrm{z}$ okresu dwudziestolecia ${ }^{18}$. Od początku bowiem dbano, aby pomniejszyć jej znaczenie i zepchnąć na margines.

Istnieją duże niezgodności w danych odnośnie do wydawanych tytułów. Jerzy Myśliński w Bibliografii prasy polskiej 1944-1948 podał liczbę 24 czasopism katolickich w 1945 r., $23 \mathrm{w}$ 1946, $19 \mathrm{w} 1947$ i zaledwie pięciu w 1948 r. ${ }^{19}$ Zdaniem Czesława Lechickiego w 1947 r. wychodziły 32 pisma, w tym siedem tygodników, 23 miesięczniki, pięć czasopism dla księży i dwa inne ${ }^{20}$. Dane zawarte w Spisach prasy katolickiej zamieszczanych w poszczególnych periodykach także były rozbieżne. W 1947 r. redakcja „Kroniki Diecezji Włocławskiej” podała, iż ukazywały się 33 tytuły, „Ładu Bożego” i „Gościa Niedzielnego” - 34 tytuły, natomiast „Głosu Katolickiego”, „Naszej Drogi”, „Tygodnika Warszawskiego”, „Tygodnika Powszechnego” - zgodnie wymieniły 29 tytułów ${ }^{21}$. Nieco inne liczby przedstawiła Barbara Fijałkowska. Według zdobytych przez nią informacji w $1950 \mathrm{r}$. w Polsce wydawano 55 pism katolickich, w tym jeden dziennik, siedem tygodników, jeden dwutygodnik, 37 miesięczników, siedem dwumiesięczników i dwa kwartalniki ${ }^{22}$. Ks. Zygmunt Zieliński twierdził natomiast, że w latach 1945-1951 znano 64 tytuły, nie licząc wiadomości diecezjalnych i informatorów ${ }^{23}$.

${ }^{18}$ W okresie Drugiej Rzeczypospolitej Kościół katolicki stanowił potęgę wydawniczą. Tempo ilościowego rozwoju prasy katolickiej przewyższało tempo rozwoju całej prasy polskiej. Łączne nakłady tytułów katolickich wynosiły ponad 25\% ogółu nakładów polskiego czasopiśmiennictwa. Źródło: A. Paczkowski, Prasa polska w latach 1918-1939, Warszawa 1980, s. 293; J. Łojek, J. Myśliński, W. Władyka, Dzieje prasy polskiej..., s. 115.

${ }^{19}$ J. Myśliński, Bibliografia prasy polskiej 1944-1948, Warszawa 1966. Za J. Stefaniak, Prasa katolicka w systemie prasowym Polski Ludowej 1945-1953, „Zeszyty Prasoznawcze” 1996 nr 1/2 s. $140-153$, s. 22

${ }^{20}$ C. Lechicki, Polska prasa katolicka..., s. 84.

${ }^{21}$ Kompletny spis wychodzacej w Polsce prasy katolickiej, „Głos Katolicki” [dalej „GK”] 1947 nr 28 s. 240; Polska prasa katolicka, „Tygodnik Powszechny” [dalej,,TP”] 1947 nr 28 s. 7; Prasa katolicka, „TW” 1947 nr 27 s. 6; J. Stefaniak, Prasa katolicka w systemie..., s. 22; w kolejnym numerze redakcja „Głosu Katolickiego” podała jednak uzupełnioną listę tytułów prasowych liczącą 34 periodyki, zob. Kompletny spis wychodzacej w Polsce prasy katolickiej, "GK" 1947 nr 44 s. 362; o ukazujących się pismach katolickich informowano także pod nagłówkiem Nadestane czasopisma, „GK” 1950 nr 20 s. 191; tamże, nr 22 s. 207; tamże, nr 23 s. 215; „GK” 1951 nr 1 s. 7.

${ }^{22}$ B. Fijałkowska, Partia wobec religii i Kościoła w PRL, t. 1: 1944-1955, Olsztyn 1999, s. 101.

${ }^{23}$ Z. Zieliński, Kościół w Polsce 1944-2002, Radom 2002, s. 74. 
Głównymi ośrodkami prasy katolickiej w latach 1945-1953 były Kraków, Warszawa i Poznań2 ${ }^{24}$, zatem największą liczbę periodyków o tym profilu posiadały odpowiednio archidiecezja krakowska, poznańska i warszawska. Udział pism katolickich w ogólnej liczbie polskich tytułów prasowych wynosił w tym okresie od 7 do $11 \%$. Kolejne lata przyniosły zmniejszanie się tego odsetka. Najwięcej tytułów prasowych ukazało się w 1948 r. - 79, w 1950 - 52, a w 1953 wraz z zamknięciem „Tygodnika Powszechnego" i przejęciem go przez Stowarzyszenie PAX komuniści uzyskali kontrolę nad całą prasą katolicką. Te przykłady świadczyły o wyraźnym zahamowaniu działalności wydawniczej Kościoła.

Najwyższe nakłady osiągały tygodniki i miesięczniki („Niedziela”, „Gość Niedzielny”, „Tygodnik Powszechny”, „Głos Katolicki”, „Rycerz Niepokalanej”, „Msza Święta” i „Posłaniec Serca Jezusowego”), najmniejsze - kwartalniki i roczniki katolickie przeważnie o charakterze naukowym, posiadające wąski krąg odbiorców. Pierwsze lata powojenne wykazały raczej stałą liczbę nakładów; wyraźnie zmniejszyła się ona w latach 1952-1953. Dobrym przykładem może być „Rycerz Niepokalanej” osiągający początkowo 500-600 tys. egzemplarzy, a w latach 1952-1953 zaledwie 50-60 tys. ${ }^{25}$

Aktywność inteligencji katolickiej w omawianym okresie, jak słusznie zauważył Jan Żaryn, wyraziła się m.in. w inicjatywach czasopiśmienniczych. Do najważniejszych pism - jego zdaniem - należały: „Tygodnik Warszawski”, „Tygodnik Powszechny”, „Głos Niedzielny” wydawany w Katowicach, poznański „Głos Katolicki” oraz włocławski „Ład Boży”26. Prasa jako jedno z najważniejszych mediów tego okresu odegrała istotne znaczenie. Wokół „Tygodnika Warszawskiego" i „Tygodnika Powszechnego" skupiły się środowiska o określonym światopoglądzie. Łamy większości wspomnianych periodyków o profilu katolickim świadczyły o nieuchronnym konflikcie światopoglądowym między Kościołem a państwem ${ }^{27}$.

\subsubsection{Ingerencje cenzury}

Podjęte w 1948 r. przez komunistów działania mające na celu ustanowienie nowego systemu prasowego spowodowały, że prasę katolicką zaczęto traktować na zasadach prasy opozycyjnej. Ataki wzmogły się po ogłoszeniu przez Episkopat Polski listu do wiernych, wzywającego do sprzeciwu wobec wydawanej prasy

${ }^{24}$ J. Łojek, J. Myśliński, W. Władyka, Dzieje prasy polskiej..., s. 71; A. Friszke, Opozycja polityczna w PRL 1945-1980, Londyn 1994, s. 36-42.

${ }^{25}$ Z. Zieliński, Kościót w Polsce..., s. 27-29.

${ }^{26}$ J. Żaryn, Dzieje Kościoła katolickiego w Polsce (1944-1989), Warszawa 2003, s. 83.

${ }^{27}$ Por. E. Kristanova, „Tygodnik Warszawski” a władza komunistyczna..., s. 357-374; M. Trąba, Cenzorskie oceny tygodników katolickich , Gość Niedzielny” " „,Niedziela” w pierwszych latach naporu ideologicznego (1948-1949), tamże, s. 375-390. 
antyreligijnej i ogólnej ateizacji społeczeństwa. Władze odpowiedziały zaostrzeniem cenzury. Periodyki krępowane były oceną cenzorów oraz działaniami organów partyjno-państwowych; często konfiskowano ich własne treści prasowe i zastępowano je treściami zalecanymi przez organy kontroli. Dla uniknięcia nieprzyjemności oraz ingerencji władz, w redakcjach katolickich zaczęto stosować swoistą autocenzurę ${ }^{28}$. Omijano drażliwe tematy, którymi były m.in. obecność katolików w ruchach społecznych, rola Kościoła w Polsce, zbrodnie NKWD, stosunek do ZSRR i inne ${ }^{29}$. Obóz lewicowy w 1948 r. dokonał następującej oceny wydawnictw: „Poważne ogniwo we wrogim froncie ideologicznym stanowi prasa katolicka. Uprawia propagandę ideologii kapitalistycznej poprzez personalizm chrześcijański i humanitaryzm" ${ }^{30}$. W latach pięćdziesiątych kontrola słowa i rygor cenzury były najdotkliwsze, a od 1948 r. wyraźnie zaostrzyły się ingerencje w prasie katolickiej.

Organem powołanym do kontroli tekstów prasowych był Główny Urząd Kontroli Prasy, Publikacji i Widowisk (GUKPPiW) wraz z podległymi mu miejskimi, powiatowymi i wojewódzkimi urzędami. Cenzura działała na podstawie dekretu Krajowej Rady Narodowej z 5 VII 1946 r. o jej utworzeniu ${ }^{31}$. Pracownicy mniejszych oddziałów w kwesti skreślenia fragmentu lub niedopuszczenia do druku całego tekstu ściśle współpracowali z naczelnikami GUKPPiW. Władze komunistyczne określiły ponadto kanon tekstów, które nie mogły ukazywać się na łamach prasy. W przypadku periodyków katolickich baczną uwagę zwracano na wszelkie opinie dotyczące przejawów życia społecznego: odniesienie do nowego polskiego ustawodawstwa (rozwody, ochrona życia od poczęcia, kary śmierci), krytykę marksizmu, opisy zjawisk nadprzyrodzonych, przedstawiania Kościoła jako ostoi polskości. Szczególnie nadzorowano też teksty, w których pisano o martyrologii w krajach komunistycznych oraz dekrety i listy pasterskie prymasa Stefana Wyszyńskiego ${ }^{32}$. W cenzurze obowiązywała specjalizacja wewnętrzna, w której elitę zawodu tworzyli m.in. specjaliści od prasy katolickiej33.

${ }^{28}$ Zob. I. Pietrzkiewicz, M. Rogoż, Prewencyjne ingerencje cenzorskie...; M. Rogoż, „Tygodnik Powszechny”...

${ }^{29}$ J. Stefaniak, Polityka władz państwowych..., s. 37-45.

${ }^{30}$ Uwagi o penetracji wrogiej propagandy obcej $w$ dziedzinie prasy, publikacji $i$ widowisk; pismo z kwietnia 1948 r. CA KC PZPR, zespół PPR, Wydział propagandy, referat prasowy. Za J. Stefaniak, Prasa katolicka $w$ systemie...

${ }^{31}$ Zanim został wydany dekret cenzura działała od dwóch lat początkowo jako Wydział Cenzury w MBP, potem pod nazwą Centralnego Biura KPPiW, a od listopada 1945 r. już jako Główny Urząd KPPiW. Szerzej zob. Główny Urząd Kontroli Prasy 1945-1949, oprac. D. Nałęcz, Warszawa 1994.

${ }^{32}$ O. Nowicka, Cenzura wobec prasy $i$ wydawnictw katolickich $w$ Wielkopolsce $w$ latach 1945-1956. W: Władze wobec kościołów i związów wyznaniowych $w$ Wielkopolsce $w$ latach 1945-1956, pod red. K. Białeckiego, Poznań 2008, s. 176-179.

${ }^{33}$ Zabijanie stowa. O cenzurze w PRL, z A. Pawlickim, T. Strzemboszem i W. Władyką rozmawiali W. Buthak i B. Polak, „Biuletyn IPN” 2004 nr 2 s. 16-17. 
Wybrane do analizy tytuły katolickich czasopism społeczno-kulturalnych również podlegały kontroli cenzorskiej, jak zresztą cała prasa katolicka. Każde z pism traktowane było jednak nieco inaczej. Stosunkowo niewiele ingerencji cenzorskich do 1948 r. było w publikacjach „Tygodnika Powszechnego”, który oceniano nawet jako pismo o „charakterze spokojnym”34. Wyraźne zaostrzenie cenzury w latach 1949-1952 przyczyniło się do odmawiania prawa do druku wiadomościom mogącym sugerować prześladowanie Kościoła, publikacjom związanym z propagowaniem różnych form życia religijnego i ukazywaniem jego znaczenia, skreślano też wzmianki o masowych ruchach wyznaniowych oraz organizowanych uroczystościach religijnych czy miejscach kultu religijnego. Przykładowo w artykule ks. Lesława Jeżowskiego Najnowocześniejszy kościót na Górnym Śląsku („TP” $1952 \mathrm{nr} 18$ s. 3) skreślono fragmenty o robotnikach będących parafianami kościoła św. Józefa w Zabrzu ${ }^{35}$. Z kolei w wypowiedzi Liturgia na co dzień („TP” 1952 nr 17 s. 5-6) wyeliminowano zdania o kulcie Ciała Chrystusa i mszy św. ${ }^{36}$, zdjęto ponadto całą wypowiedź ks. Zbigniewa Bonawentury Fróga Koniec świata $w$ świetle objawienia $i$ nauki ${ }^{37}$. Chodziło bowiem ogólnie o negację instytucji kościelnych oraz walkę z pozytywnym wizerunkiem człowieka nawracającego się, wierzącego, kapłana czy świętego. Dlatego też nie pozwalano na ukazywanie autorytetu papieża oraz eliminowano teksty dotyczące procesów beatyfikacyjnych i kanonizacyjnych. Zastrzeżenia budziły również wypowiedzi religijne i odwołujące się do nauki katolickiej jako prawdy uniwersalnej. Myśli chrześcijańskiej zarzucano irracjonalizm i pesymizm oraz odwracanie uwagi od codziennego życia. Zapewne z tego powodu wycięto w całości wywody Gertrudy von le Fort zatytułowane Hymny do Kościoła („TP” 1952 nr 21) ${ }^{38}$. Bacznie czytano informacje o życiu wiernych, o czym może świadczyć znaczne uszczuplenie m.in. wiadomości z Kroniki religijnej („TP”1952 nr 17 s. 18) ${ }^{39}$. Nie dopuszczano też tekstów ukazujących kulturowe znaczenie zakonów oraz ich roli w rozwoju oświaty i nauki. „Szkodliwy wydźwięc” w opinii cenzorów miały artykuły, w których autorzy przedstawiali trwałość kultury chrześcijańskiej. Urzędnicy, nieprzygotowani do dialogu na tematy wiary, pewniej dokonywali skreśleń w tekstach literackich oraz recenzjach dotyczących literatury, filmu, muzyki lub dzieł sztuki. $\mathrm{Z}$ dużą pieczołowitością cenzurowano również artykuły historyczne. Tym ostatnim zarzucano przede wszystkim złą interpretację zrywów narodowych, gdyż nie były przedstawiane w kontekście walki klas. Szczególne emocje cenzorów budziły przyczyny upadku powstania warszawskiego. Oto też kilka innych przykładów.

\footnotetext{
${ }^{34}$ J. Stefaniak, Polityka władz..., s. 78.

35 Archiwum Akt Nowych [dalej AAN], Główny Urząd Kontroli Prasy, Publikacji i Widowisk [dalej GUKPPiW] 238 k. 45.

${ }^{36}$ Tamże, k. 50.

${ }^{37}$ Tamże, k. 53-54.

${ }^{38}$ Tamże, k. 76 sprawozdanie z kontroli prewencyjnej nr 5.

${ }^{39}$ Tamże, k. 55.
} 
W całości nie dopuszczono wypowiedzi Roberta Seeaighta na temat ówczesnej sytuacji politycznej na obszarze Ziemi Świętej. Autor pisał w niej: „Czuje się obecność niewidocznych patroli i ciśnienie nienawiści, rozładowujące się od czasu do czasu wystrzałem w ciemności. Wszystkie miejsca święte w Jerozolimie i w jej pobliżu są w rękach Arabów"40. Z kolei w artykule Jana Mariana Święcickiego zatytułowanym Między majestatem a wolnościa skreślono fragmenty dotyczące Konstytucji 3 maja $^{41}$. W publikacji Tadeusza Chrzanowskiego Piękne malarstwo w pięknych ksiązkach („TP” $1952 \mathrm{nr} 18$ s. 6) zamieniono określenie ,zamęt husycki” na „ruch husycki”, po czym wyeliminowano wstęp przedstawiający tło historyczne i polityczne wydarzeń. Cenzorzy nie pozwolili również na zamieszczenie stwierdzenia, że katolicyzm ochronił Czechy od protestantyzmu i idącą wraz z nim germanizacją ${ }^{42}$.

Uwagę urzędników cenzury w „Tygodniku Powszechnym” zwracały często recenzje i oceny książek oraz poruszane w nich kwestie obyczajowe, demograficzne oraz filozoficzne. Niekiedy sam tytuł pozycji wydawniczej budził zastrzeżenia i był wystarczającym powodem, aby go wyeliminować. Poniższe przykłady mogą to potwierdzić. Skreślono np. cytat J. M. Święcickiego uznany za typowy sposób „odbrązowywania” Wiktora Hugo z okazji 150-lecia jego urodzin. Publicysta przytoczył bowiem z książki biograficznej Tragiczny żywot Wiktora Hugo Leona Daudeta (,TP” 1952 nr 18 s. 12) wypowiedź wnuka pisarza o jego kochance, kurtyzanie Julii Duet, a także o nieudanym małżeństwie Wiktora Hugo - żona zdradzała go z „przyjacielem” rodziny Saint Beuve'em. Cenzor nie dopuścił również następującego fragmentu: „Trudno nie stwierdzić faktu, że pomiędzy życiem pisarza a głoszonymi przezeń ideami panował niestety niejednokrotnie głęboki rozdźwięk. Piewca węzłów rodzinnych, sympatyk wydziedziczonych, obrońca uwiedzionej kobiety, której tragedię umiał wymownie przedstawić, do późnej starości uwodził służące i znany był z tego, że dla nawiązania romansu zaczepiał samotne dziewczęta" ${ }^{43}$. Ze sporą ingerencją cenzora spotkał się także artykuł ks. Romualda Zaniewskiego zatytułowany Propozycje oryginalności i plagiatu o tematyce demograficznej, gdzie publicysta wspomniał o książce Roberta Malthusa Rozprawa o prawie ludności. Nie pomogło tu nawet powołanie się na wypowiedź Karola Marksa w Kapitale i w Nędzy filozofii, że jest to ,płytki plagiat, pamflet, obliczony na sensację, nie posiadający ani jednej myśli oryginalnej" ${ }^{44}$. Ingerencjom poddano także artykuł Filozofia dziejów ks. Konstantego Michalskiego („,TP” 1952 nr 19 s. 3), w którym w przypisach skreślono trzykrotnie tytuł książki Tomizm wobec współczesnej filozofii dziejów ${ }^{45}$. Z Kroniki religijnej wycięto natomiast informację

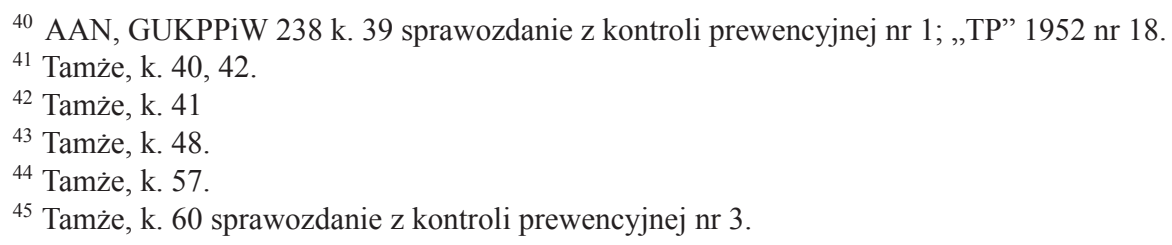


o ukazania się w Atenach nowego thumaczenia na grecki książki Joergensena poświęconej św. Franciszkowi z Asyżu ${ }^{46}$. W wypowiedzi Trudna książka, w której pisano o wydaniu pozycji Świętość Chrystusa o. Kosteckiego („,TP” 1952 nr 20 s. 4), podkreślono fragment wstępny: „Z góry już się przypuszcza, że będzie niestarannie wydana, na byle jakim papierze, no i oczywiście napisana fatalną polszczyzną, właściwie żargonem polsko-łacińskim ${ }^{47}$. Nie dopuszczono w ogóle do druku krytycznej recenzji socrealistycznej powieści Aleksandra Jackiewicza Penicylina (miała znaleść się w „TP” $1952 \mathrm{nr} 21$ ). Sławomir Błaut w niej zwrócił uwagę, że znany pisarz posłużył się metodą psychologicznej naiwności ${ }^{48}$. Szkodliwe społecznie wydało się także stwierdzenie Kisiela w rubryce Łopatą do głowy (nie dopuszczone w „TP” 1952 nr 20) dotyczące ulubionej książki z dzieciństwa pt. Sława Janusza Korczaka. Kisielewski wspominając powieść o kilku chłopcach, którzy chcieli „wyjść poza szablon i przeciętność” pisał: „Różne były koleje ich życia, różnie łamali się z trudnościami i przeszkodami, z oporem ciężarów, które pętały im skrzydła, w rezultacie osiągnęli to i owo - może nie tę sławę zdobyli, o której marzyli, wyskoczyli jednak ponad szarzyznę [...] Sława zaś jest tu w istocie synonimem wyjątkowości”49. Wyeliminowano także w całości krytyczną recenzję Nad powieścia polityczna z rubryki Wśród książek będącą omówieniem Pokolenia Bohdana Czeszki. Książka o młodych komunistach warszawskich wydana przez Czytelnika w 1951 r. i potwierdzona przez krytykę marksistowską nie mogła zostać źle oceniona w „Tygodniku Powszechnym”50.

Autorom tekstów zamieszczanych w „Głosie Katolickim”, zarzucano z kolei papizm, nacjonalizm, bojowość i atak na ZSRR. Cenzor zanotował przykładowo, że imię Ojca św. Piusa XII było wymieniane częściej niż imię Prezydenta Rzeczypospolitej ${ }^{51}$. Wymowa licznych artykułów miała też, według urzędników, propagować cuda i dyskredytować filozofię materialistyczną ${ }^{52}$. Spośród omawianych czasopism, współpracownicy „Tygodnika Warszawskiego” byli najbardziej prześladowani przez urząd cenzury jeszcze w latach 1947-1948, co wkrótce doprowadziło do całkowitego zamknięcia pisma. W lipcu 1946 r. „Tygodnik Katolicki” oceniony został nawet w jednej z notatek cenzorskich jako „pismo raczej pozytywne" ${ }^{53}$. Janusz Stefaniak odnotował natomiast liczne skreślenia w każdym z jego numerów, a od 1949 r. niemal w każdym artykule. Wśród powtarzających się motywów znalazły się m.in. oskarżenia o dywersję, atak na ustrój ko-

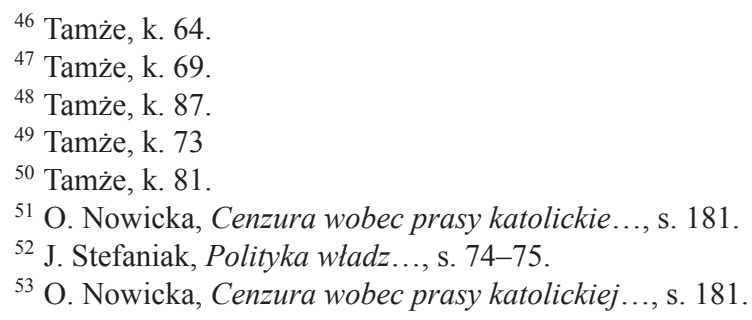


munistyczny, reakcyjną działalność kleru ${ }^{54}$. W końcu cenzor napisał: „Towarzysz Stalin nie jest towarzyszem dla reakcyjnego <<Tygodnika Katolickiego $>>{ }^{\prime 55}$. Ze względu na daleko idącą autocenzurę dobrze oceniano z reguły miesięcznik „Znak”. Stosunkowo dużo ingerencji było w „Przeglądzie Powszechnym”, w którym publikowano - zdaniem cenzorów - teksty szkodliwe i sprzeczne z interesem władzy. W latach 1950-1952 większości skreśleń nie umotywowano ${ }^{56}$.

Podobne noty cenzorskie znalazły się również w odniesieniu do innych pism zakonnych i diecezjalnych. Przykładem może być częstochowska „Niedziela”, włocławski „Ład Boży” czy katowicki „Gość Niedzielny”. W ostatnim z wymienionych cenzorzy dopatrzyli się walki z materializmem w propagowaniu czytelnictwa książek katolickich, głównie Pisma świętego i encyklik papieskich. Ostrzegano również przed szerzeniem kosmopolityzmu, który rozumiano jako informowanie odbiorców o powszechności chrześcijaństwa oraz o jego rozwoju, a także o związkach Kościoła z imperializmem. Zastrzeżenia budził też model rodziny i wychowania szerzony na łamach popularnych tygodników katolickich, który określano jako fanatyzm religijny ${ }^{57}$. Znaczne ingerencje w 1952 r. obecne były na łamach „Kółka Różańcowego”. Przykładowo w numerze piątym z tego roku wyeliminowano cały artykuł o Rajmundzie Kolbe (późniejszym świętym Maksymilianie Maria Kolbe $)^{58}$. Wolne od cenzury nie były także urzędowe pisma diecezjalne, m.in. „Rozporządzenia Urzędowe Łomżyńskiej Kurii Diecezjalnej”, „Kronika Diecezji Przemyskiej”, „Wiadomości Diecezji Łódzkiej” i in. ${ }^{59}$

Motywy ingerencji cenzorskich w latach 1948-1953, o ile je w ogóle podawano, były podobne. Często oskarżano autorów o wrogą propagandę wobec władzy i sugerowanie rzekomych prześladowań religijnych. Wypowiedzi cenzorów odznaczały się przy tym specyficznym językiem i stylem. Używano bowiem tzw. nowomowy i paszkwilanckiego dowcipu, co przyczyniło się do powstania swoistego żargonu. Efektem działań cenzury było powstanie swoistej autocenzury, którą stosowały redakcje i współpracownicy katolickich czasopism. Niektóre z tytułów prasowych, jak „Tygodnik Warszawski” i „Głos Katolicki” były wcześniej objęte ostrzejszym nadzorem jako wyjątkowo niewygodne dla władzy.

Oprócz ingerencji cenzorskich dużym utrudnieniem w wydawaniu prasy i książek było ograniczanie lub całkowity brak przydziału papieru oraz kontrolowany kolportaż. W niektórych przypadkach przyjmowano opłaty za prenumeratę bez dostarczania pisma lub odmawiano w urzędach pocztowych wpłat na indywidualną prenumeratę.

${ }^{54}$ J. Stefaniak, Polityka władz..., s. 25.

${ }^{55}$ AP w Poznaniu, Wojewódzki Urząd Kontroli Prasy, sygn. 214. Za J. Stefaniak, Polityka $w ł a d z \ldots$, s. 76.

${ }^{56}$ J. Stefaniak, Polityka władz..., s. 82-83.

${ }^{57}$ M. Trąba, Cenzorskie oceny tygodników katolickich ..., s. 381-385.

${ }^{58}$ AAN, GUKPPiW 238 k. 36.

${ }^{59}$ J. Stefaniak, Polityka władz..., s. 79-80. 


\subsection{Działalność i dorobek katolickich wydawnictw książkowych}

Dość ożywioną działalność wydawniczą w latach 1945-1948 prowadziły wydawnictwa katolickie. Wśród nich znalazły się oficyny kościelne, zakonne oraz zrzeszeń i instytucji. Przodowała poznańska Księgarnia św. Wojciecha (Albertinum) istniejąca od 1895 r. i posiadająca bogatą ofertę tekstów biblijnych, książek z zakresu teologii katolickiej i historii Kościoła oraz podręczników do nauki religii ${ }^{60}$. Do największych katolickich instytucji wydawniczych w latach 1945-1953 należały również: Wydawnictwo OO. Jezuitów w Warszawie i Apostolstwa Modlitwy w Krakowie ${ }^{61}$, Wydawnictwo Katolickiego Uniwersytetu Lubelskiego, Wydawnictwo Księży Pallotynów (Pallotinum) ${ }^{62}$ z siedzibami w Ołtarzewie i Poznaniu, Księgarnia św. Jacka w Katowicach ${ }^{63}$. Zajmujący czołowe miejsce pod względem liczby wydawanych pozycji powstały w $1949 \mathrm{r}$. Instytut Wydawniczy PAX przyczynił się do wzbogacenia katolickiego dorobku wydawniczego, mimo że jego założyciele i przedstawiciele działali w ramach instytucji prowadzącej wrogą politykę wobec kierownictwa Kościoła, zwłaszcza prymasa Wyszyńskiego.

Tabela 1. Produkcja Instytutu Wydawniczego PAX w latach 1949-1953

\begin{tabular}{|l|c|c|c|c|c|}
\hline \multicolumn{1}{|c|}{ Rok } & $\mathbf{1 9 4 9}$ & $\mathbf{1 9 5 0}$ & $\mathbf{1 9 5 1}$ & $\mathbf{1 9 5 2}$ & $\mathbf{1 9 5 3}$ \\
\hline Liczba wydanych książek & 2 & 10 & 21 & 29 & 40 \\
\hline Liczba wydanych książek z literatury pięknej & 1 & 4 & 8 & 16 & 21 \\
\hline
\end{tabular}

Źródło: A. Bromberg, Książki i wydawcy, Warszawa 1958, s. 68.

${ }^{60}$ P. Kitrasiewicz, Ł. Gołębiewski, Rynek książki w Polsce 1944-1989, Warszawa 2005, s. 24.

${ }^{61}$ Założone w 1872 r. i istniejące do dziś specjalizowało się w wydawaniu książek naukowych, katechizmów, modlitewników oraz literatury pięknej. Podtrzymując dawne tradycje starano się wydawać w nim Pismo święte. W 1946 r. ukazały się Lekcje i Ewangelie na niedziele i święta, w 1949 r. Nowy Testament, w 1950 r. Ewangelie i Dzieje Apostolskie, w 1951 r. Nowy Testament. Źródło: Wydawnictwo Apostolstwa Modlitwy 1872-1972, pod red. Z. Wilkosz i L. Grzebienia, Kraków 1972, s. 99.

${ }^{62}$ Powstało w 1908 r., w którym we Lwowie księża pallotyni zaczęli drukować czasopismo pt. „Królowa Apostołów”. Po pięcioletnim okresie zaczęto wydawać też książki. Ożywioną działalność oficyna prowadziła w latach dwudziestych i trzydziestych, którą przerwał wybuch II wojny światowej. W 1948 r. przeniesiono ją do Poznania i zmieniono nazwę na Pallotinum. Źródło: J. Frołow, Raport o książce katolickiej, Warszawa 2001 s. 97.

${ }^{63}$ Założona w 1925 r. jako Księgarnia i Drukarnia Katolicka. Po ustaniu działań wojennych reaktywowana została w 1946 r. Wydawane są w niej do dziś księgi liturgiczne (mszały), słowniki i podręczniki katechetyczne. Źródło: J. Frołow, Raport o książce..., s. 111. 
Ostatnia z wymienionych oficyn wydawała głównie współczesną literaturę piękną autorów polskich, m.in. Zofii Kossak-Szczuckiej, Jana Dobraczyńskiego, Antoniego Gołubiewa, Hanny Malewskiej. Z obcych przekładów znalazły się natomiast powieści Archibalda Josepha Cronina, Gilberta Keitha Chestertona, Sigrid Undset, Grahama Greene'a, Françoisa Mauriaca. W jej repertuarze znalazły się również prace naukowe z zakresu teologii i filozofii ${ }^{64}$.

Znaczącą produkcją książek religijnych wykazały się także: Wydawnictwo OO. Franciszkanów w Niepokalanowie, Wydawnictwo OO. Karmelitów Bosych w Krakowie (książki dotyczące duchowości chrześcijańskiej, głównie karmelitańskiej; żywoty świętych oraz tytuły z zakresu mariologii) ${ }^{65}$, Wydawnictwo Św. Krzyża w Opolu (pomoce duszpastersko-katechetyczne), Verbum i Księgarnia „Jedność” w Kielcach oraz Wydawnictwo Mariackie w Krakowie. Własne drukarnie posiadali salwatorianie $\mathrm{w}$ Trzebini koło Krakowa i siostry loretanki w Warszawie ${ }^{66}$.

W latach 1945-1947 w ogólnie szybkim wzroście produkcji wydawniczej przodowali wydawcy prywatni oraz wydawnictwa instytucji i organizacji religijnych. Rok 1947 zaznaczył się bowiem w porównaniu z rokiem 1945 sześciokrotnym wzrostem liczby opublikowanych książek religijnych oraz ponad dziesięciokrotnym zwiększeniem się ich nakładu ${ }^{67}$.

Tabela 2. Wydawcy w latach 1944-1947. Liczba książek

\begin{tabular}{|l|r|r|r|c|}
\hline \multicolumn{1}{|c|}{ Grupa wydawców } & $\mathbf{1 9 4 5}$ & $\mathbf{1 9 4 6}$ & $\mathbf{1 9 4 7}$ & $\begin{array}{c}\text { Liczba książek } \\
\text { ogólem }\end{array}$ \\
\hline Wydawcy prywatni & 380 & 1234 & 1338 & 2952 \\
\hline Instytucje i urzędy państwowe & 413 & 945 & 984 & 2342 \\
\hline Spółdzielnie & 212 & 552 & 568 & 1332 \\
\hline Stowarzyszenia, organizacje społeczne i związki & 210 & 550 & 544 & 1304 \\
\hline Instytucje i organizacje religijne & 55 & 247 & 402 & 704 \\
\hline Ogółem & $\mathbf{1 2 7 0}$ & $\mathbf{3 5 2 8}$ & $\mathbf{3 ~ 8 3 6}$ & $\mathbf{8 ~ 6 3 4}$ \\
\hline
\end{tabular}

Źródło: A. Bromberg, Książki i wydawcy, Warszawa 1966, s. 20, tab. 3.

Lata 1948-1950 charakteryzowały się rozszerzeniem produkcji książek w istniejących wydawnictwach społecznych oraz tworzeniem nowych wydawnictw państwowych. W 1948 r. działania szły w kierunku umasowienia książki, czego

${ }^{64}$ A. Bromberg, Książki i wydawcy, Warszawa 1958, s. 68.

${ }^{65}$ Istnieje od $1926 \mathrm{r}$.

${ }^{66}$ A. Bromberg, Ksiażki i wydawcy..., s. 67; J. Stefaniak, Polityka władz państwowych..., s. 31; P. Kitrasiewicz, Ł. Gołębiewski, Rynek książki..., s. 24.

${ }^{67}$ Tamże, s. 14. 
podjął się nowo założony Komitet Upowszechniania Książki. Rok 1950 kończy istnienie prywatnych oficyn, chociaż ,,agonia niektórych firm trwała jeszcze w latach pięćdziesiątych" ${ }^{68}$. Centralizacja ruchu wydawniczego nastąpiła po $1950 \mathrm{r}$.

W latach 1949-1953 funkcjonowała nadal część wydawnictw katolickich, pomimo znacznego ograniczenia ich działalności. Przykładowo - nakładem Księgarni św. Wojciecha wychodziło rocznie kilkanaście tytułów, które ukazywały się w seriach: Pisma Ojców Kościoła, Sprawy Biblijne, Starożytna Myśl Chrześcijańska, Teksty Pisma Świętego. W Pallotinum działającym od 1948 r. publikowano książki katolickie z zakresu teologii i filozofii w cyklach: Biblioteka Pomocy Seminaryjnych, Komentarz Pisma Świętego Starego Testamentu, Komentarz Pisma Świętego Nowego Testamentu. Z oficyną Ars Christiana powstałą w 1951 r. związana była natomiast seria Sztuka Sakralna w Polsce ${ }^{69}$.

Pierwsze trzy lata po wojnie charakteryzowały się dużym zróżnicowaniem wydawców prywatnych, spółdzielczych i państwowych. Ponadto można było zaobserwować szeroki zasięg czytelnictwa prasy i książek katolickich, dopóki nie zahamowały go restrykcje administracyjne, podjęte w latach pięćdziesiątych. Widoczny był również wzrost poziomu intelektualnego wydawanych czasopism i książek w porównaniu ze stanem przedwojennym ${ }^{70}$.

Kontrolę państwową nad ruchem wydawniczym pierwszych lat po II wojnie światowej sprawował Główny Urząd Kontroli Prasy, Publikacji i Widowisk ${ }^{71}$. Oprócz bezpośredniej cenzury druków prowadzono w nim rejestr wydawców dla celów ewidencyjnych. Ograniczenie dla wydawców przy jednoczesnej możliwości nadzoru stanowił przydział papieru przez Ministerstwo Informacji i Propagandy ${ }^{72}$.

\subsection{Typologia prasy katolickiej}

Prasa katolicka jako prasa specjalistyczna wymagała osobnej typologii, w której podstawowy podział mogły tworzyć periodyki według kryterium częstotliwości ukazywania się i przeznaczenia. Periodyczność stanowiła w historii czasopiśmiennictwa ważny element „masowości bądź elitarności odbioru” Utrwaloną pozycję w tradycji XX w. wśród czasopism społeczno-kulturalnych i literackich miał tygodnik. Liczebnie bowiem tygodniki górowały nad miesięcznikami, kwartalnikami i innymi periodykami o tym profilu. Drugim ważnym

${ }^{68}$ O.S. Czarnik, Między dwoma Sierpniami, Warszawa 1993 s. 204.

${ }^{69}$ P. Kitrasiewicz, Ł. Gołębiewski, Rynek ksiązki..., s. 55-56.

${ }^{70}$ J. Zabłocki, Prymas Stefan Wyszyński..., s. 40.

${ }^{71}$ Szerzej zob. Główny Urząd Kontroli Prasy 1945-1949...; O.S. Czarnik, Kultura literacka. W: Literatura polska 1918-1975..., s. 106-113.

${ }^{72}$ S.A. Kondek, Wtadza i wydawcy..., s. 87.

${ }^{73}$ A.Z. Makowiecki, Czasopiśmiennictwo literackie. W: Stownik literatury polskiej XX wieku, pod red A. Brodzkiej, Wrocław 1992, s. 136. 
elementem selekcji mógł stać się adresat. W przypadku pism katolickich wydawanych w latach 1945-1953 warto wskazać określone grupy społeczne, do których je kierowano: inteligencję („,Tygodnik Powszechny”), kapłanów („Ateneum Kapłańskie”, „Homo Dei”, „Przegląd Katechetyczny”, „Współczesna Ambona”), teologów („Ruch Biblijny i Liturgiczny”, „Collectanea Theologica”), rodziny („Ład Boży”, „Posłaniec Serca Jezusowego”, „Gość Niedzielny”), chorych („Apostolstwo Chorych”), lud („Rycerz Niepokalanej”, „Kółko Różańcowe”).

Te dwa kryteria zazwyczaj stosowano w spisach prasy katolickiej ukazujących się na łamach czasopism Kościoła ${ }^{74}$. Pod względem tematycznym periodyki miały charakter zróżnicowany. Obok poważnych pism teologicznych i naukowych („Homo Dei”), urzędowych pism diecezjalnych („Wiadomości Diecezjalne”), pism dewocyjnych („Róża Duchowna”) i związanych z organizacjami katolickimi („Caritas”), wydawano też pisma popularno-masowe („Rycerz Niepokalanej”) i społeczno-kulturalne („Tygodnik Warszawski”, „Głos Katolicki”) ${ }^{75}$. Po zakończeniu wojny starania o reaktywowanie tytułów katolickich istniejących przed wojną podjęły diecezje, zakony i organizacje katolickie. Dla omawianego okresu najbardziej właściwym kryterium typologii wydaje się być wydawca danego organu prasowego.

\subsubsection{Prasa kurii diecezjalnych, seminariów i zakonów}

Po zakończeniu działań wojennych większość administratorów diecezji wznowiło periodyki przeznaczone dla duchowieństwa, w treści których odnoszono się do życia duszpasterskiego i religijnego. Druki te o charakterze urzędowo-informacyjnym nosiły następujące tytuły: „Wiadomości Archidiecezji Warszawskiej” (1946-1953), „Wiadomości Diecezji Katowickiej” (1945-1947), „Zarządzenia Władzy Duchownej dla Archidiecezji Gnieźnieńskiej i Poznańskiej” (1945-1946) czy „Wiadomości Diecezji Lubelskiej” (1945-1953). Organem Administracji Apostolskiej Dolnego Śląska były „Wiadomości Kościelne” (1945-1952) ${ }^{76}$. Referat Duszpasterski Kurii Metropolitalnej w Poznaniu wydawał dostępny także w prenumeracie miesięcznik „Wiadomości Duszpasterskie” (1945-1952) ${ }^{77}$.

Znaczącą rolę w tej grupie odegrały periodyki społeczno-kulturalne wydawane przez poszczególne kurie diecezjalne. Przeznaczone dla inteligencji odznaczały się dobrą publicystyką i szerokim zakresem tematycznym. Za

${ }^{74}$ Np. Katolickie czasopisma wychodzace obecnie w Polsce, „GK” 1946 nr 8 s. 64; Nadestane czasopisma, „GK” $1950 \mathrm{nr} 10$ s. 79; Prasa katolicka, „TW” $1947 \mathrm{nr} 27$ s. 6; Wykaz prasy katolickiej, tamże, nr 43 s. 5.

${ }^{75}$ J. Łojek, J. Myśliński, W. Władyka, Dzieje prasy polskiej..., s. 170-171.

${ }^{76}$ Zob. zestawienie tabelaryczne Prasa katolicka $w$ poszczególnych diecezjach $w$ latach 1945-1953. W: J. Stefaniak, Polityka władz państwowych..., s. 213-220.

77 „GK” 1951 nr 7 s. 54. 
najważniejsze czasopismo ogólnopolskie tego typu uznano założony po wojnie „Tygodnik Powszechny” (1945-1953) Kurii Archidiecezjalnej w Krakowie. Wysiłkiem Administracji Apostolskiej w Gorzowie uzyskano prawo do wydawania "Tygodnika Katolickiego" (1946-1953). Przy tej okazji pisano: „Dziełu repolonizacji autochtonów, znanych z głębokiej religijności, oddałaby niepomiernie usługi religijna książka polska a nade wszystko prasa religijna, uwzględniająca równocześnie zagadnienia ogólnopolskie i regionalne warunki. Pismo takie pożądane bardzo również przez ludność świeżo osiadłą, przyczyniłoby się wybitnie do stworzenia atmosfery rodzimej”78. Do grupy czasopism diecezjalnych należał także „Głos Katolicki” (1945-1948) - organ Kurii Archidiecezji poznańskiej oraz wydawany we Włocławku „Ład Boży” (1945-1953), którego redaktorem w pierwszym okresie był późniejszy prymas Stefan Wyszyński.

W sprzyjającej jeszcze atmosferze pierwszych lat po wojnie udało się kontynuować niektóre z tytułów prasowych. Na początku 1945 r., już 11 lutego reaktywowano „Gościa Niedzielnego” (1945-1952) z podtytułem „Tygodnik dla rodzin katolickich”. Pismo wydawane było przez Kurię Diecezjalną w Katowicach, na jego łamach poruszano aktualne zagadnienia społeczne i religijne. Założone w 1923 r. przy poparciu ks. Augusta Hlonda miało charakter regionalny, a w jego zawartości oprócz wiadomości ze świata katolickiego podawano przede wszystkim bieżące wiadomości o życiu religijnym Śląska. Po wojnie redaktorem naczelnym został ks. Klemens Kosyrczyk. W latach 1952-1956 pismo zostało przejęte przez Stowarzyszenie PAX ${ }^{79}$.

Dużą popularnością głównie w środowiskach wiejskich cieszył się tygodnik „Niedziela” (1945-1953) wznowiony po II wojnie światowej w diecezji częstochowskiej. Pierwszy numer ukazał się 8 IV 1945 r. w Częstochowie z inicjatywy Zofii Kossak-Szczuckiej. Redaktorem naczelnym został ks. Antoni Marchewka, źle widziany przez władze za utrzymywanie kontaktów z działaczami Stronnictwa Pracy i podziemia. Kapłan ten został aresztowany, w latach 1947-1948 przebywał W więzieniu ${ }^{80}$. Pismo zamknięto 6 IV $1953 \mathrm{r}^{81}$

W Seminarium Duchownym we Włocławku kontynuowano natomiast wydawanie założonego w 1909 r. naukowego miesięcznika dla duchowieństwa „Ateneum Kapłańskie” (1946-1953). Funkcję redaktora naczelnego w latach 1946-1950 piastował ks. Stefan Biskupski ${ }^{82}$. Do pism ukazujących się nakładem seminariów należały także dwumiesięcznik poświęcony spawom kaznodziejstwa

${ }^{78}$ Ks. Administrator Ap. O prasie i książe katolickiej, „TK” 1948 nr 11 s. 102.

${ }^{79}$ Szerzej zob. A. Grajewski, Twój Gość, Katowice 2008, s. 45-89; 75 lat „Gościa Niedzielnego" 1923-1998, Katowice 1998.

${ }^{80}$ M. Trąba, Cenzorskie oceny tygodników..., s. 376.

${ }^{81}$ Reaktywowano je dopiero w $1981 \mathrm{r}$.

${ }^{82}$ „Ateneum Kapłańskie”. Czasopismo teologiczne założone w 1909 r. Dostępny w World Wide Web: http://web.diecezja.wloclawek.pl/Ateneum/o_nas.htm [dostęp 23.05.2012]. 
polskiego „Współczesna Ambona” (1946-1952) i miesięcznik „Msza Święta” (1946-1953), przeznaczony dla członków Towarzystwa Chrystusowego ${ }^{83}$.

Istotną rolę wśród zakonnych periodyków katolickich odegrał posiadający jeszcze XIX-wieczną tradycję jezuicki „Przegląd Powszechny” (1947-1953), który reaktywowano w $1947 \mathrm{r}^{84}$ Pismem wydawanym przez zakon był „Głos Karmelu" (1946-1952) oraz osobno wymieniany dodatek miesięczny dla rodzin „Pod Opieką św. Józefa” (1946-1952) adresowane do ludu; oba wychodziły w Wydawnictwie OO. Karmelitów Bosych. Księża dominikanie wydawali w Warszawie - „Różę Duchowną” (1947-1950), salwatorianie w Trzebini - pismo poświęcone zagadnieniom powołań kapłańskich - „Salwatora” (1947-1952), franciszkanie - „Rycerza Niepokalanej” (1945-1952), jezuici - „Przegląd Powszechny”, pallotyni w Poznaniu - „Królową Apostołów” (1947-1953). Siostry loretanki w Warszawie wydawały natomiast popularny miesięcznik zatytułowany „Kółko Różańcowe” (1946-1948). Najwięcej pism zakonnych ukazywało się w Krakowie ${ }^{85}$. Krakowskim tytułem prasowym były także „Wiadomości Straży Honorowej Najświętszego Serca Pana Jezusa" (1947-1950) ukazujące się nakładem oficyny sióstr wizytek.

Każda ze wspomnianych grup czasopism spełniała inną funkcję. Pierwsze z wymienionych, o charakterze urzędowym, służyły pomocą przede wszystkim duchowieństwu, zaś nieliczne periodyki seminaryjne przeznaczone dla kapłanów zawierały w swej treści rozważania teologiczne i z zakresu duchowości chrześcijańskiej. Najbardziej zróżnicowany charakter posiadały pisma zakonne. Wśród nich znalazły się zarówno te o wysokim poziomie adresowane do inteligencji, jak też popularne pisemka dewocyjne dla ludu. Część z tytułów prasowych Kościoła posiadała przedwojenne korzenie i tradycje. Wszystkie pisma służyły odrodzeniu życia religijnego i kulturalnego po trudnym czasie okupacji niemieckiej.

\subsubsection{Prasa katolickich towarzystw, spółdzielni wydawniczych i organizacji charytatywnych}

Osobną grupę tworzyły periodyki wydawane przez członków różnych organizacji, towarzystw i związków katolickich. Często powstawały one z inicjatywy katolików świeckich wespół z duchownymi. Najbardziej znaczącym przykładem czasopisma tego typu w omawianym okresie był „Tygodnik Warszawski” (1945-1948), wydawany przez Katolickie Towarzystwo Wydawnicze „Rodzina Polska" w Warszawie. Adresowany do inteligencji, przejawiał najbardziej

${ }^{83}$ J. Stefaniak, Polityka władz państwowych..., s. 33.

${ }^{84}$ Szerzej zob. M. Jagiełło, Trwałość i zmiana. Szkice o „Przegladzie Powszechnym” 1884-1918, Warszawa 1993.

${ }^{85}$ J. Stefaniak, Polityka władz państwowych..., s. 31. 
narodowy i „bojowy” charakter, przez co był ostro atakowany przez publicystów prasy rządowej. Na łamach stołecznego pisma reklamowano wydawany przez to samo towarzystwo „Przegląd Katechetyczny” (1946-1948) pod red. Bronisława Kuleszy. Dla inteligencji przeznaczony był także społeczno-kulturalny „Znak” (1946-1953), który pomimo podtytułu „miesięcznik” ukazywał się nieregularnie. Periodyk wydawała Spółdzielnia Wydawnicza „Znak” w Krakowie.

Niektóre periodyki skierowane do wąskiego kręgu odbiorców posiadały charakter naukowy. $Z$ inicjatywy Polskiego Towarzystwa Teologicznego w Krakowie zaczął wychodzić dwumiesięcznik „,Ruch Biblijny i Liturgiczny” (1948-1953) redagowany przez ks. Aleksego Klawka ${ }^{86}$. Na jego łamach rozważano kwestie z zakresu egzegezy biblijnej, mariologii oraz dotyczące mszy świętej. Kwartalnikiem Akademii Teologii Katolickiej w Krakowie był „Przegląd Teologiczny” znany także pod tytułem „Collectanea Theologica” (1945-1953), w którym autorzy starali się ujmować zagadnienia teologiczne w kontekście osiągnięć filozofii i nauk współczesnych ${ }^{87}$.

Drugim prężnym ośrodkiem czasopiśmiennictwa naukowego był Lublin, gdzie działał Katolicki Uniwersytet Lubelski. Pod jego szyldem ukazywały się czasopisma poświęcone teologii, biblistyce, prawu kościelnemu, historii Kościoła i liturgice. Warto wymienić w tym miejscu „Roczniki Humanistyczne” (1949-1953), „Roczniki Teologiczno-Kanoniczne” (1948-1949) oraz „Roczniki Teologiczne Lubelskie" (1947).

Przykładem pisma katolickiej akcji charytatywnej przeznaczonym dla duszpasterzy i parafian był miesięcznik „Caritas” (1945-1953) - organ Krajowej Centrali Caritas w Krakowie ${ }^{88}$. Popularnym czasopismem krakowskim docierającym co miesiąc do określonego grona odbiorców było „Apostolstwo Chorych” (1946-1953), będące z kolei inicjatywą Polskiego Sekretariatu Apostolstwa Chorych. Redagował je ks. Michał Rękas.

Wymienione powyżej pisma znacznie różniły się między sobą. Były wśród nich tytuły elitarne, przeznaczone dla inteligencji świeckiej i stanu kapłańskiego, jak też naukowe oraz popularne dla ludu.

\subsubsection{Krąg prasy Stowarzyszenia PAX}

W spisach prasy katolickiej publikowanych w pismach Kościoła pomijano tygodnik społeczno-kulturalny „Dziś i Jutro”, założony 25 XI 1945 r. przez grupę Bolesława Piaseckiego. Grono skupione wokół pisma stało się zalążkiem

\footnotetext{
${ }^{86}$ Czasopisma religijne. Ruch Biblijny i Liturgiczny, „TP” 1950 nr 9 s. 5; „Ruch Biblijny i Liturgiczny”, „TP” 1949 nr 32 s. 5; Życie katolickie, „TW” 1948 nr 14 s. 6.

${ }^{87}$ N.K., Collectanea Theologica, „TP” $1950 \mathrm{nr} 6$ s. 11.

${ }^{88}$ Z nowości wydawniczych, „GK” 1945 nr 30 s. 8.
} 
powstałego w 1947 r. Instytutu Wydawniczego PAX. Inicjatywę wydawniczą poparł Jerzy Borejsza. W stopce redakcyjnej tygodnika jako redaktor naczelny figurował Witold Bieńkowski, współpracownikami byli m.in. Jan Dobraczyński, Dominik Horodyński, Konstanty Łubieński i Wojciech Żukrowski. Od początku zespół redakcyjny opowiedział się za uznaniem nowego systemu ustrojowego. Określając siebie mianem katolików „postępowych”, programowo dążono do zbliżenia katolicyzmu z marksizmem, głoszono konieczność pełnej współpracy z władzami państwowymi i starano się niwelować opozycyjne postawy w środowiskach kościelnych. Dano temu wyraz w Liście otwartym do Pana Józefa Łady zamieszczonym na łamach „Dziś i Jutro” w 1948 r. w przeddzień Kongresu Zjednoczeniowego PPR i PPS. Tygodnik nie uzyskał oficjalnej aprobaty przedstawicieli Episkopatu i nie otrzymał tym samym asystenta kościelnego. Spotkał się również z dezaprobatą wśród inteligencji katolickiej ${ }^{89}$. W 1953 r. „Dziś i Jutro” przejęło Stowarzyszenie $\mathrm{PAX}^{90}$.

Drugim periodykiem wydawanym przez osoby wywodzące się z tego środowiska był dziennik ,Słowo Powszechne”, którego pierwszy numer ukazał się w marcu 1947 r. pod redakcją Wojciecha Kętrzyńskiego. Wydawcą był już Instytut Wydawniczy PAX powstały z przekształconego zespołu skupionego wokół „Dziś i Jutro". Założenie gazety wywołało otwarty konflikt z hierarchią kościelną. Zjazd redaktorów prasy katolickiej w Częstochowie we wrześniu 1947 r. odmówił prasie paksowskiej przymiotnika katolickiej ${ }^{11}$.

Oba pisma nie były zatem brane pod uwagę w wykazach prasy katolickiej. Wobec protestów paksowskich redakcji ustosunkowywano się do problemu, analizując publikowane przez poszczególne periodyki katolickie treści. Na łamach „Tygodnika Warszawskiego" pisano: „[...] wiadomo, że pismo tylko wtedy może się nazwać katolickim, gdy wychodzi z upoważnienia i za zezwoleniem kompetentnej władzy duchownej. Ani $<<$ Dziś i Jutro $>>$ ani $<<$ Słowo Powszechne $>>$ takiej zgody swojego biskupa nie posiada, czemu dało niejednokrotnie wyraz w swoich oficjalnych oświadczeniach"92. Redakcja „Tygodnika Powszechnego" na list otwarty do Jerzego Brauna opublikowany w „Dziś i Jutro”, w którym W. Kętrzyński protestował przeciwko nieumieszczeniu obu pism w spisie prasy

${ }^{89}$ J. Łojek, J. Myśliński, W. Władyka, Dzieje prasy polskiej..., s. 171; A.Z. Makowiecki, „Dziś i Jutro”. W: Stownik literatury polskiej XX wieku, pod red. A. Brodzkiej i in., Wrocław 1992, s. 233-234; L. Szaruga, Co czytamy?..., s. 31-32; J. Wiszniewski, Z historii prasy katolickiej w Polsce. Tygodnik Warszawski 1945-1948, Kraków 1998, s. 29-35.

${ }^{90}$ W 1955 r. „Dziś i Jutro” znalazło się na indeksie kościelnym, a w 1956 r. po połączeniu z „Tygodnikiem Powszechnym” wydawanym przez PAX zaczęło ukazywać się pod nowym tytułem - „Kierunki”. Źródło: A.Z. Makowiecki, „Dziś i Jutro”...

${ }^{91}$ J. Stefaniak, Polityka władz państwowych..., s. 36; Z. Zieliński, Kościót w Polsce $1944-2002 \ldots$, s. $77-78$.

92 J. Braun, Oświadczenie w sprawie „Dziś i Jutro”, „TW” 1947 nr 38 s. 3; mr., W sprawie spisu prasy katolickiej, „GK” 1947 nr 33 s. 278; W sprawie prasy katolickiej, „TW” 1947 nr 34 s. 8. 
katolickiej, odpowiedziała: „uważamy, że żadne pismo nie może przez wypowiadanie swoich poglądów dawać pozorów, że wyraża oficjalną myśl katolicką"93. Takie samo orzeczenie wydrukowano również w „Głosie Katolickim”94. Z okazji dwuletniej rocznicy działalności publicystycznej na łamach tegoż „Głosu” skonstatowano: „,< $<$ Dziś i Jutro $>>$ zamieścił w jubileuszowym numerze deklarację ideową i programową. Czytaliśmy ją kilkakrotnie, ale w żaden sposób nie udało się nam wymiarkować, o co w niej autorom właściwie chodzi. [...] Może któryś z czytelników rozwikła splątane w tejże deklaracji słowa i odsłoni właściwą jej treść? Chętnie wynagrodzimy ten trud jakimś honorarium”95. W „Znaku” Stefan Kisielewski stwierdził natomiast:,,$<<$ Dziś i Jutro $>>-$ według jednych enfant terrible i koń trojański w obozie katolickim, dla innych awangarda młodego, społecznie radykalnego katolicyzmu"96. Ten sam publicysta w innym miejscu pisał także: „pismo i zgrupowany wokół niego zespół młodych działaczy katolickich zajmuje w naszym życiu politycznym miejsce bardzo specjalne i w swoim rodzaju - jedyne [...] katolicyzm <<Dziś i Jutra $>>$ jest tylko przykrywką dla właściwych, politycznych jego celów"97.

Osoby skupione początkowo wokół „Dziś i Jutro”, a następnie przynależące do Stowarzyszenia PAX przyczyniły się w dużej mierze do rozbicia spójności środowiska inteligencji katolickiej. Treści obecne w zawartości prasy paksowskiej nie były też zgodne ze społeczną nauką Kościoła. Charakter tej grupy periodyków należałoby określić jako pseudokatolickie.

\subsection{Charakterystyka katolickich czasopism społeczno- kulturalnych}

\subsection{1. „Tygodnik Powszechny” (1945-1953)}

Pismo zarejestrowała Bibliografia katolickich czasopism religijnych $w$ Polsce 1945-1989 Danuty Wielgat ${ }^{98}$. Na pierwszej stronie nowego periodyku widniały słowa błogosławieństwa księcia metropolity krakowskiego Adama Stefana Sapiehy, który wyraził ufność, że „myśl katolicka znajdzie w nim godny wyraz” w przełomowych czasach powojennych ${ }^{99}$. W „Oświadczeniu Wydawnictwa” na

${ }^{93}$ W sprawie „Dziś i Jutro”, „TP” 1947 nr 38 s. 4.

${ }^{94}$ W sprawie „Dziś i Jutro”, „GK” 1947 nr 39 s. 326.

${ }^{95}$ Niejasne „Dziś i Jutro”, „GK” 1947 nr 50 s. 410.

${ }^{96}$ S. Kisielewski, Geografia czasopism w Polsce, „Znak” 1946 nr 1 s. 127.

${ }^{97}$ Tenże, ,,Dziś i Jutro”, „TW” 1946 nr 25 s. 3.

${ }^{98}$ D. Wielgat, Bibliografia katolickich czasopism religijnych $w$ Polsce 1945-1989, Lublin 1996, s. 91.

99 „TP” 1945 nr 1 s. 1. 
ostatniej stronie pierwszego numeru czytamy natomiast, że tygodnik powstał na życzenie świeckiej inteligencji Krakowa, pragnącej „pisma katolickiego, otwartego dla szerokich zainteresowań kulturalnych". Dalej pisano, że jako periodyk katolicki, apolityczny i bezpartyjny będzie utrwalać „katolicką Prawdę w sprawach społeczno-kulturalnych”100. Od początku „Tygodnik Powszechny” zyskał opinię najważniejszego katolickiego organu prasowego, którą podzielali zarówno przedstawiciele inteligencji katolickiej jak i władzy państwowej ${ }^{101}$. Ogólnopolskie pismo społeczno-kulturalne doczekało się wielu opracowań. Wśród nich znalazły się pozycje książkowe o charakterze monograficznym, biograficznym, wspomnieniowym i publicystycznym ${ }^{102}$, jak też omówienia drobniejsze w postaci artykułów ${ }^{103}$. Czasopismo pozostaje nadal w kręgu zainteresowań prasoznawczych ${ }^{104}$.

${ }^{100}$ Oświadczenie Wydawnictwa, „TP” 1945 nr 1 s. 4.

${ }^{101}$ Zob. szerzej: M. Strzelecka, Powstanie „, Tygodnika Powszechnego” i jego rola w powojennej prasie katolickiej (1945-1953). W: W kręgu prasy (przeszłość-teraźniejszość-przyszłość), pod red. G. Gzelli i J. Gzelli, Toruń 2001, t. 2, s. 103-111.

102 A. Bardecki, Zawsze jest inaczej, Kraków 1995; Bo jestem z Wilna..., z Józefą Hennelowa rozmawia Roman Graczyk, Kraków 2001; M. Jagiełł, Próba rozmowy: szkice o katolicyzmie odrodzeniowym i „Tygodniku Powszechnym” 1945-1953, t. 1: Rodowód, t. 2: „Tygodnik Powszechny” i komunizm 1945-1953, Warszawa 2001; R. Jarocki, Czterdzieści pięć lat w opozycji: (o ludziach „Tygodnika Powszechnego”), Kraków 1990; K. Koźniewski, Historia co tydzień. Szkice o tygodnikach spoleczno-kulturalnych 1944-1950, Warszawa 1977, s. 351-413; J.R. Nowak, Obludnik powszechny, Warszawa 2002; M. Strzelecka, Trudne kompromisy. Środowisko „Tygodnika Powszechnego" wobec reform systemu oświaty $i$ wychowania w latach 1945-1989, Toruń 2009; J. Żakowski, Pót wieku pod włos czyli życie codzienne „, Tygodnika Powszechnego” w czasach heroicznych, Kraków 1999.

${ }^{103}$ C. Kuta, Jak bezpieka rozbijała „,Tygodnik Powszechny”, „Gazeta Polska” 2006 nr 24 s. 14-15; T. Kornaś, Nie tylko „,Tygodnik Powszechny”, „Najwyższy Czas!” 2008 nr 4 s. 18; D. Patkaniowska, „Tygodnik Powszechny”. W: Stownik literatury polskiej..., s. 1139-1145; M. Strzelecka, Powstanie „, Tygodnika Powszechnego” i jego rola....

${ }^{104}$ Np. R. Graczyk, Cena przetrwania?...; E. Kristanova, Książka na łamach krakowskiego „Tygodnika Powszechnego” (1945-1953) w świetle reklamy wydawniczej. W: Kраків - Львів: книги, часописи, бібліотеки XIX-XX cm., t. 10, ред. Г. Врона, О. Колосовська, Г. Косентка, Львів 2011, s. 332-345; taż, Książka na łamach krakowskiego „Tygodnika Powszechnego” (1945-1953) w świetle reklamy wydawniczej. W: Kraków-Lwów. Książki, czasopisma, biblioteki XIX i XX wieku, t. 10, pod red. H. Kosętki, Kraków 2011, s. 303-317; taż, Literatura na tamach „,Tygodnika Powszechnego” w latach 1945-1953, ,, Rocznik Historii Prasy Polskiej” 2012 $\mathrm{nr} 2$; taż, Problematyka stosunków Kościót katolicki - państwo komunistyczne w publicystyce „Tygodnika Powszechnego” (1945-1953). W: Nie po myśli władzy. Studia nad cenzura i zakresem wolności słowa na ziemiach polskich od wieku XIX do czasów wspótczesnych, pod red. D. Degen i M. Żyndy, Toruń 2012, s. 180-196; M. Rogoż, ,,Tygodnik Powszechny” w 1949 r. I. Pietrzkiewicz, M. Rogoż, Prewencyjne ingerencje cenzorskie...; [notatka redakcji o zamknięciu pisma w 1953 r.], „,TP” 1956 nr 1 s. 1; W. Sonczyk, Media i dziennikarstwo w opinii , Tygodnika Powszechnego” (w kontekście obrad Okrąłego Stołu), „Rocznik Historii Prasy Polskiej” 2008 nr 1/2 s. 151-174. 


\section{Środowisko „Tygodnika Powszechnego”}

Periodyk powstał na mocy decyzji kardynała Adama Sapiehy, który w początkowym trudnym okresie pracy szczególnie wspierał członków redakcji ${ }^{105}$. Dzięki autorytetowi, którym cieszył się ten dostojnik Kościoła, pismo uzyskało odpowiednią rangę. Redakcję tworzyli początkowo: ks. Jan Piwowarczyk (posiadający decydujący głos do 1951 r.), Jerzy Turowicz (kolejny długoletni redaktor naczelny), przez krótki czas Konstanty Turowski oraz Maria Czapska ${ }^{106}$. W stopce redakcyjnej widniał natomiast anonimowy „Komitet”. Nazwisko Jerzego Turowicza jako redaktora pisma wydrukowano po raz pierwszy w numerze 30 z 14 października 1945 r. ${ }^{107}$

Łamy pisma udostępniano zarówno osobom świeckim, jak i duchownym. Zasilały je najznakomitsze pióra znawców i specjalistów: teologów, filozofów, historyków, krytyków, poetów i in. Z pomocą przyszli również pracownicy uniwersytetów i literaci. W pierwszych latach redakcję wspierał Stanisław Kutrzeba; jego śmierć była bolesnym ciosem dla zespołu ${ }^{108}$. Opiekunem pisma z ramienia ks. kardynała A. Sapiehy był natomiast ks. Stefan Mazanek. Tak o nim pisał ks. J. Piwowarczyk: ,[...] zorganizował nasze pismo, wchodząc w szczegóły pracy redakcyjnej i administracyjnej. Kierował nim prawie aż do samej śmierci. Znał nasze zamiary i projekty, wczuwał się w trudności i radził. Bez Jego pracy, bez Jego rad, zaleceń i ojcowskiej opieki $<<$ Tygodnik Powszechny >> nie byłby tym, czym jest"109.

Grono współpracowników pisma było bardzo liczne. Stałymi współpracownikami w latach 1945-1953 byli: historyk Antoni Gołubiew, znakomity felietonista Stefan Kisielewski, jeden z najlepszych polskich publicystów politycznych Paweł Jasienica (do aresztowania w 1948 r.), Zygmunt Kubiak, Hanna Malewska, Maria Morstin-Górska, Zofia Starowieyska-Morstinowa, Jacek Woźniakowski, Leopold Tyrmand, Jerzy Zawieyski i in. Na jego łamach swoje poglądy często wyrażali: Józef Marian Święcicki, Michał Strebejko, Edmund Osmańczyk, Stefan Świeżawski, Artur Górski. Problematykę literacką poruszali Juliusz Kleiner, Maria Morstin-Górska, Zofia Starowieyska-Morstinowa, Konrad Górski, Czesław Zgorzelski, Gustaw Morcinek, Stanisław Pigoń, Maria Winowska, Wacław Borowy. Antoni Gołubiew wypowiadał się o kulturze chrześcijańskiej i literaturze. Rzadziej swoje opinie przedstawiali: Wojciech Kętrzyński, Kazimierz Koźniewski, Stefan Kieniewicz, Władysław Tatarkiewicz, Mieczysław Kotlarczyk, Jerzy Zawieyski, Zygmunt Kubiak, Roman Ingarden.

105 J. Piwowarczyk, Nasza pozycja, „TP” 1947 nr 7 s. 1.

${ }^{106}$ M. Strzelecka, Powstanie ,, Tygodnika Powszechnego” i jego rola..., s. 113.

${ }^{107}$ Kalendarium historii „Tygodnika Powszechnego”. Dostpny w World Wide Web http:// www.tygodnik.com.pl/redakcja/kalendarium/45-55.html [dostęp 27. 10. 2010].

${ }_{108}$ J. Piwowarczyk, Nasza pozycja ...

109 Tenże, Śp. ks. Stefan Mazanek, „TP” 1950 nr 8 s. 3. 
Pisali również liczni duchowni: Andrzej Bardecki, Herbert Bednorz, Franciszek Blachnicki, Eugeniusz Chomrański, Aleksy Klawek (redaktor naczelny „Ruchu Biblijnego i Liturgicznego”), Bolesław Kominek, Ferdynand Machay, Konstanty Michalski, Michał Rękas, Antoni Słomkowski, Karol Wojtyła ${ }^{110}$, Jacek Woroniecki, Stefan Wyszyński. Pojawiły się też artykuły Karola Pękali. Redakcja zadbała jednocześnie, aby w kręgu piszących znalazły się najwybitniejsze obce nazwiska znane w środowiskach katolickich. Zaproszono do współpracy m.in. Jacquesa Maritaina, Gilberta Keitha Chestertona, Daniela-Ropsa, Giovanniego Papiniego, Michela Carrouges, Otto Forst Bataglię, Romano Guardiniego, Etienne Gilsona, Grahama Greene'a. Na łamach periodyku drukowano też artykuły Raissy Maritain ${ }^{111}$, fragmenty wypowiedzi Simone Weil, a także znanego krytyka literackiego Bertranda de Jouvenel. Ukazało się też wiele wypowiedzi anonimowych. Redakcja płaciła autorom honoraria ${ }^{112}$.

Środowisko „Tygodnika Powszechnego”, będące jednym z trzech najważniejszych obok grupy skupionej wokół „Tygodnika Warszawskiego” oraz „Dziś i Jutro", przyjęło postawę gotowości angażowania się w odbudowę ładu społecznego Polski. Poszukiwano możliwości oddziaływania na nową rzeczywistość powojenną i starano się „robić to, co da się zrobić”"113. Kompromis z komunistami stał się zatem nieunikniony. Pytanie dotyczyło głównie stopnia tego kompromisu przy jednoczesnym zachowaniu tożsamości ideowej i kulturowej. Unikano ostrych konfrontacji poglądów, aby móc realizować zadania dalekosiężne. Przyjęto postawę otwartą i aktywną ${ }^{114}$, a jednocześnie ostrożną. Ugoda z nową władzą ukształtowała się pomiędzy poparciem Apelu Sztokholmskiego w 1950 r. a odmową wydrukowania nekrologu dyktatora Józefa Stalina w 1953 roku.

\section{Założenia programowe}

Wstępny artykuł programowy na otwarcie pierwszego numeru przedstawił redaktor naczelny ks. Jan Piwowarczyk. Wywód rozpoczął od trafnego stwierdzenia, że „Polska musi ulec przebudowie”, w której Kościół i katolicyzm miały odegrać „szczególnie ważną rolę” ${ }^{115}$. Jako główne zadanie jawiło się stworzenie „,nowego typu kultury” i „wychowanie nowego człowieka”. Artur Górski podjął

${ }^{110}$ Pierwszą wypowiedzią jego autorstwa na łamach „Tygodnika Powszechnego” był artykuł zatytułowany Mission de France, „TP” 1949 nr 9 s. 1-2.

111 Żona znanego filozofa pisała m.in. o poezji [„,TP” $1953 \mathrm{nr} 8$ s. 5] oraz o drodze nawrócenia jej męża [„,TP” 1950 nr 11 s. 5-6, 11].

${ }^{112}$ Honoraria autorskie, „TP” $1948 \mathrm{nr} 1$ s. 10.

${ }^{113}$ Przemówienie Krzysztofa Kozłowskiego na zebraniu redakcji na 30-lecie „Tygodnika Powszechnego”. W: A. Bardecki, Zawsze jest inaczej, Kraków 1995, s. 167.

${ }^{114}$ M. Strzelecka, Trudne kompromisy..., s. 16, 18.

115 J. Piwowarczyk, Ku katolickiej Polsce, „TP” 1945 nr 1 s. 1. 
w związku z tym temat odnowy w kulturze ${ }^{116}$. Po dwóch latach redaktor pisma potwierdził program „Tygodnika Powszechnego”, konstatując, że mając świadomość czasu przełomu i kryzysu, w którym ,jedna epoka się już skończyła, a druga jeszcze nie zaczęła", przyjęto personalistyczny pogląd na świat.

Czasopismo skierowane było do inteligencji, o czym wyraźnie dowiadujemy się z oświadczenia redakcji: ,puszczamy w świat pierwszy numer z nadzieją, że znajdzie poparcie w katolickich kołach naszych warstw wykształconych" ${ }^{117}$. Dalej zaś czytamy: „Przystąpiliśmy do wydawania <<Tygodnika Powszechnego $>>$ na skutek wyrażanych często przez świecką inteligencję Krakowa życzeń założenia pisma katolickiego, otwartego dla szerokich zainteresowań kulturalnych" ${ }^{118}$. Będąc początkowo periodykiem regionalnym i krakowskim, szybko stał się ogólnopolskim. W setnym numerze ks. J. Piwowarczyk pochwalił się: „Dziś nie ma w Polsce ważniejszej miejscowości, gdzie by $<<$ Tygodnik Powszechny $>>$ nie był czytany i dyskutowany" 119 .

Określono również jego charakter, zapowiadając, że „będzie pismem apolitycznym i bezpartyjnym”. Potwierdzono to później, pisząc: , $<<$ Tygodnik $>>$ nie posiada jakiegoś wyraźnego programu politycznego, nie rządzi się jakimiś instrukcjami czy wytycznymi. Łamy pisma są otwarte dla wszystkich publicystów katolickich bez względu na ich przekonania polityczne, jeśli tylko poglądy ich dadzą się pogodzić z ortodoksją katolicką" ${ }^{120}$. W setnym numerze dowiadujemy się, że: „Wolą założyciela pisma było, by <<Tygodnik Powszechny >> był pismem katolickim o szerokiej sferze zainteresowań, by stojąc na gruncie prawdziwie katolickim i uświadamiając rzesze czytelników w sprawach religii, równocześnie obejmował swoimi zainteresowaniami wszystkie sfery twórczości i zaspokajał potrzeby duchowe współczesnego człowieka z wszystkich możliwie dziedzin"121. Nie ograniczano zatem żadnej problematyki na jego łamach.

Apelowano również do czytelników o zawiązanie współpracy i udzielanie rad w udoskonalaniu periodyku, jak również pomoc w jego rozpowszechnianiu. Po roku, podsumowując pracę redakcji i operując cytatami z „Kuźnicy” i „Wsi”, dokonano żartobliwej samooceny, ośmieszając przy okazji prasowe oceny partyjnych organów. Pisano: „Społeczeństwo polskie orientuje się doskonale w istotnych zamiarach tego pisma, które pod płaszczykiem szerzenia kultury opartej na światopoglądzie katolickim służy celom całkiem odmiennym. Na szczęście cnotliwa mina tego organu nikogo nie myli"'122. Jan Piess kontynuował w dalszym wywodzie: „Pod płaszczykiem artykułów niby na tematy religijne, literackie

\footnotetext{
${ }^{116}$ A. Górski, O odnowie w kulturze, „TP” 1945 nr 1 s. 2.

${ }^{117}$ Wydawcy, Oświadczenie wydawnictwa, „TP” 1945 nr 1 s. 4.

118 Tamże.

119 J. Piwowarczyk, Nasza pozycja...

${ }^{120}$ Tamże.

${ }^{121}$ Tamże.

122 J. Piess, Wśród czasopism. Tygodnik Powszechny, „TP” 1946 nr 13 s. 8.
} 
i społeczne prowadzi się $\mathrm{w}<<$ Tygodniku Powszechnym>> ukrytą robotę pozbawienia ludzkości jej zdobyczy, wydartych klerowi [...] chce wrócić do ciemnoty i obskurantyzmu średniowiecza [...] broniąc nierozerwalności małżeństwa, dąży tą drogą do demoralizacji społeczeństwa i rodziny [...] Z pismem tym nie sposób prowadzić jakiejś zasadniczej polemiki [...] Na szczęście pismo to nie ma żadnego oddźwięku w społeczeństwie"123.

Wydanie setnego numeru stało się również okazją do przedstawienia dokonań redakcji. Jak donosił ks. Piwowarczyk, dotychczasowy „okres prób, trudności, doświadczeń i zwycięstw” był też czasem utrwalenia pozycji pisma i jego wpływu na opinię publiczną. Zauważył też wyraźny jego „rozwój pod względem objętości, treści i zasięgu czytelników”124. Jak stwierdził, nawet „zdecydowani przeciwnicy” musieli uznać jego „mocne stanowisko” w polskiej prasie. Pisał jednocześnie: „Prawem czytelników i opinii jest przy tej okazji sądzić nasze dzieło. Prawem redakcji uwypuklić jego ideową pozycję. Krytyka czytelników przyczyni się do usunięcia braków i podniesienia wartości pisma" ${ }^{25}$. Pierwszymi krytykami tygodnika ogłosili się samozwańczo marksiści, którzy ocenili je surowo jako „wsteczne i reakcyjne” oraz „oderwane od rzeczywistości”. Twierdzili przy tym, że redakcja dostarczała czytelnikom „materiał pozbawiony wszelkiej naukowej wartości, świadomie wyczyszczony z konkretu i nie posiadający należytej historycznej czy geograficznej podbudowy"126.

Rok 1950 stanowi wyraźną cezuręw redagowaniu „Tygodnika Powszechnego”. Odtąd bowiem na łamach prasy nie można było już jawnie wygłaszać poglądów sprzecznych z ideologią marksistowską. W „Tygodniku” zmiany widoczne były chociażby w rubryce $Z$ dnia. Pojawiło się w niej więcej informacji o sytuacji kulturalnej, nagrodach stalinowskich przyznawanych $\mathrm{w}$ różnych dziedzinach, o wykonaniu narodowego planu gospodarczego i ukazaniu się życiorysu Lenina czy odsłonięciu w rocznicę jego zgonu tablicy pamiątkowej w Krakowie ${ }^{127}$. Dość często w 1950 r. pisano o apelu Komitetu Światowego Kongresu Obrońców Pokoju oraz liczbie złożonych podpisów pod Apelem Sztokholmskim ${ }^{128}$, jak też zakazie broni atomowej ${ }^{129}$. Najlepiej można zobrazować to następującym cytatem: „W wielkiej dyskusji na tematy językoznawstwa, toczącej się na łamach prasy radzieckiej, zabrał głos Józef Stalin wskazując na marksistowskie ujęcie problemów językoznawstwa i poddając surowej krytyce ujęcia pseudomarksistowskie. Artykuł Józefa Stalina pt. $<<\mathrm{W}$ sprawie marksizmu w językoznawstwie $>>$, przedrukowany w przekładzie polskim przez całą polską prasę codzienną, jest ważkim

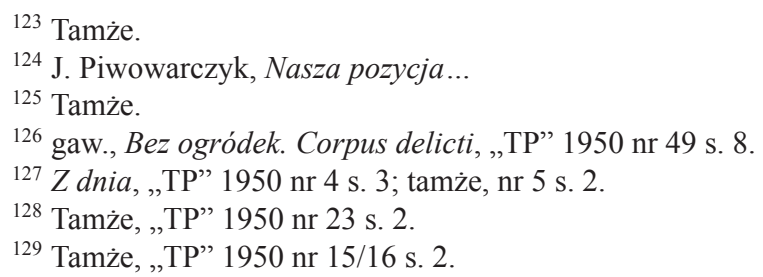


wydarzeniem w życiu umysłowym"130. Temu zagadnieniu zupełnie na poważnie poświęcono też osobną wypowiedź1 ${ }^{131}$.

Pomimo zadeklarowanej apolityczności redakcja „Tygodnika Powszechnego” nie mogła uniknąć ostrej cenzury i nakazów partyjnych. Dlatego też musiano dostosować się w pewnym stopniu do ogólnych trendów propagowanych przez nową władzę.

\section{Cechy wydawniczo-formalne}

Pierwszy numer „Tygodnika Powszechnego” z podtytułem „Katolickie pismo społeczno-kulturalne" czytelnicy otrzymali w niedzielę 24 III 1945 r. w Krakowie, gdy trwały jeszcze działania wojenne. Czasopismo - ukazujące się do dziś - posiada w swej historii kilka okresów wydawniczych. Pierwszy z nich kończy się z datą 8 II 1953 r. Wydawcą była Kuria Książęco-Metropolitalna w Krakowie. Periodyk tłoczono w Drukarni Przemysłowej K. Podgórczyka i Spółki, następnie w państwowej Krakowskiej Drukarni Prasowej przy ul. Wielopole 1. Redakcja mieściła się początkowo przy Franciszkańskiej 3, od stycznia 1946 r. w nowym lokalu przy ul. Wiślnej $12^{132}$.

Tygodnik wydawano w dużym formacie dwójki czteroszpaltowego druku. W rubryce Od redakcji pisano: „Wielu czytelników naszego pisma skarży się na zbyt drobny i mało czytelny druk. Odpowiadając im donosimy, że wkrótce prawdopodobnie będziemy mogli drukować $<<$ Tygodnik Powszechny $>>$ na lepszym papierze, co bardzo poważnie poprawi czytelność pisma. Poza tym ograniczyliśmy do minimum druk nonparalelem, (tj. najmniejszym pismem stosowanym w tygodniku np. do recenzji teatralnych), a rozważamy możliwość druku, niektórych przynajmniej artykułów, jeśli nie całego $<<$ Tygodnika $>>$, większym pismem"133. Nakład wahał się od 60 do 75 tys. egzemplarzy ${ }^{134}$. Był niewystarczający, skoro redakcja w 1945 r. przepraszała: „Z powodu małego nakładu nie mogliśmy zaspokoić wszystkich Prenumeratorów, którzy zamawiali $<<$ Tygodnik Powszechny >> we wrześniu i październiku"135. W latach 1945-1953 ukazało się dziewięć roczników w łącznej numeracji 414 zeszytów $^{136}$.

${ }^{130}$ Tamże, „TP” 1950 nr 27 s. 6.

${ }^{131}$ J.M.S. [J.M. Święcicki], Przegląd prasy. O marksistowskim językoznawstwie, „TP” 1950 nr 28 s. 7.

132 Od wydawnictwa, „TP” 1946 nr 4 s. 8.

133 Od redakcji, „TP” 1946 nr 35 s. 7.

${ }^{134}$ D. Wielgat, Bibliografia katolickich..., s. 91.

${ }^{135}$ Do p.t. prenumeratorów, „TP” 1945 nr 33 s. 3.

${ }^{136} \mathrm{~W}$ roku 1945 - 41 numerów, 1946 - 52 numery (w tym ostatni podwójny 51/52), 1947 - 52 numery (14/15 i 51/52 podwójny), 1948 - 53 numery (w tym dwa podwójne $\mathrm{nr}$ 13/14 i 52/53), 1949 - 51 (dwa podwójne 15/16 i 50/51), 1950 - 53 (trzy podwójne 15/16, 21/22, 51/52), 1951 - 52 (1/2, 12/13, 51/52), 1952 - 52 (ostatni podwójny 51/52) i $1953-8$. 
Początkowo objętość numeru liczyła zaledwie 4 strony w cenie 3 zł. Dość szybko (od numeru 15 z 1945 r.) na życzenie odbiorców powiększono tygodnik o 2 strony, o czym powiadomiła redakcja, ubolewając, że zmuszona została podnieść cenę pisma do $5 \mathrm{zf}^{137}$. Przez cały okres wydawniczy zachęcano odbiorców do prenumeraty jako, ,jedynej gwarancji stałego otrzymywania pisma"138. Jej wysokość wraz z przesyłką ustalono początkowo na 21 zł miesięcznie, a 63 zł kwartalnie ${ }^{139}$. Od numeru 19 pierwszego rocznika „Tygodnik Powszechny” liczył już 8 stron. „Skutkiem wysokich kosztów druku i papieru” od 1 II 1946 r. podniesiono koszt egzemplarza do 7 zł. Prenumerata miesięczna wyniosła wtedy 28 zł, a kwartalna $84 \mathrm{zl}^{140}$. Redakcja przyjmowała ogłoszenia w cenie $20 \mathrm{zł}$ za „1 $\mathrm{mm}$ wysokości na szerokość szpalty”. Najmniejsze ogłoszenie mogło wynosić $10 \mathrm{~mm}$. O ich przyjmowaniu szczegółowych informacji udzielała Administracja Wydawnictwa, o czym informowano w każdej stopce redakcyjnej na końcu zeszytu ${ }^{141}$. W 1947 r. przyjęto zasadę drukowania ogłoszeń po zapłaceniu za nie.

Od 13 X 1946 r. (nr 41) periodyk liczył 12 stron w cenie 12 zł. Wcześniej informowano: „W najbliższym czasie $<<$ Tygodnik Powszechny $>>$ zacznie wychodzić w objętości 12 stron, na lepszym niż dotąd papierze, z czytelniejszym drukiem i z obfitszym materiałem ilustracyjnym" ${ }^{\prime 42}$. Cenę prenumeraty podwyższono od początku października: miesięczną do $45 \mathrm{zł}$, kwartalną do $130 \mathrm{zł}$. Zaznaczono jednocześnie, że w kwartalnym abonamencie pojedynczy numer kosztował $10 \mathrm{zł}$. Nowe zamówienia miały być realizowane bez ,żadnych ograniczeń" ${ }^{143}$, wymaganiem było jedynie uiszczenie opłat z góry ${ }^{144}$. Aby zainteresowanym ułatwić wpłatę, do poszczególnych numerów periodyku dołączono czeki pocztowe ${ }^{145}$. W $1947 \mathrm{r}$. prenumerata znów zdrożała i przy opłacie miesięcznej trzeba było wydać $60 \mathrm{zł}$, a przy kwartalnej $170 \mathrm{z}^{146}$. Redakcja tłumaczyła to „poważną zwyżką cen papieru" i wzrostem innych kosztów. Pojedynczy numer kosztował 16 zł. Zmianie uległ też cennik ogłoszeń - „40 zł za $1 \mathrm{~mm}$ wysokości przez 1 szpaltę"147. Od $1947 \mathrm{r}$. zamieszczano niekiedy na początku artykułów notę redakcji. Niestety, w drugim półroczu tego roku i w kolejnym większość numerów znów liczyła 8 stron. W nagłówku zeszytu 24 z 1948 r. pojawiła się cena: „16 zł + 1 na Caritas Academica”.

${ }^{137}$ Od wydawnictwa, ,TP” 1945 nr 14 s. 4.

138 „TP” 1945 nr 35 s. 2.

${ }^{139}$ Od wydawnictwa, „TP” 1945 nr 15 s. 6.

140 „TP” $1946 \mathrm{nr} 45$ s. 2.

${ }^{141}$ Ogłoszenia, „TP” 1945 nr 16 s. 2.

142 Zmiana warunków prenumeraty i kolportażu „Tygodnika Powszechnego”, „TP” 1946 nr 38 s. 8.

143 Tamże.

144 Od administracji, „TP” $1946 \mathrm{nr} 47$ s. 12.

${ }^{145}$ Administracja, Czeki pocztowe, „TP” 1946 nr 50 s. 12.

146 „TP” 1947 nr 24 s. 12.

${ }^{147}$ Administracja, Nowy cennik prenumeraty i ogłoszeń, „TP” 1947 nr 22 s. 6. 
Wyjaśniano: „Od przyszłego numeru pobierana będzie przy rozprzedaży dopłata w wysokości 1 złoty od numeru na rzecz $<<$ Caritas Academica $>>$. Uzyskane stąd kwoty pieniężne przeznaczone są na uruchomienie prewentorium dla zagrożonych gruźlicą studentów Szkół Wyższych. Cena łączna numeru wynosić będzie zatem 17 złotych. Podwyżka ta nie dotyczy warunków prenumeraty, które pozostają niezmienione" ${ }^{148}$.

Zwiększenie objętości tygodnika wpłynęło bardzo korzystnie na jego zawartość i wygląd. Artykuły stały się obszerniejsze i na dany temat mogło wypowiedzieć się kilka osób w jednym numerze. Na łamy weszła ponadto nowa problematyka i pojawiły się nieznane dotąd nazwiska. Kolejna podwyżka miała miejsce od początku 1949 r., kiedy to cena pojedynczego numeru wyniosła $20 \mathrm{zł} \mathrm{(+} 1 \mathrm{zl}$ na „Caritas Academica”); miesięczne stałe dostarczanie pisma kosztowało $70 \mathrm{zl}$, natomiast kwartalne - 200 zł. Objętość tygodnika w 1949 r. liczyła zazwyczaj od 8 do 12 stron, jedynie zeszyt 42 został poszerzony do 14 stron, a 51/52 do 16 stron.

W 1950 r. cena w wysokości 20 zł za egzemplarz utrzymała się do zeszytu 44, a w kolejnym numerze po wymianie pieniędzy w 1950 r. spadła do 90 gr, pozostając w tej samej kwocie jeszcze w latach 1951-1952 ${ }^{149}$. Prenumerata miesięczna w 1950 r. wyniosła odpowiednio za miesiąc 70 zł, za kwartał 200 zł150; w 1952 r. zaś miesięczna 3 zł, kwartalna 9 zł. Objętość numerów w 1950 r. mniej więcej kształtowała się tak, że co drugi liczył 12 stron, a pozostałe 8 stron. Tylko trzy numery 15/16, 21/22 (cena 30 zł) oraz 51/52 liczyły 16 stron. Wydania świąteczne (np. nr 40 z 1945 r.) objętościowo zazwyczaj poszerzone były w cenie 10-18 zł.

Za pierwsze tygodniki ostatniego rocznika należało zapłacić 1,50 zł, za ostatnie zaś 2 zł; prenumerata miesięczna kosztowała 5 zł, kwartalna 15 zł. Cena ogłoszeń wyglądała następująco: ,[...] nekrologi 6 zł za $1 \mathrm{~mm}$ wysokości, 1 szpalta szerokości. Inne 9 zł za 1 mm wysokości, 1 szpalta szerokości"151. Redakcja do końca dołączała do niektórych numerów pisma blankiety nadawcze, chcąc ułatwić prenumeratorom wpłatę i uniknąć przerw w dostawie tygodnika ${ }^{152}$. Objętość w 1953 r. była nieco zróżnicowana: numery 1-4 i 6-7 liczyły 8 stron, numer 5 zaś niestandardowo 4 strony, natomiast ostatni, 8 zeszyt -10 stron. We wszystkich rocznikach zastosowano numerację w obrębie roku i ciągłą od początku istnienia czasopisma.

Nad nagłówkiem tytułu polecano artykuły warte przeczytania w danym zeszycie. Podawano inicjał imienia i nazwisko autora wraz z tytułem publikacji. Później, od 1946 r. występowały same nazwiska, a w kolejnym roku pełne imiona i nazwiska

${ }^{148}$ Redakcja i administracja, 16+1 zł na „,Caritas Academica”, „TP” 1948 nr 25 s. 5.

${ }^{149}$ Wiosną 1950 r. ówczesne władze przeprowadziły wyjątkowo niekorzystną dla społeczeństwa wymianę pieniężną, która spowodowała utratę oszczędności niemal z dnia na dzień. W związku z tym zmieniły się relacje cenowe.

${ }^{150}$ Administracja, P. t. czytelników, „TP” $1950 \mathrm{nr} 3$ s. 8.

${ }^{151}$ Stopka redakcyjna, „TP” $1953 \mathrm{nr} 1$ s. 8.

${ }^{152}$ Administracja, Blankiety nadawcze P. K. O., „TP” 1950 nr 23 s. 11. 
wraz z tytułami. Poniżej podtytułu zaś od lewej widniał numer rocznika, miejsce wydawania, dzień („niedziela”) wraz z datą ukazania się oraz numerem po prawej stronie. Od początku nad nagłówkiem wykazywano też liczbę stron i cenę pisma. Z początkiem 1946 r. zaczęto zamieszczać spis treści poprzedniego numeru (s. 2; potem s. 4), natomiast od numeru wielkanocnego z tego roku redakcja zapowiadała autorów i tytuły, które znajdą się na łamach „Tygodnika Powszechnego"153.

O częstym nawiedzaniu siedziby pisma przez interesantów może świadczyć ogłoszenie: „Redakcja zawiadamia, że przyjmuje interesantów tylko w godzinach od 11.30 do 13 z wyjątkiem poniedziałków"154.

W 1948 r. na łamach periodyku ukazała się następująca informacja: „W związku z pochodzącymi z zagranicznych źródeł (radio i prasa) wiadomościami na temat zamknięcia $<<$ Tygodnika Powszechnego $>>$ i aresztowania jego współpracowników, donosimy, że informacje dotyczące $<<$ Tygodnika Powszechnego $>>$ są fałszywe. $<<$ Tygodnik Powszechny $>>$ nie jest ani nie był zamknięty, a wszyscy członkowie jego redakcji, wraz z wymienionym imiennie ks. Janem Piwowarczykiem, Pawłem Jasienicą i Stefanem Kisielewskim przebywają na wolności"155.

Formy wypowiedzi występujące na łamach „Tygodnika Powszechnego" to artykuły, recenzje, wspomnienia, felietony, reportaże, polemiki, korespondencje, fragmenty książek, listy papieskie, przemówienia ${ }^{156}$, orędzia, komunikaty, deklaracje, konstytucje apostolskie ${ }^{157}$, fragmenty encyklik ${ }^{158}$, przeglądy prasy, nekrologi. Odbiorcy mogli zapoznać się z licznymi polemikami i dyskusjami, które zajęly istotną część pisma. Dość często polemizowano w rubrykach: Okruchy, Pod włos..., Wśród czasopism, Bez ogródek, Listy do redakcjilis9, Przegląd prasy. Głównie nie zgadzano się z wypowiedziami drukowanymi na łamach łódzkiej „Kuźnicy”160, „Odrodzenia”, „Dziennika Polskiego”, „Szpilek”"161, „Wsi” czy wolnomyślicielskiego „Głosu Wolnego"162. Czasem polemizowano również z opiniami

${ }^{153}$ W najbliższych numerach będziemy drukowali m.in., „TP” 1946 nr 16 s. 14.

154 Od redakcji, ,TP” 1947 nr 29 s. 8.

155 Tamże, „TP” 1948 nr 39 s. 3.

${ }^{156}$ Np. Mowa Prezydenta R. P. Bolesława Bieruta wygłoszona na otwarciu sesji sejmowej, „TP” 1948 nr 46 s. 3-4.

${ }^{157}$ Np. Bulla dogmatyczna o Wniebowzięciu Najświętszej Marii Panny, „TP” 1950 nr 50 s. 6-8.

${ }^{158} \mathrm{~Np}$. Pius XII, „Mirabile illud”. Encyklika papieża Piusa XII o pokoju, „TP” 1950 nr $1-2$ s. 2.

159 Listy do redakcji. Kott contra Kisielewski, „TP” 1947 nr 16 s. 11.

${ }^{160} \mathrm{~Np}$. Okruchy. Rozwody ,bez zbędnych formalności”, „TP” 1945 nr 32 s. 4; Kisiel [S. Kisielewski], Pod włos... Jastrun terrorysta, tamże, nr 36 s. 5; Okruchy. Otóż to: rzeczowo..., tamże, s. 2; w innych rubrykach również pojawiały się polemiki. Kolejno m.in. M. Ruth Buczkowski, Listy do redakcji, „TP” 1946 nr 25 s. 7; Wśród czasopism, „TP” 1947 nr 3 s. 11; J. Czekanowski, Uwagi krytyczne do krytyki „,Kuźnicy”, tamże, nr 21 s. 7-8.

${ }^{161}$ Kisiel [S. Kisielewski], Pod włos... Sabotaz, ,TP” 1946 nr 5 s. 6.

162 Np. J.M.S. [J.M. Święcicki], Bez ogródek. Zasadnicza dyskusja, „TP’ 1950 nr 29 s. 12. 
publicystów „Rzeczypospolitej”163, podawano wiadomości z łamów „Robotnika”, „Nowej Kultury”, „Strażnicy Ewangelicznej” i „Przekroju”. Zawartość „Kuźnicy”, „Odrodzenia” oraz „Dziś i Jutro” śledzono na bieżąco, o czym przekonujemy się, przeglądając rubrykę Wśród czasopism. Żywa polemika czasem wybuchała po jakimś artykule wydrukowanym w „Tygodniku Powszechnym”. Tak było w przypadku wypowiedzi Pawła Jasienicy ${ }^{164}$, która przyczyniła się do licznych głosów na łamach „Polski Zbrojnej” i artykułu w „Odrodzeniu”. Redakcja o samej polemice konstatowała: ,[... ] jest pożyteczna i prawie konieczna. Świadczy ona o pracy myśli i ścieraniu się poglądów, o twórczej postawie wobec życia [...] przybiera niejednokrotnie ostre formy [...] Jednakże nie znaczy to bynajmniej, by wszystkie metody polemiki prasowej i zwalczania przeciwnika były dopuszczalne [...] niedopuszczalne jest:

1. przekręcanie myśli autora przy pomocy odpowiednio dobranych cytatów,

2. przypisywanie autorowi intencji, których on nie miał, co udowodnił niejednokrotnie (w artykule cytowanym lub w innych artykułach), bądź stawianie gołosłownych zarzutów, których się nie udowadnia.

Są to polemiki złe i niebezpieczne" ${ }^{165}$. Sprawę zakończono w końcu rozmową $\mathrm{z}$ autorem na łamach pisma i jego merytorycznym artykułem wyjaśniającym $^{166}$. Dysputę wywołał też artykuł Aleksandra Bocheńskiego $O$ dyskusji nad Monte Cassino ${ }^{167}$. Korygowano często wypowiedzi na łamach organu protestantów w Polsce „Strażnicy Ewangelicznej”168. Zgodnie natomiast odnoszono się do publikacji „Tygodnika Warszawskiego"169 i „Tygodnika Katolickiego"170. Z obcych tytułów redakcja cytowała fragmenty z paryskiego „La Croix”, amerykańskiego miesięcznika „Reader's Digest”"171 i „Time”"172, bratysławskich „Katolickich Novin”, powoływano się niekiedy także na praskiego „Katolika” ${ }^{173}$. Odbiorcy mogli napotkać w „Tygodniku Powszechnym” również przedruki z londyńskiego miesięcznika „Nowa Polska” czy miesięcznika „Esprit”174, a także broszur przedwojennych ${ }^{175}$.

163 J. Turowicz, Orientacje i obyczaje, „TP” $1947 \mathrm{nr} 41$ s. 7.

${ }^{164}$ P. Jasienica, Od strony frontu i polityki, „TP” $1946 \mathrm{nr} 47$ s. 1, 3.

${ }^{165}$ Redakcja, Metody złe i niebezpieczne, „TP” $1947 \mathrm{nr} 1 \mathrm{s.} 1$.

${ }^{166}$ J. Kirchmayer, Rozmowa z Pawtem Jasienica, „TP” 1947 nr 6 s. 3-4; P. Jasienica, Pomimo wszystko, tamże, s. 4.

${ }^{167}$ A. Bocheński, O dyskusji nad Monte Cassino, „TP” 1946 nr 45 s. 1, 4; Dyskusji „, nad Monte Cassino” ciag dalszy, „TP” 1947 nr 7 s. 6-8.

${ }_{168}$ J.M.S. [J.M. Święcicki], Prawda jednego Kościoła, „TP” 195 nr 26 s. 3.

169 W'́ród czasopism. Nie zabijaj!, „TP” 1946 nr 50 s. 11; W'́ród czasopism. Wspomnienie o ks. Wt. Kornilowiczu, „TP” 1947 nr 18 s. 11; Bez ogródek. Mętna woda, tamże, nr 33 s. 12.

${ }^{170}$ Kronika religijna. Ofiara życia, „TP” $1947 \mathrm{nr} 37$ s. 7.

${ }^{171}$ Przegląd religijny. , Siedem powodów”..., „TP” 1947 nr 13 s. 10.

172 T., Bez ogródek. Wywiad Radziwiłta, „TP” 1947 nr 34 s. 8.

${ }^{173}$ Kronika religijna. Czym jest moralność?, „TP” 1948 nr 11 s. 7.

${ }^{174}$ M. Strebejko, The american way, „TP” $1947 \mathrm{nr} 3$ s. 5.

${ }^{175}$ Np. O. Haleckiego, Matżeństwo królowej Jadwigi w świetle historii, Torun 1938 w „ТP” 1947 nr 29 s. $1-2$. 


\section{Numery specjalne}

Wydania okolicznościowe poświęcone były znanym osobistościom z różnych okazji, jak np. Tadeuszowi Kościuszce (nr 12 z 1946 r.), Henrykowi Sienkiewiczowi w setną rocznicę urodzin (nr 19 z 1946 r.), pamięci Karola Huberta Rostworowskiego (nr 50 z 1948 r.), z powodu śmierci: Juliuszowi Osterwie (nr 25 z 1947 r.), prymasowi Polski kardynałowi Augustowi Hlondowi (nr 49 z 1948 r.) i Adamowi Sapieże (nr 46 z 1951). Ich zawartość tematyczna wiązała się z działalnością danej osoby. W artykułach wstępnych starano się zazwyczaj ukazać zasługi, historię dokonań i życiorys. Dobierano jednocześnie odpowiednio w numerze utwory poetyckie. Tygodnik był też wtedy zazwyczaj bogatszy pod względem graficznym w rysunki, podobizny, fotografie i reprodukcje.

Od zwykłych egzemplarzy różniły się także numery świąteczne, często o podwójnej numeracji i droższe. Coroczne wydania na Boże Narodzenie i Wielkanoc były objętościowo powiększone, a ich szata graficzna również bardziej urozmaicona ${ }^{176}$.

Il. 1. Reprodukcje rysunków T. Kościuszki w numerze specjalnym „Tygodnika Powszechnego”. „TP” 1946 nr 12 s. 3

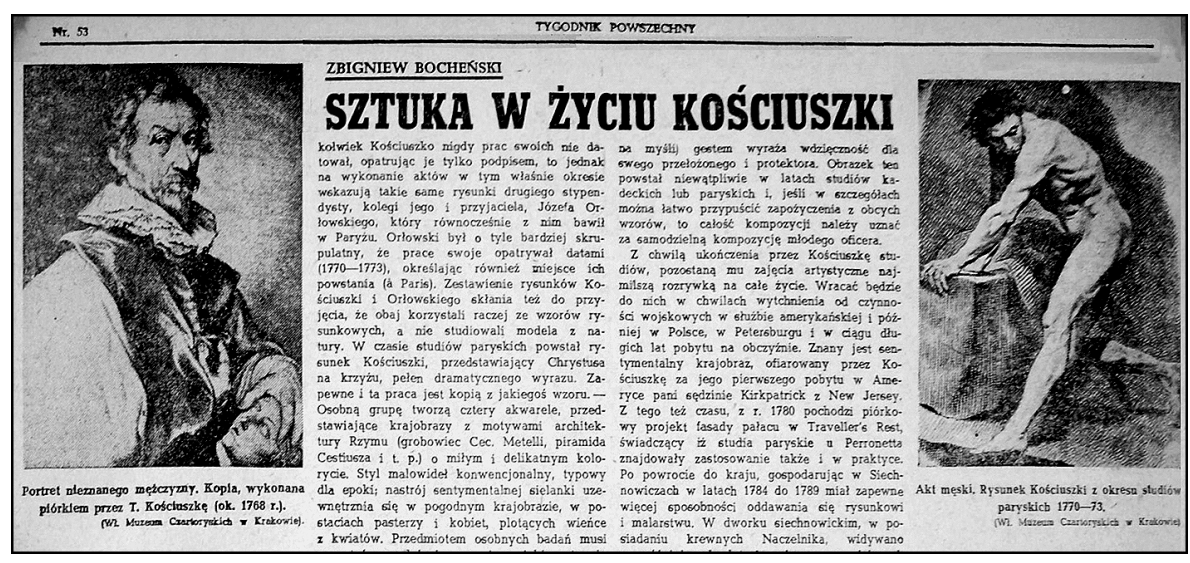

Źródło: Ze zbiorów BUŁ.

Wydania okolicznościowe i świąteczne były ciekawsze i bardziej starannie przygotowane. Wymagały też dłuższej lektury ze względu na bogatszy materiał prasowy i poszerzoną objętość.

${ }^{176}$ Np. numer podwójny 51/52 z 1946 r. liczył 20 stron, natomiast numery wielkanocny 14/15 z 1947 r. oraz na Boże Narodzenie 51/52 z 1947 r. i 52/53 z 1948 r. po 16 stron. Numerem specjalnym, powiększonym do 24 stron, był również podwójny zeszyt wielkanocny 13/14 z 1948 r. w cenie 30 zł. 


\section{Kontakty z czytelnikami}

Kontaktom z odbiorcami służyło kilka rubryk. Jedną z nich były Listy czytelników (od nru 13 z 1945 r.), w których poruszane były problemy życia społecznego ${ }^{177}$. W rubryce narzekano m.in. na niskie emerytury ${ }^{178}$, w innym miejscu broniono godności zmarłego biskupa Edwarda O'Rourke ${ }^{179}$. Odpowiedzi redakcji (obecne od nru 18 z 1945 r.) dotyczyły kontaktów bardziej bezpośrednich. Zamieszczano tu np. prośbę o spotkanie z określoną osobą. W Korespondencji (od nru 37 z 1945 r. s. 8) natomiast drukowano ważniejsze listy skierowane do redakcji „Tygodnika Powszechnego”. Odbiorcy w nich często odnosili się do wcześniej publikowanych w piśmie artykułów ${ }^{180}$. Na łamy wprowadzono też Listy do redakcji (na s. 7) po raz pierwszy w rocznicę istnienia tygodnika, które obecne były do końca jego ukazywania się. Zagościły wtedy życzenia i opinie znanych osób ówczesnego życia społeczno-politycznego. Warto przytoczyć niektóre. Stefan Żółkiewski pouczał: „Chociaż pismo Wasze istnieje już cały rok, tym nie mniej jest to zupełnie bezcelowe. Dzisiaj w Polsce mają rację bytu tylko ci dialektycy, którzy oparłszy się na adekwatnej semantyce osiągną metodologiczną poprawność empiryczno-logiczną i jedyną obiektywną prawdziwość poznania mechanizmu rewolucyjnych ewolucji społecznych jaką daje dialektyczny materializm filozoficzny [...] Powtarzam: istnienie Waszego pisma jest bezcelowe, więcej - jest szkodliwe. Twierdzę to, choć popiera Was i snobizuje się Waszą niby to opozycją cała złota młodzież ziemiańsko-dorobkiewiczowska, robiąc z Was bohaterów, gdy $\mathrm{w}$ istocie kryjecie się tchórzliwie pod sutanną i złotą kratą biskupiej cenzury - pachołki wstecznictwa. Z poważaniem ...”"181. Bolesław Piasecki pisał zaś: „Wobec rocznicy istnienia $<<$ Tygodnika Powszechnego $>>$ przesyłam życzenia odpowiedniego nastawienia linii w kierunku napięć kierunkowo-energetycznych epoki [...] przewartościowań wartości i poglądów [...] póki jeszcze nie jest za późno"182. Roman Szydłowski z Urzędu Kontroli Prasy zapewniał natomiast: „W rocznicę istnienia Waszego znakomitego pisma, życzę długich lat owocnej działalności i przyrzekam dalszą, jak dotychczas bliską i lojalną współpracę"183. W 1947 r. poważnie traktowana korespondencja odbiorców do redakcji zajęła sporo miejsca i spełniła istotną rolę we wzajemnym porozumiewaniu się. Rubryka do końca była też miejscem, gdzie korygowano wszelkie błędy merytoryczne zauważone

\footnotetext{
${ }^{177}$ Np. Listy czytelników. Niepokojące imprezy szkolne, „TP” 1945 nr 17 s. 6.

${ }^{178}$ Listy czytelników. Zapomniani, „TP” $1945 \mathrm{nr} 21$ s. 8.

179 Tamże. W sprawie Ś. p. ks. biskupa O’Rourke, „TP” $1945 \mathrm{nr} 22$ s. 8.

${ }^{180} \mathrm{~Np}$. odniesienie do artykułu A. Vetulaniego, Szwajcaria w czasie wojny, „TP” $1945 \mathrm{nr} 39$ w artykule A. Seelieb, Korespondencja. Jeszcze o Polakach w Szwajcarii, „TP” 1946 nr 2 s. 8.

${ }^{181}$ Listy do redakcji. Do redaktora „, Tygodnika Powszechnego”, „TP” 1946 nr 13 s. 8.

182 Tamże.

${ }^{183}$ Tamże.
} 
na stronach „Tygodnika Powszechnego”. Drukowano zatem również listy zawierające sprostowania ${ }^{184}$.

Widziano także potrzebę wprowadzenia części zatytułowanej $W$ oczach czytelników (od nru 26 z 1946 r. s. 8) ze względu na to, że wśród odwiedzających redakcję najwięcej było „autorów, proponujących druk artykułów”185. Niektóre zasygnalizowane sprawy można było opisać i wyjaśnić bliżej właśnie tutaj. Rubryka jednak istniała krótko.

Kolejna kolumna, Rozmowy i rady, po raz pierwszy znalazła miejsce w numerze 39 z 1950 r. na ostatniej stronie, występując odtąd na stałe. Redakcja tak thumaczyła jej pojawienie się: „Wiele zagadnień i trosk powtarza się w naszej redakcyjnej korespondencji, powraca nieustannie, niepokoi szersze kręgi naszych czytelników. Sądzimy, że poświęcenie tym kwestiom osobnej rubryki przyniesie obustronną korzyść. Nie zastrzegamy jej specjalnie dla początkujących pisarzy, ale tak się składa, że ich kłopoty dostarczają nam dotychczas dużo materiału. Mamy nadzieję, że $<<$ Rozmowy i rady $>>$ zacieśnią kontakt między nami"186.

Należący do zespołu tworzącego „Tygodnik Powszechny” utrzymywali stałe kontakty z czytelnikami w sprawach prenumeraty i zamówień. Dobrą okazją do podtrzymywania ich były też rocznice pisma. Świadczą o tym noty drukowane na łamach periodyku. Dziękowano czytelnikom i przyjaciołom, którzy nadesłali życzenia z okazji czterechsetnego numeru tymi słowami: „W zbiorowym podziękowaniu pragniemy wyrazić głęboką wdzięczność za nadesłane listy [...] fakt, że <<Tygodnik Powszechny >> miał dla wielu naszych czytelników tak duże znaczenie, jak to wynika z ich wypowiedzi - znacznie przerasta zasługi redakcji, administracji i bezpośrednich współpracowników pisma. Fakt ten zawdzięczamy szczęśliwej współpracy wszystkich piszących i wszystkich czytających. Zawdzięczamy go wspólnemu wysiłkowi - z jednej strony tych, którzy starają się przekazać drukiem myśli i wiadomości, z drugiej strony tych, którzy umieją wydobyć dla siebie z pisma to, co w nim jest najlepsze; [...] odnieść się pobłażliwie do różnych naszych pomyłek i błędów; pomóc nam radą, zapytaniem, polemiką, zachętą" 187 . Corocznym zwyczajem było też składanie sobie wzajemnych życzeń z okazji świąt Bożego Narodzenia i Wielkiej Nocy.

Prenumeratorów powiadamiano na bieżąco o wszelkich wprowadzanych zmianach. W kwietniu $1950 \mathrm{r}$. redakcja zapowiedziała przejęcie w najbliższym czasie rozprowadzania „Tygodnika Powszechnego” przez Państwowe Przedsiębiorstwo Kolportażu Ruch. W związku z tym proszono odbiorców, aby dokonywali wpłat

\footnotetext{
${ }^{184}$ Przykładowo Listy do redakcji, „TP” 1950 nr 21/22 s. 15.

${ }^{185}$ Mus [M. Sułkowska], W oczach czytelników. Zwierzęta, „TP” 1946 nr 27 s. 8.

${ }^{186}$ Redakcja, Rozmowy i rady, „TP” 1950 nr 39 s. 8.

${ }^{187}$ Redakcja, Dziękujemy, „TP” 1953 nr 1 s. 8.
} 
wcześniej, czyli do 25 każdego miesiąca wyprzedzającego termin prenumeraty ${ }^{188}$. Od 1 VI 1951 r. kolportaż komisowy „Tygodnika Powszechnego” dla urzędów parafialnych i kiosków parafialnych przejął Dział Prenumeraty Pocztowej PPK Ruch. Opłatę należało uiścić do 15 dnia miesiąca na konto Ruchu w Krakowie ul. Lubicz 42, nie zaś jak dotychczas na konto administracji pisma ${ }^{189}$. W późniejszym okresie administracja zalecała wpłaty najpóźniej do 10 każdego miesiąca. Informowała również co jakiś czas o tym, że reklamacje dotyczące wysyłek, jak też zmiany adresów należy kierować do PPK Ruch w Krakowie, ul. Stanisława Worcella 6. Wielokrotnie przypominano, że nie należy kont „Tygodnika Powszechnego" utożsamiać z kontem Ruchu, gdyż na konto administracji należało dokonywać wyłącznie wpłat dotyczących funduszu prasowego, ogłoszeń i numerów archiwalnych (nie bieżących). Ostrzegano równocześnie, że niedostosowanie się do tychże wskazówek spowodować może „niepotrzebną zwłokę w dostawie czasopisma i zbędną korespondencję"190. Od 15 I 1952 r. zgłoszenia na prenumeratę „Tygodnika Powszechnego" należało dokonywać bezpośrednio w urzędach pocztowych lub u listonoszy, należących terytorialnie do danego urzędu, na terenie którego zamieszkiwał prenumerator. W związku z tym powtarzano ogłoszenia, w których pisano o terminie wpłat za prenumeratę „DO URZĘDÓW POCZTOWYCH, LISTONOSZOM WIEJSKIM LUB MIEJSKIM”"191. Pojawiła się też drobna reklama o treści: „Jeśli chcesz otrzymywać $<<$ Tygodnik Powszechny>> wpłać prenumeratę na konto..." 192 . Zapewne ze względu na niestosowanie się abonentów do ustalonych reguł, ostatecznie zdecydowano się na powtarzanie niemal w każdym numerze w osobnej ramce czterech warunków, jakie należy spełnić, aby regularnie otrzymywać tygodnik ${ }^{193}$.

Reagowano na wszelkie ,przeoczenia” np. przy opracowaniu nowych cenników czasopism, kiedy to urzędy pocztowe wstrzymały wpłaty na prenumeratę „Tygodnika Powszechnego" ${ }^{194}$. Wysyłkę czasopisma za granicę umożliwiono przez Biuro Wydawnictw Zagranicznych Ruch przy ul. Koszykowej 31 w Warszawie ${ }^{195}$.

Jak wynika z powyższego opisu, kontakty z odbiorcami stanowiły ważną część pracy redakcji i administracji pisma. Mogą o tym świadczyć wprowadzone

${ }^{188}$ Administracja, Zmiana w prenumeracie, „TP” 1950 nr 15/16 s. 6.

${ }^{189}$ Administracja, Do p.t. prenumeratorów, „TP” $1951 \mathrm{nr} 23$ s. 6; Komunikat do p.t. kolporterów, tamże, s. 8.

${ }^{190}$ Do p.t. abonentów i czytelników , Tygodnika Powszechnego”, „TP” $1953 \mathrm{nr} 4$ s. 2; Uwaga abonenci i czytelnicy „, Tygodnika Powszechnego”, tamże, nr 7 s. 6.

${ }^{191}$ Do p.t. prenumeratorów „, Tygodnika Powszechnego”, „TP” 1952 nr 10 s. 5; tamże, nr 22 s. 6; tamże, nr 24 s. 12; tamże, nr 26 s. 10.

192 „TP” 1952 nr 29 s. 10; tamże, nr 30 s. 7.

${ }^{193}$ Administracja, Od administracji , Tygodnika Powszechnego” do abonentów i czytelników, „TP” 1952 nr 33 s. 8; tamże, nr 34 s. 7; tamże, nr 37 s. 8; tamże, nr 39 s. 7; tamże, nr 40 s. 4; tamże, nr 41 s. 8; tamże, nr 48 s. 12; tamże, nr 49 s. 12.

${ }^{194}$ Do p.t. prenumeratorów!, „TP” $1951 \mathrm{nr} 43$ s. 4.

${ }^{195}$ Komunikat, „TP” 1951 nr 47 s. 8. 
rubryki, w których drukowano zapytania i wypowiedzi czytelników. W nich też starano się odpowiadać na wszelkie wątpliwości i propozycje ze strony zainteresowanych. Częste informacje redakcyjne o prenumeracie i jej zmianach były natomiast podyktowane troską prowadzących, aby tygodnik docierał na czas.

\section{Działy i rubryki}

Początkowo nie zaznaczyły się w zawartości tygodnika wyraźnie wyodrębnione działy. Stały układ pisma ukształtował się dopiero po kilku latach. Dokonywano przy tym wielu zmian. Przykładowo w 1947 r. kompozycja pisma wyglądała następująco: artykuł wstępny (s. 1), Zagadnienia (s. 2), artykuł historyczny (np. o sanktuarium, kościele lub mieście, s. 3), problematyka literacka (s. 4-6), inna problematyka (s. 7-8), Widnokręgi (s. 9) - obecne w każdym zeszycie, dział pt. Sylwetki (s. 9) oraz Polonica (s. 9). Po nich zazwyczaj występowała problematyka zagraniczna (przykładowo sprawa Chin, podział Palestyny na dwa państwa ${ }^{196}$, sytuacja polityczna w Etiopii ${ }^{197}$ ), zagadnienia sztuki i teatru (s. 10), Przegląd religijny i Kronika (s. 11), Bez ogródek i Pod włos... (s. 12). Sporadycznie pojawiały się w latach 1948-1950 także Listy z Anglii, Listy z Francji (Krzysztofa Tatarkiewicza) i Listy ze Szwecji (Ireny Jaworowicz).

Dwa lata później, w 1949 r., układ zagadnień przedstawiał się nieco inaczej: artykuły wstępne (s. 1-5), na pierwszej stronie drukowano też orędzia i listy dostojników Kościoła, rubryka $Z$ dnia (s. 2, 4), wiersze (s. 4, 6, 7), Na ekranie (s. 6 lub 7), opowiadanie (s. 7), artykuł krajoznawczy (s. 8), artykuł kulturalny (s. 9), Kronika zagraniczna (włoska, bułgarska itd., s. 9), krótkie recenzje nowości wydawniczych (s. 10), Przeglą prasy (s. 11), Tydzień prasy polskiej (s. 11), Spotkania literackie (s. 11), Kronika religijna (s. 11), niekiedy Życie muzyczne i Książi nadesłane (s. 11), Bez gródek (s. 12), Łopata do głowy (s. 12).

$\mathrm{Na}$ pierwszych stronach podejmowano zazwyczaj problematykę społeczno-kulturalną, historyczną i literacką. Kwestie społeczne rozważane w aspekcie katolickim obecne były zazwyczaj w artykułach redaktora naczelnego - ks. J. Piwowarczyka. Niekiedy pierwszą stronę poświęcano poezji. Przykładowo miało to miejsce w numerze 19 z 1950 r., w którym wydrukowano Pieśń o blasku wody Karola Wojtyły podpisaną pseudonimem Andrzej Jawień.

Szeroką problematykę poruszano we wszystkich działach i rubrykach. Najwcześniej, gdyż od drugiego numeru z 1945 r., weszły Okruchy. Pisano w nich o różnych sprawach; rubryka istniała do $1949 \mathrm{r}$. Na pierwszych stronach

\footnotetext{
nr 50 s. 2.

${ }^{197}$ J. Karolczyk, Widnokręgi. De Valera odszedt..., „TP” 1948 nr 11 s. 3; M. Strebejko, W Etiopii, tamże, nr 41 s. 4.
}

${ }^{196}$ M. Strebejko, Kłopotliwe chińskie kresy, „TP” 1947 nr 49 s. 2; tenże, Cienka gra, tamże, 
wprowadzono początkowo Pod trupia główka (s. 3) i Kronikę (na s. 4) (od nru 3 z 1945 r.), ale zaniechano ich druku już w 1946 r.

Dość szybko na stałe weszła problematyka muzyczna (od nru 6 z 1945 r.), teatralna (nr 2) i dotycząca sztuki ( $\mathrm{nr}$ 6), co miało odzwierciedlenie w powstaniu nowych działów. Rubryką towarzyszącą odbiorcom w latach 1945-1953 było Życie muzyczne (początkowo na s. 4, potem 8) prowadzone przez Stefana Kisielewskiego. W ostatnim sierpniowym zeszycie z 1949 r. weszły Wspomnienia muzyczne Kisiela ${ }^{198}$. Recenzje teatralne Tadeusza Kudlińskiego, Zygmunta Leśnodorskiego i Leopolda Tyrmanda ukazywały się pod nagłówkiem $Z$ teatrów krakowskich. Często omawiano tu sztuki z repertuaru Teatru Rapsodycznego. Niekiedy nagłówek zmieniano na $Z$ teatrów warszawskich lub po prostu $Z$ teatrów. W latach 1949-1950 pojawiły się Spotkania teatralne, natomiast w okresie 1948-1953 do każdego numeru dołączono rubrykę Na ekranie (od nru 21 z 1948 r. s. 10).

Z czasem doszła kolumna zatytułowana $Z$ pałacu sztuki (nazwana później W pałacu sztuki) prowadzona przez Helenę Blumównę, która omawiała aktualnie organizowane wystawy w Towarzystwie Sztuk Pięknych. Wraz z powiększeniem objętości tygodnika, zagościł od numeru 41 z 1946 r. Przegląd kulturalny (s. 10). W następnych numerach zawarł on oprócz Z teatrów krakowskich, Z pałacu sztuki także Nowe filmy polskie, Życie muzyczne i inne rubryki odnoszące się do wydarzeń kulturalnych ${ }^{199}$. Zaczęto zamieszczać tu również relacje $\mathrm{z}$ wystaw malarskich i kulturalnych ${ }^{200}$. $Z$ czasem pojawiła się osobna rubryka $Z$ wystaw (od numeru 17 z 1947 r. s. 7) prowadzona nadal przez H. Blumównę. W numerze przedostatnim z 1948 r. (s. 6) można było natomiast zapoznać się z Kronika wystaw.

W trosce o utrzymanie atrakcyjności pisma w kolejnych latach redakcja wprowadzała ciągłe zmiany. Rozbudowany w tygodniku został przede wszystkim dział kulturalny, na który złożyły się artykuły o kulturze, sztuce, teatrze, malarstwie, grafice, muzyce, literaturze, kinie. Bolesław Olszewicz w latach 1945-1947 ogłaszał w „Tygodniku Powszechnym” Listę strat kultury polskiej (1939-1945).

Wydarzenia ze świata umieszczano od numeru 35 z 1945 r. w Kronice zagranicznej (s. 6). Rubryka Życie religijne, zawierająca wydarzenia z życia Kościoła w Polsce i na świecie, gościła od numeru 36 z 1945 r. (s. 6). Z początkiem 1946 r. (nr 4 s. 7) weszło Życie katolickie, zaś od 1947 r. wprowadzono Przegląd religijny wraz z Kronika (s. 10). Z czasem pojawiła się też Kronika religijna (nr 33 z 1947 s. 11), istniejąca do 1953 r., a także Kronika plastyczna. Od drugiej połowy

${ }^{198}$ Kisiel [S. Kisielewski], Wspomnienia muzyczne, „TP” 1949 nr 34 s. 1-2.

${ }^{199}$ Np. T. Kudliński, Teatr Rapsodyczny, „TP” 1946 nr 45 s. 10; Z teatrów tódzkich, tamże, nr 46 s. 10; M. Markowski, Z teatrów katowickich, tamże, nr 50 s. 10.

${ }^{200}$ H. Blumówna, Przegląd kulturalny. Wystawa malarstwa angielskiego, „TP” $1947 \mathrm{nr} 1$ s. 14; taż, Z pałacu sztuki. Wystawy architektoniczne, tamże, nr 2 s. 10; D.J., Wystawa norwidowska, tamże, nr 6 s. 11. 
1947 r. redakcja zwykła umieszczać różnego rodzaju kroniki, co kontynuowano w kolejnych latach: włoską, francuską, niemiecką, amerykańską, meksykańską, czechosłowacką, jugosłowiańską, indyjską, radziecką, skandynawską, angielską. Udostępniano w nich przegląd wydarzeń kulturalnych, czasem zagadnień społecznych w poszczególnych krajach. Do Przeglądu religijnego dołączono Z literatury katolickiej (nr 48 z 1947 s. 11), gdzie znalazły się recenzje książek.

Papieskie wskazania towarzyszyły czytelnikom od numeru 17 z 1948 r. (s. 11), natomiast w latach 1949-1950 obecne były Vivere cum Ecclesia (s. 2). Rubrykę zatytułowaną Rozważania o mszy św. wprowadzono w 1952 r. (s. 2). Sporadycznie pojawiały się Migawki misyjne (od 1949 r. nr 2 s. 11; następne w nrze 27 z 1949 s. 11).

Drobna rubryka Na marginesie wprowadzona została od numeru 19 z 1945 r. Rejestrowano w niej mało znane lub bulwersujące wydarzenia ${ }^{201}$, czasami dementowano kłamstwa propagandy antypapieskiej ${ }^{202}$.

Żartobliwe felietony Kornika w Uchu igielnym bawiły odbiorców w latach 1945-1948. Mniej więcej w tym samym czasie publikowano (od $1945 \mathrm{r}$. do kwietnia 1949 r.) felietony Kisiela w rubryce Pod włos... na ostatniej stronie „Tygodnika”. Łącznie ukazało się 140 felietonów. Publicysta w humorystyczny sposób polemizował np. z wypowiedziami Jana Kotta na łamach „Odrodzenia”203, cytował błędne definicje $\mathrm{z}$ nowego wydania słownika ${ }^{204}$, zwracał uwagę na dewaluację słów ${ }^{205}$, przypominał przysłowia narodowe ${ }^{206}$. Stefan Kisielewski zapytany w wywiadzie o opinię na temat własnej twórczości, odpowiedział: „[...] mój talent to szeroki wachlarz, którego piórka obok miękkiego puchu mają bezlitosne ostrza. Mogę wachlować i głaskać jak kota, mogę obdzierać ze skóry jak Kotta”"207. W numerze 13 z 1949 r. powiadomiono, że w redakcji czasopisma odbyło się zebranie pod przewodnictwem redaktora Michała Strebejki, a celem spotkania było ustalenie „sześcioletniego planu działalności pisma”. W jego ramach „po wysłaniu telegramu do ministra Sokorskiego obecni postanowili w ramach akcji $<<\mathrm{OP}>>$ (Oszczędzanie Przeciwnika) skasować rubrykę Pod włos"208. Faktycznie doszło do tego i S. Kisielewski po „przeszło trzy i pół roku felietonowej pracy pod wiatr" napisał swój „nekrolog”, tłumacząc, że „na pozycjach felietonowych wytrwać się dłużej nie da”i trzeba objąć „nowe pozycje” ${ }^{209}$. Na dowód tego w następnym nu-

${ }^{201}$ Np. Na marginesie. Wiec akademicki bez echa, „TP” $1945 \mathrm{nr} 19$ s. 7; M., Prawo czy widly, tamże, nr 24 s. 8.

${ }^{202}$ K-k., Na marginesie. Jeszcze o Piusie XII, „TP” 1946 nr 2 s. 6.

${ }^{203}$ Pod włos. Kott - wieczny rewolucjonista, „TP” 1945 nr 22 s. 7.

${ }^{204}$ Kisiel [S. Kisielewski], Pod włos..., Coś pozytywnego, „TP” 1945 nr 39 s. 3.

${ }^{205}$ Tenże, Pod włos..., Dewaluacja słów, „TP” 1946 nr 1 s. 5.

${ }^{206}$ Tenże, Pod wtos..., Przystowia i powiedzonka, „TP” 1946 nr 6 s. 4.

${ }^{207}$ W. Pocica, Wywiad z Kisielem, „TP” 1947 nr 1 s. 11.

${ }^{208}$ Ostatnie wiadomości, „TP” 1949 nr 13 s. 8.

${ }^{209}$ Kisiel [S. Kisielewski], Pod włos. Pożegnanie z felietonem, „TP” 1949 nr 15/16 s. 16. 
merze wydrukowano reportaż Kisiela z Targów Poznańskich ${ }^{210}$. Niedługo, gdyż jeszcze w tym samym roku po 12 numerach przerwy w pisaniu felietonów, Kisiel zdecydował się na rubrykę Łopata do głowy. Pisał: „Było Pod włos, teraz będzie Łopata do głowy. Co oznacza ta zmiana? Przede wszystkim obniżenie lotu - głowa bowiem znajduje się pod włosami. Po drugie - ugięcie się przed koniecznością i faktami: włosów jest w Polsce coraz mniej, zaś głów otwartych, lecz pustych - sporo” "211. W 1952 r. rubrykę oceniono w następujący sposób: „Stali i uważni czytelnicy $<<$ Tygodnika Powszechnego $>>$ doszli zapewne już dawno do przekonania, że dział Łopata do głowy urósł do rzędu sui generis wolnej trybuny, z której Kisiel wygłasza niekiedy rozmaite herezje, podejmuje karkołomne próby przełamywania utartych schematów myślenia i postępowania, stawia z pasją wszystko i wszystkich do góry nogami. W dziale tym Kisiel wywalczył sobie prawo pewnej licentiae topatologica i wydaje się, że zarówno redakcja jak i czytelnicy stan ten cicho zaaprobowali" 212 .

$\mathrm{Na}$ stałe przyjęła się rubryka Bez ogródek występująca każdorazowo od numeru 8 z 1946 r. na ostatniej stronie. Poruszano tu z uśmiechem rozmaite zagadnienia zarówno powojennego życia obyczajowego ${ }^{213}$, jak i przejawy życia społecznego i wydarzenia kulturalne. Odnoszono się zazwyczaj do wypowiedzi prasowych, z którymi często polemizowano lub odpowiadano atakującym. W numerze 6 z 1948 r. doszła do niej na krótko rubryka Konkursy i nagrody. Niekiedy w Bez ogródek zamieszczano sprostowania ${ }^{214}$. W numerze 13 z 1949 r. „wobec stałych utyskiwań czytelników” wprowadzono jednorazowo zamiast Bez ogródek właśnie Ostatnie wiadomości. Zarzucano bowiem redakcji „Tygodnika Powszechnego” „,nadmierną abstrakcyjność i oderwanie od aktualnych problemów dnia dzisiejszego" ${ }^{215}$. W porozumieniu z Centralną Agencją Informacyjną w Warszawie zamierzano w nich dostarczać informacje ze wszystkich dziedzin polskiego i zagranicznego życia. Rubryka - nie licząc reklam - zajęła prawie całą ostatnią stronę. Niestety, nie pojawiła się więcej.

Różnego rodzaju wiadomości drukowano w licznych nowo powstałych rubrykach. Czytelnicy mogli zapoznać się od 1945 r. z rubryką zatytułowaną Dziś (s. 4). Obecna w każdym numerze była miejscem dla bieżących spraw. Przykładowo Hanna Malewska wykazywała w niej wyższość wartości chrześcijańskich nad stoickimi ${ }^{216}$, niemoralność propagandy ${ }^{217}$, pisała o atakach na wiarę chrześcijań-

${ }^{210}$ Tenże, Liberat na Targach Poznańskich, „TP” 1949 nr 21 s. 3-4.

211 Tenże, Łopata do głowy. Wagner, zakazany Chopin i tyfus, „TP” 1949 nr 29 s. 12.

212 ab, Watpliwy chrzest, ,TP” 1952 nr 17 s. 6.

${ }^{213}$ Np. ciekawie i żartobliwie napisany fragment: W miejskim parku, „TP” $1948 \mathrm{nr} 40$ s. 12.

214 Przykładowo: Jas, Pokajanie, „TP” 1949 nr 27 s. 12.

215 Ostatnie wiadomości, „TP” 1949 nr 13 s. 8.

${ }^{216}$ H. Malewska, Dziś. Kryteria ludzkie, „TP” $1946 \mathrm{nr} 5$ s. 7.

217 Taż, Dziś. Propaganda, „TP” 1946 nr 9 s. 5. 
ską ${ }^{218}$, o katolicyzmie społecznym we Francji ${ }^{219}$. W okresie 1949-1953 ukazywała się w każdym numerze rubryka $Z$ dnia (na s. 2-5), poświęcona sprawom kulturalnym. Informowano w niej krótko o przyznanych międzynarodowych nagrodach literackich, naukowych i wyróżnieniach za przekłady. Nie zabrakło w niej też zwięzłych notek o zgonach pisarzy, poetów i uczonych, ich konflikcie z prawem i odbywaniu kar więzienia. Z niej czytelnicy mogli dowiedzieć się także o nowych wydaniach książkowych, tytułach czasopism, organizowanych wystawach i festiwalach filmowych, odsłonięciach pomników czy wiadomościach teatralnych oraz artystycznych.

Różni autorzy sygnalizowali współczesne kwestie również w nieco obszerniejszych Zagadnieniach obecnych w latach 1946-1950 r. (s. 2, 4) w każdym numerze. Tadeusz Kudliński pisał m.in. o sytuacji polskich teatrów ${ }^{220}$, inni zaś o nowych podręcznikach szkolnych ${ }^{221}$ albo stosunku społeczeństwa do nieuniknionej starości ${ }^{222}$. W okresie 1947-1949 wprowadzono z kolei rubrykę Widnokręgi (s. 4), w której uwzględniono zagraniczną problematykę kulturalną i niekiedy politycznąa223.

Literatura, jakkolwiek szeroko omawiana w periodyku poprzez liczne recenzje książkowe, artykuły o nagrodach literackich, sylwetkach pisarzy i ich twórczości, uzyskała też w numerze 32 z 1947 r. rubrykę pt. Informacje literackie (s. 6), a od numeru 38 z tegoż roku obecne w każdym zeszycie Polemiki literackie (s. 4). Nowości książkowe krótko recenzowano pod nagłówkiem $W$ trzech stowach (od nru 42 z tegoż roku). Rubryka $Z$ ruchu literackiego (s. 10) zawierała natomiast przeróżne ciekawostki literackie. Spotkania literackie obecne były od $1948 \mathrm{r}$.

Książce w 1945 r. poświecono następujące rubryki: Nowe ksiązki, Ksiązki nadestane, Ksiązki nadestane do redakcji. Redakcja informowała: „Wydawcy i autorzy pragnący, by książki ich były omawiane $\mathrm{w}<<$ Tygodniku Powszechnym $>>$ proszeni są o nadsyłanie swych wydawnictw do redakcji, o ile możności w dwóch egzemplarzach. Wszystkie te wydawnictwa będą przed recenzją odnotowane w specjalnej rubryce $<<$ Książki nadesłane $>>$ "224. Do końca prowadzono też W'́ród książek. W 1949 r. wyszczególniono Książki dla dzieci i młodzieży, czasem tylko Książi dla młodzieży ${ }^{225}$. Sporadycznie na łamach „Tygodnika Powszechnego" pojawiała się rubryka Z wydawnictw katolickich ${ }^{226}$. Nowościom książkowym poświęcone były jednocześnie Zapiski recenzenta (obecne krótko od nru 19 z 1949 r. na ostatniej stronie). W 1953 r. niekiedy dru-

218 Taż, Dziś. Obstrzat, „TP” 1946 nr 12 s. 7.

219 Taż, Dziś. Katolicyzm społeczny we Francji, „TP” 1946 nr 15 s. 6.

${ }^{220}$ T. Kudliński, Zagadnienia. Pan teatr byt chory, ,TP” 1946 nr 24 s. 2.

221 J. Karolczyk, Czy od matpy?, „TP” 1946 nr 26 s. 2.

222 Z. Starowieyska-Morstinowa, Zagadnienia. Wobec starości, ,TP” 1948 nr 41 s. 2.

${ }^{223}$ M. Strebejko, Erytrea drażliwy problem polityczny, ,TP” 1948 nr 10 s. 4.

224 „TP” 1950 nr 6 s. 12.

225 J. Radwan, Książki dla młodzieży, „TP” 1949 nr 20 s. 10.

226 Np. Z wydawnictw katolickich, ,TP” 1950 nr 28 s. 6. 
kowano Notatki o ksiażkach (od nru 6 s. 8), w których powiadamiano o nowościach wydawniczych. Występowały one równolegle ze starszą rubryką W'́ród książek. Powyższe zagadnienia staną się jeszcze przedmiotem bardziej szczegółowych rozważań w dalszej części pracy.

Od numeru 32 z 1945 r. każdorazowo wypełniała m.in. ostatnią stronę (s. 8) rubryka Czasopisma, w której przybliżano polskie tytuły prasowe wraz z ich zawartością. W kolejnych numerach (od 37 z 1945 r.) przemianowana została na W'́ród czasopism. Więcej miejsca poświęcono jej w 1946 r. po poszerzeniu pisma o kilka stron, po czym znów zmieniono nagłówek na W'́ród czasopism religijnych, Czasopisma religijne, Czasopisma katolickie. Tutaj głównie wybierano wypowiedzi opublikowane w „Znaku”, „Ruchu Biblijnym i Liturgicznym”, „Polonia Sacra" i „Collectanea Theologica”227. Po raz pierwszy w numerze 41 z 1946 r. (s. 11) wyodrębniono Tydzień prasy polskiej, gdzie drukowano według tematów ciekawsze wiadomości zaczerpnięte z niektórych tytułów prasowych z ostatniego tygodnia. Obecny był także Przeglad prasy (w 1948 r. nr 40), w którym zwrócono uwagę na wypowiedzi publicystów „Kuźnicy”, jak też na zawartość mniej znanych periodyków. Przykładowo z okazji wydania setnego numeru „Strażnicy Ewangelicznej”, dwutygodnika polskiego Kościoła ewangelicko-augsburskiego, omówiono jego łamy ${ }^{228}$. Rubrykę utrzymano do końca. Po raz pierwszy kolumna Z Zachodu znalazła się w zeszycie 32 z $1945 \mathrm{r}$. Nie zawsze obecna, raz pojawiła się pod nagłówkiem (w nrze 36 z 1945 r.) Przez prasę francuska i Przez prasę angielska $q^{229}$.

Ostatnie strony od początku istnienia „Tygodnika Powszechnego" zajęły reklamy artykułów, np. wody mineralnejej ${ }^{230}$ czy kosmetyków ${ }^{231} \mathrm{~W}$ ogłoszeniach reklamowano czasopisma ${ }^{232}$ lub zachęcano do członkowstwa w Towarzystwie Przyjaciół Katolickiego Uniwersytetu Lubelskiego. Na samym końcu pisma czasami niezbędne były Sprostowania redakcji, w których przepraszano i poprawiano błędy drukarskie lub pomyłki zaistniałe w poprzednich numerach. Na ostatniej stronie gościł (od nru 6 z 1946 r.) humor rysunkowy i słowny ${ }^{233}$.

Wiersze - od początku obecne na łamach „Tygodnika Powszechnego" - zazwyczaj drukowano w dwóch miejscach na różnych stronach. Prezentowano twórczość znanych poetów: Cypriana Kamila Norwida, Wojciecha Bąka, Leopolda Staffa, Krzysztofa Kamila Baczyńskiego, Jana Sztaudyngera, Krzysztofa Kamila Baczyńskiego, Konstantego Ildefonsa Gałczyńskiego, Jarosława Iwaszkiewicza, Paula Claudela.

227 Czasopisma katolicie, ,TP” 1949 nr 24 s. 11.

228 J.M.S. [J.M. Święcicki], Przegląd prasy. Protestantyzm i anglikanizm, „TP” 1950 nr 47 s. 7.

229 W.N., Z Zachodu. „,Morderstwo w katedrze”, „TP” 1946 nr 3 s. 5.

230 ,TP" 1947 nr 11 s. 12.

231 „TP" 1947 nr 23 s. 9.

${ }^{232}$ Np. ,Państwa i Prawa”, ,TP” 1947 nr 4 s. 4.

233 Np. ,TP” 1946 nr 6 s. 8. 
Bogatą zawartość pisma urozmaiciły ponadto rubryki obyczajowe wprowadzone przez redakcję w 1950 r. Z katalogu zalet narodowych obecną na ostatniej stronie co kilka numerów prowadził publicysta ukrywający się pod pseudonimem garb. lub Garb. Od numeru 32 z tegoż roku (s. 2, czasem na s. 6) drukowano rubrykę obyczajową Patrze $i$ stucham, pod którą podpisywał się z kolei Mors. W numerze 41 z 1952 r. weszła (na s. 4) natomiast część zatytułowana Rocznice; w niej upamiętniano poprzez noty biograficzne nazwiska znanych pisarzy i działaczy. Niektóre działy wprowadzano jakby na próbę, stąd np. krótko obecne Glossy w 1945 r., w których rozpatrywano kwestie moralne ${ }^{234}$ czy Uwagi Hanny Malewskiej z 1949 r.

Ciągłe zmiany działów i rubryk dokonane w piśmie w latach 1945-1953 dowodzą podejmowania przez współpracowników szerokiej problematyki społecznej, kulturalnej i obyczajowej. Przedstawiano ją w zależności od charakteru danego działu - w sposób poważny lub humorystyczny, starając się jednocześnie zachować odpowiednie proporcje różnych form wypowiedzi w poszczególnych numerach. Dzięki temu czasopismo wciąż budziło zainteresowanie odbiorców, którzy otrzymywali nowe i bogate w treści publikacje.

\section{Charakterystyka ogólna i ideowa pisma}

\section{Problematyka religijna, katolicka i nauka społeczna Kościoła}

$\mathrm{Na}$ łamach periodyku poruszano bardzo bogatą i różnorodną problematykę. Zawartość tytułu prasowego wyróżniały przede wszystkim aktualne zagadnienia religijne. Znalazły one odzwierciedlenie w dokumentach Kościoła ${ }^{235}$, listach i orędziach pasterskich ${ }^{236}$, komunikatach Episkopatu Polskii ${ }^{237}$, rozważaniach wielkopostnych ${ }^{238}$, niekiedy przemówieniach papieskich ${ }^{239}$ oraz osobnych artykułach $^{240}$. Szeroko omawiano społeczne kwestie katolickie ${ }^{241}$. Nie zabrakło tematów z za-

${ }^{234}$ W. Natanson, Glossy. Nikt nie może odpowiadać za cudze winy, „TP” 1945 nr 38 s. 4.

${ }^{235}$ Dokumenty. Front chrześcijańskiego sumienia. Przemówienie papieża Piusa XII do kolegium kardynatów w dniu 2 czerwca 1948, „TP” 1948 nr 27 s. 10.

${ }^{236}$ Np. O panowanie Ducha Bożego w Polsce. Wielkopostny list pasterski Episkopatu, „TP” 1946 nr 11 s. 3-4; List pasterski Episkopatu Polski, „TP” 1948 nr 45 s. 1; S. Wyszyński, Katolicki Uniwersytet Lubelski. List Prymasa Polski, „TP” 1949 nr 19 s. 5; A.S. Sapieha, Orędzie na „,Tydzień miłosierdzia", tamże, nr 39 s. 1.

${ }^{237}$ Komunika Episkopatu Polski do wiernych, „TP” 1950 nr 18 s. 1.

${ }^{238}$ E. Jastrząb, Rozmyślania wielkopostne, „TP” $1946 \mathrm{nr} 15$ s. 2.

${ }^{239}$ Pius XII, Ojca św. Piusa XII zapowiedź jubileuszu na rok święty 1950, „TP” 1950 nr 1 s. 2.

${ }^{240}$ Np. J. Maritain, Religia i kultura, „TP” 1949 nr 15/16 s. 1-2.

${ }^{241}$ J.M. Święcicki, O katolickim maksymalizmie, „TP” 1947 nr 5 s. 1, 3; M. Winowska, Obrady intelektualistów katolickich, „TP” 1948 nr 28 s. 3-4; A. Rogalski, Publicystyka katolicka w Niemczech dzisiejszych, tamże, s. 5-6; Katolicy i ekumenizm, tamże, nr 29 s. 11; J.M. Święcicki, 
kresu filozofii chrześcijańskiej ${ }^{42}$, światopoglądu chrześcijańskiego ${ }^{243}$, wartości chrześcijańskich ${ }^{24}$, humanizmu i personalizmu chrześcijańskiego ${ }^{245}$, kultury katolickiej ${ }^{246}$, sensu cierpienia ${ }^{247}$, relacji między religią i nauką ${ }^{248}$ oraz pochodzenia człowieka249. Głębszym refleksjom duchowym poświęcono cykl Rozważań o mszy świętej. W kręgu zainteresowań była też działalność stowarzyszeń i organizacji katolickich. Często pisano o działalności Caritas oraz organizowanym Tygodniu Miłosierdzia ${ }^{250}$. Odnoszono się do spraw misjii ${ }^{251}$ i zapoznawano z sytuacją katolicyzmu w innych krajach ${ }^{252}$.

Nie zabrakło trudnych tematów, jak np. dotyczących ustrojów społecznych ${ }^{253}$, stosunku katolicyzmu do liberalizmu ${ }^{254}$, ideologii marksistowskiej ${ }^{255}$ (głównie artykuły ks. Jana Piwowarczyka ${ }^{256}$ ) czy antypapieskich nastrojów w prasie polskiej po $1945 \mathrm{r}$.

O katolicka dyscyplinę, „TP” 1949 nr 14 s. 2; K. Górski, Spoleczna rola katolicyzmu w XVI-XVIII w., tamże, nr 24 s. 1-2; tenże, Społeczne oblicze katolicyzmu polskiego w latach 1815-1863, „ТP” 1950 nr 28 s. 1; H. Gaj, Religia stowa, „TP” 1951 nr 18 s. 1-2, 9; A. Bardecki, Katolicyzm w miniaturze, tamże, $\mathrm{nr} 43$ s. 3-4.

${ }^{242}$ S. Świeżawski, Myśl chrześcijańska w obronie materii, „TP” 1948 nr 27 s. 1-2; P. Szary, O wartości tomizmu, „TP” $1950 \mathrm{nr} 10 \mathrm{~s} .1-2$.

${ }^{243}$ P. Chojnacki, Rozwój i postęp światopoglądu chrześcijańskiego, „TP” $1950 \mathrm{nr}$ 15/16 s. 4-5.

244 J.M. Święcicki, Miłosierdzie - cnota wzgardzona, „TP” 1948 nr 40 s. 2.

245 J.M.S. [J.M. Święcicki], Przegląd prasy. Humanizm chrześcijański i praca, „TP” 1950 nr 14 s. 11; M. Plezia, Z dziejów światopogladu humanistycznego, tamże, nr 18 s. 2-3; J.M.S. [J.M. Święcicki], Przegląd prasy. Z zagadnień chrześcijańskiego humanizmu, tamże, nr 36 s. 11.

${ }^{246}$ J. Turowicz, Nihilizm, kultura i katolicyzm, „TP” 1950 nr 13 s. 1-2.

${ }^{247}$ M. Winowska, Najtrudniejsza rewolucja, „TP” 1947 nr 33 s. 6; M. Rękas, Chrześcijańska postawa wobec cierpienia, „TP” $1950 \mathrm{nr} 4$ s. 2.

248 J. Piwowarczyk, Religia i nauka, „TP” 1949 nr 7 s. 3.

${ }^{249}$ Z.B. Fróg, Katolik a pochodzenie człowieka, „TP” $1950 \mathrm{nr} 2$ s. 7; tenże, Ewolucja i katolicyzm, tamże, nr 14 s. 6; T. Rylska, W obronie teorii ewolucji, tamże, s. 7, 10.

${ }^{250}$ J. Piwowarczyk, ,, Caritas” w nowych warunkach, „TP” $1945 \mathrm{nr} 24$ s. 7; tenże, Tydzień dla - czlowieka, „TP” 1947 nr 40 s. 1; P. Jasienica, Trudnego życia towarzysz, „TP” 1947 nr 41 s. 7-8; J. Piwowarczyk, Etyczna wspólnota rodziny, „TP” 1948 nr 40 s. 1-2; Papieska „Caritas”, „TP” 1949 nr 6 s. 11.

${ }^{251}$ L. Czerwiec, Biali i kolorowi, „TP” $1948 \mathrm{nr} 41$ s. 5; J.R. Łoniowski, Romantyzm i realizm misyjny, tamże, nr 48 s. 4.

${ }^{252}$ Z. Starowieyska-Morstinowa, Rozkwit katolicyzmu w Anglii, „TP” 1946 nr 34 s. 5; zsm. [Z. Starowieyska-Morstinowa], Kościót w Japonii, tamże, nr 43 s. 8.

${ }^{253}$ J. Piwowarczyk, Sprawiedliwy ustrój, „TP” 1947 nr 20 s. 1.

${ }^{254}$ Dyskusję na łamach periodyku wywołał artykuł J. Piwowarczyka, Spór o liberalizm, „TP” $1950 \mathrm{nr} 20$ s. 3. Na ten temat wypowiedzieli się również: S. Kisielewski, Na okopach liberalizmu, tamże, nr 24 s. 6-7; odpowiedział J. Piwowarczyk, Atak na okopy, tamże, s. 7; J.M. Święcicki, Liberalizm - pogląd na świat czy idea?, tamże, s. 8-9.

${ }^{255}$ H. Malewska, Ewolucja marksizmu, „TP” 1946 nr 7 s. 2-3.

${ }^{256}$ Np. J. Piwowarczyk, Etyka marksizmu, „,TP” 1945 nr 34 s. 2; Socjologia marksizmu, tamże; Jeszcze marksizm, „TP” 1946 nr 3 s. 4; Wieś i marksizm, „TP” 1947 nr 18 s. 1-2. 
Redakcja w wyraźny sposób przeciwstawiała się propagandzie antypapieskiej prowadzonej przez komunistów. Starano się zatem ukazać stosunek papieża do Polski w prawdziwym świetle, m.in. w cyklu Pius XII i Polska ${ }^{257}$. Polemizowano z wypowiedziami p. ,jaszcza” z „Dziennika Polskiego”258. Właściwemu naświetleniu stosunku Stolicy Apostolskiej do Polski w czasie wojny służył ciąg wypowiedzi na podstawie dokumentów Watykan a Polska ${ }^{259}$. Problematyka papieska znalazła również odzwierciedlenie w artykułach z 1946 r. opartych na książce C.M. Cianfarny ${ }^{260}$. Przedstawiano także opinie papieża Piusa XII dotyczące własności, kultury wsi, systemu kapitalistycznego i demokracji261. W 1947 r. w każdym numerze w Przegladzie religijnym przybliżano stosunek papieża do wojny, dementując fałszywe sądy ${ }^{262}$. Jerzy Turowicz zapytywał, czym jest walka z reakcją ${ }^{263}$. Szeroko ujmowano zagadnienia stosunków państwa z Kościołem oraz roli Kościoła w powojennej Polsce ${ }^{264}$.

Na łamach pisma zareagowano na zerwanie konkordatu przez nowy rząd ${ }^{265}$. Aktualna w 1945 r. dyskusja nad reformą prawa małżeńskiego była żywo obecna zarówno w artykułach, jak i w listach pasterskich biskupów ${ }^{266}$. Ustosunkowano się również do współczesnych wymagań wobec rodziny i jej utrzymania ${ }^{267}$, a także istoty małżeństwa ${ }^{268}$, wyznania małżonków ${ }^{269}$, problemu rozwodów ${ }^{270}$.

257 J. Piwowarczyk, Pius XII i Polska, „TP” 1945 nr 14 s. 2; Red., Antypapieska kampania, tamże, Okruchy. Pius XII a Polska, tamże, nr 39 s. 7; nr 37 s. 1; Okruchy. Pius XII a zastugi i prawa Polski, „TP” 1946 nr 3 s. 3; K-k., Okruchy. Żóttodzióby dziennikarskie, tamże, s. 5.

${ }^{258} \mathrm{~K}-\mathrm{k}$, Okruchy. Ofiara histerii, „TP” 1946 nr 4 s. 2; J. Wierusz-Kowalski, Prawdziwy $i$, ,prawdziwy” katolik, tamże, nr 5 s. 6.

${ }^{259}$ A. Maglione, Stolica święta w obronie praw polskich katolików, „TP” $1946 \mathrm{nr} 17$ s. 3-4.

${ }^{260}$ M. Strebejko, Habemus papam, „TP” $1946 \mathrm{nr} 45$ s. 3; Nadciagająca burza, tamże, nr 46 s. 9; Rok 1939 w Rzymie, tamże, nr 48 s. 3-4.

${ }^{261}$ J. Piwowarczyk, Pius XII na tle „nowych czasów”, „TP” 1946 nr 25 s. 1-2; J. Karolczyk, Pius XII o kulturze wsi, „TP” 1947 nr 2 s. 9.

${ }^{262}$ L.K., Przegląd religijny. Pius XII i Ribbentrop, „TP” 1947 nr 7 s. 13; Pius XII i Mussolini, tamże, nr 8 s. 10; Papieska rocznica, tamże, nr 9 s. 9; Pius XII a triumfy ,osi”, tamże; J.P. [J. Piwowarczyk], Bez ogródek. P. Prezydent Bierut o Piusie XII, tamże, nr 16 s. 12.

263 J. Turowicz, Reakcja i ,reakcja”, „TP” 1946 nr 14 s. 1.

${ }^{264}$ A. Hlond, Rola Kościoła po wojnie, „TP” 1945 nr 34 s. 1; (kjw), Z Zachodu. Kościót a świeckość państwa, „TP” $1946 \mathrm{nr} 9$ s. 7.

${ }^{265}$ Redakcja, W sprawie konkordatu, „TP” $1945 \mathrm{nr} 27$ s. 6.

${ }^{266}$ Małżeństwo cywilne; E.Ch. [E. Chomrański], Cele matżeństwa, „TP” $1945 \mathrm{nr} 13$ s. 4; Episkopat polski w sprawie reformy prawa matżeńskiego, „TP” $1945 \mathrm{nr} 19$ s. 4; E. Chomrański, Matżeństwo wobec państwa, tamże; Nauka Kościoła o matżeństwie. List pasterski biskupów polskich z roku 1921, tamże, nr 20 s. 4-6; Dokoła ślubów i rozwodów, tamże, nr 24 s. 8; P., Okruchy. „Pokrzywdzona kobieta”, tamże, nr 38 s. 4; E. Chomrański, Nowe prawo matżeńskie, tamże, nr 41 s. 2.

${ }^{267}$ J. Piwowarczyk, Rodzina i jej podstawy, „TP” 1947 nr 12 s. 1-2; tenże, Rodzina - dziś, „TP” 1950 nr 2 s. 4.

${ }^{268}$ Z. Starowieyska-Morstinowa, Matzeństwo na nowo odkryte, „TP” $1947 \mathrm{nr} 47$ s. 4-5.

${ }^{269}$ J.K., Malżeństwo i wyznanie, „TP” $1948 \mathrm{nr} 37$ s. 11.

${ }^{270}$ J. Czekanowski, Rozwody w USA, „TP” 1950 nr 27 s. 7. 
W przeglądzie prasy zwrócono uwagę na sytuację małżeństwa w ZSRR ${ }^{271}$, a także na rozwój rodziny w ciągu wieków ${ }^{272}$. Na temat czystości miłości międzyludzkiej prowadzącej do małżeństwa i przynależności cielesnej wypowiadał się ks. Karol Wojtyła $^{273}$. Poruszano także sprawy obyczajowe ${ }^{274}$ i dotyczące aborcji ${ }^{275}$. Osobne miejsce zajęła problematyka dotycząca kobiet; rozważano m.in. przyczyny i skutki samotnego ich życia, powołania i pracy ${ }^{276}$.

Powyższe zagadnienia traktowane były priorytetowo przez redakcję, która starała się upowszechniać wypowiedzi znanych publicystów i teoretyków. W artykułach zazwyczaj dobrze argumentowano różne kwestie i poważnie podchodzono do tematyki. Wyrażanie opinii w powyższych sprawach stale ograniczała cenzura.

\section{Wychowanie}

Istotne miejsce w tygodniku zajęła problematyka szkolna i wychowawcza ${ }^{277}$. Pod nagłówkiem Dyskusja szkolna poprowadzono (od nru 26 z 1945 r.) polemikę z podjętą przez rząd reformą szkolnictwa ${ }^{278}$. Rozważano funkcje wychowania $\mathrm{w}$ przedszkolu ${ }^{279}$, zapoznawano z personalistycznym ideałem wychowawczym ${ }^{280}$ oraz wypowiadano się na temat nauczania religii $w$ szkole $^{281}$. Kwestie $\mathrm{z}$ tym związane naświetlano także w kontekście encykliki papieża Piusa XI ${ }^{282}$, zapoznawano z pedagogiką Makarenki ${ }^{283}$ i znaczeniem wychowawczym ogrodów (idea

${ }^{271}$ J.M.S. [J.M. Święcicki], Przegląd prasy. Matżeństwo w ZSRR, „TP” 1950 nr 29 s. 11.

272 J. Turowski, Przemiany społeczności rodzinnej, „TP” $1952 \mathrm{nr} 35$ s. 3-4.

273 J. Rozwadowski, Kłopotliwa sprawa, „TP” 1949 nr 46 s. 4-5; K. Wojtyła, Instynkt, miłość, malżeństwo, „TP” $1952 \mathrm{nr} 42$ s. 1-2, 11; tenże, Religijne przeżywanie czystości, „TP” $1953 \mathrm{nr} 6 \mathrm{s.}$ 1-2.

274 J.M. Święcicki, Z perspektyw obyczajowego liberalizmu, „TP” $1949 \mathrm{nr} 40$ s. $5,7$.

${ }^{275}$ W. Majdański, Życie najstabszych, „TP” 1949 nr 42 s. 6-7.

${ }^{276}$ F. Żurowska, Problem kobiety niezamężnej, „TP” 1951 nr 28 s. 3-4; taż, Dyskusja o kobiecie niezamężnej, „TP” 1952 nr 38 s. 6; Z. Starowieyska-Morstinowa, Druga strona medalu, tamże, s. 7; Przeglad prasy. O powołaniu kobiety, tamże, nr 16 s. 7.

277 Szerzej zob. M. Strzelecka, Trudne kompromisy ...

${ }^{278}$ J.R., Dyskusja szkolna. Zjazd oświatowy w Łodzi, „TP” 1945 nr 26 s. 6; K. Krobicki, Szkoła powszechna i średnia, tamże, nr 27 s. 6; M. Tazbir, Szkoła ogólnokształcaca, tamże, nr 28 s. 7; S. Pigoń, O prawdziwej reformie uniwersyteckiej, tamże, nr 29 s. 6; W. Błachut, Materialne podstawy pracy nauczycielstwa, tamże, nr $30 \mathrm{~s}$. 7; S. Sobalkowski, Wolność sumienia i nauczanie religii, tamże, nr 39 s. 7; Z. Starowieyska-Morstinowa, Udziat rodziców w pracach szkoły, „TP' $1946 \mathrm{nr} 4$ s. 7; J. Szczygiel, Agronom w szkole, tamże, nr 9 s. 7.

${ }^{279}$ S. Szuman, Wychowanie w rodzinie czy w przedszkolu, „TP” 1946 nr 39 s. 6.

${ }^{280}$ K. Górski, Problemy personalizmu pedagogicznego, „TP” $1947 \mathrm{nr} 22$ s. 7; tenże, Personalizm a programowa struktura szkolnictwa, tamże, $\mathrm{nr} 23$ s. 6.

${ }^{281}$ L.B., Religijne wychowanie matych dzieci, „TP” 1948 nr 34 s. 11; S. Szuchowa, Granice fantazji w życiu religijnym dziecka, tamże, nr 36 s. 11; L.K., Katolicy a szkoła w Czechach, „TP” 1947 nr 23 s. 10; J. Mroczkowska, Dziecko odnalezione, „TP” 1949 nr 47 s. 3-4.

282 J. Piwowarczyk, Człowiek i jego wychowanie, „TP” 1947 nr 34 s. 7.

283 J.M. Święcicki, Z pedagogiki radzieckiej, „TP” $1951 \mathrm{nr} 42$ s. 3-4. 
ogródków dziecięcych) ${ }^{284}$. Nie zabrakło także problematyki ogólnie wychowawczej ${ }^{285}$. Niekiedy w kręgu zainteresowań pozostawały szkoły wyższe wraz z ich historią. Przede wszystkim ukazywano działalność KUL-u i przypominano dzieje Uniwersytetu Jagiellońskiego ${ }^{286}$. Czytelnicy poznali też dominikańską „Szkołą Mądrości" (Eau-Vive) we Francji, w której program studiów oparto na dorobku chrześcijańskiej filozofii i nauki ${ }^{287}$.

Zagadnienia pedagogiczne zajęły ważne miejsce w czasopiśmie. Publicyści podejmowali je w duchu ewangelicznym, dając pewne wskazówki co do wychowawczej odpowiedzialności za młode pokolenie.

\section{Zagadnienia polityczne}

Zgodnie z programowym założeniem pisma, pochodzenie człowieka ${ }^{288}$, jego prawa $^{289} \mathrm{i}$ wpływ ustroju na niego ${ }^{290}$ omawiano w perspektywie personalistycznej. Kwestie polityczne starano się interpretować w duchu katolickimm ${ }^{291}$, szukając przy tym właściwej relacji jednostki do państwa ${ }^{292}$. Zastanawiano się nad założeniami liberalizmu (Dyskusja nad liberalizmem ciag dalszy) ${ }^{293}$ i kapitalizmu ${ }^{294}$. Filozoficzne podstawy marksizmu i podejście marksistów do własności prywatnej i społecznej analizował ks. J. Piwowarczyk ${ }^{295}$.

${ }^{284}$ T. Wierzbicki, Ogrody dziecięce, „TP” 1951 nr 44 s. 10.

${ }^{285}$ K. Górski, Wartości wychowawcze humanistyki, „TP” 1946 nr 5 s. 1-2; J. Piwowarczyk, Wychowanie nowego człowieka, tamże, nr 33 s. 1; tenże, Wychowanie mas, tamże, nr 50 s. 2-3.

${ }^{286}$ J. Ciechocki, K. U. L. pracuje, „TP” 1948 nr 10 s. 6-8; T. Glemma, Wydziat teologiczny U. J. przed 100 laty, tamże, nr 15 s. 2; M. Szyjkowski, 600 lat uniwersytetu Karola, tamże, nr 17 s. 5; C. Strzeszewski, Katolicki Uniwersytet Lubelski 1918-1948, tamże, nr 43 s. 1; K. Turowski, Pochwata Katolickiego Uniwersytetu Lubelskiego, tamże; J. Ciechocki, K.U.L., „TP” $1951 \mathrm{nr} 20$ s. 1-2; Odezwa Episkopatu Polski w sprawie Katolickiego Uniwersytetu Lubelskiego, tamże, nr 50 s. 2; A. Wojtkowski, Ks. Idzi Radziszewski i powstanie uniwersytetu katolickiego w Lublinie, „TP” $1952 \mathrm{nr} 21$ s. 3-4.

${ }^{287}$ M. Petry, Szkoła Madrości, „TP’ 1950 nr 15/16 s. 7.

288 O pochodzeniu człowieka, "TP” 1947 nr 9 s. 6-8; tamże, nr 10 s. 6-8; J. Zdrój, Sprawa pochodzenia człowieka, „TP” 1949 nr 5 s. 6-7; K. Lucjański, Katolik a pochodzenie człowieka, „TP” 1950 nr 8 s. 4-5.

289 J. Ciechocki, Człowiek - pojęcie najtrudniejsze, „TP” 1947 nr 41 s. 1, 8.

${ }^{290}$ S. Szymański, Prawda o człowieku, „TP” 1948 nr 51 s. 1.

${ }^{291}$ S. Kisielewski, Sytuacja polityczna, „TP” 1946 nr 6 s. 2-3; J. Piwowarczyk, Kościót a ustrój spoleczny, „TP” $1950 \mathrm{nr} 28$ s. 4.

292 J. Piwowarczyk, Człowiek - państwo, „TP” 1947 nr 14/15 s. 2-3.

${ }^{293}$ L. Tyrmand, Positki dla okopów pierwszej linii, „TP” 1950 nr 29 s. 4-5; J. Piwowarczyk, Kula w płot, tamże, s. 5; J. Zabłocki [K. Zajczniewski], Liberalizm czyli krzywda społeczna, tamże, nr 34 s. $2,10$.

${ }^{294}$ M. Str. [M. Strebejko], Ameryka Łacińska i kapitalizm, „TP” 1950 nr 29 s. 6.

295 J. Piwowarczyk, Filozofia marksizmu, „TP” 1945 nr 31 s. 1; tenże, Własność w systemie Marksa, tamże, nr 37 s. 2; tenże, Dylemat na punkcie własności, „TP” 1946 nr 11 s. 2; Wolność i własność, tamże, $\mathrm{nr} 20$ s. 1. 
Problematykę międzynarodową i europejską poruszano w różnych aspek$\operatorname{tach}^{296}$. Zastanawiano się nad trwałością pokoju światowego ${ }^{297}$ i nad istotą demokracji298. Pisano o sytuacji we Francji po wyborach 1945 r. ${ }^{299}$, a także o zagrożeniu bombą atomową ${ }^{300}$. Zdecydowanie rzadziej podejmowano problem dyplomacji ${ }^{301}$. Tematem godnym uwagi publicystów „Tygodnika Powszechnego” stała się również sprawa polskiej granicy zachodniej ${ }^{302}$ i Ziem Odzyskanych ${ }^{303}$ (nr 29 z 1952 r. był w całości poświęcony temu zagadnieniu). Na łamach pisma przedstawiono nawet plan sześcioletni ${ }^{304}$.

Kwestie polityczne jeżeli były omawiane to raczej w szerszym kontekście światopoglądowym i w sposób ogólny. Najczęściej konfrontowano je z nauką społeczną Kościoła lub oceniano pod kątem służby społeczeństwu.

\section{Problematyka wojenna i niemiecka}

W pierwszych latach powojennych pisano w tygodniku o zbrodniach niemieckich $^{305}$, obozach koncentracyjnych ${ }^{306}$, a także wyrokach Międzynarodowego

${ }^{296}$ J. Czekanowski, Przeobrażenia Europy, „TP” 1946 nr 10 s. 1-2; tenże, Czy katastrofa Europy?, tamże, nr 11 s. 4-5; E. Szykowska, Unesco, uniwersalizm i rzeczywistość, „TP” $1947 \mathrm{nr} 29$ s. 3-4; P. Jasienica, Pozory i konieczności, tamże, nr 49 s. 1-2; K. Szwarcenberg-Czerny, Stolica apostolska jako współczynnik stosunków międzynarodowych, „TP” 1948 nr 33 s. 1-2, 11; H. Dembiński, Prawa czlowieka jako problem międzynarodowy, tamże, nr 41 s. 1, 4; K. Szwarcenberg-Czerny, Problem Dunaju, „TP” 1949 nr 10 s. 3-4.

${ }^{297}$ J. Piwowarczyk, Pokój i ONZ, „TP” 1946 nr 46 s. 2-3; tenże, Papieski głos o pokoju, „TP” 1948 nr 3 s. 3; Z. Starowieyska-Morstinowa, PAX, „TP' 1949 nr 14 s. 1-2.

${ }^{298}$ I. Jaworski, Stara i nowa demokracja, „TP” 1945 nr 14 s. 1-2; A. Mycielski, Demokracja wedtug konstytucji r. 1921, tamże, nr 25 s. 1; Co to jest demokracja?, „TP” 1946 nr 24 s. 1, 3; H. Dembiński, Oligarchia i demokracja, „TP” 1947 nr 1 s. 2.

${ }^{299}$ J. Karolczyk, Przemiany we Francji, „TP” 1945 nr 33 s. 1-2.

${ }^{300}$ A. Piekara, Wynalazek, który wygrat wojnę, „TP” $1945 \mathrm{nr} 40$ s. 15.

${ }^{301}$ K. Szwarcenberg-Czerny, O dyplomacji i dyplomatach, „TP” 1947 nr 30 s. 5-6.

${ }^{302}$ L. Górski, Geograficzne podstawy granic zachodnich, „TP” $1945 \mathrm{nr} 20$ s. 1-2; tamże, nr 21 s. 5; E. Osmańczyk, O bezpieczeństwo zachodniej granicy, „TP” $1946 \mathrm{nr} 28$ s. 1-3.

${ }^{303}$ F. Ćwikowski, Polski rok - na Dolnym Ślasku, „TP” 1946 nr 15 s. 3-4; A. Kutrzebianka, Problemy Ziem Odzyskanych, tamże, nr 27 s. 6; J. Czekanowski, Prusy czy Pomorze Wschodnie, nr 33 s. 4-5; J. Brudzewski, Nauka dla Ziem Odzyskanych, „TP” 1947 nr 3 s. 4; M.A. Wasilewski, Na Mazurach, tamże, nr 8 s. 5; K. Rakowski, Zagadnienia. Zaludnienie Zachodu, tamże, nr 12 s. 2; A. Ryb., Kościół na Ziemiach Odzyskanych, tamże, nr 17 s. 8; St., Zjazd wrocławski, „TP” 1952 nr 2 s. 3-4; Nowe uprawnienia kanoniczne wikariusza kapitulnego w Gorzowie, tamże, nr 26 s. 4.

${ }^{304}$ A. Bocheński, Plan sześcioletni, „TP” 1950 nr 34 s. 6-7, 10.

${ }^{305}$ W. Adamowicz, Zbrodnie niemieckie w Polsce, „TP” 1948 nr 29 s. 7; J.P. Gawlik, Na tropach wielkiej zbrodni, ,TP” $1951 \mathrm{nr} 11$ s. 3-4.

${ }^{306}$ W. Wnuk, Hiszpanie za drutami Gusen, „TP” 1946 nr 35 s. 5; S. Stomma, Problem Oświęcimia, „TP” 1947 nr 27 s. 3-4; Z. Bączkowska, Oświęcim wiecznie żywy, „TP” 1950 nr 29 s. 3. 
Trybunału Wojskowego w Norymberdze ${ }^{307}$. Problematyka wojenna ${ }^{308}$ i niemiec$\mathrm{ka}^{309}$ była żywo i stale obecna na pierwszych stronach pisma ${ }^{310}$. Z początkiem 1947 r. znany był czytelnikom cykl artykułów Pawła Jasienicy pod nagłówkiem $Z$ pobojowiska nad Wista, w którym publicysta starał się wyjaśniać zawiłości wydarzeń wojennych ${ }^{311}$. Tematowi wojny szczególnie dużo uwagi poświęcono w numerze 26 z 1948 r. $^{312}$, następnie kontynuowano ten wątek w kolejnych zeszytach czasopisma ${ }^{313}$. Do trudnych kwestii mordów wojennych podchodzono od strony historycznej, filozoficznej ${ }^{314}$ i psychologicznej ${ }^{315}$. W cyklu III Rzesza na drodze do katastrofy zapoznawano czytelników z kulisami polityki wewnętrznej państwa niemieckiego ${ }^{316}$. Odnoszono się również do współczesnego katolicyzmu w Niemczech ${ }^{317}$. Zastanawiano się, czy było obecne wśród Niemców poczucie odpowiedzialności za krzywdy wyrządzone przez hitlerowców ${ }^{318}$. Oprócz demaskowania zbrodni wojennych ${ }^{319}$ odsłaniano tajemnice i zagadki historii Niemiec

${ }^{307}$ M. Jezierska, Obrachunek, „TP” 1946 nr 35 s. 6; J. Piwowarczyk, Wyrok w Norymberdze, tamże, nr 41 s. 1; A.J. Kamiński, Proces norymberski nauki niemieckiej, „TP” 1947 nr 20 s. 6, 8.

308 J. Dąbrowski, Po kataklizmie, „TP” 1945 nr 24 s. 1-2; K. Górski, O szarżach na czotgi, „TP” 1947 nr 11 s. 4; W. Sadowski, Przed dziesięciu laty byt Narwik, „TP” 1950 nr 21/22 s. 5.

309 J. Karolczyk, Wizerunek niemieckiego rasizmu, „TP” 1945 nr 29 s. 2; E. Osmańczyk, Niemcy w roku 1945, „TP” 1946 nr 3 s. 1-2; A. Woycicki, „Nowe Niemcy”, tamże, nr 5 s. 6; E. Osmańczyk, Hitler po raz ostatni, tamże, nr 8 s. 3-4; J. Zagórski, Sens Norymbergii, tamże, nr 17 s. 1; F.W. Foerster, Odpowiedź Churchillowi, tamże, nr 46 s. 1-2; K. Rakowski, Idee przewodnie traktatu pokojowego z Niemcami, „TP” 1947 nr 3 s. 1; A. J. Kamiński, Z zagadnień moralnych młodzieży niemieckiej, tamże, nr 4 s. 1, 3-4; T. Koniński, Franz von Papen, tamże, nr 43 s. 2; W sprawie Niemiec Zachodnich, „TP” $1950 \mathrm{nr} 45$ s. 2; Bonawentura, Sprawa niemiecka, „TP” 1951 nr 8 s. $1-2$.

${ }^{310}$ W. Lipiński, Operacja „, Overlord”, „TP” 1946 nr 25 s. 4-5.

311 P. Jasienica, Z pradem historii, „TP” 1946 nr 18 s. 2; tenże, Sprawy września, „TP” 1947 nr 3 s. 3-4; tenże, ... głodu, ognia i wojny..., tamże, nr 4 s. 3-4.

${ }^{312}$ M.in. J. Piwowarczyk, Zbiorowa odpowiedzialność narodu niemieckiego, „TP” $1948 \mathrm{nr} 26$ s. 1-2; J. Koprowski, Niemcy w ofensywie kulturalnej, tamże, s. 3-4; A. Rogalski, Publicystyka w Niemczech dzisiejszych, tamże, s. 4-5.

${ }^{313}$ W. Konopczyński, Polska myśl polityczna wobec niebezpieczeństwa niemieckiego w czasach nowożytnych, „TP” $1948 \mathrm{nr} 37$ s. 1-2.

${ }^{314}$ S. Kisielewski, Filozoficzne tto hitleryzmu, „TP” 1948 nr 38 s. 1, 9.

315 J. Karolczyk, Zagadka psychologiczna Hitlera, „TP” 1948 nr 43 s. 2; T. Koński, Widnokręgi. Próbka mentalności niemieckiej, tamże, nr 47 s. 4-5.

${ }^{316}$ M. Strebejko, Kryzys Blomberg-Fritsch, "TP” $1948 \mathrm{nr} 46$ s. 5, 9.

317 J. Piwowarczyk, Niemieccy katolicy i Polska, ,TP” 1948 nr41 s. 3-4; J.M.S. [J.M. Święcicki], Przeglad prasy. Z zagadnień niemieckich, „TP” $1950 \mathrm{nr} 30$ s. 8; M. Strebejko, Niepokojace odgłosy. (O postawę katolików zachodnio-niemieckich), tamże, nr 41 s. 2-3.

318 Tenże, Gdzie niemieckie „Confiteor”?, „TP” 1947 nr 30 s. 4; S. Kisielewski, Czy proces oświęcimski spetnit swoje zadanie?, „TP” $1948 \mathrm{nr} 3$ s. 2-3; J.M.S. [J.M. Święcicki], Przegląd prasy. Niemcy i hitleryzm, „TP” 1949 nr 48 s. 7.

${ }^{319}$ E. Ostachowski, Zbrodnie niemieckie na Pomorzu, „TP” 1949 nr 14 s. 3; J.P. Gawlik, Ciężar prawdy i pokusa niepamięci, „TP” 1952 nr 19 s. 2. 
sprzed II wojny światowej i podczas jej trwania ${ }^{320}$. Upamiętniono ponadto rocznice kampanii wrześniowej ${ }^{321} \mathrm{i}$ ustosunkowywano się do demilitaryzacji Niemiec ${ }^{322}$.

Temat ostatniej wojny często gościł na łamach pisma, podejmowany jako swoisty rozrachunek z bolesną i nieodległą jeszcze przeszłością.

\section{Historia}

Problematyka historyczna również posiadała swoje stałe miejsce w tygodniku. Przedstawiano wybrane zagadnienia z historii Polski ${ }^{323}$, z dziejów powszechnych $^{324}$ oraz historii Kościoła ${ }^{325}$. Niekiedy opisywano najnowsze losy innych państw, np. Francji, Włoch, Indii czy Izraela ${ }^{326}$.

Częściej opisywano historię sanktuariów, klasztorów, kościołów oraz ich architekturę 327 . Zapoznawano czytelników z pracami konserwatorskimi prowadzonymi w obiektach zabytkowych na terenie Polski ${ }^{328}$. Publikowano zazwyczaj reportaże i sprawozdania z postępów ich odbudowy lub rekonstrukcji. Szczególne zainteresowanie wzbudzała odbudowa stolicy ${ }^{329}$. Zachęcano też odbiorców do wzięcia udziału w kilkakrotnie organizowanych przez Radę Prymasowską ak-

${ }^{320}$ T. Koński, Kto podpalit Reichstag, „TP” 1949 nr 9 s. 6; M. Strebejko, Pamiętnik hitlerowskiego dyplomaty, „TP” 1950 nr 39 s. 2, 6.

${ }^{321}$ P. Jasienica, Dziesięciolecie, „TP” 1949 nr 35 s. 5.

322 J. Turowicz, Brunatne upiory strasza, „TP” $1951 \mathrm{nr} 47$ s. 1-2.

${ }^{323}$ O. Halecki, Matzeństwo królowej Jadwigi w świetle historii, „TP” 1947 nr 29 s. 1-2; S. Kieniewicz, Wielki czlowiek na tle historii, tamże, nr 32 s. 1-2.

${ }^{324}$ A. Dębno, W poszukiwaniu sensu historii, „TP” 1950 nr 5 s. 1-2.

${ }^{325}$ K. Górski, Geneza fałszerstw krzyżackich, „TP” $1950 \mathrm{nr} 25$ s. 1-2.

${ }^{326}$ A. Wołowski, Italia bez Mussoliniego, „TP” 1946 nr 26 s. 1; A. Gołubiew, „Pierwszy męczennik stowiański”, tamże, s. 3-4; S. Włodarski, Kraj czarnej pagody i czerwonobrodych fakirów, „TP” $1947 \mathrm{nr} 1$ s. 7-8; J. Zawieyski, „Izraelowi, bratu naszemu ..., braterstwo!”, „TP” $1948 \mathrm{nr} 25$ s. 3-4; K. Tatarkiewicz, Listy z Paryża. Prawo z dnia 26 maja 1728 roku [Francja], „TP” 1949 nr 14 s. 4; J. Piwowarczyk, Internacjonalizacja Jerozolimy, „TP” $1950 \mathrm{nr} 1$ s. 6.

${ }^{327}$ M.in. A. Szyszko Bohusz, Opactwo tynieckie, „TP” 1947 nr 16 s. 6-7; K. Koźniewski, Święta Lipka, tamże, nr 33 s. 8; E. Paukszta, Górnoślaska Jerozolima, tamże, nr 41 s. 3; W. Wnuk, Kościót wstający z ruin, „TP” 1949 nr 7 s. 6; J. Woźniakowski, Kościót jakich mało, tamże, nr 15/16 s. 7; P. Jasienica, Srebrna Góra, tamże, nr 17 s. 5-6; R. Aftanazy, Dzieje klasztoru w Lubiążu, tamże, nr 27 s. 3; j.t., Kościót w Minneapolis, „TP” 1951 nr 38 s. 6.

${ }^{328}$ S. Turczyński, Prace konserwatorskie w katedrze wawelskiej, „TP” 1948 nr 2 s. 6; M. Zawadzki, Polichromia czy nagi mur?, tamże, nr 11 s. 4; M. Bukowski, Zabytki Wrocławia w odbudowie, „TP” 1949 nr 6 s. 5-6; Odnowa Katedry wawelskiej, tamże, nr 8 s. 11; M. Ozimek, Konserwacja kościoła św. Andrzeja, tamże, nr 28 s. 11; H. Blumówna, Prace konserwatorskie w katedrze wawelskiej, tamże, nr 48 s. 3; T. Zych, Clara tumba, „TP” 1950 nr 38 s. 1-2; T. Chrzanowski, O nowoczesności i tradycjach $w$ architekturze sakralnej, „TP” $1953 \mathrm{nr} 6$ s. 6.

${ }^{329}$ M. Kurzyna, Warszawskie perspektywy, „TP” 1949 nr 9 s. 4-5; L. Tyrmand, Nowe oblicze starej Warszawy, „TP” 1950 nr 26 s. 1-2; tenże, Sacco di Varsavia, tamże, nr 37 s. 3-4. 
cjach odbudowy kościołów Warszawy i wielkiej loterii fantowej ${ }^{330}$. Zapytywano też, do jakiego stopnia należy odtworzyć zabytki polskich miast ${ }^{331}$.

Czasami tematyka historyczna wykraczała poza dzieje państw i miast, a dotyczyła ciekawostek, np. z ostatnich sekretnych przemówień Winstona Churchilla ${ }^{332}$.

\section{Kultura}

Ze względu na profil czasopisma znaczną część wypowiedzi poświęcono szeroko pojętej kulturze chrześcijańskiej ${ }^{333}$. Jerzy Turowicz podkreślił: „Sprawy kultury katolickiej w Polsce i w świecie, sprawy katolickiej oceny, wartościowania wszystkich zjawisk kultury w Polsce i kultury współczesnej. Sprawa oceny tak dorobku kultury, jak i jej głównych linii, tendencji rozwojowych, sprawa tego, co nazywamy walką o chrześcijańską kulturę jutra. Sprawy te były i są dyskutowane tak na łamach $<<$ Tygodnika Powszechnego $>>$, jak i innych czasopism katolickich"334. Rozważano wpływ i rolę polityki na kulturę oraz jej autonomiczność ${ }^{335}$, naturalną potrzebę rozwoju kulturalnego człowieka ${ }^{336}$, upamiętniano Rok Chopinowski ${ }^{337}$, dyskutowano o kulturze z perspektywy obyczajów ${ }^{338}$, pisano o jej przejawach i formach ${ }^{339}$.

W tygodniku podejmowano często temat sztuki zarówno polskiej34, jak i obcej ${ }^{341}$. Szczególnie uwzględniono jej religijny i kościelny wymiar ${ }^{342}$.

${ }^{330}$ Np. po raz trzeci loterię ogłoszono w „TP” $1950 \mathrm{nr} 41 \mathrm{s.} 6$.

${ }^{331}$ P. Jasienica, Święte popioły, „TP” 1949 nr 38 s. 1-2; J. Turowicz, 7 lat odbudowy, „ТP” 1951 nr 29 s. 1.

${ }^{332}$ M. Strebejko, ,,Torch”, „TP” 1949 nr 21 s. 5.

${ }^{333}$ A. Gołubiew, Mity XIX wieku i chrześcijańska kultura, „TP” $1946 \mathrm{nr} 1 \mathrm{~s} .1-2$; J. Turowicz, Kultura i plan, „TP” 1947 nr 46 s. 1-2; R. Speaight, Chodzi o budowanie kultury, nie o jej obronę, „TP” $1948 \mathrm{nr} 44$ s. 2.

${ }^{334}$ J. Turowicz, Myśli o kulturze, „TP” $1950 \mathrm{nr} 51 / 52$ s. 8-9.

335 Tenże, Kultura i polityka, „TP” 1948 nr 3 s. 1-2.

${ }^{336}$ M. Stokowska, Kultura i natura, ,TP” $1951 \mathrm{nr} 21$ s. 1-2.

${ }^{337}$ J.P. Gawlik, Zapomniana sprawa. (O miejsce w kraju dla Fryderyka Chopina), „TP” 1949 nr 27 s. 2.

${ }^{338}$ A. Bocheński, Gawęda o kulturze, „TP” 1952 nr 33 s. 5, 10-11.

${ }^{339}$ S. Stomma, Dyskusja o kulturze, „TP” $1952 \mathrm{nr} 37$ s. 2-3.

${ }^{340}$ A. Kot-Bahdaj, Życie kulturalne polskiego uchodźctwa na Węrzech, „TP” $1945 \mathrm{nr} 39$ s. 8; J. Doroszewska, Orzet z patyków, „TP” 1946 nr 36 s. 4 [o sztuce ludowej]; H. Blumówna, Witraże T. Wojciechowskiego, „TP” 1947 nr 14/15 s. 9; taż, O sztuce ludowej, „TP” 1948 nr 6 s. 6; taż, Toruń miasto sztuki, tamże, nr 41 s. 5; taż, Z Pałacu Sztuki. Wystawa sztuki ludowej, „TP” $1951 \mathrm{nr} 40$ s. 9.

${ }^{341}$ J. Woźniakowski, Oryginalność, kultura, sztuka, „TP” 1945 nr 39 s. 2; M. Jarczyńska, O aktualności w sztuce, o dyletantyzmie i o Breughelu, „TP” 1946 nr 51/52 s. 6; H. Blumówna, Sztuka narodów Jugostawii, „TP” 1948 nr 20 s. 12.

342 jww., Le Corbusier i Matisse budują i zdobia kościoły, „TP” 1948 nr 40 s. 9; J. Woźniakowski, Problem sztuki religijnej, „TP” 1949 nr 5 s. 1, 3; JWW., Ze współczesnej sztuki kościelnej, tamże, 
Dyskusję o współczesnych przejawach sztuki zainicjował na łamach „Tygodnika Powszechnego" Jacek Woźniakowski, który śledził zarówno wypowiedzi, jak i nowości wydawnicze na ten temat. Dużym zainteresowaniem czytelników mogły cieszyć się artykuły o muzyce i śpiewie kościelnymm ${ }^{343}$. Wypowiadano się również na temat zagadnień muzycznych w ogóle ${ }^{344}$. Stefan Kisielewski ukazał sylwetki niektórych kompozytorów, m.in. Fryderyka Chopina i Jana Sebastiana Bacha $^{345}$.

Malarstwo weszło na stałe na łamy gazet dzięki artykułom Heleny Blumówny, publikowanym od 1946 r. ${ }^{346}$ Grafikę, plastykę, rzeźbę omawiano ogólnie ${ }^{347}$ oraz przy okazji otwarcia wystaw i festiwali ${ }^{348}$. Dobrą okazją do zaprezentowania wystawy sztuki religijnej w Rzymie w 1950 r. był jubileusz Roku Świętego ${ }^{349}$. Helena Blumówna zapoznawała odbiorców na bieżąco z wystawami krakowskimi w Pałacu Sztuki ${ }^{350}$,jak teżz wystawami ogólnopolskimi w Warszawie ${ }^{351}$. Ukazywała równocześnie dorobek poszczególnych twórców, m.in. Józefa Pankiewicza,

nr 25 s. 6; J.M.S. [J.M. Święcicki], Przegląd prasy. Dyskusja o sztuce religijnej, tamże, nr 49 s. 7; J. Piwowarczyk, Sztuka religijna i artyści, „TP” 1950 nr 6 s. 4; T. Żychiewicz, Religia, sztuka, wiek XX, tamże, nr 13 s. 9; T. Zych, Kuchnia Wita Stwosza, tamże, nr 42 s. 1, 5; Egzotyka, sztuka, religia, tamże, nr 51/52 s. 7.

${ }^{343}$ R. Woźniczka, , Śpiewajcie Panu pieśń nowa...”, „TP” 1952 nr 37 s. 6-7; L. Jeżowski, Nie jest tak źle, tamże, s. 7

${ }^{344}$ S. Kisielewski, Muzyka narodowa i próby obrazoburstwa, „TP” 1946 nr 50 s. 5, 8; Z. Jachimecki, O muzyce narodowej, „TP” 1947 nr 3 s. 7, 9; W. Poźniak, Męka Pana naszego w muzyce, tamże, nr 13 s. 5, 8; K. Górski, Nie taka muzyka straszna .., jak ją Kisiel maluje, „TP” 1953 nr 3 s. $2,7$.

${ }^{345}$ S. Kisielewski, Chopin, „TP” 1949 nr 8 s. 1-2; A. Waśkowski, Polska pianistka-ostatnia uczennica Liszta [Maria z Majowskich Adelmannowa], tamże, nr 23 s. 6-7; S. Kisielewski, Po dwustu latach [Jan Sebastian Bach], „TP” 1950 nr 31 s. 1-2.

${ }^{346}$ Np. H. Blumówna, Warszawski Salon wiosenny, „TP” 1946 nr 27 s. 5-6; Malarstwo i rysunki francuskie, tamże, nr 29 s. 5; Twórczość Mehoffera, tamże, nr 30 s. 3.

${ }^{347}$ M. Jarczyńska, Sadyzm w malarstwie niemieckim, „TP” 1945 nr 24 s. 4; H. Blumówna, Nowoczesna grafika polska, „TP” 1946 nr 45 s. 7; taż, Rewia malarstwa polskiego, „TP” $1947 \mathrm{nr} 7$ s. 3, 12; J. Woźniakowski, Co się dzieje z malarstwem?, „TP” $1948 \mathrm{nr} 13 / 14$ s. 8-10; E. Gilson, Artyści i święci, „TP” $1950 \mathrm{nr} 37$ s. 2, 5.

${ }^{348} \mathrm{~Np}$. H. Blumówna, III festiwal plastyki w Sopocie, „TP” $1950 \mathrm{nr} 34$ s. 8; taż, W krakowskim pałacu sztuki, tamże, nr 38 s. 6.

${ }^{349}$ T.K., Literatura i wystawy Anno Santo, „TP” 1950 nr 23 s. 5; J. Woźniakowski, Dumania nad katalogiem, „TP” 1951 nr 11 s. 5.

${ }^{350}$ H. Blumówna, Manufaktura gobelinów w Krakowie, „TP” 1947 nr 19 s. 10; H. Pieńkowska, Wystawa portretów polskich w Tarnowie, tamże, nr 21 s. 8; H. Blumówna, Wystawy krakowskie, tamże, nr 28 s. 6; taż, Poznański salon plastyki, tamże, nr 29 s. 6; taż, Wystawa Fryderyka Pautscha, „TP” 1948 nr 3 s. 6; J. Białostocki, Trzy wystawy, tamże, nr 22 s. 10; H. Blumówna, Z pałacu sztuki. Wystawa okręgu krakowskiego, „TP” 1949 nr 11 s. 6; taż, Wystawa grafiki krakowskiego okregu ZPAP, „TP” 1953 nr 3 s. 6; taż, Wystawa Ślendzińskiego, „TP” 1950 nr 14 s. 4; taż, 101 wystawa „Sztuki”, tamże, nr 18 s. 6.

${ }^{351}$ H. Blumówna, I Ogólnopolska Wystawa Plastyki, „TP” 1950 nr 19 s. 8-9. 
Tadeusza Kulisiewicza, Stanisława Kaczora-Batowskiego, Felicjana Szczęsnego Kowarskiego, Aleksandra Gierymskiego, Leona Wyczółkowskiego, drzeworytników - Stanisława Ostoi Chrostowskiego, Ksawerego Dunikowskiego, Jacquesa Louisa Davida, rzeźbiarzy Konstantego Łaszczki czy Piusa Welońskiego ${ }^{352}$. Starano się niekiedy przybliżyć dzieła mniej znanych artystów, np. drzeworytniczki Wiktorii Goryńskiej ${ }^{353}$.

Problematyka teatralna pojawiała się $\mathrm{w}$ omawianym periodyku najczęściej przy okazji recenzowania spektakli ${ }^{354}$. Nie pomijano przy tym teatrów amatorskich $^{355}$, czasem naświetlano sytuację sceny teatralnej w danym kraju ${ }^{356}$, wspominano konkretne przedstawienia teatralne (Warszawianke Stanisława Wyspiańskiego z $1898 \mathrm{r}^{357}$ ) czy przypominano ludzi zasłużonych dla teatru (np. Stefana Jaracza ${ }^{358}$ ).

Zainteresowani mogli znaleźć na łamach „Tygodnika Powszechnego” także zagadnienia dotyczące kinematografii; artykuły na ten temat zaczęły ukazywać się nieco później, gdyż w połowie 1946 r. ${ }^{359}$ Recenzje filmowe pojawiały się częściej dopiero w latach 1947-1948 ${ }^{360}$. We wspomnianej rubryce Na ekranie zrecenzowano liczne ekranizacje, w tym oparte na dziełach literackich, jak np. Nędznicy Viktora Hugo ${ }^{361}$.

${ }^{352}$ Taż, Pankiewicz w malarstwie polskim, „TP” 1946 nr 14 s. 6-7; taż, Warszawa 1945 (Rysunki Tadeusza Kulisiewicza), „TP” 1947 nr 20 s. 8; L. Ślendziński, Profesor Stanisław Kaczor-Batowski, tamże, nr 23 s. 8; H. Blumówna, Stanisław Ostoja Chrostowski, „TP” 1948 nr 18 s. 4-5; taż, Ksawery Dunikowski, tamże, nr 45 s. 8; taż, Dziewięciu grafików, „TP” 1949 nr 6 s. 8; taż, T. Domański, Dwa wieki J.L. Davida, tamże, nr 15/16 s. 13; H. Blumówna, Dzieło Konstantego Łaszczki, tamże, nr 18 s. 10; taż, Pius Weloński (1849-1931), tamże, nr 46 s. 6; Felicjan Szczęsny Kowarski (1890-1948), „TP” 1950 nr 2 s. 5; taż, Aleksander Gierymski, tamże, nr 46 s. 8; taż, Aleksander Gierymski, tamże; taż, Leon Wyczółkowski (1852-1936), „TP” 1952 nr 26 s. 8 .

${ }^{353}$ W. Borowy, Wspomnienie o Wiktorii Goryńskiej, „TP” $1950 \mathrm{nr} 21 / 22$ s. 7.

${ }^{354}$ R. Niewiarowicz, Kulisy „,Komedii”, „TP” 1946 nr 42 s. 5-6; S. Flukowski, Szalona z Chaillot, „TP” 1947 nr 31 s. 6; W.B. [W. Borowy], Czarujaca „Burza”, tamże, nr 33 s. 9; tenże, Nowy „Hamlet”, tamże; W. Borowy, Zakończenie konkursu szekspirowskiego, tamże, nr 34 s. 5-6.

${ }^{355}$ M. Morstin-Górska, ,,Rozdroże miłości” w Nowej Górze, „TP” 1948 nr 25 s. 6.

${ }^{356}$ Z.L., Teatr katolicki we Włoszech, „TP” 1949 nr 18 s. 8.

${ }^{357}$ M. Padechowicz, Koledzy z afisza, „TP’ 1949 nr 19 s. 6.

${ }^{358}$ Z. Starowieyska-Morstinowa, Największa rola Jaracza, „TP” $1950 \mathrm{nr} 41$ s. 1.

${ }^{359}$ K. Sowa, O podstawy finansowe filmu polskiego, „TP” $1946 \mathrm{nr} 28$ s. 4; K.A. Strzałka, Film oczekiwany, tamże; L. Prorok, Powstanie na taśmie filmowej, „TP” 1947 nr 31 s. 3-4; J. Drukarz, O filmie i katolikach, „TP” 1949 nr 6 s. 4; H. Ogulewicz, Tajemnica filmu włoskiego, „TP” 1950 nr 25 s. 5-7; J.P. Gawlik, Kłopoty filmu brytyjskiego, tamże, nr 33 s. 4-5; JJS, Czeskie filmy rysunkowe i kukietkowe, tamże, $\mathrm{nr} 42$ s. 10.

360 J. Zagórski, Piosenki zakazane, „TP” 1947 nr 7 s. 4-5; J. Waldorff, Ostatnia szansa Europy, „TP” 1948 nr 30 s. 3-4.

${ }^{361}$ S. Lem, Jasne tany czyli ciemne strony Filmu Polskiego, „TP” 1948 nr 3 s. 6; JJS, Na ekranie. Nędznicy, „TP” 1952 nr 25 s. 5. 
Temat fotografiki pojawiał się sporadycznie, przykładowo przybliżono postać pierwszego fotografika polskiego - Jana Bułhaka ${ }^{362}$.

Kultura, sztuka, malarstwo i teatr zajmowały istotną i znaczną część materiału prasowego w wybranym okresie. Regularnie w „Tygodniku Powszechnym” w latach 1947-1953 oceniano również aktualne wystawy. Problematyka ta znalazła szeroki oddźwięk ze względu na kulturalny charakter pisma.

\section{Literatura}

Rozważania literackie obecne były poprzez liczne artykuły, recenzje książkowe i wywiady. Pierwsze z nich miały charakter ogólnoliteracki i krytycznoliteracki. Redakcja po zwiększeniu objętości pisma w 1947 r. zazwyczaj zamieszczała w numerze kilka ocen nowości wydawniczych (dwie lub trzy dłuższe i kilka krótszych). Rzadziej pojawiały się wywiady ze współczesnymi twórcami, które również stanowiły ważną część zagadnień literackich ${ }^{363}$. Literaturze służył też specjalnie utworzony dział zatytułowany Spotkania literackie.

Na łamach „Tygodnika Powszechnego" dyskutowano m.in. o zadaniach i roli powojennej twórczości pisarskiej i realizmie we współczesnej powieści. Ważne miejsce zajęła polemika z publicystami obozu marksistowskiego na temat literatury katolickiej ${ }^{364}$. Rocznice stawały się okazją do upamiętnienia dorobku znanych pisarzy, dramatopisarzy i poetów polskich oraz zagranicznych (jak np. Adama Mickiewicza, Johanna Wolfganga Goethego i Aleksandra Puszkina ${ }^{365}$ ). Szczególną uwagę zwrócono na działalność literacką znanych zagranicznych pisarzy katolickich (Georgesa Bernanosa, Gilberta Keitha Chestertona, Françoisa Mauriaca, Daniela-Ropsa, Sigrid Undset i in.) ${ }^{366}$. Przedstawiano dorobek poetycki m.in. Kamila Cypriana Norwida, Konstantego Ildefonsa Gałczyńskiego,

${ }^{362}$ A. Łyczycki, Ziemie Odzyskane w fotografii Buthaka, „TP” 1949 nr 20 s. 8; E. Paukszta, Wspomnienie o Buthaku, „TP” $1950 \mathrm{nr} 14$ s. 5.

${ }^{363}$ Np. W. Natanson, Przeglad kulturalny. Rozmowa z Leopoldem Staffem, „TP” $1946 \mathrm{nr} 50$ s. 10; Z. Starowieyska-Morstinowa, Klerk wojujacy. (Rozmowa z Julianem Benda), „TP” 1948 nr $13 / 14$ s. 11.

${ }^{364}$ Szerzej zob. E. Kristanova, Literatura na łamach ,, Tygodnika Powszechnego”(1945-1953), „Rocznik Historii Prasy Polskiej” 2012 nr 2.

${ }^{365}$ P. Grzegorczyk, Jan Kasprowicz, „TP” 1946 nr 31 s. 3; S. Pigoń, Mickiewicz 1798-18551948, „TP” 1948 nr 52/53 s. 3-4; A. Rogalski, „Faust” Goethego a katolicyzm, „TP” $1949 \mathrm{nr}$ 34 s. 3-4; P. Grzegorczyk, Puszkin w nowym świetle, tamże, nr 36 s. 8; tenże, Stanisław Ignacy Witkiewicz, tamże, nr 41 s. 8.

${ }^{366}$ Np. K. Oost, Katolicyzm Mauriaca, „TP” 1947 nr 7 s. 2; M. Petry, Daniel Rops, „TP” 1948 nr 34 s. 5; S. Majchrowski, Człowiek, który byt Chestertonem, „TP” 1949 nr 20 s. 1-2; M. Morstin-Górska, Sigrid Undset, tamże, nr 30 s. 1; P. Mroczkowski, Jeremiasz w Hollywood [Evelyn Waugh], tamże, nr 36 s. 1-2; W. Kwiatkowski, Bernanos - pisarz walczacy, „TP” 1951 nr 36 s. 2. 
Wojciecha Bąka, Tadeusza Borowskiego, Krzysztofa Kamila Baczyńskiego, Kazimiery Iłłakowiczówny, Leopolda Staffa. Redakcja publikowała też wiersze ks. K. Wojtyły podpisane pseudonimem Andrzej Jawieńn ${ }^{367}$.

Niekiedy zamiast artykułu wstępnego drukowano opowiadanie ${ }^{368}$. W zawartości tygodnika nie zabrakło również powieści w odcinkach (np. Antoniego Gołubiewa, Bolestaw Chrobry, w 1945 r.; Jana Józefa Szczepańskiego Polska jesień, w 1946 r.) oraz nowel.

Obszerne, liczne i cenne omówienia literackie stanowiły jedną z najważniejszych części kulturalnego bloku tematycznego pisma. Drukowane zaś opowiadania, nowele i odcinki powieści były często dobrym uzupełnieniem recenzji pozycji książkowych.

\section{Sylwetki}

Sporo miejsca w „Tygodniku Powszechnym” redagujący przeznaczyli na przybliżenie sylwetek znanych ludzi ze świata kultury ${ }^{369}$, muzyki ${ }^{370}$, teatru ${ }^{371}$, nau$\mathrm{ki}^{372}$, filozofii ${ }^{373}$, architektury ${ }^{374}$ i polityki ${ }^{375}$. Nie zabrakło też życiorysów społeczników $\mathrm{w}^{376}$ i reformatorów ${ }^{377}$.

${ }^{367}$ Np. A. Jawień [K. Wojtyła], Myśl jest przestrzenia dziwna, „TP” 1952 nr 42 s. 5.

368 Tak było w przypadku nagrodzonego opowiadania na konkursie,,Tygodnika Powszechnego”: A. Porojść, Cień, „TP” 1948 nr 11 s. 1-3.

${ }^{369}$ W. Natanson, Po śmierci Stefana Jaracza, „TP” 1945 nr 22 s. 2; Z. Leśnodorski, Karol Szymanowski, „TP” 1946 nr 15 s. 4-5.

${ }^{370}$ S. Kisielewski, Ryszard Strauss, „TP” 1949 nr 38 s. 3-4; A. Łepkowski, Śladami Bacha, „TP” 1950 nr 21/22 s. 3-4.

${ }^{371}$ S. Heine, Ze wspomnień o Helenie Modrzejewskiej, „TP” 1950 nr 2 s. 10.

${ }^{372}$ W. Ziembicki, Pasteur. W 50 rocznicę śmierci wielkiego dobroczyńcy ludzkości, „TP” $1945 \mathrm{nr} 28$ s. 3; W. Konopczyński, Człowiek - drogowskaz [Stanisław Kutrzeba], „TP” 1946 nr 3 s. 3; F. Sławski, Ś. p. Mieczysław Małecki [slawista-lingwista], tamże, nr 39 s. 5; Z. Brem, Fryderyk Zoll, „TP” $1948 \mathrm{nr} 19$ s. 5; W. Rybczyński, Lord Rutherford of Nelson, tamże, nr 27 s. 8-9; S. Pigoń, Ostatnie chwile Ignacego Chrzanowskiego [profesor literatury], „TP” 1949 nr 3 s. 3; C. Strzeszewski, Śp. Henryk Dembiński [profesor prawa], tamże, $\mathrm{nr} 29$ s. 5; W. Czapliński, Wspomnienie o profesorze Rybczyńskim [pedagog], tamże, nr 44 s. 4; J.A., Podzwonne Antoniemu Ponikowskiemu [inżynier, profesor], „TP” $1950 \mathrm{nr} 36$ s. 7; A. Klawek, Ks. Szczepan Szydelski. (W 40-lecie pracy naukowej) [teolog], „TP” 1952 nr 17 s. 4.

373 J. Piwowarczyk, Mikołaj Bierdiajew, „TP” 1948 nr 22 s. 3; tenże, Fryderyk Nietzsche, „TP” $1950 \mathrm{nr} 39$ s. $1-2$.

374 J. Jamroz, Adolf Szyszko Bohusz, „TP” 1948 nr 46 s. 8-9.

375 J.J. Szczepański, ,Święty” przeciw imperium [o M. Gandhim], „TP” 1946 nr 20 s. 5; J. Dąbrowski, Władysław Sikorski, tamże, nr 27 s. 1-2; Z. Starowieyska-Mostinowa, Lu TsengTsiang [dyplomata chiński], tamże, nr 40 s. 3-4; J. Woroniecki, W. Konopczyński, Stefan Dąbrowski, „TP” 1947 nr 31 s. 5; H. Kornaus, Stanistaw Grabski (1871-1949), „TP” 1949 nr 28 s. 5.

${ }^{376}$ W. Drop, Pionierka Akcji Katolickiej, „TP” 1947 nr 32 s. 3-4; G. Morcinek, Trud Lompy, tamże, nr 35 s. 2-3.

377 A. Mikulski, Reformator szkolnictwa $i$ wychowania, „TP” 1950 nr 36 s. 8-9. 
Osobną grupę utworzyły artykuły o duchownych ${ }^{378}$ i przyszłych świętych ${ }^{379}$. $\mathrm{Na}$ łamach periodyku opisano przebieg niektórych procesów beatyfikacyjnych ${ }^{380}$ i kanonizacyjnych ${ }^{381}$. Corocznie powracały na łamy „Tygodnika Powszechnego” artykuły o przyszłej świętej królowej Jadwidze ${ }^{382}$. Zauważono również skromnego, ale wyprzedzającego swoją epokę kardynała Henry'ego Newmana, beatyfikowanego przez papieża Benedykta XVI w 2010 r. ${ }^{383}$ Niekiedy poruszano niecodzienną problematykę, jak przykładowo ekshumacje ciał przyszłych świętych: Anieli Salawy i Adama Chmielowskiego ${ }^{384}$. Tematem niektórych wypowiedzi była konwersja kilku znanych osób na katolicyzm ${ }^{385}$. Zgony redakcja upamiętniała poprzez osobne artykuły lub nekrologi ${ }^{386}$. Skrupulatnie odnotowywano ważne

${ }^{378}$ C. Strzeszewski, Śp. ks. Antoni Szymański, „TP” 1945 nr 37 s. 5; K. Michalski, Ks. Jan Salamucha, „TP” 1946 nr 2 s. 2; S. Wyszyński, Ksiadz Władysław Korniłowicz, tamże, nr 50 s. 1, 3; J. Konopczyna, Ksiądz Karol Csesznak, „TP” 1947 nr 48 s. 3-4; T. Długosz, Ks. arcybiskup Bilczewski. (W 25-lecie zgonu), „TP” 1948 nr 16 s. 3-4; S.B.Ż., Arcybiskup Teodorowicz, tamże, nr 51 s. 2-3; S. Świeżawski, Filar wiary [o. Jacek Woroniecki], „TP” 1949 nr 31 s. 1-2; J. Piwowarczyk, Ks. Józef Archutowski [biblista], „TP” 1950 nr 18 s. 5; H. Rawa, Zapomniany jatmużnik [o. Piotr Skarga], tamże, nr 19 s. 2, 10; J. Piwowarczyk, Śp. Ks. Biskup Kubina, „TP” 1951 nr 10 s. 1; B. Kominek, Pius X, tamże, nr 22 s. 1-2; J. P. Gawlik, O biskupie Kozalu, tamże, nr 44 s. 1-2.

${ }^{379}$ J. Dąbrowski, Z myśli o królowej Jadwidze. (W rocznice śmierci), „TP” 1946 nr 29 s. 4-5; K. Michalski, Heroizm w stylu franciszkańskim. (W setna rocznicę urodzin Brata Alberta), tamże nr 34 s. 1-2; Profesor uniwersytetu - świętym [Contardo Ferrini], „TP” 1947 nr 7 s. 13; Aniela Salawa, „TP” 1949 nr 26 s. 3; Z. Kuzak, Święty chłopiec [Dominik Savio], „TP” 1950 nr 12 s. 6; J. Drukarz, Edyta Stein, „TP” 1952 nr 15 s. 15.

${ }^{380}$ H. Wyczawski, Blogosławiona Jolenta, „TP” 1948 nr 24 s. 9; H.D., Bt. Wincenty Pallotti i jego dzieło, „TP” $1950 \mathrm{nr} 7$ s. 5; n., Proces beatyfikacyjny M. Truszkowskiej, tamże, nr 28 s. 2; M. Renata, Jak błog. Pius X zostat papieżem, „TP” 1951 nr 50 s. 3-4.

${ }^{381}$ M.in. J. Piwowarczyk, Myśliciel i bohater [św. Tomasz More], „TP” 1947 nr 19 s. 3-4; J.I. Buba, Twórca bezpłatnego nauczania [św. Józef Kalasanty], „TP” 1948 nr 34 s. 3-4; P. Szary, Święty Tomasz na tle swojej epoki, „TP” $1950 \mathrm{nr} 19$ s. 6-8; H. Szewczyk, Św. Maria Teresa Goretti, tamże, nr 31 s. 8.

382 T. Glemma, Święta na polskim tronie, „TP” 1948 nr 29 s. 2-3; W. Zmarz, Brakowało naszej staranności. Wznowienie procesu beatyfikacyjnego królowej Jadwigi, „TP” 1949 nr 19 s. 3; tenże, Czeka nas praca, tamże, nr 20 s. 7; S. Sapieha, List pasterski ks. kardynała Sapiehy. W rocznice śmierci królowej Jadwigi, tamże, nr 23 s. 1; A. Górski, Śladami stóp królowej Jadwigi, tamże, nr 28 s. 1-2; M. Tobiasz, Tradycja świętości królowej Jadwigi, tamże, s. 2; P. Jasienica, Sarkofag królowej, tamże, nr 30 s. 3-4; M. Tobiasz, Otwarcie grobu królowej Jadwigi w r. 1887, tamże, s. 4.

${ }^{383}$ J.W. Kowalski, W obronie praw sumienia, „TP” $1949 \mathrm{nr} 28$ s. 9.

384 J.M.S. [J.M. Święcicki], Dwie ekshumacje, „TP” 1949 nr 27 s. 8.

${ }^{385}$ H. Slesser, Przez anglikanizm do Kościoła, „TP” 1948 nr 51 s. 4-5; A. Rogalski, Droga Alfreda Doeblina, „TP” $1950 \mathrm{nr}$ 15/16 s. 9, 15; S. Undset, Moje nawrócenie na katolicyzm, tamże nr 35 s. $1-2,5$.

${ }^{386}$ S.K., Zgon Feliksa Nowowiejskiego, „TP” 1946 nr 5 s. 8; nekrologi: Juliusza Osterwy, „TP” 1947 nr 21 s. 3; I. Pannenkowa, Maria Rodziewiczówna, „TP” 1949 nr 18 s. 5-6; Ojca Jacka Woronieckiego, tamże, nr 21 s. 3; M. Plezia, Władysław Semkowicz, tamże, nr 22 s. 8; J. Piwowarczyk, Śp. ks. Stefan Mazanek, „TP” 1950 nr 8 s. 3; A. Kossowski, Śp. Leon Biatkowski 1885-1952, „TP” 1952 nr 24 s. 3. 
wydarzenia w życiu polskiego Kościoła ${ }^{387}$, wszelkie uroczystości ${ }^{388}$, rocznice $^{389}$ i jubileusze ${ }^{390}$ poświęcone znanym osobistościom.

Publikacje, w których zapoznawano z różnoraką działalnością i życiem wybranych ludzi należały do najważniejszych a zarazem najciekawszych wypowiedzi „Tygodnika Powszechnego”.

\section{Krajoznawstwo}

W 1947 r. na dobre weszły do „repertuaru” artykuły, które można zakwalifikować do kategorii religijno-krajoznawczych. Opisywano w nich znane miejsca święte, kościoły i sanktuaria ${ }^{391}$. Łamy „Tygodnika” wypełniały również artykuły typowo krajoznawcze, zarówno przedstawiające uroki rodzimych miejscowości i regionów, jak też innych krajów ${ }^{392}$. Służył temu też przykładowo cykl Andrzeja Bobkowskiego $Z$ dziennika podróż $y^{393}$. Paweł Jasienica w formie wspomnieniowej i w ujęciu historycznym pisał o Płocku ${ }^{394}$. Dzieje pierwszego kościoła w Rzymie poświęconego Matce Bożej - Bazylice Santa Maria Maggiore na tle refleksji religijnej przedstawiła Maria Winowska ${ }^{395}$. Z zabytkami Tarnowa i ich historią zapoznał czytelników Tadeusz Chrzanowski ${ }^{396}$.

${ }^{387}$ Redakcja, Kardynat Griffin w Polsce, „TP” 1947 nr 23 s. 3; Ks. Prymas Anglii w Krakowie, tamże, nr 25 s. 10; O odbudowę kościołów warszawskich, tamże, nr 29 s. 3; Z pobytu X. X. biskupów polskich w Rzymie, „TP” $1951 \mathrm{nr} 23$ s. 1.

${ }^{388}$ J.K.M., Uroczystości rzymskie, „TP” 1946 nr 14 s. 3-4; Uroczystości ku czci patrona Warszawy, „TP” $1948 \mathrm{nr} 40$ s. 11.

${ }^{389}$ Np. z okazji 950 rocznicy śmierci św. Wojciecha: T. Glemma, Dziedzictwo św. Wojciecha, „TP” 1947 nr 17 s. 2; A. Gołubiew, W roku św. Wojciecha, tamże, nr 49 s. 7; Rocznica kanonizacji św. Wojciecha, „TP” 1949 nr 15/16 s. 16; F. Kryszak, 950 lat metropolii gnieźnieńskiej, „TP” 1950 nr 17 s. 3; W. Wicher, 25-lecie sakry biskupiej ks. biskupa Rosponda, „TP” 1952 nr 24 s. 4.

${ }^{390}$ Srebrny jubileusz ks. biskupa Tomczaka, „TP” 1952 nr 23 s. 3.

${ }^{391}$ Np. W. Krygowski, Ksiądz Stolarczyk - apostoł Zakopanego, „TP” 1948 nr 7 s. 8; K. Brzozowska, Katedra w Canterbury, tamże, nr 20 s. 5-6; M. Winowska, Pielgrzymka do Chartres, tamże, nr 30 s. 3-4; J.P. Gawlik, Święty krzyż - góra kontrastów, tamże, nr 51 s. 3-4; P. Jasienica, Gdzieś na Ślasku, „TP” 1949 nr 47 s. 5, 10; S. Kisielewski, We Wrocławiu i Szczecinie. (Wrażenia turystyczne), „TP” $1950 \mathrm{nr} 9$ s. 1-2, 8; tamże, nr 10 s. 3-4; T. Chrzanowski, Kalwaria Zebrzydowska, tamże, nr 48 s. 8-9.

${ }^{392}$ L. Prorok, „,Duch gór na sktadzie!”, „TP” 1948 nr 41 s. 8; E. Kocwa, W Szklarskiej Porębie, „TP” 1949 nr 31 s. 8; J. Stankiewicz, Kolbacz, tamże, nr 32 s. 2; B. Dudczakowa, O Kaliszu i jego ambicjach, „TP” $1950 \mathrm{nr} 19$ s. 5, 10; P. Zawadzki, Notatki z podróży po Korei, tamże, nr 28 s. 2; A. Klawek, Miscellanea o Ziemi Świętej, tamże, nr 31 s. 5; C. d'Ydewalle, Czarna Afryka. (Notatki z podróży), „TP” $1953 \mathrm{nr} 6$ s. 3, 7.

${ }^{393}$ Np. A. Bobkowski, Z dziennika podróży (6). Na Morzu Karaibskim, „TP” 1950 nr 2 s. 3-4; tenże, $Z$ dziennika podróży (7). Panama - Guatemala, tamże, nr 7 s. 3-4.

${ }^{394}$ P. Jasienica, Nad rzeka toczaca piaski, „TP” $1949 \mathrm{nr} 4$ s. 3-4.

${ }^{395}$ M. Winowska, Najstarszy kościót mariacki, „TP” $1951 \mathrm{nr} 1 / 2$ s. 5-6.

396 T. Chrzanowski, Cienie w zautkach, „TP” 1952 nr 2 s. 4-6. 
Zagadnienia krajoznawcze i w pewnym sensie pielgrzymkowe były niewątpliwie dużym urozmaiceniem tematyki poruszanej na łamach pisma. Służyły poznaniu i poszerzeniu wiedzy odbiorców, a zarazem refleksji i rozrywce. Artykuły mogły jednocześnie stać się zachętą dla czytelników do odwiedzenia pięknych zakątków kraju ojczystego oraz obcych państw.

\section{Inne}

Problematyka goszcząca na łamach „Tygodnika Powszechnego” była bardzo różnorodna. Szerokie spektrum poruszanych w periodyku zagadnień egzemplifikowały cykle tematyczne: Z galerii katolickich socjologów (w latach 1945-1946), Warszawa, Wśród czasopism literackich, Nad Wettawa (w 1945 r.), Styl chrześcijański w filozofii (artykuły autorstwa ks. Jana Salamuchy w 1946 r.), Dolny Ślask na migawkę, Dole i niedole Podhala (1946 r.), Z problemów konstytucyjnych (seria wypowiedzi ks. Jana Piwowarczyka w 1947 r.), Z teki pośmiertnej (1947 r.), Nowy kraj (1948 r.), Moralność zawodowa (1948 r.), Dokumenty (1948 r.), W kotle batkańskim (1950). W omawianym okresie publikowano także relacje osobiste współpracowników pisma pod nagłówkiem Listy z Francji, Anglii, Ameryki, a także Listy z Rzymu i Paryża.

$\mathrm{W}$ „Tygodniku” zagościły też m.in. zagadnienia z zakresu fizyki ${ }^{397}$, demografii $^{398}$, geografii ${ }^{399}$, mediów ${ }^{400}$, targów poznańskich ${ }^{401}$, ludów murzyńskich ${ }^{402}$ i wiele innych. W 1948 r. podjęto np. problematykę alkoholizmu w polskim społeczeństwie; numer siódmy z tegoż roku w całości poświęcono tej kwestii. Rozpoczęto go artykułem wstępnym Pawła Jasienicy i apelem redakcji związanym z akcją trzeźwości podjętą przez Episkopat Polski ${ }^{03}$.

nr 4 s. 9.

${ }^{397}$ W. Rybczyński, Zmierzch bezwzględnego determinizmu we wspótczesnej fizyce, „TP” 1949

${ }^{398}$ W. Borowski, Człowiek a gospodarka planowa, „TP” 1946 nr 35 s. 1-2; K. Turowski, Gospodarka planowa w koncepcji katolicko-społecznej, „TP” 1947 nr 20 s. 3-4; M. Strebejko, Straszak przeludnienia, „TP” 1949 nr 33 s. 2; tenże, Żyjemy dtużej, tamże, nr 36 s. 9-10; tenże, Demografia Polski 1939-1949, tamże, nr 37 s. 2; tenże, Liczebność urodzin spada, tamże, nr 38 s. 8; tenże, Kolebki i trumny, tamże, nr 41 s. 9-10; J.M.S. [J.M. Święcicki], Przegląd prasy. Czy Europa wymiera?, „TP” $1950 \mathrm{nr} 4$ s. 8; J. Czekanowski, Nasza rzeczywistość demograficzna, tamże, nr 45 s. 5; J.M.S. [J.M. Święcicki], Przegląd prasy. Kryzys biologiczny Europy Zachodniej, „TP” 1951 nr $1-2$ s. 10.

${ }^{399}$ M. Strebejko, Nowa mapa świata, „TP” 1947 nr 22 s. 9.

${ }^{400}$ S. Broniewski, Spoleczne zadania radiofonii, „TP” 1946 nr 4 s. 5.

${ }^{401}$ S. Kisielewski, W Poznaniu, „TP” 1950 nr 23 s. 3-4.

402 Z zagadnień murzyńskich, „TP” 1949 nr 40 s. 6.

${ }^{403}$ P. Jasienica, Tria melodia główna, „TP” 1948 nr 7 s. 1-2; Redakcja, Wezwanie do wielkiej akcji, tamże; J.M.S. [J.M. Święcicki], Kwestia alkoholizmu, „TP” $1950 \mathrm{nr} 33$ s. 7; tenże, Przeglad prasy. Przeoczenie i tolerancja, „TP” $1952 \mathrm{nr} 48$ s. 11; B. Jantar, Problem alkoholizmu w wiosce N., „TP” 1953 nr 7 s. 4-5. 
Nie zabrakło też spraw prasy. Prezentowano polskie tytuły katolickie i ich zawartość, zachęcając do czytania i prenumeraty. W ten sposób reklamowano często miesięcznik „Znak”404, „Ruch Biblijny i Liturgiczny”405, ale także czasopisma naukowe („Roczniki Filozoficzne”, „Roczniki Nauk Społecznych”406) i specjalistyczne (np. dla miłośników przyrody - rocznik „Ochrona Przyrody”407). Zapoznawano także z zagraniczną prasą różnego typu ${ }^{408}$.

Pozostała problematyka występująca na łamach krakowskiego tygodnika była równie bogata, jak mieszcząca się w wyodrębnionych tu wcześniej blokach tematycznych. Redakcja nie ograniczała w żaden sposób wypowiedzi, które można było zaklasyfikować do szeroko pojętej kultury. Pozwalano czasami publicystom na publikacje dotyczące bardzo specjalistycznych tematów.

\section{Szata graficzna}

Początkowo wygląd „Tygodnika Powszechnego” - jak przystało na powojenne czasopismo społeczno-kulturalne - był skromny. W pierwszych zeszytach jedynym urozmaiceniem pisma były reklamy, w których używano elementów graficznych. Przykładowo takimi reklamami były różne wersje ogłoszenia nutromaltu - cukru odżywczego dla dzieci. Towarzyszyły mu zabawne rysunki, np. wesołego malucha przy jedzeniu ${ }^{409}$, na rękach dorosłego ${ }^{410}$ lub dwójki dzieci z radością patrzących na opakowanie ${ }^{411}$. Rysunki towarzyszyły także ogłoszeniom anacotu - środka dezynfekującego dla dzieci ${ }^{412}$ czy kremu Nivea również z motywem dziecka ${ }^{413}$.

Pierwsze fotografie pojawiły się przy okazji artykułu Ludwika Kowalczyka Brulion histori ${ }^{144} \mathrm{w}$ listopadzie $1945 \mathrm{r}$. W numerze wydanym na Boże Narodzenie 1945 r. po raz pierwszy zagościła reprodukcja płaskorzeźby z około 1500 r. Adoracja Dzieciątk $a^{415}$ oraz zamieszczono sporo rysunków. Opowiadaniu Wojciecha Żukrowskiego towarzyszyły szkice Adama Marczyńskiego ${ }^{416}$, natomiast arty-

${ }^{404}$ Np. ,Znak”, ,TP” 1949 nr 47 s. 12.

405 ,TP" 1953 nr 3 s. 8.

406 jt, Philosophica, „TP” 1949 nr 10 s. 11; ,, Roczniki Filozoficzne”, tamże; Prawo - socjologia-ekonomia, tamże, nr 17 s. 4.

407 t., Ochrona przyrody, „TP” 1949 nr 11 s. 5.

408 Przykładowo J.M.S. [J.M. Święcicki], ,, Wissenschaft und Weltbild” [wiedeńskie czasopismo naukowe], ,TP” 1949 nr 6 s. 7.

409 „TP” 1945 nr 38 s. 2.

410 "TP" 1945 nr 39 s. 8.

411 „TP” 1946 nr 23 s. 12.

412 "TP” 1945 nr 40 s. 16.

413 „TP” 1946 nr 10 s. 6.

414 L. Kowalczyk, Brulion historii, ,TP” 1945 nr 34 s. 3.

415 „TP” 1945 nr 40 s. 1.

416 W. Żukrowski, Wojna Blablacji z Tiutiurlistanem, ,TP” 1945 nr 40 s. 8-10. 
kuł S. Kisielewskiego ${ }^{417}$ uzupełniły humorystyczne obrazki Gwidona Miklaszewskiego. Czasem przejmowano też humor rysunkowy z obcej prasy, jak to było w przypadku francuskiego „La Marseillaise”418.

W następnych zeszytach, w 1946 r., łamy „Tygodnika Powszechnego” wzbogaciły liczniejsze zdjęcia i reprodukcje ${ }^{419}$. W numerze 7 znalazło się zdjęcie ks. Jana Salamuchy (s. 3) i reprodukcje portretów Olgi Boznańskiej Portret Księżnej Adamowej Sapieżyny i Portret dziewczynek. Reprodukcje portretów zamieszczono również w numerze $10 \mathrm{z}$ tegoż roku. Na pierwszej stronie numeru 36 widniała fotografia rzeźby Najświętszej Marii Panny z katedry w Reims z XII w. Bogatsze $\mathrm{w}$ reprodukcje były również zeszyty specjalne. Przykładowo w wydaniu specjalnym poświęconym Tadeuszowi Kościuszce zamieszczono piękne rysunki i obrazy jego autorstwa $\mathrm{a}^{420}$. Obchody różnych uroczystości również stawały się okazją do zaprezentowania zdjęć pamiątkowych. Omawianiu twórczości malarskiej na łamach „Tygodnika Powszechnego” towarzyszyły również liczne reprodukcje.

\section{Il. 2. Reprodukcja rysunku autorstwa T. Kościuszki.}

„TP” 1946 nr 12 s. 3

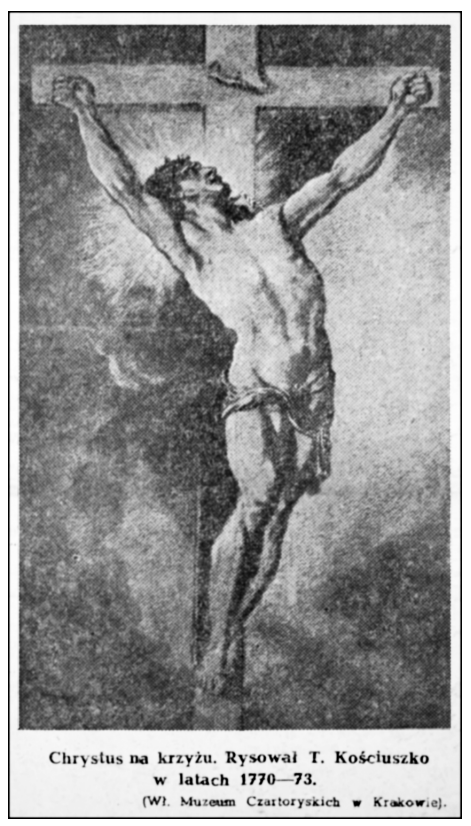

Źródło: Ze zbiorów BUŁ.

${ }^{417}$ S. Kisielewski, Wspomnienia i inwektywy, „TP” $1945 \mathrm{nr} 40$ s. 12-13.

${ }^{418}$ Z. Starowieyska-Morstinowa, Francuskie migawki, „TP” 1946 nr 6 s. 8.

${ }^{419}$ Np. fot. Ludwika Solskiego i dwa rysunki Stanisława Wyspiańskiego. T. Kudliński, Choragiew sztuki - na wieży pracy, ,TP” 1946 nr 2 s. 3

${ }^{420}$ Z. Bocheński, Sztuka w życiu Kościuszki, „TP” 1946 nr 12 s. 3. 
Szata graficzna została znacznie ubogacona po zwiększeniu objętości pisma od października tegoż roku. Znaczniejsza liczba rysunków i fotografii przyczyniła się do tego, że periodyk stał się atrakcyjniejszy w odbiorze. Przykładowo rubryce Pod włos... zaczął towarzyszyć graficzny nagłówek i liczne rysunki ilustrujące tekst.

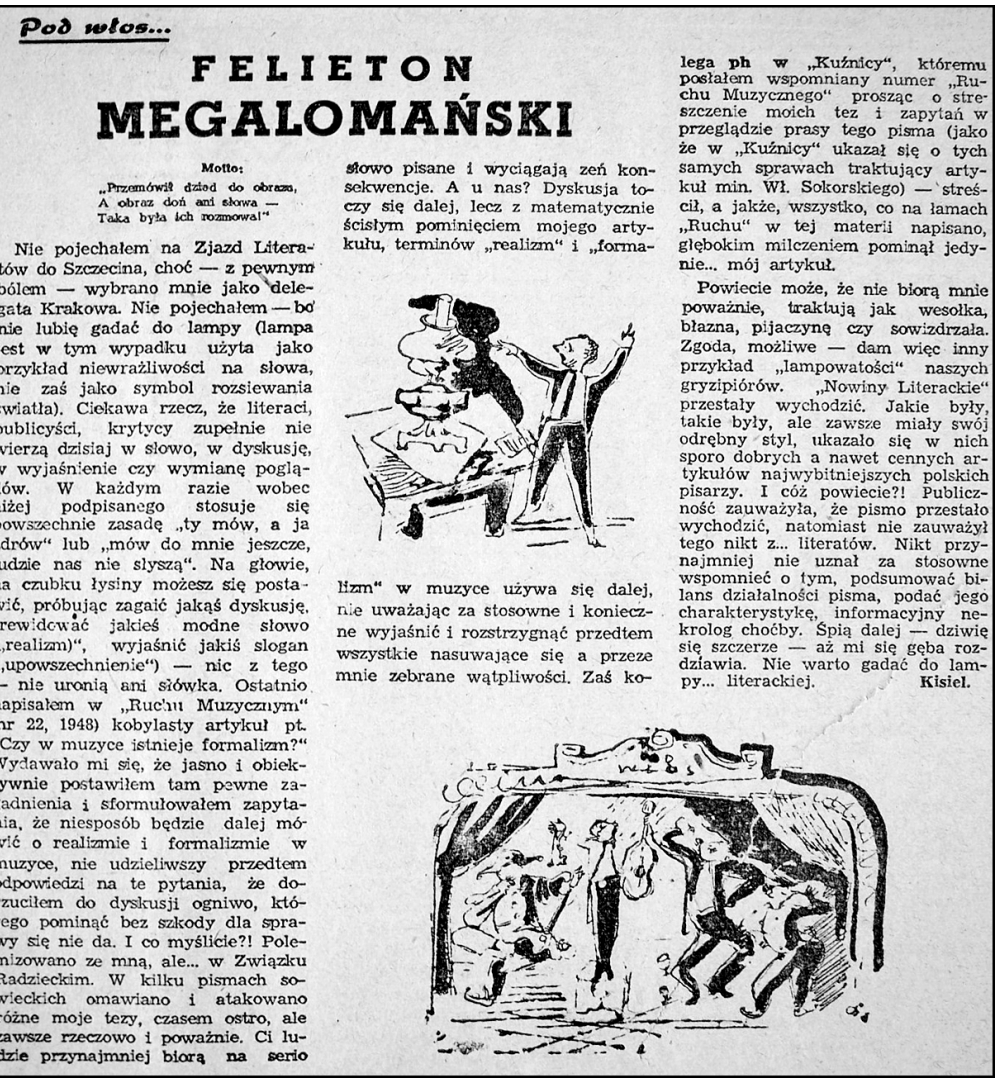

Źródło: Ze zbiorów BUŁ.

Z okazji rozpoczęcia w lutym 1949 r. Roku Chopinowskiego artykuły wstępne poświęcone kompozytorowi (zeszyt 8 z 1949 r.), przyozdobiono portretową litografią Engelmanna z roku 1833, akwafortą Stanisława Töpfera przedstawiającą go przy fortepianie, litografią według portretu Ary Scheffera oraz rysunkiem przedstawiającym muzyka, autorstwa George Sand. Zdarzały się też reprodukcje dzieł bardziej znanych malarzy, jak np. akwaforty Rembrandta Boże Narodzenie. 
W kolejnych latach w dziale $Z$ wystaw umieszczono akwarele ${ }^{421}$. Przy okazji omawiania różnorodnej problematyki starano się tekst uzupełniać reprodukcjami. Przykładowo, pisząc o ekshumacji zwłok Adama Chmielowskiego w maju 1949 r., zaprezentowano nieznany dotąd rysunek Leona Wyczółkowskiego zatytułowany Brat Albert ${ }^{422}$. Ozdobę pisma stanowiły też reprodukcje z wystaw, np. z wystawy malarstwa holenderskiego w Krakowskim Muzeum Narodowym ${ }^{423}$. Niekiedy do tekstów dołączano drobne rysunki ${ }^{424}$.

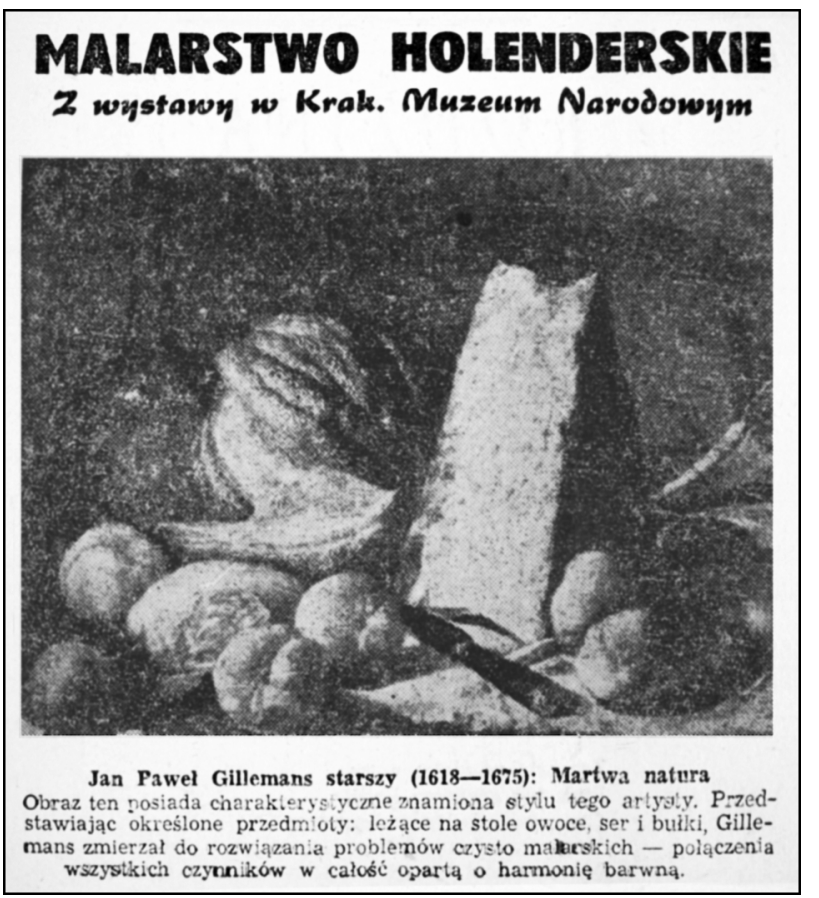

Źró dło: Ze zbiorów BUŁ.

W 1950 r. zamieszczono Ramotki świateczne Kisiela bogato ilustrowane humorystycznymi rysunkami ${ }^{425}$. Przy okazji artykułu nakreślającego sylwetkę

${ }^{421}$ Np. Z wystaw, „TP’ 1949 nr 14 s. 6.

422 J.M.S. [J.M. Święcicki], Dwie ekshumacje, „TP” 1949 nr 27 s. 8.

${ }^{423}$ Malarstwo holenderskie, „TP” 1949 nr 34 s. 6.

${ }^{424}$ Np. M.A. Wasilewski, Fotografie z Gdańska, „TP” 1949 nr 48 s. 5 z rysunkami miejsc miasta Krystyny Górskiej; Bajki murzyńskie. Dwaj złodzieje, tamże, nr 51/52 s. 12-13 z rysunkami Olgi Peczenko.

${ }^{425}$ Kisiel [S. Kisielewski], Ramotki świateczne, „TP” 1950 nr 15/16 s. 16. 
papieża Grzegorza I pokazano odbiorcom srebrną płytę z oprawy księgi z XI w. ${ }^{426}$, natomiast w Kronice plastycznej - ekslibris Róży Wolskiej wystawiony wśród prac uczniów Wyższej Szkoły Sztuk Plastycznych ${ }^{427}$. W zeszycie podwójnym wydanym na Boże Narodzenie 1950 r. dodano ozdobniki tekstowe pierwszych liter rozpoczynających artykuły. W $1951 \mathrm{r}$. w tygodniku często pojawiały się rysunki i reprodukcje, m.in. z wystawy jubileuszowej w Rzymie. Obraz El Greco zatytułowany Zesłanie Ducha Świętego zamieszczono na pierwszej stronie numerze 22 z $1952 \mathrm{r}$.

Spośród wszystkich czasopism będących przedmiotem analiz w niniejszej dysertacji szata graficzna „Tygodnika Powszechnego" była najbardziej atrakcyjna i urozmaicona. Redakcja pisma wykazała się pod tym względem dużą starannością, chcąc upowszechniać periodyk na wysokim poziomie.

\section{Zakończenie}

Łamy „Tygodnika Powszechnego” w latach 1945-1953 były bardzo bogatym źródłem tekstów religijnych, społecznych, kulturalnych i literackich. Pismo przyczyniło się w dużym stopniu do poszerzenia wiedzy oraz kształtowania opinii i gustów swoich czytelników. Służyło też propagowaniu wartości chrześcijańskich i katolickich. Odbiorcy znaleźli tu zarówno wypowiedzi obszerne i poważne, jak i liczne polemiki oraz żartobliwe felietony. Pomimo cenzury i niedopuszczenia do druku wielu artykułów, czytelny był światopogląd środowiska skupionego wokół pisma, które oponowało przeciwko opiniom zawartym w prasowych organach marksistowskich („Kuźnicy” czy „Odrodzeniu”).

Redakcja „Tygodnika Powszechnego” w 1952 r. zaczęła borykać się z coraz większymi trudnościami. Pismo swoją pozycję zawdzięczało poparciu prymasa Stefana Wyszyńskiego, co zapewniało mu pewien margines swobody. Wolność polegała na tym, że redakcja nie mogła zawsze pisać tego, co chciała, ale mogła nie publikować tego, co nie znajdowało uznania w zespole. Tę zasadę usiłowano złamać. Pod przymusem zamieszczono notatkę z procesu krakowskiego. Spór natomiast rozgorzał o to, w jaki sposób redakcja winna uczcić śmierć Józefa Stalina. Wobec uporu redaktorów, którzy nie chcieli napisać panegiryku na cześć dyktatora, zapadła decyzja władz o zawieszeniu pisma. Ostatni numer ukazał się z datą 8 III 1953 r. Tytuł prasowy został przekazany Stowarzyszeniu PAX i 12 VI 1953 r. wydano pierwszy numer redagowany przez zmienioną redakcję, która wykazała większą uległość wobec władzy. Zachowano przy tym brzmienie tytułu, numerację i winietę, co mogło sugerować jego ciągłość. Prymas Stefan Wyszyński

\footnotetext{
${ }^{426}$ H. Malewska, Budowniczy wśród ruin, „TP” 1950 nr 29 s. 1-3.

${ }^{427}$ H. Blumówna, Kronika plastyczna, „TP” 1950 nr 30 s. 6.
} 
skierował 17 VI 1953 r. do nowego zespołu, w skład którego weszli m.in. Jan Dobraczyński i Wojciech Żukrowski, notę potępiającą zawłaszczenie tytułu i odciął się w imieniu swoim i Episkopatu od nowego kształtu pisma oraz członków jego redakcji ${ }^{428}$.

\subsection{2. „Głos Katolicki” (1945-1948)}

W historii poznańskiego „Głosu Katolickiego” można wyróżnić dwa wyraźnie odmienne okresy: 1945-1948 i 1949-1956. W pierwszym pismo redagowane na wysokim poziomie o profilu religijno-społecznym adresowane było do inteligencji, w drugim - po zmianie redaktora naczelnego i wyglądu zewnętrznego - stało się religijnym pismem dla ludu. Istotne ingerencje w zawartości, profilu i redakcji „Głosu” od 1949 r. zadecydowały o uwzględnieniu w pracy tylko pierwszego okresu ${ }^{429}$. W nowym kształcie periodyku zachowano jedynie tytuł, przy znacznym ograniczeniu problematyki społecznej i kulturalnej do spraw „zakrystii Kościoła”. Zepchnięto go tym samym na margines i wyłączono z grona czasopism społeczno-kulturalnych. Aresztowanie i uwięzienie redaktora naczelnego ks. Romana Mielińskiego we wrześniu 1948 r. za przynależność do Armii Krajowej zbliżyło losy czasopisma do „Tygodnika Warszawskiego”. Pismo zarejestrowała Bibliografia katolickich czasopism religijnych w Polsce 1945-1989 Danuty Wielgat ${ }^{430}$. Tygodnik otrzymał także hasło w Encyklopedii katolickiej ${ }^{431}$.

428 Tamże, s. 247.

429 „Głos Katolicki” w latach 1949-1956 pod red. ks. Maksymiliana Rode zmienił profil na popularne czasopismo religijne dla ludu. W okresie tym ograniczono podejmowaną tematykę do spraw Kościoła. Przy dominacji problematyki religijnej, hagiograficznej, duszpasterskiej, liturgicznej, zaczęto udzielać na jego łamach praktycznych rad. Wprowadzono ciekawostki, rozrywki umysłowe i humor. Wygląd pisma również uległ zmianie poprzez liczne fotografie i rysunki. Pismo w drugim okresie (właściwie od ostatniego numeru z 1948 r.) przejęła na własność Kuria Metropolitalna w Poznaniu i tłoczyły Poznańskie Zakłady Graficzne. Redakcja mieściła się przy ulicy Groblej 1 w Poznaniu. W ostatnim numerze ubolewano, że „nie zawsze mogli wszyscy otrzymać $<<$ Głos Katolicki $>>$, co niezależnie od redakcji spowodowane było o wiele niższym nakładem niż faktyczne zapotrzebowanie. Powodem stał się powszechny brak papieru [Redakcja, Do naszych P.T. Czytelników, Sympatyków i Współpracowników!, „GK” 1956 nr 49 s. 584]. W 1949 r. pismo liczyło 12 stron, a w 1950 r. zmniejszono jego objętość do 6 stron. Periodyk po raz ostatni wydrukowano z podtytułem „Tygodnik ilustrowany” 2 XII $1956 \mathrm{r}$. Łącznie ukazało się ponad 200 zeszytów (R. 5: 51 numerów, R. 6: 39, R. 7:51, R. 8: 51/52, R. 9 posiadał nieuporządkowaną numerację, ukazały się 24 numery, w tym niektóre nienumerowane).

${ }^{430}$ D. Wielgat, Bibliografia katolickich czasopism..., s. 31.

${ }^{431}$ M. Kunowska-Porębna, „Głos Katolicki”. W: Encyklopedia katolicka, pod red. L. Bieńkowskiego i in., t. 5, Lublin 1989, szpalta 1136. 


\section{Redakcja i współpracownicy}

Założycielem i pierwszym redaktorem naczelnym "Głosu Katolickiego” w latach 1945-1948 był ks. Roman Mieliński. Tytuł ukazał się w miejsce przedwojennego „Przewodnika Katolickiego”, którego nie udało się wznowić.

Il. 5. Ks. dr Roman Mieliński.

„Przewodnik Katolicki” 1976 nr 9 s. 6

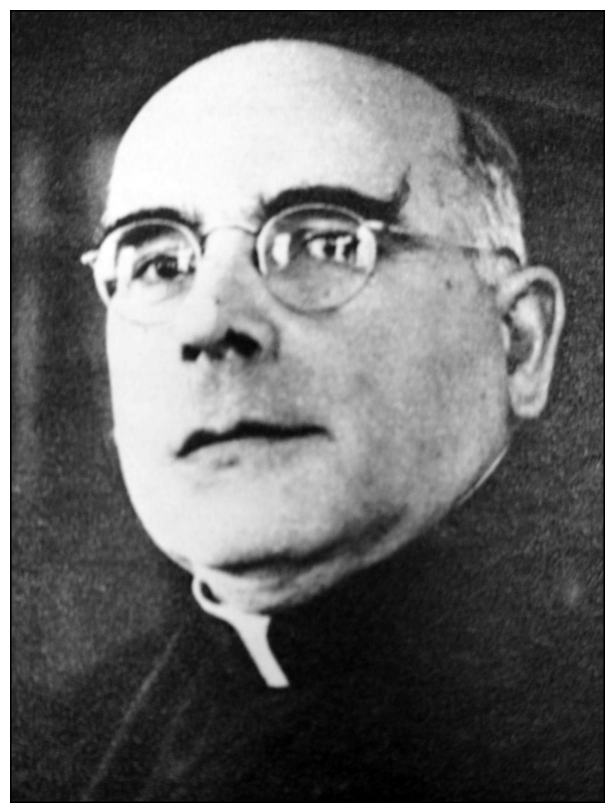

Źródło: Ze zbiorów BUŁ.

W następujący sposób pisano o nim: ,[...] $<<$ Głos $>>$ ustępował przedwojenne$\mathrm{mu}<<$ Przewodnikowi $>>$ wachlarzem tematów, objętością i szatą graficzną. Nie ustępował jednak poziomem artykułów pisanych spokojnie, celnie, bez zbędnych dłużyzn. Redaktor był autorem szeregu artykułów problemowych oraz znakomitej rubryki Co pisza inni: ich głosy - nasze echa"432. Wypowiedzi z pierwszych stron „Głosu Katolickiego” były zazwyczaj jego pióra. Ks. R. Mieliński godził pracę redaktorską z pracą duszpasterską ${ }^{433}$, będąc proboszczem parafii Św. Krzyża

${ }^{432}$ W. Raczkowski, Ks. Roman Mieliński 1906-1976, „Miesięcznik Kościelny Archidiecezji Poznańskiej” 1977 nr 2 s. 44.

${ }^{433}$ Proboszcza pamiętano jako osobę oschłą i małomówną, która wnikliwie wsłuchiwała się w swego rozmówcę od czasu do czasu rzucając trafne spostrzeżenie. Jednak dzieci bardzo garnęły się do niego. Nie znosił przesadnej etykiety towarzyskiej i potrafił przyjmować krytyczne uwagi od 
na Górczynie. W pierwszym numerze redakcja w wyraźny sposób nawiązała do tradycji „Przewodnika Katolickiego”. Rozpoczynając pracę redakcyjną nad „Głosem Katolickim”, pisano: „Mało kto z czytelników pamięta, że ostatni numer $<<$ Przewodnika Katolickiego >> ukazał się na niedzielę 3 września 1939 roku. Była to pierwsza niedziela wojny. $Z$ tego względu numer ten nie dotarł był już do rąk licznych jego czytelników [...] musiał przerwać swą 45-letnią chlubną służbę dla Kościoła i Polski” ${ }^{34}$. W pierwszej edycji „Głosu” autor ukrywający się pod pseudonimem Wuj z Baranowa w sposób gawędziarski przypomniał również tragiczne losy „Przewodnika”, który został zamknięty przez hitlerowców. Gmach, w którym miała swoją siedzibę redakcja najpierw zamieniono na hotel, następnie spalono go wraz z obecnym tam księgozbiorem ${ }^{435}$. Piszący ubolewał też nad tym, że grono skupione wokół pisma zostało „rozbite i rozproszone”, a ksiądz redaktor „,̇ył podobno gdzieś w dalekiej Hiszpanii” ${ }^{436}$. „Głos Katolicki” w założeniu utożsamiono z przedwojennym „Przewodnikiem Katolickim” i chciano wypełnić lukę zaistniałą po jego likwidacji. Tytuł drukowano zatem do czasu wznowienia „Przewodnika”437.

Z tygodnikiem współpracowali dziennikarze, teolodzy, duszpasterze, wykładowcy uniwersyteccy, naukowcy, literaci, pisarze, poeci i in. W gronie piszących na jego łamach znaleźli się: Jan Archita, Wojciech Bąk, Jan Dobraczyński, Eugeniusz Myczka, Eugeniusz Paukszta, Aleksander Rogalski, Józef Marian Święcicki, Henryk Tyszka. Niektórzy zaznaczyli swoją obecność poprzez ulubione tematy. Jan Ujda przybliżał odbiorcom sylwetki świętych, natomiast Kazimierz Szwarcenberg-Czerny fakty historyczne. Do piszących należeli również: Kazimierz Abgarowicz, Ludwik Buśkiewicz, Stanisław Cedro, Wanda Kieszkowska, Leszek Prorok, Stefan Słoniński, Jerzy Stawski. Redakcja z okazji licznych uroczystości kościelnych drukowała wypowiedzi papieży, prymasów i biskupów. Znalazły się zatem m.in. orędzia papieża Piusa XII, prymasa Stefana Wyszyńskiego i arcybiskupa Walentego Dymka. Artykuły o tematyce religijnej i społecznej pisali kapłani: Jan Czuj, Stefan Hain, Kazimierz Pielatowski, Jan Piwowarczyk, Maksymilian Rode, Jan Rostworowski i Marian Rzeszewski.

innych. Kiedy zwrócił mu uwagę 18-letni chłopak, że zbyt opryskliwie traktuje ludzi, zareagował: „Psia kość. Mnie staremu zwracasz uwagę? I w dodatku masz rację”. Źródło: Z. Pawlak, Umarły nadal mówi, „Przewodnik Katolicki” 1976 nr 9 s. 6.

${ }^{434}$ Z ostatnich chwil ,Przewodnika Katolickiego”. Hołd pruski, „GK” 1945 nr 1 s. 4.

${ }^{435}$ Wuj z Baranowa, Przypominam się, „GK” 1945 nr 1 s. 2.

436 Tamże.

${ }^{437}$ Żegnając się z czytelnikami, współpracownikami i sympatykami w ostatnim numerze „Głosu Katolickiego” czytamy natomiast: „Ze zmiennym uczuciem donosimy [...,], że bieżący numer jest już ostatni i 9 XII 1956 r. ukaże się pierwszy po wielu latach numer $<<$ Przewodnika Katolickiego $>>$ [...] donosimy na koniec naszym dotychczasowym P. T. Abonentom, że zamiast $<<$ Głosu Katolickiego $>>$ otrzymywać będą odtąd $<<$ Przewodnik Katolicki >> i wyrażamy nadzieję, że radośnie zaakceptują tę zmianę”. Źródło: Redakcja, Do naszych P. T. Czytelników, „GK” 1956 nr 3 s. 2. 


\section{Linia programowa}

Redakcja „Głosu Katolickiego" pragnęła w nowej i niełatwej rzeczywistości powojennej pokrzepić i podtrzymać na duchu swoich odbiorców. Publicyści tygodnika w licznych artykułach nawiązywali do bolesnych przeżyć wojny. Przedstawiając ogrom zniszczeń i strat, starali się jednocześnie zachować nadzieję na lepsze jutro. Podkreślając wagę męczeństwa, pisano: „Niejeden z nas już zapomniał się śmiać, niejeden stracił chęć do życia i zapał do pracy, zgnębiony nadmiarem cierpienia. Ale tak być nie może [...] ci, co odeszli spośród krewnych i przyjaciół, byli to ludzie szczególnie szlachetni i dobrzy: dojrzałe kłosy, gotowe na żniwo. Nas zaś pozostawił Pan Bóg widocznie na pokutę i na pracę, abyśmy starali się dorównać wzniosłym przykładem niezliczonych męczenników polskich”438. W innym miejscu czytamy: „Dziś kiedy wojna każdemu dała się we znaki [...] nie wolno zwalać na drugiego własnego ciężaru, kiedy on ma swojego dosyć [...] Nie czas na rozczulanie się. Ono osłabia naszą siłę obronną [...]. Czasy wymagają od nas dużo męstwa [...]. Czeka nas jeszcze dużo pracy [...] nad budową przyszłości" ${ }^{439}$. Zamiarem redakcji było zatem zaangażowanie i czynne uczestnictwo w życiu narodu po ustaniu działań wojennych. Publicysta w artykule kończącym pierwszy numer „Głosu Katolickiego” zatytułowanym Koniec wilka przypomniał straty polskiego duchowieństwa i niezwykłe zniszczenia kościołów świadomie czynione przez Niemców w czasie II wojny światowej ${ }^{440}$. Redakcja zwróciła się też do czytelników z prośbą, która była wielokrotnie powtarzana na stronach kolejnych wydań, aby nadsyłali materiały, wspomnienia i listy dotyczące męczeństwa Kościoła katolickiego w Polsce pod okupacją niemiecką. Planowano bowiem zobrazować skalę prześladowańn ${ }^{441}$. Problematyka wojenna była obecna na łamach periodyku przez cały okres jego istnienia, wyrażając linię programową.

Każdy numer otwierał zwykle krótki artykuł redaktora naczelnego dotyczący istotnych prawd wiary, religii czy szeroko rozumianej nauki społecznej Kościoła. Na łamach pisma redakcja postawiła sobie za zadanie „przypominać i gruntować naukę katolicką, by uczynić ją w pełni natchnieniem dla wszystkich naszych czynów"442. Pierwszy numer został dobrze przemyślany pod względem tematycznym. Rozpoczął go artykuł ks. Romana Mielińskiego Rządy Boże, nawiązujący do przytoczonego obok fragmentu Ewangelii na czwartą niedzielę po Wielkanocy ${ }^{443}$. Redaktor przypomniał istnienie prawa Bożego, które może zostać przez człowieka przyjęte bądź odrzucone. $\mathrm{Z}$ tych dwu postaw, jak thumaczył, uszanowania lub

\footnotetext{
${ }^{438}$ Wuj z Baranowa, Przypominam sie, , „GK” 1945 nr 1 s. 3.

${ }^{439}$ R. Mieliński, Nie pora, „GK” 1945 nr 6 s. 1.

${ }^{440}$ Koniec wilka, „GK” 1945 nr 1 s. 4.

${ }^{441}$ Potomnym ku pamięci, „GK” 1945 nr 1 s. 4.

442 Od redakcji, „GK” 1945 nr 1 s. 4.

${ }^{443}$ Jan 16, wersy 5-14.
} 
odrzucenia, a nawet „uznania prawa Bożego za wyraz zacofania, braku postępu, niezrozumienia potrzeb chwili”, rodzą się społeczeństwa harmonii lub chaosu ${ }^{444}$. Pierwszą stronę wypełnił też, korespondujący z poruszaną w zeszycie problematyką, utwór Zygmunta Krasińskiego Z psalmu dobrej woli, w którym poeta pisał:

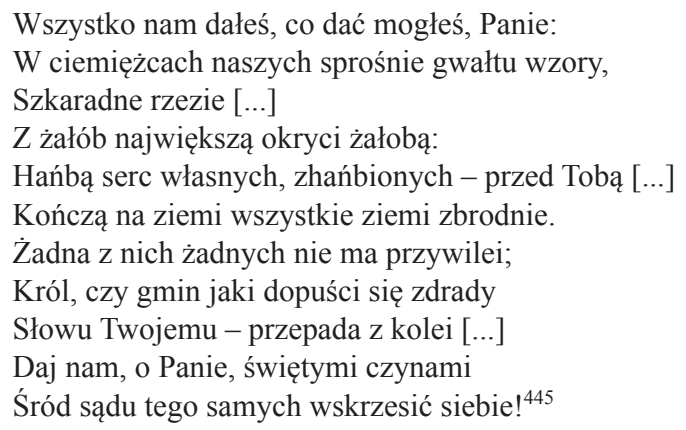

Z okazji wydania setnego numeru „Głosu Katolickiego” czytamy: ,[...] artykuły $<<$ Głosu Katolickiego $>>$ mają charakter raczej wyznania wiary, na pozór nie głosząc niczego nowego. Stąd niektórzy widzą w tym pozory zacofania, orientowania na prawo" ${ }^{446}$. Przytoczono również następujące opinie o tygodniku: „Dla jednych jest on $<<$ najzacieklejszym obrońcą katolicyzmu walczącego $>>$ („Kuźnica”), dla innych <<najbardziej ortodoksyjnym pismem $>>$ („Przekrój”), dla jeszcze innych $<<$ najbardziej na prawo zorientowanym $>>$ („Odrodzenie”). Tymczasem ma on ambicję być tylko katolickim w pełnym tego słowa znaczeniu. W rozgrywającej się walce dwóch światopoglądów: katolickiego i materialistycznego stanął zdecydowanie po stronie katolickiej”447. Wcześniej na łamach periodyku zacytowano opinię publicysty z „Kuźnicy”: „,<Głos Katolicki >> reprezentuje najbardziej zacofane i najbardziej dbałe o zewnętrzne atrybuty władzy Kościoła rzymskiego koła katolickie. Dlatego też [...] walczy jak może z wszelkimi przejawami laicyzacji życia w Polsce" $" 48$.

Założeniem redakcji pisma było również zapoznawanie odbiorców z oficjalnymi dokumentami Kościoła, co czyniono konsekwentnie na jego łamach w latach 1945-1948 drukując fragmenty encyklik, listów, orędzi i przemówień dostojników Kościoła. W licznych wypowiedziach opowiadano się za stanowiskiem papieża.

Tygodnik o profilu religijno-społecznym adresowany był $\mathrm{w}$ latach 1946-1948 głównie do inteligencji miejskiej. W pierwszym okresie podejmo-

${ }^{444}$ R. Mieliński, Rządy Boże, „GK” 1945 nr 1 s. 1-2.

${ }^{445}$ Z. Krasiński, Z psalmu dobrej woli, „GK” $1945 \mathrm{nr} 1 \mathrm{s.} 1$.

${ }^{446}$ R. Mieliński, Z okazji setnego numeru, „GK” 1947 nr 13 (100) s. 89.

${ }^{447}$ Tamże.

${ }^{448}$ Czy naprawdę zacofani?, „GK” 1946 nr 9 s. 65. [cytat z „Kuźnicy” 1946 nr 4] 
wano na jego łamach zagadnienia formacji katolickiej w warunkach nowego ustroju społecznego. Publicyści w licznych polemikach konfrontowali światopogląd katolicki z marksistowskim. Podkreślano istotną rolę małżeństwa i rodziny w życiu społecznym. Zagadnienie pracy, obrony praw i godności człowieka ukazywano przez pryzmat katolicki. Nie pomijając problematyki politycznej, zapoznawano ze stosunkiem Kościoła do konkretnych decyzji i działań propagandowych nowej władzy. Interesowano się także wychowaniem, reformą szkolnictwa i szkołą wyznaniową. Piszący stawali w obronie papieża Piusa XII w związku z zarzutami działania proniemieckiego. Pojawiała się też problematyka historyczna.

\section{Cechy wydawniczo-formalne}

Pierwszy numer „Głosu Katolickiego” z informacją w podtytule „Pismo religijne - wychodzi raz na tydzień” ukazał się 29 IV 1945 r. w Poznaniu, ostatni 19 XII 1948 r. Wydawany był w formacie czwórki przez Katolicki Komitet Wydawniczy, zaś tłoczony w Drukarni św. Wojciecha. Siedziba redakcji mieściła się w Poznaniu (Górczyn) przy ul. Częstochowskiej 16. Notka Od redakcji na ostatniej stronie informowała: „Przez cały ciąg długiej a okrutnej okupacji niemieckiej milczał każdy głos polski. Milczał też głos katolicki. Teraz, gdy po uwolnieniu ziem polskich spod przemocy niemieckiej przez zwycięskie wojska armii radzieckiej odradza się polskie drukowane słowo, zaczyna się też odzywać drukowany głos katolicki”"449. W dalszej części powiadamiano, że „względy techniczne nie pozwoliłyby ukazywał się w rozmiarach i nakładzie większym"450. Objętość pierwszych czterech numerów wynosiła bowiem zaledwie 4 strony ${ }^{451}$, następnie powiększono tygodnik do 8 stron. Jego nakład wynosił 35 tys. egzemplarzy. Redakcja nie otrzymywała żadnych zwrotów ${ }^{452}$.

W celu poszerzenia grona odbiorców zachęcano czytelników, aby przekazywali przeczytane egzemplarze innym. Na ostatniej stronie pierwszego numeru pojawiła się w związku z tym osobna reklama z wytłuszczonym hasłem: „Głosu Katolickiego nie niszcz, nie przetrzymuj w domu, przeczytaj i podaj go dalej". W kolejnych egzemplarzach możemy napotkać również pogrubiony napis w ramce: „Przeczytałeś? Podaj gazetę drugiemu”453. Część wydań rezerwowano dla czytelników z prowincji, natomiast mieszkańców Poznania zachęcano

449 Od redakcji, „GK” 1945 nr 1 s. 4.

${ }^{450}$ Tamże.

${ }^{451}$ O objętości 4 stron wydano też nr 46 z 1947 r. ,,ze względu na duże trudności na rynku papierniczym”. Od Administracji, „GK” 1947 nr 46 s. 380.

${ }^{452}$ P. Nowak, Poznańskie księgarstwo asortymentowo-wydawnicze $w$, bitwie o handel” 1946-1950. W: Niewygodne dla władzy, pod red. Degen i J. Gzelli, Torun 2010, s. 293.

453 „GK” 1945 nr 24 s. 8. 
do osobistego odbioru tygodnika od czwartku w biurze redakcji. W rubryce $O d$ Administracji proszono odbiorców o regularne wpłacanie należności za dostarczone edycje ${ }^{454}$.

Il. 6. Nagłówek pierwszego numeru „Głosu Katolickiego”.

„GK” 1945 nr 1 s. 1

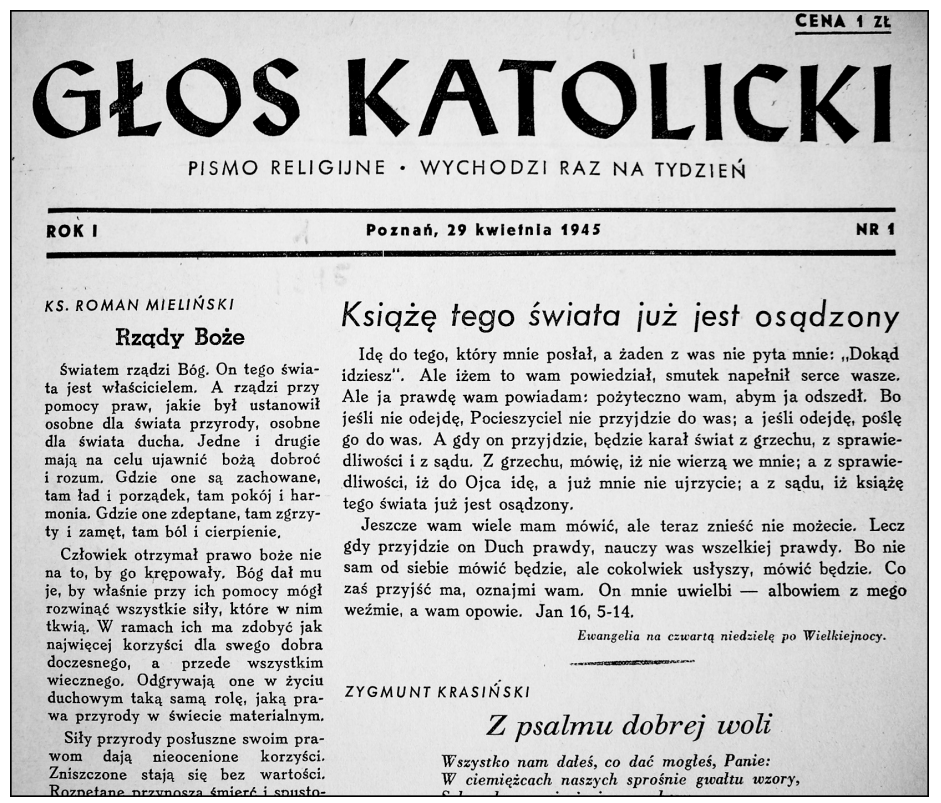

Źródło: Ze zbiorów BUŁ.

W latach 1945-1948 ukazało się łącznie 190 numerów w obrębie 4 roczników (R. 1: 35 numerów; R. 2-4 po 52 numery z jednoczesnym zachowaniem ciągłej i podwójnej numeracji). Wydania jubileuszowe obszerniejsze i droższe poświęcano różnym okazjom, m.in. 950 rocznicy śmierci św. Wojciecha ${ }^{455}$. Odbiorcy otrzymywali również zeszyty podwójne i świąteczne z okazji świąt Bożego Narodzenia ${ }^{456}$, Wielkanocy i uroczystości Zesłania Ducha Świętego ${ }^{457}$. Od początku drugiego rocznika towarzyszyła pismu ciągła numeracja stron w obrębie roku. Strony liczbowano w prawym górnym rogu.

Cena „Głosu” w latach 1945-1948 ulegała częstym zmianom. Tylko w pierwszym roku wydawania zmieniła się trzykrotnie. Najpierw wynosiła 1 zł, dość szybko jednak, gdyż od numeru piątego wzrosła do 2 zł, a następnie (od nru 32

454 Od Administracji, „GK” 1947 nr 46 s. 380.

455 „GK” $1947 \mathrm{nr} 17$.

${ }^{456} \mathrm{~Np}$. nr 52 z 1947 r. obszerniejszy 12 stron i droższy - 10 zł.

457 „GK” 1948 nr 20 w cenie 10 zł i o objętości $12 \mathrm{~s}$. 
z 1945 r. do nru 1 z 1946 r.) do 3 zł. W nagłówku na pierwszej stronie od stycznia do kwietnia 1946 r. (nry 2-16) informowano o koszcie 15 zł miesięcznie. Od numeru 17 z 1946 r. powrócono do tradycyjnej formy podawania ceny, która do kwietnia 1947 r. wynosiła 3 zł (nr 17). Następnie za tygodnik należało zapłacić 6 zł. Z początkiem 1948 r. podniesiono jego koszt do 8 zł. Pod koniec roku cena znów wzrosła, gdyż już ostatni numer świąteczny kosztował 10 zł. Kolportaż tygodnika w latach 1945-1948 odbywał się poprzez administrację. W stopce redakcyjnej na końcu periodyku podawano również cenę ogłoszeń. Przykładowo w 1947 r. wynosiła ona "1 zł za 1 łam na stronie 6-łamowej”, a w 1948 r. już 25 zł. Były to oczywiście ceny obowiązujące przed wymianą pieniędzy w $1950 \mathrm{r}$.

Zawartość „Głosu Katolickiego” układano w trzech szpaltach, które czasem rozbijano tekstami w tabelach drukowanych na dwu równoległych stronach zeszytu. Zapewne ze względów oszczędnościowych posługiwano się drobną czcionką. Redakcja miała zwyczaj nadawania artykułom dużych nagłówków przy użyciu wyszukanej czcionki, co urozmaicało tekst. Niekiedy była to kursywa, innym razem pismo naśladujące ręczne, a czasem po prostu mocno pogrubiony na czarno druk. Ważniejsze partie wypowiedzi wyróżniane przez autorów były rozspacjowane. Światło w tekście nadawały gwiazdki oraz pojedyncze i podwójne linie ciągłe. Z początkiem 1947 r. po kilku stronach pojawiła się w prawym dolnym rogu Treść numeru. Pod nagłówkiem $W$ numerze na pierwszej stronie drukowano spis treści od numeru 13 (100).

Na łamach „Głosu Katolickiego” drukowano artykuły, polemiki, fragmenty powieści, opowiadania, orędzia, przemówienia, spisy bibliograficzne. W latach 1945-1948 obecne były przedruki, m.in. z angielskiego tygodnika katolickiego „The Tablet”458, francuskiego „La Croix”459, słowackiego „Katolicke Noviny”"460, polskiego „Tygodnika Powszechnego" ${ }^{461}$.

\section{Działy i rubryki}

Struktura „Głosu Katolickiego” w latach 1945-1948 ulegała ciągłym zmianom poprzez wprowadzanie nowych działów i rubryk. Zasadniczy zrąb pozostawał jednak taki sam. Zawartość kształtowała się następująco: artykuł wstępny redaktora naczelnego, który z czasem został zastąpiony wypowiedziami innych autorów (s. 1-2), po czym zamieszczano artykuły o tematyce religijnej (s. 2-3),

\footnotetext{
${ }^{458}$ Np. U. Godzik, Odrodzenie katolicyzmu w Austrii, „GK” 1947 nr 39 s. 324-325.

${ }^{459}$ Np. Dramat współczesnego świata, „GK” 1947 nr 49 s. 399.

460 (S), Prawda o ,'świadkach Jehowy”, „GK” 1948 nr 14 s. 127.

${ }^{461}$ P. Jasienica, ,,Polnischer Kardinal - Primas war weitblickend”, GK” 1948 nr 6 s. 50.
} 
ważnych wydarzeniach z życia Kościoła ${ }^{462}$, doktrynie katolickiej i dokumentach papieskich. Ostatniemu zagadnieniu służyły dwie rubryki istniejące od początku: Listy więźniów i Dokumenty mówia (s. 4). W pierwszej z nich spisem obejmowano więzionych przez hitlerowców, w drugiej zaś, zgodnie z założeniem programowymi, pisano o działalności polskiego kleru, podawano udokumentowane miejsca kaźni i mordów wraz ze spisem nazwisk ofiar (często księży) ${ }^{463}$. Starano się bowiem ukazać prawdę o sprawie polskiej w czasie II wojny światowej ${ }^{464}$.

Po głównej części artykułowej następowała w „Głosie” część obyczajowa, gawędziarska i informacyjna. Służyły temu liczne i zmieniające się rubryki. Przykładem może być Gawęda wuja z Baranowa - (początkowo na dole s. 2-3; od nru 5 z 1945 r. na s. 5-6 i dalszych; nieobecna już w 1947 r.). Gawędy dotyczyły różnej problematyki, m.in. kościołów protestanckich, młodzieży polskiej i in. ${ }^{465}$ Stałą rubryką było $Z$ życia Kościoła katolickiego (od nru 2 z 1945 r.), która choć nie była obecna w każdym numerze, ale mniej lub bardziej rozbudowana przetrwała do końca. Informowano w niej na bieżąco o ważnych wydarzeniach i uroczystościach. Niekiedy uszczegółowiano kwestie, wyodrębniając $Z$ życia Kościoła $w$ Polsce, $Z$ życia religijnego Warszawy ${ }^{466}$ czy $Z$ życia kościelnego $w$ archidiecezji gnieźnieńskiej ${ }^{467}$. Zamiast niej czasami pojawiała się rubryka Ze świata katolickiego z podziałem na: Z Watykanu, Z Polski, Z Danii, Z Włoch, Z Hiszpanii, Ze Stanów Zjednoczonych Ameryki, Z Niemiec, Z Francji ${ }^{468}$. Obszerniejszy dwustronicowy (s. 7 i 8) dział pod nagłówkiem Ze świata katolickiego wszedł od 1947 r. Za każdym razem redakcja drukowała również jeden lub kilka wierszy rozproszonych po całym numerze. Poezję zamieszczano na pierwszej stronie, pośrodku lub na końcu; zwykle była to twórczość mało znanych poetów.

Liczne zmiany w strukturze pisma świadczyły o trosce redakcji, aby uczynić je bardziej atrakcyjnym i odpowiednim dla odbiorców.

\footnotetext{
${ }^{462}$ Np. S. Dąbrowski, Nowy polski Kardynat: Książę Metropolita Adam Stefan Sapieha, „GK” 1946 nr 8 s. 59.

${ }^{463}$ Dokumenty mówia. Działalność polskiego kleru, „GK” $1945 \mathrm{nr} 4$ s. 4; Dokumenty mówia, tamże, nr 5 s. 8.

${ }^{464}$ A. Maglione, Nota sekretarza stanu do Ribbentropa w sprawie polskiej, „GK” $1946 \mathrm{nr} 14$ s. 107.

${ }^{465}$ Wuj z Baranowa, Gawęda o protestanckich kościołach, „GK” 1945 nr 2 s. 2-3; Gawęda o ludziach spalonych, tamże, nr 3 s. 2-3; Gawęda świateczna, tamże, nr 4 s. 2-3; Gawęda o tajemnych matżeństwach, tamże, nr 5 s. 4-5; Gawęda o polskiej młodzieży, tamże, nr 6 s. 5; Gawęda o odbudowie ducha, tamże nr 12 s. 4-5; Gawęda azjatycka, tamże, nr 17 s. 4-5; Gawęda wiejska, tamże, $\mathrm{nr} 20$ s. 4-5; Gawęda miejska, tamże, nr 21 s. 5; Gawęda o wymierajacym narodzie, tamże, nr 22 s. 4-5; Gawęda o starych rodach, tamże, nr 23 s. 4-5; Gawęda o tragediach matżeńskich, tamże, nr 24 s. 5.

466 „GK” $1945 \mathrm{nr} 7$ s. 8.

467 "GK” $1945 \mathrm{nr} 8$ s. 8.

468 „GK” 1945 nr 10 s. 8; tamże, nr 11 s. 8; tamże, nr 12 s. 8; tamże, nr 13 s. 8; tamże, nr 14 s. 8 ; tamże, nr 15 s. 8 .
} 
Fragment Ewangelii wraz z nagłówkiem towarzyszył pierwszej stronie od początku powstania tygodnika do końca $1946 \mathrm{r}$. (do nru 48). Wraz z powiększeniem objętości czasopisma, od numeru 5 z 1945 r., zaczęto drukować krótkie opowiadanie $^{469}$ (czasem dwa w jednym numerze) lub powieść w odcinkach. Do każdego wydania wszedł Pamiętnik przeciętnego śmiertelnika (również od 5 z 1945 r.). Redakcja zapowiedziała go następująco: „Z dniem dzisiejszym rozpoczynamy druk pamiętnika. Pisał go zwykły, jak się mówi $<<$ szary człowiek $>>$. Opowiada o swoich codziennych zmartwieniach i kłopotach, które dziś są zmartwieniami i kłopotami większości ludzi. Że zaś opowiada o nich w sposób pogodny i $<<$ uśmiechnięty $>>$, że nieraz, a nawet często uśmiejemy się z jego przygód i nieszczęść, to może i lepiej” ${ }^{470}$. Prowadzący rubrykę istotnie posiadał talent pisarski, lekkość stylu i poczucie humoru. W kolejnym numerze (6 z 1945) na ostatniej stronie pojawiła się rubryka Prota zatytułowana Proszę o głos, która nie występowała w każdej edycji tygodnika. Redakcja zastępowała ją czasem obyczajowym Podpatrzono ${ }^{471}$ lub też rubryki te występowały równolegle ${ }^{472}$. Zagadnienia moralne prowadzone przez ks. Zygmunta Kłeckiego zagościły w trzeciej kolumnie (od nru 7 z 1945 r. s. 2$)^{473}$.

Z początkiem 1946 r. można było zapoznać się z obyczajowymi Okruchami (od nru 10 z 1946 r.), które w sposobie prowadzenia przypominały znane już Podpatrzono czy Migawki. W latach 1946-1948 czytelnicy mogli śledzić regularnie Glos z kata (obecny od nru 20 z 1946 r. s. 6) prowadzony przez Jacka. Na stronie ostatniej redakcja zdecydowała zamieścić kilka mniejszych rubryk, przez co strona stała się niezwykle bogata i różnorodna. Tutaj znalazła się m.in. część zatytułowana Nasi czytelnicy pisza. $\mathrm{Z}$ czasem drobniejszym drukiem zaczęto prowadzić rubrykę książkową, różnie nazywaną: Książki nadesłane, Z nowości wydawniczych, Nowe wydawnictwa, a także Ksiażki przysyłane do redakcji. Ostatnia strona była też miejscem korespondencji z czytelnikami. Pod nagłówkiem Odpowiedzi redakcji, Od redakcji, Z listów do redakcji zwracano się z podziękowaniem za listy np. do Gazeciarki z kiosku parafialnego, którą informowano, że sprawa zostanie poruszona na łamach tygodnika ${ }^{474}$. Czasem imiennie powiadamiano: „Nie skorzystamy”, „Nie zamieścimy”, „Nad talentem trzeba jeszcze popracować” 475 , „Intencja szczera i dobra, ale do pisania to nie wystarcza”"476 lub „Artykuł spóźniony. Prosimy o inne, krótkie i jędrne"477. Od redakcji służyła również wyjaśnieniom pojawiających

${ }^{469}$ Np. J. Baranowski, Ambrożowe serce , „GK” 1945 nr 5 s. 4; M. Ochocki, Dola, „GK” 1947 nr 31 s. $260-262$.

${ }^{470}$ F. Lusterko, Pamiętnik przeciętnego śmiertelnika, „GK” $1945 \mathrm{nr} 5$ s. 8.

${ }^{471}$ Podpatrzono, „GK” 1945 nr 7 s. 8; tamże, nr 8 s. 8;

472 „GK” 1945 nr 9 s. 8

${ }^{473}$ Np. Z. Kłecki, O strojach kobiecych, „GK” 1945 nr 12 s. 2.

474 Odpowiedzi redakcji, „GK” 1945 nr 7 s. 8.

475 Tamże, „GK” 1945 nr 16 s. 8.

476 Tamże, „GK” 1945 nr 19 s. 8.

477 Tamże, „GK” 1949 nr 5 s. 38. 
się problemów. Przykładem może być tłumaczenie, że z powodu braku papieru nie wszystkim odbiorcom dostarczano egzemplarz „Głosu” ${ }^{\text {"778 }}$. Niekiedy na ostatniej stronie pojawiało się Uśmiechnij się... ${ }^{479}$. Ważne informacje dla odbiorców związane z prenumeratą zamieszczano pod nagłówkiem Od administracji (po raz pierwszy w nrze 42 z 1947 r. s. 350).

Od kwietnia 1947 r. (nr 15 s. 6) zapoczątkowano dział Z kart przeszłości (czasem Wspomnienia z przeszłości) oraz Co pisza inni? (nr 16 z 1947 s. 6). Pierwszy z nich zdjęto w 1948 r., drugi prowadzono do końca. Na krótko zagościła na łamach „Głosu Katolickiego" kolumna Kościół na Ziemiach Odzyskanych (od nru 26 z 1948 r. s. 7), która świadczyła o zainteresowaniu sytuacją na zachodnich terenach kraju. Od połowy października 1947 r. (nr 42 s. 6) wprowadzono rubrykę Notujemy. Redakcja zwróciła się jednocześnie z prośbą do czytelników o współpracę w świeżo otwartym dziale. Pisano: „W tym celu bardzo prosimy nadsyłać z czytywanych przez siebie dzienników, czasopism, książek, broszur, ulotek te ustępy, które obrażają uczucia religijne. Ustęp taki należy wyraźnie zaznaczyć, podać dokładnie tytuł pisma, datę lub numer egzemplarza, z którego został wyjęty”480. W kolejnym już numerze "Głosu” odnotowano znalezioną na łamach „Exspressu Wieczornego” pomyłkę, w której wielkiego artystę Michała Anioła utożsamiono z Michałem Archaniołem ${ }^{481}$. Jednorazowo ukazała się kolumna Z krajów misyjnych, wprowadzona na ostatniej stronie w listopadzie $1947 \mathrm{r}$. (nr 46). Informowano w niej o procentowym udziale katolików w ogólnej liczbie obywateli danego państwa $\mathrm{i}$ ich sytuacji w różnych krajach.

Duże zmiany zarówno w wyglądzie pisma, jak i w jego strukturze zaczęto wprowadzać od października $1948 \mathrm{r}$. (nr 43). W połowie następnego miesiąca (nr 46 s. 3) zagościła Odpowiedź moralisty. Redakcja zachęcała do nadsyłania „pytań i wątpliwości moralnych” do redakcji z podpisem ,dla moralisty” ${ }^{482}$. W tym samym czasie (nr 48 s. 2) znalazła się także rubryka Śladami Chrystusa, w której drukowano znów fragmenty Ewangelii wraz z ich interpretacją oraz dział Obserwacje (s. 5). Równolegle można było zapoznać się też z Codziennymi troskami (s. 6), gdzie udzielano praktycznych rad w sprawach mody, gospodarstwa domowego, żywienia, leczenia itp. Z końcem listopada od numeru 48 z $1948 \mathrm{r}$. (s. 7) w każdym zeszycie w niewielkiej rubryczce doradzano Co czytać? (s.7). Na ostatnią stronę do każdego wydania wszedł dział $Z$ czterech stron świata. Ciekawie prowadzony, obok fotografii zawierał krótkie informacje ze świata kultury, polityki, gospodarki. Czasami dzielono problematykę na $W$ świecie i $W$ kraju. Oprócz niego na końcu redakcja zaczęła zamieszczać w ostatnich zeszytach 1948 r. Varia, m.in. humor rysunkowy, Rozmaitości i Rzeczy ciekawe.

\footnotetext{
${ }^{478}$ Od redakcji, „GK” 1945 nr 21 s. 8.

479 „GK” 1945 nr 22 s. 8.

${ }^{480}$ Notujemy, „GK” 1947 nr 42 s. 350.

${ }^{481}$ Tamże, „GK” 1947 nr 43 s. 358.

482 Odpowiedź moralisty, „GK” 1948 nr 46 s. 387.
} 
Il. 7. Rubryka Co czytać? „GK” 1948 nr 49 s. 411

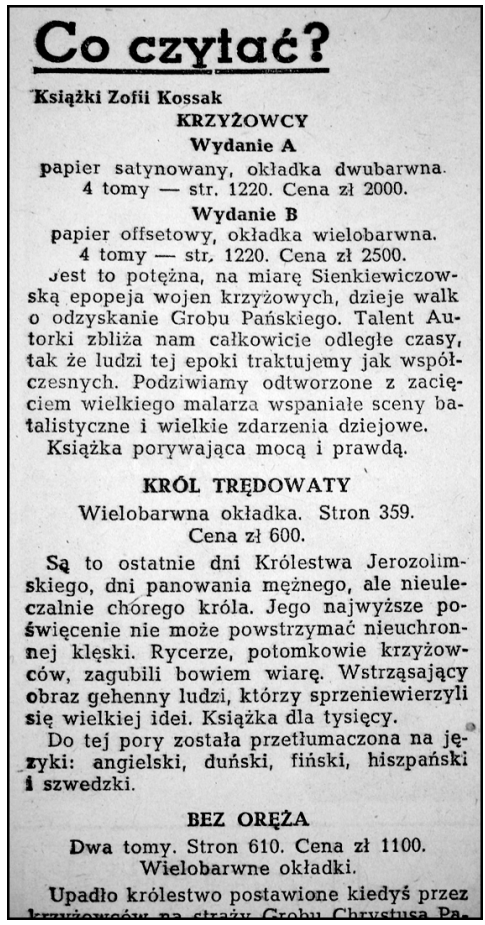

Źródło: Ze zbiorów BUŁ.

Il. 8. Dział Z czterech stron świata. „GK” 1948 nr 49 s. 412

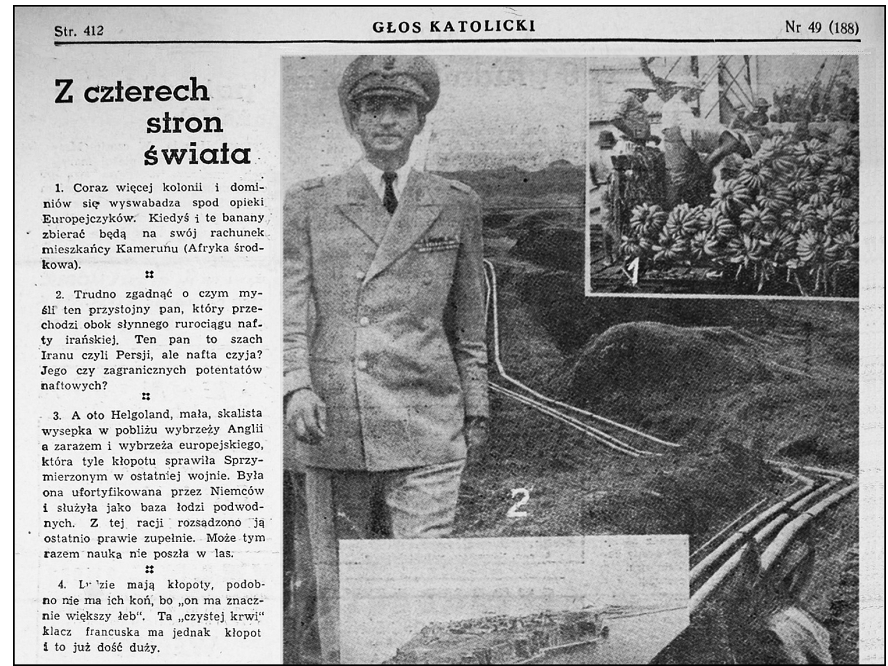

Źródło: Ze zbiorów BUŁ. 
Z powyższego przeglądu wynika, że omawiany tygodnik charakteryzował się dużą różnorodnością działów i rubryk, a jednocześnie stałą obecnością bloków tematycznych zgodnych z profilem czasopisma. Problematykę religijną i społeczną traktowano poważnie, nieco lżej obyczajową. Nie zabrakło rubryk, w których polecano książki lub udzielano praktyczne rady. Osobno i z dużą pieczołowitością potraktowano rubryki służące kontaktom z czytelnikami.

\section{Problematyka poruszana na lamach pisma}

Zagadnienia obecne na łamach „Głosu Katolickiego” były równie bogate, jak i różnorodne. Dominowała tematyka religijna. W tej kategorii mieściły się, przykładowo, rozważania Eugeniusza Myczki o zjednoczeniu jednostki ludzkiej z Bogiem i ze społecznością na mszy świętej ${ }^{483}$. Tradycję odprawiania trzech mszy świętych w Boże Narodzenie wyjaśnił ks. Władysław Śpikowski ${ }^{484}$. W okresie poprzedzającym Wigilię Bożego Narodzenia czytelnik mógł zapoznać się z pochodzeniem zwyczajów i obrzędów towarzyszących świętom ${ }^{485}$. Rozważano także kwestie ogólne dotyczące odrodzenia religijności ${ }^{486}$. Marian Rzeszewski starał się przybliżyć czytelnikowi tajemnicę Trójcy Świętej ${ }^{487}$. Spora część autorów poruszała problematykę wiary ${ }^{488}$, modlitwy ${ }^{489}$, moralności ${ }^{490}$ i działalności sekt ${ }^{491}$.

Poczesne miejsce w zawartości czasopisma zajęły rozważania odnoszące się do nauki społecznej Kościoła. Złożyły się na nie przede wszystkim omówione dokumenty papieskie. Fragmenty encyklik przytoczono m.in. w pierwszym cyklu, w którym podjęto temat Pius XII a Polska ${ }^{492}$. Z numerem 24 z 1946 r. zapoczątkowano cykl artykułów Poglądy papieża Piusa XII na

\footnotetext{
${ }^{483}$ E. Myczka, Godność i uspołecznienie (rozważania religijno-społeczne), „GK” $1946 \mathrm{nr} 51$ s. 407.

${ }^{484}$ W. Śpikowski, Trzy msze św. na Boże Narodzenie (rozważanie liturgiczne), „GK” 1946 nr 52 s. 415.

${ }^{485}$ S. Krokowski, W jedyną noc: z kart przeszłości i dzisiejszych dni, „GK” 1946 nr 52 s. 422.

${ }^{486}$ A. Rogalski, Zmierzch czy odrodzenie religijności?, „GK” 1947 nr 38 s. 313-314.

${ }^{487}$ M. Rzeszewski, Tajemnica tajemnic, „GK” 1946 nr 25 s. 1.

${ }^{488}$ W. Bąk, Dogmaty, „GK” 1945 nr 19 s. 3; tenże, Nauka, religia, czy sztuka, „GK” 1946 nr 4 s. 27.

489 B.P., O modlitwie różańcowej, „GK” 1948 nr 43 s. 363.

${ }^{490}$ E. Bankiewicz, Dom rodzinny a moralność, „GK” $1945 \mathrm{nr} 25$ s. 6; J. Wiecki, Bilans strat moralnych i materialnych, tamże, 31 s. 7; J. Archita, Źródła moralności, „GK” 1946 nr 35 s. $278-279$.

${ }^{491}$ Np. W. Trzebiński, Protestancka kultura Ameryki, „GK” 1947 nr 51 s. 417-418.

492 Pius XII piętnuje napad Niemców na Polskę, ,, GK” 1945 nr 3 s. 3; Pius XII domaga się dla Polski prawa do życia, tamże, nr 4 s. 3; Papież wyraźnie po stronie Polski nr 5 s. 3; Papież Pius XII przeciwko pogwatceniu praw narodów przez Niemcy, tamże, nr 6 s. 3; Pius XII pamięta o polskich tułaczach, tamże, nr 8 s. 3.
} 
sprawy społeczne $e^{493}$. Niejednokrotnie drukowano też przemówienia papieskie ${ }^{494}$. Często zagadnienia doktryny katolickiej podejmował redaktor naczelny ks. Roman Mieliński. Przykładowo rozważał na łamach pisma samo pojęcie katolicyzmu czynnego ${ }^{495}$. Pisał: „Zasadnicze przykazanie miłości [...] wypowiadać się ma i przejawiać czynem oraz życiem, nie słowami. Słowa same niepoparte czynem są pustym dźwiękiem, miedzią brząkającą"496. Autor zwrócił też uwagę na sprawiedliwość jako na najważniejszą cnotę moralną. W innym artykule podkreślił wagę i znaczenie nauczania Kościoła ${ }^{497}$. Katolicyzm społeczny pozostawał w kręgu zainteresowań licznych autorów ${ }^{498}$. Rozumienie pracy w duchu katolickim omówił m.in. Jerzy Stawski ${ }^{499}$.

Gruntownej formacji katolickiej miały służyć artykuły światopoglądowe, w treści których odnoszono się do założeń systemów ideologicznych ${ }^{500}$. O walce światopoglądowej materializmu z chrześcijaństwem, wymagającej u czytelników dokonania jednoznacznego wyboru, pisał Stefan Słoniński ${ }^{501}$. Starając się dać syntezę długiej polemiki między publicystami „Kuźnicy” a współpracownikami „Tygodnika Powszechnego”, konstatował: „Kto wybrał katolicyzm marksizm musi odrzucić" ${ }^{02}$. Piętnował równocześnie postawę połowiczności i kompromisu wyrażoną w powiedzeniu: „Panu Bogu świeczkę i diabłu ogarek”. Rzeczywistość określił słowami: „Dziś jest twarde i nieubłagane. Od najbardziej niezdecydowanego człowieka wymaga, by się opowiedział, pod czyim sztandarem chce budować nowy porządek świata?" ${ }^{503}$. S. Słoniński ubolewał, że „wydaje się niektórym, że można utrzymać się na powierzchni bez wyrobionego światopoglądu i trwałych zasad” ${ }^{504}$. Stwierdził także: „Katolicyzm naszych przodków często był tylko barwnym strojem, w którym - im było bardzo do twarzy. Dziś my musimy dbać o to, by nasz katolicyzm był wyznaniem, świa-

493 J. Tonneau, Z nurtem życia, „GK” 1946 nr 24 s. 195; tenże, Prawo szukania, tamże, nr 25 s. 202; Moralność się nie zmienia, tamże, nr 26 s. 210; tenże, Myśl o całości, tamże, nr 28 s. 227.

${ }^{494}$ Pius XII, ,, Wasza jest przyszłość”, „GK” 1947 nr 22 s. 186.

${ }^{495}$ R. Mieliński, Katolicyzm czynny, „GK” 1946 nr 35 s. 277.

496 Tamże.

${ }^{497}$ R. Mieliński, Kościót nauczający, „GK” 1947 nr 17 s. 143.

498 J. Archita, Katolicyzm społeczny, „GK” 1945 nr 33 s. 7; E. Myczka, Zasada wytwórczości w katolickim ruchu społecznym, „GK” $1947 \mathrm{nr} 31$ s. 258; J. Archita, Wokół zagadnienia katolicyzmu społecznego, tamże, nr 35 s. 290; Suchard, Katolicyzm społeczny, tamże, nr 37 s. 306; S. Słoniński, Katolicka nauka spoteczna, tamże, nr 41 s. 339; J.M. Święcicki, Katolicyzm prawdziwym humanitaryzmem, tamże, nr 44 s. 363; J. Archita, Społeczna nauka Kościoła, „GK” 1948 nr 20 s. 175.

${ }^{499}$ J. Stawski, Chrześcijańska koncepcja pracy, „GK” 1946 nr 43 s. 343.

${ }^{500}$ Np. K. Madaliński, Trzy światopoglady, „GK” 1945 nr 5 s. 6.

${ }^{501}$ S. Słoniński, Zrewidujmy nasz stosunek do katolicyzmu, „GK” $1946 \mathrm{nr} 39$ s. 310.

502 Tamże.

${ }^{503}$ Tamże.

504 Tamże. 
topoglądem - odbiciem duszy”505. Nawoływał do praktykowania „katolicyzmu dynamicznego", nie tylko uczuciowego, który nie znajdował konsekwencji w czynach. W innym miejscu, pisząc o działaniu katolika, kontynuował: „W tak krańcowo różnym światopoglądzie człowieka, jak komunista, widzi bliźniego. Będzie rozmawiał z komunistą-ideowcem, a nawet podejmie współpracę tam, gdzie idzie o jednako zrozumiane dobro zorganizowanej zbiorowości ludzkiej” ${ }^{506}$. Do jasnych wyborów zachęcał również Stanisław Wilkowski: „Polacykatolicy muszą wybierać. A wybór jest jasny: odrzucamy Marksa, idziemy z Chrystusem"507. Jan Archita polemizował natomiast z wypowiedziami na łamach marksistowskiej „Kuźnicy”508.

Aleksander Rogalski, rozważając nowy porządek świata, zastanawiał się, czy będzie on budowany bez udziału katolicyzmu. Odniósł się przy tym do ideologii liberalnej. Konstatował przy tym: „Zasada, na której opiera się państwo liberalistyczne, nie tylko jest fikcyjna, ale jest także niebezpieczna: doprowadza naród do rozpolitykowania, rozpala w nim namiętności partyjne, wywołuje sztuczne fale podniecenia agitacyjnego, wyborczego itp., a tym samym deprawuje go i najlepsze siły jego odwodzi od pracy konkretnej, twórczej, trwałej”509. Kończąc rozważania, wnioskował, że należy przezwyciężyć idee 1789 r., gdyż człowiek powinien przestać być ,niewolnikiem kultury zewnętrznej i ofiarą abstrakcji realistycznych filozofów" i tylko w duchu Chrystusa może nastąpić odnowienie. Problematyka demokracji podejmowana była w kontekście wartości katolickich. Jan Archita, proponując „,chrześcijańską demokrację”, wyraził opinię: „Jeśli liberałowie XIX i XX wieku wyrwali boski fundament spod demokracji, działali na niewątpliwą jej szkodę; jeśli demokraci czasów naszych potrafią w pełni ten fundament wyzyskać i na nim konsekwentnie budować, będziemy świadkami wszechstronnej, dobroczynnej demokracji wszelkich wartości i dóbr życia" ${ }^{10}$. Rogalski przy okazji zarzutów o „wstecznictwo i ciemnotę” Kościoła starał się wykazać „fałszywą optykę” i niewłaściwy punkt widzenia, dowodząc, że wszelkie poczucie demokratyczności ma swoje źródło w chrześcijaństwie. Ukazał też społeczny pierwiastek Ewangelii, dochodząc pod koniec artykułu do konkluzji: „Demokracja jest związana z chrystianizmem, a ruch demokratyczny wywodzi się z posiewu ewangelicznego" ${ }^{11}$. Kazimierz Sołtysik pisał natomiast w następujący sposób: „Problemem współczesnej doby jest problem demokratyzmu. Człowiek

505 Tamże.

${ }^{506}$ A. Słoniński, Katolik a życie publiczne, „GK” 1956 nr 1 s.1.

507 S. Wilkowski, Dziejowa chwila polskiego katolicyzmu, „GK” $1946 \mathrm{nr} 1$ s. 1.

${ }^{508}$ J. Archita, Sprawa marksizmu, „GK” 1946 nr 1 s. 6-7; tenże, Katolicyzm spoleczny i „,Kuźnica”, „GK” 1947 nr 39 s. 323.

${ }^{509}$ A. Rogalski, Katolicyzm a świat powojenny, „GK” 1946 nr 18 s.146.

${ }^{510}$ J. Archita, Religia w demokracji, „GK” 1946 nr 12 s. 90.

511 A. Rogalski, katolicyzm a demokracja, „GK” 1946 nr 13 s. 1. 
współczesny chce być równy w życiu społecznym. Chce, ażeby jego człowieczeństwo uważano za równowartościowe. Nie chce podziału społecznego na ludzi o pełnym człowieczeństwie i ludzi o półczłowieczeństwie. Nie chce podziału na podmioty i przedmioty w ludzkiej społeczności" ${ }^{12}$. Autor twierdził jednocześnie, że nie można oddzielić rozwoju moralnego i umysłowego od rozwoju socjalnego i gospodarczego. Skłonił się ku „demokratyzmowi moralno-społecznemu”, gdzie można byłoby znieść klasowość.

Nie pominięto na łamach „Głosu Katolickiego” różnic w podejściu do kwestii społecznych przez wyznawców katolicyzmu i propagatorów kapitalizmu, ukazując je przez pryzmat encyklik społecznych ${ }^{513}$. Wyraźnie pisano natomiast o potępieniu przez przedstawicieli Kościoła faszyzmu ${ }^{514}$.

$\mathrm{W}$ piśmie informowano na bieżąco o wydarzeniach z życia Kościoła w Polsce i na świecie. Przede wszystkim publikowano komunikaty z konferencji Episkopatu Polski $i^{515}$. Często drukowano orędzia i listy prymasów oraz biskupów polskich i obcych ${ }^{516}$. Adam Grzymała-Siedlecki pisał nawet o wymowie, poczuciu odpowiedzialności i stylu listów kardynała Hlonda ${ }^{517}$. Zapoznawano czytelników również z ważniejszymi przemówieniami z międzynarodowych spotkań, np. ze zjazdu ku czci kardynała Henry'ego Newmana ${ }^{518}$. Ważnym wydarzeniem dla polskiego Kościoła było uwolnienie z więzienia prymasa Augusta Hlonda aresztowanego w 1944 r. we Francji przez Niemców i bezskutecznie zmuszanego do kolaboracji. Na łamach „Głosu” wydrukowano z tej okazji telegram papieża napisany

512 K. Sołtysik, O katolicka Polskę demokratyczna, „GK” 1946 nr 34 s. 270.

513 J. Archita, Przezwyciężenie kapitalizmu, „GK” 1947 nr 43 s. 355; (S.), Odgłos papieskich encyklik spolecznych $w$ świecie, tamże, nr 51 s. 415.

${ }^{514}$ J. Archita, Kościól i faszyzm, „GK” 1946 nr 4 s. 31; J. Stawski, Totalizm chrześcijanina, „GK" 1948 nr 45 s. 380.

${ }^{515}$ Komunikat urzędowy z Konferencji Episkopatu, „,GK” 1945 nr 25 s. 1-2; Aktualne wskazania. Komunikat z Plenarnej Konferencji Episkopatu na Jasnej Górze w dniach 9-10 IX br., „GK” $1946 \mathrm{nr} 40$ s. 318.

${ }^{516}$ A.S. Sapieha, Nowe niebezpieczeństwa, „GK” $1945 \mathrm{nr} 19$ s. 1-2; Podstawy życia publicznego.List pasterski biskupów francuskich w związu z dyskusjami na temat podstaw nowej konstytucji francuskiej, „GK” $1946 \mathrm{nr} 7 \mathrm{~s} .50$; O panowanie ducha bożego w Polsce: wielkopostny list pasterski Episkopatu Polskiego, tamże, nr 13 s. 99; W. Dymek, Pokój od Boga: list pasterski wydany w dniu ingresu 30 maja 1946 roku, tamże, nr 24 s. 1-3; A. Hlond, Orędzie Kardynała Prymasa do ludności katolickiej Ziem Odzyskanych, tamże, nr 26 s. 225-226; W. Dymek, Najpiękniejsze zadanie biskupie: orędzie arcypasterskie do wiernych archidiecezji poznańskiej, tamże, nr 33 s. 262-263; Suhard, Lud z pasterzem, „GK” 1948 nr 6 s. 49-50; Największe zło dzisiejszego świata, tamże, nr 7 s. 57; W. Dymek, Zapowiedź odbudowy Katedry Poznańskiej, tamże, s. 58-59; tenże, Orędzie w sprawie Wielkopostnej Akcji Trzeźwości, tamże, nr 10 s. 82-83; Orędzie Jego Ekscelencji ks. Arcybiskupa - Metropolity Walentego Dymka na Tydzień Mitosierdzia 1948, tamże, nr 40 s. 337; List pasterski Episkopatu Polski, tamże, nr 45 s. 377-378;

517 A. Grzymała-Siedlecki, Listy Prymasowskie: Jego Eminencji ks. Kardynała Hlonda, „GK” 1946 nr 41 s. 326-328

518 J. Gawlina, Nowoczesne apostolstwo, „GK” 1946 nr 31s. 246-247. 
do Jego Ekscelencji 12 IV 1945 r. ${ }^{519} \mathrm{Na}$ stronach czasopisma oddano też głos samemu prymasowi ${ }^{520}$. Po kilkuletniej przerwie w 1946 r. powrócono do przedwojennego zwyczaju wygłaszania przez prymasa Polski corocznego przemówienia wigilijnego przez radio watykańskie ${ }^{521}$. Śledzono wybory na wysokie stanowiska kościelne w kraju, np. arcybiskupa poznańskiego ks. Walentego Dymka ${ }^{522}$. Żywo reagowano na aktualne spotkania, np. upamiętniając wizytę kardynała Bernarda Griffina w Polsce ${ }^{523}$. Zaznajamiano również z nowo wydanymi encyklikami ${ }^{524}$, listami, przemówieniami i orędziami Piusa XII z różnych okazji ${ }^{525}$. Zaznajamiano ponadto z sytuacją chrześcijan i katolików w innych krajach ${ }^{526}$.

Publicyści „Głosu Katolickiego” interesowali się szeroko pojętą problematyką katolicką̧27 i stosunkami Kościoła z państwem ${ }^{528}$. Na temat wiary starano się wypowiadać w sposób pogłębiony. Jan Archita w artykule Katolicyzm $i \dot{z} y$ cie dowodził, że modlitwa nie może być „,mechanicznym potarzaniem bezpłodnych słów, ale dwustronną rozmową i współdziałaniem z Bogiem"s29. Dostrzegł przede wszystkim potrzebę postaw i wdrażania czynem poglądów w społeczeństwo oraz „bardziej społecznego urobienia katolickiego”. Należało jego zdaniem

519 Papież wita uwolnionego z więzienia Prymasa Polski. Telegram, „GK” 1946 nr 21 s. 169.

${ }^{520}$ A. Hlond, Zadanie katolicyzmu, „GK” 1945 nr 13 s. 1; O jutro Polski, tamże, nr 14 s. 1-2; „, Odpieram ten zarzut..., jako oszczerczy”, tamże, nr 32 s. 3; Kościół Chrystusowy, tamże, nr 33 s. $1-2$.

${ }^{521}$ A. Hlond, Polska przed żłóbkiem Bożej Dzieciny: przemówienie wigilijne wygłoszone przez radio watykańskie dnia 24 grudnia 1946, „GK” 1946 nr 4 s. 25.

${ }^{522}$ F. Bogdański, Nasz Arcypasterz, „GK” 1946 nr 22 s. 174-175; H. Hubert, Ks. Arcybiskup Walenty Dymek: jako wikariusz generalny $i$ wizytator, tamże, s. 175.

${ }^{523}$ R. Mieliński, Kardynat Griffin w Polsce, „GK” 1947 nr 24 s. 201; Dzisiejsza Polska katolicka w oczach kard. Griffina, tamże, nr 31 s. 257.

524 (S), Nowa encyklika o Liturgii Ojca św., „GK” 1947 nr 52 s. 431; Nowa Encyklika Piusa XII „, Optatissima PAX”, ,GK” 1948 nr 4 s. 39.

${ }^{525}$ List Papieża Piusa XII, „GK” 1945 nr 16 s.1-2; Pius XII, Prawdziwie katolicki, „GK” 1946 nr 8 s. 1-2; Podstawy pokoju: (wyjęte z przemówienia wigilijnego), tamże, nr 9 (44) s. 66-67; Pius XII, Podwalina ludzkości, tamże, nr 18 s. 143; tenże, Kościót w świecie, tamże, nr 20 s. 1; Papiez do ludu rzymskiego, „GK” 1947 nr 5 s. 33; Wigilijne orędzie pokoju Ojca św., tamże, nr 7 s. 50; tamże, nr 8 s. 58; Pius XII, Właściwy sens pracy, tamże, nr 37 s. 306-307; tenże, Do kobiet, tamże, nr 43 s. 354; tenże, O podstawach społecznego ładu gospodarczego, ,GK” 1948 nr 18 s. 157; List papieża, tamże, nr 23 s. 193-202.

${ }^{526}$ Chrześcijaństwo $w$ Japonii, „GK” 1948 nr 12 s. 103; Kościół katolicki $w$ Indiach, tamże, nr 13 s. 115; Katolicyzm w Portugalii, tamże, nr 14 s. 126; (S), Położenie katolicyzmu w Niemczech, tamże, nr 35 s. 303; H. Tyszka, Katolicy i katolicyzm we Francji dziś a przed laty 40, tamże, nr 45 s. 381 .

${ }^{527}$ H. Tyszka, O solidarności katolickiej, „GK” 1948 nr 41 s. 350.

${ }^{528}$ Z. Choromański, Katolickie postulaty konstytucyjne, „GK” 1947 nr 17 s. 1-2; J. Archita, Polityka i wychowanie, tamże, nr 23 s. 193; S. Cedro, O zrozumienie katolickiej postawy, tamże, nr 24 s. 203; tenże, Konstytucja i konkordat, tamże, nr 26 s. 219; (S), Państwo i Kościół w Czechosłowacji, „GK” 1948 nr 25 s. 223.

529 J. Archita, Katolicyzm i życie, „GK” 1946 nr 9 s. 66. 
wyeliminować „wegetacyjność”, czyli postawy bierne, poddańcze, odosobnione i prowadzące do „samobójstwa”. Za przykład podał spędzanie płodu. „Nasz Bóg nie jest bożkiem wyciosanym z drzewa, ale żywą rzeczywistością" - pisał autor i za Jacques'em Maritainem proponował kontemplację w działaniu. Marian Rzeszewski konstatował natomiast: „Nie ma władzy, która by mogła narzucić poczucie odpowiedzialności, gdy państwo narzuca je przemocą, ludzie zawsze wykręcają się, aby służyć własnym interesom egoistycznym. Posłuszeństwo i ofiara wymagane tylko w imię państwa mogą, jak niedawno widzieliśmy, dać tylko degradację istot ludzkich”530. Dalej czytamy: „Starają się nam wmówić, że samotność jest prawem życia duchowego, że religia, modlitwa - jest sprawą prywatną [...] [lecz] wszelkie autentyczne zjawisko ludzkie jest zjawiskiem społecznym, a religia jest czymś jeszcze bardziej społecznym niż wszystkie inne"531. W kontekście moralnym rozważano także kwestie podejścia do polityki i udziału w niej katolików. Jan Archita z tej okazji pisał: „,...] [politykę] można traktować z punktu widzenia bieżących potrzeb i w płaszczyźnie układu stosunków partyjnych, jak to ma miejsce $\mathrm{z}$ inicjatywą grupy $<<$ Dziś i Jutro $>>$. Można również traktować niezależnie od praktycznych i doraźnych zabiegów i ponad współczesnymi antagonizmami" ${ }^{32}$. Druga postawa uwzględniająca katolicki pogląd na świat, jak sugerował autor, przynależała redakcji „Głosu”. Katolickie pojęcie polityki zgodnie z wypowiedzią Piusa XI określono jako zgodne z moralnością, dobrem wspólnym państwa i interesami całego społeczeństwa.

Osobno omówiono stosunki Watykanu z Polską ${ }^{533}$. Przypomniano w związku z tym encyklikę papieża Grzegorza XVI, w której głowa Kościoła potępiła powstanie listopadowe. Pisano: „Historia oddała sprawiedliwość papieżowi, notując jego przemówienie na konsystorzu w r. 1842, kiedy Grzegorz XVI dał wobec całego świata wyraz swemu żalowi, że go niegodnie oszukano, uznając tym samym obiektywną błędność swego poprzedniego stanowiska" ${ }^{34}$. Jan Archita zacytował Cypriana Norwida wypowiadającego się z kolei o papieżu Piusie IX, który ostatecznie zaprotestował przeciw rosyjskiemu bestialstwu w dławieniu powstania styczniowego. Powszechnie znane było ówczesne zarządzenie publicznych nabożeństw w Rzymie za sprawę polską i oskarżenie Rosji za prześladowania stosowane w Polsce ${ }^{55}$. Na łamach „Głosu Katolickiego" przedstawiono również stanowisko Piusa XII wobec zbrodni Niemców w Polsce, opisując wizytę Joachima von Ribbentropa u papieża 11 III 1940 r. Podczas gdy minister spraw zagranicznych Rzeszy zapewniał o zwycięstwie Niemców w wojnie, papież wymienił mu na

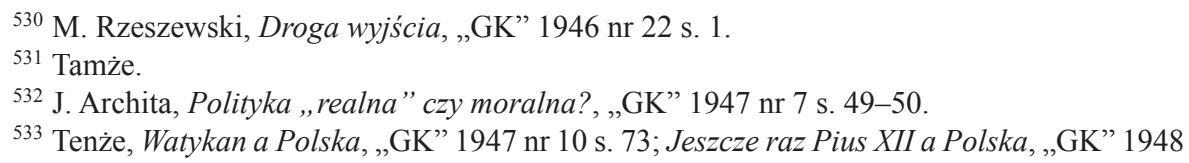


podstawie dokumentów fakty, miejsca, daty i okoliczności zbrodni, jakich najeźdźca niemiecki dopuścił się na Polakach. W innej wypowiedzi ukazano stosunek Stolicy Apostolskiej do nowych polskich granic zachodnich ${ }^{536}$. W latach 1947-1948 zaprezentowano jednocześnie cykl artykułów Papieskie zasady prawa narodów $w^{537}$.

Niejednokrotnie na stronach tygodnika poruszane były także zagadnienia ogólnospołeczne ${ }^{538}$. Szczególną uwagę poświęcono problemom małżeństwa ${ }^{539}$ i rodziny ${ }^{540}$. Dyskutowano nad wprowadzeniem ślubów cywilnych w Polsce po wojnie. Kwestię rozwodów ukazywano w kontekście encykliki Leona XIII o małżeństwie ${ }^{541}$. Kazimierz Madaliński przypomniał genezę cywilnych związków wprowadzonych przez protestantyzm w XVII w. w Holandii i Anglii, a później przez rewolucję francuską. Podejmowano także problem przerywania ciąży i pracy kobiet $^{542}$. Trudną problematykę aborcji podjęła Maria Tongwin ${ }^{543}$.

Ważne miejsce $\mathrm{w}$ tygodniku zajęły zagadnienia wychowawcze ${ }^{544}$. Podjęto m.in. temat młodzieży, która przeżywszy wojnę nosiła na sobie skutki okropnych

${ }^{536}$ Szczególne stanowisko Stolicy Apostolskiej wobec nowych polskich granic zachodnich, „GK” 1947 nr 11 s. 82-83.

${ }^{537}$ Np. K. Szwarcenberg-Czerny, Interes i siła nie moga stwarzać prawa, „GK” $1948 \mathrm{nr} 25$ s. $217-218$.

${ }^{538}$ J. Archita, O usprawnienie opieki społecznej, „GK” 1945 nr 27 s. 226; tenże, Społeczne postannictwo kobiety, tamże, $\mathrm{nr} 32 \mathrm{~s} .7$.

${ }^{539}$ W. Kufel, Ślub kościelny czy kontrakt cywilny?, „GK” $1945 \mathrm{nr} 15$ s. 3; S. Żmuda, Dla kogo? Glos dyskusyjny w sprawie reformy prawa matżeńskiego $w$ Polsce, tamże, nr 18 s. 2; Sakrament to wielki jest. Orędzie Episkopatu Polskiego do wiernych w sprawie matżeńskiej, „GK” $1946 \mathrm{nr} 1$ s. 2-3; A. Hlond, Zagadnienie rodziny chrześcijańskiej, tamże, nr 5 s. 34-35; S. Cedro, Rodzina w nauczaniu Piusa XII, „GK” 1947 nr 14 s. 111; Jacek, Gtos z kąta. Rozwody się mnoża, tamże, nr 21 s. 181.

540 J.M. Święcicki, Rodzina uświęca naród, „GK” 1947 nr 10 s. 74; J. Archita, Kobieta i rodzina, tamże, nr 20 s. 170; E. Myczka, Podstawy gospodarcze rodziny, tamże, nr 21 s. 178; S. Horbacz, „Rodzina zastępcza”, tamże, nr 36 s. 300; W. Majdański, Dziecko nienarodzone uchroń!, tamże, nr 47 s. 383; E. Serwański, O domowe ognisko rodzinne, „GK” 1948 nr 1 s. 5; S. Cedro, Kobiety, rodzina i dzieci, tamże, nr 14 s. 121; J. Archita, Przestrzeń, oddech, światto - dla rodziny, tamże, nr 42 s. 354; Z. Baranowski, Odpowiedzialność rodziców za życie dziecka, „GK” $1949 \mathrm{nr} 3 \mathrm{~s} .17-18$.

${ }^{541}$ K. Madaliński, Klęska rozwodów, „GK” 1947 nr 3 s. 17.

542 J. Archita, Sprawa rodziny, „GK” 1946 nr 33 s. 264; W. Kieszkowska, S. O. S. Sprawa jest zawsze aktualna, „GK” 1947nr 48 s. 390; J. Stawski, Chrystianizm i kobieta, „GK” 1948 nr 37 s. 313,315 .

${ }^{543}$ M. Tongwin, Optakujemy tysiace, gdy gina miliony, „GK” $1946 \mathrm{nr} 12$ s. 95.

${ }^{544}$ E. Serwański, O drogi wychowawcze powojennej młodzieży, „GK” 1947 nr 23 s. 194; S. Cedro, Przeciw świeckości w wychowaniu, tamże, nr 34 s. 283; J. Stawski, Pius XI o wychowaniu chrześcijańskim, tamże, nr 35 s. 293; S. Cedro, O ideat w wychowaniu, tamże, nr 37 s. 305; J. Archita, Państwo i wychowanie, tamże, nr 42 s. 346; S. Cedro, Z zagadnień demokratycznego wychowania, tamże, nr 48 s. 391; J. Archita, Kościół i wychowanie, tamże, nr 51 s. 415; S. Cedro, O nowy ideat wychowawczy, „GK” 1948 nr 3 s. 25; tenże, Jedność we wychowaniu, tamże, nr 4 s. 34-35. 
przeżyć wyrażających się w „zdziczeniu, schamieniu i zbrutalizowaniu” ${ }^{45}$. Wojciech Bąk sugerował zatrzymanie sądów o „takiej” młodzieży, gdyż bardzo pokrzywdzona przez los potrzebowała, jego zdaniem, czasu na dojście do normalności. Kwestie nowego ideału wychowania podjęli F. Kalinowski i Maria Woźnicka ${ }^{546}$. Od początku 1948 r. niemal w każdym numerze drukowano artykuł dotyczący tej kwestii ${ }^{547}$. W kręgu zainteresowań piszących pozostało też ogólne wychowanie społeczeństwa ${ }^{548}$. Sporadycznie natomiast pojawiały się na łamach periodyku sprawy nauczania ${ }^{549}$.

Początkowo w „Głosie Katolickim” obecna była tematyka wojenna i niemiecka ${ }^{550}$. W 1945 r. wprowadzono cykl tematyczny Niemcy a Watykan ${ }^{551}$, natomiast w 1947 r. Narodowy socjalizm a religia ${ }^{552}$. Wspomniano okrucieństwa wojny i niemieckie obozy koncentracyjne, w których można było przetrwać jedynie dzięki wierze ${ }^{553}$. Atmosferę panującą w obozach zagłady przedstawiono w 1945 r. w cyklu zeznań protokólarnych komendanta obozu w Mauthausen zatytułowany Spowiedź zbrodniarza ${ }^{554}$. W wypowiedziach nie zapomniano o Ziemiach Odzyskanych ${ }^{55}$.

${ }^{545}$ W. Bąk, Znowu o młodzieży, „GK” 1946 nr 9 s. 71.

${ }^{546}$ F. Kalinowski, Mój głos: w sprawie nowego ideału wychowawczego, „GK” $1946 \mathrm{nr} 41$ s. 330; M. Woźnicka, Wspótczesny ideat wychowawczy, $1947 \mathrm{nr} 7 \mathrm{s.} 51$.

${ }^{547}$ J. Archita, Wychowanie realistyczne, „GK” 1948 nr 9 s. 73; J. Toporski, Rodzice i dziecko, tamże, nr 12 s. 102; tenże, Rodzice i szkoła, tamże, nr 14 s. 129; S. Wański, Praca społeczna młodzieży, tamże, nr 15 s.133; K. Abgarowicz, Cześć dla rodziców, tamże, nr 23 s. 203; J. Archita, Troska o młodzież, tamże, nr 46 s. 385.

${ }^{548}$ S. Cedro, Wychowanie chrześcijańskie i patriotyzm, „GK” $1948 \mathrm{nr} 17$ s. 150.

${ }^{549}$ Przejściowy program nauczania na rok szkolny 1948/9, „GK” 1948 nr 40 s. 342.

${ }^{550}$ I. Stein, Antychrystianizm niemiecki, „GK” 1945 nr 31 s. 7; K. Szwarcenberg-Czerny, Dlaczego Niemcy musiały wypowiedzieć wojnę w 1939 roku?, tamże, nr 36 s. 298-299; L. Walkowiak, W trzecia rocznicę kapitulacji Niemiec, „GK” 1948 nr 20 s. 181; Pius XII, Kościót a Narodowy Socjalizm, tamże, nr 35 s. 297-299.

${ }^{551}$ Nuncjusz Pacelli wróg Niemiec nr 1, „GK” $1945 \mathrm{nr} 28$ s. 3; Wszyscy papieże mają szczególna sympatię dla Polski, tamże, nr 29 s. 3; Benedykt XV a Polska, tamże, nr 30 s. 3; Troska Benedykta XV o Polske, tamże, nr 31 s. 3.

$552 \mathrm{~W}$ jego ramach ukazały się następujące artykuły: A. Rogalski, Odrodzenie wierzeń pragermańskich, „GK” 1947 nr 23 s. 196; tenże, Germański instynkt niszczycielstwa, tamże, nr 25 s. 211; tenże, Kodeks moralny Nibelungów, tamże, nr 26 s. 221; tenże, Chrystianizacja Niemiec, tamże, nr 27 s. 227; tenże, Przejaw germanizmu - bunt przeciwko Rzymowi, tamże, nr 28 s. 235; tenże, Chrześcijaństwo w stużbie Antychrysta, tamże, nr 30 s. 251; tenże, Hitler - najwyższy wyraz antychrześcijańskiego rozwoju Niemiec, tamże, nr 31 s. 259.

${ }^{553}$ J. Wrzesiński, Wojna próba charakterów, „GK” 1945 nr 5 s. 7; W. Kieszkowska, Więzień $n r$ N, „GK” 1946 nr 8 s. 60; B. Hoffmann, Stużba Boża w Dachau, „GK” 1947 nr 35 s. 292-293.

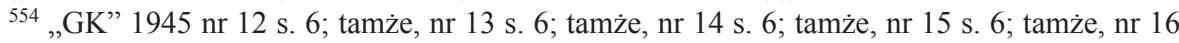
s. 6; tamże, nr 17 s. 6; tamże, nr 18 s. 6; tamże, nr 19 s. 6.

${ }^{555}$ Z. Wojciechowski, Ziemie Odzyskane dziedzictwem św. Wojciecha, „GK” $1947 \mathrm{nr} 18$ s. 154-155; J. Stawski, Duch Ziem Zachodnich, „GK” 1948 nr 12 s. 103; S. Horbacz, Jak pomóc już teraz Ziemiom Odzyskanym?, tamże, s. 106. 
Szeroki wachlarz tematyczny wzbogaciła dodatkowo problematyka historyczna $^{556}$, historyczno-krajoznawcza ${ }^{57}$ i krajoznawcza ${ }^{558}$. Ta druga obecna była w latach 1947-1948 głównie poprzez ukazywanie historii miast, zakonów ${ }^{559}$, kościołów ${ }^{560}$ i miejsc świętych ${ }^{561}$. Od $1948 \mathrm{r}$. redakcja podjęła stały temat odbudowy kościołów w Polsce powojennej ${ }^{562}$ ze zwróceniem uwagi na odbudowę katedry poznańskiej ${ }^{563}$.

$\mathrm{Na}$ łamach tygodnika przeważnie z okazji rocznic przedstawiano sylwetki znanych osób oraz ich działalność. Z okazji dwusetnej rocznicy urodzin przypomniano naczelnika Tadeusza Kościuszkę na tle wydarzeń rozbiorów Polski ${ }^{564}$. W 1947 r. czytelnicy mogli zapoznać się z cyklem Stanisława Krokowskiego Sylwetki sławnych Wielkopolan ${ }^{565}$. Nie zabrakło artykułów o innych osobistościach, np. o muzykach - Karolu Szymanowskim, Fryderyku Chopinie, o społecznikach - Józefie Lompie, naukowcach - profesorze Józefie Kostrzewskim, Bogumile Lindem, pisarzach - Bolesławie Prusie, Leonie Bloy ${ }^{566}$. Czytelnicy

${ }^{556}$ J. Adamski, Ziemie słowiańskie, „GK” 1945 nr 6 s. 6; Chrzest Polski, tamże, nr 8 s. 5; Bolesław Chrobry bicz narodu niemieckiego, tamże, nr 16 s. 6; S. Krokowski, W staropolskiej szkole, „GK” 1946 nr 34 s. 273; tenże, Lekarze i znachorzy w dawnej Polsce, tamże, nr 35 s. 281.

${ }^{557}$ Np. W. Kieszkowska, Gdańsk, „GK” 1947 nr 30 s. 252-253; J. Adamski, Na Górze św. Anny, tamże, nr 42 s. 348; taż, Parę stów o Warszawie, tamże, nr 43 s. 356-357; T. Jankowski, Ostrów Tumski przed 1000 lat, tamże, nr 49 s. 409.

${ }^{558}$ M. Kowalewski, Szklarska Poręba, „GK” 1948 nr 17 s. 152; L. Prorok, Notatnik sudeckiNieznana część Sudetów, tamże, nr 40 s. 340-341.

${ }^{559}$ H. Tyszka, Związki świętości, „GK”1947 nr 4 s. 27; tamże, nr 9 s. 67; A. Dobrzycka, Opactwo Benedyktynów w Lubiniu, tamże, nr 44 s. 365.

${ }^{560}$ F. Jaśkowiak, Poznański kościół katedralny o burzy wojennej, „GK” $1945 \mathrm{nr} 11$ s. 5; J. Woźna-Woźnicka, Katedra w Oliwie, „GK” 1947 nr 48 s. 392; 966 - z dziejów Katedry poznańskiej - 1966, „GK” 1948 nr 2 s. 15; taż, Katedra Warszawska, tamże, nr 12 s. 105; L. Prorok, Przyszła architektura morska, tamże, nr 44 s. 373.

${ }^{561}$ J. Adamski, Gietrzwałd - Warmińska Fatima, „GK” 1947 nr 49 s. 400; I. Jaworowicz, Vadstena, miasto św. Birgitty, „GK” 1948 nr 39 s. 332.

${ }^{562}$ M.in. L.Pr. [Leszek Prorok], Gdańsk odbudowuje kościoły, „GK” 1949 nr 1 s. 3; W. Dymek, Po roku wytężonej pracy, tamże, nr 10 s. 77, 79; Odnowienie dawnej świątyni Joanitów, tamże, nr 19 s. 178.

563 Odbudowa Katedry Poznańskiej, „GK” 1948 nr 40 s. 339.

${ }^{564}$ W. Kieszkowska, Naczelnik Tadeusz Kościuszko: (w dwusetna rocznicę urodzin), „GK” 1946 nr 9 s. 68-69.

${ }^{565}$ W cyklu m.in.: S. Krokowski, Sylwetki stawnych Wielkopolan, „GK” 1947 nr 32 s. 269; tenże, Tytus Działyński, tamże, nr 33 s. 277; tenże, Stanisław Szczepanowski, tamże, nr 36 s. 301; tenże, Karol Marcinkowski, tamże, nr 37 s. 309, tenże, Kazimierz Morawski, tamże, nr 40 s. 333; tenże, Karol Libelt, tamże, nr 49 s. 401.

566 J. Młodziejowski, Karola Szymanowskiego muzyka religijna, „GK” 1946 nr 16 s. 127; W. Kieszkowska, Wierny syn ziemi ślaskiej, „GK” 1947 nr 28 s. 236; J. Łuhinkowski, Laureat naukowej nagrody m. Poznania, tamże, s. 237; tenże, Samuel Bogumit Linde, tamże, nr 48 s. 393; W. Kieszkowska, Bolesław Prus, tamże, nr 51 s. 416; taż, Pisarz, który miat odwage, „GK” 1948 nr 5 s. 44-45; K. Nowowiejski, Fryderyk Chopin, „GK” 1949 nr 8 s. 61. 
mogli poznać także mniej znane postacie, jak sanitariuszkę i uczestniczkę powstań XIX w. Emilię Sczaniecką ${ }^{567}$. Ukazywano równocześnie sylwetki znanych ludzi Kościoła, m.in. zasłużonych polskich i obcych kapłanów ${ }^{568}$ oraz ówczesnego papieża Piusa XII ${ }^{569}$. Nadto przybliżono twórczość literacką pisarza religijnego jezuity Henryka Bremonda ${ }^{570}$ czy dzieła współczesnego filozofa Jacquesa Maritaina ${ }^{571}$. Na łamach tygodnika gościły liczne artykuły o świętych. W tym gronie znaleźli się papieże: św. Grzegorz Wielki i Pius $\mathrm{X}^{572}$, a także ci najbardziej znani z kanonizowanych: Longin, Stanisław Kostka, Jan Bosko, Józef, Franciszek, Teresa z Lisieux, Marcin, Jacek Odrowąż, Katarzyna ze Sieny ${ }^{573}$. Uczczono oczywiście 950 -lecie kanonizacji św. Wojciecha ${ }^{574}$, a także wielu błogosławionych i pretendujących do tego miana ${ }^{575}$. Stanisława Hulanicka w 1948 r. w cyklu Listy z Algieru przedstawiła życiorys ojca de Foucauld ${ }^{576}$. Redakcja „Głosu Katolickiego” publikowała także wspomnienia pośmiertne $e^{577}$ oraz krótkie informacje i nekrologi ${ }^{578}$.

${ }^{567}$ S. Strugarek, Emilia Sczaniecka, „GK” 1946 nr 16 s. 125.

568 J. Młodziejowski, Ksiądz Jan Dzierżoń - Ślązak, „GK” 1947 nr 17 s. 145; J. Ujda, Ks. Jan Ignacy Korytkowski w sześćdziesiąta rocznicę śmierci, „GK” 1948 nr 20 s. 177; Z. Zaborski, Ojciec Flanagan, tamże, nr 24 s. 217.

${ }^{569}$ K. Madaliński, Bojownik pokoju, „GK” $1947 \mathrm{nr} 11$ s. 81; Pius XII. Wrażenie artysty portretującego Ojca św., tamże, s. 202; Człowiek Pius XII, „GK” $1948 \mathrm{nr} 9$ s. 74-75.

${ }^{570}$ W. Trzebiński, Ojciec Henryk Bremond, „GK” 1946 nr 12 s. 91.

${ }^{571}$ Tenże, Dzieje wspótczesnego filozofa: (Jacques Maritain), „GK” $1946 \mathrm{nr} 14$ s. 110.

${ }^{572}$ W. Kieszkowska, Pius X. Papież ubogich, nędzarzy i nieszczęśliwych, „GK” 1946 nr 5 s. 36; J. Ujda, Papież Grzegorz Wielki, „GK” 1948 nr 38 s. 322.

${ }^{573}$ S. Strugarek, Święty Stanisław Kostka, „GK” 1945 nr 30 s. 3; B. Steinowa, Wielki wychowawca, „GK” 1946 nr 6 s. 45; W. Kieszkowska, Święta Katarzyna ze Sieny, tamże, nr 16 s. 124; taż, Legenda o świętym Longinie, tamże, nr 17 s. 137; taż, Święta Katarzyna ze Sieny (1347-1380), „GK” 1947 nr 21 s. 180-181; J. Stawski, Św. Franciszek z Asyżu, tamże, nr 41 s. 340; (S.), 50 rocznica śmierci św. Teresy z Lisieux, tamże, nr 44 s. 366; Z żotnierza świętym, tamże, nr 46 s. 379; W. Kieszkowska, Św. Jacek Odroważ, „GK” 1948 nr 15 s. 136; taż, Powołanie św. Katarzyny, tamże, nr 41 s. 346.

${ }^{574}$ L. Bernacki, 950-lecie kanonizacji św. Wojciecha, „GK” $1949 \mathrm{nr} 17$ s. 153-154.

${ }^{575}$ I. Bachowska, Bt. Ludwik Maria Grignion de Montfort, „GK” 1947 nr 22 s.189; Nowa błogostawiona [Maria Goretti], tamże, nr 23 s. 194-195; Tysiace dowodów w beatyfikacyjnym procesie biskupa Tihamera Totha, „GK” $1948 \mathrm{nr} 11$ s. 97; K.S.C., Proces beatyfikacyjny Brata Alberta, tamże, nr 27 s. 250; J. Rostworowski, Edmund Bojanowski, tamże, nr 32 s. $276 .$.

${ }^{576}$ S. Hulanicka, Ojciec de Foucauld, „GK” 1948 nr 15 s. 137; tamże, nr 16 s. 144; tamże, nr 17 s. 152; tamże, nr 18 s. 160; tamże, nr 19 s. 168.

${ }^{577}$ Zgon założyciela polskiej Prowincji Stowarzyszenia Księży Pallotynów [ks. Alojzy Majewski], „GK” 1947 nr 50 s. 412.

578 (S), Śmierć Gandhiego, „GK” 1948 nr 10 s. 83; nekrolog Prymasa Augusta Hlonda, tamże, nr 44 s. 369; I. Stein, Po zgonie Prymasa Polski, tamże, s. 370-371; Zgon J.E. Ks. Biskupa Stanisława Eukomskiego, tamże, nr 46 s. 385. 
Temat kultury, choć obecny od początku, zagościł częściej na łamach pisma od 1948 r. ${ }^{579}$ Zdawano relacje z wystaw ${ }^{580}$. W cyklu artykułów ukazano historię sceny polskiej ${ }^{581}$. Odbiorcy mogli przeczytać także recenzje teatralne ${ }^{582}$. Pisano o filmie ${ }^{583}$ i sztuce ${ }^{584}$.

Żywo obecna na stronach periodyku była problematyka literacka ${ }^{585}$. Przedstawiono twórczość m.in. następujących pisarzy: Jana Dobraczyńskiego ${ }^{586}$, Wojciecha Żukrowskiego ${ }^{587}$, Jerzego Zawieyskiego ${ }^{588}$, Knuta Hamsuna ${ }^{589}$, Georgesa Bernanosa ${ }^{50}$. Czczono rocznice wieszczów narodowych Adama Mickiewicza i Juliusza Słowackiego ${ }^{591}$. Rozważano motywy występujące w literaturze polskiej ${ }^{592}$. Redakcja drukowała fragmenty biografii ${ }^{593}$, książek o tematyce obozowej ${ }^{594}$ i pamiętników ${ }^{595}$. Z powieści w odcinkach w „Głosie Katolickim” ukazały się m.in. Gardonyi Gezy Gdy kwoka zagdakała w przekładzie Tadeusza Fangrata

579 J. Wrzesiński, O upowszechnienie kultury, „GK” 1945 nr 15 s. 7; K. Abgarowicz, Kultura chrześcijańska, tamże, nr 17 s. 2; M. Pospieszalski, Kulturkampf, tamże, nr 19 s. 7; K. Dadorówna, Kultura narodowa czy ogólnoludzka?, „GK” 1947 nr 2 s. 11; K. Abgarowicz, Btędne i właściwe pojmowanie kultury, „GK” 1948 nr 35 s. 303; J. Ujda, Jak Irlandia ocalita kulture europejska?, tamże, nr 37 s. 314; tenże, Franciszkanie a kultura, tamże, nr 41 s. 347; B. Osmólska-Piskorska, Kultura wytworem zbiorowości, tamże, nr 42 s. 355; taż, Kregi kultury, tamże, nr 46 s. 387; taż, Rola dawności i teraźniejszości w kulturze, tamże, nr 48 s. 364.

${ }^{580}$ W. Kieszkowska, O prawdziwa kulturę..., Na marginesie wystawy dokumentarnej w Muzeum Wlkp., „GK” 1948 nr 1 s. 4; S., Pamiątka z Wystawy Ziem Odzyskanych, tamże, nr 45 s. 382.

${ }^{581}$ Z dziejów sceny polskiej (I), „GK” 1948 nr 42 s. 356; S.K., Z dziejów sceny polskiej (II), tamże, nr 43 s. 365; tenże, $Z$ dziejów sceny polskiej (III), tamże, nr 44 s. 36.

${ }^{582}$ Na marginesie „Nocy gniewu” Salacrou, „GK” 1948 nr 14 s. 126-127; A. Rogalski, Rozdroże miłości Jerzego Zawieyskiego, tamże, nr 20 s. 176.

583 (m), O film katolicki, „GK” 1948 nr 29 s. 251; S., Dobrowolny KODEKS przemystu filmowego, tamże, nr 31 s. 266; Rozwój filmu katolickiego, „GK” 1949 nr 9 s. 71.

${ }^{584}$ A. Rogalski, Kryzys cywilizacji zachodniej $i$ jego przejawy w sztuce, „GK” $1948 \mathrm{nr} 41$ s. 348-349; J. Ujda, ,,Pieta” Michała Anioła, „GK”1949 nr 13 s. 112.

${ }^{585}$ I. Stein, U wrót literatury polskiej, „GK” $1945 \mathrm{nr} 22$ s. 7; A. Rogalski, Dzieło literackie wobec życia, tamże, nr 32 s. 6; tenże, Literatura $i$ wiara, „GK” $1946 \mathrm{nr} 5$ s. 38.

${ }^{586}$ W. Kieszkowska, Twórczość Jana Dobraczyńskiego, „GK” 1948 nr 11 s. 94-95.

${ }^{587}$ M. Tongwin, Twórczość Wojciecha Żukrowskiego, „GK” 1948 nr 38 s. 324-325; tamże, nr 39 s. 331.

${ }^{588}$ L. Prorok, Jerzy Zawieyski w Poznaniu, „GK” 1948 nr 27 s. 236.

${ }^{589}$ A. Rogalski, Sprawa Knuta Hamsuna (I), „GK” 1948 nr 12 s. 104; tenże, Knut Hamsun w Polsce. Sprawa Knuta Hamsuna (II), tamże, nr 13 s. 117; tenże, Od pogańskiego kultu życia do hitleryzmu. Sprawa Knuta Hamsuna (III), tamże, nr 19 s. 167; tenże, Gloryfikacja Szpicruty (IV), tamże, nr 37 s. 316-317.

${ }^{590}$ A. Rogalski, Jerzy Bernanos, „GK” 1948 nr 36 s. 305.

${ }^{591}$ B.L., Poznań - Mickiewiczowi, „GK” 1949 nr 4 s. 29; L. Buśkiewicz, W stulecie zgonu Juliusza Stowackiego, tamże, nr 16 s. 146.

${ }^{592}$ W. Trzebiński, Motyw Zmartwychwstania w literaturze polskiej, „GK” 1948 nr 13 s. 111.

${ }^{593}$ Np. G. Morcinek, W rzymskiej celi klasztornej, „GK” $1948 \mathrm{nr} 21$ s. 188-189.

${ }^{594}$ Modlitwa wieczorna, „GK” 1948 nr 25 s. 220.

${ }^{595}$ W. Kieszkowska, Kartki z pamiętnika, „GK” 1948 nr 35 s. 300-301. 
w 1945 r. i Nocny lot Jana Staniszewskiego w 1949 r. W jednym numerze występowały zazwyczaj dwa, czasem trzy opowiadania (jedno dłuższe, drugie krótsze). Opowiadania zaczęto częściej drukować w 1948 r. ${ }^{596}$ Książka reprezentowana była głównie poprzez recenzje ${ }^{597}$. Poświęcono jej też krótki cykl artykułów Stanisława Krokowskiego Z życia ksiązki (od nru 2 z 1948 s. 5). Problematyka upowszechniania książki przez redakcję pisma powróci w szczegółowych rozważaniach w następnych rozdziałach.

Przez cały okres wydawania „Głosu” w jego zawartości gościła poezja. Były to zazwyczaj wiersze mniej znanych poetów. W każdym numerze drukowano przeważnie kilka wierszy, które umieszczano w różnych miejscach zeszytu. Czasami niewielki wierszyk pojawiał się pośrodku strony lub w prawym czy lewym rogu. Wśród debiutujących poetów znaleźli się czytelnicy tygodnika. Niekiedy między wersami drukowano cytaty z wypowiedzi znanych osobistości: pisarzy, poetów i świętych.

Na łamach tygodnika zamieszczano również reklamy różnorodnych produktów, począwszy od sprzętów liturgicznych, dewocjonaliów, sztandarów, ornatów, biretów dla księży, poprzez meble, wyroby papierowe, stalowe, obuwie, bieliznę, aż do przypraw, pasty do zębów i in. Można było także opublikować ogłoszenie typu: „Poszukuję starszą z gotowaniem oraz dziewczynę do gospodarstwa wiejskiego, uczciwą, zdrową ${ }^{598}$. Niekiedy redakcja poświęcała na ogłoszenia całą ostatnią stronę tygodnika ${ }^{599}$.

W powyższym opracowaniu przedstawiono najważniejsze tematy występujące na łamach „Głosu Katolickiego” w latach 1945-1948 świadczące o jego profilu katolickim i społecznym. Współpracownicy pisma podjęli wiele istotnych spraw, które ukazane w świetle prawdy sprzeciwiały się propagandzie komunistycznej i fałszowaniu historii. Podjęto też trudne problemy prześladowania i walki z duchowieństwem ${ }^{600}$ oraz plagi społecznej, jaką był alkoholizm ${ }^{601}$. Opublikowano list Episkopatu Polski na temat niebezpieczeństwa rozpicia

${ }^{596}$ Malutki Davie. Wedtug Normana Macleod'a „,Good words”, „GK” 1948 nr 24 s. 218; W. Marcinkowski, Czar Świętojańskiej Nocy, tamże, nr 27 s. 237; Szczęście wedtug Fryderyka Marryat, tamże, nr 33 s. 285.

597 J.A. Kamiński, Ważki dokument historii Kościoła, „GK” 1947 nr 34 s. 284-285; R. Mieliński, Książka o Bogu, tamże, nr 41 s. 341; E. Myczka, Powieść z czasów Bolesława Chrobrego, tamże, nr 47 s. 385; M. Tongwin, Ostatnia powieść Ferdynanda Ossendowskiego, „GK” 1948 nr 2 s. 20; A. Rogalski, ,, Suknia Dejaniry” Zofii Kossak, tamże, nr 29 s. 252-253.

598 „GK” 1947 nr 8 s. 64.

599 "GK” 1947 nr 1 s. 7-8; tamże, nr 2 s. 16; tamże, nr 7 s. 56; tamże, nr 8 s. 64; tamże, nr 9 s. 72.

${ }^{600}$ K. Madaliński, Antyklerykalizm, „GK” 1946 nr 43 s. 333.

${ }^{601}$ R. Mieliński, Klęska pijaństwa, „GK” 1947 nr 6 s. 41; E. Paukszta, Już jest źle, tamże, nr 9 s. 65; M. Wnorowska-Chrempińska, W poradni przeciwalkoholowej, tamże, nr 16 s. 2; T. Dykier, Czy zwalczamy alkoholizm?, tamże, nr 46 s. 378; J.M. Święcicki, ,, Polska moda”, „GK” 1948 nr 2 s.13; K. Łaszewski, Trzeźwość narodu, tamże, nr 8 s. 67; K. Abgarowicz, Alkoholizm wrogiem duszy, tamże, nr 33 s. 283. 
społeczeństwa polskiego, szkodliwości alkoholu i o stratach, jakie ponosi z tego powodu rodzina ${ }^{602}$. Rzadko pojawiały się artykuły na temat pracy ${ }^{603}$. Czytelnik oprócz poważnych mógł znaleźć też wypowiedzi napisane lżejszym piórem. Nie zabrakło bowiem przedruków z prasy jak też zagadnień prasoznawczych ${ }^{604}$, sportowych $^{605}$, gospodarczych ${ }^{606} \mathrm{i}$ in.

\section{Szata graficzna pisma}

Zawartość „Głosu Katolickiego” przez długi czas urozmaicały jedynie reklamy, gdyż wygląd periodyku był bardzo skromny.

\section{Il. 9. „Głos Katolicki”1946 nr 9}

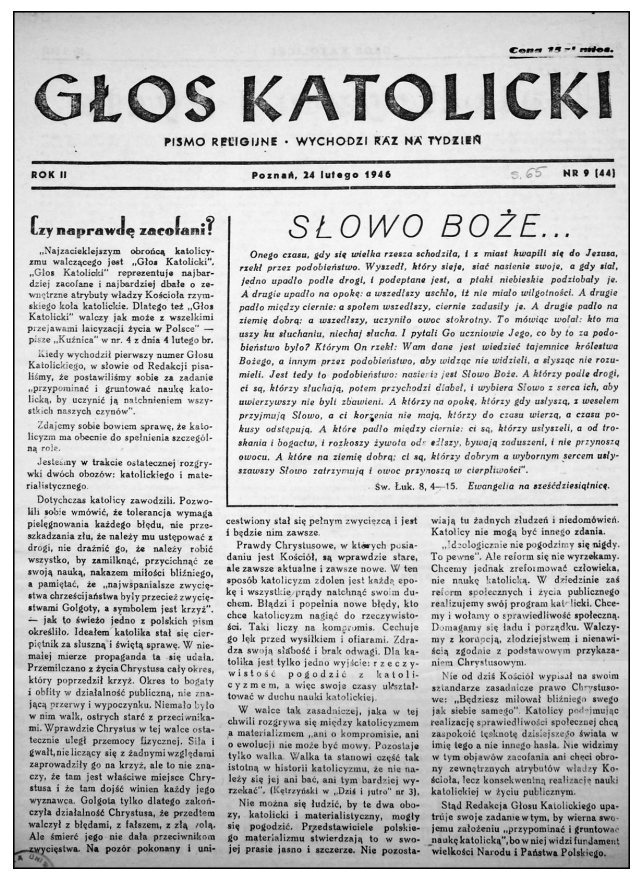

Źródło: Ze zbiorów BUŁ.

${ }^{602}$ Przestroga przed pijaństwem, „GK” 1947 nr 8 s. 59.

${ }^{603}$ (S), Praca, „GK” 1948 nr 23 s. 203.

${ }^{604}$ Np. Ze świata katolickiego. Prasa katolicka we Francji, „GK” 1947 nr 19 s. 166; Prasa katolicka w Anglii, „GK” 1948 nr 1 s. 9; Tygodnik Powszechny o stowackiej prasie katolickiej, tamże, s. 10.

${ }^{605}$ K. Madaliński, Sportowe rozważania, „GK” 1948 nr 2 s. 14; S. Jarecki, Chore lekarstwo, tamże, nr 15 s. 134-135.

${ }^{606}$ J. Wrzesiński, O trybunę myśli gospodarczej, „GK” 1945 nr 21 s. 6. 
Dopiero od końca października 1948 r. widoczne były wyraźne dążenia redakcji do wzbogacenia pisma pod względem graficznym. Po raz pierwszy w numerze $43 \mathrm{z}$ tegoż roku w artykule wstępnym na pierwszej stronie zamieszczono fotografię odbudowanego gmachu Seminarium Duchownego w Poznaniu. Odtąd każdorazowo były obecne zdjęcia. Na fotosy, zajmujące $3 / 4$ strony wraz z ich opisami (od nru 48 z 1948 r.), przeznaczono osobny dział $Z$ czterech stron świata na ostatniej stronie. Rozbudowano rownież nieco graficznie nagłówek tygodnika, który znów zmieniono w ostatnim numerze świątecznym z 1948 r. Opowiadania czasami zdobiono rysunkami.

Il. 10. „Głos Katolicki” 1948 nr 2

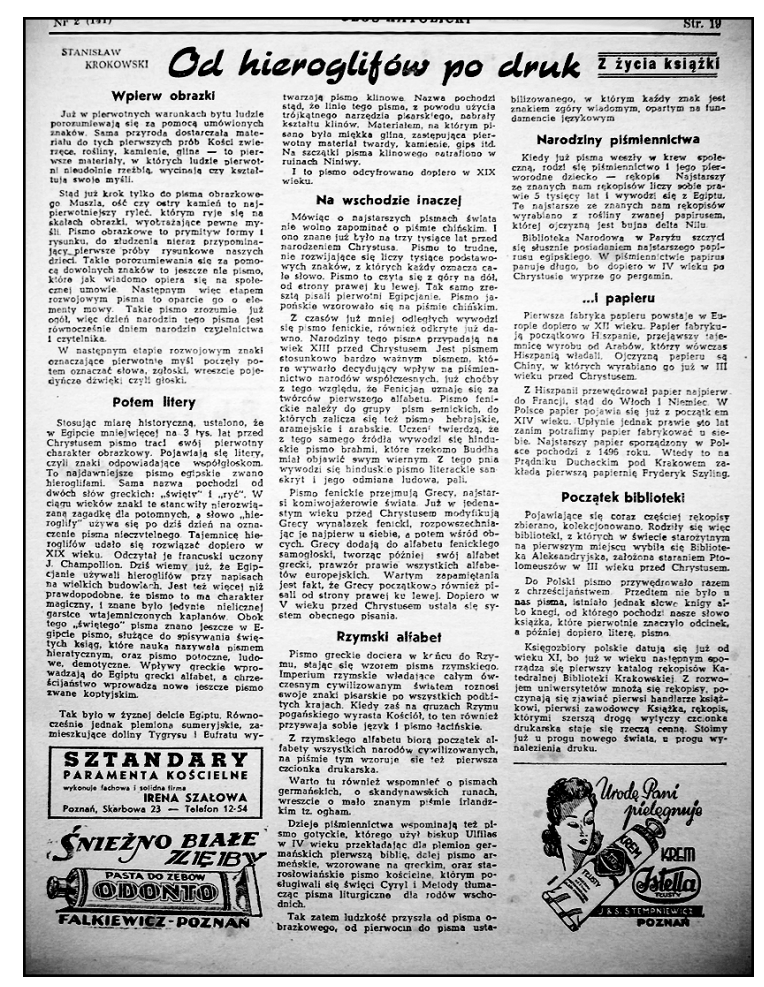

Źródło: Ze zbiorów BUŁ.

\section{Podsumowanie}

Chociaż mniej znany, to jednak „Głos Katolicki” wyróżniał się w pierwszych latach powojennych bogatą zawartością i wysokim poziomem publikacji. Autorzy artykułów dzięki podejmowaniu bieżących zagadnień dobrze odpowiedzieli na potrzeby czytelników. Tygodnik był dziełem głównie jednego człowieka 
- redaktora ks. Łabińskiego. Wymowa ideologiczna pisma nie sprzyjała władzy, dlatego też periodyk przetrwał w pierwotnym kształcie jedynie do 1948 r., po czym przymusowo zmieniono jego redakcję i profil.

\subsection{3. „Tygodnik Warszawski” (1945-1948)}

Kolejne ważne środowisko intelektualne katolików w odradzającej się Polsce tworzyli ludzie z kręgu „Tygodnika Warszawskiego”. Istniejący zaledwie kilka lat periodyk był przedmiotem analizy wielu autorów; szczególnie interesująca jest trudno dostępna w bibliotekach monografia Jana Wiszniewskiego ${ }^{607}$. Autorzy większości artykułów odnieśli się do okoliczności zamknięcia pisma, upamiętnili tragiczne losy członków redakcji i ukazali rolę czasopisma w trudnym dla wolności słowa okresie powojennym. W kręgu zainteresowań znalazły się także publikacje na jego łamach ${ }^{608} \mathrm{i}$ redaktor naczelny pisma ${ }^{609}$. Hasło dotyczące „Tygodnika Warszawskiego" zamieściła Encyklopedia , białych plam " ${ }^{610}$. Tytuł zarejestrowa-

${ }^{607}$ J. Wiszniewski, Z historii prasy katolickiej... Książka jest dostępna jedynie w Bibliotece Jagiellońskiej i Bibliotece PAU w Krakowie.

${ }^{608}$ Od wydawnictwa, „TW” 1946 nr 36 s. 1; Opieczętowanie redakcji Tygodnika Warszawskiego, „Prasa Polska” 1948 nr 16;W. Ciechanowski, Tygodnik Warszawski 1945-1948, „Ład” 1983 nr 29, s. 4; Wiele nurtów, rozmowa M. Piłki z W. Chrzanowskim, „Przegląd Katolicki” 1984 nr 18 s. 3; K. Sikorski, Tygodnik Warszawski, „Przegląd Katolicki” 1986 nr 2; W 40 rocznicę likwidacji ,, Tygodnika Warszawskiego”. Rozmowa z T. Przeciszewskim i A. Kozaneckim, „Ład” 1988 nr 38, s. 1, 7, 14; D. Morawski, Jeszcze o likwidacji „,Tygodnika Warszawskiego”, tamże, nr 44, s. 11; R. Stopikowski, Polemiki światopoglądowe na łamach „,Tygodnika Warszawskiego”, „Dzieje Najnowsze” $1995 \mathrm{nr}$ 4, s. 101-108; tenże, Problematyka gospodarczo-społeczna na łamach „Tygodnika Warszawskiego" (1945-1948), „Życie i Myśl” 1998 nr 4, s. 41-59; J. Zabłocki, Dramat „Tygodnika Warszawskiego”, „Tygodnik Solidarność” 1999 nr 15, s. 17; S. Rogala, ,,Tygodnik Warszawski” - środowisko, programy społeczne, polityczne i filozoficzne „Zeszyty Naukowe Politechniki Rzeszowskiej, Ekonomia i Nauki Humanistyczne” 2000 nr 8, s. 25-39; W.P. Szymański, Czyste ręce i Mefisto (o „,Tygodniku Warszawskim”), „Arcana” 2001 nr 4, s. 69-87; M. Rosołowski, „Tygodnik Warszawski”. W: Encyklopedia „Białych plam” t. 17, Radom 2006, s. 222-224; M. Biełaszko, ,,Tygodnik Warszawski”, i jego środowisko (1945-1948), „Biuletyn Instytutu Pamięci Narodowej” 2007 nr 4, s. 77-83; E. Kristanova, ,, Tygodnik Warszawski” (1945-1948) na tle polskiej prasy katolickiej pierwszych lat po II wojnie światowej, „Łódzkie Studia Teologiczne” 2008 nr 17, s. 247-255; taż, Reklama książki na łamach ,,Tygodnika Warszawskiego”. W: Od książki dawnej do biblioteki wirtualnej, pod red. D. Degen i M. Fedorowicz, Toruń 2009, s. 245-263; taż, „Tygodnik Warszawski” (1945-1948) a władza komunistyczna. W: Niewygodne dla władzy. Ograniczenie wolności stowa na ziemiach polskich w XIX i XX w., pod red. D. Degen i J. Gzelli, Toruń 2010, s. 357-374; M. Biełaszko, Rola prasy w ksztaltowaniu się środowisk katolickich w latach 1945-1948. Casus ,, Tygodnika Powszechnego”, ,, Tygodnika Warszawskiego" " „,Dziś i Jutro”. W: Aparat represji wobec inteligencji w latach 1945-1956, pod red. R. Habielskiego i D. Rafalskiej, Warszawa 2010, s. 155-181. .

${ }^{609}$ M. Biełaszko, Ksiądz Zygmunt Kaczyński (1894-1953) - duchowny, polityk, redaktor. W: Niezłomni ludzie Kościoła. Sylwetki, pod red. J. Żaryna, Kraków 2011, s. 95-122.

${ }^{610}$ M. Rosołowski, Tygodnik Warszawski. W: Encyklopedia „,białych plam”, t. 17, Radom 2006, s. 222-224. 
ła Bibliografia prasy polskiej 1944-1948 Jerzego Myślińskiego i Bibliografia katolickich czasopism religijnych w Polsce 1945-1989611. Czasopismo należy do grona najlepiej opracowanych i nie zostało zapomniane w literaturze przedmiotu.

\section{Redakcja i środowisko „Tygodnika Warszawskiego"}

Założyciele warszawskiego organu katolickiego przyjęli bardziej radykalne stanowisko wobec nowej rzeczywistości powojennej niż grupa „Tygodnika Powszechnego". Grono to skupiło działaczy i intelektualistów, którzy pragnęli aktywne uczestniczyć w powojennych przemianach politycznych, społecznych i kulturalnych. Skład redakcji tworzyły osoby duchowne i świeckie.

Do powstania tytułu przyczynił się Feliks Jordan, który po wydaniu pierwszego numeru wkrótce zrezygnował z pracy nad pismem ${ }^{612}$. Funkcję pierwszego redaktora naczelnego objął ks. Zygmunt Wądołowski. Decydujący wpływ na kształt periodyku wywarł kolejny jego redaktor (od czerwca 1946 r.), ks. Zygmunt Kaczyński. Jego zastępcą został literat Jerzy Braun, zaś sekretarzami byli Jerzy Kierst, Adam Grabowski i Antoni Madej. Pismo współtworzył początkowo również Marian Grzegorczyk, zmarły nagle 24 XII 1945 r. przy pracy nad artykułem do noworocznego numeru ${ }^{613}$. Ks. Edward Grzechnik natomiast „,przyjął na siebie ciężkie i niewdzięczne zadanie pokonania pierwszych trudności administracyjno-wydawniczych" ${ }^{614}$. Do zespołu redakcyjnego dołączył także Franciszek Kwasiborski. „Tych nielicznych - jak pisano - obdarzył swym zaufaniem w imieniu Kurii Arcybiskupiej ks. biskup Zygmunt Choromański, ówczesny infułat, pierwszy protektor i prawdziwy przyjaciel $<<$ Tygodnika $>>$ "615.

„Tygodnik Warszawski” stał się wyrazicielem opinii i dążeń środowiska inteligencji katolickiej związanego z Kościołem i Stronnictwem Pracy. Pismo, chociaż wydawało je Katolickie Towarzystwo Wydawnicze „Rodzina Polska”, powszechnie traktowano jako nieoficjalny organ kurii warszawskiej. Założycielami i pierwszymi redaktorami „Tygodnika Warszawskiego” byli wybitni specjaliści i działacze polityczni, związani z ruchem chrześcijańsko-demokratycznym, reprezentowanym przez Polskie Stronnictwo Chrześcijańskiej Demokracji. Niektórzy ze środowiska deklarowali przynależność w różnych

${ }^{611}$ J. Myśliński, Bibliografia prasy polskiej, s. 99; D. Wielgat, Bibliografia katolickich czasopism..., s. 91.

${ }^{612}$ S. Rogala, ,, Tygodnik Warszawski” - środowisko, programy społeczne...

${ }^{613}$ Redakcja, Śmierć Mariana Grzegorczyka, „TW” 1946 nr 1 s. 2.

${ }^{614}$ A.G., Rok pracy „, Tygodnika Warszawskiego”, „TW” 1946 nr 46 s. 3.

${ }^{615}$ Tamże. 
okresach do Narodowej Partii Robotniczej, Unii ${ }^{616}$, Stronnictwa Pracy, a także do Stronnictwa Narodowego. W skład redakcji wchodzili również ludzie niezaangażowani politycznie, związani z Akcją Katolicką i innymi stowarzyszeniami kościelnymi ${ }^{617}$.

Z pismem związani byli publicyści, literaci, historycy, filozofowie, naukowcy. Do stałych współpracowników periodyku należeli: Antoni Antczak, Wojciech Bąk, Wacław Borowy, Olgierd Budrewicz, Stanisław Bukowski, Jan Dobraczyński, Stanisław Grabski, Wiktor Hahn, Jan Hoppe, Jerzy Kierst, Feliks Koneczny, Władysław Konopczyński, Andrzej Kozanecki, Stanisław Kozicki, Tadeusz Kudliński, Stefan Lichański, Wincenty Lutosławski, Irena Pannenkowa, Stanisław Pigoń, Zuzanna Rabska, Kazimierz Studentowicz, Bolesław Szczepkowski, Czesław Strzeszewski, Józef Marian Święcicki, Władysław Tatarkiewicz, Konstanty Turowski, Włodzimierz Wnuk i in. W gronie piszących znaleźli się również publicyści ze środowiska „Tygodnika Powszechnego”: Antoni Gołubiew, Artur Górski, Konrad Górski, Paweł Jasienica, Stefan Kisielewski, Stanisław Kutrzeba, Hanna Malewska, ks. Konstanty Michalski, ks. Jan Piwowarczyk, Zofia Starowieyska-Morstinowa, Stanisław Stomma, Maria Winowska i Jerzy Zawieyski. Publikowali tu także biskupi: Zygmunt Choromański, Michał Godlewski, Wacław Majewski, Jan Stepa i Stefan Wyszyński. Inni duchowni piszący w „Tygodniku Warszawskim” to: Władysław Kwiatkowski, Zygmunt Kozubski, Józef Majka, Józef Pastuszka, Czesław Skarbek, Józef Umiński, Aleksander Usowicz, Jacek Woroniecki i Aleksander Wójcicki. Łamy organu prasowego uświetnili jednocześnie swoimi artykułami znani zagraniczni autorzy, m.in. uczony Alexis Carrel $^{618}$, oraz pisarze katoliccy: Georges Bernanos, Charle Peguy i Daniel-Rops.

Za czasów nowej redakcji, pracującej od 1946 r., widoczna była większa fachowość, pogłębiona publicystyka i ulepszona struktura pisma. „Tygodnik Warszawski” wykazywał na swoich łamach większą dynamikę w podejmowanej problematyce, poszerzonej o zagadnienia międzynarodowe. Częściej na jego łamach publikował Jerzy Braun. Przez cały okres wydawniczy wprowadzano nowe działy i rubryki.

${ }^{616}$ Unia - organizacja ideowo-wychowawcza powstała w 1940 r. w wyniku połączenia się kilku ugrupowań: „Warszawianki” Jana Hoppego, „Nowej Polski” Jerzego Brauna, „Grunwaldu” Mirosława Leśkiewicza. Na czele organizacji stanął Jerzy Braun. Struktura Unii oparta była na Akcji Katolickiej. Brali w niej udział przedstawiciel nauki, kultury i sztuki (m.in. Karol Wojtyła) nieprzejawiający ambicji sprawowania władzy politycznej. Był to raczej typowy ruch światopoglądowy, który dążył do przebudowy zasad życia społecznego w oparciu o etykę chrześcijańską.

${ }^{617}$ Likwidacja „Tygodnika Warszawskiego”. Z Andrzejem Kozaneckim i Tadeuszem Przeciszewskim rozmawiat Andrzej Wiernic, „Ład” 1988 nr 38 s. 1; zob. też W. Bujak, Historia Stronnictwa Pracy 1937-1946-1950, Warszawa 1988, s. 18-25, 139-145.

${ }^{618}$ A. Carrel, Spotkanie z Bogiem, „TW 1946 nr 13 s. 1-2. 


\title{
Linia programowa
}

O przyjętym programie mogą świadczyć nagłówki artykułów wstępnych na łamach „Tygodnika”. W wypowiedzi redaktora naczelnego zatytułowanej Nie dziedzictwem ale walka czytamy: „Każdy człowiek jest bryłą marmuru, z której może powstać posąg świętego lub występnego [...]. Świętość nie jest wynikiem produkcji seryjnej, poddawaniem ludzi pod jeden strychulec, pracy zmechanizowanej, owocem rutyny. Kościół nie czyni żniwa Bożego przy pomocy żniwiarki, która wszystko tnie na jedną miarę i układa w równe snopy. Dlatego święci nie są ludźmi masy, na których opierają się różne systemy faszystowskie. Im mniej w jednostkach własnego zdania, własnej woli, poglądu i sumienia, im bardziej są one bezimiennymi liczbami, tym lepiej odpowiadają systemowi totalnemu" ${ }^{19}$. W przytoczonym na pierwszej stronie wierszu Karola Huberta Roztworowskiego Naprzód znalazły się znamienne słowa, będące niejako proroctwem dla redagujących:

\author{
Wolę narodu mieczem pisz, \\ a gdyby zawiódł miecz i spiż, \\ Niech Ducha wróg nie zmoże! \\ [...] \\ Zgorzeje tylko głupi strach, \\ że w końcu trzeba (,och” i ,ach”) \\ cielesne zdjąć mundury \\ A trzeba! Trudno. Taki los! \\ $\mathrm{Na}$ froncie, czy w komorze \\ Tak samo zjeży ci się włos, \\ tak samo w gardle zamrze głos, \\ więc naprzód w imię Boże! ${ }^{620}$
}

Publikacjezamieszczonena kolejnych stronach, autorstwaks.Z.Kaczyńskiego Po powrocie, ks. biskupa Michała Godlewskiego Wolność a dyktatura, Jana Dobraczyńskiego $O$ charakterze narodowym czy Pawła Winnickiego Nowe oblicze Europy zapowiadały utrzymującą się do końca tendencję rozważania w tygodniku kwestii polskich na szerokim tle stosunków międzynarodowych ${ }^{621}$.

W nocie wstępnej redakcja pisała o „potrzebie wyraźnych drogowskazów” w powojennym okresie przebudowy. Przytaczając słowa Chrystusa: „Jestem Drogą, Prawdą i Życiem” podkreślano, że są one istotne dla „społeczeństwa

${ }^{619}$ Z. Wądołowski, Nie dziedzictwem ale walka, „TW” $1945 \mathrm{nr} 1 \mathrm{s.} 1$.

${ }^{620}$ K.H. Rostworowski, Naprzód!, „TW” 1945 nr 1 s. 1.

${ }^{621}$ Z. Kaczyński, Po powrocie, „TW” 1945 nr 2; M. Godlewski, Wolność a dyktatura, tamże, s. 3; J. Dobraczyński, O charakterze narodowym, tamże; P. Winnicki, Nowe oblicze Europy, tamże. 
polskiego, w szczególności, które z katolicyzmem zrosło się tysiącem lat swoich dziejów, istotą swojej kultury, najwartościowszymi cechami swego narodowego charakteru”'22. Dalej konstatowano: „W czasach, gdy wszystko się wali i wszystko chwieje, nie ma pewniejszego źródła otuchy, jaśniejszego rozwiązania zwątpień, wyraźniejszego wskazania drogi wyjścia - nad naukę Chrystusową" ${ }^{23}$. Odnośnie do przyjętego programu stwierdzano natomiast: ,[... [ nie potrzebujemy szczegółowo formułować programu [...] jest [on - E.K.] już napisany krwią wielu pokoleń, które żyły i umierały w walce o kraj i wiarę. Obcy partyjnym sporom, pragniemy dać na łamach naszego pisma wyraz tym siłom twórczym, które tkwią w społeczności katolickiej. Pragniemy przyczynić się w miarę naszych możliwości do zapewnienia lepszego jutra Polski. I mamy niepłonną ufność w Bogu, że narodowi naszemu tego lepszego jutra Opatrzność nie odmówi”'24.

Podsumowując roczną działalność zespołu, odnotowano: ,[...] nie tylko trudności wydawnicze towarzyszyły $<<$ Tygodnikowi $>>$ na przestrzeni całego roku. Jak w społeczności katolickiej spotkał się z najżyczliwszym przyjęciem, tak przeciwnicy ideowi nie pominęli żadnej sposobności, aby pracę jego utrudnić, względnie do niej zupełnie zniechęcić. To jednak nikogo z pisarzy i działaczy katolickich nie zaskakuje" ${ }^{25}$. W każdym numerze tworzący pismo starali się rozwijać założenia programowe w duchu nauki społecznej Kościoła. Chciano przy tym objąć wszystkie sfery życia narodowego: moralne, kulturalne, polityczne, społeczne i gospodarcze. Dalej czytamy: ,Jedno tylko pragniemy dzisiaj przypomnieć zarówno naszym przyjaciołom, jak i przeciwnikom, a mianowicie, że w zakresie realizacyjnym nie opieramy naszej działalności o żadną grupę polityczną dawniej czy aktualnie działającą" ${ }^{26}$. Broniono się w następujący sposób: „Nie reagowaliśmy, gdy w $<<$ Tygodniku Warszawskim $>>$ dopatrywano się siedliska endeków, to znowu innym razem chadeków, gdy zarzuca się nam raz reakcyjność, to znów niebezpieczny radykalizm. Naprawdę reprezentujemy bowiem tylko myśl katolicką, środowisko porozumienia i zejścia się tych wszystkich, którzy zajmując czynną postawę wobec wszelkich przejawów życia narodowego, pragną budować nowy świat, nasze państwo, nasz dom, rodzinę, osobowość zgodnie z Chrystusem i Jego nauką. Dla tego celu nie uchylamy się od żadnego trudu i obowiązku" ${ }^{27}$. Redakcja domagała się równocześnie stanowczo: „Nie lękamy się ani nowoczesności, ani przemian społecznych, ani ludowej formy rządów, o ile uszanowane zostaną zasady niezmiennej moralności chrześcijańskiej”"228. Opowiadano się za sprawiedliwym ustrojem społecznym,

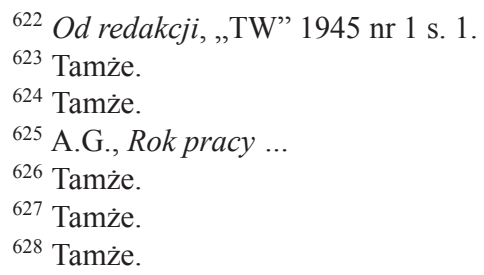


w którym nie byłoby ,ani przywilejów, ani krzywd, ani proletariatu, ani bezrobotnych, ani głodnych, ani bezdomnych" 629.

W wydaniu noworocznym z 1947 r. ks. Z. Kaczyński, przedstawiając trudną sytuację międzynarodową i polską po zakończeniu wojny, podsumował: „Byliśmy tym pismem, które ostrzegało przed iluzjami. Twierdziliśmy i twierdzimy nadal, że wojna nie jest jedynym i wyłącznym środkiem rozstrzygania sporów i trudności w dojściu do porozumienia" ${ }^{30}$.

Wypowiedzi zawarte w „Tygodniku Warszawskim” miały charakter wyraźnie polemiczny i opozycyjny wobec władzy ${ }^{631}$. Pośród trzech intelektualnych środowisk katolickich, jak też w ogóle wśród legalnie wydawanej prasy katolickiej, redakcja organu stołecznego przyjęła kurs najbardziej radykalny. Nastawiono się bowiem na bezkompromisową konfrontację z obozem rządzą$\mathrm{cym}^{632}$. Powoływano się na tradycje środowiska przedwojennego i okupacyjnego działającego na emigracji i w kraju. Od początku powstania pisma widziano dwojako jego linię programową. Ks. Z. Kaczyński zainicjował bardziej polityczny charakter tygodnika otwartego, ostrego, reagującego żywo i angażującego się w wydarzenia społeczno-polityczne. Ks. Z. Wądołowski natomiast postrzegał go raczej w kategoriach etyczno-moralnych. Ostatecznie zwyciężyła koncepcja ks. Kaczyńskiego.

Środowisko „Tygodnika Warszawskiego” zdecydowanie opowiedziało się za koncepcją „maksymalizmu społecznego”, czyli dążenia do jak najpełniejszej realizacji zasad chrześcijańskich w nowej rzeczywistości. Nauka społeczna Kościoła stała u podstaw głoszonych poglądów na temat przyszłego oblicza społeczno-politycznego Polski. Zapoznawano z treściami zawartymi w encyklikach papieskich (zwłaszcza Quadragesimo anno). Starano się zaszczepić zasady pomocniczości i dobra wspólnego. Drukowano ważniejsze wypowiedzi papieża, prymasa Polski i Episkopatu dotyczące zagadnień społecznych. W publikacjach na łamach periodyku sprzeciwiano się wprowadzanym zmianom ustrojowym przez komunistów oraz reformom społecznym. Punktem zapalnym stały się też zapowiadane wybory ${ }^{633}$.

Redakcja czasopisma była najostrzej atakowana przez publicystów prasy rządowej. W propagandowych wystąpieniach nazwano ją „rzecznikiem sił reakcji”, „wrogiem demokracji ludowej”, zwolennikiem „sojuszu kościoła z Anglią, Watykanem i imperializmem”634. Jerzego Brauna obwołano „hitlerow-

${ }^{629}$ Tamże.

${ }^{630}$ Z. Kaczyński, Na progu 1947, „TW” 1947 nr 1 s. 1.

${ }^{631}$ M. Rosołowski, Tygodnik Warszawski. W: Encyklopedia „Białych plam”, t. 17, Radom 2006, s. 222-224.

${ }^{632}$ W. Ciechomski, , Tygodnik Warszawski” 1945-1948, „Lad” 1983 nr 29 s. 4.

${ }^{633}$ O. Budrewicz, Wybory, „TW” 1946 nr 43 s. 2.

${ }^{634}$ J. Stefaniak, Polityka władz..., s. 88. 
cem"635, a środowisko skupione wokół pisma stało się obiektem zainteresowania Ministerstwa Bezpieczeństwa Publicznego ${ }^{636}$. Wkrótce nastąpiły zatrzymania. Pierwszy aresztowany został 30 V 1947 r. ks. Edward Grzechnik, po nim Hanna Iłowiecka 15 III 1948 r.; w lipcu 1948 r. pozbawiono wolności Kazimierza Studentowicza, a w sierpniu 1948 r. Antoniego Madeja, Antoniego Antczaka, Adama Grabowskiego, Józefa Kwasiborskiego i ks. Zygmunta Kaczyńskiego. W grudniu zatrzymano Jerzego Brauna. Opór stawiany przez współpracowników „Tygodnika” przyczynił się do opieczętowania i zamknięcia wydawnictwa 4 IX 1948 r. Członków redakcji skazano na wieloletnie więzienie, niektórych nawet na dożywocie (m.in. J. Brauna). W więzieniu życie zakończyli Antoni Antczak i ks. Zygmunt Kaczyński.

Kazimierz Koźniewski, notabene piszący sporadycznie na jego łamach, tak wyraził się o nim: „było pismem intelektualnie najmniej interesującym”, które mogło „istnieć tylko pod warunkiem [...] lojalności w stosunku do rewolucyjnego państwa, a nie stawki na kontrę” ${ }^{637}$. Określił też tytuł „,pismem politycznej kontrrewolucji” ${ }^{638}$, odmawiając mu miejsca w Historii co tydzień. Inny publicysta zauważył natomiast: „Wśród pism katolickich <<Tygodnik Warszawski >> pragnąłby jak najsilniej podkreślić swój charakter jako bojowy organ o upowszechnianie w naszym kraju koncepcji katolicyzmu społecznego" ${ }^{639}$. Członkowie redakcji za bezkompromisową postawę zapłacili najwyższą cenę.

\section{Cechy wydawniczo-formalne}

Pierwszy numer „Tygodnika Warszawskiego” z podtytułem „Pismo katolickie poświęcone zagadnieniom życia narodowego" ukazał się w rocznicę uzyskania przez Polskę niepodległości 11 XI 1945, ostatni - 5 IX 1948 r. Nakład wynosił blisko 20 tys. egzemplarzy. Kolportaż odbywał się poprzez prenumeratę (ok. 5 tys.) oraz własne punkty sprzedaży przy kościołach i w kioskach Ruchu. Zasadniczo tytuł prasowy był samowystarczalny i opłacalny ${ }^{640}$.

Periodyk w dużym formacie dwójki liczył osiem pięcioszpaltowych stron (tylko niektóre wydania były obszerniejsze, o objętości $12-16 \mathrm{~s} .{ }^{641}$ ). Jako wydawcę w stopce redakcyjnej pierwszego numeru podano Katolicki Komitet Wydawniczy, a następnie w czwartym numerze Katolickie Towarzystwo Wydawnicze „Rodzina

${ }^{635}$ Oświadczenie w sprawie J. Brauna, „TW” 1947 nr 37 s. 7. W artykule w „Głosie Ludu” pt. Hitlerowiec chce zabierać głos pomówiono Jerzego Brauna o kolaborację z Niemcami.

${ }^{636}$ M. Biełaszko, ,, Tygodnik Warszawski” i jego..., s. 81-83.

${ }^{637}$ K. Koźniewski, Historia co tydzień. Szkice o tygodnikach społeczno-kulturalnych 1944-1950, Warszawa 1997, s. 357-358.

${ }^{638}$ Tamże, s. 358.

${ }^{639}$ T. Kietlicz, Katolicyzm spoleczny a polityczny, „TW” 1947 nr 25, s. 6.

${ }^{640}$ C. Lechicki, Polska prasa katolicka..., s. 72; J. Wiszniewski, Z historii prasy katolickiej..., s. 43.

${ }^{641}$ Np. nr 12 i 17 z 1947 r.; nr 1 i 2 z 1948 r. 
Polska" ${ }^{642}$ z siedzibą w Warszawie. Tygodnik składano w Zakładach Graficznych „Dźwignia” przy ul. Widok 24, a od marca 1946 r. (nr 10) w Dziale Grafiki Zakładów Salezjańskich ul. ks. Siemca 6. Odbijano go zaś w Drukarni „Czytelnik” nr 2 przy ul. Marszałkowskiej 3-5 ${ }^{643}$.

Początkowo powściągliwie, co było w zwyczaju także innych redakcji (np. „Tygodnika Powszechnego”), podano jako redagujących „Kolegium redakcyjne" ${ }^{644}$. Redakcja i administracja mieściły się w Warszawie przy ul. Nowogrodzkiej 49 (Roma) na czwartym piętrze. W stopce redakcyjnej widniały również terminy przyjęć redaktora naczelnego - od wtorku do piątku w godzinach 12-13, a z początkiem 1946 r. w godzinach 11-13. Redakcję można było odwiedzać najpierw codziennie od 16 do $18^{645}$, następnie od 10 do $14^{646} \mathrm{i}$ od 10 do $18^{647}$; z nowym 1946 r. od 10 do $12^{648}$.

Łącznie wyszły cztery roczniki i 145 numerów, w tym rocznik pierwszy (zeszyty 1-7) i ostatni (1-36) niepełne; roczniki 2-3 po 51 zeszytów. Z okazji świąt wydawano niekiedy numery podwójne. Ważne wydarzenia kulturalne i z życia Kościoła stały się okazją do opublikowania numerów specjalnych ${ }^{649}$. Zazwyczaj obszerniejsze, poświęcone były m.in.: setnej rocznicy urodzin Henryka Sienkiewicza („TW” 1946 nr 20), przybyciu prymasa Augusta Hlonda do Polski (nr 22 z tegoż roku), rocznicom powstania warszawskiego (nr 31 z 1946; nr 31 z 1947; nr 31/32 z 1948), książce (nr 39 z 1946), setnemu wydaniu pisma (nr 42 z 1947), świętom (na Boże Narodzenie ${ }^{650}$ i Wielkanoc ${ }^{651}$ ).

Cena pojedynczego numeru wynosiła początkowo $6 \mathrm{zł}$. Warunki prenumeraty wraz z kosztami przesyłki kształtowały się następująco: kwartalnie -75 zł, półrocznie 150 zł, rocznie 300 zł. Należność można było uiszczać w każdym

${ }^{642}$ Założyciele Katolickiego Stowarzyszenia „Rodzina Polska” postawili sobie ambitny cel uruchomienia obok tygodnika także dziennika katolickiego, katolickiej agencji prasowej, miesięczników i własnej drukarni. Inicjatywy te miały w części kontynuować działalność i zniszczony dorobek Akcji Katolickiej, po której został jedynie budynek „Roma”. Nie udało się niestety zrealizować w większości tych planów. Najdotkliwiej społeczność katolicka odczuwała brak gazety codziennej. Zapowiadano ukazanie się miesięczników: „Przegląd Katechetyczny” i „Przegląd Katolicki”. Źródło: A.G. [A. Gołubiew], Rok pracy...

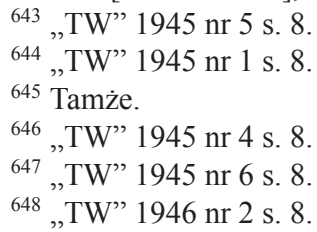

${ }^{649}$ Np. numer specjalny wydano w setną rocznicę urodzin Henryka Sienkiewicza „TW” 1946 nr 20; powrót prymasa Augusta Hlonda do Polski w 1946 r. upamiętniono numerem 22 z tegoż roku; z kolei „TW” $1946 \mathrm{nr} 31$ poświęcono drugiej rocznicy powstania warszawskiego; „TW” $1946 \mathrm{nr} 39$ w całości przeznaczono książce.
${ }^{650}$ „TW” $1947 \mathrm{nr} 51$.
${ }^{651}$ Np. „TW” 1946 nr 16; „TW” 1948 nr 13. 
urzędzie pocztowym na konto Katolickiego Towarzystwa Wydawniczego „Rodzina Polska" ${ }^{652}$. Jedynie powiększony objętościowo (12 stron) ostatni numer świąteczny z 1945 r. i pierwszy noworoczny z 1946 r. kosztowały 8 zł. Cena tygodnika wzrosła do 7 zł od numeru piątego z 1946 r., przy zachowaniu dotychczasowej ceny prenumeraty. Numery podwójne i powiększone (16 stron), były droższe $-12 \mathrm{z}^{653}$. Kolejna podwyżka nastąpiła od numeru 35 z 1946 r. - 10 zł. Prenumerata również zdrożała i wynosiła: kwartalna - 100 zł, półroczna 200 zł, roczna 400 zł (kolportaż parafialny liczono po $8 \mathrm{zł}$ za egzemplarz) ${ }^{654}$. Ostatnie świąteczne wydanie roku 1946 powiększono do 12 stron i było w cenie 15 zł. Taki koszt „Tygodnika” utrzymał się też w kwietniu 1947 r. (nry 14-17 z tego roku), po czym do końca roku (za nry 18-51) trzeba było zapłacić 20 zł. Warunki prenumeraty także uległy zmianie: miesięczna - 60 zł, kwartalna - 150 zł, półroczna 300 zł, roczna - 600 zł ${ }^{655}$. Po długim wyjaśnieniu w nocie Od wydawnictwa prenumerata ogłoszona w maju 1947 r. znów została podwyższona (nr 19): miesięczna - 80 zł, kwartalna - 200 zł ${ }^{656}$. Ceny ogłoszeń za $1 \mathrm{~mm}$ w jednej szpalcie wynosiły ,za tekstem” 50 zł, „w tekście” 75 zł. Przy seryjnych ogłoszeniach można było otrzymać „rabat według umowy” ${ }^{657}$. W przedostatnim numerze z $1948 \mathrm{r}$. informowano o wpłacie za zmianę adresu w wysokości $25 \mathrm{zz}^{1658}$. Były to oczywiście relacje cenowe aktualne przed wymianą pieniędzy w $1950 \mathrm{r}$.

Kontaktom z prenumeratorami służyła m.in. rubryka Od administracji, w której zazwyczaj pisano o warunkach zakupu i dostarczania tytułu. Odpowiadano w niej także na reklamacje. Przykładowo powiadamiano: „Administracja w miarę napływających zamówień wysyła egzemplarze pisma. Jeżeli więc w poszczególnych wypadkach poczta $<<$ Tygodnika $>>$ nie doręcza, dzieje się to nie $\mathrm{z}$ naszej winy. Prosilibyśmy reklamacje kierować do odnośnego Urzędu Pocztowego" 659 . Przypominano abonentom o opłacie z góry zarówno za nabycie pojedynczego egzemplarza periodyku, jak i za prenumeratę. Opóźnienie opłaty abonamentowej na kolejny kwartał nie powodowało od razu przerwy w otrzymywaniu tygodni$\mathrm{ka}^{660}$. W następujący sposób ostrzegano odbiorców: ,już najwyższy czas odnowić prenumeratę na I kwartał r.b., gdyż od następnego numeru przerwiemy wysyłkę wszystkim zalegającym z opłatą" ${ }^{61}$ lub „Prosimy uprzejmie o łaskawe dokonywanie wpłat, gdyż w nadchodzącym kwartale bezwzględnie przerwiemy wysyłkę

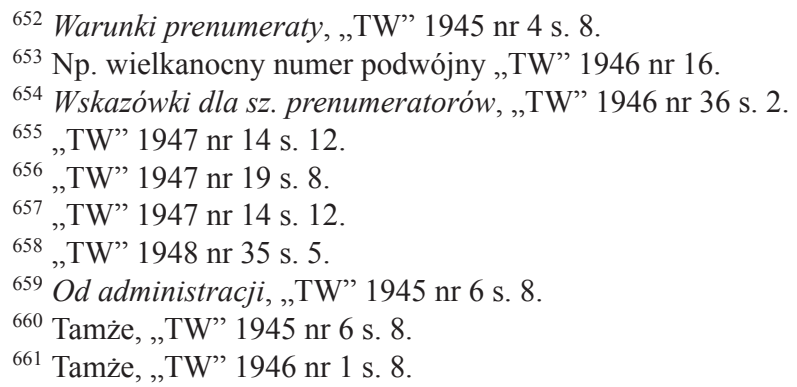


pisma wszystkim zalegającym z opłatą" ${ }^{962}$. Zwracano się jednocześnie z prośbą o czytelne pisanie nazwisk oraz adresów w listach i na blankietach ${ }^{663}$. Zapewne z powodu wciąż występujących braków w podawanych informacjach i ich nieczytelnej formy nowa redakcja w kolejnych numerach dokładnie wymieniła elementy, które powinny znaleźć się w adresie mieszkańca miasta i wsi ${ }^{664}$. W rubryce dowiadujemy się także, że po wzroście ceny periodyku do 7 zł administracja udostępniała je parafiom taniej, za 5,75zł za egzemplarz. W 1946 r. czasami kierowano krótkie zapytania lub informacje do imiennych odbiorców ${ }^{665}$. Z czasem upominano się o podawanie numeru kartoteki abonenta w celu sprawnego załatwiania spraw. Aby ułatwić uregulowanie należności za czasopismo, prenumeratorom wysyłano blankiety nadawcze $\mathrm{PKO}^{666}$.

Różnego rodzaju awarie w pracy redakcji również podawano do wiadomości czytelników. W rubryce Od redakcji czytamy: „Z powodu nagłego przerwania prądu w drukarni zmuszeni byliśmy wydać świąteczny numer $<<$ Tygodnika Warszawskiego >> [chodzi o nr 51 z 1946 r. - E.K.] bez uwzględnienia korekty. Wszystkich czytelników i autorów, których prace znajdowały się w tym numerze, redakcja bardzo przeprasza" ${ }^{667}$, po czym sprostowano błędy. Zdarzały się też ogłoszenia tego typu: „Redakcja prosi autora (Z.M.) recenzji książki ks. C. Ruthena: Podręcznik nauki i akcji społecznej na użytek młodego duchowieństwa o wypożyczenie jej na miesiąc" ${ }^{068}$. Pod tym samym nagłówkiem zapowiedziano także zawartość najbliższych numerów ${ }^{669}$.

Z kolei w rubryczce Od wydawnictwa thumaczono: „Wobec licznych listów i reklamacji ze strony naszych Czytelników i Przyjaciół wyjaśniamy, że niestety, mimo wysiłków, nie możemy pokonać trudności, aby <<Tygodnik Warszawski >> docierał do wszystkich miejscowości w Polsce i znajdował się w kioskach w ilości dostatecznej”"670. Zachęcano jednocześnie do stałej prenumeraty.

$\mathrm{Za}$ nowej redakcji tygodnik unowocześniono. Poprawiona została jego struktura wewnętrzna. Od numeru 36 z 1946 r. wprowadzono poprzez łamania na pierwszej stronie kilka bieżących tematów. Z początkiem 1947 r. również na stronie tytułowej w prawym górnym rogu pod nagłówkiem $W$ treści przyjęto zasadę podawania najważniejszych tytułów wraz z nazwiskami autorów piszącymi w danym numerze. Nowa redakcja wprowadziła stałe działy (np. Kultura i praca). Promowała periodyk m.in. poprzez krótką reklamę: „Nie wystarczy czytać

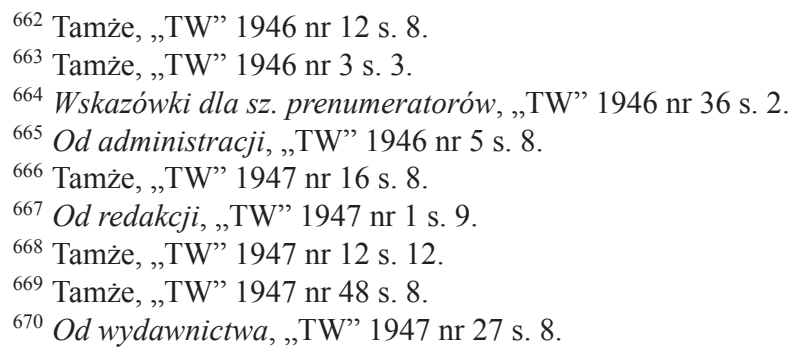


$<<$ Tygodnik Warszawski >> Trzeba prenumerować, POLECAĆ DRUGIM, żeby prenumerowali - wtedy będziesz prawdziwym przyjacielem pisma" ${ }^{671}$.

Ulubioną formą wypowiedzi na łamach „Tygodnika Warszawskiego” była polemika prasowa. Publicyści polemizowali z wypowiedziami marksistowskiej „Kuźnicy”672, „Wsi”673 i „Nowych Dróg”. Odkłamywano także informacje podawane na łamach „Nowej Epoki” ${ }^{674}$ - organu Stronnictwa Demokratycznego, humorystycznie natomiast podchodzono do niektórych wiadomości w „Przekroju”675. Współpracownicy pisma wypowiadali się też poprzez artykuły, recenzje, wywiady, felietony, przeglądy prasy, fragmenty pamiętników, listy pasterskie, przemówienia, polemiki, spisy bibliograficzne, wiersze. Obecne były również przedruki z polskich i obcych czasopism (np. „Carrefour”676, „L'Osservatore Romano”).

\section{Działy i rubryki}

Stała struktura pisma wyłoniła się już w pierwszym roczniku. Najwcześniej zagospodarowano pierwszą i ostatnia stronę. Na początku umieszczono jednokolumnową notę Od redakcji, artykuł wstępny redaktora naczelnego, wiersz i spis treści numeru, na końcu zaś wprowadzono przegląd prasy pod nagłówkiem Wśród pism. Rubryka U literatów (s. 6-7 lub 8) weszła na stałe od numeru czwartego. Omawiano w niej środowe spotkania literatów warszawskich ${ }^{677}$, niekiedy poruszane były też inne tematy, np. dotyczące sztuki dramatopisarskiej ${ }^{678}$, poezji ${ }^{679}$ i książek ${ }^{680}$. W kolejnej rubryce, Pod światto (obecnej od nru 5 z 1945 r.), prowadzonej przez Veraxa, poruszano na bieżąco różnorodną problematykę, np. stosunku państwa do Kościoła ${ }^{681}$, prawa małżeńskiego i ślubów cywilnych ${ }^{682}$, ataków na katolicyzm $^{683}$. Krótko obecne Horyzonty od ostatniego wydania z 1945 r. (s. 11)

671 ,TW” 1947 nr 23 s. 3; tamże, nr 26 s. 12.

${ }^{672}$ E. Kurowski, Nie zostaliśmy przekonani, „TW” 1945 nr 6 s. 4; J. Dobraczyński, Obrachunek bez salda, „TW” 1946 nr 5 s. 3; Kropka, Dla kogo jest „Kużnica”?, tamże, nr 51 s. 11.

${ }^{673}$ Np. J.B. Ożóg, List otwarty, „TW” 1948 nr 7 s. 8.

${ }^{674}$ Cis., Epopeja „,Nowej epoki”, ,,TW” 1945 nr 7 s. 5.

${ }^{675}$ Przekrętnik, Kocioł garnkowi, „TW” 1946 nr 2 s. 8; Kropka, Słowa nie na miejscu, tamże, nr 47 s. 3.

${ }^{676}$ Np. G. Bernanosa Rozpacz i nadzieja Francji, „TW” 1947 nr 19 s. 5.

${ }^{677}$ Np. J.W., U Literatów, „TW” 1945 nr 4 s. 7; tamże, nr 5 s. 6; j.h., tamże, nr 6 s. 6; tamże, nr 7 s. 7; ,TW” 1946 nr 17 s. 8.

${ }^{678}$ J.W., U literatów, „TW” 1946 nr 1 s. 6.

${ }^{679}$ Tenże, U literatów, ,TW” 1946 nr 8 s. 8; tamże, nr 14 s. 8.

${ }^{680}$ Tenże, U literatów, ,TW” 1946 nr 10 s. 8.

681 Verax, Pod światto, „TW” 1945 nr 5 s. 2.

682 Tenże, Pod światło, „TW” 1945 nr 6 s. 5; „,TW” 1946 nr 1 s. 7; tamże, nr 2 s. 2.

683 Tenże, Biedne głowy, ,TW” 1946 nr 15 s. 3. 
były miejscem na zwięzłe i krótkie rozważania dotyczące narodu ${ }^{684}$, cywilizacji ${ }^{685}$ itd. Wiele tematów rodziło się z przeglądu prasy polskiej, np. inspiracją do wypowiedzi stał się nowy tytuł prasowy na rynku ${ }^{686}$ czy ograniczone wiadomości z procesu w Norymberdze dotyczące prześladowań religijnych ${ }^{687}$. Z czasem rubryka zanikła, powrócono do niej w styczniu z 1948 r. (nr 5 s. 8), kiedy to podpisał się pod nią Leszek Prorok.

Nowe ksiązki wprowadzono z początkiem 1945 r. (nr 5 s. 6), a następnie Wśród książek ${ }^{68}$, Wśród nowych książek ${ }^{689}, Z$ nowych książek ${ }^{690}$; nagłówki takie pojawiały się zamiennie w kolejnych latach. Równolegle istniała rubryka Książki nadestane do redakcji ${ }^{691}$ (czasem tylko Książki nadesłane). Krótkie recenzje drukowano w rubrykach zatytułowanych Francuskie nowości wydawnicze ${ }^{692}, Z$ wydawnictw ${ }^{693}$, Książki zagraniczne ${ }^{694}$. Prowadzono jednocześnie rubryki: $Z$ wydawnictwi czasopism (od nru 45 z 1946 r. s. 8), potem tylko $Z$ wydawnictw ${ }^{695}$, czasami $Z$ wydawnictw religijnych ${ }^{696}, Z$ nowych wydawnictw ${ }^{697}$ czy $Z$ prasy ${ }^{698}$ (obecne od końca 1947 i w 1948 r.).

Felietony Stefana Kisielewskiego w części zatytułowanej Sztuka i polityka weszły od zeszytu 10 z 1946 r. (s. 3, 6). Znany i lubiany felietonista podejmował tu „pół żartem pół serio” różną problematykę: warunków, jakie stworzono artystom w powojennej Polsce ${ }^{699}$, odcinania się od dorobku kulturalnego dwudziestolecia międzywojennego ${ }^{700}$, propagandowego nastawienia wobec literatury ${ }^{701}$, przemian społeczno-gospodarczych i politycznych w kraju ${ }^{702}$. Wiele zagadnień

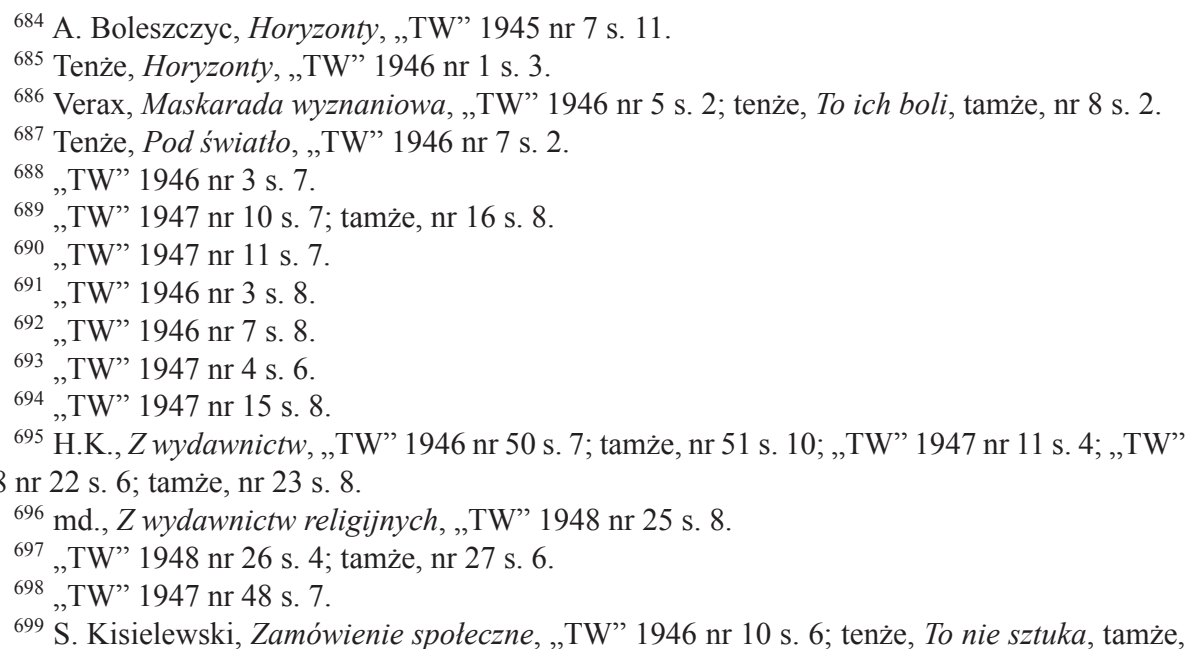
nr 11 s. 6.

700 Tenże, ,Nowe czasy”, „TW”1946 nr 12 s. 3.

701 Tenże, Epoka dydaktyki, „TW” 1946 nr 13 s. 5.

702 Tenże, Sprawa najdonioślejsza, „TW” 1946 nr 23 s. 8; tenże, O polityce i o pewnym poecie, tamże, nr 32 s. 6. 
i spraw, podobnie jak w Horyzontach, dostarczał przegląd ówczesnej prasy polskiej. Krytykę i ośmieszanie wypowiedzi prasowych w różnych polskich czasopismach krótko prowadził (od nru 15 z 1946 r. s. 5) Przekrętnik pod nagłówkiem Docinki. Ustosunkowywał się w nich m.in. do różnych wydarzeń politycznych ${ }^{703}$. Kolumna zatytułowana Przeglad prasy, obecna od ostatniej edycji z 1946 r. (nr 51 s. 11), służyła zarówno prezentacji czasopism, jak też polemice z niektórymi tytułami ${ }^{704}$. Część Zagadnienia i opinie (nr 37 z 1946 s. 7), jak podała redakcja w notce wstępnej, miała zawrzeć przegląd najważniejszych i najbardziej aktualnych spraw poruszanych w prasie. Drukowano ją rzadko, kontynuując pod koniec 1947 r., zamieniono w mniejszą kolumnę (nr 50 s. 11).

Wśród ludzi i wydarzeń wprowadzono (od nru 8 z 1946 r.) do każdego zeszytu na ostatniej stronie. W ramach działu pojawiły się początkowo Życie religijne i Kronika polityczna, po czym rozbudowano go tematycznie. Znalazły się tu zarówno wiadomości z życia Kościoła na świecie i w Polsce, jak i krótkie nowiny ze świata polityki, kultury, medycyny, informacje o zgonach znanych osób. Nowa redakcja wprowadziła na pierwszej stronie (w nrze 36 z 1946 r.) Przegląd wydarzeń z zagranicy i kraju, który pomimo przerw utrzymał się do końca. Dział zanikał i powracał w mniej lub bardziej okrojonym kształcie (na s. 1-3). Rozbudowany na całą stronę na stałe zagościł od połowy sierpnia $1947 \mathrm{r}$. (nr $33 \mathrm{~s}$. 7). W numerze listopadowym z tegoż roku (nr $46 \mathrm{~s}$. 2) przemianowano go jednorazowo na Wydarzenia i fakty, a następnie zastąpiono kolumną zatytułowaną Kronika wydarzeń (od nru 14 z 1948 r. s. 12).

Recenzje teatralne obecne (od nru 6 z 1945 r. s. 7) w rubryce $Z$ teatrów warszawskich, zmieniły następnie nagłówek na $Z$ teatrów (nr 3 z 1946 s. 7). Rubryka przetrwała do końca, mimo że nie występowała każdorazowo. Znacznie rozbudowano ją w numerach 46-50 z 1947 r. i w 1948 r. Prowadził ją wtedy Jerzy Kierst.

Liczne rubryki służyły relacjom z czytelnikami. W numerze 6 z 1945 r. po raz pierwszy pojawiła się na ostatniej stronie kolumna Od administracji. W niewielkiej rubryczce pt. Sprostowanie (po raz pierwszy znalazła się w nrze 1 z 1945 r. s. 5) odnoszono się do błędów i pomyłek w „Tygodniku Warszawskim”. Wyjaśnienia w kwestiach spornych lub sprostowania drukowano też sporadycznie w Listach do redakcji (po raz pierwszy w nrze 30 z 1946 r. s. 5) lub pod nagłówkiem Do redakcji „,Tygodnika Warszawskiego "705. Korespondencja do każdego numeru weszła w lutym 1948 r. (nr 8 s. 8). Opinie odbiorców przedstawiano w Czytelnicy pisza... (od numeru 46 z 1946 r. s. 7) i Listy czytelników (od 29 z 1948 r. s. 7 lub 8). Z numerem

${ }^{703}$ Przekrętnik, Buldog i jamniki, „TW” 1946 nr 18 s. 8.

${ }^{704}$ Np. Przegląd prasy, „TW” 1947 nr 1 s. 12. Przedstawiono dwutygodnik „Warszawa” i odniesiono się do poziomu i charakteru „Przekroju”.

${ }^{705} \mathrm{~Np}$. Listy do redakcji. Ks. Truskowski odpowiada, „TW” $1946 \mathrm{nr} 48$ s. 8; Do redakcji Tygodnika Warszawskiego, „TW” 1947 nr 19 s. 2. 
6 z 1946 r. weszła na ostatnią stronie rubryczka Odpowiedzi redakcji, w której znalazły się informacje potwierdzające otrzymanie nadesłanych tekstów i odmowę wydrukowania ich. Przykładowo odbiorcy dowiedzieli się, że: „Jesteśmy przeładowani materiałem wspomnieniowym i rocznicowym. Dlatego nie możemy z artykułu skorzystać" ${ }^{\prime 706}$. Niejednokrotnie odmawiano druku nadsyłanych wierszy ${ }^{707}$. Kolumna Od redakcji, mimo że wprowadzona została od początku istnienia periodyku, częściej pojawiała się dopiero w 1947 r. Podawano w niej krótkie informacje skierowane do odbiorców w rodzaju: „P. Smolarkiewicz - sonet otrzymaliśmy, ale nie skorzystamy”, „P.S. Szczęsny - Piękna myśl nie decyduje o poziomie wiersza”, czy „P. A.W. Sadowski Wiersze słabiutkie”708. W związku z poparciem akcji Rady Prymasowskiej odbudowy kościołów Warszawy pod nagłówkiem Od wydawnictwa powiadamiano prenumeratorów o dołączeniu do egzemplarzy „Tygodnika” przekazów na konto $\mathrm{PKO}^{709}$. Do czytelników redakcja „Tygodnika” zwróciła się po raz pierwszy $\mathrm{w}$ wydaniu poświęconym powstaniu warszawskiemu z wyjaśnieniami: „Z powodu braku miejsca nie możemy pomieścić w tym numerze całego materiału dotyczącego powstańczej Warszawy $[. .$.$] materiały te zostaną opublikowane$ w dalszych numerach sierpniowych i wrześniowych" "110.

Dział zatytułowany Wieści ze świata ${ }^{711}$, a od numeru drugiego z 1946 r. Ze świata, przynosił wiadomości z życia katolickiego. Nowa redakcja wprowadziła Kronikę życia katolickiego (w nrze 36 z 1946 r. s. 8), a w kolejnym zeszycie Przeglad katolicki (s. 7). Z początkiem 1948 r. (nr 5 s. 2) wszedł do każdego numeru dział Na widowni międzynarodowej, pod którym podpisywał się Spectator. Od końca lipca (w nrach 30-35 z tegoż roku) Przegląd międzynarodowy poprowadził Zastępca, a po nim Tenax. W Przeglądzie kulturalnym uwzględniano z kolei wszelkie imprezy w rodzaju wystaw, koncertów, recitali, wieczorów literackich, odczytów i in. (od nru 49 z 1946 s. 8). Z czasem dołączono tu wiadomości o nagrodach, konkursach, nowych przekładach książek i filmach.

W piśmie zadbano również o prowadzone na bieżąco kroniki. Jako pierwsza dostępna była Kronika naukowa (w nrze 45 z 1946 r. s. 5), po niej Kronika zagraniczna (od końca lipca $\mathrm{nr} 30$ z 1947 s. 2). W drugiej z nich rozpoczęto od refleksji na temat dwóch wystaw, wspomnienia o ankiecie dotyczącej kryzysu teatralnego i zwierzeniach francuskiego poety Blanche Balaina. Kronika kulturalna drukowana od końca lutego 1948 r. (nr 9 s. 8) zastąpiła Przeglad kultural$n y$. Podawano w niej bardziej skrótowo informacje kulturalne. Na jakiś czas weszły też $O d c z y t y^{712}$, w których skrzętnie odnotowywano wystąpienia w szerszych

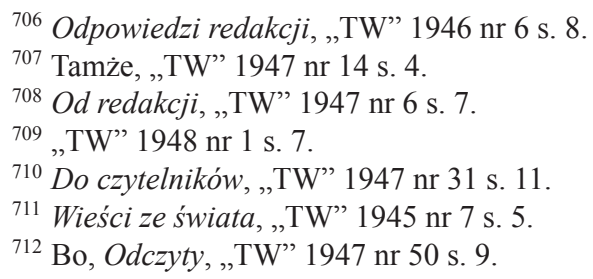


gremiach. Pod nagłówkiem $Z$ Warszawskiego Towarzystwa Teologicznego znalazły się sprawozdania ze spotkań ${ }^{713}$.

Inicjatywę drukowania Prywatnych strat kulturalnych podjęto w numerze 13 z 1946 r. ${ }^{714}$ Proszono odbiorców o nadsyłanie materiałów wraz z opisem okoliczności zniszczeń korespondencji, książek, pamiątek, obrazów, rzeźb, mebli zabytkowych itp. Nowa rubryka Miasta mówia ... obecna od lipca 1947 r. (nr 29 s. 8-9) zawierała wiadomości historyczne i współczesne o stopniu odbudowy po wojnie większych i mniejszych miast polskich. Odnoszono się w niej również do spraw zabytków oraz pomników przeszłości m.in. Częstochowy, Kielc czy prowincjonalnych Siematycz ${ }^{715}$.

Chcąc dać możliwość wypowiedzi katolickiej młodzieży akademickiej, w grudniu 1946 r. założono Kolumnę młodych. Na jej łamy zaproszono studentów z wszystkich wyższych uczelni, którzy „po katolicku myślą” i pragną ,prowadzić pracę odbudowy moralnej i społeczno-gospodarczej” w Polsce. W kwestii ideowej powtórzono znów: „Nie istnieje dla nas kryterium partyjnego klucza i nie pragniemy w najmniejszym stopniu kontynuować linii podziału, przebiegających w okresie międzywojennym i w okresie okupacji niemieckiej wśród katolickiego społeczeństwa polskiego" 716 . Dalej zastrzegano: „Nie pragniemy brać udziału w bieżącej polemice politycznej Polski Odrodzonej. Nasza rola leży nie w tym, co dzieli, ale w tym co łączy. INSTAURARE OMNIA IN CHRISTO" "17. W tej części rozważano wiele kwestii dotyczących środowisk akademickich i wychowania ${ }^{718}$. Rubryka zyskała rozgłos i cieszyła się zainteresowaniem czytelników

Z dużym działem zatytułowanym Kultura i praca odbiorcy mogli zapoznać się od 11 V 1947 r. (nr 19 s. 6) ${ }^{719}$. Wyróżniony wersalikami utrzymał się do końca. Prowadzący zaapelowali w nim do mieszkańców miast i miasteczek polskich, aby nadsyłali informacje o pomnikach przeszłości i ich stanie obecnym w regionie, zniszczonych zabytkach, źródłach dochodów i możliwości zarobkowania w danym miejscu, życiu kulturalnym, stosunkach gospodarczych i stopniu uspołecznienia ${ }^{720}$. W ramach działu przedstawiono historię, zabytki, przemysł i możliwości rozwoju m.in. Sieradza i Krakowa. W rubryce wypowiadał się J. Braun ${ }^{721}$.

${ }^{713}$ Np. „TW” 1947 nr 50 s. 11; „TW” 1948 nr 6 s. 10.

${ }^{714}$ Prywatne straty kulturalne 1939-1945, „TW” $1946 \mathrm{nr} 3 \mathrm{~s} .7$.

${ }^{715}$ B. Kędziorzanka, Kielce - stolica regionu świętokrzyskiego, „TW” 1947 nr 42 s. 8-9; K. Kołwicz, Siematycze, tamże, nr 46 s. 6-7.

${ }^{716}$ Kolumna Młodych. Od zespołu „,Kolumny Młodych”, „TW” 1946 nr 49 s. 5.

${ }^{717}$ Tamże.

${ }^{718}$ Np. A. Żup, Z zagadnień środowiska akademickiego, „TW” 1948 nr 6 s. 9; H.P., Istota wychowania katolickiego, tamże, nr 13 s. 9.

719 O nowa kulturę pracy, „TW” 1947 nr 19 s. 6.

${ }^{720}$ Kultura i praca. Apel, „TW” 1947 nr 23 s. 4.

${ }^{721}$ Z. Poloniec, Sieradz, „TW” 1948 nr 6 s. 7; J. Malik, Kraków wczorajszy i jutrzejszy, tamże, nr 15 s. 6-8; J. Braun, Zręby nowej kultury, tamże, nr 35 s. 5. 
Początkowo nieregularnie pojawiający się dział Naokoło świata wszedł na dobre wraz $\mathrm{z}$ ozdobnym nagłówkiem $\mathrm{w}$ ostatnim październikowym numerze z 1947 r. (nr 43 s. 7, potem na s. 8). Uwzględniano w nim szerzej sprawy polityczne i społeczne, m.in. pisano o warszawskich obradach partii komunistycznych i robotniczych ZSRR, Jugosławii, Bułgarii, Rumunii, Węgier i Polski, o rolnictwie w Anglii, i odpowiadano na zarzuty pojawiające się w prasie rządowej o orientację anglosaską redakcji „Tygodnika Warszawskiego”. Rubrykę prowadził Stefan Garczyński.

Część Z życia katolickiego wprowadzono na łamy „Tygodnika Warszawskiego" pod koniec maja 1947 r. (nr 21 s. 7); zawierała ona bieżące wiadomości z życia Kościoła i katolików na świecie i w Polsce. Pisano m.in. o nowo otwartych seminariach, odbudowie opactwa tynieckiego, wydaniu nowej encykliki. W następnych zeszytach kolumnę zamieszczano na ostatniej stronie, później zamieniając ją na Życie katolickie (od nru 8 z 1948 r. s. 6). W tym samym numerze redakcja umieściła Życie muzyczne (s. 8) z recenzjami koncertów.

Niedużą kolumnę Sylwetki i zdarzenia otwarto w lipcu 1948 r. (s. 7), zachęcając: „Prosimy wszystkich czytelników i przyjaciół naszego pisma o nadsyłanie nam opisów, które by mogły rzucić światło na życie naszego Narodu w okresie zawieruchy wojennej. Opisy te winny dotyczyć charakterystycznych wydarzeń lub fragmentów prac, życia i myśli wybitnych osobistości. Jesteśmy przekonani, że w ten sposób powstanie nie tylko interesująca dla czytelników rubryka, ale i uda się redakcji przy pomocy czytelników zgromadzić szereg cennych przyczynków do najnowszej historii" 722 . Jako pierwszą zamieszczono Przypadkowa rozmowe $z$ Maciejem Ratajem. Jan Dworakowski zdążył natomiast w relacjach wspomnieniowych napisać o Stefanie Jaraczu, Henryku Brunie i Stefanie Starzyńskim ${ }^{723}$.

Na ostatnich stronach „Tygodnika” w latach 1945-1946 umieszczono dział Ze świeczka po Warszawie, w którym publicyści podpisujący się pseudonimami podejmowali zagadnienia życia obyczajowego powojennej stolicy ${ }^{724}$. Prawda w oczy pojawiła się jednorazowo z numerem 16 z 1946 r. (s. 15). W niezwykle humorystyczny sposób pisano w rubryce Na kiet... (od nru 2 z 1947 r. s. 5-6) o przywarach ludzkich: mówieniu prawdy, złodziejstwie ${ }^{725}$, ,pechowym dniu”726, o niskim poziomie dowcipów na łamach „Szpilek”727. Dość szybko, niestety, jej zaniechano. Od kwietnia 1947 r. wprowadzono natomiast, również na krótko, kolumnę Tylko bez urazy..., gdzie chciano „pogawędzić byle bez urazy, na tematy

722 J.W., Sylwetki i zdarzenia, „TW” 1948 nr 29 s. 7.

${ }^{723}$ J. Dworakowski, Jeszcze o Jaraczu, „TW” 1948 nr 34 s. 8; Henryk Brun, tamże, nr 35 s. 12; Stefan Starzyński, tamże, nr 36 s. 8.

${ }^{724}$ Omikron, Prowizorycznie, „TW” 1945 nr 5 s. 8; HOZ., Paczki i dzieci, „TW” 1946 nr 1 s. 8; Omikron, Sylwestrowe echa, tamże, nr 2 s. 4.

${ }^{725}$ SWENO, Felieton o złodzieju, „TW” $1947 \mathrm{nr} 4$ s. 7.

${ }^{726}$ Tenże, Pechowy dzień, „TW” 1947 nr 5 s. 7

${ }^{727}$ Sweno, Felieton smutny, tamże, nr 6 s. 7. 
poważne i błahe"728. Zazwyczaj omawiano krótko, „z uśmiechem”, kilka bieżących spraw z życia społeczno-kulturalnego.

Pojedyncze reklamy, choć obecne od początku na różnych stronach periodyku, znalazły swoje stałe miejsce na ostatniej stronie. Ogłaszały się m.in. zakłady pogrzebowe, fabryka organów, zakłady modelarskie, wytwórnia artykułów szkolnych i biurowych.

Redakcja „Tygodnika Warszawskiego” starannie dobierała działy i rubryki według własnego uznania. Można podzielić je na prowadzone tylko przez redaktorów i współpracowników oraz na te, do których mogli pisać czytelnicy. Niektóre części w strukturze pisma z założenia zawierały tylko materiały nadesłane. W pierwszym okresie istnienia tygodnika, gdy redakcją kierował ks. Zygmunt Wądołowski, ton publikacji na łamach pisma można by określić jako umiarkowany; sytuacja zmieniła się po objęciu stanowiska przez ks. Zygmunta Kaczyńskiego - zamieszczone wypowiedzi stały się bardziej bojowe. Doniosłą rolę odegrał wtedy Jerzy Braun, pisząc pogłębione teksty znakomitym piórem literackim. Przy zdecydowanej przewadze problematyki społeczno-kulturalnej nie zabrakło w piśmie felietonów obyczajowych na wysokim poziomie.

\section{Zawartość ideowa i kulturalna „Tygodnika Warszawskiego”}

$\mathrm{Na}$ łamach omawianego czasopisma upowszechniano społeczną naukę Kościoła i opowiadano się za wartościami chrześcijańskimi. Autorzy podejmowali problematykę religijną, społeczną, polityczną, gospodarczą, kulturalną i literacką. Zagadnienia rozważane w periodyku omówił Jan Wiszniewski, ujmując je w kilka bloków tematycznych: humanizm chrześcijański - postulatem odnowy moralnej, naród - państwo, ustrój społeczno-polityczny, ustrój społeczno-gospodarczy, kultura i praca, nauka - oświata - wychowanie, Kościół - katolicyzm, granice Polski - polityka zagraniczna ${ }^{729}$.

Na pierwszych stronach (s.1-5) dominowały kwestie polityczne i społeczne. W kręgu zainteresowań współpracowników „Tygodnika Warszawskiego” były sprawy polityki zagranicznej i wewnętrznej Polski. Od początku zwracano uwagę na problematykę międzynarodową ${ }^{730}$, w tym dotyczącą Ameryki ${ }^{731}$ i Europy ${ }^{732}$.

${ }^{728}$ Piryt, Tylko bez urazy..., tamże, nr 16 s. 8.

729 J. Wiszniewski, Z historii prasy..., s. 47-106.

${ }^{730}$ B. Zawisza, Na otwarcie Zgromadzenia Organizacji Narodów Zjednoczonych, „TW” 1946 nr 2 s. 7-8; Między wschodem a zachodem, tamże, nr 46 s. 1; K. Szwarcenberg-Czerny, Watykan - Chiny - Polska, „TW” 1947 nr 27 s. 5-6; Z. Kaczyński, Stolica Apostolska wobec sytuacji międzynarodowej, tamże, nr 34 s. 1; K. Szwrcenberg-Czerny, Islam a Watykan, „TW” 1948 nr 1 s. 4-5.

${ }^{731}$ S. Majewski, Powojenna Ameryka, „TW” 1945 nr 4 s. 3-4; S. Kozicki, Polityka zagraniczna Stanów Zjednoczonych, „TW” 1946 nr 29 s. 1.

732 P. Winnicki, Nowe oblicze Europy, „TW” 1945 nr 1 s. 3; S. Majewski, Kłopoty Wielkiej Brytanii, tamże, nr 5 s. 2; P. Winnicki, W świetle wyborów za granica, tamże, nr 6 s. 1; Kryzys 
Interesowano się przebiegiem wyborów w innych krajach ${ }^{733}$, porównywano sytuację Polski z sytuacją w innych państwach ${ }^{734}$. O walce politycznej trwającej w powojennej Polsce pisał Adam Grabowski. Najbardziej widoczna była ona, zdaniem autora, na kongresach stronnictw politycznych ${ }^{735}$. Dość często o sytuacji politycznej kraju wypowiadał się ks. Zygmunt Kaczyński ${ }^{736}$. Kilkakrotnie zabrał też głos ks. Stefan Wyszyński, który rozważał kwestie ustroju społecznego zgodnego z naturą człowie$\mathrm{ka}^{737}$. Stanisław Kozicki przypominał natomiast dziedzictwo polityczne Polski ${ }^{738}$.

W pierwszych latach po wojnie żywo interesowały redakcję relacje Kościoła z państwem. Wstępnie omówiono zakres uprawnień i obowiązków obu instytucji, zaznaczając, że pomocnym między nimi może być układ konkordatowy ${ }^{739}$. Analizowano kompetencje Kościoła i państwa ${ }^{740}$. Problematykę przybliżano poprzez oficjalne wystąpienia papieża i biskupów polskich. Drukowano w związku z tym zarówno przemówienia papieskie ${ }^{741}$, jak i listy pasterskie, orędzia i odezwy Episkopatu Polski ${ }^{742}$. Czytelników zapoznano m.in. z memoriałem Episkopatu Polski wręczonym 14 III 1947 r. premierowi, a zawierającym katolickie postulaty konstytucyjne ${ }^{743}$. Ukazywano niedorzeczności w tłumaczeniu założeń nowego prawa małżeńskiego przy okazji polemiki z wypowiedziami na łamach innych pism $^{744}$. Przedstawiono też sam dekret nowego prawa małżeńskiego ogłoszony 22 I 1946 r. ${ }^{74}$ Redakcja zabrała głos w sprawie listu apostolskiego papieża do

w Anglii pogłębia się..., „TW” 1947 nr 9 s. 1; Z. Kaczyński, Francja na przełomie, tamże, nr 23 s. 2; Z.K., Europa jest jedna, „TW” $1948 \mathrm{nr} 4$ s. 2.

${ }^{733}$ Co będzie we Francji?, „TW” 1946 nr 47 s. 1.

${ }^{734}$ J. Braun, Francja a Polska, „TW” 1947 nr 26 s. 2-3; Z. Kaczyński, Polska i Ameryka, tamże, nr 33 s. 1; S. Kozicki, Polska i Czechy, „TW” 1948 nr 10 s. 1.

${ }^{735}$ A. Grabowski, Na marginesie kongresu PSL, „TW” 1946 nr 6 s. 3-4.

${ }^{736}$ Z. Kaczyński, Węcej spokoju, „TW” 1946 nr 12 s. 2; tenże, Granica bezpieczeństwa, tamże, nr 19 s. 1.

${ }^{737}$ S. Wyszyński, Naturalny ustrój społeczny, „TW” 1946 nr 4 s. 1-2.

${ }^{738}$ S. Kozicki, Dziedzictwo polityczne, „TW” $1946 \mathrm{nr} 9$ s. 4.

739 S.M., Kościól a państwo, „TW” 1945 nr 4 s. 3.

${ }^{740}$ M. Winowska, Kościót i polityka, „TW” 1948 nr 8 s. 1; G. Gonella, Państwo chrześcijańskie, tamże, nr 16 s. 3.

${ }^{741}$ Przemówienie papieża Piusa XII, „TW” $1948 \mathrm{nr} 27$ s. 1-2.

${ }^{742}$ O panowanie Ducha Bożego w Polsce. Wielkopostny List Pasterski Episkopatu, „TW” $1946 \mathrm{nr} 12$ s. 1-2; S. Dąbrowski, O chrześcijańskie zasady życia państwowego, tamże, nr 25 s. 1-2; A. Hlond, Orędzie Prymasa Polski w sprawie odbudowy kościołów warszawskich, tamże, nr 27 s. 1; tenże, Odezwa Prymasa Polski na „Tydzień Miłosierdzia”, „TW” $1947 \mathrm{nr} 41$ s. 1; List pasterski Episkopatu Polski, „TW”1948 nr 3 s. 2; List pasterski, tamże, nr 23 s. 1; A. Hlond, Orędzie kardynała prymasa do ludności katolickiej Ziem Odzyskanych, tamże, nr 25 s. 1.

${ }^{743}$ Katolickie postulaty konstytucyjne, „TW” $1947 \mathrm{nr} 15$ s. 1.

${ }^{744}$ Np. Verax, Pod światto. Nietrwała trwałość, „TW” 1946 nr 6 s. 3 [autor polemizował z artykułem S. Szera, Trwałość związku matżeńskiego, „Demokratyczny Przegląd Prawniczy” 1945 nr 1].

745 J. Nowak, Nowe prawo rodzinne, „TW” 1946 nr 15 s. 1. 
biskupów niemieckich z 1 III 1948 r., dotyczącego przymusowego wysiedlenia Niemców z Ziem Odzyskanych, co również komunistyczna prasa polska wykorzystała jako pretekst do ataku na Stolicę Apostolską ${ }^{746}$. Problematyka Ziem Odzyskanych ${ }^{747}$ towarzyszyła pismu przez cały czas.

Osobno odnotowywano ważniejsze wydarzenia z życia polskiego Kościoła. Przykładowo obszerny artykuł poświęcono wizycie w kraju prymasa Anglii kardynała Bernarda Griffina ${ }^{748}$. Na łamach pisma przeważała problematyka katolicka $^{749}$, chrześcijańska ${ }^{750}$ i religijna ${ }^{751}$. Problemy ukazywano przez pryzmat światopoglądu katolickiego ${ }^{752}$. Często rozważania szły w kierunku uwydatnienia różnic miedzy katolicyzmem a marksizmem ${ }^{753}$, światopoglądem chrześcijańskim a materialistycznym ${ }^{754}$. Przedstawiano także katolicki program reform

${ }^{746}$ W sprawie listu papieża, „TW” 1948 nr 22 s. 1; Czy stolica Apostolska milczała?, tamże, nr 24 s. 1.

${ }^{747}$ R. Łyczywek, Dwa problemy na ziemiach odzyskanych, „TW” 1946 nr 12 s. 6; W.J. Grabski, Religia a problem Ziem Odzyskanych, tamże, nr 29 s. 5; K. Rakowski, Sprawa ruchomości poniemieckich na Ziemiach Odzyskanych, tamże, nr 46 s. 2; tenże, Tendencyjne alarmy niemieckie, „TW” $1947 \mathrm{nr} 4$ s. 3; K. Radwan, W sprawie gospodarki na Ziemiach Odzyskanych, tamże, nr 12 s. 4; D.M., Kościót katolicki na Ziemiach Odzyskanych, tamże, nr 29 s. 5; I. Pannenkowa, Sprawy Ziem Zachodnich, „TW” 1948 nr 11 s. 3; D. Nałęcz, Problemy Ziem Odzyskanych, tamże, nr 36 s. 4.

${ }^{748}$ R., Prymas Anglii w Polsce, „TW” 1947 nr 23 s. 1-2; przeprowadzono ponadto wywiad: „Jestem oczarowany postawa narodu polskiego”, tamże, nr $26 \mathrm{s.} 1$.

${ }^{749}$ Np. J. Piwowarczyk, Ośrodek polskiego katolicyzmu, „TW” 1946 nr 22 s. 4; Z. Ogulewicz, Katolicyzm ,konsupcyjny”, tamże, nr 29 s. 2; J. Budkowska, Katolicka postawa wobec cierpienia, tamże, nr 32 s. 1-2; C. Strzeszewski, Katolicyzm a wspótpraca międzynarodowa, tamże, s. 3; J. Braun, Katolicyzm radykalny, tamże, nr 40 s. 3; S. Grzelecki, Istota katolicyzmu, tamże, nr 44 s. 2; K. Turowski, Wykład o katolickim ruchu społecznym, tamże, nr 48 s. 3, 7; J. Braun, Katolicyzm postęp - reakcja. (Odpowiedź na zarzuty „, Gtosu Ludu”), „TW” 1947 nr 19 s. 1-2.

750 J.M. Święcicki, Chrześcijaństwo a odrodzenie cywilizacji, „TW” $1946 \mathrm{nr} 33$ s. 5-6; J. Braun, U wrót cywilizacji chrześcijańskiej, „TW” 1947 nr 14 s. 2-3; M. Poradowski, Pogaństwo a cywilizacja chrześcijańska, tamże, nr 15 s. 2; J. Kubin, Chrześcijaństwo nie jest nauka, tamże, nr 30 s. 6; K. Studentowicz, O chrześcijański styl życia, tamże, nr 36 s. 1-2; J. Braun, Państwo chrześcijańskie, tamże, nr 45 s. 1-2; K. Studentowicz, Siła chrześcijaństwa, „TW” 1948 nr 2 s. 1; J. Braun, Zludzenia humanizmu pozachrześcijańskiego, tamże, $\mathrm{nr} 3 \mathrm{~s} .3-4$; tamże, nr 4 s. 3; J. Zawieyski, Wieczna młodość chrześcijaństwa, tamże, nr 21 s. 3.

${ }^{751}$ J. Przepiórski, Religia pełni życia, „TW” 1946 nr 21 s. 4; F. Koneczny, O nierówności religii, tamże, nr 35 s. 4; tenże, Religia sprawa najbardziej publiczna, tamże, nr 42 s. 3; J.M. Święcicki, Religia, zwyczaj i obyczaj, „TW” 1948 nr 2 s. 5.

${ }^{752}$ Np. S. Grabski, Idea chrześcijańskiego narodu, „TW” $1946 \mathrm{nr} 28$ s. 1-2.

${ }^{753}$ Polityka a nieśmiertelność, „TW” $1947 \mathrm{nr} 7 \mathrm{s.}$ 1; Skarbek, Radykalizm rewolucyjny a radykalizm konstruktywny, tamże, nr 10 s. 6; J. Braun, Marksizm a społeczeństwo przyszłości, tamże, nr 19 s. 7; S.W. Bukowski, Dwa naturalizmy, tamże, nr 29 s. 3; J. Braun, Marksizm - nauka - objawienie, tamże, nr 30 s. 1-2; M. Winowska, Komunizm czy komunia?, tamże, nr 32 s. 1; Z. Kaczyński, Etyka a komunizm, tamże, nr 36 s. 1.

${ }^{754}$ M. Poradowski, Światopogląd chrześcijański, „TW” 1947 nr 36 s. 3; Z. Kaczyński, Zanim przyszedt Marks, „TW” 1948 nr 20 s. 1. 
społecznych ${ }^{755}$ na tle nauki społecznej Kościoła i treści encyklik papieskich ${ }^{756}$, nawołując katolików do czynnej postawy społecznej ${ }^{757}$.

Podobnie, jak na łamach innych pism, towarzyszyła tygodnikowi problematyka wojenna, obozowa ${ }^{758}$, niemiecka i zbrodni hitlerowskich ${ }^{759}$. Nie pomijano też trudnych stosunków polsko-niemieckich w ciągu wieków ${ }^{760}$. Dotykano drażliwych i trudnych relacji papieża Piusa XII z Adolfem Hitlerem ${ }^{761}$. Na łamach „Tygodnika Warszawskiego" drukowano ponadto wspomnienia z ostatnich lat ${ }^{762}$, w tym obozowe ${ }^{763}$.

Nie zabrakło problematyki historycznej ${ }^{764} \mathrm{i}$ odniesień do różnych wypowiedzi z okresu dwudziestolecia międzywojennego ${ }^{765}$. W zawartości tygodnika w 1 . 1947-1948 ważne miejsce znalazły prace nad odbudową ze zniszczeń wojennych $^{766}$.

${ }^{755}$ D.K. Studentowicz, Katolicki wzorzec realizacyjny, „TW” $1947 \mathrm{nr} 16$ s. 2; tenże, Gospodarka planowa w koncepcji katolicko-społecznej, „TW” $1948 \mathrm{nr} 4$ s. 4; T.K., O sprawiedliwy ustrój spoleczny, tamże, nr 6 s. 9-10.

756 J. Braun, Katolicka doktryna społeczna w historycznym rozwoju. (W rocznice encyklik spotecznych Papieży), „TW” 1947 nr 20 s. 3; C. Skarbek, Miłość społeczna podstawa nowego ładu, nr 23 s. 7; K. Turowski, Podziat dochodu w świetle encyklik, tamże, nr 24 s. 3, 8; T. Kietlicz, Katolicyzm społeczny a polityczny, tamże, nr 25 s. 5-6; jar., Papieże ucza, tamże, nr 41 s. 2; C. Strzeszewski, Nowy katolicki kodeks społeczny, „TW” 1948 nr 16 s. 1-2; K. Studentowicz, W rocznice Wielkiej Encykliki, tamże, nr 20 s. 1-2; J. Wiśliński, Kwestia społeczna w katolicyzmie, tamże, s. 3; Z., Nowa encyklika papieska, tamże, nr 21 s. 6; jar, Encyklika o liturgii, tamże, nr 35 s. 10.

${ }^{757}$ Z. Kaczyński, O postawe czynna, „TW” 1947 nr 29 s. 1.

758 J.M. Święcicki, Okopy i obozy, tamże, s. 2; L. Biłko, Męczeństwo księży polskich w obozach niemieckich, tamże, s. 4; S. Majewicz, Obóz żywych pochodni, tamże, nr 34 s. 6; P. Turbak, Wyzwolenie obozu w Dachau, „TW” 1948 nr 17 s. 3.

${ }^{759}$ B. Szczepkowski, Palmiry, „TW” 1945 nr 4 s. 4-5; Duch Trzeciej Rzeszy, „TW” 1946 nr 37 s. 1; S. Górzyński, Niemcy dzisiejsze pod względem gospodarczym, „TW” 1947 nr 1 s. 2; J. Braun, Niemcy a Europa, tamże, nr 11 s. 1-2; I. Pannenkowa, Jak stworzyć nowe Niemcy, tamże, nr 13 s. 1-2; Epsilon, Legenda oporu w Niemczech, tamże, nr 27 s. 7; I. Pannenkowa, Niemcy i przyszłość Europy, tamże, nr 34 s. 1-2; O. Budrewicz, Weimar od podszewki, tamże, nr 44 s. 5; tamże, nr 45 s. 5-6; tamże, nr 47 s. 3; I. Pannenkowa, Mit niemiecki w Polsce i na świecie, tamże, nr 45 s. 3-4; J. Braun, Problem winy niemieckiej, „TW” 1948 nr 26 s. 1, 3; W. Rybczyński, Zatruta rola, tamże, nr 29 s. 3.

${ }^{760}$ S. Kozicki, Problem polsko-niemiecki w dziejach, „TW” 1947 nr 1 s. 4.

${ }^{761}$ Z. Zaborski, Watykan a Niemcy, „TW” 1946 nr 50 s. 6.

${ }^{762}$ Np. J. Dobraczyński, Po tej stronie. Wspomnienie z wędrówki powrotnej, „TW” $1945 \mathrm{nr} 4$ s. $6-7$.

${ }^{763}$ H. Sadkowska, Obóz z innej strony, „TW” $1945 \mathrm{nr} 7$ s. 4-5.

${ }^{764}$ P. Jasienica, Pod znakiem stulecia Kościuszki, „TW” 1946 nr 23 s. 4; W. Zienkiewicz, Grunwald 1410 - 15 VII - 1946, tamże, nr 30 s. 3; S. Kozicki, Traktat wersalski, tamże, nr 32 s. 2; J. Braun, Polski ideat państwa chrześcijańskiego, „TW” 1947 nr 18 s. 1-2; W. Konopczyński, Czterdziesty ósmy [o roku 1648], „TW” $1948 \mathrm{nr} 4$ s. 1; Z.K., Wiosna ludów, tamże, nr 7 s. 2; W. Kwiatkowski, 550-lecie kościoła i kapituły św. Jana, tamże, nr 19 s. 2; A. Górski, Legion polski w Italii w 1848 r., tamże, nr 21 s. 4-5; J. Braun, Polacy a Wiosna Ludów, tamże, nr 28 s. 1, 6; tenże, Polityka Czartoryskiego wr. 1848, tamże, nr 34 s. 3.

${ }^{765}$ S. Dąbrowski, Zamach majowy i kryzys państwa, „TW” 1946 nr 23 s. 2-3.

${ }^{766}$ W. Majewski, Rosna mury zburzonych światyń Warszawy, „TW” $1948 \mathrm{nr} 1$ s. 3. 
Zagadnienia literackie szeroko omawiano w dalszej części tygodnika (s. 6-8). Rozważano ogólne podejście do twórczości ${ }^{767}$, zastanawiano się nad polską literaturą narodową ${ }^{768}$, dotykano istotnej kwestii wysokości zarobków pisarzy ${ }^{769}$. Romantyzmu bronił na łamach „Tygodnika Warszawskiego” Jerzy Braun $^{770}$. Szczególne miejsce ze względu na profil periodyku zajęła problematyka literatury katolickiej ${ }^{711}$. Pisano o losach najwybitniejszych polskich poetów i pisarzy przez pryzmat ich twórczości: o Adamie Mickiewiczu ${ }^{772}$, Janie Kasprowiczu ${ }^{773}$, Adamie Asnyku ${ }^{774}$, Bolesławie Prusie ${ }^{775}$, Krzysztofie Kamilu Baczyńskim ${ }^{776}$, Zofii Kossak-Szczuckiej ${ }^{777}$, Józefie Weyssenhoffie ${ }^{778}$. Opublikowano nieznane listy Cypriana Kamila Norwida ${ }^{779}$. Sporadycznie przeprowadzano wywiady z pisarzami ${ }^{780}$. Jak przystało na pismo katolickie, zwracano uwagę na konwersje niektórych twórców, np. Bolesława Prusa ${ }^{781}$ i Paula Verlaine'a ${ }^{782}$. Od początku na łamach pisma gościły fragmenty pamiętników i powieści ${ }^{783}$ oraz opowiadania ${ }^{784}$.

${ }^{767}$ W. Natanson, Twórczy niepokój, „TW” 1946 nr 21 s. 4; C. Jastrzębiec-Kozłowski, Moje trzy grosze, tamże, nr $36 \mathrm{~s}$. 6; J. Braun, Twórczość irracjonalna czy twórczość rozumna?, tamże, nr 50 s. 4-5; H. Kamieniecka, Uczucie metafizyczne i twórczość, „TW”1947 nr 18 s. 4.

768 J.M. Święcicki, O unarodowienie literatury, „TW” $1946 \mathrm{nr} 18$ s. 1-2.

${ }^{769}$ K.Z. Skierski, Budżet pisarza i płynaca stąd groźba, „TW” $1947 \mathrm{nr} 8$ s. 2; W.Z., W sprawie budżetu pisarza, tamże, nr 15 s. 7.

${ }^{770}$ J. Braun, Mesjanizm a kryzys ideowy Europy, „TW” 1948 nr 22 s. 2-3.

${ }^{771}$ H. Kamieniecka, Wspótczesna katolicka literatura francuska a angielska, „TW” $1947 \mathrm{nr} 12$ s. 8; kt., Odczyt J. Zawieyskiego, „TW” 1948 nr 11 s. 6.

${ }^{772}$ W. Lutosławski, Mickiewicz w Kalifornii, „TW” 1948 nr 4 s. 6-7.

${ }^{773}$ P. Grzegorczyk, W 20-lece śmierci J. Kasprowicza (Nieznany poemat twórcy Księgi Ubogich), „TW” 1946 nr 34 s. 6; także polemika J. Pilecki, „Czy śpiącego można obudzić grzecznie?”, „TW”1948 nr 24 s. 5.

774 J. Budkowska, Spóźniony romantyk, „TW” 1947 nr 49 s. 4-5.

775 A. Górski, Bolesław Prus w poszukiwaniu prawdy życia, „TW” 1948 nr 35 s. 4.

${ }^{776}$ B. Ostromęcki, Krzysztof Baczyński, „TW” 1947 nr 50 s. 4.

${ }^{777}$ I. Pannenkowa, Prawda o pobycie Kossak-Szczuckiej w Oświęcimiu (I), „TW” 1948 nr 1 s. 5; taż, Prawda o pobycie Kossak-Szczuckiej w Oświęcimiu (II), tamże, nr 2 s. 3.

${ }^{778}$ L. Czerniewski, Przypomnienie J. Weyssenhoffa, „TW” 1946 nr 35 s. 8.

${ }^{779}$ C. Norwid, Jubileatyzm, „TW” 1947 nr 12 s. 7.

${ }^{780}$ M. Winowska, U Daniel-Rops'a, „TW” 1948 nr 31/32 s. 8-9.

${ }^{781}$ Z. Szweykowski, Nawrócenie Bolesława Prusa, „TW” 1946 nr 27 s. 1-2; I. Porębska, Na marginesie artykułu Z. Szweykowskiego „Z przeżyć religijnych Bolesława Prusa”, tamże, nr 35 s. 3.

${ }^{782}$ Z. Rabska, Nawrócenie poety, „TW” 1946 nr 13 s. 5.

${ }^{783}$ Np. Z. Wasilewski, W poszukiwaniu drogi [fragmenty z pamiętnika Życiorys (1865-1939)], „TW” 1945 nr 3 s. 7; A. Grzymała-Siedlecki, Fra Giuseppe [fragment z tomu poświęconego pamięci zmarłych w czasie wojny pisarzy polskich Wdeptani w ziemię], tamże, nr 5 s. 7; J. Dobraczyński, W rozwalonym domu, „TW"1946 nr 2 s. 6-7.

${ }^{784}$ J. Szczepkowski, Wagony śmierci, „TW” 1945 nr 6 s. 3. 
Obecna była również szersza tematyka kulturalna ${ }^{785}$. Czytelnicy mogli poznać różne sprawy dotyczące teatru ${ }^{786}$. Sporo pisano o Teatrze Rapsodycznym ${ }^{787}$. Podejmowano ponadto zagadnienia odrodzenia teatru, jego repertuaru i współczesnych mu problemów ${ }^{788}$. Recenzje teatralne pisał m.in. Jerzy Kierst ${ }^{789}$. W części kulturalnej nie zabrakło tematu sztuki ${ }^{790}$ i muzyki ${ }^{791}$. Przybliżano życiorysy kompozytorów $^{792}$ i malarzy, np. portrecisty Stanisława Niesiołowskiego ${ }^{793}$. Często na łamach tygodnika pojawiały się zagadnienia książki. Recenzowano książkowe nowości wydawnicze, jak też kolejne wznowienia w obszerniejszych artykułach. Krótkie recenzje zamieszczano w specjalnej rubryce zatytułowanej Nowe książki czy Nowa książka.

Od początku istnienia tygodnika kreślono sylwetki m.in. ludowców Wincentego Witosa, społeczników, generałów - Władysława Sikorskiego, poli-

${ }^{785}$ M. Poradowski, Cywilizacja a kultura, „TW” 1947 nr 26 s. 5; H. Kamieniecka, Życie kulturalne w Szwecji, tamże, nr 28 s. 6; JK., Uspołecznienie kultury, tamże, nr 39 s. 8; S. Zwilkoński, Wieś i kultura, „TW”1948 nr 16 s. 2; K. Szwarcenberg-Czerny, W obronie cywilizacji, tamże, nr 36 s. 1.

${ }^{786}$ T. Kudliński, Odrodzenie teatru (II), „TW” 1947 nr 50 s. 6-7; tenże, Teatralne przewidywania (I), „TW”1948 nr 6 s. 7; tenże, Teatralne przewidywania (II), tamże, nr 10 s. 8; B. Borkowski, $O$ teatr religijny $w$ Polsce, tamże, nr 15 s. 8; I. Pannenkowa, Teatr po wojnie, tamże, nr 23 s. 5; S. Krzywoszewski, Uwagi o sprawach teatru, tamże, nr 35 s. 8.

${ }^{787}$ T. Kudliński, Teatr Rapsodyczny, „TW”1946 nr 34 s. 4; J. Kierst, Pięciolecie Teatru Rapsodycznego, tamże, nr 47 s. 5; J. Braun, Norwid w Teatrze Rapsodycznym, „TW”1948 nr 5 s. 3; tenże, Arcydzieło Conrada na scenie, nr 30 s. 4.

${ }^{788}$ W. Borowy, O przektady Szekspira dla teatru, „TW” $1946 \mathrm{nr} 4$ s. 6; W. Tarnawski, Teatry angielskie, tamże, nr 14 s. 5-6; J. Zagórski, Listy teatralne, tamże, nr 16 s. 14; J. Braun, Eksperyment czy teatr społeczny?, „TW”1947 nr 8 s. 7-8; W.B., Czy śmierć teatru?, tamże, $\mathrm{nr} 21$ s. 4; M. Kotlarczyk, O polska inscenizację Szekspira, tamże, nr 38 s. 2-3; M. Kotlarczyk, Walka o nowy teatr, tamże, nr 41 s. 5; J.K., Repertuar Teatru Polskiego na sezon 1947-48, tamże, nr 43 s. 8; T. Kudliński, Odrodzenie teatru, tamże, nr 46 s. 8; J. Braun, Teatr stającej się historii, tamże, nr 48 s. $12,5$.

${ }^{789}$ J. Kierst, Dwie premiery, „TW” 1947 nr 24 s. 7; tenże, Wilki i owce, tamże, nr 25 s. 7; tenże, Wolsztyńskim teatrze, tamże, $\mathrm{nr} 44 \mathrm{~s} .7$.

${ }^{790}$ B. Ostromęcki, Sztuka i etyka, „TW” 1946 nr 48 s. 5; F. Walczowski, Społeczna rola sztuki, „TW”1947 nr 23 s. 5; I. Łoś, O sztuce religijnej, tamże, s. 6; K. Homolacs, Abstrakcjonizm i naturalizm w sztuce, „TW”1948 nr 8 s. 4, 7; A. Bunsch, O sztuce ludowej, tamże, nr 13 s. 8; J.A. Zaremba, Ceramika świętokrzyska, „tamże, nr 19 s. 6-7; M. Winowska, Religia i sztuka, tamże, nr 25 s. 3; J. Malik, Sztuka czynnikiem wychowawczym, tamże, nr 27 s. 5; F. Smentek, Rozważania o sztuce, tamże, nr 28 s. 4-5; M. Kuleszyna, Sztuka wobec uczucia i intelektu, tamże, nr 34 s. 2; F. Smanteka, Rozważania o sztuce, tamże, nr 35 s. 5.

${ }^{791}$ M. Grzegorczyk, Nasz dlug wobec Chopina, „TW” 1945 nr 1 s. 5; P. Rytel, Opera w Polsce dzisiejszej, „TW”1946 nr 12 s. 7; S. Podhorska-Okołów, Chopin w Dusznikach, tamże, nr 40 s. 4; P. Rytel, Muzyka polska a społeczeństwo, tamże, nr $41 \mathrm{~s}$. 7; tenże, Drogi muzyki właściwe a błędne, tamże, nr 49 s. 7; W. Bacewiczówna, Sprawa Filharmonii Narodowej, „TW”1947 nr 6 s. 6-7.

792 P. Rydel, Feliks Nowowiejski, „TW” 1946 nr 17 s. 6; Z. Kaczyński, Ignacy Paderewski, „TW”1948 nr 30 s. 2.

${ }^{793}$ Z. Lasocka, Stanistaw Niesiołowski, „TW” 1948 nr 9 s. 4. 
tyków - Romana Dmowskiego, dostojników Kościoła - metropolity krakowskiego księcia Adama Sapiehy, zasłużonych kapłanów - ks. Jana Ciemniewskiego, ks. Władysława Korniłowicza, ks. Jana Szmigielskiego, ks. Konstantego Michalskiego, duchowych przywódców jak Mahatmy Gandhiego, historyków, redaktorów pism - Stanisława Piaseckiego ${ }^{794}$ i innych. Czczono rocznice świętych, np. 950-lecie męczeńskiej śmierci św. Wojciecha ${ }^{795}$ i błogosławionych - Piotra Romancona (brata Benilda) ${ }^{796}$. Na ostatniej stronie zazwyczaj zamieszczano nekrologi i informacje o zgonach znanych osobistości ze świata polityki, kultury, filozofii, literatury ${ }^{797}$.

W piśmie rzadziej obecna była problematyka oświatowa i szkolna ${ }^{798}$. Zagadnienia młodzieżowe żywo dyskutowano po wprowadzeniu Kolumny mło$d y c h^{799}$. Kwestie wychowawcze dotknięto w cyklu artykułów w 1. 1947-1948 pod hasłem uczciwości $\mathrm{w}$ szkole ${ }^{800}$. Nie pominięto również nauczania na poziomie wyższym $^{801}$.

${ }^{794}$ M.N., Wincenty Witos - symbol polskiego ludu, „TW” 1945 nr 1 s. 2; Z. Kaczyński, Generat Sikorski, tamże, nr 4 s. 2-3; B. Szczepkowski, To i owo o Romanie Dmowskim, tamże, nr 5 s. 3; A. Vetulani, Ksiąze Metropolita Krakowski, „TW” 1946 nr 7 s. 1-3; A.J. Mikulski, Edward Dembowski w rzeczywistości i legendzie, tamże, nr 18 s. 5-6; W.Z., Pierwszy redaktor „,Walki”, tamże, nr 23 s. 6; W. Konopczyński, Wspomnienie o Józefie Feldmanie, tamże, nr 28 s. 4; H. Dernałowicz, Ze wspomnień o ks. Władysławie Korniłowiczu, „TW”1947 nr 15 s. 3; tenże, Ze wspomnień o ks. Władysławie Korniłowiczu, tamże; Z.K., Zgon ś.p. księdza J. Szmigielskiego, tamże, nr 44 s. 2; M. Winowska, Ksiądz Konstanty Michalski, tamże, nr 50 s. 3; O. Budrewicz, Mahatma Gandhi, „TW”1948 nr 7 s. 6; J. Braun, Apostoł odrodzenia z ducha, tamże, nr 11 s. 5; Z. Kaczyński, W piata rocznicę, tamże, nr 27 s. 3.

${ }^{795}$ A. Hlond, Prymas Polski do Polaków, „TW” 1947 nr 17 s. 1-2; W.J. Grabski, Święty Wojciech - Patron Polski dzisiejszej, tamże, s. 4-5; J. Umiński, Na 950-lecie śmierci św. Wojciecha, tamże, s. 5.

${ }^{796}$ B.S., Beatyfikacja Nauczyciela, „TW”1948 nr 16 s. 5.

${ }^{797}$ Np. pierwszy obszerniejszy nekrolog to: J.D., Zmart Gałczyński, „TW” 1945 nr 6 s. 8, który potem sprostowano dzięki informacji od żony poety, J.D., Gałczyński żyje, „TW”1946 nr 3 s. 6; T. Radkowski, Henryk Bergson, tamże, s. 3-4; Zgon wielkiego artysty, „TW”1947 nr 20 s. 8 [o zgonie Juliusza Osterwy]; w rubryce Przeglad kulturalny, „TW” $1948 \mathrm{nr} 1$ s. 10 [informacja o zgonie pisarza francuskiego Tristana Bernarda]; Życie katolickie. Georges Bernanos zmart w Paryżu, tamże nr 31/32.

${ }^{798}$ Z. Kaczyński, Oświata i nauka na obczyźnie, „TW” 1945 nr 5 s. 4; B. Niwa, Upowszechnienie oświaty, „TW”1948 nr 24 s. 2-3; F. Koneczny, Szkoła państwowa, tamże, nr 33 s. 3; B. Tumala, Z zagadnień szkolnictwa, tamże, nr 36 s. 8.

${ }^{799}$ Np. D. Morawski, Młodzież katolicka wobec rzeczywistości polskiej, „TW” 1947 nr 3 s. 6.

${ }^{800}$ J. Braun, Problem wychowania, „TW” 1947 nr 24 s. 1-2; J. Budkowa, Sprawa uczciwości w szkole, tamże, nr 45 s. 4; tamże, nr 50 s. 5; W. Rybczyński, Sprawa uczciwości w szkole, tamże, nr 51 s. 8; W. Achremowiczowa, Jeszcze o uczciwości w szkole, „TW”1948 nr 5 s. 2-3; A.P., Szukanie lepszych metod uczenia, tamże, nr 6 s. 5.

${ }^{801}$ J. Braun, Uniwersytet pod obstrzatem, „TW” 1947 nr 25 s. 1-2; B. Neski, Społeczna rola nauki, tamże, s. 6; I. Czuma, Warunki pracy K.U.L.' 'u, tamże, nr 26 s. 4. 
Poruszano też wiele innych zagadnień jak np. dotyczących moralności ${ }^{802}$, alkoholizmu ${ }^{803}$, gospodarki ${ }^{804}$, demografii ${ }^{805}$, prasy ${ }^{806}$. Pomiędzy artykuły wplatano myśli i kilka wierszy, przeważnie Wojciecha Bąka, Kazimiery Iłłakowiczówny, Jerzego Kiersta i Aleksandra Rymkiewicza.

Łamy „Tygodnika Warszawskiego” stanowią bogate źródło do badań prasoznawczych pierwszych lat po wojnie, o czym świadczyć mogą liczne opracowania. Pomimo tego, że pismu nie pozwolono istnieć dłużej niż kilka lat, zaznaczyło ono swoją mocną pozycję wśród katolickich periodyków społeczno-kulturalnych. Klarowność oraz poziom publicystyczny wypowiedzi i polemik świadczyły o wysokich walorach tygodnika. Redakcja pisma utożsamiała się głęboko z tradycjami narodowymi i wartościami patriotycznymi.

\section{Wygląd tygodnika}

Szata graficzna „Tygodnika Warszawskiego” była nader skromna. Na pierwszej stronie znajdował się pogrubionym drukiem nagłówek: tytuł z podtytułem, miejscem, datą wydania, numerem rocznika, numerem kolejnego zeszytu i ceną. Tekst drukowano w czterech szpaltach, wytłuszczając ważniejsze tytuły i podkreślając nazwisko autora pisane kursywą. Podtytuł od numeru 10 z 1946 r. zaczęto drukować wersalikami. Później (od nru 36 z 1946 r.) nad tytułem periodyku redakcja zaczęła zamieszczać nazwiska autorów wypowiadających się w danym wydaniu.

Ubogi pod względem edytorskim tygodnik starano się wzbogacić rysunkami w edycjach świątecznych ${ }^{807}$ i specjalnych oraz poprzez urozmaicenie czcionki drukarskiej (za czasów nowej redakcji). Numer specjalny - setny z kolei wzbogacony został na pierwszej stronie reprodukcją witrażu Adama Bunscha pt. Przejęcie sztandaru (na dalszych stronach zaprezentowano witraże Bunscha zatytułowane Św. Barbara i Zwiastowanie) oraz czterema rysunkami Jezierskiego ${ }^{808}$ przedstawiającymi warszawskie kościoły.

802 J. Braun, Kryzys moralny Europy, „TW” 1947 nr 12 s. 2-3.

${ }^{803}$ S. Sprusiński, Społeczne przyczyny alkoholizmu, „TW” 1948 nr 10 s. 3; m.s., tódź walczy $z$ alkoholizmem, tamże, s. 12.

${ }^{804} \mathrm{~Np}$. A. Grabowski, Ekonomia zapomniana, „TW” $1945 \mathrm{nr} 4$ s. 5-6; tenże, Ewolucje gospodarcze świata, „TW” $1946 \mathrm{nr} 2$ s. 4; tenże, O poznawalność ekonomiczna, tamże, $\mathrm{nr} 17$ s. 7; K. Studentowicz, Cele gospodarki planowej, „TW” 1948 nr 11 s. 3.

${ }^{805}$ J. Jakóbkiewicz, Potencjat demograficzny Europy, „TW” 1948 nr 14 s. 3.

${ }^{806} \mathrm{~Np}$. Optymizm prasy amerykańskiej, „TW” $1946 \mathrm{nr} 50$ s. 1; J. Braun, Oświadczenie w sprawie „Dziś i Jutro”, „TW” 1947 nr 38 s. 3; H.K., „Flammes”. Francuskie czasopismo obozowe, tamże, s. 8; Prasa polska na Śląsku, „TW” 1948 nr 11 s. 6.

${ }^{807}$ Np. „TW” 1946 nr 16; tamże, nr 50.

808 ,TW” $1947 \mathrm{nr} 42$. 


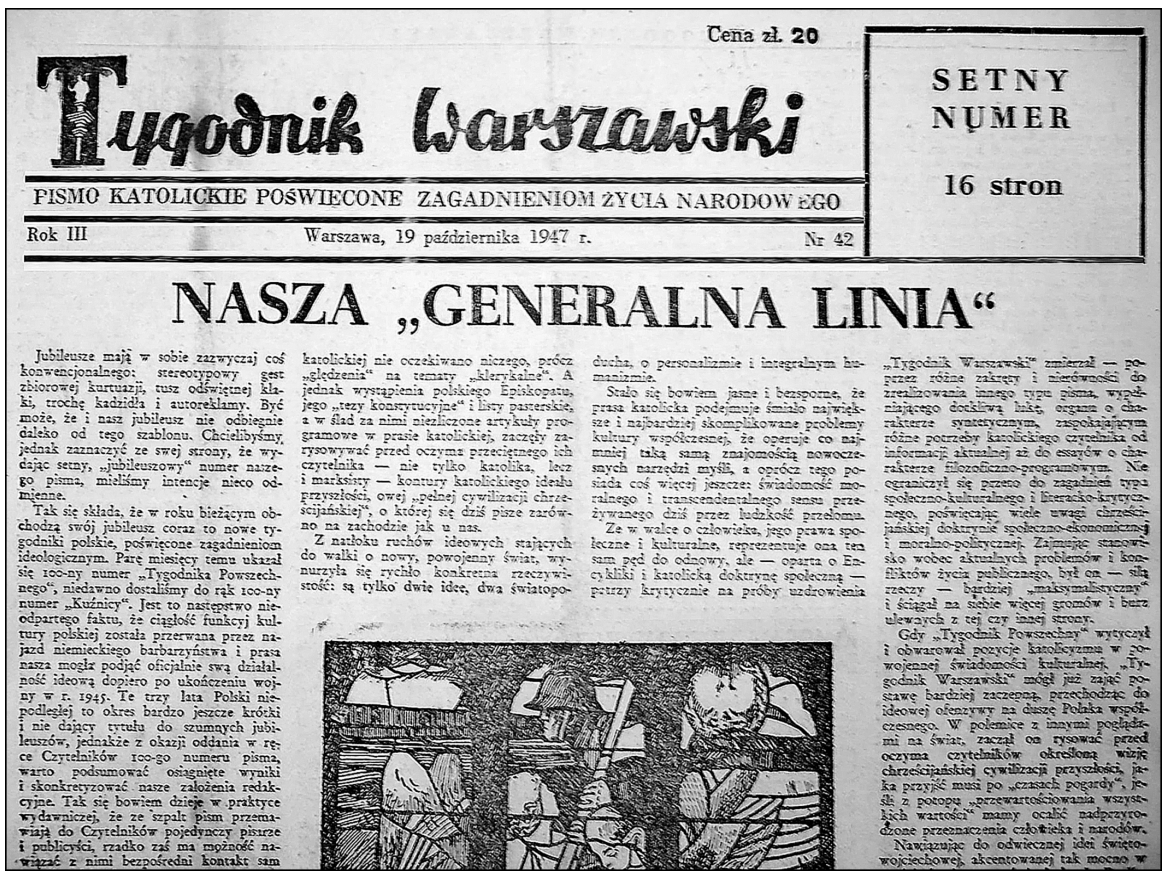

Źródło: Ze zbiorów BUŁ.

Pod koniec 1947 r. redakcja zaczęła wprowadzać elementy graficzne przy tytułach działów i w nagłówkach, np. w kolumnach Naokoło świata i Życie katolickie.

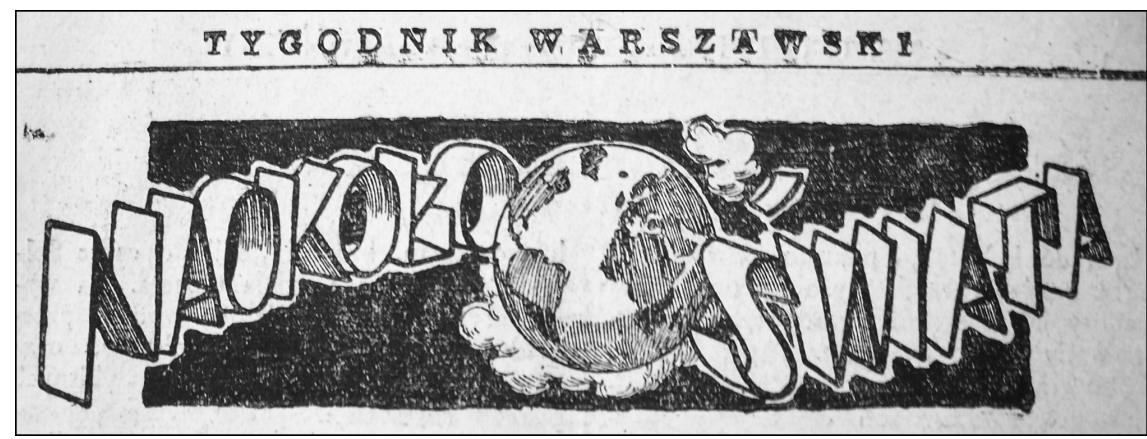

Źródło: Ze zbiorów BUŁ. 


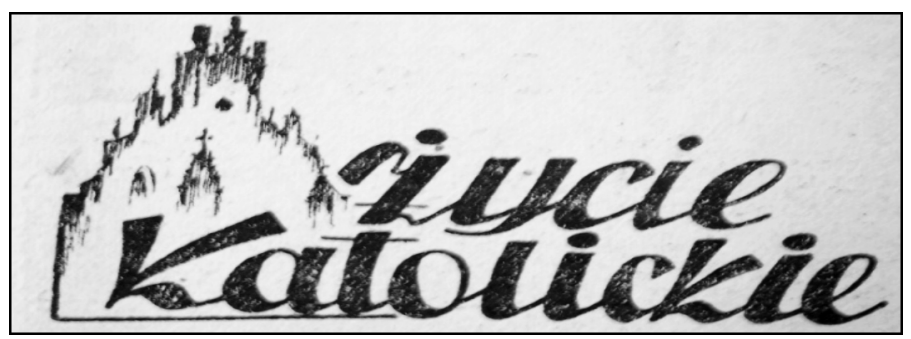

Źródło: Ze zbiorów BUŁ.

Podobnie potraktowano niektóre tytuły artykułów, przykładowo zapytano $O$ czym pisze prasa katolicka? na tle pięciu tytułów prasowych: „Tygodnika Powszechnego”, „Głosu Katolickiego”, „Niedzieli”, „Tygodnika Katolickiego” i „Gościa Niedzielnego" ${ }^{809}$.

\section{Il. 14. „TW” 1947 nr 45 s. 7}

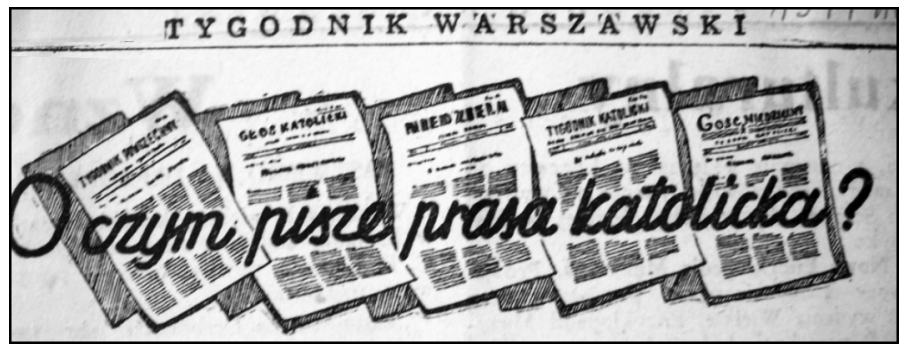

Źr ó dło: Ze zbiorów BUŁ.

Ozdobny rysunek zamieszczono w numerze świątecznym z 1947 r.

\section{Il. 15. „TW” 1947 nr 51 s. 2}

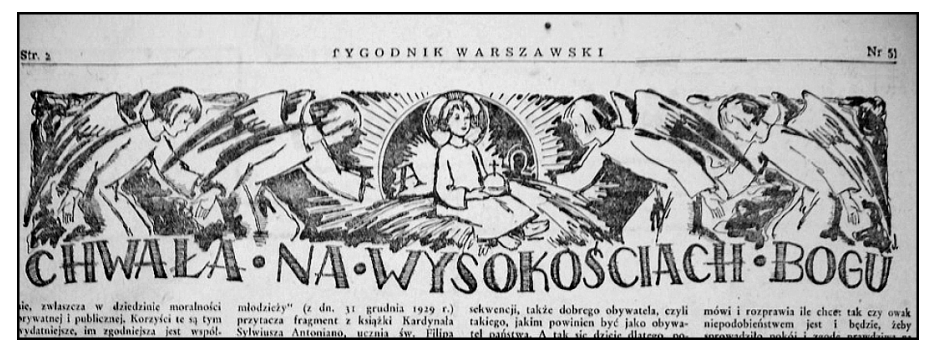

Źr ódło: Ze zbiorów BUŁ.

${ }^{809}$ S. Krokowski, O czym pisze prasa katolicka?, „TW” 1947 nr 45 s. 7. 
Na początku istnienia „Tygodnika Warszawskiego” jedynym urozmaiceniem szaty graficznej były reklamy z rysunkami. Z czasem elementy ozdobne pojawiły się przy niektórych wypowiedziach w 1948 r. ${ }^{810}$ Pismo, choć skromne w wyglądzie, było bardzo atrakcyjne pod względem zawartości.

Redakcja warszawskiego organu prasowego była w większym stopniu obiektem ataku ze strony władzy komunistycznej niż pozostałe środowiska katolickich pism społeczno-kulturalnych. Powodem zapewne był fakt, że tworzyli ją ludzie o poglądach nawiązujących do tradycji chrześcijańskiej demokracji w okresie dwudziestolecia międzywojennego. Pod zarzutem działalności antypaństwowej aresztowano w 1947 r. ks. Edwarda Grzechnika. Zatrzymania członków redakcji nasiliły się w drugiej połowie 1948 r. Wśród aresztowanych byli: Kazimierz Studentowicz, Józef Kwasiborski i Konstanty Turowski. Redaktor naczelny ks. Zygmunt Kaczyński kształtujący w dużej mierze społeczny, polemiczny i opozycyjny profil tygodnika został uwięziony i po kilkuletnich przesłuchaniach zmarł w więzieniu w 1953 r. ${ }^{811}$ Jerzego Brauna pomówiono o kolaborację z Niemcami i skazano na dożywocie ${ }^{812}$. Pismo za wyrażanie koncepcji „maksymalizmu społecznego", zdecydowaną postawę i jawne głoszenie nauki społecznej Kościoła podlegało ostrej cenzurze, a w końcu zostało zamknięte. Dzięki nieustępliwej postawie redagujących periodyk zajął ważne miejsce w powojennej prasie. Jego losy zaświadczyły o totalitarnym stosunku komunistów do wszelkich przejawów innego światopoglądu i programu niż marksistowski. „Tygodnik Warszawski” przez zaledwie kilka lat stał się ostoją wolnej myśli, a na jego łamach próbowano propagować model kultury opartej na wartościach chrześcijańskich.

\subsection{4. ,Tygodnik Katolicki” (1946-1953)}

Utworzona w 1945 r. diecezja gorzowska objęła Ziemię Lubuską, Pomorze Zachodnie ze Szczecinem, Kołobrzegiem, prałaturę pilską i Zieloną Górę. Do jesieni tegoż roku posługę duszpasterską w Gorzowie Wielkopolskim sprawowano tylko w jednym kościele. Tworzenie struktur w diecezji powierzono administratorowi apostolskiemu ks. Edmundowi Nowickiemu. Pomoc uzyskano od zakonów i napływającego z Kresów Wschodnich duchowieństwa. Dekretem Kurii Administratora Apostolskiego 1 III 1946 r. została prawnie powołana

\footnotetext{
${ }^{810}$ Np. A. Bunsch, Szklane obrazy, „TW” 1948 nr 8 s. 4.

${ }^{811}$ Zob. Instytut Pamięci Narodowej (IPN), Akta kontrolno-śledcze dotyczące ks. Zygmunta Kaczyńskiego, sygn. BU 0259/568.

${ }^{812}$ Wyszedł $\mathrm{z}$ więzienia mocno schorowany w $1956 \mathrm{r}$.
} 
parafia Chrystusa Króla w Gorzowie. W jej obręb wcielono teren miasta leżący na lewym brzegu Warty. Proboszczem parafii od 9 III 1946 r. został duchowny ze Zgromadzenia Misjonarzy Oblatów Maryi Niepokalanej o. Kazimierz Łabiński. Pomocnikiem w charakterze wikariusza i prefekta szkół miał być również oblat o. Józef Adamek ${ }^{813}$.

Pierwszy proboszcz rozpoczął organizowanie powojennego życia religijnego, społecznego i kulturalnego wśród repatriantów zasiedlających miasto ${ }^{814}$, co wcale nie było łatwe wśród „zewsząd napływającej ludności” ${ }^{15}$. Po pierwszych naprawach kościoła o. K. Łabiński przystąpił do zintensyfikowania życia parafialnego. Posiadając wrodzoną otwartość na ludzi, dar jednoczenia dzieci i młodzieży oraz niesamowite poczucie humoru ${ }^{816}$, rozpoczął szeroką działalność społeczną. Zorganizował Krucjatę Eucharystyczną, Kółko Sodalicji Mariańskiej męskiej i żeńskiej (liczące około 220 osób), Apostolstwo Modlitwy, Kółko Różańcowe dla matek, ojców, panien i młodzieży. Dzieci jednoczył śpiew w chórze dziecięcym podczas sprawowania mszy św. oraz teatrzyk, w którym wystawiano bajki, jasełka oraz przygotowywano akademie patriotyczne. Ponadto staraniem proboszcza powstały trzy przedszkola w Gorzowie na Zawarciu, w których sprawowano opiekę nad grupą liczącą 180 dzieci. Dnia 25 VI 1946 r. rozpoczęło działalność Katolickie Stowarzyszenie Młodzieży (KSM), które po pół roku zrzeszyło 223 osoby. Pracowało ono w sześciu sekcjach i posiadało własną bibliotekę. Dla zainteresowanych o. K. Łabiński organizował wycieczki niedzielne i dłuższe kilkudniowe wyjazdy w czasie wakacji (w ciągu 14 lat pobytu w Gorzowie zorganizował 152 wycieczki i 18 obozów młodzieżowych) oraz pielgrzymki do sanktuariów maryjnych. Istniały też przy parafii Chrystusa Króla kursy zawodowe, m.in. pisania na maszynie i prowadzenia korespondencji. Pod koniec 1948 r., w związku z pogorszeniem się relacji między państwem i Kościołem, władze komunistyczne przystąpiły do likwidacji KSM. Ostatnie spotkanie stowarzyszenia w Gorzowie odbyło się 5 XII 1948 r. Zlikwidowano je decyzją prezydenta

${ }^{813}$ R. Sierchula, Myśl jest bronia, , Nasz Dziennik” 2008 nr 258. Dostępny w World Wide Web http://www.naszdziennik.pl/print.php?dat=20081025\&id=my41.txt\&typ=m [dostęp 26.08.2010].

${ }^{814}$ Wielkopolskie Towarzystwo Genealogiczne GNIAZDO. Forum dyskusyjne WTG GNIAZDO. Dostępny w World Wide Web http://www.wtg-gniazdo.org/forum/viewtopic. php?f=2\&t=1666 [dostęp 26.08. 2010].

${ }^{815} \mathrm{Na}$ tereny opuszczone przez ludność niemiecką przybywały transporty z ludnością polską usuwaną z ziem, które na mocy umowy poczdamskiej przejął Związek Radziecki. Oprócz pracy charytatywnej konieczne było budowanie jedności duchowej i narodowej wśród tak różnorodnych tradycji i zwyczajów, z jakimi przybywali na te tereny Polacy. Źródło: P. Socha, Sylwetki administratorów apostolskich i biskupów Diecezji Zielonogórsko-Gorzowskiej, „Studia Zielonogórskie” 2008 t. 14 s. $12,16$.

816 Taki pozostał we wspomnieniach słuchacza z Niższego Seminarium Duchownego Ojców Oblatów w Markowicach - Krzysztofa Napory. Źródło: informacja uzyskana w trakcie rozmowy z K. Naporą w dniu 18.07.2010. 
miasta 29 I 1949 r., a władze miejskie przejęły jego majątek ${ }^{817}$. Jeszcze w 1945 r. starania administratora apostolskiego ks. Edmunda Nowickiego zmierzały do powołania w Gorzowie pisma katolickiego jako czynnika jednoczącego ludność. Założycielem „Tygodnika Katolickiego” i zarazem jego redaktorem naczelnym przez cały okres wydawniczy w latach 1946-1953 był prężnie działający oblat o. Kazimierz Łabiński. Periodyk o charakterze regionalnym, pomimo że był skierowany do „polskiego ludu” $\$ 18$ zachodniej Polski, objął swym zasięgiem szersze obszary. Krótko odnotowany został w Bibliografii katolickich czasopism religijnych $w$ Polsce 1945-1989 $9^{819}$. Nie znalazł ponadto szerszego zainteresowania wśród prasoznawców ${ }^{820}$.

\section{Redakcja i współpracownicy „Tygodnika Katolickiego”}

Przeglądając zawartość „Tygodnika Katolickiego” odbiorca może odnieść wrażenie dużej pieczy redaktora naczelnego nad całością druku. Jednocześnie może zdziwić fakt, że brakuje jego nazwiska pod artykułami. Wynikało to z tego, że o. K. Łabiński posługiwał się na łamach pisma pseudonimami, m.in. Świetliński, K. Świetliński, Nejczyk, Grzegorz i Szelest. Łącznie spod jego pióra wyszło około 400 artykułów ${ }^{821}$. Dzięki charyzmatycznej osobowości i darowi zjednywania sobie ludzi udało się redaktorowi zaprosić do grona piszących na łamach periodyku dobrze wykształconych współpracowników i znaczące osobowości. W większości były to osoby posiadające tytuły naukowe.

Do najbliższych współpracowników redakcji należeli księża: J. Klim, Józef Anczarski, N. Mędlewski oraz oblaci I. Pluszczyk, J. Nawarat, J. Mańkowski, H. Paruzel. Dodatek do pisma zatytułowany „Mały Tygodnik dla Dzieci” redagował ks. Maciej Szałagan. Problematykę wiary przybliżali również kapłani: K. Łabiński, B. Dubaniowski, Henryk Weryński, Z. Krauze, J. Rzeszewski, Józef Anczarski, Franciszek Musiel. W cyklu Konwertyci XX wieku ks. Andrzej Bardecki przedstawił nawrócenia sławnych osób. Zagadnienia religijne były także w kręgu zainteresowań osób świeckich: Zoriana Krużyńskiego, Anieli Jareckiej, Mariana Jamrozika, Jana Archity, Stanisława Julińskiego, Kazimierza

${ }^{817}$ R. Sierchula, Myśl jest bronia...

${ }^{818}$ K.Z., Na dwudziestopięciolecie kapłaństwa, „TK” 1949 nr 11 s. 97.

${ }^{819}$ D. Wielgat, Bibliografia katolickich czasopism ..., s. 90-91.

${ }^{820}$ „Tygodnik Katolicki” (1946-1953). W: K. Kunicka, B.J. Kunicki, H. Szczepański, Prasa gorzowska w latach 1945-1985, Gorzów 1987, s. 73-79; Z. Pawlak, Umarty nadal mówi, „Przewodnik Katolicki” 1976 nr 9 s. 6; L. Wilczyński, ,, Tygodnik Katolicki” na tle poczatków prasy diecezjalnej w Gorzowie i jego akcenty wielkopolskie (1945-1950), „Roczniki Teologiczne” 2001 nr 4 s. 231-240.

${ }^{821}$ R. Sierchula, Myśl jest broniq... 
Jedlińskiego (zapoznawał z bieżącymi sprawami Kościoła w Polsce) i Tadeusza Halucha. W latach 1947-1948 stale na stronie drugiej pisma gościły artykuły religijne N. Mędlewskiego. Z. Grzybowski prowadził rozważania ewangeliczne, natomiast P. Grabowska przypomniała tradycje adwentu w Polsce. Wśród biskupów piszących na łamach periodyku byli Czesław Kaczmarek i Ignacy Świrski.

Redaktor pisma wykorzystywał $\mathrm{w}$ artykułach nt. wychowania młodzieży i przygotowania do małżeństwa przedwojenne thumaczenia na język polski tekstów ks. Tihaméra Tótha. Problematykę młodzieżową w specjalnie przeznaczonym do tego dziale Sprawy młodzieżowe, jak też na pierwszych stronach tygodnika, omawiał początkowo Jan Pałka ${ }^{822}$, natomiast w latach 1948-1949 Tadeusz Haluch i Tadeusz Pomian. O wychowaniu pisali ponadto Stanisław Grabowski i Eugeniusz Paukszta, którzy ogólnie zajmowali się zagadnieniami katolickimi. Cenne porady rodzicom i wychowawcom dawała również Stefania Wesołowska, pisząc o wychowaniu katolickim.

O problemach uzależnień alkoholowych wypowiadał się zazwyczaj Kazimierz Abgarowicz. Sprawy kobiece przedstawiali natomiast Edward Serwański, Bolesław Kudelka, K. Jedliński, ks. Z. Krauze, Jan Czara. Tematy literackie bliskie były stałemu współpracownikowi pisma E. Paukszcie, prowadzącemu rubrykę Pisarze katoliccy, oraz wspomnianemu już T. Haluchowi. Wybrane sylwetki uczonych i świętych w latach 1950-1951 przedstawił Jan Ujda.

Grono dalszych współpracowników pisma było bardzo liczne. Z czasem w latach 1949-1950 pojawiły się na stronach tygodnika bardziej znane nazwiska: Pawła Jasienicy, Kazimiery Iłłakowiczówny, Marii Winowskiej (dział liturgiczny, problematyka duchowa), Antoniego Gołubiewa (nauka społeczna Kościoła). Gościli również redaktorzy innych tytułów katolickich. Przykładowo ks. Michał Rękas - redaktor naczelny "Apostolstwa Chorych” - pisał o chorych i wyjaśniał stopnie apostolstwa w przeżywania cierpienia wraz z łaską zjednoczenia z Chrystusem ${ }^{823}$. Artykuły do tygodnika nadsyłali także Zygmunt Wojciechowski, Zofia Kossak, Józef Kisielewski, Jerzy Zawieyski. Wielu autorów jednokrotnie lub kilkakrotnie wypowiadało się na łamach pisma. Należał do nich m.in. ks. Michał Sopoćko. Niektóre wypowiedzi podpisano pseudonimami trudnymi do rozszyfrowania, np. Stary gawędziarz, Uczestnik, Jan z Dobrej Woli, Sargon ${ }^{824}$. Zdarzało się również, że autora podawano na początku i na końcu artykułu. Liczne wypowiedzi podpisano tylko inicjałami lub były anonimowe.

${ }^{822}$ Św. Stanisław w życiu młodzieży, „TK” $1948 \mathrm{nr} 44$ s. 355-356.

${ }^{823}$ M. Rękas, Apostolstwo chorych, „TK” 1949 nr 3 s. 21; tenże, Niewidoczni, ale sq i mówia, tamże, $\mathrm{nr} 44$ s. 391.

${ }^{824}$ Stary gawędziarz, Bytem na wystawie, „TK” 1947 nr 43 s. 294-295; tenże, Na cmentarzu, tamże, nr 46 s. 315; Uczestnik, Uroczystości w Trzciance, s. 317; Jan z Dobrej Woli, Tylko dla kobiet, „TK” 1949 nr 10 s. 94. 
Jan Czerepacha prowadził ciekawą rubrykę zatytułowaną $W$ krzywym zwierciadle. W latach 1948-1950 czytelnicy mogli zapoznać się z opowiadaniami Teresy Przanowskiej, a w 1951 r. Pii Górskiej. Stale obecne w latach 1950-1952 były pouczające opowiadania Kazimierza Gołby, w których pisarz „konsekwentnie realizował koncepcję popularyzowania znanych postaci i faktów historycznych za pomocą prostych opowieści” ${ }^{\$ 25}$. Przedstawił też szereg sylwetek świętych i męczenników.

Różnorodną problematykę, w tym krajoznawczą, podejmowali M. Jamrozik i T. Haluch. W latach 1951-1952 znany był odbiorcom cykl krajoznawczych artykułów Tadeusza Prusa Wiśniowskiego.

Poezję w tygodniku reprezentowały najczęściej drobne wiersze Marii Dzierżyńskiej i Józefa Baranowskiego. Rzadziej zamieszczano utwory bardziej znanych poetów, jak Zygmunta Krasińskiego ${ }^{826}$, Juliana Ejsmonda ${ }^{827}$, Jerzego Lieberta $^{828}$, Karola Huberta Rostworowskiego ${ }^{829}$.

Publicystami piszącymi na łamach „Tygodnika Katolickiego” byli zatem najczęściej duchowni. Problematyka przez nich podejmowana była podobna do tej, która występowała na łamach innych czasopism społeczno-kulturalnych o profilu katolickim.

\section{Zalożenia programowe}

W pierwszym numerze „Tygodnika Katolickiego” redakcja tak określiła swoje cele: ,[...] pismo katolickie dla Ziem Odzyskanych, chciałoby odpowiedzieć na zainteresowania osiedleńców całej Polski. Wokół siebie chcemy wytworzyć jak najszczerszą atmosferę zaufania i zacieśnić między nami więzy braterstwa i przyjaźni, a z pisma stworzyć źródło prawdziwie twórczej pracy, i tym choćby w drobnej mierze przyczynić się do ulepszenia nas dla dobra Polski, wedle zasady: im więcej w nas katolicyzmu, tym więcej w nas polskości” ${ }^{830}$.

Najważniejszym założeniem członków redakcji była odbudowa moralna społeczeństwa polskiego, o czym świadczą liczne wypowiedzi w periodyku ${ }^{831}$. Pisano: „Cóż istotnie oznaczają prawa i ustroje, jeżeli ludzie nie mają i znać nie chcą zasad moralnych, bez których najlepsze instytucje i najdoskonalsze reformy albo pozostaną martwą literą, albo wręcz służyć mogą celom podłym

${ }^{825}$ Śp. Kazimierz Gołba, „TK” 1952 nr 21 s. 157.

${ }^{826}$ Z. Krasiński, Kocham Cię Chryste..., „TK” 1949 nr 14 s. 125.

${ }^{827}$ J. Ejsmond, Rozmodlony usty, ,TK” 1949 nr 36 s. 317.

${ }^{828}$ Utwory poety katolickiego Jerzego Lieberta, „TK” 1951 nr 14 s. 118.

${ }^{829}$ K.H. Roztworowski, Confiteor, „TK” 1948 nr 29 s. 213.

830 „TK” 1946 nr 1 s. 75.

${ }^{831}$ J.Ł., Z ruin i zgliszczy, „TK” 1948 nr 9 s. 59. 
i nikczemnym" ${ }^{832}$. Przemiany ustrojowe, gospodarcze i polityczne, w opinii współpracowników pisma, powinny były być poprzedzone przemianą wewnętrzną jednostki. Jeżeli bowiem zabraknie jej, to - jak twierdzono - wszelkie zmiany są złudne i ,służą jedynie $<<$ burzeniu dotychczasowych bóstw $>>$ bez stawiania $w$ ich miejsce $<<$ czegoś lepszego $>>{ }^{833}$. Wielokrotnie w wypowiedziach za gorsze od materialnych strat wojennych uznawano straty moralne. Przyszłość pokoleń widziano w szczególnej roli kobiety w małżeństwie i rodzinie $^{834}$ oraz dobrym wychowaniu. Ważną rolę w odbudowie kraju po wojnie przypisano zaś posłudze duchownych i świeckich zaangażowanych w stowarzyszeniach i organizacjach kościelnych. Podkreślano również istotną rolę, jaką odegrał Kościół w integracji Ziem Odzyskanych z resztą Polski. Duchowni i świeccy starali się bowiem ,z repatriantów, autochtonów, reemigrantów stworzyć nowy typ społeczny", trwale wrastający w przywróconą ziemięę3.

Odrodzenie moralne wraz z przemianą były możliwe jedynie na tle nauki ewangelicznej. Ukazywano znaczenie prawdy objawionej i dynamizmu chrześcijaństwa przejawiającego się w ciągłym wzroście duchowym wierzącego ${ }^{836}$. Promowano zatem na łamach tygodnika zdecydowanie katolicki światopogląd ${ }^{837}$. Charakter większości artykułów był dydaktyczny i służył wychowaniu społeczeństwa ${ }^{838}$.

Pismo uzyskało błogosławieństwo administratora apostolskiego diecezji gorzowskiej ks. Edmunda Nowickiego, który w dużej mierze przysłużył się do jego powstania ${ }^{839}$. Z okazji wydania setnego numeru „Tygodnika Katolickiego” wydrukowano słowa poparcia: „W powszechnym wysiłku narodu około odbudowy polskiego życia na zachodnich kresach wierną służbą zaznaczył się $<<$ Tygodnik Katolicki >>. Krzepi i zagrzewa, jednoczy i przyświeca, by mocno stanęła tu Polska na trwałym fundamencie Bożego prawa oparta. Niechaj więc trwa w swoim posłannictwie, niechaj szermierzy dalej i przewodzi ku wielkiej przyszłości Ojczyzny i szczęścia polskiego ludu"s40. W taki sposób skomentował też w innym miejscu ks. E. Nowicki pracę redakcji: „Garstka kapłanów na rozległą tę krainę mimo ich wzruszających ofiar zdrowia i życia, w części niezdolna jest zaspokoić łaknących ręki kapłańskiej serc polskich. Z diakońską przeto pomocą spieszy

${ }^{832}$ Tamże.

833 Tamże.

${ }^{834}$ J. Drozd, Kobieta a moralne uzdrowienie świata, „TK” $1948 \mathrm{nr} 45$ s. 365-366.

${ }^{835}$ T. Haluch, W obliczu nowej rzeczywistości, „TK” $1948 \mathrm{nr} 46$ s. 375-376.

${ }^{836}$ (J.Drz.), Realizm Chrystusa, „TK” 1949 nr 3 s. 19-20.

${ }^{837}$ M. Świetliński, My a nasz katolicki światopoglad, „TK” 1949 nr 20 s. 185-186.

${ }^{838}$ Np. J. Woroniecki, Doniostość wychowawcza liturgii eucharystycznej, „TK” $1949 \mathrm{nr} 23$ s. $213-214$.

${ }^{839}$ K.Z., Na dwudziestopięciolecie kaptaństwa, „TK” 1949 nr 11 s. 97; P. Socha, Sylwetki administratorów apostolskich i biskupów Diecezji Zielonogórsko-Gorzowskiej, „Studia Zielonogórskie” 2008 t. 14 s. 14.

${ }^{840}$ Błogosławieństwo arcypasterskie na setny numer ,,Tygodnika Katolickiego”, „TK” 1948 nr 19 s. 124. 
$<<$ Tygodnik Katolicki >> jako apostoł Bożej myśli i Bożej prawdy. Znojną wędrówką i twardą pionierką przytłoczone serca rozjaśnić pociechą Chrystusowego poselstwa i porwać wzwyż ku budowie świetlanej przyszłości - to jego powołanie" ${ }^{841}$. Biskup Paweł Socha tak pisał o inicjatywie powołania tytułu prasowego przez ks. E. Nowickiego: „Pragnął dać wiernym dobrze wydawany tygodnik, dzięki czemu wierni mogliby przeżywać razem z Kościołem i narodem swoje problemy duchowe, społeczne, religijne i kulturalne" ${ }^{442}$.

Pismo uzyskało również aprobatę księdza arcybiskupa Walentego Dymka, który wyznał ponoć, że zazdrości „Tygodnika” Gorzowowi, gdyż w Poznaniu „rozchodził się lepiej” niż kiedyś „Przewodnik Katolicki”. W redakcji pracowało zaledwie kilka osób, które wykonywały niezbędne prace administratorskie i redakcyjne. „Zdarzało się - wspominał o. K. Łabiński - że robiliśmy cały numer $\mathrm{w}$ drodze na kolanie. Pisaliśmy czasami w pociągu, czasami na noclegach i teksty wysyłaliśmy bezpośrednio do drukarni. Siedzibę naszej redakcji odwiedził dwukrotnie ksiądz prymas Stefan Wyszyński. Pamiętam, że zgonił mnie kiedyś z mojego krzesła tłumacząc, że ma ochotę sam na nim posiedzieć i młode lata powspominać. W końcu też był kiedyś młodym redaktorem i do tego robił dziennik, co chyba nie było łatwiejsze od tygodnika. Myślę, że Ksiądz Prymas czuł prawdziwy sentyment do naszej trochę niesfornej redakcji”"\$43.

\section{Cechy wydawniczo-formalne}

„Tygodnik Katolicki” ${ }^{44}$ z podtytułem „Pismo religijne dla Ziem Odzyskanych” (od 1950 r. „dla Ziem Zachodnich”) o formacie czwórki i objętości ośmiu stron trzyszpaltowego druku zaczął wychodzić 19 V 1946 r. ${ }^{845}$ Reklama ukazująca się w jego zawartości głosiła: „Czytaj co niedzielę pismo przeznaczone

${ }^{841}$ R. Sierchula, Myśl jest bronia...

842 P. Socha, Sylwetki administratorów..., s. 16-17.

${ }^{843}$ R. Sierchula, Myśl jest bronia...

${ }^{844}$ Czasopismo o tym samym tytule i podobnym profilu ukazywało się w XIX w. na Górnym Śląsku. Założył je proboszcz i kustosz budującego się sanktuarium maryjnego w Piekarach Śląskich ks. Jan Ficek w 1848 r. Było pismem Towarzystwa Mariańskiego. Tytuł stanowił pierwsze w dziejach tego regionu pismo religijne, na łamach którego podejmowano również problematykę społeczną, narodową, wychowawczą, stosunków pracy itp. Szerzej zob. J. Górecki, ,, Tygodnik Katolicki” - pierwsze polskie czasopismo religijne na Górnym Śląsku, w: tenże, Z wdzięcznościa i błaganiem u Matki Bożej Piekarskiej, Katowice 2008, s. 36-43; Założenia religijno-społeczne „Tygodnika Katolickiego” - pierwszego polskiego czasopisma religijnego na Górnym Ślasku. W: J. Wycisło, W kręgu sanktuarium maryjnego w Piekarach Ślaskich, Katowice 1997, s. 37-60 (rozdział 2); tenże, „,Tygodnik Katolicki” - pierwsze religijne czasopismo na Górnym Ślasku, „Przegląd Powszechny” 1986 nr 10 s. 96-101.

${ }^{845}$ Informacja potwierdzona też na łamach „TK”. Por. List ze Wschowy, „TK” 1950 nr 5 s. 35. 
dla polskiego ludu «Tygodnik Katolicki» ${ }^{846}$. Ostatni numer podwójny nosił datę 3-10 V 1953 r. Łącznie wydano osiem roczników, z których pierwszy i ostatni były niepełne. Rocznik pierwszy zakończono na podwójnym numerze $31 / 32$, kolejne zaś roczniki liczyły: z 1947 r. - 50 numerów, 1948 - 48 numerów, 1949 - 51 numerów, 1950 - 42 numery, 1951 r. zakończono na podwójnym numerze 47/48, 1952 - na 51/52 i 1953 - na 5 . W ciągu 8 lat wydrukowano 225 numerów.

Wydawcą pisma była gorzowska Kuria Administracji Apostolskiej, po niej zaś Ordynariat Gorzowski. Redakcja mieściła się najpierw przy ul. Woskowej $1 \mathrm{~b}$ na Zamościu (lata 1947-1948) następnie przy Drzymały 36 (w okresie 1949-1952) i przy Obotryckiej $10 \mathrm{w}$ Gorzowie Wielkopolskim. Tygodnik tłoczono kolejno: w gorzowskiej Drukarni Państwowej, później w Państwowych Gorzowskich Zakładach Graficznych, Wielkopolskich Zakładach Graficznych, Poznańskich Zakładach Graficznych, Drukarni Polskiej w Kościanie. W każdym wydaniu ze stopki redakcyjnej można było uzyskać informacje dotyczące numeru telefonu do redakcji i numeru rachunku, na który należało wpłacić za abonament. Redaktor naczelny przyjmował w godzinach $12-13$, a wydrukowanie ogłoszenia kosztowało $20 \mathrm{zl}$ „za $1 \mathrm{~mm}$ wysokości i 1 szpaltę szerokości” druku.

Pierwszy numer „Tygodnika Katolickiego” wydano w nakładzie 600 egzemplarzy. Zapowiadany z ambon, „był rozchwytywany”, co przyczyniło się do tego, że z czasem zwiększono jego nakład do 10 tys., następnie 15 tys. egzemplarzy. Redakcja otrzymywała wciąż głosy od odbiorców świadczące o zapotrzebowaniu na periodyk. Pomimo starań o wzrost nakładu w granicach 50-100 tys., uzyskano u władz jedynie pozwolenie na 40 tys. ${ }^{847}$ Swoim zasięgiem pismo objęło regiony: szczeciński, koszaliński, gdański, olsztyński, zielonogórski, pilski i gorzowski. Tygodnik był kolportowany również na terenie województw poznańskiego i warszawskiego ${ }^{848}$.

Początkowo w 1946 r. pojedynczy numer „Tygodnika Katolickiego” kosztował 4 zł, w 1947 r. - 5 zł, od stycznia do 20 VI 1948 r. 6 zł, zaś od 27 VI 1948 r. do 6 II 1949 r. 10 zł. W następnych latach cena sukcesywnie rosła. Od numeru 7 do 15 z 1949 r. za tygodnik odbiorca musiał zapłacić 15 zł; numery od 45 z 1949 r. do 34 z 1950 r. były w cenie 20 zł, a od zeszytu 35 z 1950 r. do 40 z 1950 r. - 80 gr (po wymianie pieniędzy). Świąteczne wydanie na Boże Narodzenie 1950 r. kosztowało złotówkę, po czym w latach 1951-1953 za egzemplarz należało zapłacić 70 gr. Od numeru 37 z 1952 r. do końca istnienia periodyku nie podawano jak uprzednio ceny na stronie tytułowej. Koszt

846 „TK” 1948 nr 35 s. 272.

${ }^{847}$ R. Sierchula, Myśl jest bronia...; RS, Wydarzenia. Pamięci ks. Eabińskiego - 25 listopada, „Biuletyn Instytutu Pamięci Narodowej” 2007 nr 12 s. 6-7; Nakład 40 tys. potwierdziła D. Wielgat w Bibliografii katolickich czasopism religijnych w Polsce 1945-1989..., s. 90-91.

${ }^{848}$ R. Sierchula, Myśl jest bronia... 
prenumeraty, jak informowała redakcja w stopce na końcu, początkowo wynosił miesięcznie $17 \mathrm{zł}$, a kwartalnie $50 \mathrm{zl}$, następnie wzrósł wraz z podwyżką ceny pojedynczych egzemplarzy. W 1948 r. za otrzymywanie pisma przez miesiąc należało zapłacić 25 zł, a za kwartał 75 zł. Od zeszytu 25 z 1948 r. do zeszytu 6 z 1949 r. miesięczna prenumerata wyniosła 40 zł, a kwartalna sięgnęła 120 zł. Podwyżki nastąpiły również od numeru 7 z 1949 r. do 46 z 1949 r., kiedy to za miesięczny abonament płacono $60 \mathrm{zl}$, a za kwartalny $180 \mathrm{zł}$. Od zeszytu 47 z 1949 r. do 40 z 1950 r. miesięczny abonament kosztował już 80 zł, a kwartalny 240 zł. W latach 1951-1952 prenumerata kosztowała po wymianie pieniędzy odpowiednio - 2,80 zł i 8,40 zł. Utrzymała się w takiej cenie do numeru 3 z 1953 r., po czym końcowe zeszyty kosztowały w prenumeracie 4 i 12 zł.

W miarę możliwości redakcja starała się na bieżąco wprowadzać zmiany i ulepszenia. Niestety, nie zawsze to się udawało. Objętość tygodnika od drugiego półrocza 1947 r. do lipca 1948 r. zmniejszono do sześciu stron, co zapewne spowodowane było ograniczeniami w przydziale papieru, o czym wspominała redakcja $^{849}$. O początkach tak pisał założyciel pisma o. K. Łabiński: „Praca redakcyjna nie była łatwa. Drukarnia była zniszczona i nie było zecerów. Brak było funduszy, sprzętu i personelu. Czcionki trzeba było dorabiać i dostosowywać do polskiego alfabetu. Brakowało papieru. Przydział opóźniał się i był skąpy. Dobieraliśmy papier, który raczej nadawał się do sklepów na opakowanie towaru"850. Wygląd czasopisma był zatem skromny. Z początkiem $1948 \mathrm{r}$. pisano: „mniemamy, że życzliwe ustosunkowanie się czynników państwowych dla sprawy katolickiej na Ziemiach Odzyskanych pozwoli nam powiększyć objętość naszego pisma i nakładu" "851. Rzeczywiście, w drugim półroczu $1948 \mathrm{r}$. „Tygodnik Katolicki” osiągnął 10 s., co utrzymało się przez cały 1949 rok. W latach 1950-1952 w większości zeszytów liczył 8 stron.

W latach 1946-1948 powiększono objętość o kilka stron w numerach specjalnych i podwójnych. Zeszyty liczyły wtedy zazwyczaj 12-14 stron. Numerem świątecznym był zeszyt 50 z 1947 r., bogatszy gdy chodzi o szatę graficzną i droższy - kosztował 12 zł. Egzemplarz jubileuszowy - setny z kolei, z 1948 r., liczył 14 stron i był w tej samej cenie. W rubryce Od redakcji w numerze 25 z 1948 r., poinformowano odbiorców o zwiększeniu objętości tygodnika od lipca tego roku do 12 stron, z czym związane było podwyższenie także ceny pisma z 6 do $10 \mathrm{zl}$. Odpowiednio zdrożała też prenumerata miesięczna - $40 \mathrm{zł} \mathrm{i} \mathrm{kwartalna} \mathrm{-} 120 \mathrm{zł}$. Kolporterom „Tygodnika Katolickiego” oferowano $20 \%$ rabatu ${ }^{852}$. Już za ostatni z czerwcowych numerów, który był objętościowo większy (10 stron) trzeba było zapłacić 10 zł. Redakcja zdecydowała się w kolejnych wydaniach na ciągłą

\footnotetext{
${ }^{849}$ Do naszych czytelników, „TK” 1948 nr 1 s. 3.

${ }^{850}$ R. Sierchula, Myśl jest bronia...

${ }^{851}$ Do naszych czytelników, „TK” 1948 nr 1 s. 3.

${ }^{852}$ Od redakcji, ,TK” $1948 \mathrm{nr} 25$ s. 176.
} 
numerację stron w obrębie roku (wpierw widniała ona na górze, a od numeru 2 z $1951 \mathrm{r}$. na dole strony).

Pomimo uzyskania pozwolenia na wydawanie "Tygodnika Katolickiego” i początkowej przychylności władz komunistycznych, teksty, podobnie jak we wszystkich pismach, podlegały cenzurze. Jak pisał Rafał Sierchuła: „W ciągu pierwszych dwóch lat cenzura interweniowała 160 razy. Całkowicie zdjęto 6 tekstów. W latach następnych ingerencje cenzorskie stały się jeszcze bardziej uciążliwe. Od 1949 r. ingerowano niemal w każdy numer, w 1951 r. skala ingerencji wyniosła 350 razy, zdjęto 80 tekstów. Niepoprawne politycznie były dla komunistów artykuły nawiązujące do ziem wcielonych do ZSRS czy teksty o generale Władysławie Andersie. Zaostrzającą się walkę z Kościołem doskonale oddaje przykład, kiedy to przy sformułowaniu $<<$ Chrystus zmartwychwstał $>>$ cenzor napisał - kłamstwo" "853. Tygodnik przestano wydawać w październiku 1953 r. w wyniku nacisków administracyjnych. W późniejszym okresie, w 1956 r., o. K. Łabiński próbował przy poparciu Jerzego Zawieyskiego reaktywować tytuł, jednak władze komunistyczne uniemożliwiły wszelkie starania ${ }^{854}$.

W piśmie publikowane były artykuły, recenzje, listy pasterskie, orędzia prymasa i biskupów, odezwy, mowy i przemówienia ${ }^{855}$, polemiki, sprawozdania, przeglądy, gawędy, legendy, pogadanki, felietony, wspomnienia, fragmenty opowiadań i powieści, fragmenty z książek, nowele, listy czytelników. Na łamach „Tygodnika Katolickiego" znalazły się również przedruki. Najczęściej były zaczerpnięte z polskich i obcych tytułów prasowych o profilu katolickim, np. „Tygodnika Powszechnego" "856, „Gościa Niedzielnego" Warszawskiego" "s8. Nawiązywano również do wypowiedzi zamieszczonych w „Niedzieli”, „Królowej Apostołów” ${ }^{259}$, „Posłańcu Serca Jezusowego" ${ }^{860}$, a także w numerach „Caritasu”"861, „Przeglądu Powszechnego" ${ }^{862}$ oraz poznańskiego

\footnotetext{
${ }^{853}$ R. Sierchuła, Myśl jest bronią...

${ }^{854}$ Tamże.

${ }^{855}$ Np. Z mowy Prezydenta Bieruta: Polska tworzy nowe życie lepsze i sprawiedliwe, „TK” 1948
} nr 44 s. 360; S. Wyszyński, Prymas Polski w sprawie odbudowy stolicy, „TK” 1949 nr 38 s. 335.

${ }^{856}$ P. Jasienica, Przemilczane pionierstwo, „TK” $1948 \mathrm{nr} 26$ s. 177-178; Trzeźwe wesela, „TK” 1949 nr 10 s. 92; Stosunek Kościoła do państwa, tamże, nr 18 s. 173; J. Tournay, Największe odkrycie biblijne wspótczesnej doby, tamże, nr 37 s. 326-327; Stafford Cripps - pisarzem religijnym, tamże, nr 50 s. 444; Nędza Rzymu, „TK” 1950 nr 7 s. 53; A. Klawek, O Ziemi Świętej, tamże, nr 28 s. 214; Beatyfikacja Piusa X, „TK” 1951 nr 24 s. 217.

857 „Śpiaca twierdza”?, „TK” 1947 nr 46 s. 311-312; J. Archita, Św. Józef-mąz doskonaty, „TK” 1949 nr 12 s. 106-107.

${ }^{858}$ Minat znowu jeden rok, „TK” 1948 nr 1 s. 2.

${ }^{859}$ Z. Zaborski, Kultura katolicka w krajach protestanckich, „TK” 1948 nr 25 173-174; Kogo stuchać lekarza czy kapłana, „TK” 1949 nr 19 s. 179, 181.

${ }^{860}$ E. Choromański, Serce Jezusa ideat i wzór serca męskiego, „TK” 1949 nr 23 s. 214-215.

${ }^{861}$ M. Sopoćko, Alkoholizm a moralność, „TK” 1949 nr 35-36, s. 318; Macierzyństwo w życiu normalnej kobiety, „TK” $1950 \mathrm{nr} 8$ s. 58.

${ }^{862}$ Prasa katolicka o liście papieża, „TK” 1948 nr 29 s. 208-209. 


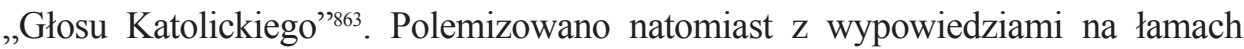
"Odrodzenia" 864 . Z obcych pism powoływano się na wiedeński tygodnik katolicki „Die Furche” ${ }^{865}$, czeskie „Katolicke Noviny” ${ }^{866}$, „Review for Religions” ${ }^{867}$ i francuski „La Croix” ${ }^{868}$. Odbiorcy mogli zatem znaleźć odpowiednie wypowiedzi dla siebie.

\section{Działy i rubryki}

W zawartości tygodnika można wyróżnić trzy zasadnicze części tematyczne:

1) odnoszące się do zagadnień wiary i religii;

2) problematykę kulturalną (literacką, historyczną, muzyczną, dotyczącą sztuki i zabytków);

3) natury praktycznej, krajoznawczej, rozrywkowej.

Pierwsze trzy strony zajmowały rozważania religijne i ewangeliczne (np. o wartości cierpienia, o powojennym kryzysie duchowym ${ }^{869}$ ) lub zagadnienia z życia katolickiego (misje, papiestwo). Podobnie jak w dotychczas omawianych czasopismach, zamieszczano życiorysy świętych, błogosławionych i pretendujących do tego miana ${ }^{870}$ (od nru 27 z 1948 r. obecna była rubryka pod nazwą Przyszli polscy święci) ${ }^{871}$. W cyklu Konwertyci XX wieku ks. A. Bardecki w latach 1947-1948 przybliżył sylwetki przedstawicieli świata kultury: Gilberta Chestertona, Einara Berruma, don Ramiro de Maeztu, naukowca Everardo Bachheusera ${ }^{872}$, którzy do-

\footnotetext{
863 J. Adamski, Gietrzwałd - Warmińska Fatima, „TK” 1948 nr 47 s. 391.

864 T.H., Na marginesie pewnego artykułu, „TK” 1948 nr 26 s. 179.

865 Ucieczka przed dzieckiem, ,TK” 1948 nr 34 s. 259, 263.

866 Ofiarność polskich katolików, „TK” 1948 nr 34 s. 265.

${ }^{867}$ Cuda w świetle medycyny, ,TK” 1949 nr 30 s. 274.
}

868 ,TK" 1951 nr 24 s. 217.

${ }^{869}$ R. Mieliński, W szkole cierpienia, „TK” 1947 nr 36 s. 247; A. Marchewka, Ratunek ludzkości, tamże, nr 37 s. 253-254.

${ }^{870}$ M. Jamrozik, Święty Tomasz z Akwinu, „TK” 1947 nr 9 s. 67; K.W., Św. Wojciech Patron Polski i Ziem Odzyskanych 946-997, tamże, nr 14 s. 107; Bohaterska Dziewica, tamże, nr 21 s. 158; M. Jamrozik, Z jawnogrzesznicy - święta, tamże, nr 29 s. 207, 209; Świątobliwa Wanda Malczewska, tamże, nr 36 s. 250-251; J. Archita, Św. Franciszek-dziś, tamże, nr 39 s. 266-267; J.H., Św. Maria Alacoque, tamże, nr 40 s. 272; M. Jamrozik, Święty Szczepan pierwszy męczennik, tamże, nr 50 s. 343; Księżna Jadwiga - święta na czasie, „TK” 1948 nr 1 s. 4-5; Błogosławiony Wincenty Kadlubek, tamże, nr 11 s. 70; Królowa Jadwiga (1371-1399), tamże, nr 22 s. 151; Opiekun wdów i sierot [Antoni Padewski], „TK” 1949 nr 23 s. 156.

${ }^{871}$ S.B.Ż., Przyszli polscy święci. Stuga Boża Celina z Chludzińskich Borzęcka, „TK” 1948 nr 27 s. 189; Przyszli polscy święci. „Bóg nie byt Panem w naszym domu”. Stuga Boża M. Maria Franciszka Siedliska, tamże, nr 32 s. 239; Brat Albert Chmielowski, „TK” 1949 nr 40 s. 352; Aniela Salawa, tamże, nr 50 s. 442.

${ }^{872}$ A. Bardecki, Gilbert Chesterton, „TK” 1947 nr 34 s. 237; tenże, Einar Berrum (Norwegia), tamże, nr 44 s. 299, 302; tenże, ,W ewangelii należy szukać moralnego ideału człowieka”, ,TK” 1948 nr 7 s. 47; Dwadzieścia dziewięć lat z dala od Boga..., tamże, nr 16 s. 106-107. 
znali nawrócenia w Kościele katolickim. W 1948 r., niestety, z tej ciekawej rubryki zrezygnowano. Od początku 1952 r. w każdym numerze pisma znajdował się dział zatytułowany Zasady wiary. W publikowanych w jego ramach tekstach tłumaczono podstawowe kwestie dotyczące wiary; przykładowo wyjaśniano, kiedy należy żegnać się krzyżem, przypominano przykazanie miłości bliźniego, dekalog, pięć przykazań kościelnych, przestrzegano przed samolubstwem, propagowano należyte oddawanie czci świętym. W pierwszej części podejmowano także tematykę rodzinną, wychowawczą, kobiecą. Zagadnienie wychowania w rodzinie było na tyle ważne, że w numerze 8 z 1949 r. wprowadzono kolumnę Dla matek. Pisano również o wartości pracy, próbowano zaradzać problemom towarzyszącym uzależnieniu alkoholowemu. Odnotowywano najważniejsze aktualne wydarzenia z życia Kościoła w Polsce i za granicą. Czytelnicy w 1947 r. mogli dowiedzieć się o wizycie prymasa Anglii w Polsce, poznać treść orędzia prymasa A. Hlonda w sprawie odbudowy kościołów warszawskich, przypomnieć sobie setną rocznicę objawienia w La Salette, przeczytać o wizytacji prymasa Polski w Szczecinie ${ }^{873}$. W 1948 r. informowano o osiemdziesiątej rocznicy powstania Akcji Katolickiej we Włoszech ${ }^{874}$. W każdym numerze podawano również czytanie na niedzielę z Nowego Testamentu (s. 2; od 1949 r. na s. 3). Z początkiem roku 1949 r. (od numeru drugiego) wprowadzono ukazujący się w każdym zeszycie Kącik pytań, a następnie Kącik zapytań (s. 2). Starano się w nim zwięźle i krótko odpowiadać na najtrudniejsze pytania odnoszące się do zagadnień wiary ${ }^{875}$, istnienia Boga ${ }^{876}$, sumienia ${ }^{877}$, nieśmiertelności duszy ${ }^{878}$, różnicy między naturą ludzką i zwierzęcą ${ }^{879}$. Teksty w ramach Kącika... przestały ukazywać się w $1950 \mathrm{r}$.

Po części religijnej zazwyczaj następowała część kulturalna i literacka. W przystępny sposób pisano o sztuce kościelnej ${ }^{880}$. Temat sztuki ludowej sporadycznie obecny był w artykułach ${ }^{881}$. Niekiedy przybliżano życie i działalność

873 T.W., Prymas Anglii w Polsce, „TK” 1947 nr 24 s. 175; A. Hlond, Za Boże jutro, tamże, nr 31 s. 219; tenże, Stowo Prymasa Polski na stulecie objawienia w la Salette, tamże, nr 37 s. 256; M.O., Wizytacja ks. Prymasa Hlonda w Szczecinie, tamże, nr 45 s. 308.

${ }^{874}$ Młode katolickie Włochy, „TK” $1948 \mathrm{nr} 45$ s. 367.

${ }^{875}$ Kącik pytań, „TK 1949 nr 2 s. 12; tamże, nr 6 s. 48; tamże, nr 7 s. 56.

876 Tamże, „TK” 1949 nr 3 s. 20; tamże, nr 4 s. 30; tamże, nr 5 s. 39.

877 Tamże, „TK” 1949 nr 8 s. 66.

878 Tamże, „TK” 1949 nr 9 s. 79; tamże, nr 10 s. 88; tamże, nr 17 s. 158.

879 Tamże, „TK” 1949 nr 11 s. 98.

${ }^{880}$ S.G., W sklepie dewocjonalia czyli o sztuce kościelnej, „TK” 1949 nr 46 s. 406-407; (j.k.), Bezcenne dzieło średniowiecznej sztuki, „TK”1950 nr 34 s. 268; St.J., Zwiastowanie w sztuce, „TK” 1951 nr 10 s. 83, 85; M. Padechowicz, Ottarz - niewolnik w pelni swej krasy, tamże, nr 16 s. 141-142.

${ }^{881}$ A.Ł., Parę stów o sztuce ludowej, „TK” 1949 nr 23 s. 217-218; T. Haluch, My a nasza sztuka religijna, ,TK” $1950 \mathrm{nr} 17$ s. 130. 
muzyków $^{882}$, więcej pisano nt. pieśni religijnych ${ }^{883}$, rzadziej informowano o koncertach $^{884}$, widowiskach ${ }^{885}$ czy wystawach $^{886}$. Czasami drukowano życiorysy uczonych ${ }^{887}$ lub podejmowano temat kultury ${ }^{888}$. Literatura reprezentowana była w każdym zeszycie zazwyczaj przez dwa fragmenty opowiadań lub powieści, niekiedy nowelę lub legendę. Sporadycznie zapoznawano czytelników tygodnika z życiem i twórczością pisarzy, poetów i dramaturgów ${ }^{889}$. W cyklu pt. Sylwetki literackie ukazał się artykuł o Janie Kasprowiczu ${ }^{890}$. W kręgu zainteresowań szczególnie byli obecni twórcy katoliccy, dlatego też od numeru 5 z 1950 r. wprowadzono serię Pisarze katoliccy. W jej ramach zwięźle i krótko przybliżono m.in. sylwetki Wojciecha Bąka, Jana Dobraczyńskiego, Władysława Jana Grabskiego, Hanny Malewskiej, Gustawa Morcinka, Eugeniusza Paukszty, Zofii StarowieyskiejMorstinowej, Jerzego Zawieyskiego ${ }^{891}$. W numerze 39 z 1950 r. pojawił się nagłówek: Kacik kulturalno-literacki ${ }^{892}$. Przy okazji artykułów o tematyce

${ }^{882}$ H.T., W 30-ta rocznicę śmierci ks. dr. J. Surzyńskiego wielkiego muzyka - patrioty, „TK” 1949 nr 28 s. 258; (K.W.), Autor pieśni: „Chwalcie taki umajone”. Ks. Karol Antoniewicz 1807-1852, „TK” 1951 nr 18 s. 158; W 50-ta rocznice śmierci Giuseppe Verdi, tamże, nr 21 s. 192; T. Prus Wiśniowski, Barczewo - miejsce rodzinne Feliksa Nowowiejskiego, „TK” 1952 nr 15 s. 114; tenże, Ze wspomnień o Karolu Szymanowskim, tamże, nr 16 s. 124.

${ }^{883}$ St.J., Wielkopostne pieśni, „TK” $1950 \mathrm{nr} 10$ s. 75; Muzyka kościelna Moniuszki, tamże, nr 27 s. 203, 206; M. Jamrozik, O pieśni kościelnej, tamże, nr 28 s. 208; A. Tokarz, O śpiewie liturgicznym i kościelnym, tamże, nr 33 s. 260-261; M. Jamrozik, Śpiew liturgii kościelnej, „TK” 1951 nr 3 s. 23; J. Anczarski, Śpiew i muzyka kościelna, tamże, nr 45 s. 393; A.J., Śpiewajmy Panu, „TK” 1952 nr 9 s. 69.

${ }^{884}$ Ja, Koncert religijny w Stupsku, „TK” 1949 nr 51 s. 452; Kult pieśni i muzyki w Seminarium Duchownym w Gorzowie Wlkp., „TK” $1950 \mathrm{nr} 7$ s. 52; Obserwator, Koncert organowy w Katedrze gorzowskiej, tamże, nr 41 s. 340.

${ }^{885}$ K.J., Widowisko męki Chrystusa w Oberammergau, „TK” $1950 \mathrm{nr} 11$ s. 84.

${ }^{886}$ Wystawa archeologiczna, „TK” $1952 \mathrm{nr} 19$ s. 145.

${ }^{887}$ K. Smuta, Mikołaj Kopernik, „TK” 1949 nr 10 s. 94; Uczony o nowych horyzontach i niespotykanej głębi (Contardo Ferrini), „TK” 1950 nr 36 s. 288-289; J. Ujda, Sylwetki naukowców polskich (Jan Sajdak), tamże, nr 39 s. 319-320.

${ }^{888}$ J. Dzierżyński, Kulturalna potęga chrześcijaństwa, „TK” 1948 nr 29 s. 207-208; Eugeniusz, O rozwój kultury artystycznej Ziem Zachodnich, „TK”1951 nr 14 s. 124.

${ }^{889}$ A. Szewczyk, W stulecie śmierci Juliusza Stowackiego, „TK” 1949 nr 16 s. 151; S.M.K., $Z$ życia Adama Mickiewicza, tamże, nr 25 s. 232; „Chcę być żotnierzem”, tamże, nr 27 s. 250; Katolicka pisarka Z. Undset, tamże, nr 36 s. 316; P.C., Karol Hubert Rostworowski, tamże, nr 41 s. 362, 365; Stafford Cripps - pisarzem religijnym, tamże, nr 50 s. 444; J. Sieradzki, Jak umierat Zygmunt Krasiński, „TK” 1950 nr 35 s. 278; Maria Konopnicka, tamże, nr 1 s. 7.

${ }^{890}$ E. Paukszta, Z cyklu: Sylwetki literackie. Jan Kasprowicz - poeta sumienia, „TK” 1949 nr 48 s. $426,428$.

${ }^{891}$ W cyklu „Pisarze katoliccy” przedstawiono: Eugeniusz Paukszta, „TK” $1950 \mathrm{nr} 5$ s. 33; Jan Dobraczyński, tamże, nr 6 s. 40, Władysław Jan Grabski, tamże, nr 7 s. 50, 53; (E.P.) [E. Paukszta], Jerzy Zawieyski, tamże, nr 9 s. 67; Gustaw Morcinek, tamże, nr 10 s. 72; Hanna Malewska, tamże, nr 11 s. 78; E.P. [E. Paukszta], Wojciech Bąk, tamże, nr 12 s. 91; Zofia Starowieyska-Morstinowa, tamże, nr 14 s. 106.

${ }^{892}$ W jego ramach ukazał się artykuł: T. Haluch, Literatura a życie, „TK” $1950 \mathrm{nr} 39$ s. 318-319. 
wychowawczej podejmowano zagadnienia czytelnictwa „dobrych książek" ${ }^{993}$. Problematyka samej książki również była obecna na łamach tygodnika. Informacji o książce służyły rubryki: towarzyszące od początku Nowości wydawnicze, Książka w Twoim ręku, Nowe książki ${ }^{894}$ oraz reklama książki. Recenzje książkowe drukowano zdecydowanie rzadziej. Od 1950 r. wszedł jednorazowo Kacik filmowy, w którym zrecenzowano komedię $e^{895}$. W 1952 r. (nry 10-12) na krótko pojawił się też Kącik historyczny; w nim pisano m.in. o powstaniu diecezji gorzowskiej, biskupstwach w Wolinie, Kamieniu i w Lubuskiem.

Redakcja dbała również o wydrukowanie każdorazowo od jednego do kilku krótkich wierszy (na s. 3-4). Wiersze były autorstwa raczej mało znanych twórców. W drugim roczniku zamieszczano Myśli, z czasem pojawiły się też cytaty pisarzy i znanych osobistości świata kultury. W 1951 r. Myśli zamieniono na Złote myśli (od nru 1) i Myśli katolickie (od nru 3). Sporadycznie w jednym wydaniu występowały jedne i drugie ${ }^{896}$. W Złotych myślach znalazły się m.in. wypowiedzi Tomasza á Kempis ${ }^{897}$, Williborda Verkade ${ }^{898}$, Ludwika Civardii ${ }^{899}$, świętych ${ }^{900}$. W 1950 r. zdecydowano się także na niewielką rubrykę zatytułowaną Przeczytaj $i$ zastanów się, w ramach której przedmiotem refleksji były m.in. fragmenty encykliki Piusa XI O matżeństwie chrześcijańskim ${ }^{901}$, Pisma świętego ${ }^{902}$, wypowiedzi Jacquesa Maritaina ${ }^{903}$.

Od początku 1948 r. w trosce o udostępnienie łamów czytelnikom wprowadzono Kolumnę młodych (s. 3), którą od numeru 11 przekształcono w nowy dział zatytułowany Sprawy młodzieżowe, Sprawy młodzieży. Z okazji jego otwarcia redakcja pisała: „W zrozumieniu wielkiego znaczenia młodzieży w dziele kształtowania katolickiego i narodowego oblicza naszych środowisk parafialnych [...] oraz doceniając potrzebę rozwiązywania jej problemów [...] starać się będziemy zdobyć jak najlepsze pióra wychowawców i przyjaciół, jak też samej młodzieży"904. Wraz z powiększeniem objętości pisma od lipca 1948 r. poszerzono część przeznaczoną dla młodzieży, podejmując $w$ jednym numerze kilka zagadnień jednocześnie.

Relacji z czytelnikami służyły Odpowiedzi redakcji, Czytelnicy pisza..., Do naszych czytelników i Dziat korespondencji. Pierwsza z rubryk obecna od

${ }^{893}$ T. Haluch, Sprawy młodzieży. Koniec i poczatek, „TK” 1949 nr 33 s. 300.

${ }^{894}$ Po raz pierwszy Nowe ksiażki, „TK” 1949 nr 30 s. 272.

895 T.H. [T. Haluch], Kacik filmowy. Przybrana córka, „TK” 1950 nr 36 s. 290.

${ }^{896}$ Np. Myśli i Myśli katolickie „TK” 1951 nr 11 s. 92, 93.

${ }^{897}$ Złote myśli, „TK” 1951 nr 1 s. 4; tamże, nr 2 s. 10.

${ }^{898}$ Tamże, „TK” 1951 nr 4 s. 30.

${ }^{899}$ Złote myśli, „TK” $1951 \mathrm{nr} 11$ s. 97.

900 Tamże, „TK” 1951 nr 34 s. 307.

${ }^{901}$ Przeczytaj i zastanów się, „TK” 1951 nr 3 s. 19.

902 Tamże, „TK” 1951 nr 9 s. 72.

903 Tamże, „TK” 1951 nr 27 s. 247.

904 Zmieniony nieco cytat Por. Sprawy młodzieżowe, „TK” 1948 nr 11 s. 72. 
początku zawierała informacje typu: „Prosimy zgłosić się do redakcji celem omówienia sprawy"905. Czytelnicy pisza... po raz pierwszy znalazła się w numerze 37 z 1949 r. (na s. 6). Rozpoczęto ją wypowiedzią polemizującą z artykułem wydrukowanym wcześniej w „Tygodniku Katolickim”906. Nieznana autorka broniła godności „starych panien”, które rzekomo zostały zlekceważone. Rubryka Czytelnicy pisza ... sporadycznie gościła na łamach tygodnika, w niej odbiorcy podejmowali różnorodne tematy ${ }^{907}$. W rubryce Do naszych czytelników zazwyczaj przypominano o prenumeracie pisma i jej warunkach ${ }^{908}$, natomiast w Dziale korespondencji, obecnym od 41 numeru z 1950 r., drukowano listy czytelników z uwagami dotyczącymi ulepszenia periodyku ${ }^{909}$, a także $\mathrm{z}$ informacjami o funkcjonowaniu ich odległych i mało znanych parafii ${ }^{110}$. Niekiedy redakcja "Tygodnika Katolickiego" odpisywała na indywidualne zapytania czytelników kierowane listownie, podając nagłówek typu $Z$ korespondencji $i^{911}$ czy Odpowiedź na list. W 1952 r. pod hasłem Serdeczne listy! podpisany pod nimi ,przyjaciel” pouczał czytelników w zakresie tzw. dobrych obyczajów.

$\mathrm{W}$ trosce o dominację problematyki regionalnej członkowie redakcji wprowadzili rubrykę poświęconą wydarzeniom religijnym Ziem Odzyskanych zatytułowaną $Z$ diecezji (s. 5, w 1949 r. na s. 10 - ostatniej), a czasem $Z$ życia diecezji, $Z$ naszej diecezji (na s. 7 przedostatniej). Rubryka obecna w latach 1950-1951, choć nie w każdym numerze, stała się miejscem publikowania nowości z życia katolickiego diecezji gorzowskiej. Informowano w niej np. o pracy Caritasu, wizytacjach duszpasterskich i działalności poszczególnych parafii w mniejszych ośrodkach (przykładowo w Trzciance Lubuskiej ${ }^{912}$, Barlinku ${ }^{913}$, Witnicy ${ }^{914}$ ), jak też i w Gorzowie ${ }^{915}$. W latach 1948-1949 (na s. 4) pojawiała się sporadycznie rubryka Z życia katolickiego Dolnego Śląska.

Początkowo stronę szóstą w „Tygodniku Katolickim” przeznaczono na Rady praktyczne. W dziale tym (zmieniającym tytuł) można było się dowiedzieć, Jak sporządzić testament ${ }^{916}$, w jaki sposób pielęgnować chorego ${ }^{917}$, jak hodować

905 Odpowiedzi redakcji, „TK” 1947 nr 4 s. 32.

906 Czytelnicy pisza..., „TK” 1949 nr 37 s. 330. Autorka wypowiedzi polemizowała z artykułem Więcej szacunku, tamże, nr 34 s. 306-307. Dyskusja ciągnęła się jeszcze przez dalsze numery Z.M., Czytelnicy pisza. W miejsce odpowiedzi Czytelniczce, tamże, nr 41 s. 366.

${ }^{907} \mathrm{~Np} . \mathrm{w}$, ,TK” $1950 \mathrm{nr} 22$ s. 175.

${ }^{908}$ Do naszych czytelników, „TK” 1949 nr 46 s. 411.

${ }^{909}$ Dziat korespondencji, „TK” 1950 nr 41 s. 341.

${ }^{910}$ Tamże, „TK” 1951 nr 3 s. 24; tamże, nr 8 s. 68.

911 Np. (P.S.J.), Z korespondencji. Czy można przystępować do Komunii świętej z przerwami?, „TK” 1951 nr 20 s. 180.

${ }^{912}$ Z diecezji. Z życia katolickiego w Trzciance Lubuskiej, „TK” 1948 nr 39 s. 313.

${ }^{913}$ Z diecezji. Pamiętne dni Barlinka, „TK” 1948 nr 44 s. 363.

${ }^{914} Z$ diecezji. Sprawozdanie z Misji w Witnicy, „TK” 1948 nr 46 s. 383.

${ }^{915}$ Z naszej diecezji. Parafia Chrystusa Króla w Gorzowie, „TK” $1951 \mathrm{nr} 5$ s. 41.

${ }^{916}$ E. Stroczewski, Jak sporządzić testament, „TK” 1947 nr 6 s. 47; tamże, nr 7 s. 53.

${ }^{917}$ Rady praktyczne, „TK” $1947 \mathrm{nr} 18$ s. 143. 
róże ${ }^{918}$, w jaki sposób wyrabia się penicylinęer1. Na przedostatniej stronie umieszczono rubrykę Dla naszych gospodyń, przemianowaną następnie na: Dla gospodyń, Rady praktyczne dla naszych gospodyń, Kacik dla gospodyń (od zeszytu 16 z 1947 r.), Dobre rady (od nru 26 z 1947), aby następnie (od nru 39 z 1947 r.) znów powrócić do pierwotnego nagłówka. W nim gospodynie mogły poznać sposób wyrobu masła, przygotowanie potraw ze śledzia, napojów chłodzących, a także dowiedzieć się jak najlepiej wyczyścić naczynia, dywany, meble, w jaki sposób skutecznie wykręcić zardzewiałą śrubę lub jak „dobrze spać". Od numeru 13 z 1947 r. na przedostatniej stronie wprowadzono Kacik dla pszczelarzy (później Dla naszych bartników). Tematyka pszczelarstwa obecna była stale na łamach pisma. Od numeru 26 z 1948 r. dział poradnikowy przekształcono w dwustronicowy Stały dodatek ,,Tygodnika Katolickiego” poświęcony sprawom gospodarczym pt. Dom i Pole. Redakcja z tej okazji informowała: „Chcemy Czytelnikom naszym dawać jak najwięcej rad praktycznych. Chodzi bowiem o podniesienie kultury domu polskiego i racjonalne prowadzenie gospodarki" ${ }^{220}$. Zachęcano jednocześnie odbiorców, aby pisali o swoich spostrzeżeniach i uwagach. W dodatku można było znaleźć przede wszystkim porady dotyczące prowadzenia gospodarstwa domowego, uprawy roli, hodowli zwierząt. Gospodyniom służono radą, jak najlepiej prasować, przygotować zapasy na zimę ${ }^{921}$, stworzyć miły nastrój w rodzinie, udzielić pierwszej pomocy ${ }^{922}$. Nie zabrakło także porad zdrowotnych ${ }^{923}$. Doradzano wreszcie więcej uśmiechu i pogody ducha ${ }^{924}$. Dział Dom i pole prowadzono do 1950 r. Z powyższą problematyką przeplatano artykuły krajoznawcze, ukazujące piękno rodzimych stron $^{925}$. Zagadnienia krajoznawcze zawarto też w Notatkach z podróż $y^{926}$ (po raz pierwszy w nrze 44 z 1949 r. s. 392).

Po dziale przeznaczonym dla gospodyń, od numeru 22 z 1949 r. weszła rubryka zatytułowana $W$ krzywym zwierciadle, w której starano się ośmieszać przyzwyczajenia i przywary narodowe. Rozważano na przykładach sens przysłowia „Zastaw się, a postaw się"927, praktyki wróżenia ${ }^{928}$, nieumiejętność trzymania ner-

918 Tamże, „TK” 1947 nr 19 s. 149.

${ }^{919}$ Lekarstwo z pleśni, „TK” 1948 nr 24 s. 164; tamże, nr 25 s. 175.

${ }^{920}$ Od redakcji, „TK” 1948 nr 26 s. 181.

${ }^{921}$ Dom i pole, „TK” 1949 nr 22 s. 207.

922 Tamże, „TK” 1949 nr 20 s. 189.

923 T. Przanowska, Strzeżmy się gruźlicy, „TK” 1948 nr 39 s. 309; Zdrowie. Poradnie higieny psychicznej, „TK” 1949 nr 9 s. 81; H.K., Dbajmy o zęby, tamże, nr 17 s. 161.

924 Więcej uśmiechu, „TK” 1948 nr 26 s. 179; O radości, „TK” 1949 nr 9 s. 79, 85; F. Musiel, Więcej radości, „TK” $1951 \mathrm{nr} 2 \mathrm{s.} 11$.

${ }_{925}$ Puszcza Jańsborska na Mazurach, „TK” 1949 nr 10 s. 91-92.

${ }^{926}$ A.Ł., Notatki z podróży. Raj odzyskany, „TK” 1949 nr 50 s. 440-441; Historia Paradyża, tamże, s. 444.

${ }^{927}$ W krzywym zwierciadle. Zastaw się a postaw się, „TK” $1949 \mathrm{nr} 22 \mathrm{s.}$ 207-208.

928 J. Czerepacha, W krzywym zwierciadle. Stoliki wirujące, wróżki, zabobony, „TK” 1949 nr 24 s. 226. 
wów na wodzy ${ }^{929}$, manię tytułowania się ${ }^{930}$, nakładanie masek ${ }^{931}$, sprawę przesadnej mody ${ }^{932}$, grzeczności ${ }^{933}$, snobizmu ${ }^{934}$, braku poczucia humoru ${ }^{935}$, słabości ludzkich ${ }^{936}$ itp. Część rozrywkową wzbogacono w latach 1949-1951 kolumną Rzeczy ciekawe (później czasami Rzeczy interesujące ${ }^{937}$, Wiadomości różne ${ }^{938}$, Wiadomości ciekawe $^{939}$, Wydarzenia ciekawe $\left.{ }^{940}\right)$. W niej podawano ciekawostki językowe, historyczne, obyczajowe, informacje o wynalazkach medycznych i naukowych, niecodzienne zdarzenia. Rozrywce i relaksowi służyła gawęda pojawiająca się od $1948 \mathrm{r}$. W numerze 28 z 1950 r. wprowadzono anegdoty w rubryce Uśmiechnij się $e^{941}$.

$\mathrm{W}$ drugim roczniku ostatnią stronę, ósmą, zajmowała rubryka $Z$ życia katolickiego (niekiedy nosząca tytuł Iskierki z życia katolickiego czy tylko Iskierki). W 1948 r. rubrykę zatytułowano Wiadomości katolickie (nr 36 s. 279-280), od listopada zaś (od nru 44) nosiła tytuł $Z$ życia katolickiego $w$ Polsce. W drugim roku wydawania tygodnika wysunięto ją na trzecią stronę. Informowano w niej np. o proklamowaniu nowego państwa Izrael, bieżących sprawach omawianych na zgromadzeniu ONZ ${ }^{942}$, wyborze nowego prezydenta we Włoszech ${ }^{943}$ itp. Oprócz niej dla lepszego zorientowania odbiorców w bieżących sprawach regionalnych dodano $Z$ życia katolickiego w Wielkopolsce. Drugą rubryką na ostatniej stronie była Co stychać w świecie, a z początkiem 1948 r. Na szerokim świecie. W listopadzie tegoż roku od numeru 44 przekształcono ją w kolumnę Ze świata, w której nieco zwięźlej i krócej podawano wiadomości. Czasami rubryki były na tyle obszerne, że zajmowały kolejno przedostatnią i ostatnią stronę. Od początku 1950 r. (nr 3) dodano w treści pisma rubrykę Kościót i świat (rzadziej Kościót $w$ świecie), w której prezentowano wiadomości z życia Kościoła powszechnego. Istniejącą nadal rubrykę Ze świata poświęcano zaś w każdym zeszycie zagadnieniom jednego państwa ${ }^{944}$. W 1950 r. Ze świata zaczęto zastępować Kronika religijna Pomorza. W $1951 \mathrm{r}$. Ze świata prawie zanikła (znalazła się jedynie w nrach $12,15,37$ z 1951).

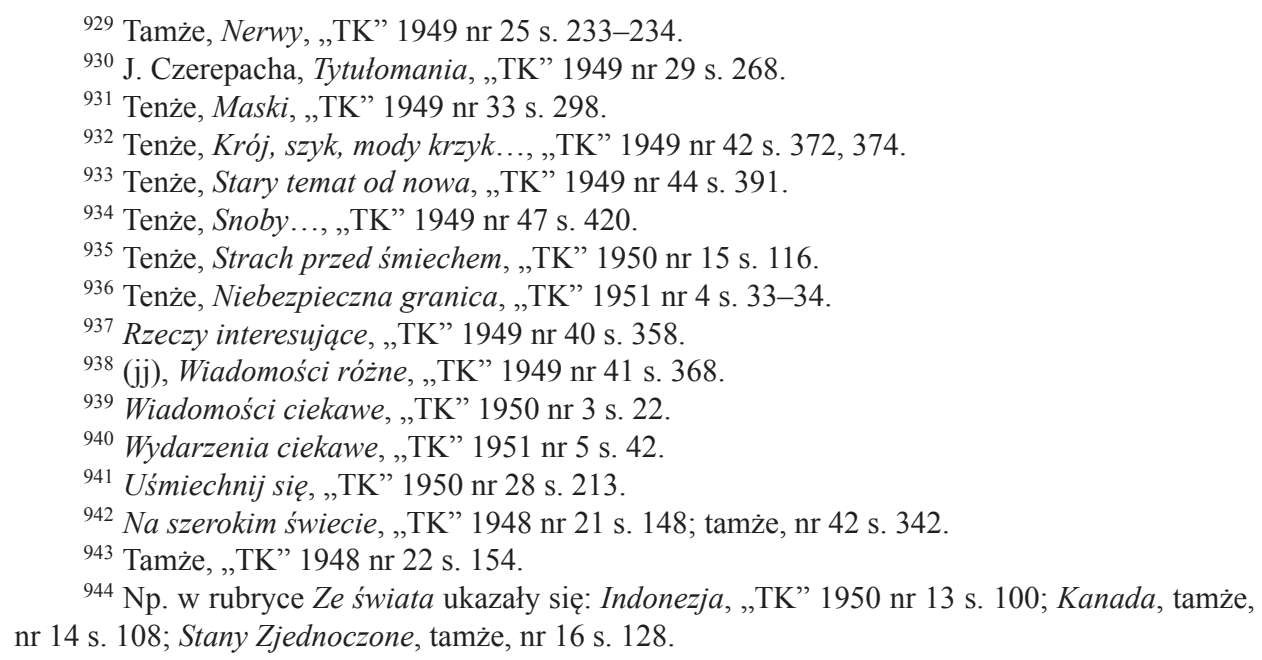


Na końcu tygodnika drukowano Nowości wydawnicze i nie zawsze obecne Odpowiedzi redakcji (lub Od redakcji). $\mathrm{Na}$ ostatniej stronie po rubryce na Szerokim świecie podejmowano w 1948 r. jedno zagadnienie międzynarodowe ${ }^{945}$ lub kulturalne ${ }^{946}$. Przykładowo rozważano wpływy polityczne państw na Morzu Śródziemnym ${ }^{947}$. Zapoznawano z sytuacją w innych krajach, np. w Chinach, na Węgrzech ${ }^{948}$. Stronę ósmą zajmowały też reklamy, które czasem bardziej rozbudowane mogły objąc $3 / 4$ strony. $Z$ czasem redakcja zdecydowała się na umieszczanie anonsów w zawartości „Tygodnika Katolickiego”. Na końcu czasopisma drukowano też Ogloszenia (od nru 33 z 1948).

Chociaż periodyk nie był obszerny objętościowo, odznaczał się różnorodnością działów i rubryk. Jedne pojawiały się, inne zanikały, co świadczyło o stałej pracy redakcji nad pismem. Chciano bowiem odpowiedzieć na zapotrzebowanie odbiorców i jednocześnie wychowywać, doradzać i bawić.

\section{Tematyka poruszana na lamach „Tygodnika Katolickiego"}

Na stronach pismazdecydowanie dominowała tematyka religijna, co odpowiadało profilowi periodyku. Rozważano kwestie moralne, dotyczące wiary i dogmatów ${ }^{949}$, powołań $\mathrm{i}$ kapłaństwa ${ }^{950}$ oraz znaczenie ofiary mszalnej ${ }^{951}$. Mistyczne przeżywanie tej ostatniej starano się ułatwić poprzez szczegółowe opisanie poszczególnych jej części w cyklu Msza św., obecnym na łamach „Tygodnika Katolickiego” w latach 1951$1952^{952}$. Wypowiadano się o istocie życia chrześcijańskiego ${ }^{953}$, sakramentach ${ }^{954} \mathrm{i}$ mo-

${ }^{945}$ Konferencja Warszawska, „TK” 1948 nr 27 s. 196; Sargon, Polityka brytyjska w Azji, tamże, nr 28 s. 206; Butgaria, „TK” 1949 nr 13 s. 124.

${ }^{946}$ Wrocław przygotowuje się do Wystawy Ziem Odzyskanych, „TK” $1948 \mathrm{nr} 21$ s. 148; Polska na Ziemiach Odzyskanych, tamże, nr 22 s. 154; Ochraniamy zabytki, tamże, nr 23 s. 160; Z. Szuman, Wystawa Przemyshu Artystycznego w Gorzowie, „TK” 1949 nr 13 s. 124.

947 A.Z., O Morzu Śródziemnym, „TK” 1948 nr 38 s. 304.

948 Wegry, „TK” 1949 nr 9 s. 86.

949 J.J., Tajemnica życia chrześcijańskiego, „TK” 1949 nr 24 s. 221-222; S. Dowmunt, Katolicyzm świadomy, „TK” 1950 nr 28 s. 207-208; P., Dogmat o Wniebowzięciu Najśw. M.P., tamże, nr 39 s. 317; J. Anczarski, Wniebowzięta, „TK” 1951 nr 29 s. 260.

${ }^{950}$ T.T., Dlaczego księża katoliccy się nie żenia, „TK” 1949 nr 50 s. 440, 443; tenże, Kapłan jest stuga wiernych, „TK” $1950 \mathrm{nr} 1 \mathrm{s.}$ 10; Powołanie kapłańskie, tamże, nr 22 s. 171.

${ }^{951}$ E. Chomrański, Msza św. dusza niedzieli chrześcijańskiej, „TK” 1949 nr 6 s. 47-48; List pasterski o Mszy św., tamże, nr 22 s. 205; Msza św. katolicka, tamże, nr 37 s. 325, 328; St.J., Niedzielne nabożeństwo pierwszych chrześcijan, „TK” $1950 \mathrm{nr} 7$ s. 47-48; A.P., Msza św. zjednoczeniem wiernych, tamże, nr 9 s. 62; Świetliński [K. Łabiński], Sakrament doskonałości, tamże, nr 11 s. 77-78; P.Ł., Msza św. - świętem rodzinnym, tamże, nr 12 s. 87; S. Dowmunt, O częstej Komunii świętej, „TK” 1951 nr 4 s. 26; H.S., O częstej Komunii świętej, tamże, nr 11 s. 90, 92.

${ }^{952}$ Cykl obecny był od numeru 37 z 1951 r. do końca istnienia pisma.

953 T. Haluch, Petnia chrześcijańskiego życia, „TK” $1950 \mathrm{nr} 20$ s. 153.

${ }^{954}$ Z. Żorecki, Bierzmowanie „Boga dar najwyższy”, „TK” 1949 nr 41 s. 359-360, 366; F. Musiel, O należyte zrozumienie chrztu świętego, „TK” $1951 \mathrm{nr} 1$ s. 3; K.P., Dlaczego idę do spowiedzi?, tamże, nr 8 s. 64; J. Anczarski, Sakrament przebaczenia, „TK” 1952 nr 10 s. 73-74. 
dlitwie ${ }^{955}$. Te zagadnienia od 1952 r. omawiano również w cyklu Katolicy w teorii i praktyce (nry 10-16). Corocznie w okresie adwentowym i w wielkim poście starano się przygotowywać odbiorców do nadchodzących świąt. Służyły temu liczne refleksje. W kręgu zainteresowań redakcji, z racji tego, że redaktor naczelny był misjonarzem, były misje Kościoła w różnych częściach świata ${ }^{956}$. Rocznice stały się dobrą okazją do uczczenia jubileuszy diecezjalnych ${ }^{957}$, zakonnych ${ }^{958}$, kapłańskich ${ }^{959}$ $i$ innych uroczystości $i^{960}$. Skrzętnie odnotowywano pielgrzymki ${ }^{961}$, odpusty, misje, procesje i wizytacje parafialne w małych miejscowościach Ziem Zachodnich ${ }^{962}$. W serii artykułów zapoznawano czytelników z działalnością zakonów, organizacji i zrzeszeń katolickich dla młodzieży ${ }^{963}$ i dorosłych ${ }^{964}$. Ważne miejsce zajęły wypowiedzi prasowe dotyczące pożytecznych inicjatyw i działalności Caritasu ${ }^{965}$ (m.in. krucjaty trzeźwości, kursów ${ }^{966}$, organizowania gwiazdki dla dzieci9 ${ }^{967}$, służby chorym $^{968}$ itp.). W świetle Pisma świętego i encyklik papieskich thumaczono kwestie wiary chrześcijańskiej ${ }^{969}$. Słowo na niedzielę starano się wyjaśniać w każdym nu-

${ }^{955}$ M. Jamrozik, Jak ptak bez skrzydet, „TK” 1951 nr 2 s. 10; J. Rzeszewski, Życie modlitwy, tamże, nr 5 s. 35-36; Modlitwa Ciała Mistycznego, tamże, nr 20 s. 173; (P.), O urzeczywistnienie treści naszej modlitwy, „TK” 1952 nr 10 s. 71-72.

${ }^{956}$ K. Świetliński, Misyjne dzieło Kościoła, „TK” $1948 \mathrm{nr} 41$ s. 323; P. Grabowska, Posłannictwo misyjne we Francji, tamże, nr 42 s. 334-335; taż, Misyjne posłannictwo Francji, tamże, nr 44 s. 356; Z terenów misyjnych, „TK” 1949 nr 34 s. 311.

${ }^{957}$ A. Wronka, Na 25-lecie diecezji gdańskiej, „TK” $1951 \mathrm{nr} 1 \mathrm{s.}$ 5-6.

958 OMI, Sto lat na Ziemi Ślaskiej - Jubileusz Sióstr Boromeuszek, „TK” 1948 nr 45 s. 372.

${ }^{959}$ K.Z., Na dwudziestolecie kapłaństwa [Administratorowi Apostolskiemu diecezji gorzowskiej ks. Edmundowi Nowickiemu], „TK” 1949 nr 11 s. 97-98; F.G. Chojnacki, Dwudziestopięciolecie kapłaństwa Prymasa Polski. Jubileuszowe uroczystości w Gnieźnie, tamże, nr 35/36 s. 321; Dwudziestopięciolecie J.E. Ks. biskupa dr. Teodora Kubiny, „TK” 1951 nr 4 s. 34.

${ }^{960}$ J. Dobropolski, Zżycia religijnego Dolnego Ślaska, „TK” 1948 nr 45 s. 373; W stolicy M. Boskiej Kodeńskiej, tamże; A.B-ki [A. Bardecki], Dwulecie Wyższego Seminarium Duchownego w Gorzowie, „TK” 1949 nr 44 s. 395; ks. P., Z diecezji. J. Eksc. Ks. Bp. Fr. Jedwabski w Połczynie Zdroju, tamże, nr 48 s. 429; A.B-ski [A. Bardecki], Pierwsze święcenia kapłańskie w Gorzowie Wlkp, „TK” 1951 nr 26 s. 242; (jj), Uroczystość ku czci O. Maksymiliana Kolbe w Niepokalanowie, tamże, nr 38 s. 342.

${ }^{961} 80.000$ pielgrzymów w Górce Duchownej, „TK” 1948 nr 39 s. 313; J. Adamski, Gietrzwałd - Warmińska Fatima, tamże, nr 47 s. 391; Z.K., Skrzetusz, Miejsce pielgrzymek na Pomorzu Zachodnim, „TK” 1949 nr 23 s. 215.

${ }^{962}$ N., Wielkie dni Torunia, „TK” 1948 nr 40 s. 320-321; Procesja różańcowa wśród ruin Starego Miasta w Warszawie, tamże, nr 42 s. 341; (jj), W Wielkopolskiej Częstochowie, „TK” 1949 nr 39 s. 350.

963 (jj), Krucjata Eucharystyczna w stużbie Chrystusa Polski i Narodu, „TK” 1949 nr 2 s. 11; Z działalności Krucjaty Eucharystycznej w Dobrym Mieście w 1949 r., tamże, nr 34 s. 312.

${ }^{964}$ Apostolstwo chorych, „TK” 1949 nr 9 s. 79; Do Towarzystwa Przyjaciót Katolickiego Uniwersytetu Lubelskiego, tamże, nr 19 s. 181; Czym jest Apostolstwo Chorych, „TK” $1950 \mathrm{nr} 22$ s. 172. 965 J.E. Ks. Administrator Apost. a ,Caritas”, „TK” 1949 nr 11 s. 100.

966 (jj), Kurs instruktorów Świetlicowych ,, Caritas” w Krakowie, „TW” 1949 nr 2 s. 17.

967 Gwiazdka „Caritas” w Gorzowie, „TW” 1949 nr 6 s. 51.

968 Z życia katolickiego w Wielkopolsce. ,Caritas” chorym, „TK” 1949 nr 37 s. 331-332.

969 Święto Chrystusa Króla, „TK” 1949 nr 43 s. 380. 
merze tygodnika (s. 2 lub 3). Zapoznawano czytelników z sytuacją katolików w innych krajach ${ }^{970}$. Przedstawiano sylwetki zasłużonych żyjących i zmarłych kapłanów (biskupów, kardynałów i papieży) ${ }^{971}$. W dziale religijnym drukowano również fragmenty z encyklik ${ }^{972}$, przemówienia papieża ${ }^{973}$, orędzia prymasa i biskupów ${ }^{974}$, listy pasterskie, komunikaty i odezwy dostojników Kościoła ${ }^{975}$. Propagowaniu religii katolickiej służyło prezentowanie historii cudownych obrazów Maryi ${ }^{976}$ oraz osobiste świadectwa osób dotkniętych przez łaskę ${ }^{977}$.

Ważne miejsce w tygodniku zajmowały artykuły przedstawiające sylwetki świętych. W latach 1946-1953 przybliżono odbiorcom m.in. życiorysy św. Anny, św. Jacka Odrowąża, św. Franciszka z Asyżu, św. Barbary ${ }^{978}$, św. Piotra i Pawła ${ }^{979}$, św. Wincentego á Paulo ${ }^{980}$, św. Jadwigi ${ }^{981}$, kanonizowanego w 1947 r. patrona Szwajcarii Mikołaja de Flue ${ }^{982}$, św. Marii Goretti ${ }^{983}$, św. Jana Vianeya ${ }^{984}$, św. Cecylii ${ }^{985}$, św. Weroniki ${ }^{986}$. Biografie polskich świętych znalazły się w cyklu

${ }^{970}$ Katolicy w krajach skandynawskich, „TK” 1951 nr 23 s. 207.

${ }^{971}$ Kardynat Stanistaw Hozjusz (1504-1579), „TK” 1947 nr 30 s. 211-212; M. Rękas, Arcybiskup o wielkim sercu, „TK” 1948 nr 18 s. 120; F.G. Chojnacki, Ś. P. Biskup Stanisław Kostka Łukomski, tamże, nr 44 s. 357; L. Kaczmarek, Papież Pius XII, „TK” 1949 nr 13 s. 118; (K.J.), O. Jacek Woroniecki nie żyje, tamże, nr 22 s. 206; S. Prusiński, Śp. Ksiądz Ignacy Grabowski, „TK” 1950 nr 15 s. 118; A.A. Olkiewicz, Ksiądz Stanisław Kujot, tamże, nr 35 s. 279; Zgon J.E. Ks. Biskupa Teodora Kubiny, „TK” 1951 nr 7 s. 59; (sk), Uroczystości pogrzebowe śp. Kardynała Sapiehy w Krakowie, tamże, nr 30 s. 270..

972 Pius XII, „,Mirabille illud”, „TK” 1951 nr 5 s. 38.

973 Ojciec św. o zdobyczach wiedzy i techniki, „TK” 1949 nr 21 s. 198; Słowo papieża, tamże, nr 51 s. 448; Przemówienie do chorych Ojca św. Piusa XII, „TK” 1950 nr 15 s. 114-115.

974 Orędzie Księdza Prymasa, „TK” 1949 nr 8 s. 68-69; E. Nowicki, Orędzie do Kapłanów $i$ Wiernych w sprawie Świętego Roku Jubileuszowego, tamże, nr 50 s. 451; T. Załuczkowski, Orędzie arcypasterskie, ,TK” $1951 \mathrm{nr} 46$ s. 398.

975 W rocznicę śmierci królowej Jadwigi. Orędzie J. Em. Ks. Kardynała A. Sapiehy Księcia Arcybiskupa Krakowskiego, „TK” 1949 nr 26 s. 242-243; Komunikat Episkopatu Polski do wiernych, „TK” 1950 nr 14 s. 102, 105.

976 Np. Z.W., Madonna Lubuska, „TK” 1948 nr 25 s. 168-169.

977 A. Łączyńska, Świadectwo o cudzie w Lourdes, „TK” 1949 nr 20 s. 188; Cuda w świetle medycyny, tamże, nr 30 s. 274; Co znalazłem w Kościele katolickim. (Wyznanie nawróconego heretyka), ,TK” 1950 nr 3 s. 18.

978 S. Juliński, Święta Anna-wzór matki, „TK” 1948 nr 29 s. 208; W. Romarowska, Św. Jacek Odrowąż, tamże, nr 36 s. 279, 283; St.J., Biedaczyna z Assyżu, tamże, nr 39 s. 307-308; Święta Barbara, „TK” 1949 nr 4 s. 33-34; tamże, nr 5 s. 44; Św. Anna wzór matki i żony, „TK” 1950 nr 23/24 s. 180; W. Turski, Świętość radości życia. O św.Franciszku z Asyżu, „TK” 1951 nr 18 s. 159.

979 P., Symbol miłości i męstwa, ,TK” 1949 nr 25 s. 229-230.

980 A.B., Wielki organizator miłosierdzia św. Wincenty a Paulo, „TK” 1949 nr 28 s. 257.

${ }^{981}$ M. Jarochowska, Wielka Ofiarnica Polski, „TK” 1949 nr 46 s. 412.

982 (J.S.), Święty-pustelnik-polityk, ,TK” 1950 nr 5 s. 34.

983 Wł.Ł., Św. Maria Goretti, „TK” 1950 nr 19 s. 148-149.

984 M. Jamrozik, Św. Jan Vianney - proboszcz z Ars, „TK” 1950 nr 25 s. 185.

985 St.J., Święta Cecylia - patronka muzyków, „TK” 1950 nr 37 s. 259.

986 St.J., Córka krzyża - św. Weronika, ,TK” 1951 nr 7 s. 54. 
Polskie wzory z 1950 r. (m.in. błogosławionych Jana Beyzyma i Bogumiłaa ${ }^{97}$ ). Wiele miejsca z okazji uroczystości poświęcono św. Wojciechowi, nazywając go patronem Ziem Odzyskanych ${ }^{988}$. Przedstawiono również liczne sylwetki błogosławionych, m.in. patrona Warszawy Ładysława z Gielniowa ${ }^{989}$ i Dominika Savio ${ }^{990}$. Nie zabrakło także osób później beatyfikowanych i kanonizowanych ${ }^{991}$. Marian Grzybowski podsumował wszystkie beatyfikacje i kanonizacje Roku Świętego $1950^{992}$. Ponadto ukazywano miejsca święte i warte odwiedzenia, starając się zaciekawić odbiorcę faktami historycznymi (m.in. Świętą Lipkęę, bazylikę w Trzebnicy ${ }^{994}$, dzieje Malborka ${ }^{995}$, Barda ${ }^{996}$, klasztoru świętokrzyskiego ${ }^{997}$, klasztoru św. Józefa w Gdańsku ${ }^{998}$ i Krakowie ${ }^{999}$, sanktuarium w Piekarach Śląskich ${ }^{1000}$ czy katedry poznańskiej ${ }^{1001}$ ).

Przeważającą w pierwszych dwóch rocznikach problematykę religijną wzbogacono w latach 1948-1950 podejmowaniem zagadnień społecznych, kulturalnych, literackich, historycznych, politycznych i międzynarodowych $\mathrm{w}$ aspekcie katolickim. Chociaż nie zmieniono brzmienia podtytułu, to $\mathrm{z}$ powodzeniem „Tygodnik Katolicki” można zaklasyfikować do grupy czasopism społecznokulturalnych okresu 1945-1953. Na jego łamach coraz częściej zaczęła bowiem gościć problematyka nauki społecznej Kościoła. Przypominano przy różnych okazjach dwie najważniejsze encykliki społeczne: papieża Leona XIII Rerum novarum $^{1002}$ i Piusa XI Quadragesimo anno. Publicyści skupiali się najczęściej na

987 J. Sieradzki, Polska Matka świętych, „TK” 1950 nr 15 s. 112; Z. Łęcki, Ojciec trędowatych, tamże, nr 20 s. 157; Błogosławiony Bogumit, tamże, nr 21 s. 165-166.

${ }^{988}$ Święty Wojciech. Patron Ziem Odzyskanych, „TK” 1948 nr 16 s. 105-106; Uroczystości Świętowojciechowe w Gnieźnie, „TK” 1949 nr 16 s. 152; F. Kryszak, W 950 rocznicę kanonizacji św. Wojciecha, tamże, nr 17 s. 160; E. Osysko, Legendarne dzieje św. Wojciecha koło Gdańska, tamże, nr 18 s. 176; tamże, nr 20 s. 191; T. Jankowski, 950 lecie pielgrzymki Ottona III do grobu św. Wojciecha, „TK”1950 nr 25 s. 188; J. Anczarski, Święty Wojciech - Rycerz Chrystusowy, „TK” $1951 \mathrm{nr} 13$ s. $112,114$.

${ }^{989}$ Stary gawędziarz, Patron Warszawy. Bt. Ladysław z Gielniowa, „TK” 1948 nr 39 s. 311-312.

990 J. Gregorkiewicz, Blogosławiony Dominik Savio, „TK” $1950 \mathrm{nr} 11$ s. 80.

${ }^{991}$ H. Weryński, Brat Albert - organizator miłosierdzia wśród najbiedniejszych, „TK” 1949 nr 45 s. $400-401$.

${ }_{992}$ M. Grzybowski, Beatyfikacje i kanonizacje, „TK” 1951 nr 2 s. 12.

993 Święta Lipka, „TK” 1948 nr 31 s. 229; T. Prus Wiśniowski, Święta Lipka, „TK” 1951 nr 34 s. 305 .

${ }^{994}$ W Bazylice św. Jadwigi w Trzebnicy, „TK” $1948 \mathrm{nr} 44$ s. 361-362.

${ }^{995}$ Malborg i jego przeszłość, „TK” $1948 \mathrm{nr} 46$ s. 381.

${ }^{996}$ L. Prorok, Bardo - Śląska Częstochowa, „TK” 1949 nr 5 s. 39, 43.

${ }^{997}$ K. Jedliński, Klasztor świętokrzyski w Eysych Górach, „TK” 1949 nr 18 s. 170.

${ }^{998}$ Kościót i klasztor św. Józefa w Gdańsku, „TK” 1949 nr 23 s. 218.

${ }^{999}$ W. Krzyżanowska, Klasztor i kościół św. Józefa w Krakowie, „TK” $1952 \mathrm{nr} 16$ s. 125.

1000 (jj), Piekary Śląskie światynia Matki Boskiej, „TK” 1950 nr 38 s. 312.

1001 J. Mańkowski, Przeszłość i teraźniejszość katedry poznańskiej, „TK” $1951 \mathrm{nr} 46$ s. 402.

1002 M.S., W obronie człowieka pracy, „TK” 1948 nr 20 s. 137. 
zagadnieniu pracy na ich podstawie. Wyjaśniano różnicę między na pozór podobnym stanowiskiem papieża a założeniami marksizmu w kwestii robotniczej ${ }^{1003}$.

Twórcom tygodnika bliska była problematyka pracy. Zapewne wynikało to nie tylko z jej znaczącej roli w życiu każdego człowieka żyjącego w społeczeństwie, ale także ze względu na okres powojenny i zachodzące w nim przemiany społeczno-polityczne. Świadczą o tym dobitnie chociażby niektóre tytuły artykułów: Chrystus w świecie pracy, Apostoł mas pracujacych (chodziło o Karola de Mazenot - założyciela zakonu Oblatów), Wychowawcze wartości pracy ${ }^{104}$. Autorzy thumaczyli w nich różnice istniejące między przesłaniem ewangelicznym a ideologią marksistowską. Komunistycznym przodownikom pracy przeciwstawiano „przodowników katolickich”"1005. Po obdarzeniu kardynała Stefana Wyszyńskiego godnością prymasa prezentowano jego opracowania o istocie pracy $^{1006}$. Ukazywano także jej wartośś ${ }^{1007} \mathrm{~W}$ ujęciu chrześcijańskim ${ }^{1008}$. Podejmowano również problematykę jej sensu ${ }^{1009}$, sprawiedliwej płacy ${ }^{1010}$, radości z jej owoców ${ }^{1011}$, a także pomocnej roli Eucharystii we wszelakiej działalności ${ }^{1012}$.

W przystępny sposób tłumaczono, na czym polegają zasady społeczne podkreślane przez papieża Piusa XII, jak sprawiedliwość, miłość i dobro wspólne ${ }^{1013}$. Zwrócono uwagę na służbę społeczną ${ }^{1014}$. Pojawiły się również tematy wcześniej nieobecne w „Tygodniku Katolickim”, o czym mogą świadczyć tytuły artykułów: Rzut oka na stosunki międzynarodowe, Miasto i wieś w katolickiej nauce społecznej, Chrystus i reformy społeczne, Cnoty społeczne, Chrześcijaństwo spoteczne", Katolicyzm a sprawa pokoju ${ }^{1015}$. Cytowano wypowiedzi Piusa XII skierowane do chłopów, dotyczące kulturalnego znaczenia wsi i jej podstaw moralnych ${ }^{1016}$. Ważnym tematem była kwestia nauki religii w szkole ${ }^{1017}$. Jednoczenie się autochtonów z innymi grupami ludności na Ziemiach Odzyskanych przybliżano

1003 Tamże.

1004 Apostol mas pracujących, „TK” 1948 nr 40 s. 317; tamże, nr 41 s. 325; Wychowawcze wartości pracy, „TK” 1950 nr 26 s. 191-192.

1005 (T.T.), Młodość zwycięska, „TK” 1949 nr 45 s. 397-398.

1006 S. Wyszyński, W pocie oblicza, „TK” 1949 nr 32 s. 32-33.

1007 M.K. Jedliński, Tajemnica wartości pracy, „TK” 1951 nr 9 s. 74.

1008 (G.N.), Chrześcijańskie pojęcie pracy, „TK” 1952 nr 17 s. 129.

1009 Bednorz, Praca jako mozół i trud, ,TK” 1948 nr 34 s. 257.

1010 J. Tucholski, Jaka płaca jest sprawiedliwa?, „TK” 1948 nr 21 s. 145.

1011 Bednorz, Praca źródłem radości, „TK” 1948 nr 33 s. 248-249.

1012 K. Jedliński, Chrystus w świecie pracy, „TK” 1948 nr 33 s. 247-248.

1013 H.R., Myśl społeczna Piusa XII, ,TK” 1948 nr 38 s. 301.

1014 M. Winowska, Zmyst Kościoła, „TK” 1949 nr 4 s. 31-32.

1015 Rzut oka na stosunki międzynarodowe, „TK” 1948 nr 13 s. 92; Miasto i wieś w katolickiej nauce społecznej, tamże, nr 14 s. 93-94; J. Tucholski, Chrystus i reformy społeczne, tamże, nr 19 s. 126-127; Cnoty społeczne, „TK” 1949 nr 7 s. 55-56; A. Gołubiew, Chrześcijaństwo społeczne, „TK” 1950 nr 16 s. 125; E. Paukszta, Katolicyzm a sprawa pokoju, tamże, nr 17 s. 134.

1016 N.N., Godność moralna stanu chłopskiego, „TK” 1949 nr 10 s. 87-88.

1017 A. Gajewski, Nauka a religia, ,TK” 1948 nr 22 s. 149-150. 
przez pryzmat szerszej problematyki społecznej ${ }^{1018}$, natomiast wydarzenia z życia Kościoła katolickiego na tle kończącego się w 1949 r. planu trzyletniego ${ }^{1019}$. Zapoznano też $\mathrm{z}$ zamierzeniami planu sześcioletniego ${ }^{1020}$. Zdarzało się nawet, że podejmowano problematykę stosunku Kościoła do państwa ${ }^{1021}$. W majowym numerze „Tygodnika Katolickiego” z 1950 r. wydrukowano tekst Porozumienia zawartego 14 kwietnia między przedstawicielami rządu i Episkopatem Polski ${ }^{1022}$, którego zawartość roztrząsano w kolejnym numerze ${ }^{1023}$. Na łamach czasopisma znalazły się również oświadczenia dotyczące stosunku Kościoła do Apelu Sztokholmskiego ${ }^{1024}$. W 1951 r. pojawił się cykl $Z$ życia codziennego, w którym starano się zwracać uwagę odbiorców na postawy katolickie ${ }^{1025}$.

Szczególnie bliska i ważna dla redakcji „Tygodnika Katolickiego” stała się problematyka małżeńska i rodzinna. Pisano zatem o istocie narzeczeństwa ${ }^{1026}$, roli rodziny w społeczeństwie ${ }^{1027}$, powołaniu do małżeństwa ${ }^{1028}$, wierności małżeńskiej $^{1029}$, o wierze małżonków ${ }^{1030}$, dialogu i relacjach między małżonkami i dziećmi $^{1031}$, o dobrym wychowaniu ${ }^{1032}$, o pozytywnych stronach wychowania w rodzinie wielodzietnej ${ }^{1033}$; starano się wyjaśniać kwestie rozwodów wedle nowego

1018 T. Jankowski, Autochtoni, Kościót i Polska, „TK” 1948 nr 8 s. 51-52; J. Dzierz., Kościót, moralność i polityka, tamże, nr 9 s. 57-58.

1019 (s), Polska maszeruje i tworzy, „TK” 1949 nr 3 s. 27.

${ }^{1020}$ E.P. [E. Paukszta], Warmia i Mazury w Planie Sześcioletnim, „TK” 1950 nr 35 s. 278-279.

1021 Stosunek Kościoła do Państwa, „TK” 1949 nr 18 s. 173.

1022 Podpisanie porozumienia, „TK” 1950 nr 13 s. 93-94.

${ }^{1023}$ Komunikat Episkopatu Polski do wiernych, „TK” 1950 nr 14 s. 102, 105.

${ }^{1024}$ Oświadczenie Episkopatu Polski w obronie pokoju, „TK” 1950 nr 20 s. 154; Oświadczenie sekretarza Episkopatu Polskiego J. E. ks. Zygmunta Choromańskiego w sprawie pokoju, tamże.

${ }^{1025}$ Np. M.Z., Z życia codziennego. Troszeczke więcej powagi, „TK” 1951 nr 26 s. 238; Nie zapominajmy, tamże, $\mathrm{nr} 29$ s. 264-265.

${ }^{1026}$ K. Świetliński [K. Łabiński], Dziewczęta i młodzieńcy w okresie przedmatżeńskim, „TK” 1949 nr 31 s. 277-280; T.T. [T. Toth?], Czego Bóg żąda od przystępujacych do sakramentu matżeństwa, tamże, nr 34 s. 306; Tóth, Jaki jest cel czystości, tamże, nr 35/36, s. 316; A.B., Dobrana para, „TK” 1951 nr 3 s. 20; Z.O., Dziewczę katolickie a Serce Boże, tamże, nr 39 s. 344, 350.

${ }^{1027}$ M.Z., Rodzina katolicka w walce o pokój, „TK” $1950 \mathrm{nr} 40$ s. 324-325.

${ }^{1028}$ M. Jamrozik, Rodzina katolicka w Planie Bożym, „TK” 1947 nr 37 s. 255-256; P.T., Blaski i cienie matżeństwa, „TK” 1949 nr 2 s. 11; E. Paukszta, Matżeństwo - czym jest?, tamże, nr 21 s. 195-196; Z.B., Po co istnieje matzeństwo?, „TK” $1951 \mathrm{nr} 16$ s. 142, 144.

1029 T.T. [T. Tóth?], O wierności matżeńskiej, „TK” 1949 nr 37 s. 326.

${ }^{1030}$ K. Świetliński, Matzonkowie i Chrystus, „TK” 1949 nr 44 s. 389-340; K.S., Matzeństwo katolickie w świetle wiary, „TK” $1950 \mathrm{nr} 16 \mathrm{s.}$ 124-125.

${ }^{1031}$ Czy mąż i żona umieja rozmawiać ze sobą?, „TK” 1947 nr 35 s. 243, 245; H.J., Rodzice i dzieci podczas wakacji, „TK” 1948 nr 24 s. 163; Stary gawędziarz, Gawęda o miłości matżeńskiej, „TK” 1949 nr 2 s. 16; Wł. N., Dlaczego dzieci mają czcić swoich rodziców, tamże, nr 19 s. 178-179; Z.M., Więcej szacunku, tamże, nr 34 s. 306-307; Wł. N., Jak należy czcić swoich rodziców, „TK” $1950 \mathrm{nr} 21$ s. 161-162; Z. Baranowski, Warunki szczęśliwego matżeństwa, „TK” $1951 \mathrm{nr} 23$ s. 208.

${ }^{1032}$ M. Morstin-Górska, Dobre wychowanie jest zawsze na czasie, „TK” $1951 \mathrm{nr} 1 \mathrm{s.} 4$.

1033 W. Majewski, Rodzina wierna naturze, „TK” 1948 nr 28 s. 197-198. 
powojennego prawa małżeńskiego w duchu ewangelicznym ${ }^{1034}$. Kładziono nacisk na dobre przygotowanie się do roli małżonki i matki ${ }^{1035}$, stąd wiele artykułów poświęcono kobiecie ${ }^{1036}$. Doceniano jej godnośćc ${ }^{1037}$, powołanie do macierzyństwa ${ }^{1038}$, widziano znacząca rolę w narodzie, społeczeństwie ${ }^{1039} \mathrm{i}$ w walce $\mathrm{z}$ alkoholizmem ${ }^{1040}$, przestrzegano ją przed zabijaniem własnych dzieci ${ }^{1041}$. Zwrócono też uwagę na zagadnienie emancypacji w duchu katolickim ${ }^{1042}$. Mężom i ojcom za wzór stawiano św. Józefa ${ }^{1043}$, doradzano modlitwę w trudnościach małżeńskich ${ }^{1044}$. Ideałem dla głowy rodziny miała być postawa miłości samego Jezusa ${ }^{1045}$, dla matki - rodzicielki Jezusa ${ }^{1046}$, zaś wzorem rodziny - Święta Rodzina z Nazaretu ${ }^{1047}$. Drukowano na łamach „Tygodnika Katolickiego" fragmenty z encykliki papieża Piusa XI Casti connubii (O matżeństwie chrześcijańskim ${ }^{1048}$ ) i ukazywano rodzinę na tle nauczania społecznego Kościoła ${ }^{1049}$. W 1951 r. wprowadzono cykl zatytułowany Dla rodziców $i$ wychowawców, w którym podjęto $\mathrm{z}$ kolei zagadnienia wychowania seksualnego ${ }^{1050}$.

${ }^{1034}$ K. Jedliński, Bicz Boży, „TK” 1948 nr 48 s. 395; S. Wesołowska, Co trzeba robić by nie było rozwodów, „TK” 1949 nr 24 s. 224; Z. Baranowski, Dzieje malzeństwa, „TK” 1951 nr 19 s. 170.

${ }^{1035}$ Pius XII, Ojciec św. mówi do matek, „TK” 1949 nr 2 s. 15; Dla matek. Na progu uświadomienia, tamże, nr 15 s. 138; Z. Lipski, Odpowiedzialność matki, tamże, nr 17 s. 132; K.S., Matka a czystość stanowa, tamże, nr 23/24 s. 177-178; K.S., Żona-matka-Kościót, tamże, nr 25 s. 183-184.

1036 Kobieta a postęp, „TK” 1947 nr 23 s. 292; H. Haluschka, Idealna kobieta, idealna żona, tamże, nr 44 s. 301-302; J. Frei, Błędy matek, „TK” 1948 nr 16 s. 107, 109; A. Jarecka, Kobieta w rodzinie, tamże, nr 33 s. 249; Matkom także potrzeba odpoczynku, „TK” $1949 \mathrm{nr} 18$ s. 172; T.T., Kobieta a wierność malżeńska, tamże, nr 38 s. 334; Z. Szewczak, Niepokalana a dzisiejsza kobieta, tamże, nr 48 s. 424, 426.

1037 O któtniach, przekleństwach i nieposzanowaniu kobiety, „TK” 1949 nr 20 s. 186-187.

${ }^{1038}$ Macierzyństwo w życiu normalnej kobiety, „TK” $1950 \mathrm{nr} 8 \mathrm{~s} .58$.

1039 J.T., Kobieta a naród, „TK” $1951 \mathrm{nr} 4$ s. 28; Rola kobiety $w$ życiu społecznym, tamże, nr 6 s. 49; Rola kobiety w życiu społecznym, „TK” 1952 nr 28/29 s. 211.

${ }^{1040}$ H. Tola, Kobieta w walce o trzeźwość narodu, „TK” 1949 nr 26 s. 239-240.

${ }^{1041}$ Dla matek. Matka czy dziecko, „TK” 1949 nr 8 s. 72-73; Kogo stuchać lekarza czy kapła$n a$, tamże, nr 19 s. 179, 181.

1042 A. Bardecki, Kobieta też stwarza nowa epokę, „TK” 1950 nr 4 s. 24.

1043 J. Archita, Św. Józef-mąż doskonaty, „TK” 1949 nr 12 s. 106-107; (Ar.) [J. Archita], Św. Józef patron matżonków, „TK” 1952 nr 11 s. 81.

1044 (M.Z.), Jestem mężem i ojcem, „TK” $1951 \mathrm{nr} 4$ s. 32-33.

${ }^{1045}$ E. Choromański, Serce Jezusa ideat i wzór serca męskiego, „TK” 1949 nr 23 s. 214-215; S. Wesołowska, Idźmy w ślady Ojcowskiej Miłości Chrystusowej, tamże, nr 24 s. 223; Stary gawędziarz, Gawęda dla mężczyzn, tamże, nr 47 s. 416-417.

1046 J. Anczarski, Bogarodzica - a matki, „TK” 1951 nr 15 s. 125-126; Ewangeliczne matki, tamże, nr 37 s. 328-329.

${ }^{1047}$ Ks. K.M., Wzór chrześcijańskiej rodziny, „TK” 1950 nr 2 s. 11; E.P. [E. Paukszta], Przykład św. Rodziny, „TK” $1951 \mathrm{nr} 1 \mathrm{s.} 2$.

${ }^{1048}$ O matżeństwie chrześcijańskim, „TK” 1949 nr 10 s. 94; Największe korzyści, „TK” 1950 nr 1 s. 3.

$1049 \mathrm{Pm} .$, O katolicyzm spoleczny w rodzinie, „TK” $1950 \mathrm{nr} 3$ s. 17; Wolność a matżeństwo, tamże, nr 26 s. 193.

${ }^{1050}$ Dla rodziców $i$ wychowawców. Katolickie zasady wychowania seksualnego, „TK” $1951 \mathrm{nr}$ 7 s. 56-57; tamże, nr 8 s. 66. 
Na pierwszych stronach pisma istotną rolę odegrała także problematyka wychowawcza w rodzinie, Kościele, szkole ${ }^{1051}$ oraz w szerszym ujęciu wychowania całego społeczeństwa. Szczególną uwagę poświęcono wychowaniu dzieci ${ }^{1052}$, przysposobieniu młodzieży do małżeństwa i życia w społeczeństwie ${ }^{1053}$, jak też właściwemu przygotowaniu samego wychowawcy ${ }^{1054}$. Podkreślano ważną rolę pokoleniowej ciągłości w wychowaniu ${ }^{1055}$, doceniano trud wychowawczy ${ }^{1056}$, dawano wskazówki dobrego wychowania $^{1057}$, dostrzegano destrukcyjny wpływ wojny na moralność młodych ${ }^{1058}$. W 1950 r. podjęto w cyklu artykułów m.in. problem kradzieży ${ }^{1059}$ i uczono uprzejmości ${ }^{1060}$. Pisząc o wychowaniu często za wzór stawiano świętych ${ }^{1061}$.

Refleksje dotyczące wychowania młodzieży znalazły swoje stałe miejsce w Kolumnie młodych, a następnie w dodatku Sprawy młodzieżowe (czasami Sprawy młodzieży). Podjęto tu wiele istotnych zagadnień: wartości, wiary, kształcenia, wyboru zawodu, czytelnictwa, twórczości młodych, właściwego zachowania, punktualności, wychowania w rodzinie, a także świętowania, wiedzy religijnej, sportu czy zabawy ${ }^{1062}$. Starano się również ustosunkować do spraw

${ }^{1051}$ E. Serwański, W trosce o młode pokolenie, „TK” 1947 nr 34 s. 235-236; Wychowawcze zadanie Kościoła, „TK” 1948 nr 3 s. 21-22; (z), O chrześcijańskie szkoły, tamże, nr 25 s. 169; J.H. [J. Haluszka], Błędy i braki w wychowaniu jedynaków, tamże, s. 169-170; Z. Redzisz, Nowy regulamin, „TK” 1950 nr 33 s. 257-258; M. Jamrozik, Dobre wychowanie w rodzinie katolickiej, „,TK” 1952 nr 28/29 s. $159,210$.

1052 Z. Grzybowski, Wychowanie dziecka, „TK” 1950 nr 30 s. 228; tenże, Czy dziecko zna Boga, tamże s. 228-229; List pasterski J.E. Ks. Administratora Apostolskiego dr. E. Nowickiego do rodziców o religijnym wychowaniu dzieci, tamże, nr 38 s. 303-306; tamże, nr 39 s. 314-315.

${ }^{1053}$ K. Jedliński, Wychowanie młodzieży do życia czystego, „TW” 1948 nr 31 s. 227-228; F. Kasperkowiak, O młodzież dzisiejsza, tamże, nr 46 s. 381; T.T. [T. Toth?], Jak należy młodzież wychowywać w cnocie czystości, ,TK” 1949 nr 46 s. 406; tamże, Pomagajmy młodzieży szanować siebie, tamże, nr 47 s. 416; K. Jedliński, Wychowanie młodzieży do czystości, „,TK” 1950 nr 36 s. $285-286$.

${ }^{1054}$ L. Buśkiewicz, O właściwe przygotowanie wychowawcze rodziców, „TK” $1948 \mathrm{nr} 47$ s. 388, 391; T. Pomian, Młodzież a wychowawcy, „,TK” 1949 nr 14 s. 132; S. Grzybowski, Największy obowiązek rodziców, „TK” 1950 nr 32 s. 246.

1055 B. Kudelka, Tradycja i postęp wychowania polskiego, „TK” $1951 \mathrm{nr} 12$ s. 100-101.

1056 Trudniej dobrze wychować dziecko, niż skończyć uniwersytet, „TK” 1949 nr 17 s. 164; Z. Dragatowa, Najtrudniejszy egzamin, „TK” 1951 nr 37 s. 329.

1057 J. Domżał, Wychowanie dzieci, „TK” 1949 nr 18 s. 168; S. Wesołowska, Kilka uwag o katolickim wychowaniu, tamże, nr 26 s. 242; Od matki zależy urabianie charakteru dziecka, tamże, nr 33 s. 299; S. Grzybowski, Przykład wychowuje, „TK” 1950 nr 33 s. 256.

1058 T. Haluch, Problem młodzieżowy, „TK” 1949 nr 4 s. 34-35.

1059 Np. Z.S., Nie kradnij, „TK” 1950 nr 9 s. 64.

1060 Uczmy się uprzejmości, „TK” $1950 \mathrm{nr} 10$ s. 72, 74

${ }^{1061}$ S. Grzybowski, Św. Hieronim o wychowaniu, „TK” 1950 nr 28 s. 210; M. Jamrozik, Św. Filomena patronka młodzieży żeńskiej, tamże; Grzybowski, Wielkie wzory, ,TK” 1951 nr 6 s. 48.

${ }^{1062}$ W dziale Sprawy młodzieżowe wydrukowano m.in.: T. Tóth, Walka o nieugiętość przekonań, ,TK” 1948 nr 1 s. 5; T.H., Piszmy, tamże, nr 4 s. 164; J. Pałka, O dokształcenie młodzieży pozaszkolnej, tamże, nr 11 s. 72-73; T. Haluch, Młodzież a sport, tamże, nr 20 s. 140; tenże, O czytaniu, tamże, nr 22 s. 152; tenże, Słówko o grzeczności, tamże, nr 26 s. 180; tenże, Wierze 
poważniejszych, jak np. do udziału młodych $\mathrm{w}$ powstaniu warszawskim ${ }^{1063}$, do cnoty bohaterstwa i odwagi ${ }^{1064}$, przykazań ${ }^{1065}$, systematyczności w pracy ${ }^{1066}$, kształcenia woli i pracy nad własnym charakterem ${ }^{1067}$, dążenia do świętości ${ }^{1068}$. Od początku sierpnia 1949 r. zagadnienia te obecne były czasami w formie listów do młodych ${ }^{1069}$.

Niejednokrotnie na kartach „Tygodnika Katolickiego” poruszany był problem uzależnienia alkoholowego; oprócz wypowiedzi poważnych na ten temat, zdarzały się też żartobliwe ${ }^{1070}$. Alkoholizm ukazywano jako szczególne zagrożenie $\mathrm{i}$ „wroga człowieka”"1071 oraz przyczynę nieszczęścia dzieci osób uzależnionych ${ }^{1072}$ i całej rodziny ${ }^{1073}$. Picie trunków starano się obrzydzić na wszelkie sposoby poprzez przestrzeganie przed skutkami jak też naśmiewanie się. Pisano o zachowaniu się pod wpływem alkoholu i fatalnych często następstwach ${ }^{1074}$. Proponowaną alternatywą miały być bractwa trzeźwości organizowane przy oddziałach Caritasu, o których informowano w piśmie ${ }^{1075}$. Czytelnicy mogli poznać nawet szczegółowy przebieg niektórych spotkań ${ }^{1076}$. Zachęcano także do Wielkopostnej Akcji Trzeźwości, zaproponowanej w 1948 r. przez przedstawicieli Episkopatu Polski ${ }^{1077}$. Starano się również propagować metody walki z alkoholi-

w Boga Wszechmogącego, tamże, nr 28 s. 200; tenże, Młodzież w rodzinie, tamże, nr 40 s. 318; tenże, Będę marynarzem, tamże, nr 42 s. 336; J.W., Pamiętaj abyś dzień święty święcił, tamże, nr 46 s. 378; (G.I.), Radość i zabawa, „TK” 1949 nr 3 s. 22; List do młodzieży o tańcach i zabawach, tamże, s. 23; T. Pomian, Wiedza religijna, tamże, nr 12 s. 108; S.Sz., Sport, tamże, tamże, nr 19 s. 180.

1063 T. Haluch, Młodzież w powstaniu warszawskim, „TK” 1948 nr 32 s. 240.

1064 S. Tworkowski, Miłość i bohaterstwo, „TK” $1948 \mathrm{nr} 46$ s. 378; Cnota silnych i odważnych, „TK” 1949 nr 21 s. 198.

1065 T.H. [T. Haluch], Nie kradnij, „TK” 1948 nr 48 s. 398.

1066 T. Haluch, Sprawy młodzieży. Sprawa najważniejsza, „TK” 1949 nr 40 s. 354.

${ }^{1067}$ K. Iłłakowiczówna, Zaczynaj od siebie, „TK” 1949 nr 3 s. 22; K.S., Ksztatcenie woli, tamże, nr 16 s. 148.

${ }^{1068}$ Sprawy młodzieżowe. Sztuka świętości, „TK” 1949 nr 3 s. 22.

${ }^{1069}$ Ks. Bronisław, Odpowiadamy na listy młodzieży, „TK” 1949 nr 37 s. 329.

1070 Wielkopostna akcja trzeźwości, „TK” $1948 \mathrm{nr} 6$ s. 41; M. Sławiński, Trzeźwość podstawa sity Ziem Odzyskanych, tamże, nr 7 s. 45-46; K. Abgarowicz, O moralne odrodzenie, tamże, $\mathrm{nr} 27$ s. $187-188$.

${ }^{1071}$ K. Abgarowicz, Wróg czlowieka, „TK” 1948 nr 45 s. 368.

1072 J. Hernik, Dziecię - ofiara alkoholizmu, „TK” 1948 nr 48 s. 403; Alkohol a dziecko, „TK” 1949 nr 15 s. 137.

1073 A. Cząstka, Pijaństwo źródtem nieszczęść dla macierzyństwa, „TK” 1949 nr 39 s. 348;

A.B., Tragiczny „błogostan”, „TK” $1950 \mathrm{nr} 40$ s. 328-329.

1074 Smutne ale prawdziwe, „TK” $1949 \mathrm{nr} 8$ s. 65-66.

1075 Alkoholizm, „TK” 1948 nr 44 s. 363; (G), Akcja trzeźwości w diecezji, „TK” $1952 \mathrm{nr} 10$ s. 77.

${ }^{1076}$ L. Atya, Wieczór antyalkoholowy w Zielonej Górze, „TK” 1949 nr 14 s. 133.

1077 Wielkopostna Akcja Trzeźwości, „TK” 1949 nr 10 s. 89. 
zmem znane w Szwecji ${ }^{1078}$. Proponowano nowożeńcom wesela bez podawania trunków ${ }^{1079}$, nawołując do tego głosem autorytetów Kościoła ${ }^{1080}$. O alkoholizmie z humorem pisał Stary Gawędziarz ${ }^{1081}$. Zaprzestaniu picia służyć miały też drobne i nieco banalne reklamy w rodzaju: „Caritas wzywa: Zamiast kieliszka wódki litr mleka dla dzieci”1082 czy też „Alkohol twój wróg. Alkohol odbiera ci zdrowie, majątek i honor” ${ }^{1083}$. Posługiwano się nawet fragmentami Pisma świętego: „Pijacy nie odziedziczą Królestwa Bożego"1084. Inne nałogi również stawały się tematem do rozważań, jak palenie, uzależnienia seksualne, używanie nieprzyzwoitych wyrazów ${ }^{1085}$.

Ważną problematyką, do której redakcja pisma wielokrotnie powracała, była kwestia sekt; poświęcono im cykl artykułów. Omówiono specyfikę świadków Jehowy i innych sekt amerykańskich oraz nowe edycje Biblii przez nich rozpowszechniane ${ }^{1086}$.

Z racji regionalnego charakteru „Tygodnika Katolickiego" często podejmowano tematy odnoszące się do Ziem Odzyskanych. Pisano zatem o problemach osadnictwa na tych terenach, zagadnieniach dzielnicowości i integracji ludności ${ }^{1087}$, historii tych ziem ${ }^{1088}$, braku duszpasterzy ${ }^{1089}$. Radowano się z otwarcia nowego zakładu wychowawczego dla przyszłych seminarzystów w Słupsku, uruchomienia Wyższego Seminarium Duchownego w Gorzowie ${ }^{1090}$. Wypowiadano się również na temat roli katolicyzmu w utrzymaniu polskości na tych obszarach ${ }^{1091}$, przed-

\footnotetext{
1078 T. Koński, Jak Szwecja walczy z alkoholem, „TK” 1949 nr 7 s. 61-62.

1079 I. Świirski, W obronie godności wesela, „TK” $1949 \mathrm{nr} 31 \mathrm{s.} 283$.

${ }^{1080}$ M. Sopoćko, Alkoholizm a moralność, „TK” 1949 nr 35-36, s. 318.

${ }^{1081}$ Stary Gawędziarz, Gawęda alkoholiczna, „TK” $1948 \mathrm{nr} 7$ s. 48.

1082 „TK” 1948 nr 7 s. 47.

1083 „TK” 1948 nr 9 s. 60.

1084 „TK” 1949 nr 15 s. 139.
}

${ }^{1085}$ Nałóg palenia, „TW” 1948 nr 24 s. 163; H. Korolewski, Jeszcze o paleniu, tamże, nr 26 s. 184; Nałóg palenia, „TK” 1949 nr 7 s. 59-60; Chrystus mi wskazat, tamże, nr 13 s. 117, 123; M.Z., Walka z brzydkim nałogiem, „TK”1951 nr 45 s. 391.

${ }^{1086}$ Prawda o badaczach pisma św. i świadkach Jehowy, „TK” 1947 nr 19 s. 4; „Pismo św.”, które trzeba spalić, tamże, nr 34 s. 239; Skąd się wzięli Świadkowie Jehowy?, „TK” 1948 nr 22 s. 153; Skad Świadkowie Jehowy maja pieniądze, tamże, nr 32 s. 243.

${ }^{1087}$ B. Kudelka, Zagadnienia dzielnicowości na Ziemiach Odzyskanych, „TK” 1948 nr 13 s. 86-88, tamże, nr 15 s. 101; M.T., Poznajmy i ukochajmy Ziemie Odzyskane, tamże, s. 99-100; T. Haluch, Wszyscy jesteśmy Polakami, tamże, nr 28 s. 205-206; E.P. [E. Paukszta], Pogłębić proces wzajemnego oddziaływania, tamże, nr 40 s. 358.

${ }^{1088}$ R.C., Mieszkańcy krainy tysiaca jezior, „TK” 1948 nr 36 s. 283; I. Rutkiewicz, Jeszcze o Ziemiach Zachodnich, „TK” 1950 nr 32 s. 243-244.

${ }^{1089}$ J.M., Ksiądz na Zachodzie, „TK” 1948 nr 28 s. 203; K.Ł, Nasza praca na Ziemiach Odzyskanych, tamże, nr 32 s. 235-236.

1090 A.B-ki [A. Bardecki], Otwarcie Wyższego seminarium Duchownego w Gorzowie, „TK” 1948 nr 1 s. 7-8.

${ }^{1091}$ Z. Wojciechowski, Wkład chrześcijaństwa w Ziemie Odzyskane, „TK” 1948 nr 17 
stawiono historię pierwszej stolicy Pomorza Zachodniego - Kamienia, uczczono przybycie w 1947 r. na uroczystość Chrystusa Króla do Gorzowa Wielkopolskiego prymasa A. Hlonda, dyskutowano na temat słuszności granicy na Odrze i Nysie, broniono prawa dostępu Polski do morza ${ }^{1092}$. Interesowano się jednocześnie religijnością autochtonó $\mathrm{w}^{1093}$ oraz rozważano problematykę zachodnią w kontekście miłości młodzieży do tych ziem ${ }^{1094}$. Wydrukowano także orędzie prymasa A. Hlonda skierowane do ludności Ziem Odzyskanych ${ }^{1095}$. Często z okazji uroczystości religijnych zapoznawano z działalnością małych parafii regionu ${ }^{1096}$.

Redakcja zwracała uwagę na najważniejsze wydarzenia religijne, społeczne i kulturalne wraz z rocznicami, np. w 1947 r. na łamach „Tygodnika Katolickiego” upamiętniono uroczystości związane z 950 rocznicą męczeńskiej śmierci św. Wojciecha, pisano o przybyciu do Polski prymasa Anglii - kardynała Bernarda Gryffina, w 1948 r. uczczono Konstytucję 3 maja ${ }^{1097}$ i piątą rocznicę tragicznej śmierci generała Władysława Sikorskiego ${ }^{1098}$, natomiast w 1949 r. najważniejszym wydarzeniem stały się uroczystości związane z wyborem nowego prymasa Polski kardynała Stefana Wyszyńskiego ${ }^{1099}$.

Tematyka teatralna rzadziej gościła na łamach „Tygodnika Katolickiego”. Zaledwie raz, w numerze 10 z 1948 r., zamieszczona została recenzja teatralna ${ }^{1100}$, zaś rubryka Ze sceny jedynie w zeszycie 5 z 1949 r. na ostatniej stronie. Raz omówiono przedstawienia przygotowane przez mało znaczące trupy w okresie kolędowym $^{1101}$. Znacznie częściej gościła natomiast problematyka historyczna. Opisano

s. 111-112; P., Sprawa zawsze istotna, „TK” 1951 nr 36 s. 326.

1092 K. Makowiecki, Zaludnienie Zachodu, „TK” 1947 nr 13 s. 100-101; Z. Krauze, Troska o duchowe odrodzenie naszych ziem, tamże, $\mathrm{nr} 31$ s. 220; L. Cieszyński, Kamień - pierwsza stolica Pomorza Zachodniego, tamże, nr 35 s. 244; E. Nowicki, Orędzie arcypasterskie, tamże, nr 36 s. 248-249; Ziemie Zachodnie witaja Prymasa Polski, tamże, nr 42 s. 283; Wielkie dzieło na Ziemiach Zachodnich, tamże s. 285, 289; A.B. [A. Bardecki], Wyższe Seminarium Duchowne $w$ Gorzowie, tamże, nr 47 s. 322; T. Jankowski, Rola katolicyzmu w utrzymaniu polskości Ziem Odzyskanych, tamże, nr 50 s. 342-343; Z. Zaborski, Granice Odra, Nysa a sprawiedliwość, „TK” 1948 nr 24 s. 161-162; Morze, nasze morze..., tamże, nr 25 s. 167-168; E. Paukszta, Dominium maris baltici, „TK” $1949 \mathrm{nr} 29$ s. 267.

${ }^{1093}$ F. Przybylski, O życiu religijnym autochtonów w Gorzowie, „,TK” 1949 nr 3 s. 25.

1094 T. Haluch, Młodzież kat. a problem Ziem Odzyskanych, „TW” 1948 nr 44 s. 358.

1095 A. Hlond, Orędzie Kardynała Prymasa do ludności Ziem Odzyskanych, „TK” 1948 nr 25 s. $171-172$.

${ }^{1096}$ Np. Chrzypsko Wielkie w tradycji i działaniu, „TK” 1949 nr 32 s. 294; Uroczystość Bożego Ciała w Bogdańcu, tamże, s. 295; Radosne dni Jesionowa, tamże, nr 34 s. 113; Uczestnik, Piła Parafia św. Rodziny, tamże, nr 37 s. 330.

1097 A. Możdżer, Rocznica Narodowa, „TK” 1948 nr 18 s. 117-118.

1098 T. Haluch, Smutna rocznica, „TK” 1948 nr 26 s. 183.

1099 Ingres Prymasa Polski w stolicy, „TK” 1949 nr 9 s. 80, 83.

${ }^{1100}$ J.K., Rozdroże miłości, „TK” 1948 nr 10 s. 67.

${ }^{1101}$ Ze sceny, „TK” 1949 nr 6 s. 54. 
dzieje grodu w Biskupinie ${ }^{1102}$, losy kościołów i klasztorów na terenach Polski ${ }^{1103}$, historię Ziem Zachodnich ${ }^{1104}$. Przeplatana z historyczną tematyka krajoznawcza wzbogaciła dział rozrywkowy. Autorzy artykułów wskazywali odbiorcom miejsca warte odwiedzenia ${ }^{1105}$. Szczególnie zapoznawano z miastami i krajobrazami Ziem Zachodnich ${ }^{1106}$. Zachęcano do przechadzki po Gdańsku ${ }^{1107}$, Olsztynie ${ }^{1108}$ i Kołobrzegu ${ }^{1109}$. W artykułach krajoznawczych opisywano miasta polskie, ale też całe dzielnice kraju i proponowano szlaki wędrówek ${ }^{1110}$.

Podejmowano jednocześnie tematykę prasową i dziennikarską ${ }^{1111}$. Szczególną uwagę poświęcano $\mathrm{z}$ racji charakteru pisma prasie katolickiej ${ }^{1112}$. Uświadamiano jej ważną rolę w dokształcaniu katolików ${ }^{1113}$. Śledzono na bieżąco pracę oddziałów Caritasu na Ziemiach Zachodnich ${ }^{1114}$, a czasami informowano o ich działalności za granicą ${ }^{1115}$. Interesowano się szkołami wyższymi, głównie Katolickim

${ }^{1102}$ A. Łączyńska, Biskupin najcenniejszy i najpetniejszy dokument kultury tużyckiej, „TK” 1949 nr 29 s. 268.

1103 J. Franczak, Kościół parafialny w Lubsku, „TK” 1948 nr 35 s. 275; tamże, nr 36 s. 285; Od „Trygłowa” do wspaniałej katedry, tamże, nr 42 s. 341; Fara kościańska w nowej szacie, „TK” 1950 nr 1 s. 4; J. Kasztelan, Bytem w Lubiniu, tamże, nr 25 s. 186, 189; (jj), Górka Duchowna i światynia Matki Boskiej Pocieszenia, tamże, nr 31 s. 242; St. J., Najpiękniejsze kościoły w Polsce na cześć Najśw. Marii Panny, tamże, nr 32 s. 249-250.

${ }^{1104}$ M. Tobiasz, Nieco z historii Ziem Zachodnich. Pomorze Zachodnie, „TK” 1950 nr 26 s. $194,198$.

${ }^{1105}$ Karkonosze i Liczyrzepa, „TK” 1949 nr 35/36 s. 322; A. Ł., Notatki z podróży. Kraj lasów i sadów - Krosno Nadodrzańskie, tamże, nr 44 s. 392; Parafianin, Coś o Lagowie Lubuskim, „TK” 1950 nr 28 s. 213; T. Prus Wiśniowski, Piękno ziemi polskiej, „TK” 1951 nr 24 s. 218-219.

1106 (jj), Sieraków - miasto nad Warta, „TK” $1950 \mathrm{nr} 1 \mathrm{s.}$ 7; Chojno nad Warta wieś historyczna wśród lasów, tamże, nr 3 s. 21; H. Haluch, Z wędrówek po Pomorzu Zachodnim. Koszalin, tamże, nr 27 s. 205; Szczecin tętniący praca, tamże, nr 28 s. 211-212; K. Młynarz, Wambierzyce - Dolnośląska Jerozolima, tamże, nr 29 s. 221-222; P., W czas letnich wędrówek, „TK” $1951 \mathrm{nr} 26$ s. 238.

${ }^{1107}$ W. Turski, Gdańsk wczorajszy w perspektywie dzisiejszej, „TK” $1951 \mathrm{nr} 2$ s. 15.

1108 T. Prus-Wiśniowski, Olsztyn, „TK” 1951 nr 40 s. 355.

1109 Tenże, Kołobrzeg, „TK” 1951 nr 45 s. 394.

${ }^{1110}$ L. Frąś, Śląskie miejscowości pątnicze, „TK” 1948 nr 33 s. 250; Stary gawędziarz, Zielona Góra-Jelenia Góra, tamże, nr 39 s. 312; A.A. Olkiewicz, Kaszuby, „TK” 1951 nr 26 s. 237; T. Prus-Wiśniowski, Szlakiem jezior mazurskich, tamże, nr 36 s. 323, 325; T. Prus-Wiśniowski, Z wędrówek po Ziemi Lubuskiej, „TK” 1952 nr 20 s. 150-1951; tamże, nr 21 s. 156-157.

${ }^{1111}$ Ks. Dubaniowski, Prasa i jej wolność, „TK” 1947 nr 16 s. 122-123; Watykańska szkoła dziennikarska, „TK” $1950 \mathrm{nr} 1 \mathrm{s.} 2$.

1112 Biskupi Czechosłowacji ogłosili świeżo zasady moralności katolickiej dotyczace prasy, teatru, filmu i tańca, „TK” 1948 nr 33 s. 254; Z. Szewczyk, Zadania prasy katolickiej, „TK” 1950 nr 34 s. 264.

1113 Zadania prasy katolickiej w Polsce, „TK” $1948 \mathrm{nr} 42$ s. 339.

1114 sz., Tegoroczna ,akcja letnia” Związu ,Caritas” diec. Gorzowskiej, „TK” $1948 \mathrm{nr} 40$ s. 321; Z.S., ,C Caritas Academica” w Szczecinie, „TK”1949 nr 1 s. 6; Szwalnia „Caritas” w Lebie, tamże, nr 14 s. 133.

1115 Prace Caritas w Czechostowacji, „TK” 1949 nr 14 s. 133. 
Uniwersytetem Lubelskim ${ }^{1116}$. Przedstawiano ponadto problematykę niemieckąa $^{1117}$, pisano o stratach wśród katolików w Niemczech na skutek nazizmu ${ }^{1118}$, odnotowano utworzenie Niemieckiej Republiki Demokratycznej ${ }^{1119}$, wypowiedziano się na temat remilitaryzacji Niemiec ${ }^{1120}$ oraz prowadzono rozważania psychologiczno-historyczne dotyczące Niemców ${ }^{1121}$. W latach 1948-1949 podjęto również problematykę Chin ${ }^{1122}$.

Od połowy 1948 r. na łamach tygodnika zaczęły pojawiać się polemiki na różne tematy. Dyskusja rozgorzała w związku z niewłaściwym tłumaczeniem listu papieskiego wydanego przez Czytelnika nakładem tygodnika „Odra” w broszurze Papież Pius XII do biskupów niemieckich. Wytknięto liczne błędy zmieniające sens wypowiedzi papieskiej ${ }^{1123}$.

W gawędach służących rozrywce i relaksowi Stary Gawędziarz w humorystyczny sposób pisał o pięknie polskich gór, udziale w procesji Bożego Ciała, zwiedzaniu klasztoru w Trzebnicy, przepowiedniach i plotkach czy zabobonach ${ }^{1124}$. Jego wypowiedzi przejawiały wyraźny charakter dydaktyczny. Pod nagłówkiem $Z$ teki Starego Gawędziarza można było poczytać „o cnotach” zwierząt idących za naturą $\mathrm{w}$ wiciu gniazda, wierności, opiece nad potomstwem ${ }^{1125}$. Poruszane też były sprawy poważne, np. w związku ze śmiercią Jerzego Bernanosa, pogrzebem prymasa A. Hlonda, a także wypowiedzi o pracy papieża ${ }^{1126}$.

Tematyka artykułów zamieszczonych w „Tygodniku Katolickim” była niezwykle różnorodna, z dominacją zagadnień religijnych, rodzinnych, wychowawczych i społecznych. Intencją redakcji było, aby publikowane w periodyku teksty miały charakter informujący, pouczający, doradczy, poradnikowy, a także rozrywkowy. Każdy z odbiorców mógł znaleźć coś dla siebie.

1116 (z), Katolickie szkoły wyższe na Dalekim Wschodzie, „TK” 1948 nr 27 s. 189; (z), Stulecie Kościoła katolickiego w Indiach, tamże, nr 29 s. 209; Katolicki Uniwersytet Lubelski czeka pomocy, „TK” 1949 nr 41 s. 366; Kuźnica wiedzy i pracy katolickiej, „TK” 1951 nr 12 s. 103; Co to jest K.U.L.?, tamże, $\mathrm{nr} 13$ s. 111.

1117 T. Haluch, Problem niemiecki, „TK” 1948 nr 31 s. 234.

1118 Sytuacja katolicyzmu w Niemczech, „TK” 1948 nr 37 s. 295.

1119 T. Haluch, Niemcy a my, „TK” 1950 nr 21 s. 166.

${ }^{1120}$ T.H., Przeciw remilitaryzacji Niemiec, „TK” 1952 nr 28/29 s. 212.

${ }^{1121}$ B.K., Niemcy wczoraj i dziś, „TK” $1951 \mathrm{nr} 41$ s. 359-360.

1122 Paruzel, Chiny - Ojczyzna Kardynała Tien, „TK” 1949 nr 1 s. 7-8.

${ }^{1123}$ T.H. [T. Haluch], Na marginesie pewnego artykutu, „TK” $1948 \mathrm{nr} 26$ s. 179; To tak nie byto, tamże, nr 28 s. 199.

${ }^{1124}$ Stary Gawędziarz, O pięknie naszej ziemi, „TK” 1948 nr 21 s. 146; Gawędziarz, Obrazki z procesji Bożego Ciała, tamże, nr 25 s. 174; Stary Gawędziarz, Zwiedzilem klasztor w Trzebnicy, tamże, nr 27 s. 194-195; stary gawędziarz, Przepowiednie i plotki, tamże, nr 40 s. 320; Stary gawędziarz, Gawęda o polskich zabobonach, „TK” 1949 nr 4 s. 35.

${ }_{1125}$ Stary gawędziarz, O cnotach zwierząt, „TK” 1949 nr 21 s. 200.

1126 Tenże, Jerzy Bernanos nie żyje!, „TK” $1948 \mathrm{nr} 31$ s. 233; tenże, Wrażenia z pogrzebu Ks. Prymasa, tamże, nr 45 s. 371; tenże, Gawęda o Rzymie i papieżu, „TK” 1949 nr 17 s. 164. 


\section{Numery specjalne}

Nieco inny układ posiadały edycje specjalne wydawane z okazji świąt Bożego Narodzenia, Nowego Roku, świąt Wielkiej Nocy, uroczystości Zesłania Ducha Świętego ${ }^{1127}$ i innych. Starano się też przygotować czytelników do właściwego przystąpienia do sakramentu spowiedzi i przeżywania tajemnic wiary. Pomagano w przygotowaniu świątecznego stołu. Wydania specjalne objętościowo obszerniejsze, liczyły od 12 do 16 stron. Numer noworoczny z 1948 r. otworzył List prymasa Polski, wstępny artykuł redaktora naczelnego podsumowujący dokonania społeczne i kulturalne minionego roku oraz zapowiedzi zmian redakcyjnych. W numerach świątecznych i noworocznych redakcja zazwyczaj składała życzenia swoim czytelnikom.

Wyjątkowe wydarzenia również stawały się powodem do poszerzenia numeru. Zeszyt specjalny wydano po śmierci prymasa Polski Augusta Hlonda. Zamieszczono w nim życiorys, wspomnienia i okoliczności śmierci kardynała, opisano sam pogrzeb, na ostatniej stronie wydrukowano depesze kondolencyjne. Przypomniano jego sylwetkę w kontekście wizyty na Ziemiach Odzyskanych ${ }^{1128}$. Biskupowi diecezji gorzowskiej ks. Edmundowi Nowickiemu z okazji jubileuszu dwudziestopięciolecia kapłaństwa poświęcono numer 11 z 1949 r. Ukazano jego udział w powołaniu Caritasu i Seminarium Duchownego w Gorzowie oraz przypominano jego wizytacje duszpasterskie.

Niektóre numery pisma miały charakter monograficzny. Przykładowo w specjalnym numerze 10 z 1948 r. dotyczącym papieża Piusa XII omówiono prace głowy Kościoła w kontekście wydarzeń II wojny światowej, spraw polskich, spraw młodzieży, wynoszenia nowych świętych na ołtarze, a także papiestwa widzianego „oczami niedowiarka”. Numer 41 z 1948 r. poświęcono natomiast misjom Kościoła.

Czasami redakcja wydawała numery podwójne, np. lipcowy numer 35/36 z 1949 r., zachowujący objętość 10 stron, numer 23/24 z 1950 r. czy numer 28/29 z 1952 r.

\section{Szata graficzna}

Skromny wygląd powojennego tygodnika od początku urozmaicały czarnobiałe fotografie, rysunki i reprodukcje obrazów. W miarę możliwości redakcja zamieszczała w zwykłych numerach rysunek lub zdjęcie na pierwszej stronie nawiązujące do treści artykułu. Drukowanym w piśmie tekstom towarzyszyły zdjęcia okolicznościowe, portretowe, krajobrazowe. Rysunki i obrazy były przeważnie

\footnotetext{
1127 Np. ,TK” 1949 nr 22.

1128 ,TK” 1948 nr 43 s. 343-354.
} 
o treści religijnej. Wiele z nich przedstawiało Zbawiciela lub też wizerunki Maryi w cudownych obrazach (np. Matki Bożej Ostrobramskiej).

\section{Il. 16. „Tygodnik Katolicki” 1946 nr 1}

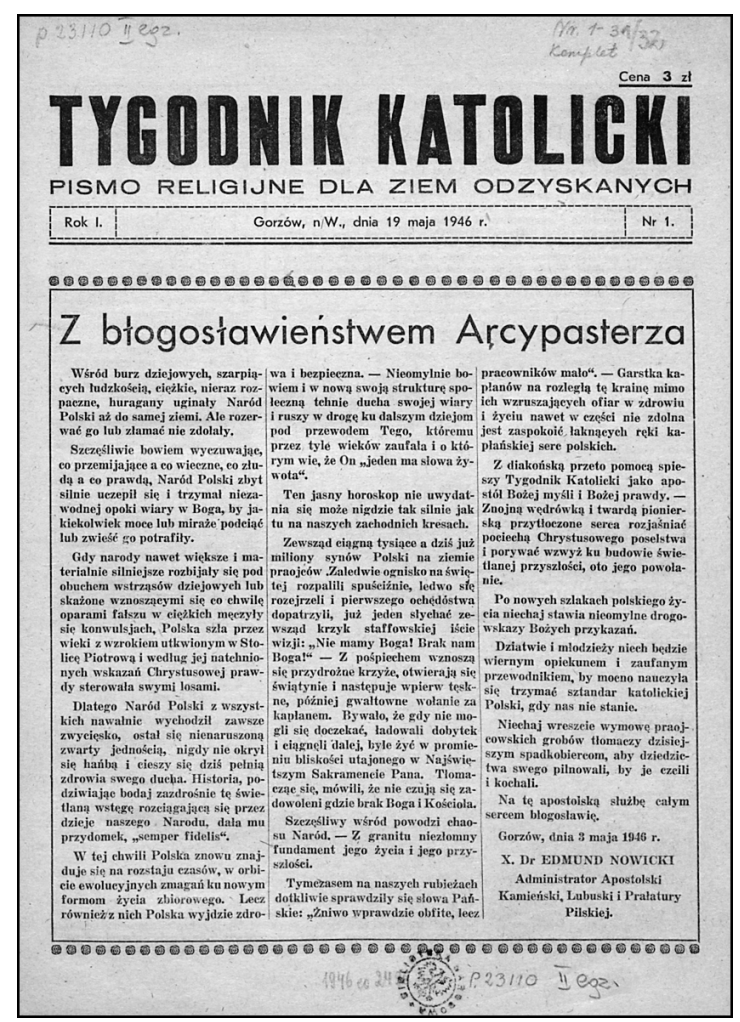

Źródło: Ze zbiorów własnych.

Jeżeli w numerze nie było żadnej fotografii ani obrazka, to starano się przynajmniej umieścić wiersz w ozdobnej ramce, tytuł artykułu złożyć ładniejszą czcionką lub dołączyć ozdobnik tekstowy. Tekst urozmaicano na różne sposoby. Przykładowo w 1951 r. nazwisko autora i tytuł opowiadania umieszczono w ramkach $^{1129}$.

Pierwszą stronę niekiedy zdobiła reprodukcja obrazów np. Królowej Apostołów („TK” 1947 nr 19), św. Joanny d'Arc (,TK” 1947 nr 21), natomiast numer wydany na Boże Narodzenie 1947 r. ilustrowała reprodukcja przedstawiająca Świętą Rodzinę oraz liczne ramki i ozdobniki przedzielające poszczególne teksty. Okładki numerów wielkanocnych i bożonarodzeniowych, na Zesłanie Ducha

${ }^{1129}$ Po raz pierwszy w numerze 39. z 1951 r., opowiadanie pt. Hanka, s. 348. 
Świętego różniły się znacznie. W kolejnym wydaniu - noworocznym z 1 stycznia 1948 r. - przedstawiono obraz wyobrażający pokłon Trzech Króli przed Dzieciątkiem Jezus. Numer wielkanocny z 1948 r. na pierwszej stronie zdobił obraz Zmartwychwstałego Jezusa z aniołami, natomiast setny zeszyt „Tygodnika Katolickiego" rysunek wyobrażający zesłanie Ducha Świętego. Najładniejsze okładki posiadały zeszyt 51 z 1949 r. wydany na Boże Narodzenie, z obrazem zstępującego z nieba anioła, i numer 9 z 1951 r. z reprodukcją wizerunku Jezusa Zmartwychwstałego. Wielkanocne wydanie z 1949 r. posiadało zmienioną czcionkę tytułową na pierwszej stronie, w całym zeszycie zamieszczono więcej rysunków i fotografii. Redakcja w rubryce Do naszych czytelników informowała, że: „bolączką [był] brak odpowiednich środków technicznych, umożliwiających dawanie piękniejszej szaty ilustracyjnej" ${ }^{1130}$.

Il. 17. Zeszyt świąteczny „Tygodnika Katolickiego” z 1946 r. nr 31/32

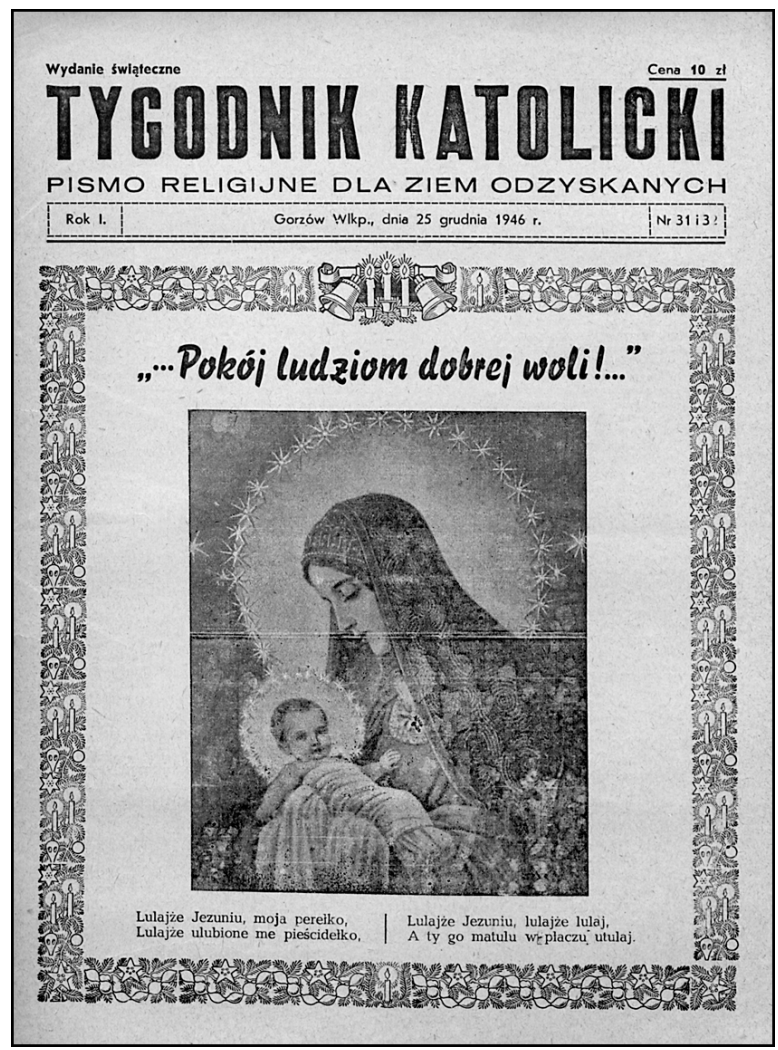

Źródło: Zbiory własne.

${ }^{1130}$ Do naszych czytelników, „TK” 1948 nr 1 s. 3. 
Z każdym (nowym) rokiem starano się zmieniać image tygodnika. Zaczynano od nadania innego wyglądu winiecie tytułowej. Od początku 1948 r. pierwszy człon tytułu pisma składano czarną czcionką, kursywą, drugi prostą białą czcionką na czarnym tle; po lewej stronie umieszczano elementy graficzne - początkowo rysunek kościoła i herby (nry 1-18 z 1948 r.), a następnie (od numeru 19 z 1948 r.) był nim statek płynący po morzu. Uroczystą i staranną okładką odznaczył się również pierwszy numer jubileuszowego Roku Świętego 1950. Przedstawiono na niej Bazylikę Świętego Piotra z podpisem „Rok święty 1950”. Zdecydowano się jednocześnie na odmienny wygląd tytułu i rysunek w nagłówku. $Z$ prawej strony zagościł obrazek watykańskiej bazyliki, który towarzyszył tygodnikowi przez cały rok. Urozmaicono czcionkę rubryki $Z$ życia katolickiego w 1949 r. Piąty rocznik zdobił rysunek w środku nagłówka, przedstawiający matkę z dzieckiem, siódmy rodzinę przy czytaniu książki, a ostatni wyobrażenie krzyża.

Il. 18. „Tygodnik Katolicki” 1953 nr 7

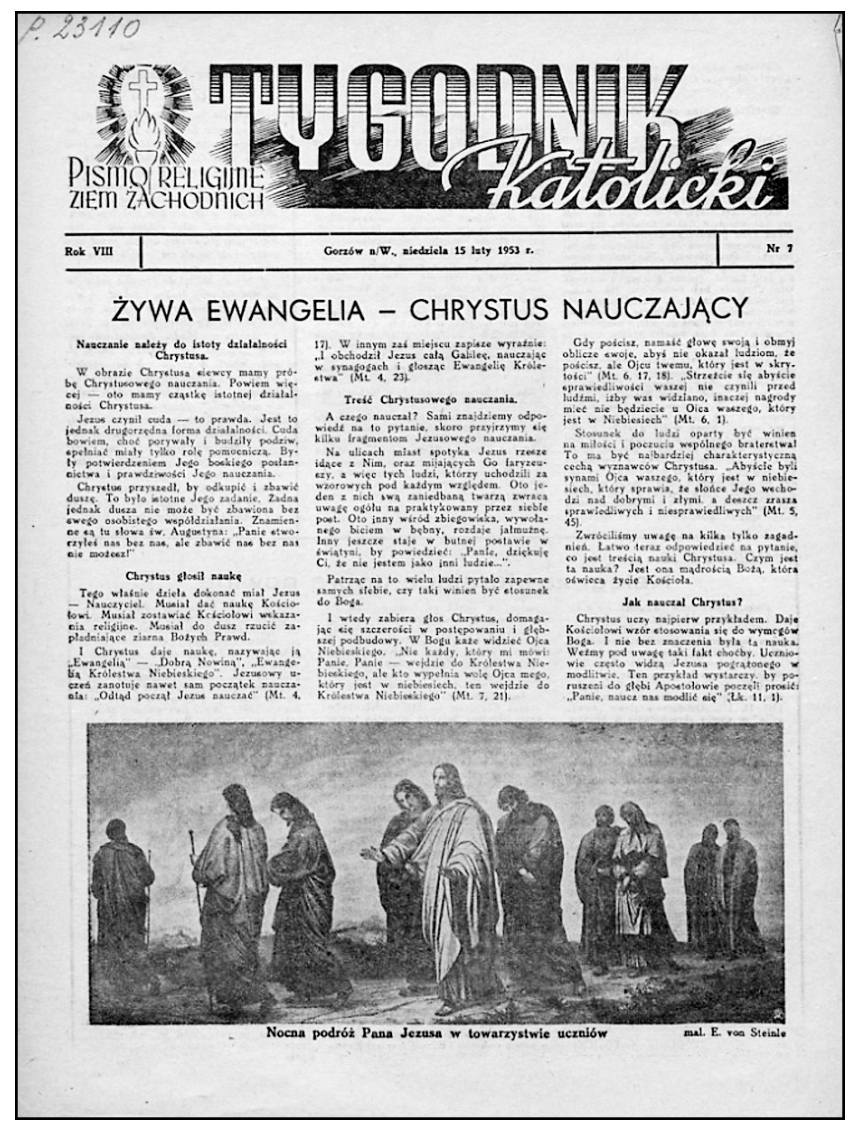

Źr ódło: Zbiory własne. 
Inne kolumny tygodnika również otrzymały staranniejszą szatę graficzną. Z początkiem 1949 r. do rubryki Ze świata dołączono rysunek kuli ziemskiej, zaś obok nagłówka działu młodzieżowego (od zeszytu 7 z 1949 r.) umieszczono rysunek dwóch młodzieńców i dziewczyny trzymających w rękach różne narzędzia: młotek, książki, cyrkiel i ekierkę. W zwykłych edycjach czasopisma czasami do tekstu na pierwszej stronie dodawano ozdobne przerywniki graficzne ${ }^{1131}$.

Stały dodatek Dom i pole wewnątrz tygodnika przyozdabiano kolejno ilustracjami przedstawiającymi robotnikó $\mathrm{W}^{1132}$, sianokosy ${ }^{1133}$, krajobraz domu i świecącego nad nim słońca ${ }^{1134}$, pracowników kolei ${ }^{1135}$. Zmieniano też wygląd nagłówka dodatku. Początkowo był on bardziej urozmaicony graficznie, od numeru 42 z 1948 r. prostszy (tytuł złożony jedynie pogrubioną czcionką). Od czasu do czasu na łamach pisma pojawiały się nieco ładniejsze nagłówki. Taki wygląd nadano np. tytułowi Matżeństwo katolickie w świetle wiary ${ }^{1136}$.

W 1952 r. na ostatniej stronie pisma publikowano cykl Obrazki z życia Pana Jezusa (nry 8-21), z licznymi reprodukcjami dzieł Gebharda Fugela. Pod obrazem ewangelicznym drukowano fragment Pisma świętego. Niekiedy edycję uzupełniał dodatek Mały Tygodnik (np. w 1948 r. nr 43 i w 1950 nr 28 i 41).

Urozmaiceniem szaty graficznej było również wprowadzenie jednej kolorystyki do poszczególnych wydań. Egzemplarze z 1953 r. drukowano w tonacji: zielonej (nr 1, 5, 32), niebieskiej (nr 2, 4, 9/10, 33), brązowej (nr 6, 35) i fioletowej (nr 7).

Wygląd zewnętrzny regionalnego „Tygodnika Katolickiego” był bardzo staranny i dobrze dopasowany do zawartości. Reprodukcje i elementy graficzne uzupełniały teksty i czyniły periodyk łatwiejszym w odbiorze.

\subsubsection{Miesięcznik „Znak” (1946-1953)}

\section{Redakcja i współpracownicy}

Do grona założycieli miesięcznika „Znak” należeli: Hanna Malewska, ks. Konstanty Michalski, Jerzy Radkowski, Stefania Skwarczyńska, Stanisław Stomma, Stefan Świeżawski i Jerzy Turowicz. Funkcję redaktora

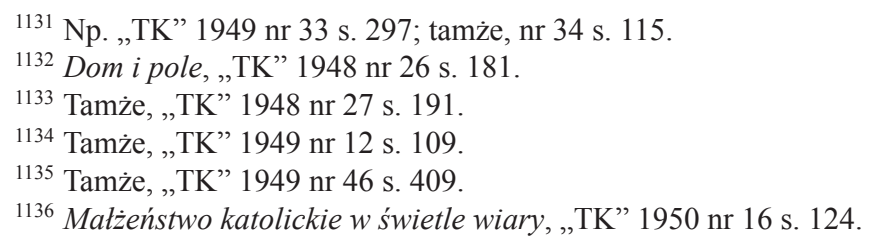


naczelnego jako pierwszy objął J. Radkowski, po nim zaś H. Malewska (od nru 3 z 1953 r.) obok nazwiska której na stronie redakcyjnej wymieniono jednocześnie S. Stommę. Skład zespołu redakcyjnego podano w czwartym numerze "Znaku” z 1947 r. Znaleźli się tu: Leon Halban, Jerzy Radkowski, Stefania Skwarczyńska, Stefan Świeżawski, Jerzy Turowicz i Jerzy Zawieyski (taki skład utrzymał się do 1949) ${ }^{1137}$. Do redakcji weszli również: Franciszek Blajda, Halina Bortnowska, Tomasz Fiałkowski, Antoni Gołubiew, Stanisław Grygiel, Zygmunt Kubiak, Maria Morstin-Górska, Marek Skwarnicki, Irena Sławińska, Zofia StarowieyskaMorstinowa, Władysław Stróżewski, Henryk Woźniakowski, Czesław Zgorzelski. Bliskimi współpracownikami „Znaku” byli znani naukowcy, pisarze, teologowie, biskupi, kardynałowie, filozofowie, historycy ${ }^{1138}$. Na jego łamach wypowiadali się m.in. Roman Brandstaetter, Karol Górski, Konrad Górski, Paweł Jasienica, Jan Parandowski, Bogdan Suchodolski, Władysław Tatarkiewicz. Osoby redagujące i współpracownicy byli w większości związani jednocześnie z „Tygodnikiem Powszechnym".

W piśmie głos zabierali również księża: Andrzej Bardecki, Innocenty Bocheński, Piotr Chojnacki, Eugeniusz Dąbrowski, Zbigniew Bonawentura Fróg, Wincenty Granat, biskup Michał Klepacz, Kazimierz Kłósak, Albert Krąpiec, Wincenty Kwiatkowski, Jan Salamucha, Franciszek Tokarz, Rudolf Weiser, Jan Wierusz-Kowalski i Karol Wojtyła. Na stronach periodyku Stefan Kisielewski podjął tematykę muzyczną ${ }^{1139}$, Stefania Skwarczyńska literacką ${ }^{1140}$ a Jerzy Zagórski teatralną ${ }^{1141}$.

Wśród współpracowników zagranicznych w latach 1946-1953 należy wymienić przede wszystkim francuskich intelektualistów katolickich: Paula Claudela, jezuitę i pisarza katolickiego Jeana Danielou (redaktor „Etudes” i „Dieu Vivant”), Stanisława Fumeta (redaktora „Temps Présent”), Etienne'a Gilsona, niemieckiego teologa i kapłana pochodzenia włoskiego Romano Guardiniego, Jacquesa Maritaina, trapistę Tomasza Mertona, Emanuela Mouniera (redaktora „Espirit”), niemieckiego historyka i pisarza katolickiego Reinholda Schneidera, dominikanina Antonina Dalmatiusa Sertillangesa ${ }^{1142}$ i Gustave Thibona. Publikowano również wypowiedzi i fragmenty z twórczości Gilberta Keitha Chestertona,

1137 „Znak” 1947 nr 4 s. redakcyjna; „Znak” 1949 nr 4 s. nlb.

${ }^{1138}$ D. Patkaniowska, ,Znak”. W: Stownik literatury polskiej XX wieku, pod red. A. Brodzkiej, Wrocław 1992 s. 1229. Zob. też: J. Turowicz, 75 x miesięcznik „Znak”, „TP” $1960 \mathrm{nr} 42$; „Znak” w latach 1946-1958, „Znak” $1962 \mathrm{nr}$ 10; J. Hennelowa, ,Ten temat się nie przeżyl”, rozmowa z H. Malewską, „TP” 1968 nr 12; Prawie wszystko o „Znaku”, „TP” 1971 nr 18; J. Bukowski, Dwadzieścia pięć lat „Znaku”, „Więź” 1971 nr 10; J. Turowicz, „Znak” Hanny Malewskiej, „TP” 1973 nr 28; Czterdzieści lat „Znaku”. Numer jubileuszowy, „Znak” 1986 nr 6.

1139 S. Kisielewski, Czy muzyka jest niehumanistyczna?, „Znak” 1948 nr 3 s. 222-231.

${ }_{1140}$ S. Skwarczyńska, Dramat Jerzego Zawieyskiego, „Znak” 1949 nr 3 s. 200-225.

${ }^{1141}$ J. Zagórski, Kłopoty teatralne, ,Znak” 1946 nr 3 s. 355-364.

1142 Więcej o nim w „Znak” 1949 nr 6 s. 477-478. 
Clive'a Staplesa Lewisa, Gustave Thibona, Gertrudy von le Fort, Sigrid Undset. Redakcja zwykła zaznaczać przy końcu artykułów, że zostały one napisane „specjalnie dla prasy polskiej".

\section{Linia programowa}

Pismo posiadało zbliżoną linię programową do "Tygodnika Powszechnego" ze względu na to samo grono redaktorów i współpracowników. Wspólnie tworzono bowiem nowe środowisko intelektualne katolików świeckich w Krakowie. „Znak”, będąc miesięcznikiem, zachował jednak charakter bardziej elitarny, docierając do węższego grona odbiorców. Ponadto do publikacji na jego łamach wybierano teksty w sposób bardziej specjalistyczny ${ }^{1143}$.

W słowie Od redakcji otwierającym pierwszy zeszyt, czytamy: ,[...] świadomi odpowiedzialności, jaką dźwiga wobec narodu każda jednostka i grupa społeczna, podejmujemy wydawanie $<<$ Znaku $>>$ z wolą czynnego współuczestnictwa $\mathrm{w}$ tworzeniu nowej rzeczywistości $\mathrm{z}$ jasno określoną linią programową. Z podłoża najautentyczniejszego i najpełniejszego Katolicyzmu chcemy wywieść człowieka, zdolnego dzisiejszej rzeczywistości podołać, napór jej wytrzymać i zwycięsko poddać ją sobie. Sięgając do wiekowych tradycji polskiej kultury wyrosłej na podłożu Katolicyzmu, pragniemy wysiłki współczesnych Katolików sprząc razem pobudzając ich do szukania w prawdzie katolickiej rozwiązania podstawowych problemów życia indywidualnego i zbiorowego, z którym zmaga się świat powojenny. Określając w ten sposób naszą zasadniczą postawę, ustosunkowujemy się jednak pozytywnie do szeregu dokonań poza obrębem Katolicyzmu [pisownia oryginalna - E. K.]" ${ }^{1144}$. Dalej redaktorzy tłumaczyli, że jakkolwiek katolicyzm jest dla nich prawdą absolutną i ostateczną, to na płaszczyźnie egzystencjalnej, kulturowej, historycznej i współczesnej przyjmują niektóre osiągnięcia jednostek i grup, których poglądy i ideologie dalekie były jego założeniom. Pisano także: „W szczególności pragniemy zetknąć się z żywotnymi dziś a przekonaniom naszym krańcowo przeciwstawnymi światopoglądami, jak marksizm i neopozytywizm, nie na płaszczyźnie ślepej negacji, lecz rzeczowej wymiany poglądów" "145.

Redakcja zapowiadała propagowanie katolicyzmu społecznego zgodnego z tradycją Kościoła, jak też współczesnymi przejawami myśli katolickiej w przebudowie świata powojennego. Na łamach „Znaku” zapoznawano zarówno z poglądami Jaquesa Maritaina, jak i jednego z czołowych przedstawicieli lewicy katolickiej we Francji Emanuela Mouniera. Jerzy Turowicz pisał o drugim z nich

\footnotetext{
1143 D. Patkaniowska, ,Znak”...

1144 „Znak” 1946 nr 1s. 1-2.

1145 Tamże, s. 2.
} 
jako o „wybitnym katolickim myślicielu”, a po jego śmierci zapowiadał powrót do jego twórczości „bo właśnie o te idee, o które walczył Mounier, walczy i $<<$ Znak $>>$ : o wyciągnięcie społecznych konsekwencji z katolicyzmu, o chrześcijaństwo historycznie skuteczne, o budowanie cywilizacji personalistycznej na miejsce cywilizacji burżuazyjnej"1146. Dążono także do odbudowy państwa i kultury. Przyjęto jednak postawę krytyczną do niektórych przejawów ówczesnego życia. Zespół „Znaku”, świadomy potrzeb reform społecznych, gospodarczych i kulturalnych, zapowiedział poparcie dla „praw jednostki, wolności myśli i słowa" ${ }^{1147}$. Wśród zadań pisma wymieniono pogłębienie życia religijnego w warstwach inteligencji polskiej. Chciano też informować swoich odbiorców o postępach ruchu katolickiego w myśl zasady, że do lepszego świata dochodzi się nie tylko przez przeobrażenie życia zbiorowego, lecz przede wszystkim poprzez „,przebudzenie dusz ludzkich” ku wierze w Chrystusa ${ }^{1148}$.

Redakcja „Znaku” nawiązywała do tradycji wydawanego w okresie międzywojennym warszawskiego kwartalnika „Verbum”"149, chcąc uformować nowe środowisko katolików świeckich w Polsce w oparciu o przesłanki francuskiego personalizmu. Od początku deklarowano ,pluralizm, otwarcie na inne światopoglądy, w tym również - na dialog z marksizmem" "150. W latach 1946-1953 starano się realizować program katolicyzmu społecznego, stąd pojawiła się polemika z ideologią marksistowską. W zawartości pisma często starano się ukazać katolicyzm w relacji do innych światopoglądów i ideologii ${ }^{1151}$.

W artykule wstępnym pierwszego zeszytu ks. Konstanty Michalski, pytając o sens i cel w dziejach, pisał: „Wyjeżdżając na głuchą wieś, zabrałem ze sobą trzy tylko książki: Nowy Testament, Summę teologiczna św. Tomasza i Boska Komedie Dantego. Czytałem własnymi i obcymi oczyma te trzy dzieła, podkreślając ich teksty ołówkami wszelkich kolorów, by sobie jakoś systematycznie odpowiedzieć na pytanie $<<$ dokąd idziemy $>>$ " ${ }^{152}$. Autor słusznie zauważył, że pytanie to rodziło się w „chwilach katastrof i wielkich przemian dziejowych”"153, podobnych do tych, jakie miały miejsce ówcześnie.

\footnotetext{
1146 J.T. [J. Turowicz], Umart Emanuel Mounier, ,Znak” 1950 nr 2 s. 148.

1147 ,Znak” 1946 nr 1 s. 3.

1148 Tamże.
}

1149 Katolicki kwartalnik religijno-kulturalny i filozoficzny, wydawany w latach 1934-1939 w Warszawie. Założony przez ks. Władysława Korniłowicza. Pismo na swoich łamach propagowało założenia personalizmu chrześcijańskiego. Szerzej zob. ,,Verbum” (1934-1939): pismo i środowisko, t. 1: Materiały do monografii, t. 2: Wybór artykułów, oprac. M. Błońska, M. KunowskaPorębna, S. Sawicki, Lublin 1976.

${ }^{1150}$ D. Patkaniowska, ,,Znak”...,s. 1230.

${ }^{1151}$ Np. R. Mehl, Zdarzenia - książki-ludzie. Katolicyzm-protestantyzm, „Znak” 1950 nr 2 s. $148-151$.

1152 K. Michalski, Dokąd idziemy, ,Znak” 1946 nr 1 s. 4-25.

1153 Tamże, s. 8. 


\section{Cechy wydawniczo-formalne}

Ogólnopolski miesięcznik społeczno-kulturalny „Znak”, o profilu katolickim, wydawany w Krakowie, istnieje do dziś. Pierwszy numer w formacie A5 ukazał się w czerwcu 1946 r. Ostatni z okresu stalinowskiego wyszedł w marcu 1953 r. ${ }^{1154}$ Skierowany do inteligencji katolickiej, w zamierzeniu redakcji miał utrzymać charakter polemiczny i dyskusyjny. Pismo zarejestrowano w Bibliografii katolickich czasopism religijnych w Polsce 1945-19891155, doczekało się też drukowanej i elektronicznej wersji bibliografii zawartości z lat 1946-1996 ${ }^{1156}$.

Z notki na ostatniej stronie dowiadujemy się, że wydawcą czasopisma była Spółdzielnia Wydawnicza „Znak”, tłoczono je w Drukarni Udziałowej w Krakowie ${ }^{1157}$, a później w Państwowych Krakowskich Zakładach Graficznych i Drukarni Prasowej (Wielopole 1) ${ }^{1158}$. Nakład podany na stronie redakcyjnej w 1952 r. wynosił 6 tys. egzemplarzy ${ }^{1159}$, a następnie 4,5 tys. i 5 tys. egzemplarzy $^{1160}$. Zeszyt ostatni z 1953 r. wyszedł w nakładzie 2185 egzemplarzy na papierze siódmej klasy ${ }^{1161}$.

Początkowo periodyk ukazywał się nieregularnie, za co redakcja każdorazowo przepraszała czytelników ${ }^{1162}$. Niektóre zeszyty „Znaku” pomimo wytłuszczonego podtytułu „miesięcznik” były łączone i obejmowały kilka miesięcy (od dwóch do czterech), o czym świadczyły wymienione w nagłówku nazwy miesięcy. Przykładowo w numerze trzecim z 1946 r. wzięto pod uwagę okres od września do grudnia. Redakcja tłumaczyła: ,[...] z przyczyn od nas niezależnych, materiał zamieszczony w niniejszym numerze dochodzi do rąk czytelników z wielkim opóźnieniem. Na przyszłość mamy podstawy sądzić - pismo będzie ukazywać się regularnie"1163. Niestety, zeszyty 4-6 z 1947 r. również objęły kilka miesięcy (styczeń-marzec, kwiecień-czerwiec i lipiec-wrzesień). Niektóre edycje pisma odbiorcy otrzymali z miesięczną przerwą (np. nr 2 z marca i $\mathrm{nr} 3$ z kwietnia 1948 r.). Periodyk zachował względną regularność jedynie w latach 1948-1949. Miesięcznik zasadniczo ukazywał się nieregularnie ze znacznymi opóźnieniami.

${ }^{1154}$ W marcu 1953 r. pismo zawieszono i w latach 1953-1956 nastąpiła przerwa w jego wydawaniu.

${ }^{1155}$ D. Wielgat, Bibliografia katolickich czasopism religijnych..., s. 102.

${ }^{1156}$ M. Filipiak, Bibliografia miesięcznika „Znak” 1946-1996, Kraków 1997; dostępna jest również poszerzona wersja online. Dostępny w World Wide Web http://www.miesiecznik.znak.com. $\mathrm{pl} /$ bibliografia.html [dostęp 18. 12. 2010].

1157 „Znak” 1946 nr 1 s. 136.

1158 „Znak” 1948 nr 1 s. redakcyjna; „Znak”1950 nr 5 s. redakcyjna.

1159 „Znak” 1952 nr 2 s. redakcyjna.

1160 „Znak” 1952 nr 3 s. redakcyjna; tamże, nr 4 s. redakcyjna.

1161 „Znak” 1953 nr 1 s. redakcyjna.

1162 Redakcja i administracja, Do naszych czytelników, „Znak” 1946 nr 3 s. 369.

1163 Tamże, s. 39. 
Ogółem w latach 1946-1953 wyszło osiem roczników i 35 numerów. Poszczególne roczniki były niepełne, pomimo zachowania ciągłej numeracji zeszytów ${ }^{1164}$. Na stronie redakcyjnej w pierwszym numerze umieszczono „tymczasowy” adres redakcji i administracji w Krakowie, przy ul. Piłsudskiego 6, w lewej oficynie na trzecim piętrze. Redaktor przyjmował interesantów w poniedziałki, środy i piątki od 11.30 do 13.30 . W numerze czwartym z $1947 \mathrm{r}$. podano inny adres, przy ul. Sobieskiego 3, m. 8 również na trzecim piętrze. Zmieniły się także numer telefonu i terminy przyjęć redakcji (poniedziałki i piątki w godz. 11.00-13.00). Z początkiem 1949 r. redakcja przyjmowała interesantów częściej, codziennie od 10 do 12 oprócz sobót. Pracownicy administracji dostępni byli natomiast codziennie od 9.00 do 12.00.

Cena pojedynczego zeszytu w $1946 \mathrm{r}$. wynosiła $40 \mathrm{zł}$, natomiast prenumerata kwartalna - 115 zł, a półroczna - 230 zł. Koszty kolejnych edycji rosły, o czym informowano na stronie redakcyjnej. Numer drugi kosztował już $50 \mathrm{zł}$, prenumerata kwartalna $145 \mathrm{zl}$, a półroczna $290 \mathrm{zl}$; trzeci $60 \mathrm{zl}$, prenumerata kwartalna - 180, półroczna - 360. W rubryce Do naszych czytelników wyjaśniano: „Znacznie zwiększone koszta druku spowodowały podwyższenie ceny numeru oraz zmianę warunków prenumeraty" ${ }^{165}$. Za zeszyt czwarty z 1947 r. należało zapłacić $90 \mathrm{zł}$, a za prenumeratę kwartalną 250 zł, co tłumaczono znaczną podwyżką cen papieru'1166. Kolejne wydania (od 6 z 1947 r. - do 1 z 1949 r.) utrzymały stałą cenę 100 zł, przy zachowaniu prenumeraty w wysokości 250 zł za trzy numery. Cena wzrosła znów w lutowym numerze „Znaku” z 1949 r. do 120 zł za pojedynczy egzemplarz i 320 zł za prenumeratę kwartalną. Redakcja obwieściła: „Z dniem 1 stycznia 1949 r. koszty druku czasopisma zostały podwyższone o 90\%. Wydawnictwo nasze walczące z największymi trudnościami finansowymi znalazło się wskutek tej podwyżki w ciężkiej sytuacji. Dlatego koniecznym staje się podniesienie ceny" 1167 . W zeszycie szóstym z tegoż roku wprowadzono dodatkowo prenumeratę „wspierającą 900 zł”. W ostatnim grudniowym wydaniu z 1949 r. w rubryce Do czytelników czytamy: „Trudne warunki finansowe zmuszają redakcję do nowej podwyżki prenumeraty. Od stycznia $1950 \mathrm{r}$. tj. od numeru 22-go prenumerata mies. $<<$ Znak $>>$ wynosić będzie zł 420, za poszczególny numer 150 zł [...] Podwyżka ta jest podyktowana koniecznością i mamy nadzieję, że będzie z wyrozumiałością przyjęta przez czytelników, którzy dali nam tak wiele dowodów życzliwości”"168. Na końcu początkowego zeszytu z 1950 r. zachęcano:

${ }^{1164}$ Pierwszy rocznik składał się z 3 numerów: czerwcowego, sierpniowego i październikowo-listopadowego; rocznik drugi zawarł numery 4-7: styczeń-luty, marzec-kwiecień, maj-czerwiec i lipiec; roczniki z lat 1948-1950 były kompletne, uwzględniając wszystkie miesiące w roku; periodyk ukazywał się nieregularnie w latach 1951-1953. Rocznik szósty zawarł 4 numery: styczeń, kwiecień, lipiec-sierpień i listopad; kolejny rocznik to zeszyty z: lutego, kwietnia-maja, sierpnia i października; w ramach ostatniego rocznika wyszedł tylko jeden numer za styczeń-luty.

${ }^{1165}$ Do naszych czytelników, „Znak” 1946 nr 3 s. 369.

${ }^{1166}$ Redakcja i administracja, Do naszych czytelników, „Znak” 1947 nr 4 s. nlb.

1167 Od redakcji, „Znak” 1949 nr 2 s. nlb.

${ }^{1168}$ Redakcja, Do czytelników, „Znak” 1949 nr 7 s. 617. 
„Tylko prenumerata gwarantuje regularny odbiór pisma i zapewnia mu podstawy egzystencji. Apelujemy do wszystkich czytelników aby zostali prenumeratorami $<<$ Znaku $>>$ "1169. W ostatnim, piątym numerze z 1950 r. na stronie redakcyjnej widniała cena zeszytu po wymianie pieniędzy w wysokości 4,50 zł i prenumerata za 12,60 zł. Od początku 1951 r. informowano czytelników, że cena zeszytu w prenumeracie kosztuje 4,20 $\mathrm{z}^{1170}$. Nowe prenumeraty miały być „,bezwzględnie” zgłaszane do „Ruchu” do 20 dnia każdego miesiąca ${ }^{1171}$. Kolejny komunikat informował, że kolportaż „Znaku” dla urzędów parafialnych, kiosków przykościelnych oraz księgarni również odbywa się za pośrednictwem „Ruchu” 1172 .

Na końcu zeszytu pod spisem treści podawano ceny ogłoszeń do miesięcznika. Cała strona na ogłoszenie kosztowała 4000 zł, pół strony 2200 zł, natomiast 1/4 strony 1200 zł. Ogłoszenia przyjmowano wyłącznie za pośrednictwem Polskiej Agencji Reklamy „Par”, która posiadała swoje siedziby w: Krakowie (przy Rynku Głównym 46), Poznaniu (przy ul. F. Ratajczaka 7), Bydgoszczy (pl. Wolności 7), Inowrocławiu (Św. Ducha 45) i Toruniu (ul. Mostowa 38) ${ }^{1173}$.

Od zeszytu 6 z 1947 r. przed spisem treści pod nagłówkiem Od redakcji na ostatniej stronie czasami drukowano zapowiedź zawartości najbliższych numerów ${ }^{1174}$. W rubryce wyjaśniano również przyczynę wzrostu kosztów za miesięcznik. Niekiedy redakcja na początku artykułu drukowała notę wprowadzającą do problematyki w nim poruszanej lub zapoznawała z okolicznościami jego powstania $^{1175}$. Czasem ukazywała się też nota biograficzna o autorze wraz z jego dorobkiem literackim ${ }^{1176}$.

Pierwszy rocznik zawierał 3 numery o łącznej liczbie 368 stron. Każdy zeszyt pokaźny objętościowo liczył zazwyczaj około 90-100 stron, były też zeszyty liczące sto kilkadziesiąt stron (140). Artykuły ukazujące się na łamach miesięcznika miały różną objętość, od kilku do kilkudziesięciu stron. W obrębie rocznika obowiązywała ciągła numeracja. Nakład wynosił 7-15 tysięcy egzemplarzy ${ }^{1177}$. Formy wypowiedzi były urozmaicone; m.in. przedruki artykułów z prasy europejskiej (francuskiej, angielskiej, szwajcarskiej, austriackiej) i amerykańskiej - wy-

${ }^{1169}$ Redakcja, Do czytelników, „Znak” 1950 nr 1 s. 89.

1170 „Znak” $1951 \mathrm{nr} 1$ s. redakcyjna.

${ }^{1171}$ Komunikat, „Znak” 1951 nr 1 s. 88.

1172 Administracja, Komunikat, „Znak” 1951 nr 2 s. 184.

1173 „Znak” 1946 nr 1 s. 140.

${ }^{1174}$ Np. Od redakcji, „Znak” 1947 nr 6 s. 688; „Znak” 1949 nr 1 s. 96.

$1175 \mathrm{~Np}$. taką notę zamieszczono we wstępie do artykułu K.L. Konińskiego, Ku pewności, „Znak” 1949 nr 1 s. 1-19. Poinformowano w niej, że artykuł pochodzi z teki pośmiertnej autora, zawiera luki spowodowane niemożnością odczytania fragmentów rękopisu, a tezy w nim zawarte mogą „,budzić zastrzeżenia”, za które redakcja nie brała odpowiedzialności.

1176 Nota o Grahamie Green'ie, „Znak” 1949 nr 6 s. 489-490.

1177 D. Patkaniowska, ,Znak”... s. 1229; D. Wielgat w Bibliografii katolickich..., s. 102 podała nakład: 15 tys. -4 tys. -5 tys. egz. 
korzystywano tu takie tytuły jak „Espirit” $i$ „Ètudes” ${ }_{1178}$, „Etudes Carmélitaines” ${ }_{1179}$, „Reader's Digest"1180, „The Tablet”"181, „Time"1182, „Combat”"183, „Nouvelle Revue Théologique"1184; „l'Illustré”, „Die Furche”"185, „Chemins du Monde”"1186. Powoływano się ponadto na wypowiedzi z „Le Bulletin des Missions” ${ }^{1187}$, „La Vie Intellectuelle"1188, „Le Vie Spirituelle”"1189, „Jeunesse de l'Eglise”"190 i rodzimego „Tygodnika Powszechnego”. Posługiwano się różnymi gatunkami literackimi i dziennikarskimi: fragmentami większych całości - książek ${ }^{1191}$, powieścią w odcinkach, recenzjami, kazaniami ${ }^{1192}$, listami ${ }^{1193}$, listami pasterskimi, przemówieniami i mowami ${ }^{1194}$ oraz orędziami ${ }^{195}$.

\section{Zawartość i działy pisma}

Dwa stałe działy towarzyszyły pismu w latach 1946-1953: część artykułowa i Zdarzenia - ksiazzki - ludzie. Na łamach „Znaku” w pierwszej, najobszerniejszej części (s.1-120) podejmowano przede wszystkim zagadnienia światopoglądowe.

${ }^{1178}$ Np. enuncjacja kardynała A. Liénart, Chrześcijanin wobec postępu wiedzy, „Znak” 1948 nr 1 s. 45-53 z grudniowego numeru „Ėtudes” z 1947 r.; wypowiedź C.E. Magny, Mit Ilissesa czyli zwycięstwo Eliot' a, „Znak” 1949 nr 3 s. 269-272 - przedruk z sierpniowego numeru „Espirit” z 1948 r.; List z Niemiec, tamże, nr 7 s. 609-612 - przedruk z sierpniowego „Espirit” z 1949 r.

${ }^{1179} \mathrm{~Np}$. J. Golm. [J. Golmont], Tajemnica radości, „Znak” $1950 \mathrm{nr} 2$ s. 153-158.

${ }^{1180}$ Np. Biolog - świadkiem wiary, „Znak” $1948 \mathrm{nr} 1 \mathrm{s.}$ 77-82.

${ }^{1181}$ M. Str., Miecz proroka, „Znak” 1948 nr 1 s. 92-94; Kościół a konstytucja USA,„Znak” 1949 nr 1 s. 88-91; ,ZZasięg umystu”, tamże, nr 3 s. 281-282.

1182 B.R., O wspótczesnej sztuce religijnej, „Znak” 1948 nr 1 s. 94-95.

${ }^{1183}$ K. Horodyska, Echa śmierci Gandhiego w prasie francuskiej, ,Znak” 1948 nr 2 s. 164-169.

1184 J. Daniélou, Myśl chrześcijańska, „Znak” 1948 nr 4 s. 365-372.

1185 Ucieczka przed dzieckiem, „Znak” $1948 \mathrm{nr} 4$ s. 380-381.

1186 Sto. [S. Stomma], Zdarzenia-książki-ludzie, Czy katastrofa cywilizacji?, „Znak” 1947 nr 7 s. 757-760; Los jednostki w świecie wspótczesnym, „Znak” 1948 nr 4 s. 372-377.

${ }^{1187}$ Zdarzenia-książi-ludzie. Dzieło misyjne wobec problemu kultur narodowych, „Znak” 1949 nr 1 s. 86-88.

${ }^{1188}$ M., Zdarzenia-książki-ludzie. O swobodę dyskusji w Kościele, „Znak” 1949 nr 2 s. $182-183$.

${ }^{1189}$ F.K., Kongres muzyki kościelnej, „Znak” 1950 nr 5 s. 451-453.

${ }^{1190}$ Zdarzenia-ksiązki-ludzie. Niewiara wierzacych, „Znak” 1949 nr 3 s. 255-262.

${ }^{1191}$ K. Michalski, Heroizm chrześcijański, „Znak” 1948 nr 2 s. 97-129. Na końcu redakcja informuje, że jest to fragment większej całości, która ukaże się w bieżącym roku nakładem Wydawnictwa Mariackiego.

${ }^{1192}$ M. Riquet, Katolik wobec przemian społecznych, „Znak” 1948 nr 3 s. 269-275.

${ }^{1193}$ P. Claudel, List do przyjaciela, „Znak” 1948 nr 2 s. 150-152.

${ }^{1194}$ E. Gilson, Ulubionym tworem Bożym jest rozum: (mowa akademicka), „Znak” $1948 \mathrm{nr} 3$ s. $232-245$.

1195 „Zmyst Boży”: (le sens de dieu): wielkopostne orędzie kardynała E. Suharda, „Znak” 1948 nr 4 s. 326-360; Z orędzia Prymasa Polski do narodu, „Znak” 1949 nr 2 s. 97-98. 
Przeważała problematyka społeczna ${ }^{1196}$, filozoficzna ${ }^{1197}$ (w tym tomizm ${ }^{1198}$ ) i religijna ${ }^{1199}$. Najczęściej gościła problematyka chrześcijańska ${ }^{1200}$, teologiczna ${ }^{1201}$ (seria artykułów ks. Wincentego Granata m.in. dotycząca modlitwy, łaski ${ }^{1202}$ ) i katolic$\mathrm{ka}^{1203}$. Ustosunkowywano się także do niektórych zagadnień apologetycznych ${ }^{1204}$ czy ewolucjonizmu ${ }^{1205}$. Ksiądz Kazimierz Kłósak polemizował z zakwestionowaniem dowodu istnienia Boga przez Adama Shaffa w książce Wstęp do teorii marksizmu ${ }^{1206}$, filozoficzny dowód na istnienie Boga omówił w kolejnym artykule ojciec Albert Krąpiec ${ }^{1207}$. Braku sprzeczności między wiedzą a wiarą dowodził ks. Zbigniew Bonawentura Fróg ${ }^{1208}$. Na temat Całunu Turyńskiego pisał ks. Eugeniusz Dąbrowski ${ }^{1209}$, natomiast o konflikcie duszy i ciała Gustave Thibon ${ }^{1210}$.

Redakcja zamieszczała ponadto orędzia kardynałów i prymasa ${ }^{1211}$. W sposób zdawkowy, bez komentarza redagujących informowano o bieżących sprawach

${ }^{1196}$ J. Turowicz, W stronę uspolecznienia, „Znak” 1946 nr 1 s. 63-92; S. Stomma, Maksymalne i minimalne tendencje społeczne katolików, tamże, nr 3 s. 257-275;

${ }^{1197}$ K. Michalski, Dokąd idziemy?, „Znak” 1946 nr 1 s. 4-25; W. Tatarkiewicz, Filozofia Newmana, „Znak” 1948 nr 1 s. 1-7; K. Kłósak, Podziat kierunków filozoficznych u diamatyków, „Znak” 1951 nr 2 s. 126-140; A. M. Krąpiec, Zdrowy rozsądek i filozofia, „Znak” 1952 nr 3 s. 185-201.

${ }^{1198}$ S. Świeżawski, Dlaczego tomizm?, „Znak” 1946 nr 2 s. 153-181; M. Klepacz, Święty Tomasz na tle dziejów myśli ludzkiej, „Znak” 1948 nr 3 s. 193-221; W. Granat, O nowe spojrzenie na tomizm, tamże, nr 7 s. 604-617; I. Bocheński, ABC tomizmu, „Znak” 1950 nr 2 s. 89-126; A. Krąpiec, Egzystencjalizm tomistyczny, „Znak” $1951 \mathrm{nr} 2$ s. 108-123.

${ }^{1199}$ H. Malewska, Faryzeizm, „Znak” 1946 nr 3 s. 315-321; J. Maritain, Wielkość i nędza metafizyki, „Znak” 1948 nr 6 s. 525-543; R. Schneider, Człowiek przed sądem historii, „Znak” 1952 nr 3 s. 202-213.

${ }^{1200}$ G.K. Chesterton, Świadectwo heretyków, „Znak” 1947 nr 5 s. 541-56; K. Michalski, Heroizm chrześcijański, „Znak” 1948 nr 2 s. 97-129; A. Liénart, Chrześcijanin wobec postęu wie$d z y$, tamże, nr 1 s. 45-53; J. Maritain, Problem Królestwa Bożego, „Znak” 1949 nr 7 s. 521-530.

1201 J.W. Kowalski, Nowe kierunki teologii, „Znak” 1948 nr 1 s. 8-23; K. Kłósak, Metoda badań natury duszy, „Znak” $1950 \mathrm{nr} 1$ s. 13-26; J.W. Kowalski, Nowe kierunki w teologii, tamże, nr 3 s. 194-206.

1202 W. Granat, Istota modlitwy, „Znak” 1949 nr 6 s. 463-476; tenże, Gtód taski, „Znak” 1950 nr 1 s. 1-12; tenże, Natura a laska, tamże, nr 3 s. 207-221.

${ }^{1203}$ A. Gołubiew, Dlaczego jestem katolikiem?, „Znak” 1951 nr 1 s. 28-66; A. Bardecki, Typy powotania kaptańskiego, „Znak” 1952 nr 2 s. 117-133.

${ }^{1204}$ W. Kwiatkowski, Experimentum fidei w apologetyce nowoczesnej, „Znak” $1949 \mathrm{nr} 3$ s. $226-244$.

${ }^{1205}$ K. Kłósak, Czy upadek ewolucjonizmu antropologicznego?, „Znak” 1949 nr 4 s. 300-307; W. Eborowicz, Aktualne zagadnienia biblijne w świetle encykliki Humani Generis, „Znak” $1951 \mathrm{nr} 4$ s. 302-322.

${ }^{1206}$ K. Kłósak, Kinetyczny dowód istnienia Boga wobec nowych zarzutów, „Znak” $1949 \mathrm{nr} 5$ s. $392-401$.

${ }^{1207}$ A. Krąpiec, Raz jeszcze o kinetycznym dowodzie istnienia Boga, „Znak” $1950 \mathrm{nr} 4$ s. $281-295$.

${ }^{1208}$ Z.B. Fróg, Watykan przeciwko nauce?, ,Znak” 1952 nr 3 s. 226-232.

${ }^{1209}$ E. Dąbrowski, Sprawa Całunu Turyńskiego, „Znak” 1950 nr 4 s. 309-321.

${ }^{1210}$ G. Thibon, Niechaj czlowiek nie rozłacza ..., „Znak” $1950 \mathrm{nr} 5$ s. 378-397.

1211 E. Suhard, , Zmyst Boży”. Wielkopostne orędzie, „Znak” 1948 nr 4 s. 326-360. 
w stosunkach Kościoła z państwem. Ograniczono się w zasadzie do drukowania tekstów oficjalnych dokumentów, m.in. porozumienia kwietniowego i oświadczenia sekretarza Episkopatu Polski biskupa Z. Choromańskiego dotyczące Apelu Sztokholmskiego ${ }^{1212}$.

Ważny blok tematyczny stanowiła problematyka kulturalna ${ }^{1213}$ (głównie z zakresu kultury katolickiej) ${ }^{1214}$ i literacka. Omawiano twórczość znanych polskich i obcych poetów, pisarzy oraz dramaturgów m.in. Cypriana Kamila Norwida, Adama Mickiewicza, Stefana Żeromskiego, Jerzego Bernanosa, Thomasa Stearnsa Eliota, Lwa Tołstoja, Jerzego Lieberta, Jerzego Zawieyskiego ${ }^{1215}$. Rzadziej w miesięczniku drukowano wiersze ${ }^{1216}$. Sporadycznie zajmowano się problematyką sztuki ${ }^{1217}$. Pismo zamieszczało liczne recenzje książek, fragmenty dramatów, powieści i pamiętników ${ }^{1218}$, opowiadania ${ }^{1219}$, fragmenty książek ${ }^{1220}$. Wypowiadano się też o dramacie chrześcijańskim ${ }^{1221}$ i literaturze katolickiej ${ }^{1222}$. Na początku 1951 r. redakcja ogłosiła ankietę dla czytelników „Znaku”, zadając pytanie o książki ostatniego stulecia, które odegrały największą rolę w kształtowaniu poglądu na świat i postawy moralnej ${ }^{1223}$.

1212 Z. Choromański, Kościót jest za pokojem, „Znak” 1950 nr 3 s. 185-186.

1213 C. Dawson, U podtoża kultury, „Znak” 1949 nr 5 s. 377-391.

1214 J. Salamucha, O katolicka kulturę intelektualna, ,Znak” 1947 nr 5 s. 481-499; J. Turowicz, Sprawa kultury katolickiej w Polsce, tamże, s. 500-540.

${ }^{1215}$ M. Morstin-Górska, Norwid a wspótcześni, „Znak” 1948 nr 1 s. 27-44; J.M. Święcicki, Z tragedii wielkiego humanisty, tamże, nr 2 s. 137-149; I. Sławińska, Jerzy Bernanos, „Znak” 1948 nr 5 s. 385-397; W. Dulęba, Poezja T. S. Eliota, tamże, nr 7 s. 623-627; I. Sławińska, Groza stowa. (O poezji Jerzego Lieberta), „Znak” 1949 nr 2 s. 118-133; S. Skwarczyńska, Dramat Jerzego Zawieyskiego, „Znak” nr 3 s. 200-225; W. Borowy, O wierszach religijnych Mickiewicza, tamże, nr 7 s. 531-547; M. Morstin-Górska, Tragedia Lwa Totstoja, „Znak” 1951 nr 2 s. 89-107.

1216 T.S. Eliot, Wiersze, „Znak” 1948 nr 7 s. 628-633; J. Liebert, Wiersze, „Znak”1949 nr 2 s. $150-155$.

${ }^{1217}$ L. Niemojewski, Świat sztuki, „Znak” 1950 nr 4 s. 265-280; J. Zawieyski, Problemat artysty, „Znak” $1951 \mathrm{nr} 3$ s. 202-220; J. Woźniakowski, Pierwiastki religijne w sztuce plastycznej, tamże, s. 221-228; L. Niemojewski, Orędowniczka z Torcello, „Znak” 1952 nr 4 s. 255-267.

${ }^{1218}$ M.in. A. Gołubiewa, Adam, „Znak” 1948 nr 3 s. 246-263; A. de Saint-Exupéry, Cytadela, „Znak” 1949 nr 5 s. 403-409; tenże, Pilot bojowy, tamże, s. 409-415; Przeżyła czasów wiele, „Znak” $1950 \mathrm{nr} 1 \mathrm{s.} 33-53$.

${ }^{1219}$ Np. J. Zawieyskiego, Koniec ucieczki, „Znak” 1949 nr 7 s. 548-550.

${ }^{1220}$ Np. T. Mertona, Posiew kontemplacji, „Znak” 1952 nr 1 s. 17-40; tamże, nr 2 s. 134-159; tamże, nr 3 s. 214-225; tamże, nr 4 s. 268-286; „Znak” 1953 nr 1 s. 28-41.

${ }^{1221}$ W. Ostrowski, Zdarzenia - książki - ludzie. Nowy dramat chrześsijański w W. Brytanii, „Znak” 1949 nr 4 s. 367-371; Z. Nosalewska, Dramat chrześcijański Claudela, tamże, nr 7 s. $578-583$.

1222 S. Skwarczyńska, ,Literatura katolicka” jako termin w nauce o literaturze, „Znak” 1950 nr 3 s. 222-233; J. Dobraczyński, Postać księdza we wspótczesnej literaturze katolickiej, „Znak” 1953 nr 1 s. $1-27$.

${ }^{1223}$ Redakcja, Ankieta, „Znak” 1951 nr 3 s. 276-277. 
Podobnie jak na łamach innych katolickich czasopism społeczno-kulturalnych tego okresu poruszano $\mathrm{w}$ artykułach zagadnienia niemieckie ${ }^{1224} \mathrm{i}$ dotyczące Ziem Odzyskanych ${ }^{1225}$. Rzadziej podejmowano zagadnienia historyczne ${ }^{1226} \mathrm{i}$ wychowawcze ${ }^{1227}$.

Realizując założenia programowe personalizmu (nie zawsze katolickiego w rozumieniu Mouniera ${ }^{1228}$ ), zapoznawano czytelników ze współczesnymi prądami umysłowymi we Francji ${ }^{1229}$. Drukowano wypowiedzi francuskich intelektualistów, np. Stanisława Fumeta ${ }^{1230}$, dominikanina Antonina Dalmatiusa Sertillangesa ${ }^{1231}$ oraz „bezimienne wypowiedzi świeckich katolików”1232. Odnoszono się także do katolicyzmu w relacji do innych światopoglądów i kierunków politycznych, m.in. wobec marksizmu ${ }^{1233}$. Pisano o prawdzie ${ }^{1234}$, wierze ${ }^{1235}$, życiu ${ }^{1236}$, naturze osoby ludzkiej ${ }^{1237}$, rozumieniu piękna ${ }^{1238}$ i miłościci ${ }^{1239}$. W pierwszym dziale „uznano za słuszne, aby poruszyć zagadnienie nowoczesnej sztuki religijnej” w celu wywołania szerszej dyskusji publicznej ${ }^{1240}$, ze względu na to, że temat został zapomniany. Redakcja „Znaku” opracowała ankietę, w której zadano cztery pytania ${ }^{1241}$. Rozesłała ją do

${ }^{1224}$ L. Halban, Problem kultury niemieckiej, „Znak” 1946 nr 1 s. 26-50; Niemcy o sobie. Czy naród niemiecki jest winien?, „Znak” 1947 nr 6 s. 666-676.

${ }^{1225}$ P. Jasienica, Prawo stabszych, „Znak” 1948 nr 4 s. 289-303.

1226 J.J. Szczepański, Zapomniana wielkość historyczna, „Znak” 1949 nr 2 s. 156-167; A. Gołubiew, Tysiaclecie, „Znak” 1950 nr 3 s. 187-193; H. Malewska, Alfred Wielki w historii i legendzie, „Znak” 1951 nr 2 s. 141-157.

${ }^{1227}$ P. Chojnacki, O wychowaniu i charakterze, „Znak” 1952 nr 2 s. 97-116.

${ }^{1228}$ Emmanuel Mounier, będąc jednym z czołowych przedstawicieli lewicy katolickiej oraz twórcą nurtu tzw. personalizmu otwartego, w 1932 założył miesięcznik „Esprit”.

1229 J. Daniélou, Życie umystowe we Francji, „Znak” 1946 nr 1 s. 93-109; Redakcja, Dyskusje między katolikami francuskimi, tamże, nr 3 s. 284-286; E. Mounier, Przekrój ideowy Francji roku 1946, tamże, s. 287-305.

${ }^{1230}$ S. Fumet, Ecce homo, „Znak” 1947 nr 4 s. 369-373.

${ }^{1231}$ A.D. Sertillanges, Rzeczywistość niewidzialna, „Znak” 1949 nr 6 s. 477-488.

${ }^{1232}$ My-ludzie z ulicy, „Znak” 1949 nr 6 s. 506-509.

1233 J. Turowicz, Katolicyzm i radykalizm, „Znak” 1947 nr 4 s. 374-389; J. Daniélou, Chrześcijanin wobec marksizmu, tamże, nr 6 s. 612-620.

${ }^{1234}$ B. Suchodolski, O prawdzie, „Znak” 1947 nr 4 s. 390-409; W. Granat, Wartość prawdy, „Znak” 1949 nr 2 s. 99-117.

${ }^{1235}$ G.K. Chesterton, Pięć zgonów wiary, „Znak” 1947 nr 7 s. 733-740.

${ }^{1236}$ B. Suchodolski, O wielorakości życia czlowieka, „Znak” $1948 \mathrm{nr} 5$ s. 417-444; tenże, Dwie osie życia ludzkiego, „Znak” 1949 nr 1 s. 33-57.

${ }^{1237}$ S. Świeżawski, Osoba ludzka - jej natura i zadania, „Znak” 1950 nr 5 s. 361-377.

1238 Tenże, Wytwórczość a piękno, „Znak” $1951 \mathrm{nr} 3$ s. 185-201.

${ }^{1239}$ W. Granat, Miłość przetwarzająca, „Znak” $1951 \mathrm{nr} 4$ s. 281-301.

${ }^{1240}$ Red., Problem nowoczesnej sztuki religijnej (Ankieta „Znaku”), „Znak” 1947 nr 7 s. 741.

${ }^{1241}$ Poproszono adresatów o wyrażenie opinii w następujących kwestiach: przyczyny upadku sztuki religijnej, istnienie we współczesnej sztuce religijnej wartościowych tendencji i osiągnięć, trudności i możliwości odrodzenia sztuki religijnej oraz sztuka religijna a współczesne potrzeby duchowe, „Znak” 1947 nr 7 s. 741. 
wybranych krytyków i artystów, po czym otrzymane odpowiedzi opublikowano w miesięczniku zachęcając czytelników do wyrażania opinii. Niekiedy w dziale artykułowym dawano nagłówek w wydaniu: Z pism klasyków katolicyzmu ${ }^{1242}$.

Od pierwszego zeszytu w spisie treści zamieszczonym na końcu tomu wyraźnie oddzielono część artykułową od działu Zdarzenia - ksiązki - ludzie (s. 121-136), który był stale obecny do 1953 r. Znalazły w nim odzwierciedlenie sprawy bieżące dotyczące kraju i zagranicy. Prezentowano tu m.in. informacje o reformach w Anglii, pogromie kieleckim Żydów, procesie w Norymberdze, zagadnienia $\mathrm{z}$ zakresu muzyki ${ }^{1243}$, sztuki ${ }^{124}$, teatru ${ }^{1245}$ i filmu ${ }^{1246}$. W Zdarzeniach... znalazły się również rozważania nt. literatury, informacje o nagrodach literackich i tytułach czasopism oraz recenzje książek ${ }^{1247}$. Podejmowano równocześnie poważniejsze problemy: katolicyzmu społecznego ${ }^{1248}$, stosunku egzystencjalizmu do chrześcijaństwa w przeglądzie prasy zagranicznej ${ }^{1249}$, szkolnictwa za granicą czy eutanazji ${ }^{1250}$. Znalazły się tu też przemówienia papieża z okazji świąt Bożego Narodzenia ${ }^{1251}$, listy pasterskie ${ }^{1252}$, sprawy misji ${ }^{1253}$, spotkań międzynarodowych ${ }^{1254}$ i zagranicznych kongresów katolickich ${ }^{1255}$. Wśród innych wątków wymienić warto tutaj wzmianki o bombie atomowej ${ }^{1256}$, ciekawostki astronomiczne ${ }^{1257}$, nowinki

1242 „Znak” 1949 nr 6 s. 477.

${ }^{1243}$ Muzyka wojenna, „Znak” 1949 nr 1 s. 91-92; F.K., Kongres muzyki kościelnej, „Znak” $1950 \mathrm{nr} 5$ s. $451-453$.

${ }^{1244}$ B.R., O współczesnej sztuce religijnej, „Znak” $1948 \mathrm{nr} 1$ s. 94-95; K.H., O nowa sztuke religijna, ,Znak” 1949 nr 5 s. 446-447; T.R., Kościół w Assy-odrodzenie sztuki religijnej, „Znak” 1951 nr 1 s. 86-87.

1245 J. Zagórski, Klopoty teatralne, „Znak” 1946 nr 3 s. 355-364; m., Dramat przeznaczenia ludzkiego w teatrze współczesnym, „Znak” $1950 \mathrm{nr} 3$ s. 258-264; „Barabasz” na scenie paryskiej, „Znak” $1951 \mathrm{nr} 2$ s. 174-175.

1246 W.T.J., Film katolicki, „Znak” 1948 nr 7 s. 663-665; A. Karyszkowska, ,,Międzynarodowy przeglad filmowy”, „Znak” $1949 \mathrm{nr} 3$ s. 283-286.

1247 M.J., Wznowienie „Hochland'u”, „Znak” 1948 nr 1 s. 87-88.

1248 K. Wick, Katolicyzm spoleczny na rozstajnych drogach, „Znak” 1948 nr 1 s. 90-92. [przedruk z szwajcarskiego czasopisma „Vaterland”]; M. Riquet, Katolik wobec przemian spotecznych, tamże, nr 3 s. 269-275; M.S., Ewolucja doktryny katolicko-społecznej, tamże, nr 5 s. 466-468 [przedruk z „Ètudes”].

1249 E. Mokłowska, Egzystencjalizm a myśl chrześcijańska, „Znak” 1948 nr 2 s. 169-174.

${ }^{1250}$ A. Witek, Problem eutanazji, „Znak” $1950 \mathrm{nr} 1$ s. 76-80.

${ }^{1251}$ Tragiczny paradoks, „Znak” 1948 nr 2 s. 159-163.

${ }^{1252}$ E.C. Suhard, Rozkwit czy zmierzch Kościoła?, „Znak” 1947 nr 6 s. 648-666.

1253 J.R. Łoniowski, Klopoty misyjne protestantów, „Znak” 1949 nr 5 s. 421-428; H. Dernałowicz, Świeckie misjonarki, tamże, nr 6 s. 510-513; J.R. Łoniowski, Wzrost zainteresowań misyjnych u protestantów, „Znak” $1950 \mathrm{nr} 1$ s. 64-73; K.H., „Ad Lucem”, tamże, nr 3 s. 250-251.

${ }^{1254}$ Międzynarodowe zjazdy katolickie, „Znak” $1948 \mathrm{nr} 1$ s. 82-84; W. Mańczak, O.N.Z. dyskutuje nad ,Karta praw człowieka”, tamże, nr 2 s. 177-180.

${ }^{1255}$ M.J., 73 Katholikentag, „Znak” 1949 nr 7 s. 607-609.

1256 Zdarzenia - ksiażki - ludzie, „Znak” 1947 nr 4 s. 461-469; W rok po eksperymencie na Bikini, ,Znak” 1948 nr 4 s. 382-383.

${ }^{1257}$ Astronomia w przededniu rewolucyjnych odkryć, „Znak” 1948 nr 2 s. 180-186. 
o wynalazkach naukowych i technicznych ${ }^{1258}$. Od numeru czwartego z $1947 \mathrm{r}$. wprowadzono więcej tematów i wiadomości przedstawiano bardziej skrótowo. Cyklicznie pisano o sytuacji katolicyzmu w innych krajach ${ }^{1259}$, o tradycji religii wschodnich $^{1260}$, o wznowieniu zagranicznych tytułów katolickich ${ }^{1261}$, o umysłowości mistyków ${ }^{1262}$, o zgonach znanych osób (np. Mahatmy Gandhiego, Emanuela Mouniera $^{1263}$ ). Z kolei od zeszytu czwartego z 1949 r. wprowadzono na krótko w ramach działu $Z$ żałobnej karty nekrologi ${ }^{1264}$. O śmierci kardynała Adama Sapiehy poinformowano na początku lipcowego zeszytu z 1951 r. ${ }^{1265}$ Stałe miejsce zarówno w części artykułowej, jak i w Zdarzeniach... znalazły portrety znanych filozofów ${ }^{1266}$, historyków ${ }^{1267}$, duchowych przywódców ${ }^{1268}$, duszpasterzy ${ }^{1269}$, kardynałów ${ }^{1270}$, teologów ${ }^{1271}$, przyszłych świętych ${ }^{1272}$ i świętych ${ }^{1273}$, zasłużonych kobiet $^{1274}$. Zabrakło powyższego działu jedynie w kilku edycjach „Znaku” (nr 4 z 1950 r. i 1-3 z 1952 r.)

${ }^{1258}$ Nowe maszyny matematyczne, „Znak” 1949 nr 2 s. 186-189; Z nowości naukowych, tamże, nr 4 s. 373-374; Z nowości naukowych, tamże, nr 7 s. 616; Z nowości naukowych, „Znak” $1950 \mathrm{nr} 1$ s. $85-86$.

1259 J.D., Wspótczesny katolicyzm angielski, „Znak” $1947 \mathrm{nr} 6$ s. 676-681; M. Tur., Katolicyzm w Stanach Zjednoczonych, tamże, nr 7 s. 769-773; Katolicy w Anglii $i$ Walii, „Znak” 1948 nr 4 s. 377-379; Kościól a konstytucja USA, „Znak” 1949 nr 1 s. 88-91; Życie umysłowe katolików angielskich, „Znak” 1950 nr 1 s. 80-84; B.M., Kościół katolicki w nowych Indiach, tamże, nr 2 s. 170-172.

1260 A.W., U Dalaj-Lamy i Penczen-Lamy, „Znak” 1950 nr 2 s. 179-184.

${ }^{1261}$ M.J., Wznowienie „Hochland'u”, „Znak” 1948 nr 1 s. 87-88.

1262 Umystowość mistyków, „Znak” 1951 nr 1 s. 80-85.

1263 Zdarzenia - ksią̇ki-ludzie. Echa śmierci Gandhiego w prasie francuskiej, „Znak” 1948 nr 2 s. 164-169; J. T., Umart Emanuel Mounier, „Znak” 1950 nr 2 s. 146-148.

${ }^{1264}$ M.in. nekrologi: o. Jacka Woronieckiego, kardynała Emanuela Suharda, pisarki i laureatki nagrody Nobla Sigrid Undset, „Znak” 1949 nr 4 s. 337.

${ }_{1265}$ Redakcja, Adam Stefan Sapieha, „Znak” 1951 nr 2 s. nlb.

${ }^{1266}$ B. Miciński, Portret Kanta, „Znak’ 1947 nr 6 s. 621-647; J. Turowicz, Testament x. Konstantego Michalskiego, „Znak” 1948 nr 2 s. 130-136.

1267 J. Turowicz, Christopher Dawson, „Znak” 1949 nr 5 s. 416-420.

${ }^{1268}$ H. Elzenberg, Gandhi w perspektywie dziejowej, „Znak” $1948 \mathrm{nr} 5$ s. 398-416; J. Turowicz, O. Jacek Woroniecki, „Znak” 1949 nr 4 s. 338-343.

${ }^{1269}$ Quidam [A. Górski], Ksiądz Władystaw Korniłowicz, „Znak” 1947 nr 6 s. 593-611.

1270 J. Zawadzki, Zdarzenia - ksiażki-ludzie. Kardynat Mercier, „Znak” 1951 nr 2 s. 158-164.

1271 R., Karl Barth, „Znak” 1950 nr 3 s. 248-249.

1272 M. Morstin-Górska, Wobec heroizmu realistycznego. O Bracie Albercie, „Znak” $1946 \mathrm{nr} 2$ s. 143-152; Zdarzenia - ksiązki - ludzie. W drodze do Nazaretu [o Karolu de Foucauld], „Znak” $1951 \mathrm{nr} 1$ s. $78-80$.

1273 Joinville, Z „Żywota św. Ludwika”, „Znak” 1948 nr 2 s. 153-158; M. Winowska, Św. Elżbieta Węgierska, „Znak” 1949 nr 1 s. 20-32; H. Dernałowicz, Zdarzenia - książki - ludzie. Święty - pustelnik - polityk [Mikołaj de Flue], tamże, nr 3 s. 262-266; J.R. Łoniowski, Zdarzeniaksiązki-ludzie. Japonia czci św. Franciszka Ksawerego, tamże, nr 7 s. 603-607.

${ }^{1274} \mathrm{~Np}$. M. Morstin-Górska, Dwie postacie kobiece francuskiego ruchu oporu Simone Weil i Marietta Martin, „Znak” 1949 nr 7 s. 589-602. 
Na końcu działu w Kronice obecny był przegląd wiadomości z różnych czasopism, najczęściej z „Twórczości”, „Nauki i Sztuki”, „Tygodnika Powszechnego”, „Tygodnika Warszawskiego”, „Dziś i Jutro”, „Odrodzenia” czy „Kuźnicy”1275. Redakcja na kilku stronach w sposób krytyczny odnosiła się do najważniejszych i najciekawszych artykułów z przeglądu polskiej prasy. Praktyka przeglądu prasy zaniknęła w kolejnych latach.

Po dziale Zdarzenia - ksiązki - ludzie niekiedy drukowano Sprostowania, natomiast w rubryce Do czytelników zwracano się z naglącymi sprawami. W drugiej z wymienionych rubryk powiadamiano odbiorców o posiadaniu poprzednich roczników „Znaku”, które można było nabyć pojedynczo lub w kompletach ${ }^{1276}$. Książki nadesłane do redakcji lub Spis książek nadesłanych do redakcji zamieszczano na ostatnich stronach. Rzadko ostatnie strony zajmowały reklamy (tytułów prasowych i książek).

Część zatytułowana Poszukiwania (licząca 19 stron) pojawiła się jednokrotnie (nr 4 z 1947 r.) pomiędzy częścią artykułową a Zdarzeniami..., podobnie też Fragmenty piśmiennictwa średniowiecznego (nr 3 z 1948 s. 264-268) i kolumna pod nagłówkiem List do redakcji. W tej ostatniej zacytowano wypowiedź czytelniczki „Znaku” na temat Całunu Turyńskiego ${ }^{1277}$.

\section{Kontakty z czytelnikami}

Od drugiego zeszytu pojawiła się rubryka Do czytelników, czasem Do naszych czytelników. W niej redakcja przeważnie przepraszała za opóźnienie w wydawaniu pisma, informowała o wzroście kosztów prenumeraty i wszelkich problemach związanych z kolportażem periodyku ${ }^{1278}$.

Od początku tworzący pismo, nie chcąc narzucać swoim odbiorcom „strawy duchowej”, zachęcali do współpracy: „Przedstawiając czytelnikom $<<$ Znaku $>>$ problemy, żywo nas obchodzące [...] pragniemy usłyszeć w zamian opinie, postulaty, sprzeciwy, wątpliwości lub aprobatę"1279. Oczekiwano zatem dialogu listowego oraz nadsyłania różnorodnych materiałów do działu Zdarzenia - książki - ludzie, który w zamiarze redagujących miał stać się z czasem „zwierciadłem współczesności" 1280 . Nie obiecywano jednocześnie spełnienia wszystkich życzeń. W ostatnim numerze z 1950 r. powiadamiano o przejęciu rozprowadzania „Znaku” przez Państwowe Przedsiębiorstwo Kolportażu „Ruch”, w związku

1275 „Znak” 1946 nr 1 s. 121-136; tamże, nr 2 s. 224-254.

${ }^{1276}$ Roczniki: 1-2 (numery 1-7) kosztowały 275 zł, 3 (numery 8-14) - 525 zł, komplet - 800 zł. Do czytelników, „Znak” 1949 nr 3 s. 288.

1277 W. Weiss-Dąmbska, List do redakcji, „Znak” 1950 nr 5 s. 455-456.

1278 Do naszych czytelników, „Znak” 1946 nr 3 s. 369; „Znak” 1947 nr 4 s. nlb.

1279 Redakcja, Do czytelników, „Znak” 1946 nr 2 s. 254.

1280 Tamże. 
z czym należało wpłacać za prenumeratę z góry na konto i adres PPK „Ruch” - „Tygodnik Powszechny” (,Znak”) Karków, ul. Lubicz 42. Zwrócono się jednocześnie z apelem do czytelników, którzy dotąd nabywali periodyk w sprzedaży, aby zechcieli zostać prenumeratorami ${ }^{1281}$.

Zgodnie z zapowiedzią podjęto $\mathrm{w}$ Zdarzeniach... bardzo różnorodną problematykę, np. bezpieczeństwa w dobie broni atomowej ${ }^{1282}$, reformy szkolnictwa we Francji ${ }^{1283}$. Przy ważnych okazjach redakcja zwracała się do czytelników bardziej osobiście. Pisano: „Są ludzie, których imionami nazywane są epoki. Gandhi do nich należał. [...] Śmierć jego jest sprawą całej ludzkości [...]"1284. W numerze 2 z 1948 r. pojawiły się rubryki w Zdarzeniach ... uściślające poruszaną problematykę, a zatytułowane Nowe drogi nauki i Nowe problemy prawne.

Artykuły przybliżające czytelnikom ludzi i ich dorobek twórczy były raczej obszerne (20-30 stron). Niektóre zeszyty miały charakter monograficzny, np. poglądom kardynała Johna Henry’ego Newmana poświęcono zeszyt 1 z 1948 r., przedstawiając jego myśl filozoficzną, teologiczną i fragmenty rozważań. Omówiono także poglądy filozoficzne Władysława Tatarkiewicza ${ }^{1285}$ i ks. biskupa Michała Klepacza ${ }^{1286}$ oraz zapoznano z teologicznymi wypowiedziami o. Jana Wierusza-Kowalskiego ${ }^{1287}$. Niekiedy okazją do opracowania wspomnień była śmierć znanej osobistości Kościoła ${ }^{1288}$. Jak przystało na pismo katolickie, nie zabrakło również życiorysów osób kanonizowanych lub pretendujących do tego miana $^{1289}$.

\section{Szata graficzna}

Jednokolorową i stonowaną okładkę podzielono na trzy części. Oprócz dużego i pogrubionego tytułu, zajmującego $1 / 3$ strony wraz z podtytułem „miesięcznik", widniały na niej spis zawartości zeszytu (imiona i nazwiska autorów wraz z tytułami artykułów) oraz nazwy miast Kraków-Łódź-Lublin, numer rocznika, miesiąc i rok ukazania. W prawym dolnym rogu za pomocą dużej

${ }^{1281}$ Redakcja, Do czytelników, „Znak” 1950 nr 5 s. 456.

1282 Warunki bezpieczeństwa $w$ dobie broni atomowej (wg. The Saturday Evening Post), „Znak” 1946 nr 3 s. 338-341.

1283 Wokót reformy szkolnictwa we Francji, „Znak” 1946 nr 3 s. 350-352.

${ }^{1284}$ Redakcja, Gandhi, ,Znak” 1948 nr 1 s. 96.

1285 W. Tatarkiewicz, Filozofia Newmana, ,Znak” 1948 nr 1 s. 1-7.

${ }^{1286}$ M. Klepacz, Święty Tomasz na tle dziejów myśli ludzkiej, „Znak” 1948 nr 3 s. 193-221.

1287 J.W. Kowalski, Nowe kierunki teologii: problem wiary w teologii angielskiej, „Znak” 1948 nr 1 s. $8-23$.

1288 J. Turowicz, Testament x. Konstantego Michalskiego, ,Znak” 1948 nr 2 s. 130-136.

${ }^{1289}$ M. Morstin-Górska, Wobec heroizmu realistycznego: o Bracie Albercie, „Znak” $1946 \mathrm{nr} 2$ s. 143-152; Joinville, Z „Żywota świętego Ludwika”, „Znak” 1948 nr 2 s. 153-158. 
cyfry oznaczano kolejny zeszyt. Jedynym urozmaiceniem szaty graficznej czasopisma była kolorowa czcionka na okładce, np. w numerze 4 z 1947 r. zastosowano czerwoną. Wygląd „Znaku” z założenia był dość skromny. Niektóre działy posiadały mniejszą czcionkę, druk był jednoszpaltowy. Ostatnią stronicę zajmował napis In hoc signo vinces. Nie wydawano zeszytów okolicznościowych i świątecznych.

Il. 19. Pierwszy zeszyt „Znaku” z 1946 r.

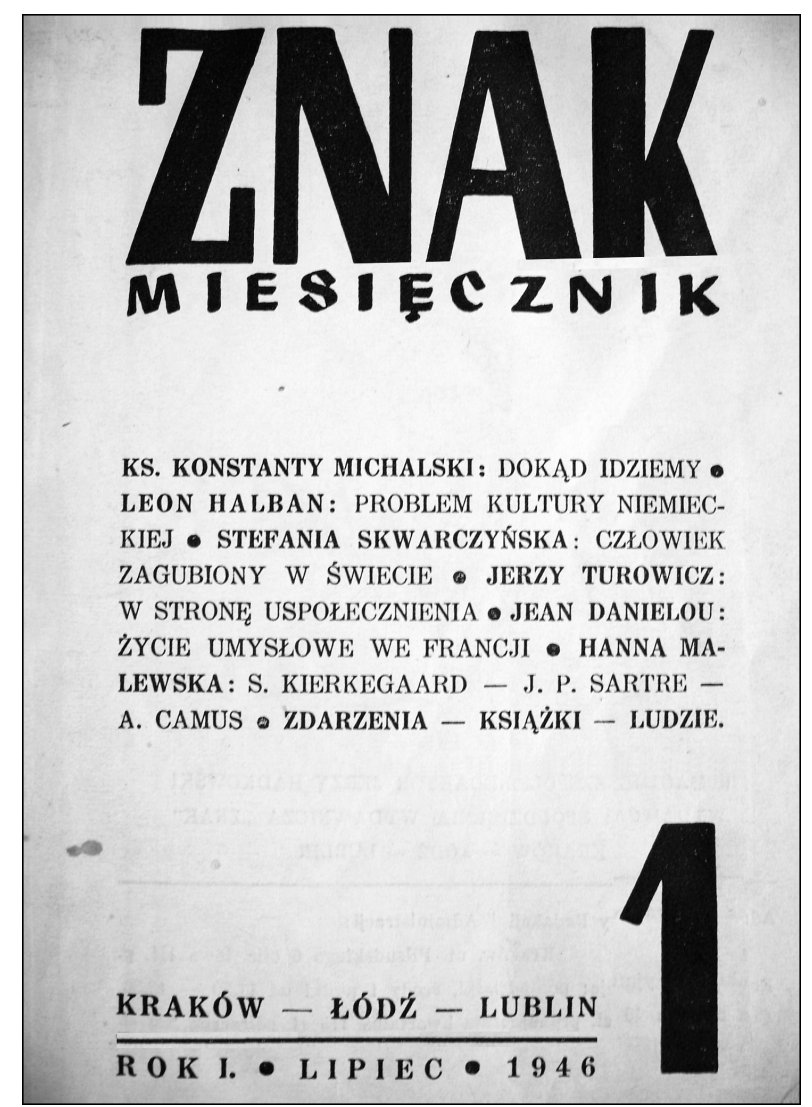

Źr ódło: Ze zbiorów BUŁ.

Ukazujący się nieregularnie miesięcznik „Znak” posiadał nieco odmienny charakter od dotychczas omówionych czasopism społeczno-kulturalnych. Jego łamy zapełniały często rozważania religijne i filozoficzne, dzięki którym zyskał miano bardziej elitarnego periodyku. Niezwykle skromna szata graficzna współgrała z wysoce intelektualną zawartością. 


\subsection{6. „Przegląd Powszechny” (1947-1953)}

Po II wojnie światowej wznowiono „Przegląd Powszechny” - pismo jezuickie o długiej tradycji wydawniczej ${ }^{1290}$. Miesięcznik zachował charakter religijny, kulturalny i społeczny, o czym informowano w podtytule. W pierwszym, grudniowym, numerze, a kolejnym 224 tomie ${ }^{1291}$, czytamy: „Zdaje nam się, że $<<$ Przegląd Powszechny >> nie musi się publiczności polskiej przedstawiać. Nie zjawia się bowiem dopiero dziś [...] Przeciwnie, należy on do najstarszych w Polsce czasopism w ogóle" ${ }^{1292}$. W okresie powojennym periodyk o charakterze elitarnym posiadał nadal zasięg ogólnopolski ${ }^{1293}$.

\section{Redakcja i wspólpracownicy pisma}

Współpracowników „Przeglądu Powszechnego” wspominano w następujący sposób: „Jego wczorajsi pionierzy wyginęli prawie wszyscy na swych posterunkach lub w koncentracyjnych obozach. Na ich miejsce przychodzą inni, młodsi. Zmienia się obsada, ale dzieło trwa [...] o wyraźnie zakreślonym obliczu" ${ }^{1294}$. Na końcu grudniowego zeszytu z 1947 r. widniała informacja: „Redagują pisarze Towarzystwa Jezusowego"1295. Redaktorem naczelnym w latach 1947-1952 był Stanisław Wawryn. Na kilka miesięcy przed zamknięciem tytułu prasowego w latach 1952-1953 redakcję objął Jan Piwiński, który zredagował zaledwie trzy ostatnie numery ${ }^{1296}$.

Wśród piszących na łamach „Przeglądu Powszechnego” zachowano nadal zasadę trzech grup. Pierwszą tworzyli ojcowie jezuici związani z wydawnictwem i wykładowcy jezuiccy, drugą - księża duchowni nie należący do zakonu jezu-

${ }^{1290}$ Pierwszy numer „Przeglądu Powszechnego” [dalej „PP”] ukazał się w 1884. W okresie wydawania pisma istniejącego do dziś można wyróżnić kilka etapów: 1884-1939 (z przerwą w 1. 1914-1915), 1947-1953 i od 1982 r. do chwili obecnej. Redaktorami naczelnymi byli jezuici: założyciel Marian Morawski (w 1. 1884-1901), Stanisław Kobyłecki (1901-1902), Jan Pawelski (1902-1918), Jan Urban (1919-1933), Jan Rostworowski (1933-1936), Edward Kosibowicz (1936-1939). Najpierw wydawane w Krakowie, a następnie, od 1936 r., w Warszawie. Źródło: M. Jagiełło, Trwałość i zmiana. Szkice o „Przegladzie Powszechnym” 1884-1918, Warszawa 1993, s. 5; Z. Jakubowski, „Przegląd Powszechny” 1884-1985, Warszawa 1987, s. 82; J. Rostworowski, Pamięci trzech b. redaktorów „Przegladu”, „PP” 1947 nr 12 s. 14-20.

${ }^{1291}$ Tom poprzedni 223 zawarł zeszyty z lipca i sierpnia 1939 r. oraz został przerwany na stronie 208. Działania wojenne nie pozwoliły na ukazanie się numeru wrześniowego i spowodowały przerwę w wydawaniu pisma w 1. 1939-1946. „PP” 1947 nr 12 s. 2.

1292 Redakcja, „PP” 1947 nr 12 s. 3.

1293 Z. Jakubowski, ,,Przegląd Powszechny”1884-1985 ..., s. 163.

${ }^{1294}$ Redakcja, „PP” 1947 nr 12 s. 3.

1295 „PP” 1947 nr 12 s. 80.

1296 Z. Jakubowski, ,, Przeglad Powszechny” 1884-1985 ..., s. 53. 
itów, trzecią zaś osoby świeckie (profesorowie uniwersyteccy, literaci, artyści) ${ }^{1297}$. W okresie 1947-1953 wśród jezuitów wypowiadających się na łamach miesięcznika znaleźli się: Włodzimierz Kamiński, Aleksander Kisiel, Franciszek Macios, Józef Majkowski, Leon Mońko, Jan Popiel, Jan Popłatek, Walenty Prokulski, Jan Rosiak, Jan Rostworowski, Paweł Siwek, Franciszek Tokarz, Bogusław Waczyński, Stanisław Wawryn, Józef Wieteska i Kazimierz Wilczyński. Wypowiadali się oni raczej w odezwach i artykułach okolicznościowych. Liczne i zróżnicowane grono duchownych, którzy nie podlegali regule jezuickiej tworzyli biskupi i księża. Głos zabrali na łamach pisma m.in. prymas August Hlond, biskupi: Herbert Bednorz, Antoni Pawłowski, Wincenty Urban, oraz redaktorzy innych pism: Jan Piwowarczyk i Michał Rękas. Do grona współpracowników należeli także księża: Józef Dajczak, Franciszek Dziasek, Franciszek Jemelka, Kazimierz Kłósak, W. Kowalski, Zygmunt Kozubski, Anzelm Kubit, Józef Pastuszka, Marian Rzeszewski, Franciszek Sawicki, Alfons Schletz, Aleksander Usowicz, Eugeniusz Weron, Władysław Wicher, Józef Winkowski, Jacek Woroniecki, H. Zarembowicz. Krąg świeckich zasilili natomiast: Wojciech Bąk, Czesław Białobrzeski, Adam Bochniak, Maria Chojecka, Stanisław Chyliński, Paweł Czartoryski; w zakresie literatury: Wiktor Doda, Tadeusz Dworak, Tadeusz Grabowski, Władysław Konopczyński, Jan Korzonek, Zofia Starowiejska-Morstinowa, Irena Pannenkowa, Zbigniew Pędziński, Milada Pollakowa, Olgierd Porycki, Maria Winowska. $\mathrm{Na}$ temat kultury polskiej wypowiadali się m.in. Karol Górski, Konrad Górski, Kazimierz Krobicki; krytykę różnego rodzaju uprawiali: Bolesław Hertyński, Stanisław Kamiński, Celina Komornicka, Marek Krupiński, Zygmunt Lichniak, Zenon Łukaszewicz, Marian Olszewski, Jacek Orpieński, Bogdan Ostromęcki, Marian Plezia, Irena Sławińska, Jerzy Starnawski, Kazimierz Tymieniecki, Jan Ujda, Ryszard Wasita, Hanna Waśkiewicz, Paweł Wołowski. O teatrze pisali Jerzy Kierst i L. Mańko, zagadnienia z historii Polski poruszał natomiast Jerzy Pilecki. Różna problematyka była w kręgu zainteresowań: Piotra Lejeu i Józefy Mariańskiej. Zagadnienia filozoficzne omawiali Wacław Niedźwiadek i Jan Nowakowski. Historii Kościoła dotyczyły artykuły siostry Marii Renaty. Problematykę niemiecką w latach 1948-1949 podjął Aleksander Rogalski, naukę społeczną Kościoła Czesław Strzeszewski, zagadnienia gospodarcze Kazimierz Studentowicz, a kwestie prawne Kazimierz Szwarcenberg-Czerny. Marian Józef Święcicki odnosił się do zagadnień pedagogicznych, literaturoznawczych i socjologii kultury.

Zasadą powojennego zespołu redakcyjnego „Przeglądu Powszechnego” było, aby przy tak dużej różnorodności tematycznej artykuły nadsyłane do redakcji nie przekraczały 10 stron druku' ${ }^{1298}$.

1297 Tamże, s. 97, 105-107; A. Kaleta, Tematyka i metody popularyzacji książki na łamach „Przegladu Powszechnego,..., s. 371.

1298 „PP” 1947 nr 12 s. 80. 


\section{Założenia programowe}

Zadanie „Przeglądu Powszechnego” określono w następujący sposób: „Pismo nasze poświęcić się pragnie, w miarę swych skromnych sił dziełu kulturalnej odbudowy kraju a zwłaszcza dziełu krzewienia w polskiej duszy rodzimych obyczajów i charyzmatów [...] w duchu miłości i prawdy"1299. W tonie chciano zachować „umiar i spokój pozytywnego wykładu” ${ }^{300}$. Każdy zeszyt pod nagłówkiem zawierał cytat z Psalmu 143 „Błogosławiony lud, którego Panem Bóg jego”. Wydanie noworoczne z 1948 r. rozpoczęto wstępem pióra prymasa Polski Augusta Hlonda, w którym czytamy o inicjatywie odbudowy świątyń warszawskich, oraz zapowiedzią, iż ,[...] nie ustanie remont dusz. Będziemy dalej odgruzowywać serca, rozorywać ugory życia, zdzierać zaćmy myślowe. Wśród burzy, która dziejom nowe koryto żłobi, będziemy kształtować człowieka wierzącego, wspartego na Bożym przykazaniu. [...] Nowych czasów nie pojmujemy jako grobu ducha" ${ }^{1301}$.

Od początku istnienia periodyk skierowano do inteligencji, co jednak w nowych warunkach skorygowano: „Dziś jawi się jednak nowa kategoria osób, które skromniejsze może nawet wykształcenie, wyniesione ze szkoły, umiały dziwnie rozszerzyć i pogłębić, czy to przez późniejsze kontakty z książką czy to przez żywy i świadomy udział w powszechnym doświadczeniu. Jasnym jest bowiem, że w tyglu cierpienia, przy bystrej obserwacji i refleksji nad sobą, umysł człowieka o wrodzonej inteligencji - mniejsza o to czy będzie to robotnik, rzemieślnik, chłop czy kupiec - tak szybko życiowo dojrzewa i uczy się sztuki samodzielnego myślenia, iż smutnym byłoby anachronizmem ograniczać zastępy naszej inteligencji tylko do cenzusu czysto formalnego wykształcenia. I my tego czynić nie chcemy"1302. O naukowości miesięcznika świadczyły, oprócz stylu wypowiedzi i dobrej argumentacji, liczne przypisy w artykułach.

\section{Cechy wydawniczo-formalne}

Pierwszy numer powojenny czasopisma czytelnicy mogli nabyć w grudniu 1947 r., ostatni zaś z okresu stalinowskiego w styczniu 1953 r. (nr 731). Miesięcznik ukazywał się w Wydawnictwie Księży Jezuitów w Warszawie, a tłoczono go „na papierze V klasy” w Drukarni Spółdzielczej „Słowo”"1303, a od po-

\footnotetext{
${ }^{1299}$ Redakcja, „PP” 1947 nr 12 s. 3.

1300 Tamże, s. 4.

${ }^{1301}$ A. Hlond, List noworoczny, „PP” 1948 nr 1 s. 3.

1302 Redakcja, „PP” 1947 nr 12 s. 3.

${ }^{1303}$ Wcześniej drukowano je kolejno w drukarniach: Wł. L. Anczyca, E. i K. Kozieńskich, drukarni „Czasu” i w jezuickiej drukarni krakowskiej zwanej Drukarnią „Przeglądu Powszechnego”. Źródło: Z. Jakubowski, „, Przegląd Powszechny” 1884-1985 ..., s. 75.
} 
czątku 1949 r. w Spółdzielni Wydawniczej „Chłopski Świat” mieszczącej się przy Al. Jerozolimskich $83^{1304}$. Nakład wynosił 5 tys. egzemplarzy ${ }^{1305}$. Redakcja urzędowała przy ul. Rakowieckiej 61. Łącznie w latach 1947-1953 ukazało się siedem roczników, w tym 57 zeszytów.

Każdy zeszyt zaopatrzony spisem treści (w pierwszym numerze na końcu, a następnie na początku) liczył około 80 stron. W nagłówku pierwszej strony znalazły się następujące informacje: od lewej numer tomu, rok i miesiąc, cena, kolejny zeszyt w obrębie roku i w nawiasie od początku wydawania, pod nimi tytuł pisma, podtytuł, motto oraz zawartość. Na samym dole podawano adres redakcji z nazwą wydawnictwa.

Pojedynczy egzemplarz kosztował 100 zł, a od początku 1952 r. - 5 zł (numery podwójne 10 zł). Prenumerata, którą można było zamówić w administracji wydawnictwa wynosiła początkowo $1000 \mathrm{zł}$ rocznie, 500 półrocznie i $250 \mathrm{kwar}$ talnie. Czytelnikom podano także numer konta bankowego i numer telefonu do administracji. Koszt prenumeraty uległ zmianie od początku 1950 r. po wymianie pieniędzy. Za roczne otrzymywanie pisma należało zapłacić 60 zł, za półroczne odpowiednio 30 zł. Powiadamiano odbiorców, że PPK „Ruch” będzie wysyłał czasopismo tylko tym prenumeratorom, którzy dokonali wpłaty do 15 dnia w miesiącu poprzedzającym przedpłatę ${ }^{1306}$. O wygasłej prenumeracie nie informowano. W celu uniknięcia przerwy w otrzymywaniu miesięcznika oraz ,uciążliwej dla obu stron korespondencji w sprawie nieotrzymanych numerów" proszono „o łaskawe wpłacanie prenumeraty przynajmniej na pół roku z góry” ${ }^{307}$. Redakcja przypominała w ostatnich zeszytach każdego kończącego się roku o jej wznowieniu na przyszy rok. Na początku numeru wrześniowego z 1952 r. czytamy, że „Odtąd $<<$ Przegląd Powszechny $>>$ nabywać można tylko w prenumeracie pojedynczej tj. jeden odbiorca otrzymywać może tylko jeden egzemplarz pisma"1308. Zeszyty archiwalne i zaległą prenumeratę należało opłacać tylko w administracji „Przeglądu Powszechnego”"1309. Wysyłano je za pobraniem pocztowym lub po uzyskaniu należności wpłaconej z góry. Informowano ponadto o posiadanych zeszytach z poprzednich lat. Cena numeru archiwalnego z lat 1947-1950 wynosiła 3 zł, a z roku 1951 - 4 zł. Pismo w 1952 r. zamawiano do księgarni i kiosków za pośrednictwem wojewódzkich oddziałów PPK „Ruch”"1310.

W styczniowym zeszycie z 1948 r. czytelnicy dowiedzieli się również o tym, że redakcyjne korespondencje i recenzyjne książki, w dwóch egzemplarzach, należało kierować na adres redakcji. Z notatki redakcyjnej dowiadujemy

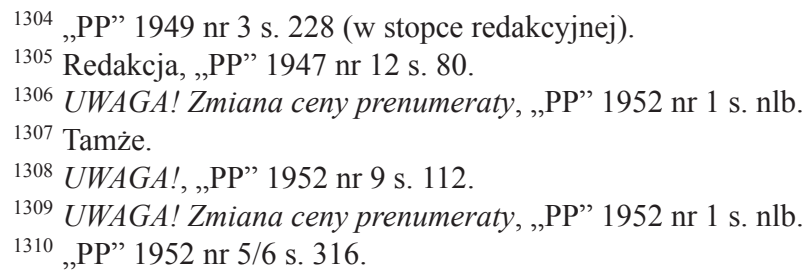


się o dniach i godzinach przyjęć redaktora naczelnego: we wtorki godz. 10-12 i czwartki godz. 17-191311. Na jeden tom składało się sześć numerów miesięcznika, a zatem zeszyty styczeń - czerwiec stanowiły jeden tom, a lipiec-grudzień już kolejny. Zdarzały się zeszyty podwójne, np. 7/8 z 1948 r., 5/6 i 7/8 z 1952 r. Przez cały okres wydawniczy zachowano numerację ciągłą, a strony paginowano w obrębie jednego tomu.

Formy wypowiedzi obecne na łamach „Przeglądu Powszechnego” to artykuły, recenzje, przeglądy prasy, fragmenty książek, polemiki. Piszący odnosili się głównie do wypowiedzi na łamach „Znaku” oraz „Dziś i Jutro”.

\section{Działy i rubryki „Przeglądu Powszechnego”}

Pierwszą, a zarazem najobszerniejszą część stanowiły Artykuły, wśród których dominowały konstatacje o tematyce religijnej ${ }^{1312}$, filozoficznej ${ }^{1313}$, etycznej ${ }^{1314}$, moralnej, teologicznej ${ }^{1315}$ i naukowej ${ }^{1316}$. Ustosunkowywano się do różnic światopoglądowych istniejących między materializmem a idealizmem ${ }^{1317}$, do różnych kierunków filozoficznych i ich przedstawicieli ${ }^{1318}$, teorii współczesnego

1311 „PP” 1948 nr 1 s. nlb.

1312 A. Kisiel, Piłat i Chrystus czyli o względności i bezwzględności prawdy, „PP” 1948 nr 8 s. 132-141; J. Rostworowski, Inter nova et vetera. Z liturgicznych rozważań i zagadnień, „PP” 1949 nr 1 s. 3-12; J. Rosiak, Idąc nauczajcie, tamże, nr 5 s. 337-346; tenże, Religia uczucia, „PP” 1950 nr 11s. 361-379; J. Majkowski, Spór o psychologię religii, „PP” 1951 nr 1 s. 35-46; J. Pastuszka, Typy życia religijnego, tamże, nr 2 s. 90-104; J.M. Święcicki, Dwie formy religijności, tamże, nr 8 s. $196-206$.

1313 A. Kuśmierz, Różnicowanie istnienia, „PP” 1949 nr 11 s. 290-301; F. Sawicki, Bóg filozofii a Bóg religii, „PP” 1950 nr 9 s. 209-217; J. Majkowski, Filozofia religii O. Mariana Morawskiego, „PP”1952 nr 9 s. 142-156.

${ }^{1314}$ K. Studentowicz, Etyka chrześcijańska w życiu publicznym, „PP” 1948 nr 4 s. 241-252.

1315 J. Rostworowski, Czy teologia katolicka potrzebuje odnowy?, „PP” 1949 nr 1 s. 92-105; M. Rzeszewski, Z teologii nawrócenia, „PP” 1951 nr 10 s. 332-336; J. Rostworowski, Katolicka myśl teologiczna wobec natury i działalności sakramentów, „PP” $1952 \mathrm{nr} 3$ s. 157-175.

1316 K. Kłósak, Życie psychiczne a synteza białek $w$ neuronach, „PP” 1949 nr 2 s. 115-123; J. Dorda, Kompetencje naukowego poznania, tamże, nr 4 s. 233-247; tamże, nr 5 s. 347-356; P. Czartoryski, Zagadnienie podziału nauk społecznych, „PP” 1950 nr 8 s. 187-202; L. Mońko, Teoria otwartych układów w biologii, tamże, nr 11 s. 380-390; tenże, Zasada indukcji, „PP” 1951 nr 4 s. 335-348; tenże, Węgiel radioaktywny jako wskaźnik chronologiczny, tamże, nr 8 s. 158-176; tenże, Zagadnienie życia w pobliżu zera absolutnego, „PP” 1952 nr 11 s. 303-323.

1317 C. Białobrzeski, Fizyka wobec materializmu i idealizmu, „PP” 1948 nr 1 s. 7-42.

1318 A. Kisiel, O trzech podstawowych prawdach życia (na marginesie egzystencjalizmu), „PP” 1948 nr 1 s. 43-51; F. Sawicki, Sören Kierkegaard, tamże, nr 2 s. 81-91; tenże, Filozofia egzystencjalna niemiecka, tamże, nr 3 s. 185-195; tenże, Jean Paul Sartre, tamże, nr 4 s. 253-264; tenże, Chrześcijańska filozofia egzystencjalna, tamże, nr 5 s. 340-350; K. Kłósak, Konflikt nowożytnej fizyki teoretycznej z perypatetyczna filozofia przyrody w ujęciu Jakuba Maritaina, „PP” 1949 nr 1 s. 24-39. 
kryzysu kultury ${ }^{1319}$, do dóbr doczesnych ${ }^{1320}$, kwestii gospodarczych i ekonomicznych w relacji do moralności ${ }^{1321}$ oraz do zagadnień pochodzenia człowieka i ewolucjonizmu ${ }^{1322}$. Zgodnie z profilem miesięcznika liczni publicyści podejmowali problematykę chrześcijańską ${ }^{1323} \mathrm{i}$ katolicką ${ }^{1324}$. Ukazywano istotę boskoludzką Kościoła ${ }^{1325}$, prowadzono rozważania ewangeliczne ${ }^{1326}$ oraz dotyczące kwestii wiary i modlitwy ${ }^{1327}$. Wypowiadano się jednocześnie nt. duszy ludzkiej $^{1328}$ i rozważano problematykę maryjną ${ }^{1329}$ oraz osobę Jezusa Chrystusa ${ }^{1330}$. Zagadnienia ujmowano niejednokrotnie $\mathrm{w}$ aspekcie psychologicznym lub filozoficznym. W duchu nauczania papieży wyjaśniano relację do nacjonalizmu ${ }^{1331}$,

\footnotetext{
${ }^{1319}$ K. Górski, Teorie wspótczesnego kryzysu kultury, „PP” 1948 nr 5 t. s. 321-331.

${ }^{1320}$ S. Wawryn, Dobra ziemskie sa dla ludzi, „PP” $1948 \mathrm{nr} 1$ s. 105-11; J. Górka, Pozaświatowy cel życia a stosunek człowieka do rzeczy tej ziemi, „PP” 1949 nr 5 s. 345-374.

${ }^{1321}$ K. Studentowicz, Planowanie gospodarcze a moralność, „PP” $1948 \mathrm{nr} 1 \mathrm{~s} .121-127$; tenże, Warunki racjonalnej kalkulacji w gospodarce planowej, tamże, nr 7 s. 73-83; C. Strzeszewski, Człowiek ekonomiczny, „PP” $1950 \mathrm{nr} 7$ s. 34-43.

1322 J. Rostworowski, Początek pierwszego człowieka, „PP” 1949 nr 5 s. 309-322; K. Kłósak, Hipoteza I. Oparina o powstaniu życia, „PP” $1950 \mathrm{nr} 1 \mathrm{s.} 45-56$.

${ }^{1323}$ K. Kłósak, Nowy typ cywilizacji chrześcijańskiej w ujęciu J. Maritaina, „PP” 1948 nr 9 s. $213-222$.

${ }^{1324}$ W. Kamiński, O naszym katolicyzmie, „PP” 1948 nr 4 s. 265-274; tenże, W sprawie przyszłości marksizmu, tamże, nr 5 s. 360-370; J. Winkowski, Polski katolicyzm wczoraj i dziś, tamże, nr 8 s. 121-131; J.M. Święcicki, Z renesansu polskiego katolicyzmu, „PP” $1949 \mathrm{nr} 4$ s. 248-255; nr 5 s. 357-364; J. Rostworowski, Katolickiego na świat pogladu istotny fundament, „PP” 1951 nr 3 s. 161-172; J. Majkowski, Katolicyzm budzacej się świadomości dziecka, tamże, s. 185-196; J.G. Piwiński, Charakterystyczne cechy myśli katolickiej, tamże, nr 4 s. 313-323; J.M. Święcicki, Dwie formacje katolicyzmu, tamże, nr 9 s. 264-273.

1325 J. Rosiak, Chrystus mistyczny, „PP” 1949 nr 4 s. 256-268.

1326 Tenże, Tu es Petrus, „PP” 1949 nr 6 s. 407-418; tamże, nr 7 s. 46-57; K. Wilczyński, Boski wysłannik. Fragmenty ewangeliczne, „PP” $1950 \mathrm{nr} 1$ s. 38-44; K. Wilczyński, Syn Człowieczy, tamże, nr 3 s. 191-199; H. Zarembowicz, Teologia św. Jana Ewangelisty, tamże, s. 200-208.

1327 J. Rostworowski, Trudność aktu wiary a trudności przeciw wierze, „PP” $1949 \mathrm{nr}$ 9 s. 193-202; tenże, Modlitwa liturgiczna a modlitwa prywatna, tamże, nr 11 s. 275-289; J. Rosiak, Intelektualizm wiary, „PP” $1950 \mathrm{nr} 6$ s. 381-404; J. Rostworowski, Wierzę w grzechów odpuszczenie, tamże, nr 7 s. 21-33; J. Rosiak, Wiara, tamże, s. 137-160; J. Majkowski, Z psychologii częstej spowiedzi, tamże, nr 9 s. 309-318; J. Rosiak, Wiara i uczucie w katolicyzmie, „PP” 1951 nr 1 s. 3-23; M. Rzeszewski, Psychologia nawrócenia, tamże, nr 2 s. 122-134; tenże, Pokuta i przebaczenie, tamże, nr 9 s. 281-288; J. Rostworowski, Istota modlitwy, „PP” 1953 nr 1 s. $5-14$.

${ }^{1328}$ K. Kłósak, Substancjalność duszy ludzkiej ze stanowiska doświadczenia bezpośredniego, „PP” 1950 nr 7 s. 3-20.

1329 J. Rostworowski, Pośredniczka wszystkich task, „PP” 1950 nr 7 s. 161-169; tamże, nr 8 s. 218-228; tenże, Dzieje dogmatu Wniebowzięcia w świadomości Kościoła, tamże, nr 9 s. $281-296$.

${ }^{1330}$ J. Rosiak, Jezus Chrystus Syn Boży, „PP” 1952 nr 2 s. 91-111; tenże, Chrystus $i$ historia, tamże, nr 5/6 s. 317-346.

${ }^{1331}$ W. Kamiński, Kryzys nacjonalizmu, „PP” 1948 nr 8 s. 149-162.
} 
kapitalizmu ${ }^{1332}$ i filozofii marksizmu ${ }^{1333}$. Odnoszono się do treści encyklik papieskich $^{1334}$. Omawiano trudne zagadnienia natury ludzkiej ${ }^{1335} \mathrm{i}$ zastanawiano się nad relacją nauki do religii ${ }^{1336}$. Problematykę seksualną, macierzyńską i kobiecą ukazywano przez pryzmat katolicki ${ }^{1337}$.

Podobnie jak w pozostałych omówionych w pracy tytułach katolickich, podejmowano $\mathrm{w}$ pierwszych latach problematykę wojenną, obozową i niemiecką ${ }^{1338}$. Komentowano również aktualne problemy dotyczące powojennych stosunków Kościoła z państwem. Potwierdzeniem może być noworoczny zeszyt z 1948 r., który otworzył obszerny i rzetelnie napisany artykuł dotyczący zerwania konkordatu przez rząd polski po wojnie ${ }^{1339}$. Na łamach „Przeglądu Powszechnego" wydrukowano również tekst Porozumienia zawartego między państwem a Kościołem 14 IV 1950 r. wraz z Komunikatem Episkopatu Polski do wiernych ${ }^{1340}$. Jednocześnie ustosunkowano się do pierwszego z wymienionych dokumentów ${ }^{1341}$.

Pojawiały się też na łamach „Przeglądu” zagadnienia historyczne i historiograficzne ${ }^{1342}$. Zapoznano z historią obrazu Matki Boskiej z Dzieciątkiem w Kościele Jezuitów w Nowym Sączu ${ }^{1343}$. Ukazywano sylwetki znanych osobistości ze świata polityki, religii, literatury, fizyki, malarstwa: Mahatmy Gandhiego, Napoleona Bonaparte, Augusta Hlonda, Adama Sapiehy, o. Jacka Woronieckiego,

${ }^{1332}$ G. dalla Torre, Kościół a kapitalizm, „PP” 1949 nr 6 s. 389-396; P. Czartoryski, Człowiek w oczach kapitalizmu, „PP” 1952 nr 4 s. 272-287.

${ }^{1333}$ W. Kamiński, W sprawie przyszłości marksizmu, „PP” 1948 nr 5 s. 360-370; K. Kłósak, Dialektyczne prawo przechodzenia ilości w jakość, „PP” 1949 nr 7 s. 69-79; tenże, Dialektyczne prawo jedności i walki przeciwieństw, tamże, $\mathrm{nr} 8 \mathrm{~s}$. 161-168.

1334 J. Górka, Encyklika „Humani Generis” o kwestii początku człowieka, „PP” 1951 nr 3 s. $197-206$.

1335 J. Pastuszka, Dwa oblicza człowieka, „PP” 1948 nr 2 s. 81-91; tenże, Człowiek czasowy $i$ wieczny, „PP” 1950 nr 4 s. 239-252.

${ }^{1336}$ L. Mońko, Konflikt czy symbioza nauki i religii objawionej?, „PP” $1950 \mathrm{nr} 1$ s. 8-15.

1337 Z. Kozubski, Problem seksualny w ujęciu katolickim, „PP” 1948 nr 6 s. 413-426; E. Mironowicz, Kobieta wspótczesna a dziecko, tamże, s. 439-446; H. Bednorz, Problem czystości u Bernanosa, „PP” 1949 nr 7 s. 94-101; J. Mariańska, Dominanta życia kobiety, „PP” 1951 nr 11 s. $414-428$.

${ }^{1338}$ W. Wicher, Chrześcijańska miłość bliźniego i obozy koncentracyjne, „PP” 1947 nr 12 s. 42-47; A. Rogalski, Kryzys Niemiec a kryzys cywilizacji zachodniej, „PP” 1948 nr 6 s. 401-412; A. Rogalski, Problem terapii Niemiec, tamże, nr 7 s. 27-36.

${ }^{1339}$ K. Szwarcenberg-Czerny, Problem polskiego Konkordatu, „PP” 1948 nr 1 s. 4-14.

${ }^{1340}$ Porozumienie między Rzadem R. P. a Episkopatem Polski, „PP” 1950 nr 4 s. 221-224; Komunikat Episkopatu Polski do wiernych, tamże, s. 225-226.

${ }^{1341}$ S. Wawryn, Sprawy Kościoła, „PP” 1950 nr 6 s. 366-380.

1342 J. Pilecki, Czy koniec legendy kościuszkowskiej?, „PP” 1948 nr 10 s. 313-320; W. Konopczyński, Dzieje nauki historycznej w Polsce, „PP” 1949 nr 7 s. 27-45; tenże, Dzieje nauki historycznej w Polsce. Okres III, tamże, nr 8 s. 145-160; J. Korzonek, O umiejętnym wykładzie historii, „PP” $1951 \mathrm{nr} 4$ s. 324-334; tenże, Ocena dziet historycznych, tamże, nr 7 s. 58-65.

${ }^{1343}$ A. Bochniak, Cudowny obraz Matki Boskiej, „PP” 1950 nr 2 s. 101-106. 
o. Tomasza Mertona, Jerzego Zawieyskiego ${ }^{1344}$, Williama Fabera ${ }^{1345}$, Andrzeja Marii Ampèra, Marii Curie-Skłodowskiej, Leona Wyczółkowskiego ${ }^{1346}$, jak też mniej znanych: reformatora ks. Stanisława Warszewickiego, filozofa i teologa Franciszka Suareza, społecznika, nauczyciela i reformatora szkolnictwa ks. Józefa Bernarda Bogedaina, lekarza ludowego Ludwika Perzyny, publicysty i literata Ernesta Hello, myśliciela Piotra Wusta czy zakonnicy Mabel Digby ${ }^{1347}$. Przybliżono też życiorysy wielu przyszłych świętych: Maksymiliana Kolbego, Urszuli Ledóchowskiej, bł. Wincentego Pallottiego ${ }^{1348}$. Ukazano osobowości kardynałów: Jana Henryka Newmana, Mikołaja Wisemana, Henryka Edwarda Manninga ${ }^{1349}$. Upamiętniono szczególnie 950 rocznicę kanonizacji pierwszego patrona Polski św. Wojciecha ${ }^{1350}$, zapoznano z duchową drogą św. Ignacego Loyoli ${ }^{1351}$, ukazała się też seria artykułów o św. Stanisławie Kostce ${ }^{1352}$. Pisano o różnych drogach dochodzenia do świętości ${ }^{1353}$. Odnośnie do problematyki świeckiej, wypowiedziano się na temat roli języka polskiego w duszpasterstwie w czasie zaborów ${ }^{1354}$ i o reformie obyczajowej XVI wieku ${ }^{1355}$.

W mniejszym zakresie na łamach „Przeglądu Powszechnego” obecne były zagadnienia społeczne, np. przyrostu naturalnego ${ }^{1356}$, wartości pracy ${ }^{1357}$, bezrobo-

1344 W. Kamiński, Wobec śmierci Mahatmy, „PP” 1948 nr 3 s. 208-217; J. Rostworowski, Śp. ks. prymas kard. Hlond, tamże, nr 10 s. 281-287; Z. Starowieyska-Morstinowa, Jerzy Zawieyski, „PP” 1949 nr 5 s. 323-336; A. Usowicz, O. Jacek Woroniecki, tamże, nr 8 s. 121-133; J. Piwowarczyk, Śp. kardynat Sapieha, „PP” 1951 nr 1 s. 3-10; J.M. Święcicki, O role dziejowa Napoleona, „PP” 1952 nr 5/6 s. 396-412; M. Renata, Tomasz Merton, tamże, nr 11 s. 289-302; tamże, nr 12 s. 387-400.

1345 S.M. Renata, William Faber, „PP” 1951nr 9 s. 251-263.

${ }^{1346}$ F. Sawicki, Przyrodnik wierzacy i niewierzacy, „PP” 1949 nr 8 s. 134-144; A. Zieliński, „Pasja życia” dla sztuki, „PP” 1950 nr 9 s. 250-256.

1347 J. Popłatek, Ks. Stanisław Warszewicki, „PP” 1948 nr 7 s. 61; J. Rosiak, Suarez, tamże, nr 11 s. 353-367; F. Kącki, Józef Bernard Bogedain, „PP” 1950 nr 8 s. 257-272; A. Schletz, Ludwik Perzyna - lekarz wiejskiego ludu, „PP” 1951 nr 9 s. 222-237; P. Winiarski, Z dziejów wielkiej duszy, „PP” 1952 nr 3 s. 185-197; F. Manthey, Piotr Wust-chrześcijański myśliciel, tamże, nr 5/6 s. 347-362; M. Renata, Matka Mabel Digby, tamże, s. 423-432; tamże, nr 7/8 s. $80-87$.

1348 J. Rostworowski, Męczennik Niepokalanej, „PP” 1949 nr 6 s. 397-406; W. Jasiński, Matka Urszula Ledóchowska, tamże, nr 7 s. 3-15; E. Weron, Bt. Wincenty Pallotti, „PP” 1950 nr 1 s. 3-7.

${ }^{1349}$ M. Renata, Kardynat Newman, „PP” 1950 nr 7 s. 50-62; taż, Kardynat Wiseman (1802-1865), tamże, nr 8 s. 170-186; taż, Kardynat Manning, tamże, nr 9 s. 319-332.

${ }^{1350}$ J. Wieteska, Na szlakach św. Wojciecha, „PP” 1949 nr 6 s. 419-425.

1351 J. Rostworowski, Droga rozwoju wielkiej duszy, „PP” 1949 nr 7 s. 16-26.

1352 J. Majkowski, Typologia świętego Stanisława Kostki, „PP” $1950 \mathrm{nr} 5$ s. 301-318; tenże, Psychika św. Stanisława Kostki, tamże, nr 6 s. 405-423; tenże, Psychologia ascezy i mistyki św. Stanistawa Kostki, tamże, nr 7 s. 81-99.

1353 J. Majkowski, Sprawdziany świętości, „PP” 1952 nr 10 s. 193-201.

${ }^{1354}$ W. Urban, Język polski w duszpasterstwie, „PP” $1951 \mathrm{nr} 8$ s. 177-195.

1355 J.M. Święcicki, Wielka reforma XVI wieku, „PP” 1951 nr 10 s. 307-323.

1356 Tenże, Z pogranicza etyki i kwestii ludnościowej, „PP” 1950 nr 2 s. 107-118.

${ }^{1357}$ S. Jędrusik, Elementy wartości pracy, „PP” $1950 \mathrm{nr} 11$ s. 333-340. 
$\operatorname{cia}^{1358}$. Niekiedy gościła problematyka wychowawcza i dotycząca rozwoju osobowości ${ }^{1359}$. Przedstawiono m.in. wytyczne chrześcijańskiej reformy społecznej, ponadczasowość myśli społecznej św. Augustyna, moralne kryterium uspołecznienia $^{1360}$. Cyklicznie omawiane były zagadnienia z zakresu socjologii religii i wiedzy ${ }^{1361}$. Nie zabrakło problematyki literackiej ${ }^{1362}$ i kulturalnej ${ }^{1363}$. Niekiedy decydowano się na odmienną problematykę, dotyczącą np. wsi czy medycyny. Zabierano głos na temat nowych teorii, nt. sensu dziejów oraz celu istnienia człowieka.

Drugi dział, zatytułowany Przeglą piśmiennictwa, występujący w każdym numerze, zawierał recenzje nowości wydawniczych (zajmujące 7-9 stron). Pod nagłówkiem Ksiązki (powieści) lub Literatura, Historia, Dzieła religijno-ascetyczne, Przegląd literatury dla dzieci i młodzieży zamieszczano recenzje różnego autorstwa (zwykle opiniowali Zygmunt Lichniak i ks. Jan Popłatek) kilku, a od 1949 r. czasem kilkunastu książek ${ }^{1364}$. Po raz pierwszy w numerze 7 z 1948 r. wydrukowano Notatki bibliograficzne, z krótkimi recenzjami nowości wydawniczych. Później (w nrze 1 z 1949 r.) przemianowano je na Przeglad nowości biograficznych, a następnie Recenzje i notatki (nr 5 z 1949 r.), czy Przegląd wydawnictw pedagogicznych (nr 7 z 1949 r.), Recenzje ksiażek (nr 3 z 1950 r.). Po nich drukowano spis ksiąg nadesłanych do redakcji przez różne wydawnictwa. Krótko istniał ostatni człon działu zatytułowany Czasopisma prowadzony przez Jana Popłatka. Dokonując przeglądu ich zawartości, pragnął zachęcić czytelników do ich zauważenia i nabycia. Warto docenić w tym miejscu podawanie przez redakcję szczegółowych danych bibliograficznych omawianych książek i tytułów prasowych. W tomie 225 doszły Przeglady prasy, w tym od zeszytu drugiego na stałe wszedł Przeglad prasy gospodarczej (3 strony), którego zabrakło już w 1949 r.

${ }^{1358}$ P. Czartoryski, Bezrobocie w krajach kapitalistycznych, „PP” 1952 nr 2 s. 112-123.

1359 J. Dajczak, Wychowanie osobowości, „PP” $1950 \mathrm{nr} 2$ s. 119-130; tenże, Intuicja i obserwacja w wychowaniu, „PP” $1952 \mathrm{nr} 10$ s. 212-230.

${ }^{1360}$ S. Michna, Ogólne wytyczne chrześcijańskiej reformy społecznej, „PP” $1948 \mathrm{nr} 10$ s. 321-333; C. Strzeszewski, Aktualność myśli społecznej św. Augustyna, „PP” 1949 nr 2 s. 106-114; S. Jędrusik, Moralne kryterium uspołecznienia, „PP” $1950 \mathrm{nr} 11 \mathrm{s.}$ 402-408.

${ }^{1361}$ F. Sawicki, Socjologia religii, „PP” 1948 nr 10 s. 302-310; tenże, Socjologia wiedzy, tamże, nr 11 s. 377-387;

${ }^{1362}$ Np. J.M. Święcicki, Miłośnicy „,głowy najdroższej” w „, Quo vadis”, „PP” 1948 nr 12 s. 388-400; A. Rogalski, Literatura i wiara, „PP” 1949 nr 1 s. 13-23; tenże, W strone metafizyki. Duchowe oblicze dzisiejszej literatury angielskiej i amerykańskiej, tamże, nr 3 s. 178-186; W. Rola, Piękno i dobro dzieła literackiego, „PP” 1952 nr 1 s. 46-51; Eremita, Śladami Nikodema, tamże, nr 12 s. 355-368.

${ }^{1363}$ W. Rola, Klopoty i troski kulturalne, „PP” $1951 \mathrm{nr} 9$ s. 274-280.

${ }^{1364}$ Np. w Przegladzie piśmiennictwa, „PP” 1949 nr 3 s. 202-217 zrecenzowano 19 pozycji, natomiast w kolejnym, 9 numerze, 12 pozycji. 
Trzeci, niewielki dział zatytułowano $Z$ zagadnień sumienia (s. 70-71). Odpowiadano $\mathrm{w}$ nim na trudne pytania moralne, np. o bezkarność zła ${ }^{1365}$. Zrezygnowano $\mathrm{z}$ niego $\mathrm{w}$ drugiej połowie $1948 \mathrm{r}$.

W pierwszym tomie powojennym (t. 224 z 1947 r.), po wyżej wymienionych działach, znalazło się siedmiostronicowe Sprawozdanie z ruchu religijnego, moralnego i społecznego (s. 74-80; 9 stron), od następnego tomu (t. 225 z 1948 r.) redakcja nieco zmieniła tytuł kolumny - Sprawozdanie z ruchu religijnego, kulturalnego i społecznego. Wyodrębniono w nim Sprawy Kościoła, gdzie ks. Aleksander Kisiel, a potem ks. Stanisław Wawryn opiniowali sprawy istotne. Pisali o nowych encyklikach papieskich, przytaczając tekst np. encykliki Piusa XII Humani Genesis ${ }^{1366}$, jubileuszach papieskich ${ }^{1367}$, informowano o imprezach katolickich, kościołach odszczepieńczych, odniesiono się do prasowej kampanii antypapieskiej w Polsce w związku z listem Piusa XII do biskupów niemieckich (o sprzyjaniu Niemcom), o sprzecznych z nauką społeczną Kościoła wypowiedziach na łamach „Dziś i Jutro” ${ }^{368}$. Odnotowywano w rubryce wystawy i zjazdy, np. Wystawę Ziem Odzyskanych, Drugą Ogólnopolską Wystawę Plastyki, wystawę w Muzeum Narodowym w Warszawie pt. Wiek Oświecenia w Polsce, II Ogólnopolską Wystawę Fotografiki, wystawę odbudowanych kościołów Archidiecezji Wrocławskiej, Zjazd Historyków Polskich ${ }^{1369}$. Czasami zamiast nagłówka Sprawy Kościoła zaczynano wprost od tytułów omawianych wydarzeń: Nowy Prymas Polski, Wiara i życie (gdzie znalazły się informacje dotyczące ruchu religijnego we Francji; nr 1 z 1949 r.). W drugim zeszycie z 1950 r. zrezygnowano z wyżej przedstawionej części miesięcznika.

Każdorazowo w dziale religijnym, kulturalnym i społecznym pod nagłówkiem Ze świata sceny (s. 76-80) zamieszczano recenzje teatralne pióra Jerzego Kiersta (głównie teatrów warszawskich: Państwowego Teatru Polskiego, Teatru Rozmaitości, Teatru Kameralnego, Państwowego Teatru Nowego, ale także krakowskiego Teatru Rapsodycznego, łódzkiego Państwowego Teatru Wojska Polskiego). Odbiorcy dowiadywali się jednocześnie o bieżących wydarzeniach, np. o otwarciu Teatru Satyryków w Warszawie ${ }^{1370}$.

1365 Z zagadnień sumienia, „PP” 1948 nr 2 s. 148-149.

${ }^{1366}$ Pius XII, Sprawy Kościoła. Encyklika „Humani Generis”, „PP” 1951 nr 2 s. 140-159.

1367 J. Wieteska, Pięćdziesięciolecie kapłaństwa Ojca Św. Piusa XII, „PP” 1949 nr 4 s. 295-299.

${ }^{1368}$ S. Wawryn, List Ojca św. do niemieckich biskupów. Kampania antypapieska, „PP” 1948 nr 6 s. 463-471; tenże, Pomyłki i złudzenia p. Łubieńskiego. Stanowisko grupy „Dziś i Jutro”, „PP” 1949 nr 3 s. 218-226; tenże, ,Dziś i Jutro” a katolicka doktryna spoleczna, tamże, nr 6 s. 438-453.

${ }^{1369}$ Sprawozdanie z ruchu religijnego, kulturalnego i społecznego. Echa wrocławskie, „PP” 1948 nr 10 s. 347-350; Sprawozdanie ze świata kulturalnego, „TP” 1952 nr 2 s. 146-148; Sprawozdanie z ruchu kulturalnego. Wiek Oświecenia w Polsce, tamże, nr 3 s. 225-228; Pięć wystaw, tamże, nr 4 s. 306-309; Wystawa odbudowanych kościołów Archidiecezji Wrocławskiej, tamże, $\mathrm{nr} 7 / 8$ s. 97.

${ }^{1370}$ Ze świata sceny, „PP” $1952 \mathrm{nr} 3$ s. 228-230. 
Od tomu 225, obejmującego pierwsze półrocze 1948 r., wprowadzono na stałe Ze świata filmu (3 strony), gdzie nie tylko recenzowano filmy historyczne, dramatyczne, biograficzne, sensacyjne, psychologiczne, komedie, ale też odnoszono się do pewnych tendencji w sztuce filmowej i podejmowanej tematyce ${ }^{1371}$. W kręgu zainteresowań pozostawały ekranizacje zarówno produkcji polskiej, jak i amerykańskiej, czeskiej oraz radzieckiej. W jednym numerze wypowiadano się zazwyczaj na temat kilku z nich. Krytykowano „bezwartościowe, seryjne i tandetne filmy, przeważnie amerykańskiej produkcji"1372. W ostatnim wydaniu „Przeglądu Powszechnego" z 1948 r. w rubryce tej wydzielono: Filmy radzieckie, Filmy czeskie, Film włoski.

$$
* * *
$$

Założenia programowe, cechy wydawniczo-formalne i wygląd poszczególnych czasopism społeczno-kulturalnych o profilu katolickim w latach 1945-1953 różniły się znacznie, jednak problematyka podejmowana na ich łamach służyła ogólnie upowszechnianiu wartości kultury chrześcijańskiej i sprawie katolickiej. Najbogatszy pod względem tematycznym i szaty graficznej był „Tygodnik Powszechny". Ciekawe polemiki publicystów związanych ze środowiskiem krakowskiego pisma od 1950 r. w dużym stopniu zniesiono. Skromniejszy natomiast „Tygodnik Warszawski” w założeniu redakcji posiadał w najwyższym stopniu charakter czynny, narodowy i ,bojowy”. Za śmiałe i bezkompromisowe wypowiedzi drukowane na jego łamach pismo zostało zamknięte wcześniej, gdyż już w 1948 r., a członkowie redakcji uwięzieni. Losy stołecznego organu prasowego należały do najbardziej tragicznych. W tym samym roku przestał wychodzić społeczno-religijny „Głos Katolicki”, zmieniono bowiem jego redakcję i profil. Najbardziej religijny charakter posiadał regionalny „Tygodnik Katolicki”, który odegrał ważną rolę w życiu Ziem Odzyskanych. Pozostałe periodyki przetrwały do 1953 r. Najbardziej elitarne z omawianej grupy czasopism były miesięczniki „Przegląd Powszechny” i „Znak” ze względu na filozoficzne i teologiczne ujęcie wielu rozważanych kwestii.

Wypowiedzi na łamach katolickich czasopism społeczno-kulturalnych, głównie „Tygodnika Powszechnego”, „Tygodnika Warszawskiego” i „Głosu Katolickiego" ostro atakowali publicyści prasy rządowej. Łamy ich były bowiem trybuną odmiennego od marksistowskiego światopoglądu i próbą szerzenia kultury o wartościach nieprzemijających.

${ }^{1371} \mathrm{~Np}$. Ze świata filmu. Zagadnienie tematu i tendencji, „PP” $1948 \mathrm{nr} 4$ s. 318-320; B.O., Ze świata filmu. Myśl religijna w sztuce filmowej, „PP” $1949 \mathrm{nr} 5 \mathrm{s.}$ 387-388.

1372 Ze świata filmu, „PP” $1948 \mathrm{nr} 8$ s. 199. 



\section{ROZDZIAŁ 3}

\section{Recenzje książek na łamach wybranych periodyków}

Redakcje przedstawionych sześciu katolickich czasopism o profilu społeczno-kulturalnym starały się propagować czytelnictwo poprzez promowanie „dobrych książek”. Służyły temu liczne na ich łamach omówienia, w zdecydowanej większości zachęcające do sięgnięcia po dany tytuł. Recenzenci zwracali uwagę odbiorców przede wszystkim na nowości książkowe lub reedycje warte przeczytania. Potwierdzić to mogą niektóre nagłówki recenzji publikowanych w pismach. W najbardziej bogatym w omówienia „Tygodniku Powszechnym" tytuły brzmiały następująco: Książka, która powinna być czytana, Doniosta książka, Zastużona książka, O pewnej pożytecznej ksiażce, Książka najpiękniejsza, Książka doznań prawdziwych, Ksiązka głęboko ludzka, Książka dla mężczyzn, Książka piękna, ale niepokojąca. Publicyści „Tygodnika Warszawskiego" proponowali natomiast: Najbardziej poczytna książke, Książę która urzeka, Dobra książkę dla młodzieży, Powieść nagrodzona, czy Piękne wydawnictwo. Abonenci mogli dowiedzieć się więcej o książkach, śledząc również stałe rubryki stołecznego pisma: Nowe ksiązki, Wśród ksiażek, Wśród nowych ksiażek, Z wydawnictw, Ksiażki dla młodzieży i Notatki o ksiażkach. Na kartach „Głosu Katolickiego" polecano nowości m.in. pod powtarzającymi się nagłówkami Książka dla wszystkich i Co warto czytać? Czytelnicy „Tygodnika Katolickiego" mogli zapoznać się z Ciekawa powieścia i Książka potrzebna, natomiast „Głosu Katolickiego” z Oryginalnym modlitewnikiem. Rzadziej recenzenci ostrzegali czytelników przed Książka nie na czasie. Współpracownicy „Przeglądu Powszechnego” zadbali, aby każdy zeszyt w latach 1947-1953 zamykał Przeglad piśmiennictwa z podtytułem Książi lub Recenzje ksiązek. Drukowano w nim od kilku do kilkudziesięciu opinii o nowościach wydawniczych o różnorodnej tematyce. Oceny krytyków literackich pojawiały się także w Notatkach bibliograficznych ${ }^{1}$. W miesięczniku „Znak” dla zainteresowanych książkami przeznaczono część Ksiązki - ludzie - zdarzenia, czasami zatytułowaną Zdarzenia - książki - ludzie.

${ }^{1}$ Notatki bibliograficzne, „PP” 1948 nr 7 s. 110-113. 
Recenzje przybierały w periodykach różne formy. Odbiorcy mogli przeczytać zarówno kilkustronicową pogłębioną analizę książki (głównie na kartach „Tygodnika Powszechnego”, „Tygodnika Warszawskiego” i „Przeglądu Powszechnego"), jak też zwięźle ujęte informacje w kilku zdaniach o poruszanej w niej problematyce i wyglądzie. Recenzent wyrażał niekiedy swoje zdanie poprzez odpowiednio dobrane cytaty z dzieła, przeplatane interpretacją lub też zwyczajnie zapoznawał z jego treścią. Czytelnicy "Tygodnika Powszechnego" i „Tygodnika Warszawskiego" poznawali oceny raczej pojedynczych tytułów, redakcja „Przeglądu Powszechnego" z kolei w Przegladdzie piśmiennictwa preferowała recenzje zbiorcze.

Uwagę publicystów przyciągały zarówno tytuły bardziej znane, jak i pozycje przemilczane w prasie, o czym może świadczyć wypowiedź Jacka Woźniakowskiego: „byle powieściątko wywołuje w naszej prasie gromkie recenzje, a o książkach, które w wyniku żmudnej pracy odsłaniają nam niejeden ciekawy problem i niejeden horyzont naszej przeszłości - głucho"2. Recenzje książkowe - niezwykle różnorodne zarówno pod względem charakteru, jak i rodzaju omawianej literatury - stanowiły najobszerniejszy materiał prasowy przebadanych czasopism. Warto zatem dokonać własnej typologii omówień oraz przeprowadzić analizę statystyczną i opisową wyłonionych grup publikacji zwartych.

\subsection{Ilościowa prezentacja recenzji omówionych książek oraz ich wydawców}

W ujęciach tabelarycznych przedstawiono osobno policzone recenzje i książki zrecenzowane na łamach sześciu wybranych czasopism. Za takim rozwiązaniem przemówiły różnice występujące w danych liczbowych. Liczba recenzji nie odpowiadała bowiem liczbie zrecenzowanych książek, gdyż te same pozycje były ocenione na łamach kilku periodyków lub też w jednym z czasopism publicyści odnosili się do nich kilkakrotnie w różnych latach. Polecanych książek było zatem mniej niż opublikowanych recenzji. Tytuł rozdziału sugeruje zaś szerokie ujęcie spraw dotyczących recenzji książek i pozwala na taki podział.

\subsubsection{Recenzje}

Łącznie w uwzględnionych sześciu tytułach w latach 1945-1953 ukazało się 1375 recenzji, które zostały wykazane wraz ze szczegółowymi danymi bibliograficznymi w załączniku na płycie CD-ROM dołączonej do pracy. Dwa

\footnotetext{
2 J. Woźniakowski, Simone Cenoviz Polacco..., „TP” 1949 nr 44 s. 4.
} 
ujęcia tabelaryczne zatytułowane Spis ksiażek autorów polskich zrecenzowanych $w$ omawianych czasopismach społeczno-kulturalnych w latach 1945-1953 oraz Spis ksiażek autorów obcych zrecenzowanych $w$ omawianych czasopismach spoteczno-kulturalnych $w$ latach 1945-1953 pomogły w uzyskaniu szczegółowych danych statystycznych $\mathrm{w}$ dalszych częściach rozdziału. Liczbę recenzji w poszczególnych latach na łamach wybranych czasopism przedstawia tabela 3.

Tabela 3. Liczba recenzji książek na łamach „Tygodnika Powszechnego” („TP”), „Przeglądu Powszechnego” („PP”), „Tygodnika Warszawskiego” („TW”), „Głosu Katolickiego” („GK”) i „Znaku" w 1. 1945-1953

\begin{tabular}{|c|c|c|c|c|c|c|}
\hline Rok & „TP” & „PP” & „TW" & „GK” & „TK” & „Znak" \\
\hline 1945 & 3 & - & - & - & - & - \\
\hline 1946 & 40 & - & 44 & 10 & - & 3 \\
\hline 1947 & 143 & - & 92 & 15 & 3 & 3 \\
\hline 1948 & 154 & 72 & 90 & 34 & 5 & 6 \\
\hline 1949 & 121 & 74 & - & - & 3 & 6 \\
\hline 1950 & 60 & 73 & - & - & 3 & 2 \\
\hline 1951 & 58 & 72 & - & - & 8 & 2 \\
\hline 1952 & 44 & 107 & - & - & 1 & 1 \\
\hline 1953 & 7 & 5 & - & - & 1 & - \\
\hline Razem & 640 & 403 & 226 & 59 & 24 & 23 \\
\hline
\end{tabular}

Źr ódło: Obliczenia własne.

Czytelnicy katolickich czasopism społeczno-kulturalnych w latach 1945-1953 mogli zapoznać się z największą liczbą recenzji książkowych na łamach „Tygodnika Powszechnego” (640), „Przeglądu Powszechnego” (403) i „Tygodnika Warszawskiego” (226). W pozostałych trzech tytułach opublikowano w tym okresie znacznie mniej omówień: w „Głosie Katolickim” nie osiągnięto 60, a w „Tygodniku Katolickim” i „Znaku” ukazało się nieco powyżej 20 recenzji.

$\mathrm{Na}$ podstawie przeprowadzonych badań statystycznych można stwierdzić, że w grupie wybranych tytułów prasowych zdecydowanie przeważyły recenzje książek autorów rodzimych. Było ich ponad dwukrotnie więcej (972) niż ocen tytułów autorstwa obcego (403). Publicyści periodyków śledzili zatem przede wszystkim nowości polskiego rynku wydawniczego, których w pierwszych latach powojennych ukazywało się więcej niż tłumaczeń obcej literatury. Sporadycznie odnoszono się natomiast do książek pisanych w językach obcych i wydanych za granicą. Widoczne było to $\mathrm{w}$ dwóch najbardziej znanych katolickich tytułach prasowych tego okresu: „Tygodniku Powszechnym” i „Tygodniku Warszawskim”. 
Spośród ogólnej liczby 640 recenzji zamieszczonych w pierwszym z wymienionych czasopism tylko 179 dotyczyło książek zagranicznych, pozostałe 461 to prezentacje prac autorów polskich. Redakcja drugiego z tygodników również większą uwagę poświęciła nowościom krajowym, o czym świadczy przeważająca liczba 183 recenzji książek autorów polskich nad liczbą 43 omówień tytułów autorów obcych. Niemal dwukrotnie więcej recenzji książek rodzimych znalazło się w „Przeglądzie Powszechnym” (polskich 268, obcych 135), „Głosie Katolickim” (polskich 39 i obcych 20) i „Tygodniku Katolickim” (polskich 16 i obcych 8). Jedynie w „Znaku” przeważały wypowiedzi na temat książek zagranicznych (18 obcych i 5 polskich). Najwięcej opinii w czterech z sześciu tytułów („Tygodniku Powszechnym”, „Przeglądzie Powszechnym”, „Tygodniku Warszawskim” i „Głosie Katolickim”) ukazało się w latach 1947-1949. W dwóch pozostałych „Tygodniku Katolickim” i „Znaku” liczba ocen książkowych była raczej stała w skali roku (1-8). Najmniej wypowiedzi opublikowano natomiast $\mathrm{w} 1953 \mathrm{r}$.

Jak już wspomniano, promocji książki na łamach sześciu czasopism miało służyć dobre przedstawianie większości nowości wydawniczych, o czym świadczą pozytywne recenzje stanowiące ponad połowę ogółu wszystkich opinii (765). Chwalono w nich książkę przede wszystkim za jej kompozycję, ujęcie tematu, nowe treści, sumienne opracowanie, język oraz wygląd i cechy wydawniczo-formalne. Pozostałe recenzje ze względu na ich charakter podzielono na omawiające, krytyczne, negatywne i polemiczne ${ }^{3}$. Istotną cechą pierwszych z nich było wierne przedstawienie tematyki oraz treści dzieł z zachowaniem wstrzemięźliwości w ich ocenie. Ogólnemu omówieniu książek towarzyszyły czasami uwagi dotyczące szaty zewnętrznej. W recenzjach krytycznych publicyści zwracali uwagę na słabe strony testów, nie negując jednak ich ogólnej wartości, przydatności i potrzeby ukazania się na rynku. Starano się przy tym, aby uwagi krytyczne były raczej zachętą i pomocą dla autorów w dalszej ich działalności. Wymieniano niekiedy szczegółowo błędy, które należało w kolejnym wydaniu wyeliminować, ażeby tym samym podwyższyć poziom wydawniczy publikacji. Opinie negatywne wyróżniały się wyraźnym stwierdzeniem, że książka nie jest warta przeczytania lub też jest wprost szkodliwa. Sporadycznie publikowano recenzje polemiczne, spotkać je można tylko w trzech najbardziej bogatych w oceny tytułach („Tygodniku Powszechnym”, „Przeglądzie Powszechnym” i „Tygodniku Warszawskim”). Publicyści odciskali na nich piętno własnego i rozpoznawalnego stylu, często wykazywali się także znakomitym poczuciem humoru. Pod tym względem wyróżniali się Stefan Kisielewski i Paweł Jasienica polemizujący ostro i niezwykle dowcipnie z marksistami wypowiadającymi się na łamach „Kuźnicy”. Polemiki

\footnotetext{
${ }^{3}$ Bernard Olejniczak omawiając dział recenzji na łamach „Przeglądu Bibliotecznego” w latach 1946-1966 wymienił recenzje krytyczne, opisowe i wzmianki. Źródło: B. Olejniczak, „Przegląd Biblioteczny” w latach 1946-1966, „Przegląd Biblioteczny” 1967 R. 35 s. 134.
} 
zabrakło w „Głosie Katolickim”, „Tygodniku Katolickim” i „Znaku”. W tabelach 4-9 zobrazowano szczegółowo procentowy udział poszczególnych rodzajów recenzji w każdym z tytułów prasowych.

Tabela 4. Liczba recenzji według ich charakteru na łamach „TP” w latach 1945-1953

\begin{tabular}{|l|c|c|}
\hline Charakter recenzji książki & Liczba recenzji & Udzial procentowy \\
\hline Pozytywna & 400 & 62,50 \\
\hline Omawiająca & 136 & 21,25 \\
\hline Krytyczna & 50 & 7,81 \\
\hline Negatywna & 45 & 7,03 \\
\hline Polemiczna & 9 & 1,41 \\
\hline Razem & 640 & 100,00 \\
\hline
\end{tabular}

Źr ó dło: Obliczenia własne.

Tabela 5. Liczba recenzji według ich charakteru na łamach „PP” w latach 1947-1953

\begin{tabular}{|l|c|c|}
\hline Charakter recenzji książki & Liczba recenzji & Udzial procentowy \\
\hline Pozytywna & 148 & 36,72 \\
\hline Omawiająca & 192 & 47,64 \\
\hline Krytyczna & 48 & 11,91 \\
\hline Negatywna & 14 & 3,47 \\
\hline Polemiczna & 1 & 0,25 \\
\hline Razem & 403 & 100,00 \\
\hline
\end{tabular}

Źr ó dło: Obliczenia własne.

Tabela 6. Liczba recenzji według ich charakteru na łamach „TW” w latach 1945-1948

\begin{tabular}{|l|c|c|}
\hline Charakter recenzji książki & Liczba recenzji & Udział procentowy \\
\hline Pozytywna & 157 & 69,47 \\
\hline Omawiająca & 39 & 17,26 \\
\hline Krytyczna & 14 & 6,19 \\
\hline Negatywna & 14 & 6,19 \\
\hline Polemiczna & 2 & 0,88 \\
\hline Razem & 226 & 100,00 \\
\hline
\end{tabular}

Źr ó dło: Obliczenia własne. 
Tabela 7. Liczba recenzji według ich charakteru na łamach „GK” w latach 1945-1948

\begin{tabular}{|l|c|c|}
\hline Charakter recenzji książki & Liczba recenzji & Udział procentowy \\
\hline Pozytywna & 43 & 72,88 \\
\hline Omawiająca & 13 & 22,03 \\
\hline Krytyczna & 3 & 5,08 \\
\hline Razem & 59 & 100,00 \\
\hline
\end{tabular}

Źr ódło: Obliczenia własne.

Tabela 8. Liczba recenzji według ich charakteru na łamach „TK” w latach 1946-1953

\begin{tabular}{|l|c|c|}
\hline Charakter recenzji książki & Liczba recenzji & Udzial procentowy \\
\hline Pozytywna & 12 & 50,00 \\
\hline Omawiająca & 9 & 37,50 \\
\hline Krytyczna & 2 & 8,33 \\
\hline Negatywna & 1 & 4,17 \\
\hline Razem & 24 & 100,00 \\
\hline
\end{tabular}

Źr ó dło: Obliczenia własne.

Tabela 9. Liczba recenzji według ich charakteru na łamach „Znaku” w latach 1946-1953

\begin{tabular}{|l|c|c|}
\hline Charakter recenzji książki & Liczba recenzji & Udzial procentowy \\
\hline Pozytywna & 14 & 60,87 \\
\hline Omawiająca & 5 & 21,74 \\
\hline Krytyczna & 4 & 17,39 \\
\hline Razem & 23 & 100,00 \\
\hline
\end{tabular}

Źró dło: Obliczenia własne.

Ponad 60\% pochwalnych ocen wydrukowano w każdym z czterech czasopism (,TP”, „TW”, „GK” i ,Znaku”). Największy udział procentowy tychże odnotowano w „Głosie Katolickim” (73\%), „Tygodniku Warszawskim” (69\%) i „Tygodniku Powszechnym” (63\%). Redakcja „Znaku” również preferowała recenzje zalecające książkę, czego dowodzi ich 61\% udział. Dokładnie połowę wszystkich opinii w „Tygodniku Katolickim” stanowiły omówienia o charakterze pozytywnym. Inaczej było jedynie w „Przeglądzie Powszechnym”, gdyż recenzje tego typu (37\% całości) uplasowały się po recenzjach omawiających (48\%).

Drugą co do liczebności grupę wypowiedzi o książkach utworzyły recenzje bezstronne o charakterze prezentującym, które zaklasyfikowano w pracy do 
omawiających. We wszystkich tytułach oprócz „Przeglądu Powszechnego”, zajęły drugie miejsce. Około $20 \%$ udziału w ogólnej liczbie recenzji miały na łamach „Tygodnika Powszechnego” (21\%), „Głosu Katolickiego” (22\%) i „Znaku” (22\%). Najwięcej wypowiedzi omawiających, po „Przeglądzie Powszechnym” (48\%) ukazało się w „Tygodniku Katolickim” (38\%), natomiast ich liczba na łamach „Tygodnika Warszawskiego” osiągnęła 17\% całości.

Wyniki przeprowadzonej analizy wykazały również, że znacznie rzadziej nowości wydawnicze prezentowane w latach 1945-1953 na łamach sześciu tytułów prasowych spotkały się z krytycznym i negatywnym podejściem recenzentów. Surowa ocena niektórych fragmentów publikacji lub jej wydania, przekładu czy wyglądu nie oznaczała jeszcze, że książka nie była godna uwagi. Często bowiem przy końcu wypowiedzi można było poznać niemalże hymn pochwalny na jej cześć. Za przykład może posłużyć recenzja Mariana Plezi, w której czytamy: „Ta garść uwag krytycznych nie powinna jednak umniejszać naszego uznania dla omawianej pracy, na które zasługuje ona z szeregu względów". Po czym czytelnik dowiedział się o wartości dzieła, sumiennym jego opracowaniu, ,nowych stwierdzeniach” w badaniach historycznych oraz obfitej literaturze przedmiotu. Recenzje, w których publicyści wytknęli liczne błędy występujące w książkach, a równocześnie podkreślali walory (poznawcze, naukowe, estetyczne, rozrywkowe i in.) publikacji, w ostateczności polecając je odbiorcom, znalazły się w kolejnej grupie omówień krytycznych. Stosunkowo największy krytycyzm, przy jednocześnie niewielkiej liczbie zrecenzowanych książek, przejawili publicyści „Znaku” (17\% wszystkich opinii). Jako drugi zaklasyfikował się „Przegląd Powszechny” (12\%), a po nim - z podobnymi wynikami w przedziale od 5 do $8 \%$ - pozostałe pisma. Porównywalny udział procentowy ocen krytycznych i jednoznacznie negatywnych wystąpił w „Tygodniku Warszawskim” (6\%) i „Tygodniku Powszechnym” (krytycznych 7,81\%, a negatywnych 7,03\%). Na łamach "Przeglądu Powszechnego” i "Tygodnika Katolickiego" złe opinie o książce stanowiły zaledwie około 4\% ogółu. Jakiejkolwiek recenzji negatywnej zabrakło natomiast w "Głosie Katolickim” i „Znaku”.

Najmniej liczną grupę stanowiły recenzje polemiczne, które wystąpiły w nieznacznym udziale procentowym $(0,25-1,4 \%)$ tylko na łamach wspomnianych trzech tytułów.

Wszyscy recenzenci wypowiadający się na łamach sześciu czasopism katolickich przynależeli do kilku środowisk. Pierwsze tworzyli znani katoliccy krytycy literatury oraz uczeni i publicyści stale współpracujący z redakcjami. Drugą kapłani biegli w nauce społecznej Kościoła, zagadnieniach religijnych

\footnotetext{
${ }^{4}$ M. Plezia, Nowa praca o św. Stanisławie, „TP” 1951 nr 38 s. 5 [Danuta Borawska, Z dziejów jednej legendy, Warszawa 1950].
} 
i teologicznych. Ostatnią grupę tworzyli sporadyczni, często okazjonalni współpracownicy pism.

Na łamach „Tygodnika Powszechnego” najbardziej aktywnym recenzentem był pierwszy redaktor naczelny ks. Jan Piwowarczyk, który w licznych ocenach książkowych ujmował temat zazwyczaj w sposób pogłębiony na tle szeroko pojętego katolicyzmu. Z bogatą ofertą wydawniczą na bieżąco zapoznawał znany historyk Paweł Jasienica. Największe zainteresowanie odbiorców zapewne budziły dobrze uzasadnione i podszyte humorem wypowiedzi polemiczne. Zofia Starowieyska-Morstinowa znana była stałym czytelnikom tygodnika z licznych recenzji powieści i opowiadań. W krakowskim piśmie publikowane były także literackie oceny Jerzego Zagórskiego. Piotr Grzegorczyk natomiast pod stałym nagłówkiem Książki o książkach uwzględnił m.in. najważniejsze polskie pozycje naukowe w zakresie bibliologii powojennej. Na opinię Włodzimierza Maciąga o świeżo wydanych tomikach w Półce z poezja i Półce z wierszami czekali miłośnicy tego gatunku literatury. Szczegółowy wykaz najpłodniejszych, a zarazem dobrze znanych recenzentów wraz z preferowaną problematyką i liczbą wypowiedzi opublikowanych w „Tygodniku Powszechnym” przedstawiono w tabeli 10 .

Tabela 10. Recenzenci książek na łamach „TP” w latach 1945-1953

\begin{tabular}{|r|l|l|c|}
\hline Lp. & Autor recenzji & Recenzowany rodzaj literatury i problematyka & $\begin{array}{l}\text { Liczba } \\
\text { recenzji }\end{array}$ \\
\hline 1 & \multicolumn{1}{|c|}{2} & \multicolumn{1}{|c|}{3} & 4 \\
\hline 1 & Ks. Jan Piwowarczyk & $\begin{array}{l}\text { katolicka, społeczna, filozoficzna, naukowa, } \\
\text { obozowa }\end{array}$ & 42 \\
\hline 2 & Paweł Jasienica & $\begin{array}{l}\text { katolicka, historyczna, wojenna, regionalistyczna, } \\
\text { polityczna }\end{array}$ & 32 \\
\hline 3 & $\begin{array}{l}\text { Zofia Starowieyska- } \\
\text { Morstinowa }\end{array}$ & katolicka, literacka, powieści, opowiadania & 27 \\
\hline 4 & Antoni Gołubiew & kulturalna, literacka, powieści & 26 \\
\hline 5 & Maria Morstin-Górska & katolicka, literacka, powieści, opowiadania & 21 \\
\hline 7 & Jerzy Zagórski & literacka & 19 \\
\hline 8 & Marian Plezia & $\begin{array}{l}\text { księgoznawcza, bibliotekarska, bibliografie, } \\
\text { tomiki poezji }\end{array}$ & 16 \\
\hline 9 & Maria Jarczyńska & katolicka, historyczna & 14 \\
\hline 10 & Józef Marian Święcicki & katolicka, powieści & 13 \\
\hline 11 & Stefan Kisielewski & literacka, powieści & 12 \\
\hline
\end{tabular}


Tabela 10 (cd.)

\begin{tabular}{|c|c|c|c|}
\hline 1 & 2 & 3 & 4 \\
\hline 12 & Włodzimierz Maciąg & tomiki poezji & 11 \\
\hline 13 & Wacław Rola & powieści, opowiadania & 10 \\
\hline 14 & Włodzimierz Wnuk & literacka, marynistyczna & 7 \\
\hline 15 & Jerzy Zagórski & tomiki poezji & 7 \\
\hline 16 & Jan Dobraczyński & katolicka, literacka, powieści & 6 \\
\hline 17 & Józefa Golmont & literacka, powieści, opowiadania & 6 \\
\hline 18 & Juliusz Kleiner & literacka & 6 \\
\hline 19 & N.K. & prawnicza, historyczna & 6 \\
\hline 20 & Wojciech Żukrowski & literacka, powieści, opowiadania & 6 \\
\hline 21 & Jan Paweł Gawlik & hitlerowska & 5 \\
\hline 22 & Zygmunt Kubiak & katolicka, filozoficzna & 5 \\
\hline 23 & Stefan Lichański & literacka, powieści, opowiadania & 5 \\
\hline 24 & Jerzy Turowicz & historyczna, katolicka & 5 \\
\hline 25 & Jan Wierusz-Kowalski & katolicka, teologiczna & 5 \\
\hline 26 & Jacek Woźniakowski & biografie & 5 \\
\hline 27 & Konrad Górski & literacka, powieści & 4 \\
\hline 28 & Stefan Kieniewicz & historyczna, biografie & 4 \\
\hline 29 & Władysław Konopczyński & historyczna & 4 \\
\hline 30 & Leszek Kuc & literacka & 4 \\
\hline 31 & Edmund Parthénay & tomiki poezji & 4 \\
\hline 32 & Janina Radwan & literatura dla młodzieży & 4 \\
\hline
\end{tabular}

Uwaga: Uwzględniono autorów co najmniej czterech recenzji.

Źródło: Obliczenia własne.

W „Przeglądzie Powszechnym” najważniejszą rolę w recenzowaniu książek odegrał ks. Jan Rostworowski, wypowiadający się najchętniej na tematy teologiczne i religijne. Charakter jego opinii pozostawał w ścisłym związku z tradycją i nauczaniem Kościoła. Stąd czytelnicy mogli natknąć się niekiedy na jego surowe oceny zawartości omawianych pozycji wydawniczych, podczas gdy te same książki w „Tygodniku Powszechnym” odbierane były z aprobatą recenzentów. Większość ocen głównie dotyczących książek literackich napisali: Zygmunt Lichniak (52), Olgierd Porycki (26) i Marek Krupiński (22). 
Tabela 11. Recenzenci książek na łamach „PP” w latach 1947-1953

\begin{tabular}{|c|l|l|c|}
\hline Lp. & Autor recenzji & Recenzowana literatura i problematyka & $\begin{array}{c}\text { Liczba } \\
\text { recenzji }\end{array}$ \\
\hline 1 & ks. Jan Rostworowski & $\begin{array}{l}\text { katolicka, teologiczna, hagiograficzna, } \\
\text { historyczna, naukowa }\end{array}$ & 93 \\
\hline 2 & Zygmunt Lichniak & $\begin{array}{l}\text { literacka, powieści, opowiadania, tomiki poezji, } \\
\text { wojenna }\end{array}$ & 52 \\
\hline 3 & Olgierd Porycki & $\begin{array}{l}\text { literacka, księgoznawcza, powieści, tomiki } \\
\text { poezji }\end{array}$ & 26 \\
\hline 4 & Marek Krupiński & literacka, powieści, opowiadania & 22 \\
\hline 5 & M.K. & tomiki poezji, opowiadania, literacka & 19 \\
\hline 6 & Zbigniew Pędziński & literacka, językoznawcza & 17 \\
\hline 7 & Wacław Rola & powieści, opowiadania, literacka, katolicka & 14 \\
\hline 8 & L. Mońko & medyczna, naukowa, powieści wojenne & 12 \\
\hline 9 & Marian Olszewski & literacka, tomiki poezji, powieści & 9 \\
\hline 10 & Zofia Starowieyska- & opowiadania, powieści & 9 \\
\hline 11 & Maria Chojecka & literacka, bibliograficzna & 8 \\
\hline 12 & J.K & pedagogiczna, naukowa & 8 \\
\hline 13 & N.K. & tomiki poezji, powieści & 8 \\
\hline 14 & Józef Marian Święcicki & katolicka, powieści & 4 \\
\hline 15 & S.B. & katolicka, rozważania & psychologiczna, pedagogiczna \\
\hline 16 & H.S. & & 8 \\
\hline
\end{tabular}

Uwaga: Uwzględniono autorów co najmniej czterech recenzji.

Źródło: Obliczenia własne.

Recenzje wydawnicze na łamach „Tygodnika Warszawskiego” wychodziły głównie spod pióra Antoniego Madeja (50 opinii), który zabierał głos w zasadniczych problemach katolickich, regionalistycznych i literackich. Po nim najczęściej wypowiadali się: Halina Kamieniecka (17), Zuzanna Rabska (14) i Wiktor Hahn (11). Pozostali recenzenci wedle wyliczeń osiągnęli niższą pozycję w tabeli pod względem ilości napisanych artykułów (4-8). Pięciu z najaktywniejszych publicystów posługiwało się pseudonimami, z których dwóch nie udało się rozszyfrować. Do tej grupy zaklasyfikowano 13 nazwisk. Bardziej dokładne dane podane zostały w tabeli 12 . 
Tabela 12. Recenzenci książek na łamach „TW” w latach 1945-1948

\begin{tabular}{|c|l|l|c|}
\hline Lp. & Autor recenzji & Recenzowana literatura i problematyka & $\begin{array}{l}\text { Liczba } \\
\text { recenzji }\end{array}$ \\
\hline 1 & Antoni Madej & $\begin{array}{l}\text { katolicka, powieści, książki dla młodzieży, } \\
\text { regionalistyczna }\end{array}$ & 50 \\
\hline 2 & $\begin{array}{l}\text { H.K. [Halina } \\
\text { Kamieniecka] }\end{array}$ & powieści, historyczna, obozowa & 17 \\
\hline 3 & Z.R. [Zuzanna Rabska] & katolicka, opowiadania, literatura dla dzieci & 14 \\
\hline 4 & Wiktor Hahn & powieści, tomiki poezji & 11 \\
\hline 5 & Wanda Bacewiczówna & wspomnienia, opowiadania & 8 \\
\hline 6 & Irena Pannenkowa & powieści, biografie, katolicka & 8 \\
\hline 7 & Bogdan Ostromęcki & tomiki poezji, literacka & 5 \\
\hline 8 & Jerzy Braun & katolicka & 4 \\
\hline 9 & jar, (jar) [Jan Archita] & katolicka & 4 \\
\hline 10 & Jerzy Kierst & dramat & 4 \\
\hline 11 & Stanisław Kozicki & historyczna, naukowa & 4 \\
\hline 12 & md. & katolicka, literatura dla młodzieży & 4 \\
\hline 13 & R. & literacka, powieści & \\
\hline
\end{tabular}

Uwaga: Uwzględniono autorów co najmniej czterech recenzji.

Źródło: Obliczenia własne.

Redakcja „Głosu Katolickiego” oceny nowości książkowych powierzyła głównie pięciu osobom, najwięcej wypowiedzi na tematy religijne opublikowali Jerzy Stawski (10) i Aleksander Rogalski (7). Pozostali publicyści, których nazwiska widnieją w tabeli 13, napisali po cztery opinie.

Tabela 13. Recenzenci książek na łamach „GK” w latach 1945-1948

\begin{tabular}{|c|l|l|c|}
\hline Lp. & Autor recenzji & Recenzowana literatura i problematyka & $\begin{array}{c}\text { Liczba } \\
\text { recenzji }\end{array}$ \\
\hline 1 & Jerzy Stawski & katolicka & 10 \\
\hline 2 & Aleksander Rogalski & katolicka, rozważania rekolekcyjne & 7 \\
\hline 3 & Jerzy Adamski & kulturalna, historyczna, katolicka & 4 \\
\hline 4 & Eugeniusz Myczka & katolicka & 4 \\
\hline 5 & Maria Tongwin & powieści dla młodzieży, opowiadania & 4 \\
\hline
\end{tabular}

Uwaga: Uwzględniono autorów co najmniej czterech recenzji.

Źródło: Obliczenia własne. 
W zestawieniach nie uwzględniono recenzentów, którzy napisali od jednego do trzech tekstów, przyjęto bowiem kryterium czterech publikacji dla aktywniejszych publicystów. Nie sporządzono wobec tego analogicznych przedstawień tabelarycznych w odniesieniu do „Tygodnika Katolickiego” i ,Znaku”. W tygodniku bowiem wszyscy recenzenci opublikowali po jednej opinii o książce, a dwie recenzje pozostały anonimowe. Na łamach krakowskiego miesięcznika znalazło się jedynie sześć recenzji Stanisława Stommy, pozostali piszący, m.in. Jan Dobraczyński, Konrad Górski, Hanna Malewska, Zofia Starowieyska-Morstinowa, Maria Winowska, wypowiedzieli się w jednej lub najwyżej dwóch ocenach.

Najwięcej opinii opublikowali liczni współpracownicy „Tygodnika Powszechnego" (32 osoby), omawiając książki o tematyce katolickiej, literackiej, historycznej, wojennej $\mathrm{i}$ in. Równie bogatą tematykę, jak wynika z tabeli, mieli na swoim koncie mniej liczni (16 osób), ale za to piszący więcej recenzji publicyści „Przeglądu Powszechnego” (ks. Rostworowski sporządził aż 93 oceny książek). Na łamach „Tygodnika Warszawskiego” najbardziej opiniotwórczym piórem dysponował Antoni Madej (52); mniejszy dorobek w tym zakresie mieli kolejni trzej publicyści. Większość natomiast (9) swoje poglądy wyraziła w kilku publikacjach (4-8). Przedmiotem dywagacji były rozprawy naukowe, hagiografie, biografie, powieści, zbiory opowiadań, dramaty, tomiki poezji, publikacje teoretyczno-literackie, dzieła zbiorowe, antologie, książki popularnonaukowe, niekiedy broszury.

\subsubsection{Książki zrecenzowane}

Niektóre tytuły książkowe uzyskały opinię kilku recenzentów na łamach czasopism i były oceniane wielokrotnie w różnych latach. Przykładowo chętnie proponowano czytelnikom kilkutomową powieść historyczną Antoniego Gołubiewa Bolesław Chrobry. Otrzymała ona pozytywne głosy w czterech z sześciu periodyków („Tygodniku Powszechnym”, „Przeglądzie Powszechnym”, „Tygodniku Warszawskim” i „Tygodniku Katolickim”), przy czym tylko w krakowskim organie prasowym zrecenzowana została czterokrotnie (w roku 1947, 1950 oraz dwukrotnie w 1952 r.). Powieść wojenna Jana Dobraczyńskiego $W$ rozwalonym domu uzyskała łącznie siedem ocen w latach 1946-1948 (w „Głosie Katolickim”, „Tygodniku Powszechnym”, „Tygodniku Warszawskim” i „Przeglądzie Powszechnym”). W dalszej części pracy sporządzono osobne zestawienia tabelaryczne, w których zaprezentowano liczbę książek zrecenzowanych różniącą się od przedstawionych wyżej recenzji.

We wszystkich sześciu czasopismach recenzenci dostrzegli książki nagradzane autorów rodzimych i obcych. W grupie promowanych nowości wydawniczych znalazły się zarówno pozycje najbardziej znane, jak i te niezauważane oraz celowo pomijane. Brano pod uwagę wszystkie gatunki oraz formy literackie i nieliterackie. Książka była przez to szeroko propagowana. W zaprezentowanych katolickich periodykach społeczno-kulturalnych w okresie 1945-1953 zrecenzowano 1105 książek 
(775 pozycji polskich i 330 zagranicznych). Dane odnośnie do poszczególnych lat prezentują tabele14 i 15.

Tabela 14. Liczba książek autorów polskich zrecenzowanych na łamach wybranych tytułów prasowych w 1. 1945-1953

\begin{tabular}{|c|r|r|r|r|r|c|}
\hline \multicolumn{1}{l|}{ Rok } & \multicolumn{1}{|l|}{,TP” } & „PP” & „TW" & „GK” & „TK” & „Znak" \\
\hline 1945 & 3 & - & - & - & & - \\
\hline 1946 & 35 & - & 39 & 7 & - & 1 \\
\hline 1947 & 117 & - & 75 & 7 & 3 & 1 \\
\hline 1948 & 112 & 58 & 67 & 25 & 5 & 1 \\
\hline 1949 & 85 & 39 & - & - & 2 & 1 \\
\hline 1950 & 37 & 55 & - & - & 2 & - \\
\hline 1951 & 34 & 36 & - & - & 3 & - \\
\hline 1952 & 22 & 75 & - & - & 1 & 1 \\
\hline 1953 & 5 & 3 & - & - & - & - \\
\hline Razem & 450 & 266 & 181 & 39 & 16 & 5 \\
\hline
\end{tabular}

Źródło: Obliczenia własne.

Z analizy wspomnianego spisu zrecenzowanych książek autorów polskich (na dołączonej płycie CD) wynika, że na łamach „Tygodnika Powszechnego” w latach 1945-1953 oceniono aż 450 książek, w powojennym „Przeglądzie Powszechnym" w krótszym okresie 1947-1953 nieco mniej - 266 pozycji, a w przedwcześnie zamkniętym „Tygodniku Warszawskim” (1945-1948) udało się zaopiniować 181 nowości. Zdecydowanie mniej pozycji wydawniczych w porównaniu z wymienionymi wyżej danymi zrecenzowano w pozostałych trzech tytułach: „Głosie Katolickim” (1945-1948), „Tygodniku Katolickim” (1946-1953) i miesięczniku „Znak” (1946-1953), gdyż razem zaledwie 60. We wszystkich pismach najwięcej opinii o książkach publicyści zamieścili w latach 1947-1948, a najskromniej książkę prezentowano w latach krańcowych: 1945 i 1953. Rok zakończenia drugiej wojny światowej był czasem wyłonienia się nowych tytułów prasowych (,Tygodnika Powszechnego”, „Głosu Katolickiego” i „Tygodnika Warszawskiego"), kształtowania się ich programów wraz z układem zawartości, co zapewne spowodowało początkowo brak większego zainteresowania książką w recenzjach. Trudny dla prasy katolickiej końcowy rok 1953 naznaczony został z kolei atmosferą zagrożenia i niepewności dla redakcji, które jeszcze pracowały. W przypadku istniejących czasopism ukazały się tylko początkowe numery, po czym tytuły zamknięto. Spowodowało to zapewne mniejsze zainteresowanie recenzjami. Omówiono bowiem zaledwie kilka książek w „Tygodniku Powszechnym” i „Przeglądzie Powszechnym”, pomimo że w jezuickim periodyku 
najwięcej nowości wydawniczych autorów polskich w relacji do wszystkich lat zaproponowano w roku poprzednim (w 1952 r. ukazało się ich 75).

W latach 1945-1953 liczba książek rodzimych twórców ocenianych w ciągu roku w różnych periodykach wahała się od 1 do 117 . Najwięcej, bo 117 pozycji bibliograficznych zrecenzowano w 1947 r. w „Tygodniku Powszechnym”. W najbardziej płodnych pod względem recenzji wspomnianych trzech pismach liczba książek oscylowała najczęściej w przedziale 30-40 tytułów rocznie. Najwięcej pozycji oceniono w latach 1947-1949. Od roku 1950 można zaobserwować wyraźną tendencję zniżkową, wyjątek stanowił jedynie „Przegląd Powszechny”. Nie istniały już „Tygodnik Warszawski” i „Głos Katolicki”.

\subsubsection{Wydawnictwa}

Książki zrecenzowane w sześciu katolickich czasopismach społeczno-kulturalnych ukazały się głównie nakładem polskich oficyn. Należały do nich wydawnictwa państwowe, spółdzielcze i prywatne. Ostatnie z wymienionych działały głównie w latach 1945-1948. Z racji profilu periodyków w ich zawartości promowano również książki tłoczone w firmach zakonnych, diecezjalnych i należących do towarzystw katolickich. Nazwy oficyn występujące na kartach tytułowych książek przedstawiono $\mathrm{w}$ tabelach sporządzonych osobno do każdego periody$\mathrm{ku}$. W zestawieniach nie uwzględniono drukarni reprezentowanych przez jedną lub dwie pozycje bibliograficzne; minimum trzy tytuły książkowe powodowały umieszczenie wydawcy w tabeli.

Oferta wydawnicza obecna w „Tygodniku Powszechnym” była najbardziej bogata i różnorodna spośród proponowanych w pozostałych pięciu pismach (zob. tabela 15).

Tabela 15. Wydawcy zrecenzowanych książek autorów polskich i obcych na łamach „TP” w latach 1945-1953

\begin{tabular}{|c|l|l|c|}
\hline Lp. & Nazwa wydawnictwa lub wydawcy & Siedziba & $\begin{array}{c}\text { Liczba zrecenzo- } \\
\text { wanych książek }\end{array}$ \\
\hline 1 & \multicolumn{1}{|c|}{2} & 3 & 4 \\
\hline 1 & Czytelnik & Warszawa & 68 \\
\hline 2 & Książka & Warszawa & 42 \\
\hline 3 & Państwowy Instytut Wydawniczy & Warszawa & 24 \\
\hline 4 & Instytut Wydawniczy PAX & Warszawa & 24 \\
\hline 5 & Wydawnictwo Instytutu Zachodniego & Poznań & 21 \\
\hline 6 & Towarzystwo Naukowe KUL & Lublin & 20 \\
\hline 7 & Wiedza & Warszawa & 20 \\
\hline
\end{tabular}


Tabela 15 (cd.)

\begin{tabular}{|c|c|c|c|}
\hline 1 & 2 & 3 & 4 \\
\hline 8 & Gebethner i Wolff & Warszawa & 17 \\
\hline 9 & Albertinum Księgarnia św. Wojciecha & Poznań & 14 \\
\hline 10 & Wydawnictwo Mariackie & Kraków & 14 \\
\hline 11 & $\begin{array}{l}\text { Wydawnictwo Zakładu Narodowego im. } \\
\text { Ossolińskich }\end{array}$ & Wrocław & 13 \\
\hline 12 & Awir & Katowice & 12 \\
\hline 13 & Książka i Wiedza & Warszawa & 12 \\
\hline 14 & Książnica Atlas & Wrocław-Warszawa & 11 \\
\hline 15 & Eugeniusz Kuthan & Warszawa-Kraków & 10 \\
\hline 16 & Verbum & Kielce & 10 \\
\hline 17 & Księgarnia św. Jacka & Katowice & 9 \\
\hline 18 & Trzaska, Evert i Michalski & Warszawa & 8 \\
\hline 19 & Pallotinum & Poznań & 7 \\
\hline 20 & Wielkopolska Księgarnia Wydawnicza & Poznań & 6 \\
\hline 21 & $\begin{array}{l}\text { Wydawnictwo Księgarni Stefana } \\
\text { Kamińskiego }\end{array}$ & Kraków & 6 \\
\hline 22 & Księgarnia Zdzisława Gustowskiego & Poznań & 5 \\
\hline 23 & Panteon & Warszawa & 5 \\
\hline 24 & Polska Akademia Umiejętności & Kraków & 5 \\
\hline 25 & Władysław Bąk & Łódź-Wrocław & 5 \\
\hline 26 & Związek Zawodowy Literatów Polskich & $\begin{array}{l}\text { Kraków-Warszawa- } \\
\text { Łódź }\end{array}$ & 5 \\
\hline 27 & $\begin{array}{l}\text { Katolickie Towarzystwo Wydawnicze } \\
\text { „Rodzina Polska” }\end{array}$ & Warszawa & 4 \\
\hline 28 & M. Kot & Kraków & 4 \\
\hline 29 & Krajowa Centrala Caritas & Częstochowa & 3 \\
\hline 30 & Księgarnia Akademicka & Poznań & 3 \\
\hline 31 & Mieczysław Fuksiewicz i Spółka & Warszawa & 3 \\
\hline 32 & Radiowy Instytut Wydawniczy & Warszawa & 3 \\
\hline 33 & Veritas & Tarnów & 3 \\
\hline 34 & Wydawnictwo Milicji Niepokalanej & Niepokalanów & 3 \\
\hline 35 & Wydawnictwo Przełom & Kraków & 3 \\
\hline 36 & Zapiór Tadeusz „Wiedza, Zawód, Kultura” & Kraków & 3 \\
\hline & Różne wydawnictwa & - & 196 \\
\hline & Razem & - & 618 \\
\hline
\end{tabular}

Uwaga: W zestawieniu pominięto wydawców z liczbą zrecenzowanych książek mniejszą niż trzy. Źr ódło: Obliczenia własne. 
Najwięcej omówionych druków zwartych zostało wydanych w warszawskiej Spółdzielni Wydawniczej Czytelnik (68), Książce (42) i Instytucie Wydawniczym PAX (24). Zgodnie z profilem największego koncernu wydawniczego najliczniej zaprezentowana została literatura piękna, w której dominowały powieści i opowiadania. Wśród 29 zrecenzowanych powieści znalazła się współczesna literatura polska i klasycy rosyjscy. Druga ze spółdzielni, należąca do Polskiej Partii Robotniczej, o wyraźnie politycznym profilu, na łamach krakowskiego tygodnika reprezentowana była również przez literaturę piękną (głównie opowiadania i tomiki poezji), rzadziej przez książkę popularnonaukową. Pod szyldem Instytutu Wydawniczego PAX (dalej IW PAX) ukazały się natomiast powojenne wydania Nowego Testamentu, Katechizmu religii katolickiej oraz Prolegomena do Nowego Testamentu ks. Eugeniusza Dąbrowskiego. Książkę literacką tegoż wydawnictwa reprezentowały powieści i opowiadania o tematyce katolickiej.

Bezpośrednio po nich z około 20 pozycjami uplasowało się kilka domów wydawniczych. Utworzone po II wojnie światowej Wydawnictwo Instytutu Zachodniego w Poznaniu w swej ofercie posiadało głównie książkę historyczną, m.in. w cyklach: Prace Instytutu Zachodniego, Ziemie Staropolski, Studia nad Dziejami Gospodarczymi Okupacji Niemieckiej, Biblioteka Czeska. Tematyka ocenianych w „Tygodniku Powszechnym” książek tegoż wydawnictwa miała charakter regionalny, dotyczyła historii i kultury Ziem Zachodnich. W gronie autorów, których książki wydawało Towarzystwo Naukowe KUL, znaleźli się Juliusz Kleiner, Stefan Świeżawski i Leon Halban. Z oficyny Towarzystwa wyszły głównie naukowe publikacje teoretycznoliterackie i filozoficzne, które dostrzegli publicyści krakowskiego organu prasowego. Spółdzielnia Wydawnicza Wiedza, specjalizująca się w literaturze pięknej, wprowadziła na rynek liczne powieści i opowiadania. Do zrecenzowanych $\mathrm{w}$ tygodniku należały m.in. powieść wojenna Ksawerego Pruszyńskiego Droga wiodła przez Narwik, która była pierwszą książką w dorobku drukarni ${ }^{5}$, Nowele włoskie Jarosława Iwaszkiewicza i Pożegnanie z Maria Tadeusza Borowskiego. Wśród znanych powieści wydrukowanych przez długowieczną firmę Gebethnera i Wolffa zauważonych przez recenzentów znalazły się: Jana Dobraczyńskiego $W$ rozwalonym domu, dwie powieści historyczne Karola Bunscha Ojciec i syn oraz Imiennik, jak też Władysława Orkana Drzewiej.

Po kilkanaście tytułów książkowych zaproponowano publicystom tygodnika krakowskiego z dorobku wydawnictw, które w tabeli 13 figurują na pozycjach 9-14. Książka literacka o tematyce katolickiej przeważyła w ofercie Albertinum Księgarni św. Wojciecha (m.in. Konfesjonat i Trzecia zmiana Jana Władysława Grabskiego). Tutaj też zainicjowano znaną serię Jasnych Książek oraz czytelnicy mogli nabyć powojenne wydanie Pisma świętego Nowego Testamentu. Wydawnictwo Mariackie w Krakowie dostarczyło odbiorcom książki filozoficzne

\footnotetext{
${ }^{5}$ A. Bromberg, Książi i wydawcy, Warszawa 1958, s. 94.
} 
(m.in. o. Jacka Woronieckiego Katolicka etyka wychowawcza t. 1-2) oraz komentarz do Ewangelii autorstwa ks. Józefa Kaczmarczyka Życie i działalność Jezusa Chrystusa w świetle czterech Ewangelii. Czytelnicy „Tygodnika Powszechnego" asortyment naukowego Wydawnictwa Zakładu Narodowego im. Ossolińskich poznali przez pryzmat różnej problematyki, w tym księgoznawczej, literackiej i historycznej. Awir wraz z połączoną w 1948 r. instytucją Książka i Wiedza oraz Książnicą Atlas w recenzjach znane były głównie z udostępniania zagranicznych i rodzimych powieści. W pierwszym wydrukowano: Mariki Stiernstedt Zamach w Paryżu, Archibalda Josepha Cronina Klucze królestwa i Zielone lata, Sinclaira Lewisa Matżeństwa czy Wojciecha Żukrowskiego Ręka ojca, w drugim natomiast Aleksandra Ścibora-Rylskiego Węiel. Trzy powieści holenderskiego pisarza Jo van Ammers-Küllera Patrioci, Taniec wokół gilotyny i Wierność rodu Tavelincków, dwa tytuły Tadeusza Kudlińskiego Farbowane lisy i Świętokradca, jeden Jana Wiktora Skrzydlaty mnich ukazały się w Książnicy Atlas.

W pozostałych instytucjach, które zajęły w tabeli niższe miejsce, powieści zaoferowano m.in. w oficynie Eugeniusza Kuthana. Książka literacka obecna była ponadto $\mathrm{w}$ repertuarze wydawniczym Władysława Bąka, Trzaski, Everta i Michalskiego oraz w Wielkopolskiej Księgarni Wydawniczej, Wydawnictwie Księgarni Stefana Kamińskiego, Księgarni Zdzisława Gustowskiego. Czytającym recenzje „Tygodnika Powszechnego" Związek Zawodowy Literatów Polskich, Katolickie Wydawnictwo „Rodzina Polska” i Wydawnictwo Przełom dały się poznać jako publikujący tomiki poezji polskich twórców. Książka naukowa, w tym dzieła teoretycznoliterackie przeważyły w Wydawnictwie Polskiej Akademii Umiejętności. Książka katolicka należała głównie do asortymentu: Verbum (specjalizującego się m.in. w encyklikach papieskich w serii Z Akt Stolicy Apostolskiej), Księgarni św. Jacka (Ewangelie i Dzieje Apostolskie, mszał oraz literackie biografie świętych Gilberta Keitha Chestertona), Pallotinum, Krajowej Centrali Caritas i Veritas (rozważania religijne). Na stronach tytułowych niektórych egzemplarzy ocenianych książek widniały również inne oficyny mniej lub bardziej znane ${ }^{6}$.

Na łamach „Przeglądu Powszechnego”, zajmującego drugie miejsce pod względem liczby zrecenzowanych książek w latach 1947-1953, pojawiła się równie różnorodna oferta wydawnicza. Czołówka (pozycje 1-4) w tabeli 16 wygląda podobnie jak w przypadku „Tygodnika Powszechnego”, z jedyną różnicą w pozycji 2.

\footnotetext{
${ }^{6}$ Po dwa tytuły książkowe zrecenzowano w „TP” z takich wydawnictw, jak: Wydawnictwo Św. Krzyża, Oficyna Księgarska, Poligrafika, Polskie Wydawnictwo Muzyczne, Poznańskie Towarzystwo Przyjaciół Nauk, Wydawnictwo Studium Słowiańskiego Uniwersytetu Jagiellońskiego, Towarzystwo Ludoznawcze, Wrocławskie Towarzystwo Naukowe, Wydawnictwo Apostolstwa Modlitwy i Wydawnictwo Państwowego Instytutu Historii Sztuki.
} 
Tabela 16. Wydawcy zrecenzowanych książek autorów polskich i obcych na łamach „PP” w latach 1947-1953

\begin{tabular}{|c|c|c|c|}
\hline Lp. & Nazwa wydawnictwa lub wydawcy & Siedziba & $\begin{array}{l}\text { Liczba zrecenzo- } \\
\text { wanych książek }\end{array}$ \\
\hline 1 & 2 & 3 & 4 \\
\hline 1 & Czytelnik & Warszawa & 47 \\
\hline 2 & Książka i Wiedza & Warszawa & 29 \\
\hline 3 & Państwowy Instytut Wydawniczy & Warszawa & 25 \\
\hline 4 & Instytut Wydawniczy PAX & Warszawa & 19 \\
\hline 5 & $\begin{array}{l}\text { Wydawnictwo Zakładu Narodowego im. } \\
\text { Ossolińskich }\end{array}$ & Wrocław & 18 \\
\hline 6 & Towarzystwo Naukowe Warszawskie & Warszawa & 14 \\
\hline 7 & Verbum & Kielce & 11 \\
\hline 8 & Albertinum Księgarnia św. Wojciecha & Poznań & 9 \\
\hline 9 & Pallottinum & Poznań & 9 \\
\hline 10 & Towarzystwo Naukowe KUL & Lublin & 9 \\
\hline 11 & Gebethner i Wolff & Warszawa & 7 \\
\hline 12 & Wiedza & Warszawa & 7 \\
\hline 13 & Wielkopolska Księgarnia Wydawnicza & Poznań & 7 \\
\hline 14 & Wydawnictwo Mariackie & Kraków & 7 \\
\hline 15 & Letouzey & Paryż & 6 \\
\hline 16 & Wydawnictwo Instytutu Zachodniego & Poznań & 6 \\
\hline 17 & Książnica Atlas & $\begin{array}{l}\text { Wrocław- } \\
\text { Warszawa }\end{array}$ & 5 \\
\hline 18 & Polska Akademia Umiejętności & Kraków & 5 \\
\hline 19 & Wydawnictwo Milicji Niepokalanej & Niepokalanów & 5 \\
\hline 20 & Wydawnictwo OO. Karmelitów Bosych & Kraków & 5 \\
\hline 21 & Zapiór Tadeusz „Wiedza, Zawód, Kultura” & Kraków & 5 \\
\hline 22 & Awir & Katowice & 4 \\
\hline 23 & Beauchesne & Paryż & 4 \\
\hline 24 & Eugeniusz Kuthan & $\begin{array}{l}\text { Warszawa- } \\
\text { Kraków }\end{array}$ & 4 \\
\hline 25 & Książka & Warszawa & 4 \\
\hline 26 & Księgarnia Zdzisława Gustowskiego & Poznań & 4 \\
\hline 27 & Poznańskie Towarzystwo Przyjaciół Nauk & Poznań & 4 \\
\hline 28 & Wydawnictwo Apostolstwa Modlitwy & $\begin{array}{l}\text { Kraków- } \\
\text { Warszawa }\end{array}$ & 4 \\
\hline
\end{tabular}


Tabela 16 (cd.)

\begin{tabular}{|c|l|l|c|}
\hline \multicolumn{1}{|c|}{2} & \multicolumn{1}{|c|}{3} & 4 \\
\hline 29 & Wydawnictwo św. Krzyża & Opole & 4 \\
\hline 30 & Desclée de Brouwer & Paryż & 3 \\
\hline 30 & Księgarnia Akademicka & Poznań & 3 \\
\hline 31 & Księgarnia św. Jacka & Katowice & 3 \\
\hline 32 & Panteon & Warszawa & 3 \\
\hline 33 & Państwowe Zakłady Wydawnictw Szkolnych & Warszawa & 3 \\
\hline 34 & Prasa Wojskowa & Warszawa & 3 \\
\hline & Inne & & 98 \\
\hline & Razem & & 403 \\
\hline
\end{tabular}

Uwaga: W zestawieniu pominięto wydawców z liczbą zrecenzowanych książek mniejszą niż trzy. Źr ódło: Obliczenia własne.

Publicyści „Przeglądu Powszechnego” najczęściej recenzowali książki wydane przez Spółdzielnię Wydawniczą Czytelnik. Oficyna ta posiadała największą ofertę polskiej książki literackiej (powieści, opowiadań i tomików poezji). W swoim repertuarze zaproponowała też kilka publikacji teoretycznoliterackich będących marksistowską interpretacją literatury. Z dzieł obcych twórców omówiono m.in. Aleksego Tołstoja Piotr I, Michaiła Szołochowa Cichy Don, Nikołaja Gogola Poranek dygnitarza i inne opowiadania ale także Erskine'a Caldwella Druga Amerykę. Wśród zrecenzowanych nowości wydanych w Książce i Wiedzy przeważyły powieści i opowiadania obcych pisarzy m.in. Ilii Erenburga, Hansa Fallady, Emila Zoli, Guy de Maupassanta. IW PAX zasłużył się głównie w dostarczaniu na rynek książek literackich i katolickich. Tutaj ukazały się powieści Jana Dobraczyńskiego, Georgesa Bernanosa, Grahama Greene'a i Henri Daniela-Ropsa. Z prozy polecano także tytuły powieściowe wydane przez Książnicę Atlas, wydawnictwo Awir, firmę wydawniczą Eugeniusza Kuthana i Księgarnię Zdzisława Gustowskiego.

Osobne miejsce w „Przeglądzie Powszechnym” zajęła książka naukowa. Piątą pozycję w tabeli uzyskały wysoko cenione publikacje najstarszej oficyny w kraju - Zakładu Narodowego im. Ossolińskich, z których najwięcej omówiono pozycji teoretycznoliterackich i księgoznawczych. Redakcja uwzględniła w ocenach także dorobek trzech towarzystw: Towarzystwa Naukowego Warszawskiego, Towarzystwa Naukowego KUL i Poznańskiego Towarzystwa Przyjaciół Nauk. Pierwsze z nich zwróciło uwagę recenzentów przy okazji publikacji teoretycznoliterackich i historycznych, drugie udostępniło przede wszystkim dzieła teologiczne, psychologiczne i z zakresu prawa, ostatnie natomiast 
znane było czytelnikom z monografii językoznawczych. Zainteresowanym polecano również książki o różnej problematyce z Wydawnictwa Polskiej Akademii Umiejętności.

Książka katolicka dominowała w produkcji edytorskiej kurii diecezjalnych i zakonów. Odbiorcy „Przeglądu Powszechnego” poznali rozważania modlitewne, rekolekcyjne i ewangeliczne z Verbum i Wydawnictwa Apostolstwa Modlitwy (m.in. Tomasza á Kempis $O$ naśladowaniu Chrystusa), powieści ze wspomnianej serii Jasnych Książek Albertinum oraz naukowe rozprawy teologiczne i rozważania wydane w Pallotinum. Homilie i kazania w cyklu Złoty Wiek Myśli Chrześcijańskiej dostępne były w Wydawnictwie Mariackim. Podręczniki uniwersyteckie z filozofii i teologii można było nabyć w Wydawnictwie Św. Krzyża w Opolu, natomiast hagiografie były obecne w katalogu wydawniczym Księgarni św. Jacka. Z kolei Wydawnictwo OO. Karmelitów Bosych posiadało w swojej ofercie dzieła św. Jana od Krzyża Drogę na Górę Karmel, Noc ciemna i Pieśń duchowa. Wydawnictwo Milicji Niepokalanej oferowało natomiast bardziej popularną literaturę religijną.

Uwagę w tabeli zwracają trzy zagraniczne wydawnictwa Letouzey, Beauchesne i Desclée de Brouwer z siedzibą w Paryżu, które znalazły się w zestawieniu dzięki recenzjom ks. Jana Rostworowskiego. Publicysta śledził bowiem na bieżąco francuskojęzyczne słowniki, encyklopedie i traktaty o charakterze teologicznym. Krakowska oficyna pod nazwą Zapiór Tadeusz „Wiedza, Zawód, Kultura" w opiniach piszących mogła zainteresować czytelników podręcznikami akademickimi i poradnikami zawodowymi.

W recenzjach „Tygodnika Warszawskiego” poza znacznie mniejszą liczbą tytułów książkowych widoczna jest także wyraźnie uboższa oferta wydawnicza, co zobrazowano w tabeli 17.

Podobnie jak w odniesieniu do omówionych wcześniej pism, na pierwsze miejsce wysunęła się literatura piękna upowszechniana przez Czytelnika. Przodowały także z jednakową liczbą zrecenzowanych powieści i opowiadań Książka oraz Wiedza, występujące jeszcze osobno. Z katalogu wydawnictwa Awir recenzenci wybrali przede wszystkim powieści zagraniczne (m.in. Françoisa Mauriaca i Archibalda Josepha Cronina). Znane Wydawnictwo Instytutu Zachodniego zwróciło uwagę publicystów pracami naukowymi, reportażami i broszurami o tematyce historycznej, niemieckiej, regionalnej oraz marynistycznej. Oficyna Władysława Bąka dała się poznać odbiorcom tygodnika z tomików poezji.

Inaczej, jak wynika $\mathrm{z}$ analizy statystycznej, wyglądała natomiast oferta wydawnicza w recenzjach opublikowanych w „Głosie Katolickim” (zob. tabela 18). Nie uwzględniono tu zbyt wielu wydawców i wykazano zainteresowanie przeważnie literaturą religijną. Do wykazu doszło jedynie nieobecne dotąd w zestawieniach Wydawnictwo Sióstr Loretanek. Redakcja śledziła głównie wydania 
nowych encyklik w polskim thumaczeniu we wspomnianym już cyklu Z Akt Stolicy Apostolskiej.

Tabela 17. Wydawcy zrecenzowanych książek autorów polskich i obcych na łamach „TW” w latach $1945-1948$

\begin{tabular}{|c|l|l|c|}
\hline Lp. & Nazwa wydawnictwa lub wydawcy & Siedziba & $\begin{array}{l}\text { Liczba zrecenzo- } \\
\text { wanych książek }\end{array}$ \\
\hline 1 & Czytelnik & Warszawa & 17 \\
\hline 2 & Eugeniusz Kuthan & $\begin{array}{l}\text { Warszawa- } \\
\text { Kraków }\end{array}$ & 11 \\
\hline 3 & Książka & Warszawa-Łódź & 11 \\
\hline 4 & Wiedza & Warszawa & 11 \\
\hline 5 & Wydawnictwo Instytutu Zachodniego & Poznań & 9 \\
\hline 6 & Awir & Katowice & 7 \\
\hline 7 & Władysław Bąk & Wrocław-Łódź & 7 \\
\hline 8 & Albertinum Księgarnia św. Wojciecha & Poznań & 6 \\
\hline 9 & Książnica Atlas & Wrocław- & 6 \\
\hline 10 & Księgarnia św. Jacka & Warszawa & 5 \\
\hline 11 & Gebethner i Wolff & Katowice & 4 \\
\hline 12 & Towarzystwo Naukowe KUL & Warszawa & 3 \\
\hline 13 & Wydawnictwo Apostolstwa Modlitwy & Lublin & 3 \\
\hline 14 & Drukarnia i Księgarnia św. Wojciecha & Warszaw- & 3 \\
\hline 15 & $\begin{array}{l}\text { Katolickie Towarzystwo Wydawnicze } \\
\text { „Rodzina Polska” }\end{array}$ & Poznań & 3 \\
\hline 16 & Księgarnia Stefana Kamińskiego & Kraków & 3 \\
\hline 17 & Stanisław Arct & Warszawa & 3 \\
\hline 18 & Trzaska, Evert i Michalski & Warszawa & 3 \\
\hline 19 & Verbum & Kielce & 3 \\
\hline 20 & Wielkopolska Księgarnia Wydawnicza & Poznań & 3 \\
\hline 21 & Wydawnictwo Mariackie & Kraków & 3 \\
\hline 22 & Inne & & 3 \\
\hline 23 & Razem & & 3 \\
\hline
\end{tabular}

Uwaga: W zestawieniu pominięto wydawców z liczbą zrecenzowanych książek mniejszą niż trzy.

Źr ódło: Obliczenia własne. 
Tabela 18. Wydawcy zrecenzowanych książek autorów polskich i obcych na łamach „GK” w latach 1945-1948

\begin{tabular}{|c|l|l|c|}
\hline Lp. & Nazwa wydawnictwa lub wydawcy & Siedziba & $\begin{array}{l}\text { Liczba zrecenzowa- } \\
\text { nych książek }\end{array}$ \\
\hline 1 & Verbum & Kielce & 7 \\
\hline 2 & Albertinum Księgarnia św. Wojciecha & Poznań & 5 \\
\hline 3 & Wydawnictwo Instytutu Zachodniego & Poznań & 4 \\
\hline 4 & Eugeniusz Kuthan & Warszawa & 3 \\
\hline 5 & Wydawnictwo Mariackie & Kraków & 3 \\
\hline 6 & Wydawnictwo Sióstr Loretanek-Benedyktynek & Warszawa & 3 \\
\hline & Inne & & 33 \\
\hline & Razem & & 58 \\
\hline
\end{tabular}
niż trzy.

Uwaga: W zestawieniu pominięto wydawców z liczbą zrecenzowanych książek mniejszą

Źródło: Obliczenia własne.

W „Tygodniku Katolickim” odnotowano w opiniach w większości po jednej książce z różnych wydawnictw ${ }^{7}$, jedynie po pięć tytułów ukazało się w Drukarni i Księgarni św. Wojciecha (podawanej pod nazwą Albertinum Księgarnia św. Wojciecha) i w IW PAX. Podobnie w „Znaku”, wśród 23 pozycji (pięć polskich książek i 18 obcych) znaczna część wyszła spod prasy różnych oficyn wydawni$\mathrm{czych}^{8}$. Po dwie z ocenionych pozycji pochodziło z firmy Eugeniusza Kuthana, Gebethnera i Wolffa oraz IW PAX.

Na łamach sześciu katolickich pism znacznie mniej oceniono pozycji książkowych autorów obcych. Przodowały w tym dwa z uwzględnionych tytułów „Tygodnik Powszechny” (168 tytułów książkowych) i „Przegląd Powszechny” (133 książki). Najmniej pozycji zagranicznych zaopiniowano w „Tygodniku Katolickim”, gdyż tylko osiem. Szczegółowe dane podano w tabeli 19.

W skali roku liczba recenzji wynosiła od jednej do 35. Najwięcej opinii o tytułach zagranicznych, podobnie jak w przypadku książek autorów polskich, ukazało się w „Tygodniku Powszechnym” w latach 1947-1949. W „Przeglądzie Powszechnym" najwyższe wyniki (powyżej 30 pozycji zrecenzowanych) osiągnięto w latach 1949 i 1951-1952.

${ }^{7}$ Były nimi: Czytelnik, Dobra Książka, Drukarnia Katolicka, Księgarnia Ogniwo, Księgarnia Ziem Zachodnich, Państwowe Zakłady Wydawnictw Szkolnych, Wielkopolska Księgarnia Wydawnicza, Pallotinum, Verbum, Wydawnictwo Apostolstwa Modlitwy, Wydawnictwo św. Krzyża, Zapiór Tadeusz „Wiedza, Zawód, Kultura”, Związek Młodzieży Przemysłowej i Rękodzielniczej.

${ }^{8} \mathrm{Z}$ polskich m. in. Oficyna Księgarska, Verbum, z zagranicznych: Roy Publishers, Brentano New York, Gallimard, Librairie Plon, Office de Publicité, Castreman-Tournai. 
Tabela 19. Liczba książek autorów obcych zrecenzowana na łamach wybranych tytułów prasowych w 1. 1945-1953

\begin{tabular}{|c|r|r|r|r|r|r|}
\hline Rok & \multicolumn{1}{|l}{ „TP” } & „PP” & „TW" & „GK” & „TK” & „Znak” \\
\hline 1945 & - & - & - & - & - & - \\
\hline 1946 & 4 & - & 4 & 3 & - & 2 \\
\hline 1947 & 29 & - & 16 & 8 & - & 2 \\
\hline 1948 & 40 & 14 & 23 & 9 & - & 5 \\
\hline 1949 & 34 & 35 & - & - & 1 & 5 \\
\hline 1950 & 20 & 17 & - & - & 1 & 2 \\
\hline 1951 & 20 & 34 & - & - & 5 & 2 \\
\hline 1952 & 19 & 31 & - & - & 1 & - \\
\hline 1953 & 2 & 2 & - & - & - & - \\
\hline Razem & 168 & 133 & 43 & 20 & 8 & 18 \\
\hline
\end{tabular}

Źr ó dło: Obliczenia własne.

Trudności w przedstawieniu wydawców zrecenzowanych książek wydanych za granicą wystąpiły z powodu niepodania ich nazw w niektórych przypadkach. Publicyści wykazali bowiem mniejsza dbałość w notowaniu dokładnych informacji bibliograficznych, jak czynili to w przypadku rodzimej literatury. Do najczęściej wymienianych wydawnictw obcych należały: Desclée de Brouwer, Letouzey, Gallimard, Librairie, Plon i The Camridge University Press. Największe zainteresowanie przejawiano nowościami wydawniczymi, których oryginalnym językiem był francuski, angielski, niemiecki i rosyjski; stanowiły one prawie $69 \%$ recenzowanych książek autorów obcych9.

W trzech najbogatszych w recenzje książkowe czasopismach: „Tygodniku Powszechnym”, „Przeglądzie Powszechnym” i „Tygodniku Warszawskim” przeważały druki Spółdzielni Wydawniczej Czytelnik. Wysokie miejsce zajmowały też Książka, Wiedza, Książka i Wiedza, Państwowy Instytut Wydawniczy. Pomimo katolickiego profilu periodyków drukarnie Kościoła zajęły dalsze pozycje. Jedynie redakcja „Głosu Katolickiego” preferowała publikacje Verbum i Albertinum Księgarni św. Wojciecha.

Repertuar wydawniczy przedstawiał się w latach 1945-1953 bardzo imponująco, jeżeli idzie o liczbę i różnorodność omawianych książek, zwłaszcza w trzech wyżej wspomnianych pismach. Każdy z czytelników mógł zatem z polecanych książek wybrać odpowiednią dla siebie lekturę. Zdecydowanie większy wybór

${ }^{9} \mathrm{~W}$ pozostałej grupie publikacji autorów zagranicznych dominowały druki wydane wcześniej po łacinie, czesku, włosku i grecku. Pojedyncze książki ukazały się w oryginale w językach: estońskim, chińskim, norweskim i słowackim. 
i dostęp odbiorcy mieli do tytułów książkowych autorów rodzimych. Publicyści narzekali w wypowiedziach prasowych na brak przekładów zagranicznych pozycji na polskim rynku wydawniczym.

Po części statystycznej przedstawiona zostanie w sposób opisowy zawartość wybranych recenzji książkowych w poszczególnych periodykach. Obfity materiał prasowy nie pozwolił na przedstawienie wszystkich wypowiedzi. Uwzględniono przy tym najczęściej omawianą literaturę pod względem gatunku i problematyki we wszystkich czasopismach społeczno-kulturalnych. Na czoło wysunęła się książka katolicka (nieliteracka) ze względu na profil uwzględnionych pism, gdyż opinie o niej zajęły ważne miejsce w publikacjach. Dość liczne i istotne były również recenzje rozpraw historycznych, które omówione będą jako następne. Najwięcej uwagi na łamach sześciu wybranych tytułów poświęcono ocenie książki literackiej, głównie powieściom. Ostatni podrozdział dotyczy książek o innej problematyce, których omówień również nie brakowało.

\subsection{Książka katolicka (nieliteracka)}

Współpracownicy pism, śledząc nowości wydawnicze, szczególną uwagę poświęcili książce katolickiej o tematyce religijnej, mistycznej i teologicznej. Mianem książki katolickiej możemy określić wydawnictwo zwarte, w którego treści szerzy się naukę Chrystusa, tradycję Kościoła i wartości chrześcijańskie. Książka katolicka to też taka, która posiada imprimatur władz kościelnych (miejscowego biskupa). Do tej kategorii można zaliczyć nie tylko „księgę ksiąg” Biblię, mszały, katechizmy oraz modlitewniki, ale także hagiografie, dzieła teologiczne oraz książki nawiązujące w swej treści do szeroko pojętej katolickiej nauki społecznej i tematyki religijnej.

Do pozycji tego rodzaju zaliczono zatem w opracowaniu przede wszystkim natchnioną księgę Pisma świętego, w tym Nowy Testament oraz komentarze do Ewangelii, egzegezy biblijne, pisma Ojców Kościoła, literaturę mistyczną, hagiografie i biografie przyszłych świętych. Osobną grupę tworzyły wypowiedzi dotyczące dokumentów Kościoła, głównie nowo ogłoszonych encyklik papieskich, nowych wydań katechizmów, mszałów, dzieł teologicznych i opracowań z zakresu filozofii chrześcijańskiej. Kolejny zespół stanowiły różnorodne studia i rozważania o tematyce religijnej: dogmatycznej, dogmatyczno-moralnej, ewangelicznej, liturgicznej, rekolekcyjnej i modlitewnej. Najczęściej ujęte były one w formie rozpraw naukowych, pism, wykładów, kazań i homilii, rzadziej podręczników do religii i poradników. Na łamach katolickich pism społeczno-kulturalnych recenzowano też broszury o wydarzeniach religijnych. Publicyści - głównie „Tygodnika Powszechnego" i „Przeglądu Powszechnego” - zauważali zarówno zagraniczne, jak i polskie wydania katolickich słowników oraz encyklopedii. 
Najwięcej recenzji (103) książek katolickich ukazało się w „Przeglądzie Powszechnym"; omówiono na jego kartach więcej dzieł autorów zagranicznych (57) niż polskich (46). Recenzentem większości pozycji był ks. Jan Rostworowski (69). Z ogólnej liczby 85 ocen opublikowanych na łamach „Tygodnika Powszechnego" więcej niż połowa dotyczyła książek autorów polskich (57). Najaktywniejszym recenzentem krakowskiego pisma był ks. Jan Piwowarczyk (14 opinii). W „Głosie Katolickim” z 28 recenzji ogółem, dzieł polskich dotyczyło 16, zaś zagranicznych - 12. Większość opinii sformułował Jerzy Stawski (11). Redakcja „Tygodnika Warszawskiego” zamieściła w okresie wydawania pisma prawie tę samą liczbę recenzji książek rodzimych (13), co i obcych (12). Głos zabierali przede wszystkim Antoni Madej (5), Jerzy Braun (3) i Jan Archita (3). Czytelnicy „Znaku” mogli zapoznać się z sześcioma opiniami o obcych drukach i z dwiema o polskich, natomiast „Tygodnika Katolickiego” z czterema książkami polskimi i dwiema zagranicznymi. Ze wszystkich 255 ocen zdecydowaną większość, gdyż aż 160 stanowiły recenzje pozytywne, po nich omawiające w liczbie 76, krytyczne 11 i osiem negatywnych.

Książki katolickie recenzowane na łamach katolickich czasopism społecznokulturalnych wyszły spod prasy m.in. następujących wydawnictw: Verbum (16 tytułów), Albertinum Księgarnia św. Wojciecha (15), Wydawnictwa Mariackiego (12), Pallotinum (9), IW PAX (8), Księgarni św. Jacka (8), Wydawnictwa Apostolstwa Modlitwy (7).

W omówieniach nie tylko informowano czytelników o ukazaniu się nowości książkowych, wznowień lub polskich przekładów, ale przede wszystkim starano się dostarczyć rzetelną o nich opinię. Zachętą do kupna i obcowania z wartościowymi księgami miały być w większości pozytywne oceny. W podrozdziale uwzględniono wybrane recenzje książek, które wydawały się reprezentatywne dla danych periodyków. Niektóre nowości książkowe dostrzeżone zostały przez publicystów różnych czasopism i te również wzięto pod uwagę. Niekiedy uwzględniono dla przykładu rzadziej spotykaną ocenę negatywną książki lub mniej znany lecz polecany tytur.

\subsubsection{Przekłady Nowego Testamentu i komentarze do Ewangelii}

W przypadku Pisma świętego na łamach pism odnoszono się zazwyczaj do nowego wydania i tłumaczenia. Recenzenci oceniali, na ile przełożony tekst jest zrozumiały dla współczesnego odbiorcy oraz zwracali uwagę na styl i język przekładu. Ponadto wyliczali zauważone błędy lub sugerowali dokładniejsze przełożenie niektórych fragmentów biblijnych. Szczegółowe wskazówki podawano w celu uwzględnienia ich w następnym wydaniu świętej księgi. Na stronach „Tygodnika Powszechnego" pozytywnie ustosunkowano się do pierwszego i drugiego wydania Nowego Testamentu w przekładzie ks. Eugeniusza Dąbrowskiego (Poznań 
1946, 1947). Ukazywano je jako godne zauważenia na tle licznych edycji Biblii w powojennej Europie i w Polsce, a także jako alternatywę wobec wydań protestanckich. Przekład dokonany przez ks. Dąbrowskiego doceniono za dobre i staranne przygotowanie, poprawność językową oraz warstwę literacką. Tę ostatnią thumacz konsultował z profesorem języka polskiego - Witoldem Doroszewskim ${ }^{10}$. „Wydanie podręczne” Nowego Testamentu Księgarni św. Wojciecha z okazji pięćdziesięciolecia działalności wydawniczej w 1947 r. spotkało się z dobrą oceną ks. Felicjana Kłonieckiego. Recenzent pochwalił w nim przede wszystkim obszerne komentarze do Listów św. Pawła, zgodne z najnowszymi wynikami badań biblijnych ${ }^{11}$. Dowodem „entuzjastycznego przyjęcia przez publiczność i biblistów” miało być, zdaniem omawiających, wyczerpanie nakładu w ciągu kilku miesięcy ${ }^{12}$. Publicyści fachowo odnieśli się do obu wydań, stosując trzy zasady dobrego thumaczenia według św. Hieronima. Dobrze wypadły one pod względem zrozumienia tłumaczonego tekstu z łaciny, sporadycznie opartego na tekście greckim (pierwsza zasada). Przytoczono na przykładach jednolity styl przekładu ks. Dąbrowskiego, odnosząc się do zasady wierności sensu zdań lub słów (stopień zależności tłumaczenia od oryginału - druga zasada). Z uznaniem spotkała się też trzecia reguła, tzw. archaizacji języka (czyli wyboru prozy literackiej do poszczególnych wersetów), którą tłumacz zastosował w umiarkowany sposób. W drugiej części artykułów omawiający zazwyczaj porównywali na wybranych przykładach różnice występujące między nowym thumaczeniem a tekstem opracowanym przez ks. Jakuba Wujka ${ }^{13}$. Podobnie odebrano powojenne wydanie Nowego Testamentu na łamach „Przeglądu Powszechnego” i „Głosu Katolickiego”. Ks. Jan Rostworowski uznał przekład „za bardzo udany”'14, natomiast Kazimierz Madaliński podkreślił jego „wybitnie praktyczny charakter”. Według drugiego z recenzentów, wydanie powinno „znaleźć się w każdym katolickim domu” oraz przyczynić się do tego, aby „Pismo św. przestało być książką rzadką"15. Krytycznie odniesiono się natomiast do szaty zewnętrznej drugiej edycji, pisząc: „Papier nowego wydania jest dużo gorszy od pierwszego i druk o wiele mniej staranny”'16.

Z aprobatą o. Jana Wierusza-Kowalskiego na łamach „Tygodnika Powszechnego" spotkał się także nowy przekład Ewangelii i Dziejów Apostolskich ks. Feliksa Gryglewicza, wydany w 1947 r. przez Księgarnię św. Jacka w Katowicach. Pomimo krytyki wprowadzenia „własnej interpretacji” w miejscach, gdzie tekst naznaczony był dwuznacznością, recenzent ostatecznie uznał dokonania ks.

\footnotetext{
10 J.T. Milik, Nowy Testament po polsku, ,TP” 1950 nr 30 s. 4.

${ }^{11}$ F. Kłoniecki, Przekład Nowego Testamentu, „TP” 1947 nr 50 s. 6.

12 J.T. Milik, Nowy Testament...

13 J.W. Kowalski, Lectio divina, ,TP” 1950 nr 26 s. 2, 11; J.T. Milik, Nowy Testament..., s. 4, 7.

${ }^{14}$ J. Rostworowski, Przegląd piśmiennictwa. Książki, „TP” 1948 nr 4 s. 295.

${ }^{15}$ K. Madaliński, Niewykorzystane księgi, ,TP” 1947 nr 50 s. 407.

16 J. Wierusz-Kowalski, Lectio divina, ,TP” 1950 nr 26 s. 11.
} 
Gryglewicza za „wzbogacenie biblistyki polskiej”. Prosty i zrozumiały język miał przyczynić się, zdaniem publicysty, do upowszechnienia Ewangelii wśród szerszych rzesz społeczeństwa ${ }^{17}$. Edycję „z radością powitano” także w jezuickim organie prasowym ${ }^{18}$.

$\mathrm{O}$ autorstwie, sposobie pisania Ewangelii i jej odczytywania pisał natomiast ks. Aleksander Fedorowicz. Dając pogłębioną analizę tej niezwykłej księgi pisanej przez czterech ewangelistów pod natchnieniem Ducha Świętego, nazwał ją „książką niepokojącą i wstrząsającą" ${ }^{19}$. Sprawiła to, jego zdaniem, „obiektywna i wstrzemięźliwa treść" ukazująca najpełniej osobę Jezusa Chrystusa. Podkreślając, że strona literacka nie odgrywa w niej najważniejszej roli, pisał: „Można czytać obojętnie pamiętniki Cezara, trudniej jest obojętnie czytać apologię Sokratesa, ale w żaden sposób nie można obojętnie czytać Ewangelii" ${ }^{20}$. Prawdziwości i autentyczności tekstów ewangelicznych poprzez prześledzenie historii ich powstania i świadectwo znanych pisarzy starożytnych dowodził Hieronim Gaj ${ }^{21}$.

Pomocą w zrozumieniu tekstu Ewangelii miały być wszelkiego rodzaju egzegezy biblijne, komentarze, objaśnienia i wstępy, na które recenzenci katolickich czasopism społeczno-kulturalnych zwracali równie baczną uwagę. Omawiano je z założeniem, że „Wstęp do Pisma świętego nie może nigdy zastąpić właściwego czytania tekstu"22, lecz jedynie ułatwić jego zrozumienie.

Diametralnie różną ocenę w periodykach otrzymał natomiast podręcznik dla studentów teologii ks. Dąbrowskiego zatytułowany Prolegomena do Nowego Testamentu (wyd. I Opole 1948; wyd. II Warszawa 1952). Na łamach „Tygodnika Powszechnego" uzyskał dwie pozytywne opinie ${ }^{23}$. Dominikanin Efrem Gliński pochwalił autora za przejrzysty sposób przedstawienia problemów oraz uwzględnienie w drugim wydaniu krytycznych uwag recenzentów ${ }^{24}$. Ks. Jan Rostworowski natomiast w „Przeglądzie Powszechnym” zganił Prolegomena za „nierównomierność tonu i poziomu”. Niektóre fragmenty bowiem ,nadawały się stanowczo głównie do podręcznika, inne do popularnego dla świeckiej inteligencji wykładu, inne jeszcze do rzeczywistej, w wielkim stylu, naukowej rozprawy"25. Sam tytuł zaś określił jako brzmiący „nieco szumniej niż wstęp”. Poddał krytyce także brak odpowiedniego wprowadzenia „w głębię ducha” listów św. Pawła. Przewidywał również, że „obficie cytowana i arcyuczona literatura” będzie „ponad poziomem

${ }^{17}$ Tenże, Ewangelie z greckiego..., „TP” 1948 nr 28 s. 11.

${ }^{18}$ Przeglad piśmiennictwa, „TP” 1949 nr 10 s. 249.

${ }^{19}$ A. Fedorowicz, Książka piękna, ale niepokojąca, „TP” $1950 \mathrm{nr} 40$ s. 3.

${ }^{20}$ Tamże.

${ }^{21}$ H. Gaj, Mateusz, Marek, Lukasz, Jan, „TP” 1951 nr 41 s. 1-2.

22 J. Wierusz-Kowalski, Lectio divina..., s. 2.

${ }^{23}$ Tamże, s. 2, 11; E. Gliński, „Prolegomena” księdza Dąbrowskiego, „TP” 1952 nr 45 s. 3.

${ }^{24}$ E. Gliński, ,Prolegomena” księdza Dąbrowskiego..., s. 3.

25 J. Rostworowski, Przegląd piśmiennictwa, „PP” 1949 nr 11 s. 321. 
i poza zasięgiem czytelników, dla których książka zdaje się być przeznaczona"26. Recenzent podważył też zaproponowany przez biblistę późniejszy czas powstania Ewangelii według św. Mateusza.

Wśród niewielu prac o Piśmie świętym ukazujących się na polskim rynku zauważono komentarz do Ewangelii ks. Józefa Kaczmarczyka Życie i działalność Jezusa Chrystusa w świetle czterech Ewangelii (Kraków 1949), o. Atanazego Fica Jezus Chrystus (Poznań 1951-1952) i ks. Eugeniusza Dąbrowskiego Życie Jezusa Chrystusa wopisie ewangelistów (Poznań 1951). Egzegezy te przywitano z entuzjazmem, gdyż były cennym objaśnieniem do powojennych przekładów Nowego Testamentu. W pierwszym z nich autor poddał tekst dokładnej analizie filologicznej, dogmatycznej i historycznej. Dzięki opisom wydarzeń, historii narodu żydowskiego i jego obyczajów czytelnik otrzymał ,pełny obraz życia Zbawiciela" ${ }^{27}$. Ks. Jan Piwowarczyk słusznie zauważył też, że książka spełniła dwojaką rolę. $Z$ jednej strony służyła jako komentarz do Ewangelii, a z drugiej stanowiła osobny zarys historyczny „czyniąc zadość powszechnie odczuwanej potrzebie". Przemyślane i szczegółowe komentarze sprawiły, że zdaniem redaktora „Tygodnika Powszechnego” była to „książka bogata” i pożyteczna przy czytaniu Ewangelii. Za „gruntowne dzieło”, które przyda się kaznodziejom, katechetom, osobom zakonnym oraz "średnio wykształconemu czytelnikowi” uznał je ks. Rostworowski ${ }^{28}$. Pochwałę omawiającego znalazł też „prosty i bezpretensjonalny język” oraz nieuleganie autora „modnym, a mało uzasadnionym teoriom niektórych biblistów” ${ }^{29}$. „Wydarzeniem dużej wagi” dla katolików miało być ukazanie się dzieła przedwcześnie zmarłego biblisty o. Atanazego Fica zatytułowane Jezus Chrystus. Zofia Starowieyska-Morstinowa nazwała je „piękną i pożyteczną książką", którą doceniła przede wszystkim za naukowy i drobiazgowy komentarz historyczny oraz stronę dogmatyczną. Zaletą książki z punktu widzenia czytelniczego miały być ,przejrzysty układ, prosty i jasny styl" oraz pasjonująco przedstawione dyskusje naukowe. Pozycja stanowiła też dobre przygotowanie do niełatwej lektury Ewangelii ${ }^{30}$. W omawiającej recenzji na łamach „Przeglądu Powszechnego” dowiadujemy się ponadto o „miłym i starannym wydaniu" tej dwutomowej pracy ${ }^{31}$. Recenzenci odnosili się niejednokrotnie do wyglądu publikacji oceniając druk, układ graficzny, papier czy okładkę. Stanisław Czarnota w następujący sposób pisał o oprawie książki ks. Dąbrowskiego Życie Jezusa Chrystusa w opisie ewangelistów: ,Zamykam książkę i jeszcze raz przyglądam się uważnie karcie tytułowej. Centralne miejsce

\footnotetext{
${ }^{26}$ Tamże, s. 322.

27 J. Piwowarczyk, Z Ewangelia w ręce..., „TP” 1949 nr 10 s. 9.

${ }_{28}^{28}$ J. Rostworowski, Przeglad piśmiennictwa, „PP” 1949 nr 3 s. 212.

${ }^{29}$ Tamże.

${ }^{30}$ Z. Starowieyska-Morstinowa, Polskie dzieło o Chrystusie, „TP” 1952 nr 12 s. 5-6.

31 J. Rostworowski, Przegląd piśmiennictwa. Recenzje książek, „PP” 1952 nr 4 s. 290-291.
} 
zajmuje Głowa Chrystusa pędzla Fra Angelico, a wokół niej nowoczesne linearne rozwiązanie czterech znanych symboli ewangelistów. Nad wizerunkiem Głowy Zbawiciela widnieje stylizowany $P A X$ oraz alfa i omega. Prócz tego na okładce umieszczono - oczywiście - nazwisko autora, tytuł dzieła, nazwę wydawnictwa. Wszystko razem w kolorach białym i różowym. Sądzę, że byłaby tu na miejscu większa prostota i w ogóle ładniejsza okładka" ${ }^{2}$. Czarnota porównał komentarz z przedwojennym opracowaniem jezuity Władysława Szczepańskiego Bóg-Człowiek w opisie ewangelistów (wyd. III 1936), zapytując jednocześnie, w jakiej formie należałoby propagować biografię Chrystusa wśród świeckich katolików. Stwierdził przy tym, że bardziej przystępna byłaby ,jednokształtna Ewangelia” o małym formacie $(14$ x $10 \mathrm{~cm})$ stanowiąca „vademecum praktykującego katolika" ${ }^{33}$.

Publicyści wypowiadający się na temat nowych przekładów Pisma świętego zwracali uwagę na użyteczność i powszechność dla szerszego ogółu odbiorców. $\mathrm{Z}$ tego punktu widzenia oceniali nie tylko przekład, ale też format i szatę graficzną ksiąg. Zalecali czytelnikom korzystanie z pomocy przy czytaniu Ewangelii, jednocześnie przestrzegając przed pozostaniem tylko przy nich. Ważniejszy bowiem miał być odbiór ,żywego Słowa Bożego" niż zapoznanie się jedynie z jego interpretacją i wyjaśnieniem.

\subsubsection{Pisma Ojców Kościoła}

Zachętą do studiowania i zakupu dzieł Ojców Kościoła miały być recenzje powojennych przekładów i wznowień. Szczególne miejsce na łamach katolickich periodyków zajęła „zasłużona i szczęśliwie wskrzeszona” poznańska seria Pism Ojców Kościoła, w ramach której ukazał się Apologetyk Tertuliana (Poznań 1947) i Księga reguly pasterskiej św. Grzegorza Wielkiego (Poznań 1948). Na temat pierwszej z pozycji wypowiedział się w „Przeglądzie Powszechnym” Jan Ujda, wyrażając aprobatę dla sumiennego przekładu i opracowania filologa klasycznego „obeznanego z literaturą starochrześcijańską" Jana Sajdaka ${ }^{34}$. Księgę reguly pasterskiej recenzent określił jako „książkę dydaktyczną”, którą powinno się „umieć czytać”, tak jak i pozostałe dzieła „klasyków myśli chrześcijańskiej”. Ten sam recenzent na łamach „Głosu Katolickiego” przypomniał, że została ona nazwana ze względu na poczytność w różnych wiekach „złotą książką" ${ }^{35}$. Pochwalono ponadto staranne wydanie, przypominając, że tomy Pism Ojców Kościoła ,powinny

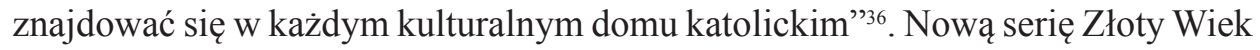

\footnotetext{
${ }^{32}$ S. Czarnota, ,, Jednoksztaltna” Ewangelia, „,TP” 1951 nr 48 s. 2.

${ }^{33}$ Tamże.

${ }^{34}$ J. Ujda, Przegląd piśmiennictwa, „PP” 1948 nr 3 s. 219-220.

${ }^{35}$ Tenże, Papież Grzegorz Wielki, „GK” 1948 nr 38 s. 322.

${ }^{36}$ J. Wierusz-Kowalski, Dzieło Grzegorza Wielkiego, „TP” 1948 nr 30 s. 11.
} 
Myśli Chrześcijańskiej zainicjowano po II wojnie światowej w Wydawnictwie Mariackim w Krakowie. Zapoczątkowano ją tomami Wybór homilii i kazań św. Bazylego (Kraków 1947) oraz Dwadzieścia homilii i mów św. Jana Złotoustego (Kraków 1947). Homilie obu Ojców Kościoła w opracowaniu i thumaczeniu „,najlepszego polskiego hellenisty” Tadeusza Sinko znalazły odzwierciedlenie w pozytywnych recenzjach na łamach „Tygodnika Powszechnego”, „Przeglądu Powszechnego" i „Tygodnika Warszawskiego" ${ }^{37}$. Nowe wydanie Wyznań św. Augustyna (Kraków 1949) w thumaczeniu patrologa ks. Jana Czuja zostało zauważone tylko w krakowskim tygodniku. Ks. Edward Florkowski, przypominając „niezwykłą i jedyną w swoim rodzaju autobiografię”, przytoczył liczne jej fragmenty. Tłumaczenie opatrzone obszernym wstępem oraz komentarzem „wiernie oddawało sens oryginału”, jednocześnie „odznaczając się poprawną i gładką polszczyzną" 38 .

W przypadku klasyków piśmiennictwa chrześcijańskiego zauważano w recenzjach cykle wydawnicze, w ramach których wznawiano najważniejsze dzieła. Wspomnienie o nowym wydaniu Wyznań jedynie na łamach „Tygodnika Powszechnego" może świadczyć o mniejszym zainteresowaniu publicystów innych czasopism społeczno-kulturalnych nowymi edycjami dzieł Ojców Kościoła, zwłaszcza że literatura tego rodzaju była raczej trudna w odbiorze nawet dla wykształconego czytelnika.

\subsubsection{Dzieła mistyków}

Ważną rolę w omówieniach książkowych odegrały najbardziej znane dzieła mistyków Kościoła katolickiego. Wspomniano o nich przy okazji licznych wznowień w latach 1948-1949. Pierwszy polski przekład „klasycznego pomnika mistyki katolickiej”, jakim była Księga Miłosierdzia Bożego czyli Dialog św. Katarzyny Sieneńskiej wydano w „godnej szacie zewnętrznej” w kieleckim Verbum w 1948 r. Maria Morstin-Górska przypomniała na łamach „Tygodnika Powszechnego” niezwykłe okoliczności powstania dzieła, które dyktowane było w czasie długich ekstaz świętej. Z recenzji odbiorcy dowiedzieli się, że czternastowieczna mistyczka, „będąc prostą córką farbiarza”, umiejętność czytania i pisania nabyła w późniejszym wieku poprzez tzw. ,wiedzę wlaną”, otrzymaną bezpośrednio od Boga. Z racji wykształcenia recenzentka „Tygodnika Powszechnego” skupiła się na przekładzie Leopolda Staffa i formie literackiej słynnych dialogów. W pozytywnej recenzji pisała: „otwierając Dialog św. Katarzyny możemy zachwycać się nie tylko jego

${ }^{37}$ M. Plezia, Homilie św. Bazylego, „TP” 1947 nr 35 s. 5; tenże, Złotousty, „TP” 1948 nr 7 s. 7; tenże, Przeglad piśmiennictwa, „PP” 1948 nr 9 s. 262-264; md., Z wydawnictw religijnych, „TW” 1948 nr 25 s. 8.

${ }^{38}$ E. Florkowski, Nowe wydanie „,Wyznań” św. Augustyna, „TP” 1949 nr 44 s. 7. 
treścią, ale również i stylem mocnym, prostym i surowym, nie przypominającym w niczym popularnych książek dewocyjnych zeszłego wieku"39.

Ks. Jan Rostworowski na łamach „Przeglądu Powszechnego” ustosunkował się pozytywnie do nowego przekładu ks. Władysława Lohna „nieśmiertelnej książeczki” Tomasza á Kempis O naśladowaniu Chrystusa (Kraków 1948). Omówił również przekład karmelity Bernarda od Matki Bożej trylogii św. Jana do Krzyża zatytułowanej Droga na górę Karmel (Kraków 1948), Noc ciemna (Kraków 1949) i Pieśn duchowa (Kraków 1949) ${ }^{40}$. Uwagę recenzenta zwróciło też wydanie znanego Traktatu o prawdziwym nabożeństwie do Najświętszej Marii Panny św. Ludwika Marii Grignion de Monfort (Niepokalanów 1948), o którym pisał: „Święty Autor, choć talentem pisarskim dysponuje w słabej tylko mierze, gorącością swego czystego serca i głęboką wiarą w to, co pisze, wiele dusz pocią-

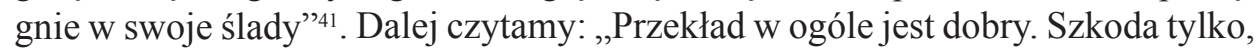
że korekta wypadła słabo" ${ }^{2}$.

Z okazji czterechsetnej rocznicy zatwierdzenia przez papieża Pawła III Księgi ćwiczeń duchownych św. Ignacego Loyoli publicysta „Głosu Katolickiego” zaproponował czytelnikom „niełatwe arcydzieło kierownictwa dusz”, które w okresie od swego powstania wywarło duży wpływ na „wewnętrzne życie Kościoła”43.

Przedstawienie i ocena wznowień pozycji należących do literatury mistycznej stawała się dobrą okazją do przypomnienia najważniejszych faktów z życia świętych autorów i okoliczności powstania ksiąg, od czego zazwyczaj rozpoczynano recenzje prasowe. Przez to były one ciekawsze i w dużej mierze wzbogacały wiedzę odbiorców. W recenzjach uwzględniono nowe wydania najbardziej znanych dzieł mistyków Kościoła katolickiego.

\subsection{4. Życiorysy świętych}

Istotną grupę stanowiły oceny polskich i obcych dzieł hagiograficznych, w których krytyce poddawano przede wszystkim rzetelność badań źródłowych, umiejętność autorów przedstawiania faktów historycznych, jak też działania nadprzyrodzonej łaski w życiu osób kanonizowanych. Wypowiedzi zdawały się uświadamiać jednocześnie odbiorcom, jak trudno jest opracować dobre biografie świętych.

Pozytywne opinie w czterech z wybranych katolickich czasopism społecznokulturalnych otrzymała monografia ks. Dąbrowskiego pt. Dzieje Pawła z Tarsu

${ }^{39}$ M. Morstin-Górska, Księga Miłosierdzia Bożego czyli Dialog, „TP” 1948 nr 35 s. 3.

${ }^{40}$ X.J.R. [J. Rostworowski], Przegląd piśmiennictwa, „PP” 1949 nr 5 s. 381; tenże, Przeglą piśmiennictwa, tamże, nr 3 s. 216-217; tenże, Przeglad piśmiennictwa, tamże, nr 11 s. 321; tenże, Przegląd piśmiennictwa, tamże 1950 nr 9 s. 279.

${ }^{41}$ X.J.R. [J. Rostworowski], Przegląd piśmiennictwa, „PP” 1949 nr 3 s. 216.

${ }^{42}$ Tamże.

${ }^{43}$ ND., Czterysta lat ćwiczeń duchownych, „GK” 1948 nr 37 s. 318. 
(Warszawa 1947, t. 2), należąca do trylogii zatytułowanej Początki chrześcijaństwa. Ten niezwykły i pokaźny objętościowo życiorys (ponad 600 stron) Apostoła Narodów polecano ze względu na „mistrzowsko przeprowadzoną" metodę historyczną, wszechstronne zbadanie źródeł, „obiektywność sądów” oraz ,jasność stylu w przekładaniu zawiłych problemów", który uczynił z dzieła naukowego „książkę dla wszystkich”44. Hanna Malewska, polecając Dzieje szerokim kołom inteligencji na łamach „Znaku”, nazwała ją „dziełem niezwykłego znaczenia dla światowej historiografii katolickiej”45. Pisała: „To, co kreśli ks. Eugeniusz Dąbrowski, to ściśle udokumentowana, wolna od wszelkiego panegiryzmu, a jednak wspaniała i przejmująca epopeja pierwotnego Kościoła"46. Ponadto autor wykorzystał w niej najnowsze zdobycze archeologii, wykazał dobrą znajomość prądów filozoficznych i religijnych oraz sporządził cenną bibliografię. Nie chcąc streszczać książki, recenzentka sugerowała „przeczytanie jej w całości” ${ }^{47}$. Czesław Jastrzębiec-Kozłowski w „Tygodniku Warszawskim” podkreślił z kolei, iż „rzecz jest napisana nadzwyczaj zajmująco” i stanowi „książkę, która wzbogaca”48. Publicysta podziwiał również erudycję autora oraz ,potoczysty, równy, starannie unikający naleciałości emocjonalnych" język. Zwrócił także uwagę na uwydatnienie przez biblistę poznania umysłowego, któremu św. Paweł poświęcił w swoich mowach wiele miejsca. Wojciech Bąk w „Głosie Katolickim” o dziele ks. Dąbrowskiego wyraził się w następujący sposób: „Obowiązkiem każdego inteligenta polskiego jest zapoznanie się z książką. Pozwoli mu ona zrozumieć, że świętość to nie tylko cnotliwość i pobożność, ale najczęściej także genialność umysłu i aktywność w dziele budowania imperium Miłości”49.

Zainteresowanie publicystów katolickich pism wzbudziły również dwie hagiografie Joanny d'Arc oparte na najnowszych badaniach francuskich autorów: L. Fabre'a i Jasquesa Cordiera. O trudnościach w napisaniu życiorysu świętej dowiadujemy się z recenzji, w których podkreślono dużą rolę legendy w przypadku Dziewicy Orleańskiej. E. Mokłowska, pozytywnie odnosząc się do książki Fabre'a w „Znaku”, pisała: „Legenda otaczająca postacie sławnych ludzi czyni z nich pozbawione życia symbole, zamyka całe bogactwo wielkiej indywidualności w uproszczonej formie panegiryku czy pomnika" ${ }^{50}$. W ten sposób zubożono sylwetkę Joanny, gdyż: „Historia jej życia i czynów, zapomniana szybko przez współczesnych, niezrozumiana i zniekształcona w XVIII stuleciu przez Chapelaina i Woltera, doczekała się dopiero w XIX (Michelet, H. Martin) i XX w.

\footnotetext{
${ }^{44}$ J. Wierusz-Kowalski, O Pawle z Tarsu, „TP” 1948 nr 2 s. 3-4.

${ }^{45}$ H. Malewska, Dzieje Pawła z Tarsu, „Znak” 1947 nr 7 s. 773.

46 Tamże, s. 774.

${ }^{47}$ Tamże, s. 775.

${ }^{48}$ C. Jastrzębiec-Kozłowski, Paweł z Tarsu, „TW” 1948 nr 3 s. 6.

${ }^{49}$ W. Bąk, Święty Pawet, „GK” 1948 nr 26 s. 228.

${ }^{50}$ E. Mokłowska, Nowa książka o Joannie d'Arc, „Znak” 1948 nr 6 s. 574.
} 
(Péguy i Claudel) właściwego ujęcia" ${ }^{51}$. Fabre poświęcił świętej gruntowne studia, trwające ponad 30 lat, a będąc ,człowiekiem wierzącym” chciał ukazać wiele szczegółów historycznych we właściwym świetle. Zdaniem recenzentki praca była „owocem głębokiego pietyzmu” i autor ukazał w niej „bogaty i wszechstronny obraz epoki”, starając się jednocześnie „rzucić nowe światło” na zawikłany i tajemniczy proces świętej. Krytyczną opinię o książce Jeanne d'Arc Cordiera (Paryż 1948) wydała natomiast na łamach „Tygodnika Powszechnego" Zofia Zawiszanka. Doceniając „rewizjonistyczne założenia” autora podczas analizy dostępnych źródeł, „rzeczowy ton i jasność wykładu” zwróciła uwagę jednocześnie na liczne przemilczenia w bezspornych kwestiach działania łaski i daru proroctwa otrzymanego przez Joannę. Zawiszanka konstatowała także: „Przedstawiwszy na swój sposób bieg wypadków, wpakowuje wszystko, co mu się nie wydaje wiarygodne do rozdziału Propaganda i legenda. Trudno zaprzeczyć, że tak jedna jak i druga istniała i działała” ${ }^{2}$, broniąc tej drugiej kontynuowała „Legenda to też ważny element w historii - jej stosunek do prawdy nie jest ścisły, ani obliczalny, a jednak byłoby naiwnością traktować ją jak bajdy, z palca wyssane..." ${ }_{53}$.

Lektura książki o. Jacka Woronieckiego Święty Jacek Odrowąż $i$ wprowadzenie Zakonu Kaznodziejskiego do Polski skłoniła Pawła Jasienicę do zwiedzenia ruin zapomnianego kościoła pod wezwaniem św. Jacka w Warszawie. Historyk pochwalił pracę przede wszystkim za „faktualizm”, który „uwypuklił znaczenie i wielkość opisywanej postaci” oraz za „cenny materiał do poznania epoki” ${ }^{4}$. Pozycja ta została równie dobrze odebrana przez Konrada Górskiego na łamach „Przeglądu Powszechnego”. Recenzent nie dostrzegł bowiem w niej sztucznego stylu będącego „plagą hagiografii”, lecz „bardzo ciekawie przedstawiony zarys dziejów” polskich dominikanów w XIII w. Wyraził też życzenie, aby „książka stała się drogowskazem dla hagiografii polskiej"55.

Sylwetkę św. Tomasza More na podstawie książki Heleny Morawskiej przedstawił w obszernej recenzji omawiającej ks. Jan Piwowarczyk. Nazywając ją „,doskonałą książką", zwrócił uwagę również na jej szatę zewnętrzną. Chwaląc znaną kielecką firmę wydawniczą Verbum za wysoki poziom typograficzny, pisał: „Piękny krój czcionek, nienaganne odbicie i estetyczny układ treści stawiają ją w rzędzie najlepszych druków współczesnych. Znać rękę ludzi, którzy przykładają wagę nie tylko do treści, ale i formy wydawnictwa" ${ }^{56}$.

Naukę św. Tomasza z Akwinu w bardzo ciekawy sposób wyłożył w jego biografii Gilbert Keith Chesterton. W pochwalnej ocenie Zofia Starowieyska-

\footnotetext{
${ }^{51}$ Tamże.

${ }^{52}$ Z. Zawiszanka, Z nowych badań nad Joanna d'Arc, „TP” 1951 nr 26 s. 7.

${ }^{53}$ Tamże, s. 8.

${ }^{54}$ P. Jasienica, Gruzy i komentarze, „TP” 1948 nr 11 s. 6.

${ }^{55}$ K. Górski, Przegląd piśmiennictwa, „PP” 1948 nr 7 s. 101-103.

${ }^{56}$ J. Piwowarczyk, Myśliciel i bohater, „TP” 1947 nr 19 s. 4.
} 
-Morstinowa uświadamiała: „Znając Chestertona wiemy, że biorąc do ręki jego Świętego Tomasza nie wpływamy na spokojne, epiczne wody biografii, lecz przeciwnie, że wkrótce znajdziemy się na arenie. Tak się też dzieje od pierwszych zaraz kart tej książki: od razu zaledwo ją otworzymy, widzimy jak potężny byk spuściwszy groźnie łeb idzie z nastawionymi rogami, by uderzyć w całą zaskorupiałą górę przesądów, jaka narosła na średniowieczu, jego filozofii, a także na potężnej postaci Akwinaty" ${ }^{57}$. Autor bowiem w tomizmie oprócz „rehabilitacji świata” dostrzegł „rehabilitację rozumu”. Na kartach książki recenzentka „odczuła odkrywczą radość Chestertona, który swoimi czyni wielkie podstawowe prawdy katolickiego światopoglądu"s8. Polecaną książkę nazwano „fascynującą i żywą” choć wymagającą skupienia, a dobre tłumaczenie na język polski ułatwiało jej odbiór.

W kręgu zainteresowań redakcji pism katolickich były też pozycje, w których przedstawiano dzieje kultu świętych. Na łamach „Tygodnika Powszechnego" i „Przeglądu Powszechnego” zauważono książkę Danuty Borawskiej $Z$ dziejów jednej legendy (Warszawa 1950). Marian Plezia pochwalił badaczkę przede wszystkim za sumienne dążenie do prawdy przy analizowaniu genezy kultu św. Stanisława od czasu jego śmierci do chwili kanonizacji w 1253 r. Problematyka została ukazana na szerokim tle historycznym z uwzględnieniem obfitej bibliografii. Za największą zasługę recenzent uznał szereg nowych stwierdzeń Borawskiej odnośnie do kultu świętego, m.in. wykazanie, że przed przeniesieniem do katedry św. Wacława ciało św. Stanisława spoczywało w kościele św. Michała na Wawelu (dziś nieistniejącym), a nie na Skałce ${ }^{59}$. Ks. Jan Rostworowski docenił natomiast pracę za „spokojny obiektywizm” i ,pietyzm dla Świętego, przez całe prawie stulecia, tendencyjnie zniesławianego po zgonie" ${ }^{60}$. Z okazji 950-lecia śmierci św. Wojciecha wydano na luksusowym papierze, ozdobioną ilustracjami, księgę pamiątkową zatytułowaną Św. Wojciech 997-1947 (Gniezno 1947). Zawarte w niej rozprawy znanych biskupów i naukowców przypomniały wydarzenia z życia świętego oraz rolę jego kultu. Antoni Gołubiew, wyrażając aprobatę dla wydawnictwa, oczekiwał w przyszłości monografii o patronie Polski ${ }^{61}$. Jerzy Adamski na łamach „Głosu Katolickiego” starał się zwrócić uwagę czytelników na „,napisaną prostym językiem” niewielką książeczkę o. Barnaby Stokowy pt. Góra św. Anny, w której zawarto historię ośrodka kultu religijnego na Górnym Śląsku' ${ }^{62}$.

\footnotetext{
${ }^{57}$ Z. Starowieyska-Morstinowa, Wót sycylijski i kpiarz angielski, „TP” 1950 nr 24 s. 3.

${ }^{58}$ Tamże.

${ }^{59}$ M. Plezia, Nowa praca o św. Stanistawie, „TP” 1951 nr 38 s. 5.

${ }^{60}$ J. Rostworowski, Przegląd piśmiennictwa. Recenzje ksiażek, „PP” 1951 nr 3 s. 229.

${ }^{61}$ A. Gołubiew, W roku św. Wojciecha, „TP” 1947 nr 49 s. 7.

${ }^{62}$ J. Adamski, Na Górze św. Anny, „GK” 1947 nr 42 s. 348.
} 
Ks. Jan Rostworowski na stronach „Przeglądu Powszechnego” wymienił zalety i wady wielotomowego i naukowego opracowania żywotów świętych, dokonanego przez benedyktynów w Paryżu ${ }^{63}$.

Należy wspomnieć w tym miejscu o omówieniach pozycji wydawniczych, które jeszcze nie pretendowały do miana hagiografii, gdyż osoby przez nie przedstawiane doczekały się kanonizacji dopiero za pontyfikatu papieża Jana Pawła II. Stanowiły jednak dobrą popularyzację czynów i życia przyszłych świętych. Oceniono m.in. entuzjastycznie skreślone studium siostry Magdaleny Kujawskiej Matka Urszula Ledóchowska (Kielce 1947), „napisaną jednym tchem" książkę Jana Dobraczyńskiego o Maksymilianie Kolbe Skapiec Boży (Niepokalanów 1946) czy „doniosłe” i naukowe dzieło historyka ks. Konstantego Michalskiego Brat Albert, w setna rocznice urodzin 1945-1946 (Kraków 1946) ${ }^{64}$. Z trzech recenzji książki o matce Ledóchowskiej dwie były krytyczne. Zofia Starowieyska-Morstinowa ganiła autorkę za „nie zawsze uzasadniony zachwyt” w przedstawieniu przyszłej świętej, „niedopowiedzenia historyczne" i założoną metodę nie ukazywania zakonów w „złym świetle”. W ocenie czytamy: „Nie łagodne i lekkie ślizganie się po obłokach doprowadza ludzi do świętości, lecz przeciwnie, twarde, ciężkie uparte łamanie się tak ze sobą jak i z trudnościami zewnętrznymi. Pomijanie wszelkich trudności, malowanie samymi światłami, bez uwzględnienia cieniów, nie wychodzi obrazowi na dobre. I niewątpliwie w tym duchu byłaby sama matka Urszula dzieło swej córki poprawiła” ${ }^{65}$. W opinii ks. Jana Piwowarczyka „nieprzemijającą wartość" w kolejnej biografii, tym razem Adama Chmielowskiego, stanowiła pogłębiona psychologicznie „synteza jego indywidualności” oraz doskonale wydobyte przez ks. Michalskiego fazy rozwoju duchowego bohatera. Dzięki opisowi postać Brata Alberta stawała się bliższa, a książka mogła wzbudzić refleksje u zainteresowanych jej lekturą. W recenzji sugerowano bowiem: „Czytelnik, który ją przemyśli, będzie uderzony niezwykłością tego ludzkiego fenomenu" ${ }^{66}$.

O wartości niezwykłych książek, jakimi były życiorysy świętych, decydowały rzetelnie przeprowadzone badania źródeł historycznych, jak i samo ujęcie tematu. W tego typu literaturze, jak zaznaczyli piszący, nie wystarczyły tylko fakty historyczne ukazane przez autorów, ale potrzeba było przede wszystkim właściwego przedstawienia działania łaski Bożej w życiu i czynach bohaterów.

${ }^{63}$ J. Rostworowski, Przegląd piśmiennictwa. Recenzje książek, „PP” 1950 nr 4 s. 297-298; „PP” 1951 nr 1 s. 66.

${ }^{64}$ Tenże, Przeglad piśmiennictwa. Ksiązki, „PP” 1948 nr 5 s. 371-372; (jar) [J. Archita], O Matce Ledóchowskiej, „TW” 1948 nr 3 s. 2; zsm. [Z. Starowieyska-Morstinowa], Szara matka, „TP” 1948 nr 9 s. 7; I. Pannenkowa, Świętość i bohaterstwo, „TW” 1947 nr 5 s. 8; Także szaleniec Boży, „TW” 1946 nr 45 s. 4; J. Piwowarczyk, Heroiczne wyżyny, „TP” 1946 nr 37 s. 5-6.

${ }^{65} \mathrm{zsm}$. [Z. Starowieyska-Morstinowa], Szara matka...

${ }^{66}$ J. Piwowarczyk, Heroiczne wyżyny, „TP” 1946 nr 37 s. 6. 


\subsubsection{Biografie zasłużonych kapłanów}

Osobną, choć nieznaczną grupę recenzji tworzyły omówienia prac o życiu i działalności zasłużonych ludzi Kościoła. Najwięcej opinii o tego typu publikacjach ukazało się na łamach „Tygodnika Powszechnego”. Aleksander Usowicz na podstawie świeżo wydanej książki ks. Alfonsa Schletza pt. Józef Jakubowski, żołnierz i kapłan (Kraków 1945) zapoznał odbiorców pisma z osobą znawcy artylerii i inżynierii wojskowej oraz uczestnikiem insurekcji kościuszkowskiej ${ }^{67}$. Druga z kolei praca, profesora Mariana Tyrowicza, poświęcona została „pionierowi wyzwoleńczych zrywów” XIX wieku, „wiernemu wyznawcy myśli niepodległościowej" oraz uczestnikowi i kapelanowi powstania listopadowego - ks. Piotrowi Ściegiennemu. Zatytułowana Sprawa ks. Piotra Ściegiennego (Warszawa 1948), stanowiła oryginalną pracę popularyzującą nieznane dotąd wyjątki z rękopisów polskiego kapłana. W nich podjął on tematy moralne oraz zapoznał ze szczegółami pracy spiskowej, za którą skazany został na 25-letnią zsyłkę na Sybir ${ }^{68}$. Spod pióra profesora Stanisława Kościałkowskiego wyszła pięknie wydana broszura O. Maksymilian Rytło T.J. 1802-1848 (Bejrut 1945), ukazująca liczne podróże misyjne „znakomitego kaznodziei” ${ }^{69}$. Książka, pomimo że ukazała się na wychodźstwie w Libanie, została dopuszczona przez cenzurę w kraju. Z kolei na łamach „Przeglądu Powszechnego” zauważono „piękną i sumienną pracę" ks. Stefana Biskupskiego Krzysztof Żórawski, polski kanonista XVIII wieku (Włocławek 1950). Z niej dowiadujemy się o znaczeniu „wybitnego kodyfikatora ustawodawstwa kościelnego w Polsce" i o jego licznych rozporządzeniach i listach pasterskich, które „podniosły religijnego ducha i sławę diecezji płockiej”" W „Tygodniku Powszechnym” o tej samej książce czytamy, że została napisana na podstawie „bogatych materiałów archiwalnych” oraz „odznaczała się przejrzystością i dokładnością stanowiąc cenne źródło do poznania stanu Kościoła w Polsce w XVIII wieku" "?1 .

Z zagranicznych osobistości Kościoła przypomniano sylwetkę znanego prymasa Belgii przy okazji pierwszej obszerniejszej pracy wydanej w Polsce, zatytułowanej Kardynat Mercier (Katowice 1949). Napisaną z „wielkim pietyzmem” przez siostrę Marię Leonię, polecano ją na łamach „Przeglądu Powszechnego"72.

${ }^{67}$ A. Usowicz, Żotnierz i kapłan, „TP” 1946 nr 43 s. 8.

${ }^{68}$ K. Lewicki, Książka o ks. Ściegiennym, „TP” 1949 nr 25 s. 7.

${ }^{69}$ W. Zajączkowski, Działalność misyjna o. Rytty, „TP” 1949 nr 42 s. 10; profesor Kościałkowski po przebyciu tułaczego szlaku wraz z Armią Polską na Wschodzie, po dłuższym pobycie w Libanie zamieszkał w Wielkiej Brytanii.

${ }^{70}$ X.J.R. [J. Rostworowski], Przeglad piśmiennictwa. Recenzje ksiązek, „PP” $1950 \mathrm{nr} 4$ s. 300 .

${ }^{71}$ Polski kanonista XVIII w., „TP” 1950 nr 6 s. 11.

${ }^{72}$ Z.F., Przegląd piśmiennictwa. Książki, „PP” $1950 \mathrm{nr} 1$ s. 58. 
Autorka wykorzystała w opracowaniu wypowiedzi tego wszechstronnego „kardynała, naukowca, pedagoga, działacza społecznego, kandydata do beatyfikacji i kanonizacji” lej: „W formie popularnej, przeznaczonej dla ogółu katolików [...] [nakreślono - E. K.] sylwetkę człowieka, który zdecydowanie przeciwstawił się anarchii światopoglądowej swej epoki stwarzając świadomie na użytek własny i świata harmonijną syntezę wiary i nauki"’74.

W przedstawionych wyżej życiorysach ukazywano zasługi i działalność ludzi Kościoła, którzy byli nie tylko kapłanami, ale (niektórzy byli żołnierzami) pełnili różne funkcje i posługi w życiu społecznym, narodowym i naukowym.

\subsubsection{Encykliki, katechizmy i modlitewniki}

Na łamach katolickich czasopism społeczno-kulturalnych żywą reakcję publicystów budziło wydanie w języku polskim encyklik papieskich. Największy rozgłos uzyskała encyklika Piusa XII o liturgii zatytułowana Mediator Dei (Kielce 1948), w thumaczeniu o. J. Wierusza-Kowalskiego. Dwukrotnie wspomniano o niej w „Głosie Katolickim” i „Tygodniku Warszawskim”, przedstawiając jej zawartość i okoliczności powstania ${ }^{75}$. Ogłoszona w czasie ożywiania się ruchu liturgicznego i poświęcona „nauce o istocie Mszy św.”, miała stanowić „ukoronowanie dzieła poprzednich Papieży" ${ }^{\prime \prime}$. Jej „,wielkie znaczenie dla pogłębienia życia religijnego" doceniono w wypowiedziach "Tygodnika Warszawskiego" i polecano ją „,szerokim kołom inteligencji katolickiej”"7. Zapowiedź ukazania się dokumentu Kościoła wraz z obszernym omówieniem warunków społeczno-politycznych, w jakich on powstał, i streszczeniem zawartości dostarczył, sam tłumacz na stronach „Tygodnika Powszechnego" "78. Z okazji tysiąc czterechsetnej rocznicy śmierci św. Benedykta wydano encyklikę Fulgens Radiatur (Rzym 1947), o której powiadamiała krótka wzmianka w „Głosie Katolickim”79. Redakcje poinformowały również odbiorców o wydaniu kolejnych dwóch dokumentów papieskich dotyczących modlitw o pokój na świecie: Optatissima Pax (Rzym 1947) i Auspicia Quaedam (Rzym 1948) ${ }^{80}$. Jerzy Stawski śledził natomiast

${ }^{73}$ J. Gallus, Ksią̇ka o petnym człowieku, „TP” 1950 nr 6 s. 11.

${ }^{74}$ Tamże.

75 (S), Nowa encyklika o Liturgii Ojca św., „GK” 1947 nr 52 s. 431; J. Stawski, Encyklika o liturgii, „GK” 1948 nr 31 s. 269; Nowa Encyklika, „TW” 1948 nr 1 s. 10; jar [J. Archita], Encyklika o liturgii, tamże, nr 35 s. 10.

${ }^{76}$ J. Stawski, Encyklika o liturgii...

77 jar [Archita Jan], Encyklika o liturgii...

78 J. Wierusz-Kowalski, Magna charta liturgii, „TP” 1948 nr 5 s. 1-2.

${ }^{79}$ Ze świata katolickiego. Nowa encyklika, „GK” 1947 nr 18 s. 157.

${ }^{80}$ Nowa encyklika Piusa XII „, Optatissima Pax”, „GK” 1948 nr 4 s. 39; Z., Nowa encyklika papieska, „TW” $1948 \mathrm{nr} 21$ s. 6. 
kolejne polskie wydania encyklik w wydawnictwie Verbum w cyklu Z Akt Stolicy Apostolskiej ${ }^{81}$. Publicyści „Tygodnika Katolickiego” nie zamieścili żadnego omówienia encykliki. Wspomniano jedynie o ukazaniu się opracowania ks. A. Tondiniego pt. Encykliki maryjne ${ }^{82}$.

Rzadziej w czasopismach można było natrafić na oceny katechizmów czy modlitewników. Pracę katechety i przygotowanie do sakramentów miał ułatwić Katechizm podstawowy dla dzieci w opracowaniu ks. Czesława Piotrowskiego, w którym zachowano tradycyjną formę pytań i odpowiedzi ${ }^{83}$. Dorosłym do pogłębienia znajomości prawd wiary polecano Katechizm życia chrześcijańskiego ks. Jana Ziei ${ }^{84}$. Dzieje katechizmu i jego najważniejsze reformy przy okazji świeżo wydanego przez IW PAX Katechizmu religii katolickiej (Warszawa 1951) przybliżył ks. Andrzej Bardecki. W nowej edycji zauważył przede wszystkim uwzględnienie ,etyki pozytywnej, współczesnej pedagogiki i teologii" ${ }^{85}$. Oryginalną formę i piękną szatę graficzną posiadał wydany nakładem Księgarni Krakowskiej modlitewnik Wielbij duszo moja, Pana!... (Kraków 1948). W jego zawartości, jak wiadomo z opisu, zestawiono utwory religijne polskich poetów (m.in. jezuity Macieja Kazimierza Sarbiewskiego, Stanisława Wyspiańskiego, Leopolda Staffa) wraz z fragmentami „,pism pisarzy kościelnych”" ${ }^{86}$. W Przegladzie piśmiennictwa na łamach miesięcznika jezuitów odnotowano dwa modlitewniki dla dorosłych: Będziesz miłowat i Jezu dobry Pasterzu wydane również nakładem IW PAX w $1951 \mathrm{r}$. W omówieniu pierwszego z nich recenzent wskazał na liczne błędy w strukturze ${ }^{87}$, natomiast o drugim pisał z niezwykłą szczerością, że był jeszcze „gorszy od poprzedniego" ${ }^{88}$. Na negatywną opinię złożyły się oprócz braku podstawowych modlitw m.in. „niemiły dla oka format”, gdyż była to zbyt dużych rozmiarów cienka objętościowo książka, bezbarwny i blady druk oraz zlewające się z w tekście czcionki objaśnień z tekstem właściwym ${ }^{89}$.

W przedstawionej wyżej grupie wydawnictw recenzenci mogli wyrazić więcej krytycznych uwag na temat modlitewników, co też uczyniono w przypadku jednego z nich. Dokumenty papieskie nie podlegały na łamach pism katolickich negatywnym opiniom, starano się zatem w głównej mierze w recenzjach omawiających upowszechniać je wśród wiernych.

${ }^{81}$ J. St. [J. Stawski], Encyklika „,Quadragesimo anno” w nowym wydaniu, „GK” 1946 nr 35 s. 283; tenże, Pius XI o wychowaniu chrześcijańskim, „GK”, 1947 nr 35 s. 293.

82 (W.D.), Encykliki maryjne, „TK” 1951 nr 23 s. 204.

83 „TK” 1948 nr 21 s. 147.

${ }^{84}$ Katechizm życia chrześcijańskiego, „TK” 1949 nr 24 s. 226.

${ }^{85}$ A. Bardecki, Reforma katechizmu, „TP” 1951 nr 49 s. 1-2.

${ }^{86}$ Oryginalny modlitewnik, ,GK” 1948 nr 32 s. 277.

${ }^{87}$ Przeglad piśmiennictwa. Recenzje książek, „PP” 1952 nr 1 s. 66.

${ }^{88}$ Przeglad piśmiennictwa, „PP” 1952 nr 3 s. 216.

${ }^{89}$ Tamże. 


\subsubsection{Dzieła teologiczne, prace z zakresu filozofii chrześcijańskiej i nauki społecznej Kościoła}

Recenzje prac teologicznych i filozoficznych na łamach „Przeglądu Powszechnego" wychodziły spod pióra ks. Jana Rostworowskiego. Publicysta wypowiadał się na temat dzieł zarówno polskojęzycznych, jak i obcojęzycznych. Warto zwrócić uwagę na niektóre wybrane omówienia. W jezuickim periodyku zauważono dwie rozprawy dotyczące nauczania doktora Kościoła św. Augustyna. W pierwszej z nich zatytułowanej Nauka św. Augustyna o klamstwie na tle historycznym (Lublin 1948) Zdzisława Golińskiego czytelnicy mogli poznać definicję kłamstwa i jego podział dokonany przez „,pioniera katolickiej nauki o kłamstwie" - św. biskupa Hippony ${ }^{90}$. Z opinii o drugiej książce, autorstwa Ryszarda Paciorkowskiego, Chrześcijaństwo w apologetycznej myśli św. Augustyna (Poznań 1952), można było dowiedzieć się, że autor, posługując się bogatym aparatem naukowym, dobrze przedstawił siłę argumentacji św. doktora ${ }^{91}$. Hanna Waśkiewicz wśród „książek, które na zachodnioeuropejskich rynkach księgarskich dawno już przestały być nowościami wydawniczymi, a u nas zachowują ten charakter w kilka lat nawet po ukazaniu się", wydobyła rozprawę wybitnego znawcy filozofii tomistycznej o. Gallusa M. Mansera Das Naturrecht in thomistischer Beleuchtung (Fryburg 1944). Praca stanowiła, zdaniem opiniującej, „udaną próbę” własnej koncepcji rozwiązania zagadnienia prawa naturalnego $\mathrm{w}$ oparciu o dorobek pisarski św. Tomasza i „czołową pozycję” w podjętej tematyce. Napisana z „rzadko spotykaną sumiennością naukową" oraz jasnością wywodów, była dostępna dla czytelnika z niewielkim przygotowaniem filozoficznym ${ }^{92}$. Trzy pozytywne recenzje uzyskała dwutomowa praca o. Jacka Woronieckiego Katolicka etyka wychowawcza (Kraków 1948), odnosząca się do zagadnień teologii moralnej ${ }^{93}$. Za „książkę chybioną" uznał natomiast ks. Rostworowski rozważania teologiczne na temat częstego odprawiania mszy św. jezuity Karla Rahnera pt. Die vielen Messen und das eine Opfer (Fryburg 1951). W negatywnej ocenie czytamy: „Szkoda, że ta książka się ukazała, bo może w rzeczy ważnej, a należącej do codziennego życia Kościoła, wprowadzić zamęt w niejeden umysł"94.

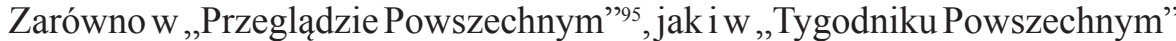
dostrzeżono dogmatyczne studium o. Romualda Kosteckiego Świętość Chrystusa,

${ }^{90}$ S. Wawryn, Przegląd piśmiennictwa. Recenzje książek, „PP” 1950 nr 4 s. 299-300.

${ }^{91}$ X.J.R. [J. Rostworowski], Przeglad piśmiennictwa. Recenzje ksiażek, „PP” $1952 \mathrm{nr} 10$ s. $256-257$.

${ }^{92}$ H. Waśkiewicz, Przegląd piśmiennictwa, „PP” 1949 nr 11 s. 322-325.

${ }^{93}$ J. Piwowarczyk, Podstawy etyki, „TP” 1948 nr 18 s. 3; tenże, System etyki jednostkowej, nr 50 s. 6; J. Stawski, Katolicka etyka wychowawcza, „GK” 1948 nr 32 s. 277.

${ }^{94}$ J. Rostworowski, Przegląd piśmiennictwa. Recenzje ksią̇ek, „PP” 1952 nr 1 s. 66.

95 Tenże, Przegląd piśmiennictwa. Recenzje ksiązek, „PP” $1952 \mathrm{nr} 4$ s. 291-292. 
Głowy Ciała mistycznego (Poznań 1952). Ks. Eugeniusz Weron, pozytywnie komentując „trudną książkę”, pochwalił również jej „wytworną szatę graficzną" ${ }^{96}$. W trzech z wybranych tytułów prasowych pozytywną recenzję zamieszczono także o książce ks. Michała Müllera O radosnym miłowaniu Boga (Ołtarzew 1947), będącej syntezą drogi duchowej św. Franciszka Salezego. Recenzent „Przeglądu Powszechnego" nazwał ją „dziełem w wielkim stylu”, a jego wartość postrzegał w „próbie ujęcia zagadnień ascetycznych na szerokiej płaszczyźnie”. Wytknął jedynie autorowi wyraźną „niechęć do ascezy późnego średniowiecza”" ${ }^{97}$. Jan Archita, na łamach „Tygodnika Warszawskiego” wyróżniając książkę za bogactwo treści i szczegółowy wykład, napisał: „Opracowanie inne w typie od znanych dotychczas, a przestarzałych, jest pozycją dodatnią w naszym bilansie wydawniczym" ". Jerzy Stawski w artykule „Głosu Katolickiego” skupił się na marginesie wydanej pracy bardziej na osobie samego świętego $0^{99}$. U wszystkich recenzentów przekład nie budził zastrzeżeń. „Książką niezastąpioną w polskiej literaturze religijnej” oraz „konieczną pozycją w bibliotece każdego światłego katolika”, zdaniem publicysty „Głosu Katolickiego”, było dzieło ks. Aleksandra Żychlińskiego Teologia życia wewnętrznego (Kielce 1947) ${ }^{100}$. Dobrą opinię o tej samej pozycji wyraził też publicysta „Tygodnika Powszechnego"101.

Współpracownicy czasopism społeczno-kulturalnych wypowiadali się niekiedy na temat książek, które można zakwalifikować do pozycji z szeroko pojętej dziedziny nauki społecznej Kościoła lub nawiązujących do niej. Najbardziej upoważnionym do tego rodzaju omówień na łamach „Tygodnika Powszechnego” był ks. Jan Piwowarczyk, który zrecenzował m.in. książkę profesora Adama Krzyżanowskiego Chrześcijańska moralność polityczna (Warszawa-Kraków 1948) wydaną w oficynie Eugeniusza Kuthana. W wypowiedziach znanego naukowca docenił przede wszystkim ,atmosferę afirmacji ducha ludzkiego jako twórczego czynnika w dziejach”, uznanie zasady „,moralnego prawa natury ludzkiej” i ,podkreślenie prymatu etyki w życiu społecznym"102. Ponadto przedstawiona przez autora teoria współczesnego państwa była w wielu punktach zgodna z koncepcją katolicką wyrażoną w encyklikach społecznych. W tej samej książce recenzent „Znaku” podkreślił zasługi i historyczną rolę Kościoła, jaką ukazał uczony notabene „nie deklarujący się jako badacz katolicki”. Wypowiedź zakończył wnioskiem: „Rozważania Krzyżanowskiego zamyka teza o niewystarczalności samych tylko reform politycznych. Reformy najlepiej pomyślane nie dadzą głębszych i trwałych skutków, gdy nie łączą się w sposób istotny z pracą moralną nad doskonaleniem jednostki,

\footnotetext{
${ }^{96}$ E. Weron, Trudna książka, „TP” 1952 nr 20 s. 4.

97 J.M.T.J., Dzieła religijno-ascetyczne, „PP” 1948 nr 8 s. 187.

98 jar [J. Archita], O ideale życiowym Patrona pisarzy, „TW” 1948 nr 20 s. 5.

99 J. Stawski, , O radosnym miłowaniu Boga”, „GK” 1948 nr 12 s. 105.

100 Życie wewnętrzne w świetle teologii, „GK” 1948 nr 31 s. 269.

101 J.J., Dogmat łaski w życiu wewnętrznym, ,TP” 1948 nr 7 s. 11.

102 J. Piwowarczyk, Rola chrześcijaństwa, ,TP” 1948 nr 48 s. 9.
} 
a przez jednostki nad doskonaleniem państwa” ${ }^{103}$. Walorem książki była też „naukowa rzeczowość i brak frazeologicznych ułatwień" ${ }^{104}$. Publicyści obu pism wyrazili zadowolenie $\mathrm{z}$ jej ukazania się $\mathrm{w}$ okresie powojennym, w którym podejmowano próby zakwestionowania zasad powszechnej i obiektywnej moralności katolickiej. Opracowanie nazwano również „,ciekawą książką”.

Jedną z „najświetniejszych syntez współczesnych nauki społecznej Kościoła” była, zdaniem Jerzego Brauna, rozprawa autorstwa filozofa i prawnika Guido Gonelliego pt. Zasady tadu społecznego. Publikacja oparta na encyklikach społecznych stanowiła próbę „katolickiej doktryny realizacyjnej”. Doktryna ta głosiła zasadę jedności polityki i moralności, a w dalszej perspektywie ,jedność etyki prywatnej i publicznej”"105. Zapoznając szczegółowo czytelników „Tygodnika Warszawskiego" z zawartością poszczególnych rozdziałów, Braun dostrzegł wiele zbieżnych poglądów z tzw. ruchem unijnym w Polsce. Eugeniusz Myczka na łamach „Głosu Katolickiego” polecił powstałą na gruncie polskim pracę Konstantego Turowskiego Gospodarka planowa w koncepcji katolicko-społecznej (Kraków 1947). Starannie przygotowany wykład autor przedstawił również na podstawie encyklik społecznych i wielu dzieł katolickich myślicieli społecznych. Wyodrębnił przy tym „swoistość społecznej nauki katolickiej”, która w swym założeniu w gospodarce nie kieruje się zyskiem, wzbogaceniem ani siłą polityczną, lecz zasadą sprawiedliwości i miłości społecznej. Turowski zaznaczył również, że naród jest „organizmem moralnym”, a planowość nie ogranicza się tylko do dziedziny gospodarczej, ale powinna uwzględniać także przyrost naturalny oraz środki służące rozwojowi rodziny ${ }^{106}$. Do zagadnień małżeństwa i płciowości nawiązał wykładowca Uniwersytetu Warszawskiego ks. Zygmunt Kozubski w książce zatytułowanej Podstawy etyki płciowej (Poznań 1947), o której wspomniał Antoni Madej ${ }^{107}$. W pozytywnej opinii czytamy: „Książka spełnia dobrze zakreślony cel. Zaznajamia spokojnie i rzeczowo ogół katolicki z bardzo niepokojącymi problemami czasów współczesnych, niosących na sobie cały olbrzymi ciężar skutków wielkiego nieładu moralnego, jakim z natury rzeczy jest każda wojna [...] Dlatego trzeba przyjąć z wielką uwagą wszelkie pozytywne wskazania dotyczące uregulowania i podniesienia poziomu moralnego w życiu płciowym”108. „Książką na czasie" - pomimo zastrzeżeń co do niektórych wniosków autora - nazwano dwutomowe rozważania na temat populacji Walentego Majdańskiego Kotyski i potęga (Niepokalanów 1946) oraz Polska kwitnaca dziećmi (Niepokalanów 1947). Majdański bronił w nich życia nienarodzonych i propagował liczną rodzinę,

\footnotetext{
${ }^{103}$ M.J., Chrześcijańska moralność polityczna, „Znak” 1948 nr 7 s. 647.

104 Tamże, s. 644.

105 J. Braun, Podstawy ładu społecznego, „TW” 1948 nr 17 s. 1-2.

${ }^{106}$ E. Myczka, Synteza wolności i planowości, „GK” 1948 nr 3 s. 27-28.

${ }^{107}$ A. Madej, W kręgu myśli chrześcijańskiej, „TW” 1948 nr 17 s. 4.

${ }^{108}$ Tamże.
} 
czyniąc też małżonków odpowiedzialnymi za liczebność i przyszłość narodu ${ }^{109}$. W trosce o odrodzenie powojennego życia najważniejszej komórki społecznej powstała książka znanego biskupa Czesława Kaczmarka Podstawy życia rodzinnego (Kielce 1947), zauważona przez publicystów „Przeglądu Powszechnego”, „Tygodnika Katolickiego” i „Głosu Katolickiego”. Łącząca w swej treści jasny wykład nauki Kościoła katolickiego i praktyczne wskazówki wprowadzania zasad w życie, nazwana została „książką potrzebną” i „dla wszystkich” ${ }^{110}$.

Pozycje wydawnicze $z$ teologii, filozofii chrześcijańskiej i nauki społecznej Kościoła omawiane na łamach katolickich czasopism społeczno-kulturalnych w latach 1945-1953 były w zdecydowanej większości dobrymi pracami naukowymi znanych autorów. Chwalono je za gruntowne opracowanie, naukową metodę, obszernie wykorzystaną literaturę przedmiotu i logiczny wykład. Wśród wydawców dzieł teologicznych w Polsce wyróżniły się trzy oficyny: Wydawnictwo Mariackie, Pallotinum i Verbum. W ocenach zauważano pozycje zarówno obce, jak i rodzime, dotyczące kluczowych zagadnień społecznych (ustroju, wychowania, życia rodzinnego, moralności, godności osoby ludzkiej) widzianych przez pryzmat nauki Kościoła. Ich rolę przedstawiano na tle ówczesnych warunków społeczno-politycznych, w których wartości chrześcijańskie były kwestionowane i podważane.

\subsubsection{Rozważania religijne}

Propagowaniu książek o tematyce religijnej służyły recenzje należące do najliczniejszej grupy omówień. Polecano utwory znane i wyjątkowe w tym dziale piśmiennictwa, jak też zupełnie niezauważone przez krytyków. Warto zatem przytoczyć wybrane opinie nt. książek autorów obcych i polskich, które ukazały się w zawartości pism katolickich.

Miejsce jednego z najpiękniejszych dzieł katolickich obok Wyznań św. Augustyna i Myśli Pascala znalazła Apologia pro vita sua Johna Henry'ego Newmana (Kraków 1948) ${ }^{111}$. W książce kardynał (beatyfikowany w 2010 r. przez papieża Benedykta XVI) opisał swoją drogę konwersji na katolicyzm. Zdaniem ks. J. Rostworowskiego tom ten „był najbardziej charakterystyczny i najbardziej osobisty” dla „największego religijnego geniusza XIX wieku”12. Polskiego przekładu dokonał Stanisław Gąsiorowski, który w ocenie publicysty „wywiązał się z tego trudnego zadania w ogóle dobrze", pomimo drobnych błędów i braku przypisów wyjaśniających, kim były osoby i instytucje występujące w Apologii. Oryginalną

${ }^{109}$ E. Myczka, Napetniajcie ziemię..., „GK” 1947 nr 32 s. 266-267.

${ }^{110}$ Nowości wydawnicze, „TK” 1947 nr 3 s. 23; J. Stawski, Ksiażka dla wszystkich, „GK” 1948 nr 8 s. 69; X.J.R. [ks. J. Rostworowski], Przegląd piśmiennictwa. Książki, „PP” 1949 nr 3 s. $210-211$.

${ }^{111}$ J. Wierusz-Kowalski, W obronie praw sumienia, „TP” $1949 \mathrm{nr} 28$ s. 9.

112 J. Rostworowski, Przegląd piśmiennictwa. Recenzje i notatki, „PP” 1949 nr 5 s. 380. 
i wnikliwą interpretację rozwoju duchowego św. Ignacego z Loyoli, w opinii publicysty, przekazał w niewielkiej pracy Saint Ignace de Loyola et la genèse des Exercices (Tuluza 1948) jezuicki teolog niemiecki Hugo Rahner ${ }^{113}$. W jednym z numerów „Znaku” w dziale Zdarzenia - ksiązki - ludzie czytamy o tym, że „sensacją rynku księgarskiego w 1948 r. w USA była książka o treści religijnej” zakonnika trapisty o. Thomasa Mertona The Seven Storey Mountain. Wydana w nakładzie 172 tys. egzemplarzy, rozeszła się w ciągu kilku miesięcy. W 1949 r. autor opublikował dwie kolejne książki: Seeds of Contemplation i Elected Silence, które przyjęto z „dużym zainteresowaniem” i, jak pisano, „wywołały liczne echa prasowe”. Ponadto ujęcie zagadnień duchowych, erudycja autora oraz opisana ,głęboka autentyczność własnego przeżycia" sprawiły, że stały się cennymi pozycjami światowej literatury katolickiej ${ }^{114}$. Wśród obcych wydawnictw polecano też mniej popularne utwory nieprzetłumaczone dotychczas na język polski. Czesław Jastrzębiec-Kozłowski zaproponował odbiorcom „Tygodnika Warszawskiego” „niezwykłą książkę” Henri Pourrata La Bienheureuse Passion (Paryż b.r.). Pisał o niej: „Bardzo możliwe, że ludzi niewierzących ta książka nie nawróci; ale prawie nie podobna mi przypuścić, by człowiek rozumny mógł ją przeczytać bez wstrząsu. Jest to lektura, która czytelnika przeobraża" ${ }^{115}$. Autor $\mathrm{w}$ jej treści przedstawił życie Chrystusa od momentu sądu przed Piłatem do czasu zmartwychwstania, dostarczając czytelnikowi pogłębioną refleksję wydarzeń. Pourrat $\mathrm{w}$ jednym $\mathrm{z}$ fragmentów zwrócił uwagę ponadto na rolę pracy człowieka, która powinna go udoskonalać. Przy tej okazji napisał: „Grzeszy stolarz, który robi liche stoły. Grzeszy pisarz, który pisze nudną książkę"”11.

Z rodzimych pozycji religijnych zaprezentowano w trzech pozytywnych recenzjach wartościowe rozważania biskupa Czesława Kaczmarka Nadprzyrodzone życie dusz w Chrystusie i w Kościele (Kielce 1947) ${ }^{117}$. Podobnie przyjęto i przekonywano czytelnika do czterech „pożytecznych” rozprawek wydanych pod wspólnym tytułem Przyjaźń chrześcijańska (Kielce 1948) w ramach serii Biblioteczka Szkoły Chrystusowej wydawnictwa Verbum ${ }^{118}$. Uwagę odbiorców starano się skierować także na wydane w „nowej szacie” przez Albertinum Księgarnię św. Wojciecha Rozważania (Poznań 1946) ,jednego z czołowych przedstawicieli inteligencji polskiej" Stanisława Kasznicy ${ }^{119}$. Dziennik religijnych przeżyć autora ukazał się jeszcze w okresie dwudziestolecia międzywojennego, natomiast w czasie trwania

113 Tenże, Przeglad piśmiennictwa. Recenzje książek, „PP” 1951 nr 10 s. 346-347.

${ }^{114}$ M.J., Zdarzenia - książki - ludzie. Popularny trapista, „Znak” 1949 nr 5 s. 429.

${ }^{115}$ C. Jastrzębiec-Kozłowski, Męka Pańska, „TW” 1948 nr 8 s. 3.

116 Tenże.

117 J. Majkowski, Przegląd piśmiennictwa, „PP” 1948 nr 7 s. 103-104; J. Stawski, Książka dla wszystkich, „GK” 1948 nr 8 s. 69; J. Braun, Oportret vos nasci denuo, „TW” 1948 nr 9 s. 5.

118 J. Stawski, Przyjaźń chrześcijańska, „GK” 1948 nr 25 s. 221; jar [J. Archita], Zbiór studiów o przyjaźni chrześcijańskiej, „TW” 1948 nr 36 s. 6; O.J.W.K., Przyjaźń chrześcijańska, „TP” 1948 nr 26 s. 11; X.J.R. [J. Rostworowski], Przegląd piśmiennictwa, „PP” 1949 nr 3 s. 214-215.

119 A. Rogalski, Książka głęboko ludzka, „GK” 1946 nr 50 s. 399. 
działań zbrojnych w latach 1939-1945 miały miejsce trzy jego wydania za granicą (w Londynie i Hanowerze). „Urok książki”, zdaniem Aleksandra Rogalskiego, „płynął z bezpośredniości spowiedzi, z autentyczności przeżyć i z prostoty formy”. Autor napisał ten ,manifest wiary”, będąc w środowisku, w którym ,przeżycia religijne uchodziły powszechnie za wstydliwy margines”, a „religia trąciła staroświeckością”. W opinii recenzenta ta ,głęboko chrześcijańska” pozycja była nadal aktualna w powojennej „nowej, jakże dziwnej i groźnej epoce”, dalekiej od „realizacji ideałów humanizmu”"120. Na łamach „Znaku” Irena Gombrowicz zachęcała natomiast do przeczytania najnowszej książki Jerzego Zawieyskiego Owoc czasu swego (Kielce 1949). Głębokie religijne refleksje oraz unikanie moralizatorstwa cechowały ponadto niezwykłe „zbratanie z czytelnikiem” i umiejętność przybliżania „odwiecznych prawd" współczesnemu człowiekowi ${ }^{121}$.

Osobną grupę stanowiły recenzje rozważań liturgicznych, rekolekcyjnych, modlitewnych i zbiory kazań. Jerzy Stawski polecił czytelnikom "Głosu Katolickiego” książkę ,ppioniera ruchu liturgicznego w Austrii” ks. Piusa Parscha Wtajemniczenie $w$ ofiarę Mszy świętej (Kraków 1947) ${ }^{122}$. Kilka lat później w „Przeglądzie Powszechnym" omówiono pozytywnie pierwszy tom dzieła tego samego autora pt. Rok liturgiczny (Poznań 1950) ${ }^{123}$. Zachęcano także do sięgnięcia po naukową rozprawę Jeana Daniélou Bible et Liturgie (Paryż 1951), w której jezuita ukazał wpływ Pisma świętego na liturgię chrześcijańską ${ }^{124}$. „Postępującym w życiu wewnętrznym" pomocne mogły być rozważania M. V. Bernadota Od Eucharystii do Trójcy Przenajświętszej (Kielce 1949) ${ }^{125}$. W opinii ks. Jana Rostworowskiego „ogromną przysługę wiernym" miało oddać sześć tomików komentarzy objaśniających liturgię w całym roku kościelnym siostry Marii Renaty Vivere cum Ecclesia (Kraków 1949) ${ }^{126}$. Rozważania o Najświętszym Sakramencie ks. Zygmunta Przyjemskiego, zatytułowane Eucharystia (Niepokalanów 1950), napisane z ,żywą wiarą”, mogły się przydać „prostym i średnio wykształconym”"127.

Na łamach periodyków proponowano czytelnikom zapoznanie się m.in. z naukami konferencyjnymi dla zakonnic ${ }^{128}$, inteligencji ${ }^{129} \mathrm{i}$ ogółu wiernych ${ }^{130}$, a także

${ }^{120}$ Tamże.

${ }^{121}$ I. Gombrowicz, „, Owoc czasu swego”, „Znak” 1949 nr 3 s. 267-268.

122 J. Stawski, Zbliżenie do liturgii Kościoła, „GK” 1948 nr 17 s. 151.

${ }^{123}$ M. Renata, Przegląd piśmiennictwa. Recenzje ksiązek, „PP” $1950 \mathrm{nr} 5$ s. 361-362.

124 J. Rostworowski, Przegląd piśmiennictwa, „PP” $1951 \mathrm{nr} 10$ s. 348-349.

${ }^{125}$ Przeglad piśmiennictwa, „PP” 1949 nr 11 s. 329.

${ }^{126}$ J. Rostworowski, Przegląd piśmiennictwa, „PP” 1950 nr 1 s. 62-63.

${ }^{127}$ X.J.R. [J. Rostworowski], Przegląd piśmiennictwa. Recenzje książek, „PP” $1951 \mathrm{nr} 1$ s. $64-65$.

${ }^{128}$ L. Zmaczyński, Dary Ducha świętego, „TP” 1947 nr 35 s. 7. [Ambroise Gardeil, Duch św. $w$ życiu chrześcijańskim, Kielce 1944].

${ }^{129}$ X.J.R., [J. Rostworowski], Przegląd piśmiennictwa. Książki, „PP” 1950 nr 1 s. 63. [M. Bednarz, W Chrystusie Panu naszym, Kraków 1948].

${ }^{130}$ A. Rogalski, Uprawa Bożej roli, „GK” 1948 nr 4 s. 35. [Jan Czuj, Nauki rekolekcyjne, Warszawa 1947]. 
książeczkami z rozważaniami różańcowymi ${ }^{131}$. „Zachwyt” zarówno u słuchających, jak i czytających budziły wydane przed II wojną światową kazania niemieckiego kapłana pochodzenia włoskiego Romano Guardiniego - katolickiego teologa, filozofa religii i liturgisty. Przekładu polskiego doczekały się w okresie okupacji hitlerowskiej, a po ustaniu działań wojennych wydano je nakładem Księgarni św. Jacka pt. O Bogu żywym (Katowice 1947). Recenzent „Tygodnika Powszechnego" tak pisał o twórczości Guardiniego: „autor pisze o kwestii nie tylko przestudiowanej, ale również głęboko przeżytej, przetrawionej, pisze z całą gorącością południowca, ze zrozumieniem głębokiego psychologa i z umiejętnością wielkiego artysty” ${ }^{132}$. Ks. Jan Piwowarczyk jako „cenną pozycję” w rodzimej literaturze religijnej przedstawił konferencje światopoglądowe biskupa Jana Stepy Bóg, świat, człowiek (Tarnów 1947) ${ }^{133}$. W omówieniach zauważono też krótkie kazania dla dzieci ks. Teodora Nogala Takich jest królestwo niebieskie (Poznań 1948) i ks. Władysława Mirskiego Do kogo pójdziemy? (Włocławek 1947). Pierwsze mogły być dobrą pomocą dla katechetów ${ }^{134}$, drugie zaś - przeznaczone dla duszpasterzy - stanowiły ,doskonały materiał do zwięzłych a bogatych w myśli kazań" 135 .

Propagowana w pismach literatura religijna była przeznaczona zarówno dla czytelnika wykształconego, jak też miała charakter bardziej popularny. Stanowiła cenną pomoc dla duszpasterzy i zakonnic, ale mogła również pogłębić życie religijne katechetów oraz zwykłych wiernych.

\subsubsection{Encyklopedie i slowniki katolickie}

Najbardziej aktywny recenzent „Przeglądu Powszechnego” ks. Jan Rostworowski śledził powojenne francuskojęzyczne wydawnictwa encyklopedyczne i słownikowe. Większość z nich ukazała się w latach 1950-1952 w paryskim wydawnictwie Letouzey. Cel omówień tego rodzaju publikacji ks. Rostworowski określił w jednej z wypowiedzi, konstatując w charakterystycznym dla siebie stylu: „Chodzi najpierw o to, by dostarczyć w sprawach katolickich pewnych wiadomości ludziom, którzy by nie sięgnęli do ogromnych i fachowych, teologicznych dykcjonarzy, po wtóre zaś o to by, o ile możności przedstawić te wiadomości

${ }^{131}$ J.W.K., Wydawnictwa maryjne, „TP” 1948 nr 26 s. 11; X.J.R. [J. Rostworowski], Przegląd piśmiennictwa, „PP” 1949 nr 3 s. 215. [Romuald Kostecki, Modlitwa różańcowa, Kielce 1948]; L.M., Przegląd piśmiennictwa, tamże, nr 11 s. 328; JMS. [J. M. Święcicki], O chrześcijańską kulturężycia, „TP” 1949 nr 22 s. 11. [Jan Archita, O chrześcijańska kulturę życia, Niepokalanów 1948].

${ }^{132}$ W.Cz., Pisarz-duszpasterz, „TP” $1948 \mathrm{nr} 34$ s. 9; pozytywna recenzja kazań ukazała się też w warszawskim czasopiśmie: M. Antoni, Ku źródłom prawdy, „TW” 1948 nr 4 s. 5.

${ }^{133}$ J. Piwowarczyk, Światopogląd katolicki, „TP” 1947 nr 36 s. 6.

${ }^{134}$ S.B., Przegląd piśmiennictwa, „PP” $1949 \mathrm{nr} 11$ s. 327.

135 J.M. Święcicki, Wartościowa pozycja, „TP” 1950 nr 13 s. 8. 
pod kątem widzenia przemian, jakimi rzeczy katolickie mogą ulegać w drodze, od wczoraj do dziś i do domyślnego jutra"136. Publicysta przedstawił drugi tom zaplanowanej na siedem części encyklopedii Catholicisme (Paryż 1950), wskazując na niektóre starannie opracowane hasła, jak Concordat, Communion czy Communisme. Kończąc omówienie encyklopedii podkreślił: „Nie podobna zresztą w krótkiej wzmiance wyliczyć wszystkich prac tego zeszytu, zasługujących na pochwałę. Można tylko - nie bez pewnego uczucia zazdrości - powinszować tak autorom, jak kierownikowi i wydawcom tego dzieła, że około zdrowego uświadomienia katolickiego zdobywają sobie coraz to nowe zasługi" ${ }^{137}$. Oceniając zeszyt jedenasty dostrzegł dobre kierownictwo i wyraźny rozwój tego wydawniczego przedsięwzięcia. Docenił w nim m.in. „Dużą zwięzłość, idącą w parze ze ścisłością informacji, ograniczenie wykazu literatury do tego, co najważniejsze, wybitną współczesność, złączoną z duchem prawdziwie kościelnym"138. Zarówno w periodyku jezuickim, jak i „Tygodniku Powszechnym” pozytywnie oceniono polską encyklopedię hagiograficzną Święci i błogosławieni Kościoła katolickiego (Poznań 1947) biskupa Karola Radońskiego. „Wyczerpujący” zbiór świętych i błogosławionych „wszystkich ras i narodów”, był zdaniem opiniującego „książką ciekawą". Należało w niej także pochwalić przyjętą przez autora metodę nieuwzględniania legend, a jedynie prawdy historycznej „stwierdzonej przez naukę" ${ }^{139}$. Ks. Jan Piwowarczyk zwrócił również uwagę na estetyczną szatę zewnętrzną wydawnictwa, dobry papier, druk i barwną okładkę, wyrażając nadzieję, że książka będzie ,pożądanym gościem w każdym katolickim domu”140.

Zdecydowanie więcej na łamach jezuickiego miesięcznika ks. Rostworowski zrecenzował słowników o charakterze biblijnym, liturgicznym i teologicznym. W jego opinii „profesorowie Pisma świętego" mieli z „wielką wdzięcznością powitać" suplement do wydanego kilkanaście lat wcześniej Dictionnaire de la Bible, w którym zawarto liczne życiorysy wybitnych biblistów katolickich i protestanckich oraz hasła pojęciowe ${ }^{141}$. Ten sam publicysta omówił również dykcjonarz archeologii i liturgii Dictionnaire d'archeologie chrétienne et de liturgie (Paryż 1950) ${ }^{142}$ oraz mistyki chrześcijańskiej Dictionnaire de Spiritualité, Ascétique et

${ }^{136}$ X.J.R. [J. Rostworowski], Przegląd piśmiennictwa. Recenzje książek, „PP” $1950 \mathrm{nr} 4$ s. 298.

${ }^{137}$ Tamże.

${ }^{138}$ X.J.R. [J. Rostworowski], Przegląd piśmiennictwa. Recenzje książek, „PP” $1951 \mathrm{nr} 11$ s. 429.

${ }^{139}$ Notatki bibliograficzne, „PP” 1948 nr 7 s. 112; J.P. [J. Piwowarczyk], Encyklopedia świętych, „TP” 1948 nr 20 s. 15.

${ }_{140}^{14 . P .}$ [J. Piwowarczyk], Encyklopedia świętych ...

${ }^{141}$ X.J.R. [J. Rostworowski], Przegląd piśmiennictwa. Recenzje książek, „PP” $1951 \mathrm{nr} 1 \mathrm{s.}$ 64; „PP” 1952 nr 9 s. 172.

142 J. Rostworowski, Przegląd piśmiennictwa. Recenzje książek, „PP” 1950 nr 4 s. 298-299; „PP” 1951 nr 8 s. 207-208; „PP” 1952 nr 9 s. 172-173. 
Mystique (Paryż 1950, 1952) ${ }^{143}$. Polskim wydawnictwem krytycznie ocenionym przez Mariana Plezię było drugie wydanie przedwojennego Słownika kościelnego tacińsko-polskiego (Miejsce Piastowe 1948) w thumaczeniu i opracowaniu ks. Alojzego Jougana ${ }^{144}$. Przywitany ,z zadowoleniem” ze względu na ogólny brak polskich zestawień haseł objaśniających łacinę liturgiczną, zawierał jako praca kompilacyjna (powstała na bazie tłumaczenia z kilku słowników zagranicznych) liczne błędy językowe i historyczne, które recenzent skrupulatnie wymienił. Korzystanie ze słownika utrudniały ponadto brak wytłuszczonych drukiem haseł, przesuwanie wyrazów na niewłaściwe miejsca, brak należytej interpunkcji. Plezia wnioskował przy tym: „Zdaje się, że nakładca starał się o obniżenie za wszelką cenę kosztów druku, [...] [zrezygnował - E.K.] nawet ze starannej korekty drukarskiej, nie mówiąc już o papierze. Dlatego w porównaniu np. ze słownikiem Sleumera robi jego polska przeróbka o wiele mniej korzystne wrażenie, a nasze własne słowniki szkolne także wyżej od niej pod tym względem stoją" ${ }^{145}$. Pomimo niedociągnięć i krytycznego przedstawienia wydawnictwa publicysta na koniec stwierdził, że słownik może być „bardzo pożyteczny”. Życzył też „poczytności” oraz „rychłego przystąpienia do nowej, ulepszonej edycji”.

Wydawnictwa encyklopedyczne i słownikowe wymagały bardziej szczegółowego potraktowania przy omówieniach, dlatego też na przykładach opracowanych haseł wykazywano ich poziom naukowy. Brak opracowań słowników specjalistycznych przyczyniał się do przyjmowania z aprobatą każdego wznowienia, nawet jeśli nie było ono należycie przygotowane.

\section{Podsumowanie}

Wybór książek katolickich (nieliterackich) prezentowanych w recenzjach był bogaty i różnorodny, począwszy od opinii o nowych przekładach Nowego Testamentu, komentarzach do Ewangelii, dziełach mistycznych, hagiografiach, kończąc na rozważaniach religijnych i słownikach. Pisano o autorstwie Ewangelii, jej zawartości, sposobie odczytywania, egzegezie, książkach na niej opartych. Zrecenzowano nowy Katechizm religii katolickiej wydany w 1951 r. przez Instytut Wydawniczy PAX. Dostrzeżone zostały również mniej znane polskie pozycje. Opinie o książce katolickiej ukazywały się najczęściej na łamach „Tygodnika Powszechnego”, „Przeglądu Powszechnego” i „Tygodnika Warszawskiego”, rzadziej w „Głosie Katolickim”, „Tygodniku Katolickim” i „Znaku”. Recenzentem w różnych tytułach prasowych mogła być ta sama osoba, jak to było w przypadku

${ }^{143}$ X.J.R. [J. Rostworowski], Przegląd piśmiennictwa. Recenzje książek, „PP” $1951 \mathrm{nr} 3$ s. 230; „PP” $1952 \mathrm{nr} 10$ s. 256.

${ }^{144}$ M. Plezia, Lacina kościelna i jej polski stownik, „TP” 1950 nr 39 s. 4-5.

145 Tamże, s. 5. 
pozytywnych wypowiedzi Mariana Plezi o dziełach Ojców Kościoła Wschodniego. Większość opracowań na łamach „Tygodnika Powszechnego” dotyczyła jednej pozycji, rzadziej autorzy ocenili dwie lub trzy książki w jednej recenzji.

\subsection{Publikacje historyczne}

Książkowe tytuły o tematyce historycznej ceniono za rzetelne przedstawianie faktów, dobre wykorzystanie nieznanych dotąd źródeł, znajomość epoki, sposób przedstawienia wydarzeń i nowe spojrzenie na dzieje. W latach 1945-1953 na łamach katolickich czasopism społeczno-kulturalnych przeważały recenzje książek, w których podejmowano zagadnienia wojenne, obozowe i kwestie niemieckie. Oprócz licznych relacji o okrucieństwach hitleryzmu, zamieszczonych w wydanych bezpośrednio po wojnie drukach, obecne były pozycje, w których autorzy próbowali dokonać prawdziwej syntezy. Chciano jednocześnie znaleźć wythumaczenie w pogłębionej psychologicznej i religijnej interpretacji przyczyn. Liczne oceny dotyczyły publikacji o różnorodnej tematyce historycznej. Poruszano problematykę danego regionu lub okresu. Publicyści starali się jednocześnie zwrócić uwagę czytelników na wydawnictwa obejmujące mniej lub bardziej znane wydarzenia w historii świata i Polski. Do tej części pracy zaliczono również omówienia wspomnień i pamiętników oraz biografii. Zdecydowana większość recenzji naukowych rozpraw historycznych ukazała się na łamach „Tygodnika Powszechnego” i „Tygodnika Warszawskiego”, rzadziej „Głosu Katolickiego”.

\subsubsection{Książki poświęcone przebiegowi II wojny światowej}

W pierwszych latach po II wojnie światowej na rynku księgarskim pojawiły się pozycje, w których starano się przedstawić zarówno cały ten okres, jak też działania zbrojne na poszczególnych odcinkach frontu. Opracowania te stanowiły dorobek autorów polskich i obcych.

Paweł Jasienica na łamach „Tygodnika Powszechnego” ubolewał w jednej z recenzji nad brakiem dostępu do francuskich nowości wydawniczych, zapytując: „rozmaite układy z Francją są, tylko francuskich książek u nas po dawnemu nie ma. Nieustannie rosną nasze intelektualne zaległości i opóźnienia. I kiedy my to wszystko zdążymy odrobić? Bo przecież nie zależy nam chyba na tym, by nasza wiedza najnowszej historii utrzymywała się na poziomie prowincjonalnym"146. Ten sam historyk w ciekawy sposób omówił książkę szwajcarskiego pułkownika Edgara Schumachera Geschichte Zweiten Weltkrieges (Zürich 1946), przedstawiając działania militarne Niemców w czasie II wojny światowej. Recenzent zwrócił

${ }^{146}$ P. Jasienica, Wnioski z lektury, „TP” 1947 nr 28 s. 3. 
szczególną uwagę na wypowiedzi dotyczące spraw polskich w książce; zestawiając je tabelarycznie porównał ponadto z częstotliwością występowania zagadnień polskich w innej rozprawie zatytułowanej Druga wojna światowa (Kraków 1947). Krytyka obu lektur wypadła na korzyść książki Schumachera, pomimo wykorzystania przez niego jedynie źródeł niemieckich. Druga z książek zrecenzowana została wcześniej również przez Jasienicę, jak też przez Kazimierza Koźniewskiego. Negatywną opinię o Drugiej wojnie światowej Koźniewski rozpoczął w następujący sposób: „Ostatnio ukazała się na rynku książka - przed którą należy przestrzegać czytelnika, by nie narażać go na zbędny wydatek 580 zł, a równocześnie trzeba wyrazić zasadnicze zastrzeżenia wobec tych czynników, które są odpowiedzialne za przydział papieru dla tej publikacji”"147. Zarzucając autorowi wybitnie amerykański punkt widzenia w stosunku do ostatniej wojny, określił pozycję jako „propagandową”, „niepotrzebną” i „bezwartościową” dla polskiego czytelnika. Głównym błędem twórców zbiorowego dzieła miało być przemilczanie spraw polskich, które jeśli były w ogóle wspomniane, to w sposób „lakoniczny” lub „,zdeformowany” (za przykład posłużył m.in. skąpo przedstawiony udział polskich żołnierzy w walkach pod Monte Cassino). Najbardziej bulwersujący dla publicysty był fakt braku choćby ,jednego słowa” o powstaniu warszawskim. W polemicznej recenzji Jasienica, uznając argumentację Koźniewskiego za „zupełnie fałszywą", a krytykę za zbyt ostrą, bronił książkę jako ciekawą i „,zapoznającą nas z punktem widzenia jednego z dwu największych mocarstw świata"148. Ponadto wytknął poprzednikowi niedokładne czytanie, polecając lekturę strony, na której znalazł jednak wzmiankę o powstaniu.

Seweryn Włodarski jednoznacznie dobrze ustosunkował się do publikacji polskiego autora Jerzego Płażewskiego o tym samym tytule Druga wojna światowa (Łódź 1947), będącą chronologicznym ułożeniem wydarzeń od Monachium do Poczdamu (28 IX 1938 - 2 VIII 1945). Pochwalił „benedyktyńską pracę” autora oraz „treściwy i plastyczny” sposób przedstawiania faktów, co uczyniło z książki „fascynującą lekturę"149. W przejrzystym układzie można było z łatwością odszukać zarówno najważniejsze, jak i zupełnie nieznane wydarzenia historyczne.

Po opracowaniach dotyczących całego okresu trwania wojny należy zwrócić uwagę na recenzje książek, w których podjęto się przedstawienia jednego zagadnienia z historii najnowszej. Zawartość wojskowej publikacji pułkownika Władysława Zaczkiewicza Lotnictwo polskie w kampanii wrześniowej 1939 r. (b. m. 1947), ze szczegółowymi danymi liczbowymi zaczerpniętymi z meldunków, rozkazów i sprawozdan, zaprezentował w recenzji omawiającej Michał Jastrzębiec. $Z$ podanych $\mathrm{w}$ pracy informacji wynikała „dziesięciokrotna przewaga" sił lotniczych Niemiec nad Polską oraz poważne $78 \%$ straty polskich sił

\footnotetext{
${ }^{147}$ K. Koźniewski, Skandal z „Druga wojna”, „TP” 1947 nr 18 s. 8.

${ }^{148}$ P. Jasienica, Właściwe proporcje, „TP” $1947 \mathrm{nr} 22$ s. 5.

${ }^{149}$ S. Włodarski, Daty i fakty, „TP” 1947 nr 40 s. 6.
} 
powietrznych ${ }^{150}$. Publicysta docenił Zaczkiewicza przede wszystkim za chęć przybliżenia prawdy o wojnie poprzez napisanie o działaniach wroga niezgodnych z prawem międzynarodowym oraz niedotrzymaniu umowy pomocy lotniczej przez władze Francji. Dobry odbiór na łamach "Tygodnika Powszechnego" i ,Tygodnika Warszawskiego” znalazła książka Włodzimierza Wnuka Walka podziemna na szczytach (Poznań 1948), stanowiąca „,rzetelny reportaż naszpikowany datami, cyframi i nazwiskami”, a odnoszący się do okresu okupacji niemieckiej na Podhalu ${ }^{151}$. Autor podjął w nim odtworzenie tzw. ,sprawy góralskiej”. W świetle dokumentów ukazał, nieudaną jego zdaniem, niemiecką akcję germanizacyjną znaną pod nazwą Goralenvolk w latach 1939-1944, a podjętą de facto przez trzy osoby: Witalisa Wiedera, Henryka Szatkowskiego i Wacława Krzeptowskiego. Wyjaśnił podłoże zdrady góralskiej i ruchu oporu górali, przedstawiając „materiał rehabilitujący" ogół Podhalan ${ }^{152}$. Antoni Madej w warszawskim piśmie skupił się przede wszystkim na ukazaniu bohaterów ruchu oporu opisanych przez Wnuka, polecając upamiętnienie wiedzy o nich w podręcznikach harcerskich. Nieco inaczej, chociaż równie pozytywnie, pozycja została zrecenzowana w krakowskim tygodniku. Zofia Starowieyska-Morstinowa konstatowała: ,[...] książka Wnuka brzmi tu i ówdzie trochę jak mowa obrońcy [górali - E. K.], co książce historycznej nigdy na dobre nie wychodzi, to jednak widzi się w niej rzetelny wysiłek do oddania prawdy. Tego, co było złe, Wnuk nie ukrywa [...] prawdy nie przemilcza” ${ }^{153}$. W dalszej części wypowiedzi pochwaliła „żywy i bezpośredni” język autora, uznając pozycję za „książkę żarliwą". Jako wadę wymieniła natomiast skłonność autora do „patosu i zbytecznego liryzmu”.

Odmienne oceny publicystów „Tygodnika Powszechnego” i „Przeglądu Powszechnego" uzyskała natomiast książka Stanisława Podlewskiego Przemarsz przez piekło (Warszawa 1949), w której opisane zostały walki powstańcze Warszawy w 1944 r. Stefan Kisielewski w dobrze znany stałym odbiorcom pisma właściwy sobie humorystyczny sposób wykpił w rubryce Łopata do głowy nie tylko pozycję wydawniczą, ale również sens samego zrywu. Pisał: ,[...] książka jest wstrząsająca i powinna być w setkach tysięcy egzemplarzy rozprowadzona po kraju, jako $<<$ łopatologiczna >> lekcja historii, ukazująca z jednej strony bezgraniczne, niewiarygodne wprost bohaterstwo i poświęcenie, $\mathrm{z}$ drugiej - straszliwą, przerażającą i absurdalną wizję zniszczenia [...] Podlewski ukazuje proporcje i perspektywy całości - wystarczy tego, aby nie spać szereg nocy. Nie spać - i myśleć" ${ }^{154}$. Podając też kilka drastycznych opisów z książki konstatował: „Jeśli polityka jest realizowaniem możliwości, to w założeniach Powstania Warszawskiego polityki nie było: był to

\footnotetext{
${ }^{150}$ M. Jastrzębiec, Wrzesień zaczynat się w powietrzu..., „TP” 1947 nr 38 s. 4-5.

151 Z. Starowieyska-Morstinowa, Podhale podczas okupacji, „TP” 1948 nr 35 s. 7.

152 A. Madej, Walka podziemna na wyżnach, „TW” 1948 nr 31/32 s. 9.

153 Z. Starowieyska-Morstinowa, Podhale podczas okupacji, „TP” 1948 nr 35 s. 7.

154 Kisiel [S. Kisielewski], Łopata do głowy. Polityka, ,TP” 1949 nr 30 s. 8.
} 
czyn - antypolityczny, antykonstruktywny, jałowy, niszczycielski gest"155. Zygmunt Lichniak podszedł natomiast do książki z większą powagą, oceniając ją dobrze ${ }^{156}$.

$\mathrm{O}$ walkach jednej z dywizji pisał Jan Marowski w książce-reportażu zatytułowanej Śladami czolgów Pierwszej Dywizji Pancernej od Caen do Wilhelmshaven (Wrocław 1948). Paweł Jasienica wydając dobrą opinię o niej jako pracy wnoszącej „,istotny wkład” w wiedzę o ostatniej wojnie, docenił fakty podane przez autora-uczestnika m.in. o tym, że ,polski dowódca i polski oddział wśród powszechnego zdziczenia pamiętał o rycerskim nakazie niekrzywdzenia niewinnych"157. Kazimierz Koźniewski wypowiadając się negatywnie o zbyt „płytkiej i sloganowej” broszurze Jana Mulaka Wojsko podziemne 1939-1945 (Warszawa 1946), oprócz braku jednolitej metody opracowania skrytykował liczne przeoczenia, błędy i zbyt wygórowaną cenę druku. W opinii wnioskował: „Podejrzewamy jeszcze nie czytając książeczki, że mamy i tym razem do czynienia z nierzetelną (a drogą: 150 zł za 76 stron to jest dwakroć drożej niż takie książki jak Pruszyńskiego 13 Opowieści, czy nawet ogromna powieść Dobraczyńskiego Najeźdźcy) broszurką propagandową, której treść maskowana jest wiele zapowiadającym tytułem"158.

Formę rzeczowego wykładu z licznymi przykładami nadał swej książce brytyjski marszałek Montgomery of Alamein Od Normandii do Battyku (Katowice 1948), relacjonujący przebieg operacji wojsk sprzymierzonych w zachodniej i północno-zachodniej Europie w okresie od 6 VI 1944 r. do 5 V 1945 r. Autor „po wojskowemu konkretny w opisach" dostarczył, zdaniem Olgierda Budrewicza, „pasjonującą lekturę” polskiemu czytelnikowi, przedstawiając planowość akcji i własne refleksje ${ }^{159}$. Dość obszerną recenzję omawiającą książkę Johna Herseya Hiroshima (Harmondsworth 1946) napisał Michał Strebejko. Czytelnik tego dzieła mógł na podstawie zeznań świadków poznać po części tragedię ludności cywilnej po wybuchu bomby atomowej ${ }^{160}$.

Paweł Jasienica polecił czytelnikom „Tygodnika Powszechnego” w zbiorczej recenzji wspomnienia wojenne Janusza Jasieńczyka Po Narwiku był Tobruk (Warszawa 1947) i Bohdana Arcta Messerschmitty w stońcu (Wrocław 1947). Omówienie rozpoczął w charakterystycznym dla siebie stylu: „Nie mogę się uskarżać, czytałem niemało relacji o perypetiach Drugiej Wojny Światowej. Ale nie wiem, czy zdołałbym wymienić wiele książek równie bezpośrednich, szczerych i rzetelnych jak wspomnienia Jasieńczyka. By od razu zrównoważyć te zachwyty - wymienię co grubsze mankamenty. Autor stanowczo zbyt hojnie szafuje onomatopeją" ${ }^{161}$. Dalej stwierdził, że Jasieńczyk „rozumnie konstruując swoją

\footnotetext{
155 Tamże.

156 Z. Lichniak, Przegląd piśmiennictwa. Książki-dokumenty, „TP” 1949 nr 5 s. 375-380.

157 P. Jasienica, Piasek, czotgi, messerschmitty, „TP” 1948 nr 19 s. 6.

${ }^{158}$ K. Koźniewski, Historyczna kasza i propagandowy sos, „TP” 1947 nr 17 s. 5.

${ }^{159}$ O. Budrewicz, Konfrontacja z rzeczywistościa, „,TW” 1948 nr 15 s. 4.

${ }^{160}$ M. Strebejko, Hiroshima, ,TP” 1947 nr 36 s. 3-4.

161 P. Jasienica, Piasek, czołgi, messerschmitty ...
} 
opowieść" osiągnął zamierzony cel, jakim było pokazanie, ,jak bytował i walczył polski żołnierz pod Tobrukiem". Drugi tytuł książkowy Bohdana Arcta (znanego już z głośnego wcześniej pamiętnika $W$ pogoni za Luftwaffe, Wrocław 1946) ${ }^{162}$ dostarczył odbiorcom „emocjonujących opisów” z „powietrznych przeżyć” autora od jesieni 1941 r. do września 1944 r. Jasienica wspomniał w recenzji m.in. o ozdobnych i pięknych drzeworytach autora. „Dokumentem epoki” wojny pisanym przez profesora Ludwika Hirszfelda - „Polaka i chrześcijanina żydowskiego pochodzenia" były niezwykle bogate pamiętniki wydane pod tytułem Historia jednego życia (Warszawa 1946). Wanda Bacewiczówna na łamach „Tygodnika Warszawskiego" doceniła książkę za „głęboki humanitaryzm”, obiektywizm w przedstawianiu stosunków polsko-żydowskich, wydarzeń z getta i obozów oraz za „,wiele cennych myśli”. Warto przytoczyć fragment, w którym Hirszfeld zwierzył się: „Książkę tę napisałem po to, by umarli mieli głos. By świat słyszał ich jęki. I słyszał tak długo, jak długo działać będzie bezmiar ich bólu i żar mojego słowa. Nie wolno mordować bezbronnych..." ${ }^{163}$.

Wspomnienia Tadeusza Kudlińskiego z więzienia śledczego SS w Krakowie w czasie okupacji zatytułowane Mantelupa ks. Jan Piwowarczyk uznał za „dojrzały talent pisarski”" i głęboką refleksję świadczącą o życiu duchowym autora ${ }^{164}$. Halina Krzemieniecka pochwaliła tę samą pozycję za ,skrystalizowany światopogląd", pogodną wiarę w życie i jego wartości ${ }^{165}$.

Żywo obecna na kartach pism problematyka wojenna znajdowała odzwierciedlenie w licznych recenzjach książkowych. Zauważano każdą lekturę zagraniczną, pisząc nieraz jej ocenę na podstawie wydania w języku obcym, wyrażając też potrzebę polskiego thumaczenia. Omawiający obce rozprawy zwracali uwagę, na ile oddają one prawdę historyczną o sprawie polskiej w czasie drugiej wojny światowej i na ile mogą wzbogacić wiedzę polskich czytelników. Książki te ze względu na widoczną niedbałość historyczną, spotkały się z ostrą krytyką publicystów. Ważne miejsce zarówno w literaturze wojennej, jak i łagrowej zajmowały wspomnienia świadków.

\subsubsection{Książki o tematyce obozowej}

Powojenny rynek wydawniczy obfitował w tytuły książkowe należące do tzw. literatury łagrowej. Niektóre z nich omawiano na łamach pism katolickich. W większości były to tzw. książki-dokumenty z najbardziej znanych hitlerowskich obozów koncentracyjnych. Najwięcej tego typu literatury powstało w formie

\footnotetext{
162 Z.R. [Z. Rabska], Kronika literacka, ,TW” 1947 nr 1 s. 5.

163 W. Bacewiczówna, Historia jednego życia, „TW” 1947 nr 9 s. 6.

164 J. Piwowarczyk, Więzienie i twórczy duch, „TP” 1946 nr 34 s. 6.

${ }^{165}$ H. Kamieniecka, Koszmar widziany przez niebieskie okulary, ,TW” 1947 nr 1 s. 11.
} 
osobistych wspomnień i pamiętników. Pisały je osoby będące ofiarami systemu hitlerowskiego i byli więźniowie, którym udało się przeżyć pobyt w miejscu kaźni. Rzadziej wypowiadali się obserwatorzy lub sprawcy zbrodni.

Książką o charakterze dokumentalnym, zawierającą m.in. opis straszliwych warunków życia kapłanów w najstarszym z obozów niemieckich, Dachau, oraz spis statystyczny duchownych więźniów była wydana w języku czeskim publikacja ks. Bedrzich Hoffmanna A kto vas zabije... (Pŕerov 1946). Odnotowano ją w krakowskim i warszawskim tygodniku. Jak dowiadujemy się z opracowania, Himmler w 1940 r. postanowił w tym obozie skupić największą część duchowieństwa, z czego 2/3 wszystkich uwięzionych kapłanów stanowili Polacy. Ks. Jan Piwowarczyk w omawiającej recenzji zapoznał czytelników z mniej znanymi faktami upokorzeń księży w obozie, a także z ogromnymi liczbowymi stratami polskich kapłanów oraz ich szczególną postawą poświęcenia i odwagi ${ }^{166}$. Józef Andrzej Kamiński polecił książkę historykom, wyrażając nadzieję, że zostanie ona przetłumaczona na wiele języków. Pisał: ,,...] książce wystawić należy świadectwo jak najprzychylniejsze z każdego punktu widzenia. Opracowana jest niezmiernie systematycznie i dokładnie, wydana bardzo pięknie"167. Wspomnienia z tego samego obozu śmierci spisał ks. Ludwik Bujacz pt. Dachau (Łódź 1946), wyjawiając w nich nieznany wcześniej fakt o wysłaniu przez więźniów trzech delegatów do dowództwa amerykańskiego tuż przed wyzwoleniem w 1945 r. Wojska amerykańskie były już bardzo blisko, ale obóz znajdował się jeszcze we władaniu Niemców. Groziło to wymordowaniem więźniów tuż przed wkroczeniem Amerykanów. Dzięki informacji o zarządzeniu przez SS zlikwidowania wszystkich więźniów można było uratować tysiące z nich. Za duży mankament książki, której autorem była osoba duchowna, ks. Jan Piwowarczyk uznał pominięcie we wspomnieniach opisu życia religijno-moralnego, dobitnie podkreślając: „Od Księdza spodziewalibyśmy się czegoś więcej. Więcej tzn. i szerzej i głębiej" ${ }^{168}$.

$\mathrm{Na}$ podstawie korespondencji i relacji więźniów obozu na Majdanku oraz licznych wykazów powstała „książka-dokument” napisana przez Ludwika Christiansa Piekło XX wieku (Warszawa 1946), która zdaniem Ireny Pannenkowej miała zająć w „literaturze obozowej szczególne miejsce”169. Autor przytoczył w niej „fakty, daty i liczby”, uzupełniając tekst licznymi „makabrycznymi w swej wymowie fotografiami”. Nowością dla czytelników mogły być listy więźniów, w których wyrazili wdzięczność za systematyczną opiekę lubelskiego PCK.

Ks. Jan Piwowarczyk zwrócił uwagę na książkę niemieckiego autora Eugeniusza Kogona Der SS-Staat (Frankfurt 1946) o obozie w Buchenwaldzie,

\footnotetext{
166 J. Piwowarczyk, Dzieło nienawiści, „TP” 1947 nr 3 s. 6.

${ }^{167}$ J.A. Kamiński, Ważki dokument historii Kościoła, „TW” 1947 nr 34 s. 284.

168 J.P. [J. Piwowarczyk], Jeszcze o Dachau, ,TP” 1946 nr 34 s. 6.

169 I. Pannenkowa, Książka-dokument, ,TW” 1946 nr 48 s. 8.
} 
będącą „obiektywnym źródłem do poznania systemu obozów koncentracyjnych Hitlera" ${ }^{170}$. Autor, pisząc na podstawie osobistych przeżyć, gdyż w latach 1938-1945 był tam uwięziony, przedstawił przykłady demoralizacji, egoizmu, zwyrodnienia esesmanów i ich niski poziom umysłowy. $\mathrm{Z}$ jego wspomnień czytelnik mógł dowiedzieć się więcej o fakcie, że w tym miejscu kaźni przebywało najwięcej więźniów politycznych. Byli to głównie komuniści i katolicy niewyrażający zgody na współpracę z Hitlerem. Warto przytoczyć fragment recenzji: „Co trzymało siły duchowe więźniów? Z pewnością nie materializm filozoficzny. Kogon opowiada, że wielu z tzw. lewicowców, dla których religia była dotąd czymś <<śmiesznym i reakcyjnym>>, w obozie zaczęło się nią interesować i z niej czerpać. Ba, sami nawet pomagali katolikom w chronieniu księży przed transportami, by móc z ich duszpasterskich usług korzystać. $<<$ Przede wszystkim Polacy $>>$ - stwierdza Kogon - prowadzili intensywne życie religijne"171. Ta „pouczająca książka”, tym cenniejsza, że autorstwa Niemca, zdaniem recenzenta informowała o „moralnym upadku Niemiec”. Ks. Piwowarczyk stwierdził również: „Każdy, kto będzie w przyszłości pisał o zbrodniach Hitlera i będzie szukał wyjaśnień możliwości tych zbrodni w duszy niemieckiej, znajdzie w niej niewyczerpane źródło pouczeń. Ale jest to książka także krzepiąca [...] Jest potępieniem, skruchą i wezwaniem do poprawy. Byłoby rzeczą ciekawą wiedzieć, jak niemiecki czytelnik na tę książkę reaguje..." ${ }^{172}$. Relacje z obozu w Buchenwaldzie w pogłębiony psychologicznie sposób zdał także Zygmunt Zaleski w pozycji wydanej w języku francuskim Expérience psychologique et sociale des camps de concentration allemands (Paryż 1946). Na jej treść złożył się odczyt profesora i pogadanka w paryskiej Bibliotece Polskiej. Pomimo że nie przyniosła „nowych danych, jeśli chodzi o okrucieństwa i bestialstwo hitlerowskich zbirów", to stanowiła dobre studium „człowieka prawego, który nie zatracił cech nawet w takim piekle, jakim był obóz niemiecki" "173. Zalewski z rozrzewnieniem wspominał rozmowy z towarzyszami podczas krótkich chwil wytchnienia, np. z Regnignym o poezji Norwida, z profesorem Champenonis o sprawach europejskich Wschodu, $\mathrm{z}$ architektem Sowirdeau o urbanistyce. W recenzji czytamy: ,To co autor chciał zadokumentować i co przeprowadził konsekwentnie na kartach tej wzruszającej publikacji, to ludzki, pełen ewangelicznej prostoty i dobroci stosunek człowieka do człowieka; te piękne odruchy miłości bliźniego, które przejawiają się wśród najsroższych tortur, mających na celu unicestwienie w więźniach człowieczeństwa" $"$ "174.

Przeżycia naukowców podczas II wojny światową opisał Ludwik Hirszfeld w pamiętnikach pt. Historia jednego życia (Warszawa 1946), które stały się

\footnotetext{
${ }^{170}$ J. Piwowarczyk, Konz. Lager w oczach Niemca, „TP” 1947 nr 34 s. 2-3.

171 Tamże, s. 3.

172 Tamże.

${ }^{173}$ Z.R. [Z. Rabska], Z niwy piśmienniczej na obczyźnie, „TW” 1946 nr 45 s. 6.

${ }^{174}$ Tamże.
} 
„dokumentem epoki”. Dostarczył w nich „bogactwo naukowego materiału” $i$,wiele cennych myśli", chcąc udzielić głosu pomordowanej inteligencji w czasie ostatniej wojny. Ponadto książka profesora „Polaka i chrześcijanina, ale żydowskiego pochodzenia”, zdaniem Wandy Bacewiczówny, „wniosła w problem polsko-żydowski" wiele jasności i obiektywizmu. Stała się również oskarżeniem rzuconym uczonym niemieckim „za udział w zbrodni hitlerowskiej lub jej tolerowanie”175. „Niecodziennym wydarzeniem” wydawniczym i cennym źródłem dla historyka oraz przyszłego badacza faszyzmu stała się napisana w więzieniu Autobiografia (1951) byłego komendanta obozu w Oświęcimiu Rudolfa Hoessa. Jan Paweł Gawlik w recenzji ,jednej z najbardziej tragicznych książek" zapytywał, na ile była ona szczerym wyznaniem zbrodniarza, a na ile tylko wyrachowanym „bluffem" mającym ewentualnie ocalić mu życie (pamiętnik bowiem pisany był przed rozprawą). Chłodna i bogata w szczegóły relacja Hoessa była też przedstawieniem hitlerowskich zbrodni wojennych z punktu widzenia sprawcy. Gawlik kończąc, przyznawał: „Z poczuciem odrazy i przygnębienia kończę lekturę pamiętnika. Niewątpliwie nie jest to książka zwyczajna [...] Odkładam ją wewnętrznie wzburzony, jak ktoś, komu dane było zobaczyć otchłań najgłębszego upadku człowieka"176. Pamiętnik z oświęcimskiego obozu koncentracyjnego w duchu katolickim napisała natomiast Zofia Kossak. Na tytuł $Z$ otchłani (Częstochowa 1946) zwrócili uwagę publicyści „Tygodnika Powszechnego” i „Głosu Katolickiego” kreśląc pozytywne oceny. W poważnej opinii Jasienica największy walor opisu piekła obozu dostrzegł w „,moralnej diagnozie zjawiska”. Recenzent polemizował również na temat tej książki na łamach „Tygodnika Powszechnego” z „głośną a brutalną” recenzją Tadeusza Borowskiego w „Odrodzeniu”"177. Stanisław Strugarek nazwał tę samą książkę „szczerze katolicką", przewidując, że czytelnik chętnie do niej powróci ${ }^{178}$. Zofia Starowieyska-Morstinowa za "książkę komunikatywną” i „lekturę ze wszech miar pożyteczną” uznała wspomnienia z różnych obozów niemieckich pt. Do domu Aleksandry Weyssenhoff-Zielewiczowej ${ }^{179}$. Literatka podobnie jak Zofia Kossak - ,ustosunkowała się do wszystkiego, co przeżyła” w sposób chrześcijański, pisząc z wielką szczerością o wszystkim, co dobre i złe.

Publicyści katoliccy w trudnej literaturze obozowej doceniali umiejętność autorów odnajdywania nadziei i ukazywania nawet drobnych świadectw człowieczeństwa w planowych niemieckich miejscach zagłady. Spodziewano się także bardziej pogłębionego psychologicznie i religijnie opisu, gdyż akty i sposoby wyniszczania ludzi były raczej ogólnie znane. Wyżej oceniano zatem relacje zawierające osobistą refleksję piszących, jak też ich poczucie obowiązku ukazania prawdy o zbrodniach hitlerowskich.

\footnotetext{
175 W. Bacewiczówna, Historia jednego życia, ,TW” 1947 nr 9 s. 6.

176 J.P. Gawlik, Pamiętnik Rudolfa Hoessa, ,TP” 1952 nr 50 s. 8.

177 P. Jasienica, Spowiedź udręczonych, „TP” 1947 nr 40 s. 3.

178 S. Strugarek, ,,Z otchtani”, „GK” 1946 nr 40 s. 321.

179 Z. Starowieyska-Morstinowa, Nie wolno zapominać, ,TP” 1948 nr 33 s. 11.
} 


\subsubsection{Książki o tematyce okupacyjnej}

Znaczna grupa recenzji dotyczyła książek o tematyce niemieckiej i okupacyjnej. Przedmiotem oceny była np. książka Alfonsa Klafkowskiego Okupacja niemiecka $w$ świetle prawa narodów (Poznań 1946). Naświetlono w niej niemieckie założenia prawne w aspekcie narodowosocjalistycznej doktryny, wedle której wyznawano zasadę, że ,prawem jest to, co przynosi pożytek narodowi niemieckiemu, a bezprawiem, co mu szkodzi"180. Henryk Dembiński wyjaśniał w związku z tym: „Dlatego też pozostał między <<prawem >>, podyktowanym przez okupanta, a prawem międzynarodowym, związek czysto platoniczny", co widoczne było $\mathrm{w}$ „,bezceremonialnym wcieleniu rozległych obszarów Rzeczypospolitej wprost do Rzeszy" "181. Książka stanowiła ponadto dobry wykład, w którym wykorzystano mało znane źródła. Na łamach „Tygodnika Powszechnego” doceniono również warsztat źródłowy publikacji prokuratorów Tadeusza Cypriana i Jerzego Sawickiego zatytułowanej Agresja na Polskę w świetle dokumentów (Warszawa 1946), wydanej przez Główną Komisję Badania Zbrodni Niemieckich. Autorzy książki nie skupili się tylko na oskarżeniu polityki niemieckiej, ale starali się też osądzić polskie działania polityczne ${ }^{182}$. Rozliczeniom niemieckich zbrodni wojennych poświęcony był zbiór przemówień oskarżycielskich na procesach hitlerowskich zbrodniarzy wojennych zawarty w Oskarżamy (Kraków 1949) tych samych autorów. Stanisław Stomma polecił ją czytelnikom ze względu na podjęcie w ogóle tematu ludobójstwa oraz staranne opracowanie i „krasomówstwo" ${ }^{183}$. Staraniem prymasa Augusta Hlonda ukazały się Męczeńskie dzieje archidiecezji warszawskiej 1939-1945, stanowiące źródło ówczesnej historii najnowszej. Pozycja powstała na podstawie ankiety opracowanej przez Zofię Olszanowską-Skowrońską, która przedstawiła w kilku działach straty osobowe poniesione przez archidiecezję warszawską podczas ostatniej wojny. Książką „nadzwyczaj cenną”, zawierającą zeznania Żydów ocalałych z niemieckiego pogromu, były wydane przez Żydowską Komisję Historyczną w Krakowie Dokumenty zbrodni i męczeństwa (Kraków 1945). Choć ks. Piwowarczyk docenił ją jako dokument dowodowy zbrodni niemieckich i ,materiał dla studiów socjologa, psychologa i psychiatry", to nie polecał jej młodym czytelnikom. Uzasadnił to następująco: „W tym piekielnym widowisku sam szatan porusza sznurki [...] Jest coś trującego w tym oparze krwi i zbrodni, jest coś niepokojącego w rozmaitości stosowanych metod i okrucieństw [...] rodzi się pytanie: co też jeszcze można było wymyślić? I to jest ten moment niebezpieczny, moment zainteresowania się zbrodnią i pomysłowością w zbrodni”'184.

\footnotetext{
${ }^{180}$ H. Dembiński, $W$ świetle prawa narodów, „TP” 1946 nr 47 s. 9.

181 Tamże.

${ }^{182}$ P. Jasienica, Winowajcy, „TP” 1947 nr 21 s. 9.

183 S. Stomma, $W$ walce z ludobójstwem, „TP” 1950 nr 6 s. 6.

${ }^{184}$ J.P. [J. Piwowarczyk], Z dziejów zbrodni, męczeństwa i buntu, „TP” 1946 nr 9 s. 6.
} 
Kwestię Niemiec rozpatrywano pod różnym kątem, recenzując prace autorów obcych. O zdecydowanej dezaprobacie papieża Piusa XI wobec polityki Hitlera pisał francuski historyk Karol Pichon w Le Vatican devant la guerre et la paix, ukazując ,prawdziwy stosunek Stolicy Apostolskiej do Niemiec hitlerowskich”"185. Tadeusz Koński omówił na łamach „Tygodnika Powszechnego” dwie pozycje zagraniczne. W jednej z nich znany biografista Emil Ludwig, zastanawiając się nad sposobami „uzdrowienia Niemiec” (m.in. takimi środkami jak rozbrojenie, odebranie wpływów państwowych, zaniechanie odszkodowań wojennych i rewindykacji terytorialnych) w książce Zdobycie moralne Niemiec (Milano 1946), podał prawdziwą - według niego - charakterystykę narodu wyznającego tylko dwie zasady: „komendę i posłuszeństwo"186. Natomiast Wilhelm Röpke w wydanym po wojnie opracowaniu Problem Niemiec (Milano 1946), oprócz wielu zarzutów pod adresem naszych zachodnich sąsiadów, którzy „łatwo poszli na lep propagandy nacjonalsocjalistycznej”, owo uzdrowienie widział w zniesieniu barier celnych i umożliwieniu Niemcom ,powrotu do dawnych tradycji wolności”187. Na kartach krakowskiego tygodnika zauważano także oceniane pozytywnie nowości wydawnicze Jana Petersona, podejmującego temat niemieckiego ruchu oporu ${ }^{188}$. Stosunki polsko-niemieckie były przedmiotem badań dwóch znanych polskich historyków: Zygmunta Wojciechowskiego i Józefa Feldmana. Monografię drugiego $\mathrm{z}$ nich Problem polsko-niemiecki $w$ dziejach (Katowice 1946) przedstawiono na łamach „Tygodnika Powszechnego” i „Tygodnika Warszawskiego”. Władysław Czapliński w pozytywnej opinii szczegółowo przedstawił wywody profesora, które ,prostowały szereg błędnie przyjętych poglądów, pod wpływem nauki niemieckiej"189. Stanisław Kozicki, zdając równie dokładne relacje z treści książki, docenił „syntetyczne wnioski” autora ${ }^{190}$. Warto wspomnieć jeszcze o jednej pozytywnej recenzji nagrodzonej w konkursie tygodnika „Odra” książce Edmunda Osmańczyka Sprawy Polaków (Katowice 1946), która również odnosiła się do stosunków polsko-niemieckich. Recenzent warszawskiego organu prasowego pisał o niej: „Osmańczyk odważnie wytacza postulaty niepopularne, zdolne wywołać u czytelnika <<ostre podrażnienie wątroby >>, a mimo to głęboko słuszne, jak np. konieczność możliwie rychłej, pokojowej współpracy naszej z Niemcami”"191. Podkreślono w omówieniu także „szczerą troskę pisarza o wagę praw moralnych, odrodzenie prawd chrześcijańskich i odwoływanie się do związków z kulturą zachodnią"192.

${ }^{185}$ Pius XI wobec Hitlera, „TP” 1947 nr 6 s. 10.

186 T. Koński, Niemcy o Niemcach, „TP” 1947 nr 41 s. 9.

187 Tamże.

${ }^{188}$ Dokument niemieckiego podziemia, „TP” $1951 \mathrm{nr} 10$ s. 5; J. Golmont, Ułamki wielkiej przygody, tamże.

${ }^{189}$ W. Czapliński, Stosunki polsko-niemieckie, „TP” 1946 nr 45 s. 8.

${ }^{190}$ S. Kozicki, Problem polsko-niemiecki w dziejach, „TW” 1947 nr 1 s. 4.

${ }^{191}$ A. Ski., Sprawy Polaków, „TW” 1947 nr 17 s. 12.

192 Tamże. 
W ocenach nowości wydawniczych o problematyce niemieckiej i okupacyjnej zwracano uwagę na wykorzystane źródła i ukazanie prawdy historycznej. Formułowano ponadto założenia przyjęte w pracach oraz nowatorskie wnioski.

\subsubsection{Rozprawy dotyczące historii Kościoła}

Cztery tytuły książkowe poświęcone historii Kościoła na łamach „Przeglądu Powszechnego" przedstawił ks. Jan Rostworowski. W krótkiej wypowiedzi zdecydowanie negatywnie ocenił Zarys historii Kościoła katolickiego dla wiernych (Kraków 1948) ks. Romana Archutowskiego i ks. Józefa Rychlickiego, w której konstatował: „Myśl jak najlepsza i bardzo pożyteczna; wykonanie zostawia sporo do życzenia [...]. Jak na te koła, dla których rzecz jest przeznaczona, za wiele wyliczania, za mało opowiadań" ${ }^{193}$. Skrytykował dysproporcje w opisie zagadnień oraz wygląd książki: ,Już sam format, o fatalnym papierze i lichym druku, a nadto sposób rozłożenia i podawania treści, wprowadza nas w szablon podręczników szkolnych”"194. Z krytyczną oceną spotkała się też francuskojęzyczna „monumentalna historia Kościoła” ks. profesora R. Auberta zaplanowana na 26 tomów. Po wymienieniu licznych zalet opracowania, jak m.in. wykorzystanie oryginalnych dokumentów, życiorysów, prywatnych wspomnień i listów, „po mistrzowsku” przedstawiona charakterystyka kierunków i prądów ideowych oraz „wzorowo jasny język", recenzent wyliczył błędy. Do nich należały przede wszystkim brak „nadprzyrodzonego sposobu patrzenia na rzeczy” przez autora oraz „sympatyzowanie z liberalizującymi tendencjami w Kościele”. Za „główny błąd cennego dzieła" ks. Rostworowski uznał umniejszenie i zlekceważenie osoby papieża Piusa IX, który „nie znalazł w Księdzu Aubert życzliwego historyka”. Autor bowiem wyraził się „lekceważąco o inteligencji” głowy Kościoła. Publicysta „Przeglądu Powszechnego” doradził ponadto większą powściągliwość w „bezwzględnych sądach" i większy obiektywizm. Omówił również książki, które w swojej treści przybliżały historię instytucji lub konkretnego kościoła. Przykładem mogą być dwie pozycje: Klasztor i kościót św. Józefa SS. Bernardynek w Krakowie (Kraków 1947) ks. Romualda Gustawa i Kolegium Duchowne w Petersburgu (Lublin 1950) ks. Aleksego Petraniego. Pierwsza z nich była „gruntowną monografią”. Dzięki wykorzystaniu wszystkich możliwych źródeł udało się sprostować wszelkie wcześniejsze niejasności co do powstania zgromadzenia i klasztoru. Książka, „skreślona zupełnie obiektywnie i z dużą znajomością rzeczy”, była do tego „pięknie wydana" ${ }^{195}$. Do bogatej literatury o instytucji służącej caratowi pod pozorem troski o dobro katolickich poddanych dołączyła pozycja ks. Aleksego Petraniego Kolegium

\footnotetext{
${ }^{193}$ X.J.R. [J. Rostworowski], Przegląd piśmiennictwa, „PP” 1951 nr 3 s. 224.

${ }^{194}$ Tamże.

195 X.J.R. [J. Rostworowski], Przegląd piśmiennictwa, „PP” 1951 nr 1 s. 65.
} 
Duchowne w Petersburgu (Lublin 1950). Szczegółowo i bezstronnie zostały w niej wymienione liczne ,pomyłki lub tendencyjne fałsze innych autorów” ${ }^{196 .}$

W tej części zwracają uwagę krytyczne spostrzeżenia zawarte w recenzjach ks. Jana Rostworowskiego na łamach „Przeglądu Powszechnego”.

\subsubsection{Opracowania historyczne o różnej tematyce}

Na kartach „Tygodnika Warszawskiego” i „Tygodnika Powszechnego” ukazało się kilka omówień nowych opracowań naukowych z zakresu historii powszechnej. W obu pismach zauważona została praca wybitnego uczonego Adama Krzyżanowskiego Wiek dwudziesty (Warszawa-Kraków 1947), będąca syntetycznym ujęciem wydarzeń politycznych, gospodarczych i demograficznych lat 1914-1939. Dobrą opinię Krzysztofa Łady uzyskała za „rzeczową ocenę” tego okresu w skali światowej, ,poprawne rozumowanie i wysnuwanie logicznych wniosków” oraz „optymizm co do przyszłości” polskiego ekonomisty. Recenzent pisał ponadto: „Opracowań tego rodzaju jest w ogóle bardzo mało, a w tym okresie jest to chyba pierwsze opracowanie na świecie. Prof. Krzyżanowski jest niejako kontynuatorem słynnego, przetłumaczonego również na język polski, dwutomowego dzieła Bertranda Russela Wiek dziewiętnasty (1814-1914)"'197. Publicyści obu tygodników podkreślili fakt pominięcia przez Krzyżanowskiego „problemu Rosji radzieckiej”, co znalazło wytłumaczenie w tym, że proces dziejowy nie został tam zamknięty i "tym samym nie nadawał się do traktowania”"198. W rzeczywistości okoliczności polityczne (cenzura) uniemożliwiły autorowi i wydawnictwu, by powyższą sprawę ująć obiektywnie. Jan Kieniewicz uznał przez to wartość dzieła za umniejszoną, a w recenzji omawiającej porównał jego zawartość z książką Henryka Jabłońskiego Opinia, parlament, prasa (Warszawa 1947) ${ }^{199}$. Stwierdził również, że obie prace nie oddają przez to w pełni opinii o dziejach. Czesław Jastrzębiec-Kozłowski w „Tygodniku Warszawskim” streścił część pierwszą „entuzjastycznie ocenionej" przez ówczesną krytykę francuską rozprawy Grousseta Rene Bilan de l'histoire (Paryż 1946), chcąc zapoznać czytelników z „najbardziej frapującymi sformułowaniami autora" ${ }^{200}$. Władysław Konopczyński w dwóch recenzjach przedstawił zbiorową pracę The Cambridge History of Poland from Augustus II to Pitsudski 1697-1935 (Cambridge 1941). Jak dowiadujemy się z pierwszej z nich, pomysł opublikowania książki zrodził się w polskiej ambasadzie w Londynie w 1935 r. podczas wizyty grupy polskich historyków w Cambridge na zaproszenie tamtejszych kolegów. Inicjatorem wydawnictwa był

\footnotetext{
196 J. Rostworowski, Przeglą piśmiennictwa. Recenzje książek, „PP” 1950 nr 10 s. 258-259.

197 K. Łada, Wiek dwudziesty, „TW” 1947 nr 9 s. 6.

198 J. Kieniewicz, Dwugłos o Anglosasach i świecie wspótczesnym, „TP” 1947 nr 36 s. 2.

${ }^{199}$ Zob. też J. Kieniewicz, Opinia, parlament, prasa, „TP” 1947 nr 14/15 s. 13.

${ }^{200}$ C. Jastrzębiec-Kozłowski, Bilans historii, „TW” 1948 nr 35 s. 2-3.
} 
Harold Temperley. Starano się o współpracę naukowców z obu państw, w rezultacie czego na 30 zaplanowanych rozdziałów 14 podrozdziałów napisali Anglosasi, resztę Polacy. Publikacja powstała w latach 1936-1941, napotykając na trudności. Narady z 30 autorami prowadzono korespondencyjnie, niełatwo było zatem zapobiec powtórzeniom i sprzecznościom w wypowiedziach, wreszcie nie wszyscy współautorzy przeżyli wojnę - musieli ich zastąpić autorzy zagraniczni. Ostatecznie tom drugi, którego zawartość recenzent szczegółowo przedstawił, szybko został wyczerpany ${ }^{201}$. W kolejnym omówieniu ten sam recenzent przedstawił wady i zalety dzieła w świetle przeglądu zagranicznych wypowiedzi, których ukazało się około $40 \mathrm{w}$ przeciągu roku w różnych czasopismach naukowych po wydaniu drugiej części. Przegląd był o tyle ważny, że „wydawnictwo słynnej firmy w najbardziej rozpowszechnionym języku świata rozeszło się po pięciu częściach globu i że wzięli je do rąk czytelnicy różnych narodów, dotąd karmieni głównie książkami niemieckimi" ${ }^{202}$. Opinie o dziele wyrazili zarówno historycy, jak też „oczytani publicyści”, m.in. profesorowie: Basil Williams, R. Seton Watson, William J. Rose, A. Bruce Boswell, oraz znający się na rzeczy Francis Genn, Doreen Warriner, Julia Swift Orvis. Większość pochwaliła inicjatywę wydawniczą za wypełnienie luki w badaniach historycznych i ukazanie się „na dłuższy czas podręcznika klasycznego". Zastrzeżenia dotyczyły braku jednolitości dzieła, co było nieuniknione przy licznych autorach. Niektórzy wyrazili również swoje wątpliwości co do ,jednostronnego, polskiego punktu widzenia”, a nawet „zniekształcenia prawdy i przemilczeń”. Inny z recenzentów, jak pisał Konopczyński, „nie znajdował w książce wyjaśnienia, dlaczego ze wschodu właśnie wyszli najwięksi polscy patrioci, jak Kościuszko i Mickiewicz"203. Żałowano jednocześnie, że tom drugi wyprzedził pierwszy oraz wskazano na brak bibliografii, której wydanie zaplanowano na później. Konopczyński wnioskował przy końcu: „Ale na te szkody jest rada. Trzeba wydać jak najprędzej tom pierwszy, a ponieważ drugi został rozchwytany, przedrukować z uzupełnieniami i poprawkami”204.

Z kolei podręcznik uniwersytecki Dzieje Polski nowożytnej (Warszawa 1936) Władysława Konopczyńskiego przypomniał na łamach „Tygodnika Powszechnego" Władysław Czapliński. W pochwalnej recenzji czytamy, iż oparty w „lwiej części” na źródłach archiwalnych, stał się w okresie dwudziestolecia międzywojennego „wydarzeniem naukowym dużej miary”. Zdaniem omawiającego „nieprzeciętna książka rasowego historyka politycznego” wywarła znaczny wpływ na poglądy odbiorców w kwestiach przeszłości Polski. Uczyła „trzeźwego spojrzenia" na stosunki społeczne i sprawy polskiej polityki zagranicznej.

\footnotetext{
${ }^{201}$ W. Konopczyński, ,, Cambridge History of Poland”, „TP” 1949 nr 24 s. 2.

${ }^{202}$ Tenże, Cambridge History of Poland w ogniu anglosaskiej krytyki, „TP” 1949 nr 25 s. 4-5.

${ }^{203}$ Tamże, s. 4.

204 Tamże, s. 5.
} 
Czapliński pisał ponadto: „W książce Konopczyńskiego nie ma też ani źdźbła samouwielbienia narodowego, taniego optymizmu, czy jakiegokolwiek mesjanizmu narodowego. Na szeregu kartach mówi autor prawdę tak gorzką, że jednostkom wychowanym na wierze w wybrany naród może się ona wydać nie do zniesienia”"205. Nakład tego „doskonałego podręcznika dla ucznia wybitnie zdolnego" zachował się w czasie zawieruchy wojennej i spełniał swoje zadania nawet w czasie okupacji. Recenzent zachęcał do wydania poprawionej i uzupełnionej edycji książki ${ }^{206}$.

Publicyści pism katolickich zauważyli także rozprawy, w których podejmowano opis dziejów regionu lub danej epoki. Dwie książki profesora Kazimierza Piwarskiego o dziejach Śląska i Prus Wschodnich wydane po II wojnie światowej przez Instytut Śląski i Instytut Bałtycki otrzymały pozytywną recenzję Kazimierza Lepszego. Zdaniem omawiającego, dobrze przygotowany historyk dostarczył „syntetyczną pracę” o wielowiekowych tradycjach przynależności ziemi śląskiej do państwa polskiego. Lepszy dowodził przy tym: „Książka Piwarskiego jest jednym z argumentów, który wiąże i scala Śląsk z Polską. Szczerze patriotyczna, choć obiektywna, emocjonująca, choć pisana spokojnie, swym realizmem i swą trzeźwością najlepiej poucza i najlepiej kształci”207. Zwięzłym i pouczającym wykładem o historii politycznej była druga pozycja Piwarskiego Dzieje Prus Wschodnich w czasach nowożytnych (Gdańsk-Bydgoszcz 1946), będąca kontynuacją książki Karola Górskiego Dzieje Prus Krzyżackich. Do epoki średniowiecza odniesiono się przy okazji czterech książek zrecenzowanych w krakowskim tygodniku: Pierwsze państwo słowiańskie Gerarda Labudy, Szkice XI wieku Tadeusza Wojciechowskiego, Kościót średniowieczny spadkobierca kultury antycznej Mariana Plezi i Kultura umystowa wieków średnich Stefana Świeżawskiego. Zawartość pierwszej obszernie streścił Marian Plezia, chwaląc profesora za podjęcie tematu wczesnego średniowiecza i krytyczne opracowanie ${ }^{208}$. Drugą z nich Jan Parandowski nazwał „dziełem genialnym” gdyż, jak pisał: „Zamiast olśniewać rezultatem swych badań Wojciechowski czyni nas świadkami swej pracy. Rozkłada dokumenty, czyta je razem z nami, objaśnia, zwierza się z trudności, jakby szukał u nas rady czy wskazówki [...] żąda od nas nie samej lektury, ale i pewnej współpracy. To właśnie jest źródłem rozkoszy w obcowaniu z jego książką. Ma się wrażenie, że rzecz nie jest gotowa, ale dopiero się tworzy - w naszych oczach i jakby z naszym udziałem"209. W ciekawej recenzji czytamy dalej: „Praca Wojciechowskiego była piękna, ponieważ wy-

\footnotetext{
${ }^{205}$ W. Czapliński, O pewnej pożytecznej książce, „TP” 1947 nr 23 s. 7.

206 Tamże, s. 8.

${ }^{207}$ K. Lepszy, Pierwsze polskie opracowanie dziejów Śląska i Prus Wschodnich, „TP” 1947

${ }^{208}$ M. Plezia, Doniosta ksiązka, „TP” $1950 \mathrm{nr} 36$ s. 5-6.

209 J. Parandowski, Tadeusz Wojciechowski, „TP” 1949 nr 29 s. 2.
} 
woływała jakby z nicości daty, zdarzenia i ludzi" ${ }^{210}$. Pozostałe dwie publikacje, dobrze ocenione przez Jerzego Turowicza, zostały wydane w serii Wykłady i Przemówienia nakładem Towarzystwa Naukowego KUL ${ }^{211}$. Krytyczną ocenę uzyskała na łamach „Tygodnika Warszawskiego” pozycja Józefa Putka Mroki średniowiecza (Warszawa 1947) wydana przez Wiedzę. Znana jeszcze przed II wojną światową, napisana została, zdaniem recenzentki, w celu „zohydzenia katolicyzmu jako systemu społecznego”, przez co była „książką irytującą". Przy okazji wyliczania przez autora średniowiecznych tortur, kaźni, walki z czarownicami, klątw, pogromu innowierców czytamy: „wskazują one na quantum nieusuwalnego zła w naturze ludzkiej, na jej zboczenie przez grzech z drogi prawdy, którego żaden ustrój mechanicznie nie wyrówna: ani oparty na powierzchownym teocentryzmie, ani na laickim humanizmie. Odnowienie i naprawa człowieka może przyjść tylko na drodze wewnętrznego przewrotu duchowego w łączności z boskim prawem" "212. Halina Krzemieniecka zwróciła przede wszystkim uwagę na intencję, $\mathrm{z}$ jaką $\mathrm{w}$ danej epoce podejmowano takie a nie inne postępowanie.

Streszczenie książki Polska-Czechy. Dziesięć wieków sąsiedztwa autorstwa profesorów Tadeusza Lehra-Spławińskiego, Kazimierza Piwarskiego i Zygmunta Wojciechowskiego zamieścił na łamach „Tygodnika Warszawskiego” Stanisław Kozicki. Zalecił ją przy tym szerokim kołom czytelników ze względu na wiernie oddaną prawdę historyczną w stosunkach obu państw ${ }^{213}$.

Marian Plezia z radością przywitał nowy przekład Sprzysiężenia Katyliny $i$ wojny z Jugurta Salustiusza Krispusa Gaiusa (Warszawa 1947) w thumaczeniu oraz opracowaniu profesora Kazimierza Kumanieckiego. Zacytował przy tym liczne fragmenty z dzieła. Tomik zaopatrzony obszernym, 50-stronicowym wstępem, wydany w serii Biblioteka Meandra, stanowił, zdaniem recenzenta „trwałą pozycję” w powojennym dorobku piśmienniczym ${ }^{214}$. Doczekano się też polskiej edycji $O$ wojnie domowej Juliusza Cezara z przedmową i przypisami Jana Parandowskiego. Plezia docenił przekład, w którym uchwycono przede wszystkim myśl oraz swobodny i przejrzysty styl Cezara ${ }^{215}$.

Recenzowano również opracowania bardziej szczegółowych zagadnień, czego przykładem mogą być następujące tytuły: Zbiegostwo chłopów $w$ dawnej Polsce jako zagadnienie ustroju społecznego (Warszawa 1948) Stanisława Śreniowskiego; Gwiazda Władystawa Sikorskiego (Warszawa 1946) Stanisława Strumph-Wojtkiewicza; $Z$ epoki renesansu i baroku na Lubelszczyźnie (Lu-

\footnotetext{
210 Tamże.

211 J. Turowicz, Spojrzenia na średniowiecze, „TP” 1949 nr 46 s. $5,7$.

212 H.K. [H. Krzemieniecka], Mroki średniowiecza, „TW” 1947 nr 33 s. 8.

213 S. Kozicki, Polska i Czechy, „TW” 1948 nr 10 s. 1-2.

${ }^{214}$ M. Plezia, Rzymski historyk rewolucji, ,TP” 1947 nr 23 s. 9.

215 Tenże, Nareszcie polski Cezar, „TP” 1952 nr 42 s. 7.
} 
blin 1949) ks. Ludwika Zalewskiego; Brazylia i jej dzieje (Kraków 1948) profesora Tadeusza Stanisława Grabowskiego; Nawroty polskich ruchów zbrojnych 1830-1834 (Poznań 1948) Wisławy Knapowskiej; Dzieje floty polskiej (Gdańsk 1947) profesora Kazimierza Lepszego ${ }^{216}$. Większość z nich otrzymała dobrą opinię poza pierwszą, którą skrytykowano.

Styl wypowiedzi różnił się w poszczególnych tytułach prasowych. Publicyści „Tygodnika Warszawskiego" w recenzjach i ocenie książek wykazywali większe przywiązanie do polskiej historii, tradycji i patriotyzmu. Ich opinie pisane były częściej w tonie poważnym, czasem nawet patetycznym. Oceny opublikowane na łamach „Tygodnika Powszechnego" utrzymane były w swobodniejszym tonie, czasem nawet żartobliwym, czego dobrym przykładem mogą być recenzje Pawła Jasienicy i Stefana Kisielewskiego. Ważne miejsce w powojennej lekturze zajęły świadectwa osobistych przeżyć.

\subsubsection{Biografie}

Pokaźną liczbę recenzji zajęły omówienia biografii władców, polityków, społeczników, historyków, pedagogów, artystów, malarzy, kompozytorów i innych.

Monografia Zdzisława Kaczmarczyka zatytułowana Kazimierz Wielki (1333-1370), wydana w serii Biblioteka Wiedzy o Polsce, wypełniła lukę w polskim historycznym dorobku naukowym. Zdaniem Antoniego Madeja praca w dużym stopniu przybliżyła postać ostatniego króla Polski z rodu Piastów na tle odległej epoki. Przedstawiono w niej bowiem ówczesną sytuację polityczną, organizacyjną, obronną i kulturalną kraju. Książka wyróżniła się ponadto „pozytywnie wśród zespołu prac historycznych" ${ }^{217}$. Za najlepszą monografię w historiografii polskiej ostatniego ćwierćwiecza uznana została przez Jerzego Eugeniusza Płomieńskiego praca profesora Józefa Feldmana Stanisław Leszczyński (Wrocław 1948). „Wzorowa metodologicznie” i oparta na licznych archiwaliach oraz materiałach rękopiśmiennych, ukazała podwójne oblicze króla. Z jednej strony historyk zapoznał czytelników z „odpychającym obliczem duchowym” Leszczyńskiego, dążącego za wszelką cenę do władzy pomimo braku predyspozycji i dojrzałości do rządzenia, a z drugiej strony ukazał filozofa i mecenasa kultury oraz autora teoretycznego dzieła dotyczącego naprawy Rzeczypospolitej Glos wolny, wolność ubezpieczający. Wartość książki widziano także w zaznajomieniu nie tylko z historią polityczną Polski, ale także Szwecji, Turcji, Prus, Francji oraz

${ }^{216}$ P. Jasienica, Dzieje katastrofy, „,TP” 1947 nr 11 s. 6; A.G. [A. Gołubiew], ,,Armata” polska na morzu, „TP” 1948 nr 7 s. 7; N.K., Z historii chłopów, „TP” 1949 nr 31 s. 4; J. Kleiner, Dar dla miłośników przeszłości, „TP” $1950 \mathrm{nr} 9$ s. 7-8; L. Prorok, Dzieje floty polskiej, „TW” $1948 \mathrm{nr} 7$ s. 5; S. Kozicki, Ameryka Łacińska, tamże, nr 23 s. 3; M. Tobiasz, Książki o rewolucyjnym Krakowie, tamże, nr 35 s. 10.

${ }^{217}$ A. Madej, Wiedza o Polsce, ,TW” 1948 nr 8 s. 6. 
Rosji $^{218}$. Zainteresowanie recenzentów „Tygodnika Powszechnego” i „Tygodnika Warszawskiego" wzbudziła biografia pióra Ksawerego Pruszyńskiego pt. Margrabia Wielopolski (Warszawa 1946). W krytycznej ocenie pozycji Stefan Kieniewicz pisał: „,Szkoda, że ten życiorys, pisany z werwą i talentem, uderzający chwilami trafnością spostrzeżeń, mieści zarazem tyle ważniejszych i drobnych nieścisłości. Jest ich naprawdę bardzo wiele [...] Tłumaczą się one warunkami, w których powstała książka oraz nieprzygotowaniem fachowym autora” ${ }^{219}$. W zdecydowanie negatywnej recenzji Władysław Jabłonkowski nazwał ją ,panegirykiem” Aleksandra Wielopolskiego, konstatując: „W książce za wiele jest rzeczy zbytecznych: plotki i anegdotki, szyderstwa i szykany z niemiłym zapaszkiem dzisiejszości, zdarzają się i fałsze, za mało natomiast powagi oraz rzetelności dziejopisarskiej. Poza tym nie przynosi ona nic nadto, czego by się nie znało z dawniejszych prac o A. Wielopolskim. Z tych wszystkich względów, gdyby nie była napisana, nie straciłby nic na tym wielki cień Margrabiego, a i wybredniejszy czytelnik"220. Ta sama postać historyczna stała się inspiracją dla Adama Mieczysława Skałkowskiego do napisania trzytomowej monografii historycznej Aleksander Wielopolski (Poznań 1947), którą z kolei dobrze oceniła Irena Pannenkowa. Przedstawiając treść książki pochwaliła autora przede wszystkim za „obiektywizm ujęcia i oceny”, rzetelność badawczą i talent pisarski ${ }^{221}$. O „bogobojnym opiekunie kościołów toruńskich" i radnym miasta Torunia w dwóchsetną rocznicę zgonu rozprawkę zatytułowaną Jakub Kazimierz Rubinkowski (Toruń 1949) napisała Janina Przybyłowa, o której wspomniano jedynie na łamach „Przeglądu Powszechnego" 222 .

Pozytywne recenzje otrzymała także najnowsza praca historyczna o Stanisławie Konarskim pióra Juliusza Nowaka-Dłużewskiego, a wydana w 1951 r. przez IW PAX. Relacjonująca w pierwszej części życie Konarskiego, a w drugiej zapoznająca z dziełami politycznymi i pedagogicznymi znanego reformatora, nazwana została „pierwszorzędnym studium” ”22. Józef Marian Święcicki pomimo „słabo skreślonego tła historycznego" docenił dzieło za obiektywizm w przedstawieniu sylwetki Konarskiego, którego związki z magnaterią i niektóre działania doczesne ,nie bardzo harmonizowały z sukienką zakonnika”. Na uznanie zasłużyło także uwzględnienie współczesnych poglądów w przedstawieniu epoki baroku oraz ,jędrny i dosadny" styl autora ${ }^{224}$. Literaturę biograficzną wzbogaciła również ,pozycja ze wszech miar dodatnia” o innym znanym pedagogu, autorstwa Hanny Mortkowicz-Olczakowej, pt. Janusz Korczak (Kraków 1949),

\footnotetext{
218 J.E. Płomieński, Książka o „,królu-filozofie”, „,TP” 1949 nr 26 s. 5.

219 S. Kieniewicz, Prawda margrabiego, „TP” 1946 nr 32 s. 4.

${ }^{220}$ W. Jabłonkowski, Książka nie na czasie, „TW” 1946 nr 29 s. 6.

${ }^{221}$ I. Pannenkowa, Przed sądem historii, ,TW” 1948 nr 14 s. 4-5.

222 Monografia Rubinkowskiego i nieznane jego ,, silva rerum”, „PP” 1952 nr 10 s. 249-255.

223 J. Rostworowski, Przegląd piśmiennictwa. Recenzje książek, „PP” 1951 nr 5 s. 455.

${ }^{224}$ J.M. Święcicki, Konarski żywy, ,TP” 1951 nr 30 s. 9.
} 
w której „szczęśliwie ujęto” ciekawą postać wychowawcy, nazywanego wielokrotnie „buntownikiem i marzycielem”225.

Zarówno w warszawskim, jak i krakowskim tygodniku dobrze ustosunkowano się do ,pierwszego tomu szeroko pomyślanej monografii” Mieczysława Tobiasza pt. Wojciech Korfanty (Katowice 1947). Irena Pannenkowa przywitała z aprobatą życiorys polskiego przywódcy narodowego związanego z Górnym Śląskiem. Biografia nie mogła ukazać się w okresie międzywojennym ze względu na ograniczenia cenzury. W opracowaniu „historycznie zasłużonego” obrońcy polskości i publicysty solidnie wykorzystano materiał źródłowy, wypełniając ,jedną z najdotkliwszych luk w dziejach ostatniego półwiecza"226. Ks. Jan Piwowarczyk, uznając książkę za „cenny przyczynek” do dalszych badań nad życiem Korfantego (pierwszy tom objął okres do wybuchu I wojny światowej), pisał równocześnie: „Mógł autor bez szkody dla całości obrazu opuścić własne - nie zawsze ciekawe - refleksje o wypadkach, a dać obiektywny obraz młodości" ${ }^{227}$. Zawartość biografii autorstwa Witolda Jakóbczyka pt. Doktór Marcin (Poznań 1946) obszernie przedstawił w recenzji Władysław Konopczyński. Przy okazji jej wydania stwierdził: „Książka o Karolu Marcinkowskim jest śliczna, bije z niej męska młodość. Łączy jasny, żywy wykład z bezpośredniością odtworzenia"228. Negatywną recenzję skreślił natomiast Paweł Jasienica o biografii dziewiętnastowiecznego polityka niepodległościowego Tomasza Teodora Jeża (Zygmunta Miłkowskiego), pióra Kazimierza Koźniewskiego. Jego zdaniem autor przedstawił „burzliwe koleje Jeżowego żywota” nie wykorzystując „rozległej literatury” na ten temat. Jasienica miał jednocześnie zastrzeżenia do „linii pisarskiej K. Koźniewskiego" i jego rozumowania historycznego ${ }^{229}$.

Redakcja „Tygodnika Powszechnego” zamieściła ponadto recenzje innych książek biograficznych. Przykładem mogą być pozytywne oceny następujących publikacji: Władysława Kotwicza Józef Kowalewski orientalista (1801-1878) (Wrocław 1948), Józefy Orańskiej Szymon Czechowicz (Poznań 1948), Heleny Blumówny Olga Boznańska (Warszawa 1949), Tadeusza Peipera Krzysztof Kolumb odkrywca (Warszawa 1949), Kazimiery Treterowej Kraków, jego miasto (Kraków 1950) ${ }^{230}$. We wszystkich streszczono zawartość opracowań oraz zwrócono uwagę na sposób przedstawienia sylwetek; doceniono wykorzystany materiał źródłowy i znawstwo przedmiotu. Dwie z książek (Treterowej i Boznańskiej) pochwalono również za warstwę epistolograficzną.

${ }^{225}$ Z. Starowieyska-Morstinowa, Buntownik i marzyciel, „TP” 1949 nr 36 s. 7.

${ }^{226}$ I. Pannenkowa, Ksiażka o Wojciechu Korfantym, „TW” 1947 nr 6.

227 J.P. [J. Piwowarczyk], Życie budziciela Ślaska, „TP” 1947 nr 31 s. 7.

${ }^{228}$ W. Konopczyński, O największym lekarzu-społeczniku, „TP” 1947 nr 1 s. 10.

${ }^{229}$ P. Jasienica, Z historia na bakier, „TP” $1949 \mathrm{nr} 28$ s. 3.

${ }^{230}$ W. Zajączkowski, Filomata - orientalista, „TP” 1949 nr 34 s. 7; J. Woźniakowski, Boznańska, tamże, nr 42 s. 9; tenże, Simone Cenovitz Polacco, tamże, nr 44 s. 4; Z. StarowieyskaMorstinowa, Na początku byta ciekawość..., „TP” $1950 \mathrm{nr} 4$ s. 10; B.G., Przegląd piśmiennictwa, „PP” 1951 nr 10 s. 355-356; T. Zych, Kraków-jego miasto, „TP” 1951 nr 29 s. 8. 


\subsubsection{Pamiętniki i wspomnienia}

Omówienia opracowań autobiograficznych znalazły miejsce głównie w krakowskim „Tygodniku Powszechnym”. Zarówno wspomnienia, jak i pamiętniki oraz dzienniki pochodziły z różnych okresów i były świadectwem danej epoki. W tej części pominięto literaturę o tematyce wojennej i obozowej, którą omówiono wcześniej. Wydane po wojnie pamiętniki i wspomnienia nie dotyczyły tylko wojny i obozów. Interesującą lekturę stanowiły książki nt. życia naukowego i obyczajowego pierwszej połowy XIX w. Wyszły one spod pióra ludzi nauki, działaczy komunistycznych, pisarzy $i$ in.

„Niezwyczajną książką”, zdaniem Tadeusza Estreichera, były sześciotomowe pamiętniki wybitnego, lecz mało znanego szerokim kręgom społeczeństwa profesora historii medycyny Uniwersytetu Jagiellońskiego Fryderyka Hechla, odnalezione w 1927 r. w Akademii Umiejętności. W pozytywnej recenzji odbiorcy mogli poznać ich losy, jak też życzenie naukowca, aby „pozostały opieczętowane przez lat pięćdziesiąt po jego śmierci, po czym przeczytane i albo uprzystępnione dla czytelników albo skazane na dalszy pobyt w zamknięciu na nowe pół wieku, gdyby jeszcze były zbyt aktualne i drażliwe"231. Z przewidzianych trzech tomów w opracowaniu naukowym Władysława Szumowskiego ukazały się w roku 1939 dwa pierwsze, obejmujące lata burzliwej młodości, licznych podróży i okres naukowy u schyłku Rzeczypospolitej Krakowskiej. W pamiętnikach, jak zauważył recenzent, Hechel przedstawił obraz życia pierwszej połowy XIX w., dając wyraz swej „niechęci do księży i katolicyzmu”. Estreicher stwierdził jednak: „niechęć do katolicyzmu była może większa na papierze niż w życiu: swą jedyną córkę Helenkę wychowują Hechlowie tak, że pod wpływem otoczenia krakowskiego doszedłszy do odpowiedniego wieku, Helenka przechodzi na katolicyzm"232. Pamiętniki polecano gorąco odbiorcom, gdyż „czytało się je z zajęciem rosnącym w miarę posuwania się lektury" ${ }^{233}$. Zofia Starowieyska-Morstinowa skrytykowała nieścisłości historyczne występujące we wspomnieniach Karola Estreichera Nie od razu Kraków zbudowano, doceniając równocześnie dobrą znajomość rodzimej sztuki ${ }^{234}$ wykazaną przez autora.

Niezwykle ciekawy artykuł na temat pamiętników zadeklarowanego działacza komunistycznego i pisarza Lucjana Rudnickiego Stare i nowe (Warszawa 1948) zamieścił w „Tygodniku Powszechnym” Paweł Jasienica. Wartość książki dostrzegł w podjętej tematyce społecznej na tle niewielkiego Sulejowa, a następnie powojennej łódzkiej fabryki, ale także w „pasji autora” i „mocnym tonie

\footnotetext{
${ }^{231}$ T. Estreicher, Człowiek nauki, taki jakim byt, „TP” 1945 nr 19 s. 8.

${ }^{232}$ Tamże.

${ }^{233}$ Tamże.

${ }^{234}$ Z. Starowieyska-Morstinowa, Kraków, który minąt, „TP” 1947 nr 32 s. 7.
} 
uczuciowym”. Zastrzegł równocześnie: „Komplementy te nie oznaczają wcale, bym się z ideowym stanowiskiem Rudnickiego zgadzał. Obchodzi się on zupełnie bezceremonialnie ze światopoglądem, którego my tu w tym $<<$ Tygodniku $>>$ bronimy. Ale cóż - jedną z rzeczy, których bronimy, jest właśnie zasada szacunku dla cudzych przekonań. Zwłaszcza, jeśli ktoś przekonania te wyznaje bezinteresownie i szczerze, a w obronie ich latami całymi poniewierał się po turmach i zsyłkach. Rudnicki, ongi żarliwy katolik, od dawna już rozstał się z tym $<<$ fanatyzmem $>>$ i z zamkniętymi oczyma dał nurka w inny"235. Sam autor pamiętników wyznał, jak zacytował Jasienica, że bycie komunistą zawdzięczał w dużej mierze swej babce Okrasińskiej - „,godnej córce Kościoła” i „zajadłej katoliczce”, która nauczyła go „sięgać po rzeczy wielkie i pchała na trudne szlaki”. Recenzent z właściwą sobie szczerością przyznawał w dalszej części: „Tezy jego są zjawiskiem oryginalnym na tle poglądów ludzi jego obozu, dopatrujących się w chrześcijaństwie swoistego $<<$ opium $>>$ przeznaczonego na to, by utrzymywać masy w moralnym i umysłowym bezwładzie" ${ }^{236}$.

Książka historyczna obecna w różnych formach (rozpraw naukowych, dzieł zbiorowych, biografii, wspomnień czy broszur) zajęła w recenzjach ważne miejsce. Wychodziła ona spod prasy Czytelnika, Wydawnictwa Instytutu Zachodniego, Wydawnictw: Towarzystwa Naukowego KUL, Towarzystwa Naukowego Warszawskiego, Poznańskiego Towarzystwa Przyjaciół Nauk i innych. Recenzenci w omówieniach najczęściej podkreślali, że praca wypełniała lukę w badaniach historycznych, oparta była na archiwaliach, jak też przedstawiała nowe, dotychczas nieznane zagadnienia lub odkłamywała wcześniej przyjęte uogólnienia historyczne. Chwalono również autorów za odmienną interpretację wydarzeń.

\subsection{Książka literacka}

\subsubsection{Powieści}

W katolickich czasopismach społeczno-kulturalnych nie zabrakło licznych odniesień do powieści polskich i zagranicznych. Publicyści zainteresowani byli szczególnie powieścią katolicką i historyczną. W dalszej kolejności zapoznawano z prozą o tematyce wojennej, obyczajowej, politycznej, społecznej, socrealistycznej, sensacyjnej i marynistycznej. Ogólnie w latach 1945-1953 na łamach „Tygodnika Powszechnego” zamieszczono 203 recenzje, w Przeglądzie Powszechnym”- 91, „,Tygodniku Warszawskim”- 60, „Głosie Katolickim”-11, „Tygodniku Katolickim” - 10, „Znaku” - 6; daje to łącznie 381 publikacji.

${ }^{235}$ P. Jasienica, Cieniom babki Okrasińskiej, „TP” 1948 nr 45 s. 9.

236 Tamże, s. 10. 
Spośród 203 omówień zawartych w „Tygodniku Powszechnym”, 113 stanowiły recenzje powieści polskich, a pozostałe 90 obcych. Rodzima literatura przeważyła również w ocenach „Przeglądu Powszechnego” (51 polskich i 40 obcych), „Tygodnika Warszawskiego” (47 polskich, 13 obcych), „Głosu Katolickiego” (9 rodzimych, 2 zagraniczne) i „Tygodnika Katolickiego” (6 polskich i 4 obce). W „Znaku” na sześć recenzji tylko jedna dotyczyła polskiej powieści. We wszystkich pismach, oprócz „Tygodnika Katolickiego”, dominowały recenzje pozytywne. W „Tygodniku Powszechnym” opublikowano 114 recenzji pozytywnych, 40 omawiających, 25 negatywnych, 17 krytycznych i siedem polemicznych; w „Przeglądzie Powszechnym” 44 pozytywnych, 24 omawiające, 21 krytycznych i dwie negatywne. Redakcja warszawskiego organu prasowego zamieściła natomiast 43 pozytywne opinie, osiem omawiających, pięć krytycznych, trzy negatywne i jedną polemiczną. Czytelnicy „Głosu Katolickiego” w latach 1945-1948 mogli przeczytać dziewięć pozytywnych recenzji oraz po jednej omawiającej i krytycznej, „Znaku” zaś trzy pozytywne, dwie omawiające i jedną krytyczną. Jedynie w „Tygodniku Katolickim” zagościło więcej recenzji omawiających (4), pozostałe to trzy pozytywne i jedna krytyczna.

Powieść w katolickich czasopismach społeczno-kulturalnych oceniali najczęściej: Antoni Gołubiew, Paweł Jasienica, Stefan Kisielewski, Marek Krupiński, Zygmunt Lichniak, Antoni Madej, Olgierd Porycki, Wacław Rola, Zofia Starowieyska-Morstinowa i Józef Marian Święcicki. Większość książęk ukazała się w Spółdzielni Wydawniczej Czytelnik, Instytucie Wydawniczym PAX, Państwowym Instytucie Wydawniczym, Awirze, firmie Eugeniusza Kuthana oraz Gebethnera i Wolffa, Wiedzy, Książce, po połączeniu: Książce i Wiedzy, Księgarni św. Wojciecha, Książnicy Atlas.

\subsubsection{Powieść katolicka}

Ważne miejsce wśród recenzji nowości prozy literackiej zajęły na łamach czasopism omówienia powieści katolickich. Zaliczono do nich dzieła, w których podjęto problematykę katolicką, odniesiono się do życia wewnętrznego człowieka, jego moralności czy też ukazano jakiś problem lub wybory ludzkie na tle rzeczywistości duchowej. Aleksander Rogalski zadanie powieści katolickiej rozumiał jako „dawanie świadectwa rzeczywistości nadprzyrodzonej”237, natomiast Jerzy Zawieyski konstatował: „Dzieło literackie może ani razu nie posłużyć się imieniem Boga, może w pojęciach językowych ani razu nie zahaczyć o świat pojęć katolickich, a równocześnie może być dziełem katolickim, poprzez obecność owego sensus catholicus, który stanowi nurt wewnętrzny dzieła, jego atmosferę, jego $<<$ niebo $>>$, wyraźnie odbite w kałużach i błocie życia"238.

\footnotetext{
${ }^{237}$ J.M.S. [J.M. Święcicki], Przegląd prasy. Natura, wola i łaska, „TP” 1952 nr 6 s. 7.
}

${ }^{238}$ J. Zawieyski, Zagadnienie literatury katolickiej, „TP” 1947 nr 23 s. 4. 
W ogólnej dyskusji na łamach prasy dotyczącej literatury katolickiej rozważano zazwyczaj samo jej pojęcie oraz rolę pisarza katolickiego. Stefania Skwarczyńska pisała: „Nazwa [literatury katolickiej - E.K.] może służyć w nauce o literaturze dla oznaczenia ogółu dzieł literackich, których treści wyznaczone są przez założoną w roli planu konstrukcyjnego katolicką teorię rzeczywistości ${ }^{239}$. Konrad Górski, przestrzegając przed tendencjami umoralniającymi, rolę pisarza katolickiego dostrzegał głównie w ukazywaniu językiem literackim rzeczywistości duchowych doświadczeń. Samego prozaika o takim światopoglądzie pojmował jako „człowieka, który nie tylko w swym życiu osobistym realizuje postawę katolicką, ale którego twórczość oparta jest na problematyce katolickiej”240. Zofia Starowieyska-Morstinowa napominała z kolei przed rozumieniem ,pisarza katolickiego" jako synonimu świętego. Za ważne uznała natomiast odkrywanie przez niego „dobra, piękna i szczęścia świata” oraz ukazywanie „człowieka pogodzonego z porządkiem Bożym"241.

Publicyści wybranych na potrzeby niniejszej analizy czasopism recenzowali książki katolickie zarówno autorów zagranicznych, jak i polskich. W podrozdziale zachowano zasadę przedstawienia najczęściej recenzowanych tytułów i porównania opinii o nich $\mathrm{w}$ poszczególnych pismach. Wspomniano równocześnie o pojedynczych ocenach, które uznano za istotne ze względu na wybitnych przedstawicieli tego gatunku. Zdarzało się bowiem, że chętnie lub często recenzowano powieści cieszące się popularnością, nie zaś dzieła znanych i uznawanych pisarzy katolickich.

Najwięcej kontrowersji wśród recenzentów wzbudziła powieść angielskiego pisarza Grahama Greena Sedno sprawy (Warszawa 1950). Opublikowano o niej aż osiem opinii na łamach różnych periodyków. Czterokrotnie zabrano głos w „Tygodniku Powszechnym”, z czego dwie wypowiedzi miały charakter pozytywny, po jednej zaś krytyczny i negatywny. Na łamach „Przeglądu Powszechnego” przedstawiono o Sednie sprawy pozytywną i omawiającą opinię. W,,Tygodniku Katolickim” i „Znaku” zaznaczano obecność powieści na rynku księgarskim poprzez omawiające artykuły. Jako pierwsza w krakowskim periodyku najnowsze dzieło jednego z „najwybitniejszych pisarzy współczesnych” przedstawiła Maria Morstin-Górska. Ustosunkowując się do ówczesnej krytyki, napisała: „Jedni oburzają się, że podobna książka mogła wyjść spod pióra wierzącego pisarza - inni, a wśród nich także duchowni, stwierdzają stanowczo jej religijną głębię i wyjątkowe zrozumienie nadprzyrodzonego świata. [...] Sprzeczność sądów świadczy tu o niepowierzchownym sięgnięciu w Sedno sprawy"242. Autorka artykułu należała do tych,

${ }^{239}$ S. Skwarczyńska, ,Literatura katolicka” jako termin w nauce o literaturze, „Znak” 1950 nr 3 s. 233.

${ }^{240}$ K. Górski, Rola pisarza katolickiego w dobie współczesnej, „,TP” 1946 nr 37 s. 1.

${ }^{241}$ Z. Starowieyska-Morstinowa, O wolności pisarza katolickiego, „TP” $1948 \mathrm{nr} 31$ s. 1.

${ }^{242}$ M. Morstin-Górska, Sensacja i mistyka, „TP” 1948 nr 52/53 s. 5. 
którzy w treści odnaleźli „oryginalność” powieści i sens polegający na ostatecznym opowiedzeniu się człowieka za Bogiem lub przeciw Niemu. Zofia StarowieyskaMorstinowa, aprobując również „przejrzystą powieść”, zaznaczyła: „Przeczytanie tej książki nie jest przygodą literacką. Jest przygodą życiową" ${ }^{243}$. Pochwalając uwzględnienie przez pisarza świata doczesnego i nadprzyrodzonego, doceniła demaskowanie grzechu i ukazanie go w ,jego istotnej brzydocie i wstydzie”. Nazywając Sedno sprawy „głęboko katolicką książką” uzasadniała: „Mówią wrogowie Greene'a, że Skobie był złym katolikiem, bo głosu sumienia nie posłuchał, bo oparł się natarczywemu wołaniu Bożemu. Być może. Greene zresztą nie twierdzi nigdzie, że Scobie był dobry. Ale czytając historię jego upadku, wiemy że dobrym katolikiem jest Greene. Z jak wielkim wzruszeniem i przejęciem, z jak gorącą i żywą wiarą patrzy na człowieka, który sprzeciwia się łasce. [...] jak bardzo przekonywująco umie przedstawić owo niewyczerpane Boże miłosierdzie, które ściga człowieka aż w mroki śmierci”244. Wacław Rola na łamach „Przeglądu Powszechnego” w pozytywnej recenzji nazwał z kolei książkę ,powieścią przepełnioną miłosierdziem”, a jej autora „pisarzem drapieżnym”. Dostrzegając piękny język dzieła oraz doskonałe polskie thumaczenie Jacka Woźniakowskiego stwierdził ponadto: „Tragiczne, nieszablonowe życie Scobiego przedstawia Greene z rzadkim mistrzostwem artystycznym. Książka jest wspaniale skonstruowana, nigdzie nie nuży, ustawia sceny w bezbłędnej perspektywie"245. Pogłębione rozważania o treści i wymowie Sedna sprawy przeprowadził w tym samym miesięczniku Józef Marian Święcicki ${ }^{246}$. Recenzent „Tygodnika Katolickiego” pisał z kolei: „Zamykając książkę Greene’a czujemy jednocześnie współczucie i odrazę. Ale pomimo ponurego nastroju powieści wyczuwamy, że jest w niej coś więcej, niż upadek i grzech. Jest w niej potężny obraz miłosierdzia Bożego"247. Zarzut braku społecznego wymiaru w tej samej powieści postawił natomiast Zygmunt Kubiak, zapytując: „Dlaczego [Green - E.K.] nie ukazuje perspektyw walki o człowieka w skali społecznej?"248. Próbując odpowiedzieć, recenzent dopatrzył się ,zubożonego widzenia świata” u pisarza, jak też „mieszczańskiej skazy wielkiej sztuki". Zdecydowanie negatywnie o Sednie sprawy wypowiedziała się Anna Iwaszkiewiczowa, uzasadniając, że ,jest to książka napisana z wielkim talentem i bardzo sugestywnie, przez co jest książką głęboko niemoralną, w najistotniejszym tego słowa znaczeniu gorszącą i z punktu widzenia katolickiego - bardzo szkodliwą" ${ }^{249}$. Uznając ją także za „książkę dywersyjną", a bohatera za „odrażającego”, zastanawiała się, ,,po co w ogóle Greene ją napisał i dlaczego uważana jest za powieść

\footnotetext{
${ }^{243}$ Z. Starowieyska-Morstinowa, Grzech zdemaskowany, „TP” $1950 \mathrm{nr} 31$ s. 3.

244 Tamże.

${ }^{245}$ W. Rola, Recenzje książek, „PP” 1950 nr 7 s. 135.

246 J.M. Święcicki, O sedno „, Sedna sprawy”, „PP” 1951 nr 4 s. 376-387.

${ }^{247}$ M.M., Dramat grzesznika, „TK” 1952 nr 20 s. 150.

${ }^{248}$ Z. Kubiak, Poszukiwanie prawdy o czlowieku, „TP” 1950 nr 32 s. 3.

${ }^{249}$ A. Iwaszkiewiczowa, Jeszcze o ,, Sednie sprawy”, „,TP” $1951 \mathrm{nr} 49$ s. 6.
} 
katolicką?" ${ }^{250}$, podczas gdy zadaniem literatury katolickiej było ukazywanie wielkości działania łaski w słabym człowieku. Z losami bohatera książki zapoznał szczegółowo czytelników „Znaku” Jan Dobraczyński251.

Do twórczości Greene'a nawiązano także przy okazji Broni na sprzedaż (Warszawa 1951) 252, Potegi i chwaty oraz Końca romansu ${ }^{253}$. Jak odmiennie odebrano drugą z książek świadczył fakt, że została zakazana przez Episkopat w Irlandii za podjęcie „drażliwych tematów”, podczas gdy w Anglii cieszyła się najwyższym uznaniem w prasie katolickiej ${ }^{254}$.

Tyle samo opinii co Sedno sprawy uzyskały w prasie katolickiej Dzieje Chrystusa (Warszawa 1950) Henri Daniela-Ropsa, dzieło literackie i zarazem historyczne, które przetłumaczono na wiele języków i rozeszło się w kilku nakładach. Publicyści podzielili się na dwie równe grupy, zarówno gdy chodzi o zwolenników, jak i przeciwników dzieła. W „Tygodniku Powszechnym” napisano dwie pozytywne i jedną polemiczną ocenę. Recenzenci „Przeglądu Powszechnego” byli zgodni, publikując trzy krytyczne artykuły (w tym dwie należały do ks. Jana Rosiaka). Dobrze przyjęto książkę w „Tygodniku Katolickim” i w „Znaku”255. Dla Jerzego Ciechockiego Dzieje Chrystusa były „piękną książką” ze względu na ,jej rzeczowość i gorącą miłość Daniela-Ropsa do postaci Chrystusa", zaznaczając jednocześnie, że stanowiły dobre „wprowadzenie do Ewangelii” ${ }^{256}$. Podobnie Zygmunt Kubiak książkę znanego pisarza i historyka nazwał ,najbardziej przekonywującą rekonstrukcją dziejów ewangelicznych", będącą „,doniosłym wydarzeniem w dziejach kultury katolickiej”"257. Krytyczny głos na łamach „Przeglądu Powszechnego” zabrał ks. Jan Rosiak, polemizujący również z zarzutami publicystów wydrukowanymi w „Tygodniku Powszechnym”258. Oprócz „błędnego ujęcia postaci Chrystusa” dostrzegł bowiem nieścisłości teologiczne, o których „lojalnie informował czytelnika"259. Dwukrotnie zrecenzowano (w opinii omawiającej i krytycznej) na łamach „Tygodnika Powszechnego” „literacką monografię biblijną” Daniela-Ropsa zatytułowaną Od Abrahama do Chrystusa (Warszawa 1952) ${ }^{260}$.

${ }^{250}$ Tamże.

${ }^{251}$ J. Dobraczyński, Zdarzenia-książki-ludzie. Pierwsza książka Greene’a po polsku, „Znak” 1950 nr 1 s. $57-64$.

${ }^{252}$ M. Krupiński, Przeglad piśmiennictwa. Problem otwarty, „PP” 1952 nr 3 s. 212-215.

${ }^{253}$ Nowa powieść Greene'a, „TP” 1951 nr 39 s. 4.

${ }^{254}$ Z. Starowieyska-Morstinowa, Dwie postawy, „TP” 1948 nr 17 s. 6.

${ }^{255}$ W. Krzyżanowska, Nowa książka o Chrystusie, „TK” 1951 nr 46 s. 401; E. Dąbrowski, „Dzieje Chrystusa” Daniela Ropsa, „Znak” 1951 nr 3 s. 266-275.

${ }^{256}$ J. Ciechocki, Dzieje Chrystusa, „TP” 1951 nr 14 s. 4.

${ }^{257}$ Z. Kubiak, Ksiażka o Chrystusie, „TP” $1951 \mathrm{nr} 39$ s.

${ }^{258}$ J. Rosiak, ,,Dzieje Chrystusa”, „PP” $1951 \mathrm{nr} 4$ s. 349-375; tenże, Przegląd piśmiennictwa, tamże, nr 5 s. 443-450; tenże, Teksty mówia co innego, „TP” 1951 nr 47 s. 5-6.

259 J. Rosiak, Teksty mówią...

${ }^{260}$ C. Jakubiec, Literacka monografia biblijna, „TP” $1952 \mathrm{nr} 46$ s. 6-7; Z. Kubiak, O drogocennym ,pięknoduchostwie”, tamże, s. 7. 
Nie mniej sporów wzbudziły zbeletryzowane dzieje św. Teresy z Lisieux, napisane przez flamandzkiego prozaika Maxence van der Meerscha pt. La petite sainte Thérèse (Paryż 1947), które otrzymały diametralnie różne oceny na łamach pism. Niektórym publicystom trudno było uznać autora za pisarza katolickiego, o czym może świadczyć wypowiedź ks. Józefa Majkowskiego w jednym z zeszytów „Znaku”. Pisał bowiem: „Maxence van der Meersch. $<<$ Pisarz katolicki $>>$. Wielki. Może wielki, ale czy katolicki? - Odpowiedź zależy od znaczenia, jakie ktoś wiąże z tym przymiotnikiem, gdy zestawia powyższe dwa wyrazy. Nikt nie zaprzeczy, że autor Corps et ames umiał niekiedy po katolicku pisać. I sam zaliczał się do pisarzy i apostołów katolickiej myśli. A jednak - chociaż naprawdę trudno nam w to uwierzyć - był on tylko, jak tego dowodzą jego krytycy, albo wiecznym katechumenem, albo katolikiem niepraktykującym"261. W recenzji czytamy również o „karykaturalnym przedstawieniu $<<$ małej drogi $>>$ ” co miało wynikać ze związków pisarza ze światopoglądem protestanckim. Krytycyzm wobec książki wykazali także publicyści „,Tygodnika Powszechnego”. Jan Dobraczyński zarzucił prozaikowi przedstawienie życia duchowego świętej w „sposób nieścisły i przesadzony”, „przeinaczenie faktów” z życia klasztornego, a na końcu błędnie zinterpretowaną naukę św. Teresy, uzasadniając wszystko w obszernej recenzji ${ }^{262}$. W Przegladzie prasy Jan Marian Święcicki zestawił jedynie opublikowane już wcześniej omówienia prasowe ${ }^{263}$. Dobrze o dziele wypowiedział się natomiast recenzent „Tygodnika Warszawskiego”, twierdząc, że życie świętej zostało opisane z „uwielbieniem, miłością i podziwem”, dzięki czemu książkę czyta się ,jednym tchem", a van der Meersch wykazał odwagę w surowej ocenie przełożonych Kościoła ${ }^{264}$.

Trzykrotnie zrecenzowano dzieło Archibalda Josepha Cronina Klucze królestwa (Katowice 1948). Z pozytywnej opinii Marii Morstin-Górskiej można dowiedzieć się, że autor dał w powieści obraz katolickiego kleru angielskiego, wysuwając ,jedno kapitalne oskarżenie”, że „świętość pozostaje w tym środowisku niedoceniona i niezrozumiana"265. Recenzentka uważała próbę pisarza wykreowania świętego w postaci głównego bohatera - księdza - za pomyślną. Antoni Madej przedstawiając treść książki określił ją jako „bardzo żywą, interesującą i zdynamizowaną”, którą czyta się „bez potknięć i zahamowań”266. Z powyższymi wypowiedziami nie zgodził się z recenzentami Józef Marian Święcicki w krytycznej recenzji opublikowanej w „Przeglądzie Powszechnym”, gdzie zakwestionował

${ }^{261}$ J. Majkowski, Święta Teresa z Lisieux, „PP” $1951 \mathrm{nr} 7$ s. 66.

262 J. Dobraczyński, Wokót „La petite sainte Thérèse” van der Meerscha, „TP” $1951 \mathrm{nr} 30$ S. 3,12 .

263 J.M.S. [J.M. Święcicki], O prawdziwe oblicze Małej św. Teresy, „TP” 1951 nr 50 s. 7.

${ }^{264}$ W.N., Św. Teresa, „TW” 1948 nr 16 s. 8.

${ }^{265}$ M. Morstin-Górska, Nowe powieści Cronina, „TP” 1948 nr 7 s. 9.

${ }^{266}$ A. Madej, Klucze królestwa, „TW” 1948 nr 7 s. 5. 
katolickość powieści, zwracając uwagę na „zewnętrzny aktywizm” bohatera bez ukazania jego życia wewnętrznego oraz wychwalanie przez pisarza cech raczej humanitaryzmu niż chrześcijaństwa ${ }^{267}$.

Przychylność krytyków zdobyła powieść mało znanego w Polsce szkockiego pisarza Bruce'a Marshalla Chwała córy królewskiej (Warszawa 1949), która rozeszła się w trzech edycjach IW PAX. Dla Marii Winowskiej była to „dziwna książka, bez intrygi, bez romantycznego wątku, bez sensacji”, opisująca historię życia od młodości do grobu księdza Smitha, która zdobyła rekordową poczytność w Anglii ${ }^{268}$. Z recenzji Marka Krupińskiego dowiadujemy się, że o szerokim odbiorze powieści zadecydował „rewolucjonizm Marshalla” ujawniający się w ,żarliwej atmosferze" i ,intensywnych i szczerych przeżyciach bohaterów”269. Krupiński w podsumowaniu pisał: „Właśnie dzięki szerokiej perspektywie życia, dzięki przepojeniu tego szarego życia żywym światłem wiary i dzięki nieodpartej a prostej w swych środkach sile argumentacji książka Marshalla jest próbą nowej, ale zdrowej syntezy natury i łaski, ludzkiego życia i Chrystusowej Ewangelii" Według recenzenta „Tygodnika Katolickiego” powieść była „książką śmiałą”, w której autor wystrzegał się występować w roli nudnego moralizatora, natomiast wolał posługiwać się „błyskotliwym stylem pełnym zabawnych spięć” ${ }^{271}$. Dobrze o innej powieści Marshalla Każdemu po groszu (Londyn 1946) wypowiedział się Jan Dobraczyński, pozytywnie również ocenił Cud ojca Malachasza tegoż autora Tadeusz Brzeziński²72.

$\mathrm{Z}$ aprobatą przyjęto na łamach pism katolickich dwutomową powieść Franza Werfla Pieśń o Bernadecie (Poznań 1948) wydaną w serii Jasnych Książek nakładem Księgarni św. Wojciecha. Zdaniem Amelii Łączyńskiej autor będący niemieckim Żydem wykazał wybitny talent w nakreśleniu sylwetki przyszłej świętej, jak też innych bohaterów ${ }^{273}$. Podobnie Zofia Zawiszanka i ks. Jan Rosiak docenili „mistrzowską rękę w traktowaniu sylwetek”, jak też „psychologiczną wnikliwość" Werfla, zauważając wyraźny wpływ jego osobistych przeżyć w przedstawieniu historii cudu w Lourdes ${ }^{274}$.

Dwukrotnie wypowiedziano się na temat Galigai Françoisa Mauriaca w „Tygodniku Powszechnym". Maria Dobraczyńska oddała głos samemu pisarzowi, cytując fragment z przedmowy do powieści. W niej zaś znany francuski

267 J.M. Święcicki, Ryzykowna symbioza, „PP” 1949 nr 3 s. 165-177.

${ }^{268}$ M. Winowska, ,W Wzystka jej chwała od wewnatrz”, „TP” 1949 nr 46 s. 1-2.

${ }^{269}$ M. Krupiński, Przegląd piśmiennictwa. Optymistyczna wizja życia, „PP” 1951 nr 10 s. 345.

270 Tamże.

${ }^{271}$ T.H., ,, Chwała córy królewskiej” B. Marshalla, „TK” 1950 nr 25 s. 189.

${ }^{272}$ T. Brzeziński, Fruwający dancing, „TP” 1951 nr 20 s. 4-5; J. Dobraczyński, Ksiądz Smith po raz drugi, tamże, nr 34 s. 2-3.

273 A. Łączyńska, Świadectwo o cudzie w Lourdes, „TK” 1949 nr 20 s. 188.

${ }^{274}$ J. Rosiak, Przegląd piśmiennictwa, „PP” 1949 nr 2 s. 132-134; Z. Zawiszanka, Powieść o Lourdes, „TP” $1950 \mathrm{nr} 19$ s. 9. 
pisarz, oprócz wyjaśnienia znaczenia tytułu powieści (pragnienie i wstręt), zapowiedział sięgnięcie do rzadko studiowanego problemu „nienawiści płci” ${ }^{775}$. Jan Dobraczyński, analizując twórczość „pisarza zmysłów” przy okazji nowego utworu, zauważył obecność szczerze wypowiadanego niepokoju w jego powieściach oraz powtarzające się motywy. Na końcu konstatował: „Mauriac nie posunął naprzód naszej wiedzy o świętości. Ale pokazał nam wiele oporów, na które napotyka świętość w głębi duszy ludzkiej”276. Do głębokiego zastanowienia nad działaniem natury i łaski inspirowała także, zdaniem Haliny Kamienieckiej, inna powieść tego prozaika, zatytułowana Ciało i krew (Katowice 1947) ${ }^{277}$. Krytycznie natomiast Maria Morstin-Górska podeszła w „Znaku” do Faryzeuszki (1947), podkreślając ,znaną już atmosferę książek Mauriaca dusznej od wezbranych namiętności, ukrywających się w mroku burzliwej nocy, rozświetlanej nagle błyskawicami Łaski”, a zarzucając słabą w porównaniu do innych powieści kreację psychologiczną bohaterów oraz „nieobecność dotychczasowego tła przyrody”278.

Twórczość pisarza młodego pokolenia Jeana Cayrola czytelnicy czasopism społeczno-kulturalnych poznali dzięki recenzjom nagrodzonej w 1947 r. wyróżnieniem Renaudota trzytomowej powieści Będę żyt mitościa innych. Z opinii Jeana Bourilly, napisanej specjalnie dla „Znaku”, dowiadujemy się o „bardzo osobistym pisarstwie" Cayrola i podjęciu tematu powojennego życia człowieka, który przeżył obóz koncentracyjny. O bohaterze czytamy: „W swoim życiu bitego psa - Armand napotyka parę ludzi Alberta i Lucette. [...] Życie jego umacnia się, podnosi przez miłość, którą inni żywią do siebie i przez miłość, którą on sam żywi do innych"279. W aprobującej wypowiedzi recenzent "Tygodnika Powszechnego", poznawszy wszystkie części powieści, zapytywał, czy autor „tej dziwacznej, ponurej i brutalnej trylogii” obrał "szczęśliwą drogę" w ostatecznym ukazaniu, że „nikt na świecie nie jest zbyteczny” ${ }^{280}$.

Pisząc o literaturze katolickiej nie sposób pominąć głośnych i niełatwych w odbiorze powieści francuskiego prozaika Georgesa Bernanosa Pod stońcem szatana (Warszawa 1949), Pamiętnik wiejskiego proboszcza (Warszawa 1950) i Zakłamanie (Warszawa 1952), które również zrecenzowano na łamach pism ${ }^{281}$. Nazwisko Gilberta Keitha Chestertona pojawiło się przy okazji omówienia zbeletryzowanego życiorysu pt. Św. Franciszek z Asyżu (Katowice 1948), natomiast

275 M. Dobraczyńska, Nowa powieść Mauriaca, „TP” 1952 nr 10 s. 3.

${ }^{276}$ J. Dobraczyński, ,, Galigai”, czyli wieczny niepokój Mauriaca, „TP” 1952 nr 19 s. 7.

${ }^{277}$ H. Kamieniecka, ,C Ciało i krew”, „TW” 1947 nr 36 s. 3.

${ }^{278}$ M. Morstin-Górska, Zdarzenia-książki-ludzie. Ostatnia powieść Mauriac'a: „Faryzeuszka”, „Znak” 1948 nr 5 s. 473-475.

279 J. Bourilly, Zdarzenia-książki-ludzie. ,, Będężył miłością innych”, „Znak” 1948 nr 3 s. 286.

${ }^{280}$ Ludzki wrak, „TP” 1951 nr 43 s. 4.

${ }^{281}$ Z. Starowieyska-Morstinowa, $W$ walce z szatanem, „TP” 1949 nr 35 s. 7-8; R. Wasita, Recenzje książek, „PP” 1950 nr 7 s. 135-136; J. Golmont, Dramat spraw niewidzialnych, „ТP” 1952 nr 47 s. 5-6. 
Evelyn Waugh - z powodu zaprezentowania książki będącej sukcesem wydawniczym w Anglii i Ameryce, zatytułowanej Powrót do Brideshead ${ }^{282}$. W katolickich czasopismach społeczno-kulturalnych dobrze wypowiedziano się również o powieściach pióra Gertrudy von le Fort i Sigrid Undset ${ }^{283}$. Zainteresowanie czytelników francuskich wzbudziła także twórczość katolickiego pisarza młodego pokolenia Gilberta Cesbrona Święci zstępuja do piekła, o czym dowiadujemy się $\mathrm{z}$ recenzji Jana Dobraczyńskiego ${ }^{284}$.

Z polskich twórców katolickich, najczęściej w opiniach pojawiały się dwa nazwiska: Jan Władysław Grabski (pięć recenzji, w tym cztery pozytywne napisano na temat Konfesjonatu oraz dwie o powieści $W$ cieniu kolegiaty ${ }^{285}$ i Tadeusz Kudliński (trzy razy oceniono Świętokradcę) ${ }^{286}$. Publicyści docenili jednocześnie tytuły książkowe Jana Dobraczyńskiego, takie jak Święty miecz, Klucz mądrości, Listy Nikodema i Mocarz ${ }^{287}$, które uzyskały pochwalne głosy.

Podsumowując tę część rozważań, należy stwierdzić, że w omówieniach dominowała angielska i francuska powieść katolicka. Autorzy zagraniczni przodowali bowiem $\mathrm{w}$ tej odmianie prozy. Współpracownicy polskich pism nie obawiali się ich kontrowersyjnych dzieł ani rozgorzałej wokół nich polemiki. Większość zresztą przyjmowała nowości wydawnicze z zaciekawieniem i pogłębioną refleksją. Z polskich powieściopisarzy przybliżono przede wszystkim twórczość Jana Dobraczyńskiego i Jana Władysława Grabskiego. Ten rodzaj powieści ze względu na profil periodyków odegrał istotną rolę i był starannie śledzony przez publicystów.

${ }^{282}$ J.K., Franciszkańskie odkrycia Chestertona, „TP” 1949 nr 8 s. 11; zsm [Z. StarowieyskaMorstinowa], Milion egzemplarzy, „TP” $1948 \mathrm{nr} 4$ s. 8.

${ }^{283}$ M. Winowska, Zdarzenia-książki-ludzie. Wszystko co twoje moje jest..., „Znak” $1949 \mathrm{nr} 2$ s. 168-175 [Gertruda von le Fort, Der Kranz der Engel (Chusta Weroniki), Monachium 1947]; J.M. Święcicki, Wielki epos katolickiego humanizmu, „TP” 1952 nr 44 s. 1-3 [Sigrid Undset, Olaf syn Auduna, Warszawa 1952].

${ }^{284}$ J. Dobraczyński, Misjonarz w Sagny, „TP” 1953 nr 2 s. 5-6.

${ }^{285}$ Z. Lichniak, Przegląd piśmiennictwa. Literatura: Książki klubowe, „PP” $1948 \mathrm{nr} 8$ s. 176-177; B.S., Konfesjonat, „GK” 1948 nr 43 s. 366; Z. Starowieyska-Morstinowa, Świat ogladany z konfesjonatu, „TP” 1948 nr 38 s. 3; Ciekawa powieść, „TK” 1948 nr 33 s. 253; J. Bednarski, Grabski i Wiktor o kapłaństwie katolickim, „PP” 1949 nr 1 s. 40-45; Z. Starowieyska-Morstinowa, Trudna droga, „TP” 1949 nr 49 s. 3; F. Blachnicki, Postawa otwartej dtoni, „TP” 1950 nr 50 s. 4, 13.

${ }^{286}$ A. Madej, $W$ kręgu twórczości i miłosierdzia, „TW” $1947 \mathrm{nr} 47$ s. 5; Z. StarowieyskaMorstinowa, Święty czy syn marnotrawny, „TP” 1948 nr 3 s. 7; taż, Przegląd piśmiennictwa. Ksiażki, „PP” 1948 nr 2 s. 139-140.

${ }^{287}$ Z. Starowieyska-Morstinowa, Śmiała próba, „TP” 1948 nr 4 s. 11; P. Jasienica, Drogi świata, „TP” 1949 nr 42 s. 5; M. Krupiński, Przegląd piśmiennictwa. Recenzje książek, „PP” 1950 nr 6 s. 447-448; Z. Starowieyska-Morstinowa, Zwycięstwa i klęski chrześcijan, „TP” 1951 nr 32 s. 1; C. Komornicka, Przegląd piśmiennictwa. Recenzje ksiażek, „PP” 1951 nr 7 s. 131-133; Z. Starowieyska-Morstinowa, Nikodem pisze Haggade, „TP” 1952 nr 15 s. 6; Eremita, Śladami Nikodema, „PP” 1952 nr 12 s. 355-367. 


\subsubsection{Powieść historyczna}

Wśród recenzowanych pozycji książkowych ważne miejsce zajęła powieść historyczna; krytycznemu omówieniu poddano przede wszystkim dzieła polskich autorów. Zygmunt Lichniak zauważył, że „bujny renesans powieści historycznej” był zasługą prawie „wyłącznie pisarzy świata katolickiego”288. Do ich grona należeli m.in. Antoni Gołubiew, Jan Władysław Grabski, Zofia Kossak, Hanna Malewska i Karol Bunsch.

Jednogłośnie dobrze przyjęto powieść historyczną, a zarazem katolicką, pt. Bolesław Chrobry (Warszawa 1947-1951) A. Gołubiewa, wydawaną w częściach nakładem Spółdzielni Wydawniczej Czytelnik. Znalazła ona bowiem przychylność w ośmiu recenzjach. Publicyści „Tygodnika Powszechnego” zabrali głos czterokrotnie. Starowieyska-Morstinowa za „oryginalność powieści” uznała zbiorowego bohatera, jakim był naród polski, podkreślając przy tym ,głęboką religijność” autora. W następujący sposób uzasadniała: „Dla Gołubiewa chrześcijaństwo jest siłą żywą, żywotną, jest jedyną siłą zdolną organizować życie, budować ład i być źródłem cywilizacji i kultury”289. Trzeci tom cyklu, zatytułowany Złe dni (Warszawa 1950), dokładnie streściła Maria Morstin-Górska. Dostrzegając w „optymizmie” książki jej społeczną wartość, stwierdziła: „pomimo opisów samych klęsk mało znam książek tak podnoszących wiarę w nasze żywotne siły i naszą przyszłość" ${ }^{290}$. Dla Stefana Kisielewskiego powieść stała się „,niezwykłą książką”, poprzez posiadanie ,jedności treści z konstrukcją”, zaś w swej problematyce religijno-moralnej służyła zamierzonemu światopoglądowi autora ${ }^{291}$. Jan Marian Święcicki dokonał znów na łamach krakowskiego tygodnika przeglądu dotychczasowych opinii prasowych o dziele ${ }^{292}$. Publicysta „Przeglądu Powszechnego” konstatował: „Uderza w Bolesławie Chrobrym mistrzowska, pełna i żywa panorama świata. [...] wielkim triumfem Gołubiewa jest przekonywujące konstruowanie postaci ludzkich" ${ }^{293}$. W tym samym miesięczniku najobszerniejszą recenzję napisał Wiktor Doda, doceniając w powieści metodę pisarską i „,własną wizję życia z czasów Chrobrego" 294 . Recenzent „Tygodnika Katolickiego” zachwycał się: „Wartość książki jest wyjątkowa. Literatura polska otrzymała rzecz wysoce oryginalną i piękną. Tym większa nasza duma, że dzieło tak wysokiej klasy artystycznej wyszło spod pióra pisarza katolickiego"295.

${ }^{288}$ Z. Lichniak, Przegląd piśmiennictwa. Polska powieść historyczna po wojnie, „PP” 1948 nr 7 s. 104 .

${ }^{289}$ Z. Starowieyska-Morstinowa, Polska szumiaca puszcza, „TP” 1947 nr 22 s. 6.

${ }^{290}$ M. Morstin-Górska, Królewska przegrana, „TP” $1950 \mathrm{nr} 49$ s. 1.

${ }^{291}$ S. Kisielewski, O Golubiewie i jego książce, „TP” 1952 nr 41 s. 1-2.

292 J.M.S. [J.M. Święcicki], Przegląd prasy. Bolesław Chrobry, „TP” 1952 nr 39 s. 7.

${ }^{293}$ W. Rola, Przegląd piśmiennictwa. Recenzje ksiązek, „PP” $1950 \mathrm{nr} 11$ s. 429.

${ }^{294}$ W. Doda, Uroki czasów Chrobrego, „PP” $1952 \mathrm{nr}$ 5/6 s. 381-395.

${ }^{295}$ Eugeniusz, Wielki epos o Polsce piastowskiej, „TK” 1951 nr 12 s. 106. 
Większość publicystów zwróciła uwagę na żywiołowość powieści i archaiczny język ${ }^{296}$.

Zygmunt Lichniak za przykład „wybitnego osiągnięcia” uznał Sagę o Jarlu Broniszu (Poznań 1946-1948) Jana Władysława Grabskiego ${ }^{297}$. Na temat poszczególnych części serii powieściowej, która ukazała się nakładem Księgarni św. Wojciecha i Wielkopolskiej Księgarni Wydawniczej, publicyści wypowiedzieli się siedmiokrotnie (pięć recenzji pozytywnych oraz dwie krytyczne). Chronologicznie pierwszą wypowiedź w 1946 r. publicystka „Tygodnika Powszechnego" rozpoczęła od krytyki: „Książka [...] wypłynęła z dwóch źródeł: z narodowej troski autora o los ziem zachodnich i z rozmiłowania w baśniowym i barwnym świecie normandzkich sag. Z tych też dwóch źródeł płyną jej wady i zalety" ${ }^{298}$. Do pierwszych zaliczyła „publicystyczną narrację” zbytnio nawiązującą do współczesności, jak też nieumiejętność Grabskiego „wysnucia własnej, oryginalnej koncepcji filozoficznej i historiozoficznej”. Ubolewając nad tym stwierdziła: „Wadą jest, że z przestudiowanego materiału nie dał nam tego, co w każdej książce, tak historycznej jak i nie historycznej, jest zawsze najciekawsze: własnej konstrukcji myślowej; że zamierzona przez autora konstrukcja, nie jest oryginalna i nie jest ciekawa. Ciekawe jest jedynie opowiadanie”299. Podkreśliła natomiast „czytelniczą atrakcyjność" powieści dzięki żywym obrazom i ukazaniu ,świata pełnego uroku i poezji” oraz „historyczne udokumentowanie” powieści. Przy końcu recenzji Starowieyska-Morstinowa konstatowała: „Powieść Grabskiego - mimo niewątpliwych niedociągnięć ideowych i jeszcze większych artystycznych - nadawałaby się doskonale na podkład do filmu. Byłby to na pewno film trudny i kosztowny, ale dobrze wykonany mógłby być wspaniały, a jako film propagandowy polskości ziem zachodnich niesłychanie pożyteczny" ${ }^{300}$. Więcej o treści Sagi dowiadujemy się z kolejnej recenzji w „Tygodniku Powszechnym”, tym razem pochwalnej, pióra Wojciecha Żukrowskiego. Recenzent zwrócił uwagę na wartość „spraw religijnych" obecnych w powieści poprzez wprowadzenie postaci św. Wojciecha i długie dialogi o wierze występujące w trzecim tomie ${ }^{301}$. Dwie pozytywne oceny poszczególnych części trylogii napisała Irena Pannenkowa na łamach „Tygodnika Warszawskiego". Wiadomo z nich, że za pierwsze dwa tomy Grabski został wyróżniony nagrodą „Odry”, a ostatni był jej zdaniem „,najciekawszy”302. Pisała przy tym: „zdecydowaną postawę ideologiczną uznać należy także za wartość wybitnie pozytywną całego dzieła, które stanowi oryginalny twórczy, solidny wkład do

${ }^{296}$ A. Madej, Wielka powieść historyczna, „TW” 1947 nr 46 s. 9.

${ }^{297}$ Z. Lichniak, Przegląd piśmiennictwa. Polska powieść historyczna po wojnie, „PP” 1948

nr 7 s. $104-107$.

${ }^{298}$ Z. Starowieyska-Morstinowa, Na tropie słowiańskich Wikingów, „TP” 1946 nr 24 s. 4.

299 Tamże.

${ }^{300}$ Tamże.

${ }^{301}$ W. Żukrowski, Epopea stużebna, „TP” 1947 nr 27 s. 6.

302 I. Pannenkowa, Nad kolebka Polski - szumiato morze, „TW” 1947 nr 3 s. 7. 
literatury Polski Odrodzonej”303. Eugeniusz Myczka ustosunkowując się jedynie do pierwszej części epopei w recenzji „Głosu Katolickiego” zarzucił pisarzowi „zupełne pominięcie podłoża społecznego Polski piastowskiej”304. Wypowiedź Eugeniusza Paukszty, znana czytelnikom „Tygodnika Katolickiego”, wskazała na elementy marynistyczne w powieści ${ }^{305}$. Wszyscy recenzenci pochwalili źródłowe i historyczne przygotowanie autora.

Jednoznacznie dobrze w pięciu artykułach publicyści pism katolickich ocenili Suknię Dejaniry (Poznań 1948) Zofii Kossak, wydaną przez Pallottinum. Z radością w krakowskim tygodniku powitała książkę Zofia Starowieyska-Morstinowa, pisząc o zasłudze autorki ,przedstawienia bolesnej prawdy chłopskiej XVII wieku" i subtelnie pokazanej świętości bohatera powieści Kazimierza Korsaka, którego należało rozpoznać „po owocach” życia. Podziw recenzentki wzbudziła strona literacka dzieła, jak też staranna szata graficzna ${ }^{306}$. Stanisław Pigoń w kolejnym artykule zapoznał czytelników z tekstami dotyczącymi wątków biograficznych Korsaka, przyznając dziełu „wersję najbogatszą, ideowo najwyrazistszą i artystycznie najwyższą" ${ }^{307}$. Wedle Aleksandra Rogalskiego pisarka wykazała się „doskonałą znajomością epoki”, dając własną interpretację wydarzeń i umiejętnie „przyciągając uwagę czytelnika”. Jako „dzieło dojrzałego talentu” nazwał je „książką odkrywczą"308. Na głównym temacie powieści, którym był przełom duchowy w życiu bogatego szlachcica i na „rozgrywającej się akcji w jego duszy”, skupił uwagę Zygmunt Lichniak, określając ją jako „ciekawe studium psychologiczno-historyczne” oraz ,jedno z głębszych i piękniejszych treści” wzbogacających literaturę katolicką ${ }^{309}$. W opinii Antoniego Madeja książka dzięki swej problematyce miała być ,zawsze aktualna”, gdyż „poruszała problem nie dość jasno dostrzegany przez zlaicyzowaną i wypraną z kultury chrześcijańskiej społeczność ludzką" ${ }^{310}$. Recenzent „Tygodnika Warszawskiego” przewidywał też „wielką poczytność" Sukni Dejaniry.

Trzykrotnie odniesiono się w czasopismach społeczno-kulturalnych do powieści Kamienie wołać będa (Poznań 1946) Hanny Malewskiej i Wybrańców gwiazd (Poznań 1948) Jana Dobraczyńskiego. Z recenzji Zygmunta Lichniaka odbiorcy „Przeglądu Powszechnego” mogli dowiedzieć się o słusznie wyróżnionej pierwszą nagrodą katolicką po wojnie powieści Malewskiej, będącej „krzepiącym

303 Taż, Rzeczywistość i saga, „TW” 1947 nr 17 s. 11.

${ }^{304}$ E. Myczka, Powieść z czasów Bolesława Chrobrego, „GK” 1947 nr 47 s. 385.

${ }^{305}$ E. Paukszta, Morze w polskiej powieści piastowskiej, „TK” $1951 \mathrm{nr} 22$ s. 198.

${ }^{306}$ Z. Starowieyska-Morstinowa, Wielka przygoda Kazimierza Korsaka, „TP” 1948 nr 36 s. $6-7$.

${ }^{307}$ S. Pigoń, Z pana - chtop, „TP” 1949 nr 12 s. 4.

308 A. Rogalski, ,, Suknia Dejaniry” Zofii Kossak, „GK” 1948 nr 29 s. 252-253.

${ }^{309}$ Z. Lichniak, Przegląd piśmiennictwa. Polska powieść historyczna po wojnie, „PP” 1948 nr 7 s. $107-108$.

${ }^{310}$ A. Madej, ,, Suknia Dejaniry”, ,TW” 1948 nr 27 s. 6. 
dokumentem subtelnej i wysokiej kultury literackiej”311. Niezwykłą „rzetelność pisarską" publicysta dostrzegł w nakreślonym przez pisarkę obrazie średniowiecza, nacechowanym ,głębokim odczuciem ducha epoki i nurtującego ją katolicyzmu” oraz „przekonywującym przedstawieniu typów ludzkich” ${ }^{112}$. Pisał: „bogactwo typów jest jednym z najbardziej pociągających momentów powieści Malewskiej. Są one tak zróżnicowane, tak obficie wyposażone w odrębne, sobie tylko właściwe cechy, tak dalekie od szablonu i banału literackich figurek, że żywotnością swoją, swoją bliskością wiążą czytelnika z epoką, każą mu ją rozumieć i po swojemu cenić czy kochać”313. Do „powieści o katedrze w Beauvais” inaczej podszedł Antoni Gołubiew w krytycznym artykule adresowanym do czytelników „Tygodnika Warszawskiego”. Pomimo że „książka zostawiała wrażenie wielkości epoki, którą opisywała”, recenzent za jej główną wadę uważał „nieufność wobec czytelnika”. Tłumaczył to w następujący sposób: „Malewska za dużo mówi, za wyraźnie i za jasno. Niepokoi się, czy zrozumieliśmy prawdę o średniowieczu, czy widzimy wizję - jej wizję”, sugerując dalej: „Dzieło sztuki jest tylko zapoczątkowaniem, nie zaś dopełnieniem. Jest przebiciem skorupy, którą się człowiek otoczył; skorupy lenistwa, egoizmu i obojętności wobec Boga i świata. Czytelnik musi być współtwórcą dzieła, on właśnie winien je dopełnić” ${ }^{14}$. Na wytrawną recenzentkę „Tygodnika Powszechnego” książka oddziałała „radością” jej autorki, która pisząc o „wszystkich okropnościach średniowiecza”, nie pozbawiła bohaterów „możności osiągnięcia szczęścia” ${ }^{15}$.

Na szczególną uwagę czytelników zasłużyło, zdaniem Lichniaka, wartościowe dzieło Wybrańcy gwiazd, będące dowodem osiągnięcia przez ich autora „wyższego szczebla wtajemniczenia literackiego” oraz klarowniejszego „bardziej Dobraczyńskiego języka"316. Ks. Eugeniusz Dąbrowski przewidywał, że książka Dobraczyńskiego znajdzie wielu chętnych czytelników, a „fabuła trzymać będzie w napięciu uwagę do końca" ${ }^{317}$. Zarzucił jedynie autorowi ,przesadny realizm" w odtworzeniu życia Wschodu na przykładzie częstych opisów haremów. Zaznaczył: „Wydaje mi się, że jeżeli już nie całkowite usunięcie, to znaczne zmniejszenie opisów tego typu, nieraz wyraźnie jaskrawych i w niczym nie wiążących się z akcją głównych bohaterów - powieści tej wyszłoby na dobre" ${ }^{318}$. Według Józefa Mitkowskiego zaś była to „typowa, dobrze napisana powieść historyczna" ${ }^{\prime 19}$.

\footnotetext{
311 Z. Lichniak, Przeglad piśmiennictwa. Polska powieść..., s. 108.

312 Tamże.

313 Tamże, s. 109.

${ }^{314}$ A. Gołubiew, Kamienie wołać będa, „TW” 1946 nr 35 s. 5.

${ }^{315}$ Z. Starowieyska-Morstinowa, Katedra radosna, „TP” 1946 nr 13 s. 4-5.

316 Z. Lichniak, Przegląd piśmiennictwa. Polska powieść historyczna..., s. 109-110.

${ }^{317}$ E. Dąbrowski, ,Wybrańcy gwiazd”, „TP” 1948 nr 23 s. 9.

318 Tamże.

319 J. Mitkowski, Jeszcze o „, Wybrańcach gwiazd”, „TP” 1948 nr 25 s. 2.
} 
Warto wspomnieć również, że po dwie recenzje ukazały się w pismach na temat tytułów powieściowych Karola Bunscha Ojciec i syn (Warszawa 1946) oraz Imiennik (Warszawa 1949), które wydano nakładem oficyny Gebethnera i Wolffa ${ }^{320}$. Starowieyska-Morstinowa o Imienniku Karola Bunscha napisała negatywną recenzję. W niej podkreśliła: „Niedobrze na ogół wychodzi kościół w obrazie Bunscha. Nie tylko święty Stanisław odsądzony jest od czci i wiary, nie tylko wszyscy prawie kapłani i biskupi, to szalbierze, chciwcy i oszuści, ale sam Kościół to instytucja, która w życie kraju nie wnosi nic" ${ }^{\prime 221}$.

Powieści historyczne autorstwa pisarzy zagranicznych rzadko były przedmiotem recenzji publicystów katolickich czasopism społeczno-kulturalnych. Nie były to też tytuły reprezentatywne dla twórczości tego typu. W pojedynczych recenzjach zwrócono tu uwagę czytelników m.in. na „doskonałą powieść historyczną” Sigrid Undset Krystyna córka Lawransa, „przytłaczającą swoim naturalizmem” książkę Gustawa Flauberta (notabene umieszczoną w spisie ksiąg zakazanych) Salammbo, ,,dość dziwaczną” choć ,piękną literacko” pozycję Simone de Beauvoir Wszyscy ludzie sa śmiertelni czy książkę Aleksego Tołstoja Piotr I, po lekturze której „brały człowieka uczucia bardzo różne” ${ }^{22}$. W Spółdzielni Wydawniczej Książka wznowiono Rob Roya (Warszawa 1948) Waltera Scotta, o czym wspomniał Antoni Gołubiew, poszukując różnic między angielską a polską powieścią romantyczną ${ }^{323}$.

Prozę o tematyce historycznej, jak wynika z licznych i pogłębionych ocen, dobrze zaprezentowali polscy twórcy. Czytelnicy pism katolickich zapoznający się z recenzjami mogli bez problemu wybrać z bogatej powojennej oferty odpowiedni dla siebie tytuł.

\subsubsection{Powieść o tematyce wojennej}

Do najnowszej historii nawiązywały powieści tematycznie odnoszące się do II wojny światowej. Oceniający je publicyści zwracali uwagę na sposób przedstawienia, prawdę o przeżyciach oraz ogólną wymowę dzieła. Przed zbyt trudną prawdą o wojnie przestrzegano w ten sposób, że nie polecano książek dorastającej młodzieży.

Trzech wydawców posiadała siedmiokrotnie zrecenzowana i w większości chwalona $\mathrm{w}$ wypowiedziach prasowych pierwsza powojenna powieść Jana

${ }^{320}$ T. Kudliński, Powieść o Mieszku i Bolestawie, „TP” 1947 nr 13 s. 8; A. Madej, U źródet państwowości polskiej, „TW” 1947 nr 11 s. 4; Z. Starowieyska-Morstinowa, Król i biskup, „TP” 1949 nr 44 s. 2-3; M. Plezia, Czy doprawdy tekst autentyczny?, „TP” 1951 nr 5 s. 5.

${ }^{321}$ Z. Starowieyska-Morstinowa, Król i biskup ... s. 3.

322 goa [A. Gołubiew], Krystyna córka Lawransa, „TP” 1948 nr 15 s. 8; Z. StarowieyskaMorstinowa, Cele niedostateczne, tamże, nr 23 s. 3-4; P. Jasienica, Dlaczego oni?, tamże, nr 44 s. 3-4; O. Porycki, Przegląd piśmiennictwa. Recenzje ksiązek, „PP” 1952 nr 9 s. 174.

${ }^{323}$ Goa [A. Gołubiew], Spotkania literackie. Po staroświecku, „TP” 1948 nr 27 s. 9. 
Dobraczyńskiego $W$ rozwalonym domu (Warszawa 1946). Książkę opublikowano w Spółdzielni Wydawniczej Czytelnik, oficynie Gebethnera i Wolffa oraz Księgarni Zdzisława Gustowskiego. Irena Sławińska uważała ją za „szczególny dokument" poświęcony walczącym dzieciom Warszawy; doceniła przede wszystkim „powściągliwość artystyczną” pisarza i „głęboki sens” ukazywanego cierpienia, które miało „przywracać miłość”. Tłumaczyła: „Na gruzach rozwalonych domów - powstaje nowy dom, dom przemienionego człowieka" ${ }^{22}$. Inna publicystka „Tygodnika Powszechnego”, Hanna Malewska, kreśląc recenzję „ze stanowiska świadka” wydarzeń stwierdziła: „Nie trzeba było być t a $\mathrm{m}$, by móc dziś ocenić prawdę tej książki, ale dla tych, co byli, ma ona szczególny walor przypomnienia, wskrzeszenia, asocjacji, za które winniśmy autorowi prawdziwą wdzięczność" ${ }^{325}$. W opinii Jerzego Adamskiego książka Dobraczyńskiego należała do tych czytanych ,jednym tchem”, których bohaterowie ,żyją w wyobraźni” odbiorców ${ }^{326}$. Pozytywnie odniósł się do powieści także ks. Jan Rostworowski w „Przeglądzie Powszechnym”327. Obok aprobującej recenzji Piotra Grzegorczyka w „Tygodniku Warszawskim" ${ }^{228}$ wydrukowano surową ocenę Haliny Kamienieckiej, w której publicystka wyliczyła kilka „poważnych usterek”. Odniosła bowiem wrażenie, że „temat przygniótł autora”, poza wieloma szczegółami postać ojca Marka mająca ukazać „katolicki światopogląd autora” wypadła „niewyraźnie”, a w „niektórych partiach uczuciowych książki pisarz wpadał w ton melodramatu" 329 . Na końcu wypowiedzi konstatowała: ,[...] autor swych zamierzeń w książce w pełni nie przeprowadził. Nie zharmonizował całości. Właściwie rzeczy najważniejsze są tu ledwo dotknięte. Książkę tę trzeba traktować jako próbę. Być może w następnych książkach Dobraczyński wypowie się pełniej, szerzej doszedłszy sam do pewnych konkluzji bardziej ustalonych - pogłębi nurt życia duchowego w postaciach swych bohaterów”330. Polemiczną opinię na „objaw arogancji w krytyce literackiej” Tadeusza Borowskiego na łamach „Kuźnicy” napisał Jerzy Ejan, kwestionując nazwanie książki Dobraczyńskiego „zabawną”, a jej główny sens „wierutnym kłamstwem" ${ }_{331}$.

Z twórczości Dobraczyńskiego, pomimo wytknięcia błędów, zauważono w recenzjach „Tygodnika Powszechnego" i „Tygodnika Warszawskiego” Najeźdźców (Warszawa 1946-1947). Konradowi Górskiemu brakowało w powieści „psychologicznego pogłębienia”, a Stefan Kisielewski dostrzegł „błąd kompozycji”, „brak środków wyrazu”, „,nazbyt uproszczone i schematyzowane postacie

\footnotetext{
${ }^{324}$ I. Sławińska, Rozwalony i odbudowany dom, „TP” $1946 \mathrm{nr} 43$ s. 7.

${ }^{325}$ H. Malewska, Jeszcze o „Rozwalonym domu”, „TP” 1946 nr 47 s. 6.

${ }^{326}$ J. Adamski, Obrońcy ,, Starówki”, „GK” 1946 nr 46 s. 368.

${ }^{327}$ Ks. J.R. [J. Rostworowski], Przegląd piśmiennictwa, „PP” 1948 nr 12 s. 413.

${ }^{328}$ P. Grzegorczyk, Powieść Dobraczyńskiego, „TW” 1946 nr 47 s. 7-8.

${ }^{329}$ H. Kamieniecka, Powieść Dobraczyńskiego, „TW” 1946 nr 47 s. 8.

${ }^{330}$ Tamże.

${ }^{331}$ J. Ejan, Krytyk na hulajnodze, „TW” 1947 nr 2 s. 3.
} 
drugoplanowe” oraz ,potworną korektę" ${ }_{332}$. Dwukrotnie zabrano także głos na łamach pism katolickich na temat następujących książek: Ksawerego Pruszyńskiego Droga wiodła przez Narvik (Warszawa 1945), Józefa Nikodema Kłosowskiego Jarzmo (Warszawa 1947) i Bohdana Czeszko Pokolenie (Warszawa 1951) ${ }^{333}$.

Mniejszą uwagę publicyści poświęcili omówieniom powieści zagranicznych, gdyż w czasopismach w latach 1945-1953 znalazło się zaledwie kilka recenzji. Na stronach „Tygodnika Powszechnego" i „Przeglądu Powszechnego” dostrzeżono Szosę Wołokołamska (Warszawa 1947) wydaną przez Spółdzielnię Wydawniczą Książka ${ }^{334}$. Za „dobrą książkę” Starowieyska-Morstinowa uznała Burze (Warszawa 1950) Ilii Erenburga, podobnie pozytywną opinię o niej wydał Wacław Rola ${ }^{335}$. Wybitna szwedzka pisarka Marika Stiernstedt w Zamachu w Paryżu ukazała stolicę Francji pod okupacją niemiecką, o czym dowiadujemy się z recenzji Jana Parandowskiego, którego zainteresował szczególnie wątek polski i religijny w powieści ${ }^{336}$.

\subsubsection{Powieść społeczno-obyczajowa}

Inaczej wypadła w recenzjach zamieszczonych w czasopismach społecznokulturalnych powieść obyczajowa obcego autorstwa, gdyż w tym przypadku zaproponowano czytelnikom znacznie większy wybór tytułów książkowych. Ze względu na ogólny brak ocen tych samych powieści zagranicznych (dwukrotnie zrecenzowano zaledwie trzy z nich) zdecydowano się tę część opracować na podstawie wyboru ważniejszych i ciekawszych wypowiedzi, w tym też negatywnych.

W omówieniach znalazły się przede wszystkim wznowienia znanych pozycji z literatury światowej. Wacław Borowy przedstawiając czytelnikom „Tygodnika Powszechnego" „przekonywujące uwagi” André Rousseaux ze zbioru Littérature du XX siécle, ,godnym uznania” nazwał nową edycję cyklu powieściowego pt. Rodzina Thibault (Warszawa 1948) Rogera Martina

${ }^{332}$ K. Górski, „Najeźdżcy” Dobraczyńskiego, „TW” 1947 nr 9 s. 9; S. Kisielewski, Dobraczyński oczyszczony, „TP” 1947 nr 37 s. 5-6.

${ }^{333}$ M. Jarczyńska, Droga wiodła przez Narvik, „TP” 1946 nr 28 s. 5-6; Z.R. [Z. Rabska], Nowe ksiązki, „TW” 1946 nr 4 s. 8; J. Kleiner, Powieść o wsi walczacej, „TP” 1947 nr 43 s. 5; „Jarzmo” Kłosowskiego, „TW” 1947 nr 28 s. 5; W. Rola, Przeglad piśmiennictwa. Recenzje książek, „PP” 1952 nr 3 s. 217-219; M. Krupiński, Przegląd piśmiennictwa. Recenzje książek, tamże nr 12 s. $410-423$.

${ }^{334}$ P. Jasienica, Opowieść o wojsku czerwonym, „TP” 1947 nr 47 s. 6; L. Mońko, Przeglad piśmiennictwa. Książi, „PP” 1949 nr 4 s. 285-290.

335 Z. Starowieyska-Morstinowa, Człowiek - rzecz dziwna, „TP” $1950 \mathrm{nr} 48$ s. 8-9; W. Rola, Przeglą piśmiennictwa. Recenzje ksiażek, „PP” $1951 \mathrm{nr} 2$ s. 137-138.

${ }^{336}$ J. Parandowski, Między Sztokholmem a Paryżem, „TP” 1947 nr 50 s. 3. 
du Gard, która ukazała się nakładem Spółdzielni Wydawniczej Książka ${ }^{337}$. Za wzór roman-fleuve (,powieści rzeki”) Olgierd Porycki uznał Buddenbrooków (Warszawa 1951) Tomasza Manna, książkę będącą w jego opinii, ,artyzmem techniki pisarza". Jej walorem było również trafne uchwycenie przemijania czasu $^{338}$. Przy okazji nowych wydań książkowych przypomniano na łamach pism katolickich twórczość najwybitniejszych naturalistów. „Błędy i osiągnięcia" francuskiego naturalizmu Porycki zasygnalizował w recenzji Germinala (Warszawa 1951) Emila Zoli. Zwracając uwagę na nacisk autora położony na determinujący wpływ dziedzicznych czynników biologicznych w życiu jego bohaterów, stwierdził: „Trudno o bardziej sprzeczne z katolicyzmem ujęcie problemu wolnej woli. Rola jej, ograniczona warunkami ekonomiczno-społecznymi i obciążeniami biologicznymi, staje się po prostu ich mechaniczną wypadkową. Nie krytyka więc społeczna, niejednokrotnie słuszna, lecz fałszywe rozumienie człowieka leżało u podstaw negatywnego ustosunkowania się Kościoła katolickiego do twórczości Emila Zoli” 339 . Na kartach „Przeglądu Powszechnego” dostrzeżono także dwie powieści innego czołowego pisarza tego nurtu - Guy de Maupassanta. W pierwszej z nich, zatytułowanej Piotr i Jan, nakreślił „typowe studium z dziejów mieszczańskiej rodziny" schyłku XIX w., które posiadało zdaniem recenzenta „głębszą wymowę” ${ }^{340}$. „Przekrój życia różnych środowisk” w ustroju kapitalistycznym wraz z „obnażeniem każdej słabostki i pustki wewnętrznej swego bohatera" pisarz ukazał w dobrej artystycznie powieści Piękny pan (Warszawa 1952), o czym dowiadujemy się z innej recenzji omawiającej ${ }^{341}$. Ówczesną powieść niemiecką reprezentował natomiast powojenny bestseller Ericha Marii Remarque'a Łuk triumfalny (1945), którego zawartość została szczegółowo przedstawiona przez Józefa Mariana Święcickiego ${ }^{342}$.

Z przedstawicieli powieści angielskiej ten sam recenzent szczegółowo omówił „klimat” i „charakterystyczne rysy” Wichrowych wzgórz (Warszawa 1950) Emily Brontë. Brak duchowego przeobrażenia Heathcliffa i nikła rola w akcji powieści „,pierwiastka religijnego” przyczyniły się do stwierdzenia: „Religia służy tutaj co najwyżej do tego, aby nauczyć ludzi elementarnej uczciwości, pewnego humanitaryzmu, nosi charakter wyraźnie gwarancjonistyczny, tj. zmierza w pierwszym rzędzie do zapewnienia doczesnego powodzenia człowiekowi. Ale ten gwarancjonizm jest tu tylko bardzo słabo zaznaczony, bo Bóg zdaje się nie mieć na wydarzenia wydatniejszego wpływu"343.

\footnotetext{
${ }^{337}$ W. Borowy, $O$,,Rodzinie Thibault”, „TP” 1949 nr 38 s. 4.

${ }^{338}$ O. Porycki, Przegląd piśmiennictwa. Recenzje książek, „PP” $1952 \mathrm{nr} 7 / 8$ s. 89-90.

${ }^{339}$ Tenże, Przeglad piśmiennictwa. Recenzje książek, „PP” $1951 \mathrm{nr} 7 \mathrm{~s} .133$.

340 ol. por. [O. Porycki], Przegląd piśmiennictwa. Recenzje książek, „PP” 1952 nr 11 s. 335-336.

${ }^{341}$ M. Olszewski, Przegląd piśmiennictwa. Recenzje książek, „PP” 1953 nr 1 s. 72-73.

342 J.M. Święcicki, E.M. Remarque - epigon biologizmu, „TP” 1949 nr 2 s. 3-4.

${ }^{343}$ Tenże, Monomania „głowy najdroższej”, „PP” $1951 \mathrm{nr} 2$ s. 114.
} 
O zagranicznej powieści dla młodzieży wspomniano przy okazji nowego wydania przez oficynę Wiedza trzech powieści Rudyarda Kiplinga: Kima, Księgi dżungli i Puka z Pukowej Górki (Warszawa 1948). Spotkały się one z ostrą krytyką publicystów „Kuźnicy” i „Wsi”, którzy bardzo surowo ocenili twórczość „piewcy imperializmu angielskiego” ${ }^{344}$. Antoni Gołubiew w polemicznej wypowiedzi, przyznając na początku, że Kipling ,istotnie wychowywał swe społeczeństwo na panów świata”, zganił Zdzisława Skwarczyńskiego i Helenę Wichrzycką za błędne wnioski, wynikłe z ,uproszczeń socjologicznych" w schematycznej interpretacji dzieł angielskiego pisarza. Wyjaśnił jednocześnie: „Kim wiele mówi o Indiach, Księga dżungli o prawach pierwotności, a Puk o samej Anglii. Nie tylko to, o czym pisze $<<$ Kuźnica $>>$, można z tych książek wyczytać, tj. nie sam jeno imperializm” i dalej: „Zresztą myślę, że ważniejsze od tego, co czytamy, jest to, jak czytamy. Tego $<<$ jak $>>$ winna uczyć krytyka literacka. I krytyka omawiając Kima ma prawo i obowiązek powiedzieć czytelnikowi, że życie nie jest tylko grą. Ale zaraz: nie wydawać... nie wznawiać... nie dopuszczać... nie pokazać. Może to jednak przesada" ${ }^{345}$. Gołubiew wystąpił zatem przeciw narzucaniu marksistowskiej interpretacji dzieł oraz propozycji, aby niektórych pozycji nie publikować. W „Przeglądzie Powszechnym" z repertuaru książkowego dla młodzieży omówiono Pierścień i różę (Warszawa 1951) William Makepeace Thackeraya oraz Podróże Guliwera (Warszawa 1949) Jonathana Swifta ${ }^{346}$.

Ilościowo w recenzjach i tak przeważyły propozycje książkowe rodzimych autorów. Po cztery opinie pozytywne otrzymały powieści Jerzego Zawieyskiego Droga do domu (Warszawa 1946) i Eugeniusza Paukszty Trud ziemi nowej (Poznań 1948). Pierwsza z pozycji wydawniczych, nazwana przez Starowieyską-Morstinową „doniosłym wydarzeniem” w polskim życiu umysłowym i literackim, ukazana została jako ,antyteza książek Proustowskich”. Recenzentka uzasadniła to poszukiwaniem autora w bohaterach ,jednolitości wewnętrznej i sensu życia poprzez szczegółowe rozwijanie ich $<<$ curriculum vitae $>>$ " w przeciwieństwie do znanego pisarza, który „użył czasu jako siły niszczącej i dał w swym dziele przewage pierwiastkom analitycznym nad pierwiastkami syntetycznymi” ${ }^{347}$. Maria Chojecka wysoko oceniła natomiast „poziom moralny pamiętnika”, w którym główny bohater „porachował się ze swoim sumieniem” w historii swego życia ${ }^{348}$. Do pogłębionych rozważań zawartych w powieści dobrze odnieśli się również współpracownicy „Tygodnika Warszawskiego” i „Znaku” ${ }^{49}$. Trud

${ }^{344}$ Goa. [A. Gołubiew], Spotkania literackie. Nie upraszczać, „TP” 1948 nr 25 s. 5.

345 Tamże.

${ }^{346}$ M. Krupiński, Przegląd piśmiennictwa. Recenzje książek, „PP” 1951 nr 2 s. 135-136;

O. Porycki, Przeglad piśmiennictwa. Recenzje ksiażek, „PP” $1951 \mathrm{nr} 8$ s. 211-212.

${ }^{347}$ Z. Starowieyska-Morstinowa, W poszukiwaniu straconego czlowieka, „TP” 1946 nr 20 s. 4.

${ }^{348}$ M. Chojecka, Przeglad piśmiennictwa. Książki, „PP” 1948 nr 3 s. 218.

${ }^{349}$ M. Morstin-Górska, Najpiękniejsza przygoda, „TW” 1946 nr 27 s. 5. 
ziemi nowej był debiutem literackim Eugeniusza Paukszta, w którym choć „wątek powieściowy był zbyt wątły, tło jednostronnie malowane”, a styl niezbyt „należycie opracowany", został doceniony za zainteresowanie autora tematem Ziem Odzyskanych $^{350}$. Była to bowiem pierwsza powieść o tej problematyce. Władysław Jan Grabski w recenzji książki stwierdził: „Pisząc jak umiał, dał nam uczciwy a wzruszający obraz osiedlania się grupy repatriantów wileńskich na Pomorzu, zakorzeniania się ich na ziemi wykarczowanej z niemczyzny [...] Książka jest szczera i apolityczna” ${ }^{351}$. Jan Załuski w „Tygodniku Katolickim” pochwalił ją za „gruntowne” opisy etapów kształtowania się życia na tych terenach oraz osobiste doświadczenia i przemyślenia autora ${ }^{352}$. „Powieścią pionierską" o „społecznej i dokumentarnej wartości" stała się natomiast dla Wandy Kieszkowskiej, która zwróciła również uwagę odbiorców „Głosu Katolickiego” na liczne opisy przyrody i charakterystykę postaci ${ }^{353}$. Równie pozytywnie do książki odniósł się Zygmunt Lichniak na łamach „Przeglądu Powszechnego"354.

Trzy pochwalne oceny otrzymała pozycja Władysława Dunarowskiego Leżąc krzyżem (Warszawa 1947) ${ }^{355}$. Z aprobatą przyjęto także Farbowane lisy (Wrocław 1947) Tadeusza Kudlińskiego oraz zauważono Miód z opoki (Poznań 1947) Szczepana Jeleńskiego ${ }^{356}$.

Zdecydowanie rzadziej w „Tygodniku Powszechnym” występowały recenzje wyraźnie dezaprobujące książkę. Warto zwrócić uwagę na niektóre zarzuty stawiane przez recenzentów. Przykładowo Zofia Starowieyska-Morstinowa świeżo wydaną pozycję Eugenii Kocwy Maria wyrusza w świat nazwała „co najmniej pomyłką" ${ }^{357}$, natomiast Antoni Gołubiew za książkę szkodliwą społecznie uznał Sprzysiężenie Stefana Kisielewskiego ${ }^{358}$. Do Sprzysiężenia nawiązał też redaktor Jerzy Turowicz, pisząc: ,książka Kisielewskiego nie jest katolicka, jest pogańska, niemal antykatolicka, wobec tego Kisielewski nie jest pisarzem katolickim, dlaczego więc $<<$ Tygodnik Powszechny $>>$ drukował go i lansował jako jednego ze swych czołowych publi-

${ }^{350}$ W.J. Grabski, Trud ziemi nowej, „TP” $1948 \mathrm{nr} 11$ s. 7.
${ }^{351}$ Tamże.
${ }^{352}$ J. Załuski, ,,Trud ziemi nowej” Eugeniusza Paukszty, „TK” $1948 \mathrm{nr} 19$ s. 133.
${ }^{353}$ W. Kieszkowska, Debiut powieściowy Eugeniusza Paukszty, „GK” $1948 \mathrm{nr} 14$ s. 124-125.
${ }^{354}$ Z. Lichniak, Przegląd piśmiennictwa. Książki, „PP” $1948 \mathrm{nr} 4$ s. 297-298.
${ }^{355}$ S. Kisielewski, Noc inteligentów nie zgnitych, „TP” $1947 \mathrm{nr} 48$ s. 10; A. Madej, Farbowane lisy, „TW” 1947 nr 30 s. 5; Z. Starowieyska-Morstinowa, Przeglad piśmiennictwa. Ksiażki, „PP” 1948 nr 2 s. 138-139; S. Lichański, Powieść o prawdziwej wsi, „TW” 1948 nr 30 s. 6; zsm. [Z. Starowieyska-Morstinowa], Wieś na co dzień, „TP” 1948 nr 21 s. 10; Przegląd piśmiennictwa. Ksiązka, „PP” 1948 nr 4 s. 298-300.

${ }^{356}$ Z. Lichniak, Przegląd piśmiennictwa. Książki, „PP” 1948 nr 4 s. 300-302; A. Rogalski, „Miód z opoki” Szczepana Jeleńskiego, „GK” 1948 nr 8 s. 68-69; A. Szelążek, Miód z opoki, „TW” $1948 \mathrm{nr} 9$ s. 3.

${ }^{357}$ Z. Starowieyska-Morstinowa, Niemiarodajny debiut, „TP” 1946 nr 50 s. 8.

${ }^{358}$ A. Gołubiew, ,, Sprzysiężenie” Stefana Kisielewskiego, „TP” 1947 nr 2 s. 7. 
cystów?" ${ }^{359}$. W dalszej części wypowiedzi wythumaczył to niechęcią redakcji do zamykania się w „getcie”, dowodząc zbliżania się autora do katolicyzmu.

Głównie na łamach „Tygodnika Powszechnego” analizowano powieści, które reprezentowały światopogląd odmienny od katolickiego. Zofia StarowieyskaMorstinowa w negatywnej recenzji o Inkluzowym wianie (Warszawa 1946) Józefa Mortona - współpracownika i redaktora „Chłopskiej Drogi” oraz „Wsi” - pisała: „Ta pouczająca historia dramatycznej walki między szlachetnym postępowym wolnomyślicielem a tępymi katolickimi obskurantami nie jest też pozbawiona wartości literackich [...] I choć prawdę deformuje i paczy, czyni to z pasją i namiętnością rzadko w tym natężeniu spotykaną"360. Książką, w której za „głównego winowajcę" uznano Kościół, była pozycja Jana Wiktora zatytułowana Skrzydlaty mnich (Wrocław 1947) ${ }^{361}$, natomiast Królewna i jej panny - jak pisała recenzentka - mogłaby być pożyteczną książką dla młodzieży, także książką popularną, gdyby nie była „cała jakby osypana pudrem pornograficznym”"362. „Powieścią laicką” i „,szkodliwą społecznie” nazwał Leszek Kuc Pożegnania Stanisława Dygata ${ }^{363}$.

W recenzjach powieści często zwracano uwagę na sposób przedstawiania wątków religijnych. W niezwykle umiejętny sposób Jan Karol Wayda pisał o fragmentach Miasteczka na dłoni Jana Drdy (chwaląc notabene książkę w znacznej części recenzji za pogodny ton): „I - rzecz dziwna - w jednym wypadku traci Drda swój spokojny, wyrozumiały uśmiech. Ilekroć mówi o kościele i proboszczu, zatraca swój obiektywistyczny humanizm. Jakaś niepojęta zaciekłość i złość cechuje Drdę, ilekroć wraca do postaci proboszcza Volmana: ksiądz nie posiada ani jednej cechy dodatniej, jest hipokrytą, chciwcem, żarłokiem, dusigroszem, kłamcą, egoistą obojętnym na los bliźnich. Drda ma przekonywującą i sympatyczną tolerancję względem wszystkich, zdoła wytłumaczyć pijaka, kłusownika, zabijakę - ale gdy mowa o proboszczu, odnajduje tylko zjadliwość" 364 . Podobnie w ocenie Józefa Mariana Święcickiego czytamy o wprowadzeniu przez Herberta George Wellsa do powieści zatytułowanej Ludzie jako bogowie postaci ojca Amertona tylko po to, aby dać ,upust swojej niechęci, a nawet nienawiści do katolicyzmu" 365 . W opinii o biografii Cervantesa Bruno Franka czytamy natomiast: „jakkolwiek ma się wrażenie, że książka jest owocem sumiennych studiów historycznych, bardzo wyraźnie występuje w niej dziwna tendencyjność, gdy chodzi o sprawy religii i Kościoła. Autor nie ukrywa tu swej niechęci. Nie wydaje się, by starał się sprawę zbadać; powtarza wszystkie komunały, jakimi od wieków wrogo-

\footnotetext{
359 J. Turowicz, Sprawa Stefana Kisielewskiego, „TP” 1947 nr 14/15 s. 5.

${ }^{360}$ Z. Starowieyska-Morstinowa, Powieść i nowela, „TP” 1947 nr 13 s. 9.

361 Tamże.

362 Tamże.

${ }^{363}$ L. Kuc, Zamiast obiadu - ananasy, „TP” 1948 nr 20 s. 13.

364 J.K. Wayda, Powieść o miasteczku, ,TP” 1947 nr 48 s. 9.

365 J.M. Święcicki, Ludzie jako bogowie, „TP” 1948 nr 29 s. 4-6.
} 
wie Kościoła starali się obniżyć jego autorytet i poderwać powagę"366. Mało znany polskiemu czytelnikowi przedstawiciel angielskiej powieści XIX w. William Makepeace Thackeray w Targowisku próżności wykreował pesymistyczną wizję człowieka. Nie uważał bowiem, aby sumienie ludzkie było istotnym czynnikiem normującym współżycie ludzi. Pisarz uważał, że jest ono słabe i łatwe do uśpienia, natomiast od złego czynu powstrzymuje człowieka lęk przed karą, a nie wewnętrzny głos moralny. Recenzentka zauważyła: „Pochłonięty śmiesznościami i głupotą pisarz rzadko kieruje swą myśl w stronę Bożego Majestatu. Kiedy to już jednak robi, wsącza gorycz do swych rozważań"

Wreszcie opiniowano książki na wskroś ateistyczne, jak np. Wszyscy ludzie sa śmiertelni Simone de Beauvoir (żony Sartre'a i wyznawczyni egzystencjalizmu), którą publicystka nazwała „książką dziwaczną”, ale jednocześnie „ciekawą, a nawet cenną” ze względu na ukazanie ,przerażającego ładunku zniszczenia, jaki się w światopoglądzie egzystencjalistów kryje" ${ }^{368}$. Jeżeli w powieściach zabrakło w ogóle wątku religijnego, pisano o tym. Leszek Kuc stwierdził odważnie o cyklu Kazimierza Brandysa Między wojnami: ,autor, mimo swej zapowiedzi nie odtworzył losu człowieka $<<$ w jego pełnym rozmiarze $>>$. Nie ma mowy o pełnym obrazie człowieka bez spojrzenia $<<$ z perspektywy Boga $>>[\ldots] \mathrm{Z}$ analizy utworów jak i z wypowiedzi autora wynika jasno, że ten wymiar rzeczywistości został w omawianych utworach pominięty. Obraz uległ zniekształceniu [...] Zamiast więc realistycznej prawdy o człowieku, otrzymujemy laicki, materialistyczny mit o nim" ${ }^{\prime 69}$.

W szerokim wyborze powieści obyczajowej publicyści pism katolickich szczególnie wyczuleni byli na wątki religijne. $Z$ właściwym sobie znawstwem polemizowali z fałszywymi opiniami o Kościele i nieprawdziwą interpretacją prawd wiary. Wyraźnie zaznaczali brak w dziełach warstwy metafizycznej i wynikające z tego zubożenie powieści. W propozycjach czytelniczych nie zabrakło książek przeznaczonych dla młodzieży.

\subsubsection{Inne odmiany tematyczne powieści}

Tematyka omawianych pozycji książkowych wykraczała poza przedstawioną wyżej problematykę. Na łamach pism katolickich chętnie odnoszono się do prozy, w której autorzy podejmowali zagadnienia społeczne. Nie stroniono także od oceny powieści politycznej i socrealistycznej. Dla relaksu i rozrywki czytelnikom proponowano książki sensacyjno-kryminalne, fantastyczne i marynistyczne.

\footnotetext{
${ }^{366}$ Z. Starowieyska-Morstinowa, W cieniu Filipa II, „TP” 1950 nr 42 s. 8.

${ }^{367}$ A. Szala, Mistrz ciemnych barw, „TP” $1951 \mathrm{nr} 39$ s. 9.

${ }^{368}$ Z. Starowieyska-Morstinowa, Cele nieostateczne, „TP” $1948 \mathrm{nr} 23$ s. 3-4.

${ }^{369}$ L. Kuc, To jeszcze nie realizm, „TP” 1949 nr 12 s. 3.
} 
Z dawnych znanych polskich powieści nawiązano do Chłopów Władysława Reymonta i Placówki Bolesława Prusa. „Rewizjonistyczne tezy” wobec pierwszej z nich postawił Józef Marian Święcicki na stronach „Przeglądu Powszechnego”. Pisał, że „wbrew konwenansowym sądom, postawa duchowa Reymonta jest w Chłopach wybitnie rozszczepiona, pełna różnych, nieraz już zasadniczych przeciwieństw, a nawet sprzeczności, na skutek czego główne zadanie pisarza: uchwycenie profilu cywilizacyjnego polskiej wsi, nie wyszło szczęśliwie" ${ }^{370}$. Udowodnił to na przykładach z powieści, zwracając uwagę m.in. na „smutny obraz stosunków rodzinnych”, postać Macieja Boryny nazwanego „prawym chrześcijaninem” oraz „rażące mitologizowanie postaci” ${ }^{371}$. W konkluzji swej wypowiedzi stwierdził: „Zaczerpnięty z klimatu moderny liberalizm obyczajowy, rozgrzeszający aspiracje i namiętności jednostki, uprawniający jej instynkty i impulsowe zachcianki koliduje tutaj wyraźnie z dążeniami wiejskiej postawy zmierzającej do zaprowadzenia ładu i rygoru moralnego" ${ }^{372}$. Publicysta "Tygodnika Warszawskiego" przypomniał natomiast Placówkę, chwaląc „humanitaryzm Prusa”, będący głosem o „bolesnych stronach życia” i „krzywdzie szarego człowieka”, wolnym jednak od „klasowej ciasnoty i nienawiści” ${ }^{773}$. Nowe wydanie „dzieła sztuki dużego kalibru", W roztokach Władysława Orkana, zapowiedział w pozytywnej recenzji Stanisław Pigoń. Przedstawił je jako „obraz rzetelnie pokazanego życia wiejskiego" i cenną książkę 374 .

Dobrze odebrano powieść o środowisku wiejskim zatytułowaną Leżąc krzyżem (Warszawa 1947) Władysława Dunarowskiego. Pochwalona za „nie podrobiony autentyzm" i ,walory literackie”, budziła zastrzeżenia Stefana Lichańskiego z powodu braku ,jakiegoś układu odniesienia, który by opisywaną przez autora rzeczywistość pozwalał w pełni zrozumieć i odpowiednio zawartościować”375. Za przykład powieści politycznej może posłużyć Bieg do Fragalà (Warszawa 1952) Juliana Stryjowskiego pisany „trochę w żywiole publicystycznym”"376. Książką do „szpiku kości bolszewicką” Paweł Jasienica nazwał w recenzji omawiającej Cichy Don (Kraków 1946) Michała Szołochowa $a^{377}$.

Trzykrotnie w „Tygodniku Powszechnym” zabrano głos na temat Wegla Aleksandra Ścibora-Rylskiego. Powieść była „udaną próbą realizacji zadań wytyczonych prozie realizmu socjalistycznego", jak dowiadujemy się z wypowiedzi Wacława Roli, docenioną za „umiejętność kreślenia postaci” i „dobre opanowanie

370 J.M. Święcicki, W pótwiecze „,Chłopów”, „PP” 1952 nr 1 s. 33.

${ }^{371}$ Tamże, s. $30-44$.

372 J.M. Święcicki, W półwiecze „Chłopów”, „PP” 1952 nr 1 s. 45.

373 J. Skrzanecki, Placówka, „TW” 1947 nr 35 s. 3.

${ }^{374}$ S. Pigoń, ,, W roztokach” Orkana, „TW” 1946 nr 24 s. 6-7.

${ }^{375}$ S. Lichański, Powieść o prawdziwej wsi, „TW” 1948 nr 30 s. 6.

${ }^{376}$ M. Krupiński, Przegląd piśmiennictwa. Nagrodzone książki, „PP” 1952 nr 12 s. 419-420;

Z. Starowieyska-Morstinowa, W Rocca di Zolfo, „TP” 1952 nr 49 s. 7.

${ }^{377}$ P. Jasienica, Cichy Don, „TP” 1949 nr 40 s. 1-2. 
rzemiosła pisarskiego" ${ }^{378}$. Recenzent zaznaczył jednak, że „W Węlu dostrzeżemy niepełne, wypaczone perspektywy zagadnienia człowieka, jakieś zawężenie ludzkich ambicji, dążeń, tęsknot - ograniczenie ich do zewnętrznej, doczesnej, a więc nie jedynej i niewystarczalnej płaszczyzny życia ludzkiego"379. Publicysta podpisany pseudonimem „gaw” w polemicznej recenzji bronił z kolei pierwszej polskiej „powieści produkcyjnej z konfliktem socjalistycznym” przed krytyką Tadeusza Drewnowskiego w ,Życiu Literackim”, który zarzucił autorowi „przerysowanie i uprymitywnienie psychologii postaci” ${ }^{380}$. W innej, również polemicznej, wypowiedzi Jan Paweł Gawlik nie zgodził się ze stwierdzeniami Zygmunta Lichniaka na łamach „Dziś i Jutro”, odnoszących się do mało przekonującego przedstawienia negatywnych postaci w książce. Słowo krytyki uznał za puste i bez rzeczowego uzasadnienia; stwierdził też ,,...] warsztat Lichniaka skostniał, sądy straciły ostrość i precyzję. Wśród instrumentów oceny znalazła się sztampa. [...] Chwilami wydaje się, że Lichniak nie czyta recenzowanych książek"381. Z krytyczną opinią Marka Krupińskiego spotkała się ,schematyczna powieść produkcyjna z idealnym przodownikiem pracy" - Romana Husarskiego Nowy mur (Warszawa 1951). Zarzutem recenzenta był sposób przedstawienia zmian w bohaterach jedynie poprzez „formułki słowne”, brak „wyraźnej nici myślowej” w fabule oraz nieobecność zwartej i skończonej kompozycji ${ }^{382}$.

Wbrew konwencji powieści detektywistycznej powstała z kolei Zbrodnia $w$ dzielnicy pótnocnej (Poznań 1948) Stefana Kisielewskiego, który skomplikował „zbytnio fabułę, tak, że czytelnik już w końcu nie rozumie nic" ${ }^{383}$. StarowieyskaMorstinowa pozytywnie oceniając pozycję, pisała: „Najważniejszą zaletą książki - zaletą literacką, nie detektywistyczną - jest oddalenie autora od przedmiotu. I tym się najbardziej różni Zbrodnia $w$ dzielnicy pótnocnej od swych koleżanek $<<$ po rodzaju>>. Od pierwszej kartki wiemy, że autor się bawi, że pisze dla żartu, dla $<<$ kawału $>>$, że jak prestidigitator żongluje tylko barwnymi kulkami" ${ }^{384}$. Stefan Kisielewski z kolei czytelnikom „Tygodnika Powszechnego” zaproponował nowo wydaną sensacyjno-kryminalną powieść Grahama Greene'a Broń na sprzedaż (Warszawa 1951), zastanawiając się, dlaczego pisarze katoliccy chętnie uciekają się do tego gatunku prozy (Chesterton, Bernanos). Znany publicysta zwrócił uwagę, że w powieści „,nie ma prawie mowy o religii, bardzo zaś niewiele o Bogu, a mimo to od pierwszych stron wprowadzeni jesteśmy w ową podstawową antynomiczność moralną, nie pozwalającą wątpić, że książkę tę napisano w myśl pewnej określonej postawy, że pisał ją świadomie człowiek głęboko

\footnotetext{
${ }^{378}$ W. Rola, ,, Węgiel, węgiel niosa z głębiny...”, „TP” $1951 \mathrm{nr} 17$ s. 5.

${ }^{379}$ Tamże, s. 10.

${ }^{380}$ gaw, Bez ogródek. Pokusa łatwości, „TP” 1951 nr 19 s. 12.

381 J.P. Gawlik, O rzetelną krytykę, „TP” 1951 nr 25 s. 7.

${ }^{382}$ M. Krupiński, Przegląd piśmiennictwa, „PP” 1952 nr 3 s. 219-220.

${ }^{383}$ Z. Starowieyska-Morstinowa, Znowu pod włos, ,TP” 1948 nr 17 s. 12

384 Tamże.
} 
przejęty katolicyzmem” ${ }^{385}$. W pozytywnej ocenie podkreślił „przenikliwe i bezlitosne” obnażanie „nędzy i brzydoty świata” przez autora ${ }^{386}$. Dorobek literacki Kazimierza Truchanowskiego powiększył się o „ciekawą” powieść fantastyczną zatytułowaną Zmowa demiurgów (Warszawa 1947), którą Bohdan Ostromęcki uznał za „poważny i pożądany wkład w naszą literaturę"

W osobnej grupie omówień znalazły się powieści marynistyczne. Do starszej młodzieży adresowany był Wielki sztorm (Warszawa 1947) Ryszarda Manugiewicza; w opinii Władysława Wnuka autor zawarł w powieści zbyt wiele „,nużącej dydaktyki” i dzieło było „klasycznym przykładem zdeformowanej artystycznie książki" pisanej na tzw. zamówienie społeczne. Recenzent nie zgodził się także z występującym w niej „szkodliwym nałogiem” rodzimej literatury gloryfikowania polskich zdolności i cech ${ }^{388}$. Klasyczna pozycja literatury amerykańskiej Hermana Melville'a Bestia morska (Warszawa 1948), również o tematyce morskiej, wedle opinii publicysty była „dziełem niejednolitym pod względem filozofii życia, ale ciekawym i oddającym znakomicie ducha Ameryki z połowy XIX wieku”, a jednocześnie „książką dość nudną" ${ }^{899}$. W rubryce „Głosu Katolickiego” zatytułowanej Co warto czytać? odbiorcy mogli dowiedzieć się, że ta sama powieść była pierwszą thumaczoną na język polski z dorobku tego autora ${ }^{390}$. Z kolei Antoni Gołubiew w rubryce „Tygodnika Powszechnego” Spotkania literackie zachęcił czytelników, aby rozpoczęli lekturę dzieł Josepha Conrada od Zwierciadła morza (Warszawa 1949). Krytycznie do debiutu Andrzeja Lepkowskiego Ludzie znad zatoki (Warszawa 1952) podszedł Zenon Łukasiewicz w recenzji zamieszczonej w „Tygodniku Katolickim”. Pomimo ,urzekających partii opisowych przyrody” i zapowiadającego się talentu pisarskiego zanotował niekonsekwencje w powieści, która na początku przejawiła charakter wyraźnie reportażowy. Zabrakło w niej też ciągłej i jednolitej akcji ${ }^{391}$. Pierwszą powieścią morsko-awanturniczą znanego polskiego pisarza wydaną po wojnie była Czarna Feluka (Łódź 1948) pochwalona za żywą akcję, a jednocześnie ,powściągliwość i umiar w dozowaniu przygód i fantastycznych sytuacji” oraz bogate słownictwo morskie ${ }^{392}$.

Recenzje powieści stanowiły liczną i ważną grupę wypowiedzi prasowych głównie w „Tygodniku Powszechnym”, „Przeglądzie Powszechnym” i „Tygodniku Warszawskim”. Redakcje pozostałych tytułów prasowych: „Głosu Katolickiego”, „Tygodnika Katolickiego” i „Znaku” raczej zamieszczały je sporadycznie. Na temat niektórych nowości wydawniczych wypowiedziano się w kilku

\footnotetext{
${ }^{385}$ S. Kisielewski, Przeciwieństwa się stykaja, „TP” 1951 nr 26 s. 8.

386 Tamże, s. 9.

${ }^{387}$ B. Ostromęcki, Zmowa demiurgów, „TW” 1948 nr 4 s. 7.

${ }^{388}$ W. Wnuk, Z wydawnictw marynistycznych, „TP” $1948 \mathrm{nr} 20$ s. 14.

${ }^{389}$ K.W., Dwaj amerykańscy klasycy, „TW” 1949 nr 29 s. 9.

${ }^{390}$ Co warto czytać?, „GK” 1948 nr 29 s. 253.

${ }^{391}$ Z.M. Łukasiewicz, Debiut Andrzeja Łepkowskiego, „TK” 1953 nr 33 s. 231.

${ }^{392}$ A. Madej, Powieść korsarska, „TW” 1948 nr 24 s. 10.
} 
pismach. Czasami recenzje były zgodnie pochlebne, jak w przypadku historycznej powieści katolickiej Bolesław Chrobry, a niekiedy wyrażały zupełnie odmienne oceny, czego dobrym przykładem może być Sedno sprawy. Recenzowano powieści rodzime, jak też zagraniczne (angielskie, francuskie, amerykańskie i inne) przeznaczone dla dorosłych i młodzieży. Zauważano też dzieła nagradzane. Dużo uwagi poświęcano w wypowiedziach wątkom religijnym, światopoglądowym i moralnym.

Utwory powieściowe oceniano pod kątem walorów artystycznych, kompozycyjnych, refleksyjnych, jak również pod względem warstwy terminologicznej, językowej oraz stylu. Zwracając pilną uwagę na konstrukcję, śledzono „zamazanie gatunkowe" ${ }^{393}$, czyli brak wyraźnego rozgraniczenia np. między powieścią a reportażem i pamiętnikiem. Pozycje książkowe chwalono za wymowę i sens, podjęty temat i sposób jego ujęcia. Ustosunkowywano się również do nowego wydania czy thumaczenia, ganiąc niedbały przekład lub korektę.

\subsubsection{Opowiadania i nowele}

W promocji książki na łamach wybranych tytułów katolickich nie pominięto mniejszych form literackich, jak opowiadania i nowele. Ze względów praktycznych ujęto je w jednym podrozdziale i w spisie recenzowanych książek pod wspólną nazwą „opowiadania”. Najczęściej polecano je w recenzjach „Tygodnika Powszechnego" (57 omówień), „Przeglądzie Powszechnym” (30) i „Tygodniku Warszawskim” (17). W pozostałych tytułach prasowych „Głosie Katolickim” (3), „Znaku” (1) i „Tygodniku Katolickim” (1) oceny tego typu pojawiały się sporadycznie. Należy zaznaczyć, że na 57 recenzji w krakowskim tygodniku siedem przypadło tylko na opowiadania autorów obcych, w „Przeglądzie Powszechnym” jedynie sześć dotyczyło utworów zagranicznych, natomiast w „Głosie Katolickim”, Tygodniku Warszawskim” i „Znaku” zamieszczono po jednej wypowiedzi z literatury obcej. Łącznie w omawianych periodykach ukazało się 110 recenzji.

W „Tygodniku Powszechnym” na 57 recenzji większość miała charakter pozytywny (31), po nich uplasowały się omawiające (18), negatywne (5) i krytyczne (3). Łamy „Przeglądu Powszechnego" dostarczyły odbiorcom najwięcej opinii omawiających (10) i krytycznych (9), następnie zaś pozytywnych (7) i negatywnych (4). W „Tygodniku Warszawskim” przeważyły pozytywne opinie (10), poza tym wydzielono też trzy omawiające, trzy negatywne i jedną krytyczną. „Głos Katolicki” zamieścił zaledwie dwie pozytywne recenzje i jedną krytyczną, „Znak” jedną omawiającą, a „Tygodnik Katolicki” jedną pozytywną.

${ }^{393}$ N.K., Przegląd piśmiennictwa. Recenzje książek, „PP” 1952 nr 4 s. 295 [Anna Kowalska, Wielka próba, Warszawa 1951]. 
Zofia Starowieyska-Morstinowa była najbardziej aktywną recenzentką opowiadań na łamach „Tygodnika Powszechnego” (opublikowała 21 opinii). Kilkakrotnie pod ocenami książek podpisali się: Maria Jarczyńska (6), Maria Morstin-Górska (4), Wacław Rola (4) i Włodzimierz Maciąg (3). Po dwie recenzje napisali: Józefa Golmont, Bogusław Grodzicki, Zofia Lewinówna, Stefan Lichański i Wojciech Żukrowski. Raz swe opinie wyrazili: ks. Franciszek Blachnicki, Maria Dobraczyńska, Antoni Gołubiew, Paweł Jasienica, Stefan Kisielewski, Stanisław Łapiński, Hanna Malewska, Włodzimierz Wnuk i osoba ukrywająca się pod inicjałami J.C. Na łamach „Przeglądu Powszechnego” przeważały recenzje Zygmunta Lichniaka (10) i Zofii Starowieyskiej-Morstinowej (4). Trzy opinie o książkach wyrazili Wacław Rola, Marek Krupiński i Olgierd Porycki. W „Tygodniku Warszawskim” na temat opowiadań najczęściej głos zabierali: Antoni Madej (5), Wanda Bacewiczówna (2) i Zuzanna Rabska (2). Maria Tongwin na łamach „Głosu Katolickiego” napisała dwie recenzje, w „Tygodniku Katolickim” raz wypowiedział się Zygmunt Lichniak, w „Znaku” natomiast ukazała się jedna recenzja anonimowa.

Ze względu na dość bogaty materiał prasowy w podrozdziale uwzględniono tylko niektóre wypowiedzi o tomach opowiadań. Wybrano książki najczęściej recenzowane $\mathrm{w}$ różnych czasopismach katolickich, jak też twórczość autorów najchętniej omawianą przez publicystów. Uwzględniono przy tym nagrodzone nowości oraz kilka debiutów.

Zdaniem Wacława Roli napisanie opowiadania było trudniejsze niż powieści, wymagało bowiem od pisarza większej ,samokontroli, dyscypliny, rygorów pisarskich i oszczędności wyrazu" ${ }^{394}$. Jak stwierdził, w tym gatunku literackim nie w pełni mieściły się trzy opowiadania Jana Dobraczyńskiego, wydane pod wspólnym tytułem Największa miłość (Warszawa 1950), które ukazały się nakładem IW PAX. Zdaniem recenzenta Jeep było jednym z „feralnych” przykładów, który rozbiło koncepcję ideową całego tomu. W nim bowiem, jak twierdził recenzent, Dobraczyński ,sprowadził wszystko do wymiarów ziemskich”, nie pamiętając, że w religii katolickiej największy wymiar miłości pochodzi od Boga. Po wyliczeniu błędów formalnych Rola docenił jednak tom za „ciekawy materiał do przemyśleń”, dobrze nakreślone sylwetki oraz tok akcji opowiadań ${ }^{395}$. Bardziej pogłębioną pod względem teologicznym recenzję, również na łamach „Tygodnika Powszechnego”, skupiając się na opowiadaniu zamykającym tę samą książkę, napisał ks. Franciszek Blachnicki. Zauważył duże podobieństwo w sposobie przedstawienia zagadnienia świętości w noweli Największa miłość z powieścią Władysława Grabskiego $W$ cieniu kolegiaty. Analizując treść opowiadania, problem dążenia do świętości ujął w zdaniu: „o świętości ostatecznie nie decyduje poryw woli ludzkiej, lecz wybór

${ }^{394}$ W. Rola, Nowa książka Dobraczyńskiego, „TP” 1950 nr 37 s. 9.

${ }^{395}$ Tamże. 
łaski”"396. Zygmunt Lichniak w pozytywnej opinii o zbiorze rosnącą popularność i poczytność utworów Dobraczyńskiego wytłumaczył stałym rozwojem literackim pisarza. Dowodem na to miał być fakt, że „każda kolejna jego książka była lepsza od poprzedniej" ${ }^{397}$. Marek Krupiński, podobnie jak pozostali recenzenci, uznał, że debiutancki tom opowiadań Dobraczyńskiego został źle skonstruowany „zarówno pod względem formy jak i treści”, przyznając pierwszeństwo opowiadaniu tytułowemu, które wypadło „najbardziej interesująco" ${ }^{398}$. Opowiadania czterokrotnie ocenione na łamach czasopism katolickich, pomimo wytknięcia przez omawiających ich słabych stron, zostały przyjęte z uznaniem.

Podczas lektury tomów Nowa miłość i Stara cegielnia Jarosława Iwaszkiewicza czytelnik miał uświadomić sobie „odwieczne zmaganie człowieka o wartości najwyższe, których ceną było życie lub śmierć" ${ }^{399}$. Odbiorcy mogli dowiedzieć się z recenzji, że nagrodę Odrodzenia przyznano pisarzowi za pierwszy z nich i Nowelom włoskim (Warszawa 1947) ${ }^{400}$, które w opinii Zofii StarowieyskiejMorstinowej nie były „szczytami twórczości” znanego prozaika. Zbiór zatytułowany Nowa miłość, ,niejednolity” tematycznie, zawierał m.in. opowiadanie Joanna od Aniołów, które „wiele narobiło hałasu” i wyglądało jak , przykre drwiny z rzeczy poważnych" ${ }^{\prime 01}$. W innej recenzji ta sama publicystka wyraziła się o nim jako o ,artystycznie fałszywym” i budzącym „mimo wszystko niesmak”402. Wanda Bacewiczówna uznała natomiast tom za „książkę pociągającą”, doceniając ją za analizę psychologiczną, ,rozległość i niezwykłość tematyki” oraz różnorodność przedstawionych typów ludzkich ${ }^{403}$. Pierwszy z wymienionych tytułów książkowych otrzymał dobre opinie recenzentów w „Tygodniku Powszechnym” i „Tygodniku Warszawskim”. Z większym krytycyzmem odniosła się do niego w „Przeglądzie Powszechnym” Starowieyska-Morstinowa, atakując - głównie w obu recenzjach - wspomniane opowiadanie Joanna od Aniołów. W opinii „Tygodnika Powszechnego" zauważyć można było ponadto zdecydowanie więcej łagodności w wypowiedzi.

Na łamach katolickich czasopism społeczno-kulturalnych zgodnie zaprezentowano twórczość Wojciecha Żukrowskiego jako niezwykle „żywotną i żarliwą” $\mathrm{w}$ tematyce oraz artystycznie dobrą. W trzech różnych tytułach prasowych zabrano głos na temat dwóch tomów opowiadań: Piórkiem flaminga (Katowice 1948) i Z kraju milczenia (Warszawa 1946). Pierwszy ze zbiorów pochwaliła Zofia

${ }^{396}$ F. Blachnicki, Pokusa świętości, „TP” 1951 nr 7 s. 5.

${ }^{397}$ Z. Lichniak, Nowe osiagnięcia J. Dobraczyńskiego, „TK” 1950 nr 29 s. 219-220.

${ }^{398}$ M. Krupiński, Przegląd piśmiennictwa. Recenzje książek, „PP” $1950 \mathrm{nr} 10$ s. 353-354.

${ }^{399}$ Z. Starowieyska-Morstinowa, Dwa tomy, „TP” $1946 \mathrm{nr} 47$ s. 8.

${ }^{400}$ Zob. W. Żukrowski, Nowele włoskie, „TP” 1947 nr 42 s. 7.

${ }^{401}$ Z. Starowieyska-Morstinowa, Przegląd piśmiennictwa. Książki: powieści, „PP” $1948 \mathrm{nr} 1$ s. $60-61$.

${ }^{402}$ Taż, Dwa tomy, „TP” 1946 nr 47 s. 8.

${ }^{403}$ W. Bacewiczówna, Nareszcie proza poza czasem, „TW” 1947 nr 2 s. 6. 
Starowieyska-Morstinowa za „fantazję, doskonałą groteskę i oryginalny dowcip”. W jej opinii „opowiadania przewrotne” nie tylko „dzieliły, drażniły, ale i urzekały”. Na końcu recenzji konstatowała: „Toteż gdy się czyta tę książkę tak błahą z pozoru, a o tak wielkim ciężarze gatunkowym, tak zdawałoby się śmieszną a $\mathrm{w}$ gruncie rzeczy tragiczną - ma się wrażenie, że w niej każda myśl twardnieje rzeczownikiem, każde uczucie krzepnie w obraz. Słowo jest bryłą, zdanie sceną pełną ruchu, a książka tak jest napęczniała od soków żywotnych, tak zjeżona wypukłością rzeczywistości, że strach ją zamykać, aby nie sprasować na zwykłą papierową historię - wibrującej na jej kartach bujności życia" ${ }^{404}$. Hanna Malewska za „dużej miary osiągnięcie” uznała drugi ze zbiorów Żukrowskiego, pisząc jednocześnie: ,nie było i nie będzie chyba głosu, który by temu zaprzeczył” ${ }^{{ }^{2}}$. W zawartości analizowanych tu czasopism katolickich rzeczywiście takiego głosu nie było, gdyż opowiadania otrzymały pochlebne recenzje zarówno w „Tygodniku Powszechnym”, jak i w „Tygodniku Warszawskim” oraz „Głosie Katolickim”. Malewska nazwała starannie wydany przez Czytelnika tom „odważną, polską, niezwykłą i piękną książką”, a tok opowiadania narratora „,naturalnym i przejrzystym". Tak istotna w książce o tematyce wojennej strona religijna była, jej zdaniem, niezwykle przekonywająca, a przez to książka mogła być „kłopotliwa dla marksisty"406. Wanda Bacewiczówna dostrzegła natomiast w niej „ukochanie ziemi i piękna”. Pisała, jak przystało na recenzenta „Tygodnika Warszawskiego”: „Wszystkie opowiadania przepełnione są uczuciem żarliwego patriotyzmu i religijności, uczuciem, które z taką oczywistością wypływa z autora, że musi wzruszyć najbardziej nawet chłodnego czy sceptycznego czytelnika"407. Zauważono również Żukrowskiego Nowele włoskie (Warszawa 1947), które otrzymały pozytywne oceny w „Tygodniku Powszechnym” i „Przeglądzie Powszechnym”408.

Zgodnie w różnych periodykach zaopiniowano także Trzynaście opowieści Ksawerego Pruszyńskiego (Warszawa 1946) ${ }^{409}$. Wierność autora własnemu stylowi w żołnierskich opowiadaniach stała się powodem pochlebnej wypowiedzi Starowieyskiej-Morstinowej, która pozostała pod urokiem „miłej książki” ze względu na jej „nutę głęboko tragiczną i silnie humorystyczną”. Charakterystyczną cechą miał być też „gorliwy patriotyzm” Pruszyńskiego, który „wykrył wiele polskich nędz" z perspektywy człowieka znającego sytuację innych krajów europejskich. Recenzentka wychwyciła również stosunek autora do religii, pisząc o nim:

\footnotetext{
${ }^{404}$ Z. Starowieyska-Morstinowa, Świat do góry nogami, „TP” 1947 nr 51/52 s. 9.

${ }^{405}$ H. Malewska, Ksiażka o zwycięstwach, „TP” 1946 nr 33 s. 4.

406 Tamże.

${ }^{407}$ W. Bacewiczówna, Książka która urzeka, „TW” 1946 nr 36 s. 7.

${ }^{408}$ W. Żukrowski, Nowele wtoskie, „TP” 1947 nr 42 s. 7; Z. Starowieyska-Morstinowa, Przegląd piśmiennictwa. Książki: powieści, „PP” 1948 nr 1 s. 60-61.

${ }^{409}$ H.K. [H. Kamieniecka], Na drogach wojny, „TW” 1947 nr 8 s. 6; Z. Starowieyska-Morstinowa, Wielki reportaż, „TP” 1947 nr 12 s. 8; taż, Przegląd piśmiennictwa. Książki: powieści, „PP” 1948 nr 1 s. 64.
} 
,jest jakże polski, tradycyjnie - polski: mało filozoficzny, ale za to bardzo sentymentalny" 110 .

Dziewięć tytułów opowiadań znalazło odzwierciedlenie w recenzjach „Tygodnika Powszechnego” i „Przeglądu Powszechnego”. Spośród chętnie omawianych na łamach krakowskiego pisma książek Adolfa Rudnickiego ${ }^{411}$ znalazła się dobrze odebrana Pateczka (Warszawa 1950) wydana w cyklu Klubu Literackiego „Odrodzenie"412. O powojennych wydaniach opowiadań informowano też czytelników jezuickiego miesięcznika, zwracając uwagę na podjęty „z wysokim kunsztem” w Pałeczce temat środowiska literackiego ${ }^{413}$. Dwie zupełnie odmienne interpretacje w obu periodykach znalazły opowiadania obozowe Tadeusza Borowskiego Pożegnanie z Marią (Warszawa 1948). Paweł Jasienica odcinając się wyraźnie od wyznawanego przez „zdolnego pisarza” światopoglądu marksistowskiego, pisał: „Trzeba czytelnikowi przypomnieć, że pomiędzy tym, co wyznaje Borowski, a nami $\mathrm{z}<<$ Tygodnika $>>$ wznosi się ideologiczna barykada" "414. Nie godząc się z autorem, że mieszczańska moralność przyczyniła się do „okupacyjnego koszmaru”, wyjaśnił: „Niemcy nie dlatego stały się państwem zbrodniczym, że ich obywatele myśleli po mieszczańsku, lecz dlatego, iż naród niemiecki opanowany został żądzą totalnej władzy nad światem" ${ }^{415}$. Z kolei Zygmunt Lichniak w zbiorowej recenzji pięciu książek wyodrębnił Pożegnanie z Maria jako pozycję najlepszą, uznając równocześnie opowiadanie (obok pamiętnika i autobiografii) za „najwyższą formę literacką". Zaletą wypowiedzi Borowskiego miała być konstrukcja literacka posługująca się „,układem zdarzeń”, nie zaś ich interpretacją, „operowanie kontrastem, zwięzłym opisem i plastycznym językiem”. Lichniak, zapowiadając „bliższe objaśnienia” w przyszłym artykule, stwierdził zaskakująco, że „Tadeusz Borowski, będąc z nazwy i deklaracji kim innym, z głębi ducha jest chrześcijaninem" ${ }^{\prime 16}$. Pisał: „Może uda się Borowskiemu swoją przekorą i młodzieńczym jeszcze $<<$ stawianiem dęba >> zwieść i zaszachować powierzchownych czytelników, ale dla tych, którzy serio przeżywają jego utwory, wyrazistość problematyki $<<$ par excellence $>>$ moralnej i $<<$ par excellence $>>$ chrześcijańskiej, która cechuje prawie każdą konfigurację faktów w jego opowiadaniach, daje radość kontaktu z pisarzem, który nazwami i deklaracjami okłamuje siebie i innych, a w rzeczywistości czerpie z najczystszych źródeł najgłębiej rozumianego chrystianizmu"417. Obaj recenzenci

${ }^{410}$ Z. Starowieyska-Morstinowa, Wielki reportaż...

${ }^{411}$ Zob. M. Jarczyńska, Adolf Rudnicki, „TP” 1947 nr 3 s. 8-9; zsm. [Z. StarowieyskaMorstinowa], Książki Rudnickiego, „TP” 1948 nr 23 s. 4; Z. Lewinówna, Patos i prostota, „TP” 1949 nr 36 s. 4.

${ }^{412}$ W. Rola, Największy temat wspótczesności, „TP” 1950 nr 39 s. 6.

${ }^{413}$ M. Krupiński, Przegląd piśmiennictwa. Recenzje książek, „PP” 1951 nr 3 s. 227-228.

${ }^{414}$ P. Jasienica, Którędy wyjście?, „TP” 1948 nr 28 s. 6.

${ }^{415}$ Tamże.

${ }^{416}$ Z. Lichniak, Przegląd piśmiennictwa, „PP” 1949 nr 2 s. 131.

${ }^{417}$ Tamże. 
zgodnie natomiast pochwalili ,świetną formę” i „mistrzowskie przedstawienie rzeczywistości łagrowej”. Warto dodać, że opowiadania obozowe T. Borowskiego były wówczas przedmiotem wielu sporów i nieporozumień, co znalazło wyraz w artykułach zamieszczonych w prasie partyjno-państwowej. Rzeczowa, obiektywna, oryginalna i życzliwa ocena Z. Lichniaka na łamach "Przeglądu Powszechnego" zasługuje tym bardziej na podkreślenie.

Z nowości w serii Klubu Dobrych Książek przedstawiono dwa debiutanckie tomiki Stanisława Zielińskiego Przed świtem (Warszawa 1949) i Dno miski (Warszawa 1949). O ile w pozytywnej recenzji Wacław Rola widział w autorze „bynajmniej nie powierzchownego obserwatora”, to Bogusław Grodzicki po omawiającej analizie zawartości utworów stwierdził wyraźnie „,powierzchowność i naskórkowość obserwacji”"418. Recenzenci zgodnie zalecali pisarzowi na przyszłość wyjście poza tematykę obozową i wojenną. Z różną opinią na łamach pism katolickich można było się zapoznać odnośnie do sześciu opowiadań Janusza Rychlewskiego wydanego pod wspólnym tytułem Człowiek z gutaperki (Warszawa 1949). Zdaniem Starowieyskiej-Morstinowej był to „obiecujący debiut”, w którym pomimo błędów językowych i stylistycznych zastosowano właściwą kompozycję oraz rozmaite formy opowiadania opisowego, psychologicznego i wojennego ${ }^{419}$. Lichniak, choć dostrzegł w książce wiele zalet właściwych dla „dobrze zapowiadającego się pisarza”, to skrytykował pozytywnego i tytułowego bohatera - ,,człowieka, który uparł się, że przeżyje wojnę i ją przeżył”. Jego zdaniem „słabość koncepcyjna” książki polegała na tym, że „Rychlewski nie wytłumaczył $<<$ człowieka $z$ gutaperki $>>$ w kategoriach moralnych czy społecznych, a uczynił go tylko funkcją pewnych sił biologicznych" ${ }^{220}$. Odnotowano również w krakowskim tygodniku i jezuickim miesięczniku pojawienie się na rynku księgarskim trzech zbiorów opowiadań: Karabela z Meschedu Ksawerego Pruszyńskiego (Warszawa 1948) ${ }^{421}$, Ludzie spod miedzy Władysława Dunarowskiego ${ }^{422}$ i Godzina śródziemnomorska Jana Parandowskiego (Warszawa 1949), które oceniono pozytywnie w obu tytułach prasowych ${ }^{423}$.

Odbiorcy „Tygodnika Powszechnego" i „Tygodnika Warszawskiego” mogli równocześnie poznać opinie o trzech tytułach książkowych będących zbiorami opowiadań. Skrajnie odmiennie zrecenzowano Noc Jerzego Andrzejewskiego

${ }^{418}$ W.R. [W. Rola], Przeglad piśmiennictwa. Recenzje ksiązek, „PP” 1950 nr 10 s. 355; B. Grodzicki, Opowiadania Zielińskiego, „TP” $1950 \mathrm{nr} 40$ s. 9.

${ }^{419}$ Z. Starowieyska-Morstinowa, Ksiązka doznań prawdziwych, „TP” 1950 nr 10 s. 10.

${ }^{420}$ Z. Lichniak, Przeglad piśmiennictwa. Literatura kieszonkowa, „PP” $1950 \mathrm{nr} 2$ s. 144-145.

${ }^{421}$ Tenże, Przeglad piśmiennictwa. Literatura, „PP” 1948 nr 6 s. 451; Z. Lewinówna, „Karabela z Meschedu”, „TP” 1948 nr 37 s. 7.

422 zsm. [Z. Starowieyska-Morstinowa], Wieś na co dzień, „TP” 1948 nr 21 s. 10; Z. Lichniak, Przegląd piśmiennictwa. Ksią̇ki, „PP” 1948 nr 4 s. 298-300.

${ }^{423}$ Z. Starowieyska-Morstinowa, Oberża pod gwiazdami, „TP” 1949 nr 37 s. 4; K. Górski, Przegląd piśmiennictwa. Recenzje książek, „PP” $1950 \mathrm{nr} 6$ s. 446-447. 
(Warszawa 1945) i Sztukę umierania Zenona Skierskiego (Kraków 1946). Pierwszy zbiór stała recenzentka krakowskiego pisma określiła jako „wielkie osiągnięcie moralne i artystyczne” oraz „prawdziwe dzieło sztuki”. Przypomniała, że przed II wojną światową „zbyt pochopnie okrzyknięto Andrzejewskiego pisarzem katolickim” za Ład serca, pisząc jednocześnie, że choć autor w Nocy „od źródeł katolickiego wartościowania wyraźnie się odcina, [skłaniając się ku marksizmowi - E.K.], w konsekwencjach zatrzymuje rezultaty katolickiej myśli i światopoglądu" "424. Porównując obie pozycje odważyła się nazwać recenzowaną książkę „bardziej katolicką” niż wspomniany Ład serca. Edward Jastrząb, wymieniając wiele błędów kompozycyjnych w poszczególnych opowiadaniach, określił Noc jako „nierówną książkę”. O Wielkim Tygodniu wyraził się w następujący sposób: „Duży zamiar epicki wciśnięty w ramy nadmiernie rozdętej i szczegółowej noweli, całkiem zawiódł" ${ }^{225}$, natomiast Przed sadem było „doskonałym opowiadaniem” z dobrym, lecz zawiłym tematem. W negatywnej opinii zarzucił „dosłowność w widzeniu rzeczywistości” przez Andrzejewskiego i pisanie o „rzeczach powszechnie wiadomych". W dłuższym wywodzie zwrócił uwagę na to, że tematyka okupacyjna wytworzyła tzw. ,samograje literackie”, w których przy minimalnej inwencji twórczej autora sama treść utworów wzbudzała w czytelnikach „olbrzymi ładunek spontanicznej i nie wymuszonej ekspresji” ${ }^{{ }^{2} 26}$. Problematykę wojenną podjął również Kazimierz Zenon Skierski w tomie Sztuka umierania (Kraków 1946), negatywnie ocenionym na łamach „Tygodnika Powszechnego”, a pozytywnie w „Tygodniku Warszawskim”. Starowieyska-Morstinowa nie zgodziła się z odpowiedzią autora na zapowiedziane już częściowo w tytule pytanie, jak umierać. Stwierdziła: „Odpowiedź nie zadowala nas przede wszystkim jako katolików. Jest stanowczo z katolickim światopoglądem sprzeczna. Nigdy w żadnych warunkach nie może się katolik zgodzić z tym, aby $<<$ dobijanie przyjaciela, podawanie przyjacielowi trucizny, duszenie dziecka $\gg>$ było rzeczą dobrą i etyczną"427. Ponadto zarzuciła Skierskiemu brak głębi i perspektywy filozoficznej w książce oraz zbyt długie monologi bohaterów. Wojciech Natanson o tych samych opowiadaniach napisał z kolei, że są „osiągnięciem poważnym”, a stanowiska autora uznał za „bardzo interesujące”. Docenił w nich „dążenie do wyrwania bezbronnych z objęć zagłady i skierowania ich ku walce" i po ich przeczytaniu „nie odczuł przygnębienia”. Nawiązał do swoistej eutanazji, za którą postawiono Skierskiemu zarzuty z punktu widzenia etyki katolickiej, jednocześnie zapytując: „,zy jest samobójstwem we właściwym znaczeniu słowa skrócenie sobie życia przez konspiratora, który, znajdując się w mocy wroga, z niezbitą pewnością oczekuje śmierci - a równocześnie lęka się załamania, aby nie zdradzić przyjaciół

\footnotetext{
${ }^{424}$ Z. Starowieyska-Morstinowa, Książka o nieładzie serc, „TP” 1946 nr 8 s. 6.

${ }^{425}$ E. Jastrząb, Dobre i złe, „TW” 1946 nr 17 s. 3.

426 Tamże.

${ }^{427}$ Z. Starowieyska-Morstinowa, Młode wino, „TP” 1946 nr 22 s. 4.
} 
i nie zaszkodzić sprawie?"428. Pochwały publicystów obu tygodników zebrały opowieści rzymskie Stanica Hanny Malewskiej. Uważano, że jest to „wartościowa książka”, w której udało się Malewskiej „sugestywnie i wnikliwie” oddać atmosferę Rzymu w okresie starożytnym ${ }^{429}$.

Warto również - oprócz porównania opinii recenzentów o tych samych zbiorach opracowań w różnych tytułach prasowych - wspomnieć krótko o niektórych jeszcze wypowiedziach w „Tygodniku Powszechnym”, na łamach którego opublikowano najwięcej recenzji opowiadań.

Zwrócono uwagę na Opowiadania z książek $i$ z gazet Tadeusza Borowskiego (Warszawa 1949), będące „raczej żarliwym potępieniem kapitalizmu niż apoteozą marksizmu" ${ }^{430}$. Za wartość uznano w opowiadaniach Michała Rusinka Młody wiatr (Warszawa 1950) „prawdziwą, głęboką humanistyczną szczerość i odwagę w stawianiu zagadnień społecznych"ł31. Krytycznie podeszła do wydania tomu Straszny dom Jana Dobraczyńskiego Starowieyska-Morstinowa, pisząc: „Książka, w której koniec tekstu uderza nosem w kolorową okładkę, robi wrażenie człowieka, który pod ubraniem nie ma bielizny [...] brakiem nie tylko estetycznym, jest brak spisu rzeczy”432. Dalej ad autorem stwierdziła: ,,[...] w prawie wszystkich książkach Dobraczyńskiego jest sporo zdań podanych w tekście po niemiecku. Otóż, ile zdań, tyle błędów! Nie wiem, czy okazywanie wzgardy nieprzyjacielowi przez robienie błędów gramatycznych w jego języku jest celowym środkiem walki" ${ }^{433}$. Ta sama recenzentka doceniła natomiast opowiadania Wojciecha Bąka Twarze (Łódź 1948)434 i Jana Parandowskiego Godzina śródziemnomorska (Warszawa 1949) ${ }^{435}$. W 1953 r. pozytywnie recenzowano nawet literaturę socrealistyczną, czego przykładem może być opinia o opowiadaniach Stefana Otwinowskiego zatytułowanych Spotkania z uśmiechem ${ }^{436}$.

W odniesieniu do obcych twórców za ważne wydarzenie kulturalne uznano nowe wydanie Opowieści wybranych (Warszawa 1952) Josepha Conrada ${ }^{437}$. Zrecenzowano głośne i kontrowersyjne w opinii amerykańskich kół katolickich opowiadania zatytułowane Ksiąze ciemności (1947) Jamesa Farla Powersa. Recenzentka pisała: „czytelnika katolickiego może zainteresują przede wszystkim opowiadania, w których spotka się z przedstawicielami katolickiego

${ }^{428}$ W. Natanson, Sztuka umierania, „TW” 1946 nr 33 s. 5.

${ }^{429}$ Z. Starowieyska-Morstinowa, Epiczne wprawki, „TP” 1947 nr 36 s. 6; A. Madej, Opowieści rzymskie, „TW” 1947 nr 32 s. 7.

${ }^{430}$ W. Rola, ,, Igraszki uczonego dowcipu”, ,TP” $1950 \mathrm{nr} 40$ s. 9.

431 Tenże, ,, To byto tak dawno..., ,, „TP” 1951 nr 19 s. 4.

432 Z. Starowieyska-Morstinowa, Straszne domy, „TP” 1947 nr 49 s. 6.

${ }^{433}$ Tamże.

${ }^{434}$ Taż, Komentarz życia, „TP” 1949 nr 5 s. 4.

${ }^{435}$ Taż, Oberża pod gwiazdami...

${ }^{436}$ Taż, Technika pointylistyczna, „TP” $1953 \mathrm{nr} 2$ s. 7.

${ }^{437}$ A. Gołubiew, Nowele Conrada, „,TP” 1953 nr 5 s. 1-2. 
duchowieństwa amerykańskiego" ${ }^{438}$. Zwrócono uwagę na często podejmowany w ówczesnej prozie wątek księdza katolickiego. Główną postacią tomu był ksiądz Burner (ang. burner - palnik); takim żartobliwym nazwiskiem obdarzył bohatera opowieści dziekan. Autor wykreował postać człowieka rozmiłowanego w wygodzie życia, nieco łakomego, leniwego i chciwego, gdyż chciał w ten sposób ukazać niebezpieczeństwo kryjące się w dobrobycie. W recenzji czytamy też: „Amerykańscy księża z opowiadań Powersa nie są ani specjalnie źli, ani nadludzcy. Są bardzo zwyczajnymi ludźmi, których wygoda życia uczyniła w zakresie swej pracy bezczynnymi. Każdy z nich marzy o tym tylko, aby mieć lepsze niż obecnie auto, więcej czasu na własne przyjemności, czek na wyższą sumę przysłany od parafian, korzystniejszą polisę ubezpieczeniową..." przez co pisarz chciał ukazać, że „przywiązanie do wygody i dobrobytu [...] podcina pędy najgłębszej idei" ${ }^{339}$.

Pomimo że „Tygodniku Powszechnym” sporadycznie opiniowano debiuty literackie, to wśród nowel dostrzeżono m.in. debiut Izy Kuźmińskiej Wspólny pokój, w którym autorka podjęła tematy moralne ${ }^{40}$ oraz Marii Jarochowskiej Buraczane liście, gdzie autorka, opisując zwycięski strajk chłopów w majątku ziemskim w 1935 r., ,zajęła określoną, marksistowską postawę ideową i artystyczną"

Można stwierdzić, że niektórzy recenzenci katoliccy, chociaż negowali podstawy ideowe socrealizmu, to jednak starali się wybrać z jego dorobku teksty lepiej napisane, w których poszukiwali wartości literackich. W opowiadaniach i nowelach zauważano przykładowo zdolność obserwacji i portretowania postaci przez autorów, zwracano uwagę na styl i język, jakim się posługiwano, ale przede wszystkim oceniano wymowę utworów

Recenzje opowiadań, choć mniej liczne na łamach pism katolickich, przyczyniły się do propagowania czytelnictwa.

\subsubsection{Wydania poezji}

Recenzje tomików poezji pojawiły się jedynie w trzech tytułach prasowych: „Tygodniku Powszechnym” (48 recenzji), „Przeglądzie Powszechnym” (32) i ,Tygodniku Warszawskim” (21). W sumie publicyści wspomnianych periodyków wyrazili opinie o 101 zbiorach poetyckich. Redakcje pozostałych czasopism - „Głosu Katolickiego”, „Tygodnika Katolickiego” i „Znaku” - w latach 1945-1953 nie zamieściły ani jednego omówienia tego typu.

\footnotetext{
${ }^{438}$ M.D. Dobraczyńska, Książę ciemności, „TP” 1952 nr 18 s. 7.

439 Tamże.

${ }^{440}$ mmg. [M. Morstin-Górska], Trzy debiuty, ,TP” 1948 nr 16 s. 7.

441 W. Rola, Trudny debiut, ,TP” 1951 nr 38 s. 4.
} 
Najwięcej omówień opublikowano w „Tygodniku Powszechnym”, na ich łączną liczbę 48 tylko sześć dotyczyło twórczości zagranicznych poetów. W recenzjach krakowskiego pisma naliczono 21 pozytywnych ocen, 17 omawiających, osiem krytycznych i dwie negatywne. Redakcja jezuickiego miesięcznika w latach 1947-1953 zamieściła 32 recenzje, z czego 11 to oceny poezji obcej. Na łamach „Przeglądu Powszechnego" najliczniejszą grupę stanowiły opinie omawiające (17), po nich pozytywne (12), a następnie negatywne (2) i jedna krytyczna. $\mathrm{W}$ warszawskim organie prasowym zaledwie $\mathrm{w}$ dwóch recenzjach przedstawiono tomiki poezji obcych twórców. Na łączną liczbę 21 omówień zdecydowanie najwięcej - gdyż aż 15 - to pozytywne odniesienia do nowości poetyckich, na pozostałe rodzaje recenzji przypadło po dwie opinie (omawiające, krytyczne, negatywne).

W dwóch tytułach prasowych „Tygodniku Powszechnym” i „Tygodniku Warszawskim", publicyści zachęcali do sięgnięcia po książkę, promując ją głównie w pochlebnych wypowiedziach. Jedynie w "Przeglądzie Powszechnym” przeważyły opinie omawiające. We wszystkich pismach redakcje niechętnie zamieszczały złe oceny jakiegokolwiek tomiku poezji, o czym może świadczyć liczba zaledwie dwóch negatywnych recenzji w każdym z czasopism w latach 1945-1953. Najchętniej recenzje tomików poezji w krakowskim piśmie zamieszczał Jerzy Zagórski (14), po nim Włodzimierz Maciąg prowadzący Półke z wierszami i Półke z poezja (7) oraz Maria Jarczyńska (4). W „Tygodniku Warszawskim" najbardziej płodnym recenzentem tego gatunku literatury był Antoni Madej (6). W dalszej kolejności uplasowali się Bogdan Ostromęcki, Robert Stiller i Wiktor Hahn; każdy z nich zamieścił po trzy recenzje. Na łamach „Przeglądu Powszechnego" najczęściej wypowiadali się publicyści ukrywający się pod inicjałami M.K. (8) i N.K. (5) oraz ks. Jan Rostworowski i Marian Olszewski (po cztery opinie każdy).

Najliczniejszą grupę tomików promowanych w przedstawionych wyżej pismach społeczno-kulturalnych stanowiły tytuły wydane nakładem Czytelnika (16), Książki (9), nieco mniej edycji wyszło nakładem Książki i Wiedzy (7) oraz Katolickiego Towarzystwa Wydawniczego Rodzina Polska (6) i Związku Zawodowego Literatów Polskich (6). Cztery z omawianych pozycji wydrukowano w Wydawnictwie Władysława Bąka. Po trzy tytuły zbioru poezji zaprezentowano z Wydawnictwa Zakładu Narodowego im. Ossolińskich, Wiedzy i Wydawnictwa OO. Karmelitów Bosych, po dwie antologie takich wydawnictw, jak Gebethner i Wolff, Eugeniusz Kuthan, Wielkopolska Księgarnia Wydawnicza, Wydawnictwo Instytutu Zachodniego, Wydawnictwa Przełom i Panteon. Jednocześnie w krakowskim piśmie i w „Przeglądzie Powszechnym” przy okazji pojawienia się nowości księgarskich zwrócono uwagę na twórczość Krzysztofa Kamila Baczyńskiego, Kazimiery Iłłakowiczówny, Aleksandra Rymkiewicza i Jana Sztaudyngera.

Podobnie jak w przypadku opowiadań, przedmiotem rozważań w tym podrozdziale będą tomiki najczęściej propagowane w różnych czasopismach katolickich 
oraz twórczość wybranych poetów polskich i obcych, na którą zwracano szczególną uwagę czytelników.

Publicyści wszystkich wspomnianych wyżej tytułów prasowych odnotowali Wiersze (Poznań 1947) poety młodego pokolenia Nika Rostworowskiego. Odbiorcy otrzymali dwie recenzje omawiające - w "Tygodniku Powszechnym” i „Przeglądzie Powszechnym” - oraz jedną pozytywną w „Tygodniku Warszawskim”. Edmund Parthénay pod nagłówkiem $W$ kręgu Skamandra i Kwadrygi, analizując wiersze pod względem formalnym, wykazał wyraźny wpływ nurtów okresu dwudziestolecia międzywojennego na twórczość poety. Oprócz tego zwrócił uwagę na wątki religijne, pisząc: „Jest zresztą rzeczą niewątpliwą, że ideologia chroni Rostworowskiego od wielu wykolejeń. Jego katolicyzm, bardzo jeszcze młodzieńczy, jest jednocześnie całkiem oczywisty i wyznacza postawę poety nawet $\mathrm{w}$ wierszach, które nie mają [...] wyraźnej tematyki religijnej $[\ldots]$ postawa katolicka nie pozwala poecie na łatwizny formalne i rzeczowe. $Z$ drugiej strony - ta postawa daje mu wolność i, choćby się to wydawało paradoksem, większą swobodę $\mathrm{w}$ wyborze tematyki. U żadnego chyba z poetów marksistowskich nie widzimy tak szerokiego wachlarza tematycznego. Wielokierunkowość ujęta w racjonalne łożysko jest najbardziej możliwa właśnie w katolicyzmie"442. Zygmunt Lichniak w przeciwieństwie do przedstawionych wyżej poglądów dostrzegł w twórczości poety „walkę z szablonem przedwojennej poetyki skamandryckiej”, której wpływy w kolejnych utworach wyraźnie ustąpiły. Podobnie jak Parthénay docenił ją także za „szczerze przeżywany katolicyzm”"443. Bogdan Ostromęcki uznał natomiast debiutancki tomik za "godny polecenia, poznania i przeczytania” a poetę za ,zdradzającego talent poetycki”444.

Jerzy Zagórski na łamach „Tygodnika Powszechnego” przypomniał o dawnym zwyczaju wchodzenia poetów w życie literackie poprzez „grupy”, zaznaczając, że po wojnie ich rolę przejęły tzw. „studia” dla młodych zakładane przy oddziałach Związku Literatów, kluby literackie oraz specjalnie wydzielone kolumny młodych w pismach. Ubolewał przy tym, że ówczesnych debiutantów częściej łączył ,wspólny warsztat niż wspólne wyobrażenie”. W zbiorowej recenzji zaprezentował tomiki przedstawicieli grupy Próg, którzy zamieszczali swoje wiersze m.in. na kolumnie „Tygodnika Warszawskiego”. Jednym z nich był „opóźniony debiut” zatytułowany Płomień nad czołem Jerzego Kiersta (Warszawa 1947), wydany przez Katolickie Towarzystwo Wydawnicze „Rodzina Polska”445. Antoni Madej wydobył w interpretacji tomiku cechy polskiej sztuki, narodowe idee i wiarę ojców, podkreślając, że była to „poezja szerokiego oddechu idei górnych”. Analizując poszczególne wiersze, pisał: „Mimo ruin kościołów (Kościót Zbawiciela), mimo zniszczenia bibliotek $<<$ pod wyrwaną tarczą chodnika z otwartymi skrzydłami

${ }^{442}$ E. Parthénay, Półka z poezjami, „TP” 1948 nr 9 s. 7.

${ }^{443}$ Z. Lichniak, Przegląd piśmiennictwa. Ksiązki, „PP” 1948 nr 5 s. 374.

${ }^{444}$ B. Ostromęcki, Wiersze Nika Rostworowskiego, „TW” 1948 nr 33 s. 6.

445 J. Zagórski, Pogromcy ruin, „TP” 1947 nr 17 s. 7. 
jak ptak martwa książka... (Książa w płomieniach), mimo zdruzgotania domu rodzinnego $-<<$ czarny szkielet domu o żebrach potrzaskanych $>>$ (Na gruzach) w poezji Kiesta wyczytać możemy tę pewność, która przenika każdego Polaka, że $<<$ Dzieło Zbawiciela jasne jest jak szum rzeki, gdy świt się z niej wyzwala $>>$, że czasy pohańbienia człowieka przetrwa" ${ }^{\$ 46}$. Twórczość poetycką innego przedstawiciela grupy Próg, Bogdana Ostromęckiego, zaprezentowano poprzez Popiót niepodlegty (Warszawa 1947). Jego utwory, choć „formalnie odmienne” od wierszy Kiersta, mieściły się jeszcze, zdaniem Madeja, w „kategoriach światopoglądu chrześcijańskiego”. Obu twórców recenzent „Tygodnika Warszawskiego” przedstawił jako, „piewców stolicy”"447.

W zawartości „Tygodnika Powszechnego” i „Tygodnika Warszawskiego” recenzenci wyrazili pochlebne opinie o antologii poetyckiej opracowanej przez Stefana Papée pt. Tadeusz Kościuszko w literaturze polskiej (Kraków 1946). „Opracowana sumiennie i z dużą znajomością przedmiotu” zawarła 48 utworów o Kościuszce najbardziej znanych poetów i prozaików polskich XVIII-XX w. ${ }^{448}$ W publikacji warszawskiego periodyku Wiktor Hahn wspomniał też o wydanej równolegle antologii Kościuszko w pieśni $i$ w poezji (Łódź 1946), w której uwzględniono przede wszystkim utwory przedstawicieli nowej generacji, przez co oba wydawnictwa uzupełniały się pod względem zawartości ${ }^{449}$.

Jednocześnie w krakowskim piśmie i w „Przeglądzie Powszechnym” przy okazji pojawienia się nowości księgarskich zwrócono uwagę na twórczość Krzysztofa Kamila Baczyńskiego, Kazimiery Iłłakowiczówny, Aleksandra Rymkiewicza i Jana Sztaudyngera. Stanisław Lem, rozpoczynając recenzję o Śpiewie z pożogi Krzysztofa Kamila Baczyńskiego (Warszawa 1947), pisał z żalem: „Szczególne prawa rządzą naszą krytyką poetycką. Wiele miesięcy upłynęło od ukazania się tomu Baczyńskiego, a ani jeden poważny krytyk nie przemówił w imieniu jego poezji [...] Czekałem długo sądząc, że milczenie jest przypadkowe i głos zabierze ktoś kompetentniejszy ode mnie. Tak się nie stało. Chcę więc powiedzieć, co myślę o tej poezji, która wierzy i w Boga i w człowieka" ${ }^{450}$. Po czym w obszernej wypowiedzi rozważył na przykładach cechy formalne jego wierszy, podkreślając wybitny talent poety. Podobnie pozytywnie odniósł się do twórczości poległego w powstaniu warszawskim młodego twórcy Zygmunt Lichniak, uznając „debiut za triumfalny i tragiczny". Recenzenci dostrzegli związki poety z romantyzmem, a ponadto jego dojrzałość i ,indywidualność poetycką"451. W krótkich wypowiedziach zapoznano czytelników ze Strofami wrocławskimi Jana Sztaudyngera (Poznań 1947), w których

${ }^{446}$ A. Madej, Boże sieci, „TW” 1947 nr 33 s. 6.

447 Tenże, Poezja głębokiego nurtu, „TW” 1947 nr 44 s. 4.

${ }^{448}$ A. Goł. [A. Gołubiew], Wydawnictwa kościuszkowskie, „TP” 1946 nr 12 s. 6; W. Hahn, Dwie antologie poetyckie o Kościuszce, „TW” 1946 nr 12 s. 8.

${ }^{449}$ W. Hahn, Dwie antologie poetyckie...

${ }^{450}$ S. Lem, Zamilkty poeta, „TP” 1948 nr 1 s. 9.

${ }^{451}$ Z. Lichniak, Przegląd piśmiennictwa. Ksiązki, „PP” 1948 nr 5 s. 373-374. 
poprzez podjęte motywy regionalne i „polskość Wrocławia” w mitologii i legendach poeta „zasłużył się niewątpliwie na froncie kulturalnej walki o przyłączenie Ziem Zachodnich" ${ }^{452}$. Z aprobatą odniesiono się również w obu pismach do Wierszy Kazimiery Iłłakowiczówny (Łódź 1949). Śledząc rozwój jej talentu poprzez zawarte w tomie wiersze z lat 1912-1947 doceniono ją za „samodzielność i oryginalność" ${ }^{453}$. Piotr Grzegorczyk przypominając, że w okresie dwudziestolecia międzywojennego była „najwybitniejszą poetką katolicką”, wyróżnił jej twórczość za sposób pisania „z głębi serca"454. Zainteresowanie u publicystów wzbudziła także poezja Aleksandra Rymkiewicza. „Rodzajem pamiętnika patriotycznego i kroniką dziejów wojennych", zdaniem Marii Jarczyńskiej, były liryki zebrane pod programowym tytułem Z narodem (Warszawa 1947) ${ }^{455}$. Wiesław Szymański, zapoznając czytelników z poszczególnymi strofami wierszy, nazwał poetę „kronikarzem narodu, wojen, łez i goryczy", natomiast w kolejnym jego tomie Warszawskie cegły (Warszawa 1951) największą wartość dostrzegł w zmianie tematu i uwzględnieniu powojennej rzeczywistości ${ }^{456}$. W opinii wyrażonej na łamach "Przeglądu Powszechnego" zwrócono uwagę na ,indywidualne cechy” i „własne środki poetyckie” w poezji Rymkiewiczat ${ }^{457}$.

Warto wspomnieć również o zauważonej w „Tygodniku Powszechnym” nagrodzie miasta Łodzi przyznanej „poecie komunistycznemu” Mieczysławowi Jastrunowi za tom Rzecz ludzka (Warszawa 1946) ${ }^{458}$. Późniejsze zbiory Rok urodzaju (Warszawa 1950) i Barwy ziemi (Warszawa 1951), potraktowane jako „eksperyment poetycki" o bogatej tematyce (m.in. współzawodnictwa pracy, walki o pokój, odbudowy kraju, okupacji), omówione zostały przez Mariana Olszewskiego w „Przeglądzie Powszechnym”459. Liryki Leopolda Staffa zebrane w tomikach Martwa pogoda (Warszawa 1946) i Wybór poezji (Warszawa 1946) pochwalono w „Tygodniku Warszawskim” za doskonałą formę, głęboko filozoficzną refleksję, liryzm i „,przyjęcie postawy religijnej” przez poetę ${ }^{460}$. Dość krytyczną opinię o okrojonym wydaniu Spółdzielni Wydawniczej Czytelnik Wierszy wybranych (Warszawa 1946) Staffa wyraził Jerzy Zagórski w „Tygodniku Powszechnym”. Swoje zastrzeżenia ujął następująco: „Tom wierszy to nie ulotka. Za 10, co ja mówię za 5 lat, z całokształtu redaktor będzie wybierał zupełnie inaczej niż dziś. Pierwszy tom, który miałby być przekazaniem utworów najtrwalszych, za parę lat

${ }^{452}$ W. Maciąg, Półka z wierszami, „TP” 1948 nr 24 s. 6; Z. Lichniak, Przegląd piśmiennictwa. Ksiażki, „PP” 1948 nr 5 s. 375.

${ }^{453}$ M. Krupiński, Przegląd piśmiennictwa. Recenzje książek, „PP” 1950 nr 9 s. 275.

${ }^{454}$ P. Grzegorczyk, Wiersze Itłakowiczówny, „TP” 1950 nr 7 s. 6.

${ }^{455}$ M. Jarczyńska, Wiersze Rymkiewicza, „TP” 1948 nr 4 s. 8.

${ }^{456}$ W. Szymański, Kronikarz wojen i dnia dzisiejszego, „TP” 1953 nr 3 s. 5.

${ }^{457}$ M.K., Przeglad piśmiennictwa, „PP” 1952 nr 11 s. 332-333.

${ }^{458}$ J. Zagórski, Poezja kamienna i dyskretna, „TP” 1946 nr 25 s. 6.

${ }^{459}$ M. Olszewski, Przegląd piśmiennictwa. Recenzje książek, „PP” $1952 \mathrm{nr} 9$ s. 180-181.

${ }^{460}$ A. Olędzka, Liryka L. Staffa, „TW” 1948 nr 19 s. 9. 
może być nudnawym dokumentem dzisiejszych odchyleń... Jest nieszczęściem naszego rynku, że nie tylko firmy prywatne, ale nawet spółdzielnie kalkulują wedle zasad szybkiego obrotu" ${ }^{461}$.

$\mathrm{W}$ recenzjach zabierano niejednokrotnie głos w sprawie powojennych wydań wybranych utworów znanych dawnych i współczesnych polskich poetów. Sumiennie, zdaniem recenzenta, opracował Stanisław Adamczewski Wybór poezji Jana Kochanowskiego (Łódź 1946) ${ }^{462}$. Z aprobatą przyjęto również dwunastotomowe popularnonaukowe i najpełniejsze wówczas wydanie Dzieł Juliusza Stowackiego (Wrocław 1949) Zakładu Narodowego im. Ossolińskich ${ }^{463}$. Po nim ukazał się nakładem Państwowego Instytutu Wydawniczego „W starannej szacie zewnętrznej" i dobrym układzie, tom Poezje i listy wybrane Słowackiego (Warszawa 1951) w wyborze Pawła Hertza ${ }^{464}$. Jako ,spełnienie ważnego postulatu narodowego i naukowego" odnotowano pojawienie się na rynku księgarskim Vade-mecum Cypriana Norwida (Warszawa 1947) ${ }^{465}$. Na łamach „Tygodnika Warszawskiego" wysoko oceniono twórczość „poety żyjącego poza klimatem swych czasów" - Bolesława Leśmiana - polecając czytelnikom jego Wybór poezji (Warszawa 1946) wydany przez Spółdzielnię Wydawniczą Książka ${ }^{466}$. Z obszernej recenzji pióra Jerzego Zagórskiego dowiadujemy się, że wydanie tomu Ocalenie Czesława Miłosza (Warszawa 1945) stało się „dużym wydarzeniem literackim”467. Wacław Rola zaprezentował Poezje zebrane Jerzego Lieberta (Warszawa 1951) IW PAX jako „wartościową publikację”, która mogła być przydatna „młodym poetom katolickim" ${ }^{468}$.

Publicyści katolickich periodyków społeczno-kulturalnych, zwracając szczególną uwagę na obecność wątków religijnych w przedstawianej poezji, wyrażali dezaprobatę w przypadku ich braku. Stanisław Lem, obserwując zbyt słabe zainteresowanie publiczności poezją Tadeusza Różewicza i udzielając twórcy kilka merytorycznych uwag, pisał m.in.: „Rzecz inna, że poezja bez Boga jest o całe niebo (dosłownie) uboższa od opartej o pierwiastki metafizyczne, i daleko trudniej przychodzi jej pomaganie człowiekowi i przezwyciężanie jego

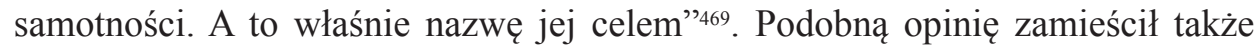
w „Tygodniku Powszechnym” Jerzy Zagórski o tomiku Miejsce na ziemi Juliana Przybosia (Warszawa 1945), konstatując: „Chęć ograniczenia pola widzenia skazuje Przybosia na odrzucanie pewnych możliwości twórczych, jaką dają doznania

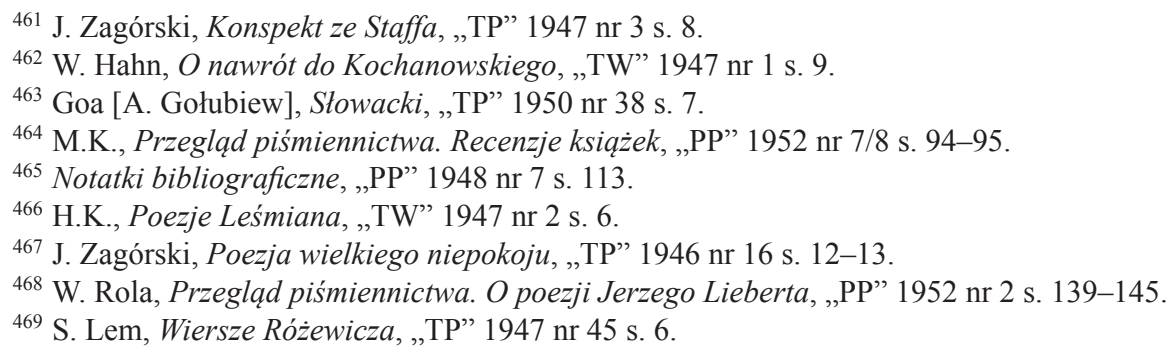


metafizyczne. Poezja nie musi ocierać się o metafizykę. Gdy jej jednak zaprzecza programowo, skazuje się na pewne zubożenie doznań, które są doznaniami człowieka pełnego, który nie tylko stopę opiera na ziemi, lecz i odbija od tej ziemi i głową stara się wypłynąć na powierzchnię zjawisk"

Wypowiadano się czasem o debiutach. Przykładem może być dobrze przyjęty przez Marię Jarczyńską na kartach „Tygodnika Powszechnego” tom wierszy Stanisława Ziembickiego Powrót do miasta (Warszawa 1947) oraz niezwykle humorystycznie napisana negatywna opinia Roberta Stillera w „Tygodniku Warszawskim" o niewielkim tomiku Jana Pocka Zgrzebne pieśni (Łódź 1947). Stiller pisał bowiem: „Chciałoby się ten tomik pochwalić. I tytuł ładnie dobrany, i okładka, i szczerze chłopskie serce odzywa się ciągle zza nieporadnych strof. Niestety wiersze te są naprawdę niżej krytyki [...] niektóre to wprost klasyczne parodie. Pocek nie umie już sadzić kartofli, tylko $<<$ wiśnie, jarzębiny i kwiaty złote >> [...] Szkoda męczyć dalej. Może Pocek będzie kiedyś poetą. Ale niechże Ludowy Instytut Kultury w Łodzi zaczeka jeszcze z wydawaniem jego utworów, bo naprawdę szkoda: paczyć samego autora, pogrążać jego nazwisko, trwonić pieniądze" 471 .

Z obcej poezji współpracownicy „Tygodnika Powszechnego” i „Przeglądu Powszechnego" podzielili się z czytelnikami uwagami na temat wydanych w języku polskim antologii poezji rosyjskiej, francuskiej, hiszpańskiej i węgierskiej. Omówiono pierwszą i drugą edycję dzieła Dwa wieki poezji rosyjskiej (Warszawa 1947) w ,ambitnym opracowaniu” Mieczysława Jastruna i Seweryna Pollaka. W opinii omawiających dostarczono polskim odbiorcom nie tylko dobrze przemyślany wybór z rosyjskiej twórczości poetyckiej z okresu dwóch wieków, ale także $\mathrm{z}$,półtora wieku jej polskich przekładów” "472. Zastrzeżenia u recenzentów dotyczyły jedynie braku uwzględnienia niektórych twórców w zbiorze, jak też niedostatecznego uwydatnienia innych. Publikację Spółdzielni Wydawniczej Czytelnik jednogłośnie doceniono zaś za piękną szatę graficzną. Na temat pierwszego w języku rodzimym przekładu Wierszy wybranych Mikołaja Niekrasowa (Warszawa 1951), dokonanego przez Leopolda Lewina, głos zabrał Marian Olszewski, chwaląc zarówno twórczość rosyjskiego poety, jak i polskie tłumaczenie ${ }^{473}$. Do „nowatorów w poezji” czyniącymi ją „orężem rewolucji” należał Włodzimierz Majakowski, którego wiersze, rzadko tłumaczone przed II wojną światową na język polski, znalazły odzwierciedlenie w wyborze przekładów opracowanym przez Adama Ważyka. Recenzent, choć wytknął w Wierszach i poematach (Warszawa 1949) brak wstępu z podstawowymi wiadomościami biograficznymi

${ }^{470}$ J. Zagórski, Poezja - zamknięte koło, „TP” 1945 nr 30 s. 8.

${ }^{471}$ R. Stiller, Nieporozumienie i pośpiech, „TW” $1947 \mathrm{nr} 39$ s. 8.

${ }^{472}$ P. Grzegorczyk, Wiersze rosyjskie po polsku, ,TP” 1948 nr 4 s. 3-4; H.K., Przeglad piśmiennictwa. Recenzje książek, „PP” $1952 \mathrm{nr} 5 / 6$ s. 440-441.

${ }^{473}$ M. Olszewski, Przegląd piśmiennictwa. Recenzje ksiązek, „PP” 1953 nr 1 s. 70-71. 
i krytycznie odniósł się do „przyporządkowania poezji wyłącznie walorom społecznym", docenił w wydaniu paralelne podanie tych samych utworów w dwu przekładach ${ }^{474}$. Bogdan Ostromęcki na stronach „Tygodnika Warszawskiego” szeroko odniósł się do rozwoju rozmaitych prądów w poezji francuskiej sprowokowany ,jednostronnym stanowiskiem" politycznym i światopoglądowym Adama Ważyka w przedmowie do Antologii wspótczesnej poezji francuskiej (Warszawa $1947)^{475}$. Zadowolenie z powodu ukazania się pięknie ozdobionego drzeworytami tomu Wielki testament Franciszka Villona (Warszawa 1950) wyraził Olgierd Porycki w „Przeglądzie Powszechnym”. Estetyczne wydanie książki z fotografiami kart tytułowych pierwszych wydań poezji, dwubarwnym drukiem, ilustracyjnym papierem i ładną okładką ,,czyniły z dzieła cenną pozycję w domowej biblioteczce" ${ }^{476}$. Ten sam recenzent zapoznał czytelników z twórczością wybitnego poety hiszpańskiego, „mistrza lapidarnego wiersza” i „celnej metafory”, jakim był Federico Garcia Lorca przy okazji wydania tomu pt. Romancero cygańskie (Warszawa 1949) i Wyboru wierszy (Warszawa 1950). W krótkiej opinii zwrócił m.in. uwagę na „głęboki nurt humanistyczny' i ,szczery katolicyzm” poety ${ }^{47}$. W jezuickim miesięczniku przedstawiono także Wybór poezji (Warszawa 1951) „największego poety narodowego Węgier” Sandora Petöfiego, którego „życie osobiste sprzęgło się z twórczością"; walczył bowiem o wyzwolenie kraju spod władzy Habsburgów ${ }^{478}$.

Podsumowując rozważania na temat recenzji tomików poezji, opublikowanych w katolickich czasopismach społeczno-kulturalnych w latach 1945-1953, należy zauważyć, że zajmowały one dość ważne miejsce w trzech z wybranych tytułów. Pokaźny udział procentowy omówień w ogólnej liczbie recenzji świadczył o zainteresowaniu publicystów nowościami z tego gatunku literackiego. W pierwszych latach powojennych, jak wynika z przeglądu opinii, dominowała w poezji tematyka wojenna. Recenzowano liryki najbardziej znanych polskich poetów, tworzących jeszcze w okresie dwudziestolecia międzywojennego. Nie pominięto $\mathrm{w}$ omówieniach również nowo wydanych antologii wierszy wieszczów narodowych, takich jak Słowacki i Norwid. Poezja obca, zdecydowanie rzadziej omawiana, znalazła jednak swoje miejsce w wybranych tłumaczeniach. Największą uwagę poświęcono poezji rosyjskiej. W przypadku antologii wierszy twórców zagranicznych zwracano uwagę na dobór, proporcje przedstawianej twórczości w stosunku do innych poetów ze względu na rolę jaką odegrali oraz przekład. Doceniano w nich niejednokrotnie dobre opracowanie i wstęp zapoznający czytelników z rozwojem danej poezji. Publicyści odnosili

\footnotetext{
${ }^{474}$ P. Grzegorczyk, Majakowski po 20 latach, „TP” 1950 nr 25 s. 2 i 3.

${ }^{475}$ B. Ostromęcki, Drogi poezji francuskiej, „TW” 1947 nr 18 s. 5.

${ }^{476}$ ol. por. [O. Porycki], Przegląd piśmiennictwa, „PP” 1952 nr 3 s. 221.

477 Tenże, Przegląd piśmiennictwa. Recenzje książek, „PP” $1951 \mathrm{nr} 7$ s. 134.

${ }^{478}$ M.K., Przegląd piśmiennictwa. Recenzje książek, „PP” 1952 nr 9 s. 175-176.
} 
się zazwyczaj do strony formalnej twórczości, talentu poety i podejmowanej tematyki podkreślając cechy indywidualne. Jak przystało na publicystów pism katolickich, szczególną uwagę zwracano na wątki religijne. W licznych omówieniach nie zapomniano wspomnieć o wyjątkowo istotnej stronie graficznej polecanych tomików.

\subsubsection{Dramat}

Najmniejsze zainteresowanie w porównaniu z innymi rodzajami i gatunkami literackimi recenzenci wybranych pism katolickich w latach 1945-1953 wykazali wobec dramatu. W przeciągu bowiem ośmiu lat ukazało się łącznie zaledwie 14 recenzji: w „Tygodniku Powszechnym” (5 omówień), „Tygodniku Warszawskim” (5), „Przeglądzie Powszechnym” (3) i „Głosie Katolickim” (1). W krakowskim tygodniku zamieszczono cztery oceny dramatów rodzimych (w tym 2 recenzje pozytywne, 1 omawiającą i 1 negatywną) oraz jedną ocenę pozytywną obcego dramatu. Na łamach drugiego tytułu prasowego wyrażono opinie tylko o dramatach polskiego autorstwa (2 pozytywne, 2 krytyczne i 1 omawiającą). Redakcja miesięcznika zamieściła trzy recenzje omawiające (2 dramatu obcego i 1 rodzimego), natomiast jedyna wypowiedź w „Głosie Katolickim” o charakterze pozytywnym dotyczyła polskiego utworu. W „Tygodniku Powszechnym” po jednym tytule sztuki zrecenzowali: Antoni Gołubiew, Maria Jarczyńska, Zygmunt Kubiak, Leszek Kuc i ks. Andrzej Zuberbier. Najbardziej aktywnym recenzentem tego gatunku literackiego w warszawskim periodyku był Jerzy Kierst (3 recenzje), po jednej zaś opinii opublikowali Tadeusz Kudliński i Józef Marian Święcicki. W „Przeglądzie Powszechnym” znalazły się dwie recenzje tłumaczeń z literatury światowej podpisane inicjałami M.K. oraz jedna wzmianka o rodzimym dramacie Mariana Olszewskiego.

Pod względem wydawniczym trudno znaleźć prawidłowości przy tak nieznacznej liczbie recenzji. Jedynie firma wydawnicza Eugeniusza Kuthana i kieleckie Verbum wydały po dwie pozycje dramatów. Pozostałe pojedyncze druki wyszły z następujących wydawnictw: Czytelnik, Książka, Książka i Wiedza, Państwowy Instytut Wydawniczy, IW PAX i Wydawnictwo Zakładu Narodowego im. Ossolińskich. Inicjatywę wydawniczą przejawiły także: Krajowa Centrala Caritas, Dobra Książka, Centralny Komitet Żydów Oilskich oraz Towarzystwo Teatru i Muzyki Ludowej.

Ze względu na niewielką liczbę wypowiedzi prasowych na temat dramatu w podrozdziale omówiono wszystkie recenzje.

Uwagę recenzentów „Tygodnika Powszechnego”, „Tygodnika Warszawskiego” i „Głosu Katolickiego” zwróciła twórczość dramatopisarska Jerzego Zawieyskiego, którego utwory zostały dobrze przyjęte. Dramaty zyskały rozgłos dzięki inscenizacjom w teatrach Warszawy, Krakowa i Poznania. Rozdroże miłości 
(Warszawa 1947) nazwane zostało przez Jerzego Kiersta ,jednym z najpiękniejszych utworów dramatycznych" literatury powojennej. W omówieniu sztuki recenzent zaakcentował „awangardowość problematyki i środków wyrazu”, tłumacząc: „W odniesieniu do problematyki nową siłą Rozdroża jest jego koncepcja zasadnicza, przezwyciężająca naturalistyczne pojmowanie świata i sztuki. [...] Światem rządzi bowiem nie tylko człowiek, ale i Opatrzność. Porządek przyrodzony przenika się w trudny sposób z porządkiem nadprzyrodzonym. [...] Opatrznościowy zbieg zasługi i łaski”479.

Ta sama sztuka miano „najpoważniejszej w dramaturgii” ówczesnej zyskała natomiast w ocenie Aleksandra Rogalskiego. Publicysta przedstawiając szczegółowo treść dramatu uwydatnił jego wątek religijny. Pisał: „Zasadnicza myśl sztuki, jej klimat duchowy nie budzi wątpliwości. Jest to sztuka katolicka. Nie tylko dlatego, że jej głównym bohaterem jest kapłan katolicki, przedstawiony w oświetleniu dodatnim, ale że jej problematyka jest katolicka. Mamy przed sobą dramatyczną walkę o dobro duchowe kobiety, wyposażonej w głębokie wartości, ale która wskutek fatalnych uroków swego ciała, oddziałała niszcząco na gromadę ludzką, w jakiej żyła [...]. Mimo dramatycznego napięcia i tragicznego (pozornie) zakończenia Rozdroże miłości tchnie pokojem i optymizmem"480. Na ów pokój, który obecny jest w utworach dramatycznych Zawieyskiego, zwrócił uwagę również ks. Andrzej Zuberbier pisząc przy okazji Owocu czasu swego (Kielce 1949) obszerną refleksję religijną. W końcowej konkluzji czytamy: „Owoc czasu swego przynosi tak wiele myśli i stawia tak różne zagadnienia $\mathrm{w}$ dziedzinie stosunku sztuki do religii, że nie sposób tu szerzej o tym mówić. Niech wystarczy ta jedna poruszona myśl. Każda sztuka - muzyka, literatura, plastyka - ściśle religijna czy też nie mówiąca nic o Bogu, jeżeli potrafi człowieka pchnąć w głąb, zastanowić, potrząsnąć, zaniepokoić, wyrwać z codzienności - usposabia go i przygotowuje, choćby w małym stopniu, do przeżyć religijnych. Przez to zaś pomaga zdobyć prawdziwy spokój. Rolę taką spełnia i sztuka Jerzego Zawieyskiego, na którego myślach oparte są te refleksje" ${ }^{381}$. Zagadnienie cierpienia rozważane było w Mężu doskonatym na podstawie swobodnie przedstawionej historii biblijnej Hioba. Zdaniem Leszka Kuca dramatopisarz nie tylko utrzymał w sztuce łączność z tradycją literacką (związki z twórczością Jeana Giraudoux), ale wprowadził też własne cechy. Omawiający docenił ponadto „artyzm utworu” oraz „filozoficzne nasycenie języka poetyckiego" ${ }^{482}$. Dwa ostatnie dramaty wytłoczono w kieleckiej oficynie, o której dowiadujemy się z recenzji: „Zgodnie z tradycją wydawnictwa Verbum Mąż doskonaty ukazał się w pięknym opracowaniu graficznym. Książkę wydano nakładem szkoły imienia św. Stanisława Kostki w Kielcach. Wydanie

${ }^{479}$ J. Kierst, Rozdroże miłości, „TW” 1948 nr 15 s. 9.

${ }^{480}$ A. Rogalski, Rozdroże miłości Jerzego Zawieyskiego, „GK” 1948 nr 20 s. 176.

${ }^{481}$ A. Zuberbier, Pokój niepokojący, „TP” $1950 \mathrm{nr} 3$ s. 2.

${ }^{482}$ L. Kuc, Dno cierpień i szczyt historii, „TP” 1948 nr 50 s. 5. 
dramatu czytamy na opasce, $<<$ jest wyrazem zrozumienia przez szkołę katolicką kulturalnych wartości dobrej książki >>"483.

Problematykę chrześcijańską podjął również Adam Bunsch w dramacie Przyszedt na ziemię święty (Kraków 1947), który został poświęcony osobie Brata Alberta. Fachową ocenę utworu pod względem konstrukcyjnym, kompozycyjnym, artystycznym i scenicznym udostępnił odbiorcom Tadeusz Kudliński na łamach „Tygodnika Warszawskiego". W pozytywnej recenzji docenił Bunscha za dojrzały pogląd na świat, własny styl, przystępny i zrozumiały charakter twórczości. Określając go mianem „pisarza chrześcijańskiego”, konstatował: „Ogólne stanowisko moralne autora jest chrześcijańskie, gdyż wyraża się w ujęciu świata jako skażonego, złego, który jednak ma otwartą drogę poprawy i ta droga jest właśnie osią dramatów, odsłaniających prawdę, że nikt na tym świecie nie jest dosłownie zły, raczej nieszczęśliwy czy opuszczony i posiadający ukryte zadatki dobra" ${ }^{48}$. Ciekawa była kreacja głównego bohatera sztuki - dziś świętego Adama Chmielowskiego. Ponadto Kudliński wzmiankował w przypisie o stronie zewnętrznej książki: „Jest zasługą Caritasu wydanie tego dramatu w pięknej szacie graficznej, a zarazem z wyraźnym celem pożytkowym" ${ }^{\prime 45}$.

Rozważania krytyczne nad przedstawieniem kwestii honoru, małżeństwa i ofiary złożonej dla „wyższej wartości” w dramacie Uciekła mi przepiórecz$k a$ (Wrocław 1946) Stefana Żeromskiego po mistrzowsku z chrześcijańskiego punktu widzenia przeprowadził Józef Marian Święcicki w jednej z recenzji „Tygodnika Warszawskiego”. Na przykładach z treści utworu wykazał, że znany pisarz pozostał $\mathrm{w}$,kręgu ideologii laicystycznego humanitaryzmu”. Uzasadniał to w następujący sposób: „W literaturze - nie tylko polskiej - niewiele znajdziemy utworów, w których postawa honoru uległa tak druzgocącemu przezwyciężeniu [...]. [Główny bohater Przełęcki - E.K.] wartość tę musi złożyć w ofierze innej, wyższej jeszcze wartości. Jedno mu wszakże jeszcze pozostało, co go wiąże z postawą honoru, a odróżnia od stanowiska chrześcijańskiego: świadomość własnej wielkości, duma człowieka wzgardzonego przez wszystkich, ale usprawiedliwionego przed samym sobą. [...] Chociaż podziwiamy moralną wzniosłość Przepióreczki, to jednak musimy stwierdzić, że jej rozwiązanie oparte na pełnym szczytowego samozaparcia wallendrodyzmie bohatera, jest z chrześcijańskiego punktu widzenia - pomyłką" ${ }^{486}$. Dalej thumacząc, że „Nie było wcale potrzebne, aby Przełęcki niszczył swoją dobrą sławę, ani wskazanym, żeby tę swoją ofiarę oparł na kłamstwie” recenzent dał inne rozwiązanie, pisząc: „trzeba było tylko Bożej pomocy i Bożej łaski, która ludziom dobrej woli nie bywa odmawianą" ${ }^{\text {"47 }}$.

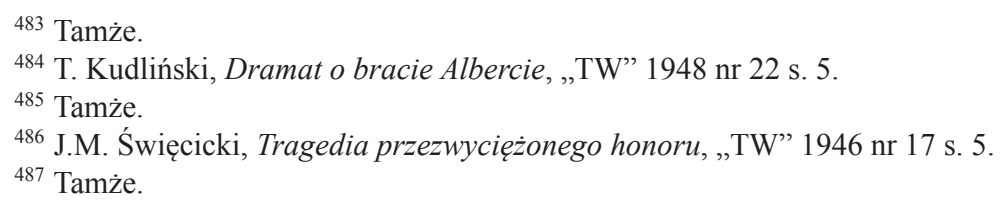


Podkreślił także, że „Bez przemienienia serc odniesione przez Przełęckiego zwycięstwo było czysto zewnętrzne", a rozwiązanie jedynie ludzkie. Konkludując, napisał: „I te podźwięki liberalnego poglądu na świat sprawiają, że ta skądinąd nam tak bliska sztuka, naszego zmysłu katolickiego w pełni nie zadowala. Jako próba wyjścia poza postawę honoru ku innym wyższym wartościom, zasługuje na szczególne uznanie; oprzeć się jednak nie możemy wrażeniu, że w oparciu o ideologię chrześcijańską wypadłaby ona nierównie bardziej przekonywująco"488.

Pogłębione i obszerne rozważania na temat Dwóch teatrów (Kraków 1947) Jerzego Szaniawskiego przedstawił Jerzy Kierst przy okazji pojawienia się sztuki na deskach warszawskich teatrów. Po zapoznaniu czytelników ze schematem strukturalnym utworu i opisem możliwych rodzajów teatru, przedstawił tezę zastąpienia proponowanego przez Szaniawskiego „Teatru Snów” „teatrem duszy” i połączenia go z teatrem realistycznym. Dopiero takie podejście, w opinii publicysty, dałoby pełnię wymowy o istocie spraw. Na końcu ciekawej recenzji czytamy: „Dwa teatry ten jedyny chyba w swoim rodzaju udramatyzowany wykład na temat istoty dramatu, a jednocześnie urzekający poemat sceniczny, istotnie odkrywa nowe widzenie świata i zmusza realistów do zastanawiania się nad tym, co było przed podniesieniem kurtyny i co będzie po jej zapuszczeniu, a marzycielom usuwa kurtynę sprzed oczu i zmusza ich do patrzenia na jasno oświetloną scenę" ${ }^{489}$.

Jerzy Kierst krytycznie w warszawskim organie prasowym odniósł się do Odwetów (Warszawa 1948) Leona Kruczkowskiego wydanych przez Książkę, a wystawionych na scenie Polskiego Teatru Państwowego. Na początku recenzji ostrzegał: „Ta szczególnie ostra gra przeciwieństw jest niebezpieczeństwem, zagrażającym zarówno autorowi, widzowi, jak i krytyce. Niebezpieczeństwo polega na tym, by $\mathrm{z}<<$ przeżyciami estetycznymi>> nie mieszać przeżyć ideowopolitycznych, by miłych lub niemiłych akcentów politycznych nie podstawiać na miejsce kryteriów artystycznych, by - wreszcie - zagadnień humanistycznych nie podporządkować sloganom"490. Kierst napisał te uwagi krótko przed oficjalnym wprowadzeniem socrealizmu do literatury polskiej w 1949 r. Zwracając uwage na to, że dramatopisarz nakreślił „dość wąskie granice teoretycznie przyjętego obiektywizmu” stwierdził: „Polska Ludowa walcząca o referendum musiała walczyć z ludźmi i grupami posiadającymi określone, pozytywne programy polityczne, określone idee, cele i prawdy. Właściwy dramat idei wiosną 1946 r. rozegrał się na tej właśnie płaszczyźnie. I wszakże to oczywiste, że nie zapadła jeszcze kurtyna, że następne akty tego dramatu rozgrywają się po dziś dzień w atmosferze mocno napiętej polemiki ideowej. Przede wszystkim polemiki humanizmu marksistowskiego z humanizmem chrześcijańskim"491. Recenzent zakwestionował

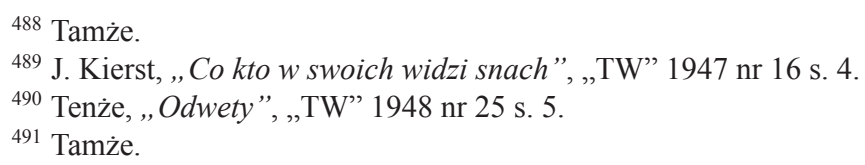


również tytuł sztuki „wiążący się z jednej strony z płaszczyzną ideowo-polityczną, z drugiej z pionem psychologiczno-moralnym" ${ }^{492}$, thumacząc z punktu widzenia katolickiego: „chodzi tu o rzecz bardzo prostą, że wszelki odwet pochodzi z nienawiści, że zatem jedynym sposobem przerwania lańcucha odwetów jest milość, sprawiedliwość i zadośćuczynienie” ${ }^{493}$. Stwierdził ostatecznie, że „zbyt mocna deklaracja polityczna autora osłabiła dramatyczność sztuki" ${ }^{994}$.

Marian Olszewski wspomniał jedynie o „starannym” wydaniu przez IW PAX Utworów zebranych (Warszawa 1952) Tadeusza Gajcego, w których obecny był dramat zatytułowany Homer i Orchidea ${ }^{495}$.

Z obcych dramatów uwzględniono w opiniach trzy polskie przekłady. „Tonem entuzjazmu" napisana została przez Zygmunta Kubiaka niezwykle fachowa recenzja „świetnego przekładu” Tragedii (Warszawa 1952) Ajschylosa dokonana przez profesora Stefana Srebrnego. W opinii zatytułowanej „Sukces polskiej poezji” dostrzegł przede wszystkim ,świetność artystyczną”, ,gęsty i aforystyczny język, na który patrzałby z uznaniem chyba i sam Norwid" oraz - co ciekawe - na głębokie związki z tradycją polskiej poezji. Uzasadnił to następująco: „Ajschylos prof. Srebrnego jest dziełem poezji polskiej, podobnie jak Jerozolima wyzwolona Piotra Kochanowskiego czy Villonowski Wielki testament Boya. Taki przekład greckiego poety, jaki dostaliśmy został umożliwiony przez tradycję poezji polskiej, przez to, że polski język poetycki został ukształtowany zwycięstwami artystycznymi Kochanowskiego, Szarzyńskiego, Mickiewicza, Norwida i tylu innych pisarzy. Przekłady nie są bynajmniej peryferią literatury. Mierzenie się z literaturą grecką i rzymską jest sprawdzianem uniwersalizmu i kultury danego kraju. W kraju mającym kulturę zaściankową nie mógłby powstać dobry przekład Ajschylosa. To jasne" ${ }^{496}$. Drugim przekładem tego samego naukowca był wydany w tym samym czasie przez Zakład Narodowy im. Ossolińskich Król Edyp Sofoklesa (Wrocław 1952), omówiony w „Przeglądzie Powszechnym”. W krótkiej recenzji czytamy: „Prof. Srebrny, niedawny laureat nagrody PEN-Clubu w dziedzinie tłumaczeń, łączy w sposób bardzo dla tego rodzaju naukowców pożądany - rozległą wiedzę o świecie starożytnym ze swobodą w posługiwaniu się żywą naturalną polszczyzną w tłumaczeniach" "497. Nowy przekład Zofii Siwickiej Otella, Króla Lira, Makbeta (Warszawa 1951) Williama Shakespeare'a porównano z dotychczas znanymi opracowaniami Jana Paszkowskiego i Jana Kasprowicza ${ }^{498}$.

Obecne na łamach pism katolickich omówienia dramatów były reakcją na nowy spektakl grany na polskich scenach lub nowe wydanie przekładu

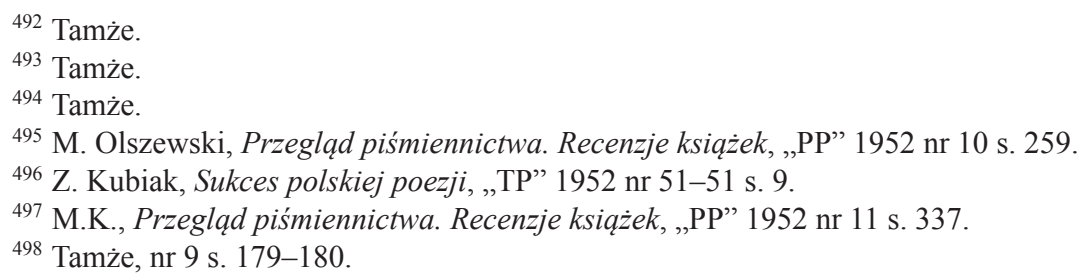


w języku polskim. Zgodnie z profilem periodyków oceny pierwszych dokonywano pod kątem przekazywanych wartości w konfrontacji z światopoglądem chrześcijańskim. Drugie natomiast stanowiły ważniejsze w odczuciu publicystów katolickich polskie tłumaczenia powojenne z literatury światowej (greckiej i angielskiej). Recenzenci dramatów należeli do grona znawców teatru i literatury.

\subsubsection{Publikacje literaturoznawcze, językoznawcze i historycznoliterackie}

Osobną grupę recenzji na łamach wybranych periodyków tworzyły omówienia dotyczące publikacji teoretycznoliterackich. W latach 1945-1953 redakcja "Tygodnika Powszechnego" opublikowała 37 opinii, zaś „Przeglądu Powszechnego” 32 wypowiedzi tego typu. Nieliczne były recenzje dotyczące zagranicznych książek. Krakowski organ prasowy zamieścił tylko jedną ocenę dzieła obcego autorstwa, a jezuicki miesięcznik dwie recenzje. W „Tygodniku Warszawskim” na sześć opinii dwie odnosiły się do publikacji obcych. W „Znaku” zaś czytelnicy mogli poznać zaledwie jedną recenzję i to krytyczną na temat polskiego opracowania. Łącznie liczba ocen publikacji literaturoznawczych wyniosła 76.

W „Tygodniku Powszechnym” zdecydowanie przeważyły pozytywne opinie, gdyż było ich aż 28 . Pozostałe wypowiedzi według przyjętej w pracy typologii ukształtowały się następująco: trzy omawiające, trzy krytyczne, dwie polemiczne i jedna negatywna. Najbardziej aktywnym recenzentem tego rodzaju publikacji był Czesław Zgorzelski (16 recenzji), a po nim Juliusz Kleiner (5 opinii) i Konrad Górski (3). Pozostali publicyści zamieścili w periodyku najwyżej dwie recenzje (Antoni Gołubiew i Marian Plezia).

W piśmie jezuitów dominowały, podobnie jak w przypadku tomików poezji, recenzje omawiające (19). Ponadto ukazało się siedem ocen pozytywnych i sześć krytycznych. Publicystą najczęściej zabierającym głos był Zbigniew Pędziński, który podzielił się swoją opinią o 19 książkach. Wacław Rola i Marek Krupiński zamieścili po trzy oceny.

Z ogólnej liczby sześciu recenzji ogłoszonych w „Tygodniku Warszawskim” cztery miały charakter pozytywny, jedna polemiczny i jedna omawiający. W tej niewielkiej liczbie wypowiedzi o wydaniach teoretycznoliterackich nie było publicystów dominujących. Wszyscy bowiem, oprócz recenzenta ukrywającego się pod kryptonimem W. Chw., napisali po jednej recenzji (Antoni Madej, Tomasz Burzecki oraz podpisujący się W.N. i Cz.J.K.).

Jedyna recenzja w „Znaku”, napisana przez Konrada Górskiego, miała charakter krytyczny. W zawartości „Głosu Katolickiego” i „Tygodnika Katolickiego” nie zamieszczono natomiast opinii o publikacji teoretycznoliterackiej. 
Zaopiniowane na łamach pism katolickich książki o zagadnieniach literaturoznawczych w większości posiadały charakter naukowy, stąd większość tytułów wydana została przez towarzystwa naukowe, takie jak Towarzystwo Naukowe KUL (7 pozycji), Towarzystwo Naukowe Warszawskie (6) i Poznańskie Towarzystwo Przyjaciół Nauk (3). Pod szyldem Wydawnictwa Zakładu Narodowego im. Ossolińskich wyszło siedem publikacji, natomiast z oficyny drukarskiej Polskiej Akademii Nauk - sześć książek. Największa liczba opracowań ocenionych w periodykach firmowana była przez Spółdzielnię Wydawniczą Czytelnik (9). Kilka z tytułów ukazało się w wydawnictwach: Gebethner i Wolff(3), Eugeniusz Kuthan (2), Książka (2) i Państwowy Instytut Wydawniczy (2).

W gronie zauważonych opracowań znalazły się publikacje teoretyczne dotyczące poezji, prozy, językoznawstwa oraz dorobku poszczególnych twórców literatury polskiej i światowej. Nie zabrakło również ocen prac historycznoliterackich dotyczących poszczególnych epok, prądów i kierunków literackich. Ze względu na formę można analizowane piśmiennictwo podzielić na rozprawy naukowe, monografie, studia; były to prace zbiorowe, podręczniki oraz zbiory esejów, rzadziej broszury. Zdecydowanie więcej głosów prasowych odnosiło się do różnych prac, natomiast stosunkowo niewiele tych samych publikacji książkowych omówiono równolegle w kilku tytułach prasowych.

$\mathrm{W}$ podrozdziale uwzględniono przede wszystkim oceny wydawnictw, które stały się przedmiotem rozważań przynajmniej w dwóch wypowiedziach oraz wybrane opinie o książkach należących do poszczególnych grup tematycznych.

Czesław Zgorzelski, rozpoczynając recenzję książki Wacława Borowego O poezji polskiej w wieku XVIII (Kraków 1948), pisał: „Polonistyka nie może w tym roku narzekać na nieurodzaj. Po dowody wystarczy sięgnąć do wydawnictw Akademii Umiejętności [...] podjęto snać w całej pełni pracę, której 75-letni jubileusz mija właśnie w roku bieżącym" ${ }^{499}$. Z wymienionych pozycji opracowanie Borowego przedstawił jako „najgodniejsze uczczenie jubileuszu” i ,niezwykłą książkę”. O jego niezwykłości zadecydowały nie tylko konsekwentnie zrealizowane założenia znanego profesora i krytyka, ale także sposób napisania i odważna oraz dobrze uzasadniona argumentacja. Na temat oryginalności kryterium oceny twórczości osiemnastowiecznych poetów polskich recenzent konstatował: „Nie epoka przeto i nie jej prądy stoją w centrum uwagi autora, ale osobowość twórcza pisarza i to, co w dorobku jego nosi walor prawdziwej poezji w dzisiejszym odczuciu" "500. Stąd też w książce dano „nowe oświetlenie” i nową „hierarchię literacką" poszczególnym poetom, przez co niektórzy mniej znani uzyskali wyższą ,,rangę”, a doceniani i chwaleni na tle epoki zostali „,przesunięci” przez Borowego niżej. Na końcu wnioskował o książce: „Wyrównana, jednolita - zdumiewa zarówno sztuką doboru cytatów, jak i talentem sugestywnego

${ }^{499}$ C. Zgorzelski, Poeci XVIII wieku - na ,cenzurowanym”, „TP” 1948 nr 27 s. 3.

${ }^{500}$ Tamże, s. 4. 
ujmowania swych myśli w zdania proste, zwięzłe, a zawsze swoiście ukształtowane, tętniące jakby naturalną intonacją słowa wygłaszanego bezpośrednio do słuchaczy” ${ }^{501}$. Recenzent „Tygodnika Warszawskiego” posługujący się pseudonimem Zet w polemicznej ocenie bronił ,świetnej pracy” profesora Borowego przed zarzutami Stefana Żółkiewskiego na łamach „Kuźnicy”, natomiast Z.K. Ciechanowska w „Przeglądzie Powszechnym” zamieściła w pełni pozytywną opinię ${ }^{502}$. Dwukrotnie na łamach „Tygodnika Powszechnego" i jednokrotnie w miesięczniku jezuitów zabrano głos w sprawie książki Konrada Górskiego Poezja jako wyraz (Toruń 1946). Chronologicznie pierwszą publikację stanowiła polemiczna odpowiedź samego autora na ostrą krytykę Kazimierza Budzyka w recenzji zatytułowanej Szkodliwa książka zamieszczonej w „Kuźnicy”. Górski w bardzo rzeczowej i pełnej humoru wypowiedzi ustosunkował się do głównych zarzutów ,przedstawiciela tzw. formalizmu w badaniach literackich” oraz „autora kilku rozprawek i artykulików z zakresu stylistyki”. Broniąc się, wyjaśnił: „Pan Budzyk przypisuje mi tezę, że $<<$ istnieje duch $>>$ i ubolewa, że też mi nie przyszło na myśl, iż $<<$ duch nie istnieje naprawdę $>>$. Otóż podejmuję się udowodnić przed sądem, że w całym tekście mojej książki nie ma twierdzenia, jakoby istniał jakiś $<<$ duch $>$. Nie jestem heglistą i żaden $<$ duch $>$ nie jest mi potrzebny do szczęścia, ani do uzasadnienia mojej teorii poezji. Mówię o $<<$ wytworach duchowych $>>$ jako zobiektywizowanym wyniku naszych przeżyć i stanów psychicznych [...] Pan Budzyk tak się jednak boi wszelkich sugestii spirytualistycznych, że przeczytawszy o wytworach $<<$ duchowych $>>$ zaraz dojrzał diabła i zaczął machać swoim materialistycznym kropidłem umoczonym w naukowej wodzie" ${ }^{503}$. Kończąc, żałował, że recenzent przejawił „tyle demagogii i sekciarskiej zaciekłości”. Pisał jednocześnie: „Jeszcze raz sprawdziło się powiedzenie Chestertona, że najgorszymi bigotami są bigoci ateizmu. Nie znam oczywiście poglądów religijnych p. Budzyka i nie chodzi mi o nie. Chodzi mi o tę ciasnotę horyzontów, znamienną przede wszystkim dla wojujących ateistów i uniemożliwiającą pewnym ludziom dostrzeżenie jakichkolwiek wartości w dziełach jednostek, które inaczej myślą, niż oni”"504. Dopiero z artykułu Władysława Tatarkiewicza opublikowanego w kolejnym numerze „Tygodnika Powszechnego” odbiorcy mogli dowiedzieć się, że była to „książka o dużych zaletach” i „książka dla znawców”, w treści której autor zawarł nie tylko teorię poezji, ,ale także sztuki i piękna w ogóle” oraz rozważania o estetyce i języku. Znany filozof za główne założenia dzieła uznał spirytualistyczne wywody Górskiego prowadzące do wniosku, że ,poezja jest wyrazem ducha”, natomiast

501 Tamże, s. 5.

502 Zet., Zagadnienia i opinie. Na marginesie polemiki o Poezji wieku XVIII, „TW” 1948 nr 35

s. 12; Z.K. Ciechanowska, Przegląd piśmiennictwa, „PP” 1949 nr 2 s. 136-137.

${ }^{503}$ K. Górski, Recenzja recenzji, „TP” 1947 nr 18 s. 4.

504 Tamże, s. 5. 
„osiągnięcia formy mierzone są wzniosłością treści" ${ }^{505}$. Myśli zawarte w książce wyjaśnił też prościej, tak jakby recenzentom pokroju Budzyka: „Piękno rzeczy pochodzi stąd, że jest wyrazem treści duchowej, i tym jest wyższe, im wyższa jest ta treść. Mówiono dawniej, że głowa kapusty, jeżeli jest dobrze namalowana, jest estetycznie tyleż warta, co głowa Madonny [...] Górski się na to nie zgadza, według niego wartość ich równa nie jest i różnica jest nie natury moralnej, lecz właśnie estetycznej. $<<Z$ dwóch dzieł sztuki to jest cenniejsze, którego treść duchowa była cenniejsza do wyrażenia $>>"{ }^{506}$. Po roku od ukazania się rozprawy Poezja jako wyraz głos zabrała Irena Sławińska, wspominając: „Żale i potępieńcze swary, jakie wzbudziła swego czasu książka prof. Górskiego, właściwie już umilkły. Nie będziemy wracać do polemiki, zapoczątkowanej przez $<<$ Kuźnicę $>>$ w tonie, dalekim od pragnień Norwida, aby umieć się $<<$ pięknie i mocno różnić>>". Dostrzegając zbieżności poglądów autora ze świeżo wydanym zbiorem wykładów Karola Du Bosa Qu'est ce que la littérature? (1946) we Francji stwierdziła jednocześnie: „Ilekroć badacze czy teoretycy literatury zbliżają się do zagadnień, tylekroć w bardzo jaskrawy sposób ujawnia się zależność ich rozwiązań od założeń zasadniczych, po prostu od poglądu na świat. Przepaść rośnie coraz bardziej. Materialistyczne twierdzenie, że $<<$ wszelkie dzieła sztuki są w ostatecznej instancji zdeterminowane warunkami ekonomicznymi > (teza teorii socjologicznej w sformułowaniu K. Budzyka) jest dla spirytualisty tak samo niemożliwe do przyjęcia jak dla materialisty - zapewne - pojęcie $<<$ treści duchowej $>>{ }^{507}$. Rozważania ,istoty dzieła, jego powstania, procesu twórczego" przy odmiennym światopoglądzie teoretyków prowadziło w ostateczności, jak pisała, „do zupełnego rozejścia się stanowisk” bez możliwości porozumienia ${ }^{508}$.

Charakter podręcznika miała praca Stanisława Furmanika Podstawy wersyfikacji polskiej (Warszawa 1947) zauważona w dwóch tytułach prasowych. Zdecydowanie negatywnie została oceniona przez Czesława Zgorzelskiego, który zarzucił opracowaniu nieprecyzyjne zdefiniowanie pojęć, pominięcie wielu zagadnień, wątpliwości w kwestii „,praktycznej użyteczności książki” w nauce o wierszu, a w końcu nawet zasadność jej powstania w czasie, gdy polska wersyfikacja była jeszcze na „etapie pionierskim"509. Zbigniew Pędziński, słynący z krytycznych uwag o wielu tytułach książkowych, w tym przypadku przedstawił recenzję omawiającą. Pomimo występujących w podręczniku nieścisłości terminologicznych oraz „braku historycznego spojrzenia na omawiane zagadnienie”, to jednak za jego zaletę uznał ambitną próbę autora „stworzenia

${ }^{505}$ Tamże, s. 4-5.

${ }^{506}$ W. Tatarkiewicz, Poezja jako wyraz, „TP” 1947 nr 24 s. 3.

${ }^{507}$ I. Sławińska, Przeglad piśmiennictwa. Recenzje książek. Rysunek łamigłówki, „PP” 1948 nr 9 s. 265.

${ }^{508}$ Tamże, s. 264-265.

${ }^{509}$ C. Zgorzelski, Nowa ksiązka o wersyfikacji, „TP” 1948 nr 29 s. 9. 
podbudowy nauki o wierszu polskim" i chęć opisania wszystkich jego elementów ${ }^{510}$. Na łamach „Tygodnika Warszawskiego” dobrze odniesiono się do broszury Jana Parandowskiego Literatura a wspótczesność (Lublin 1946), wydanej przez Towarzystwo Naukowe KUL. Recenzent zwrócił uwagę na poglądy autora, w których pomimo odrębności ,życia literatury” w społeczeństwie podkreślił jej związki z czasem powstania i otaczającą ją rzeczywistością ${ }^{511}$.

W kręgu rozważań teoretycznych pozostawał zbiór esejów poświęcony „psychologii twórczości literackiej” Jana Parandowskiego Alchemia słowa (Warszawa 1951), który dobrze odebrano na łamach „Tygodnika Powszechnego” i „Przeglądu Powszechnego”, a skrytykowano w „Znaku”. Książka Parandowskiego wzbudziła podziw Antoniego Gołubiewa. Docenił ,erudycję autora i jego rozległą wiedzę”, co zaowocowało niezwykle ciekawie napisaną, obszerną i pochwalną recenzją ${ }^{512}$. Samo podjęcie trudnego tematu ,powołania, pracy, natchnienia, tworzywa literackiego, stylu” itp., zdaniem Bogusława Grodziskiego, ,zasługiwało na głębsze uznanie”. Omawiając zawartość poszczególnych części, recenzent zauważył „imponujący rozpiętością i żywością ujęcia materiał", utrzymanie się Parandowskiego „,Z daleka od skrajności” w interpretacji, ,jasną i celową kompozycję książki” oraz „dobry styl i bogactwo słownictwa”. W końcu nazwał Alchemię słowa „publikacją pożyteczną”. Konstatował przy tym: „Każdemu, kto ją przeczyta, da ona głęboki wgląd w pracę twórców literatury. Młodych pisarzy nauczy rzetelnej roboty, czytelników - lepszego rozumienia dzieł sztuki i ich autorów"s13. Zastrzeżenia z punktu widzenia „społecznego oddziaływania” omawianej książki wyraził na łamach „Znaku” Konrad Górski krytykując przyjętą przez „,znakomitego stylistę” formę „gawędy o literaturze”. Pisał z przekonaniem: „Alchemię słowa czyta się z wielką rozkoszą, ale po zamknięciu jej niewiele się z niej pamięta. Po prostu materiał wiadomości ułożony według zasady swobodnego kojarzenia gawędziarskiego, a nie według logicznego kręgosłupa zagadnień, nie układa się w organiczną całość i skutkiem tego nie trzyma się pamięci”s14. Wyrażając życzenie, aby książka zdobyła jak największy krąg odbiorców, stwierdził jednocześnie, że Parandowski „zadał zdecydowany cios” przeciętnym czytelnikom, którym wydaje się, że „dzieło literackie równie łatwo i przyjemnie się pisało, jak się łatwo i przyjemnie czyta" ${ }^{515}$. Autor rozprawy Poezja jako wyraz, posługując się równie rozległą wiedzą i dobrym stylem, wytknął ponadto „drobne braki erudycyjne" i „twierdzenia mało uzasadnione”, prostując błędy na przykładach ${ }^{516}$.

\footnotetext{
${ }^{510}$ Z. Pędziński, Przegląd piśmiennictwa. Recenzje książek, „PP” 1952 nr 7/8 s. 91-92.

${ }^{511}$ W.N., Napór wspótczesności, „TW” 1946 nr 16 s. 14.

512 A. Gołubiew, Alchemia stowa, „TP” 1951 nr 20 s. 6-7.

${ }^{513}$ B. Grodzicki, Przegląd piśmiennictwa. Alchemia słowa, „PP” $1951 \mathrm{nr} 5$ s. 454.

${ }^{514}$ K. Górski, Zdarzenia-książki-ludzie. O „Alchemii słowa” Jana Parandowskiego, „Znak”
} 1952 nr 4 s. 297.

515 Tamże, s. 298.

516 Tamże, s. 299-304. 
Osobną grupę recenzji - drukowanych głównie w „Tygodniku Powszechnym” i „Przeglądzie Powszechnym” - tworzyły omówienia nowości wydawniczych, w których poruszano zagadnienia związane z twórczością poszczególnych pisarzy i poetów. Rodzimych przedstawicieli literatury godnie reprezentowały liczne opracowania powojenne, na temat których wypowiadano się w czasopismach społeczno-kulturalnych. Najwięcej opinii w wybranych tytułach w latach 1945-1953 ukazało się na temat opracowań dotyczących dorobku literackiego Adama Mickiewicza (7 recenzji), mniej o utworach Cypriana Norwida (2) (17 $^{517}$ Bolesława Prusa $(2)^{518}$, pojedyncze zaś o utworach Jana Kochanowskiego ${ }^{519}$, Władysława Reymonta $^{520}$, Leopolda Staffa ${ }^{521}$ i Stefana Żeromskiego ${ }^{522}$. Z obcych thumaczeń zauważono m.in. prace teoretyczne o twórczości Williama Shakespeare ${ }^{523}$, Honoré Balzaka, Stendhala i Emila Zolis ${ }^{52}$.

Eseje Juliana Przybosia wydane pod wspólnym tytułem Czytając Mickiewicza (Warszawa 1950) zostały dostrzeżone przez publicystów „Tygodnika Powszechnego” i „Przeglądu Powszechnego”. Fachową a zarazem krytyczną opinię o zbiorze wydał Czesław Zgorzelski, kwestionując jednostronność w odbiorze dzieł wieszcza narodowego z punktu widzenia jedynie współczesnej poetyki i subiektywnej oceny opracowującego studium Juliana Przybosia. Poeta bowiem ograniczył swoje konkluzje jedynie do spraw artyzmu Mickiewicza, pomijając zupełnie tak istotne dla powstania dzieła tło historycznoliterackie. Marek Krupiński w omawiającej recenzji wspomniał o próbie przewartościowania utworów wielkiego poety przez Przybosia, który ,za pozycje martwe" uznał Konrada Wallenroda i czwartą część Dziadów ${ }^{525}$. W „Tygodniku Powszechnym” kompetentnie i pozytywnie oceniono ponadto dwutomową monografię Juliusza

${ }^{517}$ M. Chojecka, Przegląd piśmiennictwa. Recenzje książek, „PP” 1948 nr 9 s. 267-268 [Kazimierz Wyka, Cyprian Norwid, Toruń 1949]; X.J.R. [J. Rostworowski], Przegląd piśmiennictwa, „PP” $1950 \mathrm{nr} 1$ s. 58-59 [Konrad Górski, O Norwidzie pięć studiów, Toruń 1949].

${ }_{518}$ J. Kleiner, Twórczość Prusa w świetle monografii Zygmunta Szweykowskiego, „TP” 1947 nr 40 s. 6 [Zygmunt Szweykowski, Twórczość Bolesława Prusa, t. 1-2, Poznań 1947]; M.Ch. [M. Chojecka], Recenzje i notatki, „PP” 1949 nr 5 s. 381 [Feliks Araszkiewicz, Problem kultury religijnej w twórczości Bolestawa Prusa, Lublin 1947].

${ }^{519}$ C. Zgorzelski, Z historii literatury, „TP” 1948 nr 18 s. 3 [Stanisław Windakiewicz, Jan Kochanowski, Kraków 1947].

${ }^{520}$ W.R. [W. Rola], Przegląd piśmiennictwa. Recenzje ksiązek, „PP” 1950 nr 10 s. 357-358 [Maria Rzeuska, ,, Chtopi” Reymonta, Warszawa 1950].

${ }^{521}$ P. Grzegorczyk, Księga ku czci Staffa, „TP” 1949 nr 19 s. 2 [Księga pamiątkowa ku czci Leopolda Staffa 1878-1948, Warszawa 1948].

${ }^{522}$ C. Komarnicka, Przegląd piśmiennictwa. Recenzje książek, „PP” 1952 nr 5/6 s. 442-443

[Stefan Żeromski, Warszawa 1951].

${ }^{523}$ M. Krupiński, Przegląd piśmiennictwa. Recenzje książek, „PP” 1951 nr 10 s. 259-260

[M. Morozow, Szekspir, Warszawa 1950].

${ }^{524}$ O. Porycki, Przegląd piśmiennictwa, „PP” 1951 nr 10 s. 351-352 [György Lukacs, Balzac, Stendhal i Zola, Warszawa 1951].

${ }^{525}$ M. Krupiński, Przegląd piśmiennictwa. Recenzje książek, „PP” 1951 nr 2 s. 139. 
Kleinera pt. Mickiewicz (Lublin 1948) i „odpowiadającą postulatom badań literackich i zamówieniu społecznemu" pozycję naukową $Z$ badań nad legenda Mickiewiczowska (Lublin 1948) Stefana Kawyna ${ }^{526}$. Obie książki autorstwa profesorów uniwersyteckich wydało Towarzystwo Naukowe KUL. Na kartach jezuickiego miesięcznika, w którym liczba recenzji publikacji teoretycznoliterackich dorównywała liczbie ogłoszonych w „Tygodniku Powszechnym”, zaprezentowano również dwa opracowania badacza młodszego pokolenia, profesora Wacława Kubackiego - Arcydramat Mickiewicza (Wrocław 1951) (rzecz o III części

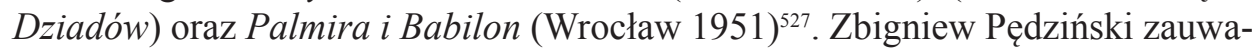
żając „wręcz rewolucyjne nowatorstwo głoszonych tez” i ,niepospolitą erudycję” Kubackiego, jednocześnie napisał o słabych stronach pracy. „Mechanicznie zastosowana" przez naukowca metoda komparatystyczna przyczyniła się, jego zdaniem, do zatarcia „W wielu punktach granicy między oświeceniem i romantyzmem”. Wyjaśniał przy tym: „Ze studiów Kubackiego dowiadujemy się wiele o wpływach literatury i kultury oświecenia działających na Mickiewicza, ale stanowczo za mało o przyczynach, które uczyniły z niego wieszcza romantycznego. Wreszcie przywiązywanie zbyt wielkiej wagi do cytatów sprawiło, że autor szczególnie rażąco dla katolika upraszcza zagadnienia teologiczne i religioznawcze, posuwając się aż do imputowania katolicyzmowi poglądów jemu wprost obcych, a zaczerpniętych z teozofii”" ${ }^{28}$. „Arcyciekawe studia” o charakterze publicystycznym Tadeusza Boya-Żeleńskiego zebrane w tomie O Mickiewiczu (Warszawa 1949) przedstawił również w „Przeglądzie Powszechnym” Olgierd Porycki ${ }^{529}$.

Spośród omówień książek z zakresu historii i teorii literatury w „Tygodniku Powszechnym” i „Przeglądzie Powszechnym” warto zwrócić uwagę na niektóre z nich. Negatywną recenzję z charakterystycznym dla siebie humorem napisał Stefan Kisielewski o książce Jana Kotta Mitologia i realizm (Warszawa 1946). Kwestionując przyjęte przez autora założenia metodologiczne, wytknął mu „swego rodzaju literackie sekciarstwo" oraz pozostawanie ,apostołem pewnego tylko rodzaju literatury”. Informował czytelników: ,[...] metoda Kotta jest metodą eliminującą. Konsekwentnie eliminuje on i tępi wszystkie $<<$ mity $>>$. Pomijając już mit religijny, odrzucany w samym założeniu, zwalcza Kott po kolei wszystko to, co w dziejach myśli ludzkiej dążyło do jakiegokolwiek stałego systemu praw metodologicznych. [...] Cała książka okazuje się w istocie tylko książką o tym, czego Kott nie lubi” ${ }^{30}$. Kończąc rozważania ironicznie wnioskował: „Książka Kotta przekonała mnie częściowo do niego, bo go demaskuje. Miała być przez krytykę

${ }^{526}$ K. Górski, ,,Mickiewicz” Juliusza Kleinera, „TP” 1949 nr 29 s. 5-6; J. Kleiner, Z dziejów legendy Mickiewiczowskiej, „TP” 1949 nr 31 s. 4.

${ }^{527}$ Z. Pędziński, Przegląd piśmiennictwa, „PP” 1952 nr 3 s. 221-222.

${ }^{528}$ Tamże.

${ }^{529}$ O. Porycki, Przeglad piśmiennictwa, „PP” $1951 \mathrm{nr} 5$ s. 458.

${ }^{530}$ S. Kisielewski, ,, Mitologia” zwycięża!, „,TP” 1946 nr 29 s. 4. 
i walkę pozytywna, twórcza i pobudzająca - w istocie jest tragicznie zniechęcająca" ${ }_{331}$. Odpowiedzią na zarzuty „dyletanctwa” i ,mistycznego psychologizowania”, z jakimi wystąpił J.A. Król na łamach „Wsi” pod adresem książki profesora Stanisława Pigonia Zarys najnowszej literatury ludowej (Kraków 1946), była polemiczna recenzja Czesława Zgorzelskiego ${ }^{532}$. Po scharakteryzowaniu zawartości pierwszego polskiego historycznoliterackiego opracowania literatury ludowej recenzent na przykładach obronił rzekomo słabe strony książki, wyjaśniając przy końcu: „Gra szła tu o coś innego, że prof. Pigoń kilkakrotnie akcentuje religijność chłopów, ich $<<$ wewnętrzną powagę $>>,<<$ surowy rygoryzm moralny wobec życia i skupione uciszenie wobec śmierci >> To właśnie stanowi grzech pierworodny prof. Pigonia w oczach p. Króla i nakazywało zdyskwalifikować jego książkę za wszelką cenę" ${ }^{533}$. Juliusz Kleiner w obszernej recenzji zwrócił uwagę czytelników na dwa wartościowe pod względem naukowym opracowania Stefanii Skwarczyńskiej Z teorii literatury, cztery rozprawy (Łódź 1947) i Systematyka głównych kierunków w badaniach literackich (Łódź 1948) ${ }^{534}$, natomiast Marian Plezia dobrze odniósł się do dwutomowej pracy Tadeusza Sinki Literatura grecka (Kraków 1947-1948) s35. $^{53}$.

„Niedociągnięcia” w pracy zbiorowej $O$ sytuacji $w$ historii literatury polskiej (Warszawa 1951) i Stefana Żółkiewskiego Badania nad literatura pol$s k a$ (Warszawa 1951) omówił na łamach „Przeglądu Powszechnego” Zbigniew Pędziński. Styl obu książek określił jako „publicystykę naukową”, zarzucając równocześnie zbyt ogólnikowe potraktowanie zagadnień, o czym świadczyć miał m.in. brak przypisów i niewłaściwe przypisanie badaczy do kierunków filozoficznych i metodologicznych. Radą Pędzińskiego było szybkie wydanie rozszerzonej wersji książek ${ }^{536}$. Ten sam recenzent podobnie krytycznie ustosunkował się do wcześniej wydanych szkiców Żółkiewskiego Stare i nowe literaturoznawstwo (Wrocław 1950), w których autor wyraźnie nawiązywał do „,nowej marksistowskiej metody badań literackich" ${ }_{337}$.

W jezuickim miesięczniku znalazło się też kilka opinii na temat opracowań dotyczących węższych zagadnień, kierunków lub epok literackich. Do trwałego dorobku nauki o literaturze Pędziński zgodził się zaliczyć po „uzupełnieniu i rewizji niektórych poglądów" $Z$ dziejów naturalizmu w Polsce (Wrocław 1951) Jana Zygmunta Jakubowskiego i Spór o Zolę w Polsce (Wrocław 1951) Jana

${ }^{531}$ Tamże.

${ }^{532}$ C. Zgorzelski, O pięknej książce i uczonym recenzencie, „TP” $1946 \mathrm{nr} 44$ s. 8-9.

${ }^{533}$ Tamże, s. 9.

${ }^{534}$ J. Kleiner, Z teorii literatury, „TP” 1949 nr 20 s. 9.

${ }^{535}$ M. Plezia, Na marginesie „Literatury hellenistycznej”, „TP” $1948 \mathrm{nr} 5$ s. 5; tenże, Dar jubileuszowy, „TP” $1949 \mathrm{nr} 27$ s. 7.

${ }^{536}$ Z. Pędziński, Przegląd piśmiennictwa. Recenzje książek, „PP” 1952 nr 9 s. 176-177.

537 Tenże, Przegląd piśmiennictwa. Recenzje książek, „PP” $1952 \mathrm{nr} 5 / 6$. 
Nowakowskiego. Porównując w wypowiedzi obie prace, wytknął „wycinkowy” charakter studiów oraz „wysnuwanie ostrych konkluzji i ocen” Jakubowskiemu, jak też brak ,precyzji terminologicznej” Nowakowskiemu ${ }^{538}$. Na uwagę Mariana Olszewskiego zasłużyły materiały do studiów Stanisława Łempickiego Renesans $i$ humanizm w Polsce (Warszawa 1952), które jednak jego zdaniem „nie mogły pretendować do miana syntetycznej i wyczerpującej charakterystyki" omawianej epoki ${ }^{539}$. Kolejna praca zbiorowa, Pozytywizm, wydana przez Zakład Narodowy im. Ossolińskich, która w zamierzeniu autorów miała „naświetlić okres" z marksistowskiego punktu widzenia, została krytycznie oceniona przez Pędzińskiego. Stały recenzent miesięcznika postawił pracy kilka poważnych zarzutów, pisząc: „Próba ujęcia całokształtu twórczości Prusa na kilkudziesięciu stronach jest oznaką niewątpliwie dużej odwagi Markiewicza, ale i zarazem małej odpowiedzialności. [...] Równie niewyczerpujące i powierzchowne są studia Żmigrodzkiej o Orzeszkowej, Kubackiego i Sandlera o Świętochowskim, Janion o Chmielowskim. Błędy tych prac są jednakowe - brak wyczerpującej i opartej o kategorie poetyki opisowej analizy twórczości poszczególnych pisarzy, uwzględnianie zbyt małego tła porównawczego" ${ }^{540}$. Zastrzeżenia omawiającego wzbudziła także krytyka niektórych autorów nacechowana radykalnością ocen bez uzasadnienia oraz mało precyzyjna analiza prądów filozoficzno-społecznych pozytywizmu ${ }^{541}$.

Niektóre omówienia na łamach katolickich pism dotyczyły opracowań naukowych z zakresu językoznawstwa. Najwięcej opublikowano ich w „Przeglądzie Powszechnym” (8 opinii). Zaletę „obiektywnego i rzeczowego wykładu” posiadała książka profesora Tadeusza Milewskiego Zarys językoznawstwa ogólnego (Lublin 1947) doceniona przez Czesława Zgorzelskiego w „Tygodniku Powszechnym” ${ }^{442}$. Procesy rozwojowe języka polskiego oraz analizę błędów we współczesnym słownictwie ,Z umiłowaniem przedmiotu” przedstawił Witold Doroszewski w Rozmowach o języku (Warszawa 1948) ${ }^{543}$. Książkę pozytywnie oceniono również na łamach „Tygodnika Powszechnego" ${ }^{544}$. „Nowatorstwo wysuniętych hipotez" cechowało natomiast pracę profesor Marii Dłuskiej Prozodia języka polskiego (Kraków 1947) ${ }^{545}$. Na stronach „Przeglądu Powszechnego” wyrażono również opinie o książkach, w których podjęto bardziej szczegółowe zagadnienia z zakresu językoznawstwa. Przykładem może być rozprawa naukowa Witolda Taszyckiego zatytułowana Dawność tzw. mazurzenia w języku polskim (Warszawa 1948),

\footnotetext{
${ }^{538}$ Tenże, Przegląd piśmiennictwa. Recenzje ksią̇ek, „PP” $1952 \mathrm{nr} 7 / 8$ s. 90-91.

${ }^{539}$ M. Olszewski, Przegląd piśmiennictwa. Recenzje książek, „PP” 1952 nr 11 s. 334-335.

${ }^{540}$ Z. Pędziński, Przegląd piśmiennictwa. Recenzje książek, „PP” 1953 nr 1 s. 74.

${ }^{541}$ Tamże, s. 74-75.

${ }^{542}$ C. Zgorzelski, Z zagadnień stylistyki, „TP” 1947 nr 24 s. 9.

${ }^{543}$ M.Ch. [M. Chojecka], Przegląd piśmiennictwa. Recenzje książek, „PP” 1948 nr 9 s. 267.

${ }^{544}$ C. Zgorzelski, Rozmowy o języku, „PP” 1949 nr 2 s. 9.

${ }^{545}$ Z. Pędziński, Przegląd piśmiennictwa. Recenzje książek, „PP” 1952 nr 7/8 s. 92.
} 
która wywołała ożywioną dyskusję znanych językoznawców na temat tezy autora o początkach języka polskiego na terenach Małopolski ${ }^{546}$. Poważną lukę w dorobku polskiego językoznawstwa, zdaniem Pędzińskiego, wypełniła z kolei „wyczerpująco opracowana" monografia Zenona Sobierajskiego Gwary kujawskie (Poznań 1952) ${ }^{547}$. Tego samego autora Elementy gwarowe w utworach Kasprowicza (Poznań 1950) w sposób omawiający przedstawił natomiast Marek Krupińskiis8. Niezwykłą aprobatę wyraził Pędziński dla „sumiennej i nowatorskiej” pracy Ludwika Zabrodzkiego Usilnienie i lenicja w językach indoeuropejskich i ugrofińskim (Poznań 1951). Jak dowiadujemy się z recenzji, naukowiec wprowadził ustaloną przez siebie terminologię i dokonał obszernej analizy porównawczej w obrębie różnych języków ${ }^{549}$. Trzy przedstawione wyżej pozycje wydane zostały nakładem Poznańskiego Towarzystwa Przyjaciół Nauk. Z obcych wydawnictw na uwagę recenzenta zasłużyła dwutomowa monografia Sjeliszczewa Język starosłowiański (Moskwa 1951-1952) bogata w szereg oryginalnych spostrzeżeń autora i polecana pracownikom naukowym oraz studentom filologii słowiańskiej ${ }^{550}$.

Redakcje dwóch z sześciu wybranych katolickich czasopism społecznokulturalnych zamieszczały w latach 1945-1953 recenzje publikacji teoretycznoliterackich. Zdecydowana większość omawianych opracowań miała charakter naukowy, co wiązało się z określonym sposobem recenzowania i angażowaniem kompetentnych specjalistów w różnych działach literatury. Takich też publicystów, często z tytułami naukowymi, zatrudniano w „Tygodniku Powszechnym” i „Przeglądzie Powszechnym”; warto tu wspomnieć np. Juliusza Kleinera i Czesława Zgorzelskiego. Na łamach obu pism przedstawiono szeroki wachlarz tematyczny z dziedziny literatury dostępnej na rynku polskim. Sporadycznie recenzowano prace obcych autorów. W "Tygodniku Powszechnym” dominowały omówienia pojedynczych tytułów książkowych, rzadziej dwóch lub trzech pozycji bibliograficznych. Inaczej postępowała redakcja „Przeglądu Powszechnego”, gdzie w dziale Przeglad piśmiennictwa zamieszczała zazwyczaj recenzje zbiorcze (od kilku do kilkunastu opinii w jednym zeszycie). Dane bibliograficzne książek wykazane na początku działu, a nawiązujące w swej treści do bliskiej sobie problematyki, recenzent przedstawiał zwykle krócej, niekiedy porównując je ze sobą. W ocenach naukowych publikacji teoretycznoliterackich zwracano uwagę przede wszystkim na zastosowaną przez autora metodę, nowatorstwo w przeprowadzonych badaniach, głoszone tezy, sposób ujęcia tematu, uwzględnienie tła historycznego, zastosowaną terminologię oraz język i styl. Część omówień stanowiły kompetentne oceny przekładów, przygotowane przez znanych literatów.

\footnotetext{
${ }^{546}$ M.K., Przegląd piśmiennictwa, „PP” 1951 nr 2 s. 136.

${ }^{547}$ Z. Pędziński, Przegląd piśmiennictwa. Recenzje książek, „PP” 1952 nr 11 s. 338-339.

${ }^{548}$ M. Krupiński, Przegląd piśmiennictwa. Recenzje książek, „PP” 1951 nr 2 s. 138-139.

549 Z. Pędziński, Przegląd piśmiennictwa, „PP” 1952 nr 11 s. 338.

${ }^{550}$ Przegląd piśmiennictwa. Recenzje książek, „PP” 1952 nr 10 s. 263-264.
} 


\subsection{Książki $z$ innych dziedzin}

Publicyści katolickich czasopism społeczno-kulturalnych, głównie „Tygodnika Powszechnego”, „Przeglądu Powszechnego” i „Tygodnika Warszawskiego", zapoznawali odbiorców z książkami o bardzo zróżnicowanej tematyce. W tabeli 20 syntetycznie ujęto problematykę najczęściej recenzowanych pozycji wydawniczych. Ze względu na bardzo różnorodną i specjalistyczną tematykę prezentowanych w podrozdziale książek omówiono statystycznie i ogólnie poszczególne grupy zagadnieniowe, skupiając się jedynie na tytułach recenzowanych kilkakrotnie. Pojedyncze pozycje opatrzone zostaną jedynie krótką informacją, zaś analiza recenzji przedstawiona będzie możliwie skrótowo, aby nie zwiększać objętości już i tak dużego rozdziału, co mogłoby uczynić tę część niejasną ze względu na nadmiar wiadomości.

Tabela 20. Liczba tytułów książkowych o różnej tematyce na łamach „TP”, „PP”, „TW”, „TK”, „GK” i „Znaku” w 1. 1945-1953

\begin{tabular}{|l|l|c|}
\hline Lp. & Tematyka & Liczba tytułów książkowych \\
\hline 1 & kulturalna, architektoniczna, sztuki & 21 \\
\hline 2 & polityczna & 20 \\
\hline 3 & $\begin{array}{l}\text { księgoznawcza, bibliograficzna, } \\
\text { bibliotekarska, bibliofilska, księgarska, } \\
\text { czytelnictwa }\end{array}$ & 17 \\
\hline 4 & filozoficzna & 16 \\
\hline 5 & regionalistyczna & 11 \\
\hline 6 & gospodarcza & 9 \\
\hline 7 & psychologiczna & 9 \\
\hline 8 & społeczna & 7 \\
\hline 9 & wychowawcza & 76 \\
\hline 10 & inna & 203 \\
\hline & Razem & \\
\hline
\end{tabular}

Źr ó dło: Obliczenia własne.

W kategorii „książki z innych dziedzin” liczebnie przeważyły nowości, których autorzy zajęli się problematyką kultury, sztuki i architektury. Omówiono 21 tytułów książkowych; były to w zdecydowanej większości rodzime pozycje, gdyż tylko jedna książka była autorstwa obcego. Największą liczbę recenzji w latach 1945-1953 zamieścili publicyści „Tygodnika Powszechnego”. Z 11 odnotowanych wypowiedzi, przeważającą część stanowiły omówienia pozytywne (9), 
ponadto odbiorcy poznali po jednej recenzji omawiającej i negatywnej. W zawartości „Tygodnika Warszawskiego” i „Przeglądu Powszechnego” zamieszczono po siedem recenzji. W „Tygodniku” dominowały pozytywne głosy o książkach (5 pozytywnych, 1 omawiająca i 1 negatywna), natomiast w „Przeglądzie” więcej było wypowiedzi o charakterze omawiającym (6 omawiających i 1 pozytywna). Redakcja „Głosu Katolickiego” opublikowała w całym okresie wydawania periodyku jedną dobrą ocenę.

Publicyści „Tygodnika Powszechnego” i ,Tygodnika Warszawskiego” wysoko ocenili książki Stanisława Bystronia Kultura ludowa (Warszawa 1947) i Bogdana Suchodolskiego Uspołecznienie kultury (Warszawa 1947) ${ }^{551}$. Pozycja zatytułowana Kultura polska a niemiecka (Poznań 1946) Mariana Friedberga znalazła przychylność recenzentów „Tygodnika Powszechnego” i „Głosu Katolickiego"552. Dwukrotnie zaś w krakowskim tygodniku zabrano głos w sprawie Kultury prapolskiej (Poznań 1947) Józefa Kostrzewskiego - wydanej w serii Prac Instytutu Zachodniego - i Urbanistyki Tadeusza Tołwińskiego ${ }^{553}$. Pozytywnie ocenioną pozycją zagraniczną była książka Henryka Gotliba Wędrówki malarza (Warszawa 1947) wydana przez oficynę Gebethnera i Wolffa ${ }^{554}$. Do sztuki nawiązano głównie na łamach „Przeglądu Powszechnego” przy okazji kilku specjalistycznych prac poświęconych architekturze Pomorza Zachodniego oraz zabytkom Krakowa, Poznania i Gdańska ${ }^{555}$.

Drugie miejsce pod względem ilościowym zajęły recenzje książek politycznych. Liczba omówionych książek z zakresu wiedzy o polityce niewiele ustępowała liczbie uwzględnionych publikacji kulturoznawczych. Wśród 20 pozycji było sześć zagranicznych. Podobnie jak w poprzedniej grupie tematycznej, przeważyły recenzje opublikowane na łamach ,Tygodnika Powszechnego” (ogółem 12, w tym 5 pozytywnych, 4 omawiające, 2 krytyczne i 1 negatywna). Na łamach „Tygodnika Warszawskiego” sformułowano pięć opinii (3 pozytywne, 1 omawiającą i 1 negatywną), natomiast miesięcznik jezuicki zamieścił

${ }^{551}$ A. Gołubiew, Od prakolebki do dnia dzisiejszego, „TP” 1947 nr 48 s. 1-2; Wśród nowych książek, „TW” 1947 nr 16 s. 8.

552 J. Skoczek, Kultura polska i niemiecka, „TP” 1947 nr 5 s. 8-9; J. Adamski, Ksiażka o Polsce wieków średnich, „GK” 1947 nr 2 s. 14.

${ }^{553}$ B. Ostromęcki, ,Urbanistyka”, „TP” 1948 nr 23 s. 9; tenże, „Urbanistyka”, „TP” 1949 nr 27 s. 9.

554 J. Woźniakowski, Wędrujemy z malarzem, „TP” 1948 nr 37 s. 9-10.

${ }^{555}$ Notatki bibliograficzne, „PP” 1948 nr 7 s. 113 [Krystyna Sinko-Popielowa, Zaginiony nagrobek św. Jacka w Krakowie, Kraków 1948]; X.J.R. [J. Rostworowski], Przegląd piśmiennictwa. Recenzje ksiązek, „PP” $1950 \mathrm{nr} 11$ s. 428 [Zygmunt Świechowski, Architektura granitowa Pomorza zachodniego w XIII wieku, Poznań 1950]; tamże, „PP” 1952 nr 4 s. 293 [Adam Dubowski, Zabytkowe kościoly Poznania, Poznań 1952]; tamże, nr 5/6 s. 444 [Gdańsk zabytkowy w roku 1950, Gdańsk 1951]; X.J.R. [J. Rostworowski], Przegląd piśmiennictwa. Recenzje książek, tamże, nr 9 s. 173 [Stanisław Bobiński, Gdańsk wczesnodziejowy, na podstawie analizy planu, Gdańsk 1952]. 
zaledwie dwa teksty oceniające (1 recenzję omawiającą i 1 krytyczną). W „Znaku” skreślono również dwie wypowiedzi (1 pozytywną i 1 krytyczną) o książkach autorów niepolskich.

Rzadko spotykane negatywne omówienia dotyczyły sensacyjnej i mającej rzekomo ukazać prawdę o działaniu papiestwa książce Virginio Scattoliniego Tajne dokumenty dyplomacji watykańskiej i pozycji stawiającej w złym świetle stronę polską w kwestii wysiedlenia Niemców ze Śląska - Tragödie Schlesiens 1945-46 in Dokumenten (Monachium 1952) ${ }^{556}$. W omawianej grupie zagadnieniowej jednogłośnie na łamach „Tygodnika Powszechnego" i „Przeglądu Powszechnego" skrytykowano Aleksandra Bocheńskiego Dzieje glupoty w Polsce (Warszawa $1947)^{557}$. Dobrze natomiast publicyści krakowskiego tygodnika i „Tygodnika Warszawskiego" przyjęli Feliksa Młynarskiego Niemcy a przyszłość Europy (Kraków 1947) ${ }^{558}$. Ponadto w polskich i obcych pozycjach znalazły się pojedyncze recenzje różnych tytułów książkowych. W rodzimych opracowaniach autorzy wypowiedzieli się m.in. o granicy polsko-niemieckiej, zagadnieniach ustrojowych, prowadzeniu polskiej polityki ${ }^{59}$. Pozytywny głos otrzymała marksistowska rozprawa Maurycego Anhalta Źródła postępu technicznego w kapitalizmie (Warszawa 1946). Recenzent stwierdził: „Nie wdając się tutaj w zasadniczy spór o prawdziwość i aktualność założeń marksizmu, a biorąc książkę, jak jest, a więc jako dzieło jednego z najwybitniejszych u nas ekonomistów tego kierunku, trzeba je ocenić jako pracę poważną" ${ }^{560}$. Obce opinie o tematyce politologicznej i ekonomicznej dotyczyły polityki europejskiej i światowej ${ }^{561}$.

Jak wynika z przeprowadzonej analizy, ważne miejsce na łamach pism zajęła problematyka księgoznawcza. Do tej grupy tematycznej włączono wszystkie pozycje, w których autorzy nawiązywali w jakikolwiek sposób do zagadnień

${ }^{556}$ zet, ,Tajne dokumenty dyplomacji watykańskiej”, „TW” 1948 nr 19 s. 4; J. Golmont, „Przeszkodzić sianiu nienawiści...”, „TP” $1952 \mathrm{nr} 7$ s. 1-3.

${ }^{557}$ P. Jasienica, Cień Machiawela, „TP” 1947 nr 31 s. 6-7; W. Kamiński, Przegląd piśmiennictwa. Ksiązki, „PP” 1948 nr 3 s. 220-221.

${ }^{558}$ T. Koński, Niemcy a przyszłość Europy, „TP” 1947 nr 29 s. 5; I. Pannenkowa, Niemcy i przyszłość Europy, „TW” 1947 nr 34 s. 1-2.

${ }^{559}$ K.J.W., Dwie broszury o Ziemiach Odzyskanych, „TP” 1946 nr 9 s. 6 [Maria Kiełczewska, O lewy brzeg Odry, Poznań 1946; taż, Odra-Nysa, najlepsza granica Polski, Poznań 1946]; Sto. [S. Stomma], Zagadnienia ustrojowe, „TP” 1948 nr 19 s. 6 [Grzegorz Leopold Seidler, Rozważania nad norma ustrojowa, Kraków 1947]; P. Jasienica, Mistrz i uczniowie, „TP” 1949 nr 29 s. 3-4 [J. Giertych, Pół wieku polskiej polityki, b.m. 1947].

${ }^{560}$ A. Mirek, Kapitalizm pod lupa marksisty, „TP” 1947 nr 33 s. 10.

${ }^{561}$ M.in. S. Stomma, Zdarzenia-ksiażki-ludzie. Anachronizm suwerenności, „Znak” $1947 \mathrm{nr} 5$ s. 567-573 [Emery Reves, Anatomie de la paix, Bruksela 1947]; P. Jasienica, Relacje dwóch ambasadorów, „TP” 1947 nr 14/15 s. 3 [Léon Noël, L'agression allemande contre la Pologne, Paryż 1946; Grégoire Gafencu, Préliminaires de la guerre a l'est de l'accord de Moscou (21 aout 1939) aux hostilités en Russie (22 juin 1941), Paryż 1944]; S.K. Rostworowski, Książki-zdarzenia-ludzie. Kryzys legitymizmu, „Znak” 1948 nr 2 s. 189-192 [Giulelmo Ferrero, Pouvoir, b.m.1943]. 
książki. Znalazły się tutaj zarówno pozycje o charakterze teoretycznym i naukowym, będące po części podręcznikami akademickimi i bibliotekarskimi, jak też bibliografie. Należało uwzględnić również pojedyncze tytuły. Do tematyki bibliofilskiej nawiązał Jan Michalski w pamiętniku zatytułowanym 55 lat wśród ksiażek (Wrocław 1950) ${ }^{562}$, księgarskiej Stanisław Arct Odbudowa książki w Polsce (Warszawa 1946) ${ }^{563}$, czytelnictwo zaś reprezentowało wznowione, czwarte wydanie książki Heleny Radlińskiej Książka wśród ludzi (Warszawa 1946). Obliczenia statystyczne wykazały łącznie 18 tytułów książkowych, z których tylko jeden należał do literatury obcej. Najwięcej recenzji (w liczbie 12) ukazało się na łamach „Przeglądu Powszechnego" (w tym 10 omawiających i 2 pozytywne). Po tym miesięczniku na drugim miejscu uplasował się, w odróżnieniu do wcześniej przedstawionej problematyki kulturalnej i politycznej, „Tygodnik Powszechny” (8 recenzji: 4 omawiające, 3 pozytywne, 1 krytyczna), jako trzeci był „Tygodnik Warszawski" ( 3 opinie, w tym 2 pozytywne i 1 negatywna). Opiniodawcami książek w formie recenzji byli głównie Piotr Grzegorczyk (6 opinii), Olgierd Porycki (3) i Maria Chojecka (3). Pozostali recenzenci, jak Jerzy Starnawski, Jacek Woźniakowski oraz ukrywający się pod inicjałami B.G., J.K., W.K. ${ }^{564}$ napisali po jednej ocenie. Współpracownicy „Tygodnika Powszechnego” i „Przeglądu Powszechnego" zauważyli cztery pozycje z dziedziny nauki o książce: rozszerzone wydanie Życia książki (Kraków 1951) Jana Muszkowskiego, Studia nad książa poświęcone pamięci Kazimierza Piekarskiego (Wrocław 1951), Teorię bibliografii $w$ zarysie (Wrocław 1951) Stefana Vrtela-Wierczyńskiego oraz $Z$ dziejów i techniki książki (Wrocław 1951) Józefa Grycza. Wszystkie książki, oprócz autorstwa Muszkowskiego, ukazały się pod szyldem Wydawnictwa Zakładu Narodowego im. Ossolińskich. Oceny miały charakter pozytywny lub omawiający.

Piotr Grzegorczyk w zbiorowej recenzji pt. Ksiązki o ksiązkach odniósł się do wyżej wymienionych pozycji. Za „,nader ważne” i przystępnie napisane uznał Życie książki Muszkowskiego, w której docenił „doprowadzenie w każdym dziale do stanu obecnego przedstawionych zagadnień" oraz zapoznanie odbiorcy z aktualnymi przepisami prawnymi. W recenzji czytamy: „Dzięki temu umiejętnemu powiązaniu książki z życiem wzrosła jej praktyczność, żywość i aktualność" ${ }_{65}$. O jej wyglądzie czytamy: „Ilustracje na ogół dobrze dobrane, z czterobarwną miniaturą z kodeksu Behema, na czele, co wynagradza w części prawie zupełne pominięcie działu dawnego zdobnictwa książki" ${ }^{566}$. Olgierd Porycki, zapoznając z okolicznościami powstania podręcznika, napisał: „Praca Muszkowskiego daje

562 B.G., Przegląd piśmiennictwa, „PP” $1951 \mathrm{nr} 10$ s. 354-355.

${ }^{563}$ Z.R., Odbudowa książki w Polsce, „TW” 1946 nr 39 s. 8.

${ }^{564}$ Zob. Indeks osobowy na końcu pracy. Niestety, większości kryptonimów nie udało się rozwiązać.

565 P. Grzegorczyk, Książki o książkach...

566 Tamże. 
niewątpliwe podstawy w zakresie wiedzy bibliotekoznawczej i po jej gruntownym przestudiowaniu jaśniejszymi stają się dzieła specjalistów" 567 . Ze względu na piękną szatę graficzną książkę polecił nie tylko pracownikom bibliotek, ale także „właścicielom domowych bibliotek”. Jerzy Starnawski z radością powitał tom Studiów nad książka poświęconych pamięci Kazimierza Piekarskiego (Wrocław 1951), otwierający (według numeracji) zainicjowaną przez Kazimierza Budzyka i Alodię Gryczową w 1949 r. serię Książka w Dawnej Kulturze Polskiej ${ }^{568}$. Za „wartościową publikację” Studia... te uznał również Grzegorczyk ${ }^{569}$. Obaj recenzenci, skupiając się na zawartości dzieła, wydali o nim dobre opinie. Doceniono również „bibliofilski wygląd” książki ${ }^{570}$. W dziedzinie bibliografii nauka polska zyskała, zdaniem recenzentów, ,niezwykle cenne dzieło" powstałe na podstawie wykładów uniwersyteckich profesora Stefana Vrtela-Wierczyńskiego. Po przedstawieniu bogatej „rozumowanej historii rozwoju poglądów na książkę i naukę o niej od czasów starożytnych aż do chwili obecnej" w dziesięciu rozdziałach, Grzegorczyk skonstatował: „Obszerna literatura przedmiotu i indeksy zamykają cenne i pożyteczne dzieło prof. Wierczyńskiego, nie mające w tym zakresie równego sobie w literaturze europejskiej, godne przeto przełożenia na obce języki" ${ }^{571}$. Polecił je nie tylko specjalistom, ale także pragnącym ,głębiej spojrzeć na dzieje kultury". Maria Chojecka natomiast największą wartość naukowego opracowania dostrzegła w samodzielnych i własnych poglądach autora ${ }^{572}$. W recenzjach zasygnalizowano również pojawienie się na rynku księgarskim bardziej „popularyzatorskiej” pracy Józefa Grycza Z dziejów i techniki książki (1951) ${ }^{573}$.

Na łamach pism śledzono również nowości z zakresu bibliografii. Wśród zestawień bibliograficznych zwrócono w dwóch pismach uwagę na Polska bibliografie prawa kanonicznego od wynalezienia druku do 1940 roku (Lublin 1947) w opracowaniu zakonników Joachima Bara i Wojciecha Zmarza. Z omówień dowiadujemy się o zaplanowanych dwóch tomach oraz szczegółów o jej opracowaniu, układzie i wykazach ${ }^{574}$. Krytycznie natomiast odniesiono się do pokaźnego objętościowo dwutomowego Katalogu wydawnictw Polskiej Akademii Umiejętności 1873-1947, który mógłby stanowić wartościową bibliografię, gdyby „,autorzy nie

567 ol. por. [O. Porycki], Przegląd piśmiennictwa. Recenzje książek, „PP” 1952 nr 11 s. 339.

568 J. Starnawski, Przegląd piśmiennictwa. Nowy tom z zagadnień wiedzy o książce, „PP” 1952 nr 4 s. $288-290$.

${ }^{569}$ P. Grzegorczyk, Ksią̇ki o ksiażkach, TP” 1952 nr 26 s. 7.

${ }^{570}$ J. Starnawski, Przegląd piśmiennictwa ...

${ }^{571}$ P. Grzegorczyk, Książki o książkach...

${ }^{572}$ M.Ch. [M. Chojecka], Przegląd piśmiennictwa. Recenzje ksiązek, „PP” 1951 nr 9 s. $290-291$.

573 O. Porycki, Przegląd piśmiennictwa, „PP” 1952 nr 4 s. 302-303; P. Grzegorczyk, Książki o ksiązkach...

${ }^{574}$ Notatki bibliograficzne, „PP” $1948 \mathrm{nr} 7$ s. 111; Grabowski, Bibliografia prawa kanonicznego, ,TW” 1948 nr 20 s. 8. 
obrali najłatwiejszej i najprostszej metody" - spisania w porządku alfabetycznym publikacji w ramach wydziałów, pomijając hasła przedmiotowe. Postulowano uzupełnienie wydawnictwa o indeks przedmiotowy ${ }^{575}$.

Czwarte miejsce przypadło książkom (w liczbie 16), w których autorzy poruszyli szeroko pojęte zagadnienia filozoficzne. Z 16 recenzji sześć dotyczyło druków obcych. Najwięcej opinii przygotowali publicyści periodyku krakowskiego - osiem ocen (4 pozytywne, 2 omawiające, 1 krytyczna i 1 negatywna), po nich zaś warszawskiego tygodnika - siedem opinii (4 pozytywne, 3 omawiające). W „Przeglądzie Powszechnym” i „Głosie Katolickim” opublikowano po jednej recenzji omawiającej. Wśród publicystów oprócz Antoniego Madeja (2 wypowiedzi) nie było nazwisk wyróżniających się częstotliwością występowania. W gronie oceniających tego typu opracowania znaleźli się m.in. księża: Jan Piwowarczyk, Jan Rostworowski, Aleksander Usowicz, Kazimierz Kłósak i Stanisław Niczyperowic, a także Janina Budkowa, Zygmunt Kubiak oraz Aleksander Bocheński. Dwukrotnie zrecenzowano Władysława Tatarkiewicza O szczęściu (Kraków 1947) i Jerzego Kalinowskiego Teoria reguty społecznej i reguly prawnej Leona Duguit (Lublin 1949). Obie otrzymały pozytywną opinię na łamach „Tygodnika Powszechnego” oraz w sposób omawiający przedstawiono je w „Przeglądzie Powszechnym” i „Głosie Katolickim”"

Problematyka regionalistyczna zajęła kolejne miejsce pod względem liczby omówionych prac (11 tytułów książkowych) w 16 recenzjach prasowych, w których zdecydowanie zachęcano odbiorców do sięgnięcia po daną książkę (13 pozytywnych ocen). Redakcja „Tygodnika Powszechnego” znów zamieściła najwięcej wypowiedzi ( 8 ocen, w tym 5 pozytywnych, 2 omawiające i 1 krytyczną). W pozostałych periodykach wydrukowano po kilka tylko dobrych ocen książek. Czytelnicy „Tygodnika Warszawskiego” mogli poznać trzy omówienia, „Przeglądu Powszechnego” i „Głosu Katolickiego” po dwa, natomiast „Tygodnika Katolickiego" jedno. Aktywnymi publicystami byli: Władysław Wnuk (3), Antoni Madej (3) i Piotr Skiba (2). Polecano przede wszystkim druki Wydawnictwa Instytutu Zachodniego w Poznaniu, rodzimych autorów. Uwagę recenzentów czterech pism katolickich zwróciła praca zbiorowa tego wydawcy pod redakcją Kiryła Sosnowskiego i Mieczysława Suchockiego zatytułowana Dolny Ślask (Poznań 1947). Tom wydany w cyklu Ziemie Staropolski, w opinii Pawła Jasienicy był „dziełem na wskroś oryginalnym”, w którym dostarczono „dowody polskości Śląska" ${ }^{77}$. Antoni Madej, omawiając zawartość pracy, nazwał ją „piękną monografią” i stwierdził: „Książka, biorąc pod uwagę jej szatę artystyczną i ogromny trud

${ }^{575}$ P. Grzegorczyk, Wśród bibliografii, „TP” 1949 nr 27 s. 6.

${ }^{576}$ (ar), Co warto czytać?, „GK” 1948 nr 29 s. 253; K. Kłósak, Summa o szczęściu, „TP” 1949 nr 11 s. 3-4; N.K., Z filozofii prawa, tamże, nr 39 s. 10; J. Rostworowski, Przegląd piśmiennictwa, „PP” 1949 nr 10 s. 245.

${ }^{577}$ P. Jasienica, Po linii tradycji, „TP” 1948 nr 15 s. 9. 
pracy naukowej i twórczej, włożonej w nią, nie jest droga. Kosztuje tylko 1000 zł. Sądzimy, że wszystkie biblioteki szkolne, publiczne, samorządowe wkrótce zaopatrzą się w nią," ${ }^{778}$. O jej rzetelności, pożyteczności i pięknym wyglądzie dowiadujemy się również z recenzji Adama Dubowskiego, który kończąc omówienie, napisał: „Książkę tę muszą przeczytać wszyscy, a przede wszystkim... Wielkopolanie" Piotr Skiba jedynie wzmiankował o istnieniu publikacji ${ }^{580}$. Dwukrotnie zrecenzowano Z biegiem Odry (Poznań 1946) autorstwa Marii Czekańskiej; publikacja ukazała się również nakładem Instytutu Zachodniego i doczekała się dobrego odbioru na łamach „Tygodnika Powszechnego” i „Głosu Katolickiego”. Książka, będąca „starannym i przejrzystym opisem Ziem Zachodnich”, mogła stać się, zdaniem Włodzimierza Wnuka, ,pomocniczym podręcznikiem dla młodzieży szkolnej”s81. Egon Naganowski, przyjmując książkę z radością, nazwał ją „małą encyklopedią Ziem Odzyskanych" "582. W kręgu problematyki Ziem Zachodnich pozostały reportaże Kazimierza Koźniewskiego Żywioły (Poznań 1949), dobrze odebrane w „Tygodniku Powszechnym” i „Przeglądzie Powszechnym”

Zagadnieniami gospodarczymi zajęto się w 10 recenzjach w kilku pismach. Na plan pierwszy znów wysunął się krakowski tygodnik (6 ocen książkowych: 2 pozytywne, 3 omawiające i 1 krytyczna), a po nim „Przegląd Powszechny" (2 pozytywne opinie). Po jednej recenzji omawiającej zamieszczono w „Tygodniku Warszawskim” i „Głosie Katolickim”. Ks. Jan Piwowarczyk wyróżnił się trzema opiniami, natomiast pozostali recenzenci zabrali głos jednokrotnie, m.in. Eugeniusz Myczka, ks. Jan Rostworowski i Jan Czekanowski. Spośród dziewięciu omówionych książek, jedna była obcego autorstwa. Praca Konstantego Turowskiego Gospodarka planowa w koncepcji katolicko-społecznej (Kraków 1947) wzbudziła zainteresowanie współpracowników „Tygodnika Powszechnego" i „Głosu Katolickiego”. Doceniona została za propozycję autora wprowadzenia do gospodarki obok kolektywizmu i kapitalizmu trzeciego kierun$\mathrm{ku}$ - katolicko-społecznego ${ }^{584}$. Ks. Jan Piwowarczyk tak wyraził się o niej: „,...] wnosi wiele zdrowych i nowych myśli. Dla katolików, chcących zestroić życie gospodarcze z nakazami katolickiej moralności, będzie stanowić cenny drogowskaz i punkt oparcia w ożywionej dyskusji na tematy ustrojowe" ${ }^{\text {"55. }}$. Pozostałe tytuły książkowe otrzymały po jednej recenzji.

578 A. Madej, Piękne wydawnictwo, „TW” 1948 nr 3 s. 6.

579 A. Dubowski, Dolny Ślask, „GK” 1948 nr 2 s. 20.

${ }^{580}$ P. Skiba, Oblicze Dolnego Ślaska, „TP” 1949 nr 27 s. 11.

${ }^{581}$ W.W. [W. Wnuk], „TP” 1946 nr 50 s. 8.

582 E. Naganowski, Encyklopedia Ziem Odzyskanych, „GK” 1946 nr 48 s. 386.

${ }^{583}$ P. Jasienica, Z historia na bakier, „TP” 1949 nr 28 s. 3; Z. Lichniak, Przeglad piśmiennictwa. Ksiązki-dokumenty, „PP” 1949 nr 5 s. 375-380.

584 J.P. [J. Piwowarczyk], Gospodarka planowa, „TP” 1948 nr 5 s. 6; E. Myczka, Synteza wolności i planowości, „GK” $1948 \mathrm{nr} 3 \mathrm{~s}$.

585 J.P. [J. Piwowarczyk], Gospodarka planowa... 
Równolegle do książek z zakresu gospodarki publicyści zainteresowali się tytułami, w których podjęto kwestie psychologiczne (również 8 pozycji). Wśród 11 opinii w trzech pismach przeważały głosy promujące książkę (7 pozytywnych). Na pierwsze miejsce pod względem liczby ocen wysunął się po raz drugi „Przegląd Powszechny” (6 recenzji: 3 pozytywne, 2 omawiające i 1 krytyczna). W „Tygodniku Powszechnym” recenzenci swoje zdanie o publikacjach wyrazili w czterech pozytywnych artykułach, natomiast w warszawskim organie prasowym - w jednym. Pojedyncze publikacje podpisali dobrze znani recenzenci, jak Jerzy Braun, Antoni Gołubiew, ks. Kazimierz Kłósak czy Zygmunt Lichniak. Książki wydane zostały przez różne oficyny. Dwie pozycje bibliograficzne stanowily druki zagraniczne. Trzykrotnie odniesiono się w wymienionych czasopismach do podręcznika ks. Józefa Pastuszki Psychologia ogólna (Lublin 1947), który ukazał się dzięki staraniom Towarzystwa Naukowego KUL ${ }^{586}$.

$\mathrm{Na}$ ostatnim miejscu w tabeli uplasowały się równolegle zagadnienia społeczne i wychowawcze. Z ogólnej liczby siedmiu książek o tematyce socjologicznej, trzy stanowiły prace obcego autorstwa. Na książkę społeczną zwrócono uwagę tylko w „Tygodniku Powszechnym” (5 recenzji: 2 omawiające, 2 negatywne, 1 pozytywna) i „Znaku” (1 pozytywna i 1 omawiająca). Pod artykułami podpisali się: dwukrotnie ks. Jan Piwowarczyk oraz raz Konstanty Turowski, Józef Marian Święcicki, Stanisław Stomma, Stanisław Kowalski i podpisujący się R.S. W recenzjach nie było powtarzających się tytułów książkowych. Czytelnikom przedstawiono m.in. dwie negatywnie ocenione pozycje: Bolesława Kuźmicza Katolicy wobec przemian społecznych (Warszawa 1947) i Janusza Pytlaka Uczmy się ekonomii (Warszawa 1946) ${ }^{587}$. O pierwszej z nich czytamy: ,Tytuł broszury bardzo pociągający, treść natomiast dowodzi nienależytego opanowania przedmiotu i jednostronnego podejścia do tematyki. Broszura zawiera krytyczną ocenę pracy katolików na odcinku reform społeczno-gospodarczych. Krytycyzm zawsze jest pożyteczny, jeśli jest utrzymany we właściwych granicach i jeżeli przedmiot jest rzeczowo i obiektywnie potraktowany. Nie można tego powiedzieć o broszurze Kuźmicza. Autor w działalności katolików widzi tylko braki, cienie, a nie widzi zupełnie blasków" "588. Stanisław Stomma natomiast w „Znaku” docenił znaną naukową pozycję polskiego antropologa i socjologa Bronisława Malinowskiego Freedom and civilization (Nowy Jork 1944) ${ }^{589}$.

Zaledwie siedem książek (4 autorów polskich i 3 obcych) reprezentowało problematykę wychowawczą. Naliczono osiem recenzji; cztery z nich dotyczyły publikacji polskich, i również cztery - zagranicznych. Redakcja „Przeglądu

${ }^{586}$ K. Kłósak, Nowy podręcznik psychologii, „TP” 1947 nr 18 s. 8; J. Braun, Psychologia ogólna, „TW” 1947 nr 32 s. 4-5; J. Rostworowski, Przeglą piśmiennictwa, „PP” 1949 nr 10 s. 241-243.

${ }^{587}$ R.S., Uczmy się historii, „TP” 1947 nr 21 s. 9; K. Turowski, Katolicy i sprawy spoleczne, tamże, nr 33 s. 11.

${ }^{588}$ K. Turowski, Katolicy i sprawy społeczne, „TP” 1947 nr 33 s. 11.

${ }^{589}$ S. Stomma, Zdarzenia-książki-ludzie. Na czym polega wolność, „Znak” $1948 \mathrm{nr} 5$ s. 461-466. 
Powszechnego" opublikowała pięć wypowiedzi (2 omawiające i 3 pozytywne), w pozostałych periodykach „Tygodniku Powszechnym”, „Tygodniku Warszawskim” i „Tygodniku Katolickim” wydrukowano po jednym pozytywnym omówieniu. Uwagę recenzentów w dwóch $\mathrm{z}$ wybranych pism zwróciła książka Antoniego Makarenki Poemat pedagogiczny (Warszawa 1949), wydana przez Książkę i Wiedzę. W jezuickim miesięczniku napisano: „Laik biorący do ręki książkę Makarenki jest lekko zaniepokojony tytułem. $<<$ Poemat $>>$ i to w dodatku $<<$ pedagogiczny $>>$... Jakaś liryka na tematy wychowania czy może teoretyczna rozprawa, której nadano tak niefortunną nazwę? ... I to jeszcze trzy tomy, trzy tomy po dwieście kilkadziesiąt stron każdy! Po przeczytaniu jednak kilku pierwszych rozdziałów nasz niepokój rozwiewa się. Opowieść, a raczej pamiętnik, kierownika kolonii dla nieletnich przestępców jest nie tylko doskonale napisany pod względem literackim. Chwilami jest tak pasjonujący jak najbardziej sensacyjna powieść" ${ }^{590}$. Poemat będący opisem pierwszych doświadczeń wychowawczych autora z młodzieżą przypadł również do gustu recenzentce „Tygodnika Powszechnego", która napisała: „Jest to książka, która z miejsca podbija czytelnika dziwnym czarem, szczerością i prawdą życia, wobec której wszelkie pedagogiczne teoretyzowanie wydaje się pustą, bezpłodną gadaniną" ${ }^{591}$. Przytaczając poszczególne etapy zamierzeń Makarenki podjętych w celu stworzenia nowego systemu pedagogicznego, pisała również: „W 1920 r. naładowany wszelkiego rodzaju mądrościami pedagogicznymi, staje bezradny wobec elementu młodocianych przestępców. Nocami zatapia się w literaturze pedagogicznej, by w dzień konstatować jej bezużyteczność” i „rozdźwięk między teorią a praktyką pedagogiczną" ${ }^{592}$. Późniejszy „geniusz pedagogiczny” Makarenki rozwinął się głównie na praktyce, gdyż: „Czytał w żywych, otwartych książkach daleko sprawniej i z większą korzyścią pedagogiczną, niż w papierowych tomach”, mawiając „Bo wszyscy wiedzą co, ale nie wiedzą jak" ${ }^{\prime 593}$. W pozostałych recenzjach nawiązano m.in. do pracy wychowawczej Janusza Korczaka przy okazji wznowienia dwóch przedwojennych jego wydań książkowych, dotyczących oświaty i wychowania w Polsce oraz ZSRR, a także przypomniano pozycję znanego pedagoga Fryderyka Wilhelma Foerstera ${ }^{594}$. Za „wyjątkową publikację”, w której Maria

${ }^{590}$ H.S., Przeglad piśmiennictwa. Recenzje książek, „PP” $1950 \mathrm{nr} 6$ s. 449.

${ }^{591}$ Z. Ciszek, Prawda czy poemat, „TP” $1950 \mathrm{nr} 48$ s. 7.

592 Tamże.

593 Tamże.

${ }^{594}$ H.S., Przeglad piśmiennictwa. Recenzje książek, „PP” 1950 nr 5 s. 364-365 [Janusz Korczak, Jak kochać dziecko, Warszawa 1948; tenże, Prawo dziecka do szacunku, Warszawa 1948]; Przegląd piśmiennictwa. Recenzje ksiązek, tamże, nr 6 s. 451-452 [Henryk Barycz, Rozwój historii oświaty, wychowania i kultury w Polsce, Kraków 1949]; C.C., Przegląd piśmiennictwa. Recenzje książek, tamże, nr 9 s. 276 [Beatrice King, Oświata i wychowanie w ZSRR, Warszawa 1950]; K. Gołba, Popuszczanie cugli, „TK” 1951 nr 15 s. 132 [Fryderyk Wilhelm Foerster, Stare i nowe wychowanie, Katowice 1938]. 
Grzegorzewska „dotknęła rzeczy zasadniczej” w pracy nauczyciela, uznano Listy do młodego nauczyciela (Warszawa 1947) ${ }^{595}$.

W łącznej liczbie 203 zrecenzowanych książek, zaliczonych tu do publikacji z różnych dziedzin, sporą część (86) stanowiły pozycje nieuwzględnione w tabeli, tzw. inne, gdyż ich udział był mniej znaczący (1-5 tytułów). Kilka zrecenzowanych tytułów książkowych reprezentowało następujące dziedziny wiedzy: ideologię (głównie marksistowską) ${ }^{596}$, medycynę, biologię, prawo, geografię, marynistykę, etnografię, dziennikarstwo ${ }^{597}$. Pojedyncze pozycje dotyczyły zaś bardzo specjalistycznych zagadnień - muzealnictwa, demografii, genetyki, zegarmistrzostwa czy sportu ${ }^{598}$. Wśród opiniowanych publikacji były także książki podróżnicze.

595 Jag., W'śród nowych ksiązek, „TW” 1947 nr 42 s. 16.

${ }^{596}$ Za książkę „nieudaną”, a nawet „kompromitującą” uznał ks. Jan Piwowarczyk Komunizm i moralność (Warszawa 1948) Rogera Garaudy’ego; J. Piwowarczyk, Moralność materialistyczna, „TP” 1948 nr 23 s. 4.

${ }^{597}$ Np. J.B.Sl., Czy stać nas na luksus setek czasopism?, „TW” 1946 nr 28 s. 8 [Mieczysław Kafel, Ekonomiczne oblicze zawodu dziennikarskiego w Polsce, Kraków 1945]; S. Górzyński, $O$ lewy brzeg Odry, „TW” 1947 nr 6 s. 6; [Maria Kiełczewska, O podstawy geograficzne Polski, Poznań 1946]; kt, Uroda morza, „TW” 1948 nr 7 s. 7 [Roman Pollak, Uroda morza w polskim stowie, Poznań 1947]; J.P. [J. Piwowarczyk], Życie międzypaństwowe, „TP” 1948 nr 29 s. 11 [Julian Makowski, Podręcznik prawa międzynarodowego, Warszawa 1948]; T.S. Grabowski, Flizury tużyckie i Jacki Jabłonkowskie, „TP” 1949 nr 28 s. 8 [Agnieszka Dobrowolska, Strój Jacków Jabłonkowskich, Lublin 1947-1948]; M.J. Lutosławska, Pochwała starości, „TP” 1950 nr 9 s. 6-7 [Adolf Lucas Vischer, Das Alter, als Schicksal und Erfüllung, b.m.].

${ }^{598}$ W. Majdański, Na froncie dziecka, „GK” 1947 nr 49 s. 398 [Józef Jakóbkiewicz, Walka z grożącym wyludnieniem Europy, Warszawa 1947]; O.B., Pseudopodręcznik dziennikarstwa, „TW” 1947 nr 20 s. 4 [Tadeusz Zbigniew Hanusz, Dziennikarstwo, Łódź 1947]; H. Blumówna, Podręcznik muzealnictwa, „TP” 1948 nr 5 s. 5 [Muzealnictwo, pod red. S. Komornickiego i T. Dobrowolskiego, Kraków 1947]; L. Mońko, Przegląd piśmiennictwa, „PP” 1949 nr 3 s. 208-209 [Stanisław Skowron, Zarys nauki o dziedziczności, Kraków 1947]; S. Kisielewski, Tematy sportowe, „TP” 1952 nr 37 s. 4 [Adolf Rudnicki, Kartki sportowe, Warszawa 1952]; Z. Groński, Przeglad piśmiennictwa. Recenzje ksiązek, „PP” 1953 nr 1 s. 75-76 [Wawrzyniec Podwapiński, Zegarmistrzostwo, Niepokalanów 1949-1952]. 



\section{ROZDZIAŁ 4}

\section{Promocja książki}

Książkę na łamach katolickich czasopism społeczno-kulturalnych upowszechniano także przez reklamę prasową, informacje o nowościach wydawniczych, przeglądy piśmiennictwa oraz spisy książek nadesłanych do redakcji. Niekiedy tytuły książkowe stawały się inspiracją do podjęcia na łamach pism głębszych rozważań. Ogłoszenia reklamowe nowości wydawniczych były zgodne z profilem pism $^{1}$. Ze względu na zawartość można było je podzielić na wydawnicze, księgarskie oraz tytułów i serii książkowych.

Wzmianki o aktualnych wydaniach książkowych ukazywały się zazwyczaj w osobnych rubrykach, podobnie nazywanych w różnych czasopismach. W „Tygodniku Powszechnym” były to Nowe ksiażki, Wśród książek, Notatki o ksiażkach, natomiast na łamach „Tygodnika Warszawskiego”: Nowe ksiażki, Nowe wydawnictwa, $Z$ wydawnictw, $Z$ nowych ksiazek, Przeglad wydawnictw. Redakcja „Tygodnika Katolickiego” powiadamiała o nich odbiorców pod nagłówkiem Nowości wydawnicze, natomiast czytelnicy „Głosu Katolickiego” podobne wiadomości mogli znaleźć również w Nowych ksią̇kach, jak też w kolumnach zatytułowanych $Z$ nowości wydawniczych, Nowe wydawnictwa i Co czytać? Zabrakło analogicznych rubryk na łamach „Przeglądu Powszechnego" i „Znaku”.

Zwięźle pisano o tytułach książkowych również w przeglądach piśmiennictwa. Najbardziej dowolny i przypadkowy dobór pozycji występował w Ksiązkach nadestanych do redakcji, obecnych we wszystkich wybranych pismach.

${ }^{1} \mathrm{O}$ reklamie prasowej pisali m.in. M. Brzostowski, Reklama prasowa, Warszawa 1976; D. Hombek, Reklama wydawnicza i księgarska w ,, Gazecie Warszawskiej” w latach 1764-1795, Kielce 1988; T. Hussak, Reklama i propaganda ksiązki, Warszawa 1970; I. Imańska, Ruch wydawniczo-księgarski w świetle ogłoszeń prasowych w „Kurierze Polskim” (1729-1760). W: W kreggu prasy, pod red. G. Gzelli, Toruń 1999; A. Janiak-Jasińska, Aby wpadto w oko...: o reklamie handlowej w Królestwie Polskim w początkach XX wieku na podstawie ogłoszeń prasowych, Warszawa 1998; H. Kurta, Rola i znaczenie reklamy w środkach informacji masowej, Warszawa 1965; tenże, Reklama prasowa: wybrane zagadnienia, Warszawa 1969; Z. Staniszewski, J. Szczepaniec, Ogłoszenia prasowe jako źródto wiedzy o książe w Polsce XVIII w., „Ze Skarbca Kultury” $1960 \mathrm{nr}$ 1 s. 1-6; J. Szapiro, Ogłoszenie w czasopiśmie, „Prasa” 1935 nr 12 s. 12. 
Najwięcej tematów omówionych w nawiązaniu do refleksji po lekturze książkowej znalazło się na łamach „Tygodnika Powszechnego”, nieco mniej w „Głosie Katolickim” i „Tygodniku Warszawskim”.

\subsection{Reklama książek}

Reklama książki w latach 1945-1953 znalazła stałe miejsce na łamach „Tygodnika Powszechnego”, „Tygodnika Warszawskiego”, „Głosu Katolickiego”, „Przeglądu Powszechnego” i „Tygodnika Katolickiego”. Rzadziej pojawiała się natomiast w „Znaku”2. Redakcje periodyków katolickich nie wyodrębniały osobnych działów, drukując ogłoszenia zazwyczaj na końcu zeszytu. Przybierały one różną formę. Ze względu na cechy formalne można było wyróżnić anonse pojedynczych pozycji książkowych oraz ogłoszenia zbiorowe, proponujące od kilku do kilkunastu tytułów. Odbiorcy mogli ponadto poznać ofertę nowości wydawniczych $\mathrm{z}$ adnotacją treściową lub same ich dane bibliograficzne. Łamom prasowym towarzyszyła przeważnie reklama tekstowa, rzadziej tekstowo-graficzna, pod względem chronologicznym zaś dominowała bieżąca nad prospektywną. W każdym z czasopism ze względu na wielkość można było odnaleźć reklamy małe, średnie i duże.

Ogłoszenia prasowe drukowane w „Tygodniku Powszechnym” informujące o nowościach książkowych były początkowo niewielkie. Sytuowano je zwykle w prawym lub lewym dolnym rogu na końcu pisma. $Z$ czasem przybrały większe rozmiary, choć częściej występowały małe i średnie bieżące reklamy książki bez adnotacji. Najwięcej drobnych anonsów (w liczbie 80) ogłosiła krakowska firma Juliana Kurkiewicza mieszcząca się przy placu Mariackim 5. Z innych prywatnych wydawnictw, które promowały książki liturgiczne i książeczki do nabożeństwa obok sprzętu liturgicznego, szat liturgicznych, figur świętych i dewocjonaliów, wyróżniły się firma znana pod nazwą Mieczysław Fuksiewicz i Spółka ${ }^{3}$ oraz wydawnictwo Eugeniusza Kuthana (po pięć reklam każde)4. W wybranym okresie wydrukowano tylko osiem dużych ogłoszeń. Największe stanowiła półstronicowa prospektywna reklama Spółdzielni Wydawniczej Czytelnik, zachęcająca do przedpłaty na Narodowe wydanie dzieł Adama Mickiewicza z okazji 150 rocznicy urodzin poety. „Spuściznę duchową” wieszcza zaplanowano bowiem wydać w czterech seriach i 15 tomach. Cztery tomy pierwszej edycji w cenie $800 \mathrm{zł}$

\footnotetext{
${ }^{2} \mathrm{~W}$ miesięczniku ukazało się zaledwie 12 ogłoszeń.

${ }^{3}$ Reklamowano trzy tytuły: Żelazna korona i Stanica Hanny Malewskiej („TP” $1948 \mathrm{nr} 24$ s. 12; tamże, nr 25 s. 6), Przemarsz przez piekło Stanisława Podlewskiego (,TP” 1949 nr 19 s. 8; tamże, nr 20 s. 12; tamże, nr 32 s. 12).

${ }^{4}$ Reklamowano trzy tytuły: Żelazna korona i Stanica Hanny Malewskiej („TP” $1948 \mathrm{nr} 24$ s. 12; tamże, nr 25 s. 6), Przemarsz przez piekło Stanisława Podlewskiego („TP” 1949 nr 19 s. 8; tamże, $\mathrm{nr} 20$ s. 12; tamże, nr 32 s. 12).
} 
(dwukrotnie taniej w przedpłacie niż w sprzedaży księgarskiej) w nakładzie 100 tys. egzemplarzy miały ukazać się - jak powiadamiano - 15 XI 1948 r. Z reklamy wiadomo również, że przedsięwzięcie było „pod wysokim protektoratem Prezydenta RP Bolesława Bieruta", poparte uchwałą Krajowej Rady Narodowej z dnia 5 V 1945 r. i powstawało na zlecenie Ministerstwa Kultury i Sztuki5. Drugą co do wielkości była znów reklama prospektywna, tym razem z graficznym nagłówkiem, proponująca odbiorcom 38 ,arcydzieł literatury światowej” Spółdzielni Wydawniczej Wiedza ${ }^{6}$. „Ulgową sprzedaż” zbiorowego wydania Pism Bolesława Prusa w 20 tomach „w estetycznej szacie graficznej, na papierze dziełowym" zapowiedziała Spółdzielnia Wydawnicza Książka ${ }^{7}$. Znaczne rozmiary przybrało także ogłoszenie, które brzmiało następująco: „Na dni oświaty znajdzie się na półkach wszystkich księgarń” monografia Ignacego Chrzanowskiego Joachim Lelewel. Człowiek i pisarz ${ }^{8}$. Pozostałe duże anonse reklamowały nowości Spółdzielni Wydawniczej Czytelnik ${ }^{9}$ i krakowskiego wydawnictwa, księgarni, czytelni i antykwariatu Stefana Kamińskiego ${ }^{10}$.

Pierwszą niewyszukaną próbą graficznego ujęcia ogłoszenia w krakowskim periodyku była reklama Przedwiośnia Stefana Żeromskiego ${ }^{11}$. Z nielicznych ogłoszeń ilustrowanych najładniejszym była reklama katowickiej Oficyny Wydawniczej promującej Czas nieludzki Stefana Otwinowskiego i Miejsce wśród ludzi Krystyny Fuzakowskiej, z motywem książki i ozdobnym obramowaniem ${ }^{12}$. Ogłoszenie reklamowe albumu pt. Zgon i pogrzeb ks. kardynała dr. Augusta Hlonda zawierało reprodukcję okładki ${ }^{13}$, podobnie reklama Nowego Testamentu w tłumaczeniu ks. Eugeniusza Dąbrowskiego ${ }^{14}$ czy 200 miast wraca do Polski Władysława Jana Grabskiego ${ }^{15}$. Ozdobną ramkę otrzymało także PAX-owskie wydanie książki do nabożeństwa dla dzieci Jezus malusieńki ${ }^{16}$.

Zdarzało się, że w numerze zabrakło jakiejkolwiek reklamy książki (np. w latach 1949-1950 ogłoszenia były pojedyncze i sporadyczne ${ }^{17}$ ), innym razem mogły być dwie-trzy (np. nr 31 z 1950 r.) lub jedna duża. Nagłówki zachęcające do kupna książki formułowano następująco: „Miłośnikom pożytecznej książki

5 „TP” 1948 nr 27 s. 3.

6 „TP” 1947 nr 10 s. 4.

7 „TP” 1948 nr 29 s. 9.

8 „TP” 1946 nr 18 s. 6.

9 „TP” 1946 nr 15 s. 8; tamże, nr 21 s. 7.

10 „TP” 1946 nr 21 s. 6; tamże, nr 23 s. 10.

11 „TP” 1946 nr 17 s. 7.

12 „ТР” 1946 nr 19 s. 6.

13 „TP” 1949 nr 17 s. 10.

14 „TP” 1950 nr 5 s. 4.

15 „TP” 1947 nr 19 s. 12.

16 „TP” 1950 nr 49 s. 8.

${ }^{17} \mathrm{~W} 1949$ r. brak jej w numerach: 30, 33, 37, 42, 46, 47, natomiast w 1950 r. w numerach: $4,11-16,18,19,21-25,28,30,32-37,39,40,47,48,50$. 
polecamy”, „Wydatek na dobrą książkę - to wydatek najlepszy”, „Książka warta upowszechnienia”, „Dla inteligencji katolickiej”, „Już wyszła z druku książka”. Promocji sprzyjały też różne okazje, o czym świadczą hasła: „Na gwiazdkę polecamy”, „Dobra książka najlepszym podarkiem gwiazdkowym”, „Na Wielki Post polecamy dobrą książkę”, „Na I Komunię św. najpiękniejszym podarkiem jest dobra książka". Ogłoszenia - oprócz nagłówka - zawierały zazwyczaj tytuł dzieła, nazwisko autora i nazwę wydawnictwa wraz z adresem, cenę (w tym upusty i rabaty), informacje o sposobie nabycia książki, ewentualnie krótką recenzję lub informację o oprawie książki.

Redakcja „Tygodnika Warszawskiego" nie wyodrębniła osobnego działu reklamowego, zamieszczając ogłoszenia zwykle na końcu. Pierwsze reklamy obecne w początkowych zeszytach z 1945 r. również były niewielkich rozmiarów $(6 \times 6 \mathrm{~cm})$ i znajdowały sie na ostatniej stronie. Nie zabrakło też ogłoszeń rozrzuconych po numerze na stronach $2-7$. W przypadku ,numeru powiększonego" objętościowo, o czym redakcja informowała wytłuszczonym drukiem na pierwszej stronie, reklamy drukowano w ostatniej części pisma (s. 12, 15 lub 16, w zależności od liczby stron). Reklama książki od 1946 r. zaczęła być stałym elementem treści, powiększona czasem do znaczniejszych rozmiarów (11 x $13 \mathrm{~cm})$. Czytelnicy mogli odnaleźć ją zazwyczaj w prawym dolnym rogu strony. Pod względem graficznym ogłoszenia były niewyszukane, gdyż zawierały jedynie krótki tekst w czarnym obramowaniu.

W anonsach stołecznego tygodnika wyróżniano zazwyczaj pogrubioną i powiększoną czcionką tytuł książki. Niekiedy najważniejszy redakcji wydawał się autor, którego imię i nazwisko eksponowano, innym razem nazwa wydawnictwa. Nazwisko autora otrzymywało wówczas wersję druku spacjowanego lub złożonego odmienną czcionką. Reklama rzadko towarzyszyła pierwszemu i drugiemu rocznikowi „Tygodnika Warszawskiego”. W niektórych numerach nie było bowiem żadnej. Dopiero od rocznika drugiego zaczęto drukować zazwyczaj kilka ogłoszeń o różnej tematyce ${ }^{18}$. Pierwsza reklama książkowa, a zarazem najczęściej powtarzana (aż 55 razy) w kolejnych rocznikach, to informacja o możliwości nabycia Katechizmu. W bogatej ofercie wydawniczej pisma można wyróżnić reklamy pojedynczych pozycji książkowych oraz ogłoszenia zbiorowe księgarni i wydawnictw, proponujące od kilku do kilkunastu tytułów ${ }^{19}$.

Na łamach „Głosu Katolickiego” ogłoszenia reklamowe rozpoczynano hasłami: „Nowość!”, „Nadzwyczajna nowość!”, „Aktualna książka”, „Dla dzieci na gwiazdkę i okres świąteczny”, „Na I Komunię świętą najpiękniejszym podarkiem

${ }^{18}$ Za przykład może posłużyć odlewnia dzwonów Jakuba Kruszewskiego i syna w Wągrowie, cukiernia Jana Gajewskiego, warszawski sklep optyczny Z. Matyszkiewicza. „TW” 1946 nr 6 s. 8.

${ }^{19}$ Zob też. E. Kristanova, Reklama ksiązki na łamach „Tygodnika Warszawskiego" (1945-1948). W: Od książki dawnej do biblioteki wirtualnej, pod red. D. Degen i M. Fedorowicz, Torun 2009, s. 245-263. 
- dobra książka" lub po prostu od nazwy wydawnictwa. Promowano zarówno pojedyncze tytuły, jak też informowano o zbiorczej ofercie wydawniczej. W okresie istnienia pisma, w latach 1945-1948, zagościło na jego łamach 31 anonsów.

Reklama książki w „Przeglądzie Powszechnym” pojawiła się już w pierwszym powojennym numerze miesięcznika. Występowała nieregularnie na tylnej okładzinie pisma, zawierając krótkie adnotacje treściowe. W uwzględnionym okresie wydawniczym nie posiadała elementów graficznych.

Redakcja „Tygodnika Katolickiego” drukowała ogłoszenia książkowe najczęściej pod nagłówkiem Nowości wydawnicze, Książka w twoim ręku i Biblioteka Dobrej Ksiązki. Oprócz pozycji dla dorosłych, w ofercie znalazły się tytuły książkowe dla dzieci i młodzieży. Dodawano do nich niekiedy adnotacje odnośnie do treści. Zaledwie jedna reklama posiadała dodatek graficzny.

Ogłoszenia w „Znaku”, choć sporadyczne, były przeważnie dużych rozmiarów, zajmując całą lub połowę strony; zazwyczaj nie posiadały żadnych ozdobników.

\subsubsection{Reklama wydawnicza}

Anonse wydawnicze drukowano we wszystkich katolickich czasopismach społeczno-kulturalnych. Tworzyły one najliczniejszą grupę ogłoszeń. Bogatą ofertę przedstawiły wydawnictwa zakonne, prywatne oraz spółdzielnie wydawnicze.

Najczęściej tytuły książkowe na łamach „Tygodnika Powszechnego” proponował Instytut Wydawniczy PAX (46 reklam), w większości w ogłoszeniach dotyczących pojedynczych tytułów. Spośród 37 reklamowanych pozycji dominowała oferta Nowego Testamentu w przekładzie ks. Eugeniusza Dąbrowskiego ${ }^{20}$. Reklama ubogacona została reprodukcją czarno-białej okładki nowego wydania. W tej samej formie wystąpiła także w „Tygodniku Katolickim”21 i „Znaku”22. Jednokrotnie polecono czytelnikom Katechizm religii katolickiej i modlitewnik dla dorosłych zatytułowany Będziesz miłowat Pana Boga twego ${ }^{23}$. Ogłaszano ponadto znane powieści zagraniczne: Pod stońcem szatana, Pamiętnik wiejskiego proboszcza, Zaktamanie Georgesa Bernanosa ${ }^{24}$, Olaf syn Auduna Sigrid Undset $^{25}$, Chwata córy królewskiej Bruce'a Marshalla ${ }^{26}$, sensacyjną powieść

${ }^{20}$ M.in. w pojedynczych reklamach „TP” $1950 \mathrm{nr} 1$ s. 6 ; tamże, $\mathrm{nr} 6$ s. 11; tamże, nr 7 s. 8; tamże, nr 8 s. 8; tamże, nr 10 s. 12; tamże, nr 11 s. 2.

${ }^{21}$ „TK” 1950 nr 6 s. 46; tamże, nr 7 s. 54; tamże, nr 9 s. 68.

${ }^{22}$ Reklama zajęła całą stronę miesięcznika. „Znak” $1950 \mathrm{nr} 1 \mathrm{s.} 88$.

23 „TK” 1951 nr 40 s. 358.

${ }^{24}$ „TP” 1952 nr 42 s. 9; tamże, nr 50 s. 8; tamże, nr 23/24 s. 176, s. 182; „Znak” 1949 nr 4 s. nlb.

25 „TP” 1952, nr 33 s. 12.

${ }^{26}$ „TK” 1949 nr 48 s. 430; tamże, nr 23/24 s. 176, s. 182; „TK” 1951 nr 27 s. 248. 
Broń na sprzedaż i Sedno sprawy Grahama Greene'a ${ }^{27}$. Czytelnikom zachwalano także zbiór nowel Gilberta Keitha Chestertona Przygody księdza Browna ${ }^{28}$, Opowieści wybrane Josepha Conrada ${ }^{29}$ oraz dwie nowości książkowe autorstwa Daniela-Ropsa Dzieje Chrystusa i Od Abrahama do Chrystusa ${ }^{30}$. Z polskich powieści w ogłoszeniach znalazła się powieść zatytułowana Bolesław Chrobry Antoniego Gołubiewa ${ }^{31}$, a z twórczości Jana Dobraczyńskiego: Klucz madrości, Listy Nikodema i Największa miłośćc ${ }^{32}$. Oprócz tego Spółdzielnia Wydawnicza oferowała bajkę dla dzieci Przygody Gucia pingwina Aleksandra Rymkiewicza (sześć razy) ${ }^{33}$ i biografię Stanisław Konarski Juliusza Nowaka-Dłużewskiego (pięć razy) ${ }^{34}$. Nie zabrakło również tomików poezji Jerzego Lieberta i Tadeusza Gajcego $^{35}$.

W „Tygodniku Warszawskim” ważne miejsce zajęły reklamy książkowe Katolickiego Towarzystwa Wydawniczego „Rodzina Polska” mieszczącego się w Warszawie przy ul. Nowogrodzkiej 49 (22 anonse). Formę pojedynczego ogłoszenia przyjęły informacje o historycznym dokumencie, a zarazem ,fascynującym pamiętniku" będącym świadectwem niemieckiego bestialstwa w Polsce, zatytułowanym Piekło XX wieku Ludwika Christiansa (9-krotna reklama) ${ }^{36}$. W zbiorowych reklamach zaproponowano poezje Na krawędzi Romana Sadowskiego, Popiół niepodległy Bogdana Ostromęckiego, Płomień nad czołem Jerzego Kiersta oraz poemat Powrót do miasta Stanisława Ziembickiego ${ }^{37}$.

Warszawskie Wydawnictwo Księży Jezuitów zamieszczało zazwyczaj dodatkowe informacje o reklamowanych tytułach i preferowało większe zbiorowe ogłoszenia. Dominowała oferta książki katolickiej. Na łamach „Przeglądu Powszechnego" polecano nowości jedynie tej oficyny. Pod wydrukowanym wersalikami nazwiskiem autora i tytułem książki zamieszczano kilka zwięzłych zdań o jej przeznaczeniu, zawartości, tłumaczeniach na języki obce i szacie zewnętrznej. Pod nagłówkiem Ksiażki ascetyczne $i$ teologiczne polecano rozważania modlitewne ojców zakonnych, np. Modlitwa na każda godzinę Piotra Charlesa, Boski przyjaciel Józefa Schryversa czy Siedem ostatnich stów arcybiskupa

27 „TP” 1951 nr 21 s. 3; „TP” 1952 nr 42 s. 9; „TK” 1950 nr 23/24 s. 176, 182; „TK” 1951 nr 22 s. 202.

28 ,TP” 1951 nr 37 s. 8; „TP” 1952 nr 42 s. 9.

29 „TP” 1953 nr 4 s. 8.

30 „TK” 1951 nr 14 s. 123 ; „TP” 1952 nr 26 s. 10.

31 „TP” 1952 nr 36 s. 8.

32 „TK” 1950 nr 23/24 s. 176, 182; „TK” 1951 nr 27 s. 248; „TK” 1952 nr 15 s. 118.

${ }^{33}$ M.in. „TP” 1951 nr 14 s. 7; „TP” 1952 nr 22 s. 4; tamże, nr 42 s. 9.

${ }^{34}$ M.in. „TP” 1951 nr 19 s. 9; tamże, nr 25 s. 2; tamże, nr 26 s. 9; „TP” 1952, nr 42, s. 9; tamże, nr 50 s. 8; „TK” 1951 nr 20 s. 182; „Znak” 1951 nr 2 s. 184.

35 „TP” 1952 nr 42 s. 9; tamże, nr 50 s. 8.

36 M.in. „TW” 1946 nr 42 s. 8; tamże, nr 43 s. 8; tamże, nr 44 s. 2; „TW” 1947 nr 4 s. 8; tamże, nr 7 s. 3.

${ }^{37}$ M.in. „TW” 1947 nr 28 s. 2; tamże, nr 31 s. 7; tamże, nr 36 s. 2; tamże, nr 50 s. 10. 
Fultona J. Sheena. Wykład prawd wiary zawierała Mała dogmatyka dla świeckich Leona Rudloffa. Oferowano także opowiadania zatytułowane Obrazki z życia Zbawiciela Jana Rostworowskiego, kazania i konferencje Christianus sum! Edwarda Kosibowicza. Zachęcano do kupna książek do nabożeństwa „w wygodnym formacie" dla dorosłych i ,ślicznej oprawie” dla młodzieży męskiej i żeńskiej Jezu kocham Ciebie Stanisława Bajko. W rachunku sumienia i sakramencie pokuty miało pomóc Przygotowanie do spowiedzi i Komunii świętej. Młodzieży mogły wydać się interesujące następujące pozycje: Życie piękne i czyste oraz $Z$ tajników przyrody Tihaméra Tótha, dziewczętom On i Ty, chłopcom zaś Ty $i$ Ona $^{38}$. W kolejnych reklamach „na miesiąc czerwiec” informowano m.in. o następujących nowościach: zbiorze Orędzie miłości i miłosierdzia skierowane do siostry Józefy Menendez, Apostolstwie serca Jezusowego jezuity Henriego Ramiere oraz Przyjaźni Chrystusowej Karola Parra ${ }^{39}$. Na gwiazdkę zaoferowano „dobrą książkę dla każdego” oraz „doskonały podarek” dla dzieci, młodzieży i dorosłych. Za „książkę pociągającą i aktualną” uznano Ku petni chrześcijaństwa Aleksandra Kisiela, czytelniczkom zareklamowano Chrystus a kobiety Piotra Kettera. „Rzeczowe uzasadnienia” i ,życzliwą polemikę” na tematy wiary można było znaleźć w Apologetyce podręcznej Stanisława Bartynowskiego ${ }^{40}$. Na okres wielkopostny polecono dodatkowo obszerne rozprawy rekolekcyjne $W$ szkole św. Ignacego Hardy'ego Schilgena, wspomniane wyżej refleksje nad słowami Zbawiciela pt. Siedem ostatnich stów F.J. Sheena oraz cztery chrystocentryczne dzieła Pinarda de la Boullaye ${ }^{41}$. W reklamach występujących w każdym zeszycie w 1949 r. dodawano zazwyczaj 2-3 nowe pozycje powtarzając w większości tytuły znane już odbiorcom z wcześniejszych ogłoszeń. Przykładowo nowością były Miłość i bohaterstwo ks. Stanisława Tworkowskiego ${ }^{42}$. W latach 1950-1953 ogłoszenia książkowe redakcja zastąpiła spisami zatytułowanymi Poszukiwane książki, a następnie Poszukiwane książki i czasopisma.

Oferta Wydawnictwa Księży Jezuitów obecna była również na łamach „Tygodnika Powszechnego” i „Tygodnika Warszawskiego”. Dzięki niej dowiadujemy się np. o „zgrabnym i wygodnym formacie” książki do nabożeństwa jezuity Stanisława Bartynowskiego Módlmy się oraz w prospektywnej reklamie o pożytecznych głównie dla kapłanów Kazaniach o Niepokalanym Sercu Marii ${ }^{43}$. Pod nagłówkiem Nadzwyczajna nowość wystąpiło nietypowe ogłoszenie następującej treści: „W pierwszych dniach grudnia ukazał się starannie wydany tomik wierszyczków ośmioletniej poetki warszawskiej,

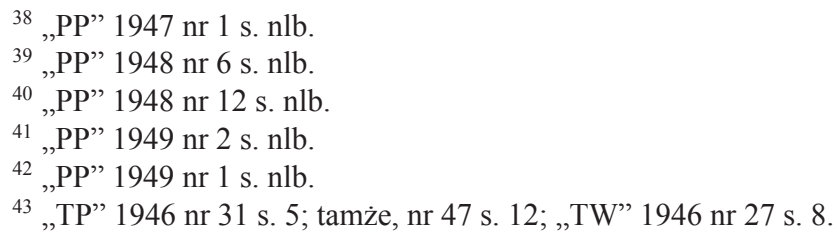


bogato i wielobarwnie ilustrowany. Znakomity podarek, zwłaszcza dla młodzieży" ${ }^{\prime 4}$. W zbiorczym ogłoszeniu znalazły się książki o treści religijnej (np. broszury Szaleństwo krzyża jezuity Raoula Plusa, U źródła żywych wód biskupa Ottokara Prohaszki) i młodzieżowe (Adam $i$ Ewa Helene Haluschki, On $i$ Ty Hardy'ego Schilgena, $Z$ tajników przyrody Tihaméra Tótha $)^{45}$. W jednym z anonsów w adnotacji treściowej o Światowych damach I. Debouit czytamy, że w książce ukazano „Znakomite i bogate sylwetki moralne kobiet, a zwłaszcza z humorem potraktowane ich wady główne" ${ }^{46}$. Redakcja „Tygodnika Katolickiego" ogłosiła tegoż wydawnictwa Życie Jezusa Michała Willama, Syn człowieczy ks. Jana Rosiaka, konferencje zatytułowane Bóg Chrystus Kościót ks. Zygmunta Kozubskiego ${ }^{47}$ oraz rozważania dla młodzieży Miłość i bohaterstwo ks. Stanisława Tworkowskiego ${ }^{48}$.

$\mathrm{Na}$ kolejnym miejscu pod względem liczby reklam uplasowało się krakowskie Wydawnictwo Mariackie, które zamieściło 24 reklamy (30 tytułów) w „Tygodniku Powszechnym”, dwie w „Tygodniku Warszawskim” i jedną zbiorczą w „Tygodniku Katolickim”. Większość widniejących w anonsach tytułów książkowych miało, podobnie jak we wcześniejszych ofertach wydawniczych, charakter religijny. Najczęściej pojawiały się ogłoszenia następujących książek: Zarys etyki i ascetyki katolickiej ks. Józefa Winkowskiego ${ }^{49}$, Katolicka etyka wychowawcza o. Jacka Woronieckiego ${ }^{50}$, Dlaczego wierzę? ks. Franciszka Sawickiego ${ }^{51}$, Wierze $w$ Kościót powszechny biskupa Tihaméra Tótha ${ }^{52}$, Życie $i$ działalność Jezusa Chrystusa ks. Józefa Kaczmarczyka ${ }^{53}$. Polecano także Materializm dialektyczny ${ }^{54}$ i Myśl katolicka wobec teorii samorództwa $a^{55}$ autorstwa ks. Kazimierza Kłósaka. Nie zabrakło również „w pięknej i trwałej oprawie" Modlitewnika dla ludu opracowanego przez ks. Ferdynanda Machaya ${ }^{56}$. Zainteresowanym zaproponowano powieść o św. Piotrze autorstwa Juliusza Kędziory zatytułowaną Szymon - syn Jony ${ }^{57}$.

${ }^{44}$ Chodziło o Wierszyczeńki 8-letniej poetki Haliny Podhorskiej, „TP” 1946 nr 50 s. 11; „GK” 1946 nr 52 s. 421.

45 „GK” 1947 nr 50 s. 411; „TP” 1947 nr 49 s. 2; „TW” 1947 nr 7 s. 7; tamże, nr 49 s. 8.

46 „TW” 1947 nr 23 s. 7.

47 „TK” 1948 nr 10 s. 68; tamże, nr 17 s. 115.

48 „TK” 1948 nr 1 s. 10.

49 „TP” 1947 nr 36 s. 6; „TP” 1948 nr 36 s. 12; tamże, nr 41 s. 11; tamże, nr 48 s. 9; „TW” 1948 nr 24 s. 7.

${ }^{50}$ „TP” 1948 nr 11 s. 8; tamże, nr 29 s. 12; tamże, nr 30 s. 12.

51 „TP” 1948 nr 22 s. 11; tamże, nr 23 s. 12; „TW” 1948 nr 24 s. 7.

52 „TP” 1948 nr 22 s. 11; tamże, nr 23 s. 12; „TW” 1948 nr 24 s. 7.

53 „TP” 1949 nr 9 s. 8; tamże, nr 10 s. 10.

${ }^{54}$ „TP” 1948 nr 47 s. 8.

55 „TP” 1948 nr 10 s. 11.

56 „TP” 1947 nr 31 s. 4.

57 „TW" 1948 nr 30 s. 8. 
Wydawnictwo św. Krzyża z siedzibą w Opolu zamieściło w „Tygodniku Powszechnym" osiem reklam (16 tytułów), w pozostałych czasopismach łącznie 11 ogłoszeń (po 4 w „Tygodniku Katolickim” i „Tygodniku Warszawskim” oraz $3 \mathrm{w}$ „Głosie Katolickim”). Zachęcano do nabycia „dobrej książki” jako podarku na pierwszą komunię św.: Owoce Bożego sadu Artura Chojeckiego i Gorejace serca Adama Bagińskiego ${ }^{58}$. We wszystkich księgarniach dostępne było drugie wydanie rozważań eucharystycznych Idy Kopeckiej Jeśli kto pragnie ${ }^{59}$. Za 100 zł można było kupić „materiał wieczornicowy” pt. Na święto Chrystusa Króla ${ }^{60}$. Warto było także, wedle anonsu, zapoznać się z Historia Kościoła ks. Józefa Umińskiego, Wstępem do filozofii i Zarysem ontologii ks. Eugeniusza Dąbrowskiego ${ }^{61}$. W zależności od oprawy w oficynie można było zakupić Mały modlitewnik dla młodzieży w wersji tańszej i droższej ${ }^{62}$.

Zakonne Wydawnictwo Księży Pallotynów (Pallotinum) ogłosiło 16 reklam, z których większość miała charakter zbiorczy i posiadała krótkie adnotacje treściowe odnośnie do proponowanych pozycji bibliograficznych. Polecano książki do nabożeństwa, z zakresu życia wewnętrznego, katechetyczne oraz powieści. Wydawnictwa przeznaczone były dla różnych grup wiekowych, zarówno dla dorosłych, jak też dla dzieci i młodzieży. Najmłodszym, ,nie umiejącym jeszcze czytać”, zaproponowano książeczkę z obrazkami zatytułowaną Trzyletnia Jadwinia w Kościele $e^{63}$. Reklamowano ją jako ,piękny podarek” oraz pomoc dla pracujących w przedszkolach i ochronkach. Książką zatwierdzoną przez Ministerstwo Oświaty i będącą ,pomocą do nauki religii dla dzieci” była Pierwsza komunia święta na wsi, w cenie 150 zł. Lekturą odpowiednią dla przedszkolaków i dzieci uczęszczających do młodszych klas szkoły powszechnej miał być Straszny wilk ${ }^{64}$. Nastolatkom zaoferowano Modlitewnik dla młodzieży $y^{65}$, starszym natomiast trzynaste wydanie „ułożonej w duchu św. Teresy od Dzieciątka Jezus” książki Jak kochać Jezusa. Powieściami godnymi polecenia młodym, wedle opinii reklamodawców, były Nieuchwytne skarby, Irusia, Rywalka ks. Stanisława Pasławskiego i Tajemnica spowiedzi Józefa Szpilmana ${ }^{66}$. Dorosłym zaproponowano prozę Zofii Kossak: Krzyżowców, Króla trędowatego, Bez oręża, Suknię Dejaniry ${ }^{67}$ oraz

58 „TP” 1948 nr 18 s. 8; tamże, nr 19 s. 3; tamże, nr 20 s. 7; „TW” 1948 nr 18 s. 6; tamże, nr 19 s. 11; „GK” 1948 nr 18 s. 163; tamże, nr 19 s. 179.

59 „TW" 1947 nr 44 s. 6; „GK” 1947 nr 45 s. 375.

60 ,TW" 1947 nr 39 s. 7.

61 „TP” 1949 nr 36 s. 12

62 ,TP” 1947 nr 43 s. 8.

${ }^{63}$ M.in. zbiorowa reklama, ,TP” 1948 nr 19 s. 8.

64 „GK” 1948 nr 1 s. 7; ,TW” 1947 nr 46 s. 3.

65 „GK” 1947 nr 32 s. 271; „TW” 1947 nr 32 s. 8; „TP” 1948 nr 19 s. 8.

66 „GK” 1948 nr 18 s. 161; ,TK” 1948 nr 19 s. 136.

${ }^{67}$ „GK” 1948 nr 49 s. 411. 
Gustawa Morcinka Byli dwaj bracia ${ }^{68}$. Poszerzoną ofertę Pallotinum wydrukowano na łamach „Tygodnika Powszechnego”, „Tygodnika Warszawskiego”, „Głosu Katolickiego" i „Tygodnika Katolickiego”. Zaproponowano w niej m.in. dwie książki ks. Franciszka Bogdana Ojcze nasz i Zdrowaś Mario oraz ks. Michała Millera $O$ radosnym miłowaniu Boga. Przystępne omówienie warunków „dobrej i owocnej spowiedzi" można było poznać dzięki pozycji pt. Sakrament przebaczenia, a życiorys ks. Józefa Kosibowicza w Pod korcem autorstwa ks. Ignacego Podgórskiego ${ }^{69}$. W pojedynczych reklamach zachęcano do zakupu m.in. Rodziny wobec nadchodzacej epoki Walentego Majdańskiego ${ }^{70}$; pod nagłówkiem Co czytać zaproponowano „książkę o dużej wartości wychowawczej i literackiej” Wilhelma Huenermanna Ojciec Damian ${ }^{71}$, a „na wszystkie niedziele i święta” lekturę pt. Lekcje i ewangelie $e^{72}$.

Czytelnicy katolickich czasopism społeczno-kulturalnych mogli zapoznać się także z produkcją wydawniczą powstałego w 1945 r. w Poznaniu naukowego Wydawnictwa Instytutu Zachodniego. Specjalizowało się ono w książkach o tematyce dotyczącej Ziem Zachodnich, państwa niemieckiego, stosunków polsko-niemieckich i dziejów okupacji hitlerowskiej w Polsce ${ }^{73}$. Dzięki reklamie znane były następujące nowości: Śląsk w okresie okupacji Alojzego Targa, Doktór Marcin Witolda Jakóbczyka, Miasta niemieckie dzisiaj Peregrinusa ${ }^{74}$, Granica pokoju Juliusza Kolipińskiego ${ }^{75}$. Na „Najpiękniejszy podarek gwiazdkowy" nadawało się, zdaniem reklamodawców, drogie wydanie bogato ilustrowanej Monografii Ziem Odzyskanych (1 tys. zł) i Monografii Odry (2 tys. zł) ${ }^{76}$. Dwie książki otrzymały krótkie recenzje, a były to Polski romantyzm w czeskim życiu duchowym Mariana Szyjkowskiego i Kultura prapolska Józefa Kostrzewskiego ${ }^{77}$. W prospektywnej reklamie zapowiadano ukazanie się pierwszego polskiego opracowania przebiegu II wojny światowej Od Westerplatte do Hiroszimy Witolda Supińskiego ${ }^{78}$. Graficzne ujęcie otrzymała reklama pozycji zatytułowanej 200 miast wraca do Polski Władysława Jana Grabskiego ${ }^{79}$.

68 „TK” 1948 nr 48 s. 404.

69 „GK” 1948 nr 1 s. 7; „TK” 1948 nr 19 s. 136; „TP” 1947 nr 45 s. 8; „TP” 1948 nr 19 s. 8; „TW” 1947 nr 46 s. 3.

${ }^{70}$ „TP” 1946 nr 10 s. 3.

71 ,TK” 1948 nr 40 s. 318.

72 ,TK” 1951 nr 8 s. 78.

${ }^{73}$ Wydawnictwo istnieje do dziś. Więcej informacji na stronie domowej. Dostępny w World Wide Web: http://www.iz.poznan.pl/index.php?p=wydawnictwo\&lang=pl [dostęp: 10 XI 2009].

74 „TP” 1946 nr 51/52 s. 19.

75 „TP” 1948 nr 15 s. 2; tamże, nr 23 s. 12.

76 „TP” 1947 nr 50 s. 6.

77 „TP” 1947 nr 23 s. 11.

78 „TP” 1947 nr 35 s. 8; tamże, nr 39 s. 5; „TW” 1947 nr 35 s. 2.

79 „TW” 1947 nr 18 s. 7. 


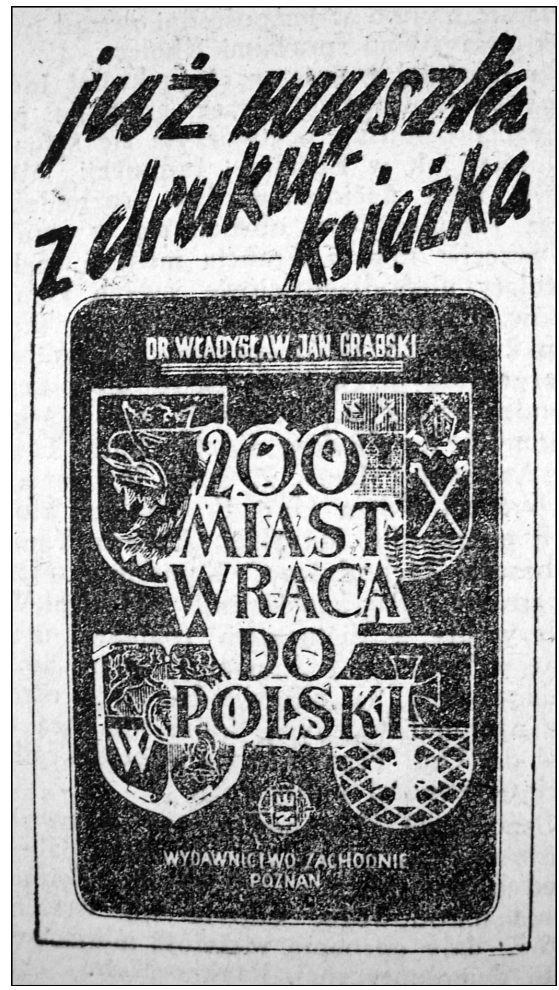

Źródło: Ze zbiorów BUŁ.

Redakcja „Tygodnika Warszawskiego" zamieściła ponadto zbiorcze ogłoszenie nt. książek o tematyce geograficznej i kulturalnej. Znalazły się tutaj m.in. O podstawy geograficzne Polski Marii Kiełczewskiej, Ziemia Lubuska. Opis geograficzny i gospodarczy Bogumiła Krygowskiego i Stanisławy Zajchowskiej, dwutomowa Kultura polska a niemiecka Mariana Friedberga oraz Zdobnictwo ludowe Ziemi Pyrzyckiej Bożeny Stelmachowskiej ${ }^{80}$.

W reklamach obecnych na łamach „Tygodnika Powszechnego” ważne miejsce zajmowały pozycje książkowe Towarzystwa Przyjaciół Katolickiego Uniwersytetu Lubelskiego (13 ogłoszeń), którego oferta występowała pod hasłami: „Bez dobrej modlitwy nie ma dobrego życia”, „Życie bez modlitwy - to życie bez sensu i treści”, „Jak dobrze i zawsze się modlić?”. Odbiorcy mogli zakupić Modlitwę na każda godzinę Piotra Charlesa najpierw w cenie 400, a następnie

${ }^{80}$,TW” 1946 nr 43 s. 8. 
$500 \mathrm{zt}^{81}$. Z wydawnictw o tematyce religijnej zauważono także Bóg jest świattościa ks. Stanisława Olszewskiego ${ }^{82}$. „Na Wielki Post” w kategorii „,dobrej książki" zaproponowano Obrazki z życia Zbawiciela ks. Jana Rostworowskiego ${ }^{83}$. Książką pomocną w rozwiązywaniu problemów wychowawczych i „ciekawszą niż najlepsza powieść" miała być Wielka tajemnica Włodzimierza Okońskiego zareklamowana także w „Głosie Katolickim” i „Tygodniku Warszawskim”" Pozycję Zarys socjologii ks. Franciszka Mirka ${ }^{85}$ ogłoszono jako pierwszy polski podręcznik nauki o społeczeństwie. Nowością wartą zakupienia miała być trzytomowa ilustrowana monografia Mickiewicz „znakomitego historyka literatury polskiej" Juliusza Kleinera, wydana z okazji 150 rocznicy urodzin poety $^{86}$, oraz poruszająca zagadnienia metafizyki tomistycznej książka Stefana Świeżawskiego $B y t^{87}$. Ostatni z tytułów dwukrotnie zareklamowano również na łamach „Znaku”"8s.

Poznańskie Wydawnictwo Seminarium Zagranicznego wydrukowało 12 reklam (10 reklam pojedynczych tytułów i dwie zbiorowe) z 32 propozycjami książkowymi tylko w krakowskim tygodniku. Redakcja "Tygodnika Warszawskiego" przez cały okres istnienia periodyku wydrukowała sześć anonsów tej oficyny (5 pojedynczych i jeden zbiorowy), natomiast w „Głosie Katolickim” znalazły się zaledwie dwie reklamy. W ofercie, jak przystało na charakter czasopism, przeważała książka katolicka. Propagowano ilustrowany Mszalik dla dziatwy i młodzie$\dot{z} y$ ks. Stanisława Bielawskiego ${ }^{89}$, nowe wydanie (dwukolorowy druk i płócienna oprawa) zbioru modlitw i pieśni Mój niedzielny mszalik ${ }^{90}$, rozważania dla kapłanów Regina Cleri biskupa Kowalskiego ${ }^{91}$. Klerykom polecono zaś Mały ceremonia ${ }^{92}$, modlitewnik i śpiewnik Chwalcie Pana ${ }^{93}$ oraz Intronizację Najświętszego Serca Pana Jezusa o. Mateo Boeveya ${ }^{94}$. Rodzinom zaproponowano Matżeństwo $z$ ustanowienia Bożego ks. Ludwika Ziętka ${ }^{95}$, młodzieży natomiast „interesującą powieść" Wacek i jego pies Ferdynanda Ossendowskiego ${ }^{96}$. Reklama zbiorowa,

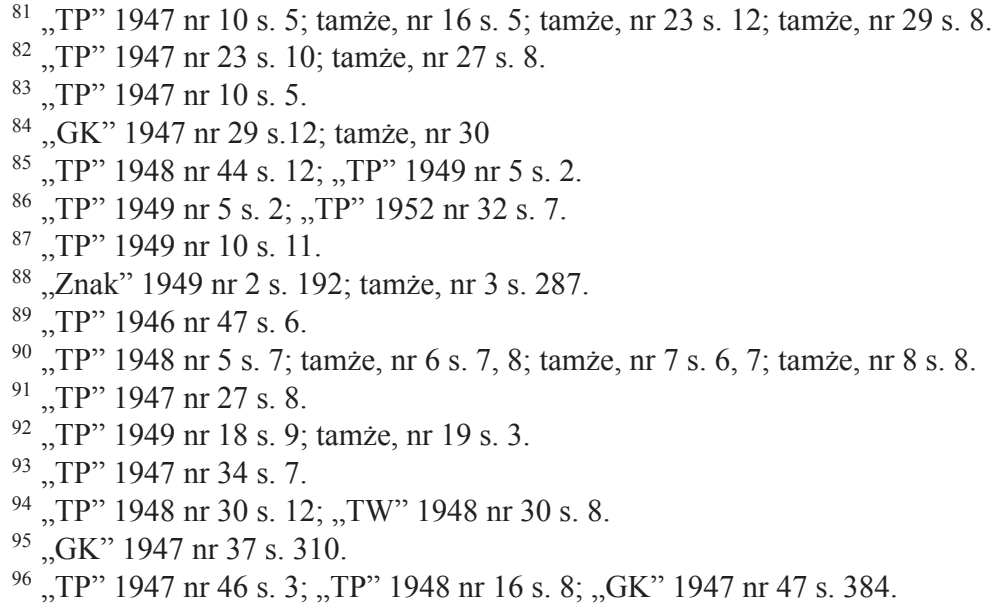


wśród licznych tytułów, zawierała pozycje znane z okresu dwudziestolecia międzywojennego, takie jak Podręcznik Akcji Katolickiej ks. Ludwika Civardi oraz Religia i kultura Jacquesa Maritaina. W anonsach zagościły również Nędza i my Daniela-Ropsa oraz Ku doskonatości Willibrorda Verkade ${ }^{97}$.

Istniejące do dziś krakowskie Wydawnictwo Apostolstwa Modlitwy najczęściej reklamowało się w „Tygodniku Katolickim” (9 ogłoszeń); w pozostałych czasopismach w latach 1945-1953 ukazało się łącznie osiem reklam (5 w „Tygodniku Powszechnym”, 2 w „Głosie Katolickim” i jedna w „Tygodniku Warszawskim”). Bogata oferta książki katolickiej uwzględniła m.in. kazania zatytułowane Śladami Skargi; Młodzieniec dobrze wychowany biskupa Tihaméra Tótha ${ }^{98}$; Dobra wola ks. Józefa Schryversa99; Zarys doskonatości zakonnej jezuity J. Meynckensa; O sakramencie chorych ks. Ernesta Matzela ${ }^{100}$; Znak na niebie i Serce Matki Jezusa ks. Kazimierza Wilczyńskiego oraz Serce Matki Bożej ks. Franciszka Kwiatkowskiego ${ }^{101}$. Pod hasłem „Ostatnie nowości” znalazły się natomiast: Filozofia wieczysta ks. Franciszka Kwiatkowskiego, Jak założyć i prowadzić Apostolstwo Modlitwy ks. Józefa Andrasza oraz Śnieżka Franciszka Finna ${ }^{102}$.

Ogłoszenia Wydawnictwa OO. Karmelitów Bosych z siedzibą w Krakowie (5 ogłoszeń) znalazły miejsce jedynie w „Głosie Katolickim” i „Tygodniku Katolickim”. W prospektywnej reklamie pierwszego z pism zapowiedziano w latach 1947-1948 ukazanie się 10 tomów Vivere cum Ecclesia ,pionierki ruchu liturgicznego" zakonnicy Marii Renaty od Chrystusa. Można je było zamawiać bezpośrednio w wydawnictwie lub za pośrednictwem księgarni „bez obowiązku nabywania poprzednich czy następnych" części ${ }^{103}$. Osobno informowano o wydaniu drugiego tomu, który jako „książka dla wszystkich wielce pożyteczna” winna była przede wszystkim trafić do „rąk kapłanów i osób zakonnych” jako pomoc w rozważaniu istoty świąt Bożego Narodzenia ${ }^{104}$. Zwrócono uwagę także na dwie pozycje karmelity Bernarda od Matki Bożej: Bez zmazy... i Jej śladem, z których pierwszą stanowiły rozważania o Matce Bożej, a drugie o św. Teresie od Dzieciątka Jezus ${ }^{105}$.

Oficyny prywatne działające $\mathrm{w}$ pierwszych latach powojennych stosunkowo rzadko zamieszczały reklamę książkową na łamach katolickich czasopism społeczno-kulturalnych. Zaledwie po kilka anonsów ukazało się pod szyl-

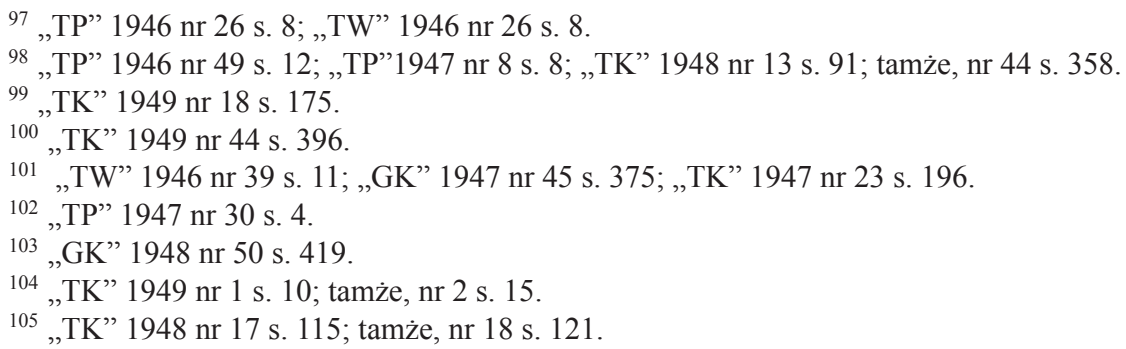


dem Gebethnera i Wolffa ${ }^{106}$, Trzaski, Everta i Michalskiego ${ }^{107}$, Mieczysława Fuksiewicza i Spółki ${ }^{108}$ oraz Michała Arcta ${ }^{109}$. O możliwości zakupu znanej książeczki $O$ naśladowaniu Chrystusa Tomasza à Kempis odbiorcy dowiedzieli się z oferty Wydawnictwa K. Rutski z Łodzi (dwie reklamy) ${ }^{110}$. Po jednym ogłoszeniu do redakcji „Tygodnika Powszechnego” dostarczyli: Galster, Lauter i Rutkowski, Wydawnictwo W. Nagłowskiego i Księgarnia Zdzisława Gustowskiego ${ }^{111}$.

Osobną grupę tworzyły reklamy spółdzielni wydawniczych. Na łamach „Tygodnika Powszechnego" najczęściej ogłaszał się Czytelnik (9 reklam) ${ }^{112}$, po nim Wiedza (6 reklam) $)^{113}$ oraz Diecezjalna Spółdzielnia Wydawnictw Religijnych Veritas (3 reklamy) ${ }^{114}$. Po jednym ogłoszeniu podały Polska Spółdzielnia Księgarska i Papiernicza Nauka z Bydgoszczy ${ }^{115}$, Spółdzielnia Wydawnicza Książka ${ }^{116}$, Spółdzielnia Wydawnicza Wieś ${ }^{117}$, Warszawska Spółdzielnia Księgarsko-Wydawnicza Światowid ${ }^{118}$ i Polska Agencja Wydawnicza z Łodzi ${ }^{119}$. Dwietrzy reklamy wydrukowały: warszawskie Wydawnictwo Panteon (trzy ${ }^{120}$, Instytut

${ }^{106}$ M.in. Lad serca Jerzego Andrzejewskiego, Listy ze wsi Władysława Orkana („TP” 1946 nr 30 s. 7; „TW” 1946 nr 39 s. 11), Żylaki, hemoroidy oraz ich bezoperacyjne leczenie J. Kosta („TP” 1948 nr 12 s. 8).

${ }^{107}$ Proponowało książki w seriach Biblioteka Wiedzy i Biblioteka Kultury, „TP” 1948 nr 1 s. $12 ;$,TW” 1948 nr 14 s. 8.

${ }^{108}$ Rytm matżeński J.O. Briena („TK” 1949 nr 51 s. 454); Stanica Hanny Malewskiej („TW” 1947 nr 42 s. 15).

${ }^{109}$ Reklamujące Wojtusiowa izbę Janiny Porazińskiej („TP” 1946 nr 24 s. 8) i Polskie tradycje demokratyczne Bogdana Suchodolskiego („TP” 1946 nr 46 s. 11); Wstęp do nauki prawa Piętki, Prawo osobowe Wisłockiego („TW” 1946 nr 22 s. 8); w ramach serii Biblioteka Kultury ukazała się książka Bogdana Suchodolskiego Uspołecznienie kultury (,TW” 1947 nr 12 s. 12) .

110 „TP” 1947 nr 40 s. 5; tamże, nr 44 s. 10.

111 „TP” 1946 nr 13 s. 8; „TP” 1947 nr 32 s. 6; „TP” 1950 nr 31 s. 11.

${ }_{112}$ M.in. Kaczka-dziwaczka Jana Brzechwy, W pustyni i w puszczy Henryka Sienkiewicza, Granica Zofii Nałkowskiej i in., „TP” 1946, nr 15 s. 8; Ludzie stamtąd Marii Dąbrowskiej, Przedwiośnie Stefana Żeromskiego, tamże, nr 17 s. 7; tamże, nr 21 s. 7; Front nad Wista Stanisława Piętaka, tamże, nr 29 s. 7; Z kraju milczenia Wojciecha Żukrowskiego, tamże; tamże, nr 33 s. 2.

${ }^{113}$ M.in. Kamienie na szaniec Aleksandra Kamińskiego, „TP” 1946 nr 39 s. 7; W serii Arcydzieła Literatury Światowej ukazały się: Jaszczur Honoré de Balzaca, Dekameron Giovanniego Boccaccia, Bracia Karamazow Fiodora Dostojewskiego, Pierwsza księga dżungli Rudyarda Kiplinga i in., „TP” 1947, nr 10 s. 4; Antologia współczesnej poezji francuskiej Adama Ważyka, tamże, nr 11 s. 9; Colas Breugnon Romaina Rollanda, tamże, nr 28 s. 7.

${ }^{114}$ M.in. Zadania duszpasterstwa na tle epoki ks. Jana Stepa, „TP” $1948 \mathrm{nr} 4$ s. 2; Kazania pasyjne ks. Władysława Lesiaka, tamże, nr 6 s. 8; Adoracja Najświętszego Sakramentu, „TP” 1949 nr 2 s. 12.

115 „TP” 1947 nr 6 s. 2.

116 „TP” 1948 nr 29 s. 9.

117 „TP” 1946 nr 32 s. 6.

${ }_{118}$ Reklamowano tu Książę wśród ludzi Heleny Radlińskiej, „TW” 1946 nr 31 s. 8.

119 „TP” 1947 nr 50 s. 8.

120 „TP”1946 nr 43 s. 4, tamże, nr 46 s. 9; „TP” 1948 nr 36 s. 9. 
Wydawniczy Kultura (trzy) ${ }^{121}$, Wydawnictwo Milicji Niepokalanej (dwie) ${ }^{122}$, tynieckie Wydawnictwo Opactwa OO. Benedyktynów (dwie) ${ }^{123}$, krakowski Ex libris (dwie) ${ }^{124}$. Zaledwie raz ogłosiły się wydawnictwa: oo. redemptorystów, kobiece Mój Dom, Poligrafika i Przełom ${ }^{125}$. W zawartości „Tygodnika Warszawskiego” ukazało się pięć reklam Czytelnika, z których wiadomo było o wydaniu m.in. opowiadań Wojciecha Żukrowskiego Z kraju milczenia, Jana Dobraczyńskiego W rozwalonym domu i Stanisława Piętaka Front nad Wistą ${ }^{126}$. Prospektywna reklama była zachętą do przedpłaty na narodowe wydanie dzieł Adama Mickiewicza ${ }^{127}$.

Il. 21. Reklama książki. „TW” 1946 nr 3 s. 5

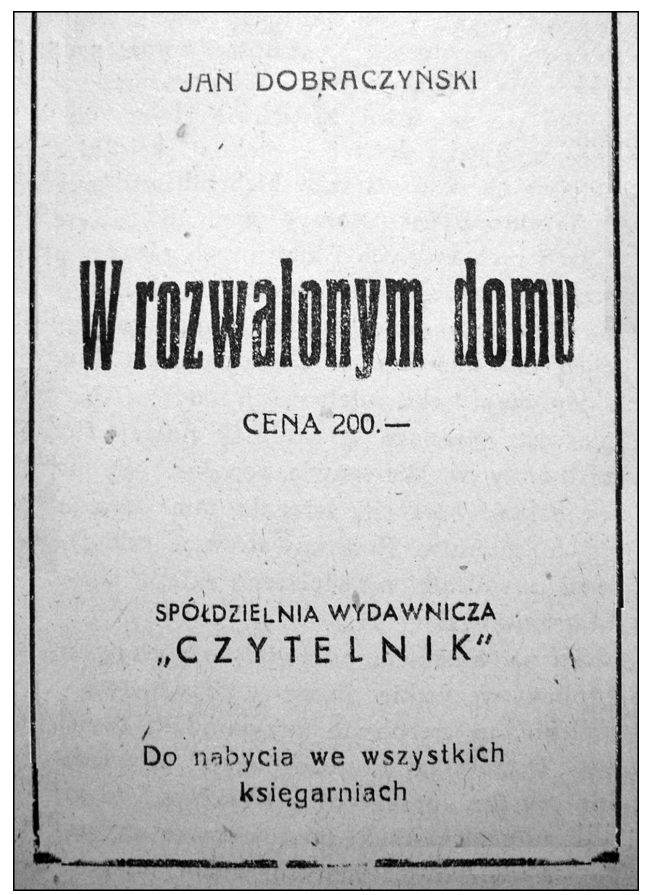

Źródło: Ze zbiorów BUŁ.
Il. 22. Reklama książki. „TW” 1946 nr 39 s. 7

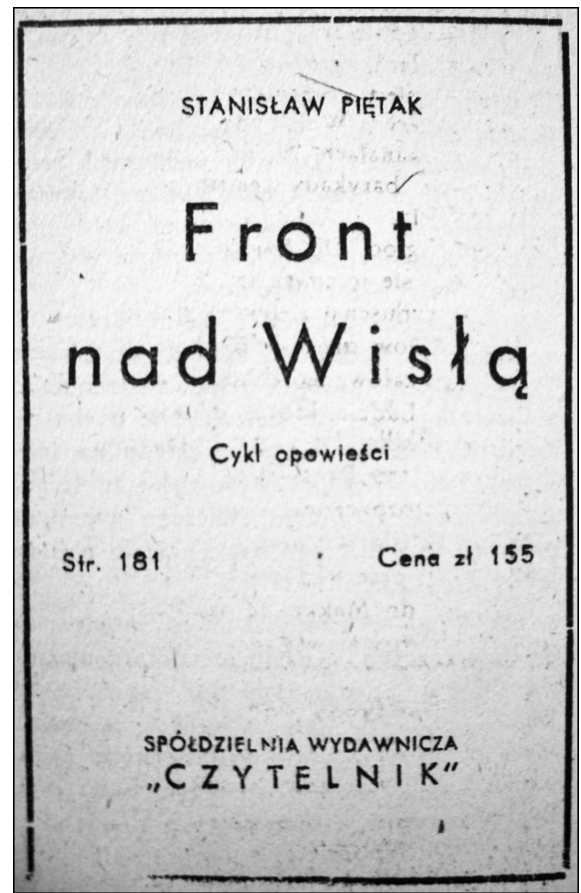

121 „TP” 1947 nr 10 s. 6; tamże, nr 11 s. 10; tamże, nr 12 s. 12.

122 „ТР” 1948 nr 39 s. 7; tamże, nr 42 s. 6.

123 „TP” 1946 nr 19 s. 6; tamże, nr 30 s. 6.

124 „TP” 1946 nr 45 s. 12; tamże, nr 46 s. 12.

125 „TP” 1947 nr 13 s. 4; tamże, nr 16 s. 10; tamże, nr 17 s. 6; tamże, nr 41 s. 11.

126 „TW” 1946 nr 29 s. 7; tamże, nr 31 s. 5; tamże, nr 39 s. 7.

127 „TW” 1948 nr 26 s. 5. 
O książkach do nabożeństwa wspominano też przy okazji reklamowania dewocjonaliów, naczyń liturgicznych, obrazów i innych sprzętów. Na tym polu wyróżniły się trzy krakowskie firmy: Juliana Kurkiewicza (tylko na łamach „Tygodnika Powszechnego" ukazało się ponad 80 reklam) ${ }^{128}$, Józefa Angrabajtisa (ponad 20 również w krakowskim periodyku) ${ }^{129}$ i Józefa Cebulskiego (ponad 10 tamże) ${ }^{130}$. W podobny sposób ogłaszała się Ars Christiana ${ }^{131}$, Res Sacra ${ }^{132}$ oraz Zakład Sztuki Kościelnej Kazimierza Schaefera ${ }^{133}$.

Il. 23. Całostronicowa reklama prospektywna w „TW” 1948 nr 26 s. 5

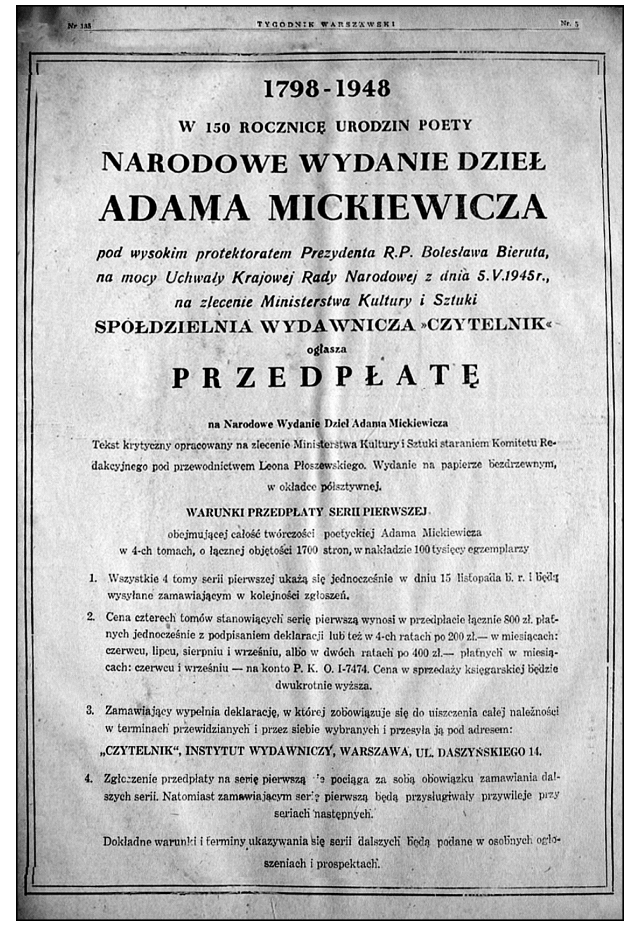

Źródło: Ze zbiorów BUŁ.

Reklama wydawnicza była dostosowana do profilu pisma. Jak przystało na katolickie periodyki ogólnopolskie, wśród ogłaszających się wydawnictw

${ }^{128}$ M.in. „TP” 1945 nr 41 s. 8; „TP” 1946 nr 33 s. 6; tamże, nr 35 s. 7; „TP” 1947 nr 50 s. 8; „TP” 1948 nr 4 s. 6; „TP” 1949 nr 32 s. 5.

129 „TP” 1946 nr 51/52 s. 8; „TP” 1947 nr 2 s. 2; „TP” 1948 nr 47 s. 8; „TP” 1949 nr 2 s. 11.

${ }^{130}$ M.in. „TP” 1946 nr 17 s. 8; tamże, nr 19 s. 6; tamże, nr 22 s. 8.

${ }^{131}$ M.in. „TP” 1951 nr 40 s. 6; tamże, nr 41 s. 8; „TP” 1952 nr 19 s. 8; tamże, nr 20 s. 7.

132 „GK” 1947 nr 30 s. 254; „TW” 1947 nr 29 s. 4; tamże, nr 30 s. 8.

133 „TP” 1946 nr 19 s. 7; „TP” 1949 nr 45 s. 404; tamże, nr 50 s. 446. 
przeważały instytucje o charakterze religijnym z całego kraju. Promowane książki w większości należały do działu religii i szeroko pojętej nauki społecznej Kościoła. Drugą grupę stanowiły pozycje o tematyce filozoficznej, etycznej, socjologicznej i literackiej. Prawie każda oficyna reklamowała modlitewniki. Oferta objęła przede wszystkim literaturę nt. życia duchowego, śpiewniki, hagiografie, Nowy Testament, encykliki, kazania i nauki rekolekcyjne oraz perykopy. Beletrystykę reprezentowała tzw. powieść katolicka ${ }^{134}$, historyczna i sensacyjna. Odbiorcom proponowano na różne okazje kupno „dobrej książki”. Do tej kategorii zaliczano: dzieła zbiorowe, monografie, słowniki, biografie, opowiadania, nowele, eseje, zbiory reportaży, tomiki poezji, bajki dla dzieci, listy, albumy, partytury, nuty, broszury $i$ in. Prezentowane książki autorów rodzimych i obcych zazwyczaj najpierw były reklamowane, a następnie recenzowane na łamach pisma ${ }^{135}$. Anonse, w większości bez recenzji, miały swoich konkretnych adresatów: przeznaczone były dla inteligencji, dla dorosłych, dla dzieci i młodzieży, dla kapłanów, dla duchowieństwa, dla dziewcząt itd. Niekiedy podawały cenne informacje o szacie graficznej książek.

\subsubsection{Reklama księgarska}

Anonse księgarzy nakładców odegrały na łamach katolickich czasopism społeczno-kulturalnych w latach 1945-1953 równie ważną rolę jak wydawców. Ich oferta czasem pokrywała się z propozycją wydawniczą.

Pierwsza pod względem liczby reklam uplasowała się Księgarnia Zdzisława Gustowskiego w Poznaniu (29 ogłoszeń), w której można było zakupić przede wszystkim literaturę piękną. Za pośrednictwem księgarni z centralą przy ul. Św. Marcina 34 i filii przy ul. Wielkiej 10 udostępniono powieści autorów polskich i zagranicznych. Dzięki ogłoszeniom czytelnicy na bieżąco śledzili twórczość Jana Dobraczyńskiego. W latach 1947-1950 upowszechniano poprzez skromną reklamę Straszny dom ${ }^{136}$, Szatę godowa ${ }^{137}$, Święty miecz ${ }^{138}$, W rozwalonym domu ${ }^{139}$ i Wybrańców gwiazd ${ }^{140}$. Kilka anonsów, obok Strasznego domu, promowało powieść Marii Rodziewiczówny Dewajtis ${ }^{141}$. Jednokrotnie na łamach

${ }^{134}$ Termin, z którym nie wszyscy literaturoznawcy się zgadzali. Mówiąc inaczej pisarzy katolickich, jak np.: Gustaw Morcinek, Zofia Kossak-Szczucka, Gilbert Keith Chesterton, Daniel-Rops.

${ }^{135}$ Np. recenzja: E. Florkowski, Nowe wydanie „,Wyznan’” św. Augustyna, „TP” 1949 nr 44 s. 7, poprzedzona była w poprzednich dwóch numerach reklamą dzieła.

136 „TP” 1947 nr 39 s. 5; „TW” 1947 nr 38 s. 3; tamże, nr 42 s. 15.

137 ,TP” 1947 nr 2 s. 12; „TW” 1947 nr 3 s. 8.

138 „TP” 1949 nr 31 s. 8; tamże, nr 32 s. 12.

139 „TP” 1948 nr 46 s. 11.

140 "GK” 1948 nr 24 s. 214; „TP” 1948 nr 23 s. 9; „TP” 1950 nr 1 s. 8; „TW” 1948 nr 25 s. 8.

141 „TP” 1947 nr 39 s. 5; „TW” 1947 nr 38 s. 3; tamże, nr 42 s. 15. 
„Tygodnika Powszechnego” i „Tygodnika Warszawskiego” pojawiła się jako nowość Zbrodnia $w$ dzielnicy pótnocnej Stefana Kisielewskiego ${ }^{142}$ oraz Anima vilis Rodziewiczówny ${ }^{143}$. Obcą literaturę reprezentowały natomiast następujące pozycje książkowe: Generat jego królewskiej mości Daphne du Maurier ${ }^{144}$, Abdel-Kader Johna Knittela ${ }^{145}$, Sonata Kreutzerowska Lwa Tołstoja ${ }^{146}$, Gerakowie Ziemia Elina Pelina ${ }^{147}$. Ilustrowane książeczki dla dzieci oraz bajki i opowiadania pojawiły się „Na gwiazdkę”. Oferta objęła m.in. takie tytuły jak Niepostuszna żabka, Przygody Janka Sobie-Panka, Skrzydlaty świat, Bajki Andersena oraz powieści Straszny dziadunio i Lato leśnych ludzi Rodziewiczówny ${ }^{148}$.

Z działających po wojnie księgarni nakładowych najchętniej w katolickich czasopismach społeczno-kulturalnych zbiorczą reklamę zamieszczała katowicka Księgarnia św. Jacka (łącznie 27 reklam) oferująca głównie literaturę religijną. Pod nagłówkiem Poleca na sezon szkolny znalazły się katechizmy: Katechizm diecezjalny, Mały katechizm ilustrowany ks. A. Przybyły, Katechizm przygotowawczy ks. A. Siary oraz Osobowość duszpasterza młodzieży ks. M.L. Kaczmarka i modlitewnik dla młodzieży Chwalmy Pana. Ostatni z tytułów książkowych można było zakupić w oprawie płóciennej (za 150 zł), kartonowej (85 zł) i w najtańszej wersji broszurowej ( $65 \mathrm{zl}$ ). W tym samym anonsie znalazła się oferta dla najmłodszych Zajęcia z dziećmi w wieku przedszkolnym Stanisławy Marciszewskiej ${ }^{149}$. Pod hasłem „Ukazał się dawno oczekiwany” zaproponowano również Mszał w opracowaniu ks. Romana Tomanka ${ }^{150}$. Odbiorcy dowiedzieli się również o najnowszym wydaniu „w zgrabnym formacie kieszonkowym” popularnego Mszalika niedzielnego tegoż ks. Tomanka oraz o Mszale żałobnym ${ }^{151}$. Pozycje książkowe dla dzieci, młodzieży i dorosłych wystąpiły pod hasłem „Jako prezent na św. Mikołaja oraz prezent gwiazdkowy". Maluchom zaproponowano dwie ilustrowane książeczki Obrazki dla dzieci Posadzowej i Mały Jezus siostry Barbary Żulińskiej, natomiast młodzieży powieści Dziewczyna z chmur i Rekord Władka Dzięcioła autorstwa Marii Wardasówny oraz „przeżycia kapitana Polskich Wojsk lotniczych w Anglii” podczas II wojny światowej pt. Kurs na Polskę Jerzego Głębockiego ${ }^{152}$. Dorośli

142 „TP” 1948 nr 15 s. 10; „TW” 1948 nr 14 s. 7.

143 „TP” 1947 nr 26 s. 12.

144 „TP” 1949 nr 15/16 s. 16.

145 „TP” 1947 nr 9 s. 5; „TW” 1947 nr 9 s. 2; tamże, nr 11 s. 7; tamże, nr 12 s. 12; tamże, nr 13 s. 7 ; tamże, nr 15 s. 7.

146 „TK” 1949 nr 50 s. 445; „TP” 1949 nr 50/51 s. 14.

147 „TP” 1949 nr 31 s. 8; tamże, nr 32 s. 12.

148 „TP” 1946 nr 50 s. 9; „TW” 1946 nr 50 s. 2.

149 „TK” 1946 nr 18 s. 8; tamże, nr 37 s. 7; tamże, s.8; tamże, nr 38 s. 6; tamże, nr 39 s. 7; „TW” 1946 nr 38 s. 8; tamże, nr 39 s. 11.

150 „TP” 1947 nr 18 s. 12.

151 „TK” 1950 nr 3 s. 22; „TP” 1948 nr 47 s. 8.

${ }^{152}$ Książka Głębockiego była też reklamowana osobno w pojedynczym anonsie „TP” 1948 nr 47 s. 4. 
mogli nabyć ponadto U źródeł chrześcijańskiej myśli filozoficznej ks. Franciszka Sawickiego, O Bogu żywym Romano Guardiniego, Sw. Tomasz Gilberta Keitha Chestertona i $S^{\prime}$. Jacek Odroważ o. Jacka Woronieckiego ${ }^{153}$. W pojedynczej reklamie adnotowanej ogłoszono w zawartości „Głosu Katolickiego” ukazanie się nowego wydania Ewangelii i Dziejów apostolskich w thumaczeniu ks. Feliksa Gryglewicza ${ }^{154}$. Zgodnie z ogłoszeniem „Na święto Chrystusa Króla” wydano pomoce do organizowania akademii i ,upiększania nabożeństw popołudniowych w kościele" zatytułowane Ku czci Chrystusa Króla i Wezwanie do Chrystusa Króla ${ }^{155}$. Na łamach „Tygodnika Katolickiego” i „Znaku” reklamowano także „piękną książkę” siostry Marii Leonii o prymasie Belgii zatytułowaną Kardynat Mercier ${ }^{156}$. Z literatury pięknej polecono m.in. historyczną powieść Beatum scelus Zofii Kossak, Listy z mojego Rzymu Gustawa Morcinka oraz znane przed II wojną światową eseje Walentego Majdańskiego pt. Giganci ${ }^{157}$.

Ogólną reklamę bez podawania tytułów książek drukowała w „Głosie Katolickim" Księgarnia Feliksa Czekalskiego w Poznaniu, mieszcząca się przy ul. Podgórnej 10 (22 ogłoszenia), w której składano także nuty. Działał przy niej również antykwariat ${ }^{158}$. Na składzie posiadała „książki naukowe, szkolne i powieściowe” ${ }^{159}$, „lektury i podręczniki uniwersyteckie” ${ }^{160}$, „Książki - nuty - mapy i żurnale mód”'161, „wielki wybór książek dla dzieci, młodzieży i starszych” oraz „duży wybór kolęd”162. Do zakupu zachęcano poprzez hasła „Najmilszym upominkiem gwiazdkowym jest dobra książka” ${ }^{163}$ lub „Książka najpiękniejszym podarkiem gwiazdkowym"164.

Pod nazwą Albertinum z dużą częstotliwością w 1947 r. ukazywała się na łamach „Tygodnika Powszechnego” ogólna reklama Księgarni św. Wojciecha (10 ogłoszeń). Z niej wiadomo było, że ,gromadzi - wydaje - rozpowszechnia tylko książkę dobrą, a szczególnie książkę katolicką"165. Z innego ogłoszenia dowiadujemy się natomiast, że w swojej ofercie posiadała „książki treści religijnej, beletrystycznej i naukowej" ${ }^{166}$. Z tytułów do wyboru podawano Ewangelie i Dzieje apo-

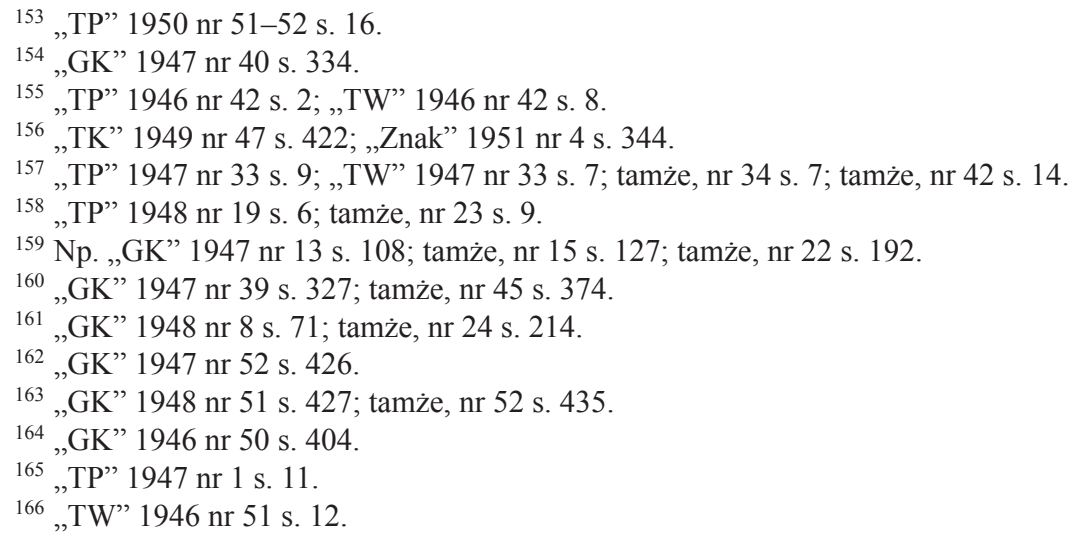


stolskie w przekładzie ks. Eugeniusza Dąbrowskiego ${ }^{167}$ oraz Bóg jest świattościa ks. Stanisława Olszewskiego ${ }^{168}$. Redakcja „Głosu Katolickiego” przedstawiła 20 pozycji wydawniczych, w których przeważyła literatura maryjna ${ }^{169}$. Łącznie we wszystkich katolickich czasopismach społeczno-kulturalnych opublikowano 19 anonsów. Reklamę tytułów książkowych zamieściła też Drukarnia i Księgarnia św. Wojciecha (4 anonse), proponując „książki religijne, naukowe, szkolne i dla młodzieży”170, Księgarnia Drukarni św. Wojciecha (2 anonse) ${ }^{171}$ i pod nagłówkiem Wydawnictwo „Albertinum” - Księgarnia św. Wojciecha (również 2 anonse).

Księgarnia Krakowska, posiadająca bogatą ofertę książek katolickich, ogłaszała się jedynie w „Tygodniku Powszechnym”. W jej siedzibie przy ul. Św. Krzyża 13 można było nabyć encyklikę Rerum novarum Leona XIII, jak też opracowanie społecznych encyklik papieskich ks. Jana Piwowarczyka Kryzys społeczno-gospodarczy $w$ świetle katolickich zasad i wydaną pod pseudonimem dr S. Zuzelski (ks. Stefan Wyszyński) Stolica Apostolska a świat powojenny ${ }^{172}$. Dla kapłanów przeznaczono różnego rodzaju brewiarze oprawione w półskórek i w skórę ${ }^{173}$ oraz cykle nauk rekolekcyjnych: ks. Jana Grabowskiego Na wzgórzu Golgoty, ks. Ludwika Kasprzyka Kazania pasyjne, ks. Józefa Winkowskiego Przełom wewnętrzny czy ks. P. Bobera $W$ góre serca ${ }^{174}$. Dział teologiczny i filozoficzny reprezentowały dwa tomy Teologii moralnej ks. Antoniego Borowskiego oraz Filozofia miłości Franciszka Sawickiego ${ }^{175}$. W ofercie obecne były także Wyznania św. Augustyna w thumaczeniu ks. Jana Czuja ${ }^{176}$. Nie zabrakło również książeczek do nabożeństwa dla młodzieży w kolorowej oprawie płóciennej, w osobnych wydaniach dla dziewcząt i chłopców ${ }^{177}$, podręczników do nauki religii katolickiej $^{178}$ oraz książek dla narzeczonych i nowożeńców ${ }^{179}$. Z powieści zaproponowano Krzyżowców Zofii Kossak, Kamienie wołać będą Hanny Malewskiej i pierwszy tom Sagi o Jarlu Broniszu zatytułowany Zrękowiny w Uppsali ${ }^{180}$.

Podobnie tylko na łamach krakowskiego pisma informowano o nowościach Księgarni św. Anny (10 anonsów). Sprzedawano w niej podręczniki uniwersytec-

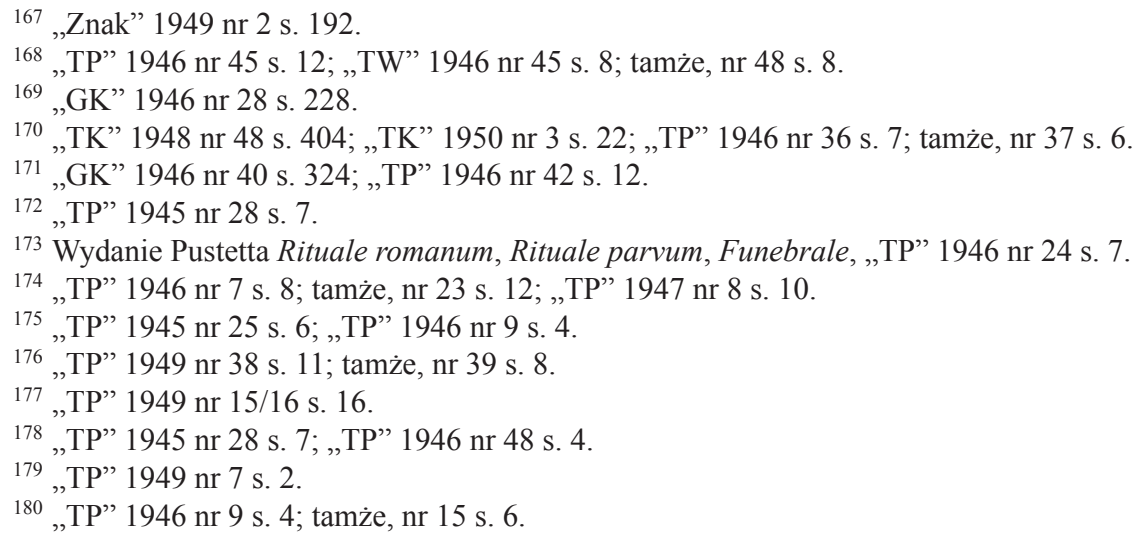


kie z zakresu matematyki, fizyki, chemii, anatomii i prawa ${ }^{181}$. Ogólna reklama niewielkich rozmiarów powiadamiała także o możliwości zakupienia podręczników szkolnych dla szkoły podstawowej, gimnazjum i liceum oraz „nowości z wszystkich dziedzin"182. Odbiorcy mogli nabyć następujące powieści: Cytadele Archibalda Cronina, Przeminęto z wiatrem Margaret Mitchell, Najeźdźców Jana Dobraczyńskiego ${ }^{183}$ i Nieurodzaj Zenona Skierskiego ${ }^{184}$.

Z reklamy w „Tygodniku Powszechnym” czytelnicy dowiedzieli się o otwarciu w 1945 r. Oficyny Księgarskiej w Warszawie przy ul. Marszałkowskiej 34185. $\mathrm{Na}$ łamach pisma najczęściej reklamowano Wiersze Konstantego Ildefonsa Gałczyńskiego ilustrowane przez Jana Knothe (4 razy) ${ }^{186}$. Dostępni byli również Najeźdźcy Dobraczyńskiego i Dzieje Pawła z Tarsu ks. Eugeniusza Dąbrowskiego $^{187}$. Dwukrotnie polecono Czas nieludzki Stefana Otwinowskiego ${ }^{188}$, Twarze przed lustrem Mariana Promińskiego ${ }^{189}$, Filozofie pracy $i$ narodu Mirosława Starosty ${ }^{100}$. W „Tygodniku Warszawskim” prezentowano natomiast Ballade o Warszawie i Poematy Jerzego Brauna ${ }^{191}$. W obu pismach wydrukowano w latach 1945-1953 łącznie 13 reklam.

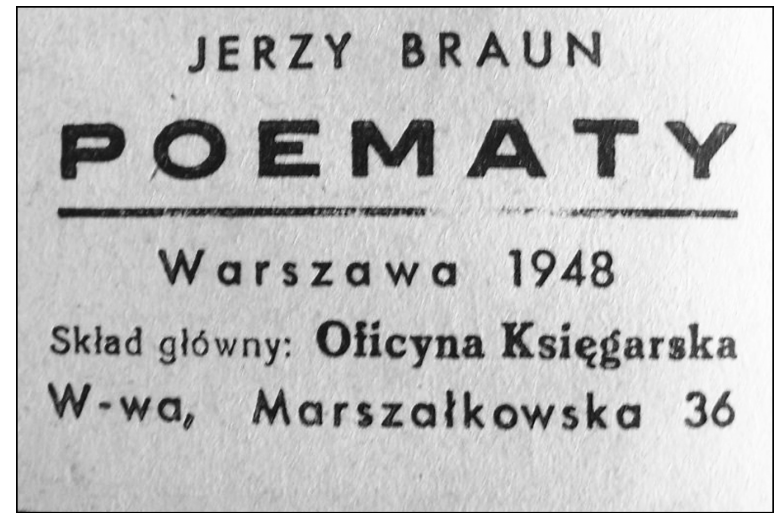

Źr ódło: Ze zbiorów BUŁ.

181 „TP” 1947 nr 22 s. 2; tamże, nr 24 s. 10; tamże, nr 43 s. 8.

182 „TP” 1947 nr 35 s. 8; tamże, nr 39 s. 8.

183 „TP” 1947 nr 13 s. 2; tamże, nr 20 s. 9; tamże, nr 21 s. 12.

184 „TP” 1948 nr 1 s. 9; tamże, nr 5 s. 5.

185 „TP” 1945 nr 28 s. 7.

186 „TP” 1946 nr 25 s. 6; tamże, nr 30 s. 2; tamże, nr 34 s. 8; tamże, nr 36 s. 2.

187 „TP” 1946 nr 51/52 s. 18; „TP” 1947 nr 44 s. 12.

188 „TP” 1946 nr 19 s. 6; tamże, nr 29 s. 8.

189 „TP” 1947 nr 4 s. 2.

190 „TP” 1946 nr 47 s. 5.

191 „TW” 1947 nr 4 s. 6; tamże, nr 13 s. 10. 
W Krakowie działały również Księgarnia Stefana Kamińskiego i Księgarnia Katolicka Stanisława Lubieńskiego, które reklamowały się jedynie w „Tygodniku Powszechnym" (pierwsza 9 i druga 8 ogłoszeń). Różnorodną ofertę pierwszej z nich tworzyły m.in. nowele Sztuka umierania Kazimierza Zenona Skierskiego ${ }^{192}$, Kabała historii Zofii Starowieyskiej-Morstinowej ${ }^{193}$ i „napisana w oryginale po polsku” powieść angielskiej autorki Lilian Seymour-Tułasiewicz Dag - córka Kasi ${ }^{194}$. Na składzie posiadano ponadto podręczniki uniwersyteckie z zakresu fizyki, prawa, gospodarki i dyplomacji oraz wspomnienia obozowe ${ }^{195}$. Za pośrednictwem Księgarni Katolickiej, znanej wcześniej jako Księgarnia Władysława Mitkowskiego, mieszczącej się przy ul. Mikołajskiej 3, wysyłano za pobraniem pocztowym „książki religijne i świeckie" do bibliotek parafialnych i świetlicowych ${ }^{196}$. Wydano tu również: encyklikę zatytułowaną $O$ mistycznym ciele Chrystusa, Mszat na wszystkie dni roku ${ }^{197}$ oraz "dziełko nadające się na upominki okolicznościowe i świąteczne” pt. Zasady i rady na każdy dzień w roku św. Franciszka Salezego ${ }^{198}$.

Podobnie tylko odbiorcy „Tygodnika Powszechnego” mogli przeczytać, że wrocławska Księgarnia Katolicka zmieniła w 1947 r. nazwę na Księgarnia św. Jadwigi (5 anonsów), pozostając w lokalu przy ul. Ruskiej 26. W jej reklamach informowano o posiadaniu książek religijnych, bez podania tytułów książkowych $^{199}$. Niemieckie słowniki do Starego Testamentu czytelnicy periodyku mogli nabyć z kolei w Księgarni Naukowej we Wrocławiu ${ }^{200}$.

Z niewielu anonsów (13) Wielkopolskiej Księgarni Wydawniczej zainteresowani mogli dowiedzieć się o wydaniu „powieści historycznej z czasów Chrobrego" Władysława Jana Grabskiego Śladem Wikingów, która stanowiła drugą część Sagi o Jarlu Broniszu, oraz powieści o Norwidzie Żniwo na sierpie Hanny Malewskiej. Oferowano także Dwie wiosny Jana Parandowskiego ${ }^{201}$. Jako „Najlepszy podarek gwiazdkowy dostępny dosłownie dla wszystkich” zaproponowano „wspaniałe dzieło" Marii i Zygmunta Wojciechowskich Polska Piastów. Polska Jagiellonów $w^{202}$.

W ośmiu reklamach kieleckiej Księgarni „Jedność”, znanych głównie odbiorcom „Tygodnika Powszechnego”, propagowano encyklikę o liturgii Piusa XII

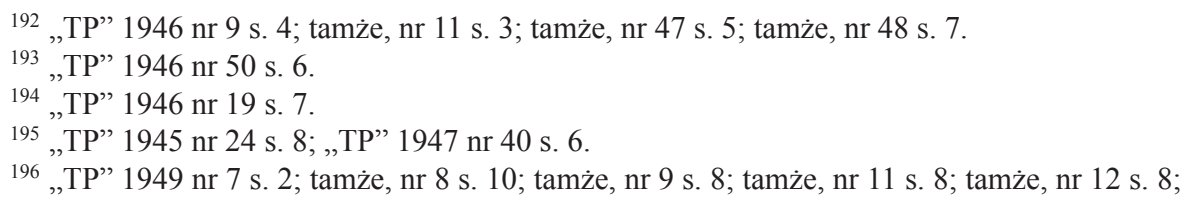
tamże, nr 14 s. 6.

197 „TP” 1945 nr 22 s. 6; „TP” 1949 nr 14 s. 6.

198 „Znak” 1948 nr 7 s. 672.

199 „TP” 1947 nr 19 s. 9; tamże, nr 20 s. 11; tamże, nr 47 s. 8; „TP” 1948 nr 21 s. 10; tamże, nr 23 s. 12.

200 „TP” 1948 nr 51 s. 5; „TP” 1949 nr 13 s. 8; tamże, nr 44 s. 8.

201 „GK” 1946 nr 52 s. 428; „TP” 1946 nr 50 s. 12; tamże, nr 51/52 s. 18; „TW” 1946 nr 48 s. 2; tamże, nr 50 s. 8; „TW” 1947 nr 2 s. 8.

202 „GK” 1946 nr 51 s. 412; ,TP” 1946 nr 50 s. 12; tamże, nr 51/52 s. 18; „,TW” 1946 nr 50 s. 2. 
Mediator Dei, Nadprzyrodzone życie dusz i Podstawy życia rodzinnego biskupa Czesława Kaczmarka, Kościót i jego wnętrze w świetle przepisów prawno-liturgicznych ks. Jana Danilewicza oraz nauki rekolekcyjne dla dziatwy Na biezni duchowej ks. Jana Grabowskiego ${ }^{203}$. W niektórych anonsach Księgarnia „Jedność” ogłaszała się z Wydawnictwem Verbum (13 anonsów). W ten sposób zareklamowano m.in. Encyklikę o chrześcijańskim wychowaniu i Quadragesimo anno papieża Piusa XI, O mistycznym ciele Jezusa Chrystusa Piusa XII, Księgę miłosierdzia Bożego, czyli Dialog św. Katarzyny ze Sieny ${ }^{204}$ i Owoc czasu swego Jerzego Zawieyskiego ${ }^{205}$.

$\mathrm{Na}$ łamach katolickich czasopism społeczno-kulturalnych bogatą ofertę książkową przedstawiła również Księgarnia Związku Caritas (druki ogłaszano także pod nazwą Krajowej Centrali Caritas, Składnicy Katolickich Wydawnictw i Artystycznych Dewocjonalii Caritas) z siedzibami w Tarnowie, Krakowie, Wrocławiu i Częstochowie (łącznie 12 reklam). Na składzie posiadała Kazania pasyjne i kazania dla młodzieży Chrystus w życiu św. Stanisława Kostki autorstwa ks. Władysława Lesiaka, W naszym biurze Caritas ks. Jana Bochenka, , Caritas” we współczesnej pracy duszpasterskiej ks. Karola Pękali ${ }^{206}$. „Na Tydzień Miłosierdzia" wydano: kazania i czytanki O godność człowieka ks. Władysława Lesiaka, Materiaty na wieczornice Caritasowa Zofii Żoreckiej, dramat Przyszedt święty na ziemię Adama Bunscha, Chorzy w życiu Kościoła Michała Rękasa ${ }^{207}$. W „Znaku” zareklamowano Brata Alberta i Dusze dać ks. Konstantego Michalskiego $^{208}$. Pod hasłem „Dla inteligencji katolickiej” zaproponowano wspomnienia o doktorze Adamie Biliku pt. Sylwetka nowoczesnego katolika ${ }^{209}$. Dla młodzieży przeznaczono Modlitewnik liturgiczny oraz studium psychologicznowychowawcze Duszpasterz mtodzieży ks. Stanisława Parasa ${ }^{210}$, a dla dzieci wierszowaną książeczkę O takomym Styczniu i o psotnym Marcu Hanny Ogulewicz z ilustracjami Julitki Białowiejskieje'11.

Kilka ogólnych i tytułowych anonsów opublikowano w „Tygodniku Katolickim" pod szyldem Księgarni św. Antoniego w Gorzowie Wielkopolskim. $\mathrm{Na}$ składzie posiadano książki teologiczne, książeczki dla dzieci, podręczniki szkolne, powieści ${ }^{212}$. Łódzka Księgarnia Towarzystwa W.O. „Przyszłość”

203 „TP” 1948 nr 5 s. 7; tamże, nr 29 s. 8; tamże, nr 38 s. 11; tamże, nr 41 s. 12; tamże, nr 42 s. 6; tamże, nr 43 s. 7; tamże, nr 51 s. 8; „TP” 1950 nr 1 s. 8.

204 „TP” 1946 nr 33 s. 6; „TP” 1947 nr 29 s. 4; tamże, nr 48 s. 12; „TP” 1948 nr 30 s. 8; „TP”

1949 nr 27 s. 12; tamże, nr 39 s. 11; „TW” 1946 nr 39 s. 11; „TW” 1947 nr 47 s. 7.

205 „TP” 1949 nr 10 s. 12; tamże, nr 13 s. 8.

206 „GK” 1945 nr 25 s. 8; „GK” 1946 nr 47 s. 379 ; „TP” 1945 nr 32 s. 6; tamże, nr 34 s. 7; „TP”

1946 nr 7 s. 8; „TW” 1946 nr 8 s. 8; tamże, nr 12 s. 4; tamże, nr 13 s. 6.

207 „GK” 1947 nr 40 s. 335.

208 "Znak" 1946 nr 3 s. 368.

209 „TW” 1947 nr 26 s. 11.

210 „TP” 1946 nr 44 s. 12; „TP” 1948 nr 12 s. 8; „TW” 1948 nr 22 s. 8.

211 "GK” 1947 nr 1 s. 8.

212 „TK” 1949 nr 11 s. 104; tamże, nr 16 s. 153; tamże, nr 18 s. 176; tamże, nr 47 s. 422; tamże, nr 50 s. 446. 
- niedaleko siedziby kurii biskupiej przy ul. Piotrkowskiej 263 - oprócz dewocjonaliów posiadała „księgi liturgiczne, kaznodziejskie, ascetyczne, do nabożeństwa, beletrystyczne, katechizmy”213. Jak wiadomo z czterech reklam w „Tygodniku Warszawskim", stołeczna Księgarnia Braci Bogdańskich i Spólki oferowała książki ze wszystkich dziedzin, a jej pracownicy wyszukiwali książki antykwaryczne i kupowali książki różnej treści ${ }^{214}$. Pojedyncze ogłoszenia wydrukowały: Księgarnia św. Teresy w Olsztynie ${ }^{215}$, Księgarnia Wysyłkowa Librarium ${ }^{216}$, Księgarnia Postęp ${ }^{217}$, Księgarnia Rolnicza ${ }^{218}$, Księgarnia Gdańska A. Krawczyński $^{219}$, Księgarnia Powszechna ${ }^{220}$, Księgarnia Instytutu Wydawniczego Nasza Księgarnia ${ }^{221}$, Księgarnia Homo ${ }^{222}$, Księgarnia Kazimierza Schaefera ${ }^{223}$, Księgarnia Akademicka $^{224}$ i Księgarnia S. Arcta ${ }^{225}$. Na łamach „Głosu Katolickiego” poinformowano o otwarciu 16 VI 1947 r. w Poznaniu przy ul. Marszałka Focha Księgarni Dobra Książka, która miała prowadzić sprzedaż książek własnego wydawnictwa księży Pallotynów oraz „książki kościelne, szkolne, naukowe i powieściowe”226.

Oferta księgarska obecna w periodykach katolickich była bogata i różnorodna. Nie ograniczała się do książki katolickiej, gdyż znalazły się w niej także podręczniki uniwersyteckie, wspomnienia, nowele, powieści, a nawet nuty. Podobnie jak w przypadku reklamy wydawniczej księgarze nie zapominali o zaproponowaniu książki różnym grupom czytelników. Stąd w ogłoszeniach pozycje dla dzieci, młodzieży i dorosłych.

\subsubsection{Reklama tytułów i serii książkowych}

W pismach obecne były również ogłoszenia samych tytułów książkowych wraz z nazwiskiem autora, niekiedy ceną i krótką adnotacją lub informacją o szacie graficznej. Redakcja do stałych elementów dodawała czasami hasło w rodzaju: „Nowość!”, „Ostatnia nowość”, „Nowa książka”, czy „Już wyszła w druku”.

213 „TP” 1945 nr 25 s. 5; „TP” 1946 nr 11 s. 6; „,ТР” 1947 nr 3 s. 12; tamże, nr 42 s. 12; „ТР” 1948 nr 18 s. 7.

214 „TW” 1946 nr 49 s. 5; tamże, nr 51 s. 12; „TW” 1947 nr 1 s. 12; tamże, nr 14 s. 11.

215 „TP” 1948 nr 16 s. 8; tamże, nr 40 s. 11.

216 „TP” 1946 nr 44 s. 8.

217 ,TP” 1946 nr 23 s. 6.

218 „TP” 1945 nr 24 s. 2.

219 „TP” 1946 nr 31 s. 2.

220 „TW” 1946 nr 39 s. 11.

221 „TW” 1946 nr 51 s. 12.

222 „TP” 1948 nr 1 s. 12.

223 „TP” 1947 nr 50 s. 6.

224 „TP” 1947 nr 3 s. 10.

225 "TW” 1946 nr 22 s. 8.

226 „GK” 1947 nr 26 s. 222. 
Zgodnie z profilem periodyków poczesne miejsce zajmowała reklama książki katolickiej.

Zdecydowanie najczęściej proponowaną na stronach „Tygodnika Warszawskiego" pozycją był "najtańszy i najbardziej nadający się dla młodzieży” Katechizm, wydanie piąte i szóste ${ }^{227}$.

Il. 25. Najczęściej reklamowana pozycja w „TW”.

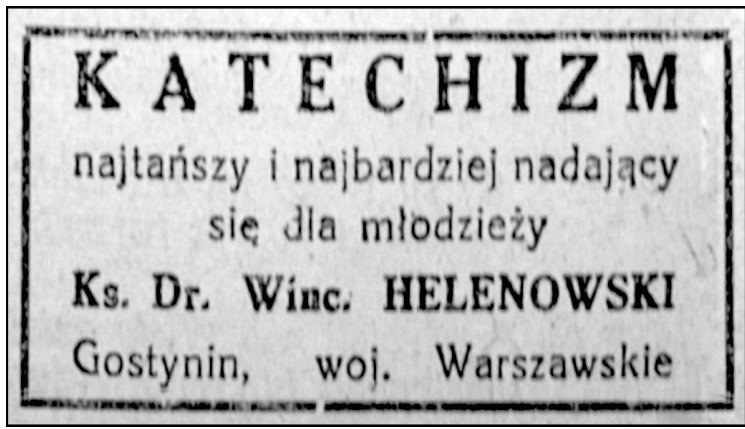

Źr ódło: „TW” 1945 nr 7 s. 7. Ze zbiorów BUŁ.

Reklama mogła mieć kilka wersji i zdarzało się, że redakcja zamieszczała ją dwukrotnie w jednym numerze czasopisma. Pierwsza - tylko tekstowa, bez ramki była niewielka i pojawiała się zazwyczaj w prawym lub lewym dolnym rogu strony. Podawano w niej objętość, numer wydania, zawartość, cenę oraz sposób wysyłki ${ }^{228}$. W niektórych anonsach Katechizm występował wraz z dwoma innymi pozycjami: Nabożeństwo różańcowe i Tajemnice żywego różańca. Taką samą formę reklama przybrała w „Głosie Katolickim” i „Tygodniku Katolickim”229. Czytelnikom zaproponowano także inny „zwięzły, praktyczny, przejrzysty i krótki, a jednak wyczerpujący" Katechizm w opracowaniu ks. Waleriana Głowacza, który można było zakupić za 15 zł bezpośrednio u autora ${ }^{230}$. W „Tygodniku Katolickim" znalazło się też ogłoszenie informujące o ukazaniu się Katechizmu sodalicyjnego w układzie ks. Jerzego Harrassera ${ }^{231}$.

Dwukrotnie wydrukowano informacje o cyklu kazań pasyjnych ks. Józefa Winkowskiego zatytułowanych Aby żywot mieli...232, a jeden raz ogłoszono

227 „TW” 1945 nr 7 s. 7.

${ }^{228}$ M.in. „TW” 1946 nr 12 s. 8; tamże, nr 13 s. 3; tamże, nr 14 s. 4; tamże, nr 15 s. 8; tamże, nr 16 s. 16; tamże, nr 17 s. 5; tamże, nr 18 s. 8; tamże, nr 21 s. 4; tamże, nr 22 s. 8; tamże, nr 23 s. 6; tamże, nr 45 s. 7; tamże, nr 46 s. 8; tamże, nr 50 s. 8.

${ }^{229}$ Np. „GK” 1947 nr 44 s. 367; tamże, nr 45 s. 374; tamże, nr 47 s. 387; „TK” 1947 nr 50 s. 348; „TK” 1948 nr 1 s. 14; tamże, nr 2 s. 20; tamże, nr 3 s. 25; tamże, nr 4 s. 32; „TW” 1947 nr 18 s. 7; „TW” 1948 nr 1 s. 12; tamże, nr 5 s. 6.

${ }^{230}$ „TK” 1946 nr 6 s. 5; tamże, nr 9 s. 8; tamże, nr 13 s. 8.

231 „TK” 1948 nr 14 s. 98.

232 „TP” 1947 nr 4 s. 11; „TP” 1947 nr 6 s. 12. 
znane Dzieje Chrystusa Daniela-Ropsa ${ }^{233}$. Zareklamowano także znaną książkę św. Ludwika Grigniona de Montforta Tajemnica Maryi ${ }^{234}$. Kilka ofert dotyczyło następujących modlitewników i śpiewników: Droga krzyżowa, gorzkie żale i pieśni wielkopostne ${ }^{235}$, bogato ilustrowanej książeczki Śpiewaj Polsko cała ${ }^{236}$ oraz dwóch kieszonkowych ,śpiewników-modlitewników” w płóciennej oprawie z wyborem pieśni maryjnych ${ }^{237}$. Pierwszą reklamą książki w „Głosie Katolickim” było ogłoszenie z adnotacją treściową o tytule Św. Juda Tadeusz Apostoł ks. Stanisława Szpetnara ${ }^{238}$. W innym anonsie, przedstawiającym okładkę świeżo wydanej książki, poinformowano o ukazaniu się staraniem Prymasowskiej Rady Odbudowy Kościołów Warszawy albumu z uroczystości pogrzebowych prymasa Augusta Hlonda w cenie 200 zł. Dochód ze sprzedaży, jak napisano, miał być przeznaczony na odbudowę katedry św. Jana w Warszawie ${ }^{239}$.

Il. 26. Reklama książki. „TP” 1949 nr 17 s. 10

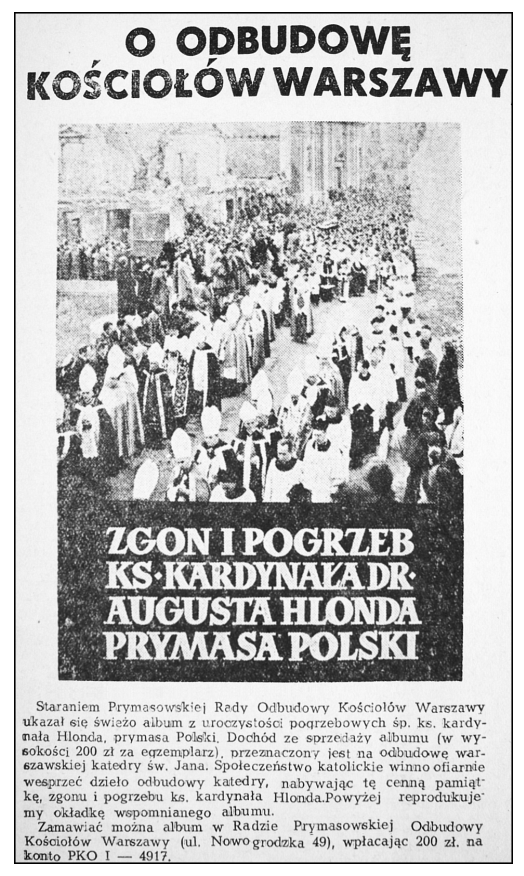

Źródło: Ze zbiorów BUŁ.

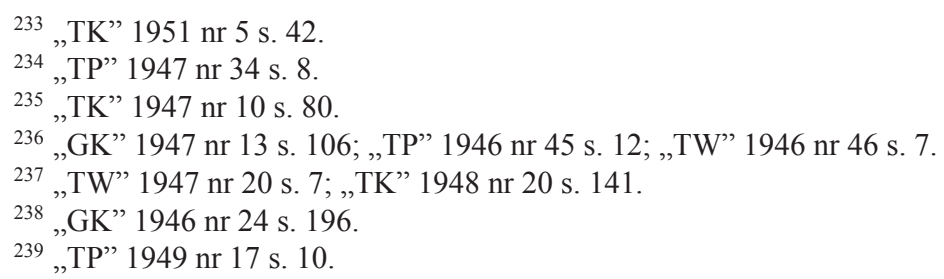


Jako pomoce dydaktyczne polecano podręczniki autorstwa ks. Wacława Kosińskiego zatwierdzone przez Ministerstwo Wyznań Religijnych: Dydaktyka, Katechetyka i Metodyka nauczania religii ${ }^{20}$. Dostępna była także Katechetyka ks. Józefa Łapota ${ }^{241}$.

Pod hasłami: „Dobre książki”, „Od dawna oczekiwane”, „Nasza lektura” i „Książka w Twoim ręku” składano propozycje lektury dla dzieci i młodzieży. Znalazły się tu m.in. książeczka do nabożeństwa dla młodzieży Magnificat ${ }^{242}$, ilustrowana Nowa historia biblijna, Mszalik dla dziatwy i młodzieży ${ }^{243}$, „ciekawa i pożyteczna książka" Religia w życiu młodzieńca oraz Młodzieniec z charakterem Tihaméra Tótha ${ }^{244}$, „do użytku młodzieży żeńskiej” rozmyślania ewangeliczne Dat mi moc Felicji Żurowskiej ${ }^{245}$, Pan Drops i jego trupa Jana Brzechwy ${ }^{246}$, czwarte wydanie Baśni kaszubskich Zuzanny Rabskiej ${ }^{247}$. We wszystkich księgarniach młodzież mogła nabyć powieści Marii Wardasówny Dziewczyna z chmur i Rekord Władka Dzięcioła ${ }^{248}$.

Dorosłym jako „najlepszą powieść katolicką" i „,wspaniałą książkę” polecono w adnotowanej reklamie Pieśń o Bernadecie Franciszka Werfla ${ }^{249}$. Z innych znalazły się Suknia Dejaniry Zofii Kossak ${ }^{250}$, „powieść o królowej Jadwidze” zatytułowana Wianki Ludwika Świeżawskiego ${ }^{251}$ i „powieść o Norwidzie” pt. Żniwo na sierpie Hanny Malewskiej ${ }^{252}$.

„Dobrą radą i pomocą we wszystkich dziedzinach wiedzy i życia praktycznego" służyć miała Żywa encyklopedia reklamowana kilkakrotnie w „Głosie Katolickim”253. Pod hasłem „Książka w ręku małżonków” polecono Miłość w matżeństwie ks. Baranowskiego, Miłość, rodzina, matżeństwo ks. Stanisław Brossa, Z tajników pożycia matżeńskiego Iwana Eugena Georgaa ${ }^{254}$ oraz Malżeństwo w świetle prawa i życia ks. Kazimierza Grądzkiego ${ }^{255}$.

${ }^{240}$ „TP” 1947 nr 8 s. 10; tamże, nr 10 s. 7; „TP” 1948 nr 44 s. 12; „TW” 1947 nr 9 s. 5; tamże, nr 10 s. 5 ; tamże, nr 11 s. 7.

241 „TP” 1947 nr 33 s. 11; tamże, nr 38 s. 6.

242 „TK” 1946 nr 2 s. 6.

243 „TK” 1946 nr 22 s. 8.

244 "TK" 1948 nr 36 s. 280.

245 "TK” 1949 nr 30 s. 283.

246 "TK" 1946 nr 2 s. 6.

247 "TW" 1947 nr 1 s. 12.

248 „TK” 1949 nr 45 s. 404; tamże, nr 46 s. 414; tamże, nr 47 s. 422; tamże, nr 49 s. 438.

249 „TK” 1949 nr 8 s. 73; tamże, nr 12 s. 108.

250 „TK” 1949 nr 9 s. 84.

251 „TK” 1950 nr 21 s. 168.

252 „TW” 1946 nr 51 s. 12.

253 „GK” 1947 nr 42 s. 351; tamże, nr 47 s. 387; tamże, nr 48 s. 394; tamże, nr 49 s. 402.

254 „TK” 1949 nr 39 s. 345.

255 "GK" 1948 nr 43 s. 367. 
Il. 27. Reklama serii Jasnych Książek. „TW” 1948 nr 13 s. 11

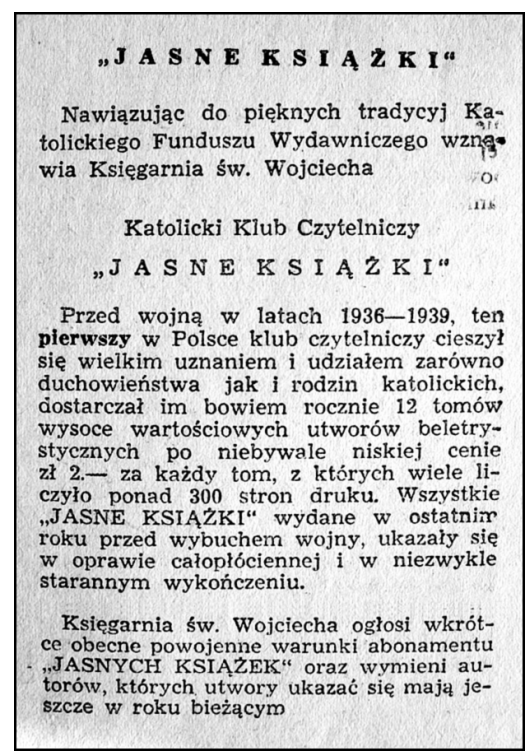

Źródło: Ze zbiorów BUŁ.

Na łamach większości czasopism społeczno-kulturalnych (oprócz „Przeglądu Powszechnego") w tym samym czasie ukazała się informacja identycznej treści o wznowieniu przez Księgarnię św. Wojciecha przedwojennego Katolickiego Klubu Czytelniczego „Jasnych Książek”. Przypomniano, że ten pierwszy w Polsce Klub Czytelniczy w latach 1936-1939 „,ieszył się wielkim uznaniem i udziałem zarówno duchowieństwa, jak i rodzin katolickich"256. Członkom dostarczano w ciągu roku 12 starannie wydanych tomów „wysoce wartościowych utworów beletrystycznych" po niskiej cenie wynoszącej 2 zł za każdą książkę. Warunki uczestnictwa odbiorcy poznali w kolejnym ogłoszeniu. Do Katolickiego Klubu „Jasnych Książek” mógł przynależeć każdy czytelnik, który był zobowiązany do uiszczenia tzw. ceny klubowej (2/3 ceny księgarskiej) każdej kolejno wydanej w serii pozycji. Jedynym warunkiem była niemożność nabycia „książki drugiej przed nabyciem pierwszej, ani trzeciej przed nabyciem pierwszych dwóch" ${ }^{257}$. Seria miała objąć początkowo sześć znanych tytułów książkowych: Konfesjonat Władysława Jana Grabskiego, Przedziwny wódz Zofii Zawiszanki, Tarcza i kaptur Pii Górskiej, Pieśń o Bernadecie Franciszka Werfla, Niepożegnani

256 „GK” 1948 nr 13 s. 113; „TK” 1948 nr 12 s. 80; „TP” 1948 nr 11 s. 4; „TW” 1948 nr 13 S. 113.

257 Jasne Ksiązki. Katolicki Klub Literacki, „GK” 1948 nr 24 s. 210; „TK” 1948 nr 23 s. 158; „TP” 1948 nr 24 s. 10; „Znak” 1948 nr 4 s. 384. 
Adama Grzymały-Siedleckiego i Listy starego diabła do młodego Clive'a Staplesa Lewisa. Krótko omówiono zawartość każdej z książek, zachęcając do przystąpienia do Klubu ${ }^{258}$. W następnych reklamach zapraszano do zapisów za pośrednictwem redakcji pism i kupna pierwszej pozycji wydawniczej259. Dwutomowa powieść współczesna Grabskiego „licząca 554 strony dużego formatu w trójbarwnej okładce projektu Jana Knothe" kosztowała przed wymianą pieniędzy w $1950 \mathrm{r}$. $580 \mathrm{zł}$ wraz z przesyłką, podczas gdy jej cena księgarska wyniosła $870 \mathrm{zł}^{260}$.

Prześledzenie ogłoszeń utwierdziło w przekonaniu o terminowym wywiązywaniu się pracowników Albertinum z dostarczania zainteresowanym drugiej, trzeciej i czwartej pozycji z serii Jasnych Książek. Podawano przy okazji ukazania się każdej z nich bliższe dane o fabule powieści, ilustracjach i oprawie ${ }^{261}$. Z informacji reklamowej wynikało też, że książki wydawane w ramach serii spotkały się z dużym zainteresowaniem czytelników ${ }^{262}$. Ostatnie anonse z końca $1948 \mathrm{r}$. i początku 1949 r., jakie pojawiły się na łamach „Tygodnika Powszechnego”, donosiły o zaistniałych trudnościach w przesyłce zainteresowanym pierwszych dwóch tomów. Pisano bowiem: „Klub Jasnych Książek przeżywa obecnie pewien kryzys: pierwszych dwóch tomów poczyna braknąć. Wydawnictwo pragnie powtórzyć nakłady, wymaga to jednak co najmniej paru miesięcy"263, w związku z czym postanowiono jednak nadal pozyskiwać nowych członków, rezygnując jedynie z zasady kolejności nabywania książek. Ostrzegano jednocześnie, że pomimo prawa do pierwszeństwa pierwszych zgłoszonych klubowiczów, w przypadku zwłoki w zamawianiu i opłacie nie mogli liczyć oni na zagwarantowanie przechowywania egzemplarzy, „na które był popyt ogromny”264. O ile w przedostatnim ogłoszeniu jeszcze zapowiadano czwartą i piątą pozycję serii, to ostatnie brzmiało następująco: „W ukazywaniu się kolejnych pozycji Jasnych Książek nastąpiła dłuższa przerwa. Wydawnictwo za naszym pośrednictwem zwraca się do ogółu odbiorców z prośbą, aby zechcieli zdobyć się na uzasadnione wyrozumienie i cierpliwość. Wydawnictwo zapewnia, że o wszelkiej zmianie planów czy też o ponownym ukazywaniu się książek nie omieszka powiadomić każdego, kto zgłosił chęć otrzymywania Jasnych Książek. Na razie prosimy o nie przekazywanie żadnych wpłat bez wezwania ze strony Administracji Wydawnictwa" ${ }^{265}$. Na

258 Tamże.

259 „GK” 1948 nr 30 s. 263; tamże, nr 31 s. 270; tamże, nr 32 s. 280; tamże, nr 33 s. 282; „TK” 1948 nr 26 s. 183; tamże, nr 30 s. 219; „TP” 1948 nr 29 s. 11.

260 „GK” 1948 nr 33 s. 287; tamże, nr 36 s. 307; tamże, nr 38 s. 322; tamże, nr 40 s. 344; ,TP” 1948 nr 34 s. 11

261 „TK” 1948 nr 37 s. 294; tamże, nr 45 s. 368; „TK” 1949 nr 3 s. 24; „TP” 1948 nr 39 s. 8; tamże, nr 47 s. 8

262 „TK" 1949 nr 3 s. 24.

263 Jasne Ksiązki, „TP” 1948 nr 51 s. 8.

264 Tamże.

265 Jasne Książki, ,TP” 1949 nr 11 s. 7. 
łamach wybranych periodyków katolickich zabrakło dalszych wiadomości o losach serii.

Członkowie Towarzystwa Przyjaciół Katolickiego Uniwersytetu Lubelskiego w latach 1946-1949 na kartach „Głosu Katolickiego”, „Tygodnika Katolickiego”, „Tygodnika Powszechnego” i „Tygodnika Warszawskiego” promowali serię Biblioteki Dobrej Książki.

Il. 28. Reklama serii Biblioteka Dobrej Książki. „TW” 1947 nr 38 s. 8

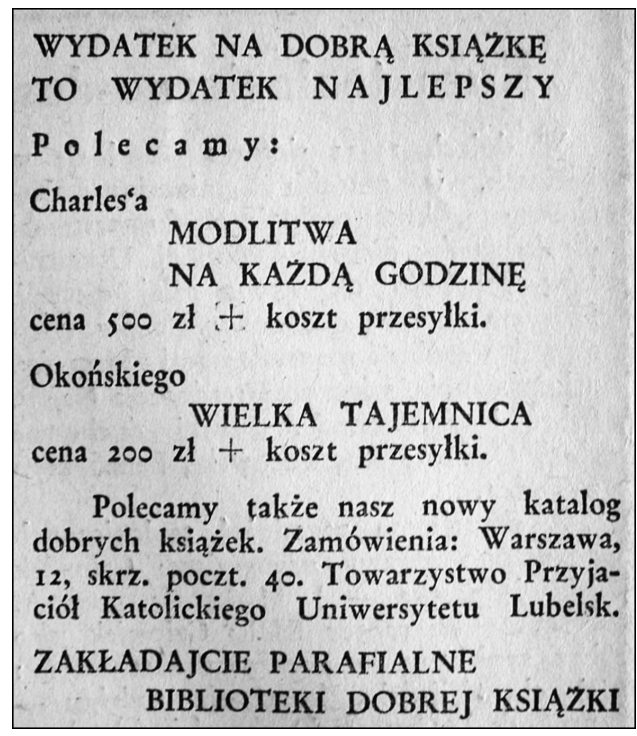

Źr ó dło: Ze zbiorów BUŁ.

W anonsie polecającym pozycję pt. Dobry Bóg Emila Fiedlera widniał nagłówek: „Pamiętaj o Jasnej Górze. Ciężko Ci w życiu? Pomyśl jak wygląda Twoje życie duchowe i wzmocnij je przez codzienną lekturę Dobrej Książki" ${ }^{266}$ Inne z ogłoszeń, reklamujące Człowiek w całej swojej prawdzie ks. Ruperta Meyera, posiadało następującą treść: „Dobra książka to prawdziwy przyjaciel, a codzienne obcowanie z nim pomoże Ci wprowadzić w życiu codziennym ład i spokój - nieocenione wartości, bez których życie jest bardzo ciężkie”267. Hasłami „Czytajcie Dobre Książki” i „Przeczytaj Dobrą Książkę” starano się zachęcić odbiorców do zakupu pozycji pt. Modlitwa na każda godzinę Charles'a oraz Bóg jest światto$\dot{s} c i a$ ks. Stanisława Olszewskiego ${ }^{268}$. „Dobra Książka” miała pomóc w przeżyciu

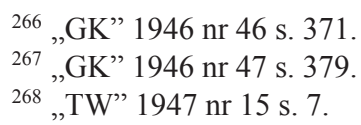


okresu Wielkiej Nocy, polecono tu Światła tajemnic i Płomienne serca Stanisława Jeleńskiego oraz Rozważania Stanisława Kasznicy ${ }^{269}$. Oprócz tego w ogłoszeniach namawiano do zakładania w każdej parafii Biblioteki Dobrej Książki ${ }^{270}$, służąc wysyłką instrukcji, katalogów i książek. Ostrzegano równocześnie przed „złym słowem drukowanym” i „złą książką”, pisząc: „Żądajcie od proboszcza Dobrej Książki, nie marnujcie drogiego czasu na czytanie byle czego"271. W nagłówkach ogłoszono również „Walkę z analfabetyzmem” i zachęcano do nieoszczędzania pieniędzy na zakup wartościowych pozycji ${ }^{272}$. O bogatym asortymencie Biblioteki Dobrej Książki można było dowiedzieć się ze spisu dostępnych pozycji (wraz z ich ceną) wydrukowanym na łamach „Tygodnika Katolickiego”. Komplety złożone z kilkunastu książek zawierały wydawnictwa o tematyce religijnej (m.in. encykliki, katechizmy, modlitewniki, rozważania), powieści (m.in. Jana Dobraczyńskiego, Władysława Jana Grabskiego, Antoniego Gołubiewa, Zofii Kossak-Szczuckiej, Jamesa Olivera Curwooda), książki dla dzieci i młodzieży (Henryka Sienkiewicza, Tihaméra Tótha, Marii Wardasówny) ${ }^{273}$. Zamówienia można było kierować poprzez skrzynkę pocztową lub na adres ul. Rakowiecka 41 (lub 61) w Warszawie.

Zaledwie jeden raz pojawiła się w „Tygodniku Katolickim” reklama serii Biblioteki Ogrodniczej, w ramach której czytelnicy mogli zakupić trzy tytuły książkowe „na sezon wiosenny”: Urządzenie i pielęgnowanie sadu Antoniego Gładysza, Kwiaty w mieszkaniu Stefana Makowieckiego, Domowy wyrób moszczów pitnych. Administracja mieściła się w Tarnowie przy ul. Matejki 13, a książki wysyłano po otrzymaniu wpłaty ${ }^{274}$.

Redakcje katolickich czasopism społeczno-kulturalnych przeważnie drukowały bieżące ogłoszenia tekstowe. Rzadziej ukazanie się książki zapowiadała reklama prospektywna, rozpoznawalna dzięki hasłom: „Wkrótce ukaże się”, „Wkrótce w sprzedaży”, „W najbliższym czasie ukażą się”, „W najbliższych dniach ukażą się" itp. Elementy graficzne w ogłoszeniach na łamach analizowanych czasopism należały do rzadkości. Najwięcej miejsca w materiale prasowym zajęła reklama wydawnicza, po niej zaś księgarska. Swoją ofertę przedstawiały przede wszystkim najbardziej znane wydawnictwa katolickie, choć niejednokrotnie odbiorcy zapoznawali się także z propozycjami książkowymi wydawnictw spółdzielczych i państwowych. Nie zabrakło także anonsów pojedynczych tytułów.

269 Tamże.

270 „TP” 1947 nr 18 s. 8; „TW” 1947 nr 38 s. 8.

271 „GK” 1947 nr 20 s. 174; ,TW” 1947 nr 18 s. 7; tamże, nr 37 s. 7.

272 „GK” 1947 nr 37 s. 311; „,TP” 1947 nr 44 s. 11; ,TW” 1947 nr 15 s. 7; tamże, nr 43 s. 7.

273 "TK" 1949 nr 46 s. 414; tamże, nr 48 s. 430.

274 Tamże, nr 18 s. 172. 


\subsection{Informacje o nowościach wydawniczych}

Redaktorzy „Tygodnika Powszechnego”, „Głosu Katolickiego”, „Tygodnika Katolickiego” i „Tygodnika Warszawskiego” wprowadzili do treści periodyków bieżące informacje o nowościach wydawniczych. Dobierano je według uznania redakcji, stąd wynikły podobieństwa i różnice w przedstawianych repertuarach wydawniczych. Nowości występowały w osobnych i specjalnie do tego przeznaczonych działach i rubrykach, a czasami przy okazji innych wiadomości kulturalnych.

Nagłówki brzmiały podobnie. W pierwszym z tygodników w latach 1945-1947 prowadzono rubrykę Nowe książki, a po niej w okresie 1948-1953 bardziej obszerny dział Wśród książek. Niezależnie od nich, od początku 1951 r. do zamknięcia pisma w 1953 r. obecna była równolegle kolumna Notatki o ksiażkach. Redakcja „Głosu Katolickiego" zdecydowała się na krótkie dane bibliograficzne wraz z kilkuzdaniowymi adnotacjami o zawartości książek w rubryczce $Z$ nowości wydawniczych (rzadziej występującej pod nazwą Nowe wydawnictwa i Nowe książki). Te same informacje o drukach mogli uzyskać odbiorcy „Tygodnika Katolickiego”, śledząc repertuar wydawniczy wykazany w Nowościach wydawniczych (sporadycznie w Nowych wydawnictwach i początkowo w Dobrych książkach). Nagłówki najczęściej zmieniano w „Tygodniku Warszawskim”, a brzmiały one następującą: Nowe ksiażki, Nowe wydawnictwa, $Z$ wydawnictw, $Z$ nowych ksiazzek, Z nowych wydawnictw, $Z$ wydawnictw zagranicznych, Przeglad wydawnictw i Wśród nowych ksiązek.

Najobszerniejszy materiał prasowy w rubrykach zawierających informacje o nowościach publikowano na łamach „Tygodnika Powszechnego”. W Nowych ksiązkach, pojawiających się początkowo, w co trzecim zeszycie omawiano od jednej do trzech pozycji; w latach 1946-1947 recenzje stały się obszerniejsze i uwzględniały nawet 5-7 książek ocenianych w podziale tematycznym. Repertuar wydawniczy był dość bogaty i różnorodny, recenzenci dobrani zaś wedle znajomości problematyki. Podpisywali się zarówno pełnym imieniem i nazwiskiem, jak też samymi inicjałami. Czytelnikom proponowano pozycje z zakresu prawa $^{275}$, historii Polski ${ }^{276}$, Ziem Zachodnich ${ }^{277}$, teologii i religii ${ }^{278}$ (m.in. encykliki ${ }^{279}$, egzegezy biblijne $\left.{ }^{280}\right)$ i biografistyki ${ }^{281}$. Dominowała też literatura wojenna i obozo-

275 J.P. [J. Piwowarczyk], Nowe ksiażki. Studia prawne, „TP” 1945 nr 18 s. 5; tenże, Nowe książki. Państwo i prawo, „TP” 1946 nr 45 s. 9.

276 Tenże, Nowe książki. Narodowe odrodzenie Ślaska, „TP” 1945 nr 30 s. 8.

${ }^{277}$ A. Gołubiew, Nowe książi. Kolonizacja niemiecka na wschód od Odry, „TP” $1946 \mathrm{nr} 43$ s. 8; kjw, Nowe książi. Historia Ziem Zachodnich, tamże, nr 22 s. 7.

${ }^{278}$ J.P. [J. Piwowarczyk], Nowe książki. Wykład mszy św., „TP” 1946 nr 26 s. 7; J. WieruszKowalski, Nowe ksiażki. Mysterium Christi, tamże, nr 32 s. 6; J.P. [J. Piwowarczyk], Nowe ksiażki. Przyroda i religia, „TP” 1947 nr 11 s. 9; J.P. [J. Piwowarczyk], Nowe ksiażki, tamże, nr 19 s. 10.

${ }^{279}$ Nowe ksiązki. Encyklika ,Quadragesimo anno”, „TP” 1946 nr 42 s. 9.

${ }^{280}$ J.P. [J. Piwowarczyk], Nowe ksiązki. Literatura religijna, „TP” 1947 nr 8 s. 9.

${ }^{281}$ S.J.T., Książka o Kottątaju, „TP” 1946 nr 33 s. 5; K. Lepszy, Nowe ksią̇ki. Zygmunt Stary - epigon średniowiecza, tamże, $\mathrm{nr} 43$ s. 9. 
wa $^{282}$. Nie zabrakło podręczników ${ }^{283}$, przewodników ${ }^{284}$ oraz literatury rozrywkowej $^{285}$ (pamfletów, aforyzmów, satyr i fraszek). Książkę literacką reprezentowały powieści ${ }^{286}$, opowiadania ${ }^{287}$ i tomiki poezji ${ }^{288}$. Te ostatnie przeważnie recenzował Jerzy Zagórski. Osobną grupę tworzyły omówienia tytułów książkowych dla młodzieży. Przykładowo zapowiedziano ukazanie się W pustyni $i$ w puszczy Henryka Sienkiewicza w wydaniu Spółdzielni Wydawniczej Czytelnik ${ }^{289}$. Redakcja tygodnika w przemianowanym od 1948 r. dziale na W'́ród książek zaproponowała bogaty wybór lektur. Nadal zwracano uwagę na podobną problematykę i te same rodzaje literackie. W omówieniach brano pod uwagę książki rodzimego i obcego autorstwa. Dobrze przyjęto dramat Jerzego Zawieyskiego Mąz doskonaty czy wznowione studium zatytułowane Świat bez duszy Daniela-Ropsa ${ }^{290}$. Nie pominięto literatury marynistycznej ${ }^{291}$, książek o tematyce małżeńskiej ${ }^{292}$, marksistowskiej293, literatury dla dzieci ${ }^{294}$, pozycji o tematyce księgoznawczej ${ }^{295}$. Nie zawsze książki oceniano dobrze.

Inny charakter przybrała natomiast wprowadzona w 1951 r. na ostatniej stronie „Tygodnika Powszechnego” (czasami występowała na s. 2-6) kolumna zatytułowana Notatki o ksiązkach. W zwięzły sposób podawano w niej okoliczności powstania dzieła, informacje o jego wydawcy, nakładzie, szczegóły

${ }^{282}$ S.W., Nowe książki. Trzy książki o Niemcach i wojnie, „TP” 1946 nr 36 s. 7; ag, Nowe książki. Walki Polaków na Zachodzie, tamże, nr 41 s. 9; K-k, Nowe książki. Katownia w Gusen, tamże, nr 42 s. 8; K-k, Księża w Dachau, tamże, nr 44 s. 8; W. Wnuk, Nowe książki. Książka o Śląsku walczącym, tamże, s. 9; J. Kleiner, Nowe książki. Książka o Majdanku, „TP” 1947 nr 9 s. 10.

283 jw., Nowe książki. Podręcznik sadownictwa, „TP” 1946 nr 23 s. 11; Z. Ciechanowska, Ksiązka o bibliotekarstwie, tamże, nr 11 s. 7.

284 a.g., Nowe książki. Czy prawda o Dolnym Śląsku?, ,TP” 1946 nr 47 s. 7.

${ }^{285}$ Nowe ksiązki, „TP” 1946 nr 27 s. 8.

${ }^{286}$ H. Malewska, Powieść o Mieszku I, „TP” 1945 nr 36 s. 8.

287 ZSM. [Z. Starowieyska-Morstinowa], Opowiadania, ,TP” 1947 nr 5 s. 9.

288 J. Zagórski, Nowe książki. Przekład z Majakowskiego, „TP” 1946 nr 41 s. 9; tenże, Nowe książi, tamże nr 45 s. 7-8; tenże, Poezja chłodna, tamże nr 48 s. 7; zsm. [Z. Starowieyska-Morstinowa], Nowe książki. Wiersze o Warszawie, „TP” 1947 nr 2 s. 8.; j. zag. [J. Zagórski], Nowe ksiązki. Poezje, tamże, nr 8 s. 9; tenże, Nowe książki. Polski Malraux, tamże, nr 9 s. 10; tenże, Nowe ksiązi. Samotny bard poznański, tamże, nr 10 s. 9; tenże, Nowe książki. Wiersze przechodnia, tamże, nr 11 s. 9.

289 ag, Nowe książki, „TP” 1946 nr 19 s. 7.

290 t., Wśród książek. „,Mąż doskonaty”, „,TP” 1948 nr 30 s. 10; J.M.S. [J.M. Święcicki], Wśród książek. Świat bez duszy, „TP” 1949 nr 26 s. 6.

${ }^{291}$ K.M., Wśród książek. Z marynistyki angielskiej, „TP” 1949 nr 32 s. 10; L. Prorok, Wśród ksiązek. Początek marynistycznej tradycji, „TP” 1952 nr 24 s. 7.

292 J.P. [J. Piwowarczyk], Wśród książek. Świeckie małżeństwo w Polsce, ,TP” 1948 nr 42 s. 9; tenże, Wśród książek. Matżeństwo w nowym świetle, „TP” 1949 nr 3 s. 11.

293 Tenże, Wśród książek, „TP” 1948 nr 40 s. 10.

294 J. Słotwiński, Wśród książek. „,Kurs cieniarstwa” dla dzieci, „TP” 1952 nr 8 s. 4.

295 ag., Wśród książek. Oprawa książki, „TP” 1949 nr 14 s. 6; M. Plezia, Habent sua fata libelli, tamże, nr 17 s. 8; I. Sławińska, Wśród książek. O miłości do ksiąg, „TP” 1951 nr 28 s. 6. 
o nowym wydaniu, obcojęzycznym przekładzie, tłumaczach, serii, zawartości, wyglądzie zewnętrznym, cenie czy możliwości subskrypcji. Niekiedy kilkuzdaniową wiadomość uzupełniano wzmianką o autorze, jak czytamy: „Jacques Maritain, najwybitniejszy współczesny filozof katolicki, napisał ostatnio książkę pt. Człowiek i państwo, która miała się ukazać w marcu br. w USA. Zapewne równocześnie ukaże się wydanie francuskie. Maritain od czasu opuszczenia stanowiska ambasadora Francji przy Watykanie, jakieś dwa lata temu, dzieli swój czas między katedrę filozofii na uniwersytecie w Princeton (USA) a założoną przez dominikanów pod Paryżem $<<$ Szkołą Mądrości $>>$ w L'Eau Vive"296.

Notki dotyczyły znanych i mniej znanych powieści. Przykładowo wspomniano o „ostatnim dziele $\mathrm{z}$ pośmiertnej spuścizny Bernanosa” - powieści Zly sen ${ }^{297}$, o wydanej w nakładzie 10 tys. egzemplarzy Broni na sprzedaż Grahama Greene'a ${ }^{298}$. W niepodpisanej przez nikogo rubryce informowano także o dopiero wydanych dziełach naukowych ${ }^{299}$, studiach historycznoliterackich $^{300}$, wykładach uniwersyteckich, referatach ${ }^{301}$, albumach ${ }^{302}$, korespondencjach $^{303}$, pamiętnikach ${ }^{304}$, książkach dla dzieci (np. wydanych w serii zagranicznej Biblioteki Narodowej ${ }^{305}$ ) i innych. W notatce z 1952 r. czytamy: „Nakładem Książki i Wiedzy ukazały się ostatnie tomy 13-tomowego wydania dzieł Stalina. Wydanie to obejmuje przekład polski wszystkich dzieł Stalina opublikowanych dotąd w języku rosyjskim. Łączny nakład wydania polskiego wynosi 1 milion 300 tysięcy egzemplarzy, natomiast łączny nakład wszystkich wydanych przez Książkę i Wiedzę w języku polskim prac Stalina wynosi niemal 6 milionów egzemplarzy" ${ }^{306}$. Niekiedy zapowiadano tytuły, które były również osobno recenzowane na łamach „Tygodnika Powszechnego”, jak było w przypadku „cennej dla wszystkich miłośników sztuki” książki o życiu i pracy Bogdana Tretera Kraków - jego miasto. Z Notatek o książkach można było dowiedzieć się o jej „nadzwyczaj pieczołowitym opracowaniu przez żonę artysty” i pięknej szacie graficznej ${ }^{307}$. W jednej ze wzmianek w 1951 r. zapowiedziano

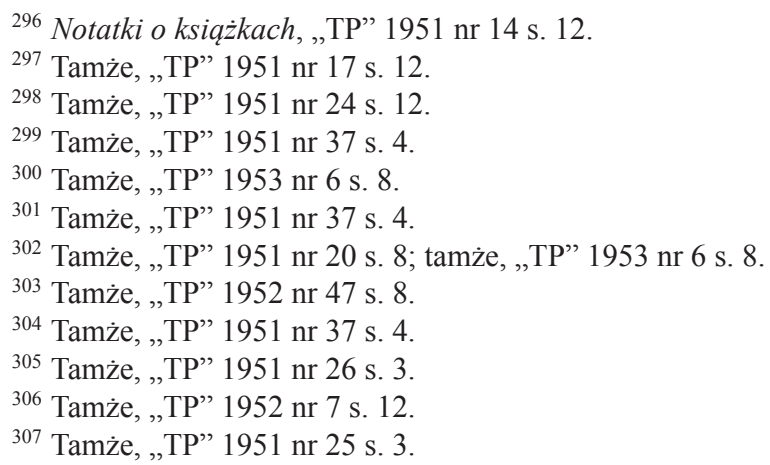


także kilkanaście nowych wydawnictw Biblioteki Narodowej Ossolineum ${ }^{308}$. Dość często na początku Notatek o książkach ogłaszano nowości książkowe IW PAX ${ }^{309}$. Odbiorcy dowiedzieli się m.in. o tureckim przekładzie Quo vadis Henryka Sienkiewicza w serii klasyków literatury światowej i węgierskim tłumaczeniu Lalki Bolesława Prusa ${ }^{310}$. Pisano również o ciekawostkach związanych z książką, jak np. o wydanych Dziennikach Samuela Pepysa, które autor zajmujący wysokie stanowisko w państwowej służbie angielskiej napisał szyfrem, dając potomnym dokument o współczesnej mu epoce ${ }^{311}$. Niekiedy redakcja informowała o ukazaniu się kolejnego numeru czasopisma i sygnalizowała jego zawartość (np. informacja o nowym 28 numerze „Znaku” ${ }^{12}$, nowym „Biuletynie Historii Sztuki” ${ }^{313}$ i pierwszym zeszycie miesięcznika „W Obronie Pokoju” ${ }^{314}$ ) lub też o nowej inicjatywie wydawnictwa periodycznego (np. powołaniu przez Łódzkie Towarzystwo Naukowe „Przeglądu Nauk Historycznych i Społecznych"315).

Informacje o nowościach pojawiały się także w innych działach i rubrykach „Tygodnika Powszechnego”. W latach 1949-1952 dość często występowały w dziale $Z$ dnia, w którym jednorazowo mogło ukazać się kilka wiadomości dotyczących różnych książek. Odbiorcy dowiadywali się o licznych przekładach różnych dzieł, np. o ukazaniu się w Kijowie ukraińskiego tłumaczenia Pana Tadeusza ${ }^{316}$, rosyjskim przekładzie Krzyżaków, Starej baśni, Ludzi bezdomnych i Komorników opublikowanych w Moskwie ${ }^{317}$, fińskim przekładzie Chłopów $w^{318}$, węgierskich przekładach Kordiana i chama oraz antologii poezji i prozy Adama Mickiewicza ${ }^{319}$, zapowiedzi czeskiego wydania Płomieni Stanisława Brzozowskiego w Pradze ${ }^{320}$, rosyjskim przekładzie Fundamentów Jerzego Pytlakowskiego ${ }^{321}$, angielskim przekładzie powieści Święty grzesznik znanego pisarza niemieckiego Tomasza Manna ${ }^{322}$. Najczęściej wiadomo było

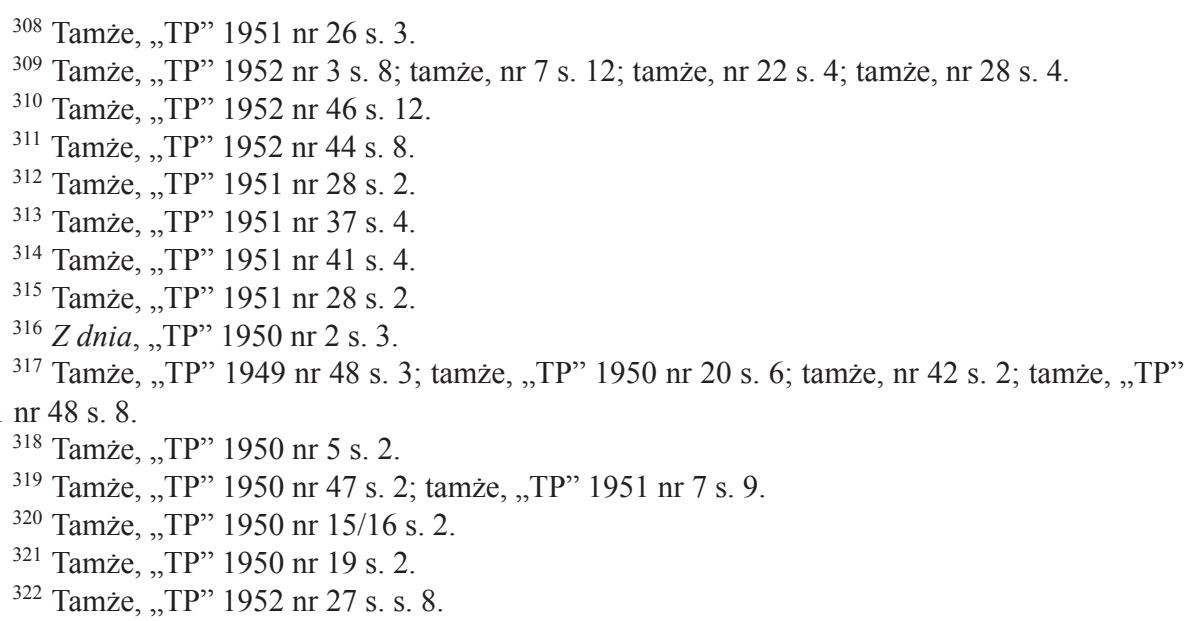


o tłumaczeniach rosyjskich i czeskich. Do wiadomości podawano też informacje o bieżących polskich wydaniach dzieł obcych autorów: Sedna sprawy Grahama Greene'a ${ }^{323}$, Dziejów Chrystusa Daniela-Ropsa ${ }^{324}$, Kapitatu Karola Marksa $^{325}$ albo o powieściach wydanych za granicą Helena i Ludzie pod bronia Evelyn Waugh ${ }^{326}$, Każdemu po groszu Bruce'a Marshalla ${ }^{327}$. Odbiorcy mogli poznać też książki wydane w serii Biblioteki Narodowej Zakładu Narodowego im. Ossolińskich Życie Karola Wielkiego Einharda w przekładzie Jana Parandowskiego i tomik fraszek ,nie znanego dotąd autora z przełomu XVII i XVIII w." Adama Korczyńskiego ${ }^{328}$. Nie zabrakło także informacji o dziełach rodzimych autorów: „Nowa książka Jana Parandowskiego, wydana nakładem Gebethnera i Wolffa, to dawno oczekiwana Alchemia stowa [...]. Kilka esejów wchodzących w skład książki drukował swego czasu $<<$ Tygodnik Powszechny $>$. Staranna szata zewnętrzna i trafnie dobrane liczne ilustracje podnoszą wartość książki”" ${ }^{22}$. Przy okazji różnych okolicznościowych uroczystości pisarzy i poetów, informowano o wydaniu ich pozycji. W dziale $Z$ dnia czytamy: „Znany działacz robotniczy i pisarz Lucjan Rudnicki obchodził ostatnio 70 urodziny. Dotychczas ukazały się 2 tomy wspomnień Rudnickiego Stare $i$ nowe, autor ich pracuje obecnie nad trzecim tomem" 330 lub „W wydawnictwie Mercure de France ukazał się zbiorowy tom stanowiący międzynarodowy hołd złożony Balzacowi z okazji jego rocznicy, z inicjatywy UNESCO..." ${ }^{331}$. Powiadamiano jednocześnie o wznowieniach i nakładach książek, np. słynnej powieści Bernanosa Pamiętnik wiejskiego proboszcza opublikowanej w IW PAX w nakładzie 10 tys. egzemplarzy ${ }^{332}$. Niejednokrotnie można było dowiedzieć się o drukowaniu opowiadań i powieści w odcinkach na łamach prasy, np. Misi w „Kurierze Codziennym” ${ }_{333}$, Żywego człowieka Chestertona i Śmierć przychodzi po arcybiskupa Willi Cathera w "Słowie Powszechnym” ${ }_{334}$. Pisano o niektórych cennych inicjatywach wydawniczych, jak np. przygotowywaniu w Związku Radzieckim ,jedynej w swoim rodzaju” encyklopedii dla dzieci ${ }^{335}$, 3-tomowej Encyklopedii puszkinowskiej przez Instytut Literatury Rosyjskiej

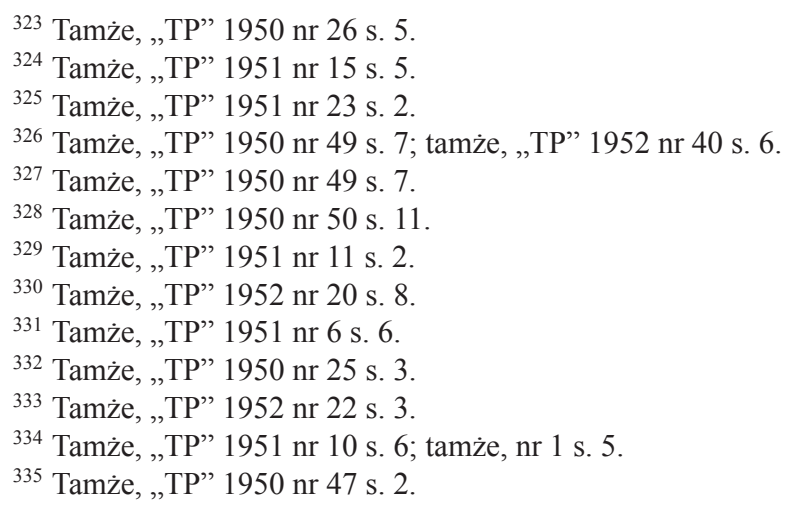


Akademii Nauk ZSRR w Leningradzie ${ }^{336}$ czy prac nad powstaniem słownika polsko-bułgarskiego w Bułgarskiej Akademii Nauk" ${ }^{337}$. Czasami podawano ciekawostki typu: „Najnowszą pracę literacką Ksawerego Pruszyńskiego stanowi biograficzna Opowieść o Adamie Mickiewiczu, nadawana obecnie w programie Polskiego Radia" ${ }^{338}$. Wspomniano również o wydaniu przez Greene’a książki dla dzieci Mała sikawka straży pożarnej ${ }^{339}$.

Redakcja „Tygodnika Powszechnego" w Kronice religijnej powiadamiała odbiorców o ukazaniu się nowych książek katolickich. Z rubryki wiadomo było o „,nowym tomie poprawionej Wulgaty” ${ }^{340}$, japońskim przekładzie Pisma świętego $^{341}$, o wydaniu w 1952 r. mszału w Rzymie ${ }^{342}$, mszaliku w języku czeskim ${ }^{343}$, „rekordowym 15-milionowym nakładzie” popularnego mszalika angielskiego ks. Stedmana ${ }^{344}$, ukazaniu się nowego katechizmu w Kanadzie ${ }^{345}$ oraz włoskiej Encyklopedii katolickiej ${ }^{346}$. Zapowiadano polskie tłumaczenie encykliki Mediator Dei (20 XI 1947) Piusa XII, która miała się ukazać nakładem Verbum w zbiorze $Z$ akt Stolicy Apostolskiej ${ }^{347}$, wydaniu nawołującej do pokoju Mirabile Illud (6 XII 1950) (48 $^{34}$ encyklice o soborze w Chalcedonie Sempiternus Rex Christus Piusa XII (8 IX 1951 r.) ${ }^{349}$. Dzieje duszy św. Teresy od Dzieciątka Jezus, jak wiadomo z kroniki, przetłumaczono na język malgaski ${ }^{350}$, natomiast listy św. Teresy z Avili znalazły thumacza angielskiego w osobie Allisona Peersa ${ }^{351}$. Informowano też o innych nowościach. Przykładem mogą być: monografia o św. Teresie Wielkiej Marcéla Lépee wydana w 1951 r. we Francji ${ }^{352}$ oraz powieści katolickie Grahama Greene' ${ }^{353}$ i Gertrudy von le Fort ${ }^{354}$.

Przy okazji sprostowań i wyjaśnień dotyczących książek, informacje o nowościach gościły w krakowskim tygodniku w następujących działach i rubrykach:

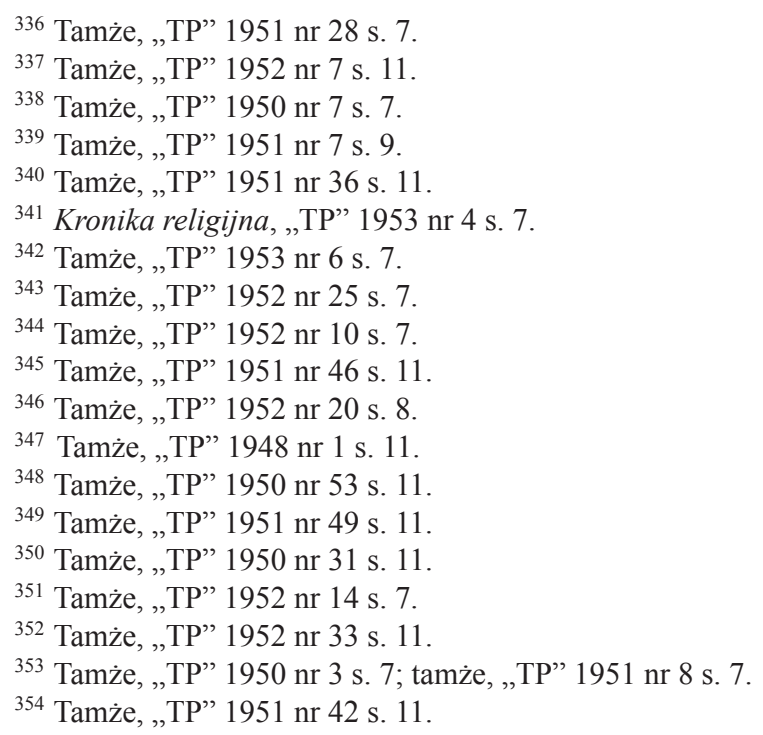


Bez ogródek ${ }^{355}$, Listy do redakcji $i^{356}$ i Kronika ${ }^{357}$. Warto przytoczyć jedno ze sprostowań zamieszczonych w Listach do redakcji: „Spółdzielnia Wydawnicza Wiedza prosi nas o zamieszczenie następującego oświadczenia na skutek orzeczenia Sądu Polubownego. Wydana przez [nią - E.K.] książka Śmierć miasta, pamiętnik Władysława Szpilmana, opracował Jerzy Waldorff - według karty tytułowej, a Władysław Szpilman według okładki, zgodnie z umową wydawniczą z dnia 19 czerwca 1946 r. jest wspólnym dziełem Szpilmana i Waldorffa, za które obaj solidarnie odpowiadają. Opuszczenie nazwiska Waldorffa na okładce książki wynikło z niewłaściwego interpretowania umowy oraz częściowo z potrzeb układu graficznego. Zmiany wprowadzone do tekstu drukowanej książki zostały dokonane ze względów niezależnych od wydawcy, jednak bez dostatecznego porozumienia się z Jerzym Waldorffem”358. W Kronice donoszono m.in. „Pierwszą książką religijną przełożoną na język rosyjski jest wydane na Węgrzech dzieło znanego katolickiego pisarza (biskupa) Tihaméra Tótha pt. Wszechmocny Bóg. Tylko kto je po rosyjsku będzie na Węgrzech czytał?" ${ }^{559}$. Z Kroniki angielskiej czytelnicy dowiedzieli się o dostępnej na rynku w 1948 r. znanej publikacji Who's who liczącej 35 tysięcy biografii ${ }^{360}$. W Kronice amerykańskiej donoszono o ostatniej książce Aldousa Huxleya Matpa $i$ istota ${ }^{361}$, natomiast w Kronice francuskiej o pozycji Emila Ludwiga Historia Niemcó $w^{362}$. Sporadycznie drukowano podobne informacje w Zapiskach recenzen$t a^{363}$. Zdarzało się, że redagujący pismo zamieszczali także pomiędzy materiałem prasowym krótką notkę o wydaniu książki ${ }^{364}$.

Niewielka rubryka w „Głosie Katolickim” występująca od zeszytu 20 z 1945 r. na końcu periodyku pt. Z nowości wydawniczych początkowo zawierała dane bibliograficzne i krótką adnotację treściową o dwóch książkach. $Z$ czasem zaczęto zapowiadać w niej więcej pozycji, wraz z uwzględnieniem różnych wydawców. W latach 1945-1948 wzięto pod uwagę m.in. repertuar wydawniczy Instytutu Zachodniego ${ }^{365}$, Wydawnictwa Zachodniego ${ }^{366}$, Wydawnictwa Towarzystwa

${ }^{355}$ Np. Bez ogródek, „TP” 1949 nr 22 s. 12; tamże, „TP” 1950 nr 14 s. 12; tamże, nr 25 s. 8; tamże, nr 30 s. 8; tamże, „TP” 1952 nr 7 s. 12; tamże, nr 8 s. 8; tamże, nr 12 s. 8; tamże, nr 39 s. 8; tamże, nr 42 s. 12.

${ }^{356}$ Listy do redakcji, „TP” 1948 nr 32 s. 10; tamże, „TP” 1950 nr 17 s. 10; tamże, „TP” 1951 nr 30 s. 4.

${ }^{357}$ Kronika, „TP” 1947 nr 6 s. 10; tamże, nr 16 s. 9; tamże, nr 25 s. 10; tamże, nr 26 s. 10.

${ }^{358}$ Listy do redakcji, „TP” 1947 nr 21 s. 11.

${ }^{359}$ Kronika, „TP” 1947 nr 24 s. 10.

${ }^{360}$ Kronika angielska, „TP” $1948 \mathrm{nr} 33$ s. 10.

${ }^{361}$ Kronika amerykańska, „TP” 1948 nr 38 s. 8.

${ }^{362}$ Kronika francuska, „TP” $1948 \mathrm{nr} 48$ s. 10.

${ }^{363}$ Zapiski recenzenta, „TP” 1949 nr 22 s. 12; tamże, nr 30 s. 12.

${ }^{364}$ Np. Książka dla Wrocławia, „,TP” $1945 \mathrm{nr} 26$ s. 8; Nowy taciński przekład psalmów, tamże, nr 30 s. 2; Encyklopedia katolicka, „TP” 1951 nr 30 s. 2; Chrystus i religie świata, „TP” 1952 nr 48 s. 3.

${ }^{365}$ Nowe wydawnictwa, „GK” 1945 nr 21 s. 8; Z nowości wydawniczych, tamże, nr 24 s. 8; tamże, „GK” 1946 nr 41 s. 332; tamże, „GK” 1947 nr 18 s. 167.

${ }^{366}$ Z nowości wydawniczych, „GK” 1948 nr 3 s. 29; tamże, nr 8 s. 69; tamże, nr 9 s. 79. 
Naukowego KUL ${ }^{367}$, Wydawnictwa Apostolstwa Modlitwy w Krakowie ${ }^{368}$, Wydawnictwa Księży Jezuitów w Warszawie ${ }^{369}$, Wydawnictwa Księży Pallotynów ${ }^{370}$, Wydawnictwa Księgarni św. Jacka ${ }^{371}$, Wydawnictwa SS. Loretanek Benedyktynek w Warszawie, Instytutu Wydawniczego Kultura w Poznaniu ${ }^{372}$, Wielkopolskiej Księgarni Wydawniczej w Poznaniu ${ }^{373}$, Wydawnictwa Verbum ${ }^{374}$, Wydawnictwa B. Matuszewski ${ }^{375}$. W jednym zeszycie proponowano książki przeważnie kilku oficyn. Rubryka gościła na łamach pisma najczęściej w co trzecim lub czwartym numerze, rzadziej występowała w zeszytach jednym po drugim. Czasami oferowano nowości dla określonej grupy czytelników, np. pod hasłem „Książki dla inteligencji” - wymieniono m.in. dwie pozycje Ludwika Civardi Apostolstwo w środowisku i Podręcznik Akcji Katolickiej, DanielaRopsa Nędza i my, Jacquesa Maritaina Religia i kultura, Willibrorda Verkade $K u$ doskonatości. Wszystkie stanowiły ofertę Wydawnictwa Seminarium Zagranicznego ${ }^{376}$. Z serii najczęściej promowano Biblioteczkę Eucharystyczną, a w niej opowiadania dla młodzieży Najpiękniejsze zwycięstwo ${ }^{377}$. Dzieciom zaproponowano tytuły, które wyszły spod prasy Państwowych Zakładów Wydawnictw Szkolnych, w tym: Najmilsi Ewy Szelburg-Zarembiny, O sprytnej wronie, psotnym kruku i ich krewniakach Jana Sokołowskiego ${ }^{378}$, Wędrowała sroczka Adama Dubowskiego ${ }^{379}$. Polecane powieści znane były powszechnie odbiorcom z reklam i recenzji na łamach katolickich czasopism społecznokulturalnych. Wymienić tu należy Szatę godowa Jana Dobraczyńskiego, Sage o Jarlu Broniszu Władysława Jana Grabskiego ${ }^{380}$ i Szymona syna Jony Piotra Juliusza Kędziory ${ }^{381}$. Niekiedy w rubryce gościła tylko jedna pozycja książkowa, jak np. reklamowany ,informator historyczny” 200 miast wraca do Polski Władysława Jana Grabskiego ${ }^{382}$. Przeważały zdecydowanie książki rodzimych

367 Tamże, „GK” 1946 nr 13 s. 104; tamże, „GK” 1947 nr 30 s. 255; tamże, „GK” 1948 nr 9 s. 79.

368 Tamże, „GK” 1947 nr 35 s. 294; tamże, „GK” 1948 nr 8 s. 69; tamże, nr 37 s. 315.

369 Tamże, „GK” 1947 nr 15 s. 130; tamże, nr 21 s. 183; tamże, nr 30 s. 255; tamże, „GK” 1948 nr 17 s. 154.

370 Tamże, „GK” 1947 nr 26 s. 223; tamże, nr 35 s. 294.

${ }^{371}$ Tamże, „GK” 1948 nr 19 s. 172; tamże, nr 48 s. 403.

372 Tamże, „GK” 1947 nr 27 s. 231.

373 Tamże, „GK” 1947 nr 43 s. 359.

374 Tamże, „GK” 1947 nr 47 s. 386; tamże, „GK” 1948 nr 20 s. 180.

375 Tamże, „GK” 1946 nr 52 s. 427.

376 Tamże, „GK” 1946 nr 25 s. 204.

377 Tamże, „GK” 1947 nr 28 s. 240.

${ }^{378}$ Tamże, „GK” 1947 nr 7 s. 55; tamże, nr 23 s. 199.

379 Tamże, „GK” 1948 nr 9 s. 79.

380 Tamże, „GK” 1947 nr 9 s. 71.

381 Tamże, „GK” 1948 nr 29 s. 255.

382 Tamże, „GK” 1947 nr 20 s. 175. 
autorów nad tytułami obcymi oraz wydawnictwa o tematyce religijnej: mszały ${ }^{383}$, rozmyślania eucharystyczne ${ }^{384}$, rozważania modlitewne ${ }^{385}$, encykliki ${ }^{386}$, dzieła teologiczne ${ }^{387} \mathrm{i}$ inne.

Informacje o nowościach wydawniczych czytelnicy "Głosu Katolickiego” mogli znaleźć także w dziale Ze świata katolickiego, w którym z kolei więcej informowano o wydawnictwach zagranicznych. Dla przykładu pisano o publikacjach Biblioteki Watykańskiej, które były drukowane także w czasie II wojny światowej ${ }^{388}$, o pracy Jacquesa Maritaina Chrześcijaństwo i demokracja ${ }^{389}$, o poczytnym i świeżo wydanym dziele Daniela-Ropsa Życie Jezusa ${ }^{390}$, o nowej francuskiej encyklopedii katolickiej pod redakcją ks. Gabriela Jacquementa zaplanowanej na siedem tomów ${ }^{391}$, o dostępnym „W końcu” na półkach księgarskich w polskim przekładzie Dialogu św. Katarzyny ze Sieny ${ }^{392}$. Nie zabrakło wiadomości również o nowej biografii Williama Shakespeare'a wydanej w Paryżu ${ }^{393}$ i o nowych książkach dotyczących życia i działalności kardynała Newmana ${ }^{394}$. Śledzono przekłady Pisma św. na język japoński ${ }^{395}$, chiński ${ }^{396}$, tybetański ${ }^{397}$, hiszpański i kataloński ${ }^{398}$. Podobnie na bieżąco zapowiadano i powiadamiano o nowych encyklikach ${ }^{399}$, pisząc jednocześnie: „Pius XII w ciągu swojego pontyfikatu, który jak dotychczas przypadł w zupełności na lata obecnej wojny, wydał cztery encykliki. Niestety na skutek odcięcia nas od Rzymu nie są one zupełnie znane w Polsce" ${ }^{" 400}$. Czytelników informowano także o ciekawostkach wydawniczych: ukazaniu się pierwszego modlitewnika dla Eskimosów ${ }^{401}$, trzeciej edycji we Włoszech modlitewnika w języku esperanto ${ }^{402}$, nowym niemieckim rytuale kościelnym ${ }^{403}$, dostęp-

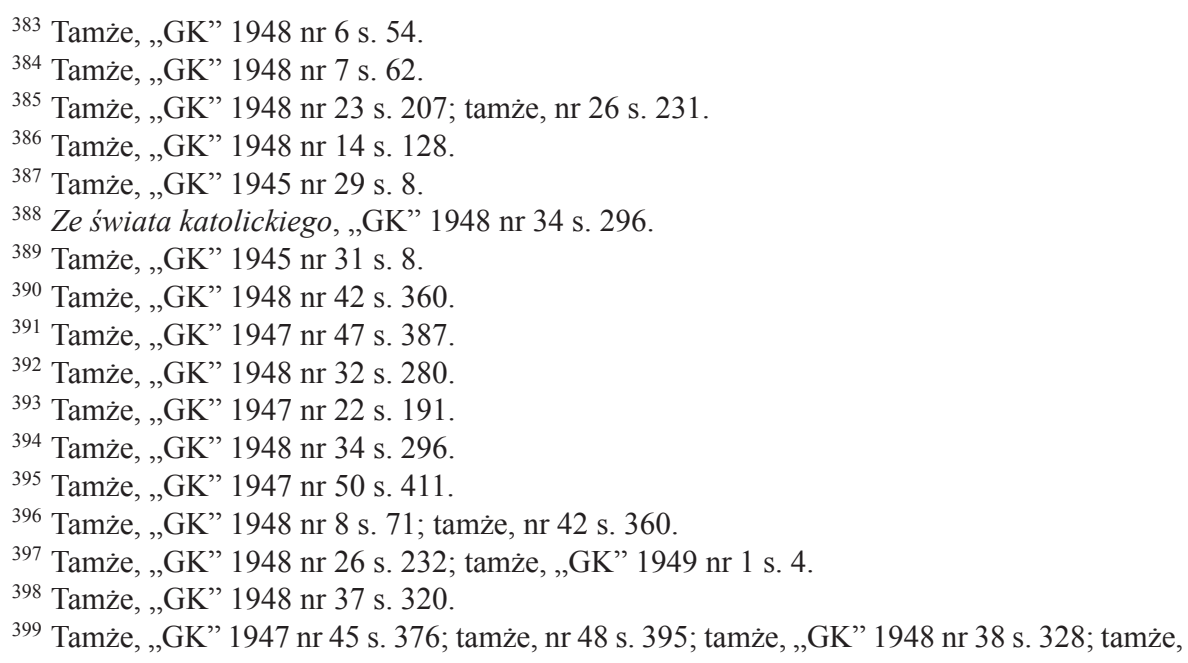


nej powszechnie na półkach księgarskich w Rzymie korespondencji papieża Piusa XII z prezydentem Rooseveltem ${ }^{404}$. Redakcja nie miała w zwyczaju powiadamiać o druku odcinków powieściowych ${ }^{405}$.

Redakcja „Tygodnika Katolickiego” wprowadziła najpierw rubrykę Dobre książki (nr 2 z 1946 r.), a po niej dłużej występujące Nowości wydawnicze (od 7 nru z 1946 r.), którą można było odnaleźć w piśmie w co trzecim lub czwartym zeszycie na ostatniej lub przedostatniej stronie. Pozycje książkowe pochodziły z tych samych wydawnictw, które wymieniono powyżej przy okazji omawiania rubryki w „Głosie Katolickim”, przy czym zdecydowanie preferowano w ofercie Wydawnictwo Apostolstwa Modlitwy. Oprócz tego w spisach wystąpiło Wydawnictwo Mariackie ${ }^{406}$, Wydawnictwo OO. Karmelitów Bosych ${ }^{407}$, Wydawnictwo Krajowej Centrali Caritas w Krakowie ${ }^{408}$, Wydawnictwo Św. Krzyża w Opolu ${ }^{409}$. Sporadycznie przedstawiano książki jednego wydawcy w podziale tematycznym, jak to było w przypadku Wydawnictwa Księży Pallotynów. Pod hasłem „Książki treści religijnej” wymieniono osiem tytułów książkowych, a pod hasłem „Książki powieściowe” zaoferowano kilka pozycji dla dzieci i młodzieży (m.in. dwie powieści ks. Stanisława Pasławskiego dla nastolatków Nieuchwytne skarby i Irusia, a dla dzieci czterobarwną książeczkę Czerwony kapturek i lekturę dla przedszkolaków Straszny wilk $\left.{ }^{410}\right)$. W innym miejscu czytamy o ,ślicznie wyilustrowanej książce" Janiny Porazińskiej Boża ściė̇ka królowej Kingi przeznaczonej dla starszych dzieci"11. W spisach „Tygodnika Katolickiego”, podobnie jak w „Głosie Katolickim”, przeważała książka katolicka: Nowy Testament ${ }^{412}$, katechizmy, modlitewniki, śpiewniki, nauki rekolekcyjne, hagiografie ${ }^{413}$. Bardziej znanymi tytułami w nowych wydaniach były m.in. Droga na górę Karmel św. Jana od Krzyża ${ }^{414}$, Święty Franciszek z Asyżu Gilberta Keitha Chestertona ${ }^{415}$, Apologia pro Vita sua Johna Newmana ${ }^{416}$. Propozycje tytułów powieściowych powtarzały

404 Tamże, „GK” 1947 nr 45 s. 376.

405 Jednokrotnie wspomniano tylko o fragmencie Szaleńców Bożych Zofii Kossak drukowanych w bratysławskich „Katolickich Novinach”, „GK” 1948 nr 18 s. 164.

406 Nowości wydawnicze, ,TK” 1947 nr 14 s. 112.

407 Tamże, ,TK” 1947 nr 16 s. 128.

408 Tamże, ,TK” 1947 nr 39 s. 270.

409 Tamże, ,TK” 1948 nr 42 s. 342; tamże, „TK” 1949 nr 41 s. 368.

410 Tamże, ,TK" 1947 nr 46 s. 318.

411 Tamże, „TK” 1947 nr 50 s. 348.

412 Tamże, ,TK” 1949 nr 31 s. 284.

413 Tamże, „TK” 1947 nr 49 s. 336; tamże, „TK” 1948 nr 4 s. 32; tamże, „TK” 1949 nr 30 s. 276.

414 Tamże, „TK” 1949 nr 22 s. 211.

415 Tamże, ,TK” 1949 nr 6 s. 54.

416 Tamże, ,TK” 1949 nr 2 s. 18. 
się, np. Szymon syn Jony Kędziory ${ }^{417}$, Dziewczyna z chmur Marii Wardasówny ${ }^{418}$, Suknia Dejaniry Kossak-Szczuckiej ${ }^{419}$. Były też i nowe książki, w innych pismach niereklamowane, jak np. dramaty: Jerzego Zawieyskiego Ocalenie Jakuba ${ }^{420}$, Zofii Kossak Gość oczekiwany ${ }^{421}$, ks. A. Gadowskiego Bohaterka chrześcijańska, ks. P. Turbaka Agnes ${ }^{422}$. Proponowano też wydawnictwa o innej problematyce, dotyczące np. ogrodnictwa - Urzadzenie i pielęgnowanie sadu ${ }^{423}$. Czasami można było znaleźć także aforyzmy, np. Kapelusz noś i przy pogodzie... Remigiusza Kwiatkowskiego ${ }^{424}$. Niekiedy kilkakrotnie polecano te same pozycje wydawnicze $^{425}$. W latach 1946-1949 redakcja z reguły dołączała krótkie adnotacje treściowe o każdej z prezentowanych książek. Nie było w nich wypowiedzi krytycznych. Nowości wydawnicze zawierały od jednej do kilkunastu pozycji. Każdorazowo w kolumnie drukowano imię i nazwisko autora, wytłuszczonym drukiem tytuł dzieła, miejsce i rok wydania, nazwę wydawnictwa i adres jego siedziby. Niekiedy informowano w rubryce o tym, że dostępny jest kalendarz noworoczny ${ }^{426}$ lub najnowszy zeszyt „Przeglądu Powszechnego" ${ }^{27}$ czy „Zucha”"28. Na łamach „Tygodnika Katolickiego” w Nowościach wydawniczych oprócz książki katolickiej dla dorosłych szeroko upowszechniano książkę dla dzieci i młodzieży ${ }^{429}$.

Informacje o nowościach redakcja drukowała także w kolumnie $Z$ życia katolickiego, gdzie znalazły się m.in. wiadomości o encyklikach ${ }^{430}$, przekładach Pisma św. i innych drukach, znane z łamów „Głosu Katolickiego” ${ }^{31}$. Do cieka-

\footnotetext{
417 Tamże, „TK” 1948 nr 26 s. 185.

418 Tamże, „TK” 1949 nr 3 s. 28.

419 Tamże, „TK” 1948 nr 25 s. 176.

${ }^{420}$ Tamże, „TK” 1948 nr 27 s. 195.

${ }^{421}$ Tamże, „TK” 1948 nr 37 s. 295.

422 Tamże, „TK” 1948 nr 40 s. 322.

${ }^{423}$ Tamże, ,TK” 1949 nr 8 s. 76.

${ }^{424}$ Tamże, „TK” 1948 nr 6 s. 43.
}

${ }^{425} \mathrm{~Np}$. Świadkowie Jehowy czyli badacze Pisma Roli, czy Śladami Skargi, Nowości wydawnicze, „TK” 1948 nr 32 s. 246; tamże, nr 34 s. 266; tamże, nr 41 s. 332.

${ }^{426}$ Np. Kalendarz Serca Jezusowego na 1948 r. Nowości wydawnicze, „TK” 1947 nr 49 s. 336; Kalendarz - informator na rok 1948 miesięcznika „Hasła Ogrodniczo-Rolniczego”, tamże, s. 335; Kalendarz „Gościa Niedzielnego” na rok 1949, tamże, „TK” 1949 nr 3 s. 28; Kalendarz Salwatora na rok 1949, tamże, nr 7 s. 64.

${ }^{427}$ Nowości wydawnicze, „TK” 1948 nr 26 s. 184.

${ }^{428}$ Tamże, „TK” 1949 nr 25 s. 238.

429 Tamże, „TK” 1949 nr 11 s. 104

430 „TK” 1947 nr 20 s. 153; Z życia katolickiego, tamże, nr 50 s. 344; tamże, „TK” 1948 nr 2 s. 17; tamże, „TK” 1949 nr 20 s. 193; Kościót i świat, „TK” 1950 nr 37 s. 261.

${ }^{431}$ M.in. o przekładach Pisma św. na język eskimoski, Z życia katolickiego, „TK” $1947 \mathrm{nr} 9$ s. 71; chiński, Z życia katolickiego, „TK” 1949 nr 5 s. 45; tybetański, Z życia katolickiego, tamże, nr 27 s. 253; japońskim thumaczeniu Ewangelii, o jubileuszowym wydaniu Wulgaty ks. Jakuba Wujka, Z życia katolickiego, tamże, nr 48 s. 429; wydawnictwach Biblioteki Watykańskiej, Z życia katolickiego, „TK” 1948 nr 33 s. 249; Dziejach duszy w języku malgaskim, Kościót i świat, „TK” 1950 nr 27 s. 205. 
wostek należały informacje o przyznaniu nagrody Nobla w dziedzinie literatury Norweżce Marii Brekker za książkę pt. Matka Maria ${ }^{432}$, a także o produkcji filmu na podstawie książki amerykańskiego jezuity O. Mursaya Czerwona konwa$l i a^{433}$, o ukazaniu się papieskiej Białej Księgi zawierającej dokumenty o stosunku Watykanu do państw prowadzących wojnę i państw napadniętych, a obejmującej okres 1933-1940434.

Odmienny był dobór - zarówno pod względem tematycznym, jak też wydawniczym - w spisach książek promowanych przez redakcję „Tygodnika Warszawskiego". W różnie nazywanych i nieregularnie występujących rubrykach recenzenci podpisujący się inicjałami, rzadziej imieniem i nazwiskiem, krótko recenzowali nowości. Znalazły się tu m.in. następujące opowiadania: Żadto Genowefy, L - jak Lucy Janusza Meissnera (Wydawnictwa Awir) ${ }^{435}, Z$ barykady $w$ doline glodu Michała Rusinka (Wydawnictwo E. Kuthana) ${ }^{436}$, Rafat z lasu Władysława Rymkiewicza (Czytelnik) ${ }^{437}$, Pożegnanie z Maria Tadeusza Borowskiego (Spółdzielnia Wydawnicza Wiedza) ${ }^{438}$. Z dramatów Zawieyskiego wybrano Męża doskonatego ${ }^{439}$. W spisie Nowe wydawnictwa znalazły się także Pan Tadeusz Adama Mickiewicza, Sezon w Alpach $i$ inne wiersze Mieczysława Jastruna $^{440}$. Powieść zagraniczną reprezentowały Stracone złudzenia oraz Blaski i nędze życia kurtyzany Honoré de Balzaca (Spółdzielnia Wydawnicza Książka) ${ }^{441}$. Pod hasłem Nowe powieści zapowiedziano T. Kudlińskiego Dziedzictwo zemsty i tom opowiadań Przyjaźń jest trudna (Książnica Atlas) ${ }^{442}$; literaturę podróżniczą zaś wyróżniono tytułem Kraj biały czy zielony Alfreda Jahna (Książnica Atlas) ${ }^{443}$. Pod nagłówkiem $Z$ wydawnictw zagranicznych powiadomiono czytelników o ukazaniu się za pośrednictwem amerykańskiej firmy Sheed and Ward w Nowym Jorku w pięknym wydaniu zbioru polskich bajek ludowych pt. Polish Folk Tales $^{444}$. Nie zabrakło również innych rodzimych bajek, zaproponowano bowiem O gęsiarce Kasieni i o cudownych listkach Pani Jesieni Lucyny Krzemienieckiej (Spółdzielnia Wydawnicza Książka ${ }^{445}$. Wybrano także kilka propozycji dla mło-

\footnotetext{
432 Z życia katolickiego, „TK” 1947 nr 49 s. 333.

${ }^{433}$ Tamże, „TK” 1949 nr 3 s. 27.

${ }^{434}$ Za granica, „TK” $1946 \mathrm{nr} 6$ s. 8.

${ }^{435}$ Z.R. [Z. Rabska], Nowe ksiażki, „TW” 1946 nr 28 s. 5.

436 Taż, Nowe ksiażki, „TW” 1946 nr 34 s. 8.

${ }^{437}$ W. Bacewiczówna, $Z$ wydawnictw, „TW” 1947 nr 4 s. 6.

${ }^{438}$ Nowe wydawnictwa, „TW” 1948 nr 27 s. 8.

439 Tamże, „TW” 1948 nr 34 s. 8.

${ }^{440}$ Tamże, „TW” 1948 nr 24 s. 10.

${ }^{441}$ W. Bacewiczówna, $Z$ wydawnictw, „TW” 1947 nr 4 s. 6.

${ }^{442}$ Nowe powieści T. Kudlińskiego, „TW” 1948 nr 23 s. 6.

${ }^{443}$ A. Madej, Z nowych wydawnictw, „TW” $1947 \mathrm{nr} 49$ s. 8.

${ }^{444}$ Z wydawnictw zagranicznych, „TW” $1948 \mathrm{nr} 9$ s. 5.

${ }^{445}$ md, Z wydawnictw, „TW” 1948 nr 23 s. 8.
} 
dzieży - U progu Stanisława Podoleńskiego, $W$ obliczu życia ks. R. Plusa ${ }^{446}$. Książka katolicka, choć nie dominowała w nowościach, była również obecna; zaznaczono bowiem wydaną przez Verbum encyklikę Piusa XII Mediator Dei, św. Jana od Krzyża Drogę na Górę Karmel (Wydawnictwo OO. Karmelitów Bosych) ${ }^{447}$, Piotra Kettera Chrystus a kobiety (Wydawnictwo Księży Jezuitów) ${ }^{448}$, Święci i błogosławieni Kościoła katolickiego (Księgarnia św. Wojciecha) ${ }^{449}$.

Wiedzę o nowościach wydawniczych w kraju i za granicą odbiorcy warszawskiego tygodnika mogli uzyskać także dzięki śledzeniu Przegladu kulturalnego, Kroniki kulturalnej i Życia katolickiego. Proponowany w nich repertuar książkowy różnił się od omawianego w pozostałych czasopismach. W pierwszej rubryce czytamy o wydaniu znanej przed II wojną światową książki Zazdrość i medycyna Michała Choromańskiego w przekładzie angielskim ${ }^{450}$, czeskim tłumaczeniu Dymów nad Birkenau S. Szmaglewskiej i Żelaznej korony Hanny Malewskiej ${ }^{451}$, nowym wydaniu wiedeńskim Teorii snów Freuda ${ }^{452}$. W Kronice kulturalnej zapowiedziano natomiast serię książkową beletryzowanych życiorysów postaci historycznych przygotowanych w Państwowym Instytucie Wydawniczym ${ }^{453}$, jubileuszowe wydanie dzieł Mickiewicza w języku litewskim ${ }^{454}$ oraz narodowe wydanie dzieł poety w 150 rocznicę urodzin ${ }^{455}$. Niekiedy powiadamiano o poszczególnych tytułach książkowych, jak np. o ostatniej opowieści powojennej Aleksandra Janty-Połczyńskiego Kłamałem aby żyćt56. Sporadycznie w Życiu katolickim informowano o nowościach, np. o wspomnianym przekładzie Szaleńców Bożych Zofii Kossak drukowanych w odcinku na łamach „Katolickich Novin”457 czy wydanych przemówieniach i orędziach papieża Piusa XII ${ }^{458}$.

We wszystkich rubrykach prezentowano nowości, które znane były z recenzji i reklam na łamach katolickich czasopism społeczno-kulturalnych. W wyborze nie zapominano o najmłodszych czytelnikach i młodzieży. Promowane książki były zgodne z profilem pism i w większości tytułów uwzględniono książki katolickie. Nie zabrakło także powieści, opowiadań i dramatów.

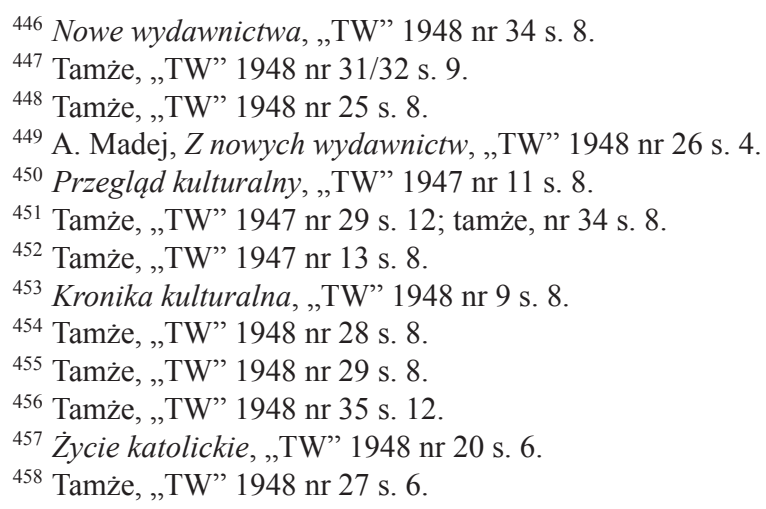




\subsection{Książki w przeglądach piśmiennictwa}

Promocja nowości książkowych występowała na łamach katolickich pism społeczno-kulturalnych również w tematycznie sporządzonych przeglądach piśmiennictwa. Największą rolę w porównaniu z pozostałymi prasowymi tytułami odegrały one w „Przeglądzie Powszechnym”, gdzie zajęły stosunkowo najwięcej miejsca. Taka forma upowszechniania nowości obecna była również w zawartości „Tygodnika Powszechnego” i „Tygodnika Warszawskiego”. Sporadycznie natomiast występowała w pozostałych czasopismach: „Głosie Katolickim”, „Tygodniku Katolickim” i „Znaku”.

W specjalnym dziale miesięcznika jezuitów zatytułowanym Przegląd piśmiennictwa przedstawiano od kilku do kilkunastu pozycji dobranych według podobieństwa problematyki. Zwięzłych komentarzy na temat poszczególnych książek dostarczali publicyści znani czytelnikom z recenzji książkowych. Rozpoczęto od krótkiego zaprezentowania pięciu historycznych opracowań ks. Alfonsa Schletza dotyczących dziejów Kościoła na ziemiach polskich ${ }^{459}$, po czym dokonano przeglądu polskich dzieł filozoficznych wydanych w latach 1946-1947 - m.in. autorstwa Franciszka Sawickiego, Romana Ingardena, Władysława Tatarkiewicza ${ }^{460}$ - i studiów dotyczących historii Słowian ${ }^{461}$. Wśród przejrzanych przez Marię Chojecką nowości biograficznych znalazły się życiorysy Fryderyka Chopina, Tadeusza Kościuszki i Roberta Owena ${ }^{462}$. Powojenny dorobek dzieł teologicznych prześledził w dwóch zeszytach ks. Antoni Pawłowski. Omówił m.in. następujące książki: Katolicka etykę wychowawcza o. Jacka Woronieckiego, Bóg - świat - człowiek biskupa Jana Stepy, Syn Człowieczy ks. Jana Rosiaka, Życie pozagrobowe ks. Aleksandra Żychlińskiego ${ }^{463}$. Odbiorców „Przeglądu Powszechnego" zapoznano także z pozycjami książkowymi z zakresu polskiej historiografii po ostatniej wojnie ${ }^{464} \mathrm{i}$ badaniami naukowymi nad dziejami Komisji Edukacji Narodowej prowadzonymi w latach 1939-1949465. Zainteresowanym literaturą dla dzieci i młodzieży ${ }^{466}$ oraz wydawnictwami pedagogicznymi ${ }^{467}$

459 J. Poplatek, Przegląd piśmiennictwa. Książki, „PP” 1948 nr 2 s. 137-138.

${ }^{460}$ A. Kisiel, Przeglad wydawnictw filozoficznych w Polsce, „PP” 1948 nr 6 s. 452-457.

${ }^{461}$ K. Tymieniecki, Historia: Studia stowiańskie 1945-1948, „PP” $1948 \mathrm{nr} 8$ s. 177-184.

${ }^{462}$ M. Chojecka, Przegląd nowości biograficznych, „PP” 1949 nr 1 s. 59-61.

${ }^{463}$ A. Pawłowski, Powojenny dorobek polskiej myśli teologicznej, „PP” 1948 nr 9 s. 256-262; tamże, nr 10 s. 339-345.

${ }^{464}$ W. Konopczyński, Przegląd piśmiennictwa, „PP” 1950 nr 3 s. 210-216; K.T., Przegląd piśmiennictwa, tamże, $\mathrm{nr} 7$ s. 121-129.

${ }^{465}$ J. Poplatek, Przeglad piśmiennictwa, „PP” $1951 \mathrm{nr} 7$ s. 108-114.

466 Z. Lichniak, Przegląd piśmiennictwa, „PP” 1949 nr 1 s. 55-59; X.J.R. [J. Rostworowski], Przeglad piśmiennictwa, tamże, nr 10 s. 249.

${ }^{467}$ K.J., Przeglad wydawnictw pedagogicznych, „PP” 1949 nr 7 s. 106-111; J.K., Przegląd wydawnictw pedagogicznych, „PP” $1950 \mathrm{nr} 1 \mathrm{~s} .65-67$. 
i psychologicznymi ${ }^{468}$ również udostępniono wiedzę o najnowszych książkach. Publikacje o Cyprianie Norwidzie ${ }^{469}$, Juliuszu Słowackim ${ }^{470}$ oraz przegląd powieści i opowiadańn ${ }^{471}$ świadczyły o polskiej literaturze powojennej. Zygmunt Lichniak przedstawił rodzimą poezję chłopską wydaną w latach 1947-1949472, natomiast Olgierd Porycki omówił twórczość dziesięciu polskich poetów katolickich (m.in. Mikołaja Bieszczadowskiego, Tadeusza Chrzanowskiego, Wacława Olszewskiego, Anny Pogonowskiej i innych) ${ }^{473}$.

Redakcja „Tygodnika Powszechnego” w przeglądach piśmiennictwa przeważnie propagowała aktualnie dostępną literaturę dla dzieci i młodzieży, która w powojennym dorobku wydawców odegrała ważną rolę, stanowiąc około $45 \%$ ogólnie wydanej literatury pięknej ${ }^{474}$. Na staranną szatę graficzną, „myśl moralną" i wartości pedagogiczne książek dla najmłodszych zwróciła uwagę Zofia Starowieyska-Morstinowa. Wśród wydań wyróżniła „książki nowe, świeżo pisane i reedycje książek dawniejszych" ${ }^{\prime 475}$. Z reedycji za godne polecenia uznała Dzieci ojczyzny i Marcina Kozerę Marii Dąbrowskiej, Pojednanie Heleny Zakrzewskiej, Serce Edmunda de Amicisa. Z nowości zaś zaproponowała Wigilię Wojtusia Karola Homolacsa i Dla braciszka Aleksandry Bigay-Mianowskiej. W innej wypowiedzi zauważyła, że w ożywionym ruchu wydawniczym stosunkowo małą liczbę stanowiły nowe tytuły dla najmłodszych, przeważały natomiast wznowienia. Przy przeglądzie reedycji brakowało również nowości dla młodzieży. Znana publicystka poleciła m.in. książki Kornela Makuszyńskiego opublikowane przez oficynę Gebethnera i Wolffa, Hugh Loftinga wydane w Książce, jak też pozycje różnych wydawców i serii dla młodzieży (Czytelnika; Trzaski, Everta i Michalskiego; Państwowych Zakładów Wydawnictw Szkolnych) ${ }^{476}$. „Katolickiemu społeczeństwu” zaproponowała także powojenne wydania pozycji Ewy Szelburg-Zarembiny Niedziela, A..., a ..., a ..., kotki dwa, Nasi braciszkowie oraz Boża ścieżkę królowej Kingi Janiny Porazińskiej ${ }^{47}$. Doceniła także ostatnio wydane książeczki dla dzieci Witolda Zechentera ${ }^{478}$. W ubogiej ofercie literatury religijnej dla młodzieży jako cenne Starowieyska-Morstinowa wymieniła starannie wydane opowiadania Stugi Boże Pii Górskiej (Verbum), wiersze dla dzieci Jawor, jawor Hanny Januszewskiej (Czytelnik) i Raj na ziemi Mariana

\footnotetext{
468 J.K., Przeglad piśmiennictwa, „PP” 1950 nr 5 s. 356-360.

${ }^{469}$ M. Krupiński, Przegląd piśmiennictwa, „PP” 1950 nr 9 s. 273-275.

${ }^{470}$ K. Krobicki, Przeglad piśmiennictwa, „PP” 1950 nr 10 s. 341-349.

${ }^{471}$ W. Rola, Przegląd piśmiennictwa, „PP” 1951 nr 7 s. 121-130.

472 Z. Lichniak, Poezja chłopska, „PP” 1949 nr 8 s. 176-191.

473 O. Porycki, Przegląd piśmiennictwa, „PP” 1952 nr 1 s. 52-65.

${ }^{474}$ M. Michałowska, Literatura religijna dla dzieci i młodzieży, „TP” 1949 nr 6 s. 11.

475 Z. Starowieyska-Morstinowa, Dla młodzieży i dzieci, ,TP” 1946 nr 44 s. 7.

476 Taż, Przedwojenne i powojenne, „TP” 1947 nr 6 s. 9.

477 zsm [Z. Starowieyska-Morstinowa], Książki dla dzieci, ,TP” 1948 nr 17 s. 5.

478 Taż, Książki dla dzieci, „TP” 1948 nr 31 s. 7.
} 
Piechala ${ }^{479}$. Monika Michałowska do spisu wartościowych katolickich książek młodzieżowych dodała Płomienne serca Szczepana Jeleńskiego (Albertinum Księgarnia św. Wojciecha) i Rycerza Chrystusowego Marii Czeskiej-Mączyńskiej (w serii Jasnych Książek). Słabszą pozycją ze względu na brak opisu czasów historycznych i cnót św. Joanny d'Arc była książka Haliny Zawiszanki Przedziwny wódz (Jasne Książki) ${ }^{480}$.

Fabułę i wygląd zewnętrzny 11 nowości z lat 1945-1946 dla tej samej grupy czytelniczej opisał Antoni Gołubiew, promując m.in. Pana Dropsa i jego trupę Jana Brzechwy, Wesota gromadę Janiny Porazińskiej oraz wznowione przez Księgarnię Eugeniusza Kuthana trzy powieści Jacka Londona Przygoda, Zew krwi i Syn słońca ${ }^{481}$. Kilkadziesiąt wydawnictw dla dzieci i młodzieży w ramach piętnastronicowej biblioteczki Czytelnika i szesnastostronicowej biblioteczki M. Arcta pt. Moje Książeczki oraz Biblioteki Młodego Czytelnika przedstawił Karol Jan Wayda. Za „najpoważniejszą ówczesną pozycję literatury dla dzieci” uznał dobrze zilustrowane przez Jerzego Karolaka nowe wydanie Bajek Andersena firmy M. Kota w Krakowie. Stanisław Bobiński dostarczył natomiast „doskonałe i dowcipne" rysunki do wydanej przez M. Arcta Wojtusiowej izby Janiny Porazińskiej ${ }^{482}$. Omówił również powieści, opowiadania, bajki i wiersze dla dzieci ${ }^{483}$. Janina Radwan napisała m.in. o zaletach baśni ludowej Za siódma górą, za siódma rzeka Marii Kędziorzyny (Spółdzielni Wydawniczej Książka), Liczyrzepa, duch gór Zofii Petersowej (Wiedza), powieści Borówka Janiny Porazińskiej i Tęcza nad Wagiem Lucyny Sieciechowiczowej ${ }^{484}$. Oprócz polecanych już książek w innych przeglądach zaproponowała napisaną ,z humorem odpowiednim dla małego dziecka" Maciuś Skowronek Janiny Porazińskiej (Nasza Księgarnia), Staszek kupuje nowe buty Stefanii Szuchowej (Wydawnictwo Światowid), czy Historia o czterech pstroczkach Ireny Jurgielewiczowej (Wiedza) ${ }^{485}$. W kilku kolejnych numerach „Tygodnika Powszechnego” Radwan wraz z A. Reiterową i A. Wirską opracowały spisy wartościowych książek dla dzieci i młodzieży z krótkimi adnotacjami treściowymi. Przeważały w nich tytuły autorów polskich - Konopnickiej, Januszewskiej, Tuwima, Szelburg-Zarembiny; z obcych zaś Curwooda, Kiplinga, Londona. Wśród wydawców znaleźli się Stanisław Arct, Gebethner, Czytelnik, Wiedza, Nasza Księgarnia, Światowid, Albertinum Księgarnia św. Wojciecha ${ }^{486}$.

${ }^{479}$ Taż, Książki dla dzieci, „TP” 1948 nr 19 s. 6.

${ }^{480}$ M. Michałowska, Literatura religijna dla dzieci...

${ }^{481}$ A. Goł. [A. Gołubiew], Nowe ksiażki dla dzieci i młodzieży, „TP” 1946 nr 30 s. 7.

${ }^{482}$ K.J. Wayda, Wydawnictwa dla dzieci i młodzieży, „TP” 1946 nr 48 s. 9.

${ }^{483}$ Tenże, Torba świętego Mikołaja, „TP” 1947 nr 50 s. 3-4.

${ }^{484}$ J. Radwan, Książki dla dzieci i młodzieży, „TP” 1948 nr 38 s. 6.

${ }^{485}$ Tenże, Książki dla młodszych dzieci, „TP” 1948 nr 50 s. 9.

${ }^{486}$ J. Radwan, A. Reiterowa, A. Wirska, Dobór książek dla dzieci i młodzieży, „TP” 1949 $\mathrm{nr} 15 / 16$ s. 16; ciż, Książki dla dzieci i młodzieży, tamże, nr 17 s. 9; tamże, nr 18 s. 9; tamże, nr 50/51 s. 14-15. 
Szczególną uwagę w przeglądach „Tygodnika Powszechnego” zwrócono też na książkę katolicką. Jerzy Ciechocki dokonał oceny wydawnictw Katolickiego Uniwersytetu Lubelskiego, polecając m.in. Pierwiastek religijny $i$ narodowy $w$ psalmach ks. Adolfa Tymczaka, Prymat wartości moralnych ks. Zdzisława Golińskiego, Biblijne ujęcie stworzenia świata wobec nauki ks. Stanisława Stysia ${ }^{487}$. Pod nagłówkiem $Z$ literatury katolickiej ks. Jan Piwowarczyk zaproponował m.in. broszurę Bohaterka mitości św. Ludwika de Marillac Piusa XII, Królewskie kapłaństwo o. Jacka Woronieckiego, Osobowość chrześcijańska ks. Franciszka Sawickiego ${ }^{488}$. Przejrzano także nowości rodzime i słowackie w tym zakresie $^{489}$. Z nową literaturą katolicką i książkami o kardynale Newmanie wydanymi w Niemczech zapoznał odbiorców Aleksander Rogalski ${ }^{490}$.

Rzadziej uwzględniano $\mathrm{w}$ powyższych przeglądach powieści i poezje. Twórczość prozaiczną Grahama Greene’a przedstawił pozytywnie Jan Dobraczyński ${ }^{41}$, natomiast wybrane polskie powieści wydane w 1947 r. Karol Jan Wayda $^{492}$. Przeglady piśmiennictwa zawarte w „Tygodniku Powszechnym” dotyczyły również dzieł nt. dyplomacji, prac Christophera Dawsona i literatury podróżniczej ${ }^{493}$.

Redakcja „Tygodnika Warszawskiego” w kilku przeglądach zaoferowała pożyteczne pozycje dla dzieci i młodzieży. Zuzanna Rabska zaczęła od wydawnictw gwiazdkowych M. Arcta, Czytelnika, Trzaski, Everta i Michalskiego oraz St. Kamińskiego ${ }^{494}$. W kolejnych przeglądach promowano książeczki dla dzieci Księgarni Zdzisława Gustowskiego oraz rodzime i zagraniczne pozycje dla młodzieży Wydawnictwa Apostolstwa Modlitwy ${ }^{495}$. Jednorazowo pod nagłówkiem Przeglad wydawnictw zamieszczono pozycje Spółdzielni Wydawniczej Książka przeznaczone zarówno dla dzieci i młodzieży, jak też dla dorosłego czytelnika ${ }^{496}$. Michał Poradowski udowodnił zainteresowanie Francuzów sprawami Polski poprzez przegląd licznych publikacji powojennych. Wśród nich znalazły

487 J. Ciechocki, Wydawnictwa K.U.L., „TP” 1947 nr 24 s. 9.

488 J.P. [J. Piwowarczyk], Z literatury katolickiej, „TP” 1947 nr 38 s. 11; tenże, Z literatury katolickiej, „TP” $1948 \mathrm{nr} 4$ s. 11.

${ }^{489}$ Tenże, Slavia catholica, „TP” 1948 nr 10 s. 11; tenże, Książki religijne, „TP” 1949 nr 17 s. 10; N.K., Z literatury religijnej, tamże, nr 38 s. 9.

${ }^{490}$ A. Rogalski, Nowa literatura katolicka w Niemczech, „TP” $1950 \mathrm{nr} 12$ s. 2; tenże, Newman $w$ dzisiejszych Niemczech, tamże, nr 24 s. 9.

${ }^{491}$ J. Dobraczyński, Koniec sprawy czy jej początek?, „TP” 1952 nr 6 s. 1-3.

${ }^{492}$ K.J. Wayda, Na szlaku bojów i ... awantury, „TP” $1947 \mathrm{nr} 4$ s. 9.

${ }^{493}$ K. Szwarcenberg-Czerny, O dyplomacji $i$ dyplomatach, „TP” 1947 nr 30 s. 5-6; P. Mroczkowski, Christopher Dawson o Europie, tamże, nr 38 s. 3-4; JWW, O polskich podróżnikach, „TP” 1952 nr 19 s. 3.

${ }^{494}$ Z. Rabska, Wydawnictwa gwiazdkowe, „TW” 1946 nr 50 s. 6.

${ }^{495}$ I.P., Jeszcze ksiażeczki dla dzieci, „TW” 1947 nr 1 s. 5; A. Madej, Książi dla młodzieży, tamże, $\mathrm{nr} 50$ s. 10.

${ }^{496}$ Przegląd wydawnictw, „TW” 1948 nr 35 s. 12. 
się powieści, pamiętniki i wydawnictwa naukowe ${ }^{497}$. Halina Kamieniecka zorientowała natomiast odbiorców w ówczesnych rodzimych wznowieniach z zakresu literatury pięknej (powieściach, nowelach, opowiadaniach i dramatach) ${ }^{498}$.

Współredagujący „Głos Katolicki” i „Znak” w okresie wydawania pism zdecydowali się tylko na dwa przeglądy piśmiennictwa. Redakcja na łamach pierwszego z nich poinformowała o nowościach z 1946 r. głównie wydawnictw katolickich, a Jan Ujda przedstawił dorobek „ojca historiografii angielskiej” św. Bedy Czcigodnego ${ }^{499}$. W drugim dokonano przeglądu nowych książek angielskich i francuskich ${ }^{500}$. Na łamach „Tygodnika Katolickiego” Zbigniew Zaborski powiadomił o zagranicznych książkach znanych i mniej głośnych pisarzy katolickich ${ }^{501}$.

Przeglądy piśmiennictwa w znacznej mierze wzbogaciły wybór lektury, dodając nowe tytuły tego samego autora lub różne pozycje mieszczące się $\mathrm{w}$ jednym dziale tematycznym. W dwóch najważniejszych katolickich czasopismach ogólnopolskich: ,Tygodniku Powszechnym” i „Tygodniku Warszawskim” zauważono przede wszystkim literaturę dla dzieci i młodzieży.

\subsection{Książki nadesłane do redakcji}

Występująca prawie w każdym numerze „Tygodnika Powszechnego” kolumna Ksią̇ki nadestane do redakcji początkowo zawierała zestawienia książek o różnej tematyce i przeznaczeniu; na liście znajdowało się od kilku do kilkudziesięciu pozycji w jednym numerze. Oprócz nazwiska autora i tytułu książki podawano nazwę wydawnictwa, miejsce i rok wydania, objętość i cenę. Zaznaczano także obecność ilustracji i nazwę serii książkowej, z czasem też (od 1949 r.) nazwisko projektanta okładki, autora wstępu i tłumacza. Niekiedy tytuły książkowe powtarzały się $\mathrm{w}$ rubryce kolejnego numeru. W spisach - obok tomików poezji - występowały wspomnienia z obozów koncentracyjnych podręczniki szkolne, słowniki i dzieła naukowe ${ }^{502}$. Poezję reprezentowały tomy wierszy poszczególnych autorów, jak też antologie ${ }^{503}$. W szerokim zakresie upowszechniano książki katolickie: katechizmy, encykliki, hagiografie, modlitewniki, pomoce duszpasterskie, konferencje, podręczniki do nauki religii, przemówienia papieskie,

${ }^{497}$ M. Poradowski, Polska w książce francuskiej, „TW” 1947 nr 41 s. 4-5.

${ }^{498}$ H.K. [H. Kamieniecka], Wznowienia, „TW” 1947 nr 13 s. 7.

${ }^{499}$ Nowe wydawnictwa, „GK” $1946 \mathrm{nr} 51$ s. 411; J. Ujda, Św. Beda Czcigodny-ojciec historiografii angielskiej, „GK” 1948 nr 26 s. 229.

${ }^{500}$ H.M. [H. Malewska], „Przė̇ywamy rewolucję...”, „Znak” 1946 nr 2 s. 231-237; taż, Wśród nowych ksiażek francuskich, tamże s. 239-246.

${ }^{501}$ Z. Zaborski, Kultura katolicka w krajach protestanckich, „TK” 1948 nr 25 s. 173.

${ }^{502}$ Książki nadesłane do redakcji, „TP” $1945 \mathrm{nr} 20$ s. 8; tamże, nr 21 s. 8.

${ }^{503}$ Tamże, „TP” 1945 nr 23 s. 8. 
dzieła teologiczne i mistyczne. Zainteresowani mogli odnaleźć również biografie (Tadeusza Kościuszki ${ }^{504}$, Stanisława Estreichera ${ }^{505}$, Joachima Lelewela ${ }^{506}$, króla Jana III Sobieskiego ${ }^{507}$, Hugo Kołłątaja ${ }^{508}$ ). W bogatej literaturze powojennej polecano poradniki, różnego rodzaju podręczniki (np. fotografii, teorii literatury), reportaże, instrukcje, informatory, broszury, albumy, humoreski, fraszki i anegdoty. Zdarzały się też publikacje $\mathrm{w}$ językach obcych, jak np. dokumenty wydane przez Instytut Zachodni w języku niemieckim ${ }^{509}$ czy książka Romaina Rollanda w serii Biblioteczki Francuskiej ${ }^{510}$. Z literatury pięknej proponowano powieści, opowiadania, nowele i dramaty. Znalazły się wśród nich utwory dobrze znane polskiemu czytelnikowi, m.in. Stara baśń Józefa Ignacego Kraszewskiego ${ }^{511}$, Grażyna Adama Mickiewicza ${ }^{512}$, jak też nowe - np. Krata Poli Gojawiczyńskiej ${ }^{513}$. Spośród opowiadań przypomniano m.in. Doktora Piotra i Sitaczkę Stefana Żeromskiego ${ }^{514}$. Nie zapomniano o pozycjach dla dzieci i młodzieży, wymieniając m.in. Rybaka $i$ sosnę Ewy Szelburg-Zarembiny ${ }^{515}$, Serce Edmunda de Amicisa ${ }^{516}$, Bajki Hansa Christiana Andersena ${ }^{517}$, Syna stońca Jacka Londona ${ }^{518}$.

W latach 1947-1953 redakcja „Tygodnika Powszechnego” przedstawiała poszczególne tytuły w sposób uporządkowany, zamieszczając je w działach: powieść i nowela, poezje, literatura religijna, historia i podróże, prawo, polityka, ekonomia, zagadnienia gospodarcze, reportaże i dokumenty, nauka, broszury aktualne, książki dla dzieci i młodzieży, podręczniki i wydawnictwa szkolne, varia, historia, pamiętniki, biografia, przyroda, medycyna, geografia, teoria literatury, krytyka literacka, językoznawstwo, publicystyka, zagadnienia kulturalne, teksty klasyków, sztuka, teatr, film, filozofia i psychologia, fizyka i matematyka. Przeważały wśród nich pod względem liczbowym powieści i nowele, poezja oraz literatura religijna. Proza literacka występowała na początku lub na końcu prawie każdego zestawienia. Dość bogate były propozycje lekturowe dla dzieci i młodzieży, które mogły nieraz wyłącznie wypełniać kolumnę Książek nadesła-

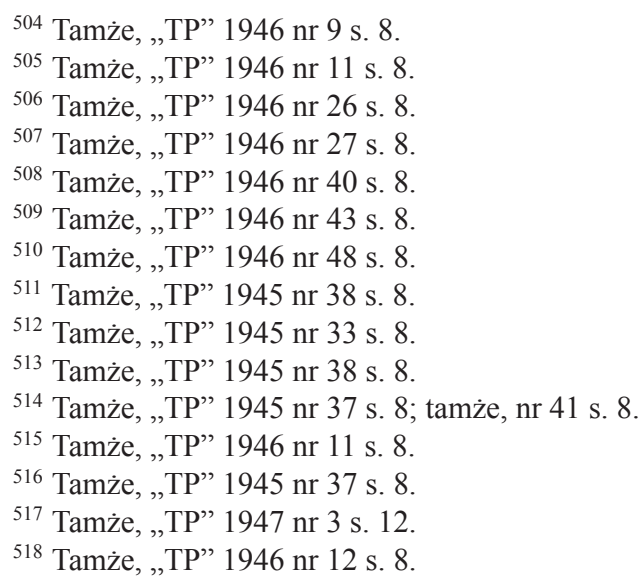


nych do redakcji danego zeszytu ${ }^{519}$. Starano się także dobierać $\mathrm{w}$ jednym numerze literaturę należącą do tego samego rodzaju. Rzadziej przedstawiano pozycje bibliograficzne pod nagłówkiem Broszury aktualne.

Zestawienia tytułów książkowych w krakowskim periodyku w omawianym okresie 1947-1953 stały się bardziej obszerne i zawierały w każdym numerze kilkadziesiąt pozycji. Wymieniane książki ukazywały się nakładem wielu wydawnictw prywatnych, zakonnych, spółdzielczych i państwowych. W pierwszych latach powojennych trudno stwierdzić, książki jakich wydawnictw były najczęściej polecane czytelnikom. Najbardziej znane oficyny charakteryzował różnorodny profil wydawniczy. W latach 1948-1952 można natomiast zauważyć przewagę druków spółdzielni Wydawniczych Książki, Wiedzy (od 1949 r. występujące pod wspólną nazwą Książka i Wiedza), Czytelnika oraz Wydawnictwa Prasa Wojskowa. W latach 1950-1951 wyróżniały się pod tym względem publikacje Państwowego Instytutu Wydawniczego oraz Zakładu Narodowego im. Ossolińskich.

Rubryka zatytułowana Ksiażki nadesłane prowadzona na łamach „Tygodnika Warszawskiego" w latach 1946-1948 nie była tak bogata w tytuły wydawnicze, jak analogiczna w „Tygodniku Powszechnym”. Przedstawiała bowiem zazwyczaj do 10 pozycji, sporadycznie zaś wykazywano kilkadziesiąt druków, wytłuszczając imię i nazwisko autora oraz tytuł. Zamieszczana była nieregularnie, czasami $\mathrm{w}$ co drugim lub trzecim numerze pisma, niekiedy rzadziej; zawierała przeważnie podstawowe dane bibliograficzne, podobnie jak w „Tygodniku Powszechnym” ${ }^{20}$. Zdarzało się, że w rubryce przedstawiano jedną pozycję bibliograficzną wraz $\mathrm{z}$ adnotacją nt. treści i oceną dzieła. Tak było w przypadku podręcznika historii zatytułowanego Polska Piastów, Polska Jagiellonów Marii i Zygmunta Wojciechowskich, októrymkrótkąnotkęnapisała IrenaPannenkowa ${ }^{521}$.Propozycje książkowe były dowolnie dobrane pod względem tematycznym i gatunkowym. Większość nowości wydawniczych powtarzała się z tytułami znanymi odbiorcom krakowskiego tygodnika ${ }^{522}$. W jednym zestawieniu figurowały zatem wykłady uniwersyteckie z powieściami, rozmyślania dla sióstr wraz z przykładowym drukiem Wojewódzkiej Żydowskiej Komisji Historycznej dotyczącym zagłady getta w Krakowie ${ }^{523}$. Spisy „Tygodnika Warszawskiego” uwzględniały często

${ }^{519}$ Np. Książki nadesłane do redakcji, „TP” 1948 nr 1 s. 12.

${ }^{520}$ Informowano o seriach, np. Biblioteczce Eucharystycznej Wydawnictwa Apostolstwa Modlitwy, Książki nadesłane, „TW” 1947 nr 12 s. 10; Ziemiach Odzyskanych Państwowego Zakładu Wydawnictw Szkolnych, Książki nadesłane, tamże, nr 13 s. 4; Biblioteczce Zagadnień Społecznych Wydawnictwa „Kultura Katolicka”, Książi nadesłane, tamże, nr 26 s. 5.

${ }^{521}$ Książki nadestane, „TW” $1946 \mathrm{nr} 45$ s. 4.

${ }^{522}$ Np. Książki nadestane, Poemat pedagogiczny Antoniego Makarenki „TW” 1947 nr 47 s. 4; Książi nadesłane, Stanisław Leszczyński Józefa Feldmana „TW” 1948 nr 19 s. 12.

${ }^{523}$ Książki nadesłane, „TW” 1946 nr 13 s. 6; tamże, nr 27 s. 8. 
książki anglojęzyczne, jak np. wiersze żołnierzy Poems from Italy ${ }^{524}$, Prefaces to Shakespeare Fourth Series Harleya Granville-Barkera ${ }^{525}$, British Justice Maurice Amosa $^{526}$. Większość z nich wydana została w Londynie. Zapoznawano czytelników także z różnego rodzaju przekładami polskimi. Redakcja informowała najczęściej o nowościach Czytelnika i Spółdzielni Wydawniczej Książka. Promowano równocześnie publikacje oficyn, których nazwy nie pojawiały się w innych pismach katolickich, przykładem może być Międzynarodowe Wydawnictwo Guild $^{527}$. W zestawieniach nie zabrakło, podobnie jak na łamach „Tygodnika Powszechnego", powieści polskich i zagranicznych, nowel, opowiadań, tomików poezji i dramatów. Czytelnicy mogli także poznać tytuły książek historycznych, katolickich, biografii, wspomnień, literatury dla dzieci i młodzieży, kodeksów karnych, pozycji o tematyce społecznej i psychologicznej. Trudno w Ksiażkach nadestanych dostrzec próbę uporządkowania omawianych lektur według jakiegoś klucza. Jedynie w kilku wydaniach „Tygodnika Warszawskiego” z 1948 r. (numery 6-11) wydrukowano propozycje książek w układzie z podziałem na wydawnictwa: Awir, Książnica Atlas, Wielkopolska Księgarnia Wydawnicza, Spółdzielnia Wydawnicza Książka, Spółdzielnia Wydawnicza Wiedza, Gebethner i Wolff, Wydawnictwo Księży Jezuitów, Wydawnictwo Władysława Bąka, Wydawnictwo Zachodnie, Wydawnictwo Katolickiego Uniwersytetu Lubelskiego, Wydawnictwo Apostolstwa Modlitwy.

Redakcja „Przeglądu Powszechnego” pod nagłówkiem Oprócz tego nadestano do redakcji w latach 1948-1952 publikowała prawie w każdym zeszycie dane bibliograficzne kilkudziesięciu książek z podziałem na wydawców. W większości były to oficyny o profilu katolickim, takie jak: Wydawnictwo Apostolstwa Modlitwy ${ }^{528}$, Wydawnictwo Mariackie ${ }^{529}$, Księgarnia św. Jacka ${ }^{530}$, Księgarnia św. Wojciecha ${ }^{531}$, Pallottinum ${ }^{532}$, Centrala Milicji Niepokalanej ${ }^{533}$, Wydawnictwo OO. Karmelitów Bosych ${ }^{534}$ i Wydawnictwo św. Krzyża ${ }^{535}$. Wzięto pod uwagę także publikacje Apostolstwa Chorych ${ }^{536}$. Repertuar wydawniczy uwzględniał zatem głównie książkę katolicką. Tu znalazły się edycje Nowego Testamentu, hagiografie, biografie ludzi Kościoła, dzieła teologiczne i filozoficzne, rozważania

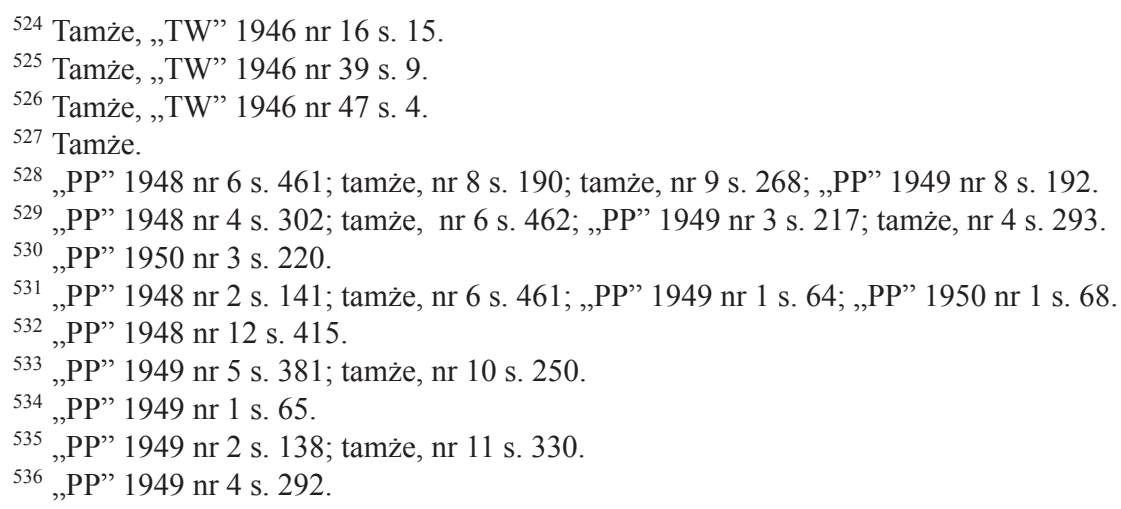


religijne, książki do nabożeństwa. Odbiorcy mogli także znaleźć prozę powieściową (Bez oręża Zofii Kossak, Byli dwaj bracia Gustawa Morcinka, Pieśń o Bernadecie Franciszka Werfla), powieści dla młodzieży (Córka Zastępu Jaskółek Lucyny Sieciechowiczowej, Kamiennym toporem Bronisławy Steinowej), dramaty (Agnes ks. Piotra Turbaka, Bohaterka chrześcijańska ks. Józefa Gadowskiego), rzadziej tomiki poezji. Spisy zawierały też dane o drukach Książnicy Atlas, Wydawnictwa Zachodniego $^{537}$, sporadycznie Czytelnika ${ }^{538}$ czy IW PAX ${ }^{539}$. Obecna była oferta wydawnicza towarzystw naukowych: najczęściej Towarzystwa Naukowego KUL ${ }^{540}$, Towarzystwa Naukowego Warszawskiego ${ }^{541}$, Towarzystwa Miłośników Historii ${ }^{542}$, Poznańskiego Towarzystwo Przyjaciół Nauk ${ }^{543}$. Towarzyszyły jej także druki wydawnictw uniwersyteckich, takich jak Uniwersytetu Marii Curie-Skłodowskiej, będące $\mathrm{w}$ większości specjalistycznymi pracami naukowymi ${ }^{544}$. Zagraniczne publikacje omawiane w „Przeglądzie Powszechnym” wychodziły spod prasy następujących wydawnictw: American Catholic Philosophical Association ${ }^{545}$, Apostolat de la Prière, Éditions Spes ${ }^{546}$, Desclée de Brouwer ${ }^{547}$, Pontificium Institutum Biblicum ${ }^{548}$, Librairie Letouzey et Anés49 $\mathrm{i}$ in.

Książki nadsyłane do redakcji „Znaku” figurowały na jego łamach w alfabetycznym porządku nazwisk autorów lub w podziale tematycznym na religijne (lub Religia, hagiografia, etyka), poezję, dramat, beletrystykę, publicystykę, utwory dla dzieci i młodzieży (ewentualnie tylko dla dzieci) i dzieła naukowe. Do tekstów z zakresu religii należały encykliki, katechizmy, dzieła mistyczne, hagiografie i modlitewniki. Najliczniejszą grupę po drukach katolickich tworzyły książki beletrystyczne rodzimych autorów. Pozycje zawarte w spisach przedstawiały wydawnictwa ogólnie znane odbiorcom pozostałych katolickich pism społecznokulturalnych. Nowością mogły być jedynie książki wydane przez Wojewódzką Żydowską Komisję Historyczną. Spisy nie były obecne w każdym zeszycie i liczyły od kilku do kilkudziesięciu pozycji ${ }^{550}$.

537 „PP” 1948 nr 3 s. 223; tamże, nr 5 s. 376.

538 „PP” 1948 nr 10 s. 345.

539 „PP” 1951 nr 11 s. 433; „PP” 1952 nr 5/6 s. 445.

540 „PP” 1948 nr 2 s. 142; tamże, nr 4 s. 302; tamże, nr 8 s. 190; tamże, nr 9 s. 268; „PP” 1949 nr 2 s. 138; tamże, nr 4 s. 293; tamże, nr 6 s. 436; tamże, nr 8 s. 192; tamże, nr 10 s. 250.

541 „PP” 1948 nr 2 s. 142; tamże, nr 8 s. 190; „PP” 1949 nr 2 s. 138; „PP” 1950 nr 3 s. 220.

542 „PP” 1949 nr 3 s. 217; „PP” 1952 nr 9 s. 182.

543 „PP” 1950 nr 11 s. 430; „PP” 1951 nr 3 s. 231; tamże, nr 9 s. 292; „PP” 1952 nr 9 s. 182.

544 „PP” 1949 nr 1 s. 65; „PP” 1952 nr 1 s. 70.

545 „PP” 1949 nr 10 s. 250.

546 „PP” 1951 nr 7 s. 139-140.

547 „PP” 1952 nr 5/6 s. 445.

548 „PP” 1950 nr 11 s. 430.

549 „PP” 1952 nr 1 s. 70; tamże, nr 5/6 s. 445.

${ }^{550}$ Książki nadestane do redakcji, „Znak” 1946 nr 2 s. 255; tamże, nr 3 s. 365-367; tamże, „Znak” 1947 nr 4 s. 477-480; tamże, nr 5 s. 591-592; tamże, nr 6 s. 687; tamże, nr 7 s. 783 ; tamże, 
W „Głosie Katolickim” zaledwie siedmiokrotnie w całym okresie wydawania periodyku, pod nagłówkami Nadesłane do redakcji, Ksiązki nadesłane, Ksią̇ki przystane do redakcji przedstawiono różne pozycje bibliograficzne: opowiadania, dramaty, reportaże, życiorysy, katechizmy, kazania, poradniki, broszury ${ }^{551}$. Niekiedy dodawano w wykazach krótkie adnotacje treściowe.

Podobnie w „Tygodniku Katolickim” nie zwracano większej uwagi na tego rodzaju zestawienia. Wydrukowano bowiem tylko kilka spisów pod nagłówkiem $D o$ redakcji nadestano, w których figurowała powieść Bolestaw Chrobry Antoniego Gołubiewa $^{552}$, a także Ofiarowanie Polski Niepokalanemu Sercu Marii ${ }^{553}$ i Bóg jest świattością ${ }^{554}$.

Książki nadesłane do redakcji, podobnie jak przeglądy piśmiennictwa, umożliwiały czytelnikom śledzącym je regularnie zapoznanie się z szerszym repertuarem wydawniczym. Na łamach najbardziej znanych tygodników katolickich - „Tygodnika Powszechnego” i „Tygodnika Warszawskiego” - uwzględniono literaturę bardzo różnorodną pod względem tematycznym i gatunkowym, natomiast w zawartości „Przeglądu Powszechnego” i „Znaku” można zauważyć przewagę książki katolickiej. We wszystkich sześciu periodykach dużo miejsca w zestawieniach zajmowała literatura piękna. W tygodnikach krakowskim i warszawskim proponowano bogaty wybór książek dla dzieci i młodzieży. Dominowały książki autorów polskich. Kolumny książek nadesłanych, w których zestawiano dane bibliograficzne, były jedną z ważniejszych form promocji książki w zawartości katolickich czasopism społeczno-kulturalnych. Powyższe zestawienia mogą być dzisiaj cennym źródłem informacji dla bibliologów, historyków kultury i innych badaczy.

\subsection{Zakres tematyczny promowanych książek}

Przeczytana książka stawała się niekiedy dla publicystów katolickich czasopism społeczno-kulturalnych inspiracją do głębszych rozważań na różne tematy. W pierwszych latach powojennych w wypowiedziach prasowych często dokonywano rozrachunku z przeszłością - analizowano przebieg działań wojennych, poniesione straty i skutki wojny. Odnoszono się także, powołując na opublikowane

\footnotetext{
„Znak” 1948 nr 1 s. 95; tamże, nr 3 s. 288; tamże, nr 5 s. 478-479; tamże, nr 6 s. 575; tamże, nr 7 s. 670-671; tamże, „Znak” 1949 nr 1 s. 94-95; tamże, nr 2 s. 190-192; tamże, nr 4 s. 375-376; tamże, nr 5 s. 447-448; tamże, nr 6 s. 519; tamże, „Znak” 1950 nr 1 s. 86-87; tamże, nr 3 s. 264; tamże, ,Znak” 1951 nr 1 s. 87.

${ }^{551}$ Książki nadesłane do Redakcji, „GK” 1946 nr 7 s. 56; Książki nadesłane, tamże, nr 18 s. 145; tamże, nr 22 s. 177; tamże, nr 40 s. 323; tamże, nr 47 s. 380; Książki przysłane do Redakcji, „GK” 1948 nr 40 s. 344; Książki przystane do Redakcji, nr 45 s. 383.

552 „TK” 1952 nr 42 s. 297.
553 „TK” 1946 nr 28 s. 8.
554 „TK” 1946 nr 25 s. 8.
} 
dotąd pozycje książkowe, do systemów politycznych, zagadnień sprawiedliwości i pokoju światowego. Niekiedy na podstawie lektury podejmowano rozważania na wybrane tematy historyczne. Biografie książkowe różnych osobistości ze świata polityki, kultury i z życia Kościoła zachęcały do ukazywania w artykułach szerszego tła epoki, w której owi bohaterowie żyli. Interesujące były w tym kontekście komentarze nawiązujące do ówczesnych warunków społeczno-kulturowych. Ważną rolę wreszcie odegrały refleksje na temat wiary i Kościoła, do których pobudziła przemyślana i dobrze dobrana lektura książkowa.

Najczęściej tego typu publikacje ogłaszane były w „Tygodniku Powszechnym”. W kręgu zainteresowań obecna była problematyka wojenna. Rozważania na temat źródeł zbrodniczego systemu hitlerowskiego, nawiązującego do filozofii i dzieł Nietzschego, przeprowadził ks. Jan Piwowarczyk na podstawie książki historyka filozofii profesora Gerharda Lehmanna Die deutsche Philosophie der Gegenwart (Berlin 1943). Po dokonaniu oceny etycznej zbrodni niemieckich i ,zburzonych ołtarzy chrześcijaństwa” pisał: ,[...] jest rzeczą charakterystyczną, że już w 1933, w parę miesięcy po dojściu Hitlera do władzy, narodowy socjalizm przystąpił do monumentalnego dzieła zbiorowego wydania wszystkich pism Nietschego w 40 tomach. Prócz tego w r. 1930 wydano je drobnym drukiem w 8 tomach, w tym samym roku zrobiono $\mathrm{z}$ nich $<<$ kieszonkowe wydanie >> w 12 tomach, wreszcie w r. $1933<<$ historyczno-krytyczne>> wydanie dla celów naukowych. Jednym słowem, robiono wszystko, co było można, by Nietzsche <<zbłądził pod strzechy>>"s55. Wiele szczegółów o stosunkach panujących we Francji przed II wojną światową, przebiegu kampanii i kapitulacji Francji przyniosła książka francuskiego korespondenta Filipa Barrèsa Charles de Gaulle (Londyn) ${ }^{556}$. „Życzliwie i ze współczuciem” natomiast o marszałku Francji Filipie Pétainie, skazanym za kolaborację z okupantem niemieckim i uznanym za zdrajcę, pisał Walter Stucki w La Fin du Régime de Vichy (Paryż), co stało się powodem do rozważań Michała Strebejko ${ }^{557}$. Sprawdziły się „prorocze przewidywania" co do II wojny światowej wybitnego pisarza angielskiego H.G. Wellsa w wydanej po dojściu do władzy Hitlera książce Kształt rzeczy przyszłych (1933). $\mathrm{Z}$ tą „osobliwą historią przyszłości” i trafnymi stwierdzeniami autora zapoznał odbiorców Tadeusz Nowak ${ }^{558}$. W wojennej atmosferze pozostawała również „pasjonująca i pouczająca” książka rumuńskiego ministra spraw zagranicznych Grzegorza Gafencu zatytułowana Derniers jours de l'Europe (Paryż 1946), która stała się sposobnością do ukazania „mało pochlebnego świadectwa” o polityce ówczesnej Europy. Paweł Jasienica pisał: „P. Gafencu nigdy nie kłamie. On dokonuje tylko subtelnego wyboru rzeczy, o których należy pisać i tych, które

\footnotetext{
555 J. Piwowarczyk, Naród Nietzschego, „TP” 1945 nr 3 s. 1.

${ }^{556}$ T. Koński, Droga do Vichy, „TP” 1947 nr 5 s. 5-6.

${ }^{557}$ M. Strebejko, Tragizm i kabotyństwo, „TP” $1948 \mathrm{nr} 36 \mathrm{~s} .10$.

${ }^{558}$ T. Nowak, Wells w roli „Proroka”, „TP” 1947 nr 22 s. 4-5.
} 
lepiej przemilczeć. Podziwiam jego pisarskie mistrzostwo!"559. Temat złamania postanowień traktatu wersalskiego, „zbrodni przeciw ludzkości” i międzynarodowego prawa w tym zakresie zagościł w „Tygodniku Powszechnym” przy okazji ukazania się książki Tadeusza Cypriana i Jerzego Sawickiego Prawo norymberskie (Warszawa-Kraków 1948). Tezy i uzasadnienia w niej zawarte zostały dobrze odebrane przez Stanisława Stommę ${ }^{560}$. Ten sam publicysta powrócił do tych zagadnień przy okazji wydania pozycji Ludobójstwo - od pojęcia do konwencji 1933-1948 Jerzego Sawickiego ${ }^{561}$. Stanisław Piotrowski w „ważkiej i pięknie wydanej książce" zatytułowanej Sprawozdanie Juergena Stroopa (Warszawa 1948) zawarł wiele szczegółów o „wielkiej akcji” zburzenia warszawskiego getta w 1943 r., o czym poinformował w swoich dociekaniach na temat tzw. „kwestii żydowskiej” w czasie II wojny światowej Paweł Jasienica ${ }^{562}$. Do przemyślanych i obszernych spostrzeżeń na temat powstania warszawskiego i kampanii wrześniowej pobudziła tego samego publicystę jedna z „,najbardziej wstrząsających" książek Przemarsz przez piekło (Warszawa 1949) Stanisława Podlewskiego ${ }^{563}$.

Inną grupę tematyczną tworzyły wypowiedzi dotyczące różnych zagadnień historycznych. Własnymi opiniami o lekturze zatytułowanej Poglady Nobilitas z okresu Nerona i ich podtoże gospodarczo-społeczne autorstwa Izy BieżuńskiejMałowist podzielił się Stanisław Łośs ${ }^{56}$. Z historią stosunków dyplomatycznych Watykanu z francuskimi władzami na przełomie XIX i XX wieku zapoznała Helena Morawska w związku z książką Quinze ans á Rome avec Camille Barrère (1898-1913) (Paryż 1948). Kolejna z pozycji Huit ans au Vatican 1932-1940 (Paryż 1947) stała się okazją do omówienia późniejszych starań o pokój papieży Piusa XI i Piusa XII ${ }^{565}$. Sytuację ekonomiczną Wielkiej Brytanii oraz prowadzoną przez angielskie rządy politykę zagraniczną po obu wojnach światowych przedstawił Alojzy Dębno na podstawie książek znanego teoretyka ekonomii Johna Maynarda Keynesa ${ }^{566}$. Historię Kościoła pierwszych czterech wieków czytelnicy mogli poznać dzięki streszczeniu dzieła Daniela-Ropsa Kościót pierwszych wieków (1948) ${ }^{567}$. Eugeniusz Romer na podstawie zawartości książki S. Łozy Czy wiesz, kto to jest? (Warszawa 1938) przedstawił szczegółowe dane statystyczne i omówił środowiska zawodowe okresu międzywojennego w Polsce ${ }^{568}$.

${ }^{559}$ P. Jasienica, Agonia pokoju, „TP” 1947 nr 37 s. 5.

${ }^{560}$ S. Stomma, Problem międzynarodowej ochrony czlowieka otwarty, „TP” $1948 \mathrm{nr} 22$ s. $5,8-9$.

561 Tenże, Ludobójstwo, „TP” 1949 nr 23 s. 2.

${ }^{562}$ P. Jasienica, ,, Wielka akcja”, „TP” 1948 nr 37 s. 2.

${ }^{563}$ Tenże, Wrzesień i sierpień, „TP” 1949 nr 19 s. 1-3.

${ }^{564}$ S. Łoś, Zbyteczni, „TP” 1953 nr 4 s. 3-4.

${ }^{565}$ H. Morawska, Wspomnienia rzymskie, „TP” 1949 nr 10 s. 1-2.

566 A. Dębno, Pośmiertne wyznanie błędów, „TP” $1950 \mathrm{nr} 23$ s. 7-8.

${ }^{567}$ Z. Starowieyska-Morstinowa, Cztery wieki historii, „TP” $1951 \mathrm{nr} 6$ s. 1-2.

${ }^{568}$ E. Romer, O inicjatywie różnych warstw narodu polskiego, „TP” $1945 \mathrm{nr} 19$ s. 3. 
Osobne miejsce zajęly w wypowiedziach prasowych „Tygodnika Powszechnego" zagadnienia z zakresu biografistyki. Kazimierz Lepszy we wspomnieniu o śp. Józefie Feldmanie zapoznał czytelników z dorobkiem naukowym profesora historii nowożytnej Uniwersytetu Jagiellońskiego. Podkreślił przede wszystkim znaczenie książki Bismarck a Polska, która jego zdaniem była „,najpiękniejszym przykładem służby obywatelskiej i patriotycznej"569. Zapowiedział również ukazanie się kolejnego opracowania tegoż autora pt. Problem polsko-niemiecki w dziejach. Biografia Mahatmy Gandhiego autorstwa Romaina Rollanda napisana w 1924 r. stała się okazją do przypomnienia osobowości i nauki tego wybitnego przywódcy narodu indyjskiego ${ }^{570}$. „Pełna i rzetelna” monografia profesora Władysława Konopczyńskiego pt. Fryderyk Wielki a Polska (Poznań 1947) przyczyniła się do ukazania sylwetki oraz ,pogardy i nienawiści” króla Prus do Polski ${ }^{571}$. Przy okazji przypomnienia mistyczki Teresy Neumann zaprezentowano wypowiedzi zaczerpnięte z kilku książek teologów zagranicznych i polskich na temat zjawisk mistycznych ${ }^{572}$. Życiorys znanego trapisty amerykańskiego Thomasa Mertona przypomniała Helena Morawska na podstawie wydanej w 1948 r. autobiografii Siedmiopiętrowa góra oraz rozważań zakonnika pt. Wybrałem milcze$n i e^{573}$. Antoni Gołubiew natomiast w żartobliwy sposób skojarzył wypowiedź napotkanego gazdy w Gorcach z wymową autobiografii wielkiego artysty Benvenuta Celliniego. Cytując „niewykształconego, ale głębokiego i mądrego” górala, który męczył się, kosząc stratowany przez kogoś w złości owies, pisał: „To nie głupio zostało zrobione, to z rozumem zrobił ten człowiek. On wiedział, jak splątać, żeby kosić było trudno, mądrze zrobił. A to jest panie, wielki grzech, bo to jest nadużycie rozumu. [...] najgorsze jest to, że rozum służy złości"'574. Powracając do czytania książki, w której talent pisarski wydawał się być najważniejszy i rozgrzeszał autora z wszelkich awantur, pojedynków, zwad i wszelkich przemyślnych szkód czynionych ze złośliwości, publicysta zauważył podobieństwo w opisywanych historiach ze stwierdzeniem gazdy.

Ważne miejsce ze względu na katolicki profil tygodnika miały opinie o wierze i światopoglądzie. Analizując ,poważną książkę” Jana Kotta Mitologia i realizm stała publicystka „Tygodnika Powszechnego” Hanna Malewska pisała: „Nie podejmujemy na tym miejscu recenzji, lecz skonfrontowanie pewnych stanowisk" "575. Porównując wymowę książki z wydaną przed wojną pracą Jacquesa Maritaina L'Humanisme intégral stwierdziła w niej „nielojalność myślową” i pominięcie przez autora „współczesnych rozwiązań chrześcijańskich”. Do dywagacji

\footnotetext{
${ }^{569}$ K. Lepszy, Ś.p. Józef Feldman, „TP” 1946 nr 26 s. 5.

570 S. Stomma, Świadectwo Mahatmy, „TP” 1948 nr 8 s. 1.

${ }^{571}$ W. Brablecowa, Tygrys a Polska, ,TP” 1948 nr 24 s. 8.

572 J. Piwowarczyk, Stygmatyczka z Konnersreuth, ,TP” 1951 nr 20 s. 2.

${ }^{573}$ H. Morawska, Wybrane milczenie, „TP” 1951 nr 15 s. 3-4.

574 Goa [A. Gołubiew], Nadużycie rozumu, ,TP” 1948 nr 45 s. 9.

575 H. Malewska, Dwa widnokręgi, ,TP” 1946 nr 29 s. 3.
} 
na temat wyższości światopoglądu moralno-religijnego nad materialistycznym oraz do przytoczenia cennych opinii zainspirowała publicystę książka angielskiego dziennikarza, będąca wywiadem z prezydentem ówczesnej Czechosłowacji Edwardem Beneszem (Londyn 1946). Z wypowiedzi prasowej nie poznajemy jednak jej tytułu ${ }^{576}$. Refleksje na temat wiary, „myślowej łatwizny” i przyczyn niewiary u młodzieży wzbudziła świeżo wydana książka B.G. Sandhursta Jak pogańska jest Anglia ${ }^{577}$. Sytuację katolicyzmu w Anglii ukazał natomiast Julian Wiśniewski na podstawie wyników ankiety opracowanej w latach 1946-1947 o tematyce religijnej, a przeprowadzonej przez towarzystwo Mass Observation. Wyniki badań poznano dzięki lekturze książki zatytułowanej Ludzie zaskoczeni (Puzzled People $)^{578}$. Do głębszych rozważań o jednostce, jej myśleniu, kontemplacji w modlitwie zainspirowała ks. Andrzeja Bardeckiego przytoczona na początku artykułu książka laureata nagrody Nobla Aleksego Carrela Człowiek istota nieznana (Kraków 1938) ${ }^{579}$. O Bogu, miłości i miłosierdziu na podstawie lektury Les intellectuels devant la Charité du Christ Étienne Henry'ego Gilsona oraz dramatu Les mains sales Jeana Paula Sartre'a snuł rozważania Jerzy Zawieyski ${ }^{580}$. Naukę Kościoła o szatanie czytelnicy poznali z kolei na podstawie wydanej przez teologów karmelitańskich w Paryżu Encyklopedii ${ }^{581}$.

Zagadnienie etyki seksualnej stało się okazją do polecenia kilku pozycji z tego zakresu, a były to Podstawy etyki ptciowej ks. Zygmunta Kozubskiego (Poznań 1947), O czystość młodzieży (Warszawa) oraz Ty i ona (Warszawa 1947) O.H. Schilgena ${ }^{582}$. Wypowiedzi dotyczące relacji rodzinnych i wychowania dzieci znalazły swoje miejsce na łamach pisma dzięki książce jezuity o. Ranweza Problèmes de formation religieuse (b.m 1946) ${ }^{583}$. Kwestie obyczajowe i relacje damsko-męskie omówiono na podstawie porównania dwóch bohaterów książkowych - pana Pickwicka i Sancho Pansy ${ }^{584}$.

Podobnie jak „Tygodnik Powszechny”, również „Głos Katolicki” i „Tygodnik Warszawski” propagowały na swoich łamach czytelnictwo, zamieszczając informacje nt. nowości wydawniczych. Podejmowana problematyka była bardzo różnorodna.

Inspiracją do ukazania czasów, w jakich żył ks. Jan Długosz, stało się jego wiekopomne dzieło Roczniki czyli kroniki sławnego Królestwa Polskiego... w 12 księ-

\footnotetext{
576 L.K., Benesz o swej „,drodze do religii”, „,TP” 1947 nr 18 s. 9.

577 zsm [Z. Starowieyska-Morstinowa], , Czworonodzy chrześcijanie”, ,TP” 1948 nr 29 s. 9.

578 J. Wiśniewski, Katolicyzm w Anglii, ,TP” 1948 nr 46 s. 1-2.

579 A. Bardecki, Październikowe refleksje, „TP” 1948 nr 41 s. 11.

580 J. Zawieyski, ,Zmierzch będzie jako potudnie... ”, ,TP” 1948 nr 42 s. 1-2.

581 T.J. Brzeziński, Encyklopedia diabelska, „TP” 1948 nr 44 s. 11.

582 J. Ciechocki, Z zagadnień etyki seksualnej, „TP” 1948 nr 21 s. 8-9.

${ }^{583}$ M. Morstin-Górska, Nowe problemy życia rodzinnego, ,,TP” 1948 nr 32 s. 5.

584 Goa [A. Gołubiew], Książka dla mężczyzn, „TP” 1949 nr 31 s. 9.
} 
gach $^{585}$. Kolejna rocznica wydania społecznych encyklik papieskich Rerum novarum i Quadragesimo anno przyczyniła się do zacytowania myśli społecznej w duchu katolickim w wykładzie Jerzego Brauna ${ }^{586}$. Do tematu ulepszenia warunków społecznych w myśl drugiego z wymienionych dokumentów Kościoła powrócił w „Głosie Katolickim” Jan Archita ${ }^{587}$. Żartobliwe a zarazem mądre rozważania o życiu i jego końcu znalazły się w rubryce Głos z kąta po zacytowaniu tytułu wydanych po wojnie nowel Sztuka umierania (Kraków 1946) Zenona Skierskiego ${ }^{588}$. Przemyślenia o podejściu człowieka do cierpienia przedstawił Henryk Tyszka po przeczytaniu książki Szczepana Jeleńskiego Miód z opoki ${ }^{589}$. Temat alkoholizmu jako swoistą „polską modę”, o której pisano w rodzimej literaturze (fraszki i pamiętniki), a także przy okazji „pijackiej autobiografii” pt. John Barcleycorn Jacka Londona podjął Józef Marian Święcicki ${ }^{590}$. Ludwik Buśkiewicz ostrzegał przed nałogiem i przywoływał apel wielkopostny przedstawicieli Episkopatu ogłoszony w 1948 r. Za przykład wrogiej propagandy uprawianej przez okupanta niemieckiego posłużyła publicyście J. Buśkiewiczowi „okropna książka” zatytułowana Deutsches Vorfeld im Osten (Kraków 1941) ${ }^{591}$. Historię bractwa św. Anny na ziemiach polskich przytoczył Jan Ujda w nawiązaniu do Księgi imion w Polsce używanych (Warszawa 1938) Jana Stanisława Bystronia ${ }^{592}$.

Na łamach „Tygodnika Warszawskiego” swój pogląd na temat odwagi i roztropności Polaków chroniących Żydów w czasie ostatniej wojny wyraził Paweł Jasienica zainspirowany lekturą Nocy Jerzego Andrzejewskiego ${ }^{593}$. O twórczości pisarskiej Józefa Ignacego Kraszewskiego w kontekście obecnej w jego prasie historii ojczystej wypowiedział się Stefan Papée ${ }^{594}$. Ciekawej analizy powieści $Z$ wojny siedmioletniej Kraszewskiego w nawiązaniu do wydarzeń okupacji hitlerowskiej dokonał z kolei Władysław Drop, podkreślając słuszne przedstawienie przez pisarza ekspansywnych skłonności „duszy pruskiej” ${ }^{995}$. Nowe wydanie Democratic Ideals and Reality Halforda Johna Mackindera posłużyło jako świadectwo przewidywania przyszłości na drodze naukowej analizy i wnioskowania $^{596}$. Do opisu trasy wycieczki na terenach Ziem Odzyskanych zachę-

\footnotetext{
585 I. Stein, Stowa Ks. Jana Długosza, „GK” 1945 nr 27 s. 7.

${ }^{586}$ E. Myczka, Zasada wytwórczości w katolickim ruchu społecznym, „GK” 1947 nr 31 s. 258.

587 J. Archita, Państwo i społeczeństwo, „GK” 1948 nr 5 s. 43.

${ }^{588}$ I dobrze umrzeć - sztuka, „GK” 1947 nr 45 s. 376.

${ }^{589}$ H. Tyszka, Cierpienie - zjawisko niesamowite, „GK” 1948 nr 7 s. 59.

590 J.M. Święcicki, ,Polska moda”, ,GK” 1948 nr 2 s. 1.

${ }^{591}$ L. Buśkiewicz, To nasz wróg, „GK” 1949 nr 11 s. 91.

592 J. Ujda, Najpopularniejsze imię kobiece w Polsce, „GK” 1948 nr 30 s. 262.

593 P. Jasienica, O ludziach odważnych, „TW” 1946 nr 13 s. 7.

594 S. Papée, Kraszewski o Kościuszce, „TW” 1946 nr 26 s. 5.

595 W. Drop, Kraszewski - malarz Prusaków, „TW” 1948 nr 36 s. 3.

596 W. Godlewski, Przyszłość świata w oczach nauki, „TW” 1947 nr 10 s. 2-3.
} 
ciła Jerzego Kiersta publikacja Józefa Kisielewskiego Ziemia gromadzi prochy. Rozpoczynając artykuł, wspominał: ,[...] czytało się ją przy karbidówce w mroku okupacji. Była to książka tropiona przez Niemców bardziej jeszcze niż prasa podziemna, bardziej niż Wiatr od morza Żeromskiego. Za książkę tę groziła kula w łeb. Mimo to nieliczne jej egzemplarze szły z rąk do rąk wyczytywane skwapliwie" ${ }^{\prime 597}$. Opinie papieskie na temat własności prywatnej i sprawiedliwości społecznej w ustroju gospodarczym na podstawie wspomnianych wyżej dwu encyklik społecznych omówił Kazimierz Studentowicz ${ }^{598}$. Rozważania o nauce, cywilizacji i kryzysie wolności przeprowadził Stefan Garczyński nawiązując do najnowszej książki Aldouxa Huxleya Nauka, wolność i pokój j99. Cytaty z rozprawek Cypriana Kamila Norwida dotyczące pracy, sztuki oraz jednoczenia się ludzi dla wspólnego celu w duchu Chrystusa przytoczył Antoni Madej600.

Przedstawiona forma promocji książek nie zaznaczyła się natomiast $\mathrm{w}$,Tygodniku Katolickim”. Omówiono w nim tylko wydarzenia na terenie Ziemi Świętej w nawiązaniu do encykliki In Multiplicibus Curis Piusa XII ${ }^{601}$. Podobnie redakcje „Przeglądu Powszechnego" i „Znaku” nie były zainteresowane takim sposobem upowszechniania czytelnictwa.

Wszystkie z wymienionych wyżej form promocji książki służyły lepszemu zorientowaniu odbiorców w nowościach książkowych głównie polskich wydawców. Zdecydowanie rzadziej pojawiały się książki opublikowane za granicą. Zarówno reklamy, jak i wszelkiego rodzaju informacje o świeżo wydanych publikacjach, przeglądy piśmiennictwa, spisy nadesłanych książek i nawiązania do przeczytanych pozycji uwzględniały bardzo bogaty repertuar wydawniczy. Świadczyła o tym różnorodna problematyka proponowanych książek; tytuły książkowe w większości służyły szerzeniu kultury zgodnej z nauką społeczną Kościoła i odpowiadały zainteresowaniom inteligencji katolickiej. Do zakupu i przeczytania książek zachęcały ciekawie sformułowane nagłówki oraz opis szaty graficznej pozycji.

${ }^{597}$ J. Kierst, Ziemie i morze odzyskane, „TW” 1948 nr 27 s. 4.

${ }^{598}$ K. Studentowicz, W rocznicę Wielkiej Encykliki, ,TW” 1948 nr 20 s. 1-2.

${ }^{599}$ S. Garczyński, Nauka, wolność i pokój, „,TW” 1947 nr 19 s. 4.

${ }^{600}$ A. Madej, Norwidowe wskazania, „TW” 1948 nr 25 s. 3.

${ }^{601}$ Wiadomości z Palestyny, „TK” 1949 nr 2 s. 16. 


\section{ROZDZIAL 5}

\section{Inne formy upowszechniania książki}

Redakcje analizowanych katolickich czasopism społeczno-kulturalnych posługiwały się wszelkimi dostępnymi im sposobami, aby zachęcić czytelnika do sięgnięcia po książkę. Publikowano więc fragmenty pamiętników, rozważań i dramatów, jak też drukowano powieści literackie w odcinkach. Okazją do promocji były również wszelkiego rodzaju spotkania i imprezy związane z książką. $\mathrm{Na}$ kartach periodyków czytelnicy mogli odnaleźć w różnych rubrykach krótkie notki dotyczące wybranych pozycji wydawniczych. Nie zabrakło wiadomości biograficznych o ludziach zawodowo lub z zamiłowania związanych z książką. Wreszcie obecne były ogólne rozważania o książce, jej obiegu i odbiorze.

\subsection{Publikacja fragmentów książek jako forma ich promocji}

Na łamach katolickich czasopism społeczno-kulturalnych w latach 1945-1953 proponowano odbiorcom lekturę poprzez zamieszczanie krótszych lub dłuższych fragmentów książek. Propagowano w ten sposób znane często czytelnikom z recenzji pamiętniki i wspomnienia, rozważania, dramaty, czytania niedzielne z Pisma świętego, wyjątki z encyklik, korespondencji i inne. Na tę formę upowszechniania czytelnictwa szczególną uwagę zwróciła redakcja „Tygodnika Powszechnego" i „Znaku”. W pozostałych tytułach prasowych pojawiała się ona sporadycznie.

\section{Fragmenty pamiętników i wspomnień}

Obszernie zaprezentowane w „Tygodniku Powszechnym” fragmenty wspomnień dotyczyły głównie przeżyć świadków ostatniej wojny. Mieczysław Pruszyński upamiętnił osobę dominikanina i profesora uniwersytetu papieskiego Angelicum - Józefa Marii Bocheńskiego (imię zakonne Innocenty) posługującego 
w charakterze kapelana w batalionie piechoty we wrześniu 1939 r., następnie działającego w Duszpasterstwie Polskich Sił Zbrojnych na obczyźnie'. Wydrukowano m.in. urywek nt. pacyfikacji dokonanej przez Niemców w 1943 r. w Liszkach i Kaszowie z mającego się ukazać dopiero nakładem Drukarni Uniwersyteckiej pamiętnika Zginęli na polu chwaty (Wrocław 1946)². Z kolei pod nagłówkiem Z pamiętnika krakowskiej tandeciarki czytelnicy poznali obrazek z codziennego życia $\mathrm{W}$ piątym roku okupacji niemieckiej ${ }^{3}$. Z niewielkiego fragmentu książki o tematyce wojennej We mgle wrześniowej można było zapoznać się z pisarstwem Stanisława Zielińskiego ${ }^{4}$. „Historyczną ilustrację bezpośrednich po wojnie czasów we Francji”, jak dowiadujemy się z noty redakcyjnej, dostarczył pamiętnik Stefana Majchrowskiego ${ }^{5}$.

W ramach literatury obozowej przedstawiono we wspomnieniach Alfreda Kazimierza Andrzeja Jaworskiego i Konstantego Wóycickiego m.in. opisy atmosfery panującej w Gross-Rosen podczas świąt Bożego Narodzenia ${ }^{6}$. Zacytowano wyjątek dotyczący losów Hiszpanów w obozach Mauthausen i Gusen napisanych przez Włodzimierza Wnuka ${ }^{7}$, którego książka ukazała się pod tytułem Byłem z wami. Ks. Marian Michalski pisał natomiast: „Do pamiętnika Profesorów Uniwersytetu Jagiellońskiego z pobytu w obozach koncentracyjnych, Sachsenhausen i Dachau, pragnę dorzucić garść wspomnień, dotyczących specjalnie sposobu przeżywania niewoli przez księży, członków Wydziału Teologicznego" ${ }^{8}$. Z tej pozycji czytelnicy poznali trzy fragmenty9. W 1949 r. w czterech odcinkach zaprezentowano natomiast zapiski Krzysztofa Sławińskiego pt. Ucieczka ${ }^{10}$. Pod tym samym tytułem w kolejnym roku wydrukowano łagrowe doświadczenia Eugenii Kocwy ${ }^{11}$. Szczegóły z pięciu dni pobytu w bunkrze śmierci można było poznać dzięki Zenonowi Rozanskiemu, który swoje wspomnienia z kompanii karnej obozu w Oświęcimiu, zatytułowane Mützen $a b . .$. (Hanower 1948), wydał w języku niemieckim ${ }^{12}$. Warunki pracy

${ }^{1}$ M. Pruszyński, Miałem raz towarzysza ..., „TP” 1945 nr 35 s. 4-6.

${ }^{2}$ S. Rospond, Pacyfikacja, „TP” 1945 nr 36 s. 5.

${ }^{3}$ S. Krasicka, Z pamiętnika krakowskiej tandeciarki, „TP” 1946 nr 42 s. 6-7.

${ }^{4}$ S. Zieliński, Ostatnia piosenka, „TP” $1948 \mathrm{nr} 40$ s. 7.

${ }^{5}$ S. Majchrowski, Notatnik francuski, „TP” $1950 \mathrm{nr} 11$ s. 4-5; tenże, Notatnik francuski, tamże, nr 12 s. 5-6.

${ }^{6}$ K.A. Jaworski, Pierwsza wigilia w obozie, „TP” 1945 nr 40 s. 11; A.K. Woycicki, Boże Narodzenie za drutami, tamże.

${ }^{7}$ W. Wnuk, Hiszpanie za drutami Gusen, „TP” 1946 nr 35 s. 6.

${ }^{8}$ M. Michalski, Księża za drutami, „TP” 1945 nr 24 s. 6.

${ }^{9}$ Tenże, Księża za drutami, „TP” 1945 nr 24 s. 6; tenże, Księża za drutami, tamże, nr 25 s. 7.

${ }^{10}$ K. Sławiński, Ucieczka, „TP” 1949 nr 28 s. 6-7; tenże, Ucieczka, tamże, nr 29 s. 6-7; tenże, Ucieczka, tamże, nr 30 s. 5; tenże, Ucieczka, tamże, nr 31 s. 10.

${ }^{11}$ E. Kocwa, Ucieczka, „TP” 1950 nr 19 s. 3-5; taż, Ucieczka, tamże, nr 20 s. 4-5; taż, Ucieczka, tamże, nr 21/22 s. 11-13; taż, Ucieczka, tamże, nr 23 s. 8-10.

${ }^{12}$ Z. Rozanski, Bunkier głodowy, tł. A.J. Kamiński, „TP” 1949 nr 47 s. 6-7. 
w podziemnej fabryce bomb - Dorze krótko opisał były więzień obozów hitlerowskich Józef Wraubek ${ }^{13}$. Redakcja „Tygodnika Katolickiego” ogłosiła część z książki ks. Wacława Jezuska Męczeński koniec arcybiskupa Antoniego Juliana Nowowiejskiego, biskupa płockiego (Płock 1947), ukazując jego niezłomną postawę wiary wobec okupanta ${ }^{14}$.

Niektóre teksty zamieszczone w „Tygodniku Powszechnym” odnosiły się do powstania warszawskiego, jak np. fragmenty z pamiętników pisanych podczas walk przez Błażeja Włodarza, Wacława Gralińskiego, sanitariuszkę Zosię czy ks. Tomasza Rostworowskiego ${ }^{15}$. Na łamach „Tygodnika Warszawskiego” wydarzenia roku 1944 opisał ich uczestnik Kazimierz Zenon Skierski ${ }^{16}$, natomiast ludzi powstania we wspomnieniach zachował Stanisław Wąsowicz ${ }^{17}$.

Wydrukowano także fragment ciekawej książki pisanej na zamówienie Spółdzielni Wydawniczej Czytelnik przez Marka Antoniego Wasilewskiego Eskapada ku wolności, w której autor odnotował osobiste losy uciekiniera z niewoli niemieckiej na terenie Jugosławii ${ }^{18}$. Z notki tłumacza poprzedzającej tekst odbiorcy dowiedzieli się o zaginięciu w czasie wojny i odnalezieniu w 1949 r. rękopisu ,jednej z najpiękniejszych książek" Georgesa Bernanosa Dzieci upokorzone $^{19}$. Obszerny opis bitwy o Osiek dnia 12 IX 1939 r. można było poznać dzięki zapiskom podpułkownika Władysława Adamczyka ${ }^{20}$, natomiast walki we wsi Aleksandrów przybliżył Jan Józef Szczepański w odcinkach pamiętnika zatytułowanego Polska jesieńn ${ }^{21}$. Wyjątki ze wspomnień Adama Grzymały Siedleckiego zatytułowane Sto jedenaście dni letargu z warszawskiego więzienia politycznego na Pawiaku w latach 1942-1943 wydrukowała redakcja „Tygodnika Warszawskiego"’22. W ostatnim z pism, w odcinkach w 1947 r. znalazły się urywki z anonimowego pamiętnika generała Reichswehry Weimar an Chaos (Paryż 1934), będącego „godnym uwagi przyczynkiem” do studiów nad życiem politycznym Niemiec okresu dwudziestolecia międzywojennego. Olgierd Budrewicz przy tej okazji napisał: „Powie ktoś, że autor pamiętnika wyciągnął tendencyjnie wszystkie brudy, by je następnie publicznie prać! Być może. Ale czasy i ludzie

${ }^{13}$ J. Wraubek, W podziemnym tagrze, ,TP” 1950 nr 15/16 s. 12.

${ }^{14}$ W. Jezusek, Ostatnie dni arcybiskupa Nowowiejskiego, „TK” $1952 \mathrm{nr} 8$ s. 58.

${ }^{15}$ W. Graliński, Na starym mieście, „TP” 1949 nr 32 s. 5; B. Włodarz, Obrona Mokotowa, tamże, nr 31 s. 6-7; Sanitariuszka „Zosia”, Z Czerniakowa do Śródmieścia, „TP” 1948 nr 31 s. 3-4; taż, Z Czerniakowa do Śódmieścia, tamże, nr 32 s. 8-9; T. Rostworowski, Przygoda, tamże, nr 41 s. $6-7$.

${ }^{16}$ K.Z. Skierski, Rejon Wolności, „TW” 1946 nr 31 s. 3-4.

${ }^{17}$ S. Wąsowicz, Nasz front byt w Warszawie, „TW” $1946 \mathrm{nr} 42 \mathrm{~s} .7$.

${ }^{18}$ M.A. Wasilewski, Podróż bez biletów, „TP” 1948 nr 10 s. 5.

${ }^{19}$ G. Bernanos, Chore ktamstwa, t1. M. Winowska, „TP” 1949 nr 21 s. 2.

${ }^{20}$ W. Adamczyk, Bitwa o Osiek, „TP” 1949 nr 35 s. 1-4.

${ }^{21}$ J.J. Szczepański, Aleksandrów, „TP” 1949 nr 36 s. 5-7; tenże, Aleksandrów, tamże, nr 37 s. 5 .

22 A. Grzymała-Siedlecki, Pierwszy dzień na Pawiaku, „TW” 1946 nr 13 s. 4. 
tych czasów byli brudni - taka jest prawda. I jeżeli Anonim pisze, że Hitler robił wrażenie człowieka obłąkanego, Hindenburg i jego towarzysze kradli, Papen był oszustem, Göring morfinistą, Röhm homoseksualistą, Lay pijakiem, a Schleicher człowiekiem bez charakteru - to wszystko to jest także prawdą"23.

Oprócz wspomnień makabry wojennej czytelnicy w publikowanych fragmentach mogli poznać także doświadczenia osobiste różnych mniej lub bardziej znanych osób. W „Tygodniku Powszechnym” ukazały się urywki zapisków z młodości Stanisława Pigonia wydane pod tytułem Z Komborni w świat (Kraków 1946)24. Przytoczono także dwa obszerne fragmenty z dziennika ,złożonego ciężką chorobą i przykutego do łoża boleści” literata i myśliciela Karola Ludwika Konińskiego zatytułowanego Nox atra ${ }^{25}$. Z notki wprowadzającej czytamy, że był to „ciekawy i wstrząsający pamiętnik z okresu duchowego rozwoju człowieka, który od pełnej niewiary w trudzie i w walce szedł uporczywie do Boga i Kościoła"26. Ostrzegano jednocześnie odbiorców przed traktowaniem książki jako „podręcznika katolickiej ascetyki i mistyki” ze względu na silny pesymizm oraz błędne sformułowania „,z punktu widzenia katolickiej doktryny” "27. Z pamiętnika spisanego przez księżnę Jadwigę z Sanguszków Adamową Sapieżynę, matkę kardynała Adama Sapiehy, wybrano fragmenty dotyczące jego osoby ${ }^{28}$. Na łamach „Znaku” pod nagłówkiem Przeżyła czasów wiele zacytowano zapewne niewydrukowane zwierzenia duchowe zmarłej w wieku 14 lat Anielki, udostępnione przez Stefanię Skwarczyńską ${ }^{29}$. Z obcych pisarzy zaprezentowano wyjątki z wydanego w 1945 r. pamiętnika zmarłego dwa lata później Charlesa Ferdinanda Ramuza i wspomnienia napisane w formie reportażu Antoine de Saint-Exupéry Ziemia, ojczyzna ludzi (późniejsze wydania książkowe nosiły tytuł Ziemia, planeta ludzi $)^{30}$. Z kolei wybrane części z dziennika zięcia Benito Mussoliniego - hrabiego Ciano „wymownie ilustrowały kapryśny, zmienny, próżny i zazdrosny" charakter dyktatora Włoch ${ }^{31}$.

W publikowanych na łamach periodyków wycinkach wspomnień przeważyły doświadczenia z okresu okupacji, gdyż literatura wojenna wraz z łagrową stanowiły jeden z najważniejszych nurtów w pierwszych latach po II wojnie światowej. Ukazały się wtedy na rynku wydawniczym liczne tytuły książkowe, co po części można zauważyć dzięki zamieszczonym w katolickich periodykach urywkom.

${ }^{23}$ O. Budrewicz, Weimar od podszewki, „TW” 1947 nr 49 s. 2.

${ }^{24}$ S. Pigoń, O honor chłopski, „TP” 1945 nr 32 s. 4.

${ }^{25}$ K.L. Koniński, Nox atra, „TP” 1950 nr 13 s. 6-7; tenże, Nox ..., tamże, nr 14 s. 3-4.

${ }^{26}$ Tenże, Nox atra, „TP” 1950 nr 13 s. 6.

${ }^{27}$ Tenże, Nox atra, „TP” 1950 nr 14 s. 3.

${ }^{28}$ Z pamiętnika księżny Jadwigi Sapieżyny, „TP” 1952 nr 30 s. 2.

${ }^{29}$ Przeżyła czasów wiele, „Znak” $1950 \mathrm{nr} 1 \mathrm{s.} 33-56$.

${ }^{30}$ C.F. Ramuz, Fragmenty pamiętnika, „TP” 1947 nr 41 s. 4-5; A. Saint-Exupéry, W sercu pustyni, „TP” 1951 nr 30 s. 7-9.

${ }^{31}$ Ciano, Udręki dyktatora, ,TP” 1948 nr 24 s. 4-5. 


\section{Fragmenty rozważań}

Redakcje czasopism społeczno-kulturalnych promowały wśród swoich czytelników książki, publikując na łamach periodyków fragmenty rozważań znanych myślicieli i pisarzy pozostających w kręgu myśli chrześcijańskiej. Czytelnicy „Tygodnika Powszechnego" mogli poznać ciekawy sposób thumaczenia istoty świąt Bożego Narodzenia przez Gilberta Keitha Chestertona w rozdziale z książki The Everlasting Man (Wiekuisty człowiek, Londyn 1936) ${ }^{32}$. Styl pisarski Daniela-Ropsa ukazano dzięki wydanemu w 1950 r. polskiemu tłumaczeniu Dziejów Chrystusa. Wyjątek z tego dzieła znalazł się również w tygodnikach krakowskim i gorzowskim ${ }^{33}$. Ks. Romano Guardini podkreślił rolę Maryi w życiu Zbawiciela oraz wyjaśnił posłannictwo Jezusa w wyjątkach z pracy Der Herr (Pan, Burg Rothenfels am Main 1937) ${ }^{34}$. Krótkie rozważanie o cierpieniu w życiu człowieka w kontekście wiary przeprowadziła francuska myślicielka żydowskiego pochodzenia Simone Weil w notatkach spisanych w 1942 r., a wydanych później wspólnie z listami w książce Attente de Dieu (Czekając na Boga, Monachium 1953) $)^{35}$. Zarówno w „Tygodniku Powszechnym”, jak i w „Znaku” zwrócono uwagę na myśli trapisty Thomasa Mertona zawarte w dziełku z 1949 r. zatytułowanym Seedes of Contemplation (Posiew kontemplacji) ${ }^{36}$. Na łamach miesięcznika zamieszczono także niewielki fragment z rozmyślań mistycznych i filozoficznych kardynała Johna Henry'ego Newmana, opublikowanych w Méditations et prières (Medytacje i modlitwy, Paryż 1925) ${ }^{37}$. Pojęcia „królestwa, kościoła i świata” starał się zdefiniować - uwydatniając błędne ich rozumienie w ciągu wieków - Jacques Maritain w jednym z przytoczonych na łamach „Znaku” rozdziałów swojej książki wydanej w 1936 r. Humanisme intégral ${ }^{38}$. Z najnowszej książki francuskiego filozofa Gustave'a Thibona, wydanej w języku francuskim w 1948 r. Nietzsche ou le déclin de l'esprit, wybrano cytat dotyczący istoty chrześcijaństwa - przyjęcie krzyża ${ }^{39}$.

Wspomniani powyżej autorzy publikowanych na łamach periodyków fragmentów dzieł należeli do elity chrześcijańskiej myśli filozoficznej; byli też

32 G.K. Chesterton, Bóg w jaskini, „TP” 1946 nr 51/52 s. 4-5.

${ }^{33}$ Daniel-Rops, Dnie galilejskie, tł. Z. Starowieyska-Morstinowa, „TP” 1950 nr 11 s. 1-2; tenże, Portret Jezusa, „TK” 1951 nr 24 s. 216.

${ }^{34}$ R. Guardini, Matka, tł. M. Morstin-Górska, „TP” 1950 nr 20 s. 1; tenże, Syn Człowieczy, tł. M. Morstin-Górska, „Znak” 1950 nr 3 s. 234-239.

${ }^{35}$ S. Weil, Nieszczęście i miłość, „TP” 1950 nr 53 s. 6-7.

${ }^{36}$ T. Merton, Wszystko co istnieje jest święte, „TP” $1951 \mathrm{nr} 27$ s. 3; tenże, Posiew kontemplacji, „Znak” 1952 nr 1 s. 17-40; tamże, nr 2 s. 134-159; tamże, nr 3 s. 214-225; tamże, nr 4 s. 268-286; tenże, Posiew ..., „Znak” 1953 nr 1 s. 28-41.

${ }^{37}$ J.H. Newman, Fragmenty z rozmyślań, „Znak” 1948 nr 1 s. 24-26.

${ }^{38}$ J. Maritain, Problem Królestwa Bożego, tł. H. Malewska, „Znak” 1949 nr 7 s. 521-530.

${ }^{39}$ G. Thibone, Miecz i krzyż, tł. H. Malewska, „Znak” 1949 nr 3 s. 193-199. 
ludźmi Kościoła. W tym gronie znaleźli się także cenieni i znani ze swoich pism kapłani. Myśli zawarte w ich wypowiedziach były niezwykle cenne i pogłębione. Niestety, tylko dwie z sześciu redakcji wybranych czasopism zwróciły na nie uwagę.

\section{Urywki dramatów}

Fragmenty dramatów rzadko pojawiały się na kartach czasopism; najchętniej drukowano je w latach 1945-1953 w „Tygodniku Powszechnym” i „Znaku”. Zaczęto od urywków dzieł scenicznych Tadeusza Kwiatkowskiego i Marii Jarczyńskiej, których tytułów nie podano ${ }^{40}$. Czytelników zapoznano także z półstronicowym cytatem z Przędziwa Jolanty (Łódź-Wrocław 1948) Jana Dobraczyńskiego ${ }^{41}$, po czym szczególną uwagę zwrócono na twórczość Jerzego Zawieyskiego m.in. przedstawiając części z Dnia sądu, Męża doskonatego, Pieśni o nadziei i Rozdroża mitości ${ }^{42}$. Zachęcano również odbiorców do sięgnięcia po dramat Przyszedt na ziemię święty (Kraków 1947) Adama Bunscha ${ }^{43}$, którego głównym bohaterem był Adam Chmielowski znany później jako Brat Albert. Wydrukowano ponadto wybrane fragmenty z dramatów Święty Franciszek (Łódź 1948) Wojciecha Bąka ${ }^{44}$ i Godzina śródziemnomorska (Warszawa 1949) Jana Parandowskiego ${ }^{45}$.

\section{Inne}

Redakcja „Tygodnika Katolickiego" w całym okresie wydawniczym pisma drukowała na drugiej stronie czytania mszalne z każdej niedzieli. Do sięgnięcia po dokumenty Kościoła zachęcano poprzez przytoczenie urywków z encyklik. Odbiorcy poznali m.in. stanowisko głowy Kościoła na temat małżeństwa

${ }^{40}$ T. Kwiatkowski, Obrona Warszawy, „TP” 1945 nr 32 s. 5; M. Jarczyńska, Konkurs na człowieka, „TP” 1946 nr 16 s. 8-9.

${ }^{41}$ J. Dobraczyński, Przędziwo Jolanty, „TP” 1946 nr 37 s. 5.

${ }^{42}$ J. Zawieyski, Rozdroże miłości, „TP” $1946 \mathrm{nr} 46$ s. 5-6; tenże, Dzień sądu, „TP” $1947 \mathrm{nr}$ 10 s. 1, 3; tamże, nr 11 s. 6-7; tamże, nr 12 s. 6; tenże, Dzień..., tamże, nr 13 s. 6-7; tenże, Mą̇ doskonaty, „Znak” 1946 nr 2 s. 196-223; tamże, nr 3 s. 322-335; tenże, Mą̇ doskonaty, „Znak” 1947 nr 4 s. 430-441; tamże, nr 5 s. 557-566; tenże, Pieśń o nadziei, „TP” 1949 nr 15/16 s. 2-3; tenże, Sokrates, „TP” 1950 nr 26 s. 6-8; tamże, nr 40 s. 6-8; tenże, Niezwyciężony Herakles, „TP” 1952 nr 35 s. 1-2; tamże, nr 36 s. 1-2, 6-7; tenże, Lament Orestesa, „Znak” 1953 nr 1 s. $42-70$.

${ }^{43}$ A. Bunsch, Przyszedt na ziemię święty, „TP” 1946 nr 49 s. 4-5; tamże, nr 50 s. 4; tamże, nr $51 / 52$ s. $7-8$.

${ }^{44}$ W. Bąk, Święty Franciszek, „TP” 1948 nr 1 s. 4-5.

45 J. Parandowski, Rozmowa z cieniem, „TP” 1948 nr 21 s. 3-4. 
oraz wezwanie do modlitwy o pokój na świecie ${ }^{46}$. Wobec fałszywej propagandy marksistów starano się na łamach katolickich czasopism społeczno-kulturalnych obiektywnie przedstawić stanowisko papieża względem Polski po napadzie Hitlera. Podkreślano wyraźne jego wsparcie moralne dla Polaków ${ }^{47}$.

Znacznie skromniej promowano literaturę epistolarną. Do tego działu można zaliczyć jedynie fragmenty z ,sympatycznej książki”, będącej zbiorem listów H. Bossego Der Führer ruft tematycznie odnoszącej się do kwestii przesiedlenia Niemców z Polski i Rosji do tzw. Warthegau, wyjątki z Listów starego diabła do młodego, mających ukazać się w serii Jasnych Książek, jednego z „czołowych moralistów angielskich" Clive'a Staplesa Lewisa, oraz nieznany list z 1852 r. Cypriana Kamila Norwida do Konstancji Górskiej ${ }^{48}$.

Fragmenty przedstawionych wspomnień, pamiętników, rozważań, dramatów czy literatury epistolarnej umożliwiały odbiorcom pism bliższe zapoznanie się ze stylem pisarskim danego autora, sposobem jego myślenia, argumentacji oraz z przeżyciami osobistymi. Była to zatem jedna z ważniejszych form promocji oraz zachęty do nabycia danej pozycji książkowej. W znacznej mierze była to literatura tematycznie nawiązująca do bolesnych przeżyć okresu ostatniej wojny.

\subsection{Powieści literackie w odcinkach}

Kształtowaniu gustów czytelniczych odbiorców katolickich czasopism społeczno-kulturalnych służyła również proza artystyczna drukowana na łamach pism (zob. Wykaz powieści drukowanych w odcinkach na płycie CD-ROM). Zapowiedź i pierwodruk prasowy stanowiły promocję przyszłego wydania książkowego. Spośród 45 fragmentów tytułów powieściowych, większość (32) opublikowano w „Tygodniku Powszechnym” i ,Znaku”. Redakcja pierwszego periodyku sporadycznie rozpoczynała od noty wprowadzającej, natomiast $\mathrm{w}$ miesięczniku za każdym razem podawano życiorys pisarza, zarys akcji powieści lub okoliczności jej powstania. W pozostałych pismach w wybranym okresie znalazło się zaledwie kilka części, zapewne dlatego, że redakcje preferowały drukowanie opowiadań, nowel, wspomnień, legend i gawęd. Tej formy promocji zabrakło w „Przeglądzie Powszechnym".

${ }^{46}$ Pius XII, ,, Mirabile illud”, „TP” 1951 nr 1/2 s. 2; Z encykliki Piusa XI O matżeństwie chrześcijańskim, „TK” 1951 nr 3 s. 19; , Mirabile illud”. Encyklika papieża Piusa XII o pokoju, „TK” $1951 \mathrm{nr} 5$ s. 38.

${ }^{47}$ Np. Pius XII uroczyście potępit hitleryzm, „GK” 1945 nr 2 s. 3; Pius XII piętnuje napad Niemców na Polskę, tamże, nr 3 s. 3; Z encykliki ,, Summi pontificatus”, „GK” 1946 nr 21 s. 169.

${ }^{48}$ W. Jarochowska, Przemiany, „GK” 1946 nr 11 s. 87; C.S. Lewis, Listy starego diabła do młodego, „Znak” 1948 nr 5 s. 452-460; tenże, Listy starego..., „Znak” 1949 nr 3 s. 245-254; Nieznane fragmenty C.K. Norwida, „Znak” $1952 \mathrm{nr} 1$ s. 71-74. 
Powieść w odcinkach wykorzystywano, by jedynie zasygnalizować publiczności ukazanie się książki. $Z$ założenia więc zamieszczano przeważnie tylko kilka fragmentów, nie drukując jej przez dłuższy czas. Wśród tytułów powieściowych dominowały dzieła rodzimych twórców, a ze względu na profil czasopism wybierano głównie prozę pisarzy uważanych za katolickich.

W periodykach zapoznano czytelników m.in. z wyjątkami z historycznej powieści Bolesław Chrobry Antoniego Gołubiewa ${ }^{49}$. Można było przeczytać też fragmenty powieści Jana Dobraczyńskiego: Dwa stosy ${ }^{50}$, Listy Nikodema ${ }^{51}$, Święty miecz i $W$ rozwalonym domu ${ }^{52}$. Twórczość Hanny Malewskiej zaprezentowano dzięki urywkom z powieści Kamienie wołać będa ${ }^{53}$, Przemija postać świata ${ }^{54}$ i Żniwo na sierpie. Zarówno w „Tygodniku Powszechnym”, jak i ,Tygodniku Warszawskim” zagościły wyimki z Drogi do domu, Nocy Huberta oraz Owocu czasu swego Jerzego Zawieyskiego. Gustaw Morcinek przedstawił w krakowskim piśmie i w „Głosie Katolickim” wyjątki z powieści Dwie korony $^{55}$. Trzykrotnie ogłoszono na łamach „Tygodnika Powszechnego” części z Cisoni Jana Gwalberta Henryka Pawlikowskiego ${ }^{56}$. Raz zaś opublikowano fragment z powieści dla dzieci Porwanie $w$ Tiutiurlistanie z rysunkami Adama Marczyńskiego ${ }^{57}$. Zapowiedziano także nigdy nie ukończoną książkę Henryka Worcella, pisaną na podstawie osobistych doświadczeń podczas przymusowej pracy w Niemczech. Ukazała się jedynie jej część w październikowym numerze „Tygodnika Powszechnego" z 1945 r. zatytułowana Wojna się kończy o pót$n o c y^{58}$. Podobnie zapewne było z niedokończoną powieścią o ,nie ustalonym

${ }^{49}$ A. Gołubiew, Bity dzwony. (Fragment powieści pt. „Bolesław Chrobry”), „TP” 1945 nr 31 s. 4-5; tenże, Gość. (Fragment z powieści pt. „Bolesław Chrobry” t. II), „TW” 1946 nr 16 s. 11-12; tenże, Pomór w Gniezdnie. Fragment z III części „Bolesława Chrobrego”, „TP” 1948 nr 52/53 s. 13-14; tenże, Głód żurawia. (Fragment z III części „Bolesława Chrobrego”), „TP” 1949 nr 27 s. 4-5; tenże, Podgrodzie, „TP” 1950 nr 43 s. 1; tenże, Emnilda, „TP” 1951 nr 12/13 s. 9-10; tenże, Duma rodu Stawnikowiców. Fragment z „Bolesława Chrobrego ”, „TP” $1952 \mathrm{nr} 20$ s. 1-2; tenże, Księstwo w Worach. Fragment z „Bolesława Chrobrego” t. IV: „Święte truchta”, tamże, nr 46 s. 2.

${ }^{50}$ J. Dobraczyński, Proces $w$ Rouen, „TP” 1946 nr 18 s. 4.

${ }^{51}$ Tenże, Listy Nikodema. Lazarz, „TP” $1951 \mathrm{nr} 40$ s. 1-2, 8.

52 Tenże, Nieznany syn, „TP” 1945 nr 19 s. 5; tenże, Lusia, „TP” 1946 nr 48 s. 5.

${ }^{53}$ H. Malewska, Wędrówka, ,TP” 1945 nr 22 s. 6.

${ }^{54}$ Taż, Wierność i zdrada, „TP” 1952 nr 40 s. 6-7.

${ }^{55}$ G. Morcinek, ,Aurea aetas”, „TP” 1948 nr 30 s. 4-5; tenże, W rzymskiej celi klasztornej, „GK” 1948 nr 21 s. $188-189$.

${ }^{56}$ J.G.H. Pawlikowski, Na cisoniowym brzyzku, „TP” 1953 nr 3 s. 3-4; tenże, Na cisoniowym..., tamże, nr 4 s. 4-5; tenże, Na cisoniowym..., tamże, nr 5 s. 4; tenże, Na cisoniowym..., tamże, nr 6 s. 2, 5 .

${ }^{57}$ W. Żukrowski, Wojna Blablacji z Tiutiurlistanem, „TP” $1945 \mathrm{nr} 40$ s. 8-10.

${ }^{58}$ H. Worcell, Wojna się kończy o pótnocy, „TP” $1945 \mathrm{nr} 30$ s. 4-5. 
jeszcze tytule” „młodej autorki” Natalii Rolleczkówny ${ }^{59}$. Niekiedy odbiorcy najpierw otrzymywali fragment książki na łamach pism, a dopiero po czasie jej recenzję. Tak było w przypadku powieści Maria wyrusza w świat Eugenii Kocwy ${ }^{60}$.

Z dorobku zagranicznych pisarzy znalazły się fragmenty ze znanych powieści: Gertrudy von le Fort Gody magdeburskie ${ }^{61}$, Bruce'a Marshalla Chwała córy królewskiej ${ }^{62}$, Sigrid Undset Gymnadenia ${ }^{63}$ i Krzak gorejący ${ }^{64}$, Franza Werfla Pieśn o Bernadecie ${ }^{65}$, Grahama Greene'a Sedno sprawy ${ }^{66}$ oraz Moc i chwała ${ }^{67}$, a także ks. Wilhelma Hünermanna Ojciec Damian. Redakcja „Tygodnika Powszechnego” udostępniła rozdział z nieznanej polskim czytelnikom powieści południowoafrykańskiego pisarza Alana Patona Cry the Beloved Country ${ }^{68}$. W „Znaku” opublikowano fragment ,prawdziwie pięknej powieści” czeskiego pisarza i dziennikarza Karela Schulza zatytułowanej Kamień i ból ${ }^{69}$.

Formą promocji powieści przez drukowanie jej w odcinkach redakcje katolickich czasopism społeczno-kulturalnych w latach 1945-1953 posługiwały się nader rzadko. Jedynie w „Tygodniku Powszechnym” stosowano ją częściej, choć nie posiadała stałego charakteru. W większości tytułów prasowych występowała sporadycznie. Jeżeli współpracownicy pism decydowali się na jej zamieszczenie, to starali się raczej wybierać bardziej znane powieści.

\subsection{Imprezy kulturalne związane z książką}

Jednym ze sposobów propagowania książki było podawanie informacji o organizowanych wystawach, konkursach i nagrodach. Najczęściej wiadomości takie ukazywały się na łamach „Tygodnika Powszechnego” i „Tygodnika Warszawskiego". Redakcja pierwszego z nich stosowała dwa sposoby powiadamiania o nich; były to zazwyczaj dłuższe artykuły Heleny Blumówny o tym, co

\footnotetext{
${ }^{59}$ N. Rolleczkówna, U Walczaka, „TP” 1948 nr 12 s. 4.

${ }^{60}$ E. Kocwa, Maria wyrusza w świat, „TP” $1946 \mathrm{nr} 39$ s. 4-5.

${ }^{61}$ G. von le Fort, Gody magdeburskie, „Znak” 1950 nr 2 s. 127-141.

${ }^{62}$ B. Marshall, Rozmowy księdza Smitha. Rozdziat z powieści „Chwała córy królewskiej”,
} „TP” 1949 nr 46 s. 2.

${ }^{63}$ S. Undset, W kościele św. Olafa. (Fragment z powieści pt. „, Gymnadenia”), „TP” $1949 \mathrm{nr} 30$ s. $1-2$.

${ }^{64}$ Taż, Krzak gorejący, „Znak” 1951 nr 3 s. 299-246.

${ }^{65}$ F. Werfel, Pieśń o Bernadecie, „TW” 1948 nr 20 s. 4-5; tenże, Wystannicy wiedzy, tamże, nr $13 / 14$ s. $12-13$.

${ }^{66}$ G. Greene, Sedno sprawy. Fragment powieści, „TP” 1949 nr 38 s. 6-7.

${ }^{67}$ Tenże, Krzyże, „Znak” 1949 nr 6 s. 489-499.

${ }^{68}$ A. Paton, Shanty Town, tł. J. J. Szczepański, „TP” 1952 nr 49 s. 3-4.

${ }^{69}$ K. Schulz, Nocna rozmowa, „Znak” 1948 nr 6 s. 544-558. 
działo się aktualnie w świecie kultury i sztuki, lub lakoniczne notatki zamieszczane w różnych rubrykach pisma (m.in. $Z$ dnia). W warszawskim periodyku podobne wiadomości drukowano zwięźle w Przeglądzie kulturalnym.

\section{Wystawy}

„Książka i jej powstanie” - taki tytuł nosiła pierwsza wystawa odnotowana przez redakcję krakowskiego czasopisma, zorganizowana jesienią 1946 r. w Szczecinie. W związku z nią pisano: „Wystawa ta - a zadaniem jej jest zbliżenie osadnika na Pomorzu Zachodnim do książki - została pomyślana niebanalnie. Reprezentowana będzie nie tylko książka współczesna, ale wystawione zostaną także stare druki i rękopisy z bibliotek szczecińskich"70. Z notki można było dowiedzieć się ponadto o zaplanowanym podczas jej trwania „pokazie graficznym” na temat genezy książki i rozwoju przemysłu drukarskiego. Więcej napisano w „Tygodniku Powszechnym” o ekspozycji otwartej w Muzeum Narodowym w Warszawie z okazji 125 rocznicy urodzin Norwida. W pięciu salach umieszczono m.in. kilkadziesiąt prac o poecie, fragmenty korespondencji Zenona Przesmyckiego świadczące o znacznym wysiłku włożonym w gromadzenie tekstów Norwida oraz ważniejsze bibliofilskie wydania jego poezji. Przygotowanie pokazu oceniono jako staranne ${ }^{71}$. Ciekawe eksponaty starożytnych rękopisów armeńskich z biblioteki w Matenadaran pokazano na wystawie moskiewskiej. Obejrzeć można było na niej również pierwszą książkę armeńską wydrukowaną w Wenecji w 1512 r. ${ }^{72}$ Helena Blumówna donosiła o wystawie książki radzieckiej otwartej pierwotnie w Warszawie, a następnie w Krakowie w 1948 r. Jak wspomniała „na nowoczesnych, metalowych półkach o wielu piętrach” udostępniono 4 tys. egzemplarzy książek we wszystkich językach narodów ZSRR, chcąc zobrazować rozwój czytelnictwa i bibliotek. Nie zabrakło na niej dzieł Marksa, Engelsa, Lenina i Stalina. Jeden z działów objął również ilustrację książkową ${ }^{73}$. Ta sama publicystka szczegółowo omówiła pierwszą zorganizowaną po II wojnie światowej wystawę grafiki w Krakowskim Pałacu Sztuki. Zwróciła uwagę na bogate zbiory, w których uwzględniono m.in. monotypie Adama Marczyńskiego. Wśród zaprezentowanych eksponatów znalazły się dzieła takich ilustratorów i rytowników, jak Jadwiga Umińska, Barbara Gawdzik-Brzozowska, Tadeusz Brzozowski, Maciej Makarewicz, Witold Skulicz i Tadeusz Olszewski. Zajmująca ,jedno z najbardziej poczesnych miejsc" w gronie twórców znaków książkowych Krystyna Wróblewska zaprezentowała natomiast w formie książkowej dwanaście

\footnotetext{
70 „, Książka i jej powstanie”, ,TP” 1946 nr 48 s. 10.

${ }^{71}$ D.J., Wystawa norwidowska, ,TP” 1947 nr 6 s. 11.

72 jww., Kronika radziecka, ,TP” 1948 nr 44 s. 10.

${ }^{73}$ H. Blumówna, Wystawa książki radzieckiej, ,TP” 1948 nr 51 s. 6.
} 
ze swoich ekslibrisów. Oprawę książkową i grafikę użytkową pokazał natomiast Adam Młodzianowski ${ }^{74}$.

W rubryce $Z$ dnia informowano także o pokazie naukowych wydawnictw radzieckich zorganizowanym w Krakowie przez Polską Akademię Umiejętności i Bibliotekę Jagiellońską ${ }^{75}$. Zarejestrowano również pierwszą w Polsce wystawę książki dziecięcej XIX i XX wieku we Wrocławiu, przypominając przy okazji najstarszą polską książkę dla najmłodszych - Wiązanie Helenki Klementyny Tańskiej-Hoffmanowej, wydaną około $1820 \mathrm{r}^{76} \mathrm{~W}$ tym samym miejscu odbiorcy mogli dowiedzieć się o pokazie różnych wydań i tłumaczeń dzieł mickiewiczowskich czy warszawskiej ekspozycji poświęconej książce Wschodu w Muzeum Narodowym ${ }^{77}$. Odnośnie do imprez za granicą znalazły się także krótkie wiadomości m.in. dotyczące paryskiej wystawy poświęconej życiu i dziełom Georgesa Bernanosa. Oprócz licznych dokumentów i fotografii pisarza zgromadzonych na niej można było obejrzeć manuskrypt niewydanej jeszcze książki Le mauvais $r e ̂ v e^{78}$. W Czechosłowacji zorganizowano w 1950 r. wystawę książki polskiej ${ }^{79}$. Ciekawostką działu był także pekiński pokaz manuskryptów „największej encyklopedii świata" z początku XV w., liczącej ponad 11 tys. tomów. Opracowano ją podczas panowania Yung Lo, trzeciego z kolei cesarza dynastii Ming. Ze względu na duże rozmiary nie została wydrukowana, a oryginalny rękopis uległ zniszczeniu. W jej powstaniu oprócz 30 uczonych miało udział 3 tys. pomocników. Na wystawie pokazano drugi jej egzemplarz, przepisany w połowie XVI stulecia ${ }^{80}$. Czytelników „Tygodnika Katolickiego” poinformowano w notkach o ekspozycji odtwarzającej warsztat Johanna Gutenberga z okazji 500 rocznicy wydania pierwszej książki drukowanej - Biblii z 1452 r. oraz o interesującej wystawie dla uczczenia 500 rocznicy założenia Biblioteki Watykańskiej ${ }^{81}$.

Krótko na temat wystaw nowości książkowych urządzonych z okazji Święta Oświaty w Bibliotece Publicznej m.st. Warszawy w 1947 r. wraz z odczytami poinformowano na łamach „Tygodnika Warszawskiego" ${ }^{2}$. Na początku czerwca $1947 \mathrm{r}$. odbył się I Ogólnopolski Zjazd w sprawie literatury dla dzieci i młodzieży zorganizowany przez Wydział Pedagogiczny Zarządu Głównego Związku Nauczycielstwa Polskiego, jak czytamy w tym samym organie prasowym. Wzięli w nim udział pisarze, ilustratorzy książek dla dzieci, bibliotekarze, wydawcy i pedagodzy. Spotkanie

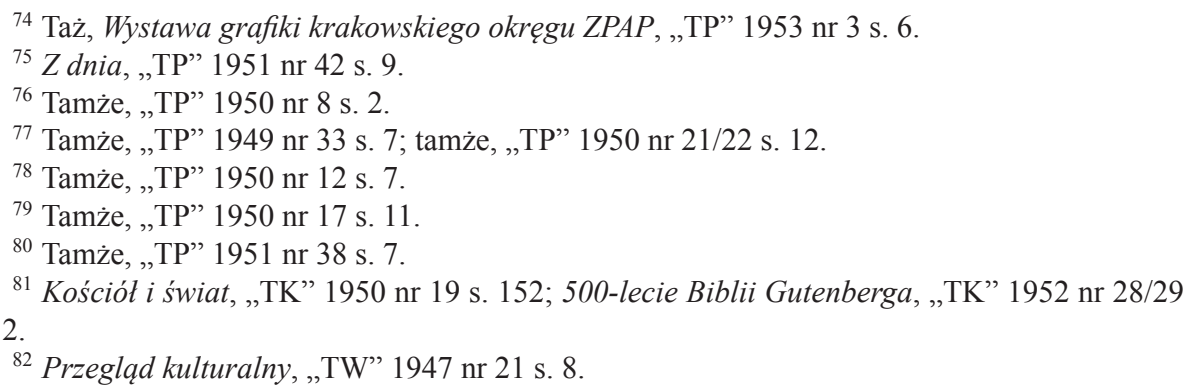


połączono z Międzynarodową Wystawą Książek dla najmłodszych, dzięki której można było zapoznać się z bogatą ofertą wydawnictw zagranicznych ${ }^{83}$. O prezentacji w tym samym prawie czasie publikacji książkowych w Strasburgu na wielkiej Wystawie Międzynarodowej Książek i Sztuki Graficznej wspomniano w Kronice zagranicznej $^{j 4}$. Poinformowano także o tym, że w związku z III Zjazdem Przemysłowym w Szczecinie w dniach 7-8 IX 1947 r. Polski Związek Zachodni zorganizował tam wystawę książki i prasy Ziem Zachodnich, obejmującą dorobek wydawniczy lat 1946-194785. Więcej napisano odnośnie do pośmiertnej prezentacji dzieł artysty Stanisława Ostoi Chrostowskiego w Muzeum Narodowym. Tu wyeksponowano m.in. ilustracje książkowe i ulubione przez artystę ekslibrysy ${ }^{86}$. Otwarciu czytelni naukowej przeniesionego do Wrocławia Zakładu Narodowego im. Ossolińskich towarzyszyła w 1947 r. wystawa rękopisów, o czym donoszono w Przeglądzie kulturalnym $^{87}$. Powojenny dorobek wydawniczy zaprezentowano z kolei na Wystawie Książki Polskiej z okazji trzeciej rocznicy oswobodzenia Inowrocławia, którą można było odwiedzić w Teatrze Miejskim. Udostępniono na niej liczne „białe kruki” z XVI-XVIII w. oraz szereg starych druków ${ }^{88}$. Zdecydowanie rzadziej w „Tygodniku Warszawskim" pisano o zagranicznych imprezach tego typu. Poinformowano bowiem zaledwie o kilku ekspozycjach: o pozostającej pod protektoratem królowej Elżbiety wystawie w Liège (Belgia) rękopisów i listów Fryderyka Chopina i Georges Sand, ekspozycji poświęconej 25-leciu śmierci Marcelego Prousta, zorganizowanej w narodowej książnicy Francji, wystawie w Paryżu polskiego exlibrisu z lat 1939-1944 oraz pokazie pomocy naukowych do nauki religii w Newcastle (Anglia) ${ }^{89}$.

Wystawy książek były jedną z najczęściej odnotowywanych imprez w periodykach, co może świadczyć o szczególnej roli tej formy upowszechniania druków. Ekspozycje - często łączone z innymi pokazami lub wystąpieniami - były w pierwszych latach po wojnie sposobem na prezentację kultury w ogóle.

\section{Nagrody i konkursy}

Promocji książki służyły też wiadomości prasowe o nagrodach i konkursach literackich. Informacja o pierwszych nagrodach z dziedziny literatury przyznanych przez departament literatury przy Ministerstwie Kultury i Sztuki ukazała się

${ }^{83}$ Tamże, „TW” 1947 nr 25 s. 8.

${ }^{84}$ Kronika zagraniczna, „TW” 1947 nr 30 s. 2.

${ }^{85}$ Przeglad kulturalny, „TW” 1947 nr 37 s. 8.

${ }^{86}$ W.B., Wystawa, ,TW” 1948 nr 20 s. 8.

${ }^{87}$ Przegląd kulturalny, „TW” 1947 nr 44 s. 8. Zbiory Ossolineum dotarły do Wrocławia w 1946 r., natomiast oficjalne wznowienie działalności nastąpiło nieco później.

${ }^{88}$ Tamże, „TW” 1948 nr 8 s. 8.

${ }^{89}$ Przegląd kulturalny, „TW” 1947 nr 49 s. 6; Przegląd kulturalny, tamże, nr 50 s. 12; Kronika kulturalna, „TW” 1948 nr 9 s. 8; Ze świata katolickiego, „GK” 1948 nr 21 s. 192. 
w Kronice „Tygodnika Powszechnego”. Wyróżniono m.in. Artura Górskiego za książkę Niepokój naszego czasu i Zofię Żeleńską za opiekę nad spuścizną literacką po mężu ${ }^{90}$. Przyznanie nagrody Górskiemu, jak czytamy w następnej notatce, „spowodowało gwałtowne ataki” na jego osobę oraz na dyrektora departamentu literatury w Ministerstwie. W związku z tym członkowie krakowskiego oddziału Związku Zawodowego Literatów Polskich zaoponowali odezwą o następującej treści: „W numerze $10<<$ Naprzodu $>>$ z dnia 1 maja br. [1945 - E.K.] ukazała się notatka dra Bolesława Drobnera, w której w związku ze sprawą nagrody literackiej dla A. Górskiego, nazwano dyrektora departamentu literatury w Ministerstwie Kultury i Sztuki, Kazimierza Czachowskiego $<<$ faszystą względnie obrońcą faszysty $>>$. Nie wnikając $\mathrm{w}$ motywy, które spowodowały przyznanie nagrody A. Górskiemu, ani też w konsekwencje urzędowe wobec dyrektora departamentu literatury, walne zebranie stwierdza, że notatka dra Drobnera, zarówno w formie jak i treści, nosi znamiona krzywdzącego i bezpodstawnego oskarżenia przeciwko pisarzowi, którego zasługi jako krytyka i organizatora życia literackiego są równie niewątpliwe, jak i jego przekonania demokratyczne" Towarzystwo Historyczne podało do wiadomości ustanowione przez Ministra Oświaty nagrody za prace z zakresu historii Ziem Odzyskanych wydane w latach 1945-1948, o czym powiadamiano w czasopiśmie ${ }^{92}$. Przedstawiono również obszerne zestawienie nagród państwowych przyznanych przez Prezydium Rządu w 1949 r., m.in. w dziedzinie literatury ${ }^{93}$. Z mniej ważnych wyróżnień zwrócono uwagę na nagrodę naukową miasta Poznania i nagrodę literacką miasta Szczecina w tym samym roku'

Szerzej ustosunkowano się w „Tygodniku Powszechnym” do francuskich nagród literackich w 1948 r. i 1950 r. Zofia Starowieyska-Morstinowa przybliżyła tematykę powieści wyróżnionych nagrodami Des Deux Magots, Prix Interallié i Prix Goncourt ${ }^{95}$. W przeglądzie nagród książkowych znalazły się również dzieła uhonorowane Grand Prix krytyki literackiej, Prix Rabelais, Prix Paul Valéry czy Grand Prix Littéraire de la Ville de Paris ${ }^{96}$. Wśród nagrodzonych we Francji powieści znalazła się m.in. Cytadela Antoniego de Saint-Exupéry, o czym donoszono w Kronice francuskiej ${ }^{97}$. Czytelnicy mogli dowiedzieć się także o zdobytej przez 51-letniego księgarza i poetę Philippe Chabanoix wielkiej nagrody literackiej miasta Paryża ${ }^{98}$.

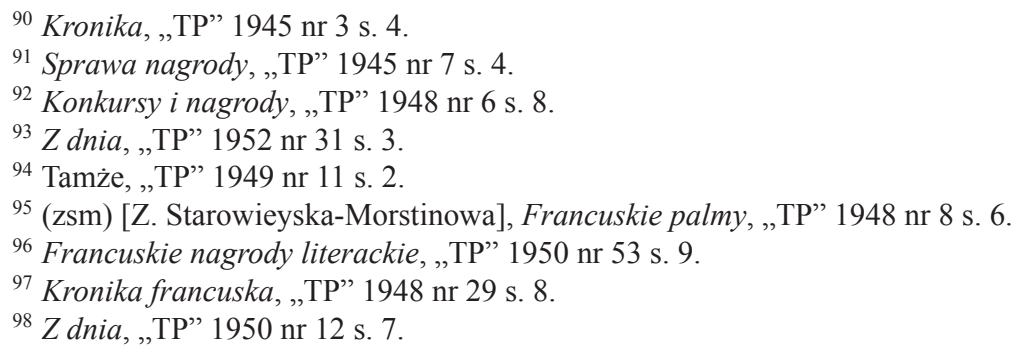


Wśród zagranicznych wyróżnień odnotowanych w „Tygodniku Powszechnym" wymienić można przyznaną w październiku $1951 \mathrm{r}$. w niedawno utworzonej NRD doroczną nagrodę państwową $\mathrm{w}$ dziedzinie literatury ${ }^{99}$. W dziale $Z$ dnia wydrukowano ponadto długą listę 16 nagród stalinowskich przyznanych „Za wybitne prace w dziedzinie literatury i sztuki” w roku 1949 w ZSRR ${ }^{100}$.

Nagrody literackie polskich miast w 1948 r. wymieniła redakcja „Tygodnika Warszawskiego" w Kronice kulturalnej. Prenumeratorzy mogli dowiedzieć się m.in. o przyznaniu przez Urząd Wojewódzki w Białymstoku sumy 50 tys. zł J. Karpińskiemu za książkę Białowieża, będącą pierwszą powojenną pracą naukowo-literacką poświęconą Białostocczyźnie ${ }^{101}$. Ukazała się także informacja o tym, że spośród czterech kandydatur do nagrody literackiej miasta Warszawy jednogłośnie wybrano książkę Kazimierza Brandysa Miasto niepokonane, w której autor opisał atmosferę panującą w stolicy w czasie okupacji ${ }^{102}$. W kolejnej kronice powiadomiono o wydanych jej przekładach w języku serbskim, czeskim i francuskim ${ }^{103}$. Jury wyróżniające twórców literatury miasta Katowic nagrodziło za całokształt działalności Jana Brzozę ze szczególnym uwzględnieniem mającej się wkrótce ukazać powieści Ziemia ${ }^{104}$. Wojewódzka Rada Narodowa w Lublinie przyznała z kolei nagrodę naukową ks. L. Zalewskiemu - prezesowi Towarzystwa Przyjaciół Nauk i założycielowi Lubelskiego Towarzystwa Miłośników Książki - za przeszło 60 pozycji wydawniczych, a głównie za prace Chłop bibliofil z XV w. i Orlęta Lubelskie. Nagrodę literacką otrzymał natomiast wiceprezes Związku Literatów Lubelskich F. Araszkiewicz za prace z dziedziny krytyki literackiej ${ }^{105}$. Czytelnicy zostali też powiadomieni o jednej nagrodzie zagranicznej - miasta Sofii, którą uzyskał młody poeta bułgarski Mikołaj Marangoza za poemat zatytułowany Opowieść o biatym domu.

Kilka informacji wydrukowanych na łamach "Tygodnika Powszechnego" i „Tygodnika Warszawskiego” dotyczyło różnego rodzaju ogłoszonych konkursów. Jury powołane przy Instytucie Wydawniczym Nasza Księgarnia w konkursie na powieść dla dzieci przyznało nagrody J. Korczakowskiej za Pałac pod grusza, K. Dębskiej za Kwiaty matki, B. Brodeckiej za Daleka drogę przed nami i K. Kieniewiczowi za Psy wielkiego Wau ${ }^{106}$.

Książki nagrodzone mogły być dobrą propozycją lekturową dla wybredniejszych czytelników. Mogli oni krytycznie ocenić poziom wyróżnionych tytułów. Była to niewątpliwie ciekawa forma promocji wydawnictw. Każdy

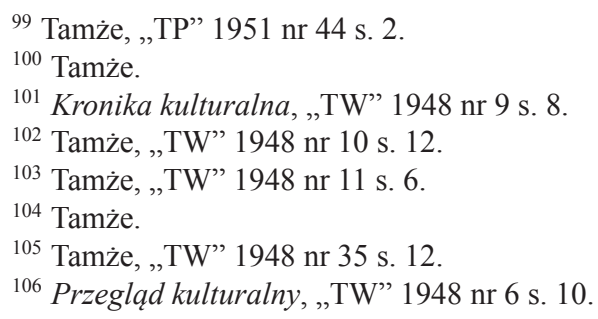


z przedstawionych wyżej sposobów upowszechniania tytułów książkowych, jak wynika z doniesień prasowych, znajdował w latach 1945-1953 swoich zwolenników wśród organizatorów i był odpowiednim sposobem prezentowania kultury.

\subsection{Notatki o książkach}

Propagowaniu zagadnień książki na łamach wybranych pism służyły również zwięzłe notki różnorakiej treści pojawiające się $\mathrm{w}$ niektórych działach i rubrykach. Pod względem częstotliwości ich występowania znów przodował „Tygodnik Powszechny”. Informowano bowiem o losach książek, podawano ciekawostki i sprostowania, niejednokrotnie ośmieszano niedorzeczne opinie wygłaszane przez publicystów obozu marksistowskiego.

W jednej z notatek czytamy o „dramatycznych przejściach” towarzyszących napisanej w czasie wojny książce Daniela-Ropsa Od Abrahama do Jezusa. Została ona wydana w czasie okupacji Francji za zgodą cenzorów niemieckich, lecz w lipcu 1943 r., po zorientowaniu się przez Niemców, że dopuszczono do druku „dzieło obrazujące wielkość Izraela”, gestapo zniszczyło cały nakład. Kolejne wydanie mogło ukazać się dopiero w 1945 r. w oswobodzonej już Francji107. Przy okazji ożywionej dyskusji na temat wyroku norymberskiego zacytowano wypowiedź londyńskiego korespondenta paryskiego dziennika „L'Ordre”, który stwierdził, że najlepszym komentarzem do procesu przeciwko niemieckim zbrodniarzom była książka o tematyce obozowej Zofii Kossak-Szczuckiej $Z$ otchłani ${ }^{108}$. O przekładach Psałterza Dawida, które nie oddawały należycie „myśli hebrajskiego oryginału" i o nowym tłumaczeniu łacińskim, będącym odpowiednią postawą do kolejnych wydań w językach nowożytnych, dowiadujemy się z notatki Przeglądu religijnego ${ }^{109}$. Na łamach „Tygodnika Powszechnego" ukazała się też wiadomość o niepełnej informacji wydrukowanej w „Kuźnicy” na temat wydania przez Państwowy Instytut Wydawniczy wraz z Czytelnikiem wszystkich ważniejszych dzieł Henryka Sienkiewicza z pominięciem Trylogii ${ }^{110}$. Podano również przedruk artykułu z „L'Osservatore Romano” o powołaniu komisji do opracowania nowych podręczników szkolnych w Japonii jako efekt protestu członków Narodowego Komitetu Katolickiego przeciw wprowadzeniu pomocy do nauki biologii będących wyrazem materialistycznego światopoglądu ${ }^{111}$. Pojawił się też komentarz odnośnie do reklamowanej w „Odrodzeniu” książki kucharskiej pt. Oszczędna kuchnia, które to „dzieło zawierało niemal wszystkie działy życia”, jakie powinny

\footnotetext{
107 Z zachodu, „TP” 1946 nr 9 s. 8.

108 jas., Głos kultury łacińskiej, „TP” 1946 nr 47 s. 10.

${ }^{109}$ Przegląd religijny, „TP” 1947 nr 18 s. 9.

${ }^{110}$ J.K., Ceterum censeo, ,TP” 1948 nr 34 s. 12.

111 Kronika religijna, „TP” 1948 nr 39 s. 8.
} 
„interesować każdą współczesną kobietę” począwszy od sztuki gotowania, robienie wódek, współżycia małżeńskiego i zapobiegania ciąży. Publicysta „Tygodnika Powszechnego” zaopiniował ją następująco: „Oszczędna kuchnia jest o tyle nieoszczędna, że kosztuje 2000 zł” zapytując jednocześnie, kto przydzielił „papier, drukarnie i litografie" na druk dobrych rad co do sztuki robienia wódek oraz zapobiegania ciąży ${ }^{112}$. Zastrzeżenie ,Z punktu widzenia racjonalnej polityki kulturalnej" przy okazji wydania w Książce i Wiedzy tomu Opowieści Aleksandra Puszkina zgłosił publicysta „Tygodnika Powszechnego". Zaznaczył, że połowę pozycji wydawniczej zajęła opowieść Córka kapitana w przekładzie Stanisława Strumph-Wojtkiewicza, pomimo że rok wcześniej ta sama pozycja ukazała się nakładem wydawnictwa Władysława Bąka w serii klasyków rosyjskich w thumaczeniu T. Stępniewskiego. Stwierdził przy tym: „Wydaje się, że coś tu jest nie w porządku. Zmarnowany czas jednego z tłumaczy (boć dwa przekłady na razie na pewno nie są potrzebne), zmarnowano też w pewnym sensie papier (bo ciągle jest go za mało, by zaspokoić wszystkie potrzeby rynku czytelniczego), stworzono wreszcie niepotrzebną wzajemną konkurencję obu książek" "113. Za organem duńskich katolików „Katolsk Ugebiad” donoszono o prawnych podstawach do wszczęcia procesu o fałszerstwo sfilmowanej powieści kardynała Wisemana zatytułowanej Fabiola. Wprowadzono nie tylko nowego bohatera głównego, ale też wymyślono trywialną scenę miłosną z tytułową bohaterką ${ }^{114}$. Sprostowano również wiadomość, wydrukowaną w jednym z numerów "Słowa Powszechnego", jakoby „pierwszą polską książką" o filmie była praca Jerzego Giżyckiego Jak powstaje film. Podpisany pseudonimem Dzięcioł przypomniał wydaną w $1924 \mathrm{r}$. rozprawę Karola Irzykowskiego Dziesiąta muza - zagadnienia estetyczne kina ${ }^{115}$.

Ciekawostką były informacje o zbiorze „książek mówiących” w waszyngtońskiej Bibliotece Kongresowej, do którego doszła także Biblia utrwalona na 135 dwustronnych płytach ${ }^{116}$. Ankieta przeprowadzona w księgarniach w Bonn wykazała, że wśród nowości powojennych przeważają książki o tematyce niemieckiej związanej z kampanią afrykańską, klęską Niemiec i osobistościami hitlerowskimi ${ }^{117}$. Bibliofil angielski Alon Keon, znalazłszy egzemplarz książki Hale’s Chronicle wydanej w 1550 r. z notatkami do dramatów, stwierdził, że należały one do Shakespeare'a, co wywołało poruszenie wśród szekspirologów ${ }^{118}$. Z jednej z notatek „Głosu Katolickiego" wiadomo było, że kartę tytułową angielskiego dzieła, poświęconego życiorysom wielkich osobistości współczesnych, przyozdobiono „nowym

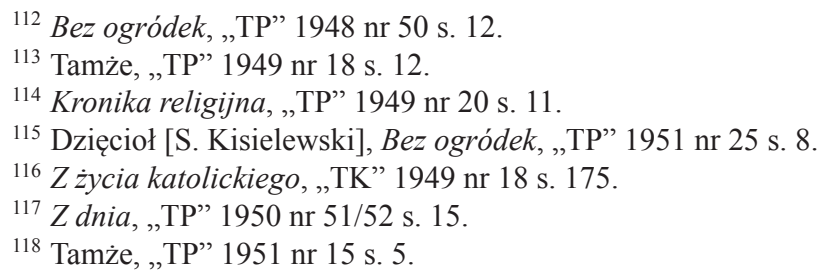


i kolorowym" portretem Ojca świętego ${ }^{119}$. Redakcja tegoż pisma poinformowała również o XIV-wiecznym psałterzu wykonanym przez artystów francuskich dla księżniczki Normandii, córki króla czeskiego Jana Luksemburskiego i małżonki króla Jana, sprzedanym za 16 tys. funtów angielskich ${ }^{120}$. Na łamach „Znaku” ukazała się natomiast notka następującej treści: „Rzymski Instytut Patologii Książki w ostatnich miesiącach leczył, a raczej $<<$ wskrzeszał $>>$ setki bezcennych białych kruków, zniszczonych w klasztorze Monte Cassino. Instytucja ta, $<<$ szpital książek >>, o światowym zasięgu działania, zalicza do swoich słynnych $<<$ pacjentów $>>$ m.in. kodeks cesarza Justyniana z VI w., rękopis wyblakły aż do nieczytelności, który w laboratorium Instytutu przy użyciu odpowiednich chemikaliów przywrócono nieomal do pierwotnego wyglądu"'121.

W „Głosie Katolickim” podano informację o egzemplarzach Pisma świętego udostępnianych za darmo w kawiarniach, restauracjach i innych miejscach publicznych z inicjatywy francuskiego przemysłowca, który na ten cel przeznaczył 10 tys. franków ${ }^{122}$. Za „karygodne niedbalstwo” uznano w notatce w ,Tygodniku Katolickim" brak u modlących się w kościele książeczek do nabożeństwa, które ułatwiałyby skupienie ${ }^{123}$. Upowszechniany przez biskupa Griffina w Trenton (Stany Zjednoczone) mszalik przyczynił się natomiast do „wtajemniczenia wiernych w ducha i piękno obrzędów mszy świętej" 124 .

Niekiedy czytelnicy ustosunkowywali się do szczegółowych informacji zawartych w publikacjach. Przykładowo w Listach do redakcji znalazło się sprostowanie do artykułu wydrukowanego w „Tygodniku Powszechnym”, w którym autor pisał na temat portretu pastora Michała Mostnika trzymającego książkę $\mathrm{z}$ tekstem dwu pierwszych przykazań „w dziwnym języku przypominającym polski”. Czytelnik potwierdził, że był to rodzimy język pisany alfabetem gotyckim ${ }^{125}$. Innym razem w notatkach prasowych doniesienia nt. książek ujmowano statystycznie, jak np. poinformowano o skierowanym przez rząd Ukraińskiej Republiki Radzieckiej transporcie zawierającym 67 tys. książek ze zbiorów lwowskiego Ossolineum do Polski, edycji podręczników na rok szkolny 1947-1948 liczącej ponad 11 mln egzemplarzy czy 718 tytułach wydanych w 1948 r. dla katolików w Stanach Zjednoczonych ${ }^{126}$.

Żartobliwie o odbiorze wydanej przez siebie książeczki Warszawski dowcip w walce napisał Marian Ruth Buczkowski. Zbiór zawierał anegdoty, satyry i „inne

119 Ze świata katolickiego, „GK” 1948 nr 16 s. 147.

${ }^{120}$ Tamże, „GK” 1948 nr 33 s. 288.

${ }^{121}$ Z nowości naukowych, „Znak” 1949 nr 7 s. 616.

122 Ze świata katolickiego, „GK” 1948 nr 39 s. 336.

${ }^{123}$ Z książka do kościoła, „TK” 1947 nr 41 s. 279.

${ }^{124}$ Mszalik za granica i u nas, „TK” 1949 nr 15 s. 137.

${ }^{125}$ A. Jureń, Listy do redakcji, „TP” $1952 \mathrm{nr} 24$ s. 9.

${ }^{126}$ Co stychać w świecie, „TK” 1947 nr 11 s. 88; tamże, nr 40 s. 276; Z życia katolickiego, „TK” 1949 nr 11 s. 104. 
przejawy pomysłowości”, będące „ważnym elementem psychologicznej walki z okupantem”. Autor stwierdził przy tym: „Starałem się zarejestrować po prostu wielką bezimienną twórczość i geniusz warszawskiej ulicy. Z natury rzeczy praca bezstronna, dokumentarna i bez pretensji. Była oczywiście w cenzurze. Wydawałoby się, że oprócz Niemców nie obruszy nikogo" "27. Tymczasem w jednym z numerów „Kuźnicy” ukazała się notatka, w której podpisany rm „wywęszył w książce sens polityczny zupełnie wyraźny” i „użył sobie co wlezie” na autorze nazywając go „kombinatorem i warszawskim cwaniakiem”. „Głębszą uwagą" recenzenta było zaś skonstatowanie, że „fasonowi młodzieńcy kończyli w Oświęcimiu, ale tylko przez własną głupotę, nic nie zdziaławszy" ${ }^{28}$. W odpowiedzi autor nie zgadzając się z publicystą marksistowskiego organu „,przyznał się” do bycia „fasonowym młodzieńcem”, który stracił w okresie okupacji pięć osób z najbliższej rodziny. Zauważył ponadto w panu rm „,wielkie kwalifikacje na wysokie stanowisko w resorcie kultury" ${ }^{\prime 29}$. W żartobliwym tonie utrzymana była również notatka o rzekomym plagiacie, który zarzucił Stefanowi Kisielewskiemu Adam Krzyżanowski, twierdząc, że niektóre zdania w jego felietonie „do złudzenia przypominały myśli” zawarte w książce Chrześcijańska moralność polityczna. Kisielewski twierdząc, że książki nie czytał, odpowiedział: „moje zmartwienie z powodu oskarżenia o plagiat jęło gwałtownie maleć, rosła natomiast jak na drożdżach satysfakcja, że oto ja pospolity ciura dziennikarski, wpadam na te same myśli co uczony profesor, chociaż wcale żeśmy się nie porozumiewali" 130 .

Na zarzuty stawiane przez Jantę-Połczyńskiego w reportażu zamieszczonym w paryskiej „Kulturze” książce Na tropach Smętka, jakoby stanowiła ona ,podstawę do prześladowań", zareagował Melchior Wańkowicz. Swoją odpowiedź zawarł w kilku punktach, dając za podstawę orzeczenie Sądu Obywatelskiego, wydane jeszcze przed II wojną światową. Swoją obronę umotywował też faktem, że z powodu książki nie spadła jeszcze na nikogo żadna represja ${ }^{131}$. Jan Marian Święcicki ubolewał natomiast, że w okresie „braku papieru na najpilniejsze wydawnictwa” znalazło się go jednak dosyć na wznowienie książki Malżeństwa koleżeńskie B. Lindsaya. Zapytywał jednocześnie, komu zależało na tym, aby propagować „typowy produkt moralnego rozkładu”, podczas gdy jeszcze w przedwojennej „Tęczy” cytowano słowa autora, który odwołał poglądy wyrażone w tej książce. Pisał: „Czyżby wydawcy wcale nie wiedzieli o zmianie poglądów Lindsaya, czy też po prostu woleli je przemilczeć”132.

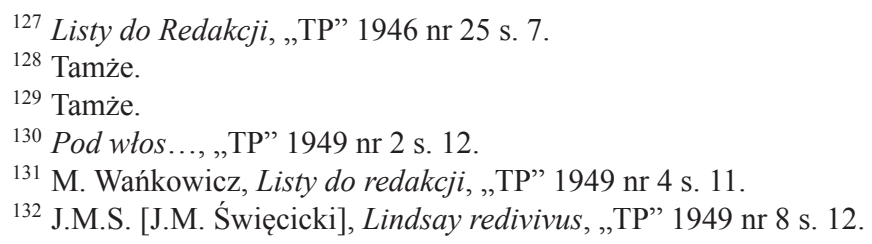


Drobne i różnorodne ogłoszenia prasowe dotyczące książek były często krótkie i ciekawie napisane, natomiast uwagi oraz sprostowania niekiedy cenne. Na uwagę zasługiwały też polemiczne głosy przy różnych okazjach związanych z książkami. Ten sposób propagowania wydawnictw sugerował czytelnikom pewne tytuły jakby niezauważalnie, w lekkim i przyjemnym tonie, mogąc również przyczynić się do upowszechnienia lektury.

\subsection{Ludzie książki}

Warto omówić osobno wspomnienia i wzmianki o bibliotekarzach, bibliografach, drukarzach, księgarzach oraz wydawcach, mimo że nie zajęły wiele miejsca na łamach katolickich czasopism społeczno-kulturalnych. Dłuższe lub krótsze wypowiedzi najczęściej występowały na łamach „Tygodnika Powszechnego”.

Zofia Sutorowska pracująca wespół z Wacławem Borowym w Bibliotece Uniwersyteckiej w Warszawie (BUW) napisała o nim pośmiertne wspomnienie. Przedstawiając go jako „wzór bibliotekarza” i „mistrza”, wymieniła wśród jego zalet umiejętności kierownicze i pedagogiczne. Do zasług Borowego zaliczyła unowocześnienie pracy w książnicy, dobre wychowanie przyszłych bibliotekarzy oraz stosowanie naukowych zasad pracy, przy czym „najbardziej pouczający był jego własny przykład"'133. Z pośmiertnej teki Tadeusza Makowieckiego opublikowano przemówienie poświęcone osobie i dziełu Borowego, które zostało wygłoszone na posiedzeniu Towarzystwa Naukowego Warszawskiego w 1951 r. Została w nim doceniona instrukcja katalogowa BUW wydana w 1926 r. pt. Prolegomena do wszelkiej przyszłej instrukcji katalogowej. Prelegent podkreślił również swoisty styl pracy bibliotekarskiej, którą nazywano powszechnie „szkołą Borowego”. Podał też mało znany fakt z czasu okupacji niemieckiej, kiedy to bibliotekarz zamieszkał w piwnicy, broniąc zbiorów książnicy ${ }^{134}$. Stwierdził też: „Widzieliśmy, jak ten człowiek wyraził się przez bibliotekarstwo, przez różne jego prace. A przecież bibliotekarstwo nie było w jego życiu głównym polem. Na pytanie, kim był Wacław Borowy - nasuwają się odpowiedzi: $<<$ krytyk, badacz, pisarz, profesor, redaktor, wydawca $>>$, a dopiero po nich $<<$ bibliotekarz $>>$. Był to boczny tor, czwarty czy piąty"135. Konrad Górski upamiętnił natomiast pośmiertnie sylwetkę badacza literatury, sztuki oraz kustosza i wicedyrektora BUW, zmarłego niedługo po Borowym - Tadeusza Makowieckiego (1900-1952). W artykule skupił się na omówieniu dorobku naukowego i literackiego oraz najmniej znanej dziedziny jego twórczości, jaką była poezja ${ }^{136}$.

\footnotetext{
${ }^{133}$ Z. Sutorowska, Wspomnienie o dobrym bibliotekarzu, „TP” $1950 \mathrm{nr} 48$ s. 4.

${ }^{134}$ T. Makowiecki, Borowy - bibliotekarz, „TP” 1952 nr 42 s. 3-4.

135 Tamże, s. 4.

${ }^{136}$ K. Górski, Tadeusz Makowiecki, „TP” 1952 nr 24 s. 5-6.
} 
W Listach do redakcji „Tygodnika Powszechnego” zamieszczono sprostowanie nadesłane przez niejakiego „Kustosza”, który zareagował na wiadomość opublikowaną w tygodniku „Świat”, iż drukarzem pierwszej książki w Polsce był Kasper Hochfeder; korespondent wytknął błąd, podając, że był nim Kasper Straube ${ }^{137}$. Redakcja pisma na początku 1952 r. uczciła pięćdziesięciolecie pracy Adama Półtawskiego artykułem o jego dorobku na polu artystycznym i drukarskim. Podkreślono jednocześnie jego zasługi w utworzeniu tzw. polskiej antykwy, nazwanej jego imieniem ${ }^{138}$. We wrześniu tegoż roku ukazała się wiadomość o zgonie artysty ${ }^{139}$. Działalność znanego wszystkim bibliofilom przed wojną Samuela Tyszkiewicza, nazywanego wedle starej drukarskiej tradycji Magisterem Typographusem, przedstawiono czytelnikom „Głosu Katolickiego”. Jak donoszono, druki z jego oficyn we Florencji i Nicei wydawane w niewielkich nakładach, na specjalnie czerpanym papierze, były „prawdziwymi dziełami sztuki”. Wśród nich wyróżniły się pięknie ozdobione drzeworytami książki Marii Ładziny. A były to książeczki do nabożeństwa Pójdźmy za Nim oraz Maryja, nasza Matka w niebie ${ }^{140}$.

W pośmiertnym wspomnieniu Mieczysława Niklewicza (1880-1948) czytelnicy „Tygodnika Warszawskiego" poznali go jako wydawcę antyniemieckiej „Gazety Warszawskiej”, miesięcznika „Przegląd Narodowy”, tygodnika „Sprawa Polska” i „Dziennika Polskiego”, natomiast podczas ostatniej wojny jako wydawcę pism konspiracyjnych ${ }^{141}$. O zasługach trzech „poznańskich ludzi książki” pracujących w XIX w. dla dobra polskiego księgarstwa napisał artykuł Stanisław Krokowski na łamach „Głosu Katolickiego”. Swoją wypowiedź rozpoczął od stwierdzenia: „Są ludzie, którzy do tego stopnia kochają książki, że poświęcają im życie. Z tych właśnie ludzi wywodzą swój ród, owi księgarze zamiłowani w swoim zawodzie, miłujący książkę ponad wszystko. Książka jest, była i będzie dla nich cennym uśmiechem i rozkoszą życia, darem bogów, a na ostatku dopiero przedmiotem zwykłego handlu i drogą do majątku. Dziś coraz mniej jest takich miłośników książki"142. Do bibliofilów zaliczył założyciela pierwszej polskiej księgarni w Poznaniu „od czasu księgarni Tomasza Szumskiego" - Jana Konstantego Żupańskiego, „organizatora poznańskiego dziennikarstwa" Walentego Stefańskiego i gorliwego działacza oświatowego wśród ludu ks. Franciszka Bażyńskiego. Pierwszy z nich, wydając „,bez wytchnienia” polskie powieści, poezje, rozprawy, dzieła naukowe, dramaty, traktaty, thumaczenia i pisemka okolicznościowe „łatał rozlatujący się budżet” księgarni, zdobywając

\footnotetext{
${ }^{137}$ Listy do redakcji, ,TP” 1952 nr 45 s. 7.

138 JWW, 5 lat pracy Adama Półtawskiego, ,TP” 1952 nr 10 s. 6.

139 Z dnia, „TP” 1952 nr 39 s. 5.

${ }^{140}$ Ze świata katolickiego, „GK” 1951 nr 46 s. 380.

${ }^{141}$ S.K. [S. Krokowski], Mieczysław Niklewicz, „TW” 1948 nr 14 s. 6.

142 S. Krokowski, O poznańskich ludziach książki, „GK” 1948 nr 14 s. 128.
} 
z trudem jałowy ówcześnie rynek wydawniczy. Starał się przy tym wypłacać autorom honoraria. Ciekawostką było, że „Jedynie szlachetny Lelewel nic nie chciał brać, oświadczając wielkodusznie Żupańskiemu w Brukseli: $<<$ Jakże mam brać od ciebie pieniądze, skoro wiem, że na sprzedaży tracisz $>>{ }^{\prime 43}$. Stefański prowadzący działalność polityczną w Wielkopolsce oprócz założonej księgarni wsławił się jako propagator polskiej myśli poprzez wydawanie prasy („Orędownika”, „Gazety Polskiej”, „Gońca Polskiego”, „Wiarusa”, „Wielkopolanina”). Ostatni z nich, duchowny, wydał natomiast około 400 książek rozmaitej treści „mających przede wszystkim naukę i rozrywkę na celu”. Kończąc wypowiedź, Krokowski nazwał ich „prawdziwymi miłośnikami dobrej książki”|44. Redakcja „Tygodnika Powszechnego" uczciła natomiast pamięć zmarłego księgarza i wydawcy Gustawa Wolffa (1872-1951), kontynuującego ze „znawstwem” pracę swego ojca Roberta, założyciela wraz z Gustawem Gebethnerem w 1857 r. znanej księgarni warszawskiej. We wspomnieniu skupiono się przede wszystkim na jego działalności tłumacza liryki europejskiej ${ }^{145}$.

Bogatą działalność wydawniczą oraz liczne publikacje z zakresu teatru i bibliologii Mieczysława Rulikowskiego przedstawiłPiotr Grzegorczyk. Przypomniał jego wykłady na Wolnej Wszechnicy Polskiej oraz zainteresowania z zakresu czytelnictwa, księgarstwa, produkcji wydawniczej oraz statystyki druków ${ }^{146}$.

Wzmiankę o Konstantym Wurzbachu (1818-1893) zamieścił Ludwik Szczepański, pisząc: „Wurzbach pełnił w latach 1836-1844 służbę wojskową w Krakowie i Lwowie, zamienił jednak bluzę oficerską na surdut bibliotekarza Biblioteki Uniwersyteckiej we Lwowie, a wreszcie został dyrektorem Biblioteki Cesarskiej w Wiedniu, gdzie rozwijał bardzo żywą działalność jako ceniony poeta oraz jako niestrudzony bibliograf i historyk"147. Głównie w „Tygodniku Powszechnym" podawano do wiadomości odbiorców informacje o zgonach ludzi związanych z książką. Przykładowo w latach 1949-1953 odnotowano w pośmiertnych notatkach w rubryce $Z$ dnia m.in. śmierć bibliofila i sekretarza Towarzystwa Miłośników Książki Justyna Sokulskiego, odejście długoletniego dyrektora Biblioteki Jagiellońskiej Edwarda Kuntzego, zgon wspomnianego dyrektora Instytutu Bibliograficznego Biblioteki Narodowej w Warszawie oraz autora szeregu prac z bibliografii i bibliologii Adama Łysakowskiego. $Z$ tego samego powodu pojawiło się również nazwisko wybitnego historyka, a zarazem dyrektora Biblioteki Kórnickiej Stanisława Bodniaka oraz historyka literatury, księgoznawcy i pracownika Biblioteki Jagiellońskiej Karola Badeckiego ${ }^{148}$.

143 Tamże.

144 Tamże.

${ }^{145}$ Gustaw Wolff, „TP” 1952 nr 5 s. 5.

${ }^{146}$ P. Grzegorczyk, Podzwonne M. Rulikowskiemu, „TP” 1951 nr 9 s. 5.

${ }^{147}$ L. Szczepański, , Z zamierzchłego miasta królów”, „TP” $1950 \mathrm{nr} 40$ s. 10.

${ }^{148} Z$ Z dnia, „ТP” 1949 nr 15/16 s. 5; tamże, „TP” $1950 \mathrm{nr} 24$ s. 3; tamże, „TP” $1951 \mathrm{nr} 4$ s. 3; tamże, „TP” 1952 nr 42 s. 2; tamże, nr 47 s. 5; tamże, „TP” 1953 nr 6 s. 3. 
Rzadziej w katolickich czasopismach drukowano nekrologi. Przykładem może być nekrolog długoletniego księgarza, pracownika i kierownika warszawskiego oddziału Księgarni Świętego Wojciecha - Henryka Świdnickiego. Dziękowano w nim m.in. za jego ,gorące umiłowanie zawodu” i ,apostolstwo dobrej książki”"149. W 1951 r. pożegnano księgarza i wydawcę, tym razem kierownika Księgarni Świętego Wojciecha w Poznaniu, Stefana Gąsiorowskiego, docenionego za „niestrudzoną i owocną pracę dla książki”, szczególnie katolickiej $^{150}$.

Wśród nielicznych ludzi książki, których życie i działalność odnotowano w katolickich czasopismach lat 1945-1953, znalazły się wybitne nazwiska. Biografie współczesnych bibliotekarzy oraz ich zasługi ukazywano głównie przez pryzmat osobistej znajomości, natomiast postacie historyczne poprzez trwały dorobek kulturalny dla potomnych.

\subsection{Ogólne rozważania o książce}

Książka była też przedmiotem teoretycznych rozważań na łamach wybranych pism. Szczególne miejsce zajęły opinie na temat Biblii, jej przekładów i interpretacji. W kręgu zainteresowań znalazły się jednocześnie zamiłowania bibliofilskie, pisano o znaczącej roli książki w rozwoju kultury i edukacji. Niejednokrotnie przedstawiono trudne losy księgozbiorów w czasie okupacji hitlerowskiej i tuż po jej zakończeniu. Domagano się wreszcie poszanowania dla ksiąg.

\section{Biblia jako ,księga ksiąg”}

Marian Rzeszewski podjął temat rozumienia Pisma świętego. Wskazał na odmienne jego interpretacje u katolików i wyznawców protestantyzmu, przypominając o zasadach uwzględnianych w jego odbiorze oraz nieomylnym charakterze autorytetu urzędu Kościoła katolickiego pod tym względem. Wypowiedział się także na temat wyłącznie naukowego badania $B i b l i i^{151}$. Z etymologicznym pochodzeniem pojęcia „ewangelia”, pierwotnymi zapiskami na papirusach, zagadnieniem jej autentyczności i autorstwa zapoznano w artykule zamieszczonym w „Tygodniku Katolickim”152. Józef Marian Święcicki zwrócił uwagę na Ewangelię jako na „książkę, która nas nigdy nie zawodzi, nie rozczarowuje, książkę, która przekracza wszystkie nasze najśmielsze wyobrażenia, książkę, która odkrywa

\footnotetext{
149 ,TW" 1946 nr 12 s. 8.

150 „TP” 1951 nr 16 s. 2.

${ }^{151}$ M. Rzeszewski, Autorytet Kościoła a Pismo św., „GK” 1946 nr 9 s. 67.

152 Ksiegi zawierające dobrą nowinę, ,TK” 1953 nr 7 s. 50.
} 
nam sens naszego życia i podaje niezawodny klucz do otworzenia zamkniętych przed człowiekiem bram szczęścia, książkę, której głównym bohaterem i autorem jest sam Bóg" ${ }^{153}$. Wartość historyczną i wiarygodność Ewangelii przedstawił ks. Jan Rosiak w „Przeglądzie Powszechnym” ${ }^{54}$. Na temat jej znaczenia w życiu człowieka wypowiedział się natomiast ks. Franciszek Blachnicki na łamach „Tygodnika Powszechnego" ${ }^{155}$. Z chronologią powstania czterech ksiąg ewangelicznych i ich charakterem (trzy z nich synoptyczne) zaznajomił odbiorców „Głosu Katolickiego" ks. Adam Pawłowski ${ }^{156}$.

Jubileusz 350-lecia wydania Biblii w przekładzie ks. Jakuba Wujka znalazł oddźwięk w postaci artykułów na łamach większości katolickich czasopism społeczno-kulturalnych. Przekłady Pisma św., począwszy od XII w. w Polsce do czasów współczesnych wraz z przedstawieniem okoliczności powstania „epokowego" thumaczenia polskiego opartego na Wulgacie, przedstawił ks. Walenty Prokulski na kartach „Przeglądu Powszechnego”. Ukazał jego wartość i sposób przekładu na konkretnych przykładach ${ }^{157}$. Zwrócił również uwagę na ogólną działalność pisarską tłumacza, stwierdzając: „Wujek profesor i kaznodzieja miał oczy otwarte na to, co działo się wówczas w kraju i za granicą. Widział, że innowiercy nie tylko głoszą kazania, lecz piszą i drukują książki, rozrzucają je i przez nie szerzą swą błędną naukę wszędzie. Wnet doszedł do przekonania, że nie wystarczy uczyć i kazać, ale trzeba pisać. Jedna dobra katolicka książka wydana przeciw błędnej nauce więcej znaczy, aniżeli tysiąc wygłoszonych kazań" 158. Najwięcej miejsca jubileuszowi poświęcono w „Tygodniku Powszechnym”. Rolę Biblii w ,przeciwstawieniu się wpływom Biblii protestanckich" i jej entuzjastyczne przyjęcie na gruncie polskim opisał ks. Eugeniusz Dąbrowski ${ }^{159}$. Z artykułu ks. Aleksego Klawka dowiadujemy się z kolei, że była to „książka polska najczęściej przedrukowywana" i mająca przez wieki największą liczbę nakładów, jak też o sporach teologicznych wokół niej i badaniach naukowych nad osobą i pracami ks. Wujka ${ }^{160}$. Uroczystości związane z jubileuszem opisał Jan Marian Święcicki stwierdzając za Tadeuszem Lehrem-Spławińskim, że „Biblia Wujka stanowi nie tylko ostateczną kodyfikację tekstu biblijnego w polskim thumaczeniu, ale jest jedną z najpopularniejszych u nas książek"161. O ogólnym uznaniu, jakim ks. Wujek cieszył się w XVI w., miał zaświadczyć fragment wstępu zacytowany w krakow-

\footnotetext{
153 J.M. Święcicki, Wieczna książa, „TK” 1950 nr 34 s. 255.

${ }^{154}$ J. Rosiak, Świadectwo ewangeliczne, „PP” 1952 nr 7/8 s. 37-59; tamże, nr 9 s. 113-141.

${ }^{155}$ F. Blachnicki, Ewangelia - forma życiowa człowieka, „TP” $1951 \mathrm{nr} 17$ s. 3, 10.

156 A. Pawłowski, Ewangelie św., „GK” 1949 nr 45 s. 430.

157 W. Prokulski, Wiekopomne dzieło, „PP” 1949 nr 11 s. 257-274.

158 Tamże, s. 263.

159 E. Dąbrowski, Znaczenie Biblii Wujka, ,TP” 1949 nr 48 s. 4-5.

160 A. Klawek, 350 lat Biblii Wujka, ,TP” 1949 nr 47 s. 1-2.

161 J.M.S. [J.M. Święcicki], Wujkowi w hołdzie, ,TP” 1949 nr 49 s. 7.
} 
skim tygodniku ${ }^{162}$, natomiast pisownię oryginalną odbiorcy mogli poznać dzięki wyjątkowi z tekstu wydrukowanego w „Tygodniku Katolickim”163.

Przekłady Pisma świętego dokonane w Polsce po wydaniu Biblii ks. Wujka ocenił w „Znaku” Artur Chojecki ${ }^{164}$, do którego wypowiedzi krytyczne sprostowanie napisał z kolei ks. Walenty Prokulski w „Przeglądzie Powszechnym”165. Wpływ „księgi ksiąg” na słownictwo i frazeologię języka polskiego jako cechę wskazującą na przynależność do kultury chrześcijańskiej starał się pokazać Jan Ujda czytelnikom „Głosu Katolickiego”"166. Przestrzegano również przed niedokładnym cytowaniem Pisma świętego i własną jego interpretacją ${ }^{167}$. Na temat wzrostu zapotrzebowania na nowe przekłady Biblii, a jednocześnie upowszechnianie jej tańszej wersji przez protestancki Światowy Związek Towarzystw Biblijnych, zwrócono uwagę w „Tygodniku Powszechnym”. Biblia protestancka, jak pisano, zawierająca liczne braki, błędy i niezgodności z katolicką egzegezą, „nie nadawała się do biblioteki katolickiej”. W celu udostępnienia właściwej wersji zaproponowano wydanie miliona egzemplarzy Nowego Testamentu w języku polskim ${ }^{168}$. Na łamach „Głosu Katolickiego” i „Tygodnika Katolickiego” ukazała się notatka o tej samej treści, w której ostrzegano przed „heretyckimi thumaczeniami” amerykańskimi i angielskimi Nowego Testamentu. Ze względu „na świadome i celowe sfałszowanie" tekstu zobowiązywano katolików do palenia tychże egzemplarzy. Czytamy również, że Pismo święte nieposiadające imprimatur „przestaje być Pismem świętym. Katolikowi zaś nie wolno takiej książki czytać, przechowywać, pożyczać i sprzedawać"169.

Tematyka biblijna zajęła szczególne miejsce na łamach omawianych pism $\mathrm{z}$ racji ich katolickiego profilu. W wypowiedziach starano się ukazać Pismo święte od strony historycznej, jak też podkreślić jego ogromną rolę w kulturze światowej i osobistym życiu człowieka. Osobną istotną kwestią było ustosunkowywanie się do jego przekładów, aż do zakazu korzystania z wersji niewłaściwych i błędnych.

\section{Bibliofilstwo}

Podstawową terminologię związaną z umiłowaniem ksiąg i jego istotą odbiorcy „Tygodnika Powszechnego" mogli poznać dzięki artykułowi O bibliofilstwie $^{170}$. Tadeusz Leszner na łamach „Głosu Katolickiego” pochwalił się natomiast

\footnotetext{
162 Wiek XVI o Wujku, „TP” 1949 nr 47 s. 2.

163 350-lecie Biblii ks. Wujka, „TK” 1949 nr 51 s. 450.

${ }^{164}$ A. Chojecki, W sprawie nowych przekładów Pisma świętego, „Znak” 1946 nr 3 s. 276-280.

${ }^{165}$ W. Prokulski, Ptaki ,niebieskie” czy ,powietrzne”?, „PP” 1948 nr 7 s. 84-91.

166 J. Ujda, Echa Pisma św. w języku polskim, „GK” 1949 nr 45 s. 432.

167 mad., Ostrożnie z Pismem św., „GK” 1948 nr 20 s. 182.

16825 mil. egzemplarzy, „TP” 1948 nr 38 s. 11.

169 „Pismo św.”, które trzeba spalić, „GK” 1947 nr 34 s. 282; „TK” 1947 nr 34 s. 239.

${ }^{170}$ Hapf., O bibliofilstwie, „TP” 1952 nr 26 s. 7.
} 
posiadaniem egzemplarza książki pt. Ex-librisy bibliotek polskich z XVII i XVIII wieku wydanej przez Wiktora Wittyga. Ten „ewenement dla ksiąg miłośnika” stanowił według niego materiał ikonograficzny do historii rozwoju w Polsce znaku książkowego ${ }^{171}$. W okresie powstania warszawskiego, piszący zmuszony do opuszczenia palącego się domu, ocalił tylko tę książkę z liczącego 30 tysięcy egzemplarzy prywatnego księgozbioru. Towarzyszyła mu ona do końca wojny m.in. podczas przymusowych robót w Niemczech i w czasie ucieczki ze szpitala, potwierdzając rzymską sentencję habent sua fata libelli. Po ustaniu działań wojennych książka stała się zaczątkiem na nowo tworzonej biblioteki prywatnej. Leszner ubolewał ponadto nad zniszczeniem przez okupanta niemieckiego setek tysięcy tomów, zwłaszcza starych druków stanowiących „cenne bibliofilskie osobliwości”. Konstatował przy tym: „Dźwignią największego, wszelkiego postępu umysłowego i moralnego jest książka; zniszczyć książkę to zniszczyć ducha"172. Za „grafomańskie wybryki” publicysta „Tygodnika Warszawskiego” uznał broszurkę księgarza i bibliofila Antoniego Trepińskiego zatytułowaną Polskie ostatki, tragedia ksiązki, z powodu następującego stwierdzenia: „Więcej były warte spalone bezcenne zbiory narodowe w podziemiach biblioteki Ordynacji Krasińskich w Warszawie, od istnień czterdziestu tysięcy żołnierzy armii powstańczej. Zaiste więcej były warte rękopisy zwiezione przedwcześnie z Rapperswilu i manuskrypty przechowywane w Bibliotece Narodowej, od stu tysięcy jakichkolwiek ludzi współczesnych"173. Oburzony stwierdzeniem Trepińskiego publicysta pisał: „Charakterystyczną cechą autora Ostatków polskich jest to, że swoją mizerotę wydał z niesłychaną pieczołowitością, na papierze bezdrzewnym, ze wszystkimi szykanami drukarskimi, że ozdobił ją doskonałymi rysunkami Głowackiego", konstatując na koniec: „Grafomani usiłują odruchowo nędzę swoich myśli przykryć bogactwem zewnętrznej formy [...]”'174.

Zamiłowania bibliofilskie różnych osób na terenach polskich na tle ogólnych dziejów książki przypomniała na łamach „Tygodnika Warszawskiego” Zuzanna Rabska. Za pierwszych miłośników ksiąg uznała benedyktynów przepisujących i sprowadzających rękopisy do swych klasztorów. Po nich zaś byli piętnastowieczni właściciele ksiąg dopominający się na drodze sądowej zwrotu pożyczonych egzemplarzy. Do grona bibliofilów zaliczyła również szesnastowiecznych drukarzy, króla Zygmunta Augusta i przedstawicieli rodów magnackich: Zamoyskich, Ossolińskich i Raczyńskich. Jak czytamy w artykule, kult książki osłabiły wojny prowadzone ze Szwedami, podczas których spłonęły liczne polskie księgozbiory. Zamiłowania bibliofilskie, zdaniem Rabskiej, odżyły za panowania Stanisława Augusta, a drukarstwo wieku XX zaznaczyło się dzięki dwóm krzewicielom

\footnotetext{
${ }^{171}$ T. Leszner, O losach pewnych ksiązek, „GK” 1945 nr 11 s. 7.

172 Tamże.

${ }^{173}$ Grafomańskie wybryki, „TW” 1946 nr 23 s. 8.

174 Tamże.
} 
„typograficznego piękna”: Wyspiańskiemu i Przesmyckiemu (Miriamowi). Tradycja gromadzenia ksiąg kontynuowana była w okresie międzywojennym; niestety działania wojenne i okres okupacji spowodowały wielkie straty materialne, a „książki ukazujące się [po zakończeniu działań wojennych - E.K.] w zgrzebnej szacie, urągały poczuciu piękna i były żałosną parodią dawnych świetnych tradycji polskiego miłośnictwa ksiąg"175. Ta sama publicystka wspomniała również o wznowieniu po ostatniej wojnie działalności Polskiego Towarzystwa Przyjaciół Książki w Paryżu. Opisując przebieg pierwszego spotkania odbytego w Bibliotece Polskiej, podała założenia kontynuacji szerzenia zamiłowania do pięknej książki i utrzymania na polu bibliofilstwa łączności z krajem ${ }^{176}$.

Aleksander Rogalski w jednym z artykułów przeprowadził rozważania nad wyborem jedynej książki do zabrania w czasie zagrożenia utraty życia. Pisał o swoistym pragnieniu posiadania ulubionej lektury w każdych warunkach: „dla wielu ludzi, głęboko związanych z kulturą, ta jedna jedyna książka, z którą się szło w ciemną przepaść dni przyszłych, którą się chciało zabrać, którą chciało się mieć przy sobie w celi więziennej, na ostatnie może dni życia" ${ }^{177}$. We wspomnieniach więziennych z czasu II wojny światowej ks. Ewarysta Nawrowskiego czytamy o skrzętnym chowaniu podarowanej mu Księgi psalmów w tłumaczeniu Leopolda Staffa. Notował w nich: „Psalmy ukryłem. Żyłem w ciągłej obawie, bo przecież dobrze wiedziałem, jaki los mnie czeka, w razie wykrycia, że przywłaszczyłem sobie własność państwową. Dwa razy gdy mówiono, że odbędzie się nocna rewizja w nocy, gdy wszyscy spali, książkę ukryłem w murze, w okrągłym otworze dla rury żelaznego piecyka. Drugim razem musiałem długo się mozolić, nim książeczkę, za głęboko wsuniętą, zdołałem uchwycić. Jeden z robotników uszył mi w płaszczu, którym co noc się przykrywałem, na dole, w rogu osobną kieszeń, w której książka była schowana. Nigdy jej nie wyciągałem, nikt w celi o niej nie wiedział" 178 .

Książkę jako „niezawodnego przyjaciela” i „,codziennego towarzysza” ukazano na łamach „Tygodnika Katolickiego”. Czytamy bowiem: „Można z nim zawrzeć głęboką przyjaźń bez pospolitych libacji, można mu nie ściskać dłoni ani się zwierzać ze swoich sentymentów, można mu nawet okazać niezadowolenie, gdy jest innych niż nasze przekonań, a on się za to nie obrazi, ani sprzeczać nie będzie..." 179 . W innym miejscu pisano o miłości do książki, jej poszukiwaniu, „magicznym uroku książkowych światów” oraz potrzebie powszechnego dostępu ${ }^{180}$.

${ }^{175}$ Z. Rabska, Kult ksiażki w Polsce, „TW” 1946 nr 18 s. 5.

176 Z.R. [Z. Rabska], Polscy bibliofile w Paryżu, „TW” 1946 nr 18 s. 7.

177 A. Rogalski, Jedyna książka, „GK” 1946 nr 1 s. 7.

${ }^{178}$ E. Nawrowski, Dzieje ksiażeczki Leopolda Staffa, „TW” $1948 \mathrm{nr} 4$ s. 9.

${ }^{179}$ Przyjaciel, który nie zdradzi, „TK” 1949 nr 29 s. 266.

${ }^{180}$ J. Bieniek, Tęcza nad wsia, „TP” 1946 nr 47 s. 7. 
Rogalski dokonał także przeglądu odpowiedzi uzyskanych na pytanie zamieszczone w czeskim dzienniku „Prager Presse” w 1937 r. o książkę, która przyczyniłaby się do przezwyciężenia kryzysu duchowego, przeżywanego w ówczesnym świecie. Kazimiera Iłłakowiczówna wymieniła Nowy Testament, podobnie Jarosław Iwaszkiewicz na pierwszym miejscu postawił „księgę ksiąg” - Ewangelię. Wśród innych propozycji znanych naukowców i literatów znalazły się m.in. mały katechizm, Promethidion Norwida, Przedwiośnie Żeromskiego, Dialogi Platona, Wyznania św. Augustyna, O naśladowaniu Chrystusa Tomasza á Kempis, Myśli Pascala i Życie Jezusa Mauriaca. Podsumowując, publicysta wywnioskował, że w decydującym momencie ludzkość zapewne podzieliłaby się na dwa obozy, w których ,jedni wybraliby Kapitat Marksa lub Manifest komunistyczny, a drudzy - Ewangelię" 181 .

Losy książek często związane były z losami ich właścicieli żyjącymi w określonych warunkach politycznych i społecznych, co zdawało się znów potwierdzać stwierdzenie habent sua fata libelli. Książka niejednokrotnie w ciągu wieków, podobnie jak ludzie, była prześladowana i niszczona, jako groźne narzędzie kultury narodu polskiego, o czym niejednokrotnie wspominano na łamach katolickich czasopism społeczno-kulturalnych w latach 1945-1953. Była też niezawodnym przyjacielem i pierwszą potrzebą kulturalną nawet podczas niewoli i w sytuacjach zagrożenia życia, co świadczyło o szczególnym do niej przywiązaniu.

\section{Sytuacja książki w Polsce po II wojnie światowej}

Wiedzę o warunkach, w jakich znalazła się polska książka w czasie wojny i tuż po jej ustaniu, dostarczyły gawędy opublikowane w pismach. Oprócz ubolewania nad ogromnymi stratami „na półkach bibliotek i zbiorów prywatnych” oraz stwierdzenia wyraźnego dzielenia losów ludzi przez książki, można było dowiedzieć się o przedsięwzięciach podejmowanych po kataklizmie wrześniowym. Zniszczenie licznych stołecznych księgarni i antykwariatów przyczyniło się, jak czytamy $\mathrm{w}$ jednej $\mathrm{z}$ wypowiedzi, do organizowania sprzedaży ulicznej książek $^{182}$. Z kolei brak nowej produkcji wydawniczej w czasie wojny spowodował, że „uganiano się za książką” i zwracano ku książkom antykwarycznym. Jednocześnie „przetrząsano, rewidowano i wartościowano” dawne zdobycze literatury, dzięki czemu odżyły powieści Józefa Ignacego Kraszewskiego, utwory wielkich twórców z Mickiewiczem, Sienkiewiczem i Wyspiańskim na czele. Sięgnięto znów po książki będące na indeksie, ,prześladowane i ścigane”, jak Krzyżacy, Placówka, Konrad Wallenrod ${ }^{183}$. Antoni Trepiński, oprócz wykazu

\footnotetext{
181 Tamże.

182 A. Trepiński, Gawęda o książkach, ,TP” 1945 nr 27 s. 6.

183 Tenże, Gawęda o książkach, „TP” 1946 nr 38 s. 7.
} 
tytułów chętnie czytanych, wskazał na potrzebę przygotowania niektórych pozycji, jak np. bibliografii filozofii polskiej, opracowania historii Kościoła w Polsce, książek dotyczących historii polskiego teatru, publicystyki i prasy polskiej czy monografii o budownictwie polskim. Ubolewał nad tym, że zarówno przed wojną jak i współcześnie wciąż brakowało „książek potrzebnych” przy jednoczesnym wydawaniu „książek zbędnych”, a rzeczywiste zapotrzebowanie rynku wydawniczego stale ignorowano. Stwierdził jednocześnie: „,wśród nawału druków zbytecznych i mało potrzebnych, dobre rzeczy giną, wypierane sprawniejszą reklamą lichoty"184. Po wyzwoleniu prowadzący liczne stoiska z książkami z powodzeniem prosperowali. Trepiński konstatował przy tym: „A przecież większość trudni się tym handlem bez znajomości rzeczy, zupełnie przypadkowo, nie odróżniając klejnotów od śmieci, zdumiona sama zjawiskiem, że interes idzie, bo nieustannie jakiś przechodzień znajduje coś dla siebie w tym literackim $<<$ chłamie $>>$ "185. Jak donosił, sprzedawcy o potrzebach klientów orientowali się raczej z bezpośredniego kontaktu z nimi. O książkach rozrzuconych wśród rumowisk i śmieci, stosami leżących na podłogach pustych mieszkań, zbieranych przez przypadkowych przechodniów po ustaniu działań wojennych, pisał publicysta „Głosu Katolickiego”. Dowiadujemy się również, że popyt na książki i „na ich szabrowanie” wzrósł w momencie, gdy można było nimi opłacać rachunki w gazowni, a w księgarni należało zapłacić wysoką cenę za jedną z nich ${ }^{186}$. Swobodne rozważania o książce jako preferowanej przez siebie formie kultury przeprowadziła Hanna Malewska. Zwierzyła się bowiem: „Wyznam, że nigdy inna forma sztuki nie przemawiała do mnie równie silnie jak literatura, jak książka. Wolę Shakespeare'a w książce niż na scenie. Platonowi zawdzięczam silniejsze przeżycie, niż $<<$ galerii greckiej $>>$ w Louvrze" 187 .

Liczne wypowiedzi odnosiły się do bolączki powojennej, jaką był zupełny brak dostępu do niektórych tytułów książkowych na rynku wydawniczym i księgarskim, przy jednoczesnym dublowaniu innych. Czesław Zgorzelski zauważył wyraźnie brak koordynacji w powojennej polityce wydawniczej, gdyż jedne utwory wydawano w kilku edycjach ,podczas gdy inne nie mniej ważne, daremnie oczekiwały na swą kolej”. W powojennej akcji pod hasłem „odbudowy książki” polskiej, prześledziwszy nieudane przedsięwzięcie narodowego wydania Dzieł Mickiewicza, na które ostatecznie zabrakło pieniędzy, domagał się wznowienia znanej przedwojennej serii Biblioteki Narodowej. Zaproponował również zainicjowanie edycji Biblioteki Ocalonych Książek i Rękopisów, która miałaby za zadanie planową i starannie przemyślaną publikację tekstów „,weteranów naszej

\footnotetext{
184 Tamże.

185 A. Trepiński, Gawęda o książkach...

186 Wuj z Baranowa, Gawęda o książkach polskich, „GK” 1945 nr 13 s. 4.

${ }^{187}$ H. Malewska, Perspektywy, ,TP” 1945 nr 23 s. 3.
} 
przeszłości"188. Zofia Starowieyska-Morstinowa w nawiązaniu do wypowiedzi Jana Kotta w „Odrodzeniu”, w której wymienił 100 książek wartych wydania, postulowała, aby na polskim rynku znalazły się przekłady książek Jeana de La Fontaine'a ${ }^{189}$. Do tego samego głosu w prasie nawiązał także Stefan Kisielewski, proponując $\mathrm{z}$ kolei ze swojej strony 10 tytułów powieści europejskich, które winny były pojawić się na rynku księgarskim ${ }^{190}$. W felietonie Ksiązki zapomniane zaproponował reedycję dzieł z okresu dwudziestolecia międzywojennego jako wyraz zachowania polskiej ciągłości kulturowej, rozpoczynając dyskusję na ten temat ${ }^{191}$. Na jego wypowiedź zareagowali Adolf Sowiński w „Nowej Kulturze” oraz Jan Marian Święcicki i Jan Dobraczyński na łamach „Tygodnika Powszechnego”. Pierwsi dwaj zgodzili się co do tego, że polityka wydawnicza powinna być polityką wychowawczą ${ }^{192}$. Jan Dobraczyński stanął zaś po stronie atakowanego Kisiela, pisząc: „Zgłaszam się na sojusznika. Gotów jestem podeprzeć żądanie, aby każda książka dwudziestolecia, posiadająca odpowiednie walory artystyczne, była wznowiona. Dlaczego? Po prostu dlatego, że jest pozycją ciekawą i wartościową, a jako taka stanowi ogniwo w łańcuchu przemian kulturalnych. U nas zbyt często uważa się, że wszystko zaczęło się od nowego i od niczego. [...] Nawet kiedy zachodzą wielkie przemiany ideologiczne, dzieła kulturalne, które je wyrażają, tkwią jakąś częścią swej istoty w przeszłości"193.

O trudnej sytuacji rynku wydawniczego i niewielu nowościach ukazujących się w 1945 r. dowiadujemy się m.in. z listu czytelników do redakcji „Głosu Katolickiego". Jeden z nich pisał o tym, że z powodu braku papieru nie ukazywały się wartościowe książki głośnych uczonych i pisarzy, ale jednocześnie wydawano mało komu potrzebne senniki ${ }^{194}$. O braku i mocno zawyżonych cenach podręczników szkolnych do gimnazjum i liceum wzmiankowano na łamach „Tygodnika Powszechnego" "195. Zmieniającą się nieco ich sytuację przedstawiła natomiast Aniela Kmita-Piorunowa w „Tygodniku Warszawskim”. Według jej opinii już w 1946 r. polska szkoła powszechna zaopatrzona została w pełni w pomoce naukowe dostosowane do nowego programu. Spod prasy Państwowych Zakładów Wydawnictw Szkolnych wyszło, jak napisała, ponadto milion egzemplarzy Elementarza Falskiego, którego cena z 700 zł spadła do 20 zł ${ }^{196}$. Niekiedy na łamach „Tygodnika Powszechnego” wypowiadano się na temat błędów

${ }^{188}$ C. Zgorzelski, O książkach, których wcią̇̇ jeszcze nie ma, „TP” 1947 nr 39 s. 5.

189 Z. Starowieyska-Morstinowa, Cenny manuskrypt w tece, „TP” 1947 nr 42 s. 3.

${ }^{190}$ S. Kisielewski, Pod wtos..., „TP” 1947 nr 42 s. 12.

${ }^{191}$ Kisiel [S. Kisielewski], Z satysfakcja, „TP” $1950 \mathrm{nr} 47$ s. 12; tenże, Bez sojuszników, tamże, nr 49 s. 8.

192 J.M.S. [J.M. Święcicki], Spór o reedycję, „TP” $1950 \mathrm{nr} 48$ s. 12.

193 J. Dobraczyński, Z pomoca Kisielowi, „TP” 1950 nr 53 s. 8.

${ }^{194}$ A. Dąbrowski, Z listów do redakcji, „GK” 1945 nr 34 s. 8.

195 w. bł., 1.000 zt 1 podręcznik szkolny, „TP” $1946 \mathrm{nr} 39$ s. 8.

${ }^{196}$ A. Kmita-Piorunowa, Książka najmilsza i najbliższa, „TW” 1946 nr 39 s. 5. 
w wydaniach i thumaczeniach książkowych, starając się udzielać sprostowań. Wypowiedzi te często utrzymywano w żartobliwym tonie ${ }^{197}$.

Jak wynika z licznych opinii prasowych, nawet w najbardziej dramatycznych warunkach wojennych i powojennych książka znajdowała swoich zwolenników, stając się dobrem potrzebnym. Motywy sięgania po nią były różne, czasem tylko materialne. W pierwszych latach po wojnie nie ustalono jednej polityki wydawniczej, co przyczyniło się w pewnej mierze do chaosu na rynku księgarskim. Niektóre tytuły dostępne były w kilku edycjach, innych zaś wcale nie można było kupić. Wypowiadający się na łamach pism zapytywali o zaistniałą sytuację, podając konkretne przykłady. Głosy publicystów wyrażane na gorąco w periodykach społeczno-kulturalnych odzwierciedliły panującą ówcześnie atmosferę i sytuację książki, przez co są cennym świadectwem o tamtym okresie.

\section{Rola książki}

Znaczenie książki pozostawało w kręgu zainteresowań głównie publicystów „Tygodnika Warszawskiego”. Książkę w kontekście społecznym rozpatrzyła Krystyna Remerowa, uwzględniając trzy sposoby jej zaistnienia na rynku: z inicjatywy autora, którego twórczość była spontaniczna, z inspiracji czynników społecznych (władz, urzędów, towarzystw i firm wydawniczo-handlowych) oraz z nastawienia czysto handlowego mającego przynieść zysk. Zwróciła uwagę na sposoby jej oddziaływania na czytelników, za które odpowiedzialny, jej zdaniem, był w głównej mierze autor. Uważała także, że książka jako czynnik postępu powinna być poddana krytyce i dyskusji ${ }^{198}$. Na „leczniczym” działaniu lektury skupiła się Zuzanna Rabska, pisząc o czytaniu w czasie okupacji niemieckiej: „Szarpani lękiem i niepokojem o los Ojczyzny, wstrząsani grozą codziennych wypadków, umierając z trwogi o życie istot najbliższych i o własną jakże kruchą egzystencję, szukaliśmy w książkach leku na groźną wówczas epidemię psychicznego załamania. Zagłębiając się w lekturę ciekawych książek, odwracaliśmy uwagę od tragedii, rozgrywających się na ulicy, w mieszkaniach, w więzieniach, tragedii, grożących każdej chwili utratą wolności i życia [...] Groźna rzeczywistość ginęła z oczu zapalonym czytelnikom”'199. Książki ponadto nie tylko były „przyjaciółmi, powiernicami i pocieszycielkami” podczas wojny, ale „tropione, prześladowane i niszczone” dzieliły losy ludzi, będąc „najboleśniejszą stratą" ${ }^{200}$. Stanisław Piotr Koczorowski ,powołanie polskiej książki” po licznych stratach wojennych upatrywał w ,przechowywaniu niepodległości tradycji duchowej narodu”, jak też we nr 32 s. 8.

197 jas., Ścisłość przekładu, „TP” 1948 nr 44 s. 12; K.M., Poprawki do objaśnień, „TP” 1952

${ }^{198}$ K. Remerowa, Ksiązka i jej społeczne powołanie, „TW” 1946 nr 39 s. 4.

199 Z. Rabska, Przyjaźń z książka, „TW” 1948 nr 23 s. 6.

${ }^{200}$ Tamże. 
wskrzeszaniu jej tam, gdzie obumarła ${ }^{201}$. Na temat roli książek dla dzieci wypowiedziała się Wanda Bacewiczówna. Za moralny obowiązek autora utworów dla dzieci uznała dbałość o ich poziom wychowawczy, wysuwając równocześnie postulat racjonalnej kontroli wydawnictw dla najmłodszych, by uniknąć łatwego zbytu tańszych, lecz mało wartościowych pozycji ${ }^{202}$.

Trudne dzieje polskiej kultury znalazły wyraz w wypowiedzi Antoniego Trepińskiego: „Nie może Polak żyć bez książki i nigdy już bez niej się nie obejdzie. Im bardziej nieubłaganie wróg tępił książkę polską, tym większy b u d z i 1 głód oraz kult polskiego słowa drukowanego. Bismarck próbował unicestwić polskość przez walkę z Kościołem, lecz pogłębił tylko przywiązanie ludu do wiary. Hitler usiłował wytępić całkowicie kulturę polską, przeznaczając miliony książek polskich na przemiał i obniżając poziom polskiego życia intelektualnego do zakresu szkół elementarnych. Zamieniał książki polskie w popiół [...] bo bał się żywotności polskiej i trwałości kultury, zawartej w książkach polskich. Prześladowaniem sprawił to, że miłość do książek wzrosła niepomiernie u pozostałych Polaków. Książka kwitła w życiu podziemnej Polski, przed książką polską roztaczają się widoki wspaniałego rozwoju"203. Rolę rodzimych druków w okresie zaborów tak postrzegał z kolei Stanisław Krokowski: „Książka polska, starannie przechowywana, spełnia swoje zaszczytne zadanie z ukrycia, staje się pocieszycielką, każe wierzyć w zwycięstwo, głosi chwałę lepszych dni”’204.

Kanonizacja Antoniego Marii Clareta w 1950 r. stała się okazją do przypomnienia jego stosunku do książki jako ważnego czynnika wspierającego rozwój życia duchowego człowieka. Jak dowiadujemy się z artykułu, nazywany „nowoczesnym apostołem" Claret był fundatorem Księgarni Katolickiej w Barcelonie, w której wydawano m.in. jego dzieła. Spośród 144 tytułów autorstwa przyszłego świętego w latach 1843-1901 poprzez dystrybucję Księgarni rozprowadzono je w nakładzie jedenastu milionów - głównie na terenie Hiszpanii i Ameryki Południowej. Przebywając w podróży, Claret miał zwyczaj wozić ze sobą skrzynię książek w celu darowania ich napotkanym ludziom ${ }^{205}$.

Na książki, które powinny znaleźć się w powojennej domowej bibliotece, powstającej też z myślą o potomnych, wskazał publicysta „Głosu Katolickiego"”206. Wśród nich wymienił Katechizm diecezjalny, Pana Tadeusza Adama Mickiewicza, Trylogie Henryka Sienkiewicza, pozycje z historii Polski, Europy i świata oraz książki fachowe i praktyczne. O przywiązaniu do każdego egzemplarza z prywatnego księgozbioru, zmieniającym się profilu oraz roli ówczesnych bibliotek prywatnych, pisał stały publicysta „Tygodnika Powszechnego” Antoni Gołubiew.

\footnotetext{
${ }^{201}$ S.P. Koczorowski, O powołaniu polskiej ksiażki, „TW” 1946 nr 21 s. 6.

${ }^{202}$ W. Bacewiczówna, Ksiązka dla najmłodszych, „TW” 1946 nr 39 s. 10.

${ }^{203}$ A. Trepiński, Gawęda o książkach, „TP” $1945 \mathrm{nr} 27$ s. 6.

${ }^{204}$ S. Krokowski, Książka zwycięża świat, „GK” 1948 nr 4 s. 36.

205 T.K., Nowoczesny apostot, „TP” 1950 nr 24 s. 2.

${ }^{206}$ Wuj z Baranowa, Gawęda o książkach polskich, „GK” 1945 nr 13 s. 4.
} 
Zauważył on tendencję do specjalizacji gromadzonych bibliotek prywatnych, przy jednoczesnej zgodności z zainteresowaniami właściciela, a odchodzenie od uniwersalnego charakteru księgozbiorów. O tym zadecydowała, w jego opinii, zwiększona powojenna produkcja wydawnicza, jak też niewielkie możliwości finansowe w nabywaniu książek. Przestrzegając przed „martwym księgozbiorem”, stwierdził: „Coraz mniej jest w naszym księgozbiorze książek przygodnych, owych intruzów, którzy przychodzą nie wiadomo skąd i po co. Szczupłość miejsca w mieszkaniu wpływa również na tę niechęć do książek nie tylko już niepotrzebnych, ale niekoniecznych. Toteż nabywając książkę, winniśmy wiedzieć dokładnie, do czego ma ona służyć, jaką rolę ma spełniać" ${ }^{207}$. Właścicielom doradził również, aby w domu posiadać książki, które się czyta i pełnią rolę „towarzysza pracy albo przyjaciela".

Znaczącą rolę książki w wychowaniu i procesie kształcenia starano się ukazać przede wszystkim w publikacjach „Tygodnika Katolickiego”. Rodzicom wychowującym dzieci polecano stworzenie choćby niewielkiej biblioteczki domowej „dobrych książek” oraz ofiarowywanie pociechom w formie prezentów książek religijnych ${ }^{208}$. Sugerowano również, jak powinna wyglądać ich szata graficzna oraz zawartośćco ${ }^{20}$. Odnośnie do lektury dla starszej młodzieży, pisano: „Kupować młodym odpowiednie książki o życiu i czynach wielkich ludzi, wkładać im do ręki powieści na tle wielkich naszych. Niech wionie na nich wielkość. Niech z nią obcują. Na pewno nachłoną z niej niemało" ${ }^{210}$. Odpowiednio dobrany zbiór książek miał również pomóc w samokształceniu ${ }^{211}$. Głos zabrano także w sprawie „książek niemoralnych i szkodliwych”, do których zaliczono nie tylko utwory zawierające w swojej treści drastyczne sceny erotyczne, ale także te „sławiące nieokiełzaną pogoń za majątkiem”, „kuszące czytelnika mirażem kariery”, „wciągające w krainę zbrodni i występku” ${ }^{212}$. Ostatecznie zaś miała być to każda książka, która „ukazywała świat w fałszywych proporcjach, nie umiejąca wskazać czytelnikowi właściwej perspektywy, w jakiej należy oglądać rzeczywistość" Marian Jamrozik zwrócił natomiast uwagę na oddziaływanie lektury, pisząc, że „,dobra i pożyteczna książka” może być „przyjacielem człowieka”. Analogicznie zaś książki, których treści zniechęcają do dobra, stają się „wrogami” czytają$\mathrm{cych}^{214}$. Poruszono też zagadnienie wzrostu przestępczości wśród młodzieży

${ }^{207}$ Goa [A. Gołubiew], Rodzina książkowa, „TP” 1950 nr 46 s. 9.

${ }^{208}$ Trudniej dobrze wychować dziecko, niż skończyć uniwersytet, „TK” 1949 nr 18 s. 164;

Z. Grzybowski, Czy dziecko zna Boga, „TK” 1950 nr 30 s. 228-229.

${ }^{209}$ Ksiażka na gwiazdkę, „GK” 1948 nr 51 s. 426.

${ }^{210}$ Z. Grzybowski, Wielkie wzory, „TK” $1951 \mathrm{nr} 6$ s. 48.

${ }^{211}$ J. Pałka, O doksztatcenie młodzieży pozaszkolnej, „TK” $1948 \mathrm{nr} 11$ s. 73.

${ }^{212}$ M. Igrut, O ksiązkach niemoralnych, „TK” $1950 \mathrm{nr} 15$ s. 117.

${ }^{213}$ Tamże.

${ }^{214}$ M. Jamrozik, Katolik a książka, „TK” 1951 nr 11 s. 98. 
w Stanach Zjednoczonych pod wpływem złej lektury ${ }^{215}$. Znakomitą książką „wychowującą chrześcijan” i „formującą duchowo" miały być Ćwiczenia duchowne św. Ignacego Loyoli, o których wspomniano z okazji 400-lecia wydania ${ }^{216}$. Na ich oryginalność i formę zwrócił uwagę na łamach "Przeglądu Powszechnego" ks. Edward Bulanda, pisząc: „Dziwna to książka, bo o niej trudno powiedzieć jak o innych $<<$ bierz i czytaj $>>$, lecz raczej $<<$ niech ona Cię weźmie i nauczy odczytywać zagadkę życia skąd wyszedłeś i dokąd idziesz?>>”217.

Kwestia szacunku dla książek też znalazła swój wyraz w wypowiedziach prasowych. Jan Czerepacha, przestrzegając przed czytaniem w trakcie jedzenia, gawędziarsko stwierdził: „Obejrzyjcie książki w czytelni czy w prywatnej nawet bibliotece. Większość z nich ma pozakładane rogi, jest poplamiona, czasem nawet porysowana ołówkiem albo popstrzona głupimi uwagami. Okładka jest brudna, wymięta. Często i kartek brakuje. Ot, ktoś chciał zawinąć śledzia, nie znalazł pod ręką kawałka innego papieru, wyrwał po prostu kilka kartek z książki. Jak nazwać takiego człowieka - zwyczajnie świnią!"”18. Piętnowano kradzież książek, ich kaleczenie, zalewanie tuszem oraz dewastowanie poprzez wycinanie fragmentów ${ }^{219}$. Czytelnik „Tygodnika Powszechnego”, podpisany jako Miłośnik książek, domagając się „kultury obchodzenia się z książką”, zaproponował „racjonalizatorski pomysł", by wprowadzić obowiązek mycia rąk w bibliotekach publicznych przed udostępnieniem księgozbioru. Wybrykami nazwał dopisywanie komentarzy w cudzej książce, zaznaczając, że „dla studiującego dzieło naukowca podkreślenie niektórych zdań" dozwolone jest tylko na własnym egzemplarzu"220.

Znaczenie książki w Polsce ukazano przez pryzmat historyczny i współczesny. Doceniono jej rolę w utrzymaniu trwałości rodzimej kultury, w wychowaniu młodego pokolenia i ogólnym rozwoju człowieka. Podkreślono ogromny wpływ, jaki wywiera ona na czytelnika, obarczając autorów odpowiedzialnością za wyrażane w nich opinie i treści. Wartość książki ukazano nie tylko od strony myśli w niej zawartych, ale kazano także dbać o jej estetykę zewnętrzną.

\section{Historia książki}

Skromnie na łamach katolickich periodyków zaznaczyły się zagadnienia związane z dziejami książki, ukazało się bowiem zaledwie kilka artykułów. Stanisław Krokowski w „Głosie Katolickim” przypomniał początki pisma i pa-

\footnotetext{
${ }^{215}$ Przestęcza literatura, „TK” 1949 nr 33 s. 299.

${ }^{216}$ L.K., 400 lat „Ćwiczeń” św. Ignacego, „TP” 1948 nr 37 s. 11.

${ }^{217}$ E. Bulanda, Jubileusz „,przedziwnej” książki, „PP” 1948 nr 8 s. 212.

${ }^{218}$ J. Czerepacha, O książce stów parę..., „TK” $1950 \mathrm{nr} 30$ s. 231.

${ }^{219}$ P.G., W sprawie niszczenia książek, „TP” $1952 \mathrm{nr} 26$ s. 7.

${ }^{220}$ Miłośnik książek, O poszanowaniu książek, „TP” $1952 \mathrm{nr} 23$ s. 8.
} 
pieru oraz pierwszych kodeksów na ziemiach polskich ${ }^{221}$. Na tle historii Kłodzka krótko przedstawiono losy Psatterza floriańskiego, błędnie sugerując wedle ówczesnego stanu wiedzy, jakoby powstał u kanoników regularnych ${ }^{222}$. Niezwykłe dzieje pergaminowej księgi Vita beatae Cunegundis, będącej własnością klarysek nowosądeckich, ukazał w artykule I ksiązki mają swój los Wiktor Bryjak. Ciekawostką był fakt ukrywania jej przez rodzinę Dzieduszyckich w czasie intensywnych poszukiwań księgi w XIX w. ${ }^{223}$ Michał Plezia natomiast przedstawił interesującą historię egzemplarza książki, która prawdopodobnie w dniach bitwy pod Waterloo była w rękach cesarza Napoleona, a następnie wraz z jego wozem została zdobyta przez fizylierów pruskich i spoczywała w jakiejś prywatnej bibliotece niemieckiej, po czym nieznanymi drogami dotarła do Biblioteki Czartoryskich w Krakowie ${ }^{224}$.

W ogólnych rozważaniach o książce zwrócono uwagę na kwestie, które ówcześnie wydawały się publicystom istotne. Przekłady Biblii, bibliofilstwo, sytuacja książki po wojnie, jej rola oraz w mniejszym stopniu historia książki tworzyły bogate tło, na którym pisano o bardziej szczegółowych zjawiskach. Wypowiedzi w większości były ciekawie napisane i zapewne budziły zainteresowanie czytelników.

\subsection{Publikacje o instytucjach obiegu książki}

Problematyka dotycząca zagadnień instytucji związanych z książką również gościła na łamach katolickich czasopism społeczno-kulturalnych w omawianym okresie. Pojawiały się bowiem publikacje dotyczące zagadnień drukarskich, wydawniczych, księgarskich i bibliotekarskich. Warto przedstawić je z podziałem na poszczególne instytucje.

\section{Drukarnie}

Początki drukarstwa i jego rozwój w Polsce w XVI-XIX przedstawił w cyklu $Z$ życia ksiażki Stanisław Krokowski na łamach „Głosu Katolickiego”. W jednej z wypowiedzi wynalazek druku ukazał jako punkt zwrotny w historii książki, zapoznając czytelników z pierwszymi drukarzami i ich drukami za granicą oraz na

${ }^{221}$ S. Krokowski, Od hieroglifów po druk, „GK” 1948 nr 2 s. 19.

${ }^{222}$ C. Ufnalewski, Tam, gdzie powstała pierwsza ksiażka polska, „TW” $1946 \mathrm{nr} 15$ s. 5-6. Badania Witolda Taszyckiego dowiodły w 1949 r., że powstał on w skryptorium na Wawelu. Dostępny w World Wide Web Wikipedia, http://pl.wikipedia.org/wiki/Psa\%C5\%82terz_floria\%C5\%84ski [data dostępu 28.03. 2012].

${ }^{223}$ W. Bryjak, I książki mają swój los, „TP” $1951 \mathrm{nr} 27$ s. 2.

${ }^{224}$ M. Plezia, Ksią̇ka spod Waterloo, „TP” 1951 nr 10 s. 4. 
terenach polskich ${ }^{225}$. W kolejnym artykule można też przeczytać o dziedziczności zawodu drukarza i powstaniu słynnych rodów drukarsko-księgarskich Aldów, Estienne'ów, Plantinów, które przyczyniły się w sztuce drukarskiej do „piękna zewnętrznego książki" i angażowały do pracy nad nią sławnych malarzy, rytowników i drzeworytników ${ }^{226}$. Humorystycznie o „wybrykach chochlika drukarskiego” w oficynie „Imć. Pana Zawadzkiego”, drukującej utwory Adama Mickiewicza napisał Antoni Gołubiew na stronach „Tygodnika Warszawskiego”227.

Współczesna tematyka drukarska obecna była zaledwie w kilku wypowiedziach. O działalności typograficznej Samuela Tyszkiewicza, który powrócił do ręcznego składu i tworzył nowe wzorce artystyczne, mówił w swym odczycie Stanisław Piotr Koczorowski podczas spotkania Towarzystwa Bibliofilów Polskich w 1947 r. ${ }^{228}$ Józef Sawajner podzielił się wspomnieniami nt. pracy w atmosferze stałego lęku przed dekonspiracją i aresztowaniem przez gestapo, a w końcu spalenia drukarni podziemnej o nazwie Tajne Wojskowe Zakłady Graficzne. Czytelnicy dowiedzieli się, że spod jej prasy oprócz licznych ulotek i materiałów zachęcających do walki z okupantem, w grudniu 1943 r. wydano ,arcydzieło konspiracji”, które pod fałszywym tytułem „gadzinówki” niemieckiej „Goniec Krakowski" w swej treści nawoływało do oporu ${ }^{229}$. Zakłady te, oprócz materiałów propagandowych i szkoleniowych, wydawały czasopisma i książki m.in. literackie. Podrobiono w nich też inną „gadzinówkę” - „Nowy Kurier Warszawski”. Ważnym wydarzeniem odnotowanym na łamach „Tygodnika Katolickiego” stało się poświęcenie przez redaktora pisma ks. Kazimierza Łabińskiego w styczniu 1948 r. Państwowych Gorzowskich Zakładów Graficznych. Uroczystość tym bardziej zasługiwała na notatkę, że spod ich prasy wychodził powyższy tygodnik $^{230}$. W periodyku poparto również inicjatywę powołania z okazji 30-lecia istnienia Katolickiego Uniwersytetu Lubelskiego Funduszu Wydawniczego im. ks. Prymasa Kardynała Augusta Hlonda. Poinformowano o zasadach jego działalności wraz z możliwością składania dobrowolnych ofiar na jego cele ${ }^{231}$.

Krótkie informacje o drukarniach polskich i zagranicznych pojawiały się czasami w rubrykach „Tygodnika Katolickiego” i „Tygodnika Powszechnego”. Przykładowo czytelnicy mogli dowiedzieć się o tym, że w 1947 r. minęło 411 lat od daty założenia w Ełku pierwszej polskiej drukarni na Mazurach ${ }^{232}$. W $1950 \mathrm{r}$. czytamy natomiast: „W dniu 22 lipca w Święto Odrodzenia został częściowo

${ }^{225}$ S. Krokowski, Wynaleziono druk, „GK” 1948 nr 3 s. 29.

${ }^{226}$ Tenże, Książka zwycięża świat, „GK” 1948 nr 4 s. 36.

${ }^{227}$ A. Gołubiew, O chochliku drukarskim i Adamie Mickiewiczu, „TW” 1946 nr 23 s. 6.

${ }^{228}$ R., Odczyt o oficynie drukarskiej S. Tyszkiewicza, „TW” $1947 \mathrm{nr} 15$ s. 7.

${ }^{229}$ J. Sawajner, W podziemiach tajnej drukarni, „TP” 1946 nr 43 s. 3-4; tamże, nr 44 s. 5-6.

${ }^{230}$ Poświęcenie drukarni, „TK” 1948 nr 8 s. 55.

${ }^{231}$ Odezwa w sprawie utworzenia Funduszu Wydawniczego im. J.E. Ks. Prymasa Kardynała Augusta Hlonda, „TK” 1949 nr 1 s. 7.

232 „TK” 1947 nr 7 s. 55. 
oddany do użytku olbrzymi Dom Słowa Polskiego w Warszawie, jedna z największych w świecie fabryk słowa drukowanego. Mianowicie została uruchomiona hala produkcyjna, obejmująca 48 linotypów oraz ogromna maszyna rotacyjna, która może drukować 320 tysięcy egzemplarzy 6-stronicowej gazety na godzinę" ${ }^{233}$. W tym samym roku odnotowano uruchomienie „nowej i wielkiej” drukarni naukowo-technicznej noszącej nazwę wielkiej rewolucji październikowejej". Z notatki dowiadujemy się również o roku założenia i liczbie pracowników paryskiego Domu Dobrej Prasy (La Bonne Presse) będącego jedną z największych ówczesnych drukarni katolickich i wydającego m.in. dziennik „La Croix” ${ }^{235}$.

Publikacje o drukarniach pojawiające się na łamach omawianych pism były najczęściej wzmiankami. Tematyka ta pojawiała się sporadycznie i nie zajęła wiele miejsca.

\section{Wydawnictwa}

Nakłady książek powojennych z produkcją wydawniczą w okresie międzywojennym porównał Antoni Trepiński. Szczególną uwagę zwrócił na różne przykłady powodzenia w sprzedaży danego tytułu, a opisana przez niego sytuacja książki przedstawiała się dobrze. Pisał, że edycje z 1945 r. uległy szybko wyczerpaniu, ,przekraczając nieraz najśmielsze oczekiwania wydawców”, w pierwszych trzech latach po wojnie panowała „doskonała koniunktura dla beletrystyki”, nawet powieści debiutantów, wznowienia i „słabsze rzeczy” dochodziły do wysokich nakładów. Niewystarczająca była natomiast, jego zdaniem, produkcja podręczników. Stwierdził przy tym: „Nakład ogólny podręczników wynosił w r. 1938 około 7 milionów egzemplarzy. Potrzeby obecne rynku księgarskiego są wielokrotnie większe niż wówczas wobec olbrzymiego niedoboru lat okupacji, tymczasem nie osiągamy bynajmniej przedwojennego poziomu wytwórczości”236. Wyższe nakłady w latach 1945/1946 publicysta postrzegał jednak jako zjawisko przejściowe, przestrzegając zarazem przed bankructwem wydawców, obniżeniem liczby egzemplarzy z powodu podwyżki cen książek.

Statystyki wydawnicze cytowano za danymi opublikowanymi w artykułach Adama Bromberga w „Kuźnicy” i „Odrodzeniu”237. Z racji profilu czasopism szczególną uwagę zwrócono na sytuację książki religijnej, m.in. na spadek ilościowy jej produkcji w latach 1947-1948 238 . Monika Michałowska w przeglądzie wydawnictw

${ }^{233} Z$ dnia, ,TP” 1950 nr 31 s. 4.

${ }^{234}$ Tamże, „TP” 1950 nr 47 s. 2.

${ }^{235}$ Z życia katolickiego, „TK” 1949 nr 25 s. 237.

${ }^{236}$ A. Trepiński, O nakładach książki powojennej, „TP” $1947 \mathrm{nr} 4$ s. 2.

${ }^{237}$ W'́ród czasopism. Interesujaca statystyka, „TP” $1947 \mathrm{nr} 12$ s. 11; Quidam, Bez ogródek. Ruchy rynku wydawniczego, „TP” $1948 \mathrm{nr} 49$ s. 8.

${ }^{238}$ Quidam, Bez ogródek. Ruchy rynku wydawniczego ... 
z zakresu literatury maryjnej w latach $1945-1950$ w Polsce, przedstawiła udział procentowy w ogólnym dorobku książek katolickich, m.in. książeczek do nabożeństwa, rozważań i kazań czy książek poświęconych określonym zagadnieniom ${ }^{239}$.

Jak dowodzono w innych wypowiedziach prasowych, sytuacja rynku wydawniczego nie była w pełni zadowalająca. Sugestie co do „celowej i przemyślanej” akcji wydawniczej dzieł z zakresu literatury polskiej przedstawił Czesław Zgorzelski, ustosunkowując się do kilku jednoczesnych edycji niektórych tytułów w różnych oficynach wydawniczych (np. Grażyna, Konrad Wallenrod Adama Mickiewicza, Siłaczka Stefana Żeromskiego) w pierwszych dwóch latach po wojnie. Zauważył przy tym: „Obracanie się w ramach szczupłego zakresu tych samych utworów, które z tych czy innych względów narzuciły się wydawcom w pierwszej kolejce, powoduje niewspółmierne potraktowanie tych potrzeb, uprzywilejowanie pewnych dzieł, pisarzy lub epok - kosztem innych, szkodliwe zaniedbanie edycji nie mniej pilnych, niż te, które po czterykroć podjęte zostały w ciągu kilkunastu ostatnich miesięcy”240. Zaproponował również, aby „utwory większego wymiaru" wydawać w cyklach lub seriach np. w serii twórczości Kraszewskiego, cyklu powieści psychologicznej, serii romansów awanturniczych czy tomików przekładów z literatury obcej ${ }^{241}$.

Brak na rynku wydawniczym przekładów książek zagranicznych był tematem jednej z wypowiedzi na łamach „Tygodnika Powszechnego”. Publicysta stwierdził: „Nie dając naszym pisarzom i czytelnikom tego, co pisze się dziś i czyta na wschód i na zachód od Polski, redukuje się wartość naszego piśmiennictwa do jakiegoś sui generis prowincjonalizmu. Peany na cześć naszej beletrystyki przypominają trochę zachwyty rodziny nad zdolnym synkiem - który nie miał jeszcze okazji porównać wartości swoich utworów z utworami spoza familijnego krę-

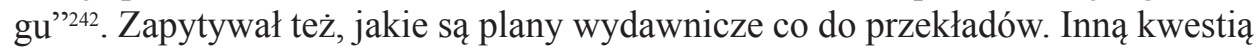
była też niemożność zakupienia książek i periodyków naukowych wydawanych przez polskie towarzystwa naukowe po przejściu w 1950 r. księgarń pod zarząd Domu Książki oraz utrata przez naukowców 40\% zniżki przy nabywaniu ich bezpośrednio $w$ towarzystwach ${ }^{243}$. Piszący domagał się chociaż jednej księgarni w Krakowie, która obsługiwałaby pracowników naukowych. Przegląd publikacji Polskiej Akademii Umiejętności, prowadzącej podziemną działalność wydawniczą podczas okupacji hitlerowskiej, przedstawił Sylwiusz Mikucki ${ }^{244}$.

Przy okazji wydawnictw powrócił temat niewystarczającej liczby publikowanych w latach 1945-1947 podręczników szkolnych ${ }^{245}$. Częstokroć zastępowano

\footnotetext{
${ }^{239}$ M. Michałowska, Polska powojenna literatura maryjna, „TP” $1950 \mathrm{nr} 9$ s. 10.

${ }^{240}$ C. Zgorzelski, Cztery „, Grażyny” i trzech „,Wallenrodów”, „,TP” 1947 nr 4 s. 8.

241 Tamże, s. 9.

242 Kor., Tajemnicze nazwiska, „TP” 1948 nr 39 s. 8.

${ }^{243}$ M., O książi naukowe, „TP” 1950 nr 41 s. 8.

${ }^{244}$ S. Mikucki, Naukowa książka w czasie wojny w Krakowie, „TP” 1945 nr 3 s. 2.

245 Wśród czasopism. Interesująca statystyka, „TP” 1947 nr 12 s. 11.
} 
je na rynku wydawniczym tzw. „literaturą skrótową” znakomicie dostosowaną do „przeciętnych belferskich przyzwyczajeń”, przeciwko której zdecydowanie wystąpił Czesław Zgorzelski ${ }^{246}$. Z pomocą przyszło Wydawnictwo Zakładu Narodowego im. Ossolińskich, które wznowiło serię znaną pod nazwą Biblioteka Narodowa. Pisano w związku z tym: „Wydawnictwa podręczników ciągle jeszcze nie mogą nadążyć zapotrzebowaniu, natomiast lektury szkolne już w rozmaitych ukazują się zbiorach. Szczególnie miłą nowość godzi się w tej chwili zanotować: odżycie $<<$ Biblioteki Narodowej $>>$. Przez dwadzieścia prawie lat redagowana przez prof. Stanisława Kota, a następnie prof. Wacława Borowego, osiągnęła z cyklu literatury polskiej 130 tomików, a w serii literatury obcej $57^{\prime}{ }^{247}$.

Osobną kwestią podejmowaną $\mathrm{w}$ artykułach była poprawność publikowanych tekstów ${ }^{248}$. Publicyści często narzekali na słabą korektę wydawniczą, złe przekłady z literatury obcej oraz ingerencję w zawartość dzieł bez zgody autorów. W liście do redakcji Jerzy Waldorff żalił się na osobiste doświadczenia z korektorami Wiedzy przy wydaniu pamiętników o Władysławie Szpilmanie Śmierć mia$s t a$, które ostatecznie przyczyniły się do skierowania sprawy na drogę sądową. Oburzony konstatował: „Pomijam to, że podczas spisywania kontraktu zarząd Wydawnictwa poinformował nas, iż książka ukaże się we wrześniu 1946 r., a korektę jej dostałem do zrobienia dopiero w listopadzie. Gorsze było, że podczas robienia korekty zauważyłem, iż szereg ustępów z mego tekstu uległy skreśleniu, a w paru wypadkach na to miejsce ktoś tam porobił dopiski. [...] Oczywiście, odsyłając korektę, zażądałem jak najenergiczniej przywrócenia mego oryginalnego tekstu. Skoro jednak książka wyszła z druku, okazało się, że „Wiedza” nie tylko nie uwzględniła ani jednego z moich żądań korektorskich, lecz nadto wydała książkę ... bez mojego nazwiska na okładce! Autorem książki, literatem został nieoczekiwanie $<<$ mianowany $>>$ przez wydawnictwo Szpilman, jej bohater"249.

Deficyt papieru, nierównomierny jego przydział przy dużej biurokracji, znaczny wzrost jego ceny, a jednocześnie marnowanie go na wydawnictwa o charakterze sensacyjnym i brukowym były sygnalizowane $\mathrm{w}$ różnych rubrykach „Tygodnika Powszechnego' i „Tygodnika Warszawskiego"250. Problem papieru omówiono w jednym z artykułów „Tygodnika Katolickiego”"251. Jedynie na łamach krakowskiego periodyku pisano o trudnej sytuacji wydawnictw w innych krajach Europy. Kryzys książki wynikający z braku papieru objął nie tylko Polskę,

\footnotetext{
${ }^{246}$ C. Zgorzelski, Zagadnienia. Literatura a la minute, „,TP” 1947 nr 13 s. 2.

247 „Biblioteka Narodowa” odżyła, „TP” 1947 nr 23 s. 8.

${ }^{248}$ M.in. C. Zgorzelski, Cztery ,Grażyny” ...

249 J. Waldorff, Niebywate praktyki wydawnicze, „TP” 1947 nr 10 s. 11.

${ }^{250}$ W. Natanson, Na marginesie. Brak papieru, „TP” 1945 nr 17 s. 6; Wun., Bez ogródek. Papier, „TP” 1947 nr 16 s. 12; tenże, Żadnych rabatów nie będzie, tamże, nr 20 s. 12; W., Bez ogródek. Nadmiar papieru, tamże, nr 49 s. 8; Przeglad prasy. O papierze, „TW” $1947 \mathrm{nr} 42$ s. 16.

${ }^{251}$ Fr.K., Dzieje papieru, „TK” 1953 nr 8 s. 62-63.
} 
ale też Francję i Anglię ${ }^{252}$. Produkcja wydawnicza, jak czytamy, nie była w stanie zaspokoić potrzeb rynku czytelniczego; zabrakło również tak rentownego dla tych państw eksportu książek ${ }^{253}$. Dużym utrudnieniom w wywozie książek ze względu na wysokie opłaty, miała we Francji zaradzić specjalnie powołana do tego Komisja Narodowej Książki Francuskiej, o czym informowano w jednej z Kronik francuskich ${ }^{254}$. O znaczącej roli kilku angielskich wydawców w produkcji książki i prasy katolickiej (m.in. londyńskie Sheed and Ward oraz Burns Oates) pisano w jednym z artykułów periodyku w $1947 \mathrm{r}^{255}$ W Kronice włoskiej donoszono natomiast o imponującej działalności wydawnictw we Włoszech ${ }^{256}$. Pokaźne nakłady książek po II wojnie światowej w Jugosławii odbiorcy poznali dzięki Kronice jugostowiańskiej ${ }^{257}$.

Na łamach „Tygodnika Powszechnego” i „Tygodnika Warszawskiego” sporadycznie drukowano artykuły, w których omawiano działalność poszczególnych krajowych wydawnictw. Odbiorców zapoznano m.in. z Wydawnictwem Zakładu Narodowego im. Ossolińskich, Polskim Wydawnictwem Muzycznym, Wydawnictwem Zachodnim, Oficyną Księgarską i niektórymi wydawcami katolickimi ${ }^{258}$.

\section{Księgarnie}

Na łamach katolickich czasopism społeczno-kulturalnych rzadko podejmowano problematykę księgarską; tylko w „Tygodniku Powszechnym” ukazało się zaledwie kilka opracowań. Antoni Trepiński starał się opisać trudną pracę ówczesnego księgarza w sprzedaży nowości książkowych. Śledził w tym celu tok sprowadzenia pozycji z wydawnictwa: zdobycie informacji bibliograficznych i adresowych wydawcy, dokonanie selekcji w zamówieniach, uwzględnienie kosztów, rabatów i opłacalności druków, odpowiednią ich reklamę, uporanie się z deficytami i utraconym zainteresowaniem klientów ${ }^{259}$. Stefan Kisielewski zwrócił uwagę na pozbawienie księgarni prawa do rozprowadzania podręczników szkolnych. Ta powinność w gospodarce planowej państwa polskiego, nazwana ,siecią zamkniętą”,

${ }^{252}$ W'́ród czasopism. Książka za granica, ,,TP” $1946 \mathrm{nr} 48$ s. 11.

${ }^{253}$ M.Cz., Ksią̇ka we Francji, „TP” 1945 nr 32 s. 4; Z. Starowieyska-Morstinowa, Przez prasę francuska, tamże, nr $36 \mathrm{s.} 7$.

${ }^{254}$ T.K., Powstanie „Komisji Narodowej Książi Francuskiej”, „TP” 1948 nr 32 s. 5.

${ }^{255}$ Ksiażka i prasa katolicka w Anglii, „TP” 1947 nr 19 s. 8.

256 (aw), Kronika włoska, „TP” 1947 nr 34 s. 6.

${ }^{257}$ Produkcja ksiażkowa Jugosławii, „TP” $1948 \mathrm{nr} 42$ s. 10.

${ }^{258}$ A. Małachowski, Ossolineum, „TP” 1952 nr 29 s. 2, 9-10; S. Kisielewski, O Polskim Wydawnictwie Muzycznym, tamże, nr 46 s. 9; Wydawnictwo Zachodnie, „TW” 1948 nr 28 s. 6; W.B. [W. Borowy], ,Oficyna Księgarska”, „TW” 1946 nr 39 s. 8; Wydawnictwa katolickie, tamże, nr 39 s. 9.

${ }^{259}$ A. Trepiński, Zagadnienia. Sprzedaż książek od strony kupca, „TP” 1946 nr 41 s. 2. 
przypadła szkołom, które nie wywiązywały się z tego prawidłowo ze względu na brak racjonalnego przydziału książek ${ }^{260}$. Odbiorcy krakowskiego tygodnika społeczno-kulturalnego dowiedzieli się także o trzech segmentach polskiego rynku księgarskiego po II wojnie światowej. Pierwszy reprezentowała literatura propagandowa (głównie broszury) wydawana przez Czytelnika oraz rywalizujące z nim spółdzielnie wydawnicze Książka oraz Wiedza, drugi - literatura faktograficzna i wspomnieniowa o tematyce wojennej i obozowej, ostatni zaś literatura naukowa wraz ze wznowieniami ${ }^{261}$. W oddziałach Domu Książki, pomimo uruchomienia w kilku większych miastach księgarni naukowych, brakowało jednak wielu pozycji z różnych dziedzin wiedzy. Jak czytamy w notatce działu Bez ogródek, były one nie do zdobycia dla naukowca, gdyż prywatnych zamówień w księgarniach nie przyjmowano ${ }^{262}$.

\section{Biblioteki}

Wśród zagadnień dotyczących instytucji obiegu książki, pojawiających się na łamach wybranych czasopism społeczno-kulturalnych, problematyka bibliotek zajęła poczesne miejsce. Oprócz informacji nt. ogólnej sytuacji bibliotekarstwa polskiego po zakończeniu działań wojennych, znaleźć można było liczne opracowania przedstawiające dzieje i działalność poszczególnych książnic, jak też księgozbiorów prywatnych. Fragmentarycznie sprawy bibliotek występowały w krótkich notatkach prasowych.

O toczących się sporach na temat ustawy bibliotecznej w latach 1934-1938 w Polsce wspomniała Zofia Sutorowska w „Tygodniku Powszechnym”, opisując powojenny stan organizacji sieci bibliotek powszechnych i ich rolę , w walce z ciemnotą" na wsi. Podkreśliła przy tym wagę szkoleń bibliotekarzy mających na celu ujednolicenie pracy bibliotecznej, a także znaczenie dobrej dystrybucji książek oraz sprawnej pracy samorządów w tworzeniu bibliotek ${ }^{263}$. Wzmiankowano o potrzebie wprowadzenia ustawy bibliotecznej w celu zorganizowania nowych czytelni i bibliotek. Postulat wysunął Eugeniusz Paukszta na łamach „Tygodnika Katolickiego” przy okazji rozważań na temat sytuacji książki na Ziemiach Odzyskanych ${ }^{264}$. Jednocześnie w innym miejscu stwierdził wzrost liczby bibliotek na terenach polskich, pisząc: „Dziś już każda gmina, niemal każda gromada, każda fabryka i ośrodek rolniczy szczyci się własną bibliotekąa" ${ }^{265}$. W akcji kulturalnej zwalczania analfabetyzmu dostrzegano ważną rolę książnic parafialnych i zachęcano do zakładania

\footnotetext{
${ }^{260}$ Kisiel [S. Kisielewski], Pod wtos ... Nos dla tabakiery, „TP” 1947 nr 41 s. 12.

${ }^{261}$ W'śód czasopism. Trzy fazy, „TP” $1946 \mathrm{nr} 48$ s. 11.

${ }^{262}$ Chrzan, Bolaczki i racjonalizacja, „TP” $1951 \mathrm{nr} 40$ s. 12.

${ }^{263}$ Z. Sutorowska, Książka dla wsi, „TP” 1948 nr 19 s. 3-4.

${ }^{264}$ E. Paukszta, Z książka polską na zachód, „TK” 1949 nr 31 s. 284.

265 (E.P.) [E. Paukszta], Wielka ofensywa kulturalna, „TK” $1951 \mathrm{nr} 16$ s. 144.
} 
tzw. bibliotek dobrej książki. Pisano m.in.: „Chodzi bowiem, żeby w powodzi słowa drukowanego nie trafiały pod strzechę książki bezwartościowe, albo nawet złe i żeby zwalczając analfabetyzm ogólny zwalczać jednocześnie analfabetyzm religijny"266. Do Dekretu o bibliotekach i opiece nad zbiorami bibliotecznymi z dnia 17 kwietnia 1946 r. ustosunkował się na łamach „Tygodnika Warszawskiego” Bogdan Horodyski. Głos zabrał głównie w sprawie braków w księgozbiorach użyteczności publicznej i wprowadzenia mocą Dekretu powszechnego udostępniania zbiorów różnego rodzaju. Uspokajał przy tym, że postanowienia nie oznaczały, by „książki miały być per fas et nefas prawowitym właścicielom wydzierane; nie znaczy też, by myślą przewodnią miało być znęcanie się nad sercem bibliofilów i zbieraczy, niekiedy dziedziczących pamiątkowe księgozbiory po ojcach i dziadach. Myślą przewodnią postanowienia jest, by książki, do takich księgozbiorów należące, mogły być dostępne dla tych czytelników, którzy ich nie mogą znaleźć w zniszczonych bibliotekach użyteczności publicznej. To właśnie dekret nazywa włączeniem księgozbiorów prywatnych i domowych do $<<$ sieci bibliotek publicznych $>>$ "267. Czas wejścia w życie zarządzenia postrzegał jako ,najcięższy dla kultury polskiej i dla polskiej książki”, gdyż stan ilościowy księgozbiorów w ciągu wojny zmniejszył się o $1 / 3$ w stosunku do stanu w 1939 r. ${ }^{268}$

Opisy losów prywatnych bibliotek na stałe zagościły na łamach „Tygodnika Warszawskiego" w 1946 r. Redakcja zachęciła odbiorców do nadsyłania opisów utraconych zbiorów i kolekcji, które drukowano pod nagłówkiem Prywatne straty kulturalne 1939-1945269. W numerze 13 z 1946 r. uzasadniano: „Uświadomienie sobie wielkości strat, które poniósł w prywatnej pracowni, czy zbiorach polski uczony, badacz, pisarz, lekarz, inżynier, plastyk, nauczyciel, adwokat, czy urzędnik, bibliofil, znawca sztuki, czy też kolekcjoner amator i w jakich stało się to okolicznościach, to przecież sprawa dla kultury polskiej nad wyraz ważna i doniosła" ${ }^{270}$. Serię artykułów rozpoczęto od przedstawienia losów bogatych zbiorów gromadzonych prawie 40 lat przez kustosza Biblioteki Narodowej w Warszawie, znanego również jako zbieracza ksiąg i bibliofila - Stanisława Koczorowskiego. Jak wiadomo z opisu właściciela, spalony w okresie okupacji księgozbiór liczył około 12 tys. tomów, były w nim m.in. starodruki, druki z dedykacjami oraz pozycje dotyczące drukarstwa i grafiki XVII-XX w. ${ }^{271}$ Stanisław Janczewski w następujący sposób

${ }^{266}$ Biblioteka parafialna, „TP” 1948 nr 10 s. 11.

${ }^{267}$ B. Horodyski, Dekret o bibliotekach, „TW” 1946 nr 39 s. 9.

268 Tamże.

${ }^{269}$ Zebrane materiały wydano w książce zatytułowanej Lista strat kultury polskiej (1.IX.1939-1.III.1946) w zestawieniu Bolesława Olszewicza. Pozycja ukazała się w Warszawie nakładem Wydawnictwa S. Arcta w 1947 r. i liczyła 336 stron. Źródło: A. Madej, Straty kultury polskiej, „TW” 1947 nr 19 s. 8.

${ }^{270}$ A. Madej, Straty kultury polskiej, „TW” $1947 \mathrm{nr} 19$ s. 8.

${ }^{271}$ S. Koczorowski, Prywatne straty kulturalne 1939-1945. Zbiory Stanisława P. Koczorowskiego, „TW” 1946 nr 14 s. 7. 
pisał o swoich stratach: „Zbyt wiele miejsca zajęłoby, gdybym chciał wymieniać wszystko, co spłonęło w moim mieszkaniu, począwszy od starych mahoni, a kończąc na bibliotece, obejmującej kilka tysięcy tomów, w tej liczbie pokaźnej ilości białych kruków" ${ }^{272}$. Z dorobku Zygmunta Wasilewskiego oprócz licznych rękopisów zagubiona została nieopublikowana praca Listy do przyjaciela, zawierająca 70 tekstów nieznanej korespondencji z Romanem Dmowskim oraz dwie książki, które miały być wydane nakładem Księgarni Gmachowskiego w Częstochowie: Przekazy XIX wieku i Załamanie ${ }^{273}$. Część księgozbioru Zuzanny Rabskiej ocalała dzięki przekazaniu jej Bibliotece Narodowej, pozostała, niestety, została splądrowana przez gestapowców ${ }^{274}$. Maksymilian Malinowski po opisie zawartości swojej biblioteki wspominał: ,[...] dnia 8 września roku 1944 o 7-ej rano wypędzono nas [...]. Zostawiłem dom, a w nim wszystko, więc obrazy Kotarbińskiego i innych z całą moją ukochaną biblioteką, o której marzyłem, iż w rękach Związku Nauczycielskiego dalej będzie służyła wsi polskiej. A może z gruzów tego domu uda się coś wydobyć? Może nie wszystko zniszczało?”275. Ciekawy księgozbiór składający się głównie z obcych dzieł w tym indyjskich, perskich, orientalistycznych i francuskich Stanisława i Jadwigi Michalskich Niemcy spalili po powstaniu warszawskim. Michalski pisał: „W celu ratowania książek umieściłem na półkach kartki, że dzieła indianistyczne należą do niemieckiego towarzystwa Deutsche Morgenländische Gesellschaft w Halli. Nie wiadomo, czy wszystkie dzieła uległy spaleniu, czy też Niemcy choć w części je wywieźli”’276. Sugerował przy tym, że władze państwa polskiego na kongresie pokojowym powinny domagać się przejęcia całego księgozbioru wspomnianego towarzystwa jako rekompensatę za zniszczenie zasobów orientalistyki w Warszawie ${ }^{277}$. Piotr Grzegorczyk zapoznał czytelników z tragicznymi losami dwukrotnie gromadzonego prywatnego księgozbioru druków ariańskich Adolfa Nowaczyńskiego, który wśród broszur posiadał białe kruki ${ }^{278}$. Biblioteka Karola Irzykowskiego spłonęła w pożarze wywołanym bombą w czasie oblężenia Warszawy w 1939 r. ${ }^{279}$ Ogień pochłonął również we wrześniu 1939 r. księgozbiór Juliana Krzyżanowskiego, który zawierał cimelia

${ }^{272}$ S. Janczewski, Prywatne straty kulturalne 1939-1945. Zbiory Stan. Janczewskiego, „TW” 1946 nr 15 s. 7.

${ }^{273}$ P. Grzegorczyk, Prywatne straty kulturalne 1939-1945. Rękopisy Z. Wasilewskiego, „TW” 1946 nr 16 s. 15.

${ }^{274}$ Z. Rabska, Prywatne straty kulturalne 1939-1945. Zbiory Z. Rabskiej, „TW” $1946 \mathrm{nr} 17$ s. 7.

${ }^{275}$ M. Malinowski, Prywatne straty kulturalne 1939-1945. Zbiory M. Malinowskiego, „TW” 1946 nr 18 s. 7.

${ }^{276}$ S.F. Michalski, Prywatne straty kulturalne 1939-1945. Biblioteka S. i J. Michalskich, „TW” 1946 nr 19 s. 7.

277 Tamże.

278 P. Grzegorczyk, Prywatne straty kulturalne 1939-1945. Zbiory A. Nowaczyńskiego, „TW” 1946 nr 20 s. 7.

${ }^{279}$ Tenże, Prywatne straty kulturalne 1939-1945. Zbiory Karola Irzykowskiego, „TW” 1946 nr 21 s. 7. 
i rzadkie pierwodruki ${ }^{280}$. Wrześniowe bombardowania nie oszczędziły także bogatych zbiorów nie tylko książkowych, ale też i obrazów, rzeźb, mebli, dywanów i pamiątek artystycznych Ludwika Solskiego, który chciał je przekazać Muzeum Narodowemu w Warszawie ${ }^{281}$. Biblioteka Mariana Gumowskiego licząca około 8 tys. woluminów została zrabowana przez gestapo w $1940 \mathrm{r}^{282}$ Bolesław Gawecki, z żalem po dwukrotnej utracie swego księgozbioru (podczas I i II wojny światowej), napisał: „Żyłkę kolekcjonerską posiadaną od dzieciństwa, wypruło ze mnie powstanie. Teraz już nic nie zbieram. Przestałem nawet pisać dziennik, choć robiłem to nie mniej ni więcej, tylko z górą 41 lat bez przerwy" "283. Całkowicie rozkradziono w czasie ostatniej wojny „szafę książek wyłącznie z dedykacjami” Stefana Dembego ${ }^{284}$.

W zawartości „Tygodnika Warszawskiego” w 1946 r. zagościł cykl Biblioteki warszawskie. W jego ramach Marian Łodyński dość szczegółowo omówił losy Biblioteki Krasińskich podczas wojny ${ }^{285}$. Większa część jej zbiorów została zniszczona przez Niemców w 1939 i 1944 r., tylko jej resztki włączono do Biblioteki Narodowej. Głos w sprawie odbudowy gmachu tejże książnicy zabrał Aleksander Oleksiński ${ }^{286}$. Jak dowiadujemy się z artykułu Bogdana Horodyskiego, szczątkowy księgozbiór Biblioteki Ordynacji Zamoyskiej Niemcy w czasie okupacji przesłali do Görbitsch ${ }^{287}$. Początki istnienia Biblioteki hr. Przeździeckich w XVIII w. i dalszą jej historię przybliżył Zygmunt Wdowiszewski. Księgozbiór poniósł ogromne straty we wrześniu $1939 \mathrm{r}$. i podczas powstania warszawskiego ${ }^{288}$. We wspomnianym cyklu przedstawiono jeszcze działalność i przebieg odbudowy w latach 1944-1946 Biblioteki Publicznej m.st. Warszawy ${ }^{289}$.

Z okazji przeniesienia zbiorów Zakładu Narodowego im. Ossolińskich z Lwowa do Wrocławia w 1946 r. Marian Górkiewicz na łamach „Tygodnika Powszechnego" przypomniał początki i losy księgozbioru, który stał się w czasach zaborów ,ogniskiem ruchu narodowego, literackiego i naukowego" ${ }^{290}$. Do lwowskiego okresu Biblioteki powrócił jeszcze raz w piśmie Aleksander

${ }^{280}$ P.G., Prywatne straty kulturalne 1939-1945. Zbiory Prof. Juliana Krzyżanowskiego, „TW” 1946 nr 27 s. 7.

${ }^{281}$ Z. Rabska, Prywatne straty kulturalne 1939-1945. Zbiory Ludwika Solskiego, „TW” 1946 nr 29 s. 7.

${ }^{282}$ M. Gumowski, Prywatne straty kulturalne 1939-1945. Zbiory Mariana Gumowskiego, „TW” 1946 nr 23 s. 7.

${ }^{283}$ B. Gawecki, Prywatne straty kulturalne 1939-1945. Biblioteka prof. B. Gaweckiego, „TW” $1946 \mathrm{nr} 25$ s. 7.

${ }^{284}$ P. Grzegorczyk, Stefan Demby, „TW” 1946 nr 13 s. 7.

${ }^{285}$ M. Łodyński, Okupacyjne dzieje Biblioteki Krasińskich, „TW” 1946 nr 44 s. 4.

${ }^{286}$ A. Oleksiński, $W$ sprawie Biblioteki Krasińskich, „TW” 1946 nr 27 s. 7.

${ }^{287}$ B. Horodyski, Biblioteka Ordynacji Zamojskiej, „TW” 1946 nr 45 s. 4.

${ }^{288}$ Z. Wdowiszewski, Biblioteka hr. Przeździeckich, „TW” 1946 nr 46 s. 4.

${ }^{289}$ Biblioteka Publiczna m. st. Warszawy, „TW” $1946 \mathrm{nr} 47 \mathrm{s.}$.

${ }^{290}$ M. Górkiewicz, Ossolineum 1817-1947, „TP” 1948 nr 28 s. 6. 
Małachowski, zapoznając czytelników bardziej szczegółowo z jej księgozbiorem. W swej wypowiedzi docenił przede wszystkim nowoczesną organizację placówki ${ }^{291}$. Historię książnicy ze szczególnym ukazaniem jej roli na Ziemiach Odzyskanych poznali także odbiorcy „Tygodnika Katolickiego" ${ }^{292}$. W tym artykule, jak też w sprostowaniu, które ukazało się w „Tygodniku Warszawskim”, zwrócono uwagę na znajdujący się w Bibliotece rękopis Pana Tadeusza ${ }^{293}$.

Z innych polskich bibliotek, na łamach „Tygodnika Powszechnego" Władysław Konopczyński obszernie przedstawił dzieje Biblioteki Załuskich, a Olgierd Porycki Bibliotekę im. Zielińskich w Płocku ${ }^{294}$. Jak wiadomo z artykułu zamieszczonego w „Tygodniku Katolickim”, podwaliną miejskiej biblioteki w Gdańsku, ocalałej w czasie II wojny światowej, stał się dar z tysiąca tomów politycznego emigranta Bonifacego d'Oria ${ }^{295}$. Ważnym „ogniskiem kulturalnym” w zachodniej Polsce stała się Biblioteka Raczyńskich, której budynek hitlerowcy doszczętnie spalili. Po ustaniu działań wojennych miała zostać odbudowana, jak można było przeczytać w „Tygodniku Katolickim”, w ramach planu 6-letniego ${ }^{296}$. Włodzimiera Jarochowska boleśnie wspominała: „Niemcy podpalili Bibliotekę Raczyńskich i gmach płonął wraz z sąsiednimi budynkami, niszczonymi systematycznie ręką germańskich zbrodniarzy, a niespalone budynki runęły trafione pociskami bomb i artylerii"’297. Jako ważny ośrodek naukowy Dolnego Śląska ukazano jedną z najzasobniejszych w tzw. silesiana bibliotek, noszącą imię Jerzego Samuela Bandtkiego w Cieplicach ${ }^{298}$.

Problematyka bibliotek rozważana była od strony prawnej i historycznej poszczególnych księgozbiorów. W wypowiedziach skupiono się raczej na ważniejszych polskich książnicach, przedstawiając ich działalność i zawartość. Rzadziej wspominano o mniej znanych placówkach kulturalnych. Zabrakło zupełnie tego typu wypowiedzi o bibliotekach zagranicznych, zapewne dlatego, że w tym czasie utrudniano publikowanie artykułów na ten temat. Wśród wypowiedzi na łamach „Tygodnika Warszawskiego" szczególnie cenne były te, w których baczną uwagę zwrócono na utracone w czasie wojny księgozbiory prywatne. Godna podziwu wydaje się być wytrwałość większości kolekcjonerów rozpoczynających gromadzenie księgozbioru od początku.

Zamykając część poświęconą ,„̇yciu książki”, warto odnotować, że w analizowanym materiale prasowym, choć problematyka ta nie była często podejmowana,

\footnotetext{
${ }^{291}$ A. Małachowski, Ossolineum ...

${ }^{292}$ K.B. Caban, Ossolineum, „TK” 1953 nr 2 s. 15.

${ }^{293}$ Rękopis „Pana Tadeusza” wśród zbiorów „Ossolineum”, „TW” 1947 nr 28 s. 3.

${ }^{294}$ W. Konopczyński, Biskup bez biblioteki, „TP” 1947 nr 33 s. 1, 3; O. Porycki, Nieznana biblioteka, „TP” $1951 \mathrm{nr} 37$ s. 2.

${ }^{295}$ L.P., Biblioteka gdańska-nadmorska strażnica wiedzy, „TK” 1949 nr 7 s. 62.

${ }^{296}$ H., Biblioteka Raczyńskich, „TK” 1951 nr 45 s. 391.

${ }^{297}$ W. Jarochowska, Jak spłonęta Biblioteka Raczyńskich i Hotel Bazar, „GK” 1945 nr 13 s. 4.

${ }^{298}$ L.P., Biblioteka naukowa w Cieplicach, TK" 1949 nr 7 s. 64.
} 
to jednak była obecna. Publicyści piszący na łamach katolickich periodyków społeczno-kulturalnych sprawy drukarń i księgarń rozważali sporadycznie, częściej natomiast dzieje i losy księgozbiorów bibliotecznych. Artykuły miały charakter księgoznawczy i zdradzały wyjątkowe zamiłowanie do książek.

\subsection{Zagadnienia czytelnictwa}

Sprawy czytelnicze podejmowano na łamach katolickich pism w różnoraki sposób. W ogólnych omówieniach oceniono sytuację czytelnictwa po ostatniej wojnie. Zwrócono uwagę na rodzaj czytanych książek i samą metodę odbioru lektury oraz na problemy zasięgu czytelnictwa. W publikacjach znalazły się też zagadnienia dotyczące preferencji czytelniczych. Szczególne miejsce w analizach zajęła książka o tematyce religijnej, przeznaczona dla młodzieży. Publicyści propagowali przede wszystkim wartościową i „dobrą książkę”.

W ogólnych rozważaniach na temat zadań literatury Stefan Kisielewski zapytywał, czy podejmowana ówcześnie problematyka wojenna i obozowa zaspokajała potrzeby czytelnicze. Negatywną odpowiedź uzasadnił tym, że czytelnik szukał raczej w powieściach odmiennej niż „oświęcimowo-majdankowej" atmosfery, skłaniając się raczej ku lekturze lżejszej i odprężającej, przy której można było odpocząćc ${ }^{29}$. Ks. Stanisław Wawryn zastanawiał się natomiast, czy straty książek poniesione podczas wojny miały wpływ na poziom czytelnictwa w Polsce. Jego upadek dostrzegał głównie na wsi, do czego przyczyniły się analfabetyzm oraz trudności, jakie sprawiało ludności wiejskiej sprawne i ciche czytanie. $Z$ artykułu dowiadujemy się również o państwowej inicjatywie zaradzenia słabemu czytelnictwu chłopów i robotników poprzez masową produkcję taniej książki, której realizacji podjął się specjalnie do tego powołany Komitet Upowszechniania Książki w 1948 r. Potrzeby i upodobania czytelnicze badano dzięki ankietom i wywiadom prowadzonym przez Instytut Kulturalno-Oświatowy Czytelnika. Publicysta jezuickiego miesięcznika stwierdził bowiem: „Tu leży sedno zagadnienia: czy puszczone w obieg książki odpowiedzą oczekiwaniom szerokich rzesz czytelniczych, dla których są przeznaczone. Bo cóż z tego, że się książkę wydrukuje w 50000 egzemplarzy, że będzie ona tania i dobrze wydana, że się ją szybko i sprawnie w terenie rozprowadzi [...] jeśli nie znajdzie przyjęcia wśród czytelników. [...] sprawność i wartość wydanej książki mierzy się ilością egzemplarzy przez ilość przeczy$\operatorname{tań}^{\prime \prime 30}$. Anna Reiterowa na podstawie pracy zbiorowej pt. Badanie czytelnictwa dość szczegółowo omówiła wyniki ankiety przeprowadzonej w 1945 r.

${ }^{299}$ S. Kisielewski, Tematy wojenne, „TP” 1945 nr 9 s. 3.

${ }^{300}$ S. Wawryn, Sprawozdanie z ruchu religijnego, kulturalnego i społecznego, „PP” $1948 \mathrm{nr} 9$ s. $272-273$. 
wśród młodzieży czterech największych miast polskich (Warszawy, Krakowa, Łodzi i Katowic). Zapoznała też czytelników z upodobaniami czytelniczymi na wsi ${ }^{301}$. Czytelnictwo mieszkańców prowincji jedynie częściowo zobrazował konkurs zatytułowany „Jakiej powieści chce dzisiejsza wieś?” ogłoszony przez redakcję tygodnika „Wieś” w 1946 r., a odnotowany w dziale Wśród czasopism „Tygodnika Powszechnego”. Kilka wyników zacytowanych z opracowania wykazało popularność polskiej powieści takich pisarzy jak Henryk Sienkiewicz, Bolesław Prus, Stefan Żeromski, Władysław Reymont czy Eliza Orzeszkowa. Rezultaty nasunęły wniosek, iż należy wznawiać popularne wydania dzieł klasyków polskich ${ }^{302}$. Kolejne fragmenty zaprezentowanego sondażu dotyczyły doświadczeń czytelniczych chłopów ${ }^{303}$. Jaka powinna być odpowiednia książka dla czytelników na wsi? - zastanawiała się Zofia Sutorowska. W odpowiedzi stwierdziła: „Ma to być książka wyraźnie pisana, więc nie tylko higienicznym drukiem na jasnym papierze, ale i dobrym, jasnym językiem, nie nazbyt bogatym. [...] Człowiek prosty pragnie książki, w której się coś dzieje - a jeszcze lepiej: niech się dzieje coś niezwykłego!"304. Temat oświaty i kultury wsi poprzez zwalczenie ,analfabetyzmu powrotnego" i rozbudzenie czytelnictwa podjął w „Tygodniku Powszechnym” Konstanty Turowski. Rozpoczynając od informacji o uchwaleniu ustawy o walce $\mathrm{z}$ analfabetyzmem z dnia 7 IV 1949 r., wymienił kilka środków, mających utrwalić przyzwyczajenia czytelnicze w kręgach wiejskich. Konstatował jednocześnie: „Czytanie winno się stać codzienną czynnością, tak jak jest nią praca zawodowa. Obecnie jest albo luksusem $\mathrm{z}$ braku dostępu do książek, albo uważane jest za zbyteczną stratę czasu" ${ }^{305}$.

Odbiorcy „Tygodnika Powszechnego" mogli poznać również upodobania czytelnicze w okresie dwudziestolecia międzywojennego, w czasie okupacji niemieckiej i współcześnie dzięki artykułowi A. Reiterowej. Okres dwudziestolecia autorka omówiła na podstawie porównania badań ogłoszonych w broszurze Maksymiliana Józefa Ziomka Czytelnictwo polskie w świetle cyfr i ankiety „Wiadomości Literackich” zatytułowanej Szerokie masy a literatura z 1933 r. Stwierdziła przy tym, że w okresie II Rzeczypospolitej chętnie czytano „lekkie powieści" autorów obcych oraz książki o tematyce wojennej. W czasie okupacji zaobserwowano dalsze zainteresowanie lżejszą literaturą rozrywkową. Po wojnie natomiast nikłe było zaciekawienie powieścią o tematyce wojennej i psychologicznej, wzrosło zaś czytelnictwo powieści historycznej (m.in. Kraszewskiego, Dąbrowskiej i Kossak). Współcześni Reiterowej odbiorcy preferowali przede

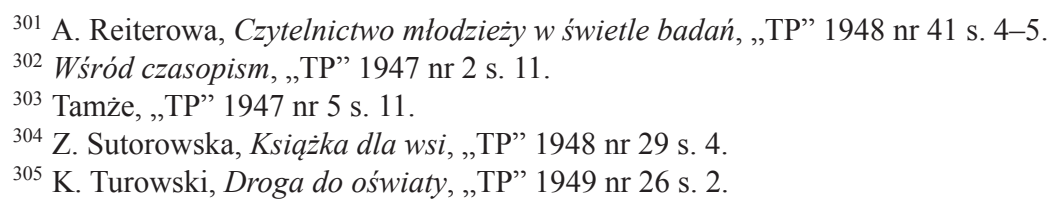


wszystkim „pogodne książki” autorów polskich, o wysokich walorach artystycznych i literackich ${ }^{306}$. Władysław Czapliński uznał natomiast za najciekawszą książkę przeczytaną przez siebie w czasie okupacji zakazaną przez Niemców antologię wierszy Pisarze ludowi wydaną przez Karola Ludwika Konińskiego ${ }^{307}$. Na łamach „Tygodnika Powszechnego" zastanawiano się również ogólnie nad wartością i czytelnictwem powieści ${ }^{308}$.

Halina Kamieniecka zapoznała natomiast z ówczesnym życiem kulturalnym w Szwecji i dobrze zorganizowaną akcją oświatową wśród mas i działaniami mającymi na celu podniesienie poziomu czytelnictwa poprzez stworzenie sieci bezpłatnych bibliotek gminnych w każdym miasteczku i osadzie ${ }^{309}$.

Na łamach „Znaku” wspomniano o religijnych tytułach książkowych, które w 1949 r. w USA zajęły czołowe miejsca na listach bestsellerów i cieszyły się dużą poczytnością. Do nich należały: powieść Wielki rybak Lloyda Douglasa, która rozeszła się w nakładzie 450 tys. egzemplarzy w przeciągu kilku miesięcy, autobiografia pt. Siedmiopiętrowa góra Thomasa Mertona oraz Pokój duszy Fultona Sheena ${ }^{310}$. We fragmencie Listu pasterskiego księdza administratora apostolskiego Edmunda Nowickiego do rodziców o religijnym wychowaniu dzieci znajdował się fragment zachęcający rodziców do głośnego czytania książek. Ks. Nowicki pisał: „, [...]wspólne czytanie daje wielorakie korzyści. Dziecko, gdy przysłuchuje się, przyjmuje wolniej i gruntowniej piękno książki aniżeli, gdy czyta samo, zwykle szybko i powierzchownie. [...] Wspólne też czytanie łączy rodzinę, a dzieci przyzwyczajają się cenić książki wartościowe"311. Na łamach „Tygodnika Katolickiego" zauważono konieczność przygotowania się młodych do lektury książek katolickich i włożenia w nią ,ppracy duchowej”. Stwierdzono ponadto, że o ile dawniej książki religijne były pisane dla osób starszych i rozprawiały „poważnie, w sposób nieraz trudny, bardzo naukowy o zagadnieniach wiary i moralności”, to w ostatnich latach: „Książka katolicka zapłonęła rumieńcem życia ... Nieraz stała się arcydziełem ... Odwieczne prawdy wiary, zasady moralności, zdarzenia z historii Kościoła, postacie świętych umiała tak pociągająco, nawet zachwycająco przedstawić, że znajdowała coraz bardziej rosnące zastępy wdzięcznych czytelników, stąd poczynała ukazywać się w bardziej poważnej ilości egzemplarzy. W dziedzinie ogólnej literatury poczęła zajmować miejsce coraz

${ }^{306}$ A. Reiterowa, Zagadnienia. Czytelnictwo dziś a przed wojna, „,TP” 1946 nr 27 s. 2.

${ }^{307}$ W. Czapliński, Najciekawsza ksiażka przeczytana w czasie okupacji, „TP” $1945 \mathrm{nr} 2 \mathrm{~s} .4$.

${ }^{308}$ M.in. GOA [A. Gołubiew], Czytelnicy o powieści, „TP” 1949 nr 32 s. 6-8; M. Grekowica, Dlaczego czytamy powieści?, tamże, nr 32 s. 6; F. Pudełko, Jaka chcę mieć powieść?, tamże,

${ }^{309}$ H. Kamieniecka, Życie kulturalne w Szwecji, „TW” 1947 nr 28 s. 6.

${ }^{310}$ W., Poczytność książek religijnych, „Znak” 1949 nr 4 s. 374.

${ }^{311}$ E. Nowicki, List pasterski do rodziców o religijnym wychowaniu dzieci, „TK” $1950 \mathrm{nr} 39$ s. 315 . 
bardziej poczesne i poczytne" ${ }^{12}$. Publicysta „Tygodnika Katolickiego" zachęcał młodzież do czytania „dobrej lektury”, pisząc: „Nie czytaj rzeczy ordynarnych, zmysłowo podniecających, śliskich. A właśnie za takimi książkami młodzież poluje, bo owoc zakazany lepiej smakuje. Takie książki zaśmiecają twoją wyobraźnię, nastawią chorobliwie twą myśl, rozbudzą zmysły, doprowadzą cię do upadku" ${ }^{\prime 13}$. Leszek Prorok natomiast przestrzegał przed zamieszczanymi w prasie „powieściami rysunkowymi”, które „psuły smak słowa pisanego” młodym czytelnikom i stanowiły „szkodliwą podaż tandety gazetowej”314. Zofia Zawiszanka w trosce o nauczenie młodzieży „,wybredności w czytaniu” i występując przeciwko nałogowi czytania, pytała: ,[...] czy aby nie czytamy w ogóle za wiele? A co za tym idzie - byle jak?"’15. Zwracając uwagę na odpowiedzialność czytelnika za to, jaką wybiera lekturę, wyraziła przekonanie, że: ,zaczytywanie się bez wyboru ni hamulca - to jeden z najszkodliwszych nałogów, bo jest nałogiem mózgu, bo odejmuje człowiekowi panowanie nad dziedziną własnych myśli, [...] a [człowiek - E.K.] raczej głupieje niż <<oświeca się>>" ${ }^{16}$.

W dziale Spotkań literackich na łamach „Tygodnika Powszechnego” Antoni Gołubiew gawędził o czytaniu. Wypowiedział się m.in. o doznanym wzruszeniu i przyjemności z przeczytania książki dla dzieci przez dorosłego. Przypominając uwagę Bronisławy Ostrowskiej, która przeznaczyła Bohaterskiego misia „dla dzieci od lat dziesięciu do stu" stwierdził, że tego rodzaju pozycje pamięta się przez całe życie i dzięki nim można nauczyć się patrzeć „,na świat oczyma dziecka" ${ }^{117}$. Wpływ lektury książki Marka Twaina zatytułowanej Przygody Tomka Sawyera ten sam publicysta ukazał w jednym z felietonów, wspominając o otrzymanym liście od swej ciotki. Jego treść brzmiała następująco: „Zlituj się, mój Drogi, dobieraj ostrożniej lekturę dla chłopca. Odkąd przeczytał Przygody Tomka Sawyera, które mu posłałeś, smarkacz stał się niemożliwy. Okazuje się, że jestem kubek w kubek podobna do ciotki Tomka i figle, które muszę znosić, przerastają moją cierpliwość. Nawet mego ukochanego kota..., ale jeśli chcesz wiedzieć, co mu zrobił, sięgnij do znakomitego dzieła Marka Twaina, na którym wychowujesz swoje potomstwo"318. Refleksja ciotki przyczyniła się do wyeliminowania z lektury kolejnej pozycji Twaina Yankes na dworze króla Artusa, będącej w opinii Gołubiewa „satyrą na średniowiecze”, ukazującą epokę w „fałszywym zwierciadle" ${ }^{119}$. W innym miejscu podzielił się z czytelnikami refleksjami o zetknięciu się z książkami w różnych okresach swego życia: w dzieciństwie, podczas porząd-

\footnotetext{
312 J.W., Lektura ksiażek religijnych, „TK” 1951 nr 29 s. 263.

313 Dziewcze katolickie a Serce Boże, „TK” 1951 nr 39 s. 344, 350.

${ }^{314}$ L. Prorok, Zagadnienia i opinie, ,TW” $1948 \mathrm{nr} 4$ s. 12.

${ }^{315}$ Z. Zawiszanka, Natóg czytania, „TP” 1947 nr 32 s. 2.

316 Tamże.

${ }^{317}$ Goa [A. Gołubiew], Drewniany pajacyk, „TP” 1948 nr 31 s. 4.

318 Tenże, Rycerz w cylindrze, „TP” 1948 nr 28 s. 9.

319 Tamże.
} 
kowania cudzej biblioteki domowej i w czasie wojny, kiedy każda pozycja była witana ,jako dar losu”. O okresie okupacji wspominał: „Wtedy to zrozumiałem, jak barbarzyńsko dotąd czytałem. Jak ilość zabijała gruntowniejsze przeżycie. Jak bardzo pobieżnie przebiegało się myślą przez strony, jak się lekturę marnowało. Przeczytanie dwudziestu książek w czasie wojny dało mi więcej, niż poprzednio dwadzieścia książek miesięcznie" ${ }^{320}$. Zgodny z tą opinią był Stefan Jarecki w artykule opublikowanym w „Głosie Katolickim”, podkreślając, że dobre czytelnictwo polega na wyborze najlepszej lektury i powolnym jej czytaniu. Główne zadanie bibliotekarzy widział w świadomym pokierowaniu doborem książek dla czytelnika, którego należało nauczyć „odróżniania plew od pereł i [skłonić] do poszukiwania jedynie tych ostatnich" "321. Antoni Trepiński pouczał natomiast: „szkoda czasu na $<<$ dobre $>>$ książki, bo poświęcać go należy jedynie na $<<$ bardzo dobre>>; również nie powinno się czytać po raz pierwszy żadnych książek, których nie warto czytać po raz drugi"'322.

Inny felietonista na łamach tego samego pisma ubolewał: „A co wam powiem, to wam powiem, ale wam powiem, że dużo śmiecia zadrukowanego kupujecie i czytacie" ${ }^{23}$. Innym razem podniesienie stanu czytelnictwa prasy katolickiej bez zwiększenia jej nakładów widział w oddaniu numeru pisma po przeczytaniu komuś, kto go jeszcze nie czytał ${ }^{324}$.

Tadeusz Haluch w dziale Spraw młodzieży na łamach „Tygodnika Katolickiego" poruszał niekiedy zagadnienia czytelnictwa. Podkreślił przede wszystkim znaczenie lektury i powody, dla których sięgamy po książkę. Polecał młodym również odpowiedni jej dobór, krytycyzm podczas czytania przy jednoczesnym odróżnianiu „książki dobrej i użytecznej” od „złej, działającej negatywnie na umysł i wyobraźnię” ${ }^{25}$. Pouczał przy tym: „Czytać należy raczej mniej, lecz gruntownie i jedynie rzeczy dobre i wartościowe. Czytamy bowiem nie dla zabicia czasu, lecz po to, aby odnieść z tego trwałą intelektualną korzyść" ${ }^{326}$. W innym miejscu doradzał: „Otrzepując z pyłu książki szkolne, zwróć swą bystrą pamięć ku niedalekiej wakacyjnej przeszłości i zapytaj sam siebie, czyś aby nie zmarnował swych wakacji swym idealnie konsekwentnym wstrętem do czytania. Jeśliś nic nie czytał - tym gorzej dla ciebie, jeśli odwrotnie: udziel sobie pochwały, bowiem czytanie dobrych i wartościowych książek kształci nie tylko twój umysł, ale i serce, pogłębia zdolność świadomego przeżywania ciekawych zjawisk naszego życia, uszlachetnia naszą duchową istotę, uskrzydla wyobraźnię"327.

${ }^{320}$ Goa [A. Gołubiew], Trzy wtajemniczenia, „TP” 1951 nr 6 s. 6.

321 S. Jarecki, Nie czytaj DOBRYCH książek, „GK” 1948 nr 17 s. 153.

322 A. Trepiński, Zagadnienia. Od Maxa Branda do Mickiewicza, ,TP” 1947 nr 16 s. 2.

323 Jacek, [J. Archita] Głos z kąta. O czytelnictwie, „GK” 1947 nr 42 s. 352.

324 Tenże, Głos z kąta. Bez tytułu, „GK” 1947 nr 48 s. 396.

325 T. Haluch, Sprawy młodzieżowe. O czytaniu, „TK” 1948 nr 22 s. 152.

326 Tamże.

327 T. Haluch, Sprawy młodzieży, ,TK” 1949 nr 33 s. 300. 
Niekiedy z notek prasowych odbiorcy dowiadywali się o zakazie czytania niektórych pozycji książkowych. Tak było w przypadku wycofanej z rynku czytelniczego przez rząd węgierski książki Moja matka kardynała Jozsefa Mindszenty’ego. Pomimo jej dużej popularności postanowieniem objęto również osoby prywatne posiadające ów tytuł ${ }^{328}$. W „Głosie Katolickim” doniesiono także o umieszczeniu dzieł Jeana Paula Sartre'a na indeksie ksiąg zakazanych ze względu na reprezentowany przez niego egzystencjalizm ateistyczny ${ }^{329}$. Na łamach „Tygodnika Powszechnego" ukazała się także wiadomość, że decyzją Kongregacji Świętego Oficjum zabroniono czytania i rozpowszechniania ośmiu książek wydanych w latach 1949-1952 a poświęconych cudom, proroctwom i stygmatom późniejszego świętego o. Pio ${ }^{330}$.

Ciekawostką była informacja o dość szybkim czytaniu alfabetem Braille’a przez niewidome dzieci mieszkające w Laskach ${ }^{331}$. Z notatki "Tygodnika Powszechnego" odbiorcy dowiedzieli się o nabożeństwie sekty indyjskiej w Londynie w $1950 \mathrm{r}$. polegającym na nieprzerwanym trwającym 50 godzin czytaniu świętej księgi sikhów ${ }^{332}$. „Kilka ciekawych danych statystycznych”, w których przedstawiono rzekomą poczytność autorów według ilości thumaczeń dokonanych w 1950 r., opublikowano w „Tygodniku Powszechnym”. Czytamy m.in.: „Na pierwszym miejscu stoją dzieła Lenina: 159 przekładów. Na drugim - dzieła Stalina: 112 przekładów"333. Nie było to oczywiście dowodem na popularność książek tych autorów, gdyż de facto pozycje te zalegały w magazynach różnych hurtowni, a po kilku latach oddano je na przemia1 ${ }^{334}$.

Starano się również pomóc odbiorcom w trudnej interpretacji tekstów biblijnych. W jaki sposób czytać Pismo święte i na jakie trudności napotykamy w zrozumieniu tekstu - można było dowiedzieć się z wypowiedzi Józefy Golmont ${ }^{335}$. Wojciech Bąk zwrócił uwagę z kolei na poetycki styl i piękno Ewangelii, której zrozumienie ułatwiają komentarze $\mathrm{e}^{336}$.

Informowano o akcjach mających przyczynić się do upowszechnienia czytelnictwa. Przykładowo dowiadujemy się, że w okresie ferii świątecznych w 1948 r. w Warszawie odbyło się spotkanie recytatorskie bajek dla dzieci Henryka Ładosza ${ }^{337}$. Dla „rozbudzenia wśród młodych zamiłowania do czytania”

328 Ze świata katolickiego, „GK” 1947 nr 8 s. 62.

${ }^{329}$ Tamże, „GK” 1949 nr 12 s. 104.

${ }^{330}$ Kronika religijna, „TP” 1952 nr 39 s. 7.

${ }^{331}$ Lipski, W zakładzie dla najnieszczęśliwszych, „TK” 1951 nr 28 s. 255-256.

332 Z dnia, „TP” 1950 nr 20 s. 6.

333 j., Kogo tlumacza?, „TP” 1952 nr 49 s. 12.

${ }^{334}$ Szerzej zob. S. Kondek, Papierowa rewolucja. Oficjalny obieg ksią̇ek w Polsce w latach 1948-1955, Warszawa 1999.

335 J. Golm. [J. Golmont], Jak czytać Pismo święte?, „Znak” 1949 nr 6 s. 500-505.

${ }^{336}$ W. Bąk, Jak czytać Ewangelię?, „GK” 1946 nr 1 s. 6.

${ }^{337}$ Przegląd kulturalny, „TW” $1948 \mathrm{nr} 4$ s. 10. 
zorganizowano konkurs recytatorski poezji Juliusza Słowackiego ${ }^{338}$. Dorosłym zaproponowano z kolei w ramach odczytów dyskusyjnych Czytelnika, pod hasłem „Autorzy wśród swych czytelników”, spotkania z Antonim Gołubiewem w kilku miastach Wielkopolski i Ziemi Lubuskiej ${ }^{339}$. Z inicjatywy Związku Zawodowego Literatów i Spółdzielni Wydawniczej Czytelnik w 1948 r. około 30 pisarzy rozpoczęło badanie stanu czytelnictwa na wsi poprzez wieczory autorskie, rozmowy indywidualne i zbieranie danych o upowszechnianiu książki ${ }^{340}$.

W jednej z wiadomości „Tygodnika Powszechnego” dowiadujemy się, że uchwałą Prezydium Rządu utworzono Radę Czytelnictwa i Książki, której zadaniem miało być „mobilizowanie, popieranie, koordynowanie i inicjowanie prac związanych ze sprawą upowszechnienia książki, szerzenia czytelnictwa, należytego rozprowadzenia książki i organizowania sieci bibliotecznej"341. W swej działalności miała ona na celu współpracę z Komitetem Upowszechniania Książki, Naczelną Dyrekcją Bibliotek, Centralnym Urzędem Wydawnictw, Przemysłu Graficznego i Księgarstwa oraz z Domem Książki.

O prowadzonych w USA kursach szybkiego czytania odbiorcy czasopism dowiedzieli się z artykułu w „Znaku” ${ }^{342}$. W krótkiej notatce zamieszczonej na łamach „Tygodnika Katolickiego” podano ciekawostkę o przyrządzie wyprodukowanym przez amerykańskich wynalazców, za pomocą którego można było czytać czterokrotnie szybciej ${ }^{343}$.

Prawie wszyscy publicyści wypowiadający się o czytelnictwie starali się w sposób wychowawczy uwrażliwić odbiorców na świadomy wybór dobrej lektury. Sugerowano także, w jaki sposób należy czytać, aby odnieść korzyść intelektualną i duchową. Ich troską było też szerzenie czytelnictwa. Na jego temat na łamach „Tygodnika Powszechnego" wypowiadali się m.in. Anna Reiterowa i Antoni Gołubiew. Opinie dotyczące omawianych zagadnień miały charakter opisowy, jak też gawędziarski i wspomnieniowy. Ważne miejsce zajęły kwestie analfabetyzmu i odpowiedniej lektury dla czytelników na wsi. Przedstawiono ponadto wyniki badań czytelnictwa.

Inne formy promocji książki były równie ważne, jak recenzje, ogłoszenia reklamowe i wszelkiego rodzaju informacje o nowościach. Uwzględnienie ich przyczyniło się do całościowego ukazania problematyki bibliologicznej na łamach katolickich czasopism społeczno-kulturalnych w latach 1945-1953. Zapowiadaną w reklamie pozycję książkową nie tylko recenzowano, ale niekiedy przytoczono też w odcinku jej fragmenty. Niektóre tytuły można było zatem poznać dogłębnie

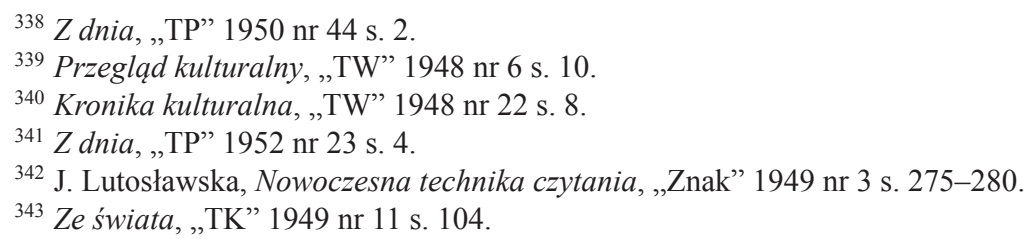


dzięki różnym sposobom zaprezentowania. Książka towarzyszyła także różnym imprezom kulturalnym i wystawom, o których publicyści chętnie wspominali na łamach pism. Ciekawą część opracowanych materiałów prasowych stanowiły rozważania o miłośnikach ksiąg i losach ksiąg w czasie wojny. W ,życie książki” wpisały się natomiast nieliczne, ale cenne wypowiedzi dotyczące instytucji obiegu książki, jak też ogólne rozważania o niej. Ostatnią problematyką zamykającą opracowanie była kwestia jej odbioru. 


\section{Zakończenie}

Najbardziej znaczące katolickie czasopisma społeczno-kulturalne wydawane w latach 1945-1953 ukazywały się w głównych ośrodkach wydawniczych prasy tego typu: Krakowie, Warszawie i Poznaniu. Analiza ich zawartości dowiodła, że periodyki te, chociaż nie należały do zakresu specjalistycznej prasy bibliologicznej, odegrały znaczącą rolę $\mathrm{w}$ promowaniu kultury książki w trudnym okresie powojennym. Ich redakcje stosowały bogate i urozmaicone formy upowszechniania, wśród których przeważyły recenzje nowości wydawniczych. Tematyka ocenianych publikacji była dość szeroka, przy jednoczesnej różnorodności rodzajów i gatunków literackich. Założeniem redaktorów, zgodnie z profilem pism, stało się zapoznawanie odbiorców przede wszystkim z książką religijną i katolicką. Przedmiotem recenzji były też powieści, w tym powieści katolickie. Dość dużym powodzeniem po wojnie cieszyła się także na rynku wydawniczym literatura o tematyce wojennej i obozowej, której oceny dominowały na łamach sześciu czasopism. W większości publicyści piszący na łamach sześciu wybranych czasopism starali się zachęcić czytelnika do sięgnięcia po książkę poprzez interesującą, pogłębioną a zarazem dobrą opinię o niej (ponad połowa recenzji miała charakter pozytywny). W przeważającej części omówiono pozycje autorów rodzimych (ponad dwukrotnie więcej), gdyż te stanowiły większy procent powojennej produkcji wydawniczej.

Opiniowane książki pochodziły z różnych oficyn wydawniczych: prywatnych, spółdzielczych i państwowych, przy czym przemiany społeczne i polityczne doprowadziły do zamknięcia prawie wszystkich firm prywatnych. Książkę katolicką udostępniały przeważnie wydawnictwa diecezjalne i zakonne. Najbardziej zróżnicowaną ofertę wydawniczą przedstawiono na łamach „Tygodnika Powszechnego”, zarówno w promocji książki literackiej, jak też naukowej i popularnonaukowej. Liczebnie przeważyła produkcja książkowa Spółdzielni Wydawniczej Czytelnik. Częściej dostrzegano nowości nagrodzone oraz wyróżnione w Polsce i za granicą, chociaż nie zapominano jednocześnie o debiutach literackich początkujących twórców. Względna swoboda wyrażania opinii widoczna była wyraźnie w publikacjach prasowych z lat 1945-1948, bowiem wolność słowa od 1949 r. została ograniczona przez cenzurę i działanie swoistej autocenzury.

Ważne miejsce w propagowaniu książki w zawartości omawianych czasopism zajęły też reklamy, informacje o nowościach, przeglądy piśmiennictwa, spisy książek nadesłanych, nawiązania do publikacji przy okazji omawianych tematów. 
Oprócz tego czytelnictwu służyć miały cytaty fragmentów książek, drukowanie powieści w odcinkach, różne wiadomości o książkach, bibliofilach, bibliotekarzach i wydawcach, jak też ogólne rozważania o charakterze bibliologicznym. Współtworzący czasopisma zadbali zatem o wielorakie sposoby upowszechniania kultury czytelniczej w kręgach inteligencji.

Relacje między państwem a Kościołem bezpośrednio wpływały na działanie instytucji religijnych, w tym uzyskanie zgody przez redakcje na rozpoczęcie lub wznowienie tytułu prasowego. Początkowo ze względów taktycznych wydawano koncesje, aby od 1948 r. ograniczyć je, a w końcu 1953 r. zawiesić lub przejąć zespół. Drastycznym przykładem bezwzględnie realizowanej polityki władz komunistycznych było zamknięcie „Tygodnika Warszawskiego”, który pomimo późniejszych starań nie odrodził się. Po kilku latach pozornych swobód władze przystąpiły do zaplanowanego eliminowania Kościoła z życia publicznego i ateizacji społeczeństwa. Rozbiciu środowiska wiernych od wewnątrz służyć miał nowy ruch tzw. księży patriotów nazywany też ruchem księży postępowych, jak też Stowarzyszenie PAX zjednujące w podobny sposób katolików świeckich. Ich ideą przewodnią miało być godzenie komunizmu z katolicyzmem. Ogólnemu zastraszeniu społeczeństwa służyć miały też inwigilacje, aresztowania przeprowadzane przez funkcjonariuszy Urzędu Bezpieczeństwa oraz prześladowania duchownych, a także procesy pokazowe ludzi Kościoła.

W warunkach indoktrynacji komunistycznej środowiska skupione wokół pism katolickich dla inteligencji starały się tworzyć model kultury niezależnej; pomimo deklarowanej apolityczności stawały się opozycyjne wobec władzy, bowiem popularyzacja wartości chrześcijańskich i tradycji Kościoła w Polsce były niezgodne $\mathrm{z}$ obowiązującą linią propagandową. Czasopisma katolickie jawiły się jako trybuna przeciwległa dla periodyków marksistowskich tego okresu. $\mathrm{Na}$ ich łamach szeroko omawiano problematykę społeczną, kulturalną, wychowawczą, literacką i inną. Zabierano też głos w sprawie punktów zapalnych w stosunkach państwa z Kościołem. Działalność redakcji wpisywała się zatem w ogólny konflikt z władzą. Tworzony model kulturalny funkcjonował bardziej w sposób pośredni niż bezpośredni, głównie poprzez podkreślanie wartości najwyższych, a tym samym proponowaną odmienną od powszechnie głoszonej hierarchię wartości. Doceniano bowiem wartości moralne, niematerialne i ponadczasowe. Towarzyszyła temu inna interpretacja historii i rzeczywistości. Realizm katolicki wynikał z filozofii tomistycznej.

Członkowie redakcji szczególną uwagę poświęcali działalności instytucji upowszechniania kultury, w tym drukarniom, wydawnictwom, księgarniom i bibliotekom. Warunki ich pracy były utrudnione z powodu powojennych zniszczeń oraz ograniczeń narzuconych przez władzę komunistyczną. Książka odpowiednio dobrana i wypromowana przez publicystów na łamach czasopism społecznokulturalnych odegrała znaczącą rolę w utrwaleniu kultury chrześcijańskiej i popularyzacji katolickich wzorców życia społecznego. Godne polecenia nowości 
wydawnicze znalazły się w powtarzanych inseratach wydawniczych i księgarskich. Do sięgnięcia po niektóre tytuły książkowe w sposób w pełni uzasadniony zachęcano $\mathrm{w}$ recenzjach znanych publicystów katolickich. O książkach, w których poruszano problematykę społeczną, filozoficzną i teologiczną w kompetentny sposób wypowiadali się księża Jan Piwowarczyk i Jan Rostworowski. Tematyka katolicka była w kręgu zainteresowań m.in. Antoniego Madeja, Jerzego Brauna i Jerzego Stawskiego. Książkę historyczną chętnie omawiał Paweł Jasienica, natomiast na temat powieści, posługując się pięknym stylem, pisała Zofia Starowieyska-Morstinowa.

Na łamach pism w znacznie mniejszym zakresie upowszechniano książki zagranicznych autorów, co było wynikiem „dbałości” cenzury zarówno o ich przekłady, jak i oceny. Mało widoczna - zapewne również ze względu na ograniczenia cenzuralne - była polemika $z$ doktryną socrealizmu w sztuce, formalnie ogłoszoną na zjeździe literatów w Szczecinie w 1949 r. Pomimo jednak ostrej kontroli druków, treści przekazywane w wybranych pismach zaświadczyły o mocnym osadzeniu ideowym $\mathrm{w}$ tradycji chrześcijańskiej. Odbiorcy dostrzegali przeciwstawność światopoglądu chrześcijańskiego i materialistycznego. Nie próbowano bowiem godzić katolicyzmu z komunizmem, jak czyniła to redakcja „Dziś i Jutro”. Starano się raczej wyjaśniać, że oba światopoglądy wyrastały z zupełnie odmiennych źródeł.

Wypracowany własny model kultury, mimo że był zwalczany przez przedstawicieli władzy komunistycznej i w 1953 r. został mocno ograniczony, jednak zaistniał na trwałe. W określonych granicach powrócił po 1956 r., w okresie po Soborze Watykańskim II oraz w nauczaniu bł. Jana Pawła II.

Autorka żywi nadzieję, że w pracy uwydatniono częściowo ważne zjawisko kulturalne jakim są związki zachodzące między książką a prasą. Katolickie czasopisma społeczno-kulturalne w latach 1945-1953 odegrały bowiem doniosłą rolę w promocji wartościowej lektury i czytelnictwa. Należy stwierdzić też, że niektóre z nich, choć kontynuowane do dziś („Tygodnik Powszechny”, „Znak’, „Przegląd Powszechny”), w zmienionych warunkach politycznych nie zachowały takiego znaczenia, jakie posiadały w okresie stalinowskim. Ujęcie interdyscyplinarne może pomóc zainteresowanym w zrozumieniu istotnej roli książki w dziejach kultury w Polsce w dramatycznych warunkach powojennych. 



\section{Bibliografia}

\section{1. Źródła archiwalne}

\section{Archiwum Akt Nowych w Warszawie}

Główny Urząd Kontroli Prasy, Publikacji i Widowisk, sygn. 93; sygn. 122; sygn. 238.

\section{Instytut Pamięci Narodowej w Warszawie}

Akta kontrolno-śledcze dotyczące ks. Zygmunta Kaczyńskiego, sygn. BU 01439/19.

Akta kontrolno-śledcze dotyczące ks. Zygmunta Kaczyńskiego, sygn. BU 01236/1209/Jacket.

Akta kontrolno-śledcze dotyczące ks. Zygmunta Kaczyńskiego, sygn. BU 0259/568.

Akta sprawy nr 706/48 przeciwko Mielińskiemu Romanowi s. Aleksandra, oskarżonemu z art. 86 §1 i 2 K.K.W.P., sygn. BU 1063/317.

Akta sprawy przeciwko Romanowi Mielińskiemu, s. Aleksadra, sygn. BU 01236/769/Jacket.

Depozyt Antoniego Antczaka: list członków Stronnictwa Pracy (Karol Popiel, Antoni Antczak,

ks. Zygmunt Kaczyński, Józef Kwasiborski, Piotr Nowakowski, Wacław Bitner, Elżbieta Konfartowa, Jerzy Lewandowicz, dr Kazimierz Studentowicz) skierowane do premiera Józefa Cyrankiewicza, sygn. BU 1607/25.

Dossier na podejrzanych przestępstwa przeciw Państwu dotyczące Kazimierza Gajewskiego [kierownika administracyjnego „Tygodnika Warszawskiego”], sygn. BU 0-423/2157.

Ks. Zygmunt Kaczyński s. Franciszka, sygn. BU 0397/640.

Ministerstwo Bezpieczeństwa Publicznego. Departament śledczy [notatki Jerzego Brauna], sygn. BU 1572/2405.

Ministerstwo Spraw Wewnętrznych [materiały dotyczą zjazdu przyjaciół i współpracowników „Tygodnika Powszechnego” i „Znaku” w 1960 r.], sygn. BU 1585/23307.

Teczka personalna Romana Mielińskiego, sygn. BU 0259/320.

Różne dokumenty i materiały, sygn. BU 1585/2939.

\section{2. Źródla publikowane}

Dokumenty do dziejów PRL: Główny Urząd Kontroli Prasy 1945-1949, oprac. D. Nałęcz, Warszawa 1994.

Dominiczak H., Organy bezpieczeństwa PRL w walce z Kościolem katolickim 1944-1990 w świetle dokumentów MSW, Warszawa 2000.

Niepodległościowe organizacje młodzieżowe na Rzeszowszczyźnie w latach 1944-1956 w świetle dokumentów, oprac. B. Wójcik, Rzeszów 2009. 
Przeciw Kościołom i religii. Sprawozdania Sekcji 5 Wydziału V Wojewódzkiego Urzędu Bezpieczeństwa Publicznego w Krakowie 1946-1952, pod red. F. Musiała, Kraków 2008.

Raina P., Cele polityki władz PRL wobec Watykanu. Tajne dokumenty 1967-1989, Warszawa 2001.

Raina P., Kościót w PRL. Kościót katolicki a państwo w świetle dokumentów 1945-1989, t. 1: Lata 1945-1959, Poznań 1994.

UB a młodzieżowe organizacje antykomunistyczne w latach 1945-1954 na Górnym Śląsku i Podbeskidziu. Metody operacyjne aparatu bezpieczeństwa w świetle dokumentów, Katowice 2010.

W obronie ojczyzny i Kościoła. Komunistyczna bezpieka wobec biskupów polskich, pod red. J. Mareckiego i F. Musiała, Kraków 2008.

Żaryn J., Stolica Apostolska wobec Polski i Polaków w latach 1944-1958: w świetle materiałów ambasady RP przy Watykanie (Wybór dokumentów), Warszawa 1998.

\section{3. Źródła drukowane}

\section{1. Źródla prasowe}

\section{Czasopisma}

„Głos Katolicki” 1945 nr 1-35; 1946 nr 1-52; 1947 nr 1-52; 1948 nr 1-52.

„Ostatnie Wiadomości PAT-KAP” 1946-1947 nr 1-153.

„Przegląd Powszechny” 1947 nr 1; 1948 nr 1-12; 1949 nr 1-12; 1950 nr 1-6 i 7/8-12; 1951 nr 1-5/6 i $7 / 8-12 ; 1952$ nr $1-5 / 6$ i $7 / 8-12 ; 1953$ nr 1.

„Tygodnik Katolicki” 1946 nr 1-31/32; 1947 nr 1-50; 1948 nr 1-48; 1949 nr 1-51; 1950 nr 1-42; $1951 \mathrm{nr} 1-47 / 48 ; 1952 \mathrm{nr} 1-51 / 52 ; 1953 \mathrm{nr} 1-5$.

„Tygodnik Powszechny” 1945 nr 1-41; 1946 nr 1-51/52; 1947 nr 1-52; 1948 nr 1-52/53; 1949 nr $1-50 / 51 ; 1950 \mathrm{nr} 1-53 ; 1951 \mathrm{nr} 1 / 2-51 / 52 ; 1952 \mathrm{nr} 1-52 / 52 ; 1953 \mathrm{nr} 1-8$.

„Tygodnik Warszawski” 1945 nr 1-7; 1946 nr 1-51; 1947 nr 1-51; 1948 nr 1-36.

„Znak” 1946 nr 1-3; 1947 nr 1-4; 1948 nr 1-12; 1949 nr 1-12; 1950 nr 1-12; 1951 nr 1-4; 1952 nr $1-4 ; 1953$ nr 1.

\section{Artykuly z prasy}

A.G., Rok pracy ,,Tygodnika Warszawskiego”, „Tygodnik Warszawski” 1946 nr 46 s. 3.

Bagiński K., Cenzura w Polsce, „Zeszyty Historyczne” 1965 t. 8 s. 129-151.

Bates J., Cenzura w epoce stalinowskiej, „Teksty Drugie” 2000 nr 1-2 s. 95-120.

Biełaszko M., ,, Tygodnik Warszawski” i jego środowisko (1945-1948), „Biuletyn Instytutu Pamięci Narodowej" $2007 \mathrm{nr} 4$ s. 77-83.

Bieńkowska B., Metody bibliologiczne w badaniach dziejów ksiązki, „Kwartalnik Historii Nauki i Techniki" 1989 nr 2 s. 331-342.

Bikont A., Jak Borejsza budowat imperium Czytelnika, „Magazyn. Gazeta Wyborcza” 1994 nr 44 s. $6-11$.

Bromberg A., Książek coraz więcej. Ruch wydawniczy w I kwartale 1948 r., „Kuźnica” 1948 nr 28 s. 9.

Bromberg A., Ksiązka w Polsce Odrodzonej, „Przegląd Księgarski” 1948 nr 3 s. 34-35; tamże, nr 4 s. $50-51$. 
Bromberg A., Rok pracy w pojedynkę. Jeszcze o konieczności i możliwości planu wydawniczego, „Kuźnica” 1948 nr 10 s. 5.

Ciechomski W., ,, Tygodnik Warszawski 1945-1948”, „Ład” 1983 nr 29 s. 4.

Ciećwierz M., Ksztaltowanie się państwowego aparatu nadzoru i kontroli prasy w Polsce w latach 1944-1948, „Kwartalnik Historii Prasy Polskiej” 1983 nr 1 s. 29-38.

Ciećwierz M., Polityka prasowa rządu polskiego w latach 1944-1948, „Kwartalnik Historii Prasy Polskiej" $1985 \mathrm{nr} 1$ s. 32.

Ciećwierz M., Z problematyki czasopiśmiennictwa katolickiego w latach 1945-1948, „Zeszyty Naukowe Filii UW w Białymstoku", Prace Historyczne, Humanistyka t. 9 nr 50 s. 187-202.

Ciszewska W., Księgarnia Naukowa T. Szczęsny i S-ka w Toruniu w latach 1945-1950, „Acta Universitatis Nicolai Copernici. Bibliologia” II-III, Toruń 1998, s. 273-315.

Chaber F., Polityczne znaczenie książki, „Przegląd Biblioteczny” 1953 nr 3 s. 20.

Czarnowska M., Ksiązka w Polsce Ludowej, „Rocznik Biblioteki Narodowej” 1965 t. 2 s. 140-160.

Cybulski R., Ruch wydawniczy w Polsce. Rzut oka na przeszłość, „Bibliotekarz” 1991 nr 11/12 s. 4.

Dąbrowska W., Dwulecie naszej produkcji wydawniczej, „Bibliotekarz” 1946 nr 8-9 s. 161-169.

Degen D., Działalność wydawnicza towarzystw naukowych a powstanie Polskiej Akademii Nauk, „Problemy Społecznego Ruchu Naukowego” 1999 nr 2.

Dembowska M., Państwowy Instytut Książki 1946-1949, „Przegląd Biblioteczny” 1971 nr 1/4 s. $81-100$.

Dunin J., O źródłach do społecznej historii książki XIX i XX wieku, „Studia o Książce” 1985 t. 15 s. $149-156$.

Dziki S., Prasa polska w latach 1944-1948, „Kwartalnik Historii Prasy Polskiej” 1984 nr 1 s. 65-77.

Eisler J., Terlecki R., Polak B., O kulturze w PRL, „Biuletyn Instytutu Pamięci Narodowej” 2002 nr 10 s. 5-23.

Faber A., Ruch wydawniczy w Krakowie w latach 1945-1948: szkic informacyjny, „Rocznik Naukowo-Dydaktyczny WSP w Krakowie. Prace Bibliotekoznawcze" II, Kraków 1984, s. $129-174$.

GK, Z pierwszych lat cenzury w Polsce Ludowej, „Spotkania” 1984 nr 27/28 s. 48-51.

HMP, Państwowe Zaktady Wydawnictw Szkolnych, „Przegląd Księgarski” 1947 nr 3-4 s. 54-56.

Jarosz D., Zapisy cenzury z lat 1948-1955, „Regiony” 1996 nr 3 s. 2-36.

Jastrzębski J., Programy i publicystyka kulturalna PPS w latach 1944-1948, „Acta Universitas Wratislaviensis. Prace Literackie" 1987 t. 27 s. 99-128.

jm., Miesięcznik ,,Caritas”, „Tygodnik Warszawski” 1946 nr 18 s. 7.

K.M., Pismo z charakterem [o „Głosie Katolickim”], „Tygodnik Warszawski” 1948 nr 15 s. 12.

Kafel M., Baza techniczna produkcji czasopiśmienniczej i ksiązkowej w okresie dziesięciolecia 1944-54, ,Zeszyty Naukowe Uniwersytetu Warszawskiego, Prasoznawstwo” 1956 nr 1 s. 7595.

Kartki z PRL. Ludzie, fakty, wydarzenia, pod red. W. Władyki, Poznań-Warszawa 2005.

Kisielewski S., ,Dziś i Jutro”, „Tygodnik Warszawski” 1946 nr 25 s. 3.

Klimowicz A., Jak pracuje Dom Książki, „Nowa Kultura” 1951 nr 19.

Kondek S.A., Czytelnik bez właściwości. Miejsce czytelnictwa w państwowym systemie obiegu ksiazek w latach 1949-1955, „Rocznik Biblioteki Narodowej” 1996 t. 32 s. 57-86.

Kondek S.A., Strategia agitatora. Wokót polskiego wydania Odwilży Ilii Erenburga, „Acta Univesitatis Lodziensis. Folia Librorum" 2006 nr 13 s. 123-143.

Kornaś T., Nie tylko „,Tygodnik Powszechny”, „Najwyższy Czas!” 2008 nr 4 s. 18.

Kosiński J., Biblioteki, książki i czasopisma naukowe w latach 1945-1975 jako komponenty kulturowego modelu nauki, „Studia o Książce” 1979 t. 9 s. 103-120.

Kristanova E., ,, Tygodnik Warszawski” (1945-1948) na tle polskiej prasy katolickiej pierwszych lat po II wojnie światowej, „Łódzkie Studia Teologiczne” 2008 nr 17 s. 247-255. 
Książnica Atlas, „Przegląd Księgarski” 1948 nr 9 s. 135-137.

Kuthan Z., Moje romanse z cenzura, „Tygodnik Kulturalny” 1989 nr 17 s. 10.

Kuta C., Jak bezpieka rozbijała „, Tygodnik Powszechny”, „Gazeta Polska” 2006 nr 24 s. 14-15.

Lechicki C., Polska prasa katolicka 1945-1948, „Kwartalnik Historii Prasy Polskiej” 1983 nr 2 s. $65-87$.

Łepkowski T., O problemie rewolucji w Polsce w latach 1944-48, „Odra” $1990 \mathrm{nr} 1 \mathrm{s.}$ 4-9.

Łętowski M., Dwa tygodniki: „Tygodnik Warszawski” i ,Tygodnik Powszechny” w życiu katolicyzmu społecznego w Polsce, „Chrześcijanin w Świecie” 1985 nr 11.

Łusakowska M., Księgarnia Trzaski, Everta i Michalskiego 1920-1959, „Księgarz” 1960 nr 9-10 s. $1-9$.

Łusakowska M., Pierwsi księgarze w wyzwolonej Warszawie, „Księgarz” $1967 \mathrm{nr} 1$.

M., Geografia ruchu wydawniczego lat 1945-1947, „Praca Księgarska” 1949 nr 12 s. 224-226.

Marszałek L., 25 lat rozwoju ruchu wydawniczego w Polsce Ludowej, „Biuletyn Polskiego Towarzystwa Wydawców Książek” 1970 nr 1 s. 1-22.

Mieliński R., Z okazji setnego numeru, „Głos Katolicki” 1947 nr 13 s. 89.

MJ, Produkcja książek spółdzielni wydawniczych w roku 1948 w liczbach, „Praca Księgarska” 1949 nr 6 s. 102-106.

Morawski D., Jeszcze o likwidacji „, Tygodnika Warszawskiego”, „Ład” 1988 nr 44 s. 11.

Nałęcz D., Główne polskie dzienniki lat 1944-48 o programie demokratyzacji kulturalnej, „Kwartalnik Historii Prasy Polskiej” 1977 nr 3 s. 21-48.

O.B., Przeglad prasy. 100 numer „, Tyg. Powszechnego”, „,Tygodnik Warszawski” 1947 nr 9 s. 8.

Od wydawnictwa, „Tygodnik Warszawski” 1947 nr 18 s. 3.

Paczkowski A., Cenzura 1946-1949: statystyka działalności, „Zeszyty Historyczne” 1996 nr 116 s. 22-57.

Paczkowski A., Prasa nowego typu 1944-1953, „Mówią Wieki” 1990 nr 8 s. 1-5.

Pawlicki A., Strzembosz T., Władyka W., Bułhak W., Polak B., Zabijanie słowa. O cenzurze w PRL, „Biuletyn Instytutu Pamięci Narodowej” 2004 nr 2 s. 4-26.

Petrozolin-Skowrońska B., Wydawcy i księgarze polscy w l. 1921-50, „Wydawca” 2006 nr 10-11.

Pfeifer-Milerowa H., Z działalności księgarstwa warszawskiego w latach 1945-1949, „Księgarz” 1978 nr 2 s. 21-32.

Piasecka R., Działalność Biura Ogłoszeń i Reklam Polskiej Agencji Prasowej w latach 1945-1949, „Zeszyty Prasoznawcze” $2001 \mathrm{nr} 1-2$.

Pietrzkiewicz I., Rogoż M., Prewencyjne ingerencje cenzorskie w „, Tygodniku Powszechnym” na przetomie lat 40. i 50., „,Rocznik Historii Prasy Polskiej” 2011 nr 1-2 s. 143-170.

Pięćdziesięciolecie Drukarni i Księgarni św. Wojciecha, „Przegląd Księgarski” 1947 nr 12 s. 324.

Plesnar Ł., Propaganda polityczna okresu stalinizmu, „Arka” 1984 nr 6 s. 31-41.

Raczkowski W., Ks. Roman Mieliński 1906-1976, „Miesięcznik Kościelny Archidiecezji Poznańskiej" 1977 nr 2 s. 42-44.

Redakcja, Nasza generalna linia, „Tygodnik Warszawski” 1947 nr 42 s. 1-2.

Rogala S., ,Tygodnik Warszawski” - środowisko, programy społeczne, polityczne i filozoficzne, „Zeszyty Naukowe Politechniki Rzeszowskiej” nr 178, „Ekonomia i Nauki Humanistyczne” 2000 nr 8 s. 25-39.

Rogoż M., „, Tygodnik Powszechny” w 1949 r. w świetle wtórnych ocen cenzorów Głównego Urzędu Kontroli Prasy, Publikacji i Widowisk, „Rocznik Bibliologiczno-Prasoznawczy” $2011 \mathrm{nr} 3$ s. $105-119$.

Rutecki K., Szubarczyk P., „,To” było 5 lipca 1946 r. Bierut podpisat dekret o cenzurze, „Biuletyn Instytutu Pamięci Narodowej” 2001 nr 7 s. 56-62.

Siekierski S., Spółdzielnia Wydawnicza „Czytelnik”, „Rocznik Biblioteki Narodowej” 1965 t. 1 s. 173-197. 
Siekierski S., Adamiec W., Państwowy Instytut Wydawniczy PAX, „Rocznik Biblioteki Narodowej” 1976-1977 t. 12-13.

Sikorski K., ,, Tygodnik Warszawski”, „Przegląd Katolicki” 1986 nr 2 s. 1, 2-3.

Spałek K., Zarys dziejów księgarstwa w Częstochowie do roku 1950, „Roczniki Biblioteczne” 1973 nr 1-2 s. 179-245.

Stanisław M., Pięć lat księgarstwa spółdzielczego PRL, „Księgarz” cz. I: 1978, nr 3 s. 24-33; cz II: 1979, nr 2 s. 15-24.

Stanisław M., Przemiany strukturalne księgarstwa w Polsce Ludowej (1), „Księgarz” 1957 nr 1 s. 4-7.

Stefaniak J., Prasa katolicka w polemikach i ocenie prasy partyjnej (w latach 1945-1953), „Zeszyty Prasoznawcze" 1996 nr 3-4 s. 139-148.

Stefaniak J., Prasa katolicka w systemie prasowym Polski Ludowej 1945-1953, „Zeszyty Prasoznawcze" 1996 nr 1-2 s. 140-153.

Stefaniak J., Prasa katolicka wobec reform spoleczno-politycznych w Polsce w latach 1945-1948, „Studia Polityczne” $2000 \mathrm{nr} 10$.

Stefaniak J., Z dziejów publicystyki katolickiej we Włocławku w latach 1945-1953, „Ateneum Kapłańskie" $2001 \mathrm{nr} 3$ s. 527-531.

Stopikowski R., Polemiki światopoglądowe na łamach „,Tygodnika Warszawskiego”, „Dzieje Najnowsze" 1995 nr 4 s. 101-108.

Stopikowski R., Problematyka gospodarczo-społeczna na tamach „,Tygodnika Warszawskiego” (1945-1948), „Życie i Myśl” 1998 nr 4 s. 41-59.

Stolarczyk B., Książka angielska u wydawcy polskiego w latach 1945-1970, „Studia o Książce” 1978 t. 8 s. $199-222$.

Szymański W.P., Czyste ręce i Mefisto: (o „, Tygodniku Warszawskim”), „Arcana” 2001 nr 4 s. 69-87. Szymański M., Pierwsze powojenne dziesięciolecie, „Księgarz” 1981 nr 4 s. 19-37.

Ślipko T., Studia jezuitów w latach PRL-u. W: „Zeszyty Naukowe Uniwersytetu Jagiellońskiego. Prace Etnogaficzne" $2001 \mathrm{nr} 36$, s. 119-130.

Tobera M., Bibliologia wobec polskiego rynku książki w latach 1944-2007, „Przegląd Biblioteczny” $2008 \mathrm{nr} 1$ s. 39-66.

Trepiński A., O nakładach ksiązki powojennej, „Tygodnik Powszechny” 1947 nr 4 s. 2.

Tryburcy Z., Organizacja państwowych przedsiębiorstw wydawniczych, „Ekonomika i Organizacja Pracy" 1951 nr 10 s. 475-480.

Trzaska F., Księgarnia wydawnicza Trzaska, Evert i Michalski, „Wydawca” 2006 nr 10/11 s. 13-16. Turowicz J., Sprawa kultury katolickiej w Polsce, „Znak” 1947 nr 5 s. 500-519.

W 40 rocznicę. Likwidacja „Tygodnika Warszawskiego”, rozmowa A. Wernica z A. Kozaneckim i T. Przeciszewskim, „, Ład” 1988 nr 38 s. 1, 7, 14.

W sprawie prasy katolickiej, „Tygodnik Warszawski” 1947 nr 34 s. 8.

Wakar A., Dzieje ruchu wydawniczego na Warmii i Mazurach w latach powojennych, „Studia Warmińskie" $1990 \mathrm{nr} 27$ s. 205-217.

Wiele nurtów, rozmowa z W. Chrzanowskim, „Przegląd Katolicki” 1984 nr 18 s. 3.

Wielgat D., Prasa katolicka i religijna w Polsce w latach 1945-1989, „Archiwa, Biblioteki i Muzea Koścelne" 1996 nr 66 s. 541-544.

Wilczyński L., ,, Tygodnik Katolicki” na tle poczatków prasy diecezjalnej w Gorzowie i jego akcenty wielkopolskie (1946-1950), „Roczniki Teologiczne” $2001 \mathrm{nr} 4$ s. 231-239.

Wiszniewski J., ,, Tygodnik Warszawski” (1945-1948), „Chrześcijanin w Świecie” 1988 nr 11.

Wznowienie „Ateneum Kapłańskiego”, „Tygodnik Warszawski” 1946 nr 47 s. 5.

Wydawnictwo Księży Jezuitów. W: Encyklopedia wiedzy o jezuitach na ziemiach Polski i Litwy 1564-1995, oprac. L. Grzebień przy współpracy zespołu jezuitów, Kraków 1996.

Z.K. [Z. Kaczyński], Dzień prasy, „Tygodnik Warszawski” 1947 nr 43 s. 1-2. 
Zabijanie słowa. O cenzurze w PRL, z A. Pawlickim, T. Strzemboszem i W. Władyką rozmawiali W. Bułhak i B. Polak, „Biuletyn IPN” 2004 nr 2 s. 4-26.

Zabłocki J., Dramat „,Tygodnika Warszawskiego”, ,Tygodnik Solidarność”1999 nr 15 s. 17.

Zabłocki J., ,, Tygodnik Warszawski”, „Ład” 1995 nr 47 s. 4.

Zachciał I., Okres powojenny i teraźniejszość księgarstwa gdańskiego, „Księgarz” 1977 nr 3 s. 4148.

Zmroczek J., Ruch wydawniczy w Polsce po roku 1945, „Zeszyty Historyczne” 1992 nr 100 s. 209231.

Żaryn J., Bilans pierwszego pięciolecia. Internowany prymas o relacjach państwo-Kościół w latach 1948-1953, „Ateneum Kapłańskie” 2004 nr 142 s. 22-32.

\subsection{Encyklopedie, słowniki, informatory biograficzne, bibliografie, katalogi}

Bibliografia prasy polskiej 1944-1948, Warszawa 1966.

Bibliografia Zawartości Czasopism za lata 1947-2004.

Bojarski J.J., Gzella A.L., Katalog prasy $i$ wydawnictw katolickich, Lublin 1994.

Cenzura PRL. Wykaz ksiażek podlegających niezwłocznemu wycofaniu 1 XI 1951 r., Wrocław 2002.

Encyklopedia ,biatych plam”, t. 3, 10, 14, 17, Radom 2000-2006.

Encyklopedia katolicka, t. 12, Lublin 2008.

Encyklopedia wiedzy o książce, Wrocław 1971.

Encyklopedia wiedzy o prasie, pod red. J. Maślanki, Wrocław 1976.

Fik M., Kultura polska po Jałcie. Kronika lat 1944-1981, Londyn 1989.

Filipiak M., Bibliografia miesięcznika „Znak” 1946-1996, Kraków 1997.

Katalog prasy polskiej, Warszawa 1957.

Konspiracja i opór społeczny w Polsce 1944-1956. Stownik biograficzny, t. 1-4, Kraków i in. 20022010.

Kościót katolicki w Polsce 1918-1990. Rocznik statystyczny, pod red. L. Adamczuka i W. Zdaniewicza, Warszawa 1991.

Książi Instytutu Wydawniczego PAX 1949-1989: przewodnik, oprac. A. Szafrańska, Warszawa 1989.

Leksykon duchowieństwa represjonowanego w PRL w latach 1945-1989, t. 1-3, pod red. J. Myszora, Warszawa 2002-2006.

Opozycja w PRL. Stownik biograficzny 1956-89, pod red. J. Skórzyńskiego, t. 1-3, Warszawa 20002006.

Polski stownik biograficzny, t. 21, Wrocław 1976.

Stownik badaczy literatury polskiej, pod red. J. Starnawskiego, t. 6, Łódź 2003; t. 10, Łódź 2009.

Stownik biograficzny katolicyzmu społecznego w Polsce, t. 1-3, Lublin 1994-1996.

Słownik literatury polskiej XX wieku, pod red. A. Brodzkiej i in., Wrocław 1992.

Stownik polskich teologów katolickich 1918-1981, pod red. L. Grzebienia, Warszawa 1983.

Słownik pracowników książki polskiej, pod red. I. Treichel, Łódź 1972, supl I: 1986, suplement II Warszawa 2000.

Wielgat D., Bibliografia katolickich czasopism religijnych w Polsce 1945-1989, Lublin 1996.

Wielka encyklopedia PWN, t. 3, 4, 10, 13, Warszawa 2001-2003.

Żmuda R., Bibliografia produkcji wydawniczej zakonów $w$ Polsce 1945-1995, t. 1, cz. 1-2, Warszawa 2000.

Żynda B., Bibliografia wydawnictw Księgarni św. Wojciecha 1895-1969: w 75-lecie działalności wydawniczej, Poznań 1970. 


\subsection{Opracowania}

Adamowski J., Kozieł A., Cenzura w PRL. W: Granice wolności słowa, Kielce-Warszawa 1999, s. $57-71$.

Albin J., Zakład Narodowy im. Ossolińskich w latach 1946-1953, Wrocław 1990.

Aleksandrowicz J., Wydawnictwa i księgarstwo w Inowrocławiu. W: Organizacja działalności kulturalnej Inowrocławia (1945-1981), pod red. J. Sługockiego, cz. II, Bydgoszcz 1982, s. 86-114.

Artyści a Stużba Bezpieczeństwa. Aparat bezpieczeństwa wobec środowisk twórczych. Materiaty pokonferencyjne, pod red R. Klimentowskiego i S. Ligarskiego, Warszawa 2008.

Augustyński Z., Miesiace walki 1945-46, Warszawa 1988.

Anusz A.A., Samotnie wśród wiernych. Kościót wobec przemian politycznych w Polsce (19441994), Warszawa 1994.

Aparat bezpieczeństwa w Polsce w latach 1950-1952: taktyka, strategia, metody, oprac. A. Dudek, A. Paczkowski, Warszawa 2000; cz. 1: Lata 1945-1947, Warszawa 1994.

Aparat represji a opór spoleczeństwa wobec systemu komunistycznego w Polsce i na Litwie w latach 1944-1956, pod red. P. Niwińskiego, Warszawa 2005.

Aparat ucisku na Lubelszczyźnie w latach 1944-1956 wobec duchowieństwa katolickiego, pod red. Z. Zielińskiego i M. Pereta, Lublin 2000.

Arct S., Odbudowa ksiązki w Polsce, podstawy faktyczne i liczbowe, Warszawa 1946.

Autor - tekst - cenzura, pod red. J. Pelca, M. Prejsa, Warszawa 1998.

Baliszewski D., Kunert A.K., Ilustrowany przewodnik po Polsce stalinowskiej 1944-1956, t. 1: 1944-1945, Warszawa 1999.

Banaszak M., Historia Kościoła katolickiego, t. 4: Czasy najnowsze 1914-1978, Warszawa 1992.

Bankowicz B., Dudek A., Ze studiów nad dziejami Kościoła i katolicyzmu w PRL, Kraków 1996.

Biedroń T., Organizacje młodzieży katolickiej w Polsce w latach 1945-1953, Kraków 1991.

Biełaszko M., Ksiądz Zygmunt Kaczyński (1894-1953) - duchowny, polityk, redaktor. W: Niezłomni ludzie Kościoła. Sylwetki, pod red. J. Żaryna, Kraków 2011, s. 95-122.

Biełaszko M., Rola prasy w ksztaltowaniu się środowisk katolickich w latach 1945-1948. Casus „,Tygodnika Powszechnego”, ,,Tygodnika Warszawskiego” i „Dziś i Jutro”. W: Aparat represji wobec inteligencji w latach 1945-1956, pod red. R. Habielskiego i D. Rafalskiej, Warszawa 2010, s. 155-181.

Bierut B., O upowszechnianiu kultury. Przemówienie na otwarcie radiostacji we Wroctawiu wygłoszone 16 listopada 1947, Kraków 1948.

Biliński L., Instytucje wydawnicze i dystrybucja ksiązki w Polsce, Warszawa 1975.

Biliński L., Książka w Polsce Ludowej. Wydawnictwa i księgarstwo, Warszawa 1981.

Biliński L., Zarys rozwoju ruchu wydawniczego w Polsce Ludowej, Warszawa 1977.

Bonusak W., Historia Polski (1944-1989), Rzeszów 2007.

Braun J., Kultura jutra czyli Nowe oświecenie, Warszawa 2001.

Bromberg A., Ksiażki $i$ wydawcy: ruch wydawniczy w Polsce Ludowej w latach 1944-1957, Warszawa 1958.

Bromberg A., Książi i wydawcy: ruch wydawniczy w Polsce Ludowej w latach 1944-1964, Warszawa 1966.

Bromberg A., Produkcja książek w Polsce w latach 1944-1947: charakterystyka ogólna, b.m.w. 1956 [nadb. Prasoznawstwo $1956 \mathrm{nr}$ 2].

Bujak W., Historia Stronnictwa Pracy 1937-1946-1950, Warszawa 1988.

Centkowski J., Prasa Spótdzielni Oświatowej Czytelnik 1944-1951, Warszawa 1971.

Chmielowiec P., Lasota M., Szarek J., Terlecki R., Kościól w godzinie próby: 1945-1989. Nieznane dokumenty i świadectwa, Kraków 2003. 
Chrypiński W., Kościól a rząd i społeczeństwo w powojennej Polsce, Londyn 1989.

Ciećwierz M., Polityka prasowa 1944-1948, Warszawa 1989.

Ciszewska W.A., Książka w Toruniu w latach 1945-1950. Ruch wydawniczo-księgarski, Toruń 2005.

Ciszewska W., Wydawnictwa toruńskie z lat 1945-1950 w opinii i ocenie cenzorów. W: Niewygodne dla władzy, pod red. D. Degen i J. Gzelli, Toruń 2010, s. 305-322.

Cywiński B., Ogniem próbowane: z dziejów najnowszych Kościoła katolickiego w Europie Środkowo-Wschodniej, t. 2: „,... i was prześladować będa”, Lublin-Rzym 1990.

Czaczkowska E.K., Kardynał Wyszyński, Warszawa 2009.

Czarnik O.S., Kultura literacka. W: Literatura polska 1918-1975, t. 3, cz. 1: 1945-1975, Warszawa 1996, s. 7-206.

Czarnik O.S., Między dwoma Sierpniami. Polska kultura literacka w latach 1944-1980, Warszawa 1993.

Czarnowska M., Ilościowy rozwój polskiego ruchu wydawniczego 1501-1965, Warszawa 1967.

Czubiński A., Historia Polski 1864-2001, Wrocław 2002.

Czubiński A., Historia Polski XX wieku, Poznań 2005.

Czubiński A., Polska i Polacy po II wojnie światowej (1945-1989), Poznań 1998.

Czubiński A., Topolski J., Historia Polski, Wrocław 1989.

Czym jest ,Wiedza?", Warszawa 1947.

Davies N., Boże igrzysko: historia Polski, Kraków 2010.

Degen D., Miodowe miesiace...: początki Państwowego Wydawnictwa Naukowego (1951-1956), Torun 2004.

Dippel S., O księgarzach, którzy przeminęli, Wrocław 1976.

Do prześladowania nie daliśmy powodu... Materiaty z sesji poświęconej procesowi Kurii Krakowskiej, pod red. R. Terleckiego, Kraków 2003.

Dobrosz J., Zniewalanie Polski, Wrocław 2006.

Dudek A., Gryz R., Komuniści i Kościót w Polsce (1945-1989), Kraków 2003.

Dudek A., Państwo i Kościót 1945-1970, Kraków 1995.

Dudek A., Pytel G., Biografia Piaseckiego, Londyn 1990.

Dzidek M., Miejsce i rola polskiego kościoła katolickiego w życiu publicznym: zarys relacji między państwem, kościołem, społeczeństwem, Torun 2007.

Dzieje państw socjalistycznych: gospodarka, społeczeństwo, polityka, pod red. J. Ciepielewskiego, Warszawa 1986.

Dziuba A.F., Przesłanie społeczne kardynała Stefana Wyszyńskiego Prymasa Polski: zarys problematyki, Warszawa 2004.

Episkopat Kościoła rzymskokatolickiego w Polsce wobec przemian społeczno-politycznych kraju w latach 1944-1974, Warszawa 1989.

Fijałkowska B., Borejsza i Różański. Przyczynek do dziejów stalinizmu w Polsce, Olsztyn 1995.

Fijałkowska B., Partia wobec religii i Kościoła w PRL, t. 1: 1944-1955, Olsztyn 1999.

Fijałkowska B., Polityka i twórcy (1948-1959), Warszawa 1985.

Fijałkowski Z., Kościót katolicki na ziemiach polskich w latach okupacji hitlerowskiej, Warszawa 1983.

Frazik W., Kopka B., Majchrzak G., Dzieje aparatu represji w PRL (1944-1989). Stan badań, Warszawa-Kraków 2004.

Friszke A., Opozycja polityczna w PRL 1945-1980, Londyn 1994.

Friszke A., Polska. Losy państwa i narodu 1939-1989, Warszawa 2003.

Friszke A., Przystosowanie i opór: studia z dziejów PRL, Warszawa 2007.

Friszke A., Strategie przystosowania ośrodków katolików świeckich. W: Polacy wobec PRL. Strategie przystosowawcze, pod red. G. Miernika, Kielce 2003, s. 11-35. 
Frołow K., Wolak J., Raport o ksiażce katolickiej. Edycja 2007, Warszawa 2007.

Gajewski J., „Książa i Wiedza”-sześćdziesiąt lat działalności, Warszawa 1978.

Garbarz A., Działalność duszpastersko-społeczna arcybiskupa Ignacego Tokarczuka, Rzeszów 2006.

Głombiowski K., Książka w procesie komunikacji społecznej, Wrocław 1980.

Goban-Klas T., Niepokorna orkiestra medialna. Dyrygenci $i$ wykonawcy polityki informacyjnej w Polsce po 1944 roku, thum. z ang. A. Minczewska-Przeczek, Warszawa 2004.

Godlewski J.F., Katolicka myśl kościelna o prawie i państwie, Warszawa 1985.

Graczyk R., Cena przetrwania? SB a ,Tygodnik Powszechny”, Warszawa 2011.

Grajewski A., Kompleks Judasza: Kościół zraniony. Chrześcijanie w Europie Środkowo-Wschodniej między oporem a kolaboracja, Poznań 1999.

Grajewski A., Świadek i uczestnik: 70 lat „,Gościa Niedzielnego” (1923-1993), Katowice 1993.

Grajewski A., Twój Gość, Katowice 2008.

Gryz R., Państwo a Kościót w Polsce 1945-1956: na przyktadzie województwa kieleckiego, Kraków 1999.

Hlond A., Dzieła: nauczanie 1897-1948, pod red. J. Koniecznego, Toruń 2003.

Isakowicz-Zalewski T., Księża wobec bezpieki, Kraków 2007.

Jagiełło M., Próba rozmowy: szkice o katolicyzmie odrodzeniowym i ,, Tygodniku Powszechnym” 19451953, t. 1: Rodowód, t. 2: „Tygodnik Powszechny” i komunizm 1945-1953, Warszawa 2001.

Jagiełło M., Trwałość i zmiana. Szkice o „, Przegladzie Powszechnym” 1884-1918, Warszawa 1993. Jakubowski Z., ,, Przegląd Powszechny” 1884-1985, Warszawa 1987.

Jarocki R., Czterdzieści pięć lat w opozycji (o ludziach „, Tygodnika Powszechnego”), Kraków 1990. Jarosz D., Polacy a stalinizm 1948-1956, Warszawa 2000.

Jarosz D., Polityka władz komunistycznych w Polsce w latach 1948-1956 a chlopi, Warszawa 1998. „Jesteście nasza wielka szansq”. Młodzież na rozstajach komunizmu 1944-1989, pod red. P. Ceranki i S. Stępnia, Warszawa 2009.

Kaliński J., Bitwa o handel 1947-48, Warszawa 1970.

Kamiński Ł., Polacy wobec nowej rzeczywistości 1944-1948. Formy pozainstytucjonalnego, żywiołowego oporu społecznego, Torun 2000.

Karpiński J., Porcja wolności, Warszawa 1989.

Kersten K., Między wyzwoleniem a zniewoleniem. Polska 1944-1956, Londyn 1993.

Kersten K., Narodziny systemu władzy: Polska 1943-1948, Poznań 1990.

Kersten K., Polacy, Żydzi, komunizm. Anatomia pótprawd 1939-68, Warszawa 1992.

Kiernicki B., ,,Tygodnik Katolicki” (1946-1953). W: Księga pamiatkowa 50-lecia organizacji Kościoła katolickiego na Ziemi Lubuskiej ..., Zielona Góra-Gorzów Wielkopolski 1998.

Kisielewski S., Na czym polega socjalizm? Stosunki państwo-Kościót w PRL, Poznań 1990.

Kitrasiewicz P., Gołębiewski Ł., Rynek książki w Polsce 1944-1989, Warszawa 2005.

Klimowicz A., Ruch wydawniczy w latach 1944-1953. Próba charakterystyki statystyczno-bibliograficznej, Warszawa 1954.

Klimowicz A., Sześćset lat w stużbie książki 1364-1964, Warszawa 1964.

Komu stuzyt PAX, pod red. S. Bober, Warszawa 2008.

Komunizm: ideologia, system, ludzie, pod red. T. Szaroty, Warszawa 2001.

Kondek S.A., Kontrola, nadzór, sterowanie. Budowa państwowego systemu wydawniczego w Polsce w latach 1945-1951. W: Piśmiennictwo - systemy kontroli - obiegi alternatywne, pod red. J. Kosteckiego i A. Brodzkiej, t. 2, Warszawa 1992, s. 209-213.

Kondek S.A., Literatura popularna w ofercie czytelniczej polskiego socrealizmu, w: Socrealizm. Fabuly - ikony - komunikaty, pod red. K. Stępnia i M. Piechoty, Lublin 2006, s. 22-32.

Kondek S.A., Organizacja obiegu ksiązek w PRL jako eksperyment bibliologiczny. W: Bibliologia. Problemy badawcze nauk humanistycznych, pod red. D Kuźminy, Warszawa 2007, s. 316-325. 
Kondek S.A., Papierowa rewolucja: oficjalny obieg ksiażek w Polsce $w$ latach 1948-1955, Warszawa 1999.

Kondek S.A., Władza i wydawcy. Polityczne uwarunkowania produkcji ksiązek w Polsce w latach 1944-1949, Warszawa 1993.

Koniec jałtańskich złudzeń: sfatszowane wybory - 19 I 1947, pod red. M. Wenklara, Kraków 2007.

Konopka H., Religia w szkołach Polski Ludowej. Sprawa nauczania religii w polityce państwa 1944-1961, Białystok 1997.

Kopiczko A., Kościół katolicki a polityka wyznaniowa po II wojnie światowej, Olsztyn 1996.

Kopiec J., Kościół w Polsce po 1945 roku, Opole 1999.

Korzon A., Polsko-radzieckie kontakty kulturalne 1944-1950, Wrocław 1982.

Kosiński K., O nowa mentalność. Życie codzienne w szkołach 1945-1956, Warszawa 2000.

Kossak J., Podstawy polityki kulturalnej PZPR, Warszawa 1977.

Kostecki J., Ruch wydawniczy na ziemiach polskich (1877-1986). W: Instytucje - publiczność sytuacje lektury. Studia z historii czytelnictwa, t. 4, pod red. J. Kosteckiego, Warszawa 1992, s. $153-224$.

Kościót rzymskokatolicki na Pomorzu Zachodnim i Ziemi Lubuskiej w latach 1945-2005, pod red. G. Wejmana, Szczecin 2005.

Kowalczyk K., Stosunki państwo-Kościót na Pomorzu Zachodnim w latach 1945-1972. Zarys problemu. W: Kościól rzymskokatolicki na Pomorzu Zachodnim i Ziemi Lubuskiej w latach 1945-2005, pod red. G. Wejmana, Szczecin 2005, s. 27-51.

Kowalczyk K., W walce o rząd dusz. Polityka władz państwowych wobec Kościoła katolickiego na Pomorzu Zachodnim w latach 1945-1956, Szczecin 2003.

Kowalik S., Eksperyment: władze PRL wobec biskupa Piotra Gołębiowskiego 1957-1980, Radom 2006.

Kozieł A., Polityka prasowa w latach 1944-1956. W: Aparat represji wobec inteligencji w latach 1945-1956, pod red. R. Habielskiego i D. Rafalskiej, Warszawa 2010, s. 123-135.

Kozieł A., Studium o polityce prasowej PZPR w latach 1948-1957, Warszawa 1991.

Kozłowska A., Markiwicz T., Piasecka J., Stosunki między państwem a kościołem rzymskokatolickim w czasach PRL, pod red. A. Chojnowskiego i M. Kuli, Warszawa 1998.

Koźniewski K., Historia co tydzień. Szkice o tygodnikach społeczno-kulturalnych 1944-1950, [t. 2], Warszawa 1977.

Koźniewski K., Historia co tydzień. Szkice o tygodnikach społeczno-kulturalnych 1950-1990, [t. 3], Warszawa 1999.

Krasucki E., Międzynarodowy komunista. Jerzy Borejsza. Biografia polityczna, Warszawa 2009.

Krawczyk A., Pierwsza próba indoktrynacji. Działalność Ministerstwa Informacji i Propagandy w latach 1944-47, Warszawa 1994.

Kristanova E., Promocja książki w prasie - lepsza czy gorsza niż przed laty? (rozważania na przyktadzie „Tygodnika Powszechnego” w latach 1945-1953 i wspótcześnie). W: 350 lat prasy polskiej, Warszawa 2012, s. 221-228.

Kristanova E., Reklama książki na łamach „,Tygodnika Warszawskiego”(1945-1948). W: Od książki dawnej do biblioteki wirtualnej, pod red. D. Degen i M. Fedorowicz, Toruń 2009, s. 245-263.

Kristanova E., ,, Tygodnik Warszawski” (1945-1948) a wladza komunistyczna. W: Niewygodne dla władzy. Ograniczanie wolności stowa na ziemiach polskich w XIX i XX w., pod red. D. Degen i J. Gzelli, Toruń 2010, s. 357-374.

Kristanova E., Ksiązka na łamach krakowskiego „Tygodnika Powszechnego” (1945-1953) w świetle reklamy wydawniczеј. W: Краків - Львів: книги, часописи, бібліотеки ХІХ-ХХ ст., t. 10, ред. Г. Врона, О. Колосовська, Г. Косентка, Львів 2011, s. 332-345.

Kristanova E., Książka na łamach krakowskiego „Tygodnika Powszechnego” (1945-1953) w świetle reklamy wydawniczej. W: Kraków-Lwów. Ksiązki, czasopisma, biblioteki XIX i XX wieku, t. 10, pod red. H. Kosętki, Kraków 2011, s. 303-317. 
Kristanova E., Problematyka stosunków Kościót katolicki - państwo komunistyczne w publicystyce „Tygodnika Powszechnego” (1945-1953). W: Nie po myśli władzy. Studia nad cenzura i zakresem wolności stowa na ziemiach polskich od wieku XIX do czasów wspótczesnych, pod red. D. Degen i M. Żyndy, Toruń 2012, s. 179-196.

Ksiązka i prasa w komunikacji społecznej, pod red. M. Judy, Lublin 2002.

Książka i Wiedza: przeszłość i teraźniejszość 1918-1968, Warszawa 1968.

Książa na Śląsku w latach 1945-1956. Zarys problematyki, pod red. M. Pawłowiczowej, Katowice 1997.

Księga Sapieżyńska, pod. red. ks. J. Wolnego, t. 2: Działalność kościelna i narodowa Adama Stefana Sapiehy, Kraków 1982.

Kumor B., Historia Kościoła, cz. 8: Czasy współczesne 1914-1992, Lublin 1995.

Kunicka K., Kunicki B., Szczepański H., Prasa gorzowska w latach 1945-1985, Gorzów 1987.

Kuszłejko J., Popularna ksiązka historyczna w latach 1944-1954. Próba charakterystyki. W: Instytucje - publiczność - sytuacje lektury. Studia z historii czytelnictwa, t. 1, pod red. J. Kosteckiego, Warszawa 1989 s. 186-207.

Laskowska J., Ruch wydawniczy w Trójmieście po II wojnie światowej (1945-1989), Gdańsk 2009. Leman W.W., Plan przemystowo-finansowy instytucji wydawniczych, Warszawa 1951.

Leman W.W., Planowanie operatywne i sprawozdawczość w instytucjach wydawnictw ksiązkowych, Warszawa 1951.

Lichniak Z., Kopa lat, Warszawa 1985.

Lichniak Z., Mowy i namowy, Warszawa 1969.

Listy pasterskie Episkopatu Polski 1945-1974, Paryż 1975.

Listy pasterskie Episkopatu Polski 1945-2000, Marki 2003.

Literatura i pisarze wobec cenzury PRL 1948-1958, pod red. K. Budrowskiej, Białystok 2009.

Literatura polska 1918-1975, t. 3, cz. 1: 1945-1975, Warszawa 1996.

Lizak W., Historia Polski: od maja 1945 do marca 1956 roku, Poznań 1998.

Ludzie wrocławskiego Kościoła po II wojnie światowej: w 30-lecie śmierci Kardynała Bolesława Kominka, pod red. I. Deca, K. Matwijowskiego, J. Patera, Wrocław 2005.

Łatyński M., Nie paść na kolana. Szkice o polskiej polityce lat powojennych, Wrocław 2002.

Łojek J., Myśliński J., Władyka W., Dzieje prasy polskiej, Warszawa 1988.

Main I., Trudne świętowanie. Konflikty wokót obchodów świąt państwowych i kościelnych w Lublinie (1944-1989), Warszawa 2004.

Maj J., Eksterminacja Narodu Polskiego na ziemiach polskich w latach 1944-1956, Warszawa 2006.

Majchrowski J., Geneza politycznych ugrupowań katolickich w Polsce: Stronnictwo Pracy, grupa „Dziś i Jutro”, Paryż 1984.

Majchrowski S., Między stowem a rzeczywistością. Problemy powieści politycznej $w$ Polsce lat 1945-1970, Łódź 1988.

Mardyła P., Duszpasterstwo w czasach stalinowskich. Władze komunistyczne wobec działalności duszpasterskiej Kościoła rzymskokatolickiego w archidiecezji krakowskiej w latach 19451956, Kraków 2009.

Mazurkiewicz A., Dyplomacja Stanów Zjednoczonych wobec wyborów w Polsce w latach 1947 i 1989, Warszawa 2007.

Media katolickie: szanse i zagrożenia. II Międzynarodowy Kongres 20-21 listopada 2009 r., Toruń 2010.

Męczennicy iświadkowie wiary. Represje komunistyczne wobec duchowieństwa na Rzeszowszczyźnie, Rzeszów 2006.

Micewski A., Kardynat Wyszyński, prymas i mąż stanu, Paryż 1982.

Micewski A., Kościót-państwo 1945-1989, Warszawa 1994

Micewski A., Wspótrządzić czy nie kłamać, Paryż 1978. 
Micewski A., Wspótrządzić czy nie kłamać? PAX i Znak w Polsce w latach 1945-1976, Warszawa 1981. Michałowska M., Ruch wydawniczy w Poznaniu w latach 1945-1971, Poznań 1972.

Mielczarek T., Od Nowej Kultury do Polityki. Tygodniki spoleczno-kulturalne i spoteczno-polityczne $P R L$, Kielce 2003.

Migoń K., Nauka o książce. Zarys problematyki, Wrocław 1984.

Migoń K., Z dziejów nauki o książce, Wrocław 1979.

Mirek A., Represje wobec osób duchownych i konsekrowanych w PRL w latach 1944-1989, Lublin 2004.

Morawska A., Serie wydawnicze w Polsce Ludowej, Warszawa 1971.

Murzański S., Między kompromisem a zdradą: intelektualiści wobec przemocy 1945-1956, Kraków 2002.

Murzański S., Wśród łopotu sztandarów rewolucji. Rzecz o „katolewicy” (1945-1989), Kraków 1998.

Muszkowski J., Życie ksiązki, Warszawa, wyd. 2 rozsz., Kraków 1951.

Natanson J., Tygodnik Odrodzenie (1944-1950), Warszawa 1987.

Nęcek R., Państwo w nauczaniu społecznym Prymasa Polski Stefana Wyszyńskiego: studium teologiczno-moralne, Kraków 2004.

Nim będzie zapomniana. Szkice o kulturze PRL-u, pod red. S. Bednarka, Wrocław 1997.

Nistsche I., Katowickie firmy wydawnicze $i$ ich produkcja typograficzna w latach 1945-1950. W: Ksiązka na Śląsku w latach 1945-1956. Zarys problematyki, pod red. M. Pawłowiczowej, Katowice 1997, s. 358-371.

Nowak P., Poznańskie księgarstwo asortymentowo-wydawnicze w „, bitwie o handel” 1946-1950. W: Niewygodne dla władzy, pod red. D. Degen i J. Gzelli, Toruń 2010, s. 275-304.

Nowak J.R., Obłudnik powszechny, Warszawa 2002.

Nowicka O., Cenzura wobec prasy $i$ wydawnictw katolickich $w$ Wielkopolsce w latach 1945-1956. W: Władze wobec kościołów i związków wyznaniowych w Wielkopolsce w latach 1945-1956, pod red. K. Białeckiego, Poznań 2008, s. 175-182.

Obrazy PRL o konceptualizacji realnego socjalizmu w Polsce, pod red. K. Brzechczyna, Poznań 2008.

Od Hitlera do Stalina, pod red. F. Musiała i J. Szarka, Kraków 2007.

Od Pitsudskiego do Watęsy: studia z dziejów Polski w XX wieku, pod red. K. Persaka, A. Dudka, A. Friszke i in., Warszawa 2008.

Orlandis J., Kościót katolicki: w drugiej połowie XX wieku, Radom 2007.

Osęka P., Rytuały stalinizmu: oficjalne święta i uroczystości rocznicowe w Polsce 1944-1956, Warszawa 2007.

Paczkowski A., Historia polityczna Polski 1944-1948, Warszawa 1985.

Paczkowski A., Polityczna historia prasy w Polsce w latach 1944-1948. W: 40 lat władzy komunistycznej w Polsce, pod red. I. Lasoty, Londyn 1986.

Paczkowski A., Pót wieku dziejów Polski 1939-1989, Warszawa 1995.

Paczkowski A., Zdobycie władzy 1945-1947, Warszawa 1993.

Państwowe Wydawnictwo Naukowe 1951-1956, Warszawa 1956.

Państwowe Wydawnictwo Naukowe 1951-1991, Warszawa 1991.

Parnowski T., Czytelnictwo w procesie demokratyzacji kultury. Problematyka czytelnictwa w Polsce Ludowej w latach 1946-50 na tle ksztaltowania się procesów spolecznych i kulturalnych, Warszawa 1964.

Partia z narodem, naród z Kościołem, pod red. F. Musiała i J. Szarka, Kraków 2008.

Paszkiewicz L.B., ,, Gazeta Ludowa”. Próba walki o wolność myśli i słowa 1945-1947, Torun 2007.

Pazera W., Kerygmat w prasie na przykladzie tygodnika „Niedziela” w latach 1945-1953, Częstochowa 2001. 
Pelpliński W., Cenzura jako instrument propagandy w PRL. W: Propaganda PRL, pod red. P. Semkowa, Gdańsk 2004.

Pieczonka M., „Księgarnia Wydawnicza Trzaska, Evert i Michalski”. Działalność wydawnicza, Kraków 1993.

Pietrzak J., Petnia prymasostwa. Ostatnie lata prymasa Polski kardynała Augusta Hlonda 19451948, t. 1-2, Poznań 2009.

Pisarek W., Analiza zawartości prasy, Kraków 1983.

Polacy wobec PRL. Strategie przystosowawcze, pod red. G. Miernika, Kielce 2003.

Polacy wobec przemocy 1944-1956, pod. red. B. Otwinowskiej i J. Żaryna, Warszawa 1996.

Polityka władz państwowych wobec Kościoła katolickiego na Pomorzu Zachodnim i ziemi lubuskiej w latach 1945-1989, pod red. T. Ceynowy i P. Knapa, Szczecin 2010.

Popiel K., Od Brześcia do Polonii, Londyn 1967.

Poznańska M., Środowiska inteligencji katolickiej wobec wizji „,nowej kultury” u zarania Polski Ludowej, Kraków 1993.

Prasa katolicka w stużbie Chrystusa Króla. Zbiór kazań na uroczystość Chrystusa Króla, Warszawa 1947.

Prasa, radio i telewizja w Polsce. Zarys dziejów, Warszawa 2001.

„Precz z komuna!’”. Niepodległościowe organizacje młodzieżowe na ziemi łódzkiej w latach 19451956, pod red. D. Roguta, Zelów 2011.

PRL z pamięci, pod red. C. Robotyckiego, Kraków 2001.

Produkcja wydawnicza w latach 1944-1953 w liczbach, pod red. M. Czarnowskiej, Warszawa 1954.

Pronobis W., Polska i świat w XX wieku, Warszawa 1991.

Prymas Tysiąclecia w komunistycznym państwie, pod red. Z. Zielińskiego, Radom 2003.

Przebudować człowieka. Komunistyczne wysiłki zmiany mentalności, pod red. M. Kuli, Warszawa 2001.

Przybysz M., Kościót rzymskokatolicki w Łodzi w latach 1945-1956, Łódź 2007.

Przybysz M., Wyspy wolności. Duszpasterstwo akademickie w Łodzi 1945-1989, Łódź 2008.

Radziwiłł A., Model ideologii wychowawczej w latach 1948-56. W: Polacy wobec przemocy 19441956, pod. red. B. Otwinowskiej i J. Żaryna, Warszawa 1996.

Raina P., Kardynat Wyszyński: droga na Stolicę Prymasowska, t. 1, Warszawa 1993.

Raina P., Kardynat Wyszyński: losy więzienne, t. 2, Warszawa 1993.

Raina P., Piasecki na indeksie watykańskim: geneza sprawy, Warszawa 2002.

Represje sowieckie wobec narodów Europy 1944-1956, pod red. D. Roguta i A. Adamczyka, Zelów 2005.

Represje wobec duchowieństwa kościołów chrześcijańskich w okresie stalinowskim $w$ krajach bylego bloku wschodniego, pod red. J. Myszora i A. Dziuroka, Katowice 2004.

Represje wobec Kościoła katolickiego na Dolnym Śląsku i Opolszczyźnie: 1945-1989, pod red. S.A. Bogaczewicza i S. Krzyżanowskiej, Wrocław 2004.

Represje wobec osób duchownych i konsekrowanych w PRL w latach 1944-1989, pod red. A. Grześkowiak, Lublin 2004.

Represje wobec sióstr zakonnych w PRL: obozy pracy dla zakonnic (1954-1956), pod red. A. Mirek, Lublin 2005.

Romaniuk M., Prymas Tysiąclecia w pamięci Polaków 1981-2011, Warszawa 2011.

Romaniuk M., Życie, twórczość i posługa Stefana Kardynała Wyszyńskiego Prymasa Tysiaclecia, t. 1-4, Warszawa 1994.

Romek Z., Nadzieje na demokratyczna cenzurę w l. 1944-45. W: Niepiękny wiek XX, Warszawa 2010, s. 329-342.

Roszkowski W., Najnowsza historia Polski 1945-1980, Warszawa 2003.

Roszkowski W., Pótwiecze. Historia polityczna świata po 1945 roku, Warszawa 2002.

Ruch wydawniczy, prasa, drukarstwo i księgarstwo w latach 1945-1954, Warszawa 1955. 
Ruch wydawniczy w liczbach 1944-1973: zestawienie retrospektywne, pod red. M. Czarnowskiej, Warszawa 1974.

Ruch wydawniczy, prasa, drukarstwo i księgarstwo w latach 1945-1954, Warszawa 1955.

Rutkowski T.P., Adam Bromberg i ,encyklopedyści”. Kartka z dziejów inteligencji w PRL, Warszawa 2010.

[Siedemdziesiat pięć] 75 lat „, Gościa Niedzielnego” 1923-1998, Katowice 1998.

Siekierski S., Ksiązka literacka. Potrzeby społeczne i ich realizacja w latach 1944-1986, Warszawa 1992.

Skoczylas M., Wybory do Sejmu Ustawodawczego: z 19 stycznia 1947 r. w świetle skarg ludności, Warszawa 2003.

Skryte oblicze systemu komunistycznego. U źródeł zła..., Warszawa 1997.

Skrzypiec J., Polityka kulturalna Polski Ludowej, Warszawa 1985.

Słabek H., Inaczej o historii Polski 1945-1989, Warszawa 2000.

Słodkowska I., Heroiczni pozytywiści. Towarzystwo „Bratnia Pomoc” Studentów Uniwersytetu Warszawskiego w latach 1945-1949. W: Od Pitsudskiego do Watęsy. Studia z dziejów Polski $w X X$ wieku, pod red. K. Persaka, A. Dudka, A. Friszke i in., Warszawa 2008 s. 141-158.

Słomkowska A., Prasa w PRL. Szkice historyczne, Warszawa 1980.

Skoczylas M., Wybory do Sejmu Ustawodawczego z 19 stycznia 1947 r. w świetle skarg ludności, Warszawa 2003.

Sokół Z., Prasa kobieca w Polsce w latach 1945-1995, Rzeszów 1998.

Sowa A.L., Od Drugiej do Trzeciej Rzeczypospolitej (1945-2001), Kraków 2001.

Spoleczeństwo - Państwo - Kościół (1945-2000). Materiały z ogólnopolskiej konferencji naukowej Szczecin, 15-16 VI 2000 r., pod red. A. Kaweckiego, K. Kowalczyka i A. Kubaja, Szczecin 2000.

Stanaszek B., Księża diecezji sandomierskiej więzieni przez władze komunistyczne po II wojnie światowej, Rzeszów 2008.

Stanaszek B., Usunąc biskupa! Władze PRL wobec ordynariusza Diecezji Sandomierskiej Jana Kantego Lorka, Sandomierz 2004.

Stawialiśmy opór... Antykomunistyczne organizacje młodzieżowe w Matopolsce $w$ latach 19441956, Kraków 2008.

Stefaniak J., Polityka władz państwowych PRL wobec prasy katolickiej w latach 1945-1953, Lublin 1998.

Stefaniak M., Działalność aparatu represji na zachodnim pograniczu Polski w latach 1945-1950, Szczecin 2008.

Stosunki między państwem a Kościołem rzymskokatolickim w czasach PRL, pod red. A. Chojnowskiego i M. Kuli, Warszawa 1998.

Strzelecka M., Powstanie „,Tygodnika Powszechnego” i jego rola w powojennej prasie katolickiej (1945-1953). W: W kręgu prasy (przeszłość-teraźniejszość-przyszłość), pod red. G. Gzelli i J. Gzelli, t. 2, Toruń 2001, s. 103-111.

Strzelecka M., Trudne kompromisy. Środowisko „, Tygodnika Powszechnego” wobec reform systemu oświaty $i$ wychowania w latach 1945-1989, Torun 2009.

Strzelecki-Gomułka R., Salwa-Syzdek E., Między realizmem a utopią: Władysław Gomułka we wspomnieniach syna, Warszawa 2003.

Suchodolski B., Uspolecznienie kultury, Warszawa 1947.

Szarota T., Upowszechnienie kultury. W: Polska Ludowa 1944-50. Przemiany spoteczne, pod red. F. Ryszka, Wrocław 1974, s. 408-470.

Szaynok B., Pogrom Żydów w Kielcach 4 lipca 1946, Warszawa 1992.

Szylko-Kwas J., „, Przeciw burżuazyjnemu pojmowaniu zadań sztuki” - tygodniki społeczno-kulturalne. W: Aparat represji wobec inteligencji w latach 1945-1956, pod red. R. Habielskiego i D. Rafalskiej, Warszawa 2010, s. 183-195.

Świadectwo Kościoła katolickiego w systemie totalitarnym Europy środkowo-wschodniej: księga kongresu teologicznego Europy środkowo-wschodniej KUL 11-15 sierpnia 1991, Lublin 1994. 
Szaruga L., Co czytamy? Prasa kulturalna 1945-1995, Lublin 1999.

Terlecki R., Miecz i tarcza komunizmu. Historia aparatu bezpieczeństwa 1944-1990, Kraków 2007.

Thiriet D., Marks czy Maryja? Komuniści i Jasna Góra w apogeum stalinizmu (1950-1956), Warszawa 2002.

Tobera M., Bibliologia wobec polskiego rynku książki w latach 1944-2007. W: Przyszłość bibliotek $w$ Polsce, Warszawa 2008, s. 82-109.

Tomasik W., Polska powieść tendencyjna 1949-1955. Problemy perswazji literackiej, Wrocław 1988

Topolski J., Historia Polski, Warszawa 1992.

Trąba M., Cenzorskie oceny tygodników katolickich „, Gość Niedzielny” $i$ „Niedziela” w pierwszych latach naporu ideologicznego (1948-1949). W: Niewygodne dla władzy. Ograniczenie wolności słowa na ziemiach polskich w XIX i XX wieku, pod red. D. Degen i J. Gzelli, Toruń 2010, s. $375-390$.

Trzynadlowski J., Zakład Narodowy im. Ossolińskich 1817-1967. Zarys dziejów, Wrocław 1967.

Urbanek M., Kisiel, Wrocław 1997.

Walicki A., Marksizm i skok do królestwa wolności. Dzieje komunistycznej utopii, Warszawa 1996.

Wallis A., Statystyczny opis warunków rozwoju kultury PRL w latach 1946-1970, Warszawa 1974.

W stużbie komuny, pod red. F. Musiała i J. Szarka, Kraków 2008.

Wenklar M., Nie tylko WiN i PSL. Opór społeczny w latach 1945-1956 w powiecie tarnowskim, Kraków 2009.

Wielka historia Polski: 1945-1956, Kraków 2001.

Wierzbicki M., Młodzież w Polsce Ludowej (1945-1956). W: Aparat represji wobec inteligencji w latach 1945-1956, pod red. R. Habielskiego i D. Rafalskiej, Warszawa 2010, s. 99-121.

Wiszniewski J., Z historii prasy katolickiej w Polsce. Tygodnik Warszawski 1945-1948, Kraków 1998.

Władze komunistyczne wobec Kościoła katolickiego w Eódzkiem 1945-1967, pod red. J. Wróbla i L. Próchniaka, Warszawa 2005.

Władze wobec kościołów i związków wyznaniowych w Wielkopolsce w latach 1945-1956, pod red. K. Białeckiego, Poznań 2008.

Wokót legendy „Ognia”. Opór przeciw zniewoleniu: Polska-Małopolska - Podhale 1945-1956. Materiały z konferencji, pod red. R. Kowalskiego, Nowy Targ 2008.

Wokót pogromu kieleckiego, pod red. Ł. Kamińskiego i J. Żaryna, Warszawa 2006.

Wołoszyn J.W., ,, Walczyć o dusze młodzieży”. Zmagania Zwiąku Młodzieży Polskiej z Kościołem katolickim na Lubelszczyźnie 1948-1957, Lublin 2009.

Woźniakowski K., Między ubezwłasnowolnieniem a opozycją. Związek Literatów Polskich w latach 1949-1959, Kraków 1990.

Wydawnictwo Apostolstwa Modlitwy 1872-1972. Historia, opracowania, bibliografia, pod red. Z. Wilkosz i L. Grzebienia, Kraków 1972.

Wysocki W.J., Osaczanie Prymasa. Kardynat Stefan Wyszyński jako „podopieczny” aparatu bezpieczeństwa w latach 1953-1956, Warszawa 2002.

Wyszyński S., Dzieła zebrane, t. 1: 1949-1953, Warszawa 1991.

Z zagadnień czytelnictwa w Polsce Ludowej, Warszawa 1952.

Zabłocki J., Prymas Stefan Wyszyński: opór i zwycięstwo 1948-1956, Warszawa 2002.

Zakony żeńskie na Ślasku w XIX i XX wieku, pod red. W. Musialika, Opole 2006.

Załubski J., Wielkopolska prasa i jej twórcy w latach 1945-1955, Warszawa-Poznań 1972.

Załubski J., Prasa wielkopolska II połowy XX wieku, t. 1: 1945-1970, Poznań 2004.

Zamiatała D., Caritas. Działalność i likwidacja organizacji 1945-1950, Lublin 2000.

Zaremba M., Komunizm, legitymizacja, nacjonalizm. Nacjonalistyczna legitymizacja władzy komunistycznej w Polsce, Warszawa 2001.

Zaremba M., Polityka strachu i jej konsekwencje. Polska 1944-1947. W: Od Pitsudskiego do Watęsy. Studia z dziejów Polski w XX wieku, pod red. K. Persaka, A. Dudka, A. Friszke i in., Warszawa 2008, s. 113-140. 
Zieliński Z., Kościót katolicki w krajobrazie minionej epoki: studia i szkice, Lublin 2008.

Zieliński Z., Kościót w kręgu rzeczywistości politycznej, Lublin 2003.

Zieliński Z., Kościót w Polsce: 1944-2002, Radom 2002.

Zieliński Z., przy współ. S. Bober, Kościót w Polsce 1944-2007, Poznań 2009.

Zieliński Z., Kościót w Polsce: 1944-2007, Poznań 2009.

Ziemba-Świda H., Młodzież PRL. Portrety pokoleń w kontekście historii, Kraków 2011.

Zimniak S., „Dusza wybrana”. Rys salezjańskich korzeni myślenia i działania kardynała Augusta Hlonda prymasa Polski (1881-1948), Rzym-Warszawa 2000.

Żakowski J., Pót wieku pod włos czyli życie codzienne „,Tygodnika Powszechnego” w czasach heroicznych, Kraków 1999.

Żaryn J., Aparat bezpieczeństwa $w$ walce z duchowieństwem katolickim 1945-1949 (zarys problemu). W: Skryte oblicze systemu komunistycznego. U źródet zła..., Warszawa 1997, s. 91-120.

Żaryn J., Dzieje Kościoła katolickiego w Polsce (1944-1989), Warszawa 2003.

Żaryn J., Kościół a władza w Polsce (1945-1950), Warszawa 1997.

Żaryn J., Księża patrioci - geneza powstawania formacji duchownych katolickich. W: Polska 1944/45-1989, t. 1, Warszawa 1995, s. 123-149.

Żaryn J., Postawy duchowieństwa katolickiego wobec władzy państwowej w latach 1944-1956.

W: Komunizm. Ideologia, system, ludzie, pod red. T. Szaroty, Warszawa 2001, s. 289-302.

Żaryn J., Sacrum i profanum. Uwagi o religijności Polaków w latach 1945-1955, W: Polska 1944/45-1989. Studia i materiaty, t. 5, Warszawa 2001 s. 274-307.

Żółkiewski S., O kulturze Polski Ludowej, Warszawa 1964.

Żółkiewski S., Społeczne konteksty kultury literackiej na ziemiach polskich, Warszawa 1995.

Żółkiewski S., Stare i nowe literaturoznawstwo, Wrocław 1950.

Żurek J., Ruch „księży patriotów” w województwie katowickim w latach 1949-1956, WarszawaKatowice 2009.

\subsection{Wspomnienia}

Bardecki A., Zawsze jest inaczej, Kraków 1995.

Błażyński Z., Mówi Józef Światto. Za kulisami bezpieki i partii 1940-1955, Londyn 1985.

Bo jestem z Wilna... z Józefą Hennelową rozmawia Roman Graczyk, Kraków 2001.

Chyliński J., Jaki byt Bolesław Bierut. Wspomnienia syna, Warszawa 1999.

Jachowski J., Wspomnienia poznańskiego księgarza i wydawcy, Poznań 1959.

Jasienica P., Pamiętnik, Warszawa 1986.

Kisielewski S., Dzienniki, Warszawa 1996.

Kraśko T., Wierność. Rozmowy z Jerzym Turowiczem, Poznań 1995.

Langer J., Kościót rzymskokatolicki w PRL, Kraków 1986.

Łopuski J., Pozostać soba w Polsce Ludowej: życie w cieniu podejrzeń, Rzeszów 2007.

Między realizmem a utopia: Władysław Gomułka we wspomnieniach syna, rozmowa E. Syzdek

z R. Strzeleckim-Gomułką, Warszawa 2003.

Rostworowski T., Szerzyć królestwo. Wspomnienia i dzienniki 1939-1972, Warszawa 2004.

Skwarnicki M., Czas ucieka, wieczność czeka, Warszawa 2007.

Stomma S., Trudne lekcje historii, Kraków 1998.

Szczepański W., Wspomnienia. Lipiec 1944-grudzień 1957, Rzeszów 2008.

Świeżawski S., Przeblyski nadchodzacej epoki, Warszawa 1998.

Świeżawski S., W nowej rzeczywistości 1945-1965, Lublin 1991.

Wyszyński S., Pro memoria. Zapiski z lat 1948-1949 i 1952-1953, Warszawa 2007.

Wyszyński S., Zapiski więzienne, Warszawa 2006. 
Zabłocki J., Dzienniki, t. 1: 1951-1965, Warszawa 2008.

Ziemba S., Czasy przełomu. Wspomnienia dziennikarza z lat 1944-1946, Kraków 1975.

Żak S., Cenzura wobec humanistyki, Kielce 1996.

Żakowski J., Trzy ćwiartki wieku. Rozmowy z Jerzym Turowiczem, Kraków 1990.

\section{3. Źródła elektroniczne}

„Ateneum Kapłańskie”. Czasopismo teologiczne założone w 1909 r. Dostępny w World Wide Web http://web.diecezja.wloclawek.pl/Ateneum/o_nas.htm [dostęp 23.05.2012].

Ciszewska W., Źródła do badań nad dziejami książki lat 1945-1950 (2007), „, Biuletyn EBIB” [online] 2007 nr 1. [Dostępny w World Wide Web: http://www.ebib.info/2007/82/a.php?ciszewska [dostęp 16.02.2007].

Kalendarium historii „Tygodnika Powszechnego”. Dostępny w World Wide Web http://www.tygodnik.com.pl/redakcja/kalendarium/45-55.html [dostęp 27.10.2010].

Lista represjonowanych WWW.ipn.gov.pl./bep. Dostępny w Word Wide Web [dostęp 5.10.2011].

Paszkiewicz L.B., Sytuacja Kościoła katolickiego w Polsce w latach 1945-1948 w świetle londyńskiego „Jutra Polski”. Dostępny w World Wide Web http://www.perspectiva.pl/perspectiva_LSTH_pdf/pdf/Paszkiewicz\%5Bs\%5D27.pdf [dostęp 5.01.2010].

Artykuły z czasopism polskich (MARC 21, 2005-); artykuły z czasopism polskich (MARC 21, 1996-2004); artykuły z czasopism polskich (MARC-BN, 1996-2004); artykuły z gazet i tygodników polskich (MARC-BN, 1996-2004); Dostępny w World Wide Web http://mak.bn.org. $\mathrm{pl} / \mathrm{w} 14 . \mathrm{htm}$ [dostęp 17.01.2012]. 



\title{
Biogramy wybranych redaktorów i publicystów
}

\begin{abstract}
Antczak Antoni (1890-1952) - pseud. Adamski, Dyrektor. Działacz narodowo-demokratyczny, samorządowiec, publicysta. Od 1920 członek Narodowej Partii Robotniczej, w 1. 1934-1937 sekretarz Główny Komitetu Wykonawczego. W 1. 1923-1938 był dyrektorem Drukarni Robotniczej w Toruniu i redaktorem naczelnym „Głosu Robotnika”. Dla ratowania drukarni zaczął wydawać nową gazetę - „Obronę Ludu”, która wkrótce stała się fenomenem wydawniczym w Polsce. W okresie 1929-1930 poseł na sejm. Od 1937 w SP, wchodził w skład władz centralnych partii, m.in. w 1. 1937-1939 członek Zarządu Głównego. W czasie okupacji niemieckiej w 1. 1939-1940 członek działającej na Pomorzu podziemnej organizacji wojskowej „Grunwald”. W 1. 1941-1944 był okręgowym Delegatem Rządu Rzeczypospolitej Polskiej na Pomorze. Jednocześnie (1942-1944) był przewodniczącym konspiracyjnego Zarządu Głównego SP. Po zakończeniu działań wojennych od VII 1945 wchodził, wraz z K. Popielem i I. Modelskim, w skład trzyosobowego Zarządu Głównego SP. Współautor decyzji o połączeniu SP z komunizującą, odłamową grupą pod nazwą Stronnictwo Zrywu Narodowego i przystąpienia do Krajowej Rady Narodowej oraz postanowienia z VII 1946 o zawieszeniu działalności partii. W tym samym roku złożył mandat poselski do KRN. Współpracował ze środowiskiem ,Tygodnika Warszawskiego”. W 1948 aresztowany przez Urząd Bezpieczeństwa Publicznego, a w 1951 osądzony i skazany pod fałszywymi zarzutami ,za szpiegostwo na rzecz imperializmu amerykańskiego" na 15 lat więzienia. Zmarł w więzieniu we Wronkach. W 1958 został uniewinniony i zrehabilitowany.

Encyklopedia PWN w trzech tomach, t. 1, Warszawa 2006, s. 76; Kto byt kim w Drugiej Rzeczypospolitej, pod red. J.M. Majchrowskiego, t. 2, Warszawa 1994, s. 223-224; K. Przybyszewski, Toruński stownik biograficzny, pod red. K. Mikulskiego, Torun 1998, s. 20-21.
\end{abstract}

Archita Jan (1912-1969) - publicysta i działacz katolicki. W 1. 1931-1936 studiował polonistykę na Uniwersytecie Warszawskim. W 1939 pełnił funkcję sekretarza Diecezjalnego Instytutu Akcji Katolickiej, a do 1951 referatu prasowego Diecezjalnego Urzędu Katechetycznego. Działalność publicystyczną rozpoczą w 1935 artykułami o tematyce społeczno-kulturalnej, m.in. w takich czasopismach jak „Pro Christo”, „Wiara i Życie”, „Przegląd Katolicki”, „Rycerz Niepokalanej”. Współpracował również z redakcją katowickiej „Polonii”. Po zakończeniu II wojny światowej opublikował około 400 artykułów w „Gościu Niedzielnym”, „Głosie Katolickim” (tu prowadził pod pseudonimem Jacek stały cykl felietonów 
pod nagłówkiem Głos z kąta), „Niedzieli”, „Tygodniku Katolickim” i „Tygodniku Warszawskim". Tłumaczył psalmy i hymny brewiarzowe, z których część wydał drukiem. Znane są jego rozważania różańcowe zatytułowane $O$ chrześcijańska kulturę życia (Niepokalanów 1948).

Edukateria.pl. Archita Jan Stanistaw. Dostępny w World Wide Web http://www.edukateria.pl/ praca/archita-jan-stanislaw/ [dostęp 30.08.2012].

Bąk Wojciech (1907-1961) - pseud. (b), Jan Kowalewicz, Konrad Wallen. (w.b.). Poeta, dramatopisarz, eseista i publicysta. W 1. 1926-1929 studiował polonistykę i filozofię na uniwersytecie w Poznaniu, a następnie w 1. 1929-1939 pracował jako nauczyciel gimnazjalny. Jako poeta zadebiutował wierszem na łamach lokalnej prasy w 1927, a w 1934 tomikiem poezji Brzemię niebieskie, za który otrzymał nagrodę „Wiadomości Literackich”. W 1928 został członkiem grupy literackiej Loża. Był jednym z czołowych i najbardziej kontrowersyjnych poetów katolickich w Polsce międzywojennej. Autor liryków religijnych i filozoficznych opublikowanych w tomach Śpiewna samotność (1936) i Monologi anielskie (1938). W drugiej połowie lat 30. współpracował z redakcjami poznańskich pism: „Tęczą”, „Pionem”, „Prosto z Mostu”, „Verbum” i „Rocznikiem Literackim”. W 1. 1937-1938 redagował poznańskie „Życie Literackie”. W 1938 odznaczony został srebrnym wawrzynem PAL; otrzymał też nagrodę literacką im. Jana Kasprowicza. Okres okupacji spędził w Warszawie i brał czynny udział w konspiracyjnym życiu literackim, drukując m.in. na łamach „Kultury Jutra”. Po powstaniu warszawskim wywieziony został do obozu pracy w Chociebużu, gdzie w czasie nalotu alianckiego doznał ciężkich obrażeń głowy. Po zakończeniu wojny wrócił do Poznania. W 1. 1945-1947 był redaktorem wznowionego „Życia Literackiego" i prezesem Poznańskiego Oddziału ZZLP. Publikował w tym czasie w „Głosie Katolickim”, ,Tygodniku Warszawskim” i „Przeglądzie Powszechnym”. Wydał kilka tomów wierszy: Piąta ewangelia (1946), Syn ziemi (1946), Dlonie z wiatru (1948) oraz zbiór esejów Zagadnienia i postacie (1947), dramaty Stuga don Kiszota i Święty Franciszek (1948) a także opowiadania Twarze (1948). Odznaczony został Srebrnym Wawrzynem Polskiej Akademii Literatury. W 1945 otrzymał nagrodę literacką miasta Poznania za całokształt twórczości, a w 1949 nagrodę literacką Episkopatu Polski za twórczość poetycką. W okresie 1946-1947 pełnił funkcję kierownika literackiego wydawnictwa brata Władysława Bąka, które zostało zlikwidowane jak inne oficyny prywatne. W okresie stalinowskim wycofał się z życia literackiego, a jego utwory nie były drukowane. W 1953 usunięto go z ZLP. Był represjonowany za poglądy polityczne i przetrzymywany w szpitalu psychiatrycznym. Zrehabilitowano go w 1956. W tym czasie ukazały się kolejne tomy wierszy Modlitewnik (1956) i Zastygłe chwile (1958). Pośmiertnie wydano m.in. jego rozważania na tematy religijne $O$ Boguczłowieku i apostołach (1971). Zmarł śmiercią samobójczą.

L.M. Bartelski, Polscy pisarze wspótcześni 1939-1991. Leksykon, Warszawa 1995, s. 16-17; E.P. [E. Paukszta], Pisarze katoliccy. Wojciech Bąk, „Tygodnik Katolicki” $1950 \mathrm{nr} 12$ s. 91; 
M.K.-B.W.: Bąk Wojciech. W: Stownik biograficzny historii Polski, pod red. J. Chodery i F. Kiryka, t. 1, Wrocław 2005, s. 63; M.U., Bąk Wojciech. W: Stownik pisarzy polskich, pod red. A. Latuska, Kraków 2003, s. 25; J. Starnawski, Bąk Wojciech. W: Stownik badaczy literatury polskiej, pod red. J. Starnawskiego, t. 6, Łódź 2003, s. 8-9; Wielka encyklopedia PWN, t. 3, Warszawa 2001, s. 339-340.

Blachnicki Franciszek ks. (1921-1987) - pseud. Eleuteriusz Prawdzic, Gabriel, Gabryel, Gabryel Mar, ks. Gabryel Mar, F.B., ks. F.B., ks. F.BI. Sługa Boży, teolog pastoralista, działacz społeczny, założyciel Ruchu Światło-Życie i jego moderator do 1982. Publikował na łamach katolickich czasopism. W młodości aktywnie działał w harcerstwie. Brał udział w kampanii wrześniowej 1939; od października 1939 w konspiracji - w Polskich Siłach Zbrojnych i Polskiej Organizacji Powstańczej (w Tarnowskich Górach był komendantem oddziału na to miasto); aresztowany przez gestapo i osadzony w Oświęcimiu; do końca wojny przebywał w różnych obozach i więzieniach. W marcu 1942 skazany przez Oberlandesgericht w Katowicach na karę śmierci, zamienioną później na karę 10 lat więzienia, która miała być wykonana po zakończeniu wojny. W kwietniu 1945 uwolniony z obozu w Lengenfeld przez armię amerykańską. Po wojnie wstąpił do Śląskiego Seminarium Duchownego w Krakowie, równocześnie do 1950 studiował na Wydziale Teologicznym Uniwersytetu Jagiellońskiego. W tymże roku przyjął święcenia kapłańskie, w 1. 1950-1956 był wikarym w parafiach śląskich. Brał udział w pracach tzw. tajnej kurii (ośrodka koordynującego działalność duchowieństwa po aresztowaniu przez władze komunistyczne biskupów katowickich) w okresie 1953-1956. W 1961 aresztowany przez władze państwowe pod pretekstem wydawania nielegalnych druków i rozpowszechniania fałszywych wiadomości o prześladowaniu Kościoła w Polsce. Skazany przez Sąd Wojewódzki w Katowicach na 13 miesięcy więzienia w zawieszeniu na trzy lata. Inspirator posoborowej odnowy liturgii. W 1. 1965-1976 redagowal „Biuletyn Odnowy Liturgii”. Pracował naukowo w Sekcji Pastoralnej Wydziału Teologicznego KUL w 1. 1961-1971. W 1965 r. uzyskał doktorat. Szerokie oddziaływanie ruchu oazowego (Krucjata Wyzwolenia Człowieka) i wystąpienia ks. Blachnickiego, w których głosił potrzebę aktywnego uczestnictwa Kościoła $\mathrm{w}$ bieżących sprawach narodu spotykały się często z szykanami ze strony władz administracyjnych (kary grzywny, trudności z uzyskaniem pozwolenia na wyjazdy zagraniczne, ingerencje w życie grup rekolekcyjnych, rewizje). W 1. 1980-1981 zaangażował się bezpośrednio w prace opozycji antykomunistycznej (prowadził rekolekcje dla członków NSZZ „Solidarność”, podczas strajków na wyższych uczelniach w Lublinie powołał Niezależną Chrześcijańską Służbę Społeczną „Prawda-Wyzwolenie”). Od 1981 r. przebywał na emigracji w RFN. Od wiosny 1982 był w polskim ośrodku Marianum w Carlsbergu, gdzie prowadził działalność duszpasterską i informacyjną. Przyczynił się do wprowadzenia reformy liturgicznej po Soborze Watykańskim II. Pozostał po nim bogaty dorobek naukowy, popularnonaukowy i ascetyczno-formacyjny. Wydał m.in. 
Charyzmat i wolność (1985), Prawda-Krzyż - Wyzwolenie. Ku polskiej teologii wyzwolenia (1985), Charyzmat Światto-Życie (1987), Godziny Taboru (1989). Pośmiertnie odznaczony Krzyżem Komandorskim OOP (1987) oraz Krzyżem Oświęcimskim (1995).

G. Bochenek, Ks. Franciszek Blachnicki. W: Opozycja w PRL. Stownik biograficzny 1956-89, t. 1, Warszawa 2001, s. 38-40; M. Marczewski, Blachnicki Franciszek Karol. W: Encyklopedia „biatych plam”, t. 3, Radom 2000, s. 102-104; M.P.G., Blachnicki Franciszek. W: Stownik biograficzny historii Polski..., s. 101.

Borowy Waclaw (1890-1950) - historyk, krytyk literatury, bibliotekarz, archiwista, edytor. Publicysta „Tygodnika Powszechnego”. Studiował filologię polską na Uniwersytecie Lwowskim. Był nauczycielem gimnazjalnym w Warszawie. W 1914 uzyskał w UJ doktorat. Od 1920 pracował w Bibliotece Uniwersytetu Warszawskiego, w 1. 1936-1938 na stanowisku dyrektora. Wykładowca polonistyki w School of Slavonic Studies and East European Studies na Uniwersytecie w Londynie w 1. 1930-1935. Od 1938 profesor Uniwersytetu Warszawskiego. Od 1922 członek Towarzystwa Naukowego Warszawskiego, a od 1932 PAU. Radca w Departamencie Sztuki Ministerstwa Wyznań i Oświecenia Publicznego. Współzałożyciel i redaktor „Przeglądu Warszawskiego” w 1. 1921-1923. Podczas okupacji w podziemiu kulturalnym. Po powstaniu warszawskim brał udział w ratowaniu zbiorów bibliotecznych stolicy. Powrócił do wykładów na UW po zakończeniu II wojny światowej. Był organizatorem i kierownikiem Zakładu Historii Literatury UW. Zainteresowania Borowego obejmowały literaturę polską od renesansu, przez epokę saską i stanisławowską, romantyzm, po Młodą Polskę. Był wybitnym badaczem i edytorem. Wydał tomy szkiców i rozpraw: Kamienne rękawiczki (1932), Dziś i wczoraj (1934), O poezji polskiej w wieku XVIII (1948), O poezji Mickiewicza (t. 1-2 1958), O Norwidzie (1960), O Żeromskim (1960). Należał do znawców literatury europejskiej. W kręgu jego zainteresowań pozostawali pisarze angielscy G.K. Chesterton (monografia G.K. Chesterton, 1929) i T.S. Eliot. Pisał o teorii i praktyce przekładów Boy jako tlumacz (1920) i Dawni teoretycy tlumaczeń (1950).

Encyklopedyczny stownik sławnych Polaków, Warszawa 1996, s. 34; M. Buś - Ja. Ch., Borowy Wacław. W: Stownik biograficzny historii Polski..., t. 1, s. 136-137; W. Sokołowska, Borowy Wacław. W: Stownik pracowników książki polskiej, pod red. I. Treichel, Warszawa-Łódź 1972, s. 84-85; Wielka encyklopedia powszechna, t. 4, Warszawa 2001, s. 307.

Braun Jerzy (1901-1975) - pseud. i krypt. b., B., bor, beta. Poeta, dramaturg, prozaik, publicysta, krytyk literatury, teoretyk teatru, filozof, polityk. Od 1913 w skautingu, był redaktorem pisma harcerskiego „Czuwaj”. Autor popularnych pieśni harcerskich (Płonie ognisko i szumia knieje) i współautor międzynarodowego hymnu harcerek (Hej, przed nami bramy świata). Ochotnik w wojnie polsko-bolszewickiej w 1920 odznaczony Krzyżem Walecznych, którego nie odebrał. Ukończył studia filozoficzne i polonistyczne w UJ. Talent pisarski wykazał już 
w wieku 14 lat. Jako eseista debiutował szkicem Kilka słów o futuryzmie (1921), jako poeta - tomikiem Najazd centaurów (1922). Członek grupy poetyckiej „Helion” i prezes krakowskiego koła „Lit-Art.”. W 1. 1926-28 redagował pierwszą edycję krakowskiego dwutygodnika „Gazeta Literacka”. Pismo o charakterze lewicującym miało być przeciwstawne dla „Wiadomości Literackich”. W okresie dwudziestolecia międzywojennego nawiązał współpracę z J. Lejtesem jako scenarzysta filmowy (Huragan, Mocny człowiek według S. Przybyszewskiego, Halka, Pod bandera milości, Odsiecz wiedeńska). Opublikował tomy wierszy: Oceaniada (1922) i Dywan rozkwitający (1924) oraz dwie powieści fantastyczne Kiedy księżyc umiera (1925) i Hotel na plaży (1927). Zainspirowany myślą mesjanistyczną J.M. Hoene-Wrońskiego napisał poezje: Ziemia i niebo (1930), Tancerz otchtani. Poezje 1928-1932 (1933), poemat Epitafium. Na odstonięcie pomnika Hoene-Wrońskiego na cmentarzu w Neuilly (1934) i niedokończoną powieść filozoficzną Cień Parakleta. Cz. I. Wiktor (1931). Po zakończonej działalności w Towarzystwie im. Hoene- Wrońskiego założył dwutygodnik (od 1937 dwumiesięcznik) „Zet”, który sam finansował i redagował w 1. 1932-1939 w Warszawie. Wypowiadał się na temat kultury postulując wytworzenie przez każdą kulturę narodową jej swoistego ideału posłanniczego oraz połączenie kultury „wysokiej” z kulturą ludową: Kultura polska na bezdrożach. O nowy ksztalt polskiej kultury narodowej (1936). Napisał też kilka dramatów, m.in. Europa (1931) i Dni Konradowe. Dramat w trzech aktach (1935). Sympatyk marszałka J. Piłsudskiego; w 1. 1936-1939 nawiązał współpracę z zespołem tygodnika „Merkuriusz Polski Ordynaryjny". Jego twórczość ukształtowała się pod wpływem katolicyzmu, katastrofizmu i polskiego romantyzmu. Podczas wojny i okupacji odegrał znaczącą rolę w życiu wojskowym, politycznym i kulturalnym Polski Podziemnej. W 1939 utworzył konspiracyjną organizację Nowa Polska, z której w 1940 wyłonił się ruch społeczno-kulturalny intelektualistów Unia (jej organem prasowym był miesięcznik redagowany w 1. 1943-1944 przez Brauna „Kultura Jutra”). W 1943 jako prezes Unii połączył ją z Stronnictwem Pracy (SP), zostając członkiem Zarządu Głównego SP w 1. 1943-1945. Uczestnik powstania warszawskiego. Ostatni delegat Rządu na Kraj. W 1. 1946-1947 wraz z ks. Z. Kaczyńskim współredagował „Tygodnik Warszawski”. Więziony w 1. 1945-1946 i 1948-1956; skazany jako „faszystowsko-hitlerowski zbrodniarz” na dożywocie. W czasie brutalnego śledztwa utracił oko. Na mocy amnestii w 1956 karę zawieszono. Został zrehabilitowany w 1958. Wraz z J. Zawieyskim działacz KIK-u w Warszawie. Pomimo złego stanu zdrowia powrócił do pracy społecznej, literackiej i publicystycznej. $\mathrm{Na}$ przełomie lat 50. i 60. był doradcą prymasa S. Wyszyńskiego. Brał również udział w pracach laikatu polskiego i ruchu ekumenicznego przed Soborem Watykańskim II. Od 1965 przebywał we Włoszech, gdzie spędził ostatnie 10 lat życia. Współpracownik Radia Watykańskiego.

J.J.P., Braun Jerzy Bronisław. W: Stownik biograficzny historii Polski.., s. 147-148; L.M. Bartelski, Polscy pisarze współcześni..., s. 41-42; M.U., Braun Jerzy. W: Słownik pisarzy 
polskich, pod red. A. Latuska, Kraków 2003, s. 54-55; Stownik biograficzny historii Polski..., t. 1, s. 147-148; J. Wojnowski, Braun Jerzy Bronisław. W: Wielka encyklopedia powszechna, t. 4, Warszawa 2001, s. 402.

Chojecki Artur (1880-1951) - poeta i thumacz. Studiował chemię w Instytucie Politechnicznym w Warszawie oraz psychologię i lingwistykę w Krakowie, Genewie i Paryżu. Od 1915 wykładał psychologię na UW, a następnie w KUL. W 1. 1918-1927 pracował w MZS w Warszawie. W poezji poruszał tematykę religijną m.in. Miesiące (1936), Owoce Bożego sadu czyli święta Anna Samosiódma (1947). Tłumaczył utwory Verhaerena i Gilberta Keitha Chestertona. Po upadku powstania warszawskiego zamieszkał w Krakowie. Publikował w ,Znaku”.

M.U., Chojecki Artur. W: Stownik pisarzy polskich..., s. 83.

Gołba Kazimierz (1904-1952) - pisarz, poeta, dramatopisarz, publicysta. Studiował polonistykę na UJ. Pracował jako nauczyciel na Śląsku. Badacz i popularyzator polskości Śląska, więzień gestapo, współpracownik wielu pism katolickich m.in. „Tygodnika Katolickiego”. Autor dramatów, powieści, opowiadań o tematyce Śląska. W okresie dwudziestolecia międzywojennego wydał tom wierszy Salwa nad brukiem (1930) oraz powieści W cieniu wielkiej legendy (1932) i Młodzieżowcy (1938). Na skutek obrażeń odniesionych podczas gestapowskich przesłuchań ostatnie 12 lat przykuty był do łóżka. Po 1945 wydano tomy jego opowiadań Wieża spadochronowa (1947) i Obrazki śląskie (1954).

M.U., Gołba Kazimierz. W: Stownik pisarzy polskich..., s. 150; Śp. Kazimierz Gołba, „Tygodnik Katolicki” 1952 nr 21 s. 157.

Gołubiew Antoni (1907-1979) - pseud. Goa, Jan Karol Wayda, Jerzy Cichocki.Powieściopisarz, eseista i publicysta. Ukończył historię na Uniwersytecie Stefana Batorego. Tam studiował również matematykę i polonistykę. Debiutował w 1925 r. na łamach czasopisma „Ogniwo” jako publicysta. Współzałożyciel i redaktor w 1931 r. pisma „Żagary”. Przed II wojną światową jeden z założycieli i redaktorów dwutygodnika „Pax” (1934-1936). W 1935 ogłosił powieść Mędrcy na arenie; po wojnie współpracował z „Odrą”. W 1. 1946-1953 i w 1956 członek zespołu redakcyjnego „Tygodnika Powszechnego”. Należał do ruchu katolickiego „Znak” i współredagował w 1. 1949-1952 miesięcznik pod tym samym tytułem. Współpracował również w tym czasie z redakcją ,Tygodnika Katolickiego”. W latach 1947-1974 wydał powieść historyczną w cyklu Bolesław Chrobry w tomach: Puszcza, Szło Nowe, Złe dni, Rozdroża. Była ona odzwierciedleniem zainteresowań autora przeszłością narodu i rolą Kościoła katolickiego w wprowadzeniu Polski na arenę międzynarodową. W jego dorobku twórczym znalazły się ponadto opowiadania o tematyce współczesnej i moralnej, eseje o tematyce religijno-filozoficznej, literackiej i historycznej oraz wspomnienia. Laureat Nagrody Młodych im. W. Pietrzaka (1948), Nagrody Fundacji im. Alfreda Jurzykowskiego (1951), nagrody Ministra Kultury i Sztuki I stopnia (1977). 
L.M. Bartelski, Polscy pisarze współcześni..., s. 113-114; Encyklopedyczny słownik sławnych Polaków..., s. 100; J.F., Golubiew Antoni. W: Stownik pisarzy polskich..., s. 150-151; T.H. [T. Haluch], Antoni Golubiew, „Tygodnik Katolicki” 1952 nr 21 s. 157; Wielka encyklopedia powszechna, t. 10, Warszawa 2002, s. 273; Współcześni polscy pisarze i badacze literatury. Słownik biobibliograficzny, pod red. J. Czachowskiej, A. Szałagan, t. 3, Warszawa 1994, s. 82.

Górski Artur (1870-1959) - pseud. i krypt. Quasimodo, Obojętny, Liberum conspiro, Truskolasy, Garda, Tur, Q, T-y, Dr A.G., A.G. Literat, krytyk literacki, pisarz, publicysta, tłumacz. Studiował prawo na UJ. Podczas studiów związał się z ruchem socjalistycznym. Należał do radykalno-postępowej i ideowej grupy Czytelni Akademickiej skupionej wokół pisma „Ognisko” (1889-1899), organizującej wieczorki mickiewiczowskie. Debiutował wierszem i prozą w 1890. Był prezesem Czytelni w 1891, agitatorem socjalizmu i antyklerykalizmu. Został oskarżony przed sądem za nawoływanie do walki z zaborcami. Współzałożycielem PPS w Krakowie oraz organu partii „Naprzód” (1892). W pełni nie utożsamiał się z poglądem na walkę klas, co wyraził zerwaniem w 1893 ze środowiskiem socjalistycznym na rzecz katolicyzmu. Wkrótce przeżył konwersję pod wpływem myśli kardynała J.H. Newmana i o. J. Woronieckiego. Jego twórczość miała charakter moralizatorski. W krakowskim „Życiu” pod pseud. Quasimodo opublikował cykl głośnych artykułów, uznanych za program nowego kierunku w kulturze i nazwę okresu „Młoda Polska” (1898). W literaturze postulował sięgnięcie po ideały etyczne zawarte w twórczości A. Mickiewicza. Domagał się moralnego odrodzenia jednostki i narodu. W twórczości wyrażał przekonanie o mesjanistycznej roli Polaków. Rolą sztuki miała być służba narodowi, zwłaszcza pozbawionego samodzielnego bytu państwowego. Uprawiał lirykę, pisał opowiadania i dramaty. W 1. 1896-1897 redagował wraz z Wilhelmem Feldmanem „Dziennik Krakowski”, na którego łamach pisał cotygodniowe felietony, recenzje teatralne i malarskie. Współpracował z wieloma pismami m.in. „Chimerą”, „Marchołtem”, „Myślą Polską”, „Nową Gazetą”, „Odrodzeniem”, „Ogniwem”, „Słowem Polskim”, „Tygodnikiem Ilustrowanym” i „Życiem”. Doktorat praw uzyskał w 1897. Był prezesem Instytutu Popierania Twórczości Literackiej. W czasie okupacji przebywał w Warszawie. Działacz konspiracyjnej i katolickiej Unii; wraz z Tadeuszem Kudlińskim kierował od 1943 Unią Kultury. Po II wojnie światowej zamieszkał w Krakowie. Na temat wartości w kulturze pisał w periodykach katolickich „Tygodniku Powszechnym” i „Tygodniku Warszawskim”. Przekładał z literatury niemieckiej, włoskiej, angielskiej. Zajmował się edytorstwem m.in. dzieł J. Słowackiego i A. Mickiewicza. Najważniejszym jego dziełem był oryginalny poemat Monsalwat. Rzecz o Adamie Mickiewiczu (1908). Wydał również Ku czemu Polska szła (1918), Na nowym progu (1918), O wieszczeniu w sztuce (1920), Głosy o ludziach i ideałach (1931), Niepokój naszego czasu (1938). Przetłumaczył: Tarczę Heraklesa Hezjoda (1919), Nowe życie Dantego Alighieri 
(1915), Sonety Szekspira (1911), Prometeusza Johanna Wolfganga Goethego, Albo-albo Sorena Kierkegaarda, Dzika kaczkę Henry'ego Ibsena, Ludzi spod bieguna Edvarda Welle-Stranda (1928), O twórczości i krytyce katolickiej Jeana Calveta (1930), Sage o Gislim wyjętym spod prawa i inne sagi islandzkie (1931). Część jego prac filozoficzno-społecznych Rzecz o nadziei (1962) wydano pośmiertnie. Odznaczony w 1927 Krzyżem Komandorskim Orderu Odrodzenia Polski. Nagrodzony Złotym Wawrzynem Polskiej Akademii Literatury (1935), Państwową Nagrodą Literacką (1938), za całokształt twórczości nagrodą im. W. Pietrzaka (1959).

Encyklopedyczny stownik sławnych Polaków..., s. 103-104; E. Kristanova, Górski Artur. W: Stownik badaczy literatury polskiej, pod red. J. Starnawskiego, t. 10, Łódź 2009, s. 115-120; Stownik pisarzy polskich..., s. 159-160; Wielka encyklopedia powszechna..., t. 10, s. 355.

Górski Konrad (1895-1990) - historyk i teoretyk literatury, edytor, krytyk literacki i teatralny. Publicysta „Tygodnika Powszechnego” i „Znaku”. Studiował polonistykę na UW, prawo w Dorpacie (Rosja) i slawistykę na Uniwersytecie w Pradze. Artylerzysta w wojnie polsko-bolszewickiej. Od 1934 nauczyciel szkół gimnazjalnych. Doktoryzował się w 1921, habilitację uzyskał w 1929, tytuł profesora nadzwyczajnego w 1934, a profesora zwyczajnego w 1945. Profesor Uniwersytetu Stefana Batorego w Wilnie (1934-1939) i UMK w Toruniu (1945-1950, 1956-1965). W 1. 1950-1956 odsunięty od wykładów z powodów ideologicznych pracował w IBL PAN. Członek licznych towarzystw naukowych, m.in. PAU, PAN, Towarzystwa Naukowego Warszawskiego, Towarzystwa Naukowego Toruńskiego. Otrzymał nagrody: Episkopatu Polski za całokształt pracy naukowej (1949), im. A. Jurzykowskiego (1972), im. W. Pietrzaka (1979) i Pen Clubu za prace edytorskie (1980). Nagrodzony doktoratem honoris causa trzech uczelni: UJ (1973), KUL (1980) i UMK (1981). Formułował program literatury katolickiej, a w artykułach, wypowiedziach i wykładach jawnie polemizował ze stanowiskiem marksistowskim. Zajmował się też teatrem, muzyką i poezją. Wydał m.in. zbiór rozpraw programowych Literatura a prady umystowe (1938) oraz prace poświęcone dziejom reformacji Grzegorz Pawet z Brzezin (1929) i Studia nad dziejami polskiej literatury antytrynitarskiej XVI w. (1949). Ważne miejsce w jego dorobku naukowym zajęły też rozważania teoretyczne Poezja jako wyraz (1946) i Studia z historii i teorii literatury $(1959,1964,1971)$. Wśród jego rozpraw historycznoliterackich znalazły się: François Mauriac (1935), Stanisław Krzemiński (1936), Erazm z Rotterdamu (1948), Jan Kasprowicz (1977), Mickiewicz-Towiański (1986). Badał warsztat językowo-stylistyczny, głównie utworów A. Mickiewicza: Sztuka edytorska (1956), Tekstologia i edytorstwo dziet literackich (1977), Mickiewicz. Artyzm i język (1978). Jeden z inicjatorów i redaktor naczelny Słownika języka Adama Mickiewicza (9 t., 1962-1977) i krytycznego wydania Dziet wszystkich poety (od 1969).

L.M. Bartelski, Polscypisarze współcześni 1939-1991, Warszawa 1995, s. 120; Encyklopedyczny słownik sławnych Polaków..., s. 104; J.S.O., Górski Konrad. W: Stownik biograficzny historii..., 
t. 1, s. 475; S. Melkowski, Górski Konrad Józef. W: Toruński słownik biograficzny, pod red. K. Mikulskiego, t. 1, Toruń 1998, s. 108-110; Wielka encyklopedia powszechna, t. 10, Warszawa 2002, s. 356.

Grzegorczyk Marian (1887-1945) - publicysta, dziennikarz, członek redakcji „Tygodnika Warszawskiego", publicysta przed II wojną światową w „Rzeczpospolitej”, „Warszawiance”, „Polsce”, „Gońcu Warszawskim”. W czasie wojny stracił całą rodzinę.

Redakcja, Śmierć Mariana Grzegorczyka, „Tygodnik Warszawski” 1946 nr 1 s. 2; J. Dobraczyński, Wspomnienie, tamże.

Herbert Zbigniew (1924-1998) - poeta, eseista, dramatopisarz. Był żołnierzem AK. Ukończył prawo w 1949 na UMK, studiował też polonistykę na konspiracyjnym uniwersytecie we Lwowie oraz ekonomię na Akademii Handlowej w Krakowie. Uczęszczał na wykłady z filozofii na UJ, UMK i UW. Podejmował dorywcze prace ekspedienta, kalkulatora, ekonomisty. W 1948 pełnił funkcję redaktora pisma „Przegląd Kupiecki”. Pracował też w Muzeum Okręgowym w Toruniu w 1950. Współpracował ze „Słowem Powszechnym” (1949-1951), „Tygodnikiem Powszechnym” (1950-1953), „Przeglądem Powszechnym”, „Dziś i Jutro”. W 1. 1956-57 był dyrektorem administracyjnym Związku Kompozytorów Polskich, w 1. 1965-1966 kierownikiem literackim Teatru im. Juliusza Osterwy w Gorzowie Wielkopolskim, w okresie 1965-1968 redaktorem miesięcznika „Poezja”. W 1. 1948-1951 i od 1955 członek Związku Literatów Polskich, a w 1972-1975 w Prezydium Zarządu Głównego ZLP. Członek Pen Clubu. Był jednym z sygnatariuszy Memoriału 59 wyrażającego protest przeciwko projektowanym zmianom w Konstytucji PRL. W 1. 1970-1971 wykładał na University of California w Los Angeles. W 1981 był w redakcji niezależnego pisma „Zapis”, ukazującego się poza cenzurą. Uczestnik ruchu związanego z NSZZ „Solidarność”. W 1. 1986-1992 mieszkał w Paryżu. Od 1989 w Stowarzyszeniu Pisarzy Polskich. W 1955 publikował na łamach „Życia Literackiego" wiersze uznane później za oficjalny debiut poetycki. Pod koniec życia współpracował z „Tygodnikiem Solidarność”. Jego twórczość była głęboko osadzona w tradycji antycznej i chrześcijańskiej. Wyrażał głęboki szacunek dla tradycji europejskiej oraz dla tradycyjnego systemu wartości ogólnoludzkich. Tworzył intelektualną poezję, w której poruszał kwestie polityczne, kulturowe, etyczne i metafizyczne. Przeciwny był doktrynie komunistycznej, surowo oceniał pisarzy, którzy po 1944 współpracowali z nową władzą. Wyrażał stanowczość i bezkompromisowość w sądach moralnych. Opublikował tomy wierszy: Struna światta (1956), Hermes, pies i gwiazda (1957), Studium przedmiotu (1961), Napis (1969), Pan Cogito (1974), Raport z oblężonego Miasta i inne wiersze (1983), Elegia na odejście (1990), Rovigo (1992), Epilog burzy (1998). Swoje poglądy wyraził też w esejach: Barbarzyńca w ogrodzie (1962), 
Martwa natura z wędzidtem (1993), Labirynt nad morzem (2000), Węzet gordyjski oraz inne pisma rozproszone 1948-1998 (2001). Dramaty to: Jaskinia filozofów (1956), Drugi pokój (1958), Rekonstrukcja poety (1960), Lalek (1961). Otrzymał liczne nagrody m.in. Nagrodę Fundacji Kościelskich (1963), austriacką Nagrodę im. Gottfrieda von Herdera (1973).

A.B., Herbert Zbigniew. W: Stownik biograficzny historii Polski..., t. 1, s. 535; Encyklopedyczny słownik sławnych Polaków..., s. 114-115; L.M. Bartelski, Polscy pisarze..., s. 132-133; A. Franaszek, Herbert Zbigniew. W: Wielka encyklopedia PWN, t. 11, Warszawa 2002, s. 249-250; Opozycja w PRL. Stownik biograficzny 1956-89, pod red. J. Skórzyńskiego, t. 3, Warszawa 2006, s. 102-104; Stownik pisarzy polskich..., s. 174-176.

Jasienica Pawel (1909-1970) - właśc. Leon Lech Beynar. Pisarz historyczny, publicysta, eseista. W 1932 ukończył studia historyczne na Uniwersytecie Stefana Batorego w Wilnie. W1. 1934-37 nauczyciel historii w Grodnie, w okresie 1937-1939 spiker w rozgłośni Polskiego Radia w Wilnie. Żołnierz kampanii wrześniowej, od 1940 członek Związku Walki Zbrojnej, następnie Armii Krajowej w stopniu podporucznika. Członek redakcji pism konspiracyjnych lat 1942-1944. W 1. 1944-1945 oficer WiN. W 1. 1946-1950 pracował w redakcji „Tygodnika Powszechnego”. Od 1952 członek Związku Literatów Polskich, 1959-1962 wiceprezes Zarządu Głównego, 1958-1962 członek Klubu Krzywego Koła (KKK), 1961-1962 prezes, od 1961 w polskim Pen Clubie, 1966-1970 wiceprezes zarządu. W wypowiedziach publicystycznych podejmował tematykę historii najnowszej i współczesne zagadnienia polityczne. Publicysta „Tygodnika Powszechnego”, „Tygodnika Warszawskiego”, „Tygodnika Katolickiego”. Na łamach krakowskiego tygodnika pisał reportaże m.in. o Ziemiach Zachodnich. Był zwolennikiem realizmu politycznego i szukania porozumienia z rządzącymi komunistami. Aresztowany w 1948, podczas zatrzymania kierownictwa Okręgu Wileńskiego AK (w 1945 był z-cą dowódcy oddziału AK Zygmunta Szendzielarza „Łupaszki”). Zwolniony w tymże roku dzięki zabiegom Bolesława Piaseckiego; śledztwo umorzono w 1949. Związał się ze środowiskiem tygodnika „Dziś i Jutro”, wszedł w 1950 do zarządu komisarycznego przejmowanego przez państwo Caritasu. Publikował w $1951 \mathrm{w}$ „Słowie Powszechnym", po czym w 1956 wystąpił przeciw Piaseckiemu po jego artykule Instynkt państwowy. Jako członek KKK występował w obronie wolności słowa i przeciw nadmiernym ingerencjom cenzury. Od 1959 systematycznie inwigilowany przez SB. Ostro krytykował politykę kulturalną partii rządzącej (podpisał List 34). Za wystąpienia krytykujące działanie ówczesnej władzy i poparcie protestów młodzieży akademickiej w marcu 1968 był atakowany w prasie rządowej i uznany za wroga PRL. Zniesławiony został przez Władysława Gomułkę. Zakazano upowszechniania jego książek. W 1948 otrzymał nagrodę im. W. Pietrzaka, w 1965 im. A. Jurzykowskiego. Popularność wśród czytelników przyniosły mu: Polska Piastów (1960), Polska Jagiellonów (1963), Rzeczpospolita Obojga Narodów (1967), Myśli o dawnej Polsce (1960). Wśród publikacji reportażowych i eseistycznych znalazły 
się: Świt stowiańskiego jutra (1952), Biały front (1953), Ostatnia z rodu. Opowieść o Annie Jagiellonce (1965).

L.M. Bartelski, Polscy pisarze wspótcześni..., s. 154-155; Encyklopedyczny słownik sławnych Polaków..., s. 133-134; J.S.O. - M. K-a, Jasienica Pawet. W: Stownik biograficzny historii Polski..., t. 1, s. 615; Stownik pisarzy polskich..., s. 199-200; Wielka encyklopedia PWN, t. 12, Warszawa 2003, s. 458; A. Friszke, Pawet Jasienica. W: Opozycja w PRL. Stownik biograficzny 1956-89, pod red. J. Skórzyńskiego, t. 3, Warszawa 2006, s. 117-120.

Kaczyński Zygmunt ks. (1894-1953) - kapłan, działacz społeczno-polityczny, publicysta, redaktor, poseł i minister II Rzeczypospolitej. Studiował teologię w Warszawie (1910-1914) oraz prawo kanoniczne w Petersburgu (1914-1918). Od 1918 sekretarz generalny Stowarzyszenia Robotników Chrześcijańskich i działacz chrześcijańskich związków zawodowych. W 1. 1919-1927 był posłem na sejm. Czynny w pracach sejmowych jako sekretarz prezydium i członek wielu komisji (m.in. ochrony pracy, prawniczej i spraw zagranicznych). Inicjator projektów ustaw z zakresu ustawodawstwa pracy. Służył jako kapelan w wojnie polsko-bolszewickiej w 1920. Dwa lata później został mianowany szambelanem papieskim przez Piusa XI i odznaczony papieskim Medalem Pro Ecclesia et Pontifice. Jeden z twórców i przywódców Chrześcijańskiej Demokracji, przyczynił się do połączenia w 1937 Polskiego Stronnictwa Chrześcijańskiej Demokracji i Narodowej Partii Robotniczej, które utworzyły Stronnictwo Pracy. Popierał generała Władysława Sikorskiego, a następnie Stanisława Mikołajczyka. W okresie dwudziestolecia międzywojennego był udziałowcem, wydawcą i redaktorem pism katolicko-społecznych, m.in. „Pracownika Polskiego” (1919-1920), „Nowego Życia” (1922), „Rzeczpospolitej” (1928), „Głosu Narodu” (1936). W 1936 wybrany został do zarządu Zjednoczenia Pisarzy Katolickich, a na odbywającym się tego roku kongresie przedstawicieli prasy katolickiej w Watykanie został członkiem Rady Międzynarodowego Związku Dziennikarzy Katolickich. W okresie 1930-1939 pełnił funkcję dyrektora Katolickiej Agencji Prasowej. W 1935 powołany na kanonika Kapituły warszawskiej. Po zamachu majowym pozostawał w opozycji do rządów sanacji. Odegrał ważną rolę w powstaniu Frontu Morges i był sympatykiem polityki generała Władysława Sikorskiego. Ścigany przez gestapo, od grudnia 1939 przebywał na emigracji. Jako reprezentant SP wszedł do Rady Narodowej. Był kapelanem prezydenta Władysława Raczkiewicza. W rządzie generała W. Sikorskiego został ministrem Wyznań Religijnych i Oświecenia Publicznego. Po ogłoszeniu przez hitlerowców w kwietniu 1943 komunikatu o odkryciu grobów katyńskich był inicjatorem przyjęcia przez rząd polski wniosku o skierowanie sprawy do MCK. W listopadzie 1945 powrócił do kraju; został proboszczem w parafii Wszystkich Świętych w Warszawie. W 1945 założyciel, a w 1. 1946-1948 redaktor naczelny „Tygodnika Warszawskiego”. W tym czasie publikował także w „popielowskim” tygodniku SP „Odnowa”. Niezwykle aktywny w życiu społecznym, posiadał doświadczenie polityczne i własną opinię na 
temat stosunków Kościoła z państwem. W poglądach przeciwny był ideologii komunistycznej. Zaangażował się w działalność „,popielowskiego” SP. Po przejęciu władzy przez grupę „Zrywu Narodowego” i wyjściu Popiela z SP (1946) dążył do stworzenia niezależnej partii katolickiej. Utrzymywał liczne kontakty z hierarchami Kościoła (prymasami A. Hlondem i S. Wyszyńskim, abp S. Sapiehą, abp A. Szlagowskim, bp S. Adamskim, bp T. Kubiną, bp Z. Choromańskim), politykami (K. Popielem, S. Mikołajczykiem, przedstawicielami władzy komunistycznej). Występował jako ekspert strony kościelnej w sprawach oświatowych w spotkaniach z przedstawicielami rządu. Był członkiem Komitetu Prymasowskiego działającego na rzecz odbudowy warszawskich kościołów (1947). Jego wszechstronna działalność była niewygodna władzy, z tego powodu w 1948 był przesłuchiwany przez Służbę Bezpieczeństwa, a następnie aresztowany i torturowany. W 1951 skazany wyrokiem Wojskowego Sądu Rejonowego w Warszawie na 10 lat więzienia. Zmarł w 1953 na atak serca w Więzieniu Mokotowskim. Relacje więźniów wskazywały, że został zamordowany. Uniewinniony i zrehabilitowany W 1958.

IPN w Warszawie: Akta kontrolno-śledcze dotyczące ks. Zygmunta Kaczyńskiego, sygn. BU 0259/568; sygn. BU 01439/19; sygn. BU 01236/1209/Jacket; ks. Zygmunt Kaczyński s. Franciszka, sygn. BU 0397/640; E. Balawajder, Kaczyński Zygmunt. W: Słownik biograficzny katolicyzmu społecznego w Polsce, Lublin 1994, t. 2; tenże, Kaczyński Zygmunt. W: Encyklopedia Katolicka, Lublin 2000, t. 8; R. Bender, Kaczyński Zygmunt. W: Encyklopedia ,białych plam”, Radom 2002, t. 9, s. 105-107; M. Biełaszko, ,Nie dam się złamać”: Księża niezłomni: Ksiądz Zygmunt Kaczyński 1894-1953. Dostępny w World Wide Web „Nasz Dziennik” http://www.naszdziennik.pl/index. php?typ=my\&dat=20070512\&id=my13.txt [dostęp 15.01.2011]; tenże, Ksiądz Zygmunt Kaczyński (1894-1953) - duchowny, polityk, redaktor. W: Niezłomni ludzie Kościoła. Sylwetki, pod red. J. Żaryna, Kraków 2011, s. 95-122; S. K-n, Kaczyński Zygmunt. W: Słownik biograficzny historii..., t. 1, s. 640; J. Żaryn, Zygmunt Kaczyński (1894-1953). W: Konspiracja i opór społeczny w Polsce 1944-1956. Stownik biograficzny, t. 1, Kraków 2002, s. 206-208.

Kisielewski Stefan (1911-1991) - pseud. Kisiel, Julia Hołyńska, Teodor Klon, Tomasz Staliński. Felietonista, publicysta, prozaik, kompozytor i krytyk muzyczny. Studiował w konserwatorium w Warszawie teorię muzyki i kompozycję oraz polonistykę i filozofię na UW. Podjął współpracę m.in. z „Buntem Młodych” i „Polityką”. Był sekretarzem dwumiesięcznika „Muzyka Polska” w okresie 1935-1937. W 1. 1938-1939 uzupełniał studia muzyczne w Paryżu. Uczestnik kampanii wrześniowej 1939 i powstania warszawskiego w 1944 w szeregach AK. Brał udział w konspiracyjnym życiu kulturalnym. W 1. 1945-1949 profesor Wyższej Szkoły Muzycznej w Krakowie (usunięty za krytykę socrealizmu w muzyce). Założyciel w 1945 i do 1948 redaktor „Ruchu Muzycznego”. Współpracował z „Tygodnikiem Powszechnym” w latach 1945-1989 (z przerwami w latach: 1953-1956, kiedy wydawanie pisma zawieszono, 1968-1971 w związku z zakazem publikacji jego artykułów, 1981-1983, czyli w okresie 
stanu wojennego). Znany jako Kisiel prowadził cykle Głowa w ściany, Bez dogmatu, Pod włos, Łopata do głowy, Gwoździe w mózgu i Wołanie na pusz$c z y$. Po 1989 w wyniku nieporozumień z redakcją „Tygodnika Powszechnego”, która zaczęła cenzurować jego felietony, odmówił dalszego publikowania tekstów w tym tygodniku i przeniósł się na łamy „Wprost”. Publikował także na łamach „Znaku”. Od schyłku lat 60. pisał w paryskiej „Kulturze”, w pismach drugiego obiegu i prasie niemieckiej. W wypowiedziach publicystycznych na temat współczesnego życia społecznego i kulturalnego prezentował stanowisko liberalno-konserwatywne, opowiadając się przeciw marksistowskiej ideologii. Odznaczał się niezależnością sądów i krytyczno-kpiarskim stosunkiem do rzeczywistości. W 1. 1957-1965 poseł na Sejm PRL z ramienia Koła Poselskiego Znak. Redaktor naczelny wydawnictwa Synkopa (Wydawnictwo Artystyczne i Filmowe). Zwolennik ruchu NSZZ „Solidarność”. W 1990 ustanowił nagrodę swojego imienia, przyznawaną corocznie najpierw przez niego samego, a po jego śmierci przez kapitułę złożoną z jego syna Jerzego i laureatów z lat poprzednich. Był autorem setek felietonów i publikacji politycznych, szeregu powieści i książek o muzyce. Laureat nagród m.in. Fundacji im. A. Jurzykowskiego (1974), im. S. Vincenza (1987), A. Bocheńskiego (1988). Wydał m.in. zbiory szkiców i felietonów Polityka i sztuka (1949), Rzeczy małe (1956), 100 razy głowa w ścianę (1972), Moje dzwony trzydziestolecia (Chicago 1979), Na czym polega socjalizm? (Londyn 1979), Bez cenzury (1983), Wołanie na puszczy (1987). W dorobku znalazły się też aforyzmy pt. Rzeczy najmniejsze (1988). W latach 1968-1980 napisał Dzienniki, wydane po jego śmierci. Ogłosił powieści: Sprzysiężenie (1947), Zbrodnia w Dzielnicy Pólnocnej (1948), Miałem tylko jedno życie (1958). Jako Tomasz Staliński - cykl powieści Widziane z góry (Paryż 1967), Cienie w pieczarze (Paryż 1971), Wszystko inaczej (Londyn 1986). Był autorem następujących szkiców muzycznych: Z muzyka przez lata (1957), Gwiazdozbiór muzyczny (1958), Muzyka i mózg (1974).

J.M. Bartelski, Kisielewski Stefan. W: Polscy pisarze współcześni..., s. 178-179; Encyklopedyczny słownik sławnych Polaków..., s. 152; J.F., Kisielewski Stefan. W: Słownik pisarzy polskich..., s. 226; Z.B., Kisielewski Stefan. W: Stownik biograficzny historii..., s. 690; J. Wojnowski, Kisielewski Stefan. W: Wielka encyklopedia PWN, t. 13, Warszawa 2003, s. 545.

Kozicki Stanisław (1876-1958) - polityk i publicysta. Studiował w Wyższej Szkole Rolniczej w Berlinie, a następnie przeniósł się na Wydział Rolniczy uniwersytetu w Halle, który ukończył w 1899. Wolny słuchacz Szkoły Nauk Politycznych we Francji w 1. 1907-1909. W Polsce związany z ruchem Narodowej Demokracji, współpracownik Romana Dmowskiego. Redaktor naczelny „Gazety Warszawskiej” od 1909. Publikował w „Przeglądzie Narodowym” i „Słowie Polskim”. W 1. 1914-1918 redagował "Gazetę Polską". Kierował zespołem „Kuriera Poznańskiego” i „Przeglądu Wszechpolskiego”. Od 1900 członek Ligi Narodowej (LN), od 1905 w składzie jej Komitetu Krajowego. W 1910 wybrany 
do Komitetu Centralnego LN i Zarządu Głównego Stronnictwa DemokratycznoNarodowego. W 1918 został członkiem Komitetu Narodowego Polski w Paryżu, mianowany sekretarzem generalnym polskiej delegacji pokojowej na konferencji paryskiej zakończonej podpisaniem traktatu wersalskiego. Po zakończeniu I wojny światowej osiadł w Poznaniu. W 1. 1922-1927 był posłem na Sejm, a w 1928-1935 senatorem. W 1935 wycofał się z polityki i podjął się pracy tłumacza i pisarza politycznego. W artykułach publicystycznych wypowiadał się na temat polityki międzynarodowej. W czasie okupacji niemieckiej był doradcą politycznym delegatury rządu londyńskiego i komendy Głównej AK. Po 1945 osiadł w Krakowie, gdzie współpracował z „Tygodnikiem Powszechnym”. W 1947 został członkiem Instytutu Zachodniego w Poznaniu. Po wyborach do sejmu w 1947 był inwigilowany przez UB, co było powodem przeniesienia się do Polanicy Zdroju, gdzie zmarł.

S. K-n, Kozicki Stanisław. W: Stownik biograficzny historii..., t. 1, s. 759-60.

Kudliński Tadeusz (1898-1990) - prozaik, krytyk teatralny. Ukończył Wydział Prawa UJ, w 1923 uzyskał stopień doktora. W 1. 1916-1918 brał udział w I wojnie światowej w wojsku austriackim. Zwolniony na skutek odniesionych ran, powrócił do Krakowa i w okresie 1918-1921 służył w Wojsku Polskim (uczestnik wojny polsko-bolszewickiej). Debiutował w 1923 na łamach krakowskiej „Gazety Literackiej” jako krytyk teatralny. W 1. 1923-1934 był jej redaktorem. Współpracował z redakcją pisma „Zet”. Ogłosił w 1928 zbiór nowel Pierwsza miłość panny Elo i inne nowele o sporcie oraz kilka powieści: Wygnańcy Ewy (1932), Rumieńce wolności (1937) i Uroki (1938). W okresie okupacji działał w konspiracyjnej organizacji katolickiej Unia. Przeżycia związane z uwięzieniem przez gestapo w 1944 opisał we wspomnieniu Mantelupa (1946). Po 1945 podjął współpracę ze środowiskiem „Tygodnika Warszawskiego”. W 1. 1948-1955 więziony był za działalność polityczną. Skazany został pod fałszywymi zarzutami na siedem lat więzienia. Po zwolnieniu, w 1. 1962-1971 przewodniczący Klubu Miłośników Teatru. W 1973 otrzymał nagrodę im. W. Pietrzaka, a w 1979 wyróżnienie miasta Krakowa. Wydał jeszcze kilka powieści: Dagerotyp $\mathrm{Mr}$. Drumma (1958), Rumieńce wolności (1959), Z tarcza czy na tarczy (1960), Gniew o Szoszanne (1963). Opublikował także zbiory szkiców teatralnych Maska i oblicze teatru (1963), Rodowód polskiego teatru (1972), Dawne i nowe przypadki ,teatrała" (1975) oraz dwa tomy wspomnień Młodości mej stolica (1970) i Starość nie radość (1985).

L.M. Bartelski, Polscy pisarze wspótcześni..., s. 215; M.U., Kudliński Tadeusz. W: Stownik pisarzy polskich..., s. 277.

Kossak-Szczucka Zofia (1890-1968) - powieściopisarka i publicystka. Studiowała w warszawskiej Szkole Sztuk Pięknych i w Genewie (1913-1914). Dzieciństwo i młodość spędziła na Wołyniu. Była związana z grupą literacką „Czartak” i prasą katolicką. W czasie okupacji redagowała konspiracyjne 
pisma „Polska Żyje” (1939-1941) i „Prawda” (1942-1943). Współpracowała z Delegaturą RP w Londynie. Powołała Radę Pomocy Żydom (Żegotę). Za tę działalność pośmiertnie odznaczona została medalem „Sprawiedliwy Wśród Narodów Świata". Więziona w obozie koncentracyjnym w Auschwitz. Wspomnienia z obozu opisała w książce Z otchłani (1946). Uwolniona w 1944 dzięki staraniom władz podziemia wzięła udział w powstaniu warszawskim. W 1. 1945-1957 mieszkała w Anglii, gdzie kontynuowała pracę pisarską. W 1951 wszystkie jej utwory objęte zostały w Polsce cenzurą i podlegały natychmiastowemu wycofaniu z bibliotek. Pisywała w „Tygodniku Katolickim”. Po powrocie do kraju osiadła w Górkach Wielkich na Śląsku. Uznawana była za następczynię Kraszewskiego i Sienkiewicza w dziedzinie powieści historycznej. Autorka dzieł o wyprawach krzyżowych. Średniowieczu poświęciła kilkuletnie studia i odbyła pielgrzymkę do Jerozolimy (Pątniczym szlakiem, 1933). Napisała m.in. powieść Krzyżowcy (1935), Król trędowaty (1937), Bez oręża (1937). Wśród powieści historycznych o tematyce polskiej należy wymienić: Beatum scelus (1924), Złota wolność (1928), Legnickie pole (1930), Trembowla (1939), Suknia Dejaniry (1939), Troja Pótnocy 966-1966 (1960). Pisała też prozę religijną: Z miłości (1926), Szaleńcy Boży (1929), Przymierze (1952), opowiadania o tematyce śląskiej: Wielcy i mali (1927), Z dziejów Śląsa (1933), Na Ślasku (1939) oraz utwory dla młodzieży: Puszkarz Orbano (1936), Bursztyny (1936), Warna (1938), Szukajcie przyjaciót (1934), Przy ognisku harcerskim (1955). Opublikowała też obyczajową sagę rodu Kossaków Dziedzictwo (t. 1-3, 1956-1967). Nagrodzona m.in. Złotym Wawrzynem PAL, Złotym Krzyżem Zasługi, Krzyżem Kawalerskim OOP.

J.S.O., Kossak-Szczucka Zofia. W: Stownik biograficzny historii Polski..., t. 1, s. 744.

Labiński Kazimierz o. (1914-1999) - pseud. Świetliński, Nejczyk, Grzegorz i Szelest. Misjonarz Oblat Maryi Niepokalanej od 1939, publicysta i społecznik. W czasie okupacji był aktywnym działaczem konspiracyjnym w powiecie kościańskim. W 1. 1940-1941 przebywał w Wilkowie Polskim jako wikariusz a następnie proboszcz. Organizował tajne nauczanie i akcje charytatywne. Po wojnie trafił do Gorzowa Wielkopolskiego, gdzie w latach 1946-1959 współtworzył Katolickie Stowarzyszenie Młodzieży oraz pełnił funkcję redaktora naczelnego „Tygodnika Katolickiego" - pisma dla Ziem Odzyskanych. W pierwszych latach po II wojnie światowej kierował pracami wydawnictwa diecezjalnego w Gorzowie. Od 1950 był dyrektorem Wydziału Duszpasterskiego i Wydziału Nauki Katolickiej w Kurii Administratora Apostolskiego. Za działalność społeczną i religijną był prześladowany przez władze komunistyczne. W 1958 aresztowany i postawiony przed sądem. Ukarany grzywną, a kilka lat później uniewinniony. W 1. 1959-1963 był proboszczem parafii św. Stanisława Kostki w Lublińcu, a następnie w Markowicach. Prowadził studium języków obcych przy sanktuarium Królowej Miłości i Pokoju oraz w Niższym Seminarium Duchownym. 
D. Szwarc, Wspomina ojciec Labiński, „Informator o Seminarium w Markowicach” $1994 \mathrm{nr}$ 8 s. 9; Dni chwaty i cierpienia. Ksiądz Kazimierz Labiński OMI (1914-1999). „Nasz Dziennik” $2008 \mathrm{nr}$ 251. Dostępny w World Wide Web http://stary.naszdziennik.pl/index.php?da$\mathrm{t}=20081025 \&$ typ $=$ my\&id=my41.txt [dostęp 4.09.2012].

Madej Antoni (1899-1989) - poeta, publicysta, thumacz. Studiował polonistykę na KUL. Był nauczycielem i działaczem Związku Nauczycielstwa Polskiego. Współpracował z redakcją „Zet”. Wydał kilka tomów poezji m.in. Pieśń o Battyku (1932) i Drzewo figowe (1938). Podczas II wojny światowej działał w konspiracyjnej katolickiej Unii. Od 1947 w redakcji „Tygodnika Warszawskiego”. Podczas politycznego procesu w 1948 skazany na siedem lat więzienia. Po uwolnieniu redagował pisma do nauki języków obcych i przygotował tomy poezji, które nie zostały wydane.

M.U., Madej Antoni. W: Stownik pisarzy polskich, pod red. A. Latuska..., s. 311.

Malewska Hanna (1911-1983) - powieściopisarka i publicystka. Ukończyła historię na KUL. Debiutowała opowieścią o młodym Platonie Wiosna grecka (1933). Nagrodę Ministerstwa Wyznań Religijnych i Oświecenia Publicznego otrzymała w 1932, trzy lata później wyróżnienie Wydawnictwa Książnicy Atlas za Żelazna koronę, a w 1948 nagrodę im. W. Pietrzaka za powieść Kamienie wotać będa. W 1. 1935-1938 nauczycielka szkół średnich w Warszawie. Podczas okupacji niemieckiej w AK (uzyskała stopień kapitana). Za udział w powstaniu warszawskim otrzymała Krzyż Walecznych. Od 1945 przebywała w Krakowie. Aktywna w ruchu katolickim. W 1. 1946-1956 członek zespołu, a następnie w okresie 1957-1973 redaktor miesięcznika „Znak”. W 1. 1945-1953 współpracownik i od 1956 w redakcji „Tygodnika Powszechnego”. Publikowała w „Tygodniku Warszawskim”. Po zawieszeniu ,Znaku” w 1. 1953-1954 archiwistka w Kórniku. W 1967 była delegatem na III Światowy Kongres Apostolstwa Świeckich w Rzymie. Interesowała się rolą chrześcijaństwa w przeszłości Europy. Wypowiadała się na temat jednostki w przełomowych momentach historycznych i etycznych problemach. Wyróżniona m.in. Nagrodą Młodych PAL w 1937 i im. W. Pietrzaka rok później oraz fundacji A. Jurzykowskiego w 1976. Wydała powieści: Kamienie wołać będa (1946), Żniwo na sierpie. Powieść o Norwidzie (1947), Żelazna korona (1948), Przemija postać świata (1954), Panowie Leszczyńscy (1961), Apokryf rodzinny (1965) oraz opowiadania Stanica (1947), Sir Tomasz More odmawia (1956) oraz O odpowiedzialności. Wybór publicystyki (1945-1976) (1981). Zajmowała się edytorstwem, przekładem tekstów filozoficznych i religijnych z języka francuskiego, niemieckiego, angielskiego i łacińskiego.

L.M. Bartelski, Polscy pisarze..., s. 252; M. Czermińska, Malewska Hanna. W: Wielka encyklopedia PWN, t. 16, Warszawa 2003, s. 494; Encyklopedyczny słownik sławnych..., s. 219; J.S.O., Malewska Hanna. W: Stownik biograficzny historii Polski..., t. 2, s. 915-916; M.U., Malewska Hanna. W: Stownik pisarzy polskich..., s. 315; Pisarze katoliccy. Hanna Malewska, „Tygodnik Katolicki" 1950 nr 11 s. 78. 
Mieliński Roman ks. (1906-1976) - właśc. Kwasigroch, pseud. Kazimierz. Redaktor, publicysta i doktor teologii. Święcenia kapłańskie otrzymał w 1931. W 1. 1932-1937 był sekretarzem kancelarii prymasa A. Hlonda w Poznaniu. W 1933 ukończył kurs dziennikarstwa przy Wyższej Szkole Humanistycznej w Poznaniu, a w 1937 studia na Wydziale Teologicznym Uniwersytetu Jana Kazimierza we Lwowie. W 1. 1937-1939 pracował w redakcji „Przewodnika Katolickiego” i „Nowej Bibliotece Kaznodziejskiej”. Aresztowany przez Niemców w 1939 był internowany w Kazimierzu Biskupim. Zwolniony w 1940 zamieszkał w Warszawie, gdzie uczestniczył w tajnym nauczaniu i działalności konspiracyjno-partyzanckiej jako dziekan okręgu zachodniego AK w randze pułkownika. Brał udział w powstaniu warszawskim. Doktoryzował się z teologii na tajnym Uniwersytecie Warszawskim. Po wojnie wyjechał do Poznania, gdzie nie mogąc wznowić „Przewodnika Katolickiego”, założył i redagował „Głos Katolicki”. Za działalność podczas okupacji aresztowany w 1948 i skazany na 10 lat więzienia. Zwolniony w 1955 dzięki staraniom arcybiskupa Walentego Dymka. Rok później wznowił „Przewodnik Katolicki”, w redakcji którego objął stanowisko redaktora naczelnego (do 1973). W 1957 powołany do Komisji Prasowej przy Konferencji Episkopatu Polski. Za zasługi na stanowisku redaktora „Przewodnika” otrzymał w tymże roku godność tajnego szambelana papieskiego.

M. Banaszak, Mielińnki Roman. W: Stownik polskich teologów katolickich 1918-1981, pod red. L. Grzebienia, Warszawa 1983, s. 475-483; K. Panuś, Mieliński Roman. W: Encyklopedia katolicka, Lublin 2008, t. 12, szp. 897-898; Z. Pawlak, Umarly nadal mówi, „Przewodnik Katolicki” 1976 nr 9 s. 6; W. Raczkowski, Ks. Roman Mieliński 1906-1976, „Miesięcznik Kościelny Archidiecezji Poznańskiej" $1977 \mathrm{nr} 2$ s. 42-44.

Morstin-Górska Maria (1893-1972) - pseud. Maria Leliwa. Poetka, publicystka, tłumaczka. Otrzymała staranne wykształcenie domowe. Studiowała na Uniwersytecie Jagiellońskim w charakterze wolnego słuchacza na Wydziale Filozoficznym. Od 1923 żona Franciszka Górskiego (botanika i późniejszego profesora UJ). W okresie międzywojennym współpracowała z redakcjami dziennika „Czas”, miesięcznika „Pax” i kwartalnika „Verbum”. W 1. 1935-38 była członkiem zarządu Krakowskiego Oddziału Związku Zawodowego Literatów Polskich. Od 1945 związana na stałe z środowiskiem „Tygodnika Powszechnego” i „Znaku”. W 1. 1952-1972 należała do zespołu redakcyjnego drugiego z pism. Wypowiadała się na tematy kulturalne i religijne, współuczestnicząc w tworzeniu katolickiej grupy intelektualnej. Debiutowała tomikiem wierszy Elegie wiosenne (1917), a w 1. 1920-1929 wydała trzy tomiki poezji: Sursum corda (1920), Błyski latarni (1922), Krag miłości (1929). W okresie powojennym najważniejszym działem twórczości były przekłady z zachodniej literatury: Niespokojna noc A. Goesa (1955), Gymnadenia S. Undset (1955), Krzak gorejacy (1967), Ziemia - ojczyzna ludzi A. de S. Exupéry (1957), Nikt nie jest samotna wyspa (1960) 
i Siedmiopiętrowa góra (1972) T. Mertona. Pośmiertnie wyszedł tom wyboru jej wierszy zatytułowany Poezje (1974).

B. Mamoń, Morstin-Górska Maria. W: Polski stownik biograficzny, t. 21, Wrocław 1976, s. $798-799$.

Paukszta Eugeniusz (1916-1979) - powieściopisarz i publicysta. Studiował prawo na Uniwersytecie Stefana Batorego oraz polonistykę i historię w KUL. Debiutował w 1938 na łamach codziennej prasy wileńskiej jako reportażysta. W czasie okupacji żołnierz AK i redaktor pism konspiracyjnych. Więziony w obozach koncentracyjnych w okresie 1942-1944. Po wyzwoleniu zamieszkał w Gliwicach, następnie w Poznaniu. Współpracownik „Odry” i redaktor „Polski Zachodniej”. Od 1950 kierownik literacki Biura Wydawniczego Państwowego Instytutu Wydawniczego w Poznaniu. Publikował felietony na łamach magazynu „Tydzień”. Współpracował z redakcjami pism katolickich m.in. „Głosu Katolickiego” i „Tygodnika Katolickiego”. W 1. 1953-1955 prezes Oddziału Poznańskiego ZLP, a od 1976 prezes Wielkopolskiego Towarzystwa Kulturalnego. Działacz Polskiego Związku Zachodniego. W 1954 otrzymał nagrodę m. Poznania, w 1957 nagrodę WRN w Zielonej Górze, w 1961 nagrodę WRN w Poznaniu, w 1966 nagrodę II stopnia ministra obrony narodowej za powieść Po burzy jest pogoda. W 1968 wyróżniony nagrodą państwową II stopnia za powieści poświęcone Ziemiom Zachodnim. W jego dorobku znalazły się powieści historyczne, współczesne, obyczajowe oraz książki dla młodzieży. Wydał m.in. Trud ziemi nowej (1948), Srebrna ławica (1953), Straceńcy (1957), Wszystkie barwy codzienności (1961), Wrastanie (1964), Przejaśnia się niebo (1967), Buntownicy (1963), Pogranicze (1961), Zawsze z tej ziemi (1976). Dla młodzieży napisał: Zatoka żarlocznego szczupaka (1957), Wiatrołomy (1962), Złote korony księcia Dardanów (1967), Młodość i gwiazdy (1972), W cieniu hetyckiego Sfinksa (1972), Ich trzech i dziewczyna (1972).

L.M. Bartelski, Polscy pisarze wspótcześni..., s. 316-317; J.Z.B., Paukszta Eugeniusz, Stownik biograficzny historii Polski..., t. 1 s. 1126-1127; Pisarze katoliccy. Eugeniusz Paukszta, „Tygodnik Katolicki” 1950 nr 5 s. 33.

Pigoń Stanisław (1885-1968) - historyk literatury, edytor, pamiętnikarz. Studiował na Wydziale Filozoficznym UJ polonistykę, filologię klasyczną i germanistykę. Stopień doktora otrzymał w 1914 u I. Chrzanowskiego, w 1921 habilitował się na UJ, w 1930 został profesorem zwyczajnym UJ. W czasie I wojny światowej żołnierz w armii austriackiej na froncie zachodnim i we Włoszech. W 1. 1918-1919 służył w wojsku polskim. Był profesorem literatury polskiej, rektorem i prorektorem Uniwersytetu Stefana Batorego. Od 1931 profesor UJ w Krakowie. W 1. 1939-1940 uwięziono go wraz z innymi profesorami UJ, osadzony w Sachsenhausen. Po uwolnieniu w 1940 wykładał na tajnym UJ. Aktywny w życiu naukowym, organizacyjnym i społecznym (członek PAU i PAN). Po 
zakończeniu wojny pracował nadal w UJ oraz w WSP w Krakowie. Publikował w „Tygodniku Warszawskim”. Przewodniczący Komitetu Redakcyjnego Słownika języka Adama Mickiewicza (1954-1961). Jego główne zainteresowania objęły epokę romantyzmu i twórczość Mickiewicza (monografia Pan Tadeusz. Wzrost, wielkość i sława, 1934). Jego zasługą było tzw. sejmowe wydanie Dziet wszystkich Mickiewicza. Interesował się również kulturą ludową, napisał m.in. Zarys nowszej literatury ludowej (1946), Na drogach i manowcach kultury ludowej (1939). Jego dorobek liczy 1343 prace.

B.F., Pigoń Stanistaw. W: Stownik biograficzny historii polski..., t. 2, s. 1159; Encyklopedyczny stownik stawnych Polaków..., s. 292.

Piwowarczyk Jan ks. (1889-1959) - pseud. Michał Patkowski. Kapłan, redaktor i publicysta. Do krakowskiego seminarium duchownego wstąpił w 1907. Święcenia otrzymał w 1911. Doktorat uzyskał na Wydziale Teologicznym UJ. W 1939 został proboszczem prepozytury św. Floriana i rektorem seminarium duchownego w Krakowie (1939-1944). Pełnił również funkcję kanonika Kapituły Metropolitalnej i został członkiem Rady Administracyjnej Archidiecezji Krakowskiej. Był jednym z najczynniejszych publicystów polskich. W okresie dwudziestolecia międzywojennego prowadził w „Głosie Narodu” (1922-1936) działy religijny i polityki zagranicznej, a w 1. 1936-1938 był jego redaktorem naczelnym. Współpracował z redakcją „Prądu” i „Kultury”. Związany z ChD (1923-1937), następnie z SP (1945-1946) . Formułował koncepcje programowe ruchu chrześcijańsko-demokratycznego w Polsce. Założyciel „Tygodnika Powszechnego". Znawca nauki społecznej Kościoła. Tłumaczył i komentował encykliki papieskie Leona XIII i Piusa XI. Jego prace dotyczyły chrześcijańskiej myśli społecznej i etyki, m.in. Rola chrześcijańskiej Demokracji w życiu społeczno-politycznym (1921), Idea chrześcijańsko-społeczna w historycznym rozwoju (1922), Socjalizm i chrześcijaństwo (1924), Korporacjonizm i jego problematyka (1936), Katolicyzm i reforma rolna (1938), Katolicka etyka spoleczna (1960, 1963). Odegrał znaczącą rolę wśród inteligencji katolickiej skupionej w Stowarzyszeniu Katolickiej Młodzieży Akademickiej „Odrodzenie”.

M.Ś., Piwowarczyk Jan. W: Stownik biograficzny historii polski..., t. 2, s. 1178-1179.

Prorok Leszek (1919-1984) - prozaik, eseista, dramaturg, reportażysta. Ukończył Wydział Prawno-Ekonomiczny UP. W czasie okupacji był żołnierzem AK i uczestnikiem powstania warszawskiego. Po zakończeniu działań wojennych pełnił funkcje dyrektora Teatru Lalki i Aktora „Marcinek”, kierownika literackiego telewizji poznańskiej, był wykładowcą estetyki teatru telewizji na UAM. Publikował na łamach „Tygodnika Warszawskiego”. W 1974 został laureatem nagrody marynistycznej im. M. Zaruskiego. Napisał m.in. powieści: Dzień nad Motława (1939), Ziarno kąkolu (1957), Wyspiarze (1961), Tarantella (1963), Drabina Jakubowa (1964), Czas stworzenia (1970), Wielki zgietk 
(1972), Smuga blasku (1982). Wydał opowiadania: Grzechy dobrych ludzi (1964), Tamta jesień (1967), Lady nieuniknione (1967), Wielkie wody (1969), Tsunami (1977), Koniec motyla (1986). Z jego esejów warto wymienić: Plemię Herostratesa (1969), Szkice battyckie i inne (1971), Inicjacje conradowskie (1987). Napisał też wspomnienia Kepi wojska francuskiego (1973) i Smutne pót rycerzy żywych (1988).

L.M. Bartelski, Polscy pisarze wspótcześni..., s. 334-335; J.F., Prorok Leszek. W: Stownik pisarzy polskich..., s. 406-407.

Rabska Zuzanna (1888-1960) - pseud. Aleksandra. Prozaik, poetka, thumaczka. Studiowała polonistykę na tzw. Latającym Uniwersytecie w Warszawie i przez krótki czas na UJ w Krakowie. Debiutowała w 1902. Współzałożycielka i aktywny członek Towarzystwa Bibliofilów Polskich w Warszawie. Współpracowała z redakcją „Kuriera Warszawskiego” w 1. 1925-1939, gdzie prowadziła Kronikę literacka. Założycielka Towarzystwa Przyjaciół Belgii. Podczas II wojny światowej więziona na Pawiaku. Zwolniona, ukrywała się w Zalesiu, Warszawie i Milanówku. Od 1944 była właścicielką wypożyczalni książek i pracownikiem warszawskiej czytelni Ex Libris. Należała do ZZLP i polskiego PEN Clubu. Autorka psychologiczno-moralistycznej prozy o tematyce współczesnej. Publikowała na łamach „Tygodnika Warszawskiego”. Tłumaczyła popularną prozę francuską, angielską i włoską. Napisała opowiadania, m.in. Zanim światta pogasna (1909), Listy miłosne (1913), Barbarzyńca (1922), Godzina prawdy (1957), powieści: Dziecko wojny (1922), Miłość Urszuli Orlikówny (1948), wspomnienia: Moje ksiażki (1925), Moje życie z ksiażka (cz. 1-2 1959-1964), poezje: Miłość mówi (1913), W płonacym lesie (1918). Wśród utworów dla dzieci znalazły się: Tajemnice Łazienek (1920), Trzy opowiastki o harcerzach (1920), Baśnie kaszubskie (1925), Magia ksiażki (1936), Ania w Łazienkach (1957).

Zuzanna Rabska. W: K. Jankowska, Podręczny stownik pisarzy polskich, Warszawa 2006, s. 459 .

Rogalski Aleksander (1912-1996) - eseista, publicysta, historyk literatury. Ukończył polonistykę na UP. W 1945 uzyskał stopień doktora za rozprawę Elementy filozoficzne w twórczości Stanisława Przybyszewskiego, habilitację otrzymał z dziedziny historii współczesnej literatury niemieckiej. Jako publicysta zadebiutował w miesięczniku „Wici Wielkopolskie” w 1934. Działacz konspiracyjnej organizacji „Ojczyzna”, uczestniczył w tajnym nauczaniu. W 1. 1942-1944 był redaktorem konspiracyjnego miesięcznika „Ziemie Zachodnie Rzeczypospolitej" w Warszawie. Uczestnik powstania warszawskiego. Od 1945 zamieszkał w Poznaniu. Redagował dziennik „Kurier Wielkopolski” (1947-1949) i miesięcznik „Życie i Myśl” (1950-1952). Funkcję redaktora naczelnego pełnił we wrocławskim tygodniku „WTK”, natomiast zastępcy redaktora naczelnego miesięcznika „Nurt”. Publikował na łamach pism katolickich, m.in. „Głosu 
Katolickiego". Nagrodę im. W. Pietrzaka otrzymał za publicystykę w 1952, nagrodę miasta Poznania w 1959, nagrodę im. Kasprowicza w 1980 oraz nagrodę I stopnia Ministra Kultury i Sztuki.

L.M. Bartelski, Polscy pisarze wspótcześni..., s. 349-350.

Starowieyska-Morstinowa Zofia (1891-1966) - krytyk literacki, publicystka, thumacz. Od 1917 żona Zygmunta Morstina. Debiutowała w 1924. Jako krytyk zaczęła od recenzji Różowej magii Marii Pawlikowskiej (1924). Początkowo w „Czasie” i „Wiadomościach Literackich” podpisywała się Zofia Morstinowa, a po zdobyciu uznania dla odróżnienia wśród piszących członków rodziny, zaczęła używać podwójnego nazwiska. Od 1931 do wybuchu wojny była stałym krytykiem „Przeglądu Powszechnego", gdzie pozwolono jej na swobodę wypowiedzi. W 1. 1945-1953 i 1957-1966 uczestniczyła w składzie redakcji „Tygodnika Powszechnego", w którym chętnie pisała recenzje książek. Z pracownikami IW PAX pozostawała w poprawnych stosunkach. Wydała tom reportaży z Polski Róże pod śniegiem (1930), wrażenia z Jugosławii Kamień $i$ woda (1937), wspomnienia Twoje i moje dzieciństwo (1939). Studiując dzieła o Włoszech napisała Kabatę historii (1945). Przetłumaczyła m.in. Dzieje Chrystusa H. Daniela-Ropsa (1950), Od Abrahama do Chrystusa (1952), Chrystus Pan i Sokrates T. Demana (1953). Wykorzystując doświadczenia pracy thumacza, napisała Fakty $i$ stowa (1956), natomiast szkice o polskich pisarzach zatytułowała Kalejdoskop literacki (1955). Opublikowała także szkic $O$ wolności pisarza katolickiego oraz opis poetyckich zjazdów pt. Ci, których spotkatam (1962). Osobiste przeżycia i trafne przemyślenia zainspirowały ją do wypowiedzi o starości w formie eseju pt. Patrze i wspominam (1965). Pośmiertnie wydano szkice zatytułowane Szukam człowieka (1973). Laureatka nagrody literackiej im. W. Pietrzaka w 1950 r.

L.M. Bartelski, Polscy pisarze wspótcześni..., s. 390; A. Biernacki, Morstinowa (StarowieyskaMorstinowa). W: Polski stownik biograficzny, t. 21, Wrocław 1976, s. 799-801; J.S.O., StarowieyskaMorstinowa Zofia. W: Stownik biograficzny historii Polski..., t. 2, s. 1449; Pisarze katoliccy. Zofia Starowieyska-Morstinowa, „Tygodnik Katolicki” 1950 nr 12 s. 106.

Stomma Stanisław (1908-2005) - pseud. Marian Jedlicz. Prawnik, publicysta, działacz polityczny, poseł na Sejm PRL w latach 1957-1976 (przewodniczący koła poselskiego Znak). Ukończył w 1932 Wydział Prawa i Nauk Społecznych na USB w Wilnie. W 1947 habilitował się na UJ. Od 1946 członek zespołów redakcyjnych „Znaku” (1946-1953 redaktor naczelny) i „Tygodnika Powszechnego”. W 1. 1947-1950 i 1956-1978 pracownik naukowy Uniwersytetu Jagiellońskiego. Członek Sodalicji Mariańskiej i organizacji „Pet”, od 1928 Stowarzyszenia Katolickiej Młodzieży Akademickiej „Odrodzenie”. W 1937 dziennikarz „Głosu Narodu” w Krakowie. W 1939 redaktor naczelny „Kuriera Wileńskiego”. W 1. 1946-1953 z Hanną Malewską redaktor miesięcznika „Znak” w Krakowie, w 1. 1945-1953 i od 1956 członek zespołu redakcyjnego „Tygodnika Powszechnego”. 
W 1. 1954-1956 bibliotekarz w Muzeum Narodowym w Krakowie. W 1956 współzałożyciel Ogólnopolskiego Klubu Postępowej Inteligencji Katolickiej, w 1957 Klubu Inteligencji Katolickiej w Warszawie, 1958-1962 jego wiceprezes, prezes KIK w Krakowie. W 1. 1981-1984 przewodniczący Prymasowskiej Rady Społecznej. Uczestnik obrad Okrągłego Stołu, członek Unii Wolności. Odznaczony Orderem Orła Białego. W 1993 otrzymał nagrodę polskiego Pen Clubu. Główne prace: Myśli o kulturze i polityce (1960), Czy fatalizm wrogości? Refleksje o stosunkach polsko-niemieckich (1980), Trudne lekcje historii (1998).

B.S., Stomma Stanistaw. W: Stownik biograficzny historii Polski..., t. 2, s. 1464-1465; Opozycja w PRL. Stownik biograficzny 1956-89, pod red. J. Skórzyńskiego, t. 3, Warszawa 2006, s. 264-266; Stomma Stanistaw. W: Wielka encyklopedia PWN, t. 26, Warszawa 2005, s. 91.

Turowicz Jerzy (1912-1999) - publicysta i działacz społeczny. W 1. 1930-1934 studiował na Wydziale Budowy Maszyn Politechniki Lwowskiej, a w 1. 1934-1939 na Wydziale Filozoficznym UJ. Od 1930 działacz Stowarzyszenia Katolickiej Młodzieży Akademickiej „Odrodzenie”. W 1939 został redaktorem „Głosu Narodu”. Od 1945 (z przerwą w 1. 1953-1956) kierował aż do śmierci zespołem „Tygodnika Powszechnego”. W 1946 zaczął współpracować z redakcją miesięcznika „Znak”, w okresie 1960-1990 był prezesem Społecznego Instytutu Wydawniczego Znak. Propagator reformy soborowej w Polsce. Podpisał List 34 (zbiorowy protest intelektualistów przeciw cenzurze). Działacz Klubów Inteligencji Katolickiej i międzynarodowych organizacji katolickich. Członek Komisji Episkopatu Polski ds. Apostolstwa Świeckich w 1. 1960-1980, a od 1984 Komisji Episkopatu Polski ds. Dialogu z Judaizmem. W 1. 1981-1985 należał do Społecznej Rady Prymasowskiej. Uczestnik Okrągłego Stołu. W 1. 90. przewodniczący Rady Etyki Mediów i Rady Fundacji im. S. Batorego. Członek SDP, ZLP i Stowarzyszenia Pisarzy Polskich. Uzyskał liczne nagrody m.in. im. Gandhiego, Międzynarodową Nagrodę Prasy w Paryżu, odznaczony Orderem Orła Białego (1994). Autor licznych publikacji m.in. Chrześcijanin w dzisiejszym świecie (1964), Kościót nie jest todzia (1988) oraz artykułów w prasie polskiej i zagranicznej.

M.P.G., Turowicz Jerzy. W: Stownik biograficzny historii Polski..., t. 2, s. 1568-1569.

Tyrmand Leopold (1920-1985) - prozaik, eseista, publicysta. Studiował na Wydziale Architektury Politechniki w Paryżu. W czasie II wojny światowej skazany przez władze radzieckie na 25 lat zsyłki, uwolniony został z transportu dzięki atakowi Niemców na Wilno. Wyjechał na roboty do Rzeszy i posiadając fałszywy paszport jeździł po Europie wykonując zawody tłumacza, kreślarza, kelnera, marynarza. W Norwegii trafił do obozu koncentracyjnego. W 1946 wrócił do kraju i podjął prace dziennikarza. Debiutował w tymże roku w „Przekroju”, a w 1. 1947-1949 był jego redaktorem. Zwolniony z redakcji państwowych gazet i ze związku dziennikarzy za komentarz na temat meczu bokserskiego PolskaZSRR, zaczął pracować w zespole „Tygodnika Powszechnego”. W 1. 1950-1953 
pisał recenzje muzyczne i teatralne. W 1955 wyjechał do Francji, a następnie do USA, gdzie wykładał literaturę słowiańską. Wydał powieści: Zły (1955), Filip (1961), Życie towarzyskie i uczuciowe (1967); opowiadania: Hotel Ansgar (1947), Gorzki smak czekolady Lucullus (1957) oraz Dziennik 1954 (1980).

L.M. Bartelski, Polscy pisarze wspótcześni..., s. 438-439; Encyklopedyczny stownik stawnych Polaków..., s. 416; Slownik pisarzy polskich..., s. 511-512.

Zawieyski Jerzy (1902-1969) - właśc. Henryk Nowicki. Dramatopisarz, prozaik, działacz społeczny. Ukończył Szkołę Dramatyczną w Krakowie. Zadebiutował jako adaptator Chłopów Reymonta na scenę w 1926. Redaktor czasopisma „Teatr Ludowy” w 1. 1926-1928. W 1. 1929-1932 przebywał we Francji, gdzie był instruktorem teatralnym wychodźstwa polskiego. Od 1933 w Warszawie. W czasie okupacji działał w podziemiu kulturalnym. Współredaktor „Tygodnika Powszechnego” w 1. 1946-1953 i „Znaku” w 1. 1946-1951. Pisał też w „Tygodniku Katolickim”. W okresie1947-1948 i od 1956 wiceprezes Związku Literatów Polskich. W 1957 członek Rady Państwa, a w 1. 1968-1969 poseł na Sejm. Nagradzany na tajnych konkursach dramatycznych w 1942 i 1944. W 1949 otrzymał nagrodę Episkopatu Polskiego. Opublikował m.in. powieści: Gdzie jesteś przyjacielu? (1932), Daleko do rana (1934), Noc Huberta (1946), Wawrzyny i cyprysy (1966), Konrad nie chce zejść ze sceny (1966); tomy opowiadań: Pokój głębi (1956), Romans z ojczyzna (1963); dramaty: Człowiek jest niepotrzebny (1934), Dyktator Faust (1934), Rozdroże miłości (1946), Mąż doskonały (1948).

L.M. Bartelski, Polscy pisarze wspótcześni..., s. 481-482; J.F., Zawieyski Jerzy. W: Stownik pisarzy polskich..., s. 556-557; J.J.P., Zawieyski Jerzy. W: Stownik biograficzny historii Polski..., t. 2, s. 1715-1716. 



\section{Spis ilustracji}

Il. 1. Reprodukcje rysunków T. Kościuszki w numerze specjalnym „Tygodnika Powszechnego”. „TP” 1946 nr 12 s. 3.

Il. 2. Reprodukcja rysunku autorstwa T. Kościuszki. „TP” 1946 nr 12 s. 3 ............................... 163

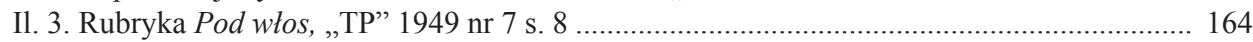

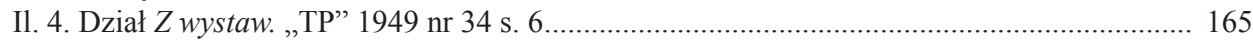

Il. 5. Ks. dr Roman Mieliński. „Przewodnik Katolicki” 1976 nr 9 s. 6 ....................................... 168

Il. 6. Nagłówek pierwszego numeru „Głosu Katolickiego”. „GK” 1945 nr 1 s. 1 ...................... 173

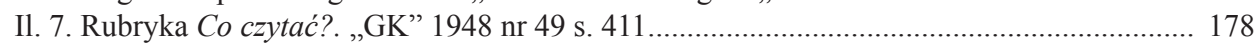

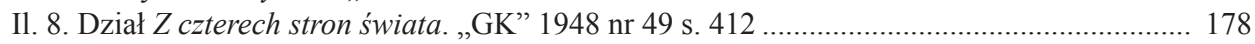

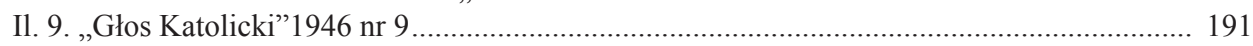

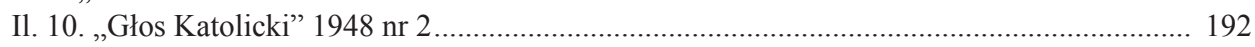

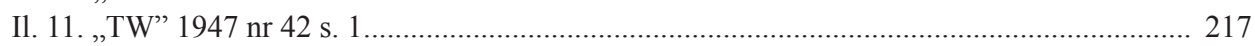

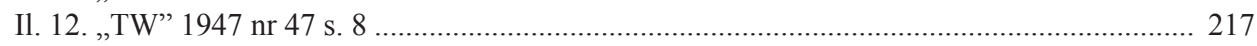

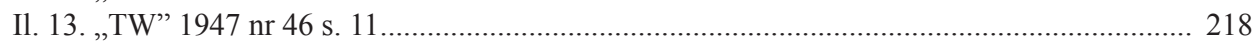

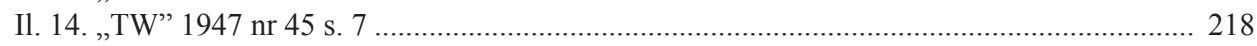

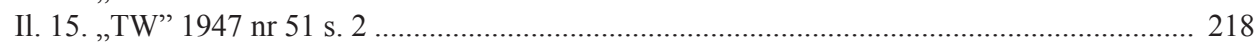

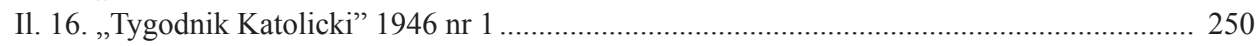

Il. 17. Zeszyt świąteczny „Tygodnika Katolickiego” z 1946 r. nr 31/32 _.................................. 251

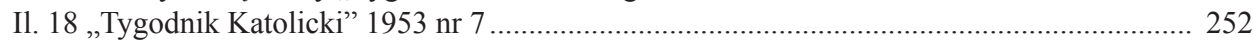

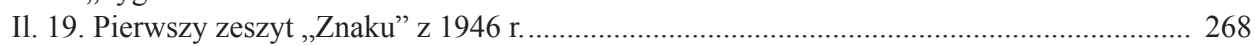

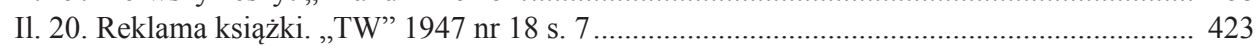

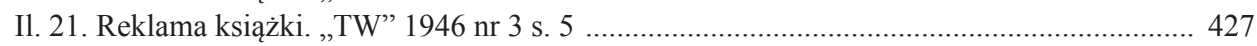

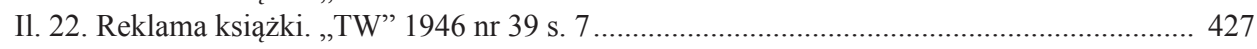

Il. 23. Całostronicowa reklama prospektywna w „TW” $1948 \mathrm{nr} 26$ s. 5 ...................................... 428

Il. 24. Reklama książki w „TW” 1948 nr 13 s. 10 .................................................................... 433

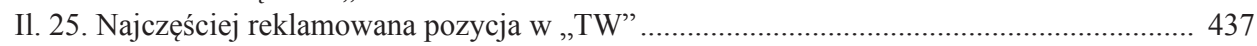

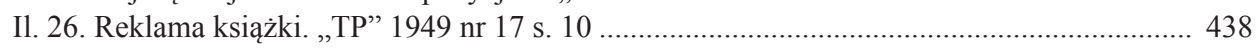

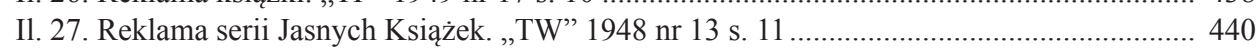

Il. 28. Reklama serii Biblioteka Dobrej Książki. „TW” 1947 nr 38 s. 8 ...................................... 442 



\section{Spis tabel}

Tabela 1. Produkcja Instytutu Wydawniczego PAX w latach 1949-1953 ................................. 117

Tabela 2. Wydawcy w latach 1944-1947. Liczba książek..................................................... 118

Tabela 3. Liczba recenzji książek na łamach „Tygodnika Powszechnego” („TP”), „Przeglądu

Powszechnego”, („PP”), „Tygodnika Warszawskiego”, („TW”), „Głosu Katolickiego”

i ,Znaku” w 1. 1945-1953 ......................................................................................... 283

Tabela 4. Liczba recenzji według ich charakteru na łamach „TP” w latach 1945-1953 ............ 285

Tabela 5. Liczba recenzji według ich charakteru na łamach „PP” w latach 1947-1953 ............ 285

Tabela 6. Liczba recenzji według ich charakteru na łamach „TW” w latach 1945-1948 .......... 285

Tabela 7. Liczba recenzji według ich charakteru na łamach „GK” w latach 1945-1948........... 286

Tabela 8. Liczba recenzji według ich charakteru na łamach „TK” w latach 1946-1953 ........... 286

Tabela 9. Liczba recenzji według ich charakteru na łamach „Znaku” w latach 1946-1953 ....... 286

Tabela 10. Recenzenci książek na łamach „TP” w latach 1945-1953 ....................................... 288

Tabela 11. Recenzenci książek na łamach „PP” w latach 1947-1953 ....................................... 290

Tabela 12. Recenzenci książek na łamach „TW” w latach 1945-1948 ...................................... 291

Tabela 13. Recenzenci książek na łamach „GK” w latach 1945-1948 ...................................... 291

Tabela 14. Liczba książek autorów polskich zrecenzowanych na łamach wybranych tytułów prasowych w 1. 1945-1953 .................................................................................. 293

Tabela 15. Wydawcy zrecenzowanych książek autorów polskich i obcych na łamach „TP”

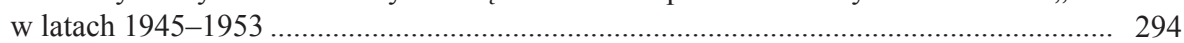

Tabela 16. Wydawcy zrecenzowanych książek autorów polskich i obcych na łamach „PP” w la-

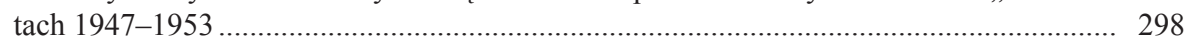

Tabela 17. Wydawcy zrecenzowanych książek autorów polskich i obcych na łamach „TW” w latach 1945-1948 ............................................................................................ 301

Tabela 18. Wydawcy zrecenzowanych książek autorów polskich i obcych na łamach „GK” w latach 1945-1948 ............................................................................................. 302

Tabela 19. Liczba książek autorów obcych zrecenzowana na łamach wybranych tytułów praso-

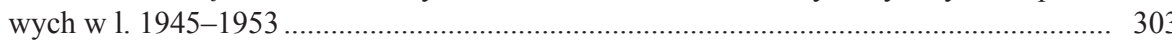

Tabela 20. Liczba tytułów książkowych o różnej tematyce na łamach TP”, „PP”, „,TW”, „TK”, „GK” i „Znaku” w 1. 1945-1953 ...................................................................................... 402 



\section{Indeks osobowy}

A

A.B. zob. Bardecki Andrzej, ks.

A. B-ski zob. Bardecki Andrzej, ks.

A.G., a.g. zob. Górski Artur

A.G. zob. Gołubiew Antoni

A.J. krypt. 231

A.Ł. krypt. 230, 234, 247

A.P. krypt. 236

A. Ryb. krypt. 151

A. Ski krypt. 337

A.W. krypt. 265

A.Z. krypt. 236

ab krypt. 143

(ar) krypt. 407

(aw) krypt. 511

Abgarowicz Kazimierz 169, 186, 189, 190, 222, 244

Abraham 351, 418, 487, 567

Achremowiczowa Wanda 215

Adamczyk Mieczysław 36

Adamczyk Władysław ppłk 475

Adamowicz W. 151

Adamski Jerzy 187, 229, 237, 291, 314, 361, 403

Adamski Stanisław, bp 57, 66, 77, 80, 82, 85, 558

Adelmannowa Maria z Majowskich 155

Aftanazy Roman 153

Ajschylos 391

Alighieri Dante 256, 553

Amicis Edmund, de 458, 462

Ammers-Küller Jo, van 297

Amos Maurice 464

Ampère Andrzej Maria 276

Anczarski Józef, ks. 221, 231, 236, 239, 242

Andersen Hans Christian 430, 459, 462

Andrasz Józef, ks. 425

Andrzejewski Jerzy 376, 377, 426, 471

Angelico, Fra (właśc. Guido di Pietro da Mugello) 309

Angrabajtis Józef 428
Anhalt Maurycy 404

Aniela Salawa, bł. 159, 229

Anna, św. 187, 238, 314, 471

Antczak Antoni 195, 199, 547

Antoni Maria Claret, św. 503

Antoni Padewski, św. 229

Antoniewicz Karol, ks. 231

Anusz Andrzej 55, 106

Anusz Anna 106

Araszkiewicz Feliks 397, 486

Archita Jan 169, 179-186, 212, 228, 229, 242, $291,305,315,317,320,323,325,471$, $521,547,548$

Archutowski Józef, ks. 159

Archutowski Roman, ks. 338

Arciszewski Tomasz 23, 26

Arct Bogdan 331-332

Arct Michał 426, 459

Arct Stanisław 301, 405

Asnyk Adam 213

Attlee Clement 27

Atya L. 244

Aubert Roger, ks. 16, 338

August II, król polski 339

Augustyn, św. 277, 310, 319, 322, 429, 432, 499

Augustyński Zygmunt 36

\section{B}

b. zob. Braun Jerzy

B.F. krypt. 565

B.G. krypt. 345, 405

B.K. krypt. 248

B.L. krypt. 189

B.M. krypt. 265

B.P. krypt. 179

B.R. krypt. 260, 264

B.S. krypt. $215,255,568$

Bacewiczówna Wanda 214, 291, 332, 335, 372, $374,455,503$

Bach Jan Sebastian 155

Bachheuser Everardo 229 
Bachowska I. 188

Baczyński Krzysztof Kamil 145, 158, 213, 380, 382

Badecki Karol 493

Bagiński Adam 421

Bagiński Kazimierz 29

Bajko Stanisław 419

Balain Blanche 206

Balawajder Edward 558

Balzac Honoré, de 397, 426, 448, 455

Banacka Marianna 11

Banaszak Marian, ks. 101, 103, 104, 563

Bandtkie Jerzy Samuel 20, 516

Bankiewicz Edward 179

Bankowicz Bożena 69, 70

Bar Joachim 406

Baraniak Antoni, bp 102, 103

Baranowski Józef 176, 223

Baranowski Zygmunt, ks. 20, 185, 241, 242, 439

Barbara, św. 216, 238

Barciński Florian 20

Barcleycorn John 471

Bardecki Andrzej, ks. 126, 128, 147, 221, 229, 237, 238, 241, 442, 244-246, 254, 261, $318,470,566$

Barnaszewski Bogusław 36

Barrere Camille 468

Barres Filip 467

Bartelski Lesław Marian 548, 551, 553, 554, 556, $557,559,560,562,564,566,567,569$

Barth Karl 265

Bartold Edward 33

Bartynowski Stanisław 419

Bataglia Otto Forst 128

Bauminger Róża 20

Baziak Eugeniusz, abp 83, 89, 95

Bazyli, św. 310

Bażyński Franciszek 492

Bączek Piotr 41

Bączkowska Zofia 151

Bąk Wojciech 145, 158, 169, 179, 186, 195, 216, $231,270,312,378,478,522,548,549$

Beauvoir Simone, de 360, 367

Bednarek Stefan 61, 104, 540

Bednarski J. 355

Bednarz M. 324

Bednorz Filip, ks. 83

Bednorz Herbert, bp 77, 82, 85, 128, 240, 270, 275
Bender Ryszard 558

Benedykt, św. 317

Benedykt XV, papież 186

Benedykt XVI, papież 159, 322

Benesz Edward 470

Beran Józef, abp 89, 95

Berelson Bernard 12

Berman Jakub 32, 59, 99

Bernacki Lucjan 188

Bernadot Marie Vincent 324

Bernanos Georges 157, 189, 195, 203, 215, 248, 262, 275, 299, 354, 369, 417, 446, 448, 475,483

Berrum Einar 229

beta zob. Braun Jerzy

Białecki Konrad 112

Białkowski Leon 159

Białobrzeski Czesław 270, 273

Białostocki Jan 155

Białowiejska Julitka 435

Bida Antoni 54, 81, 98,

Bidzińska-Jakubowska Barbara 34

Biedroń Tomasz 16, 61

Bielawski Jan 62

Bielawski Stanisław, ks. 424

Biełaszko Mirosław 13, 98, 193, 199, 558

Bienia Adam 29

Bieniek Juliusz, bp 77, 82, 85, 498

Bieńkowski Ludomir 167

Bieńkowski Witold 98, 124

Biernacki Andrzej 567

Bierut Bolesław 27, 32, 37, 39, 41, 55-57, 67, $69,73,74,78,84,86,93,94,98,99,100$, $103,134,148,228,415$

Bieszczadowski Mikołaj 458

Bieżuńska-Małowist Iza 468

Bigay-Mianowska Aleksandra 20, 458

Bilczewski Józef, abp, św. 159

Bilik Adam 435

Biskupski Stefan, ks. 121, 316

Bismarck Otto, von 469, 503

Blachnicki Franciszek, ks. 128, 355, 372, 373, $495,549,550$

Blajda Franciszek 254

Bloy Leon 187

Blumówna Helena 141, 153-156, 166, 411, 482

Bluszcz Krzysztof 61

Błachut Władysław 149

Błaut Sławomir 115 
Błońska Maria 256

Bo krypt. 206

Bober Piotr, ks. 432

Bobiński Stanisław 403, 459

Bobkowski Andrzej 160

Boccaccio Giovanni 426

Bochenek Grzegorz 550

Bochenek Jan, ks. 20, 435

Bocheński Aleksander 135, 151, 154, 404, 407, 559

Bocheński Innocenty, o. zob. Bocheński Józef Maria

Bocheński Józef Maria 55, 254, 261, 473

Bocheński Zbigniew 163

Bodniak Stanisław 493

Boevey Mateo, o. 424

Bogdan Franciszek, ks. 422

Bogdanowicz Stanisław 44

Bogdański F. 183

Bogedain Józef Bernard 276

Bolesław I Chrobry, król polski 158, 190, 292, $356,358,371,418,466,480,552$

Boleszczyc A. 204

Bombicki Maciej Roman 40

Bonawentura zob. Fróg Zbigniew Bonawentura bor zob. Braun Jerzy

Borawska Danuta 287, 314

Borejsza Jerzy (właśc. Beniamin Goldberg) 109,124

Borkowski B. 214

Borkowski Jan 37

Borowski Antoni, ks. 20, 432

Borowski Tadeusz 158, 296, 335, 361, 375, 376, 378,455

Borowski W. 161

Borowy Piotr 59

Borowy Wacław 127, 156, 195, 214, 262, 362, $363,484,491,511,550$

Borutka Tadeusz 61

Bortnowska Halina 254

Boryna Maciej, postać literacka 368

Bos Karol, Du 395

Bossy Heinrich 479

Boswell Alexander Bruce 340

Boullaye Pinard, de la 419

Bourilly Jean 354

Boy-Żeleński Tadeusz 391, 398

Boznańska Olga 163, 345

Brablecowa Wanda 469
Brandstaetter Roman 254

Brandys Kazimierz 367, 486

Brat Albert, św. zob. Chmielowski Adam

Braun Jerzy 13, 124, 194, 195, 198, 199, 207, 209-216, 219, 291, 305, 321, 323, 409, $433,471,527,550-552$

Brem Zenon 158

Bremond Henryk 188

Brodecka Barbara 486

Brodzka Alina 17, 119, 124, 254

Bromberg Adam 17, 117, 118, 296, 508

Broniewski Stanisław 161

Bronisz Jarl, postać literacka 357, 432, 434, 451

Brontë Emily 363

Bross Stanisław, ks. 439

Brudzewski Jan 151

Brun Henryk 208

Bryjak Wiktor 506

Brystygierowa Julia, płk 46, 69

Brzechwa Jan 426, 439, 459

Brzeziński Tadeusz J. 353, 470

Brzostowski Mirosław 413

Brzozowska Krystyna 160

Brzozowski Stanisław 447

Brzozowski Tadeusz 482

Buba Jan Inocenty, ks. 159

Buczek Roman 34

Buczkowski Marian Ruth 134, 489

Budrewicz Olgierd 195, 198, 212, 215, 331, 475,476

Budkowa Janina 215, 407

Budkowska Janina 211, 213

Budzyk Kazimierz 394, 395, 406

Bujacz Ludwik, ks. 333

Bujak Waldemar 32, 195

Bukowski Andrzej 20

Bukowski J. 254

Bukowski Marcin 153

Bukowski Stanisław Wiktor 211

Bukowski Stanisław 195

Bulanda Edward, ks. 505

Bułhak Jan 157

Bułhak Władysław 112

Bunsch Adam 214, 216, 219, 389, 435, 478

Bunsch Karol 296, 356, 360

Buś Marek 550

Buśkiewicz Ludwik 169, 189, 243, 471

Bystroń Jan Stanisław 403, 471 


\section{C}

Caban K.B. 516

Caldwell Erskine 299

Calvet Jean 554

Carrel Alexis 195, 470

Carrouges Michel 128

Cather Willi 448

Cayrol Jean 354

Cebulski Józef 428

Cecylia, św. 238

Cedro Stanisław 77, 169, 183, 185, 186

Celina Borzęcka z Chludzińskich, bł. 229

Cellini Benvenuto 469

Cervantes Miguel de 366

Cesbron Gilbert 355

Chabanoix Philippe 485

Champenonis 334

Chapelain Jean 312

Charles-Édouard Jeanneret-Gris 152

Charles Piotr 418, 423, 442

Chesterton Gilbert Keith 118, 128, 157, 229, 254, 261, 263, 297, 313, 314,

$354,355,369,394,418,429,431,448,453$, $477,550,552$

Chmielowski Adam 159, 165, 188, 229, 239, $315,389,400,435,478$

Chodera Janina 549

Chojecka Maria 270, 290, 364, 397, 400, 405, 406, 457

Chojecki Artur 421, 496, 552

Chojnacki F.G. 237, 238

Chojnacki Piotr 147, 254, 263

Chojnowski Andrzej 15, 43

Chomrański Eugeniusz 128, 148, 236

Chopin Fryderyk 143, 154, 155, 164, 187, 214, 457,484

Choromański Michał 456

Choromański Zygmunt, bp 39, 45, 46, 63, 77, $83,87,89,183,194,195,228$,

241, 242, 262, 558

Christians Ludwik 333, 418

Chrostowski Stanisław Ostoja 156, 484

Chruszczow Nikita 99, 100

Chrypiński Wincenty 16

Chrzan pseud. 512

Chrzanowski Ignacy 158, 415, 564

Chrzanowski Tadeusz 114, 153, 160, 458

Chrzanowski Wiesław 193

Churchill Winston 24, 27, 30, 152, 154
Chwastyk-Kowalczyk Jolanta 10

Chylińska Helena 74

Cianfarra Camille Maximilian 148

Ciano Galeazzo 476

Cichocki Jerzy zob. Gołubiew Antoni

Ciechanowska Zofia K. 394, 445

Ciechanowski W. 193

Ciechocki Jerzy 150, 351, 460, 470

Ciećwierz Mieczysław 17, 109

Civardi Ludwik, ks. 232, 425, 451

Claudel Paul 145, 254, 260, 262, 313

Conrad Joseph 21, 214, 370, 378, 418

Corbusier zob. Charles-Édouard Jeanneret-Gris

Cordier Jasques 312, 313

Cripps Stafford 228, 231ś

Cronin Archibald Joseph 118, 297, 300, 352, 433

Csesznak Karol, ks. 159

Curie-Skłodowska Maria 44, 276, 465

Curwood James Oliver 443, 459

Curzon George Nathaniel 25

Cybulski Radosław 9

Cyprian Tadeusz 336, 468

Cyrankiewicz Józef 37, 46, 56, 57, 69, 99

Cywiński Bohdan 15, 41, 43, 50, 52, 58, 64, 89-92, 102

Cywiński Bolesław 27

Czachowska Jadwiga 553

Czachowski Kazimierz 485

Czaczkowska Ewa K. 15, 83, 95, 97-104

Czapliński Władysław 158, 337, 340, 341, 519

Czapska Maria 127

Czara Jan 222

Czarnik Oskar Stanisław 10, 21, 119

Czarnota Stanisław 308, 309

Czartoryscy, rodzina 506

Czartoryski Paweł 270, 273, 275, 277

Cząstka Antoni 244

Czechowicz Szymon 345

Czekalski Feliks 431

Czekanowski Jan 134, 148, 151, 161, 408

Czekańska Maria 408

Czerepacha Jan 223, 234, 235, 505

Czermińska M. 562

Czerwiec Leon 147

Czeska-Mączyńska Maria 459

Czeszko Bohdan 362

Czubiński Antoni 14, 24-26, 28, 29, 31-34, 36- 38,40 
Czuj Jan, ks. 72, 103, 169, 310, 324, 432

Czuma Ignacy 215

Ć

Ćwikowski F. 151

\section{D}

D.J. krypt. 141, 482

Dadorówna K. 189

Dajczak Józef, ks. 270, 277

Daniélou Jean 254, 260, 263, 324

Daniel-Rops Henri 128, 157, 195, 213, 299, $351,418,425,429,438,445,448,451$, $452,468,477,487,567$

Dante Alighieri 256, 553

Dantyszek Jan 20

Daudet Leon 114

David Jacques Louis 156

Davies Norman 34, 35, 38, 40, 52, 81, 105

Dawson Christopher 262, 265, 460

Dąbrowska Maria 426, 458, 518

Dąbrowski A. 501

Dąbrowski Eugeniusz, ks. 72, 80, 81, 254, 261, 296, 305-308, 311, 312, 351, 359, 415, 417, 421, 432, 433, 495

Dąbrowski Józef 152, 158, 159

Dąbrowski Stefan 158, 175, 210, 212

Debouit I. 420

Degen Dorota 54, 126, 172, 193, 416

Dembiński Henryk 151, 158, 336

Demby Stefan 515

Dereń Bolesław 34

Dernałowicz Halina 215, 264, 265

Dębno Alojzy 153, 468

Dębska Kazimiera 486

Digby Mabel 276

Długosz Jan, ks. 470, 471

Długosz Teofil 159

Dłuska Maria 400

Dmowski Roman 215, 514, 559

Dobraczyńska Maria 353, 372, 379

Dobraczyński Jan 118, 124, 167, 169, 189, 195, 196, 203, 212, 213, 231, 262, 289, 292, 296, 299, 315, 331, 351-355, 358-361, $362,372,373,378,418,427,429,433$, $443,451,460,478,480,501,555$

Dobropolski J. 237

Dobrowolska Agnieszka 411

Dobrowolski Tadeusz 411
Dobrzycka A. 187

Doda Wiktor 270, 356

Doeblin Alfred 159

Domaniewski Janusz 20

Domański J. 42

Domański Tadeusz 156

Dominiczak Henryk 15, 39, 45, 57, 61, 62, 67, $81,85,88,92,93,95$

Dominik Savio, św. 159, 239

Dorda Jan 273

Doroszewska Janina 154

Doroszewski Witold 306, 400

Dostojewski Fiodor 426

Douglas Lloyd 519

Dowmunt S. 236

dr Zuzelski Stefan zob. Wyszyński Stefan, kard.

Dragatowa Zofia 243

Drda Jan 366

Drobner Bolesław 56, 485

Drop Władysław 158, 471

Drozd Jan 224

Drozdowski Marian Marek 25

Drukarz J. 156, 159

Drzewiecki Bronisław 33

Dubaniowski Bogdan, ks. 221, 247

Dubiel Paweł 13

Dubowski Adam 403, 408, 451

Dudczakowa B. 160

Dudek Antoni 14, 15, 25, 27, 29, 39, 42, 45-48, $56,64,67-69,72,80-83,86-88,90,93$, $96,99,101-104$

Duet Julia 114

Duguit Leon 407

Dunarowski Władysław 365, 368, 376

Dunikowski Ksawery 156

Dunin Janusz 9, 579

Duraczyński Eugeniusz 29

Dworak Tadeusz 270

Dworakowski Jan 208

Dyczewski Leon 42

Dygat Stanisław 366

Dykier Tadeusz 190

Dymek Walenty, abp 89, 95, 102, 169, 182, 183, $187,225,563$

Działyński Tytus 187

Dziasek Franciszek, ks. 270

Dzierżyński J. 231

Dzierżyńska Maria 223

Dzięcioł zob. Kisielewski Stefan 
Dziki Sylwester 108

Dziuba Andrzej Franciszek 15, 97

Dziubecki Leon 62

Dziurok Adam 15

Dzwonkowski Roman, ks. 56

Dzwonkowski Tadeusz 44

\section{E}

(E.P.) zob. Paukszta Eugeniusz

eg. krypt. 20

Edmund Bojanowski, bł. 188

Edyta Stein, św. 159

Ejan Jerzy 361

Ejsmond Julian 223

El Greco 166

Eliot Thomas Stearns 262, 550

Elżbieta II, królowa angielska 484

Engelmann Gottfried 164

Engels Fryderyk 38, 49, 74, 482

Erazm z Rotterdamu 554

Eremita pseud. 277, 355

Erenburg Ilia 299, 362

Estreicher Karol 346

Estreicher Stanisław 462

Estreicher Tadeusz 346

\section{F}

F.B. zob. Blachnicki Franciszek, ks.

F.K. krypt. 260, 264

Fr. K. krypt. 510

Faber William 276

Fabre Lucien 312, 313

Fallada Hans 299

Fangrat Tadesz 189

Fedorowicz Aleksander, ks. 307

Fedorowicz Małgorzata 193, 416

Felczak Zygmunt 62

Feldman Józef 215, 337, 343, 463, 469

Feldman Wilhelm 553

Ferrero Giulelmo 404

Ferrini Contardo 159, 231

Fiałkowski Tomasz 254

Fic Atanazy, o. 308

Ficek Jan, ks. 225

Fiedler Emil 442

Fijałkowska Barbara 15, 46, 50, 51, 54, 55, 68, $69,72,73,76,78,81,86,93,94,104,110$

Fik Marta 51, 101
Filipiak Marian 257

Finn Franciszek 425

Fiut Ignacy Stanisław 12, 13

Flanagan, o. 188

Flaubert Gustaw 360

Florkowski Edward, ks. 310, 429

Flue Mikołaj, de 238, 265

Flukowski Stefan 156

Foerster Fryderyk Wilhelm 152, 410

Fontaine Jean, de La 501

Fort Gertruda, von le 113, 255, 355, 449, 481

Franaszek Andrzej 556

Franciszek Ksawery, św. 265

Franciszek Salezy, św. 320, 434

Franciszek z Asyżu, św. 115, 188, 229, 238, 354, 453

Franczak J. 247

Frank Bruno 366

Frazik Wojciech 83

Frąś Ludwik 247

Frei Jan 242

Freud Zygmunt 456

Friedberg Marian 403, 423

Friszke Andrzej 14, 16, 25, 26, 29, 30, 36, 37, $59,111,557$

Frołow Jakub 117

Fróg Zbigniew Bonawentura, ks. 113, 147, 152, 254,261

Fryderyk Wielki, król pruski 469

Fumet Stanisław 254, 263

Furmanik Stanisław 395

Fuzakowa Krystyna 415

G

(G.I.) krypt. 244

(G.N.) krypt. 240

Gabriel zob. Blachnicki Franciszek, ks.

Gabryel zob. Blachnicki Franciszek, ks.

Gabryel Mar, ks. zob. Blachnicki Franciszek, ks.

Gadowski A., ks. 454

Gadowski Józef, ks. 465

Gafencu Grégoire 404, 467

Gaius Krispus Salutius 342

Gaj Hieronim 147, 307

Gajcy Tadeusz 391, 418

Gajewski A. 240

Gajewski Jan 416

Gajowniczek Franciszek 42 
Gałczyński Konstanty Ildefons 145, 157, 215, 433

Gandhi Mahatma 158, 188, 215, 260, 265, 267, 469, 568

Garaudy Roger 411

garb., Garb krypt. 146

Garbacik Eugeniusz 20

Garczyński Stefan 208, 472

Gard Jean Martin, du 362, 363

Garda zob. Górski Artur

Gardeil Ambroise 324

Gárdonyi Géza 189

Gaulle Charles, de 467

gaw. 130, 369

Gawdzik-Brzozowska Barbara 482

Gawecki Bolesław 515

Gawlik Jan Paweł 151, 152, 154, 156, 159, 160, 289, 335, 369

Gawlina Józef 182

Gąsiorowski Stanisław 322

Gąsiorowski Stefan 494

Genn Francis 340

Georg Iwan Eugen 439

Giela Joachim, ks. 10

Giertych Jędrzej 404

Gierymski Aleksander 156

Gilson Étienne Henry 128, 155, 254, 260, 470

Giraudoux Jean 388

Giuseppe, br. 213

Giżycki Jerzy 488

Glemma Tadeusz 150, 159, 160

Gliński Efrem 307

Gładysz Antoni 443

Głębocki Jerzy 430

Głombiowski Karol 9

Głowacz Walerian, ks. 437

Gmitruk Janusz 36, 37

goa zob. Gołubiew Antoni

Godlewski Eugeniusz 77

Godlewski Jerzy Feliks 16, 52, 74

Godlewski Michał 195, 196

Godlewski W. 471

Godzik U. 174

Goethe Johann Wolfgang 157, 554

Gogol Nikołaj Wasiljewicz 299

Gojawiczyńska Pola 462

Goliński Zdzisław, ks. 319, 460

Golmont Józefa 260, 289, 337, 354, 372, 404, 522
Gołba Kazimierz 223, 410, 552

Gołębiewski Łukasz 117-119

Gołubiew Antoni 118, 127, 153, 154, 158, 160, $194,195,197,200,222,240,254,261-$ 263, 288, 292, 314, 343, 348, 356, 359, $360,364-366,370,372,378,382,384$, $387,392,396,403,409,418,443-445$, 459, 460, 466, 469, 470, 480, 503, 504, $507,519-521,523,552,553$

Gombrowicz Irena 324

Gomułka Władysław 28, 32, 40, 68, 556

Gondek Elżbieta 9

Gonelli Guido 321

Goral Władysław 42

Göring Hermann 476

Goryńska Wiktoria 156

Gotlib Henryk 403

Goździewicz Hieronim, ks. 98

Górecki Jan 225

Górkiewicz Marian 515

Górska Konstancja 479

Górska Krystyna 165

Górska Pia 223, 440, 458

Górski Artur 127-129, 159, 195, 212, 213, 265, $445,485,553,554$

Górski Franciszek 563

Górski Karol 254, 270, 341

Górski Konrad 127, 147, 149, 150, 152, 153, $155,195,254,270,274,289,292,313$, 349, 361, 362, 376, 392, 394-398, 491, 554,555

Górski Ludwik 151

Górzyński Stefan 212, 411

Grabowska P. 222, 237

Grabowski Adam 194, 199, 210, 216

Grabowski Ignacy, ks. 238

Grabowski Jan, ks. 432, 435

Grabowski Stanisław 222

Grabowski Tadeusz 270

Grabowski Tadeusz Stanisław 343, 411

Grabski Jan Władysław 296, 355-357, 372

Grabski Stanisław 158, 195

Grabski Władysław Jan 211, 215, 231, 365, 372, $415,422,434,440,441,443,451$

Graczyk Maria Leonia 98

Graczyk Roman 11, 126

Grajewski Andrzej 11, 44, 66, 68, 69, 71-73, 81, $102,103,121$

Graliński Wacław 475 
Granat Wincenty, ks. 254, 261, 263

Granville-Barker Harley 464

Grądzki Kazimierz, ks. 439

Greene Graham 118, 128, 259, 299, 350, 351, $369,418,446,448,449,460,481$

Grekowica M. 519

Griffin Bernard, kard. 160, 183, 211, 489

Grodzicki Bogusław 20, 372, 376, 396

Grosz Jozsef, abp 90

Grosz Wiktor 35

Gruszczyński Krzysztof 104

Gruszczyński Franciszek Wojciech 20

Grycz Józef 20, 405, 406

Gryczowa Alodia 406

Grygiel Stanisław 254

Gryglewicz Feliks, ks. 306, 307, 431

Gryz Ryszard 15, 39, 42, 44-48, 56, 59-61, 67, 72, 80-83, 86-88, 90, 93, 96, 101-103

Grzebień Ludwik, o. 117, 563

Grzechnik Edward, ks. 194, 199, 219

Grzegorczyk Marian 194, 214, 555

Grzegorczyk Piotr 157, 213, 288, 361, 383, 385, 386, 397, 405-407, 493, 514, 515

Grzegorz zob. Łabiński Kazimierz, o.

Grzegorz Paweł z Brzezin 554

Grzegorz Wielki, św. 166, 188, 309

Grzegorz I zob. Grzegorz Wielki, św.

Grzegorz XVI, papież 184

Grzegorzewska Maria 410, 411

Grzelecki Stanisław 211

Grześkowiak Alicja 64

Grzybowski Marian 239

Grzybowski S. 243

Grzybowski Zdzisław 222, 243, 504

Grzymała-Siedlecki Adam 182, 213, 440, 441, 475

Guardini Romano, ks. 128, 254, 325, 431, 477

Gumowski Marian 515

Gustowski Zdzisław 295, 297-299, 361, 426, 429,460

Gutenberg Jan 483

Gzella Grażyna 126, 413

Gzella Jacek 54, 126, 172, 193

\section{H}

H.D. krypt. 159

H.K. zob. Kamieniecka Halina

H.M. zob. Malewska Hanna
H.R. krypt. 240

H.S. krypt. 236, 410

H.T. krypt. 231

Habielski Rafał 193

Habowski Mirosław 10

Hahn Wiktor 195, 290, 291, 380, 382, 384

Hain Stefan 169

Hajdukiewicz Lech 62

Halban Leon 254, 263, 296

Halecki O. 135, 153

Haluch H. 247

Haluch Tadeusz 222-224, 230-232, 236, 243$246,248,521,553$

Haluschi Helene 242, 420

Haluszka Jan 243

Hamsun Knut 189

Hanowski Adam zob. Piekarski Adam

Hanusz Tadeusz Zbigniew 411

Hapf. krypt. 496

Harrasser Jerzy, ks. 437

Hechel Fryderyk 346

Heine Stefan 158

Hejnicka-Bezwińska 74

Helenowski Wincenty, ks. 437

Hello Ernest 276

Hennelowa Józefa 126, 254

Herbert Zbigniew 555, 556

Hersey John 331

Hertyński Bolesław 270

Hezjod 553

Hieronim, św. 243, 306

Himmler Heinrich 333

Hindenburg Paul, von 476

Hirszfeld Ludwik 332, 334

Hitler Adolf 27, 152, 186, 212, 334, 337, 467, 476, 479, 503

Hlond August, prymas 32, 39, 43, 45, 46, 48-52, $56,58-60,63,69,78,89,95,121,136$, $148,182,183,185,188,200,210,215$, $230,246,248,249,270,271,275,276$, $336,415,438,507,558,563$

Hochfeder Kasper 492

Hoene-Wroński Józef Maria 551

Hoess Rudolf 335

Hoffmann Bedrzich, ks. 186, 333

Hołyńska Julia zob. Kisielewski Stefan

Hombek Danuta 10, 413

Homolacs Karol 214, 458

Hoppe Jan 195 
Horbacz S. 185-186

Horodyński Dominik 72, 124

Horodyska Krystyna 260

Horodyski Bogdan 513, 515

Hozjusz Stanisław, kard. 99, 238

Huenermann Wilhelm 422

Huet Stanisław, ks. 73

Hugo Wiktor 114, 156

Hulanicka Stanisława 188

Hünermann Wilhelm, ks. 481

Hussak Tadeusz 413

Huxley Aldous 450, 472

\section{I}

I.P. krypt. 460

Ibsen Henri 554

Ignacy Loyola, św. 276, 311, 323, 505

Igrut M. 504

Iłłakowiczówna Kazimiera 158, 216, 222, 244, $380,382,383,499$

Iłowiecka Hanna 199

Imańska Iwona 413

Ingarden Roman 127, 457

Irzykowski Karol 488, 514

Isakowicz-Zalewski Tadeusz, ks. 70-72

Iwanicki Józef, ks. 80, 81

Iwanowski Kazimierz 33

Iwaszkiewicz Jarosław 145, 296, 373, 499

Iwaszkiewiczowa Anna 350

\section{$\mathbf{J}$}

j. krypt. 522

J.A. krypt. 158

J.C. krypt. 372

(J. Drz.) krypt. 224

J.F. krypt. 553, 559, 566, 569

J. Golm. zob. Golmont Józefa

J.J. krypt. 236, 320

(jj) krypt. 235, 237, 239, 247, 320

J.J.P. krypt. 551, 569

J.K. krypt. 148, 214, 246, 355, 405, 457, 458, 487

(j.k.) krypt. 230

J.K.M. krypt. 160

J.Ł. krypt. 223

J.M. krypt. 245

J.M.T.J. krypt. 320

J.P. zob. Piwowarczyk Jan, ks.

J.R. krypt. 149
J.S.O. krypt. 554, 557, 561, 562, 567

J. St. zob. Stawski Jerzy

J.T., j.t. zob. Turowicz Jerzy

J.W. krypt. 203, 208, 244, 520

J.W.K. krypt. 325

J.Z.B. krypt. 564

Ja krypt. 231

Ja. Ch. krypt. 550

Jabłoński Henryk 339

Jacek zob. Archita Jan

Jacek Odrowąż, św. 188, 238, 313, 431

Jachimecki Zdzisław 155

Jackiewicz Aleksander 115

Jacquement Gabriel, ks. 452

Jadwiga, św., królowa polska 135, 153, 159, $229,238,239,434,476$

Jag. krypt. 411

Jagiełło Michał 11, 122, 126, 269

Jagoszewska Jolanta 61

Jahn Alfred 455

Jakóbczyk Witold 345, 422

Jakóbkiewicz Józef 216, 411

Jakubiec Czesław 351

Jakubiec Marian, ks. 77

Jakubowski Jan Zygmunt 269, 271, 399, 400

Jakubowski Józef 316

Jałbrzykowski Romuald, abp 89, 95

Jamroz Józef 158

Jamrozik Marian 221, 223, 229, 231, 237, 238, 241, 243, 504

Jan Bosco, św. 188

Jan Ewangelista, św. 274

Jan III Sobieski, król polski 462

Jan Luksemburski, król czeski i tytularny król polski 489

Jan od Krzyża, św. 300, 311, 453, 456

Jan Paweł II, bł., papież 42, 315, 527

Jan Vianey, ks., św. 238

Jan z Dobrej Woli pseud. 222

Jan Złotousty, św. 310

Janczewski Stanisław 513, 514

Janiak-Jasińska Agnieszka 413

Janion Maria 400

Jankowiak Stanisław 36

Jankowska Krystyna 566

Jankowski Stanisław 29

Jankowski Tadeusz 187, 239, 241, 246

Janta-Połczyński Aleksander 456, 490

Jantar B. 161 
Januszewska Hanna 458, 459

jar, (jar) zob. Archita Jan

Jaracz Stefan 156, 158, 208

Jarczyńska Maria 154, 155, 288, 362, 372, 375, $380,383,385,387,478$

Jarecka Aniela 221, 242

Jarecki Stefan 191, 521

Jarochowska Maria 238, 279, 379

Jarochowska Włodzimiera 479, 516

Jarocki Robert 126

Jarosz Dariusz 37, 40, 104

Jaroszewicz Piotr 56

jas. krypt. 487, 502

Jasienica Paweł (właśc. Leon Lech Beynar) $127,134,135,147,151-154,159,160$, $161,174,195,212,238,254,263,284$, $288,313,328,329,331,332,335,336$, $343,345-348,355,360,362,368,372$, 375, 404, 407, 408, 467, 468, 471, 527, 556,557

Jasieńczyk Janusz 331

Jasiński Andrzej 99

Jasiński Włodzimierz, bp 57, 77, 276

Jasiukowicz Stanisław 29

Jastrun Mieczysław 20, 134, 383, 385, 455

Jastrząb Edward 146, 377

Jastrzębiec Michał 329, 330

Jastrzębiec-Kozłowski Czesław 213, 312, 323, 339

jaszcz pseud. 148

Jaśkowiak Franciszek 187

Jawień Andrzej zob. Wojtyła Karol

Jaworowicz Irena 140, 187

Jaworski Alfred Kazimierz Andrzej 474

Jaworski Iwo 151

Jedlicz Marian zob. Stomma Stanisław

Jedliński Marian Kazimierz 221, 222, 239, 240, 242, 243

Jedwabski Franciszek, bp 237

Jeleński Stanisław 443

Jeleński Szczepan 365, 459, 471

Jemelka Franciszek, ks. 270

Jezierska M. 152

Jezus Chrystus 56, 181, 196, 197, 222, 224, 225, 228, 231, 240-242, 246, 251, 253, 256, 273, 274, 297, 300, 304, 307, 308, 311, $319,323,324,351,415,418-421,425$, $426,430,431,434,435,438,448,450$, $452,456,472,477,487,499,567$
Jezusek Wacław, ks. 475

Jeż Tomasz Teodor (właśc. Zygmunt Miłkowski) 345

Jeżowski Lesław, ks. 113, 155

Jędrusik Stanisław 276, 277

Jędrzejczak Antoni, ks. 98

JJS krypt. 156

JMS. zob. Święcicki Jan Marian

Joanna d'Arc, św. 250, 312, 313, 459

Joergensen 115

John Henry Newman, bł., kard. 159, 182, 261, $267,276,322,452,453,460,477,553$

Joinville 265, 267

Jop Franciszek, bp 83

Jordan Feliks 194

Jougan Alojzy, ks. 327

Jouvenel Bertrand, de 128

Józef Kalasanty, św. 159

Józef, św. 122, 188, 228, 242

Jóźwiak Franciszek 99

jt krypt. 162

Juda Maria 10

Juda Tadeusz, św. 438

Judasz 66, 68, 69, 71-73, 81, 102

Juliński Stanisław 221, 238

Juliusz Cezar 307, 342

Jureń Anatoliusz 489

Jurgielewiczowa Irena 459

Justynian, cesarz 489

jw. krypt. 445

jww., JWW. krypt. 154, 482

K

K.H. krypt. 264

K.J. krypt. 231, 457

kjw krypt. 444

K.M., ks. krypt. 242, 445, 502

K.P. krypt. 236

K.S, krypt. 241, 242, 244

K.S.C. krypt. 188

Kt krypt. 411

K.Z. krypt. 221, 224, 237

Kaczmarczyk Józef, ks. 297, 308, 420

Kaczmarczyk Zdzisław 343

Kaczmarek Marian Lech, ks. 430

Kaczmarek Czesław, bp 18, 45, 59, 66, 79, 80, $82,84,89,94,100,102,103,222,322$, 323,435 
Kaczmarek Lech 238

Kaczor-Batowski Stanisław 156

Kaczyński Zygmunt, ks. 13, 47, 84, 85, 108, 193, 194, 196, 198, 199, 209-212, 214, $215,219,237,551,557,558$

Kafel Mieczysław 411

Kalembka Stanisław 69, 70

Kaleta Andrzej 10, 270

Kalinowski F. 186

Kalinowski Jerzy 407

Kamieniecka Halina 204, 213, 214, 216, 290, $291,332,354,361,374,384,385,461$, 519

Kamiński Aleksander 426

Kamiński Józef Andrzej 152, 190, 333, 474

Kamiński Łukasz 58

Kamiński Stanisław 270

Kamiński Stefan 295, 297, 301, 415, 434, 460

Kamiński Włodzimierz 270, 274-276, 404

Kant Immanuel 265

Karol Foucauld, de, bł. 188, 265

Karolak Jerzy 459

Karolczyk J. 140, 144, 148, 151, 152

Karpiński Jan 486

Karski Jan (właśc. Jan Kozielewski) 28

Kasprowicz Jan 157, 213, 231, 391, 401, 548, 554,567

Kasprzyk Ludwik, ks. 432

Kasznica Stanisław 323, 443

Katarzyna ze Sieny, św. 188, 310, 435, 452

Kawecki Arkadiusz 16, 105

Kazimierz Wielki, król polski 343

Kazimierz zob. Mieliński Roman, ks.

Keon Alon 488

Kersten Krystyna 14, 23, 25, 26, 29, 31, 33, 34, $36,37,58-60$

Ketter Piotr 419, 456

Keynes John Maynard 468

Kędziora Piotr Juliusz 420, 451, 454

Kędziorzanka Barbara 207

Kędziorzyna Maria 459

Kętrzyński Wojciech 124, 127

Kiełczewska Maria 404, 411, 423, 471, 472

Kieniewicz Jan 339

Kieniewicz Kazimierz 486

Kieniewicz Stefan 127, 153, 289, 344

Kierkegaard Sören 273, 554

Kierst Jerzy 194, 195, 205, 214, 216, 270, 291, $381,382,387,388,390,418$,
Kieszkowska Wanda 169, 185-189, 365

Kietlicz Tadeusz 199, 212

Kipling Rudyard 364, 426, 459

Kirchmayer Jerzy 135

Kiryk Feliks 549

Kisiel Aleksander 270, 273, 278, 419, 457

Kisiel zob. Kisielewski Stefan

Kisielewski Józef 222, 472

Kisielewski Stefan 94, 115, 125, 127, 134, 141$143,147,150,152,155,158,160,161$, $163,165,195,204,254,284,288,330$, $343,348,356,361,362,365,366,369$, 370, 372, 398, 411, 430, 488, 490, 501, $511,512,517,558,559$

Kisielewski Tadeusz 34

Kiszczak Czesław, gen. 55

Kitrasiewicz Piotr 117-119

K-k krypt. 142, 148, 445

Klafkowski Alfons 336

Klawek Aleksy, ks. 123, 128, 158, 160, 228, 495

Kleiner Juliusz 127, 289, 296, 343, 362, 392, 397-399, 401, 424, 445

Klepacz Michał, bp 87, 89, 95, 102, 104, 254, 261,267

Klim J., ks. 221

Klon Teodor zob. Kisielewski Stefan

Kłecki Zygmunt, ks. 176

Kłoczowski Jerzy 16

Kłosowska O. 126

Kłosowski Józef Nikodem 362

Kłósak Kazimierz, ks. 254, 261, 270, 273-275, 407, 409, 420

Kmita-Piorunowa Aniela 501

Knapowska Wisława 343

Knauff Stanisław 20

Knittel John 430

Knothe Jan 433, 441

Knowles M. David 16

Kobylański Kazimierz 62

Kobyłecki Stanisław 269

Kochanowski Jan 384, 391, 397

Kochanowski Piotr 391

Kochański Aleksander 101

Kocwa Eugenia 160, 365, 474, 481

Koczorowski Stanisław Piotr 502, 503, 507, 513

Kogon Eugeniusz 333, 334

Kolbe Rajmund zob. Maksymilian Maria Kolbe, św.

Kolipiński Juliusz 422 
Kolumb Krzysztof 345

Kołłątaj Hugo 444, 462

Kominek Bolesław, kard. 128, 159

Komornicka Celina 270, 355

Komornicki Stefan 411

Konarski Edmund, ks. 70

Konarski Stanisław 344, 418

Kondek Stanisław Adam 17, 109, 119, 522

Koneczny Feliks 195, 211, 215

Konieczna Jadwiga 9

Koniński Karol Ludwik 259, 476, 519

Koniński T. 152

Konopczyna J. 159

Konopczyński Władysław 152, 158, 195, 212, $215,270,275,289,339,340,341,345$, $457,469,516$

Konopka Halina 16, 57, 73-79

Konopnicka Maria 231, 459

Konstantyn Dominik 42

Koński Tadeusz 152, 153, 245, 337, 404, 467

Kopernik Mikołaj 231

Kopiczko Andrzej 44

Kopiec Jan, bp 44

Koprowski Jan 152

Kor. krypt. 509

Korczak Janusz 115, 344, 410, 486

Korczakowska Jadwiga 486

Korczyński Adam 448

Koredczuk Bożena 9

Korfanty Wojciech 345

Korkuć Maciej 33, 34

Kornaś Tomasz 126

Kornaus H. 158

Kornik pseud. 142

Korniłowicz Władysław, ks. 95, 135, 159, 215, 256, 265

Korolewski H. 245

Korsak Kazimierz 358

Korytkowski Jan Ignacy, ks. 188

Korzonek Jan 270, 275

Kosętka Halina 10, 126

Kosibowicz Edward 269, 419

Kosibowicz Józef, ks. 422

Kosiński Krzysztof 57, 73, 75

Kosiński Stanisław, ks. 50, 51

Kosiński Wacław, ks. 439

Kossak Zofia zob. Kossak-Szczucka Zofia

Kossak-Szczucka Zofia 118, 121, 190, 213, 222, 335, 356, 358, 421, 429, 431, 432,
$439,443,453,454,456,465,487,518$, 560,561

Kossowski Aleksander 159

Kost Jakub 426

Kostecki Romuald, o. 115, 319, 325

Kostrzewski Józef 187, 403, 422

Kosyrczyk Klemens, ks. 121

Kościałkowski Stanisław 316

Kościuszko Tadeusz 136, 163, 187, 212, 340, $382,457,462$

Kot M. 295, 459

Kot Stanisław 510

Kotarbiński Tadeusz 514

Kot-Bahdaj Adam 154

Kotlarczyk Mieczysław 127, 214

Kott Jan 20, 134, 142, 398, 469, 501

Kotwicz Władysław 345

Kowalczyk Krzysztof 16, 44, 69

Kowalczyk Ludwik 162

Kowalewicz Jan zob. Bąk Wojciech

Kowalewski Józef 345

Kowalewski Marian 187

Kowalski Jan Wierusz zob. Wierusz-Kowalski Jan

Kowalski Kazimierz Józef, bp 87, 98, 424

Kowalski Stanisław 409

Kowalski Władysław, ks. 270

Kowalski Włodzimierz Tadeusz 25

Kowarski Felicjan Szczęsny 156

Kozanecki Andrzej 193, 195

Kozicki Stanisław 195, 209, 210, 212, 291, 337, $342,343,559,560$

Kozłowska Anna 43, 70

Kozłowski Krzysztof 128

Kozłowski Ryszard 69

Kozubski Zygmunt, ks. 195, 270, 275, 321, 420, 470

Koźniewski Kazimierz 10, 43, 126, 127, 153, 199, 329, 331, 345, 408

Krasińscy, rodzina 497, 515

Krasiński Zygmunt 171, 223, 231

Krasowski Stanisław 90

Kraszewski Józef Ignacy 462, 471, 499, 509, 518,561

Krauze Zachariasz, ks. 221, 222, 246

Krąpiec Albert, o. 254, 261

Kristanova Evelina 10, 11, 54, 111, 126, 157, 193, 416, 554, 579

Krobicki Kazimierz 149, 270, 458 
Krokowski Stanisław 159, 179, 187, 189, 190, $218,492,493,503,505-507$

Kropka pseud. 203

Król Jan Aleksander 399

Kruczkowski Leon 390

Krukowski Józef, ks. 52

Krupiński Marek 270, 289, 290, 348, 351, 353, $355,362,364,368,369,372,373,375$, $383,392,397,401,458$

Kruszewski Jakub 416

Krużyński Zorian 221

Krygowski Bogumił 423

Krygowski W. 160

Kryńska Elwira Jolanta 74

Kryszak Franciszek 160, 239

Krzemieniecka Halina 332, 342

Krzemieniecka Lucyna 455

Krzemiński Stanisław 554

Krzeptowski Wacław 330

Krzywoszewski Stefan 214

Krzyżanowska Wanda 239, 351

Krzyżanowski Adam 320, 339, 414, 490

Krzyżanowski Julian 514, 515

Ks. Bronisław pseud. 244

Kubacki Wacław 398, 400

Kubaj Artur 16

Kubiak Zygmunt 127, 254, 289, 350, 351, 387, 391, 407

Kubina Teodor, bp 58, 59, 159, 211, 237, 238, 558

Kubit Anzelm, ks. 270

Kuc Leszek 289, 366, 367, 387, 388

Kuczyński Józef, ks. 17

Kudelka Bolesław 222, 243, 245

Kudliński Tadeusz 141, 144, 163, 195, 214, $297,332,355,360,365,387,389,455$, 553,560

Kufel Władysław 185

Kujawska Magdalena 315

Kujot Stanisław, ks. 238

Kukołowicz Romuald 41

Kula Marcin 15, 43, 56, 57

Kulczycki Władysław, ks. 98

Kulesza Bronisław, ks. 123

Kuleszyna Maria 214

Kulisiewicz Tadeusz 156

Kumaniecki Kazimierz 342

Kunicka Krystyna 221

Kunicki Bogdan Jan 221

Kunowska-Porębna Maria 167, 256
Kuntze Edward 493

Kupiec Jolanta 29

Kurkiewicz Julian 414, 428

Kurta Henryk 413

Kurzyna Mieczysław 153

Kuśmierz A. 273

Kuta Cecylia 126

Kuthan Eugeniusz 295, 297-299, 301, 302, 320, $348,380,387,393,414,455,459$

Kutrzeba Stanisław 127, 158, 195

Kutrzebianka Anna 151

Kuzak Z. 159

Kuźmicz Bolesław 409

Kuźmińska Iza 379

Kwasiborski Franciszek 194

Kwasiborski Józef 63, 199, 219

Kwasigroch zob. Mieliński Roman, ks.

Kwiatkowski Franciszek, ks. 425

Kwiatkowski Remigiusz 454

Kwiatkowski Tadeusz 478

Kwiatkowski Wincenty, ks. 80, 254, 261

Kwiatkowski Władysław, ks. 157, 195, 212

L

L.B. krypt. 149

L.K. krypt. 148, 149, 470, 505

L.M. krypt. 325

L.P. krypt. 516

L. Pr. zob. Leszek Prorok

Labuda Gerard 341

Lagosz Wacław, ks. 80

Lane Arthur Bliss 58

Lasota Marek 83

Lasswell Harold 12

Latusek Arkadiusz 549, 552, 562

Lay 476

Lechicki Czesław 17, 107-110, 199

Lehmann Gerhard 467

Lehr-Spławiński Tadeusz 72, 342, 495

Leinwald Artur 29

Lejeu Piotr 270

Lelewel Joachim 415, 462, 493

Lelito Józef, ks. 83

Leliwa Maria zob. Morstin-Górska Maria

Lem Stanisław 156, 382, 384

Lemparty Antoni, ks. 70

Len Roman, ks. 98

Lenin Włodzimierz 38, 130, 482, 522

Leon XIII, papież 53, 185, 239, 432, 565 
Leonia Maria 98, 316, 431

Leopold Kazimierz zob. Leinwald Artur

Lepa Adam, bp 107

Lépee Marcél 449

Lepszy Kazimierz 341, 444, 469

Lesiak Władysław, ks. 426, 435

Leszner Tadeusz 496, 497

Leśnodorski Zygmunt 141, 158

Lewin Leopold 385

Lewinówna Zofia 372, 375, 376

Lewis Clive Staples 254-255, 441, 479

Lewis Sinclair 297

Libelt Karol 187

Liberum conspire zob. Górski Artur

Lichański Stefan 195, 289, 365, 368, 372

Lichniak Zygmunt 270, 277, 289, 290, 331, 348, 355-359, 365, 369, 372, 373, 375, 376, 381-383, 408, 409, 457, 458

Liebert Jerzy 223, 262, 384, 418

Liénart Achille, kard. 260, 261

Linde Samuel Bogumił 187

Lindsay Benjamin 490

Lipiński Wacław 152

Lipski Z. 242, 522

Liszt Franciszek 155

Lizak Wojciech 24-26, 28, 30, 42, 53, 64, 80, $81,89,90,94,95,101-105$

Lo Yung, cesarz chiński 483

Lofting Hugh 458

Lohn Władysław, ks. 311

Lompa Józef 158, 187

London Jack 414, 459, 462, 471

Longin, św. 188

Lorca Federico Garcia 386

Lorek Jan Kanty, bp 66

Lubiński Józef 109

Lucjański K. 150

Ludwig Emil 337, 450

Ludwik Maria Grignion de Montfort, św. 188, 311,438

Ludwik XVI, król francuski 70

Ludwika de Marillac, św. 460

Ludwik, św. 265, 267

Lusterko F. 176

Lutosławska Maria Janina 411, 523

Lutosławski Wincenty 195, 213

$\mathbf{L}$

Łabiński Kazimierz, o. 13, 193, 220, 221, 225, $228,236,237,241,507,561,562$
Łada Józef 124

Łada Krzysztof 339

Ładysław z Gielniowa, bł. 239

Ładzina Maria 492

Łapot Józef, ks. 439

Łaszczka Konstanty 156

Łaszewski Kazimierz 190

Łatyński Marek 24, 26, 29, 33, 36

Łączyńska Amelia 238, 247, 353

Łempicki Stanisław 400

Łepkowski Andrzej 158, 370

Łodyński Marian 515

Łojek Jerzy 108, 110, 111, 120

Łoniowski Józef Ryszard 147, 264, 265

Łopuski Jan 17, 27-29, 39

Łoś Irena 214

Łoś Stanisław 468

Łoza Stanisław 468

Łubieński Konstanty 124, 278

Łubieński Stanisław 434

Łuhinkowski J. 187

Łukasiewicz Zenon 370

Łukomski Stanisław Kostka zob. Stanisław Kostka, św.

Łyczycki A. 157

Łyczywek Roman 211

Łysakowski Adam 493

M

M., m. krypt. 142, 260, 264, 509

M. Ch. zob. Chojecka Maria

M. Cz. krypt. 511

M.J. krypt. 264, 265, 321, 323

M.K. krypt. 380, 383, 384, 386, 391, 401

M. K-a krypt. 557

M.P.G. krypt. 550, 568

M.S., m.s. krypt. 216, 239

M. Str. zob. Strebejko M.

M.Ś. krypt. 565

M. Tur. krypt. 265

M.U. krypt. 552, 560, 562

M.Z. krypt. 241, 245

Machay Ferdynand, ks. 128, 420

Maciąg Włodzimierz 288, 289, 372, 380, 383

Maciński Tadeusz 62

Macios Franciszek 270

Mackinder Halford John 471

Macleod Norman 190

Madaliński Kazimierz 180, 185, 188, 190, 191, 306 
Madej Antoni 194, 199, 290-292, 305, 321, $330,343,348,352,355,357,358,360$, $365,370,372,378,380-382,392,407$, $408,455,456,460,472,513,527,562$

Maeztu Ramiro, de 229

Maglione A. 148, 175

Magny C.E. 260

Majakowski Włodzimierz 385, 386, 445

Majchrowski Jacek Maria 16, 547

Majchrowski Stefan 157, 474

Majdański Walenty 149, 185, 321, 411, 422, 431

Majewski Alojzy, ks. 188

Majewski S. 209

Majewski Wacław, bp. 195, 212, 241

Majka Józef, ks. 53, 195

Majkowski Józef 270, 273, 274, 276, 323, 352

Makarenko Antoni 149, 410, 463

Makarewicz Maciej 482

Makowiecki Andrzej Zdzisław 119, 124

Makowiecki K. 246

Makowiecki Stefan 443

Makowiecki Tadeusz 491

Makowski Julian 411

Maksymilian Maria Kolbe, św. 42, 116, 237, 276, 315

Malczewska Wanda 229

Malewska Hanna 118, 127, 143, 146, 147, 166, $195,231,253,254,261,263,292,312$, $356,358,359,361,372,374,378,414$, $439,426,432,434,439,445,456,461$, $469,477,480,500,562,567$

Malik Jan 207, 214

Malinowski Bronisław 21, 409

Malinowski Maksymilian 514

Malthus Robert 114

Małachowski Aleksander 511, 515, 516

Małecki Mieczysław 158

Mann Tomasz 363, 447

Manning Henryk Edward, kard. 276

Manser Gallus M., o. 319

Mańkowski J., ks. 221, 239

Mar Gabryel, ks. zob. Blachnicki Franciszek, ks.

Marangoza Mikołaj 486

Marchewka Antoni, ks. 121, 229

Marcin, św. 188

Marcinkowski Karol 187, 345

Marcinkowski W. 190

Marczewski Marek 550

Marczyński Adam 162, 480, 482
Marecki Józef 38

Maria Franciszka Siedliska, bł. 229

Maria Leonia, s. 316, 431

Maria Teresa Goretti, św. 159, 188, 238

Maria Truszkowska, bł. 159

Mariańska Józefa 270, 275

Maritain Jacques 128, 146, 184, 188, 232, 254, $255,261,273,274,425,446,451,452$, 469,477

Maritain Raissa 128

Markiewicz Stanisław 16

Markiewicz Tadeusz 43, 70, 400

Markowski M. 141

Marks Karol 38, 42, 48, 49, 74, 114, 150, 181, $211,448,482,499$

Marowski Jan 331

Marryat Fryderyk 190

Marshall Bruce 353, 417, 448, 481

Marshall George 30

Marszewski Włodzimierz 62

Martin H. 312

Martin Marietta 265

Maślanka Julian 107

Mateusz, św. 307, 308

Matisse Henri 154

Matzel Ernest, ks. 425

Mauersberg Stanisław W. 74

Maupassant Guy, de 299, 363

Mauriac François 118, 157, 300, 353, 354, 499, 554

Maurier Daphne, du 430

Mazanek Stefan, ks. 127, 159

Mazenot Karol de 240

Mazowiecki Tadeusz 63

Mazur Franciszek 44, 87, 94, 98-100

md. krypt. 204, 291, 310, 455

Meducki Stanisław 58

Meersch Maxence, van der 352

Mehl Roger 256

Mehoffer Józef 155

Meissner Janusz 455

Melkowski Stefan 555

Melville Herman 370

Menendez Józefa 419

Mercier Désiré Felicien François Joseph, kard. 265, 316, 431

Merton Thomas, o. 254, 262, 276, 323, 469, $477,519,564$

Meyer Rupert, ks. 442 
Meynckens J., o. 425

Mędlewski Nikodem, ks. 221-222

Mianowicz Tomasz 91

Micewski Andrzej 15, 16, 63, 68, 72, 99, 105

Michalska Jadwiga 514

Michalski Jan 405

Michalski Konstanty, ks. 114, 128, 159, 195, 215, $253,256,260,261,265,267,315,435$

Michalski Marian, ks. 80, 474

Michalski Stanisław F. 514

Michał Anioł (właśc. Michelangelo Buonarroti) 77,189

Michał Kozal, bł., bp 42, 159

Michał Sopoćko, bł., ks. 222, 228, 245

Michałowska Monika 458, 459, 508, 509

Michel Patrick 90

Michelet 312

Michna S. 277

Miciński Bolesław 265

Mickiewicz Adam 157, 189, 213, 231, 262, 340, 391, 397, 398, 414, 424, 427, 447, 449, $455,456,462,499,500,503,507,509$, $521,550,553,554,565$

Mielczarek Tomasz 17

Mieliński Roman, ks. 12, 167, 168, 170, 171, 180, 183, 190, 229, 563

Miernik Grzegorz 16

Mierzwa Stanisław 29

Migoń Krzysztof 9-11, 579

Miklaszewski Gwidon 163

Mikołaj, bp 57, 430, 459

Mikołajczyk M. 44

Mikołajczyk Stanisław 27, 28, 31, 34, 36, 37, $59,60,62,557,558$

Mikucki Sylwiusz 509

Mikulski Antoni 158, 215

Mikulski Krzysztof 547, 555

Milewski Tadeusz 400

Milik Józef Tadeusz 306

Miller Michał, ks. 422

Miłośnik książek pseud. 505

Minc Hilary 32, 38, 99

Mindszenty Jozsef, kard. 90, 95, 522

Mirek Andrzej 404

Miriam zob. Przesmycki Zenon

Mirka Franciszek, ks. 424

Mirski Władysław, ks. 325

Misztal Henryk 67, 104

Mitchell Margaret 433
Mitkowski Józef 359

Mitkowski Władysław 434

Młodzianowski Adam 483

Młodziejowski Jerzy 187, 188

Młynarski Feliks 404

Modelski Izydor 547

Mokłowska E. 264, 312

Moniuszko Stanisław 231

Montgomery of Alamein Bernard, marszałek 331

Montini Giovanii zob. Paweł VI, papież

Mońko Leon 270, 273, 275, 290, 362, 411

Morawska Helena 313, 468, 469

Morawski Dominik 193, 215

Morawski Kazimierz 187

Morawski Marian, o. 269, 273

Morcinek Gustaw 127, 158, 189, 231, 422, 429, $431,465,480$

Mors. pseud. 146

Morstin Zygmunt 567

Morstin-Górska Maria 127, 156, 241, 254, 262, $265,267,288,310,311,349,352,354$, $356,364,372,379,470,477,563,564$

Mortkowicz-Olczakowa Hanna 344

Morton Józef 366

Mounier Emanuel 254-256, 263, 265

Możdżer A. 246

Mroczkowska Janina 149

Mroczkowski Przemysław 157, 460

Mulak Jan 331

Müller Michał, ks. 320

Müllerowa Lidia 16

Mursay O., o. 455

Mus zob. Sułkowska M.

Musiał Filip 83

Musiel Franciszek 221, 234, 236

Mussolini Benito 148, 153, 476

Muszkowski Jan 9, 10, 12, 405, 406

Mycielski Andrzej 151

Myczka Eugeniusz 169, 179, 180, 185, 190, 291, 321, 322, 358, 408, 471

Mysłek Wiesław 16

Myszor Jerzy, ks. 44, 54

Myśliński Jerzy 108, 110, 111, 120, 124, 194

$\mathbf{N}$

ND. krypt. 311

N.K. krypt. 123, 289-290, 343, 371, 380, 407, 460 
N.N. krypt. 240

Nałkowska Zofia 426

Napoleon I Bonaparte, cesarz Francuzów 275, 276, 506

Napora Krzysztof 220

Natanson Wojciech 146, 157, 158, 213, 377, 378,510

Nawarat J. ks. 221

Nawrot Stefan 16

Nawrowski Ewaryst, ks. 498

Nejczyk, pseud. zob. Łabiński Kazimierz, o.

Neron 468

Neumann Teresa 469

Nęcek Robert 96-97

Niczyperowic Stanisław 407

Niećka Józef Czesław 37

Niedźwiadek Wacław 270

Niekrasow Mikołaj 385

Niemojewski Lech 262

Nietzsche Fryderyk 158, 467, 477

Niewiarowicz Roman 156

Niklewicz Mieczysław 492

Nitecki Piotr 50

Noël Léon 404

Nogal Teodor, ks. 325

Norwid Cyprian Kamil 145, 157, 184, 213, 214, $262,334,384,386,391,395,397,434$, 439, 458, 472, 479, 482, 499, 550, 562

Nowaczyński Adolf 514

Nowak Jerzy Robert 126

Nowak Jan zob. Jeziorański Zdzisław

Nowak P. 172

Nowak Tadeusz 467

Nowak-Dłużewski Juliusz 344, 418

Nowakowski Jan 399, 400

Nowicka Olga 112, 115

Nowicki Edmund, ks. 219, 221, 224, 225, 237, 238, 243, 246, 249, 519

Nowicki Henryk zob. Zawieyski Jerzy

Nowowiejski Antoni Julian, bp 42, 475

Nowowiejski Feliks 159, 214, 231

Nowowiejski Kazimierz 187

\section{$\mathbf{O}$}

O.B. krypt. 411

O.J.W. K. krypt. 323

Obojętny zob. Górski Artur

Ochab Edward 87, 93, 99, 101, 102

Ogulewicz Hanna 156, 435

Ogulewicz Z. 211
Okoński Włodzimierz 424

Okulicki Leopold, gen. 29

ol. por. zob. Porycki Olgierd

Olejniczak Bernard 284

Oleksiński Aleksander 515

Olkiewicz Alfons Albin 238, 247

Olszanowska-Skowrońska Zofia 336

Olszewicz Bolesław 141, 513

Olszewski Marian 270, 290, 363, 380, 383, 383, $387,391,400$

Olszewski Stanisław, ks. 424, 432, 442

Olszewski Tadeusz 482

Olszewski Wacław 458

OMI, krypt. 237

Omikron, pseud. 208

Oost Karol 157

Oparin Aleksandr Iwanowicz 274

Ordyłowski Marek 44

Oria Bonifacy d' 516

Orkan Władysław 296, 368, 426

O'Rourke Edward, bp 137

Orpieński Jacek 270

Orzeszkowa Eliza 400, 518

Osęka Piotr 55-57

Osękowski Czesław 34, 36, 44,

Osmańczyk Edmund 127, 151, 152, 337

Osmólska-Piskorska Bożena 189

Osóbka-Morawski Edward 23, 28, 59

Ossendowski Ferdynand 190, 424

Ossolińscy, rodzina 497

Osterwa Juliusz 136, 159, 215, 555

Ostachowski Emilian 152

Ostromęcki Bohdan 213, 214, 270, 291, 370, 380-382, 386, 403, 418,

Ostrowska Bronisława 520

Ostrowski Witold 262

Osysko E. 239

Otton III, cesarz rzymsko-niemiecki 239

Otwinowska Barbara 16

Otwinowski Stefan 378, 415, 433

Owczarek Stanisław, ks. 70, 72

Owen Robert 457

Ozga Władysław 73

Ozimek M. 153

Ożóg Jan Bolesław 203

Ożóg Maria Ewa 16

$\mathbf{P}$

P. krypt. 19, 148, 247

P., ks. krypt. 236-238, 245 
P.G. krypt. 505, 515

P.Ł. krypt. 236

P.T. krypt. 241

(P.S.J.) krypt. 233

Paczkowski Andrzej 10, 14, 26, 27, 30-32, 34, $36,37,43,69,110$

Padechowicz Marian 156, 230

Pajórek Leszek 36

Pałka Jan 222, 243, 504

Pałyga Edward Józef 90

Pamuła Stanisława 12, 13

Pankiewicz Józef 155, 156

Pannenkowa Irena 159, 195, 211-214, 270, 291, 315, 333, 344, 345, 357, 404, 463

Panuś Kazimierz 563

Papée Stefan 90, 382, 471

Papen Franz, von 152, 476

Papini Giovanni 128

Parandowski Jan 254, 341, 342, 362, 376, 378, 396, 434, 448, 478

Paras Stanisław, ks. 435

Parr Karol 419

Parsch Pius, ks. 324

Parthénay Edmund 289, 381

Paruzel H. 221, 248

Pascal Blaise 322, 499

Pasiak Dorota 37

Pasławski Stanisław, ks. 421, 453

Pastuszka Józef, ks. 195, 270, 273, 275, 409

Paszkiewicz Lilla Barbara 26, 36, 43

Paszkowski Jan 391

Patkaniowska Danuta 126, 254-256, 259

Paton Alan 481

Patro Gustawa 37

Paukszta Eugeniusz, ks. 153, 157, 169, 190, $222,231,240-242,245,246,358,365$, $512,548,564$

Pawelski Jan 269

Paweł, św. 238, 306, 307, 311, 312, 433

Paweł III, papież 311

Paweł VI, papież 91

Pawlak Z. 169, 221, 563

Pawlicki Aleksandrem 112

Pawlikowska Maria 567

Pawlikowski Jan Gwalbert Henryk 480

Pawłowski Adam, ks. 495

Pawłowski Antoni, ks. 270, 457

Peers Allison 449

Péguy Charles 195, 313
Pelin Elin 430

Persak Krzysztof 61

Perzyna Ludwik 276

Peterman Radosław 44

Peterson Jan 337

Petersowa Zofia 459

Petöfi Sandor 386

Petrani Aleksy, ks. 338

Petry M. 150, 157

Pędziński Zbigniew 270, 290, 392, 395, 396, 398-401

Pękala Karol, ks. 128, 435

Piasecka Justyna 15, 43, 65, 67, 70, 80, 82, 83, 85,88

Piasecki Bolesław 63, 68, 69, 71, 72, 86, 87, 94, $98,102,123,137,556$

Piasecki Stanisław 215

Pichon Karol 337

Piechal Marian 458, 459

Piekara Arkadiusz 151

Piekarski Adam 16

Piekarski Kazimierz 405, 406

Pielatowski Kazimierz 169

Pieńkowska Hanna 155

Piess Jan 129

Pietrow Nikita 36

Pietrzkiewicz Iwona 13, 112, 126

Piętak Stanisław 426, 427

Piętka Henryk 426

Pigoń Stanisław 127, 149, 157, 158, 195, 358, $363,368,399,476,564,565$

Pilecki Jerzy 213, 270, 275

Piłka Marian 193

Piłsudski Józef, marszałek 31, 55, 339, 551

Pio, o., św. (właśc. Francesco Forgione) 522

Piotr, św. 238, 252, 420

Piotrowski Czesław, ks. 318

Piotrowski Stanisław 468

Piryt pseud. 209

Pisarek Walery 12

Pius VI, papież 70

Pius IX, papież 184, 338

Pius X, papież 61, 159, 188, 228

Pius XI, papież 53, 54, 78, 149, 184, 185, 232, $239,242,318,337,435,468,557,565$

Pius XII, papież 18, 26, 48, 52, 76, 78, 90, 91, $103,115,134,142,146,148,169,172$, 179, 180, 183-186, 188, 210, 212, 238, 240, 242, 248, 249, 278, 317, 434, 435, $449,452,453,456,460,468,472,479$ 
Piwarski Kazimierz 341, 342

Piwowarczyk Jan, ks. 127-130, 134, 140, $147-$ $153,155,158,159,161,169,195,211$, $270,276,288,305,308,313,315,319$, $320,325,326,332,334,336,345,407-$ 409, 411, 432, 444, 445, 460, 467, 469, 527,565

Platon 499, 500, 562

Plezia Marian 20, 147, 159, 270, 287, 288, 310, $314,327,328,341,342,360,392,399$, 445

Plezia Michał 506

Plis Jerzy 10

Plus Raoul 420, 456

Pluszczyk I. 221

Płażewski Jerzy 329

Płomieński Jerzy Eugeniusz 343, 344

Pm. krypt. 242

Pocek Jan 385

Podhorska Halina 420

Podhorska-Okołów Stefania 214

Podlewski Stanisław 330, 414, 468

Podoski Julian 20

Podwapiński Wawrzyniec 411

Pogonowska Anna 458

Pokorna-Ignatowicz Katarzyna 10

Poksiński Jerzy 69

Polak Barbara 112

Pollak Roman 411

Pollak Seweryn 385

Pollakowa Milada 270

Poloniec Z. 207

Pomian Tadeusz 222, 243, 244

Ponikowski Antoni 158

Poniński Antoni 69

Popiel Jan 270

Popiel Karol 31, 32, 34, 46, 62, 63, 547, 558

Popłatek Jan 270, 276, 277, 457

Poradowski Michał 211, 214, 460, 461

Poradowski Szymon 62

Porazińska Janina 426, 453, 458, 459

Porojść A. 158

Porycki Olgierd 270, 289, 290, 348, 360, 363, 364, 372, 386, 397, 398, 405, 406, 458, 516

Pospieszalski M. 189

Potyrała Bolesław 74

Pourrat Henri 323

Powers James Farl 378, 379

Poźniak Włodzimierz 155
Półtawski Adam 492

Prawdzic Eleuteriusz zob. Blachnicki Franciszek, ks.

Prokulski Walenty, ks. 270, 495, 496

Promiński Marian 433

Prorok Leszek 156, 160, 169, 187, 189, 204, $239,343,455,520,565,566$

Prostak K. 56

Proust Marcel 364, 484

Próchniak Leszek 44

Prus Bolesław 187, 213, 368, 397, 400, 415, 447, 518

Prus-Wiśniowski Tadeusz 223, 231, 239, 247

Pruszyński Ksawery 296, 331, 344, 362, 374, 376, 449

Pruszyński Mieczysław 473, 474

Przanowska Teresa 223, 234

Przeciszewski Tadeusz 193, 195

Przekrętnik pseud. 203, 205

Przesmycki Zenon 482, 498

Przyboś Julian 384, 397

Przybyła Andrzej, ks. 430

Przybyłowa Janina 344

Przybysz Milena 44, 61

Przybyszewski Kazimierz 547

Przybyszewski Stanisław 551, 566

Pudełko F. 519

Puszkin Aleksander 157, 488

Putek Józef 342

Pużak Kazimierz 29

Pylak Bolesław 97

Pytel Grzegorz 68

Pytlak Janusz 409

Pytlakowski Jerzy 447

Q

Quasimodo zob. Górski Artur

Quidam zob. Górski Artur

R

R. krypt. 211, 265, 291, 507

R.C. krypt. 245

R.S. krypt. 409

Rabanowski Jan 56

Rabska Zuzanna 195, 213, 290, 291, 332, 334, $362,372,405,439,455,460,497,498$, $502,514,515,566$

Raczkowski Wojciech 168, 563

Raczyńscy, rodzina 497, 516

Radkiewicz Stanisław 68, 99 
Radkowski Jerzy 253, 254

Radkowski T. 215

Radlińska Helena 405, 426

Radoński Karol, bp 326

Radwan III, pseud. 95

Radwan Janina 144, 289, 459

Radwan K. 211

Radziszewski Idzi, ks. 150

Rafalska Dominika 193

Rahner Hugo 323

Rahner Karl 319

Raina Peter 15, 39, 43, 67, 82, 84, 85, 89, 90, 92-95, 99, 101

Rak Romuald 66

Rakowski Kazimierz 151, 152, 211

Ramiere Henry 419

Ramuz Charles Ferdinand 476

Ranwez, o. 470

Rataj Maciej 208

Rawa H. 159

Redzisz Z. 243

Regnigny 334

Reiff Ryszard 72

Reiterowa Anna 20, 459, 517-519, 523

Rek Tadeusz 33

Remarque Erich Maria 363

Rembrandt Harmenszoon van Rijn 164

Remerowa Krystyna 502

Renata Maria 159, 270, 276, 324, 425

Rene Grousset 339

Reymont Władysław Stanisław 368, 397, 518, 569

Rękas Michał, ks. 123, 128, 147, 222, 238, 270, 435

Ribbentrop Joachim, von 148, 175, 184

Riquet Michał 260, 264

Rode Maksymilian, ks. 167, 169

Rodziewiczówna Maria 159, 429, 430

Rogala Stanisław 193, 194

Rogalski Aleksander 146, 152, 157, 159, 169, $179,181,186,189,190,270,275,277$, $291,323,324,348,358,365,388,460$, $498,499,566,567$

Rogier Ludovicus Jacobus 16

Rogowska Barbara 57

Rogoż Michał 13, 112, 126

Röhm 476

Rokossowski Konstanty 99

Rola Wacław 277, 289, 290, 348, 350, 356, 362, $369,372,375,376,378,379,384,392$, 397,458
Rola-Żymierski Michał 56

Rolland Romain 426, 462, 469

Rolleczkówna Natalia 481

Romaniuk Marian P. 99, 101

Romarowska W. 238

Romer Eugeniusz 468

Roosevelt Franklin Delano 24, 25, 27, 453

Röpke Wilhelm 337

Rose William J. 340

Rosiak Jan, ks. 270, 273, 274, 276, 351, 353, 420, 457, 495

Rosołowski Marcin 193, 198

Rospond Stanisław, bp 77, 83, 160, 474

Rostworowski Jan, ks. 169, 188, 269, 270, 273, 274, 276, 289, 290, 292, 300, 305-308, $311,314-316,319,322-327,338,339$, $344,361,380,397,403,407-409,419$, $424,457,527$

Rostworowski Karol Hubert 136, 196, 223, 231

Rostworowski Nik 381

Rostworowski S.K. 404

Rostworowski Tomasz 17, 475

Roszkowski Wojciech 14, 18, 23, 24, 26-28, 30,31

Rousseaux André 362

Rozanski Zenon 474

Rozwadowski Józef, bp 149

Rudloff Leon 419

Rudnicki Adolf 375, 411

Rudnicki Lucjan 346, 347, 448

Rulikowski Mieczysław 493

Rusinek Michał 378, 455

Russel Bertrand 339

Ruth Buczkowski Marian 134, 489

Ruthen C., ks. 202

Rutherford of Nelson, lord 158

Rybczyński Witold 158, 161, 212, 215

Rychlewski Janusz 376

Rychlicki Józef, ks. 338

Rylska Teresa 147

Ryłło Maksymilian, o. 316

Rymar Stanisław 62

Rymkiewicz Aleksander 216, 380, 382, 418

Rymkiewicz Władysław 383, 455

Rytel Piotr 214

Rzeszewski J., ks. 221, 237

Rzeszewski Marian, ks. 169, 179, 184, 270, 273, 274,494 


\section{S}

S. krypt. 189

(S) krypt. 174, 183, 188, 191, 317

(s) krypt. 241

S.B. krypt. 290, 325

S.B.Ż. krypt. 159, 229

S.G. krypt. 230

S.J.T. krypt. 444

S.K. zob. Krokowski Stanisław

S. K-n krypt. 558, 560

S.W. krypt. 445

Sadowski P.A.W. 206

Sadowski Roman 418

Sadowski W. 152

Saint-Beuve Karol 114

Saint-Exupéry Antoine, de 262, 476, 485, 563

Sajdak Jan 231, 309

Salamucha Jan, ks. 159, 163, 254, 262

Sand George 164, 484

Sandhurst B.G. 470

Sandler 400

Sapieha Adam Stefan, kard. 16, 32, 39, 42, 50$52,56,62,77-79,83,86,87,89-91,95$, $125,127,146,159,175,182,215,238$, 265-276, 476, 558

Sapieżyna Jadwiga z Sanguszków Adamowa 163, 476

Sarbiewski Maciej Kazimierz 318

Sargon pseud. 222, 236

Sartre Jean Paul 273, 367, 470, 522

Sawajner Józef 507

Sawicki Franciszek, ks. 270, 273, 276, 277, 420, 431, 432, 457, 460

Sawicki Jerzy 336, 468

Sawicki Stefan 256

Schilgen Hardy 419, 420, 470

Schleicher 476

Schletz Alfons, ks. 270, 276, 316, 457

Schneider Reinhold 254, 261

Scholz Franz 51

Schryvers Józef 418, 425

Schulz Karel 481

Schumacher Edgar, płk 328, 329

Sczaniecka Emilia 188

Seeaight Robert 114

Seelieb A. 137

Semkowicz Władysław 159

Sertillanges Antonine Dalmatius 254, 263

Serwański Edward 185, 222, 243
Seton Watson S. 340

Seymour-Tułasiewicz Lilian 434

Sęp-Szarzyński Mikołaj 391

Shaff Adam 261

Shakespeare William 214, 391, 397, 452, 464, $488,500,554$

Sheen Fulton J., abp 418, 419, 519

Siara Aleksy, ks. 430

Sieciechowiczowa Lucyna 459, 465

Siemaszkiewicz Józefa 16

Sienkiewicz Henryk 136, 200, 426, 443, 445, 447, 487, 499, 503, 518, 561

Sierchula Rafał 220, 221, 225-227

Sieroń Roman Bogusław, ks. 11

Sierow Iwan, gen. 68, 99, 100

Sikorski K. 193

Sikorski Władysław, gen. 32, 158, 214, 215, 246, 342, 557

Sinko Tadeusz 310

Sinko-Popielowa Krystyna 403

Siwek Paweł 270

Siwicka Zofia 391

Sjeliszczew A. M. 401

Skałkowski Adam Mieczysław 344

Skarbek Czesław, ks. 195, 211, 212

Skarbek Jan 16

Skarga Piotr, ks. 159, 425, 454

Skiba Piotr 407, 408

Skierski Kazimierz Zenon 213, 377, 433, 434, 471,475

Skoczek Jan 403

Skoczylas Michał 28, 35

Skorodecki Stanisław, ks. 98

Skowron Maciuś 459

Skowron Stanisław 411

Skórzyński Jan 556, 557, 568

Skrzanecki J. 368

Skrzeszewski Stanisław 74, 77

Skrzetusz, pseud. 237

Skulicz Witold 482

Skwarczyńska Stefania 253, 254, 262, 349, 399, 476

Skwarczyński Zdzisław 364

Skwarnicki Marek 254

Slesser H. 159

Sławińska Irena 254, 262, 270, 361, 395, 445

Sławiński Krzysztof 474

Sławiński Marian 244

Słomkowski Antoni, ks. 65, 128 
Słoniński Stefan 169, 180

Słotwiński Józef 445

Słowacki Juliusz 189, 231, 384, 386, 458, 523, 553

Smentek F. 214

Smolarkiewicz P. 206

Sobalkowski Szczepan 149

Sobierajski Zenon 401

Socha Pawel, bp 220, 224, 225

Sofokles 391

Sokołowska Władysława 550

Sokołowski Jan 451

Sokulski Justyn 493

Solski Ludwik 163, 515

Sołtysik Kazimierz 181, 182

Sonczyk Wiesław 126

Sonik Franciszek, bp 44

Sosnowski Kirył 407

Sowa Kazimierz 156

Sowiński Adolf 501

Speaight Robert 154

Spectator pseud. 206

Splett Karol Maria, bp 43

Sprusiński Stanisław 216

Spychalski Marian 40

Srebrny Stefan 391

St. krypt. 151

St. J. krypt. 230, 231, 236, 238, 247

Staff Leopold 145, 157, 158, 310, 318, 383, 384, 397,498

Stalin Józef 18, 23-26, 28, 29, 31, 32, 38, 40$42,52,55,57,69,100,105,116,128,130$, $166,446,482,522$

Staliński Tomasz zob. Kisielewski Stefan

Stanaszek Bogdan 66, 73

Stanisław Kostka, św. 188, 238, 276, 388, 435, 561

Stanisław Leszczyński, król polski 343, 463

Stanisław, św. 222, 287, 314, 360

Staniszewski Jan 190

Staniszewski Zdzisław 413

Starnawski Jerzy 270, 405, 406, 549, 554

Starosta Mirosław 433

Starowieyska-Morstinowa Zofia 19, 127, 144, 147-149, 151, 156-158, 163, 195, 231, 254, 288, 290, 292, 308, 313-315, 330, $335,345,346,348-351,354-360,362$, 364-369, 372-378, 434, 445, 458, 468, $470,477,485,501,511,527,567$
Stary gawędziarz pseud. 222, 239, 241, 242, $245,247,248$

Starzyński Stefan 208

Stawski Jerzy 169, 180, 182, 185, 186, 188, 291, 305, 317-320, 322, 324, 527

Stedman, ks. 449

Stefaniak Janusz 10, 13, 17, 44, 66, 70, 93, 109, $110,112,113,115,116,118,120,122$, 124, 198

Stefański Walenty 492, 493

Stein I. 186, 471

Steinowa Bronisława 188,189, 465

Stelmachowska Bożena 423

Stepa Jan bp 77, 195, 325, 426, 457

Stępka Stanisław 37

Stępniewski Tadeusz 488

Stiernstedt Marika 297, 362

Stiller Robert 380, 385

Sto. zob. Stomma Stanisław

Stokowy Barnaba, o. 314

Stokowska Maria 154

Stolarczyk, ks. 160

Stomma Stanisław 151, 154, 195, 253, 254, 260, 261, 292, 336, 404, 409, 468, 469, 567,568

Stopikowski Robert 193

Strebejko Michał 127, 135, 140, 142, 144, 148, 150, 152-154, 161, 260, 331, 467

Stroczewski E. 233

Stróżewski Władysław 254

Strugarek Stanisław 188, 335

Strumph-Wojtkiewicz Stanisław 342, 488

Stryjowski Julian 368

Strzałka Kazimierz A. 156

Strzałkowski Waldemar 29

Strzelecka Małgorzata 11, 13, 74, 75, 77, 126128,149

Strzelecki Michał 34

Strzelecki-Gomułka Ryszard 40

Strzembosz Tomasz 112

Strzeszewski Czesław 15, 53, 150, 158, 159, 195, 211, 212, 270, 274, 277

Studentowicz D.K. 212

Studentowicz Kazimierz 195, 199, 211, 212, $216,219,270,273,274,472$

Stwosz Wit 155

Styś Stanisław, ks. 460

Suarez Franciszek 276

Suchocki Mieczysław 407 
Suchodolski Bogdan 254, 263, 403, 426

Suhard Emmanuel, kard. 182, 260, 261, 264, 265

Sułkowska M. 138

Supiński Witold 422

Surzyński Józef, ks. 231

Sutorowska Zofia 491, 512, 518

Sweno, pseud. 208

Swift Jonathan 364

Swift Orvis Julia 340

Syzdek Eleonora 40

sz. krypt. 247

Szaefer Kazimierz 428

Szała Leon 100

Szałagan Alicja 553

Szałagan Maciej, ks. 221

Szarota Tomasz 66

Szapiro Jakub 413

Szaruga Leszek 17, 108, 124

Szary Piotr 147, 159

Szatkowski Henryk 330

Szaynok Bożena 58

Szczepan, św. 229

Szczepaniec Józef 413

Szczepanowski Stanisław 187

Szczepański Henryk 221

Szczepański Jan Józef 158, 263, 475, 481

Szczepański Ludwik 493

Szczepański Władysław 309

Szczepkowski Bolesław 195, 212, 215

Szczepkowski Jan 213

Szczęsny P.S. 206

Szczygieł J. 149

Szelążek Adolf 365

Szelburg-Zarembina Ewa 451, 458, 459, 462

Szelest zob. Łabiński Kazimierz, o.

Szemraj Roman, ks. płk 70, 72

Szendzielarz „Łupaszka” Zygmunt, major 556

Szera S. 210

Szewczyk A. 231

Szewczyk H. 159

Szewczyk Z. 247

Szmaglewska Seweryna 456

Szołochow Michaił 299, 368

Szpetnar Stanisław, ks. 438

Szpilman Józef 421

Szpilman Władysław 450, 510

Sztaudynger Jan 145, 380, 382

Szuba Ludwik 74

Szuchowa Stefania 149, 459
Szuman Stefan 149

Szuman Z. 236

Szumowski Władysław 346

Szumski Tomasz 492

Szwarcenberg-Czerny Kazimierz 151, 169, 185, $186,209,214,270,275,460$

Szweykowski Zygmunt 213, 397

Szydelski Szczepan, ks. 158

Szydłowski Roman 137

Szyjkowski Marian 150, 422

Szymanowski Karol 158, 187, 231

Szymański Antoni, ks. 95, 159

Szymański Stanisław 150

Szymański Wiesław Paweł 193, 383

Szymecki Stanisław 66

Szyszko-Bohusz Adolf 153, 158

Ś

Ściegienny Piotr, ks. 316

Śledzianowski Jan 58, 66

Ślendziński Ludomir 155, 156

Śpikowski Władysław, ks. 179

Śreniowski Stanisław 342

Świdnicki Henryk 494

Świechowski Zygmunt 403

Świerczewski Władysław 32

Świetliński zob. Łabiński Kazimierz, o.

Świeżawski Stefan 17, 42, 127, 147, 159, 253, $254,261,263,296,341,424$

Świeżawski Ludwik 439

Święcicki Józef Marian 20, 114, 127, 131, 134, $135,145-147,149,152,155,159,161$, $162,165,169,180,185,190,195,211-$ $213,262,270,273,274,276,277,288$, $290,325,344,348,350,352,353,355$, $356,363,366,368,387,389,409,445$, 471, 490, 494, 495, 501

Świętochowski Aleksander 400

Świrski Ignacy 222

T

T, t. krypt. $135,162,445$

T.H. zob. Haluch Tadeusz

T.K. krypt. 155, 212, 503, 511

T.T. krypt. 236, 241-243

(T.T.) krypt. 240

T.W. krypt. 230

Tańska-Hoffmanowa Klementyna 483

Tardini Domenico, kard. 89, 91 
Targ Alojzy 422

Tarnawski Władysław 214

Taszycki Witold 400, 506

Tatarkiewicz Krzysztof 140, 153

Tatarkiewicz Władysław 127, 195, 254, 261, 267, 394, 395, 407, 457

Tazbir Maksymilian 149

Temperley Harold 340

Tenax pseud. 206

Teodorowicz Józef Teofil, abp 159

Teresa od Dzieciątka Jezus, św. 188, 352, 421, 425,449

Teresa z Lisieux, św. zob. Teresa od Dzieciątka Jezus, św.

Terlecki Ryszard 36

Tertulian 309

Tetelowska Irena 12

Thackeray Makepeace William 364, 366, 367

Thibon Gustave 254, 255, 261, 477

Thiriet Damien 42, 48

Tobiasz Mieczysław 159, 247, 343, 345

Tokarz Franciszek 231, 254, 270

Tola H. 242

Tołstoj Lew 262, 299, 360, 430

Tołwiński Tadeusz 403

Tomanek Roman, ks. 430

Tomasz á Kempis 232, 300, 311, 426, 499

Tomasz More, św. 159, 313, 562

Tomczak Kazimierz, bp 160

Tondini Amleto, ks. 318

Tongwin Maria 185, 189, 190, 291, 372

Tonneau J. 180

Töpfer Stanisław 164

Toporski Jerzy 186

Torre G, dalla 275

Toth Tihamer zob. Tóth Tihamér

Tournay J. 228

Towiański Andrzej 554

Tóth Tihamér, bp 188, 222, 241, 419, 420, 425, $439,443,450$

Trąba Mariusz 111, 116, 121

Treichel Irena 550

Trepiński Antoni 497, 499, 500, 503, 508, 511, 521

Treter Bogdan 446

Treterowa Kazimiera 345

Truchanowski Kazimierz 370

Truman Harry 27, 30

Truskolasy zob. Górski Artur

Truskowski, ks. 205
Trzebiatowski Klemens 74

Trzebiński W. 179, 188, 189

Tseng-Tsiang Lu 158

Turbak Piotr, ks. 212, 454, 465

Turczyński Stanisław 153

Turkowski Romuald 34, 36

Turowicz Jerzy 127, 135, 147, 148, 153, 154, 242, 253-256, 261-263, 265, 267, 289, $342,365,366,568$

Turowski J. 149

Turowski Konstanty 127, 150, 161, 195, 211, 212, 219, 321, 408, 409, 518

Turowski Wojciech, ks. 95

Turski W. 238, 247

Tuwim Julian 459

Twain Mark 520

Tworkowski Stanisław, ks. 244, 419, 420

T-y zob. Górski Artur

Tymczak Adolf, ks. 460

Tymieniecki Kazimierz 270, 457

Tyrmand Leopold 127, 141, 150, 153, 568, 569

Tyrowicz Marian 316

Tyszka Henryk 169, 183, 187, 471

Tyszkiewicz Samuel 492, 507

$\mathbf{U}$

Uczestnik pseud. 222, 246

Ufnalewski C. 506

Uhse Bodo 20

Ujda Jan 169, 188, 189, 222, 231, 270, 309, 461, 471,496

Umińska Jadwiga 482

Umiński Józef, ks. 195, 215, 421

Undset Sigrid 118, 157, 159, 231, 255, 265, 355, $360,417,481,563$

Urban Jan 269

Urban Kazimierz 58

Urban Wincenty 270, 276

Urszula Ledóchowska, św. 276, 315

Usowicz Aleksander, ks. 195, 270, 276, 316, 407

V

Verax pseud. 203, 204, 210

Verdi Giuseppe 231

Verhaeren Emile Adolphe Gustave 552

Verkade Willibrord 232, 425, 451

Verlaine Paul 213

Vetulani Adam 137, 215

Villon Franciszek 386, 391 
Vischer Adolf Lucas 411

Vrtel-Wierczyński Stefan 405, 406

\section{W}

W. krypt. 510, 519

W.B. zob. Borowy Wacław

(w.b) zob. Bąk Wojciech

w. bł. krypt. 501

W. Cz. krypt. 325

(W.D.) krypt. 318

W.K. krypt. 405

W.N. krypt. 145, 352, 396

W.R. zob. Rola Wacław

W.T.J. krypt. 264

W.W. zob. Wnuk Władysław

Waczyński Bogusław 270

Walczak Krzysztof 10

Walczowski Franciszek 214

Waldorff Jerzy 156, 450, 510

Walkowiak L. 186

Wallen Konrad zob. Bąk Wojciech

Wallenrod Konrad 397, 499, 509

Wańka Danuta 9

Wańkowicz Melchior 490

Wański S. 186

Wardasówna Maria 430, 439, 443, 454

Warriner Doreen 340

Warszewicki Stanisław, ks. 276

Wasilewski Marek Antoni 151, 165, 475

Wasilewski Zygmunt 213, 514

Wasita Ryszard 270, 354

Waśkiewicz Hanna 270, 319

Wat Aleksander 59

Waugh Evelyn 157, 355, 448

Wawryn Stanisław, ks. 269, 270, 274, 275, 278, 319, 517

Wayda Jan Karol zob. Gołubiew Antoni

Ważyk Adam 385, 386, 426

Wądołowski Zygmunt, ks. 194, 196, 198, 209

Wąsowicz Stanisław 475

Wdowiszewski Zygmunt 515

Weil Simone 128, 265, 477

Weiser Rudolf 254

Weiss-Dąmbska W. 266

Welle-Strand Edvard 554

Wells Herbert George 366, 467

Weloński Pius 156

Wenklar Michał 29

Werfel Franciszek 353, 439, 440, 465, 481
Weron Eugeniusz, ks. 270, 276, 320

Weronika, św. 238, 355

Weryński Henryk, ks. 72, 221, 239

Wesołowska Stefania 222, 242, 243

Wetmański Leon, bp 42

Weyssenhoff Józef 213

Weyssenhoff-Zielewiczowa Aleksandra 335

Wicher Władysław, ks. 160, 270, 275

Wichrowski Zygmunt 105

Wichrzycka Helena 364

Wick Karel 264

Widacki Jan 55

Widy-Wirski Feliks 46, 62

Wieder Witalis 330

Wielgat Danuta 17, 125, 131, 167, 194, 221, 226, 259

Wielopolski Aleksander 344

Wiernic Andrzej 195

Wierusz-Kowalski Jan 148, 159, 254, 261, 267, 289, 306, 307, 309, 312, 317, 322, 444

Wierzbicki Tadeusz 150

Wieteska Józef 270, 276, 278

Wiktor Jan 297, 366

Wilczyński Kazimierz, ks. 270, 274, 425

Wilczyński Leszek 221

Wilkosz Zofia 117

Wilkowski Stanisław ks. 73, 181

Willam Michał 420

Williams Basil 340

Wincenty Kadłubek, bł. 229

Wincenty Pallotti, św. 159, 276

Winkowski Józef, ks. 270, 274, 420, 432, 437

Winnicki Paweł 196, 209

Winowska Maria 127, 146, 147, 160, 195, 210, $214,215,222,240,265,270,292,353$, 355,475

Wirska A. 459

Wiseman Mikołaj, kard. 276, 488

Wisłocki Juliusz 426

Wiszniewski Jan 124, 193, 199, 209

Wiśniewski Julian 108, 470

Wiśniowski Tadeusz Prus 223, 231, 239, 247

Witkiewicz Stanisław Ignacy 157

Wittyg Wiktor 497

Wł. Ł krypt. 238

Wł. N. krypt. 241

Władyka Wiesław 108, 110-112, 120, 124

Włodarski Seweryn 153, 329

Włodarz Błażej 475 
Wnorowska-Chrempińska M. 190

Wnuk Władysław 370, 407

Wnuk Włodzimierz 151, 153, 195, 289, 330, $372,408,445,474$

Wojciech, św. 100, 160, 173, 186, 188, 215, 229 , 239, 246, 276, 314, 357

Wojciechowska Maria 434, 463

Wojciechowski Tadeusz 154, 341

Wojciechowski Zygmunt 186, 222, 245, 337, $342,434,463$

Wojdon Joanna 74

Wojdyła Witold 74

Wojnowski Jan 552, 559

Wojtczak Albert, o. 42

Wojtkowski Andrzej 150

Wojtyła Karol 36, 128, 140, 149, 158, 195, 254

Wolff Gustaw 493

Wolff Robert 493

Wolny Jerzy, ks. 16, 50, 77

Wolska Róża 166

Wolski Władysław 46, 66, 87

Wolter (właśc. François-Marie Arouet) 312

Wołowski Aleksander 153

Wołowski Paweł 270

Worcell Henryk 480

Woroniecki Jacek, o. 95, 128, 158, 159, 195, $224,238,265,270,275,276,297,313$, $319,420,431,457,460,553$

Woźna-Woźnicka J. 187

Woźniakowski Henryk 254

Woźniakowski Jacek 127, 153-155, 262, 282, $289,345,350,403,405$

Woźnicka Maria 186

Woźniczka R. 155

Woźny Bonifacy, ks. 70, 73

Wójcicki Aleksander, ks. 195

Wójcik Zbigniew K. 28

Wóycicki Aleksander 152

Wóycicki Konstanty 474

Wraubek Józef 475

Wrona Grażyna 126

Wrona Janusz 14, 31, 32, 34, 35

Wrona Zenon 58

Wronka Andrzej, ks. 77, 237

Wróbel Janusz 44

Wróblewska Krystyna 482

Wróblewski Wojciech 55

Wrzesiński Jan 186, 189, 191

Wtorkiewicz Jarosław 36

Wuj z Baranowa pseud. 169, 170, 175, 500, 503
Wujek Jakub, ks. 306, 454, 495

Wun. krypt. 510

Wurzbach Konstanty 493

Wust Piotr 276

Wycech Czesław 37

Wycisło Janusz 225

Wyczawski Hieronim 159

Wyczółkowski Leon 156, 165, 276

Wyrzykowski Henryk 36

Wysocki Jan zob. Wysocki Wiesław Jan

Wysocki Wiesław Jan 15, 45, 49, 77, 94, 98, 99, 101

Wyspiański Stanisław 156, 163, 318, 498, 499

Wyspiański Wojciech 74

Wyszyński Stefan, kard. 15, 18, 39, 41, 43-45, $49,50,52,54,64-67,71-73,78,79,82$, $83,85,87-105,112,117,119,121,128$, $146,159,166,167,169,195,210,225$, $228,240,246,432,551,558,579$

$\mathbf{X}$

X.J.R. krypt. zob. Rostworowski Jan, ks.

Y

Ydewalle Charles, d' 160

\section{$\mathbf{Z}$}

(z) krypt. 243, 248

Z.F. krypt. 316

Z.K. zob. Kaczyński Zygmunt, ks.

Z.L. 156

Z.M. 233, 241, 370

(Z.M.) krypt. 202

Z.R. zob. Rabska Zuzanna

Z.S. krypt. 243, 247

(Z.S.M.) zob. Starowieyska-Morstinowa Zofia

Z.W. 238

Zabłocki Janusz zob. Zajczniewski Karol

Zaborski Zbigniew 188, 212, 228, 246, 461

Zabrodzki Ludwik 401

Zaczkiewicz Władysław, płk 329, 330

Zagórski Jerzy 152, 156, 214, 254, 264, 288, $289,380,381,383-385,445$

Zajchowska Stanisława 423

Zajczniewski Karol 15, 49, 50, 63-65, 95, 98, $119,150,193$

Zakrzewska Helena 458

Zakrzewski Tadeusz, bp 87, 89

Zaleski Zygmunt 334 
Zalewski Ludwik, ks. 334, 343, 486

Zambrowski Roman 32

Zamiatała Dominik, ks. 86

Zamoyscy, rodzina 497

Zaniewski Romuald, ks. 114

Zarembowicz Henryk, ks. 270, 274

Zastępca pseud. 206

Zawadzki Józef 265

Zawadzki M. 153

Zawadzki P. 160

Zawieyski Jerzy (właśc. Henryk Nowicki) 127, 153, 189, 195, 211, 213, 222, 228, 231, 254, 262, 276, 324, 348, 364, 387, 388, 414, 435, 445, 454, 455, 470, 478, 480, 551,569

Zawisza Bohdan 209

Zawiszanka Halina 459

Zawiszanka Zofia 313, 353, 440, 520

Zblewski Zdzisław 14, 25, 27, 29

Zdrój J. 150

Zechenter Witold 458

Zelk Roman, ks. 60

Zet. krypt. 394, 404

Zgorzelski Czesław 127, 254, 392, 393, 395, $397,399,401,500,501,509,510$

Zieja Jan, ks. 318

Zielińscy, rodzina 516

Zieliński A. 276

Zieliński Stanisław 376, 474

Zieliński Zygmunt, ks. 15, 41, 43, 47-49, 51-53, $56,64,69,81,91,93,105,110,111,124$

Ziembicki Stanisław 385, 418

Ziembicki W. 158

Ziętek Ludwik, ks. 424

Zimniak Stanisław 51

Zink Wojciech, ks. 103

Ziomek Maksymilian Józef 518
Zmaczyński Ludwik 324

Zmarz Wojciech 159, 406

Zola Emil 299, 363, 397

Zoll Fryderyk 158

ZSM., zsm. zob. Starowieyska-Morstinowa Zofia

Zuberbier Andrzej, ks. 387, 388

Zwilkoński S. 214

Zych Tomasz 153, 155, 345

Zygmunt August, król polski 497

Zygmunt Stary, król polski 444

\section{$\dot{\mathbf{Z}}$}

Żakowski Jacek 101, 103, 126

Żaryn Jan 14, 16, 26, 32, 41-43, 47, 48, 50-53, 55-71, 73, 77, 80, 81, 83-86, 88, 90-94, $103,105,106,111,193,558$

Żbikowska-Migoń Anna 9

Żelazko Joanna 44

Żeleńska Zofia 485

Żmigrodzka Maria 400

Żmuda S. 185

Żorecka Zofia 435

Żorecki Z. 236

Żółkiewski Stefan 137, 394, 399

Żukrowski Wojciech 124, 162, 167, 189, 289, 297, 357, 372-374, 426, 427, 480

Żulińska Barbara, s. 430

Żup A. 207

Żupański Jan Konstanty 492, 493

Żurek Jacek 70

Żurowska Felicja 149, 439

Żychiewicz Tadeusz 155

Żychliński Aleksander, ks. 320, 457

Żynda Marcin 126

Żywczyński Mieczysław, ks. 72 



\section{Indeks księgarni, wydawnictw i wydawców}

A

Akademia Teologii Katolickiej w Krakowie 123

Albertinum Księgarnia św. Wojciecha 117,119, 295, 296, 298, 300, 301, 302, 303, 305, $306,323,348,353,357,431,432,440$, $441,456,459,464,494$

Albertinum zob. Albertinum Księgarnia św. Wojciecha

American Catholic Philosophical Association 465

Angrabajtis Józef 428

Apostolat de la Prière, Éditions Spes 465

Apostolstwo Chorych zob. Polski Sekretariat Apostolstwa Chorych

Arct Michał 426, 459, 460

Arct Stanisław 301, 436, 459, 513

Ars Christiana 119, 428

Awir 295, 297, 298, 299, 300, 301, 348, 455, 464

\section{B}

Bąk Władysław 295, 297, 300, 301, 380, 464, 488

Beauchesne 298, 300

Brentano New York 302

Burns Oates 511

\section{C}

Caritas 389

Castreman-Tournai 302

Cebulski Józef 428

Centrala Milicji Niepokalanej zob. Wydawnictwo Milicji Niepokalanej

Centralny Komitet Żydów Oilskich 387

Czytelnik zob. Spółdzielnia Wydawnicza Czytelnik

\section{D}

Desclée de Brouwer 299, 300, 303, 465

Diecezjalna Spółdzielnia Wydawnictw Religijnych Veritas zob. Veritas
Dobra Książka 302, 387, 436

Drukarnia i Księgarnia św. Wojciecha zob. Albertinum Księgarnia św. Wojciecha

Drukarnia Katolicka 117, 302

E

Ex libris 427

F

Fuksiewicz Mieczysław i Spółka 295, 414, 426

G

Gallimard 302, 303

Galster 426

Gebethner i Wolff 295, 296, 298, 301, 302, 348, $360,361,380,393,403,426,448,458$, $459,464,493$

I

Instytut Bałtycki 341

Instytut Śląski zob. Wydawnictwo Instytutu Śląskiego

Instytut Wydawniczy Kultura 426-427, 451

Instytut Wydawniczy Nasza Księgarnia 436, 459,486

Instytut Wydawniczy PAX 117, 124, 294, 296, 298, 299, 302, 305, 318, 327, 344, 348, $353,372,384,387,391,415,417,447$, $448,465,567$

Instytut Zachodni 403, 408, 450, 462, 560

K

Katolicki Komitet Wydawniczy 172, 199

Katolickie Towarzystwo Wydawnicze „Rodzina Polska" 122, 194, 199-200, 201, 295, 297, 301, 380, 381, 418

Katolickie Wydawnictwo „Rodzina Polska” zob. Katolickie Towarzystwo Wydawnicze „Rodzina Polska”

Kot M. 295, 459

Krajowa Centrala Caritas 123, 295, 297, 387, 435,453 
Książka i Wiedza 295, 297, 298, 299, 303, 348, 380, 387, 446, 463, 488

Książka zob. Spółdzielnia Wydawnicza Książka

Książnica Atlas 295, 297, 298, 299, 301, 348, $455,464,465,562$

Księgarnia „Jedność” 118, 434, 435

Księgarnia Akademicka 295, 299, 436

Księgarnia Braci Bogdańskich i Spółki 436

Księgarnia Dobra Książka zob. Dobra Książka

Księgarnia Eugeniusza Kuthana zob. Wydawnictwo Eugeniusza Kuthana

Księgarnia Feliksa Czekalskiego 431

Księgarnia Gdańska A. Krawczyński 436

Księgarnia Gmachowskiego 514

Księgarnia Homo 436

Księgarnia Instytutu Wydawniczego Nasza Księgarnia zob. Instytut Wydawniczy Nasza Księgarnia

Księgarnia Katolicka 434

Księgarnia Katolicka Stanisława Łubieńskiego 434

Księgarnia Kazimierza Schaefera 436

Księgarnia Krakowska 432

Księgarnia Naukowa 434

Księgarnia Ogniwo 302

Księgarnia Postęp 436

Księgarnia Powszechna 436

Księgarnia Rolnicza 436

Księgarnia S. Arcta zob. Arct Stanisław

Księgarnia Stefana Kamińskiego zob. Wydawnictwo Księgarni Stefana Kamińskiego

Księgarnia św. Anny 432

Księgarnia św. Antoniego 435

Księgarnia św. Jacka 117, 295, 297, 299, 300, $301,305,306,325,430,451,464$

Księgarnia św. Jadwigi 434

Księgarnia św. Teresy 436

Księgarnia św. Wojciecha zob. Albertinum Księgarnia św. Wojciecha

Księgarnia Towarzystwa W.O. „Przyszłość” 435

Księgarnia Wysyłkowa Librairium 436

Księgarnia Zdzisława Gustowskiego 295, 297, 298, 299, 361, 426, 429, 460

Księgarnia Ziem Zachodnich 302

Księgarnia Związku Caritas 435

Kuria Administracji Apostolskiej 226

Kuria Archidiecezjalna w Krakowie 121

Kuria Diecezjalna w Katowicach 121

Kuria Książęco-Metropolitalna w Krakowie 131
Kuria Metropolitalna w Poznaniu 167

Kurkiewicz Julian 428, 414

Kuthan Eugeniusz zob. Wydawnictwo Eugeniusza Kuthana

L

Lauter i Rutkowski 426

Letouzey 298, 300, 303, 325

Librairie Letouzey et Ané 465

Librairie Plon 302, 303

Ludowy Instytut Kultury 385

M

M. Arct zob. Arct Michał

Międzynarodowe Wydawnictwo Guild 464

$\mathbf{N}$

Nasza Księgarnia zob. Instytut Wydawniczy Nasza Księgarnia

\section{O}

Office de Publicité 302

Oficyna Księgarska 297, 302, 433, 511

Oficyna Wydawnicza 415

Ordynariat Gorzowski 226

\section{$\mathbf{P}$}

Pallotinum 117, 119, 295, 297, 298, 300, 302, $305,322,358,421,422,436,451,453$

Panteon 295, 299, 380, 426

Państwowe Zakłady Wydawnictw Szkolnych 299, 302, 451, 458, 463, 501

Państwowy Instytut Wydawniczy 294, 298, 303, 348, 384, 387, 393, 456, 463, 487, 564

PAX zob. Instytut Wydawniczy PAX

Poligrafika 297, 427

Polska Agencja Wydawnicza 426

Polska Spółdzielnia Księgarska i Papiernicza Nauka 426

Polski Sekretariat Apostolstwa Chorych 123, 464

Polskie Wydawnictwo Muzyczne 297, 511

Pontificium Institutum Biblicum 465

Poznańskie Towarzystwo Przyjaciół Nauka 297, 298, 299, 347, 393, 401, 465

Prasa Wojskowa 299, 463

$\mathbf{R}$

Radiowy Instytut Wydawniczy 295

Res Sacra 428

Roy Publishers 302 


\section{S}

S. Arct zob. Arct Stanisław

Sheed and Ward 455, 511

Składnica Katolickich Wydawnictw i Artystycznych Dewocjonalii Caritas 435

Społeczny Instytut Wydawniczy Znak 568

Spółdzielnia Wydawnicza „Znak” 123, 257

Spółdzielnia Wydawnicza Czytelnik 72, 115, 248, 294, 296, 298, 299, 300, 301, 302, 303, 347, $348,356,361,374,380,383,385,387,393$, $414,415,426,427,445,455,458,459,460$, $463,464,465,475,487,512,517,523,525$

Spółdzielnia Wydawnicza Książka 294, 296, $298,300,301,303,348,360,362,363$, $380,384,387,390,393,415,426,455$, $458,459,460,463,464,512$

Spółdzielnia Wydawnicza Wiedza 294, 296, 298, $300,301,303,342,348,364,380,415,426$, $450,455,459,463,464,510,512$

Spółdzielnia Wydawnicza Wieś 426

\section{Ś}

Światowid zob. Warszawska Spółdzielnia Księgarsko-Wydawnicza Światowid

\section{T}

The Camridge University Press 303

Towarzystwo Ludoznawcze 297

Towarzystwo Mariańskie 225

Towarzystwo Miłośników Historii 465

Towarzystwo Naukowe KUL 294, 296, 298, 299, 301, 342, 347, 393, 396, 398, 409, $450-451,465$

Towarzystwo Naukowe Warszawskie 298, 299, 347, 393, 465

Towarzystwo Przyjaciół Katolickiego Uniwersytetu Lubelskiego 423

Towarzystwo Teatru i Muzyki Ludowej 387

Trzaska, Evert i Michalski 295, 297, 301, 426, 458,460

\section{V}

Verbum 118, 295, 297, 298, 300, 301, 302, 303, $305,310,313,318,322.323,387,388$, $435,449,451,456,458$

Veritas 295, 297, 426

\section{W}

Warszawska Spółdzielnia Księgarsko-Wydawnicza Światowid 426, 459
Wiedza zob. Spółdzielnia Wydawnicza Wiedza

Wielkopolska Księgarnia Wydawnicza 295, 297, 298, 301, 302, 357, 380, 434, 451, 464

Wojewódzka Żydowska Komisja Historyczna 463, 465

Wrocławskie Towarzystwo Naukowe 297

Wydawnictwo „Kultura Katolicka” 463

Wydawnictwo „Nasza Księgarnia” zob. Instytut Wydawniczy Nasza Księgarnia

Wydawnictwo Apostolstwa Modlitwy 117, 297, 298, 300, 301, 302, 305, 425, 451, 453, $460,463,464$

Wydawnictwo B. Matuszewski 451

Wydawnictwo Eugeniusza Kuthana 295, 297, 298, 299, 301, 302, 320, 348, 380, 387, $393,414,455,459$

Wydawnictwo Instytutu Śląskiego 341

Wydawnictwo Instytutu Zachodniego 294, 296, $298,300,301,302,347,380,407,422$

Wydawnictwo Katolickiego Uniwersytetu Lubelskiego 117, 460, 464

Wydawnictwo Księgarni Stefana Kamińskiego 295, 297, 301, 415, 434, 460

Wydawnictwo Księży Jezuitów zob. Wydawnictwo OO. Jezuitów

Wydawnictwo Księży Pallotynów zob. Pallotinum

Wydawnictwo Mariackie 118, 260, 295, 296, 298, 300, 301, 302, 305, 310, 322, 420, 453,464

Wydawnictwo Milicji Niepokalanej 295, 298, 300, 427, 464

Wydawnictwo Mój Dom 427

Wydawnictwo OO. Franciszkanów 118

Wydawnictwo OO. Jezuitów 117, 271, 418, $419,451,456,464$

Wydawnictwo OO. Karmelitów Bosych 118, $122,298,300,380,425,453,456,464$

Wydawnictwo OO. Redemptorystów 427

Wydawnictwo Opactwa OO. Benedyktynów 427

Wydawnictwo Panteon zob. Panteon

Wydawnictwo Państwowego Instytutu Historii Sztuki 297

Wydawnictwo Polskiej Akademii Umiejętności 295, 297, 298, 300, 509

Wydawnictwo Polskiej Akademii Nauk 393

Wydawnictwo Przełom 295, 297, 380, 427 
Wydawnictwo Seminarium Zagranicznego 424, 451

$387,391,393,400,405,448,463,510$, 511

Wydawnictwo Sióstr Loretanek zob. Wydawnictwo Sióstr Loretanek-Benedyktynek

Wydawnictwo Sióstr Loretanek-Benedyktynek $300,302,451$

Wydawnictwo Studium Słowiańskiego Uniwersytetu Jagiellońskiego 297

Wydawnictwo św. Krzyża 118, 297, 299, 300, $302,421,453,464$

Wydawnictwo Światowid zob. Warszawska Spółdzielnia Księgarsko-Wydawnicza Światowid

Wydawnictwo Uniwersytetu Marii Curie-Skłodowskiej 465

Wydawnictwo W. Nagłowskiego 426

Wydawnictwo Zachodnie 450, 464, 465, 511

Wydawnictwo Zakładu Narodowego im. Ossolińskich 295, 297, 298, 299, 380,

Wydawnictwo Zdzisława Gustowskiego zob. Księgarnia Zdzisława Gustowskiego

\section{$\mathbf{Z}$}

Zakład Sztuki Kościelnej Kazimierza Schaefera 428

Zapiór Tadeusz „Wiedza, Zawód, Kultura” 295, 298, 300, 302

Znak zob. Spółdzielnia Wydawnicza „Znak”

Związek Literatów Polskich zob. Związek Zawodowy Literatów Polskich

Związek Literatów zob. Związek Zawodowy Literatów Polskich

Związek Młodzieży Przemysłowej i Rękodzielniczej 302

Związek Zawodowy Literatów Polskich 295, $297,380,485,523,563$ 


\section{Od Redakcji}

Doktor Evelina Kristanova - prasoznawca, bibliolog, adiunkt w Katedrze Bibliotekoznawstwa i Informacji Naukowej UŁ. Ukończyła filologię polską w zakresie bibliotekoznawstwa i informacji naukowej na Uniwersytecie Łódzkim (1989-1994). Przez pół roku pracowała w archiwum. Od 1995 r. zatrudniona na UŁ. W 2003 r. obroniła doktorat z zakresu nauk humanistycznych na podstawie pracy Program spoteczny i kulturalny „Tęczy”(1927-1939) na tle prasy katolickiej w II Rzeczypospolitej (wydana drukiem w 2006). W latach 2004-2007 studiowała teologię na Uniwersytecie Kardynała Stefana Wyszyńskiego w Warszawie, uzyskując licencjat. W latach 2009-2012 sekretarz redakcji „Acta Universitatis Lodziensis. Folia Librorum”. Członek Łódzkiego Towarzystwa Przyjaciół Książki (od 2007 r.) i Stowarzyszenia Bibliotekarzy Polskich (od 2011 r.). Specjalizuje się w zakresie polskich czasopism społeczno-kulturalnych (w szczególności katolickich). W kręgu jej zainteresowań pozostaje problematyka książki na ich łamach. Zajmuje się również współczesnymi zagadnieniami instytucji książki w Bułgarii. Zajęcia dydaktyczne prowadzi w zakresie starych i nowych mediów. Jest autorką ponad 40 różnego rodzaju publikacji (artykuły, recenzje, biogramy, sprawozdania z konferencji) w recenzowanych wydawnictwach i czasopismach naukowych. Dorobek w wyborze przedstawia się następująco: Biblioteka Narodowa im. św. św. Cyryla i Metodego w Sofii. Historia i wspótczesność „Przegląd Biblioteczny” 2009 z. 1; Formy współczesnej książki. W: Pasja książki. Studia poświęcone pamięci profesora Janusza Dunina, pod red. J. Ladoruckiego i M. Rzadkowolskiej, Łódź 2009, s. 158-175; Prasa tradycyjna a elektroniczna - próba porównania typologii. W: Uniwersum piśmiennictwa wobec komunikacji elektronicznej, pod red. K. Migonia i M. Skalskiej-Zlat, Wrocław 2009, s. 113-129; Ksiażka na tamach krakowskiego „Tygodnika Powszechnego” (1945-1953) w świetle reklamy wydawniczej. W: Краків - Львів: книги, часописи, бібліотеки XIX-XX ст., t. 10, Ред. Г. Врона, О. Колосовська, Г. Косентка, Львів 2011, s. 332-345; Promoсja książi w prasie - lepsza czy gorsza niż przed laty? (rozważania na przykładzie „Tygodnika Powszechnego” w latach 1945-1953 i współcześnie). W: 350 lat prasy polskiej, Warszawa 2012, s. 221-228. 